\title{
SWeThen
}




\section{Tratamiento biológico de aguas residuales}

Principios, modelación y diseño 



\section{Tratamiento biológico de aguas residuales}

Principios, modelación y diseño

Editores de la versión en español:

Carlos M. López Vázquez

Germán Buitrón Méndez

Héctor A. García

Francisco J. Cervantes Carrillo

Editores de la versión en inglés:

Mogens Henze

Mark C.M. van Loosdrecht

George A. Ekama

Damir Brdjanovic

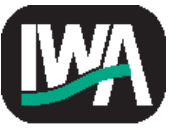

Publishing 
Publicado por: IWA Publishing

Alliance House

12 Caxton Street

London $\mathrm{SW} 1 \mathrm{H}$ OQS, UK

$\mathrm{T}:+44$ (0) 2076545500

F: +44 (o) 2076545555

E: publications@iwap.co.uk

I: www.iwapublishing.com

Primera publicación 2008

○ 2008 IWA Publishing

Publicación de la edición en español

() 2017 IWA Publishing

Imprime: Cambridge University Press

Con la excepción de su uso adecuado y justo con fines de investigación o estudio privado, o crítica o revisión, según lo permitido por la Ley de Derecho de Autor, Diseños y Patentes del Reino Unido (1998), ninguna parte de esta publicación puede reproducirse, almacenarse o transmitirse en cualquier forma o de cualquier manera, sin el permiso previo por escrito del editor o, en el caso de la reproducción fotográfica, de acuerdo con los términos de las licencias emitidas por la Agencia de Licencias de Copyright en el Reino Unido, o de acuerdo con los términos de las licencias emitidas por la organización de derechos de reproducción apropiada fuera del Reino Unido. Las consultas sobre reproducción fuera de los términos establecidos aquí deben enviarse a IWA Publishing a la dirección impresa arriba.

El editor no hace ninguna representación, expresa o implícita, con respecto a la exactitud de la información contenida en este libro y no puede aceptar ninguna responsabilidad legal o responsabilidad por errores u omisiones que puedan hacerse.

Descargo de responsabilidad

La información proporcionada y las opiniones dadas en esta publicación no son necesariamente las de IWA e IWA Publishing y no se deben tomar medidas sin una consideración independiente y asesoramiento profesional. IWA e IWA Publishing no aceptarán responsabilidad por cualquier pérdida o daño sufrido por cualquier persona que actúe o se abstenga de actuar sobre cualquier material contenido en esta publicación.

Catalogación de la Biblioteca Británica en Datos de Publicación (CIP)

Un registro de catálogo CIP para este libro está disponible en la Biblioteca Británica

Catalogación de la Biblioteca del Congreso en Datos de Publicación

Un registro de catálogo para este libro está disponible en la Biblioteca del Congreso

Cover design: Peter Stroo

Graphic design: Hans Emeis

Print ISBN: $\quad 9781780409139$

eBook ISBN: $\quad 9781780409146$

DOI: $10.2166 / 9781780409146$

This eBook was made Open Access in November 2017

(0) 2017 The Editors

This is an Open Access Book distributed under the terms of the Creative Commons Attribution Licence (CC BY-NC-ND 4.0), which permits copying and redistribution for non-commercial purposes with no derivatives, provided the original work is properly cited (http://creativecommons.org/licenses/by-nc-nd/4.0/). This does not affect the rights licensed or assigned from any third party in this book.

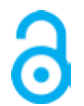

AUTORES en orden alfabético:

\section{Gary AMY}

Damir BRDJANOVIC

Yves COMEAU

George A. EKAMA

Jorge H. Orozco GARCIA

Charles P. GERBA

Mogens HENZE

Christine M. HOOIJMANS

Simon JUDD

Byung-goon KIM

Jules B. van LIER

Nidal MAHMOUD

Antonio M. MARTINS

Eberhard F. MORGENROTH

Gustaf OLSSON

Diego ROSSO

Michael K. STENSTROM

Imré TAKACS

Mark C.M. van LOOSDRECHT

Mark C. WENTZEL

Grietje ZEEMAN
UNESCO-IHE Institute for Water Education, Delft, The Netherlands

UNESCO-IHE Institute for Water Education, Delft, The Netherlands

École Polytechnique, Montréal, Canada

University Cape Town, Cape Town, South Africa

Monterrey University, Monterrey, Mexico

University of Arizona, Tucson, U.S.A.

Technical University of Denmark, Lyngby, Denmark

UNESCO-IHE Institute for Water Education, Delft, The Netherlands

Cranfield University, Cranfield, U.K.

Korean Water Resources Company - Kwater, Daejeon, Korea

Wageningen University and Research Centre, Wageningen, The Netherlands

Birzeit University, Birzeit, Palestine

Áquas do Algarve, Faro, Portugal

University of Illinois at Urbana-Champaign, Urbana, U.S.A.

Lund University, Lund, Sweden

University of California, Irvine, U.S.A.

University of California, Los Angeles, U.S.A

EnviroSim Associates Ltd., Flamborough, Canada

Delft University of Technology, Delft, The Netherlands

University Cape Town, South Africa

Wageningen University and Research Centre, Wageningen, The Netherlands 


\section{Prólogo}

En las últimas decadas, el conocimiento y entendimiento del tratamiento de aguas residuales ha avanzado extensamente evolucionando de enfoques basados en procedimientos meramente empíricos a enfoques con principios básicos que abarcan la química, microbiología, física, ingeniería de procesos y matemáticas. La gran mayoría de estos avances han madurado a tal grado que han sido codificados en modelos matemáticos para su simulación en computadoras. Para una nueva generación de jóvenes científicos e ingenieros que ingresan al área del tratamiento de aguas residuales, la cantidad, complejidad y diversidad de estos nuevos desarrollos puede ser abrumador, particularmente en países en vías de desarrollo donde no existe un fácil acceso a cursos avanzados de postgrado en tratamientos de aguas residuales.

Este libro tiene como objetivo resolver esta deficiencia ya que compila e integra el material de diversos cursos de postgrado de más de una docena de grupos de investigación de todo el mundo que han hecho contribuciones significativas para el desarrollo del tratamiento de aguas residuales.

Cabe resaltar que el presente libro forma parte de un plan de estudios en línea en tratamiento de aguas residuales; y como tal, se puede utilizar junto con notas de clase, video-lecturas filmadas por los profesores autores y ejercicios tutoriales para el autoaprendizaje de los estudiantes. Al completar este plan de estudios, el enfoque moderno de modelado y simulación para el diseño y operación de plantas de tratamiento de aguas residuales, ya sea lodos activado, remoción biológica de nitrógeno y fósforo, tanques de sedimentación secundaria o sistemas de biopelícula, puede abordarse con una visión más profunda, conocimientos más avanzados y mayor confianza.

Tanto la versión original del libro, como los materiales innovadores de aprendizaje relacionados, los cuales han sido la base para la preparación del presente libro en español, se produjeron en el marco de la Alianza IHE Delft para la Educación e Investigación del Agua (PoWER). Todo ello con la finalidad de desarrollar y ofrecer servicios de educación de posgrado, investigación conjunta y desarrollo de capacidades, adecuados a la demanda y debidamente acreditados, para individuos y organizaciones pertenecientes a países en desarrollo.

Este libro ha sido posible gracias al generoso patrocinio del Instituto IHE Delft para la Educación del Agua (antes UNESCO-IHE), de la Corporación de Recursos Hídricos de Corea (Kwater) y del Ministerio de Relaciones Exteriores del Reino de Los Países Bajos. Esto último a través del programa de cooperación establecido entre la Dirección General del Ministerio de Relaciones Exteriores e IHE Delft, programa conocido como DUPC (por sus siglas en inglés Directorate-General for International Cooperation -DGIS- of the Dutch Ministry of Foreign Affairs and IHE Delft Programmatic Cooperation).

Varias personas merecen ser destacadas ya que su contribución ha sido muy apreciada para la preparación de la edición original en inglés, entre ellas: Jetze Heun, Atem Ramsundersingh, Caroline Figueres, Jan Herman Koster, Kyul Ho Kwak, Nahm-Chung Jung, Byung-goon Kim, Peter Stroo, Hans Emeis, Vincent Becker, Angela Lorena Pinzón Pardo, Loreen Ople Villacorte, Assiyeh A. Tabatabai, Claire Taylor, Michael Dunn, Michelle Jones, David Burns; y por supuesto, todos los autores.

Adicionalmente, la presente edición en español ha sido posible gracias al invaluable e incondicional trabajo y apoyo de Benly Ramírez Higareda, Mark Hammond, Alejandro Nario, Vianey Ruíz López, Iván Moreno Andrade, Luis H. Álvarez y Aylet Vega Aguilar.

Además, reconocemos a los colaboradores que permitieron que sus datos, imágenes y fotografías se utilicen en este libro.

Finalmente, los editores le desean un estudio beneficioso del tratamiento biológico de aguas residuales y un uso exitoso para mejorar el saneamiento en todo el mundo. 


\section{Editores de la versión en Español}

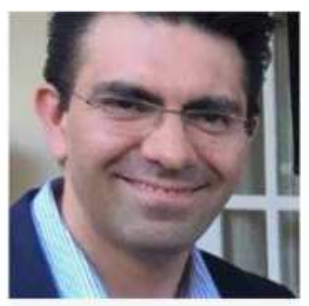

Dr. Carlos M.

Lopez-Vazquez

Carlos Manuel Lopez Vazquez es Doctor en Biotecnología Ambiental graduado con cum laude de la Universidad Tecnológica de Delft y del Instituto IHE Delft para la Educación del Agua (2009). Obtuvo su grado de Ingeniero Civil y de Maestría en la Universidad Autónoma del Estado de México en 1999 y 2003, respectivamente. Actualmente es Profesor Asociado en Ingeniería Sanitaria en IHE Delft. Su área de trabajo, docencia e investigación abarca el área de tratamiento de aguas residuales con particular énfasis en el desarrollo de tecnologías más económicas, eficientes y con menor impacto ambiental para la recuperación de recursos tales como nutrientes, energía a través de la generación de biogas y del agua misma. A nivel docente coordina e imparte diversos módulos, cursos y asignaturas en tratamiento de aguas residuales a nivel maestría y doctorado tanto presencial como a distancia, incluyendo el curso en línea 'Biological wastewater treatment: principles, modelling and design". Es coordinador y ha participado en diversos proyectos de educación, investigación y consultoría en Europa, Asia, Latinoamérica y el Caribe. Además, ha dirigido aproximadamente 50 proyectos y tesis de maestría y 10 de doctorado. Cuenta con más de 50 publicaciones científicas internacionales que incluyen 4 libros en temas relacionados con el tratamiento de aguas residuales, entre ellos "Experimental Methods in Wastewater Treatment" y "Applications of Activated Sludge Models".

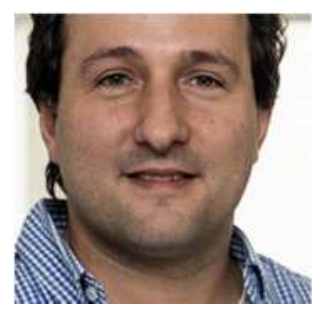

\section{Dr. Héctor A. García}

se desempeña como Senior Lecturer en Tecnologías de Tratamiento de Aguas Residuales en el instituto IHE Delft Institute for Water Education (Delft, Holanda). En 2011, recibió su título de doctor en Ingeniería Civil y Ambiental de la Universidad de Texas en Austin. Durante los inicios de su carrera profesional como Ingeniero Químico ha trabajado por aproximadamente 10 años en el sector industrial de la industria química, principalmente en procesos de producción de vitaminas y en el sector de elaboración de productos plásticos. Durante su doctorado se especializó en biorreactores de membrana y la aplicación de tecnologías innovadoras para la remoción de contaminantes emergentes de aguas residuales. Desde su incorporación al instituto IHE Delft en el año 2011, ha estado involucrado en diversas actividades de educación, investigación, y de desarrollo de capacidades locales. Ha participado activamente en la supervisión de estudiantes de post-grado tanto a nivel de maestrías y doctorados. Ha participado y lidereado varios proyectos internacionales relacionados con la implementación de tecnologías para la depuración de aguas residuales y la recuperación y reúso de recursos.

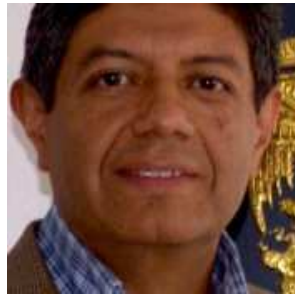

Prof. Germán Buitrón Méndez

Prof. Germán Buitrón recibió su grado en Ing. Químico en 1987 por parte de la Universidad Nacional Autónoma de México (UNAM), y sus grados de Maestría y

Doctorado por el Instituto Nacional de Ciencias Aplicadas de Tolouse, Francia, en 1990 y 1993, respectivamente. Desde 1994, trabaja en el Insituto de Ingeniería de la UNAM como Investigador Titular y Profesor del programa de Post-grado en Ingeniería Ambiental de la UNAM. Actualmente, é les el Jefe del Labotario de Procesos para Tratamiento de Agua en el Campus Juriquilla de la UNAM, en la ciudad de Querétaro, México. Sus líneas de investigación abarcan: la generación de bioenergía a partir de aguas residuales (metano, hidrógeno y electricidad); biodegradación de compuestos orgánicos tóxicos presents en aguas residuales industriales; sistemas de microalgas-bacterias para el tratamiento de aguas residuales; tratamiento de aguas residuales textiles; automatización y control de bioreactors. Ha sido autor y co-autor de más de 450 artículos científicos. También, el Prof. Buitrón ha graduado más de 65 estudiantes universitarios, de maestría y de doctorado. Es miembro del comité de administración del Grupo de Especialistas en sistemas pequeños de tratamiento de agua potable y aguas residuales de la International Water Association, de Industrias Químicas y de Digestión Anaerobia.

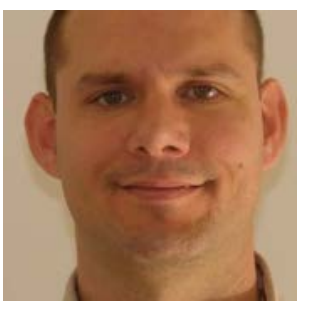

\section{Prof. Francisco J. Cervantes Carrillo}

Ingeniero Biotecnólogo por el Instituto Tecnológico de Sonora (ITSON, 1995). Maestro en Biotecnología por la Universidad Autónoma Metropolitana, Unidad Iztapalapa (UAM-I, 1998). Doctor en Ciencias Ambientales por la Universidad de Wageningen (Países Bajos, 2002). Es Profesor de la División de Ciencias Ambientales del Instituto Potosino de Investigación Científica y Tecnológica (IPICYT, San Luis Potosí, México). Ha publicado más de 100 artículos y capítulos de libro y sus publicaciones cuentan con más de 3,000 citas hasta la fecha. Ha dirigido más de 60 tesis y ha dictado cátedra en ITSON, UAM-I, IPICYT y en Universidad Noruega de Ciencia y Tecnología (NTNU-Trondheim). Ha recibido diversos premios, entre los que destacan el Lettinga Award 2007 por la Lettinga Associates Foundation, el Premio de Investigación 2008 por la Academia Mexicana de Ciencias (Área de Ingeniería y Tecnología), el Premio Heberto Castillo Martínez 2010 (en Medio Ambiente) por el Gobierno de la Ciudad de México y la Cátedra Marcos Moshinsky 2014. Sus líneas de investigación incluyen el desarrollo de sistemas biológicos de tratamiento de aguas residuales. Ha diseñado varias plantas de tratamiento de aguas residuales, actualmente en operación en distintos sectores industriales de América Latina. 


\section{Sobre el libro y el curso en línea}

La idea de realizar los cursos de aprendizaje en línea sobre tratamiento biológico de aguas residuales se concibió en 2003 cuando IHE Delft (antes UNESCO-IHE) obtuvo una subvención del gobierno holandés para desarrollar métodos y productos de aprendizaje innovadores que resultaron en la Asociación para la Educación e Investigación del Agua (PoWER).

La idea original del Profesor Damir Brdjanovic fue la de involucrar a profesores de todo el mundo que han hecho contribuciones significativas a los avances en el tratamiento de aguas residuales. Se requirieron de tres años y del patrocinio adicional de la Corporación de Recursos Hídricos de Corea (K-water) para obtener recursos financieros adicionales y comenzar a trabajar en la preparación de los materiales del curso. El marco conceptual para el libro y el curso en línea del que forma parte se acordó en Beijing durante el IWA World Water Congress and Exhibition en septiembre de 2006. Además de proporcionar capítulos para el libro, se solicitó a los autores preparar diapositivas de presentación, ejercicios tutoriales y participar en la filmación de clases grabadas en video en el estudio de IHE Delft, todas compiladas en un paquete de DVD disponible para aquellos participantes registrados para el curso en línea. IWA Publishing acordó publicar el libro y comercializar el libro y el curso de aprendizaje en línea.

Exactamente dos años después, en septiembre de 2008, se presentó al público el libro Tratamiento biológico de aguas residuales en el Congreso y Exposición Mundial sobre Agua de IWA en Viena. En el contexto del Año Internacional del Saneamiento, la primera copia del libro fue entregada a Su Alteza Real el Rey de Orange, Willem Alexander, Presidente del Consejo Asesor del Secretario General de las Naciones Unidas sobre Agua y Saneamiento. En noviembre 2017, se presentó al público la versión en español del libro en el Congreso \& Exhibición de Agua y Desarrollo de la International Water Association (IWA Water \& Development Congress \& Exhibition) celebrado en Buenos Aires, Argentina.

El curso en línea se imparte dos veces al año. El libro también se utiliza para la enseñanza como parte de una serie de clases en la especialización de Ingeniería Sanitaria del Programa de Maestría en Agua Urbana y Saneamiento de IHE Delft. Está conceptualizado de tal manera que puede usarse como un libro de texto autónomo o como parte integral del curso de aprendizaje en línea.

Se puede obtener más información sobre este curso de aprendizaje en línea y la especialización en Ingeniería Sanitaria de IHE-Delft escribiendo a Carlos López Vázquez (c.lopezvazquez@un-ihe.org) o visitando las respectivas páginas web: https://www.un-ihe.org/online-courses y https://www.unihe.org/msc-programmes/specialization/sanitary-engineering-o 


\section{Tabla de Contenido}

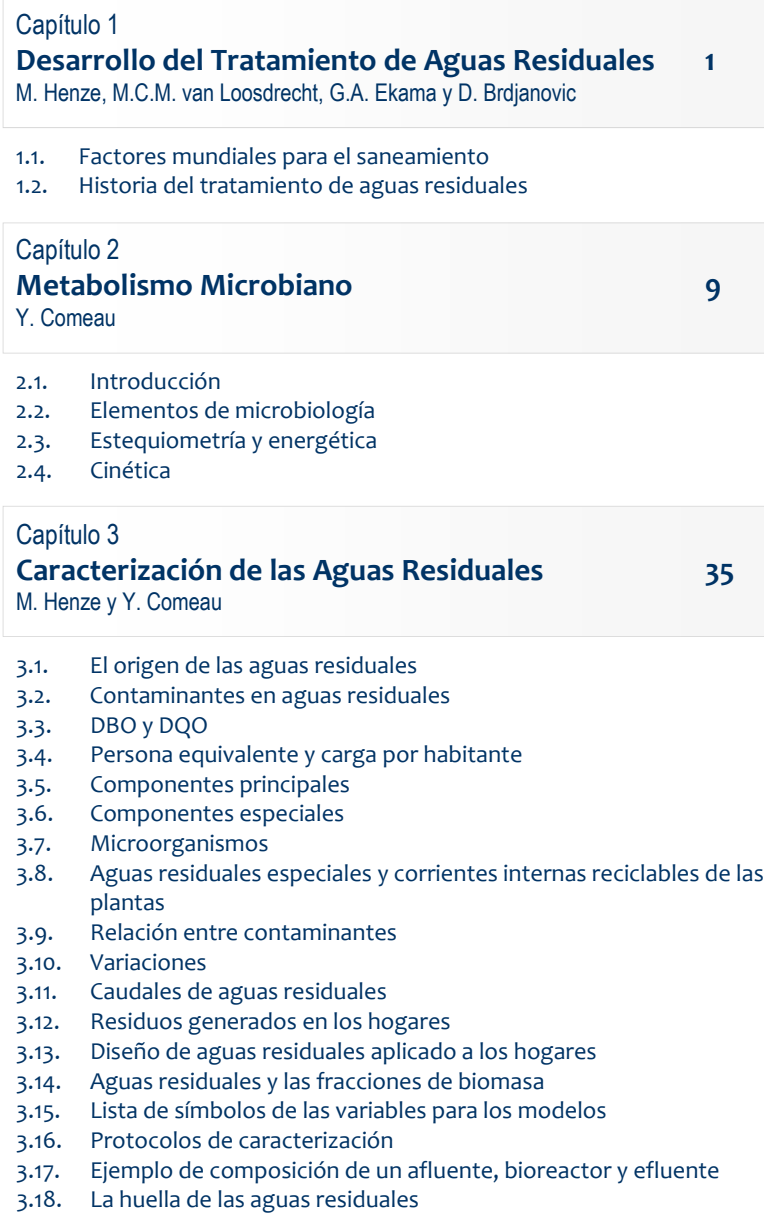

5.6. Consideraciones de diseño

5.7. Ejemplo de diseño de un sistema con nitrificación

5.8. Remoción biológica de nitrógeno mediante desnitrificación heterótrofa

5.9. Desarrollo y demostración del procedimiento de diseño

5.10. Volumen del sistema y demanda de oxígeno

5.11. Diseño operación y control del sistema

\section{Capítulo 6}

Remoción Innovadora de Nitrógeno

M.C.M. van Loosdrecht

6.1. Introducción

6.2. Impacto de los procesos en líneas secundarias

6.3. El ciclo del nitrógeno

6.4. Eliminación de $\mathrm{N}$ mediante nitrito

6.5. Oxidación anaerobia de amonio

6.6. Bio-aumentación

6.7. Conclusiones

\section{Capítulo 7}

Remoción Biológica Aumentada de Fósforo

M.C. Wentzel, Y. Comeau, G.A. Ekama, M.C.M. van Loosdrecht y D. Brdjanovic

7.1. Introducción

7.2. Principios de la remoción biológica aumentada de fósforo (EBPR)

7.3. Mecanismos de los sistemas EBPR

7.4. Optimización y desarrollo de sistemas con EBPR

7.5. Desarrollo de un modelo para sistemas con EBPR

7.6. Modelo de cultivos mixtos en estados estacionario

7.7. Ejemplo de diseño

7.8. Influencia de la EBPR en el sistema

7.9. Factores que afectan la magnitud de la remoción de $P$

7.10. Desnitrificación en sistemas con NDEBPR

7.11. Organismos acumuladores de glucógeno (GAOs)

7.12. Conclusiones y perspectivas

Capítulo 8

Eliminación de Patógenos

C.P. Gerba

8.1. Introducción

8.2. Tipos de patógenos entéricos

8.3. Presencia de agentes patógenos en las aguas residuales

8.4. Eliminación de patógenos e indicadores por proceso de tratamientos de aguas residuales

8.5. Conclusiones

Capítulo 9

Aireación y Mezclado
9.1. La tecnología de aireación

9.2. Sopladores de aire

9.3. Efectos de las condiciones operativas

9.4. Prácticas sustentables de aireación

9.5. Requerimientos de aireación 
Capítulo 10

Toxicidad

J.H.G. Orozco

305

10.1. Introducción

10.2. Determinación de la toxicidad

10.3. Modelos cinéticos para la descripción de substratos tóxicos

10.4. Tratamiento de efluentes con toxicidad

10.5. Observaciones finales

\section{Capítulo 11}

\section{Lodos Filamentosos}

M.C.M. van Loosdrecht, A.M. Martins y G.A. Ekama

11.1. Introducción

11.2. Aspectos históricos

11.3. Relación entre morfología y ecofisiología

11.4. Identificación y caracterización de bacterias filamentosas

11.5. Teorías actuales para explicar la aparición de lodos filamentosos

11.6. Acciones correctivas

11.7. Modelos matemáticos

11.8. Lodo granular

11.9. Conclusiones

\section{Capítulo 12}

\section{Sedimentación Secundaria}

I. Takacs y G.A. Ekama

12.1 Introducción

12.2 Configuraciones de los tanques de sedimentación

12.3 Medición de la sedimentabilidad del lodo

12.4 Teoría del flujo para la estimación de la capacidad de sedimentación del tanque

12.5 Resumen del uso de la teoría de carga de sólidos y otros métodos de diseño y operación

12.6 Modelado de sedimentadores secundarios

12.7 Ejemplos de diseño

\section{Capítulo 13}

Biorreactores de Membrana (MBR)

S. Judd, B. Kim y G. Amy

13.1 Principios de separación/filtración con membrana

13.2 El biorreactor de membrana (MBR)

13.3 Diseño de plantas MBR

13.4 Tecnologías de membrana comerciales

13.5 iMBR casos de estudio

\section{Capítulo 14}

Modelación del Proceso de Lodos Activados

405

M.C.M. van Loosdrecht, G.A. Ekama, M.C. Wentzel, D. Brdjanovic y C.M. Hooijmans

14.1 ¿Qué es un modelo?

14.2 ¿Por qué modelar?

14.3 Fundamentos de modelación

14.4 Desarrollo paso a paso de un modelo biocinético: ASM

$14.5 \mathrm{ASM}_{3}$

14.6 Modelación metabólica

14.7 Historia del desarrollo de los modelos de lodos activados

14.8 Paquetes de simulación

14.9 Conclusiones
Capítulo 15

Control de Procesos

439

G. Olsson

15.1 Motivación

15.2 Perturbaciones en los sistemas de tratamiento de aguas residuales

15.3 El rol del control y la automatización

15.4 Instrumentación y monitoreo

15.5 La importancia de la dinámica del sistema

15.6 Variables y solenoides manipulables

15.7 Conceptos básicos de control

15.8 Ejemplos de control de retroalimentación en sistemas de tratamiento de aguas residuales

15.9 Ahorros de costos de operación debidos al control

15.10 Integración y control de toda la planta

15.11 Observaciones finales

\section{Capítulo 16}

Tratamiento Anaerobio de Aguas Residuales

J.B. van Lier, N. Mahmoud y G. Zeeman

16.1 Sostenibilidad en el tratamiento de aguas residuales

16.2 Microbiología de las conversiones anaerobias

16.3 Predicción de la producción de $\mathrm{CH}_{4}$

16.4 Impacto de aceptores de electrones alternos

16.5 Trabajando con el balance de DQO

16.6 Inmovilización y granulación del lodo

16.7 Reactores anaerobios

16.8 Reactores anaerobios de lecho de lodos de flujo ascendente (UASB)

16.9 Cinética del proceso anaerobio

16.10 Tratamiento anaerobio de agua residual doméstica y municipal

\section{Capítulo 17}

\section{Modelación Matemática de Biopelículas}

E. Morgenroth

17.1 ¿Qué son las biopelículas?

17.2 Motivación para modelar biopelículas y ¿Cómo seleccionar los modelos matemáticos adecuados?

17.3 Enfoque del modelado de una biopelícula, asumiendo que existe un solo sustrato limitante y considerando despreciable la resistencia externa a la transferencia de masa

17.4 Ejemplo de cómo $J_{\mathrm{LF}}=\mathrm{F}\left(\mathrm{C}_{\mathrm{LF}}\right)$ puede ser utilizado para predecir el desempeño del reactor de biopelícula

17.5 Efecto de la resistencia externa a la transferencia de masa

17.6 Relación del crecimiento y decaimiento con el desprendimiento

17.7 Parámetros derivados

17.8 Difusión multi-componente

17.9 Implicaciones de la disponibilidad del sustrato en sustratos limitantes, competencia microbiológica, y desempeño del reactor

17.10 ¿Cómo es que las estructuras en 2D/3D pueden influir en el funcionamiento de la biopelícula?

17.11 Parámetros del modelo

17.12 Herramientas del modelo matemático

Capítulo 18

Reactores de biopelícula

E. Morgenroth

18.1 Reactores de biopelícula

18.2 Parámetros de diseño

18.3 ¿Cómo se pueden determinar los flujos máximos de diseño o las velocidades de carga de diseño?

18.4 Algunas otras consideraciones para el diseño 



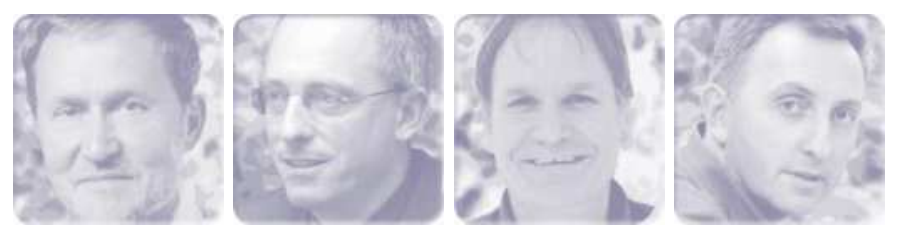

\section{Desarrollo del Tratamiento de Aguas Residuales}

\section{Mogens Henze, Mark C.M. van Loosdrecht, George A. Ekama y Damir Brdjanovic}

\subsection{FACTORES MUNDIALES PARA EL SANEAMIENTO}

El desarrollo del saneamiento fue votado como el avance médico más importante desde hace 166 años en un concurso realizado en el 2007 por el British Medical Journal (Ferriman, 2007). Esto confirma el papel absolutamente importante de contar con servicios de saneamiento adecuados para lograr y mantener una buena salud pública. En muchos países industrializados las aguas residuales son transportadas de forma segura lejos de los complejos habitacionales. Sin embargo, no siempre existen adecuados sistemas de tratamiento, especialmente en países en vías de desarrollo, en donde el saneamiento aún está muy lejos en comparación con el servicio de abastecimiento de agua. La necesidad de un adecuado saneamiento fue establecido en los objetivos del desarrollo del milenio de las Naciones Unidas. El objetivo número 7 impulsa a reducir a la mitad la población que vive sin un adecuado saneamiento. A pesar de los grandes esfuerzos, el cumplimiento de este objetivo avanza lento y aún está muy lejos. La Asamblea General de las Naciones Unidas declaró el 2008 como el Año Internacional del Saneamiento, reconociendo el impacto del saneamiento en la salud pública, la reducción de la pobreza, en el desarrollo económico y social, así como ambiental. El fin fue enfocar la atención mundial en la necesidad de iniciar la implementación de adecuadas soluciones de saneamiento para todos. Lo importante de esto es no sólo conectar a la gente con las soluciones de saneamiento, sino hacer que esta conexión se realice por una vía sustentable. Los sistemas de alcantarilladlo y las plantas de tratamiento de aguas residuales han probado ser eficientes para transportar agua y para eliminar patógenos, contaminantes orgánicos y nutrientes. Sin embargo, estas instalaciones requieren de una operación y mantenimiento apropiados, y un buen entendimiento de los procesos involucrados.

\subsection{HISTORIA DEL TRATAMIENTO DE LAS AGUAS RESIDUALES}

El desarrollo de sistemas tratamiento de aguas residuales se hizo más evidente en el siglo XX. Estos sistemas fueron considerados por mucho tiempo como un riesgo potencial para la salud y molestos en aglomeraciones urbanas. El valor fertilizante de las excretas humanas fue reconocido recientemente. Los antiguos Griegos (300 A.C. a 500 D.C.) utilizaban letrinas públicas que

(C) 2017 Mogens Henze. Tratamiento Biológico de Aguas Residuales: Principios, Modelación y Diseño. Eds. M. Henze, M.C.M. van Loosdrecht, G.A. Ekama y D. Brdjanovic. Eds. (versión en español) C.M. López Vázquez, G. Buitrón Méndez, H.A. García, F.J. Cervantes Carrillo. ISBN (versión impresa): 9781780409139, ISBN (e-Book): 9781780409146. Publicado por IWA Publishing, London, UK. 
drenaban hacia alcantarillas que transportaban las aguas residuales y pluviales hacia un colector en las afueras de la ciudad. De ahí, el agua residual era conducida hacia campos agrícolas por canaletas de ladrillo para ser utilizada en el riego y la fertilización de cultivos y huertas.

Los Romanos tomaron este sistema más adelante. Alrededor de 800 años A.C., ellos construyeron la Cloaca Maxima. Inicialmente este sistema central de alcantarillado fue utilizado para drenar el pantano sobre el cual Roma sería construida. Para el año 100 D.C. el sistema estaba casi terminado, y con conexiones a algunas casas. El agua era transportada por un acueducto desde los baños públicos y letrinas hasta el alcantarillado colocado debajo de la ciudad y finalmente hacia el Tiber. Las calles eran regularmente lavadas con agua del acueducto y el agua generada se conducía hacia las alcantarillas.

Este sistema funcionó muy bien porque contó con un gobierno efectivo y la protección del poder militar, aún para el mantenimiento de los acueductos más lejanos. Cuando el Imperio Romano colapsó, su sistema sanitario también colapsó con él. El periodo comprendido entre los años 450 y 1750 D.C. fue así conocido como la "era de la obscuridad sanitaria" (Wolfe, 1999). Durante este periodo, la principal forma de disposición de residuos fue simplemente su colocación en las calles, frecuentemente vaciando los recipientes desde las ventanas del segundo nivel. Alrededor del año 1800, un sistema colector apareció en muchas ciudades, y fue impulsado por los mismos habitantes que ya no soportaban los malos olores. También fue bien recibido por agricultores, quienes encontraron un buen uso para sus excretas. En Amsterdam, los recipientes con los desechos podrían ser descargados sobre un carro que era conducido por las calles. El carro fue curiosamente llamado como una marca de agua de colonia de la época: el carro Boldoot. Sin embargo, los derrames durante el vaciado y el transporte de los contenedores fueron inevitables, por lo que los malos olores no disminuyeron significativamente. Para entonces, surgieron planes para un sistema general de alcantarillado. Sin embargo, los altos costos de inversión e incertidumbre sobre el lavado y mantenimiento de las alcantarillas hicieron que una pronta implementación de este sistema no fuera posible.

Alrededor del año 1900 Liernur propuso un plan para colectar separadamente las aguas del inodoro, las aguas grises y las aguas pluviales. El agua del inodoro se colectaba a través de un alcantarillado que funcionaba al vacío llamado el sistema Liernur (J.M. van Bemmelen, 1886). Este sistema encontró un uso en distintos pueblos Europeos (Figura 1.1).

En esa época las aguas residuales colectadas no recibían ningún tratamiento. En lugar de esto, eran esparcidas sobre la tierra como un fertilizante. Sin embargo, la saturación de las tierras con este tipo de aguas llegó a ser un problema serio, y la continua expansión de las ciudades hizo más difícil el encontrar tierras disponibles para tal fin. La idea de que se podría dar un mejor uso a los "organismos" gradualmente empezó a surgir (Cooper, 2001).
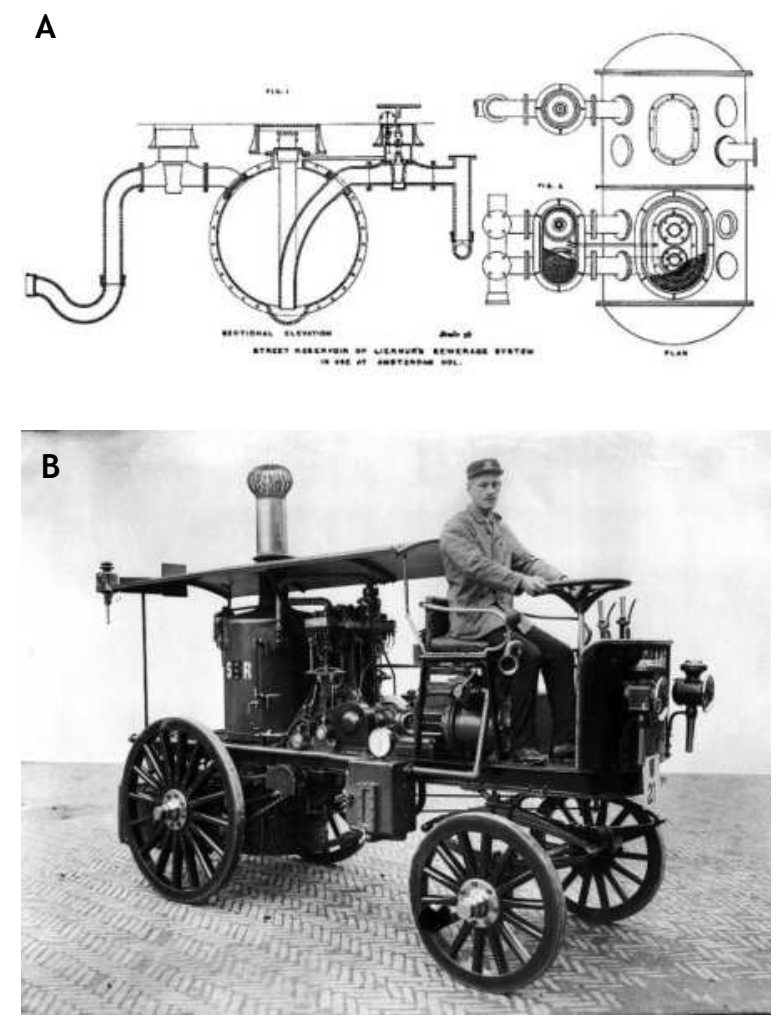

Figura 1.1 Sistema Liernur para la recolección de las aguas del inodoro (A), y el vehículo utilizado para colectar y transportar los residuos (B) (fotos: van Lohuizen, 2006).

En los Estados Unidos de América y el Reino Unido se les dio uso a estos organismos al ser aplicados para limpiar el agua en los llamados filtros biológicos, que eran sistemas con biopelículas sobre rocas provenientes del lecho de ríos. Uno de los primeros filtros biológicos se instaló en 1893 en Salford cerca de Manchester. En los Estados Unidos el primer filtro fue instalado en 1901, en Madison, Wisconsin. Entre 1895 y 1920, se instalaron muchos para tratar aguas residuales de las ciudades y pueblos en el Reino Unido. Este rápido crecimiento frenó en el Reino Unido la implementación del proceso por 
lodos activados, que fuera inventado en 1913, debido a la importante inversión que ya se había realizado en los biofiltros.

El proceso de lodos activados fue descubierto en el Reino Unido, a raíz de experimentos llevados a cabo para el tratamiento de agua en un reactor de llenado y vaciado (el precursor del actual reactor discontinuo secuencial) que produjo un efluente altamente tratado. Creyendo que el lodo había sido activado, al igual que el carbón activado, el proceso fue llamado "lodos activados" (Ardern y Lockett, 1914).

Durante la primera mitad del siglo $\mathrm{XX}$, los ríos sobre los cuales eran descargadas las aguas residuales eran considerados como parte integral del proceso de tratamiento. La razón por la cual se requieren cinco días para la determinación de la demanda bioquímica de oxígeno (DBO) se debe a que este era el tiempo máximo requerido en los ríos del Reino Unido, antes de llegar al mar. En el libro "Stream Sanitation” de Phelps (1944), se utilizan modelos matemáticos para calcular la carga orgánica máxima a partir de la curva de oxígeno, a fin de prevenir que la concentración de oxígeno disuelto disminuya por debajo del valor mínimo en relación con la descarga de aguas residuales. Con el rápido crecimiento de las ciudades fue muy evidente que los ríos no podrían ser capaces de soportar mayores cargas orgánicas. Como respuesta, se incrementaron los requisitos para el tratamiento de aguas residuales para alcanzar mejores eficiencias de eliminación de materia orgánica. Para reducir la demanda de oxígeno en los ríos, así como para eliminar los efectos nocivos del amonio, fue introducida la nitrificación. Esto propició que en Estados Unidos, Europa y Sudáfrica se construyeran algunas plantas con filtros percoladores de baja carga para eliminar materia orgánica y amonio. La digestión anaerobia fue usualmente incluida en estas plantas para tratar el lodo primario y el producido en el filtro percolador. Se pensaba que la descarga de nitrato generada en este tipo de filtros era buena porque impedía la generación de condiciones anaerobias en ríos y lagos. Sin embargo, la nitrificación en los filtros percoladores no siempre es buena (especialmente en el invierno), debido a la necesidad de eliminar altas cargas orgánicas antes que la eliminación del nitrógeno.

En la segunda mitad del siglo XX se presentó un nuevo problema en las aguas superficiales, la eutrofización. La eutrofización se origina por el rápido crecimiento de algas y otras plantas acuáticas debido a la presencia del efecto fertilizante del nitrógeno y fósforo descargado en los ríos. En la década de los años 60 ya era muy evidente que el nitrógeno y fósforo debían ser eliminados de las aguas residuales para prevenir la eutrofización. Esto motivó importantes programas de investigación, así, se introdujeron los conocimientos de bacteriología y bioenergética al tratamiento de aguas residuales. Al aplicar el modelo cinético de Monod (1949) utilizado en bacteriología, Downing et al. (1964) mostraron que la nitrificación dependía de la velocidad máxima de crecimiento específico de los microorganismos autotróficos nitrificantes, la cual es lenta en comparación con la de organismos heterotróficos. Para una planta a escala, esto significa que la edad del lodo debe ser lo suficientemente grande para alcanzar de manera consistente bajas concentraciones de amonio en el efluente. De esta forma se logró el uso del modelo cinético de Monod en el tratamiento de aguas residuales, y actualmente sigue siendo utilizado en todos los modelos de simulación del tratamiento biológico de aguas residuales. A partir de los estudios de bioenergía que fueron desarrollados de manera muy avanzada por McCarty (1964), se comprendió que el nitrato producido por nitrificación puede ser utilizado por algunas bacterias heterotróficas en lugar del oxígeno y convertirlo en gas nitrógeno. Este conocimiento permitió que se dispusiera de una sección, en el sistema de lodos activados, que no fuera aireada para inducir la desnitrificación. Con todo este nuevo conocimiento puesto exitosamente en práctica, el proceso con biomasa suspendida de lodos activados llegó a ser el sistema de tratamiento mayormente preferido. El sistema post-desnitrificación, en donde un reactor no aireado (anóxico) le sigue a un reactor aerobio, fue desarrollado en Suiza por Wurhmann (1964). Para aumentar la velocidad desnitrificante en el reactor anóxico, se utilizaron dosis de metanol como fuente de materia orgánica para ayudar al proceso. Debido a los bajos valores de nitrógeno alcanzados en el efluente con este método, su uso fue ampliamente adoptado en Estados Unidos. Sin embargo, la adición de metanol representa un costo, además que es contradictorio agregar materia orgánica al agua residual después de haberla primeramente eliminado. El sistema pre-desnitrificante desarrollado por Ludzack y Ettinger (1962) generó en consecuencia un paso lógico. En Sudáfrica, Barnard (1972) combinó la pre- y postdesnitrificación e introdujo flujos de recirculación para controlar la entrada de nitrato en el reactor predesnitrificante en el sistema de cuatro etapas llamado Bardenpho. Con este desarrollo, el proceso de lodos activados con eliminación de nitrógeno vino a ser cada vez más común. 
Una línea diferente de desarrollo fue iniciada por Pasveer (1959), basada en los estudios de Ardern y Lockett (Figura 1.2). Ellos originalmente diseñaron un proceso de llenado y vaciado. El proceso de fosas desarrollado se basó en utilizar sólo una unidad de tratamiento. No había sedimentador primario, secundario, ni digestor. En el proceso de llenado y vaciado con alimentación en continuo, ocurría de manera simultánea la nitrificación y desnitrificación. Su simplicidad y bajo costo permitieron su uso ampliamente. Más allá del sistema de fosas de Pasveer, los sistemas de fosas de oxidación operados en continuo evolucionaron, fueron basados en el mismo principio pero con un clarificador separado.

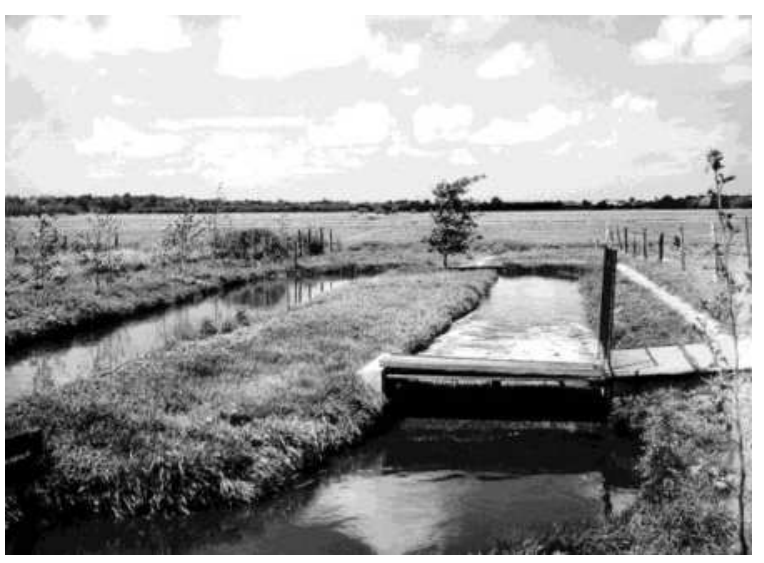

Figura 1.2 Primera aplicación del sistema de fosas de Pasveer a nivel de planta piloto (1954 Voorschoten, Holanda). La capacidad de la planta fue de 400 P.E. y $40 \mathrm{~m}^{3} / \mathrm{h}$ en época de secas (foto: van Lohuizen, 2006)

Para controlar la eutrofización no es suficiente que sólo se elimine el nitrógeno. El fósforo, principalmente en la forma de ortofosfato contenido en detergentes y residuos humanos, también requiere ser eliminado porque en muchos ecosistemas este elemento es el principal causante de la eutrofización. A diferencia del nitrógeno, el fósforo sólo puede ser eliminado al pasarlo de su fase líquida a la fase sólida. La eliminación de fósforo por precipitación química seguida a una filtración terciaria apareció durante los años 1970. En regiones donde el agua es escasa, como en los estados del suroeste de Estados Unidos, Sudáfrica y Australia, el reúso indirecto de aguas superficiales es alto y la eliminación química de fosfato causaría un rápido incremento en la salinidad de aguas superficiales. Además del hecho de que la salinidad impide el uso agrícola de las aguas tratadas, tiene un impacto importante en la duración del sistema de distribución de agua. Con objeto de mitigar estos impactos se emitieron políticas en Sudáfrica, a finales de la década de los años 1960 y principios de la década de los años 1970, que fueron encaminadas a la completa recuperación de las aguas residuales para redistribución y mitigar tanto la eutrofización como la salinización de las aguas superficiales. Si se iba a incurrir en altos costos por la remoción química del fosfato, entonces el agua debería ser completamente recuperada para reúso y ser regresada al sistema de distribución, en lugar de regresarla al ambiente. (Bolitho, 1975; van Vuuren et al., 1975).

La eliminación biológica de fosfato es el único proceso que ha sido descubierto por accidente. La primera evidencia de la eliminación biológica de fosfato ocurrió en la India en un proceso de tratamiento de aguas residuales descrito por Srinath et al., (1959). Ellos observaron que el lodo proveniente de ciertas plantas de tratamiento mostraba un excesivo consumo de fosfato (más de lo requerido para el crecimiento celular) cuando se aireaba. Con esto se demostró que el consumo de fosfato estaba ligado a un proceso biológico (inhibición por sustancias tóxicas, requerimiento de oxígeno). Más tarde, este proceso fue llamado eliminación biológica mejorada de fosfato (EBPR), y fue observado en otras plantas de tratamiento de aguas residuales. El primer proceso diseñado (el proceso PhoStrip ${ }^{\circledR}$ ) para la eliminación biológica de fosfato surgió a pesar de que el mecanismo que sustenta el proceso era desconocido (Levin y Shapiro, 1965). A principios de la década de los años 1970, debido a un aumento en la demanda de la eliminación de nitrato, así como por el ahorro de energía (por la crisis energética de los años 70) en muchos sitios en el mundo, se descubrió que la eliminación biológica de fosfato podría ser fácilmente estimulada. Por ejemplo, en 1974 al optimizar la eliminación de nitrógeno en la planta de lodos activados de Alexandria mediante el apagado de aireadores al final del afluente, Nicholls (1975) observó bajas concentraciones de fósforo (y nitrato) en el efluente. Encontró concentraciones muy altas de fosfato en la cama de lodos que había sedimentado al fondo del reactor y en la cual el afluente había descendido debido a una mayor densidad que la del sobrenadante tratado. Barnard (1976) desarrolló el principio Phoredox para la eliminación biológica de un exceso de fosfato, e introdujo ciclos anaerobios y aerobios en el sistema de lodos activados. La EBPR es ahora una tecnología bien establecida que abrió la oportunidad para la eliminación y recuperación de fosfato $\sin$ el incremento de salinidad, y con la posibilidad de retornar el agua tratada al ambiente o bien reutilizarla eficientemente. Como ocurre a menudo, los nuevos desarrollos son encontrados accidentalmente y el entendimiento de cómo funcionan viene después. Para 
entender y controlar el proceso por completo, se tomaron varios años de investigación en Sudáfrica, Canadá y Europa, y hoy en día aún existen algunos puntos que no son claros. Sin embargo, a pesar de no entender por completo los principios, los ingenieros y científicos nunca se han detenido en la construcción y operación de plantas de tratamiento de aguas residuales.

La crisis energética de la década de los años 70 , asociada con el incremento en la demanda del tratamiento de aguas residuales industriales, hicieron que la atención sobre los procesos aerobios cambiara hacia los procesos anaerobios. El lento crecimiento de las bacterias metanogénicas siempre ha sido una limitante para el desarrollo de este tipo de procesos. Para las aguas residuales industriales muy concentradas y calientes esto no resultaba un problema; además, los reactores anaerobios de flujo ascendente (UASB) desarrollados por Lettinga et al., (1980) significaron un avance en el tratamiento anaerobio. Esta tecnología no sólo es adecuada para el tratamiento de aguas residuales industriales, sino también para el tratamiento de aguas residuales de baja carga orgánica como las municipales, ya que puede ser eficientemente introducido en regiones tropicales de Sudamérica, África y Asia.

Después de un siglo de construir plantas de tratamiento de aguas residuales, muchas plantas que inicialmente fueron construidas en la afueras de áreas urbanas, hoy en día se encuentran dentro de áreas residenciales. Las grandes plantas de tratamiento llegaron a ser un problema y por esto los ingenieros empezaron a buscar opciones más compactas para el tratamiento. Además, la industria empezó a tratar sus propias aguas residuales, y para éstas, el uso del terreno es más crítico que para las municipalidades. Una línea exitosa de desarrollo fue volver a los reactores percoladores a base de biopelículas. A partir de aquí, un gran número de sistemas fueron desarrollados (filtros biológicos aireados, reactores con lecho fluidizado, reactores con biomasa suspendida, biodiscos, procesos de lodo granular o reactores de lecho móvil) para superar los problemas originales de los filtros percoladores. El desarrollo de estos reactores se originó en la década de los años 1970. Otro desarrollo iniciado en este periodo llegó a ser ampliamente introducido en la última década: el proceso de lodos activados con separación de la biomasa por membrana en lugar de sedimentadores.

Las demandas de mejores efluentes fueron cada vez mayores, forzando a mejorar las plantas de tratamiento ya existentes en lugar de construir nuevas. En el último siglo, esto ha permitido el desarrollo de nuevos procesos para ser integrados a los ya existentes en las plantas de tratamiento. Uno de los problemas abordados por estos procesos son los niveles altos de nitrógeno y fosfato liberados durante la digestión anaerobia de residuos de los lodos activados, que fueron comúnmente reciclados al proceso de lodos activados. Además de los problemas por precipitación de estruvita, esto también origina una alta recirculación de nutrientes y altas concentraciones de nitrógeno y fosfato del proceso de lodos activados cuando el licor drenado es reciclado hacia el afluente. Investigaciones en relación a esta problemática permitieron algunas innovaciones al tratamiento del licor drenado. En Holanda, fueron desarrollados distintas tecnologías como el proceso de remoción de amonio con actividad elevada vía nitrito en un sólo tanque $\left(\mathrm{SHARON}^{\circledR}\right)$, la oxidación anaerobia de amonio (ANAMMOX) y el incremento de la biomasa nitrificante $\left(\mathrm{BABE}^{\circledR}\right)$, que son procesos que mejoraron la eliminación de nitrógeno; y la cristalización de fósforo para la recuperación y reúso de este mineral.

Un aspecto que siempre ha sido importante en la operación de una planta de tratamiento de aguas residuales es su control. Esto incluye el control directo de procesos así como el control indirecto, por ejemplo la sedimentación del lodo o el crecimiento de biopelículas. El control del proceso ha sido un factor limitante desde el inicio. Ardern y Lokett así como Pasverr, trataron de minimizar costos mediante la aplicación de ciclos de llenado y vaciado donde la sedimentación se lleva a cabo en la planta de tratamiento. Esto requirió la automatización del proceso. La falta de controladores confiables en aquellos tiempos fue la razón principal que limitó el uso y la aplicación de los procesos en continuo y a gran escala. Sólo durante las últimas décadas los procesos de control han sido lo suficientemente confiables, y el uso de los reactores en lote (SBR o reactores discontinuos secuenciales) está incrementándose nuevamente. La demanda de mejores efluentes, asociada con la demanda de proteger los recursos y con la creciente complejidad de las plantas de tratamiento, también forzó la necesidad de incrementar los procesos de control para la adición de químicos, control de la aireación, y recirculación de flujos. Aunque los modelos matemáticos ya habían sido desarrollados en los primeros días de los procesos del tratamiento de aguas residuales, estos sólo llegaron a ser ampliamente usados con la introducción de computadoras personales de bajo costo y la presentación de un modelo unificado de lodos activados (Henze et al., 1987). 
El control indirecto de las propiedades del lodo también ha sido un punto problemático. El lodo filamentoso y la espuma causada por grupos específicos de bacterias han sido también importantes. El control de bacterias filamentosas mediante la aplicación de sistemas selectores (Chudoba, 1973) ha sido exitoso en muchos casos. Sin embargo, el organismo filamentoso Microthrix parvicella continua causando ciertos problemas en los procesos de eliminación de nutrientes. A pesar de la importante investigación, que ciertamente ha ayudado a obtener un mejor entendimiento de las causas y control del esponjamiento del lodo o bulking causado por bacterias filamentosas, aún no se entiende claramente cuando la sedimentación del lodo es cuantitativamente predecible para los diferentes sistemas de lodos activados. Esto significa que los tanques de sedimentación secundaria deben ser construidos más grandes a fin de almacenar lodos durante periodos de baja sedimentación. En años recientes el entendimiento de la morfología de biopelículas y del lodo suspendido ha aumentado significativamente, lo que ha llevado al desarrollo de nuevos sistemas. Uno de los avances generados es la introducción de sistemas de lodo granular aerobio y que puede ser visto como lo opuesto al lodo filamentoso o como una forma específica de un proceso de biopelícula (Beun et al., 1999).

Otra preocupación importante es la desinfección del agua y el lodo, así como la disposición final del lodo en una forma ambientalmente sustentable. La construcción de plantas de tratamiento de aguas residuales y sistemas de alcantarillado inició hace 150 años justamente por la presencia de organismos patógenos. Esto fue más o menos olvidado hasta mediados del siglo XX cuando la desinfección de los efluentes fue introducida. Esto se originó en parte por causa de los compuestos carcinogénicos generados durante la cloración de las aguas residuales. Últimamente, en algunas áreas de desinfección el uso de filtros, luz UV y la ozonización se han convertido en un tema importante otra vez. Con los avances de recuperación y manejo más específico de los procesos de tratamiento de aguas residuales, los procesos de desinfección han captado la atención últimamente. La disposición final del lodo fue inicialmente considerada como un asunto de salud debido al riesgo de dispersión de organismos patógenos. Actualmente, la disposición de lodos en terrenos agrícolas está siendo más y más limitada (al igual que las normas de seguridad alimentaria tienden a aumentar), y el manejo del lodo es cada vez más importante. Ante todo y para minimizar los problemas, el secado de los lodos viene ser un aspecto importante de investigación. Cuando el secado es realizado eficientemente, la incineración del lodo puede ser utilizada como un medio para obtener la energía contenida en el lodo.

La demanda de sistemas de tratamiento de aguas residuales aumenta continuamente, hoy en día la atención se centra en los microcontaminantes que tienen el potencial de causar efectos como disruptores o alteradores endocrinos y pueden acumularse en el ciclo del agua o afectar los ecosistemas. La falta de agua permitirá más adelante el desarrollo y la implementación de tecnologías para el tratamiento y reúso del agua, por ejemplo en Namibia, Singapur y California. El reúso del agua no se limita sólo a regiones con escasez de la misma. En áreas con agua abundante como en el oeste de Europa, las regulaciones y demandas locales pueden hacer que sea económicamente rentable en la industria el uso de efluentes de aguas residuales en lugar de agua dulce. Todos estos desarrollos toman tiempo y después de más de un siglo de desarrollarse por separado, el tratamiento de aguas residuales y la producción de agua potable, están creciendo juntos.

Finalmente, pero no menos importante, un serio problema es la capacitación y educación de una nueva generación de ingenieros y científicos para diseñar nuevas plantas de tratamiento y/o modernizar las ya existentes; así como de técnicos que las operen a fin de utilizar el potencial de las tecnologías y procesos hasta hoy encontrados. Esto es particularmente necesario en los países en desarrollo, en donde la inestabilidad económica y política ven como una pérdida el establecimiento de plantas de tratamiento de aguas. Con el desarrollo de las tecnologías durante los últimos 30 años, el dominio de la profesión no sólo se enfoca en ingeniería civil sino a otros procesos y aspectos basados en microbiología. En muchas universidades se establecieron programas académicos en ingeniería ambiental para enlazar ambas disciplinas. Actualmente, todos estos procesos y tecnologías están entrelazados para crear sistemas complejos de tratamientos en donde el uso de modelos es necesario para manejar la complejidad de los sistemas. Así, hoy en día tenemos una complejidad de tratamientos de aguas residuales como nunca antes se había visto. Esto puede llegar a ser confuso, y el intento de muchas compañías por comercializar sus propios procesos amplia esta confusión. Todos los procesos y tecnologías cuentan con los mismos procesos básicos, y como se ha dicho: "las bacterias no tienen idea de la forma del reactor $o$ del nombre de la tecnología, ellas simplemente llevan a cabo la desnitrificación si hay nitrato, una fuente de carbono y ausencia de oxígeno". 


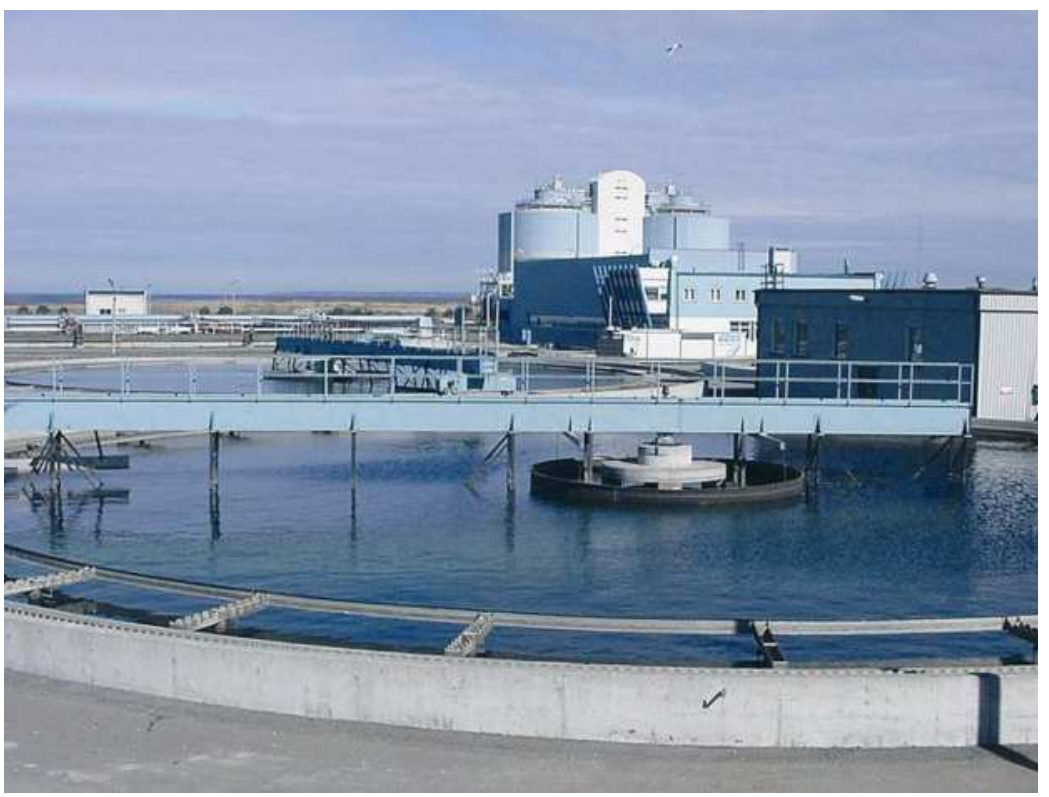

Planta moderna de tratamiento de aguas residuales diseñada para eliminar materia orgánica (DQO), nitrógeno (N) y fósforo $(\mathrm{P})$, localizada en la ciudad de Tallin, Estonia (foto: D. Brdjanovic) 


\section{REFERENCIAS}

Ardern E. and Lockett W.T. (1914) Experiments on the oxidation of sewage without the aid of filters. J. Soc Chem Ind., 33, 523.

Barnard J.L. (1973) Biological denitrification. Water Pollut. Control, 72, 705-720.

Barnard J.L. (1976) A review of biological phosphorus removal in the activated sludge process. Water $S A$ 2(3), 136-144.

Beun J.J., Hendriks A, van Loosdrecht M.C.M., Morgenroth M, Wilderer P.A., Heijnen J.J. (1999). Aerobic granulation in a sequencing batch reactor. Water Res 33(10), 2283-2290.

Bolitho V.N. (1975) Economic aspects of wastewater treatment in South Africa. Water SA, 1(3) 118-120.

Chudoba J., Grau P., Ottova V. (1973) Control of activated sludge filamentous bulking. II. Selection of microorganisms by means of a selector. Water Research, 7(10), 1389-1406.

Cooper P.F. (2001) Historical aspects of wastewater treatment. In Decentralized sanitation and reuse: concepts, systems and Implementation. Edited by Lens P., Zeeman G. and Lettinga G., IWA Publishing, London (UK), 11-38.

Downing A.L., Painter H.A. and Knowles G. (1964) Nitrification in the activated sludge process. J. Proc. Inst. Sewage Purif., 64(2) 130-158.

Ferriman A. BMJ readers choose the "sanitary revolution" as greatest medical advance since 1840 (2007) BMJ, 334 (111), doi:10.1136/bmj.39097.611806.DB

Henze M., Grady C.P.L.jr., Gujer W., Marais G.V.R., Matsuo T. (1987) Activated Sludge Model No. 1, IAWPRC Scientific and Technical Report No. 1. London, UK

Lettinga G., Van Velsen A.F.M., Hobma S.W., De Zeeuw, W. and Klapwijk A. (1980) Use of the upflow sludge blanket (USB) reactor concept for biological wastewater

\section{AGRADECIMIENTOS}

Los autores agradecen la contribución de Mariska Ronteltap en la parte introductoria de este capítulo. treatment, especially for anaerobic treatment. Biotechnol. Bioeng. 22, 699-734.

Levin G.V., Shapiro J. (1965) Metabolic uptake of phosphorus by wastewater organisms $J$ Water Pollut Control Fed, 37, 800-821

Ludzack F.J. and Ettinger M.B. (1962) Controlling operation to minimize activated sludge effluent nitrogen. J Wat Pollut. Control Fed., 34,920-931.

McCarty P.L. (1964). Thermodynamics of biological synthesis and growth. Procs. $2^{\text {nd }}$ Intnl Conf on Water Pollution Control., 2, 169-199.

Monod J. (1950) Technique of continuous culture - theory and application. Ann. Inst. Pasteur. 79, 167.

Nicholls H.A. (1975) Full scale experimentation on the new Johannesburg extended aeration plants. Water SA 1(3), 121-132.

Pasveer A. (1959) A contribution to the development in activated sludge treatment. J. Proc. Inst. Sew. Purif. 4, 436.

Phelps E,B, (1944) Stream Sanitation. John Wiley and Sons Inc., New York.

Srinath E.G., Sastry, C.A., Pillai, S.C. Rapid removal of phosphorus from sewage by activated sludge (1959) Experientia, 15(9), 339-340.

Van Bemmelen J.M. (1868) Het stelsel Liernur - Voor den afvoer der faecale stoffen in de steden, De Economist 17(1), 401-440.

Van Vuuren L.R.J. (1975) Water reclamation - quality targets and economic considerations. Water SA 1(3) 133-143.

Wuhrmann K. (1964) Hauptwirkugen und Wechselwirkugen einiger Betriebsparameter Belebtschlammsystem: Ergibnisse mehrjäriger grossversuche. Schweigerische Zeitschrift für hydrologie, XXVI(2) 218. 


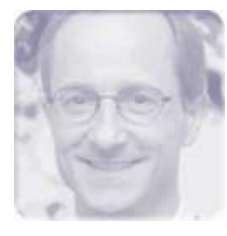

\section{Metabolismo Microbiano}

\section{Yves Comeau}

\section{$2.1 \quad$ INTRODUCCIÓN}

Las aguas residuales se originan en los hogares, instituciones, oficinas e industrias, y pueden ser diluidas con agua de lluvia, aguas subterráneas y aguas superficiales. No tratar las aguas residuales antes de su descarga en los cuerpos receptores tiene como consecuencia efectos dañinos sobre la salud humana y el ambiente, como la generación de olores, el agotamiento del oxígeno disuelto y la liberación de nutrientes, contaminantes tóxicos y patógenos.

Si bien la eliminación de la fuente de contaminación debe ser promovida, el tratamiento de aguas residuales mediante procesos físicos, químicos o biológicos es necesario para reducir al mínimo los impactos potenciales de las descargas de aguas residuales y para favorecer la recuperación de productos finales valiosos, tales como el agua misma, nutrientes y biosólidos. El tratamiento de las aguas residuales se puede lograr mediante la combinación de una variedad de procesos físicos (por ejemplo, cribado, sedimentación, filtración), químicos (como la coagulación y oxidación), térmicos (por ejemplo, secado, incineración) y biológicos (en sistemas de biomasa suspendida o fija).
El tratamiento biológico de las aguas residuales, el enfoque central de este libro, tiene como objetivo degradar o absorber la materia disuelta, coloidal o sedimentable en flóculos biológicos o biopelículas, y los compuestos solubles que incluyen la materia orgánica biodegradable o no biodegradable (algunos de los cuales pueden ser tóxicos) y nutrientes, incluyendo los macronutrientes nitrógeno y fósforo.

El tratamiento biológico de las aguas residuales se basa en la función natural de las bacterias para cerrar los ciclos elementales (por ejemplo, de C, N y P) en la tierra. En una planta de tratamiento de aguas residuales se utilizan las bacterias que naturalmente proliferan en el medio ambiente. Mediante la ingeniería del sistema, los requerimientos naturales para alcanzar la bioconversión, como la aireación y la cantidad necesaria de biomasa, pueden ser satisfechos. Además, el diseño de los procesos biológicos se basa en la creación y explotación de nichos ecológicos para seleccionar microorganismos mejores adaptados que puedan reproducirse bajo esas condiciones ambientales. La presión selectiva puede surgir a partir 
de la disponibilidad de un donador de electrones (generalmente materia orgánica), un aceptor de electrones (tales como oxígeno o nitrato), nutrientes, $\mathrm{pH}$, temperatura, hidrodinámica (arrastre de microorganismos no adheridos), entre otros factores.

En este capítulo, se presentan conceptos básicos de microbiología para comprender mejor las necesidades y funciones de los microorganismos, incluyendo la estequiometría, energética y cinética del crecimiento microbiano.

\subsection{ELEMENTOS DE MICROBIOLOGIA}

Teniendo en cuenta el papel dominante de las bacterias en el tratamiento de aguas residuales, se presentará primero su relación con otros organismos vivos, seguido de su estructura celular y sus componentes, funciones, requerimientos nutricionales, fuentes de carbono y energía, y la sensibilidad a las condiciones ambientales.

\subsubsection{Clasificación de los Microrganismos}

Hay dos tipos de organismos, procariotas y eucariotas (Figura 2.1). Los procariotas son en su mayoría organismos unicelulares que incluyen a las bacterias, cianobacterias (algas verde-azules) y arqueas (algunas se encuentran en ambientes extremos), mientras que los eucariotas son organismos unicelulares (protozoos, algas, hongos) y seres pluricelulares (hongos, plantas, animales). Información genética obtenida recientemente ha permitido agrupar los organismos de acuerdo con su origen evolutivo común.

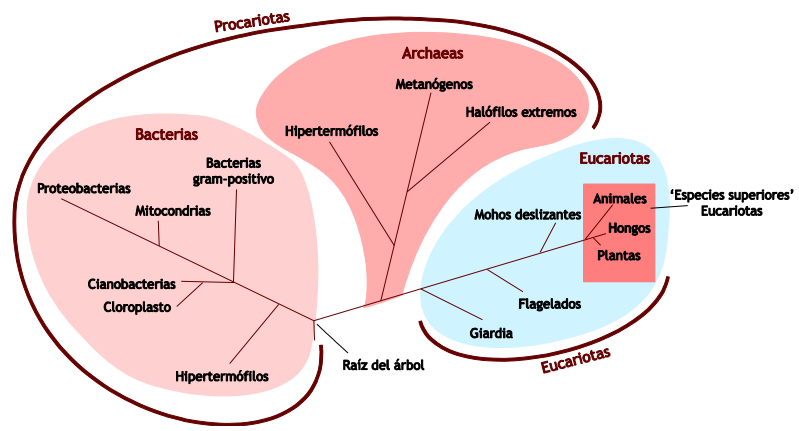

Figura 2.1 Árbol filogenético de la vida (adaptado de Madigan y Martinko; 2006)

Los organismos que se encuentran en las aguas residuales y plantas de tratamiento incluyen principalmente a microorganismos (virus, bacterias, protozoos) y algunos organismos superiores (algas, plantas, animales). La morfología de los diversos grupos de microorganismos que se encuentran en las aguas residuales y se pueden observar por microscopía se muestra de las Figuras 2.2 a 2.5.

Cocos

Estreptococos

Estafilococos

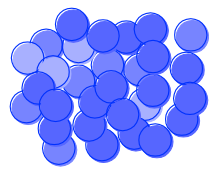

Sarcina (agrupamiento de ocho)

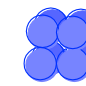

Bacilos

Cadenas de Bacilos

Espirilos

Figura 2.2 Morfología de las bacterias (adaptado de Rittmann y McCarty, 2001)

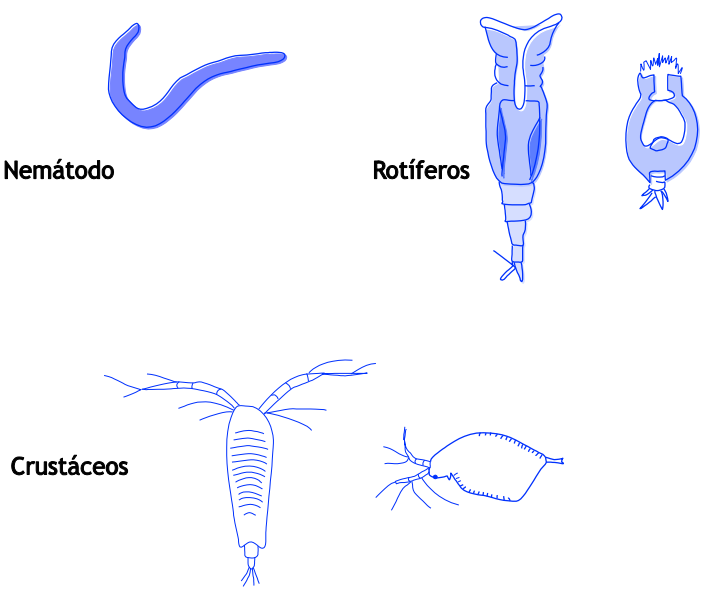

Figura 2.3 Morfología de los protozoos (adaptado de Rittmann y McCarty, 2001) 

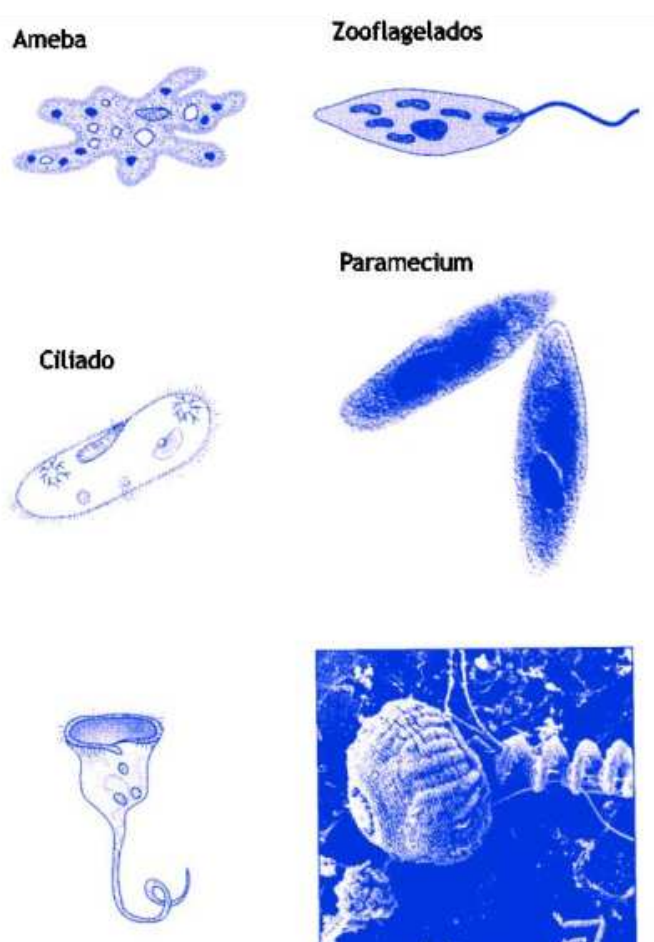

Vorticella
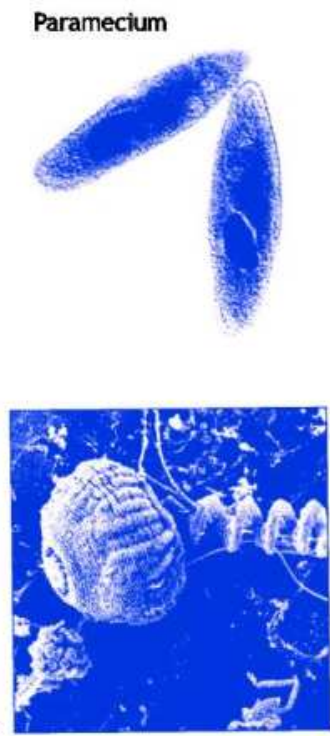

Figura 2.4 Morfología de los microorganismos multicelulares (adaptado de Rittmann y McCarty, 2001)

Los microorganismos son los catalizadores del tratamiento biológico de aguas residuales, siendo una parte muy pequeña pero importante de ellos, patógenos para los seres humanos. Los patógenos de las aguas residuales se encuentran en cada clase de microorganismos, entre los virus (por ejemplo, el virus de la hepatitis A), las bacterias (por ejemplo, Vibrio cholerae, causante del cólera), protozoos (por ejemplo, Giardia lamblia, causante de giardiasis) e incluso animales, tales como los helmintos (por ejemplo, Taenia saginata causa teniasis). Una descripción concisa de los microorganismos patógenos se puede encontrar en el Capítulo 8.

\subsubsection{Estructura de la célula y componentes}

La estructura de los organismos procariotas y eucariotas se presenta en la Figura 2.6.

Una diferencia esencial es que en los procariotas el material genético (ácido desoxirribonucleico, ADN) se encuentra como un nucleoide y en las eucariotas (palabra griega que significa núcleo) dentro de un

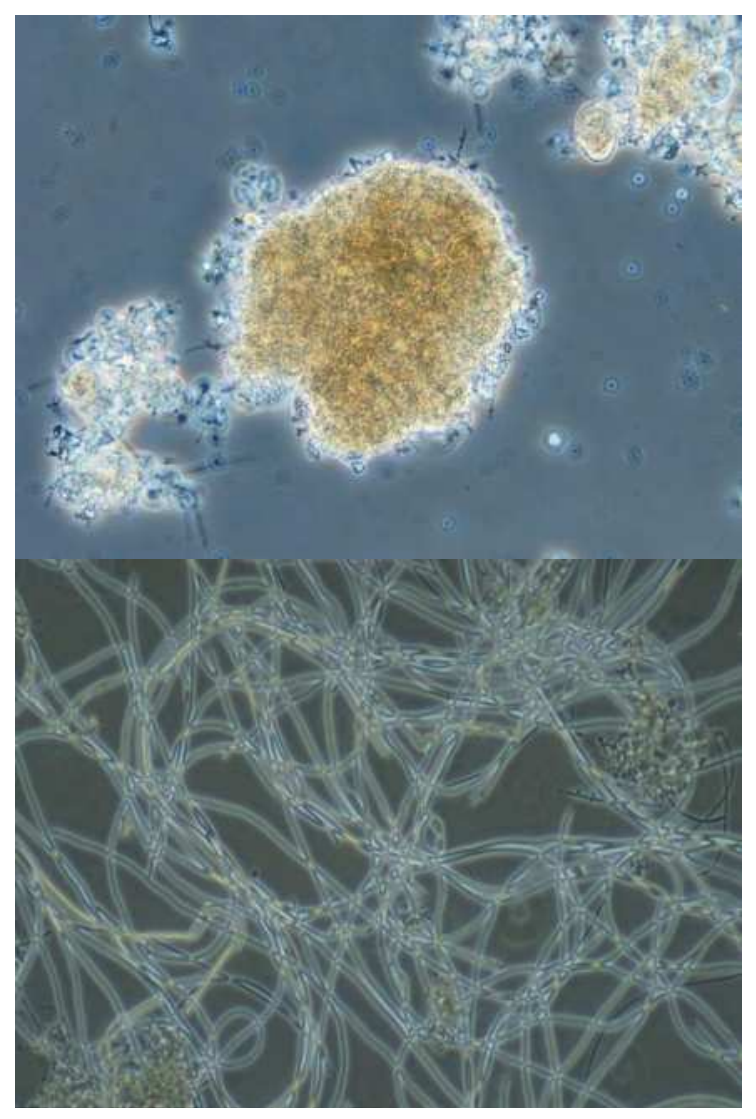

Figura 2.5 Flóculos de lodo activado con buenas propiedades de sedimentación (A) y con excesivo crecimiento filamentoso (B) (fotos: D. Brdjanovic; Eikelboom, 2000; respectivamente)

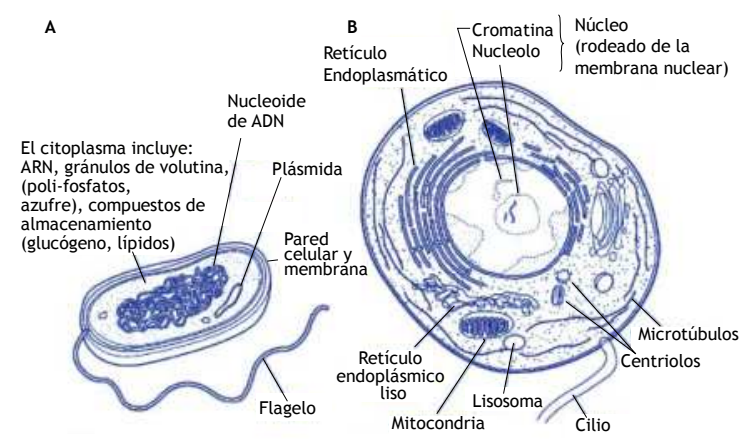

Figura 2.6 Estructura de células (A) procariota $(0,5$ a 5 micrómetros) y (B) eucariotas (5 a 100 micras) (adaptado de Metcalf \& Eddy, 2003)

núcleo rodeado por una membrana. También pueden contener ADN extra como plásmidos de cadena más corta. La energía, en los eucariotas, se genera principalmente en la mitocondria. En los procariotas, la 
membrana citoplasmática que rodea el fluido celular (o citoplasma) separa el medio intracelular y el extracelular limitando el paso de componentes disueltos creando un gradiente tanto de $\mathrm{pH}$ (con más $\mathrm{H}$ + afuera) como de carga (con más cargas positivas afuera) que se utiliza como un mecanismo para generar energía y para el transporte de metabolitos. Internamente, las células tienen una composición relativamente constante.

Las macromoléculas bacterianas incluyen proteínas, ácidos nucleicos (ADN y ARN: ácidos ribonucleicos), polisacáridos y lípidos distribuidos en varios sitios de las bacterias (Figura 2.7).

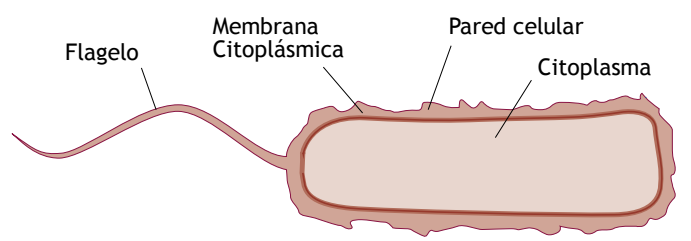

A Proteínas

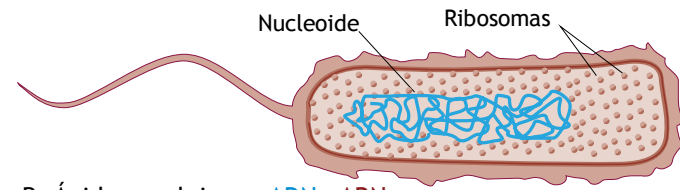

B Ácidos nucleicos: ADN ARN

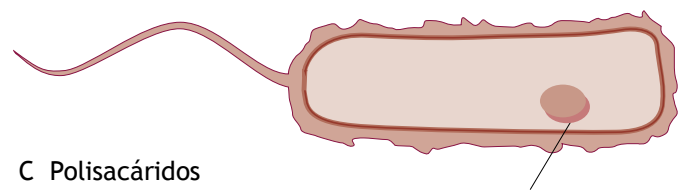

Gránulos de almacenamiento

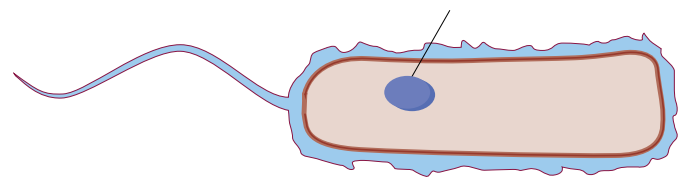

D Lípidos

Figura 2.7 Macromoléculas bacterianas y su ubicación en la célula. (A) Las proteínas se encuentran en el flagelo, la membrana citoplasmática, la pared celular y el citoplasma; (B) ácidos nucleicos (ADN y ARN) se encuentran en el nucleoide y ribosomas; (C) los polisacáridos se encuentran en la pared celular y a veces en gránulos de almacenamiento y (D) los lípidos se encuentran en la membrana citoplasmática, la pared celular y en los gránulos de almacenamiento (adaptado de Madigan y Martinko, 2006)
Los compuestos de polímeros bacterianos de importancia en el tratamiento de las aguas residuales incluyen a los poli- $\beta$-hidroxialcanoatos (PHAs), glucógeno y polifosfatos (Figuras 2.8 a 2.10). Estos compuestos desempeñan un papel como reservas de energía, así como de carbono orgánico (PHA, glucógeno) y de fósforo (polifosfatos).<smiles>[CH2-]C(C)OC(=O)CC(C)(C)OC(=O)CC(C)OC(=O)CC</smiles>

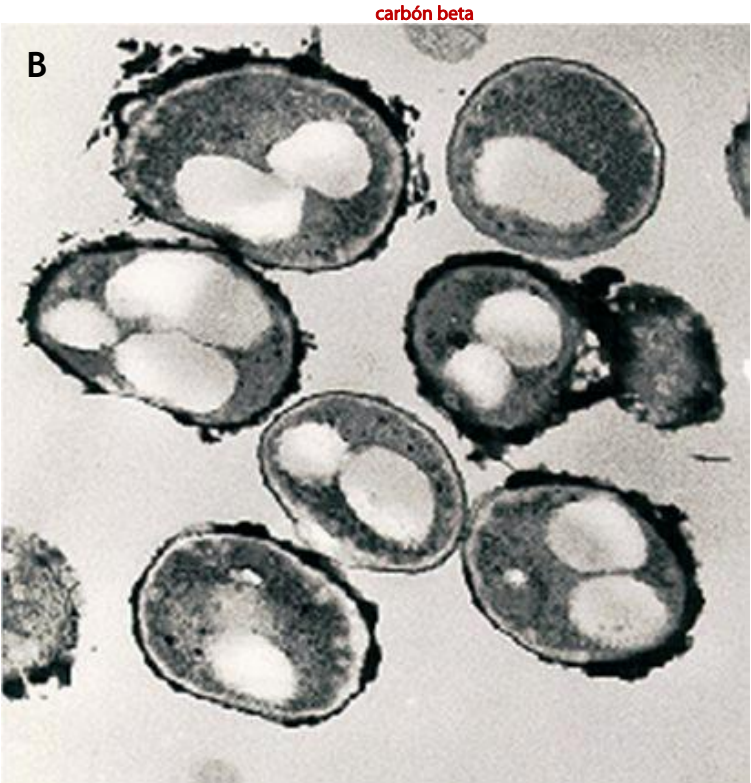

Figura 2.8 (A) Estructura de poli- $\beta$-hidroxibutirato (PHB). En poli- $\beta$-hidroxivalerato ( $\mathrm{PHV}$ ), el grupo - $\mathrm{CH}_{3}$ se sustituye por el grupo $-\mathrm{CH}_{2} \mathrm{CH}_{3}$. PHB y PHV son los dos poli- $\beta$-hidroxialcanoatos (PHA) más comunes. (B) gránulos blancos de PHA almacenados en el interior de las células (foto: MCM van Loosdrecht)

El almidón, el glucógeno y la celulosa son polímeros de glucosa que se diferencian en el tipo de enlace glucosídico entre moléculas (Figura 2.9). El cambio del tipo de unión o la geometría de esos enlaces resulta en polímeros que difieren enormemente en su resistencia. La celulosa es el polímero más resistente y se utiliza como un material estructural en las plantas y árboles. Por esta razón estos polímeros son los más difíciles de biodegradar. 
A
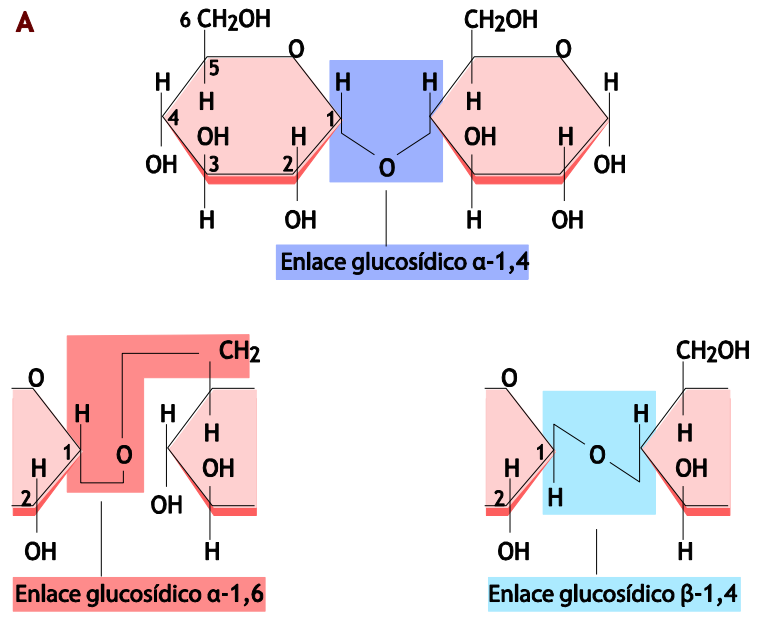

B
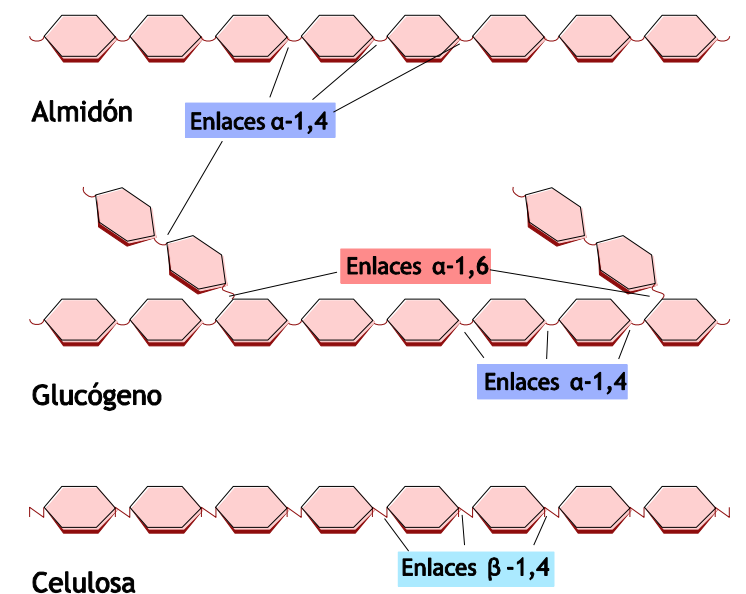

Figura 2.9 Estructura de los polisacáridos. (A) Diferencias en los enlaces glucosídicos en la posición de enlace entre las moléculas de glucosa y en la geometría ( $\alpha$ y $\beta$ ). (B) Estructura de almidón, el glucógeno (un polímero de almacenamiento bacteriano) y la celulosa (adaptado de Madigan y Martinko, 2006)

Los polifosfatos son cadenas lineales de fosfatos cuya carga negativa se estabiliza mediante cationes (Figura 2.10). El enlace fosfato-éster rico en energía es el mismo que el de la molécula universal portadora de energía dentro de la célula, el trifosfato de adenosina (ATP) que contiene una cadena de 3 fosfatos. En la mayoría de las bacterias el polifosfato se utiliza como reserva de fosfato y sólo un grupo limitado de bacterias lo usa como un compuesto de almacenamiento de energía.<smiles>[CH]OP(=O)([O-])OP(=O)([O-])OP(=O)([O-])OC</smiles>

Figura 2.10 Estructura de polifosfatos. Los polifosfatos son polímeros de moléculas de fosfato y son estabilizadas por cationes (por ejemplo, $\mathrm{Ca}^{2+}, \mathrm{Mg}^{2+}, \mathrm{K}^{+}$) interactuando con oxígeno molecular (-O-).

\subsubsection{Funciones de las bacterias}

Para que el crecimiento tenga lugar, las bacterias deben ser capaces de replicar su material genético y llevar a cabo las transformaciones químicas que permiten la síntesis de todos los componentes a partir de varios precursores y energía (Figura 2.11). Las transformaciones químicas son catalizadas por enzimas, que son proteínas. La síntesis de cualquier proteína requiere de su expresión genética. El primer paso es la transcripción del ADN (una doble cadena de ácidos nucleicos) en el ARN (una sola hebra de los ácidos nucleicos), seguida de su traducción en una proteína que se procesa para que sea funcional. Con sus constituyentes replicados, una célula bacteriana se puede dividir en dos células hijas.

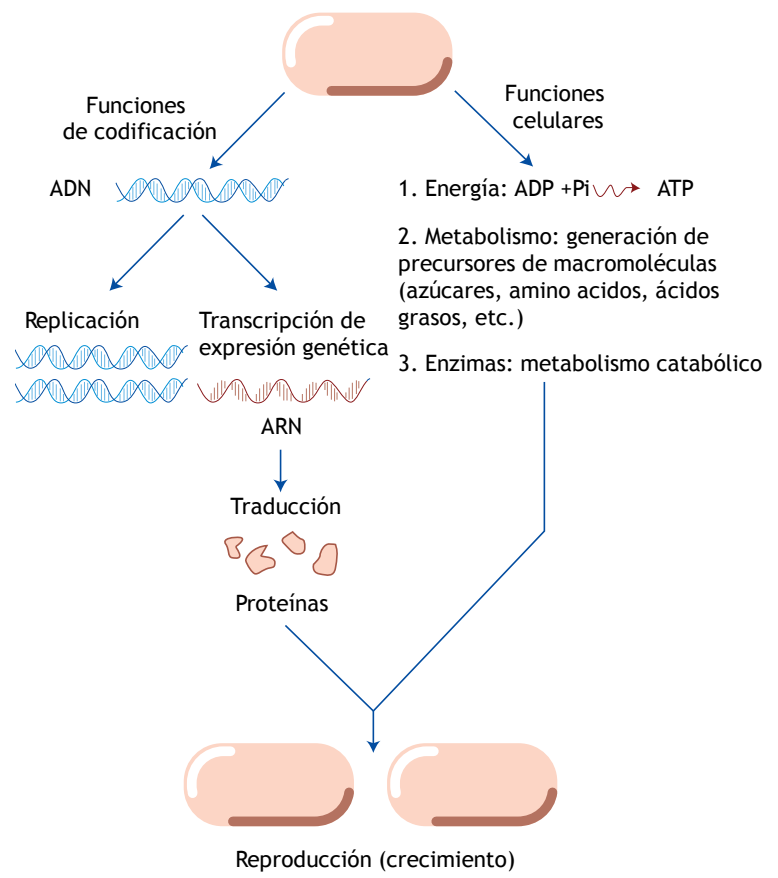

Figura 2.11 Funciones de las células. El crecimiento requiere la codificación y las funciones de la maquinaria genética para ser operacional. El ADN sirve para la replicación y la expresión genética, primero mediante la transcripción de ADN en ARN, y a continuación, la traducción del ARN en proteínas. Nota: ADN: ácido desoxirribonucleico; ARN: ácido ribonucleico (adaptado de Madigan y Martinko, 2006) 


\subsubsection{Caracterización de las bacterias}

Los microorganismos se pueden caracterizar mediante el aislamiento de cepas individuales de las comunidades microbianas con diluciones sucesivas y cultivos de enriquecimiento y después probando su respuesta a varias condiciones. Más recientemente, se han desarrollado herramientas moleculares que permiten el estudio de los microorganismos sin tener que aislarlos y cultivarlos.

La habilidad única de las bacterias para producir una proteína dada, y almacenar su código genético, se puede utilizar para detectar su presencia en muestras biológicas. El potencial de la expresión de una proteína está dado entonces por la presencia del gen en el ADN, mientras que su expresión real vendría dada por la presencia del ARN asociado en la biomasa.

\subsubsection{Hibridación fluorescente in situ}

La hibridación fluorescente in situ (Fluorescense in situ Hybridization, FISH, en inglés) consiste en preparar químicamente una cadena corta de la secuencia específica de ácidos nucleicos, un oligonucleótido, a la cual se añade un marcador o trazador de color fluorescente en su extremo. Las células son porosas al oligonucleótido añadido que se une a su cadena complementaria de ARN. Después de la eliminación de los marcadores que no se unieron, las bacterias que contienen el material genético emiten una fluorescencia que se puede observar con un microscopio fluorescente (Figura 2.12).

\subsubsection{Reacción de polimerasa en cadena y la electroforesis en gel con gradiente desnaturalizante}

Se usa la reacción de polimerasa en cadena (PCR en inglés) para amplificar el número de un gen específico en el ADN. Primero, el ADN tiene que ser extraído de una muestra biológica, se amplifica (se multiplica) por una reacción en cadena de la polimerasa y, a continuación, se identifica para confirmar su presencia. En la reacción en cadena de la polimerasa, se añaden tres componentes: una enzima polimerasa resistente a temperaturas elevadas, oligonucleótidos "delimitantes" que demarcan los extremos del gen de interés, y ácidos nucleicos de modo que pueden ser hechas las copias del gen de interés. Se impone un ciclo de altas temperatura que se traduce en la apertura (desnaturalización) del ADN y la hibridación con los oligonucleótidos añadidos. La enzima polimerasa completa entonces la replicación del gen entre los dos oligonucleótidos que flanquean. Como este ciclo se repite el número de copias del gen diana que aumenta de forma exponencial, lo que facilita su detección.

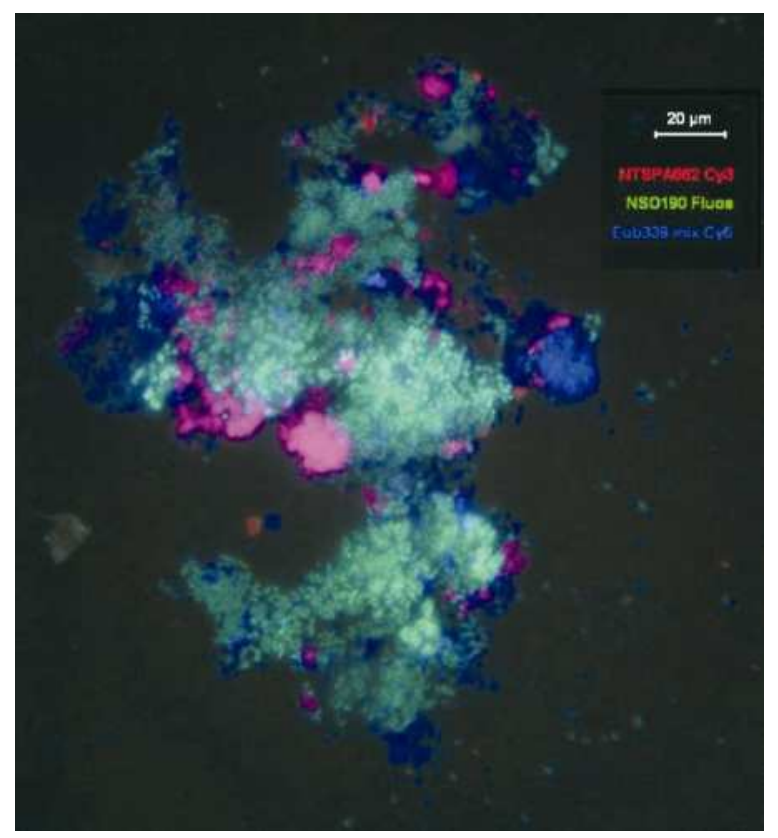

Figura 2.12 Imagen FISH de un gránulo de lodo nitrificante. Amonio oxidantes, Beta-proteobacterias (sonda NSO 190): verde; Nitrospira (bacterias nitrificantes) (sonda NTSPA 662): rojo; eubacterias (sonda EUB 338): azul (eubacterias). La barra indica una longitud de $20 \mu \mathrm{m}$. ( foto: Kampschreur, 2008)

En lugar de enfocarse en una única secuencia de ADN, muchas secuencias de genes se pueden amplificar a la vez y los fragmentos de los diversos genes amplificados pueden ser detectados por electroforesis en gel con gradiente desnaturalizante (DGGE en inglés). En el DGGE, se aplica una corriente eléctrica a un gel que contiene una concentración creciente (gradiente) de desnaturalizante. Como las diversas amplificaciones por PCR de las secuencias de genes de ADN migran, se empiezan a seccionar, se desnaturalizan, lo que ralentiza su migración en las bandas de gel y tienen rendimientos diferentes que son característicos de los genes de interés de microorganismos específicos.

\subsubsection{Bionergética bacteriana}

La energía necesaria para el metabolismo de las bacterias se obtiene a partir de reacciones químicas de óxido-reducción. Dos vías principales de generación de energía son la glucólisis y el ciclo del ácido tricarboxílico (o ciclo del ácido cítrico o ciclo de Krebs) 
en el que la glucosa (un azúcar), que se degrada en piruvato y en acetil-CoA (AcCoA), alimenta el ciclo (Figura 2.13).

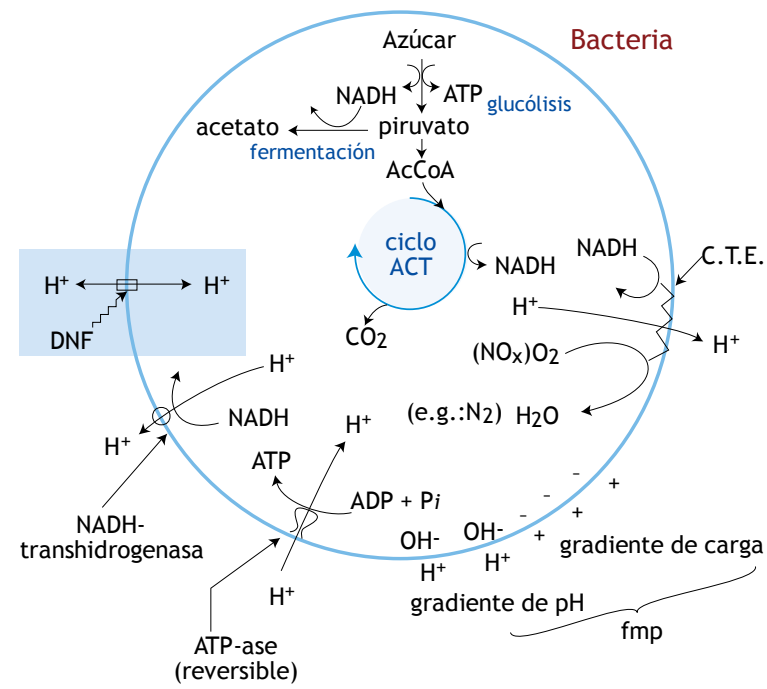

Figura 2.13 Visión general de la bioenergética bacteriana (adaptado de Comeau et al., 1986)

La energía química se transfiere a un compuesto rico en energía, el trifosfato de adenosina (ATP) y los electrones se transfieren a la forma oxidada de la coenzima dinucleótido de nicotinamida (NAD+) que se reduce a NADH. En presencia de un aceptor de electrones, tal como oxígeno $\left(\mathrm{O}_{2}\right)$ o nitrógeno oxidado $\left(\mathrm{NO}_{\mathrm{x}}\right.$ : nitrato, $\mathrm{NO}_{3}{ }^{-} \mathrm{o}$ nitrito, $\left.\mathrm{NO}_{2}{ }^{-}\right)$, el $\mathrm{NADH}$ puede transferir electrones a través de la cadena de transporte de electrones (CTE) al aceptor de electrones. En este proceso de transporte de electrones, los protones son transportados a través de la membrana del interior al exterior de la célula. El gradiente de $\mathrm{pH}$ y de carga crean una fuerza motriz de protones (FMP), que se utiliza para el transporte de diversos compuestos a través de la membrana celular y para la producción de ATP mediante la enzima ATP-asa. Durante este transporte y la generación de ATP, los protones son transportados de regreso al interior de la célula. Algunos compuestos químicos tóxicos, como el dinitrofenol (DNF), pueden neutralizar el gradiente de protones a través de la membrana y se llaman "desacopladores" ya que pueden "desacoplar" el consumo de carbono orgánico y la producción de ATP. Por lo tanto, hay tres metabolitos principales en bioenergética bacteriana, acetil-CoA, ATP y NADH. El nivel intracelular de estos compuestos actúa como un potente regulador del metabolismo de las bacterias. En ausencia de un aceptor de electrones externo, la célula no puede regenerar el NADH producido por la glucólisis. Bajo estas condiciones, el ciclo de Krebs no puede oxidar el sustrato más allá de piruvato y acetilCoA. Mediante la fermentación; sin embargo, el piruvato puede reducirse con el NADH generado por la glucólisis en productos tales como acetato y propionato.

\subsubsection{Requerimientos nutricionales para el crecimiento microbiano}

Además de la energía, los microorganismos necesitan fuentes de compuestos de carbono e inorgánicos para sintetizar los componentes celulares. Las bacterias que se encuentran en las plantas de tratamiento de aguas residuales se componen típicamente de agua 75-80\% y, por lo tanto, de $20-25 \%$ de materia seca.

El contenido de materia seca se determina a partir de una muestra líquida de volumen conocido mediante la retención de la biomasa en un filtro de fibra de vidrio que tiene un tamaño de poro nominal de aproximadamente 1.2 micras y se evapora el agua en un horno calentado a $105{ }^{\circ} \mathrm{C}$. Después de enfriarse, la biomasa seca se pesa en una balanza analítica y los resultados se expresan como sólidos suspendidos totales (SST) en $\mathrm{g} / \mathrm{m}^{3}(\mathrm{mg} / \mathrm{l})$. El filtro de fibra de vidrio seco que retuvo la biomasa se expone a $550^{\circ} \mathrm{C}$ en un horno de mufla para incinerar la materia orgánica (compuesta de $\mathrm{C}, \mathrm{H}, \mathrm{O}$ y N). La ceniza restante se considera que representa los componentes inorgánicos y se denomina ceniza o sólidos suspendidos fijos (SSF). Por diferencia, se calcula la materia orgánica denominada sólidos suspendidos volátiles (SSV). La composición típica de la materia seca (SST) de las bacterias se presenta en la Tabla 2.1.

El contenido orgánico (SSV) e inorgánicos de las bacterias son, por lo tanto, aproximadamente el $93 \%$ y el $7 \%$, respectivamente. No sólo deben estar presentes los macro nutrientes, tales como nitrógeno y fósforo, para el crecimiento celular, otros elementos también son esenciales. Estos compuestos rara vez faltan en los efluentes municipales, pero pueden estar ausentes en algunos efluentes industriales, tales como los de las industrias del azúcar o de papel.

Las fórmulas empírica propuestas para las células (biomasa activa) encontradas en los procesos de tratamiento de aguas residuales son $\mathrm{C}_{5} \mathrm{H}_{7} \mathrm{O}_{2} \mathrm{~N}$ y $\mathrm{C}_{60} \mathrm{H}_{87} \mathrm{O}_{23} \mathrm{~N}_{12} \mathrm{P}$ que se puede aproximar a $\mathrm{C}_{5} \mathrm{H}_{7} \mathrm{O}_{2} \mathrm{NP}_{1 / 12}$. Estas fórmulas determinan el contenido de materia seca 
(\%SST) para C, H, O, N y P que están relativamente cerca de los valores presentados en la Tabla 2.1. Otros elementos traza necesarios incluyen $\mathrm{Zn}, \mathrm{Mn}, \mathrm{Mo}$, Se, $\mathrm{Co}, \mathrm{Cu}$ y $\mathrm{Ni}$.

Tabla 2.1 Composición típica de las bacterias (adaptado de Metcalf \& Eddy 2003)

\begin{tabular}{|c|c|c|}
\hline $\begin{array}{l}\text { Constituyentes o } \\
\text { elementos }\end{array}$ & $\%$ SST & $\begin{array}{l}\text { Fórmula empírica de } \\
\text { las células } \mathrm{C}_{5} \mathrm{H}_{7} \mathrm{O}_{2} \mathrm{~N}\end{array}$ \\
\hline \multicolumn{3}{|c|}{ Principales constituyentes celulares } \\
\hline Proteína & 55.0 & \\
\hline Polisacáridos & 5.0 & \\
\hline Lípidos & 9.1 & \\
\hline DNA & 3.1 & \\
\hline RNA & 20.5 & \\
\hline $\begin{array}{l}\text { Otros (azúcar, amino } \\
\text { ácidos) }\end{array}$ & 6.3 & \\
\hline Iones inorgánicos & 1.0 & \\
\hline \multicolumn{2}{|c|}{ Como elementos en la célula } & $\% \mathrm{SSV}$ \\
\hline Orgánico (SSV) & 93.0 & \\
\hline Carbón & 50.0 & 53.1 \\
\hline Oxígeno & 22.0 & 28.3 \\
\hline Nitrógeno & 12.0 & 12.4 \\
\hline Hidrógeno & 9.0 & 6.2 \\
\hline Inorgánico (SSF) & 7.0 & \\
\hline Fósforo & 2.0 & \\
\hline Azufre & 1.0 & \\
\hline Potasio & 1.0 & \\
\hline Sodio & 1.0 & \\
\hline Calcio & 0.5 & \\
\hline Magnesio & 0.5 & \\
\hline Cloro & 0.5 & \\
\hline Hierro & 0.2 & \\
\hline Otros elementos traza & 0.3 & \\
\hline
\end{tabular}

\section{Catabolismo \\ Energía-rendimiento metabólico}

\subsubsection{Fuentes de carbono y energía y la diversidad microbiana}

El metabolismo es la suma de todos los procesos químicos que tienen lugar en las células vivas (Figura 2.14). Se divide en dos categorías, el catabolismo y anabolismo. Las reacciones catabólicas son las de suministro de energía de la célula. La reacción catabólica es una reacción redox en que el transporte de electrones desde el donante al aceptor de electrones genera una fuerza motriz de protones que genera ATP. Las reacciones anabólicas utilizan esta energía para la síntesis de los componentes celulares a partir de fuentes de carbono y otros nutrientes. Si los compuestos orgánicos de carbono son el sustrato entonces funcionan tanto en la reacción catabólica como en las reacciones anabólicas. Los procesos anabólicos son más o menos los mismos en todas las bacterias, mientras que los procesos catabólicos pueden variar ampliamente entre diferentes grupos microbianos.

La producción de energía requiere la presencia de un donador y un aceptor de electrones. Un compuesto reducido actúa como el donador de electrones (por ejemplo, materia orgánica o amonio), mientras que un compuesto oxidado actúa como el aceptor de electrones (por ejemplo, oxígeno o nitrato). Los estados de oxidación máximo y mínimo, con un ejemplo de una molécula correspondiente, se muestran en la Tabla 2.2 para los elementos significativos en microbiología.

Las fuentes de carbono para la biosíntesis sólo son de dos tipos, orgánicas o inorgánicas. Las fuentes de energía son de tres tipos, orgánica, inorgánica y de la luz, pero la variedad de combinaciones de donantes y aceptores de electrones genera una amplia diversidad de microorganismos (Tabla 2.3).

Anabolismo

Metabolismo Biosintético

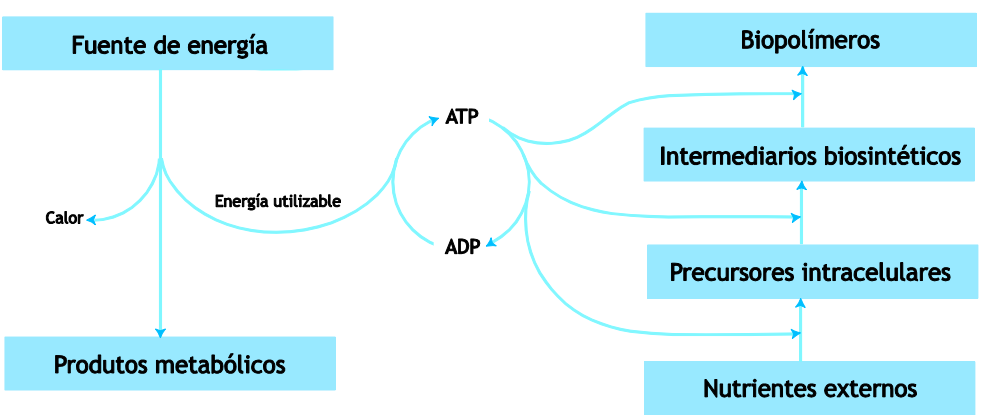

Figura 2.14 Metabolismo como una combinación de catabolismo y anabolismo (adaptado de Todar, 2007) 
Tabla 2.2 Elementos significativos en microbiología.

\begin{tabular}{|c|c|c|c|c|c|c|c|}
\hline \multicolumn{2}{|c|}{ Nombre y símbolo } & \multirow{2}{*}{$\begin{array}{l}\text { Estado de oxidación de } \\
\text { referencia }(=0) \text { y fase } \\
\mathrm{O}_{2}(\mathrm{~g})\end{array}$} & \multirow{2}{*}{$\begin{array}{l}\text { Electro-negatividad } \\
(x)\end{array}$} & \multicolumn{2}{|c|}{$\begin{array}{l}\text { Estado de oxidación } \\
\text { y el estado de mín } x\end{array}$} & \multicolumn{2}{|c|}{$\begin{array}{l}\text { Estado de oxidación } \\
\text { y el estado de máx } x\end{array}$} \\
\hline Oxígeno & $\mathrm{O}$ & & & - II & $\mathrm{H}_{2} \mathrm{O}$ & 0 & $\mathrm{O}_{2}$ \\
\hline Nitrógeno & $\mathrm{N}$ & $\mathrm{N}_{2}(\mathrm{~g})$ & 3.07 & - III & $\mathrm{NH}_{4}^{+}$ & $\mathrm{V}$ & $\mathrm{NO}_{3}^{-}$ \\
\hline Carbono & $\mathrm{C}$ & $\mathrm{C}(\mathrm{s})$ & 2.50 & $-\mathrm{IV}$ & $\mathrm{CH}_{4}$ & IV & $\mathrm{HCO}_{3}^{-}$ \\
\hline Azufre & $\mathrm{S}$ & $\mathrm{S}(\mathrm{s})$ & 2.44 & - II & $\mathrm{HS}^{-}$ & VI & $\mathrm{SO}_{4}{ }^{2-}$ \\
\hline Hidrógeno & $\mathrm{H}$ & $\mathrm{H}_{2}(\mathrm{~g})$ & 2.10 & 0 & $\mathrm{H}_{2}$ & I & $\mathrm{H}^{+}$ \\
\hline Hierro & $\mathrm{Fe}$ & $\mathrm{Fe}(\mathrm{s})$ & 1.64 & 0 & $\mathrm{Fe}$ & III & $\mathrm{Fe}^{3+}$ \\
\hline Manganeso & $\mathrm{Mn}$ & $\operatorname{Mn}(s)$ & 1.60 & II & $\mathrm{Mn}^{2+}$ & IV & $\mathrm{Mn}^{4+}$ \\
\hline
\end{tabular}

Estados de oxidación: referencia, mín, máx; Las fases son gaseosa (g) y sólida (s); Electro-negatividad se refiere a la tendencia de un átomo para atraer electrones (en un estado de oxidación alto, estos elementos (excepto los $\mathrm{H}^{+}$) son posibles aceptores de electrones para las reacciones catabólicas (adaptado de Heijnen et al., en preparación)

Tabla 2.3 Clasificación trófica de los microorganismos (adaptado de Rittmann y McCarty, 2001; Metcalf \& Eddy, 2003)

\begin{tabular}{|c|c|c|c|c|c|}
\hline \multicolumn{5}{|c|}{ Fuente de Energía } & \multirow[t]{3}{*}{ Fuente de carbono $^{1}$} \\
\hline \multicolumn{3}{|c|}{ Donador de electrones } & \multirow{2}{*}{$\begin{array}{l}\text { Aceptor de } \\
\text { electrones }\end{array}$} & \multirow[t]{2}{*}{ Productos típicos ${ }^{2}$} & \\
\hline Grupo trófico & Grupo microbiano & Tipo de donador de $\mathrm{e}^{-}$ & & & \\
\hline \multicolumn{6}{|l|}{ Quimiótrofo } \\
\hline \multirow[t]{6}{*}{ Organótrofo } & Heterótrofos aerobios & Orgánico & $\mathrm{O}_{2}$ & $\mathrm{CO}_{2}, \mathrm{H}_{2} \mathrm{O}$ & Orgánico \\
\hline & Desnitrificantes & Orgánico & $\mathrm{NO}_{3}^{-}, \mathrm{NO}_{2}^{-}$ & $\mathrm{N}_{2}, \mathrm{CO}_{2}, \mathrm{H}_{2} \mathrm{O}$ & Orgánico \\
\hline & Organismos fermentadore & es Orgánico & Orgánico & Orgánico:AGVs ${ }^{3}$ & Orgánico \\
\hline & Hierro reductores & Orgánico & $\mathrm{Fe}$ (III) & $\mathrm{Fe}$ (II) & Orgánico \\
\hline & Sulfato reductores & Acetato & $\mathrm{SO}_{4}{ }^{2-}$ & $\mathrm{H}_{2} \mathrm{~S}$ & Acetato \\
\hline & $\begin{array}{l}\text { Metanógenos } \\
\text { (acetoclásticas) }\end{array}$ & Acetato & Acetato & $\mathrm{CH}_{4}$ & Acetato \\
\hline \multirow[t]{10}{*}{ Litótrofo } & Nitrificantes: $\mathrm{AOB}^{4}$ & $\mathrm{NH}_{4}^{+}$ & $\mathrm{O}_{2}$ & $\mathrm{NO}_{2}^{-}$ & $\mathrm{CO}_{2}$ \\
\hline & Nitrificantes: $\mathrm{NOB}^{5}$ & $\mathrm{NO}_{2}^{-}$ & $\mathrm{O}_{2}$ & $\mathrm{NO}_{3}^{-}$ & $\mathrm{CO}_{2}$ \\
\hline & Bacterias Anammox ${ }^{6}$ & $\mathrm{NH}_{4}{ }^{+}$ & $\mathrm{NO}_{2}^{-}$ & $\mathrm{N}_{2}$ & $\mathrm{CO}_{2}$ \\
\hline & Denitrificantes & $\mathrm{H}_{2}$ & $\mathrm{NO}_{3}^{-}, \mathrm{NO}_{2}^{-}$ & $\mathrm{N}_{2}, \mathrm{H}_{2} \mathrm{O}$ & $\mathrm{CO}_{2}$ \\
\hline & Denitrificantes & S & $\mathrm{NO}_{3}^{-}, \mathrm{NO}_{2}^{-}$ & $\mathrm{N}_{2}, \mathrm{SO}_{4}{ }^{2-} \mathrm{H}_{2} \mathrm{O}$ & $\mathrm{CO}_{2}$ \\
\hline & Hierro oxidantes & $\mathrm{Fe}$ (II) & $\mathrm{O}_{2}$ & $\mathrm{Fe}(\mathrm{III})$ & $\mathrm{CO}_{2}$ \\
\hline & Sulfato reductores & $\mathrm{H}_{2}$ & $\mathrm{SO}_{4}{ }^{2-}$ & $\mathrm{H}_{2} \mathrm{~S}, \mathrm{H}_{2} \mathrm{O}$ & $\mathrm{CO}_{2}$ \\
\hline & Sulfato oxidantes & $\mathrm{H}_{2} \mathrm{~S}, \mathrm{~S}^{0}, \mathrm{~S}_{2} \mathrm{O}_{3}{ }^{2-}$ & $\mathrm{O}_{2}$ & $\mathrm{SO}_{4}{ }^{2-}$ & $\mathrm{CO}_{2}$ \\
\hline & $\begin{array}{l}\text { Hidrogenotróficos } \\
\text { aeróbicos }\end{array}$ & $\mathrm{H}_{2}$ & $\mathrm{O}_{2}$ & $\mathrm{H}_{2} \mathrm{O}$ & $\mathrm{CO}_{2}$ \\
\hline & $\begin{array}{l}\text { Metanógenos } \\
\text { (hidrogenotróficos) }\end{array}$ & $\mathrm{H}_{2}$ & $\mathrm{CO}_{2}$ & $\mathrm{CH}_{4}$ & $\mathrm{CO}_{2}$ \\
\hline \multicolumn{6}{|l|}{ Fotótrofo } \\
\hline & Algas, plantas & $\mathrm{H}_{2} \mathrm{O}$ & $\mathrm{CO}_{2}$ & $\mathrm{O}_{2}$ & $\mathrm{CO}_{2}$ \\
\hline & Bacterias fotosintéticas & $\mathrm{H}_{2} \mathrm{~S}$ & $\mathrm{CO}_{2}$ & $S(0)$ & $\mathrm{CO}_{2}$ \\
\hline
\end{tabular}


El nombre de estos grupos provienen de raíces griegas: chemo: química; troph: nutrición; organo: orgánico; litho: inorgánico; photo: luz; auto: auto; hetero: otro.

Los quimiótrofos obtienen energía de la oxidación de moléculas donadoras de electrones de su entorno. Estas moléculas pueden ser orgánicas (quimiorganótrofos o quimiorganoheterótrofos) o inorgánicas (quimiolitótrofos o quimiolitoautótrofos). Los quimiorganótrofos son normalmente heterótrofos y los quimiolitótrofos son normalmente autótrofos, estos nombres se utilizan indistintamente. No todos los tipos microbianos se presentan en esta tabla. Otros grupos incluyen las denominadas "respiración deshalogenante" que utilizan algunos tipos de compuestos clorados como aceptores de electrones.

A continuación se muestran ejemplos de reacciones de crecimiento microbiano con su función principal en el tratamiento de aguas residuales. Las moléculas neutrales se utilizan para las reacciones incluso si otras especies iónicas pueden ser dominantes. Las Ecuaciones 2.1 a 2.6 ilustran el metabolismo pero no están balanceadas:

- Heterótrofos aerobios: oxidación de la materia orgánica,

$\mathrm{C}_{6} \mathrm{H}_{12} \mathrm{O}_{6}+\mathrm{O}_{2}+\mathrm{NH}_{3}+$ otros nutrientes $\rightarrow$

$\mathrm{C}_{5} \mathrm{H}_{7} \mathrm{O}_{2} \mathrm{~N}+\mathrm{CO}_{2}+\mathrm{H}_{2} \mathrm{O}$

- Desnitrificantes: eliminación de nitrato,

$\mathrm{C}_{6} \mathrm{H}_{12} \mathrm{O}_{6}+\mathrm{O}_{2}+\mathrm{HNO}_{3}+\mathrm{NH}_{3}+$

+ otros nutrientes $\rightarrow$

$\mathrm{C}_{5} \mathrm{H}_{7} \mathrm{O}_{2} \mathrm{~N}+\mathrm{CO}_{2}+\mathrm{H}_{2} \mathrm{O}+\mathrm{N}_{2}$
- Organismos fermentadores: conversión de compuestos orgánicos más complejos (en este caso de glucosa a ácido acético),

$\mathrm{C}_{6} \mathrm{H}_{12} \mathrm{O}_{6}+\mathrm{O}_{2}+\mathrm{NH}_{3}+$ otros nutrientes $\rightarrow$

$\rightarrow \mathrm{C}_{5} \mathrm{H}_{7} \mathrm{O}_{2} \mathrm{~N}+\mathrm{CH}_{3} \mathrm{CO}_{2} \mathrm{H}+\mathrm{CO}_{2}$

- Bacterias autótrofas aerobias (oxidantes de amonio): eliminación de amoniaco,

$\mathrm{CO}_{2}+\mathrm{NH}_{3}+\mathrm{O}_{2}+$ otros nutrientes $\rightarrow$

$\rightarrow \mathrm{C}_{5} \mathrm{H}_{7} \mathrm{O}_{2} \mathrm{~N}+\mathrm{HNO}_{3}+\mathrm{H}_{2} \mathrm{O}$

- Metanogénicas hidrogenotróficas: producción de biogás,

$\mathrm{H}_{2}+\mathrm{CO}_{2}+\mathrm{NH}_{3}+$ otros nutrientes $\rightarrow$

$\rightarrow \mathrm{C}_{5} \mathrm{H}_{7} \mathrm{O}_{2} \mathrm{~N}+\mathrm{CH}_{4}$

- Plantas: Producción de $\mathrm{O}_{2}$ y reducción de gases de efecto invernadero,

$$
\begin{aligned}
& \mathrm{CO}_{2}+\text { luz }+\mathrm{NH}_{3}+\text { otros nutrientes } \rightarrow \\
& \rightarrow \mathrm{C}_{5} \mathrm{H}_{7} \mathrm{O}_{2} \mathrm{~N}+\mathrm{O}_{2}
\end{aligned}
$$

\subsubsection{Condiciones ambientales (oxígeno, temperatura, toxicidad)}

Las condiciones ambientales deben ser favorables para el crecimiento de los microorganismos. Los principales factores que afectan al crecimiento son el oxígeno y la temperatura, pero el $\mathrm{pH}$ (típicamente de 6 a 8) y la presión osmótica (depende de la concentración de sales) también deben ser los apropiados.

\subsubsection{Oxígeno}

La necesidad, tolerancia o sensibilidad al oxígeno molecular $\left(\mathrm{O}_{2}\right)$ varía ampliamente entre los microorganismos (Tabla 2.4). Los aerobios utilizan

Tabla 2.4 El oxígeno y los microorganismos (adaptado de Madigan y Martinko, 2006)

\begin{tabular}{lll}
\hline Grupo & Relación con el $\mathrm{O}_{2}$ & Tipo de metabolismo \\
$\begin{array}{l}\text { Aerobios } \\
\text { Obligados }\end{array}$ & Requerido (por ejemplo, 20\%) & Respiración aerobia \\
Facultativos & Mejor si presente, no esencial & $\begin{array}{l}\text { Aerobia o respiración con nitrato, } \\
\text { fermentación }\end{array}$ \\
$\begin{array}{l}\text { Microaerofílicos } \\
\text { Anaerobios } \\
\text { Aerotolerantes }\end{array}$ & Requiere bajos niveles (p.ej. 1\%) & Respiración aerobia \\
Obligados & No requerido, no afectado por su presencia & Fermentación o sulfato reducción \\
\hline
\end{tabular}


oxígeno y pueden requerirlo (estrictos), funcionar en su ausencia (facultativos) o requerirlo en niveles bajos (microaerofílico). Los anaerobios no utilizan oxígeno, pero pueden tolerarlo (aerotolerantes) o no (estrictos).

En los aerobios, las enzimas para la reducción del oxígeno $\left(\mathrm{O}_{2}\right.$ como aceptor de electrones $)$ son siempre inducidas. En contraste, las bacterias desnitrificantes que son aerobias facultativas, también tienen enzimas para la reducción de oxígeno, pero las enzimas para la reducción del nitrato (o nitrito) necesitan ser inducidas, una condición que requiere la ausencia de oxígeno. Todas las bacterias desnitrificantes también pueden utilizar oxígeno, ya que los procesos catabólicos son relativamente similares. Las reductoras de sulfato, por el contrario, no pueden utilizar oxígeno, su proceso catabólico es muy diferente de la respiración aerobia.

$\mathrm{Si}$ bien los casos de ausencia de oxígeno se denominan anóxicos $\left(\sin \mathrm{O}_{2}\right)$ o anaerobios ( $\sin$ aire) por los microbiólogos, los ingenieros hacen una distinción entre estas dos condiciones. Por lo tanto, en ausencia de oxígeno, la presencia o ausencia de nitrógeno oxidado (nitrato o nitrito) se conoce como condiciones anóxicas y anaerobias, respectivamente (Tabla 2.5).

Tabla 2.5 Definiciones de ingeniería de algunas condiciones ambientales.

\begin{tabular}{lccc}
\hline Condición & & \multicolumn{2}{c}{ Aceptor de Electrones } \\
& & Presente & Ausente \\
\hline Aerobia & OX & $\mathrm{O}_{2}$ & \\
Anóxica & AX & $\mathrm{NO}_{\mathrm{x}}$ & $\mathrm{O}_{2}$ \\
Anaerobia & AN & & $\mathrm{O}_{2} \mathrm{y} \mathrm{NO}_{\mathrm{x}}$ \\
\hline
\end{tabular}

$\mathrm{NO}_{\mathrm{x}}$ se refiere a nitrato $\left(\mathrm{NO}_{3}^{-}\right)$más nitrito $\left(\mathrm{NO}_{2}{ }^{-}\right)$

\subsubsection{Temperatura}

La temperatura tiene un efecto significativo en la tasa de crecimiento de los microorganismos (Figura 2.15). Aquellos microrganismos que operan en un intervalo de temperatura más alta tienen una mayor tasa máxima de crecimiento que los que operan en un intervalo inferior. El intervalo óptimo de temperatura para cada grupo es relativamente estrecho. Al aumentar la temperatura, se observa un aumento gradual de la tasa de crecimiento hasta que se observa una caída abrupta debido a la desnaturalización de las proteínas a una temperatura más alta. Los términos utilizados generalmente para describir estos microorganismos son psicrófilos por debajo de $15^{\circ} \mathrm{C}$, mesófilos entre $15-40{ }^{\circ} \mathrm{C}$, termófilos entre $40-70{ }^{\circ} \mathrm{C}$ e hipertermófilos por encima de $70^{\circ} \mathrm{C}$ hasta alrededor de $110^{\circ} \mathrm{C}$.

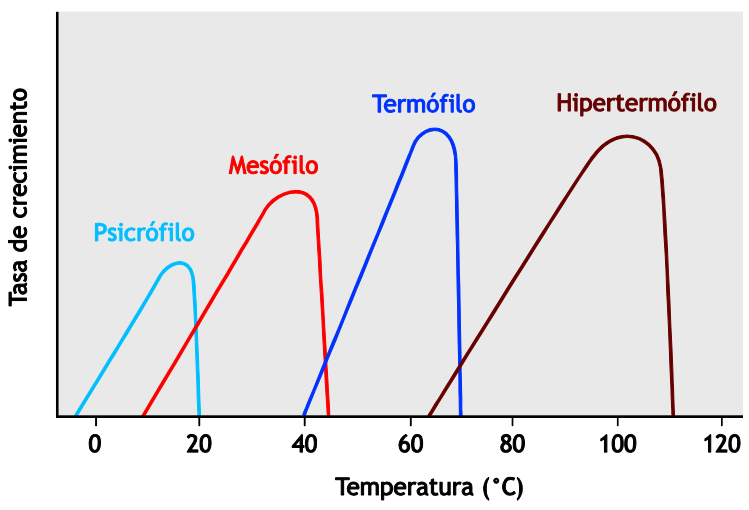

Figura 2.15 Efecto de la temperatura sobre la velocidad de crecimiento microbiano (adaptado de Rittmann y McCarty, 2001)

\subsection{ESTEQUIOMETRÍA Y ENERGÉTICA}

\subsubsection{Demanda Química de Oxígeno Teórica $\left(\mathrm{DQO}_{\mathrm{t}}\right)$ y los equivalentes de electrones}

La determinación de la demanda química de oxígeno (DQO) se realiza en el laboratorio y consiste en la oxidación de los compuestos orgánicos en presencia de una solución ácida de dicromato calentada a $150^{\circ} \mathrm{C}$ durante 2 horas. El número de electrones aceptados por el dicromato en la prueba, se expresa como equivalentes de oxígeno en $\mathrm{g}_{2} / \mathrm{m}^{3}$ (o $\mathrm{mg} \mathrm{O} / \mathrm{l}$ ).

Los equivalentes de electrones en el oxígeno se pueden determinar, ya que se sabe que $1 \mathrm{~mol} \mathrm{de} \mathrm{O}_{2}$ pesa $32 \mathrm{~g}$ y contiene 4 equivalentes de electrones (2 moléculas de $\mathrm{O} \cdot 2$ e- por molécula de $\mathrm{O}$ ). Por lo tanto, 1 equivalente de electrones (eeq) corresponde a $8 \mathrm{~g}$ de DQO (Ec. 2.7)

$1 \mathrm{eeq}=8 \mathrm{~g} \mathrm{DQO}$

Teniendo en cuenta que la materia orgánica es un donador de electrones, mientras que el $\mathrm{O}_{2}$ es un aceptor de electrones, el $\mathrm{O}_{2}$ disuelto se considera que representa una DQO negativa (Ec. 2.8).

$1 \mathrm{~g} \mathrm{O}_{2}=-1 \mathrm{gDQO}$

La demanda química de oxígeno teórica $\left(\mathrm{DQO}_{\mathrm{t}}\right)$ de un sustrato, se puede determinar mediante la utilización de una ecuación equilibrada en la cual se añade $\mathrm{O}_{2}$ y el compuesto se mineraliza a productos finales con 
amoniaco permaneciendo en su estado de oxidación $\mathrm{NH}_{3}$ (III). La DQO teórica puede diferir de la medida cuando un compuesto no reacciona en la prueba de DQO.

En la Ec. 2.9 se aporta una ecuación general para este propósito. La ecuación se refiere a la $\mathrm{DQO}_{\mathrm{t}}$ del $\mathrm{C}$, $\mathrm{H}, \mathrm{N}, \mathrm{O}$ contenidos en el sustrato (adaptado de Rittmann y McCarty 2001).

$$
\begin{aligned}
& C_{n} H_{a} O_{b} N_{c}+\frac{1}{2}(2 n+0.5-1.5 c-b) O_{2} \rightarrow \\
& n \mathrm{CO}_{2}+c N_{3}+\frac{a-3 c}{2} \mathrm{H}_{2} \mathrm{O} \\
& \text { у }
\end{aligned}
$$

DQO teórica/peso $\frac{(2 n+0.5 a-1.5 c-b) 16}{12 n+a+16 b+14 c}$

Por ejemplo la Ec. 2.10 da la mineralización de la glucosa:

$$
\begin{aligned}
& \mathrm{C}_{6} \mathrm{H}_{12} \mathrm{O}_{6}+6 \mathrm{O}_{2} \rightarrow 6 \mathrm{CO}_{2}+6 \mathrm{H}_{2} \mathrm{O} \\
& 180 \mathrm{~g} \quad 192 \mathrm{~g}
\end{aligned}
$$

Por lo tanto, $1 \mathrm{~g}$ de glucosa representa $1,067 \mathrm{~g} \mathrm{DQO}_{\mathrm{t}}$ (192/180).

Teniendo en cuenta que $8 \mathrm{~g}$ de $\mathrm{O}_{2}$ corresponde a 1 eeq, $1 \mathrm{~mol}$ de glucosa dona 24 eeq. Por lo tanto, la eliminación de $\mathrm{O}_{2}$ a partir de la ecuación anterior, la adición de 24 electrones como productos de la reacción, y de varios protones $\left(\mathrm{H}^{+}\right)$para equilibrar la carga eléctrica, y de agua para el equilibrio de $\mathrm{H}$ da la siguiente ecuación media de reacción (Ec. 2.11).

$$
\mathrm{C}_{6} \mathrm{H}_{12} \mathrm{O}_{6}+6 \mathrm{H}_{2} \mathrm{O} \rightarrow 6 \mathrm{CO}_{2}+24 e^{-}+24 \mathrm{H}^{+}
$$

Para 1 eeq, la Ec. 2.11 se convierte en:

$$
\frac{1}{24} \mathrm{C}_{6} \mathrm{H}_{12} \mathrm{O}_{6}+\frac{1}{4} \mathrm{H}_{2} \mathrm{O} \rightarrow \frac{1}{4} \mathrm{CO}_{2}+e^{-}+\mathrm{H}^{+}
$$

Un enfoque similar se puede utilizar para el aceptor de electrones. Para el oxígeno se obtiene:

$0.25 \mathrm{O}_{2}+\mathrm{H}^{+}+e^{-} \rightarrow 0.5 \mathrm{H}_{2} \mathrm{O}$
Sumando las dos ecuaciones anteriores, obtenemos la ecuación completa de la reacción de la glucosa.

De manera similar para la transformación de nitrato en gas nitrógeno (desnitrificación), el estado de oxidación de nitrógeno se reduce de $+\mathrm{V}$ a 0 .

$\mathrm{HNO}_{3}+5 \mathrm{H}^{+}+5 e^{-} \rightarrow 0.5 \mathrm{~N}_{2}+3 \mathrm{H}_{2} \mathrm{O}$

El equivalente de DQO de esta reacción es 5 eeq $/ \mathrm{mol}$ x $8 \mathrm{~g} \mathrm{DQO} / \mathrm{eeq}=40 \mathrm{~g} \mathrm{DQO} / \mathrm{mol} \mathrm{HNO}_{3}=2,86 \mathrm{~g} \mathrm{DQO} / \mathrm{g}$ $\mathrm{NO}_{3}-\mathrm{N}$. Como los electrones son aceptados pero no donados, el DQO equivalente de $1 \mathrm{~g}$ de nitratonitrógeno es por lo tanto menos 2,86 g DQO (-2,86 g $\left.\mathrm{DQO} / \mathrm{g} \mathrm{NO}_{3}-\mathrm{N}\right)=40 /(14 \mathrm{~g} / \mathrm{mol})$.

Escribir las ecuaciones con moléculas neutras o cargadas no cambia el número de electrones equivalentes de una reacción ya que el número de protones $\left(\mathrm{H}^{+}\right)$se puede ajustar.

La DQO teórica de una serie de compuestos se presenta en la Tabla 2.6. Varias ecuaciones de biomasa para obtener el peso seco de la $\mathrm{DQO}_{\mathrm{t}}$ proporcionan valores que oscilan entre 1.37 y $1.48 \mathrm{~g}$ DQO/g SSV, un valor de 1.42 se considera típico para el tratamiento biológico de aguas residuales municipales.

Para los sustratos, sin embargo, la relación $\mathrm{DQO}_{\mathrm{t}} / \mathrm{SSV}$ varía enormemente de acuerdo con el grado de reducción del sustrato. Los coeficientes se sitúan entre 0.35 para el formiato, un sustrato altamente oxidable, a 4.00 gramos de DQO por gramo de sustrato para el metano, y a 8 gramos de DQO por cada gramo de hidrógeno. Un promedio de aguas residuales municipales tendrían un DQO típico a los sólidos volátiles (filtrado más particulado) de $1.2 \mathrm{~g}$ DQO/g SV. 
Tabla 2.6 DQO teórico de varios compuestos por peso

\begin{tabular}{|c|c|c|c|c|c|c|c|}
\hline \multirow[t]{2}{*}{ Compuesto } & \multicolumn{3}{|c|}{$\begin{array}{r}\text { Peso } \\
\text { (SSV) }\end{array}$} & \multirow[b]{2}{*}{$\begin{array}{r}\mathrm{N} / \text { peso } \\
(\%)\end{array}$} & \multirow[b]{2}{*}{$\begin{array}{r}\mathrm{P} / \text { peso } \\
(\%)\end{array}$} & \multirow[b]{2}{*}{$\begin{array}{r}\mathrm{DQO}_{\mathrm{t}} \\
(\mathrm{g} / \mathrm{mol})\end{array}$} & \multirow[b]{2}{*}{$\begin{array}{r}\mathrm{DQO} / \mathrm{SSV} \\
(\mathrm{g} / \mathrm{g})\end{array}$} \\
\hline & Fórmula química & $\begin{array}{c}\text { CHON } \\
(\mathrm{g} / \mathrm{mol})\end{array}$ & $\begin{array}{r}\mathrm{C} / \text { peso } \\
(\%)\end{array}$ & & & & \\
\hline \multicolumn{8}{|l|}{ Biomasa } \\
\hline & $\mathrm{C}_{5} \mathrm{H}_{7} \mathrm{O}_{2} \mathrm{~N}$ & 113 & 53 & 12 & 0 & 160 & 1.42 \\
\hline & $\mathrm{C}_{5} \mathrm{H}_{7} \mathrm{O}_{2} \mathrm{NP}_{1 / 12}$ & 113 & 52 & 12 & 2.2 & 160 & 1.42 \\
\hline & $\mathrm{C}_{60} \mathrm{H} 8{ }_{7} \mathrm{O}_{23} \mathrm{~N}_{12} \mathrm{P}$ & 1343 & 52 & 12 & 2.3 & 1960 & 1.46 \\
\hline & $\mathrm{C}_{6} \mathrm{H}_{7.7} \mathrm{O}_{2.3} \mathrm{~N}$ & 131 & 55 & 11 & 0 & 193 & 1.48 \\
\hline & $\mathrm{C}_{18} \mathrm{H}_{19} \mathrm{O}_{9} \mathrm{~N}$ & 393 & 55 & 4 & 0 & 560 & 1.42 \\
\hline & $\mathrm{C}_{41.3} \mathrm{H}_{64.6} \mathrm{O}_{18.8} \mathrm{~N}_{7.04}$ & 960 & 50 & 10 & 3.1 & 1369 & 1.43 \\
\hline & $\mathrm{C}_{4} \mathrm{H}_{6} \mathrm{O}_{2}$ & 86 & 56 & 0 & 0 & 144 & 1.67 \\
\hline \multicolumn{8}{|l|}{ Sustancias orgánicas } \\
\hline Caseína & $\mathrm{C}_{8} \mathrm{H}_{12} \mathrm{O}_{3} \mathrm{~N}_{2}$ & 184 & 52 & 15 & 0 & 256 & 1.39 \\
\hline Orgánicos promedio & $\mathrm{C}_{18} \mathrm{H}_{19} \mathrm{O}_{9} \mathrm{~N}$ & 393 & 55 & 4 & 0 & 560 & 1.42 \\
\hline Carbohidratos & $\mathrm{C}_{10} \mathrm{H}_{18} \mathrm{O}_{9}$ & 282 & 43 & 0 & 0 & 320 & 1.13 \\
\hline Grasas, aceites & $\mathrm{C}_{8} \mathrm{H}_{6} \mathrm{O}_{2}$ & 134 & 72 & 0 & 0 & 272 & 2.03 \\
\hline Aceites: ácido oleico & $\mathrm{C}_{18} \mathrm{H}_{34} \mathrm{O}_{2}$ & 254 & 85 & 0 & 0 & 880 & 3.46 \\
\hline Proteínas & $\mathrm{C}_{14} \mathrm{H}_{12} \mathrm{O}_{7} \mathrm{~N}_{2}$ & 320 & 53 & 9 & 0 & 384 & 1.20 \\
\hline Glucosa & $\mathrm{C}_{6} \mathrm{H}_{12} \mathrm{O}_{6}$ & 180 & 40 & 0 & 0 & 192 & 1.07 \\
\hline Formiato & $\mathrm{CH}_{2} \mathrm{O}_{2}$ & 46 & 26 & 0 & 0 & 16 & 0.35 \\
\hline Acetato & $\mathrm{C}_{2} \mathrm{H}_{4} \mathrm{O}_{2}$ & 60 & 40 & 0 & 0 & 64 & 1.07 \\
\hline Propionato & $\mathrm{C}_{3} \mathrm{H}_{6} \mathrm{O}_{2}$ & 74 & 49 & 0 & 0 & 112 & 1.51 \\
\hline Butirato & $\mathrm{C}_{4} \mathrm{H}_{8} \mathrm{O}_{2}$ & 88 & 55 & 0 & 0 & 160 & 1.82 \\
\hline Metano & $\mathrm{CH}_{4}$ & 16 & 75 & 0 & 0 & 64 & 4.00 \\
\hline Hidrógeno & $\mathrm{H}_{2}$ & 2 & - & - & - & 16 & 8.00 \\
\hline
\end{tabular}

\subsubsection{Crecimiento celular}

El crecimiento celular en un cultivo en lote se caracteriza por cuatro fases durante las cuales el sustrato y la concentración de biomasa se modifican (Figura 2.16).

Las cuatro fases son:

(1) La fase de retardo (o lag) durante la cual hay poco aumento de la biomasa y poco consumo de sustrato ya que las células se adaptan a la nueva situación.

(2) La fase de crecimiento exponencial durante la cual la biomasa crece a su tasa máxima, consumiendo la mayor parte del sustrato disponible.

(3) La fase estacionaria es en la que se dispone de poco sustrato externo y la concentración de biomasa se mantiene relativamente constante.

(4) Por último, la fase de decaimiento se asocia con descomposición de la biomasa, debido al consumo del carbono interno y las reservas de energía para sus necesidades de mantenimiento, y debido a la depredación y la lisis.

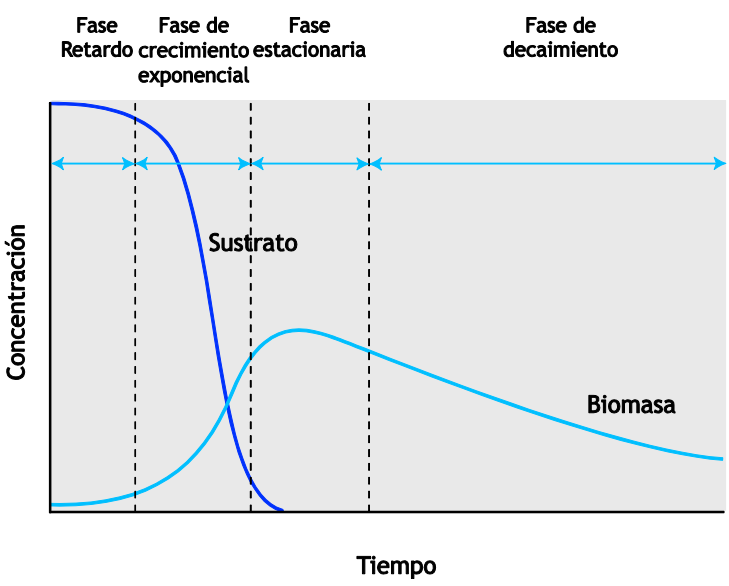

Figura 2.16 Crecimiento de biomasa en cultivo en lote (adaptado de Metcalf \& Eddy, 2003) 
Estas condiciones de crecimiento pueden encontrarse en las plantas de tratamiento de aguas residuales en el arranque (fase de retardo), en plantas altamente cargadas o la parte inicial de un proceso de flujo pistón (fase de crecimiento exponencial), en la sección intermedia y final de un proceso de flujo pistón (fase estacionaria) y en una laguna facultativa o aerobia de un digestor de lodos (fase de decaimiento).

\subsubsection{Rendimiento y energía \\ 2.3.3.1 Energía del catabolismo}

El metabolismo microbiano requiere energía para la síntesis celular. Dependiendo del tipo de aceptor/donador de electrones y la producción de energía asociada, una proporción variable de los electrones aportados por la fuente de energía estará disponible para la síntesis de biomasa. Por ejemplo, la oxidación aerobia de glucosa genera mucha más energía que su transformación en metano, lo que explica por qué la producción celular de la primera reacción es mayor que la de la segunda. La bioenergética proporciona una herramienta para cuantificar la cantidad de energía disponible para diversas reacciones biológicas, que luego pueden ser utilizadas para determinar el rendimiento en biomasa de una reacción.

La producción de energía del catabolismo depende de la oxidación y la reducción de los productos químicos disponibles para los microorganismos. En una reacción dada, el donador de electrones (DE) se oxida, mientras que el aceptor de electrones (AE) se reduce. El donador de electrones se considera que es el sustrato de alta energía o "comida" de la reacción y una gran variedad de compuestos pueden desempeñar esta función. El aceptor de electrones, por el contrario, es una forma oxidada y está disponible en un número más limitado para los sistemas biológicos (principalmente oxígeno, nitrato, nitrito, hierro (III), sulfato, dióxido de carbono).

El cambio en la energía de Gibbs $\left(\Delta G^{\circ}\right)$ es una propiedad termodinámica útil de una reacción, que caracteriza la cantidad máxima de energía (trabajo) que puede obtenerse para una reacción dada. El superíndice indica que los compuestos implicados están en condiciones estándares ( $1 \mathrm{~mol}, 1$ atmósfera y $\left.25^{\circ} \mathrm{C}\right)$. Para los procesos biológicos, a menudo la energía de Gibbs estándar se calcula a $\mathrm{pH} 7$, lo que se indica mediante la adición de una prima (') en el símbolo de la energía de Gibbs. Algunas reacciones parciales de los sistemas biológicos y los cambios de la energía de Gibbs por equivalente de electrones $\left(\Delta \mathrm{G}^{\mathrm{o}} \mathrm{kJ} / \mathrm{eeq}\right)$ se muestran en la Tabla 2.7. En la combinación de reacciones mostradas en la Tabla 2.7 se presentan los aceptores de electrones con el electrón en el lado izquierdo. Así, para una reacción de donador de electrones, los reactivos y los productos de la reacción deben intercambiarse y el signo del cambio de energía de Gibbs también debe ser cambiado. Si los resultados netos de la reacción dan un $\Delta \mathrm{G}^{0^{\prime}}$ negativo, significa que se libera energía (reacción exergónica) y que la reacción puede ocurrir de forma espontánea. A la inversa, si $\Delta \mathrm{G}^{\mathrm{o}}$ ' es positiva, será necesario el aporte de energía para que la reacción tenga lugar, y no se producirá espontáneamente (reacción endergónica).

La energía disponible a partir de la transformación de la glucosa (donador de electrones) por oxidación aerobia (con $\mathrm{O}_{2}$ como aceptor de electrones) y por la metanogénesis (con dióxido de carbono como aceptor de electrones) se ilustra en la Tabla 2.8. Estas dos reacciones de oxidación de la glucosa muestran que el metabolismo aerobio proporciona casi 7 veces más energía que la metanogénesis anaerobia. Por consiguiente, se espera que el rendimiento celular sea mucho más alto con el oxígeno que con el dióxido de carbono como aceptores de electrones. Otras reacciones biológicas se ilustran en la Figura 2.17.

\subsubsection{Fracción de síntesis y rendimiento de biomasa}

Una porción del sustrato donador de electrones se utiliza para la síntesis celular $\left(f_{s}^{0}\right.$ : fracción de síntesis real) y el resto para la producción de energía $\left(f_{e}^{0}\right.$ : fracción de energía verdadera) (Figura 2.18). Sobre una base equivalente de electrones (eeq), la suma de $f_{s}^{0}$ más $f_{e}{ }^{0}$ es igual a 1. El balance de electrones, y por lo tanto el equilibrio DQO, se mantiene.

$f_{s}^{0}+f_{e}^{0}=1$

Las células bacterianas activas generadas por el crecimiento, utilizando el donador de electrones inicial, luego se someten al decaimiento debido al mantenimiento, la depredación y la lisis celular. 
Tabla 2.7 Reacciones medias para sistemas biológicos (Metcalf \& Eddy, 2003 ${ }^{\text {a }}$, (unidad para $\Delta \mathrm{G}^{\mathrm{o}^{\prime}}$ es kJ por equivalente de electrón ${ }^{\mathrm{b}}$ )

\begin{tabular}{|c|c|c|c|c|}
\hline Parámetro & Reacción media & & $\Delta \mathrm{G}^{0^{\prime}}$ & Ec. \\
\hline \multicolumn{5}{|c|}{ Reacciones para síntesis de células bacteriales $\left(\mathrm{R}_{\mathrm{cs}}\right)$} \\
\hline $\begin{array}{l}\text { Amoníaco como fuente } \\
\text { de nitrógeno }\end{array}$ & $\frac{1}{5} \mathrm{CO}_{2}+\frac{1}{20} \mathrm{HCO}_{3}+\frac{1}{20} \mathrm{NH}_{4}^{+}+H^{-}+e^{-}$ & $=\frac{1}{20} \mathrm{C}_{5} \mathrm{H}_{7} \mathrm{O}_{2} \mathrm{~N}+\frac{9}{20} \mathrm{H}_{2} \mathrm{O}$ & & $(2.15)$ \\
\hline $\begin{array}{l}\text { Nitrato como fuente de } \\
\text { nitrógeno }\end{array}$ & $\frac{5}{28} \mathrm{CO}_{2}+\frac{1}{28} \mathrm{NO}_{3}^{-}+\frac{29}{28} \mathrm{H}^{+}+e^{-}$ & $=\frac{1}{28} \mathrm{C}_{5} \mathrm{H}_{7} \mathrm{O}_{2} \mathrm{~N}+\frac{11}{28} \mathrm{H}_{2} \mathrm{O}$ & & $(2.16)$ \\
\hline \multicolumn{5}{|c|}{ Reacciones para aceptores de electrones $\left(\mathrm{R}_{\mathrm{a}}\right)$} \\
\hline Nitrito & $\frac{1}{3} \mathrm{NO}_{2}^{-}+\frac{4}{3} H^{+}+e^{-}$ & $=\frac{1}{6} \mathrm{~N}_{2}+\frac{2}{3} \mathrm{H}_{2} \mathrm{O}$ & -93.23 & $(2.17)$ \\
\hline Oxígeno & $\frac{1}{4} O_{2}+H^{+}+e^{-}$ & $=\frac{1}{2} \mathrm{H}_{2} \mathrm{O}$ & -78.14 & $(2.18)$ \\
\hline Nitrato & $\frac{1}{5} \mathrm{NO}_{3}^{-}+\frac{6}{5} H^{+}+e^{-}$ & $=\frac{1}{10} \mathrm{~N}_{2}+\frac{3}{5} \mathrm{H}_{2} \mathrm{O}$ & -71.67 & $(2.19)$ \\
\hline Sulfito & $\frac{1}{6} \mathrm{SO}_{3}^{2-}+\frac{5}{4} H^{+}+e^{-}$ & $=\frac{1}{12} \mathrm{H}_{2} \mathrm{~S}+\frac{1}{12} \mathrm{HS}^{-}+\frac{1}{2} \mathrm{H}_{2} \mathrm{O}$ & 13.60 & $(2.20)$ \\
\hline Sulfato & $\frac{1}{8} \mathrm{SO}_{4}^{2-}+\frac{19}{16} \mathrm{H}^{+}+e^{-}$ & $=\frac{1}{16} \mathrm{H}_{2} \mathrm{~S}+\frac{1}{16} \mathrm{HS}^{-}+\frac{1}{2} \mathrm{H}_{2} \mathrm{O}$ & 21.27 & $(2.21)$ \\
\hline $\begin{array}{l}\text { Dióxido de carbono } \\
\text { (fermentación de } \\
\text { metano) }\end{array}$ & $\frac{1}{8} \mathrm{CO}_{2}+H^{+}+e^{-}$ & $=\frac{1}{8} \mathrm{CH}_{4}+\frac{1}{4} \mathrm{H}_{2} \mathrm{O}$ & 24.11 & $(2.22)$ \\
\hline \multicolumn{5}{|c|}{ Reacciones para donadores de electrones $\left(R_{d}\right)$} \\
\hline \multicolumn{5}{|c|}{ Donadores orgánicos (reacciones heterotróficas) } \\
\hline Agua residual doméstica & $\frac{9}{50} \mathrm{CO}_{2}+\frac{1}{50} \mathrm{NH}_{4}^{+}+\frac{1}{50} \mathrm{HCO}_{3}^{-}+\mathrm{H}^{+}+e^{-}$ & $=\frac{1}{50} \mathrm{C}_{10} \mathrm{H}_{19} \mathrm{O}_{3} \mathrm{~N}+\frac{9}{25} \mathrm{H}_{2} \mathrm{O}$ & 31.80 & $(2.23)$ \\
\hline Proteínas & $\frac{8}{33} \mathrm{CO}_{2}+\frac{2}{33} \mathrm{NH}_{4}^{+}+\frac{31}{33} \mathrm{H}^{+}+e^{-}$ & $=\frac{1}{66} \mathrm{C}_{16} \mathrm{H}_{24} \mathrm{O}_{5} \mathrm{~N}_{4}+\frac{27}{66} \mathrm{H}_{2} \mathrm{O}$ & 32.22 & $(2.24)$ \\
\hline Formiato & $\frac{1}{2} \mathrm{HCO}_{3}^{-}+H^{+}+e^{-}$ & $=\frac{1}{2} \mathrm{HCOO}^{-}+\frac{1}{2} \mathrm{H}_{2} \mathrm{O}$ & 48.07 & $(2.25)$ \\
\hline Glucosa & $\frac{1}{4} \mathrm{CO}_{2}+\mathrm{H}^{+}+e^{-}$ & $=\frac{1}{24} \mathrm{C}_{6} \mathrm{H}_{12} \mathrm{O}_{6}+\frac{1}{4} \mathrm{H}_{2} \mathrm{O}$ & 41.96 & $(2.26)$ \\
\hline Carbohidratos & $\frac{1}{4} \mathrm{CO}_{2}+H^{+}+e^{-}$ & $=\frac{1}{4} \mathrm{CH}_{2} \mathrm{O}+\frac{1}{4} \mathrm{H}_{2} \mathrm{O}$ & 41.84 & $(2.27)$ \\
\hline Metanol & $\frac{1}{6} \mathrm{CO}_{2}+\mathrm{H}^{+}+e^{-}$ & $=\frac{1}{6} \mathrm{CH}_{3} \mathrm{OH}+\frac{1}{6} \mathrm{H}_{2} \mathrm{O}$ & 37.51 & $(2.28)$ \\
\hline Piruvato & $\frac{1}{5} \mathrm{CO}_{2}+\frac{1}{10} \mathrm{HCO}_{3}^{-}+\mathrm{H}^{+}+e^{-}$ & $=\frac{1}{10} \mathrm{CH}_{3} \mathrm{COCOO}^{-}+\frac{2}{5} \mathrm{H}_{2} \mathrm{O}$ & 35.78 & $(2.29)$ \\
\hline Etanol & $\frac{1}{6} \mathrm{CO}_{2}+\mathrm{H}^{+}+e^{-}$ & $=\frac{1}{12} \mathrm{CH}_{3} \mathrm{CH}_{2} \mathrm{OH}+\frac{1}{4} \mathrm{H}_{2} \mathrm{O}$ & 31.79 & $(2.30)$ \\
\hline Propionato & $\frac{1}{7} \mathrm{CO}_{2}+\frac{1}{14} \mathrm{HCO}_{3}^{-}+\mathrm{H}^{+}+e^{-}$ & $=\frac{1}{14} \mathrm{CH}_{3} \mathrm{CH}_{2} \mathrm{COO}^{-}+\frac{5}{14} \mathrm{H}_{2} \mathrm{O}$ & 27.91 & $(2.31)$ \\
\hline Acetato & $\frac{1}{8} \mathrm{CO}_{2}+\frac{1}{8} \mathrm{HCO}_{3}^{-}+\mathrm{H}^{+}+e^{-}$ & $=\frac{1}{8} \mathrm{CH}_{3} \mathrm{COO}^{-}+\frac{3}{8} \mathrm{H}_{2} \mathrm{O}$ & 27.68 & $(2.32)$ \\
\hline Grasas y aceites & $\frac{4}{23} \mathrm{CO}_{2}+H^{+}+e^{-}$ & $=\frac{1}{46} \mathrm{C}_{8} \mathrm{H}_{16} \mathrm{O}+\frac{15}{46} \mathrm{H}_{2} \mathrm{O}$ & 27.61 & $(2.33)$ \\
\hline \multicolumn{5}{|c|}{ Donadores inorgánicos (reacciones autotróficas) } \\
\hline & $F e^{3+}+e^{-}$ & $=F e^{2+}$ & -74.40 & (2.34) \\
\hline & $\frac{1}{2} \mathrm{NO}_{3}^{-}+H^{+}+e^{-}$ & $=\frac{1}{2} \mathrm{NO}_{2}^{-}+\frac{1}{2} \mathrm{H}_{2} \mathrm{O}$ & -40.15 & $(2.35)$ \\
\hline & $\frac{1}{8} N O_{3}^{-}+\frac{5}{4} H^{+}+e^{-}$ & $=\frac{1}{8} \mathrm{NH}_{4}^{+}+\frac{3}{8} \mathrm{H}_{2} \mathrm{O}$ & -34.50 & (2.36) \\
\hline & $\frac{1}{6} N O_{2}^{-}+\frac{4}{3} H^{+}+e^{-}$ & $=\frac{1}{6} \mathrm{NH}_{4}^{+}+\frac{1}{3} \mathrm{H}_{2} \mathrm{O}$ & -32.62 & $(2.37)$ \\
\hline & $\frac{1}{6} \mathrm{SO}_{4}^{2-}+\frac{4}{3} H^{+}+e^{-}$ & $=\frac{1}{6} \mathrm{~S}+\frac{2}{3} \mathrm{H}_{2} \mathrm{O}$ & 19.48 & $(2.38)$ \\
\hline & $\frac{1}{8} S_{4}^{2-}+\frac{19}{16} H^{+}+e^{-}$ & $=\frac{1}{16} \mathrm{H}_{2} \mathrm{~S}+\frac{1}{16} \mathrm{HS}^{-}+\frac{1}{2} \mathrm{H}_{2} \mathrm{O}$ & 21.28 & $(2.39)$ \\
\hline & $\frac{1}{4} \mathrm{SO}_{4}^{2-}+\frac{5}{4} H^{+}+e^{-}$ & $=\frac{1}{8} \mathrm{~S}_{2} \mathrm{O}_{3}^{2-}+\frac{5}{8} \mathrm{H}_{2} \mathrm{O}$ & 21.30 & $(2.40)$ \\
\hline & $\frac{1}{6} N_{2}+\frac{4}{3} H^{+}+e^{-}$ & $=\frac{1}{3} N H_{4}^{+}$ & 27.47 & $(2.41)$ \\
\hline & $H^{+}+e^{-}$ & $=\frac{1}{2} H_{2}$ & 40.46 & $(2.42)$ \\
\hline & $\frac{1}{2} S_{4}^{2-}+H^{+}+e^{-}$ & $=\mathrm{SO}_{3}^{2-}+\mathrm{H}_{2} \mathrm{O}$ & 44.33 & (2.43) \\
\hline
\end{tabular}

${ }^{\text {a }}$ Adaptado de McCarty (1975) y Sawyer et al. (1994). ${ }^{\mathrm{b}}$ Reactivos y productos en unidad de actividad, excepto $\left[\mathrm{H}^{+}\right]=10^{-7} \mathrm{M}$ 
Tabla 2.8 Energía disponible de la transformación de glucosa

\begin{tabular}{|c|c|c|c|}
\hline \multicolumn{2}{|l|}{ Oxidación aerobia de glucosa } & \multicolumn{2}{|l|}{ Oxidación anaerobia de glucosa (metanogénesis) } \\
\hline DE: glucosa a $\mathrm{CO}_{2} ; \mathrm{AE}: \mathrm{O}_{2}$ a $\mathrm{H}_{2} \mathrm{O}$ & $\begin{array}{c}\Delta \mathrm{G}^{0} \\
(\mathrm{~kJ} / \mathrm{eeq})\end{array}$ & DE: glucosa a $\mathrm{CO}_{2} ; \mathrm{AE}: \mathrm{CO}_{2}$ a $\mathrm{CH}_{4}$ & $\begin{array}{c}\Delta \mathrm{G}^{0} \\
(\mathrm{~kJ} / \mathrm{eeq})\end{array}$ \\
\hline Donador: & & Donador: & \\
\hline$\frac{1}{24} \mathrm{C}_{6} \mathrm{H}_{12} \mathrm{O}_{6}+\frac{1}{4} \mathrm{H}_{2} \mathrm{O} \rightarrow \frac{1}{4} \mathrm{CO}_{2}+\mathrm{H}^{+}+e^{-}$ & -41.96 & $\frac{1}{24} \mathrm{C}_{6} \mathrm{H}_{12} \mathrm{O}_{6}+\frac{1}{4} \mathrm{H}_{2} \mathrm{O} \rightarrow \frac{1}{4} \mathrm{CO}_{2}+\mathrm{H}^{+}+e^{-}$ & -41.96 \\
\hline Aceptor: $\frac{1}{4} \mathrm{O}_{2}+\mathrm{H}^{+}+e^{-} \rightarrow \frac{1}{2} \mathrm{H}_{2} \mathrm{O}$ & -78.14 & Aceptor: $\frac{1}{8} \mathrm{CO}_{2}+\mathrm{H}^{+}+e^{-} \rightarrow \frac{1}{8} \mathrm{CH}_{4}+\frac{1}{4} \mathrm{H}_{2} \mathrm{O}$ & 24.11 \\
\hline Neto: $\frac{1}{24} \mathrm{C}_{6} \mathrm{H}_{12} \mathrm{O}_{6}+\frac{1}{4} \mathrm{O}_{2} \rightarrow \frac{1}{4} \mathrm{CO}_{2}+\frac{1}{4} \mathrm{H}_{2} \mathrm{O}$ & -120.10 & Neto: $\frac{1}{24} \mathrm{C}_{6} \mathrm{H}_{12} \mathrm{O}_{6}=\frac{1}{8} \mathrm{CH}_{4}+\frac{1}{8} \mathrm{CO}_{2}$ & -17.85 \\
\hline $\begin{array}{l}\text { Sobre una base de } 1 \mathrm{~mol} \text { de glucosa, la ecuación } \\
\text { neta se convertiría en }(\bullet 24) \text { : } \\
\mathrm{C}_{6} \mathrm{H}_{12} \mathrm{O}_{6}+6 \mathrm{O}_{2}=6 \mathrm{CO}_{2}+6 \mathrm{H}_{2} \mathrm{O}\end{array}$ & -2882 & $\begin{array}{l}\text { Sobre una base de } 1 \mathrm{~mol} \text { de glucosa, la ecuación } \\
\text { neta se convertiría en }(\bullet 24) \text { : } \\
\mathrm{C}_{6} \mathrm{H}_{12} \mathrm{O}_{6}=3 \mathrm{CH}_{4}+3 \mathrm{CO}_{2}\end{array}$ & -428 \\
\hline
\end{tabular}

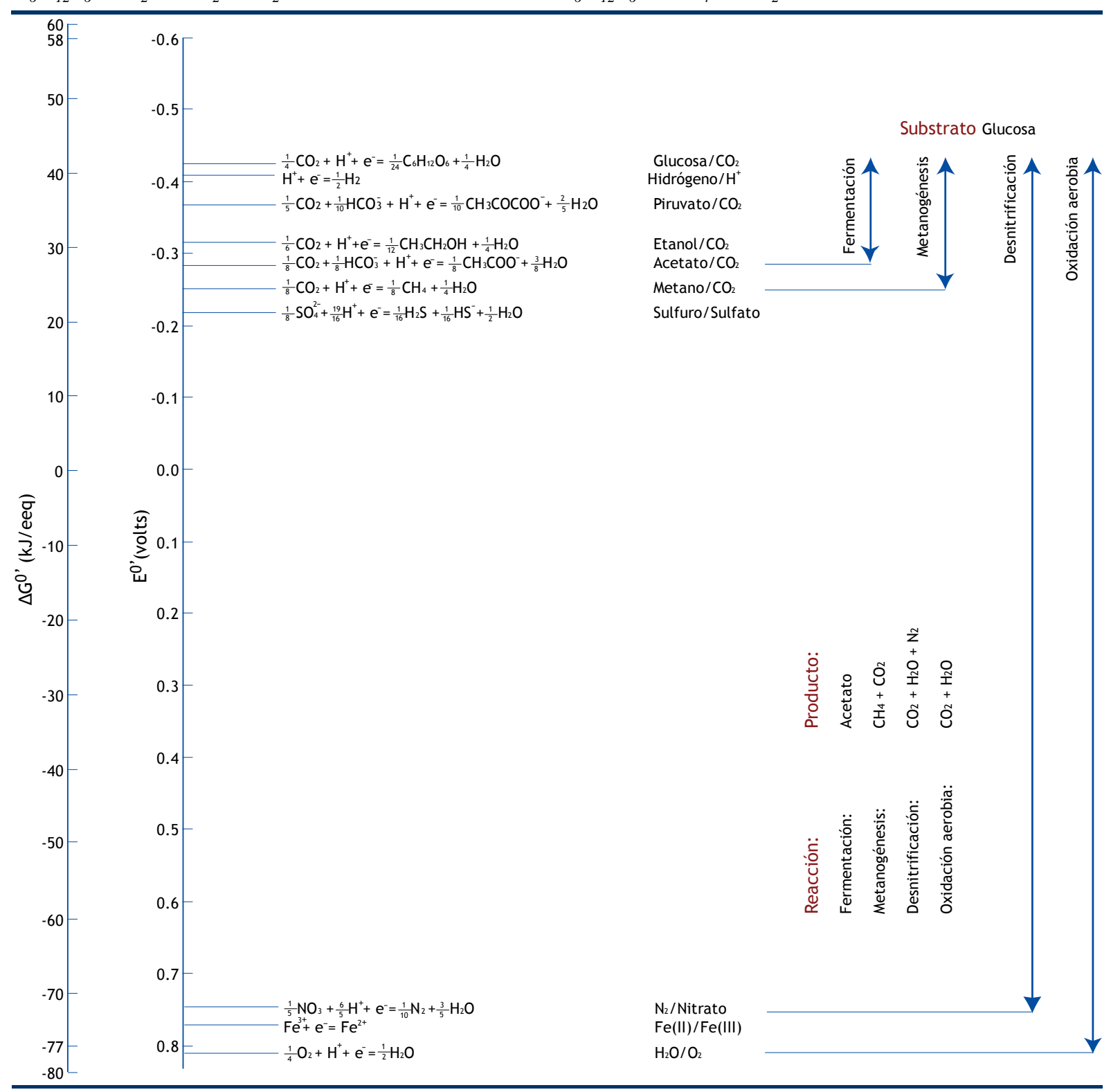

Figura 2.17 Escala de energía para pares redox con glucosa como donador de electrones (adaptado de Rittmann y McCarty, 2001) 


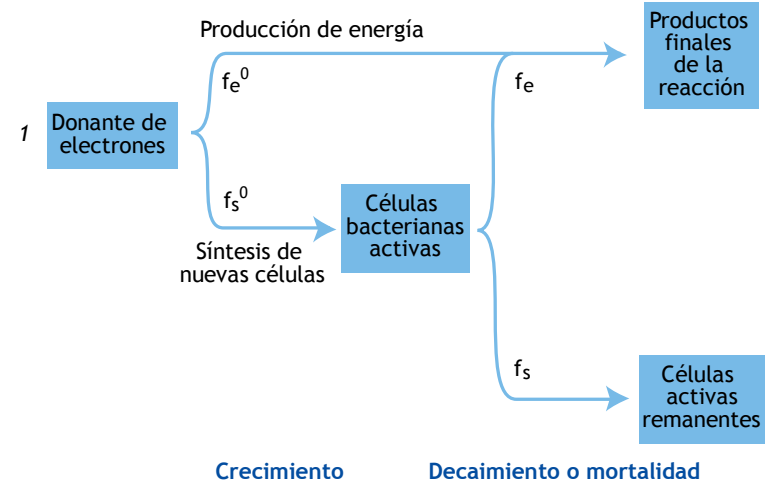

Figura 2.18 Uso del donador de electrones para la producción de energía y síntesis celular. Nota: f: fracción de los electrones donados; e: energía; s: síntesis (adaptado de Rittmann y McCarty, 2001).

Durante el decaimiento, una porción de las células bacterianas activas se convierten en donador de electrones para generar más energía y más productos finales de reacción. La división global de equivalentes de electrones entre las células activas residuales $\left(f_{s}\right.$ : fracción de síntesis observada) y productos finales de reacción ( $f_{e}$ : fracción de energía observada) sigue siendo igual a 1 .

$$
f_{s}+f_{e}=1
$$

La fracción $f_{s}^{0}$ y $f_{s}$ puede ser expresada en unidades de masa en lugar de una base eeq, y así son llamadas rendimiento verdadero (o máximo rendimiento teórico; $\mathrm{Y})$ y rendimiento observado $\left(\mathrm{Y}_{\mathrm{obs}}\right)$, respectivamente. $\mathrm{La}$ fracción $f_{s}^{0}$ puede ser usada para estimar el rendimiento verdadero $\mathrm{Y}$ :

$$
Y=\frac{f_{s}^{0} M_{c}}{8 n_{e}}
$$

donde:

$\mathrm{M}_{\mathrm{c}}$ gramos de células por mol de células empírico

8 número de gramos DQOt por eeq (ver reacción media en Ec.2.18 de Tabla

2.7)

$\mathrm{n}_{\mathrm{e}} \quad$ número de eeq por mol de células empírico por eeq

Con $\mathrm{C}_{5} \mathrm{H}_{7} \mathrm{O}_{2} \mathrm{~N}$ como fórmula empírica para las células, el peso molecular es $113 \mathrm{~g} / \mathrm{mol}$. Con amoniaco como fuente de nitrógeno para su síntesis, hay 20 eeq por mol empírico de células (Tabla 2.7, reacción en Ec. 2.15) y la ecuación anterior se puede simplificar a:

$Y=0.706 f_{s}^{o}=\frac{f_{s}^{o}}{1.42 g D Q O / g \text { células }}$

donde la proporción de 1.42 gramos DQO por gramo de células fue también calculada en la Tabla 2.6.

Similarmente, $f_{s}$, puede ser usado para estimar el rendimiento observado $\mathrm{Y}_{\mathrm{obs}}$,

$Y_{o b s}=\frac{f_{s} M_{c}}{8 n_{e}}$

\subsubsection{Rendimiento observado de la estequiometría}

Si puede obtenerse empíricamente una ecuación estequiométrica, equilibrada para la síntesis de biomasa a partir de un agua residual dada, puede calcularse el rendimiento de biomasa observado. Usando la proteína caseína para representar las aguas residuales en la experimentación de laboratorio con lodos activados, Porges et al. (1956) propuso la siguiente ecuación:

$\mathrm{C}_{8} \mathrm{H}_{12} \mathrm{O}_{3} \mathrm{~N}_{2}+3 \mathrm{O}_{2} \rightarrow$

caseína

$\rightarrow \mathrm{C}_{5} \mathrm{H}_{7} \mathrm{O}_{2} \mathrm{~N}+\mathrm{NH}_{3}+3 \mathrm{CO}_{2}+\mathrm{H}_{2} \mathrm{O}$

\begin{tabular}{|c|c|c|c|c|c|c|}
\hline & $\mathrm{C}_{8} \mathrm{H}_{12} \mathrm{O}_{3} \mathrm{~N}_{2}$ & $3 \mathrm{O}_{2}$ & $\mathrm{C}_{5} \mathrm{H}_{7} \mathrm{O}_{2} \mathrm{~N}$ & & $\begin{array}{l}1(\mathrm{Y} \\
3 \mathrm{CO}_{2}\end{array}$ & $\begin{array}{l}\text { bs) } \\
\mathrm{H}_{2} \mathrm{O}\end{array}$ \\
\hline g peso & 184 & 96 & 113 & 17 & 132 & 18 \\
\hline Suma & \multicolumn{2}{|c|}{280} & \multicolumn{4}{|c|}{280} \\
\hline g /g Caseína & 1.00 & & $0.61\left(\mathrm{Y}_{\mathrm{obs}}\right)$ & & & \\
\hline $\mathrm{g} \mathrm{DQO} / \mathrm{mol}$ & 1.42 & -1.00 & 1.39 & 0 & 0 & 0 \\
\hline g DQO & 256 & -96 & 160 & 0 & 0 & 0 \\
\hline Suma & \multicolumn{2}{|c|}{160} & \multicolumn{4}{|c|}{160} \\
\hline gDQO/gDQo & 1.00 & $0.38\left(-f_{e}\right)$ & $0.62\left(f_{s}\right)$ & & & \\
\hline
\end{tabular}

células bacterianas

Por lo tanto, el consumo de 184 g de caseína requiere $96 \mathrm{~g}$ de oxígeno y produce $113 \mathrm{~g}$ de células bacterianas y otros productos finales de reacción. Una proporción similar se espera para una planta de tratamiento de aguas residuales a gran escala durante el tratamiento de este compuesto (que es de composición similar a las aguas residuales domésticas típicas). El rendimiento 
verdadero de biomasa $(\mathrm{Y})$ es, por tanto, $0.61 \mathrm{~g}$ de biomasa por $\mathrm{g}$ de sustrato consumido (=113/184). Hay que tener en cuenta que la masa de productos es igual a la de reactivos $(280 \mathrm{~g} / \mathrm{mol}$ of caseína consumida).

Sobre la base de DQO, siendo la $\mathrm{DQO}_{\mathrm{t}}$ de caseína 1,39 g DQO/g Caseína (Tabla 2.5) da $256 \mathrm{~g} \mathrm{DQO/} \mathrm{mol}$ Caseína, y la $\mathrm{DQO}_{\mathrm{t}}$ de células bacterianas de composición C5H7NO2 siendo $1.42 \mathrm{~g} \mathrm{DQO/g} \mathrm{SSV}$, da $160 \mathrm{~g} \mathrm{DQO} / \mathrm{mol}$ Células. La fracción de síntesis observada $\left(f_{s}\right)$ es, pues, $0,62 \mathrm{~g}$ DQO/g DQO $(0.61 \times 1.42$ / 1.39).

El requerimiento de oxígeno es de $96 \mathrm{~g}$ de $\mathrm{O}_{2}$ por mol de caseína consumida, lo que corresponde a $0.52 \mathrm{~g}$ $\mathrm{O}_{2} /$ g Caseína (96/184). Por lo tanto, la fracción de la producción de energía $\left(f_{e}\right)$ es $0.38 \mathrm{~g}$ DQO de $\mathrm{O}_{2}$ por $\mathrm{g}$ DQO de caseína (0.52/1.39). Tenga en cuenta que el oxígeno tiene una DQO negativo (-1,0 g DQO / $\mathrm{g} \mathrm{O}_{2}$ ) y se mantiene el equilibrio la DQO.

$f_{s}+f_{e}=0.62+0.38=1.00$

La fracción de síntesis observada experimentalmente reportada (y no "verdadera") $\left(f_{s}\right)$ de 0.62 es bastante alta en comparación con otros valores publicados en la literatura para el tratamiento de aguas residuales. Por lo tanto, la fracción de síntesis verdadera $\left(f_{s 0}\right)$ debe ser sólo un poco más alto y las células se encontraron probablemente cerca de su fase de crecimiento exponencial, una condición en la que la fracción de energía obtenida a partir de la descomposición endógena es mínima. De hecho, el uso de la metodología que se presenta en la siguiente sección, y la reacción media y el valor de cambio de la energía libre presentado en la Tabla 2.7 para la proteína, que tiene una estructura química muy similar a la de la caseína, se puede calcular una fracción de síntesis verdadera $\left(f_{s o}\right)$ de 0.64 .

Los requerimientos de nitrógeno y fósforo para el crecimiento celular pueden ser evaluados considerando que constituyen el 12.0 y $2.0 \%$, respectivamente, de la fracción volátil de la biomasa producida (la fracción CHON) como puede ser estimado en la ecuación empírica $\mathrm{C}_{5} \mathrm{H}_{7} \mathrm{NO}_{2} \mathrm{P}_{1 / 12}$ (Tabla 2.5). En el ejemplo anterior, para $113 \mathrm{~g}$ de biomasa producida (correspondiente a $184 \mathrm{~g}$ de caseína degradada), 13,4 g de nitrógeno tendría que ser añadido, ya sea a partir de fuentes orgánicas (por ejemplo, caseína) o inorgánicas (por ejemplo, amoníaco). Del mismo modo, 2,26 g de fósforo tendría que ser añadido por $113 \mathrm{~g}$ de biomasa producida.

\subsubsection{Estimación del rendimiento verdadero a partir de la bioenergética}

La bioenergética se puede utilizar como una alternativa a la cuidadosa realización de experimentación a escala de laboratorio para determinar el verdadero (o máximo) rendimiento de una reacción. El enfoque que se presenta a continuación es una adaptación de la de Metcalf y Eddy (2003), que es una simplificación de la de Rittmann y McCarty (2001) que fue actualizado recientemente por McCarty (2007). Un enfoque alternativo ha sido desarrollado por Heijnen et al. (en preparación) que difiere principalmente de los de arriba en su estimación de la necesidad de energía anabólica por una función de disipación de energía en lugar de un factor de eficiencia. Estas referencias proporcionan detalles adicionales a los que se presenta a continuación para el desarrollo de otras reacciones media y sus cambios de energía libre, complejas reacciones de fermentación, reacciones autótrofas y condiciones no estándar.

El procedimiento simplificado que se presenta a continuación se divide en 4 etapas que consisten en determinar, (i) la energía proporcionada desde el catabolismo conociendo el donador de electrones, el aceptor de electrones y la fuente de nitrógeno para el crecimiento, (ii) la energía necesaria para la síntesis celular (anabolismo), (iii) la energía necesaria para la reacción global de crecimiento (metabolismo) y (iv) el coeficiente de rendimiento verdadero $(\mathrm{Y})$.

\section{A. Reacción que proporciona energía (catabolismo)}

La metodología para desarrollar la reacción y la producción de energía de Gibbs asociada para la reacción catabólica del donador de electrones (DE) y el aceptor de electrones (AE) fue presentado en la sección 2.3.3.1. El método de Rittman y McCarty (2001) supone que sólo una fracción (40 a $80 \%$, típicamente $60 \%$ ) de la energía disponible de una reacción de oxidación-reducción se utiliza en el anabolismo, mientras que el resto se pierde en forma de calor.

$\Delta G_{\text {cata }}=K \Delta G_{R}$

donde:

$\Delta \mathrm{G}_{\text {cata }}$ energía de Gibbs disponible para catabolismo de 1 eeq of DE (kJ/eeq) 
K fracción de energía transferida capturada (típicamente 0.60)

$\Delta \mathrm{G}_{\mathrm{R}}$ energía de Gibbs liberada por 1 eeq of DE (kJ/eeq)

\section{B. Energía requerida para síntesis de células (anabolismo)}

La energía necesaria para la síntesis de biomasa heterótrofa de un donador de electrones se calcula considerando piruvato como intermedio metabólico central y una fuente de nitrógeno para la síntesis de la biomasa.

$$
\Delta G_{\text {ana }}=\frac{\Delta G_{P}}{K^{m}}+\Delta G_{c}+\frac{\Delta G_{N}}{K}
$$

donde:

$\Delta \mathrm{G}_{\mathrm{ana}} \quad$ enegía de Gibbs requerida para anabolismo de 1 eeq of $\mathrm{DE}(\mathrm{kJ} /$ eeqDE)

$\Delta \mathrm{G}_{\mathrm{p}} \quad$ enegía de Gibbs requerida para convertir 1 eeq de $\mathrm{DE}$ en piruvato (kJ/eeqDE)

m constante: +1 si $\Delta \mathrm{G}_{\mathrm{p}}$ es positivo (endergónica) y -1 si $\Delta \mathrm{G}_{\mathrm{p}}$ es negativo (exergónica)

$\Delta \mathrm{G}_{\mathrm{c}} \quad$ enegía de Gibbs requerida para convertir 1 eeq de piruvato a células $=31.41 \mathrm{~kJ} / \mathrm{eeq}$ Células

$\Delta \mathrm{G}_{\mathrm{N}} \quad$ energía libre requerida por eeq de células para reducir nitrógeno a amoníaco $(\mathrm{kJ} / \mathrm{eeq}$ Células) $=17.46,13.61,15.85,0.00$ para $\mathrm{NO}_{3}{ }^{-}, \mathrm{NO}_{2}{ }^{-}, \mathrm{N}_{2}$ y $\mathrm{NH}_{4}{ }^{+}$, respectivamente.

El primer término de la ecuación describe la conversión del donador de electrones a piruvato, tiene un exponente $\mathrm{m}$ en la fracción eficiencia $\mathrm{K}$. En caso de que $\Delta G_{p}$ sea positivo, como sería el caso para el acetato de ser transformado en piruvato, esta reacción requeriría energía (endergónica) y el valor positivo de $\mathrm{m}$ resulta en un valor mayor (más energía necesaria) para este primer paso. En caso de que $\Delta \mathrm{G}_{\mathrm{p}}$ sea negativo, como sería el caso cuando la glucosa se transforma en piruvato, esta reacción liberaría energía (exergónica) y el valor negativo de m resultaría en un valor más bajo (menos energía necesaria).

\section{Energía total para la reacción de crecimiento (metabolismo)}

Dos ecuaciones de balance de masa pueden ser escritas, una que ya fue presentada para el donador de electrones para que sus electrones se utilicen en la obtención de energía y la síntesis (Ec. 2.53). $f_{e}^{0}+f_{s}^{0}=1$

y otra para la energía, donde se consume tanta energía en el anabolismo como la proporcionada por el catabolismo. El signo negativo representa el hecho de que el anabolismo consume en lugar de producir energía:

$-f_{s}^{0} \Delta \mathrm{G}_{\mathrm{ana}}=f_{e}^{0} \Delta \mathrm{G}_{\mathrm{cata}}$

Esta ecuación puede ser reescrita para visualizar que la energía necesaria para el crecimiento celular (anabolismo) es proporcionada por la energía liberada por el catabolismo, multiplicado por la proporción de DE oxidado a DE usado para la síntesis de células.

$-\Delta G_{\text {ana }}=\frac{f_{e}^{0}}{f_{s}^{0}} \Delta G_{c a t a}$

Puede ser reescrito para resolver las incógnitas $\left(f_{e}^{0} / f_{s}^{0}\right)$

$\frac{f_{e}^{0}}{f_{s}^{0}}=-\frac{\Delta G_{a n a}}{\Delta G_{\text {cata }}}$

Del balance de masa del DE, se pueden determinar $f_{s}^{0}$ and $f_{e}^{0}$

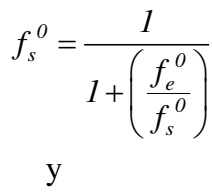

$f_{e}^{0}=1-f_{s}^{0}$

\section{Rendimiento verdadero $(Y)$}

El rendimiento verdadero, $\mathrm{Y}$, puede entonces ser expresado en fracción de masa una vez que $f_{s}^{0}$ ha sido determinado por medio de la Ec. 2.47 presentada anteriormente para una ecuación empírica de biomasa $\mathrm{C}_{5} \mathrm{H}_{7} \mathrm{O}_{2} \mathrm{~N}$ producido con amoníaco como fuente de nitrógeno.

$Y=0.706 f_{s}^{o}=\frac{f_{s}^{o}}{1.42 g \text { DQO } / g \text { células }}$

A continuación se presenta un ejemplo para estimar el rendimiento verdadero con bioenergética. 
2.3.3.5 Ejemplo: Estimar el rendimiento verdadero a partir de la bioenergética para la oxidación aerobia de glucosa con amoníaco como fuente de nitrógeno

A. Reacción que proporciona energía (catabolismo)

La reacción y la energía disponible a partir de la oxidación aerobia de la glucosa se desarrollaron previamente de las reacciones medias.

$$
\frac{1}{24} \mathrm{C}_{6} \mathrm{H}_{12} \mathrm{O}_{6}+\frac{1}{4} \mathrm{O}_{2}=\frac{1}{4} \mathrm{CO}_{2}+\frac{1}{4} \mathrm{H}_{2} \mathrm{O}
$$

$-120.10 \mathrm{~kJ} / \mathrm{eeq}$

$\mathrm{y}$

$\Delta G_{\text {cata }}=K \Delta G_{R}=0.6 \times(-120.10)=-72.06 \mathrm{~kJ} / \mathrm{eeq}$

$\frac{1}{24} \mathrm{C}_{6} \mathrm{H}_{12} \mathrm{O}_{6}+\frac{1}{4} \mathrm{H}_{2} \mathrm{O}=\frac{1}{4} \mathrm{CO}_{2}+\mathrm{H}^{+}+e^{-}$

\section{B. Energía requerida para síntesis de células} (anabolismo)

La reacción y la energía de Gibbs necesaria para convertir 1 eeq de glucosa a piruvato es:

DE:

$\frac{1}{24} \mathrm{C}_{6} \mathrm{H}_{12} \mathrm{O}_{6}+\frac{1}{4} \mathrm{H}_{2} \mathrm{O}=\frac{1}{4} \mathrm{CO}_{2}+\mathrm{H}^{+}+e^{-}$

$\left(\Delta \mathrm{G}^{0}=-41.96 \mathrm{~kJ} / \mathrm{eeq}\right)$

AE:

$\frac{1}{5} \mathrm{CO}_{2}+\frac{1}{10} \mathrm{HCO}_{3}+\mathrm{H}^{+}+e^{-}=$

$\frac{1}{10} \mathrm{CH}_{3} \mathrm{COCOO}^{-}+\frac{2}{5} \mathrm{H}_{2} \mathrm{O}$

$\left(\Delta \mathrm{G}^{0^{\prime}}=+35.78 \mathrm{~kJ} / \mathrm{eeq}\right)$

Neto:

$\frac{1}{24} \mathrm{C}_{6} \mathrm{H}_{12} \mathrm{O}_{6}+\frac{1}{20} \mathrm{H}_{2} \mathrm{O}+\frac{1}{5} \mathrm{CO}_{2}+\frac{1}{10} \mathrm{HCO}_{3}^{-}=$

$\frac{1}{10} \mathrm{CH}_{3} \mathrm{COCOO}^{-}+\frac{1}{4} \mathrm{H}_{2} \mathrm{O}$

$\left(\Delta \mathrm{G}^{0}=-6.18 \mathrm{~kJ} / \mathrm{eeq}\right)$

y:

DE: $\quad$ glucosa a $\mathrm{CO}_{2} ;\left(\Delta \mathrm{G}^{0}, \mathrm{~kJ} / \mathrm{eeq}\right)$

AE: $\quad \mathrm{CO}_{2}$ a piruvato, $\left(\Delta \mathrm{G}^{0^{\prime}}, \mathrm{kJ} / \mathrm{eeq}\right)$

$\Delta \mathrm{G}_{\mathrm{p}} \quad-6.18 \mathrm{~kJ} / \mathrm{eeq}$

M $\quad-1\left(\Delta \mathrm{G}_{\mathrm{p}}\right.$ es negativo $)$ así mismo:

$\mathrm{K} \quad 0.6$

$\Delta \mathrm{G}_{\mathrm{c}} \quad 31.41 \mathrm{~kJ} / \mathrm{eeq}$ Células

$\Delta \mathrm{G}_{\mathrm{N}} \quad 0.00 \mathrm{~kJ} /$ eeq Células con $\mathrm{NH}_{4}{ }^{+}$como fuente de nitrógeno

por lo tanto:

$$
\begin{aligned}
\Delta \mathrm{G}_{\text {ana }} & =\left(\Delta \mathrm{G}_{\mathrm{p}} / \mathrm{K}^{\mathrm{m}}\right)+\Delta \mathrm{G}_{\mathrm{c}}+\left(\Delta \mathrm{G}_{\mathrm{N}} / \mathrm{K}\right) \\
& =\left(-6.18 / 0.6^{-1}\right)+31.41+0 \\
& =+27.70 \mathrm{~kJ} / \mathrm{eeq}
\end{aligned}
$$

\section{Energía total para la reacción de crecimiento (metabolismo)}

La proporción de las fracciones $f_{e}^{0} / f_{s}^{0}$ ahora puede ser calculada

$$
f_{e}^{o} / f_{s}^{o}=-\left(\frac{\Delta G_{\text {ana }}}{\Delta G_{\text {cata }}}\right)=-\left(\frac{27.70}{-72.06}\right)=0.38
$$

$\mathrm{y}$

$f_{s}^{0}=1 /\left(1+\left(f_{e}^{o} / f_{s}^{0}\right)\right)=1 /(1+0.38)$

$=0.72 \mathrm{~g}$ Células DQO $/ \mathrm{g}$ DQO consumido

$f_{e}^{0}=1-f_{s}^{0}=0.28 \mathrm{~g}$ DQO $/ \mathrm{g}$ DQO consumido

\section{Rendimiento verdadero en unidades de masa}

El rendimiento verdadero en unidades de masa, considerando una ecuación empírica de biomasa $\mathrm{C}_{5} \mathrm{H}_{7} \mathrm{O}_{2} \mathrm{~N}$ es:

$$
Y=\frac{f_{s}^{0}}{1.42}=0.51 \mathrm{~g} \mathrm{SSV} / \mathrm{g} \text { DQO consumido }
$$

\subsection{CINÉTICA}

\subsubsection{Tasa de utilización de sustrato}

La tasa de utilización del sustrato por las bacterias depende de una serie de factores que son característicos de un grupo microbiano dado. Los parámetros más importantes son la velocidad máxima de la utilización del sustrato y constantes de saturación media e inhibición.

\subsubsection{Función de saturación}

La tasa de utilización del sustrato microbiano depende principalmente de su tasa de utilización máxima de sustrato, la cantidad de biomasa presente y la concentración de sustrato utilizado para el crecimiento.

$r_{s}=k M_{s} X$ 
donde:

$\mathrm{r}_{\mathrm{s}} \quad$ tasa de utilización de sustrato $\left(\mathrm{g} \mathrm{DQO} / \mathrm{m}^{3} . \mathrm{h}\right)$

k máxima tasa específica de utilización de sustrato (g DQO/gSSV.h)

$\mathrm{M}_{\mathrm{S}} \quad$ función de saturación de sustrato soluble $\mathrm{S}_{\mathrm{S}}$ (g DQO/g DQO)

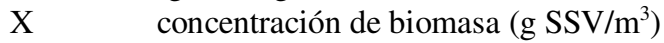

El efecto de la concentración de sustrato sobre la velocidad de reacción es considerado por la función de saturación.

$$
M_{S}=\frac{S_{S}}{\left(K_{S}+S_{S}\right)}
$$

donde:

$\mathrm{S}_{\mathrm{S}} \quad$ concentración del sustrato $\left(\mathrm{g} \mathrm{DQO} / \mathrm{m}^{3}\right)$

$\mathrm{K}_{\mathrm{S}} \quad$ constante saturación media sustrato ( $\mathrm{g}$ $\mathrm{DQO} / \mathrm{m}^{3}$ )

La función de saturación $\left(\mathrm{M}_{\mathrm{S}}\right)$ varía de 0 a 1 como función de la concentración de sustrato disponible en solución cerca de la biomasa (Figura 2.19).

La tasa de utilización del sustrato es nula en ausencia de sustrato. A la concentración constante de saturación media, el valor de la función de saturación es de 0,5 y la tasa de utilización del sustrato es la mitad del valor máximo. A nueve veces el valor de saturación media, la tasa de utilización de sustrato es $90 \%$ de su máximo y a una concentración infinitamente alta, la función de saturación alcanza un valor de 1.0 y la tasa de utilización del sustrato está en su valor máximo.

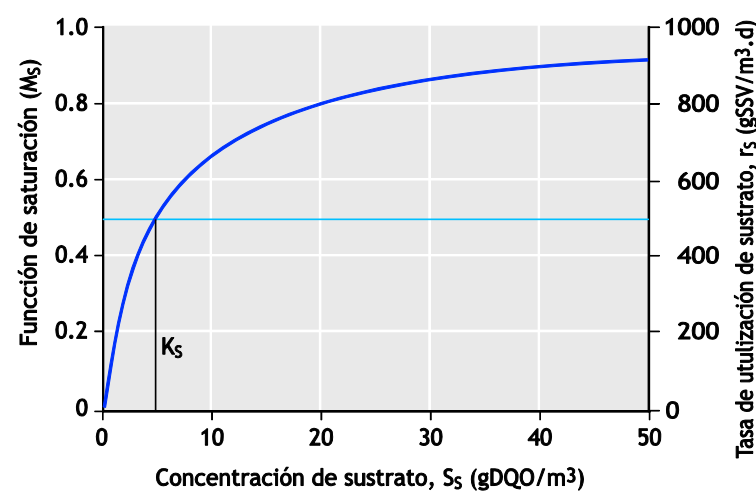

Figura 2.19 Efecto de la concentración de sustrato en la función saturación y cinética de la utilización de sustrato. Constantes usadas fueron: $\mathrm{K}_{\mathrm{s}}=5 \mathrm{gDQO} / \mathrm{m}^{3}, \mathrm{k}=4 \mathrm{gDQO} / \mathrm{gSSV} . \mathrm{d}, \mathrm{X}=250$ $\mathrm{gSSV} / \mathrm{m}^{3}$
El efecto de otros nutrientes limitantes (por ejemplo, oxígeno, amoníaco, fosfato) también podría considerarse en esta formulación de la tasa de utilización de sustrato mediante la multiplicación de las diferentes funciones de saturación (también llamadas funciones de conmutación).

$r_{S}=k M_{S} M_{S_{2}} M_{S H_{3}} M_{S P O_{4}} X$

donde $\mathrm{M}_{\mathrm{SO} 2}, \mathrm{M}_{\mathrm{SNH} 3}$ y $\mathrm{M}_{\mathrm{SPO} 4}$ representan las funciones de saturación para oxígeno, amoníaco y fosfato, respectivamente.

Según la ley de Liebig del mínimo, sin embargo, el crecimiento se considera que está limitado por sólo un nutriente. Por lo tanto, una formulación más apropiada sería considerar sólo el mínimo de las diversas funciones de saturación en la ecuación anterior.

La Ec. 2.62 necesita un ajuste con el operador MIN que se aplica a las funciones entre paréntesis y no a $\mathrm{k}$ :

$r_{s}=k \cdot \operatorname{MIN}\left(M_{S} M_{\mathrm{SO}_{2}} M_{\mathrm{SNH} 3} M_{\mathrm{SPO} 4}\right) \cdot X$

\subsubsection{Función de inhibición}

En presencia de un compuesto inhibidor, una función de saturación puede usarse para disminuir la tasa de utilización de sustrato.

$r_{S}=k I_{I} X$

donde:

I $\quad$ función de inhibición para el compuesto inhibidor $(\mathrm{g} / \mathrm{g})$

Una forma de la función de inhibición que se utiliza comúnmente es la siguiente.

$I_{I}=\frac{K_{I}}{\left(K_{I}+S_{I}\right)}$

donde:

$\mathrm{K}_{\mathrm{I}} \quad$ constante media de inhibición para el compuesto inhibidor $\left(\mathrm{g} / \mathrm{m}^{3}\right)$

$\mathrm{S}_{\mathrm{I}} \quad$ concentración del compuesto inhibidor $\left(\mathrm{g} / \mathrm{m}^{3}\right)$ 
El efecto de variar la concentración inhibidora de 0 a 10 veces su valor medio de saturación se ilustra en la Figura 2.20.

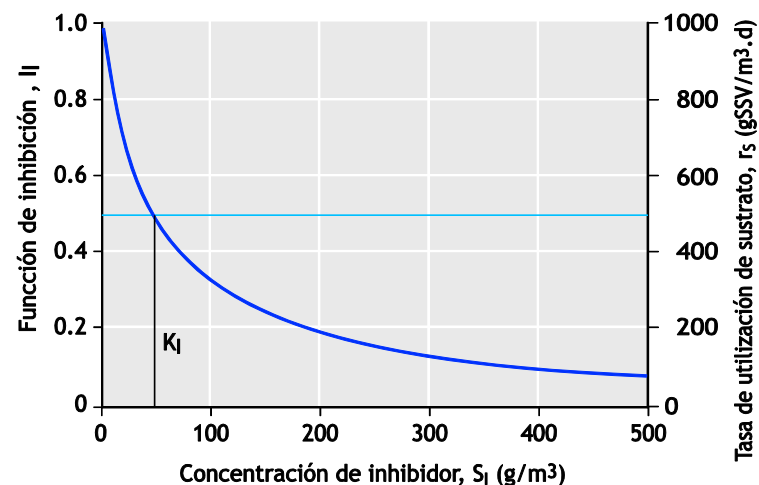

Figura 2.20 Cinética de inhibición. Constantes usadas fueron: $\mathrm{K}_{\mathrm{I}}$ $=50 \mathrm{~g} / \mathrm{m}^{3}, \mathrm{k}=4 \mathrm{gDQO} / \mathrm{gSSV} . \mathrm{d}, \mathrm{X}=250 \mathrm{gSSV} / \mathrm{m}^{3}$

La función de inhibición que se considera aquí tiene un efecto de espejo a la de la función de saturación. Ningún efecto sobre la tasa de utilización del sustrato se ve en un valor nulo de la concentración de inhibidor. A la concentración constante de saturación media, el valor de la función de inhibición es de 0,5 y la tasa de utilización del sustrato es la mitad del valor máximo. A nueve veces el valor de saturación media, la tasa de utilización del sustrato es sólo el 10\% de su máximo y a una concentración de inhibidor infinitamente alto, la tasa de utilización del sustrato se inhibe completamente. Más detalles sobre la inhibición se proporcionan en el Capítulo 10.

\subsubsection{Tasa de crecimiento}

Cuando la tasa de utilización del sustrato está en su máximo, la tasa de crecimiento también está en su máximo y su relación es, en teoría, el rendimiento verdadero.

$\mu_{\max }=Y k$

donde:

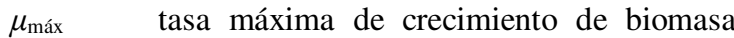
(gSSV/gSSV.d)

La tasa de crecimiento de una biomasa depende de su tasa de utilización de sustrato para la síntesis celular y en su velocidad de decaimiento que es proporcional a la concentración de biomasa presente.

$r_{g}=Y r_{s}-b X$ donde:

$r_{g}$ tasa de crecimiento de biomasa (g $\left.\mathrm{SSV} / \mathrm{m}^{3} \cdot \mathrm{d}\right)$

b tasa específica de decaimiento de biomasa (gSSV/gSSV.d)

Sustituyendo en las ecuaciones presentadas anteriormente:

$$
\begin{aligned}
& r_{g}=Y \quad k \quad M_{S} X-b X \\
& r_{g}=\mu_{\max } M_{S} X-b X \\
& r_{g}=\mu_{\max }\left(\frac{S_{S}}{K_{S}+S_{S}}\right) X-b X
\end{aligned}
$$

La tasa específica de crecimiento se obtiene dividiendo la tasa de crecimiento por la concentración de biomasa (Ec 2.71).

$$
\mu=\frac{r_{g}}{X}
$$

donde:

$\mu \quad$ tasa específica de crecimiento de biomasa (gSSV/gSSV.d)

O

$$
\mu=\mu_{\max }\left(\frac{S_{S}}{K_{S}+S_{S}}\right)-b
$$

$$
\mu=Y k\left(\frac{S_{S}}{K_{S}+S_{S}}\right)-b
$$

El efecto de la concentración de sustrato en la tasa de crecimiento específico, calculado a partir de la ecuación anterior, se ilustra en la Figura 2.21. Los siguientes aspectos son evidentes a partir de ese gráfico:

(i) La tasa específica de crecimiento máxima se obtiene en una elevada (infinita) concentración de sustrato en cuyo punto:

$$
M_{S}=\frac{S_{s}}{\left(K_{S}+S_{S}\right)}=1
$$

y

$$
\mu_{\max }=Y k-b
$$


(ii) La concentración de sustrato mínima requerida en el que la tasa de síntesis de la célula sólo es igual a su velocidad de decaimiento es cuando la tasa de crecimiento específico $(\mu)$ es cero, lo que da:

$S_{\text {Smin }}=\frac{b K_{S}}{Y k-b}$

donde:

$\mathrm{S}_{\text {Smín }} \quad$ concentración mínima necesaria para lograr una tasa de crecimiento nula ( $\mathrm{g}$ DQO $/ \mathrm{m}^{3}$ )

(iii) una concentración de sustrato nula $\left(\mathrm{S}_{\mathrm{S}}=0 \mathrm{~g} \mathrm{DQO}\right.$ $/ \mathrm{m}^{3}$ ), la tasa de crecimiento específico se vuelve negativa y es igual a la tasa de decaimiento.

$$
\mu=-b
$$

\subsubsection{Valores de parámetros estequiométricos y cinéticos}

Los valores típicos de los parámetros estequiométricos y cinéticos para varios grupos de bacterias se presentan en la Tabla 2.9. En general, un $\mathrm{fs}^{0}$ mayor (o rendimiento verdadero, Y) resulta en una mayor máxima tasa de crecimiento específico ( $\left.\mu_{\text {máx. }}\right)$ que se traduce en tasas de eliminación específica más alta $\left(\mathrm{k}=\mu_{\text {máx. }}\right.$ / Y $)$.

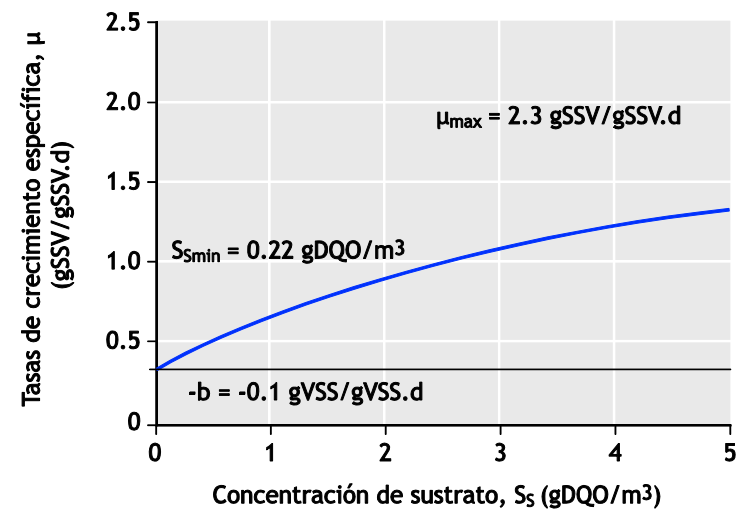

Figura 2.21 Efecto de la concentración del sustrato en la tasa de crecimiento de biomasa. Constantes usadas fueron $b=0.1$ gSSV/gSSV.d, $\mathrm{k}=4 \mathrm{gSSV} / \mathrm{gSSV} . \mathrm{d}, \mathrm{K}_{\mathrm{s}}=5 \mathrm{gDQO} / \mathrm{m}^{3}, \mathrm{Y}=0.6$ gSSV/gDQO

Tabla 2.9 Valores típicos de parámetros de estequiometría $\left(\mathrm{fs}_{\mathrm{s}}^{\circ}, \mathrm{Y}\right)$ y cinética $\left(\mathrm{q}_{\max }, \mu_{\max }\right.$ para varios grupos bacterianos (adaptada de Rittmann y McCarty 2001)

\begin{tabular}{|c|c|c|c|c|c|c|}
\hline Donador de electrones & & $\begin{array}{l}\text { Aceptor de } \\
\text { electrones }\end{array}$ & $\mathrm{fs}_{\mathrm{s}}^{0}$ & $\mathrm{Y}$ & $\mu_{\text {máx }}$ & $\mathrm{K}$ \\
\hline Grupo microbiano & Donador $\mathrm{e}^{-}$ & & & & & \\
\hline \multicolumn{7}{|l|}{ Quimiorganótrofos } \\
\hline Heterótrofos aerobios & Azúcar & $\mathrm{O}_{2}$ & 0.70 & $0.49 \mathrm{gSSV} / \mathrm{gbDQO}$ & 13.2 & $27.0 \mathrm{~g} \mathrm{bDQO} / \mathrm{gSSV} . \mathrm{d}$ \\
\hline Heterótrofos aerobios & No azúcar & $\mathrm{O}_{2}$ & 0.60 & $0.42 \mathrm{gSSV} / \mathrm{gbDQO}$ & 8.4 & $17.0 \mathrm{~g} \mathrm{bDQO} / \mathrm{gSSV} . \mathrm{d}$ \\
\hline Desnitrificantes & Orgánico & $\mathrm{NO}_{3}^{-}, \mathrm{NO}_{2}^{-}$ & 0.50 & $0.25 \mathrm{gSSV} / \mathrm{gbDQO}$ & 4.0 & $16.0 \mathrm{~g} \mathrm{bDQO} / \mathrm{gSSV} . \mathrm{d}$ \\
\hline $\begin{array}{l}\text { Organismos } \\
\text { Fermentadores }\end{array}$ & Azúcar & Orgánico & 0.18 & $0.18 \mathrm{gSSV} / \mathrm{gbDQO}$ & 1.2 & $10.0 \mathrm{~g} \mathrm{bDQO} / \mathrm{gSSV} . \mathrm{d}$ \\
\hline Sulfato reductores & Acetato & $\mathrm{SO}_{4}^{2-}$ & 0.08 & $0.057 \mathrm{gSSV} / \mathrm{gbDQO}$ & 0.5 & $8.7 \mathrm{~g} \mathrm{bDQO} / \mathrm{gSSV} . \mathrm{d}$ \\
\hline $\begin{array}{l}\text { Metanógenos } \\
\text { (acetoclásticos) }\end{array}$ & Acetato & Acetato & 0.05 & $0.035 \mathrm{gSSV} / \mathrm{gbDQO}$ & 0.3 & $8.4 \mathrm{~g} \mathrm{bDQO} / \mathrm{gSSV} . \mathrm{d}$ \\
\hline \multicolumn{7}{|l|}{ Quimiolitótrofos } \\
\hline Nitrificantes :AOB & $\mathrm{NH}_{4}^{-}$ & $\mathrm{O}_{2}$ & 0.14 & $0.34 \mathrm{gSSV} / \mathrm{gNH}_{4}-\mathrm{N}$ & 0.9 & $2.7 \mathrm{~g} \mathrm{NH}_{4}-\mathrm{N} / g S S V . d$ \\
\hline Nitrificantes :NOB & $\mathrm{NO}_{2}^{-}$ & $\mathrm{O}_{2}$ & 0.10 & $0.08 \mathrm{gSSV} / \mathrm{gNO}_{2}-\mathrm{N}$ & 0.5 & $1.1 \mathrm{~g} \mathrm{NO}_{2}-\mathrm{N} / \mathrm{gSSV} . \mathrm{d}$ \\
\hline $\begin{array}{l}\text { Metanógenos } \\
\text { (hidrogenotróficos) }\end{array}$ & $\mathrm{H}_{2}$ & $\mathrm{CO}_{2}$ & 0.08 & $0.45 \mathrm{gSSV} / \mathrm{gH}_{2}$ & 0.3 & $1.1 \mathrm{~g} \mathrm{H}_{2} / \mathrm{gSSV} . \mathrm{d}$ \\
\hline
\end{tabular}

bDQO: DQO biodegradable. AOB: bacterias oxidantes de amonio. NOB: bacterias oxidantes de nitrito.

$\mu_{\max }$ en $\mathrm{g} \mathrm{SSV} / \mathrm{g} \mathrm{SSVd}$

$\mathrm{k}=\mu_{\max } / \mathrm{Y}=\mathrm{r}_{\max }$ específica (por unidad de biomasa) 


\section{REFERENCIAS}

Comeau Y., Hall K.J., Hancock R.E.W. and Oldham W. K. (1986) Biochemical model for biological enhanced phosphorus removal. Wat. Res. 20, 1511-1521.

Eikelboom D.H. (2000) Process Control of Activated Sludge Plants by Microscopic Investigation ISBN: 9781900222297 , pg.156

Heijnen J.J., Kleerebezem R. and van Loosdrecht M.C.M. (in preparation) A generalized method for thermodynamic state analysis of environmental systems.

Kampschreur M.J. Tan N.C.G., Kleerebezem R., Picioreanu C., Jetten M.S.M., van Loosdrecht M.C.M. (2008) Effect of dynamic process conditions on nitrogen oxides emission from a nitrifying culture. Environ. Sci. Techn., 42(2), 429-435.

McCarty P.L. (2007) Thermodynamic electron equivalents model for bacterial yield prediction: Modifications and comparative evaluations. Biotech. Bioeng. 97(2), 377 388.

Metcalf \& Eddy Inc. (2003) Wastewater Engineering Treatment and Reuse, $4^{\text {th }}$ ed., McGraw-Hill, New York.

Madigan M.T. and Martinko J.M. (2006) Brock Biology of Microorganisms (11 th ed.). San Francisco, CA, Pearson Education, Inc.

Rittmann B.E. and McCarty P.L. (2001) Environmental Biotechnology - Principles and Applications. New York, McGraw-Hill.

Todar K. (2007) Microbial metabolism (Electronic version). Retrieved September 17, 2007 from http://www.bact.wisc.edu/themicrobialworld/metabolis m.html

\section{NOMENCLATURA}

\begin{tabular}{|c|c|c|}
\hline \multicolumn{2}{|c|}{ Símbolo Descripción } & \multirow{2}{*}{$\begin{array}{l}\text { Unidades } \\
\text { gSSV/SSV.d }\end{array}$} \\
\hline $\mathrm{b}$ & Tasa específica de decaimiento de biomasa & \\
\hline$f_{e}$ & Fracción de energía observada por DQO usado & gDQO/gDQO \\
\hline$f_{e}{ }^{0}$ & Fracción verdadera de energía por DQO usado & gDQO/gDQO \\
\hline$f_{s}$ & Fracción de síntesis observada por DQO usada & gDQO/gDQO \\
\hline$f_{s}^{0}$ & Fracción verdadera de síntesis por DQO usado & gDQO/gDQO \\
\hline$I_{I}$ & Función de inhibición para el compuesto inhibidor & $\mathrm{g} / \mathrm{g}$ \\
\hline$k$ & Máxima tasa específica de utilización de sustrato & gDQO/gSSV.h \\
\hline$K$ & Fracción de energía transferida capturada & $\mathrm{kJ} / \mathrm{kJ}$ \\
\hline$K_{I}$ & Constante media de saturación para el compuesto inhibidor & $\mathrm{g} / \mathrm{m}^{3}$ \\
\hline$K_{S}$ & Constante media de saturación para el sustrato & $\mathrm{gDQO} / \mathrm{m}^{3}$ \\
\hline$m$ & Constante: +1 si $\Delta \mathrm{Gp}$ es positivo y -1 si $\Delta \mathrm{Gp}$ is negativo & \\
\hline$M_{c}$ & Peso de células por mol empírico de células & $\mathrm{g} / \mathrm{mol}$ \\
\hline$M_{S}$ & Función de saturación para sustrato soluble SS & gDQO/gDQO \\
\hline$n_{e}$ & Número de electrones equivalentes por mol empírico de células & $\mathrm{eeq} / \mathrm{mol}$ \\
\hline$r_{g}$ & Tasa de crecimiento de biomasa & $\mathrm{gSSV} / \mathrm{m}^{3} \cdot \mathrm{d}$ \\
\hline$r_{S}$ & Tasa de utilización de sustrato & $\mathrm{g} \mathrm{DQO} / \mathrm{m}^{3} \cdot \mathrm{h}$ \\
\hline$S_{I}$ & Concentración del compuesto inhibidor & $\mathrm{g} / \mathrm{m}^{3}$ \\
\hline$S_{S}$ & Concentración del sustrato & $\mathrm{gDQO} / \mathrm{m}^{3}$ \\
\hline$S_{\text {Smin }}$ & Concentración mínima requerida para alcanzar una tasa de crecimiento nula & $\mathrm{gDQO} / \mathrm{m}^{3}$ \\
\hline$X$ & Concentración de biomasa & $\mathrm{gSSV} / \mathrm{m}^{3}$ \\
\hline Y & Rendimiento verdadero & gSSV/gDQO \\
\hline$Y_{o b s}$ & Rendimiento observado & $\mathrm{gSSV} / \mathrm{gDQO}$ \\
\hline$\Delta G_{\text {ana }}$ & energía de Gibbs requerida para el anabolismo de 1 eeq de donador de electrones (DE) & $\mathrm{kJ} / \mathrm{eeqDE}$ \\
\hline$\Delta G_{c}$ & enegía de Gibbs requerida para convertir 1 eeq de piruvato a células & $\mathrm{kJ} / \mathrm{eeqDE}$ \\
\hline$\Delta G_{\text {cata }}$ & energía de Gibbs disponible para catabolismo de 1 eeq de DE & $\mathrm{kJ} / \mathrm{eeq}$ \\
\hline$\Delta G_{N}$ & energía libre requerida por eeq de células para reducir nitrógeno a amoníaco & $\mathrm{kJ} / \mathrm{eeqDE}$ \\
\hline
\end{tabular}


$\Delta G^{o^{\prime}} \quad$ Cambio en la energía libre de Gibbs en condiciones estándares $\left(25^{\circ} \mathrm{C}, 1 \mathrm{M}, 1 \mathrm{~atm}\right)$ pero $\mathrm{pH} 7 \mathrm{~kJ} / \mathrm{mol}$

$\Delta G_{p}$ enegía de Gibbs requerida para convertir 1 eeq de DE a piruvato $\mathrm{kJ} / \mathrm{eeqDE}$

$\Delta G_{R} \quad$ energía de Gibbs liberada por 1 eeq de DE $\quad \mathrm{kJ} / \mathrm{eeq}$

\section{ABREVIACIONES}

\begin{tabular}{|c|c|}
\hline Abreviación & Descripción \\
\hline$\overline{\mathrm{ADP}}$ & Difosfato de adenosina \\
\hline $\mathrm{ADN}$ & Ácido desoxiribonucleico \\
\hline AMP & Monofosfato de adenosina \\
\hline AN & Anaerobio \\
\hline $\mathrm{AOB}$ & Bacterias oxidantes de amonio (por sus siglas en inglés ammonia oxidizing bacteria) \\
\hline ARN & Ácido ribonucleico \\
\hline ATP & Trifosfato de adenosina \\
\hline $\mathrm{AX}$ & Anóxico \\
\hline CTE & Cadena de transporte de electrones \\
\hline bDQO & DQO Biodegradable \\
\hline DQO & Demanda química de oxígeno \\
\hline $\mathrm{DQO}_{\mathrm{t}}$ & Demanda teórica química de oxígeno \\
\hline DGGE & Electroforesis en gel con gradiente desnaturalizante \\
\hline $\mathrm{Fi}$ & Fósforo inorgánico \\
\hline FISH & Hibridación fluorescente in situ (por sus siglas en inglés Fluorescence in situ Hybridization) \\
\hline FMP & Fuerza motriz de protones \\
\hline NOB & Bacterias oxidantes de nitrito (por sus siglas en inglés nitrite oxidizing bacteria) \\
\hline OX & Aerobio \\
\hline PCR & Reacción de polimerasa en cadena \\
\hline PHA & Polihidroxialcanoatos \\
\hline SST & Sólidos suspendidos totales \\
\hline SSV & Sólidos suspendidos volátiles \\
\hline
\end{tabular}

\section{SÍMBOLOS}

\begin{tabular}{lll}
\hline Símbolos Griegos & Explicación & Unidades \\
\hline$\mu$ & Tasa de crecimiento específica de biomasa & gSSV/gSSV.d \\
$\mu_{m a ́ x}$ & Máxima tasa de crecimiento específica de biomasa & gSSV/gSSV.d \\
\hline
\end{tabular}




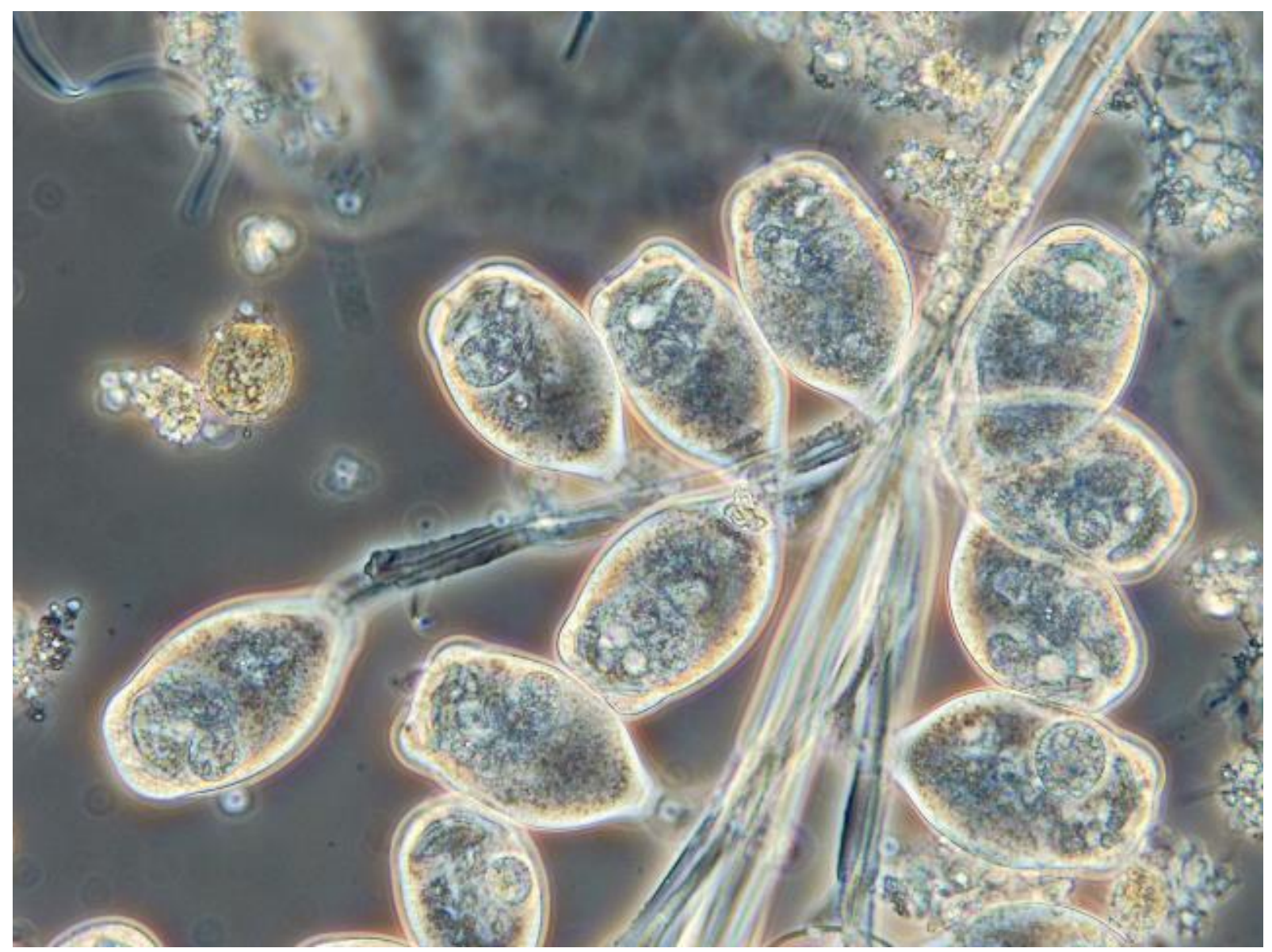

Colonia de protozoos en un ecosistema de lodos activados: (foto: D. Brdjanovic). 


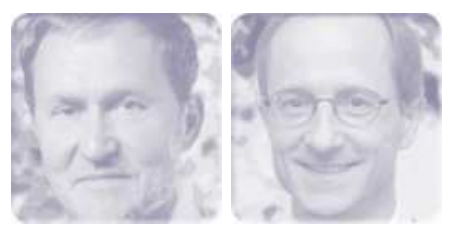

\section{Caracterización de las Aguas Residuales}

\section{Mogens Henze y Yves Comeau}

\subsection{EL ORIGEN DE LAS AGUAS RESIDUALES}

La producción de residuos generados por las actividades humanas es inevitable. Una parte significativa de estos residuos termina en las aguas residuales. La cantidad y calidad de las aguas residuales es determinada por varios factores. No todos los seres humanos o industrias generan la misma cantidad de residuos. La cantidad y tipo de residuos que se producen en los hogares se ve influenciada por el comportamiento, estilo y nivel de vida de los habitantes, así como por el marco técnico y jurídico en el que las personas se encuentran. En los hogares muchos residuos terminan como desechos sólidos y líquidos, y existen muchas posibilidades de cambiar las cantidades y composición de los dos flujos de residuos generados. Para la industria son aplicables consideraciones similares.
El diseño adoptado para el sistema de alcantarillado afecta significativamente la composición de las aguas residuales. En la mayoría de los países en desarrollo se utilizan los sistemas de alcantarillado separados. En ellos el agua de lluvia es transportada en zanjas, canales o tuberías. En algunos casos, las antiguas tramas urbanas combinan los sistemas de alcantarillado con diferentes tipos de aguas residuales (Tabla 3.1). En los sistemas combinados, una parte (pequeña o grande) del total de las aguas residuales es descargada en cuerpos de agua locales, a menudo sin ningún tratamiento.

Tabla 3.1 Tipos de Aguas Residuales

Aguas residuales urbanas

Aguas residuales domésticas

Aguas residuales de instituciones

Aguas residuales industriales

Infiltración en el sistema de alcantarillado

Pluviales

Lixiviados

Agua residuales de fosas sépticas
Aguas residuales generadas internamente en las plantas de tratamiento

Sobrenadante de espesores

Sobrenadantes de digestores

Aguas de rechazo de la deshidratación de lodos

Drenajes de lechos de secado de lodos

Agua drenada de lechos de secado de lodos

Aguas de limpieza de filtros

Aguas de limpieza de equipos

(c) 2017 Mogens Henze. Tratamiento Biológico de Aguas Residuales: Principios, Modelación y Diseño. Eds. M. Henze, M.C.M. van Loosdrecht, G.A. Ekama y D. Brdjanovic. Eds. (versión en español) C.M. López Vázquez, G. Buitrón Méndez, H.A. García, F.J. Cervantes Carrillo. ISBN (versión impresa): 9781780409139, ISBN (e-Book): 9781780409146. Publicado por IWA Publishing, London, UK. 
Tabla 3.2 Contaminantes presentes en las Aguas Residuales domésticas (basado en Henze et al., 2001)

\begin{tabular}{|c|c|c|}
\hline \multicolumn{3}{|c|}{ Contaminantes de las Aguas Residuales } \\
\hline Microorganismos & $\begin{array}{l}\text { Organismos patógenos como bacterias, virus y } \\
\text { huevos de helminto. }\end{array}$ & $\begin{array}{l}\text { Riesgo para actividades acuáticas, baños y } \\
\text { el consumo de mariscos }\end{array}$ \\
\hline $\begin{array}{l}\text { Materia orgánica } \\
\text { biodegradable }\end{array}$ & $\begin{array}{l}\text { Disminución del oxígeno disuelto en ríos, lagos y } \\
\text { fiordos. }\end{array}$ & Muerte de peces, olor. \\
\hline Otros compuestos orgánicos & $\begin{array}{l}\text { Detergentes, plaguicidas, grasas y aceites, } \\
\text { colorantes, solventes, fenoles, cianuro. }\end{array}$ & $\begin{array}{l}\text { Efectos tóxicos, inconvenientes estéticos, } \\
\text { bio-acumulación en la cadena alimenticia }\end{array}$ \\
\hline Nutrientes & Nitrógeno, fósforo, amoniaco & $\begin{array}{l}\text { Eutrofización, agotamiento del oxígeno } \\
\text { disuelto, efectos tóxicos. }\end{array}$ \\
\hline Metales & $\mathrm{Hg}, \mathrm{Pb}, \mathrm{Cd}, \mathrm{Cr}, \mathrm{Cu}, \mathrm{Ni}$ & Efectos tóxicos, bio-acumulación. \\
\hline Otros compuestos inorgánicos & Ácidos, por ejemplo sulfuro de hidrógeno, bases & Corrosión, efectos tóxicos. \\
\hline Efectos térmicos & Agua caliente & $\begin{array}{l}\text { Cambios en las condiciones de vida de la } \\
\text { flora y fauna. }\end{array}$ \\
\hline Olor (y gusto) & Sulfuro de hidrógeno & Inconvenientes estéticos, efectos tóxicos. \\
\hline Radioactividad & & Efectos tóxicos, acumulación \\
\hline
\end{tabular}

\subsection{CONTAMINANTES EN AGUAS RESIDUALES}

Los contaminantes presentes en las aguas residuales se pueden dividir en diferentes categorías como se puede observar en la Tabla 3.2. La contribución de cada contaminante puede variar de manera significativa.

\subsection{DBO Y DQO}

La material orgánica es el principal contaminante en las aguas residuales. Tradicionalmente, la materia orgánica ha sido medida como DBO o DQO. La determinación de la DQO es "rápida y sucia" (si se usa mercurio). La determinación de la DBO es lenta y engorrosa debido a la necesidad de realizar diluciones en serie.

Los ensayos de DQO miden, mediante la oxidación química con bicromato, la mayoría de la materia orgánica presente en la muestra. La determinación de la DQO es necesaria para para los balances de masa en el tratamiento de aguas residuales. El contenido de DQO se puede subdividir en fracciones útiles para el análisis y diseño de los procesos de tratamiento. La determinación de la DQO soluble y la suspendida es muy útil. Es necesario tener cuidado con la falsa DQO determinada con permanganato, ya que este método solamente mide una parte de la materia orgánica, y debe usarse únicamente con relación a la planificación del análisis de la DBO.

La DQO teórica de una sustancia dada puede ser calculada por la ecuación de oxidación. Por ejemplo, la DQO teórica del etanol se calcula basándose en la siguiente ecuación:

$$
\mathrm{C}_{2} \mathrm{H}_{6} \mathrm{O}+3 \mathrm{O}_{2} \rightarrow 2 \mathrm{CO}_{2}+3 \mathrm{H}_{2} \mathrm{O}
$$

Para $46 \mathrm{~g}$ de etanol se requieren $96 \mathrm{~g}$ de oxígeno para una oxidación completa a dióxido de carbono y agua. La DQO teórica del etanol es por lo tanto 96/46 $=2.09$.

El ensayo de la DBO mide el oxígeno consumido para la oxidación de una parte de la materia orgánica. La determinación de la DBO tiene su origen en el control de efluentes y ésta es la razón de que su uso sea tan extendido. $\mathrm{El}$ ensayo estándar de $\mathrm{DBO}$ dura 5 días $\left(\mathrm{DBO}_{5}\right)$, pero en algunos casos se utilizan otras alternativas, $\mathrm{DBO}_{1}$ si se necesita una determinación rápida $\mathrm{o}^{\mathrm{DBO}_{7}}$ si la simplicidad es la principal opción, como en Suecia y Noruega. Si es necesaria la determinación de toda (o casi toda) la materia orgánica biodegradable, se utiliza la $\mathrm{DBO}_{25}$. Es posible estimar el valor de DBO con una única medida (Tabla 3.3).

Tabla 3.3 Relación entre DBO y DQO para aguas residuales urbanas.

\begin{tabular}{lllll}
\hline $\mathrm{DBO}_{1}$ & $\mathrm{DBO}_{5}$ & $\mathrm{DBO}_{7}$ & $\mathrm{DBO}_{25}$ & DQO \\
\hline 40 & 100 & 115 & 150 & 210 \\
200 & 500 & 575 & 750 & 1,100 \\
\hline
\end{tabular}

En este capítulo, el termino DBO se referirá al ensayo estándar de la $\mathrm{DBO}_{5}$.

La Figura 3.1 muestra la dependencia del tiempo y la temperatura sobre el ensayo de la DBO. Es importante que el ensayo de la DBO sea realizado en condiciones estándares. 




Figura 3.1 El ensayo de la DBO es dependiente de la duración y temperatura. El estándar es a $20^{\circ} \mathrm{C}$ y 5 días

\subsection{PERSONA EQUIVALENTE Y CARGA POR HABITANTE}

Las aguas residuales de otras fuentes no sanitarias, usualmente se expresan en unidades de Persona Equivalente (PE). PE puede ser expresada por volumen o DBO. Las dos definiciones más utilizadas a nivel mundial son:

$$
\begin{aligned}
& 1 \mathrm{PE}=0.2 \mathrm{~m}^{3} / \mathrm{d} \\
& 1 \mathrm{PE}=60 \mathrm{~g} \mathrm{DBO} / \mathrm{d}
\end{aligned}
$$

Esas definiciones se basan en valores. La contribución real de una persona, conocido como Carga por Habitante $(\mathrm{CH})$, puede variar (Tabla 3.4). Las variaciones pueden ser causadas por: tipo y número de conexiones a la red de alcantarillado, factores socio-económicos, estilo de vida, tipo de instalación doméstica, etc.

Tabla 3.4 Variación de la carga por habitante (Henze et al., 2001)

\begin{tabular}{lcc}
\hline Parámetro & Unidad & Intervalo \\
\hline DQO & g/hab.d & $25-200$ \\
DBO & g/hab.d & $15-80$ \\
Nitrógeno & g/hab.d & $2-15$ \\
Fósforo & $\mathrm{g} / \mathrm{hab} . \mathrm{d}$ & $1-3$ \\
Caudal & $\mathrm{m}^{3} / \mathrm{hab} . \mathrm{d}$ & $0.05-0.40$ \\
\hline
\end{tabular}

Persona Equivalente y Carga por Habitante son usualmente confundidos o mezclados, por lo que se debe ser cuidadoso al utilizarlos y de asegurarse de definir claramente en que se basan. PE y $\mathrm{CH}$ están basados en promedios estadísticos, y se utilizan para tener una estimación de la carga de los procesos de tratamiento de aguas residuales. No deben ser calculados a partir de datos basados en intervalos cortos de tiempo (horas o días). La Carga por Habitante varía de país a país, como lo muestran los valores anuales de la Tabla 3.5.

\subsection{COMPONENTES PRINCIPALES}

Las concentraciones que se encuentran en las aguas residuales son una combinación de la carga contaminante y de la cantidad de agua que se mezcla con el contaminante. Por lo tanto, la carga diaria o anual de contaminantes puede ser una buena base para una evaluación de la composición de las aguas residuales. La composición de las aguas residuales municipales varía considerablemente de una ubicación a otra. Incluso en una ubicación determinada la composición variará con el tiempo. Esto es debido en parte a las variaciones en las cantidades de las sustancias vertidas. Sin embargo, las razones principales son las variaciones en el consumo de agua de los hogares y la infiltración y/o pérdidas durante el transporte, en la red de alcantarillado.

La composición típica de las aguas residuales domésticas/municipales se puede observar en la Tabla 3.6, donde las aguas residuales concentradas (alto) representan los casos con bajo consumo de agua y/o infiltración. Las aguas residuales más diluidas (bajo) representan los casos alto consumo de agua y/o infiltración. Las aguas pluviales diluirán aún más las aguas residuales, cuanto más componente de agua pluvial tenga, menor será la concentración en comparación con las aguas residuales diluidas.

Tabla 3.5. Carga por habitante en varios países en kg/hab.año (basado en Henze et al., 2002)

\begin{tabular}{lccccccc}
\hline Parámetro & Brasil & Egipto & India & Turquía & USA & Dinamarca & Alemania \\
\hline DBO & $20-25$ & $10-15$ & $10-15$ & $10-15$ & $30-35$ & $20-25$ & $20-25$ \\
SST & $20-25$ & $15-25$ & & $15-25$ & $30-35$ & $30-35$ & $30-35$ \\
N total & $3-5$ & $3-5$ & & $3-5$ & $5-7$ & $5-7$ & $4-6$ \\
P total & $0.5-1$ & $0.4-0.6$ & & $0.4-06$ & $0.8-1.2$ & $0.8-1.2$ & $0.7-1$ \\
\hline
\end{tabular}


Tabla 3.6 Composición típica de aguas residuales municipales crudas con aportes menores de efluentes industriales (en $\mathrm{g} / \mathrm{m}^{3}$ )

\begin{tabular}{lccc}
\hline Parámetro & Alto & Medio & Bajo \\
\hline DQO total & 1,200 & 750 & 500 \\
DBO soluble & 480 & 300 & 200 \\
DQO suspendida & 720 & 450 & 300 \\
DBO & 560 & 350 & 230 \\
AGV (como acetato) & 80 & 30 & 10 \\
N total & 100 & 60 & 30 \\
N Amoniacal & 75 & 45 & 20 \\
P total & 25 & 15 & 6 \\
Ortho-P & 15 & 10 & 4 \\
SST & 600 & 400 & 250 \\
SSV & 480 & 320 & 200 \\
\hline
\end{tabular}

La forma de distribución del nitrógeno y fósforo en las aguas residuales tiene influencia sobre las opciones de tratamiento posibles. Dado que la mayoría de los nutrientes se encuentran presentes en formas solubles, no pueden ser removidos por decantación, filtración, flotación u otro tipo de separación sólido - líquido. La Tabla 3.7 muestra valores típicos para esos compuestos.

En general, la distribución entre materia soluble y suspendida es importante con relación a la caracterización de las aguas residuales (Tabla 3.8).

Dado que la mayoría de los procesos de tratamiento de aguas residuales se basan en la biodegradación biológica,

Tabla 3.7 Contenido típico de nutrientes en aguas residuales municipales crudas con aportes menores de efluentes industriales (en $\mathrm{g} / \mathrm{m}^{3}$ )

\begin{tabular}{lccc}
\hline Parámetro & Alto & Medio & Bajo \\
\hline N total & 100 & 60 & 30 \\
N Amoniacal & 75 & 45 & 20 \\
N Nitrato + Nitrito & 0.5 & 0.2 & 0.1 \\
N Orgánico & 25 & 10 & 15 \\
N Total Kjeldahl & 100 & 60 & 30 \\
P total & 25 & 15 & 6 \\
Orto-P & 15 & 10 & 4 \\
P Orgánico & 10 & 5 & 2 \\
\hline
\end{tabular}

Tabla 3.8 Distribución de materia soluble y suspendida para una concentración media de aguas residuales (en $\mathrm{g} / \mathrm{m}^{3}$ )

\begin{tabular}{lccc}
\hline Parámetro & Soluble & Suspendido & Total \\
\hline DQO & 300 & 450 & 750 \\
DBO & 140 & 210 & 350 \\
N total & 50 & 10 & 60 \\
P total & 11 & 4 & 15 \\
\hline
\end{tabular}

la degradabilidad de los componentes es importante (Tabla 3.9)

Tabla 3.9. Degradabilidad de aguas residuales de concentración media (en $\mathrm{g} / \mathrm{m} 3$ )

\begin{tabular}{lccc}
\hline Parámetro & Biodegradable & Inerte & Total \\
\hline DQO total & 570 & 180 & 750 \\
DQO soluble & 270 & 30 & 300 \\
DQO partículas & 300 & 150 & 450 \\
DBO & 350 & 0 & 350 \\
N total & 43 & 2 & 45 \\
N Orgánico & 13 & 2 & 15 \\
P total & 14.7 & 0.3 & 15 \\
\hline
\end{tabular}

\subsection{COMPONENTES ESPECIALES}

La mayoría de los compuestos que podemos encontrar en las aguas residuales no son el objetivo principal del tratamiento, pero contribuyen a la toxicidad de las aguas residuales, ya sea en relación a los procesos biológicos de tratamiento o a las aguas receptoras. Las sustancias que se encuentran en el efluente podrían terminar en un sistema de abastecimiento de agua potable, dependiendo de si se trata de extracción de agua superficial. Los metales presentes en las aguas residuales pueden influir en la posibilidad de reutilización de los lodos de tratamiento de aguas residuales como abono para cultivos. En la Tabla 3.10 se pueden observar valores típicos de metales en aguas residuales municipales.

Tabla 3.10 Contenido típico de metales en aguas residuales municipales crudas con aportes menores de efluentes industriales (en $\mathrm{g} / \mathrm{m}^{3}$ ) (Henze 1982, 1992, Ødegaard 1992, de Henze et al., 2001)

\begin{tabular}{lrrr}
\hline Metal & Alto & Medio & Bajo \\
\hline Aluminio & 1,000 & 600 & 350 \\
Cadmio & 4 & 2 & 1 \\
Cromo & 40 & 25 & 10 \\
Cobre & 100 & 70 & 30 \\
Plomo & 80 & 60 & 25 \\
Mercurio & 3 & 2 & 1 \\
Níquel & 40 & 25 & 10 \\
Plata & 10 & 7 & 3 \\
Zinc & 300 & 200 & 100 \\
\hline
\end{tabular}

La Tabla 3.11 muestra una serie de parámetros hidroquímicos para aguas residuales domésticas/municipales. 
Tabla 3.11 Diferentes parámetros en aguas residuales municipales (de Henze, 1982)

\begin{tabular}{lrrrr}
\hline Parámetros & Alto & Medio & Bajo & Unidad \\
\hline Viscosidad abs. & 0.001 & 0.001 & 0.001 & $\mathrm{~kg} / \mathrm{m} . \mathrm{s}$ \\
Tensión sup. & 50 & 55 & 60 & $\mathrm{Dyn} / \mathrm{cm}^{2}$ \\
Conductividad & 120 & 100 & 70 & $\mathrm{mS} / \mathrm{m}^{1}$ \\
pH & 8.0 & 7.5 & 7.0 & \\
Alcalinidad & 7 & 4 & 1 & $\mathrm{Eqv} / \mathrm{m}^{3}$ \\
Sulfuro & 10 & 0.5 & 0.1 & $\mathrm{gS} / \mathrm{m}^{3}$ \\
Cianuro & 0.05 & 0.030 & 0.02 & $\mathrm{~g} / \mathrm{m}^{3}$ \\
Cloruro & 600 & 400 & 200 & $\mathrm{gCl} / \mathrm{m}^{3}$ \\
\hline
\end{tabular}

Las aguas residuales también pueden tener contaminantes específicos como los xenobióticos (Tabla 3.12).

Tabla 3.12 Parámetros especiales en las aguas residuales, xenobióticos con efectos tóxicos y otros (en $\mathrm{mg} / \mathrm{l}$ )

\begin{tabular}{lrrr}
\hline Parámetros & Alto & Medio & Bajo \\
\hline Fenol & 0.1 & 0.05 & 0.02 \\
Ftalatos, DEHP & 0.3 & 0.2 & 0.1 \\
Nonil-fenoles, NPE & 0.08 & 0.05 & 0.01 \\
PAHs & 2.5 & 1.5 & 0.5 \\
Cloruro de Metilo & 0.05 & 0.03 & 0.01 \\
LAS & 10,000 & 6,000 & 3,000 \\
Cloroformo & 0.01 & 0.05 & 0.01 \\
\hline
\end{tabular}

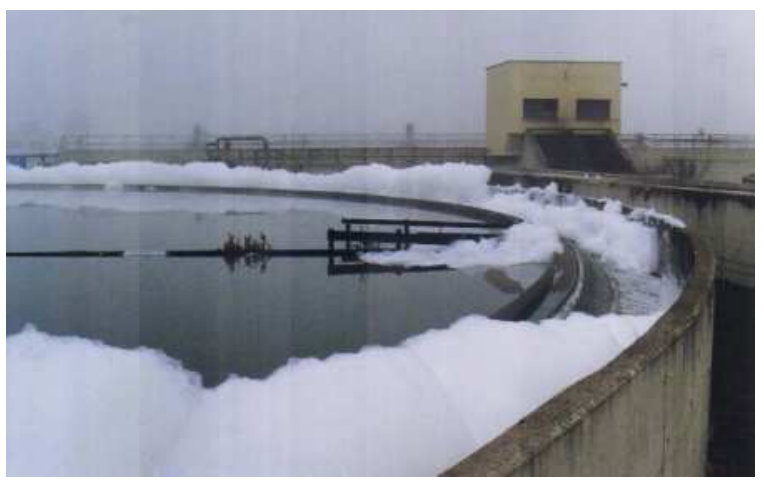

Figura 3.2 Los detergentes en altas concentraciones crean problemas en la operación de las plantas de tratamiento de aguas residuales. (foto: $M$. Henze)

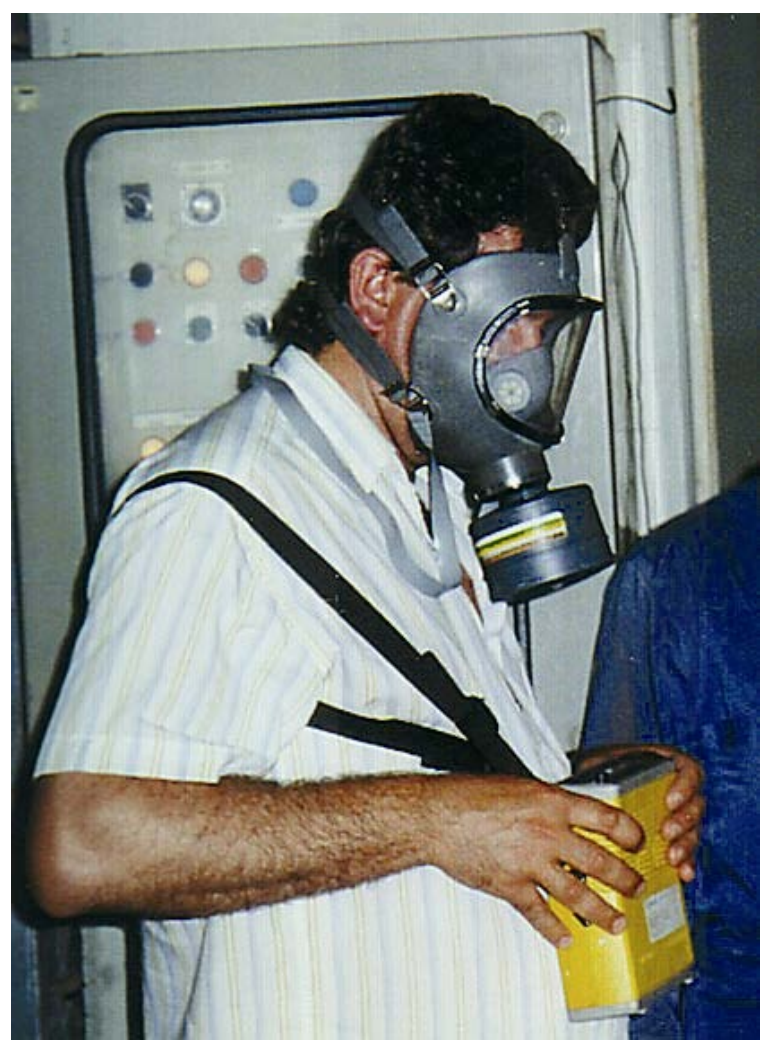

Figura 3.3 El sulfuro de hidrógeno se encuentra usualmente en el afluente de las plantas de tratamiento, en especial en los casos en los que el sistema de alcantarillado es a presión. Es muy tóxico y puede ocasionar la muerte del personal de la planta si no se toman las precauciones necesarias. La imagen muestra una medición en una estación de bombeo con alta concentración de sulfuro de hidrógeno en el aire (foto: M. Henze).

\section{7}

\section{MICROORGANISMOS}

Las aguas residuales son infecciosas. El manejo histórico de las aguas residuales fue impulsado por el deseo de eliminar los elementos infecciosos presentes en ellas para alejarlos de las poblaciones de las ciudades. En el siglo XIX, los microorganismos fueron identificados como la casusa de las enfermedades. Éstos se encuentran en las aguas residuales provenientes principalmente de los excrementos humanos, así como de la industria alimenticia. La Tabla 3.13 da una idea de la concentración de microorganismos en aguas residuales domésticas. Para mayor información sobre los microorganismos patógenos y su tratamiento, el lector debe consultar el Capítulo 8. 
Tabla 3.13 Concentración de microorganismos en aguas residuales (número de microorganismos por $100 \mathrm{ml}$ ) (basado en Henze et al., 2001)

\begin{tabular}{lrr}
\hline Microorganismo & Alto & Bajo \\
\hline E. coli & $5 \cdot 10^{8}$ & $10^{6}$ \\
Coliformes & $10^{13}$ & $10^{11}$ \\
Cl. perfringens & $5 \cdot 10^{4}$ & $10^{3}$ \\
Streptococcae Fecal & $10^{8}$ & $10^{6}$ \\
Salmonela & 300 & 50 \\
Campylobacter & $10^{5}$ & $5 \cdot 10^{3}$ \\
Listeria & $10^{4}$ & $5 \cdot 10^{2}$ \\
Staphylococus aureus & $10^{5}$ & $5.10^{3}$ \\
Colifagos & $5 \cdot 10^{5}$ & $10^{4}$ \\
Giardia & $10^{3}$ & $10^{2}$ \\
Lombrices intestinales & 20 & 5 \\
Enterovirus & $10^{4}$ & $10^{3}$ \\
Rotavirus & 100 & 20 \\
\hline
\end{tabular}

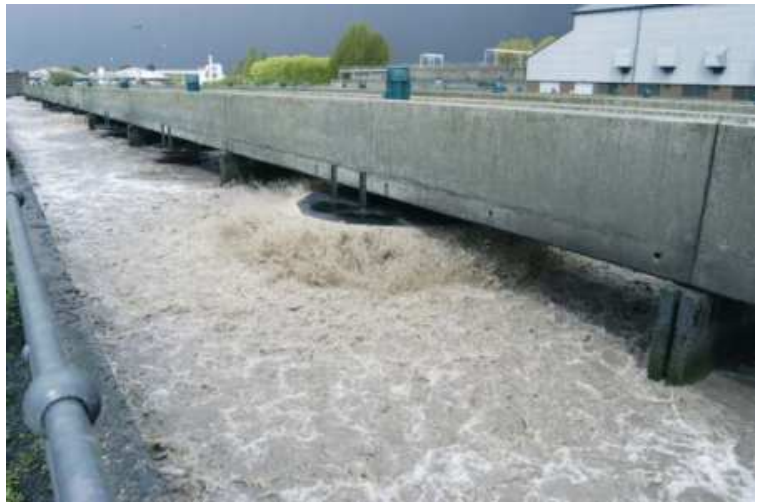

Figura 3.4 La aireación superficial en una planta de lodos activados genera aerosoles con una alta concentración de microorganismos. Esto representa un riesgo para la salud de los empleados de la planta de tratamiento y en algunos casos para los vecinos. (Foto: D. Brdjanovic)

Una alta concentración de microorganismos puede causar un importante riesgo a la salud cuando se descargan aguas residuales crudas a las aguas receptoras.

\subsection{AGUAS RESIDUALES ESPECIALES $Y$ CORRIENTES INTERNAS RECICLABLES DE LAS PLANTAS}

No son sólo las aguas residuales provenientes del sistema de alcantarillado las que una planta de tratamiento tiene que manejar. Cuanto mayor sea la planta, más cantidad de agua residual interna es reciclada y los flujos de ingresos $\mathrm{y}$ externos tienen que ser gestionados.
Si el sistema de captación tiene áreas de manejo descentralizadas de aguas residuales, los lodos de fosa séptica ingresan a la planta con camiones cisterna. La Tabla 3.14 muestra una composición típica de estos lodos.

Tabla 3.14 Composición de lodos barométricos (en $\mathrm{g} / \mathrm{m}^{3}$ ) (de Henze et al., 2001)

\begin{tabular}{|c|c|c|}
\hline Compuesto & Alto & Bajo \\
\hline DBO total & 30,000 & 2,000 \\
\hline DBO soluble & 1,000 & 100 \\
\hline DQO total & 90,000 & 6,000 \\
\hline DQO soluble & 2,000 & 200 \\
\hline $\mathrm{N}$ total & 1,500 & 200 \\
\hline N Amoniacal & 150 & 50 \\
\hline P total & 300 & 40 \\
\hline SST & 100,000 & 7,000 \\
\hline SSV & 60,000 & 4,000 \\
\hline Cloruro & 300 & 50 \\
\hline $\mathrm{H}_{2} \mathrm{~S}$ & 20 & 1 \\
\hline $\mathrm{pH}$ & 8.5 & 7.0 \\
\hline Alcalinidad $^{1}$ & 40 & 10 \\
\hline Plomo & 0.03 & 0.01 \\
\hline Fe total & 200 & 20 \\
\hline Coliformes fec. ${ }^{2}$ & $10^{8}$ & $10^{6}$ \\
\hline
\end{tabular}

${ }^{1}$ en miliequivalentes/1

2 en $\mathrm{N}^{\mathrm{o}} / 100 \mathrm{ml}$

Es una situación típica en muchos países en desarrollo. Los lodos de fosas sépticas a menudo crean problemas en las plantas de tratamiento biológico debido a la carga repentina generada por la descarga completa de un camión barométrico. En las plantas de tratamiento que sirvan a una población superior a los 100.000 habitantes equivalentes, no se verificarán problemas por las descargas de los camiones cisterna. Para los casos de plantas de tratamiento de menor porte, la descarga de los camiones cisterna se debe realizar a un tanque de almacenamiento (Figura 3.5), desde el que se bombea de manera dosificada a la planta de tratamiento en períodos de baja carga (usualmente en la noche).

Otra importante carga externa a la planta de tratamiento suelen ser los lixiviados de rellenos sanitarios o vertederos de residuos (Figura 3.6 y Tabla 3.15).

El lixiviado puede ser transportado o bombeado a la planta de tratamiento central. Sin embargo, en muchas ocasiones se vierte a la alcantarilla más cercana al relleno sanitario. Los lixiviados pueden tener altas concentraciones de DQO soluble e inerte que pasa a través de la planta sin ningún decremento o cambio. En algunos casos donde la legislación no permite la descarga de 


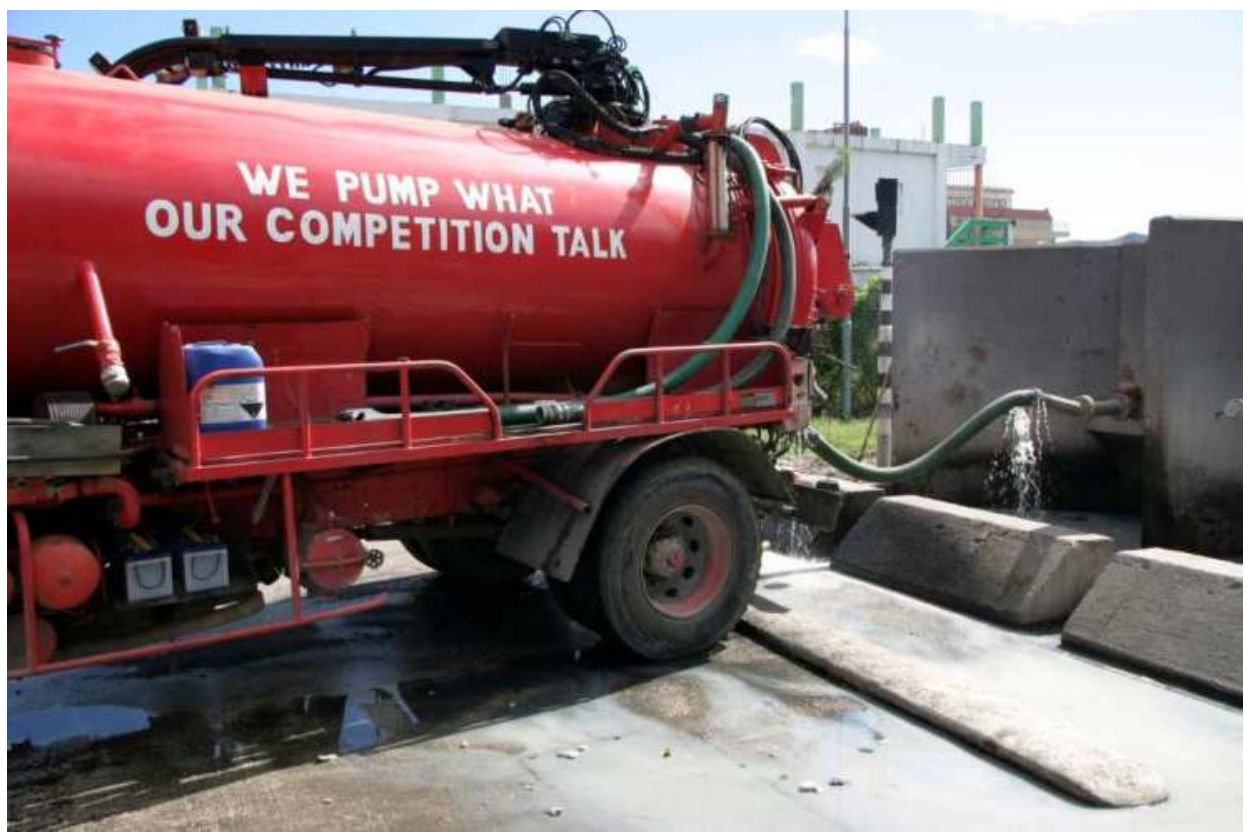

Figura 3.5 Camión cisterna descargando el contenido de fosas sépticas de hogares en un tanque de almacenamiento en la plata de tratamiento de Illidge Road en St. Maarten, N.A. (foto: D. Brdjanovic)

lixiviados sin tratamiento, será necesario un pretratamiento en el propio relleno sanitario antes de descargar a la red de alcantarillado público.

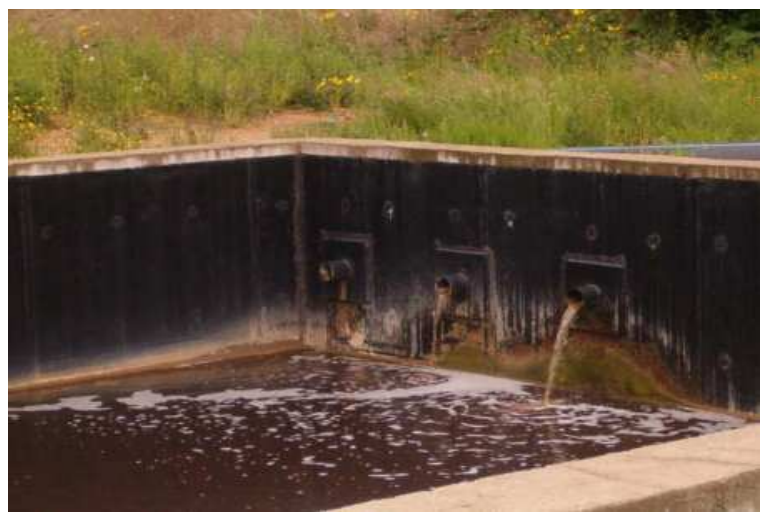

Figura 3.6 Captación y almacenamiento del lixiviado proveniente del relleno sanitario de Sarajevo en Bosnia y Herzegovina (Foto: F. Babić)

Las cargas internas de las plantas de tratamiento se generan por el sobrenadante de los espesores y digestores (Figura 3.7), el agua extraída en los procesos de deshidratación de lodos y de lavados de filtros e instalaciones. El sobrenadante de los digestores suele ser de una carga interna significativa, en especial en relación al amoníaco (Tabla 3.16). Esto puedo producir una sobre carga de nitrógeno en el caso de la eliminación biológica de nitrógeno (ver Capítulo 6).
Tabla 3.15 Caracterización de los lixiviados (en g/m³)

\begin{tabular}{lrr}
\hline Parámetros & Alto & Bajo \\
\hline DQO total & 16,000 & 1,200 \\
DQO soluble & 15,800 & 1,150 \\
DBO total & 12,000 & 300 \\
N total & 500 & 100 \\
N Amoniacal & 475 & 95 \\
P total & 10 & 1 \\
SST & 500 & 20 \\
VSS & 300 & 15 \\
Cloruro & 2,500 & 200 \\
$\mathrm{H}_{2} \mathrm{~S}$ & 10 & 1 \\
pH & 7.2 & 6.5 \\
\hline
\end{tabular}




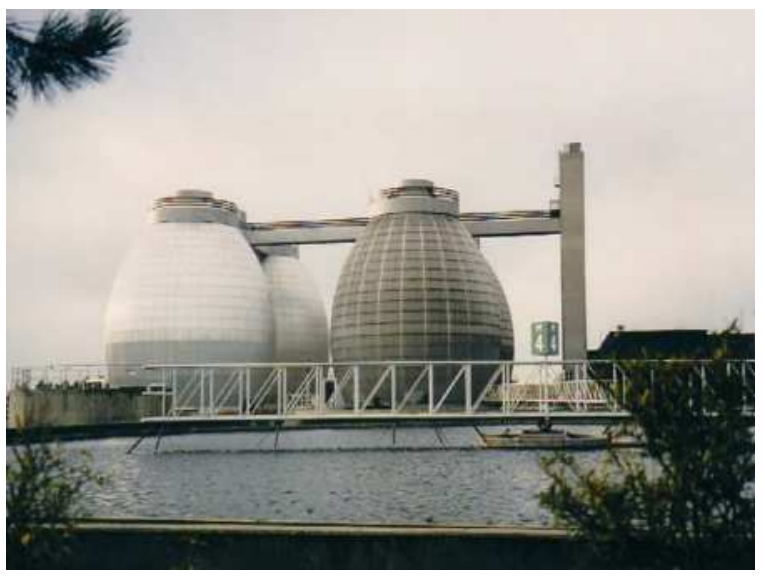

Figura 3.7 Los digestores producen sobrenadantes que pueden generar problemas en las plantas de tratamiento de aguas residuales debido a las altas cargas de nitrógeno y otras sustancias (foto: M. Henze)

Tabla 3.16 Sobrenadante de Digestor (en $\mathrm{g} / \mathrm{m}^{3}$ )

\begin{tabular}{lrr}
\hline Compuesto & Alto & Bajo \\
\hline DQO total & 9,000 & 700 \\
DQO soluble & 2,000 & 200 \\
DBO total & 4,000 & 300 \\
DBO soluble & 1,000 & 100 \\
N total & 800 & 120 \\
N Amoniacal & 500 & 100 \\
P total & 300 & 15 \\
SST & 10,000 & 500 \\
SSV & 6,000 & 250 \\
$\mathrm{H}_{2} \mathrm{~S}$ & 20 & 2 \\
\hline
\end{tabular}

El agua proveniente de los procesos de deshidratación de lodos puede contener altas concentraciones de material soluble, tanto orgánico como inorgánico (Figura 3.8 y Tabla 3.17).

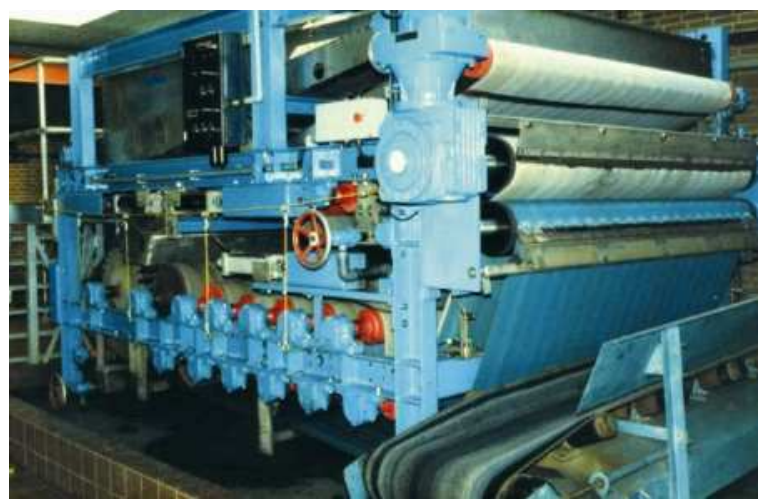

Figura 3.8 Filtro de Bandas para deshidratar lodos: la captación del agua de rechazo se da por debajo del equipo (Foto: D. Brdjanovic)
Tabla 3.17 Composición del agua proveniente de la deshidratación de lodos (en $\left.\mathrm{g} / \mathrm{m}^{3}\right)$

\begin{tabular}{lrr}
\hline Compuesto & AltoBajo \\
\hline DQO total & 4,000 & 800 \\
DQO soluble & 3,000 & 600 \\
DBO total & 1,500 & 300 \\
DBO soluble & 1,000 & 250 \\
N total & 500 & 100 \\
N Amoniacal & 450 & 95 \\
P total & 20 & 5 \\
SST & 1,000 & 100 \\
SSV & 600 & 60 \\
$\mathrm{H}_{2} \mathrm{~S}$ & 20 & 0.2 \\
\hline
\end{tabular}

El agua de lavado del filtros (Tabla 3.18) puede crear problemas debido a una sobrecarga hidráulica en los tanques de sedimentación en las plantas de tratamiento. En algunos, se puede verificar una sobrecarga con sólidos en suspensión. El agua de lavado de filtros en las plantas de tratamiento más pequeñas debe ser incorporada lentamente.

Tabla 3.18 Agua de lavado de filtros (en $\mathrm{g} / \mathrm{m}^{3}$ )

\begin{tabular}{lrr}
\hline Compuesto & Alto & Bajo \\
\hline DQO total & 1,500 & 300 \\
DQO soluble & 200 & 40 \\
DBO total & 400 & 50 \\
DBO soluble & 30 & 10 \\
N total & 100 & 25 \\
N Amoniacal & 10 & 1 \\
P total & 50 & 5 \\
SST & 1,500 & 300 \\
SSV & 900 & 150 \\
$\mathrm{H}_{2} \mathrm{~S}$ & 0.1 & 0.01 \\
\hline
\end{tabular}

\subsection{RELACIÓN ENTRE CONTAMINANTES}

La relación entre los diferentes contaminantes presentes en las aguas residuales tiene una importancia destacada al momento de seleccionar y operar los procesos de tratamiento de estas. Un agua residual con baja relación $\mathrm{C} / \mathrm{N}$ va a necesitar aportes externos de una fuente de carbono con el fin de que las funciones biológicas de desnitrificación funcionen rápido y eficientemente. Las aguas residuales con altas concentraciones de nitrato o bajas concentraciones de ácidos grasos volátiles (AGVs) no serán adecuadas para una eliminación biológica del 
fósforo. Aquellas con alta relación $\mathrm{DQO} / \mathrm{DBO}$ indican que una porción importante de la materia orgánica será difícil de degradar biológicamente. Cuando los sólidos suspendidos tengan un alto componente de volátil (relación SSV/SS), indica que podrán ser digeridos con éxito en condiciones anaerobias.

Si bien la mayor parte de la carga contaminante en las aguas residuales proviene de los hogares, instituciones y la industria, son sólo una parte del total de generado. Una parte significativa del agua en la red de alcantarillado se origina a partir de las aguas pluviales, (en algunos países de los deshielos) o de la infiltración en la red de agua subterránea. Así, la concentración de los contaminantes de las aguas residuales se ve diluida, sin embargo la relación entre ellos no se ve modificada. En la Tabla 3.19 se muestra las relaciones típicas en aguas residuales municipales.

Tabla 3.19 Relaciones típicas entre contaminantes en aguas residuales municipales

\begin{tabular}{lrrr}
\hline Relación & Alto & Medio & Bajo \\
\hline DQO/DBO & $2.5-3.5$ & $2.0-2.5$ & $1.5-2.0$ \\
AGV/DQO & $0.12-0.08$ & $0.08-0.04$ & $0.04-0.02$ \\
DQO/TN & $12-16$ & $8-12$ & $6-8$ \\
DQO/TP & $45-60$ & $35-45$ & $20-35$ \\
DBO/TN & $6-8$ & $4-6$ & $3-4$ \\
DBO/TP & $20-30$ & $15-20$ & $10-15$ \\
DQO/SSV & $1.6-2.0$ & $1.4-1.6$ & $1.2-1.4$ \\
SSV/SST & $0.8-0.9$ & $0.6-0.8$ & $0.4-0.6$ \\
DQO/COT & $3-3.5$ & $2.5-3$ & $2-2.5$ \\
\hline
\end{tabular}

La relación entre los contaminantes en un análisis de aguas residuales dado, se puede utilizar para investigar anomalías generadas por descargas especiales en el sistema de alcantarillado, a menudo de industrias o también para verificar posibles errores analíticos. Las proporciones entre las concentraciones de los componentes que se muestran en la Tabla 3.6 se pueden utilizar como una guía. Si alguna de las relaciones se encuentra por fuera de los valores indicados en la Tabla 3.6 se deberá investigar con profundidad las posibles causas hasta encontrar la razón del apartamiento. Si la causa del apartamiento es una descarga industrial, otros contaminantes no analizados (aún), también podrían desviarse de los valores esperados. Dado que estos apartamientos pueden afectar significativamente los procesos de tratamiento de efluentes las causas de su aparición deben ser investigadas y aclaradas.

\subsection{VARIACIONES}

La concentración de los contaminantes en las aguas residuales varía con el tiempo. En muchos casos, se observan variaciones diarias, en algunos semanales y otros serán una función de los ciclos de producción industrial que descarguen a la red. Las variaciones son importantes para el diseño, funcionamiento y control de la planta de tratamiento. Por ejemplo, en el caso del nitrógeno amoniacal, la fuente principal es la orina, que a menudo presenta un patrón diurno de vertido como se puede observar en la Figura 3.9

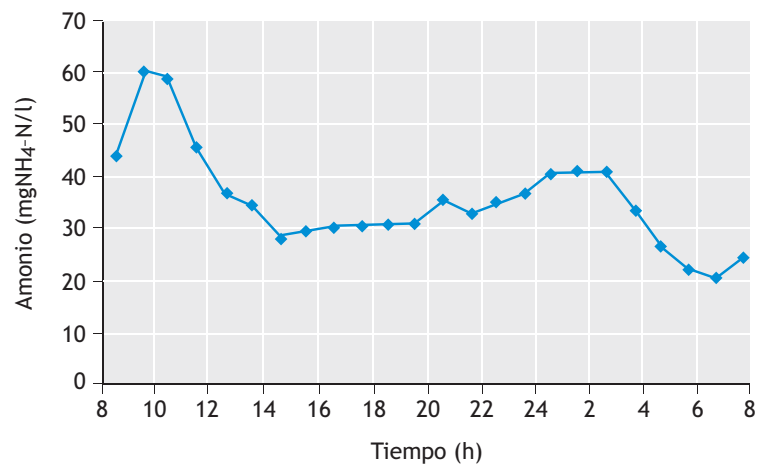

Figura 3.9 Variación diaria del contenido de amoníaco en el afluente de la planta de tratamiento de Galindo en España

Las variaciones en el caudal, DQO y sólidos suspendidos pueden ser significativas como se puede observar en la Figura 3.10
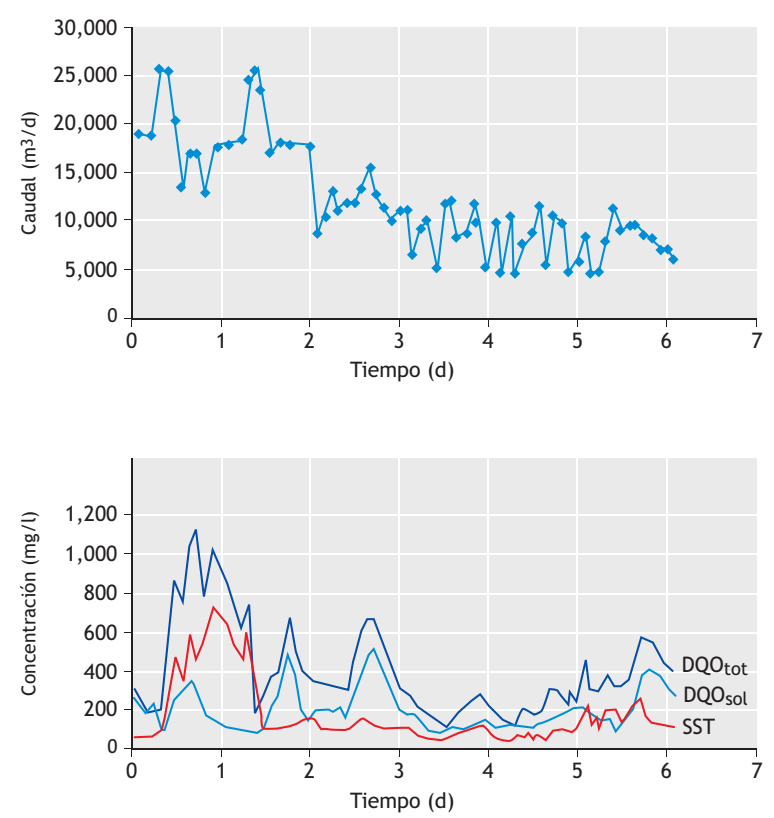

Figura 3.10 Variaciones en el caudal, DQO y sólidos suspendidos (Henze et al., 2002) 
El muestreo de aguas residuales es complejo debido a las variaciones en el caudal y de la concentración de contaminantes. Se debe tener presente que los resultados analíticos obtenidos en una campaña de monitoreo pueden variar considerablemente en función del procedimiento de muestreo escogido. Los materiales flotantes como el aceite y las grasas, así como los más pesados como arena y gravilla son difíciles de muestrear.

Diferentes técnicas son aplicadas a la hora de muestrear aguas residuales:

- Muestreo de agarre (una muestra recogida en una botella o balde a una hora fija). Este tipo de muestreo tiene resultados muy variables.

- Muestreo proporcional en el tiempo (son muchas muestras, por ej. una muestra cada una hora que al final se mezclan para obtener una única muestra final). Este tipo de muestreos puede ser adecuado si el agua residual no tiene grandes variaciones de concentración de contaminantes.

- Muestreo proporcional al caudal (en general se realiza durante $24 \mathrm{hr}$ y se extraen muestras de un volumen representativo del caudal presente). Este método da una estimación fiable de la calidad (o no calidad) del agua residual.

- Variaciones en $24 \mathrm{hr}$ (por ej. una muestra por hora es analizada para obtener la variación de la concentración de contaminantes en el tiempo). Es un sistema utilizado para modelados.

- Muestreo semanal (proporcional por tiempo o flujo). Como en el caso anterior son útiles para diseñar y/o modelar.

\subsection{1}

\section{CAUDALES DE AGUAS RESIDUALES}

En las aguas residuales los caudales varían con el tiempo y el lugar. Esto hace que sean difíciles de medir con precisión. La unidad básica para el caudal es volumen de agua residual $\left(\mathrm{m}^{3}\right)$ por unidad de tiempo (día). Las unidades utilizadas para expresar el caudal de diseño de diferentes equipos en la plata de tratamiento son variables. Para unidades con bajo tiempo de retención hidráulico como las rejas y los desarenadores, el caudal de diseño se expresa en $\mathrm{m}^{3} / \mathrm{s}$, mientras que para los tanques de sedimentación se expresa en $\mathrm{m}^{3} / \mathrm{h}$. En la Figura 3.11 se muestran cálculos típicos de diseño para agua residuales domésticas.

El caudal medio diario, $\mathrm{Q}_{\mathrm{d}, \mathrm{med}}$ es calculado como el caudal anual dividido por 365 . El caudal medio horario, $\mathrm{Q}_{\mathrm{h}, \mathrm{med}}$ es el caudal diario dividido por 24.

El caudal máximo horario puede calcularse de dos maneras, ya sea (i) con el caudal promedio diario multiplicado por la constante horaria máxima, fh,max (es una constante que varía con el tamaño de la cuenca de captación: para grandes ciudades será 1.3-1.7, para pequeñas 1.7-2.4), o (ii) dividiendo el caudal promedio diario por el factor horario, $\mathrm{t}_{\mathrm{h}, \mathrm{d}}$ (este factor es 10-14 horas para pequeñas poblaciones y 14-18 horas para grandes ciudades)

\subsection{RESIDUOS GENERADAS EN LOS HOGARES}

Las cantidades de aguas residuales y otros contaminantes generados en los hogares varían de país en país. Esas variaciones están influenciadas por el clima, factores socio-económicos, uso de tecnología en el hogar y otros factores.

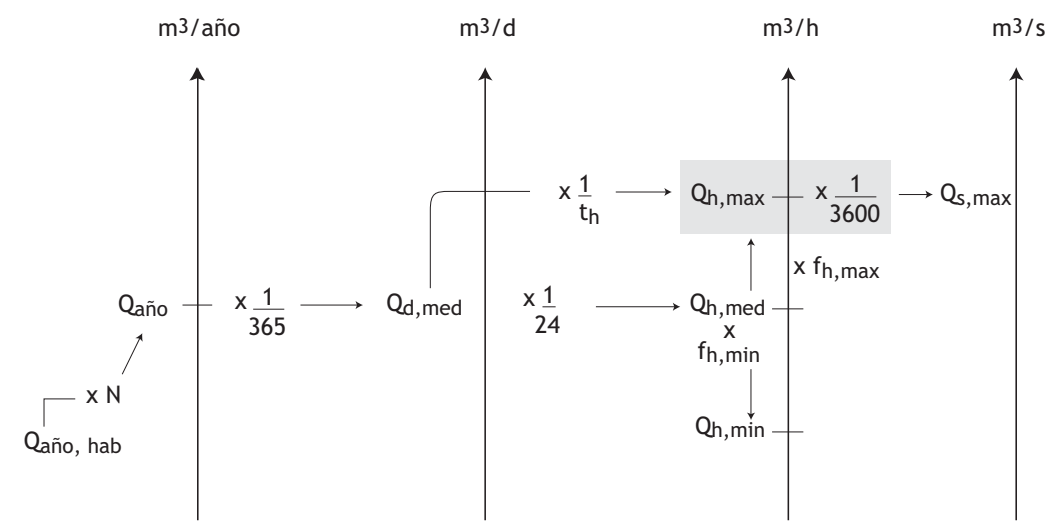

Figura 3.11 Cálculo de los caudales de diseño para aguas residuales municipales con aportes menores de efluentes industriales 
La cantidad de residuos orgánicos y nutrientes producidos en los hogares se puede observar en la Tabla 3.20. Con dicha tabla se puede evaluar cómo afectan los cambios en la composición de las aguas residuales.

En el caso de los residuos domésticos, la composición de las aguas residuales y los residuos sólidos es el resultado de la contribución de varias fuentes dentro del hogar. Es posible cambiar la cantidad y composición de los flujos de residuos. La cantidad de un flujo de residuos dado puede ser incrementado o disminuido con el objetivo de mejorar la composición final. Por ejemplo, una disminución en la cantidad de residuos presentes en el agua residual puede lograrse de dos maneras: ( $i$ ) una disminución global de los residuos generados en el hogar $\mathrm{y}$, (ii) desviación de cierto tipo de residuos a los residuos sólidos del hogar.

No existe una alternativa evidente para disminuir los residuos generados fisiológicamente, aunque la dieta influye en la cantidad de residuos producidos por el organismo humano. De esta manera, se debe aceptar dicha generación como una consecuencia de la actividad humana. La separación de los residuos del inodoro (fisiológicos y antropogénicos) de la línea de agua se refleja en un decremento significativo de la carga orgánica, de nitrógeno y de fósforo de las aguas residuales. Se ha aplicado la separación en origen de los residuos, sin embargo, continúan teniendo que ser transportados lejos del hogar y en algunos casos de la ciudad.

Existen varias opciones técnicas para el manejo separado en la fuente de residuos, como pueden ser:

- Unidades sanitarias secas, usadas mundialmente.

- Inodoro de compostaje, utilizado principalmente en hogares agrícolas (preferentemente con separación de orina con el fin de optimizar el proceso de compostaje).
- Tanques sépticos seguidos de infiltración en el terreno o transportado por un sistema de alcantarillado.

La orina es el principal contribuyente de nutrientes en los residuos domésticos, por lo tanto separando la orina, se reducirán las cargas de nutrientes en las aguas residuales de manera significativa (Figura 3.12). La separación de la orina logra reducir el contenido de nitrógeno en las aguas residuales domésticas a un nivel en el que la eliminación de nitrógeno no es necesaria.

Los residuos de cocina contienen una cantidad significativa de materia orgánica que tradicionalmente termina en las aguas residuales. Es relativamente fácil desviar algunos residuos líquidos de cocina a los residuos sólidos a través de la aplicación del sistema de cocina llamado "tecnología limpia (cleantech)", obteniendo de este modo una reducción significativa en la carga orgánica total de las aguas residuales (EPA Danesa 1993). La cocina de "tecnología limpia" significa que los residuos de alimentos se desechan en el cubo de la basura y no en la alcantarilla junto con agua del grifo. La parte desviada de los residuos sólidos orgánicos de la cocina puede ser eliminada de la misma manera que los demás residuos sólidos de la casa. El agua residual gris de la cocina se podría utilizar para el riego o, después del tratamiento, para el inodoro. Los residuos líquidos de cocina también contienen productos químicos de uso doméstico, cuyo uso puede afectar la composición y la carga de este tipo de residuos.
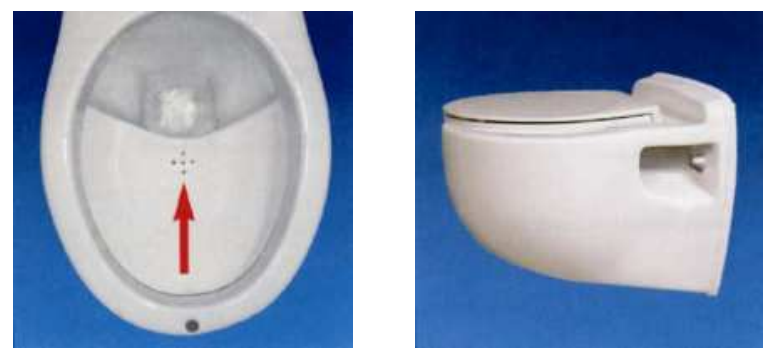

Figura 3.12 Inodoro separador de orina

Tabla 3.20 Fuentes de contaminantes en las aguas residuales domésticas y su peso en los estilos de vida "no ecológicos" (de Sundberg, 1995; Henze, 1997)

\begin{tabular}{lcccccc}
\hline Parámetro & Unidad & \multicolumn{2}{c}{ Inodoro } & Cocina & Baño/Lavarropa & Total \\
\hline Agua Residual & \multicolumn{7}{c}{ Total $^{1}$} & Orina & & 18 & 55 \\
DQO & $\mathrm{m}^{3} /$ año & 19 & 11 & 18 & 3.7 & 47.2 \\
DBO & $\mathrm{kg} /$ año & 27.5 & 5.5 & 16 & 1.8 & 21.9 \\
$\mathrm{~N}$ & $\mathrm{~kg} /$ año & 9.1 & 1.8 & 11 & 0.4 & 5.1 \\
P & $\mathrm{kg} /$ año & 4.4 & 4.0 & 0.3 & 0.1 & 0.87 \\
K & $\mathrm{kg} /$ año & 0.7 & 0.5 & 0.07 & 0.15 & 1.6 \\
\hline
\end{tabular}

${ }^{1}$ Incluida orina 
Las aguas residuales de lavandería y baño tienen una carga contaminante menor que proviene de los productos químicos utilizados en el hogar, y cuyo uso puede afectar la composición y la carga de esta fracción de residuos. Los residuos de lavandería y baños pueden ser utilizados junto con las aguas residuales de cocina tradicional para el riego. También se pueden volver a utilizar para el inodoro. En ambos casos se necesita un buen tratamiento previo.

La fracción biodegradable de los residuos sólidos de la cocina puede ser retirada por separado o combinada con residuos de cocina tradicionalmente desechados con agua, para su posterior tratamiento o compostaje anaerobio en la planta de tratamiento de aguas residuales.

En muchos países se utilizan en la cocina unidades de eliminación (trituradoras) para el manejo de la fracción biodegradable de los residuos sólidos de los hogares. A veces, esta opción se descarta debido a que aumenta la carga de desechos vertidos al sistema de alcantarillas. Sin embargo, los residuos se generan en los hogares, y deben ser transportados fuera de los mismos y fuera de las ciudades por algún medio. La descarga de residuos sólidos a la red de alcantarillado no cambia la carga total de residuos producidos por el hogar, pero cambiará el medio de transporte y el destino final de éstos.

\subsection{DISEÑO DE AGUAS RESIDUALES APLICADO A LOS HOGARES}

El uso de una o más de las técnicas de gestión de los residuos en los hogares mencionadas anteriormente en combinación con mecanismos de ahorro de agua hacen posible diseñar aguas residuales con una composición específica, que será la óptima para su posterior manejo. Existen varias acciones para lograr una reducción de la carga contaminante (Tabla 3.21)

Tabla 3.21 Reducción de la carga de residuos a las aguas residuales por la separación en inodoro y cocina de tecnología limpia “Cleantech" (en g/hab.d) (de Henze, 1997)

\begin{tabular}{lccc}
\hline Tecnología & Tradicional & $\begin{array}{c}\text { Inodoro con } \\
\text { separación }^{1}\end{array}$ & $\begin{array}{c}\text { Cocina } \\
\text { Cleantech }^{2}\end{array}$ \\
\hline DQO & 130 & 55 & 32 \\
DBO & 60 & 35 & 20 \\
N & 13 & 2 & 1.5 \\
P & 2.5 & 0.5 & 0.4 \\
\hline
\end{tabular}

${ }^{1}$ Gabinete de agua $\rightarrow$ inodoro seco/compostaje.

${ }^{2}$ Parte de los residuos de cocina son desviados del fregadero al depósito de residuos sólidos.
La suma de la reducción de la carga y el ahorro de agua es un argumento adicional para el enfoque del diseño de aguas residuales (un ejemplo se muestra en la Tabla 3.22).

Tabla 3.22 Concentración de contaminantes en aguas residuales crudas con separación en inodoro y cocina de tecnología limpia (en $\left.\mathrm{g} / \mathrm{m}^{3}\right)$ (de Henze 1997)

\begin{tabular}{lccc}
\hline $\begin{array}{l}\text { Producción de aguas } \\
\text { residuales }\end{array}$ & 250 l/hab.d & 160 l/hab.d & 80 l/hab.d \\
\hline DQO & 130 & 200 & 400 \\
DBO & 80 & 125 & 250 \\
$\mathrm{~N}$ & 6 & 9 & 19 \\
$\mathrm{P}^{1}$ & 1.6 & 2.5 & 5 \\
\hline
\end{tabular}

${ }^{1}$ Asumiendo detergentes sin fosfatos

Los cambios obtenidos en la composición de las aguas residuales también influyen en la composición de la DQO. Esto puede resultar en cambios en la relación entre la fracción soluble y la suspendida, o cambios en la biodegradabilidad de la materia orgánica, por ejemplo, aportando más o menos materia orgánica degradable en una fracción determinada de aguas residuales. La composición de las aguas residuales tiene una influencia significativa en la selección de los procesos de tratamiento a utilizar. Mediante el cambio de la tecnología utilizada en los hogares y al desviar la mayor cantidad posible de residuos orgánicos al sistema de alcantarillado, es posible obtener características de aguas residuales como los que se muestran en la Tabla 3.23.

Tabla 3.23 Concentración de contaminantes en aguas residuales crudas con una carga máxima de residuos orgánicos (en $\mathrm{g} / \mathrm{m}^{3}$ ) (Henze, 1997)

\begin{tabular}{lccc}
\hline $\begin{array}{l}\text { Producción de aguas } \\
\text { residuales }\end{array}$ & 250 l/hab.d & 160 1/hab.d & 80 l/hab.d \\
\hline DQO & 880 & 1,375 & 2,750 \\
DBO & 360 & 565 & 1,125 \\
$\mathrm{~N}$ & 59 & 92 & 184 \\
$\mathrm{P}^{1}$ & 11 & 17 & 35 \\
\hline
\end{tabular}

${ }^{1}$ Asumiendo detergentes sin fosfatos

La tendencia a tener bien detalladas las aguas residuales y su fracción de biomasa, es el resultado de la creciente utilización de los modelos matemáticos en el tratamiento de aguas residuales. A fin de utilizar las fracciones de DQO, N y $\mathrm{P}$ en el contexto más general del modelado matemático, se pueden observar en la Tabla 3.26 (ubicada en los anexos de este capítulo) la lista de las variables de estado usadas por los modelos seleccionados. Con esto, los autores proponen una lista de las variables de estado más utilizadas (segunda columna de la Tabla 3.26). Para la descripción de cada componente presente en 
la tabla, el lector puede consultar la lista de referencias al pie de la página de la tabla.

La separación más común es la separación de residuos del inodoro del resto de las aguas residuales. Esto resultará en la generación de aguas residuales negras y grises, estas características se pueden ver en la Tabla 3.24. Para más detalles sobre las aguas grises, ver Ledin et al. (2000).

Tabla 3.24 Características de las aguas residuales negras y grises. Los bajos valores se pueden deber a altos consumos de agua. Los consumos bajos de agua o alta carga contaminante de la cocina pueden causar los valores altos (basado en Henze, 1997; Sundberg, 1995; Almeida et al,. 2000)

\begin{tabular}{lcccc}
\hline Parámetro & \multicolumn{2}{c}{ Aguas grises } & \multicolumn{2}{c}{ Aguas negras } \\
& Alto & Bajo & Alto & Bajo \\
\hline DQO & 700 & 200 & 1,500 & 900 \\
DBO & 400 & 100 & 600 & 300 \\
$\mathrm{~N}$ & 30 & 8 & 300 & 100 \\
$\mathrm{P}$ & 7 & 2 & 40 & 20 \\
$\mathrm{~K}^{1}$ & 6 & 2 & 90 & 40 \\
\hline
\end{tabular}

${ }^{1}$ Exclusivo del contenido en el suministro de agua

\subsection{AGUAS RESIDUALES Y LAS FRACCIONES DE BIOMASA}

La relación entre los diversos componentes de materia orgánica e inorgánica, nitrógeno y de fósforo de las aguas residuales o lodos se pueden observar en la Figura 3.13 (presentada en los anexos de este capítulo). La definición de cada término se presenta en la Tabla 3.26. Para una descripción más detallada de cada componente que aquí se presenta, el lector puede consultar la lista de referencias adjunta.

Los nombres de las variables varían entre las referencias dependiendo de la preferencia de los autores. En este libro, la notación utilizada para las variables no se ha normalizado, pero se ha iniciado una discusión sobre este punto entre los investigadores interesados en modelar (Comeau et al., 2008) y las siguientes indicaciones se sugieren como lineamientos para la notación de las variables.

En primer lugar, una letra indica el tamaño del componente (letra mayúscula en cursiva):

- $S:$ soluble

- $C$ : coloidal

- $X:$ particulado

- $T: \quad$ total $(=S+C+X)$.
El tamaño de partícula de la materia coloidal dependerá de la finalidad del modelo utilizado y el método de su determinación, y típicamente puede estar en el intervalo de 0.01 a 1 micra. El modelado de la materia coloidal ha aumentado en importancia en los últimos años debido a la necesidad de alcanzar concentraciones muy bajas de efluentes, una condición en que, el comportamiento de la materia coloidal se vuelve significativo. Los sistemas avanzados de tratamiento que incluyen membrana o procesos de adsorción se utilizan cada vez más para estos fines. En algunos casos, puede ser útil unir las letras que indican el tamaño de la materia (p. ej. $C X$ ).

Los subíndices se utilizan para describir el componente o su naturaleza (p. ej. F: fermentable; OHO: organismos heterótrofos ordinarios). Las comas se pueden añadir para indicar que un componente es parte de otro (por ejemplo

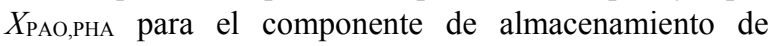
polihidroxialcanoatos (PHA) de organismos que acumulan fósforo; PAOs).

Los organismos se propone sean designados con siglas que terminan con la letra "O" (p. ej. ANO: organismos nitrificantes de amonio).

Cada variable de estado se considera independiente de las otras (lo cual no es cierto para las variables combinadas). Así, por ejemplo, el almacenamiento de PHA por parte de las PAOs ( $X_{\mathrm{PAO}}$, PHA $)$ no es considerado como parte de la PAOs $\left(X_{\mathrm{PAO}}\right)$.

La materia total (T) se compone de componentes inorgánicos $(\mathrm{IG})$ y orgánicos $(\mathrm{ORG})$, estando este último dividido en materia biodegradable (B) y no biodegradable (U). El término "no biodegradable" se propuso en lugar de inerte, sobre todo para evitar el uso de la letra "I" para minimizar el riesgo de confusión con la materia inorgánica.

Los nombres de las variables pueden ser utilizados en cualquier ubicación dentro de un sistema de tratamiento de aguas residuales. Se propone utilizar un superíndice para indicar la ubicación de la variable en el sistema, (p. ej. $\mathrm{X}_{\mathrm{OHO}}{ }^{\text {inf }}$ para la concentración OHOs en el afluente). Teniendo en cuenta que algunos compuestos de partículas no biodegradables de los afluentes se acumulan en los lodos activados como una función de la edad del lodo y el tiempo de retención hidráulico, a veces es necesario identificar su fuente y su ubicación (p. ej. $\mathrm{X}_{\mathrm{INF}, \mathrm{U}}$ OX para el componente no biodegradable del afluente en la zona aerobia $[\mathrm{OX}]$ del proceso). 
Cada componente se expresa en unidades de concentración en peso seco (p. ej. mg $\left.\mathrm{S}_{\mathrm{AGV}} / 1\right)$. Los diferentes constituyentes de cada componente contribuirán a su concentración en otras unidades como DQO, DBOU (DBO última), $\mathrm{DBO}_{5}$, residuos (sólidos), nitrógeno y fósforo utilizando factores de conversión apropiados según sea necesario para su expresión en estas unidades. Por ejemplo, expresar la concentración de AGV en unidades de DQO requeriría la variable de estado para ser expresado como $\mathrm{S}_{\mathrm{AGV} \text { DQo }}$ el subrayado se utiliza como separador para especificar las unidades utilizadas. Sin embargo, ya que los componentes de la materia orgánica en los modelos de lodos activados se expresa en unidades de DQO por defecto, el símbolo propuesto para el nombre de la variable en esta tabla se muestra sin el subrayado para indicar las unidades de DQO (por ejemplo $\mathrm{S}_{\mathrm{AGV} \text { DQO }}$ se muestra como $\mathrm{S}_{\mathrm{AGV}}$ ). Del mismo modo, los componentes que contienen sólo nitrógeno o fósforo no tienen unidades especificadas con el nombre de la variable en las unidades que se indican en la columna de las unidades. ( $\mathrm{S}_{\mathrm{PO} 4}$ por ejemplo, en lugar de $\left.\mathrm{SPO}_{\mathrm{P}} \mathrm{P}\right)$.

Cuando un componente contribuye a la DQO, DBO (si es biodegradable), residuos (sólidos), nitrógeno y fósforo, una estrella (*) se muestra en la columna correspondiente de la Figura 3.13. Se debe tener en cuenta que, para expresar variables en unidades de residuos, ya que los componentes se expresan en unidades de peso seco, no es estrictamente necesario incluir la notación " $\mathrm{R}$ ". Opcionalmente, puede ser utilizado para especificar que el compuesto se expresa en unidades de residuos, especialmente si los símbolos se definen en unidades básicas de DQO, como suele hacerse en modelos de lodos activados.

Los componentes de DBO son de la DBO carbonosa. La $\mathrm{DBO}_{u}$ es aproximadamente $10 \%$ menos que los componentes correspondientes a la DQO biodegradable. La relación $\mathrm{DBO}_{5} / \mathrm{DBO}_{u}$ depende del tipo de agua residual pero normalmente es de 0.67 . El oxígeno se considera que ejerce tanto una DQO como DBO negativas.

\subsection{LISTA DE SÍMBOLOS DE LAS VARIABLES PARA LOS MODELOS}

Una lista de los símbolos de las variables de estado utilizadas para varios modelos de lodos activados se muestra en la Tabla 3.26. También se describen algunas variables de estado y variables combinadas que no fueron utilizadas en estos modelos, pero que se muestran en la Figura 3.13.

\subsection{PROTOCOLOS DE CARACTERIZACIÓN}

Impulsados por las necesidades del modelado matemático de los sistemas de lodos activados, varios protocolos sistemáticos para la calibración del modelo de lodos activados se desarrollaron e incluyen diferentes protocolos de caracterización de aguas residuales. Cuatro protocolos principales fueron desarrollados por varios grupos de investigación. La naturaleza de estos protocolos varía de los más simplificados y más bien prácticos, a los de mayor complejidad principalmente de interés académico y de investigación.

- El protocolo STOWA (Hulsbeek et al., 2002)

- El protocolo BIOMATH (Vanrolleghem et al., 2003)

- El protocolo WERF para calibración del modelado (Melcer et al., 2003)

- Las guías Hochschulgruppe (HSG) (Langergraber et al., 2004).

Cuál protocolo utilizar va a depender de la finalidad del modelado. El lector podrá consultar al Capítulo 14 para más detalles sobre el modelado de tratamiento de lodos activados.

Fracciones típicas de la DQO total en afluentes de aguas residuales crudas y efluentes primarios se muestran en la Tabla 3.25 (adaptado de EnviroSim, 2007).

Tabla 3.25 Fracciones típicas de DQO total para efluentes crudos y primarios

\begin{tabular}{ccc}
\hline $\begin{array}{c}\text { Variable } \\
\text { de estado }\end{array}$ & \multicolumn{2}{c}{ Fracción de la DQO total } \\
\hline & $\begin{array}{c}\text { Agua residual } \\
\text { cruda } \\
0.03-0.08\end{array}$ & ${\text { Efluente } 1^{\text {rio }}}$ \\
$\mathrm{S}_{\mathrm{U}}$ & $0.0-0.08$ & $0.05-0.10$ \\
$\mathrm{~S}_{\mathrm{VFA}}$ & $0.05-0.18$ & $0.0-0.11$ \\
$\mathrm{~S}_{\mathrm{F}}$ & $0.47-0.53$ & $0.06-0.23$ \\
$\mathrm{C}_{\mathrm{INF}, \mathrm{B}}$ & $0.16-0.19$ & $0.29-0.36$ \\
$\mathrm{X}_{\mathrm{INF}, \mathrm{B}}$ & 0.1 & $0.29-0.36$ \\
$\mathrm{X}_{\mathrm{OHO}}$ & 0.13 & 0.1 \\
$\mathrm{X}_{\mathrm{U}}$ &
\end{tabular}




\subsection{EJEMPLO DE COMPOSICIÓN DE UN AFLUENTE, BIOREACTOR Y EFLUENTE}

Un ejemplo de los valores de concentración para varias variables de estado y variables combinadas para el afluente, la zona aireada y de los efluentes del proceso Phoredox se puede observar en la Figura 3.14.

\subsection{LA HUELLA DE LAS AGUAS RESIDUALES}

'Muéstrame tus aguas residuales y te diré quién eres'. Las aguas residuales generadas por una persona en particular, permiten identificar muy detalladamente su estilo de vida. Todas las actividades humanas quedan registradas y se reflejan en las aguas residuales, los alimentos que comemos, los materiales que usamos en nuestras casas así como los materiales y los procesos de producción aplicados en la industria. A través de las aguas residuales se puede obtener información sobre enfermedades, el sexo, si se está embarazada, la utilización de drogas, la higiene personal, la alimentación, la conciencia ambiental, el alcoholismo, etc. La 'huella' que dejamos en las aguas residuales afecta al ambiente. No es el agua residual que estropea el ambiente; son los seres humanos que contaminan el agua.

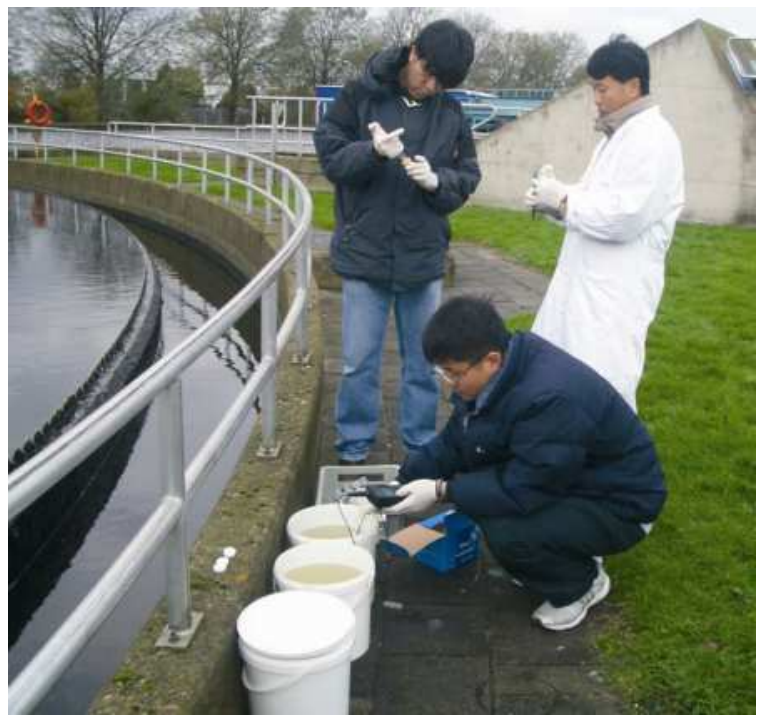

La ejecución de un programa de muestreo y monitoreo requiere experiencia y recursos financieros, pero como contrapartida genera varios beneficios incluyendo la optimización del diseño de la planta, un mejor funcionamiento de las plantas de tratamiento de aguas residuales $\mathrm{y}$ ahorros a nivel general (foto: K-water) 
Tabla 3.26 Lista de símbolos de variables para varios modelos

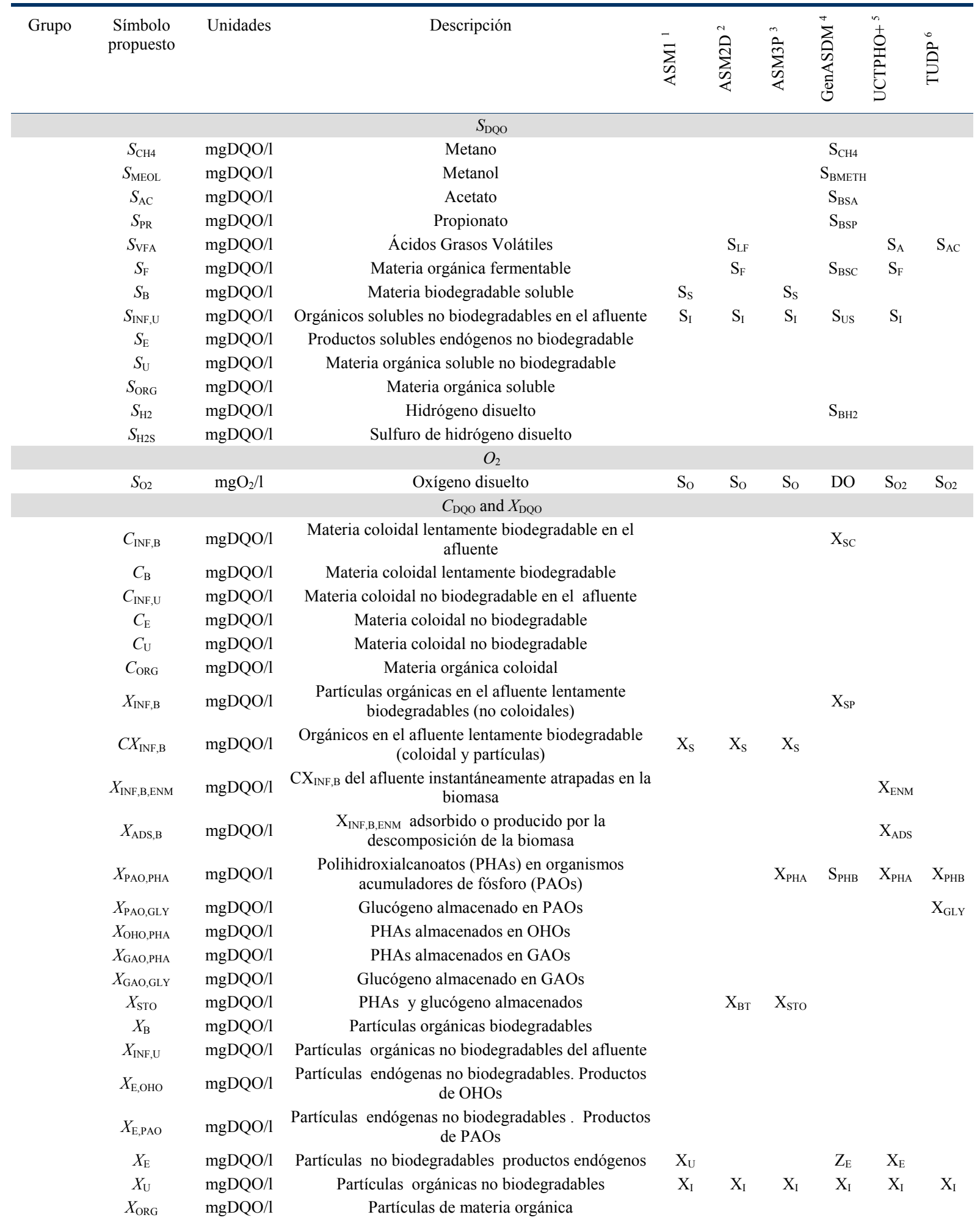


Tabla 3.26 Continúa

\begin{tabular}{|c|c|c|c|c|c|c|c|c|c|}
\hline Grupo & $\begin{array}{l}\text { Símbolo } \\
\text { propuesto }\end{array}$ & Unidades & Descripción & $\sum_{\text {S }}^{-}$ & $\stackrel{N}{\sum_{\infty}^{\infty}}$ & 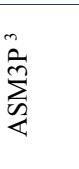 & 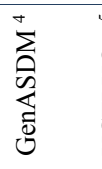 & 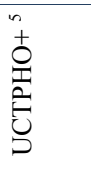 & $\stackrel{\circ}{:}$ \\
\hline \multicolumn{10}{|c|}{ Organismos } \\
\hline & $X_{\mathrm{OHO}}$ & $\mathrm{mgDQO} / 1$ & Organismos heterótrofos ordinarios (OHOs) & $\mathrm{X}_{\mathrm{B}, \mathrm{H}}$ & $\mathrm{X}_{\mathrm{BH}}$ & $\mathrm{X}_{\mathrm{H}}$ & $\mathrm{Z}_{\mathrm{BH}}$ & $\mathrm{X}_{\mathrm{H}}$ & \\
\hline & $X_{\mathrm{AOO}}$ & $\mathrm{mgDQO} / 1$ & Organismos que oxidan amonio & & & & $\mathrm{Z}_{\mathrm{BA}}$ & & $\mathrm{X}_{\mathrm{NH}}$ \\
\hline & $X_{\mathrm{NOO}}$ & $\mathrm{mgDQO} / 1$ & Organismos que oxidan nitrato & & & & $Z_{\mathrm{BN}}$ & & $\mathrm{X}_{\mathrm{NO}}$ \\
\hline & $X_{\mathrm{ANO}}$ & $\mathrm{mgDQO} / 1$ & Organismos nitrificantes autotróficos $\left(\mathrm{NH}_{4}{ }^{+}\right.$a $\left.\mathrm{NO}_{3}^{-}\right)$ & $\mathrm{X}_{\mathrm{B}, \mathrm{A}}$ & $\mathrm{X}_{\mathrm{BA}}$ & $\mathrm{X}_{\mathrm{A}}$ & & $\mathrm{X}_{\mathrm{AUT}}$ & \\
\hline & $X_{\text {AMO }}$ & $\mathrm{mgDQO} / 1$ & Organismos anaerobios oxidantes de amoníaco & & & & $Z_{\text {ВАMO }}$ & & \\
\hline & $X_{\mathrm{PAO}}$ & $\mathrm{mgDQO} / 1$ & Organismos acumuladores de fósforo (PAOs) & & $\mathrm{X}_{\mathrm{BP}}$ & $\mathrm{X}_{\mathrm{PAO}}$ & $\mathrm{Z}_{\mathrm{BP}}$ & $\mathrm{X}_{\mathrm{PAO}}$ & $\mathrm{X}_{\mathrm{PAO}}$ \\
\hline & $X_{\mathrm{GAO}}$ & $\mathrm{mgDQO} / 1$ & Organismos acumuladores de glucógeno (GAOs) & & & & & & \\
\hline & $X_{\text {MEOLO }}$ & $\mathrm{mgDQO} / 1$ & $\begin{array}{l}\text { organismos anóxicos que utilizan metanol } \\
\text { metilotróficos }\end{array}$ & & & & $Z_{\text {BMETH }}$ & & \\
\hline & $X_{\mathrm{ACO}}$ & $\mathrm{mgDQO} / 1$ & Organismos metanogénicos acetoclásticos & & & & $Z_{\mathrm{BAM}}$ & & \\
\hline & $X_{\text {Нмо }}$ & $\mathrm{mgDQO} / 1$ & Organismos metenogénicos hidrogenotróficos & & & & $\mathrm{Z}_{\mathrm{BHM}}$ & & \\
\hline & $X_{\mathrm{PRO}}$ & $\mathrm{mgDQO} / 1$ & Organismos acetogénicos propiónicos & & & & $\mathrm{Z}_{\mathrm{BPA}}$ & & \\
\hline & $X_{\mathrm{SRO}}$ & $\mathrm{mgDQO} / 1$ & Organismos sulfato reductores & & & & & & \\
\hline & $X_{\text {BIOM }}$ & $\mathrm{mgDQO} / 1$ & Organismos (biomasa) & & & & & & \\
\hline \multicolumn{10}{|c|}{ Inorgánicos } \\
\hline & $X_{\mathrm{INF}, \mathrm{IG}}$ & mgISS/1 & $\begin{array}{c}\text { Partículas inorgánicas en el afluente (excluidas otras } \\
\text { variables de estado) }\end{array}$ & & & & & & \\
\hline & $X_{\mathrm{ORG}, \mathrm{IG}}$ & mgISS/1 & $\begin{array}{c}\text { Inorgánicas asociadas a material orgánica (incluidos } \\
\text { organismos) }\end{array}$ & & & & & & \\
\hline & $X_{\mathrm{MAP}}$ & $\mathrm{mgISS} / 1$ & Estruvita (fosfato de amonio y magnesio) & & & & $\mathrm{X}_{\mathrm{STRU}}$ & & \\
\hline & $X_{\mathrm{HAP}}$ & $\operatorname{mgISS} / 1$ & Hidroxiapatita & & & & $\mathrm{X}_{\mathrm{HAP}}$ & & \\
\hline & $X_{\mathrm{HDP}}$ & $\operatorname{mgISS} / 1$ & Fosfato dicálcico dihidratado & & & & $\mathrm{X}_{\mathrm{HDP}}$ & & \\
\hline & $X_{\mathrm{FEP}}$ & $\operatorname{mgISS} / 1$ & Fosfato de hierro precipitado & & & & & & \\
\hline & $X_{\mathrm{ALP}}$ & $\operatorname{mgISS} / 1$ & Fosfato de aluminio precipitado & & & & & & \\
\hline & $X_{\mathrm{MEP}}$ & $\mathrm{mgISS} / 1$ & Fosfatos metálicos precipitados & & $\mathrm{X}_{\mathrm{MEP}}$ & & & & \\
\hline & $X_{\mathrm{ALOH}}$ & $\operatorname{mgISS} / 1$ & Hidróxido de aluminio precipitado & & & & & & \\
\hline & $X_{\mathrm{FEOH}}$ & $\mathrm{mgISS} / 1$ & Hidróxido de hierro precipitado & & & & & & \\
\hline & $X_{\mathrm{MEOH}}$ & $\mathrm{mgISS} / 1$ & Hidróxidos metálicos precipitados & & $\mathrm{X}_{\mathrm{MEOH}}$ & & & & \\
\hline & $T_{\mathrm{ME}}$ & $\mathrm{mgME} / \mathrm{l}$ & Metales (Al - Fe) & & & & $\mathrm{C}_{\mathrm{ME}}$ & & \\
\hline & $X_{\mathrm{PAO}, \mathrm{PPL}}$ & $\mathrm{mgP} / 1$ & Fosfatos almacenados como PAOs liberables & & & & $\mathrm{PP}_{\mathrm{LO}}$ & & \\
\hline & $X_{\mathrm{PAO}, \mathrm{PPH}}$ & $\mathrm{mgP} / 1$ & Fosfatos almacenados como PAOs no liberables & & & & $\mathrm{PP}_{\mathrm{HI}}$ & & \\
\hline & $X_{\mathrm{PAO}, \mathrm{PP}}$ & $\mathrm{mgP} / 1$ & Polifosfatos almacenados en PAOs & & $\mathrm{X}_{\mathrm{PP}}$ & $\mathrm{X}_{\mathrm{PP}}$ & & $\mathrm{X}_{\mathrm{PP}}$ & $\mathrm{X}_{\mathrm{PP}}$ \\
\hline & $\mathrm{X}_{\mathrm{IG}}$ & $\mathrm{mgISS} / 1$ & Material particulado inorgánico & & & & & & \\
\hline & $X_{\mathrm{B} \_\mathrm{P}}$ & $\mathrm{mgP} / 1$ & $\begin{array}{l}\text { P contenido en partículas de materia orgánica } \\
\text { biodegradable }\end{array}$ & & & & $\mathrm{X}_{\mathrm{OP}}$ & & \\
\hline & $X_{\mathrm{U}_{-} \mathrm{P}}$ & $\mathrm{mgP} / 1$ & $\begin{array}{l}\mathrm{P} \text { contenido en partículas de materia orgánica no } \\
\text { biodegradable }\end{array}$ & & & & $\mathrm{X}_{\mathrm{IP}}$ & & \\
\hline & $C_{\mathrm{INF}, \mathrm{IG}}$ & $\operatorname{mgISS} / 1$ & $\begin{array}{c}\text { Inorgánicos coloidales en el afluente (excluidas otras } \\
\text { variables de estado) }\end{array}$ & & & & & & \\
\hline & $C_{\mathrm{ORG}, \mathrm{IG}}$ & $\operatorname{mgISS} / 1$ & Inorgánicas asociadas a material orgánica coloidal & & & & & & \\
\hline & $C_{\mathrm{IG}}$ & $\mathrm{mgISS} / 1$ & Inorgánicas presentes en materia coloidal & & & & & & \\
\hline & $S_{\mathrm{NH} 4}$ & $\mathrm{mgN} / 1$ & Amonio $\left(\mathrm{NH}_{4}^{+}+\mathrm{NH}_{3}\right)$ & $\mathrm{S}_{\mathrm{NH}}$ & $\mathrm{S}_{\mathrm{NH}}$ & $\mathrm{S}_{\mathrm{NH}}$ & $\mathrm{S}_{\mathrm{NH} 3}$ & $\mathrm{~S}_{\mathrm{NH} 4}$ & $\mathrm{~S}_{\mathrm{NH} 4}$ \\
\hline & $S_{\mathrm{NO} 2}$ & $\mathrm{mgN} / 1$ & Nitrito $\left(\mathrm{HNO}_{2}+\mathrm{NO}_{2}^{-}\right)$ & & & & $\mathrm{S}_{\mathrm{NO} 2}$ & & $\mathrm{~S}_{\mathrm{NO} 2}$ \\
\hline & $S_{\mathrm{NO} 3}$ & $\mathrm{mgN} / 1$ & Nitrato $\left(\mathrm{HNO}_{3}+\mathrm{NO}_{3}^{-}\right)$ & & & & $\mathrm{S}_{\mathrm{NO} 3}$ & & $\mathrm{~S}_{\mathrm{NO} 3}$ \\
\hline & $\mathrm{S}_{\mathrm{NOX}}$ & $\mathrm{mgN} / 1$ & Nitrito + nitrato & $\mathrm{S}_{\mathrm{NO}}$ & $\mathrm{S}_{\mathrm{NO}}$ & $\mathrm{S}_{\mathrm{NO}}$ & & $\mathrm{S}_{\mathrm{NO} 3}$ & \\
\hline & $S_{\mathrm{PO} 4}$ & $\mathrm{mgP} / 1$ & Fósforo inorgánico soluble (o- $\mathrm{PO}_{4}$ test) & & $\mathrm{S}_{\mathrm{P}}$ & $\mathrm{S}_{\mathrm{PO} 4}$ & & $\mathrm{~S}_{\mathrm{PO} 4}$ & $\mathrm{~S}_{\mathrm{PO} 4}$ \\
\hline & $S_{\mathrm{PO} 4}+X_{\mathrm{MEP}}$ & $\mathrm{mgP} / 1$ & Fosfato total ( $\mathrm{P}$ soluble + metal-P) & & & & $\mathrm{cPO}_{4}$ & & \\
\hline
\end{tabular}


Tabla 3.26 Continúa

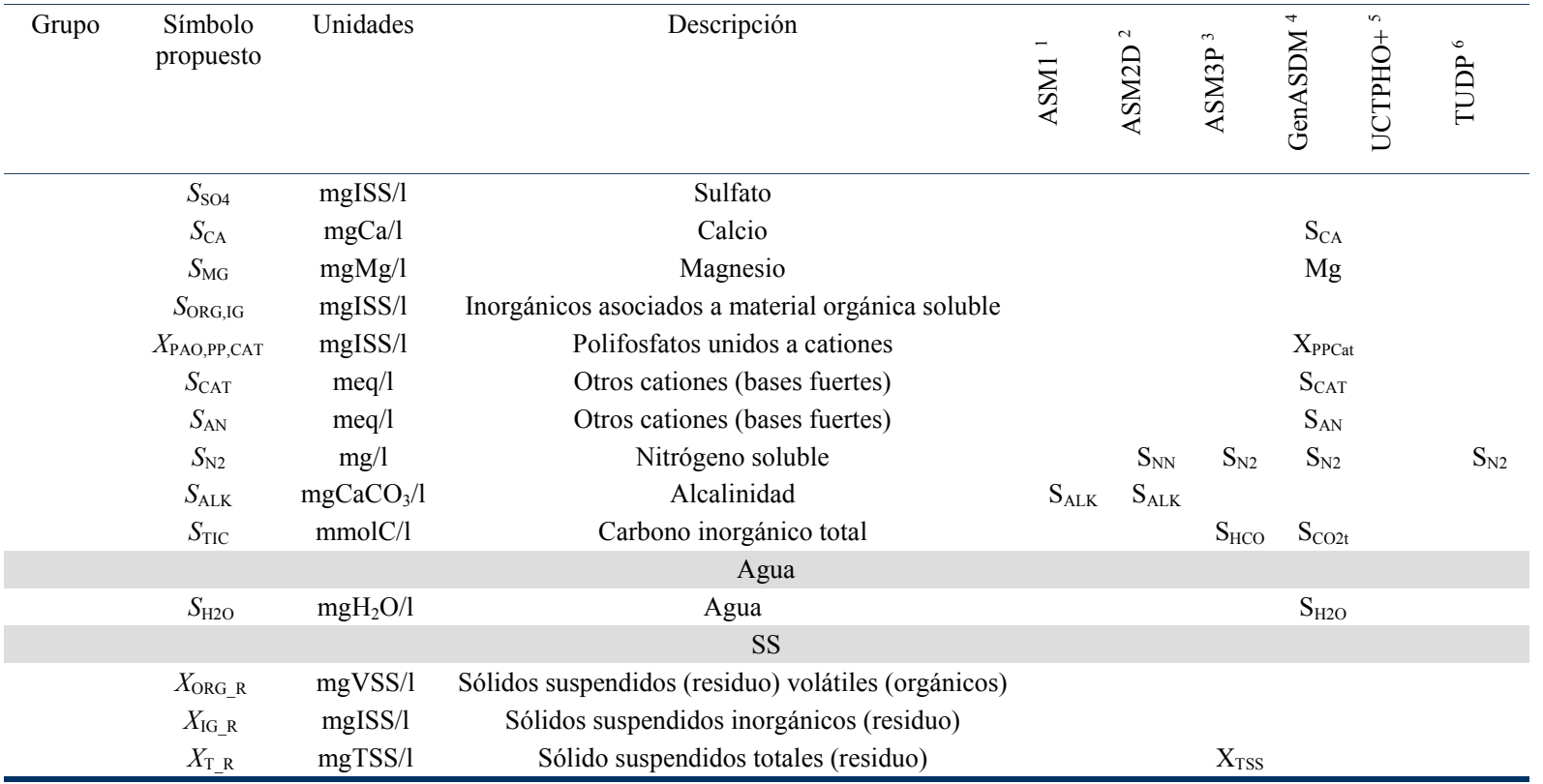

${ }^{1}$ ASM1: Henze et al. (1987)

${ }^{2}$ ASM2D: Henze et al. (1999)

${ }^{3}$ ASM3-P: Rieger et al. (2001)

${ }^{4}$ General ASDM: EnviroSim (2007)

${ }^{5} \mathrm{UCTPHO}+$ : Hu et al. (2007)

${ }^{6}$ TUDP: de Kreuk et al. (2007)
Nota: 1) Dado que, los componentes de materia orgánica en los modelos de lodos activados se expresaron por defecto en unidades de DQO, el símbolo propuesto para nombrar a la variable en esta tabla se muestra sin el subrayado para indicar las unidades de DQO (por ejemplo $\mathrm{S}_{\mathrm{VFA} \text { COD }}$ se muestra como $\mathrm{S}_{\mathrm{VFA}}$ ). Del mismo modo, los componentes que contienen únicamente nitrógeno o fósforo no tienen unidades especificadas en el nombre de la variable con las unidades que se indican en la columna de las unidades. 2) Algunos compuestos que no eran independientes de las variables mostradas en la figura 3.13 no se muestran en esta figura (p. ej., como $\mathrm{X}_{\mathrm{INF}, \mathrm{B}, \mathrm{ENM}}$ y $\mathrm{X}_{\mathrm{ADS}, \mathrm{B}}$ que están relacionados con $\left.\mathrm{CX}_{\mathrm{INF}, \mathrm{B}}\right)$. 




Figura 3.13 Fraccionamiento de los componentes de la materia orgánica e inorgánica, y las relaciones entre su contenido en peso seco, DQO, DBO, residuos (sólidos), nitrógeno y fósforo de acuerdo con la nomenclatura de los modelos matemáticos de lodos activados más utilizados (continúa...) 


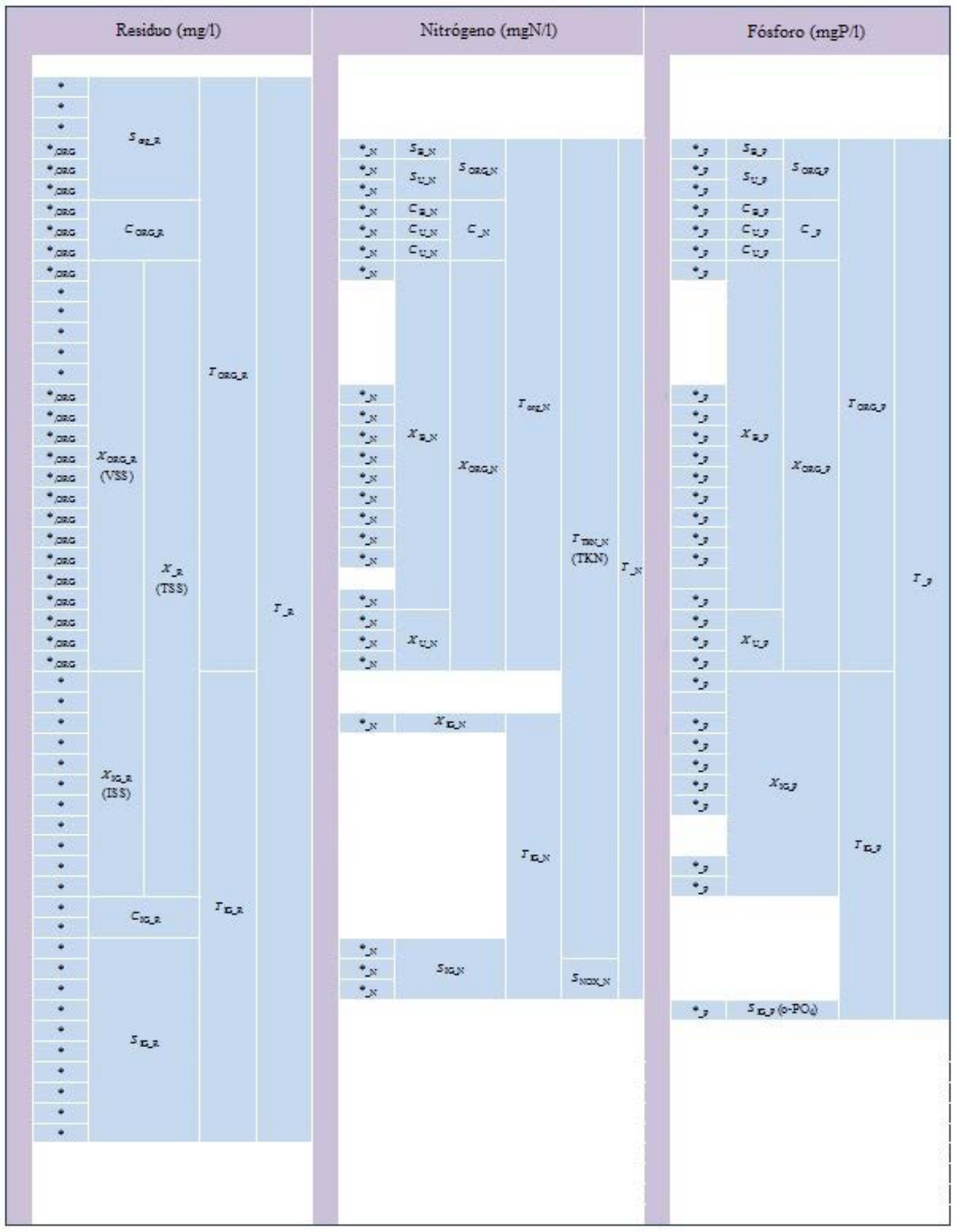

Figura 3.13 (Continúa...) 


\begin{tabular}{|c|c|c|c|c|c|}
\hline & Variables do cuado & Unitedes & Inflosens & Asrobico & Eflusesis \\
\hline \multirow{20}{*}{ 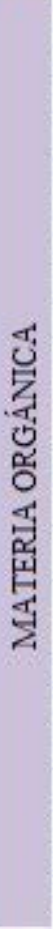 } & $S_{\mathrm{Can}}$ & $\mathrm{mgDQO} / 1$ & 0 & 0.03 & 0.03 \\
\hline & $S_{\text {SIEOLL }}$ & $\mathrm{mgDQO} / 1$ & 0 & 0 & 0 \\
\hline & $S_{A C}$ & $\mathrm{mgDQO} / 1$ & 15 & 0 & 0 \\
\hline & $s_{v_{2}}$ & $\mathrm{mgDQO} / 1$ & 5 & 0.01 & 0.01 \\
\hline & $S_{F}$ & $\mathrm{mgDQO} / 1$ & 30 & 1.7 & 1,7 \\
\hline & $S_{\mathrm{NFU}}$ & $\mathrm{mgDQO} / 1$ & 25 & 25 & 25 \\
\hline & $C_{\text {INFB }}$ & $\mathrm{mgDQO} / 1$ & 15 & 0 & 0 \\
\hline & $X_{\mathrm{NFB}}$ & $\mathrm{mgDQO} 1$ & 110 & 93 & 0,3 \\
\hline & $X_{\text {PAONHA }}$ & $\mathrm{mgDQO} / 1$ & 1 & 12 & 0.04 \\
\hline & $X_{\text {OHO }}$ & $\mathrm{mgDQO} / 1$ & 30 & 1318 & 4.8 \\
\hline & $x_{A 00}$ & $\mathrm{mgDQO} / 1$ & 1 & 40.0 & 0.15 \\
\hline & $x_{\mathrm{N}}$ & $\mathrm{mgDQO} / 1$ & 1 & 29.8 & 0.11 \\
\hline & $x_{\text {Avo }}$ & $\mathrm{mgDQO} / 1$ & 1 & 18.5 & 0.07 \\
\hline & $x_{740}$ & $\mathrm{mgDQO} / 1$ & 1 & 153.6 & 0.56 \\
\hline & $x_{\text {MEOLO }}$ & $\mathrm{mgDQO} / 1$ & 1 & 17.1 & 0.06 \\
\hline & $x_{\text {Aco }}$ & $\mathrm{mgDQO} / 1$ & 1 & 7.3 & 0.03 \\
\hline & $x_{\text {Hvo }}$ & $\mathrm{mgDQO} / 1$ & 1 & 8.6 & 0.03 \\
\hline & $x_{\text {no }}$ & $\mathrm{mgDQO} / 1$ & 1 & 8.3 & 0.03 \\
\hline & $x_{\text {IFF }}$ & $\mathrm{mgDQO} / 1$ & 35 & 681 & 2.5 \\
\hline & $X_{E O W D}$ & $\mathrm{mgDQO} / 1$ & 0 & 221 & 0.8 \\
\hline \multirow{16}{*}{ 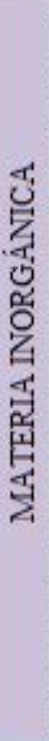 } & $x_{\text {Mas }}$ & mgSSI/1 & 0 & 0 & 0 \\
\hline & $x_{\text {Has }}$ & $\mathrm{mgSSI} / 1$ & 0.1 & 1.9 & 0.01 \\
\hline & $x_{\text {LDV }}$ & mgSSI/1 & 0.1 & 0.0 & 0.0 \\
\hline & $X_{\text {paOm }}$ & $\mathrm{mgP} / 1$ & 0 & 31 & 0.11 \\
\hline & $X_{\text {PAONh }}$ & $\mathrm{mgP} / 1$ & 0 & 10 & 0.04 \\
\hline & $S_{\mathrm{NH} 4}$ & $\mathrm{mgN} / 1$ & 16 & 1.8 & 1.8 \\
\hline & $s_{\mathrm{NO} 2}$ & $\mathrm{mgN} / 1$ & 0.1 & 0.2 & 0.2 \\
\hline & $S_{\mathrm{NOS}}$ & $\mathrm{mgN} / 1$ & 1.0 & 4.1 & 4.1 \\
\hline & S no4 & $\mathrm{mgP} / 1$ & 2.2 & 0.55 & 0.55 \\
\hline & Sa & $\mathrm{mgCa} / \mathrm{t}$ & 66 & 66 & 66 \\
\hline & $S_{350}$ & $\mathrm{mgMg} /$ & 12 & 11 & 11 \\
\hline & SCAT & meq 1 & 2.5 & 2.4 & 2.4 \\
\hline & SAN & meq/1 & 3.0 & 3.0 & 3.0 \\
\hline & $S_{122}$ & $\mathrm{mgDQO} / 1$ & 0 & 0.3 & 0.3 \\
\hline & $S_{N 2}$ & $\mathrm{mgN} / 1$ & 15 & 19 & 19 \\
\hline & $S_{O_{2}}$ & $\mathrm{mgO}_{2} / 1$ & 0.0 & 2.0 & 2.0 \\
\hline
\end{tabular}

\begin{tabular}{|c|c|c|c|c|c|}
\hline \multicolumn{2}{|c|}{ Varisbles contbinadus } & Unidedes & Influsenso & Ascrobiso & Effusents \\
\hline \multirow{3}{*}{$\mathrm{DQO}$} & $S C$ COD & $\mathrm{mgDQO} / 1$ & 90 & 27 & 27.5 \\
\hline & $x \cos$ & $\mathrm{mgDQO} / 1$ & 184 & 2608 & 9.6 \\
\hline & $T$ COD & $\mathrm{mgDQO} / 1$ & 274 & 2636 & 37.0 \\
\hline \multirow{3}{*}{$\mathrm{DBO}_{s}$} & $S$ BODS & $\mathrm{mgO}_{2} 1$ & 46 & I & 1.2 \\
\hline & $X$ BODS & $\mathrm{mgO}_{2} / 1$ & 80 & 973 & 3.6 \\
\hline & $T$ BODS & $\mathrm{mgO}_{2} 1$ & 126 & 975 & 4.8 \\
\hline \multirow{3}{*}{ Residvos } & $X_{\text {OReR }}$ & mgSSV/1 & 118 & 1775 & 6.5 \\
\hline & $X_{10 \mathrm{R}}$ & mgSSI/1 & 17 & 524 & 1.9 \\
\hline & $x_{2}$ & $\mathrm{mgSST} / 1$ & 135 & 2299 & 8.4 \\
\hline \multirow{4}{*}{ Nitrógeno } & $S_{\mathrm{TEN} N}$ & $\mathrm{mgN} / 1$ & 17.3 & 3.3 & 3.3 \\
\hline & $X_{\text {TRON }}$ & $\mathrm{mgN} / 1$ & 9.7 & 191 & 0.7 \\
\hline & $T_{\text {TSN S }}$ & $\mathrm{mgN} / 1$ & 27.0 & 194 & 4.0 \\
\hline & $T_{\mathrm{N}}$ & $\mathrm{mgN} / \mathrm{A}$ & 28.1 & 198 & 8.3 \\
\hline \multirow{3}{*}{ Fósforo } & $x_{\mathrm{B}}$, & $\mathrm{mg} / 1$ & 1.8 & 1.7 & 0.01 \\
\hline & $x_{U}$, & $\mathrm{mgP} / 1$ & 0.3 & 10.7 & 0.04 \\
\hline & $T$, & $\mathrm{mgP} / 1$ & 6.6 & 118 & 0.98 \\
\hline
\end{tabular}

Figura 3.14 Concentraciones de diversos componentes de un proceso Phoredox operado con un tiempo de retención de lodos de $5 \mathrm{~d} \mathrm{SRT} \mathrm{a} 12^{\circ} \mathrm{C}$ 


\section{REFERENCIAS}

Almeida M.C., Butler D. and Friedler E. (2000) At source domestic wastewater quality. Urban Water 1, 49-55.

Comeau Y., Takacs I., Ekama G.A., Rieger L., Vanrolleghem P., Corominas L., Hauduc H., Jeppsson U., Batstone D., Morgenroth E., van Loosdrecht M.C.M. (2008) Standardized notation of parameters Discussions.

de Kreuk M. K., Picioreanu C., Hosseini M., Xavier J. B., van Loosdrecht M. C. M. (2007). Kinetic model of a granular sludge SBR - influences on nutrient removal. Biotech. Bioeng, 97(4), 801-815.

EnviroSim (2007) General activated sludge-digestion model (General ASDM). BioWin3 software, EnviroSim Associates, Flamborough, Ontario.

Henze M., Grady C.P.L., Gujer W., Marais G.v.R. and Matsuo T. (1987) Activated sludge model No.1. IAWPRC Scientific and Technical Reports No.1. IWA Publications, London.

Henze M. (1992) Characterization of wastewater for modelling of activated sludge processes. Wat. Sci. Tech. 25(6), 1-15.

Henze M. (1997) Waste design for households with respect to water, organics and nutrients. Wat. Sci. Tech. 35(9), $113-120$.

Henze M., Gujer W., Mino T., Matsuo T., Wentzel M.C., Marais G.v.R., van Loosdrecht, M.C.M. (1999) Activated Sludge Model No.2d, ASM2d. Wat. Sci. Tech. 39(1), 165-182.

Henze M., Harremoës P., la Cour Jansen J. and Arvin E. (2002) Wastewater Treatment: Biological and Chemical Processes, 3rd ed, Springer-Verlag, Berlin.

Hu Z., Wentzel M.C., Ekama G.A. (2007) A general kinetic model for biological nutrient removal activated sludge systems - Model development. Biotech. Bioeng. 98(6), 1242-.1258.
Hulsbeek J.J.W., Kruit J., Roeleveld P.J., van Loosdrecht M.C.M. (2002) A practical protocol for dynamic modelling of activated sludge systems. Wat. Sci. Tech. 45(6), 127-136.

Langergraber G., Rieger L., Winkler S., Alex J., Wiese J., Owerdieck C., Ahnert M., Simon J., Maurer M. (2004) A guideline for simulation studies of wastewater treatment plants. Wat. Sci. Tech. 50(7), 131-138.

Roeleveld P.J., van Loosdrecht M.C.M. (2002) Experience with guidelines for wastewater characterisation in The Netherlands. Wat. Sci. Tech. 45(6), 77-87.

Sin, G. (2004) Systematic calibration of activated sludge models. PhD. Thesis, Faculty of Agricultural and Applied Biological Sciences, Ghent University, Belgium.

Sundberg A. (1995) What is the content of household wastewater. Swedish EPA, Stockholm, Report no. 4425.

Triebel W. (1982) Lehr und Handbuch der Abwassertechnik. (Wastewater Techniques: Textbook and Manual), 3rd edn, Verlag von Wilhelm Ernst, Berlin, germany.

United States Environmental Protection Agency (1977) Process Design Manual. Wastewater Treatment Facilities for Sewered Small Communities. US EPA, Cincinnati, $\mathrm{OH}$.

Vanrolleghem P.A., Insel G., Petersen B., Sin G., De Pauw D., Nopens I., Doverman H., Weijers S., Gernaey K. (2003) A comprehensive model calibration procedure for activated sludge models. In: Proceedings 76th Annual WEF Conference and Exposition, Los Angeles 11-15 October.

WERF (2003) Methods for Wastewater Characterization in Activated Sludge Modeling. - Water Environment Research Foundation report 99-WWF-3, WERF and IWA Publishing, 575p. 


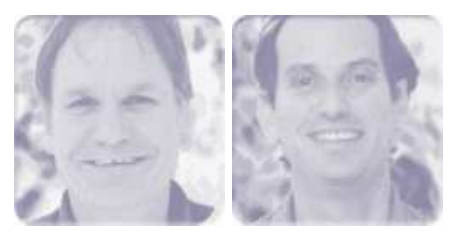

\section{4}

\section{Remoción de Materia Orgánica}

\section{George A. Ekama and Mark C. Wentzel}

\subsection{INTRODUCCIÓN \\ 4.1.1 Transformaciones en un reactor biológico}

En un sistema de lodos activados es necesario caracterizar las aguas residuales físicamente (solubles, no sedimentables (coloidales y/o suspendidas), sedimentables, inorgánicas y orgánicas) y biológicamente (biodegradables y no biodegradables). Las transformaciones físicas, químicas y biológicas de los componentes orgánicos e inorgánicos de las aguas residuales que se producen en un reactor biológico se describen en la Figura 4.1. Algunas de estas transformaciones son importantes para obtener la calidad requerida en el efluente, mientras que otras no son importantes para la calidad del efluente pero si lo son para el diseño y operación del sistema. En la Figura 4.1 cada una de las fracciones orgánica e inorgánica del agua residual se dividen en una fracción soluble y particulada, esta última adicionalmente se subdivide en una fracción suspendida (no sedimentable) y sedimentable. Cada una de las tres fracciones orgánicas, tienen a su vez componentes biodegradables y no biodegradables. La fracción de material inorgánico particulado se compone de fracciones sedimentables y suspendidas (no sedimentables), mientras que la fracción de material inorgánico soluble comprende las fracciones tanto precipitables como no precipitables, y componentes que pueden ser utilizados biológicamente por los organismos y otros que no lo pueden ser.

Los constituyentes orgánicos biodegradables presentes en un reactor biológico, sean estos solubles, no sedimentables o sedimentables, pueden ser transformados en organismos heterótrofos ordinarios (OHO, $\mathrm{X}_{\mathrm{BH}}$ ), los cuales pasan a formar parte de los sólidos suspendidos orgánicos (volátiles) (SSV) en el reactor. Cuando estos organismos mueren, dejan tras de sí material orgánico no biodegradable y no soluble, llamado residuo endógeno $\left(\mathrm{X}_{\mathrm{EH}}\right)$, compuesto principalmente del material no biodegradable de la pared celular. Este residuo endógeno se incorpora a la masa de sólidos suspendidos volátiles en el reactor (SSV). La fracción de material orgánico particulado (suspendido y sedimentable), no biodegradable $\left(\mathrm{X}_{\mathrm{I}}\right)$ se adhiere o es absorbida junto con la masa de OHOs y de residuo endógeno. Juntos, estos tres componentes $\left(\mathrm{X}_{\mathrm{BH}}\right.$ $+\mathrm{X}_{\mathrm{EH}}+\mathrm{X}_{\mathrm{I}}$ ) forman el componente orgánico de los

(c) 2017 George A. Ekama. Tratamiento Biológico de Aguas Residuales: Principios, Modelación y Diseño. Eds. M. Henze, M.C.M. van Loosdrecht, G.A. Ekama y D. Brdjanovic. Eds. (versión en español) C.M. López Vázquez, G. Buitrón Méndez, H.A. García, F.J. Cervantes Carrillo. ISBN (versión impresa): 9781780409139, ISBN (e-Book): 9781780409146. Publicado por IWA Publishing, London, UK. 
sólidos sedimentables que se acumulan en el reactor biológico ( $\mathrm{SSV}, \mathrm{Xv})$. Los componentes inorgánicos (sedimentables y suspendidos), junto con los componentes inorgánicos solubles precipitables, forman la masa de sólidos sedimentables inorgánicos (SSI). Los compuestos inorgánicos solubles biológicamente utilizables son absorbidos por la biomasa y se convierten en parte de esta o se transforman a la fase gaseosa, en cuyo caso escapan a la atmósfera. Los compuestos inorgánicos solubles no precipitables y no aprovechables biológicamente escapan con el efluente.

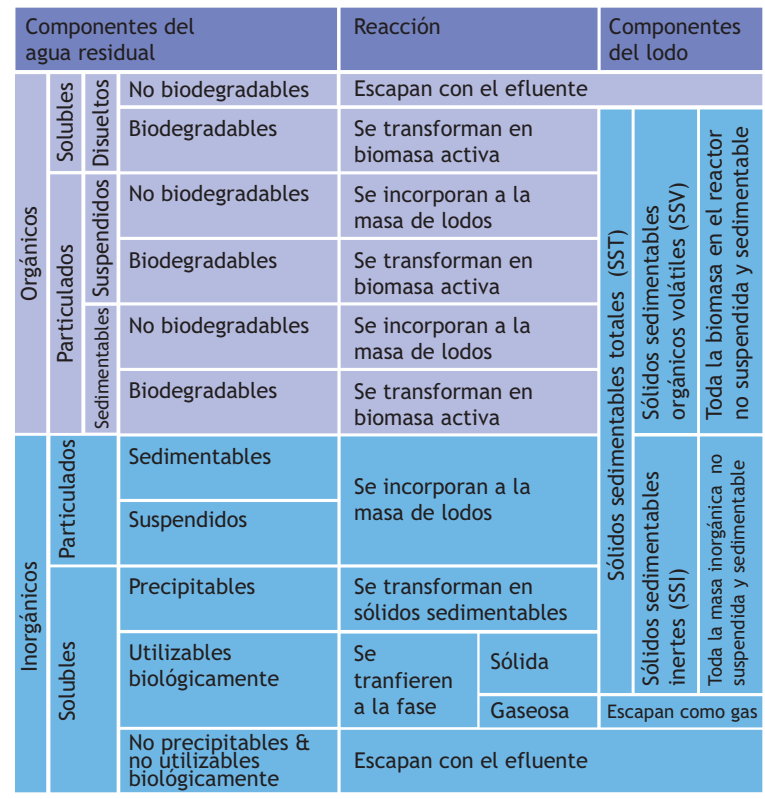

Figura 4.1 Reacciones globales de transformación de los compuestos orgánicos e inorgánicos del agua residual. Transformación de los componentes particulados y solubles en las fases sólida y líquida a la fase sólida como componentes del lodo, y a las fases líquida y gaseosa escapando con el efluente y a la atmósfera respectivamente.

Debido a la eficiente capacidad de floculación de la masa orgánica en el lodo activado, todo el material sólido, ya sea biodegradable o no biodegradable, orgánico o inorgánico, se convierte en sólidos sedimentables. Una cantidad muy pequeña de sólidos suspendidos o coloidales (no sedimentables) se produce en un reactor de lodos activados, pero cuando esto sucede, estos sólidos no pueden ser retenidos en el sistema y escapan con el efluente.

El nivel de detalle requerido en la caracterización de las aguas residuales para el diseño de un sistema de lodos activados no está determinado únicamente por los procesos físicos, químicos y biológicos que tienen lugar en el sistema, sino también por el nivel de sofisticación de los procedimientos que deban aplicarse para el diseño de las unidades. Esto está determinado en gran medida por los requerimientos de calidad del efluente en términos de materia orgánica $(C)$, nitrógeno $(N)$ y fósforo $(\mathrm{P})$. Generalmente, entre más estrictos sean los requisitos de calidad del efluente en términos de $\mathrm{C}, \mathrm{N}$ y $\mathrm{P}$, más complejo será el sistema de lodos activados que se requiere, y a su vez los procedimiento de diseño deberán ser más avanzados y realistas. Entre más sofisticados y refinados sean los procedimientos de diseño, más detallada y refinada deberá ser la caracterización de las aguas residuales a tratar (un fraccionamiento detallado aplicable a las aguas residuales se presenta en la Sección 3.14).

Para la eliminación únicamente de materia orgánica, la determinación de la carga orgánica del agua residual en términos de la demanda bioquímica de oxígeno ( $\left.\mathrm{DBO}_{5}\right)$ y de los sólidos suspendidos (SS, sedimentables y/o no sedimentables) es suficiente. El conocimiento de los diferentes componentes orgánicos que forman parte de la $\mathrm{DBO}_{5}$ y los $\mathrm{SS}$ generalmente no son necesarios. Esto se debe a que existen diversas relaciones empíricas que se han desarrollado las cuales vinculan las cargas de $\mathrm{DBO}_{5}$ y de $\mathrm{SS}$ a la respuesta esperada y al rendimiento del sistema de lodos activados en lo que concierne a la producción de lodos y a la demanda de oxígeno.

Los compuestos orgánicos de las aguas residuales también pueden ser evaluados en términos de la demanda química de oxígeno (DQO), pero debido a que la DQO es un parámetro que incluye tanto al material orgánico no biodegradable como al biodegradable, es necesario realizar una caracterización más detallada y elemental, por ejemplo, separando las fracciones biodegradable, no biodegradable, soluble y particulada. La fracción no biodegradable y particulada de la DQO tiene una influencia considerable en la producción diaria de lodos y en su acumulación en un reactor biológico. Por otra parte, la fracción no biodegradable y soluble de la DQO determina la concentración esperada de la DQO filtrada en el efluente.

La caracterización de las aguas residuales en función de los compuestos de $\mathrm{N}$ y $\mathrm{P}$ no es necesaria si no se desea realizar el proceso de nitrificación, remoción de $\mathrm{N}$ o remoción de $\mathrm{P}$ en el sistema. $\mathrm{Si}$ se incluye la nitrificación como parte del sistema de tratamiento, se requiere tener conocimiento sobre los compuestos del $\mathrm{N}$ que forman parte del afluente, 
incluyendo el nitrógeno total de Kjeldahl (NTK) y el amoníaco libre y salino (FSA, por sus siglas en inglés, Free and Saline Ammonia). Con la eliminación biológica de nitrógeno (desnitrificación), la información que se requiere es aún mayor: ahora no solo se necesita conocer la carga orgánica en términos de la DQO (no la $\mathrm{DBO}_{5}$ ), sino que además es indispensable conocer la calidad y la cantidad de algunos de los compuestos orgánicos que forman parte de la carga total de la DQO. Adicionalmente, los compuestos nitrogenados necesitan caracterizarse y cuantificarse de la misma forma. Por último, con la eliminación biológica de $\mathrm{P}$, se requiere de una caracterización aún más detallada de los compuestos orgánicos, además de la caracterización de los compuestos de fósforo de interés.

La calidad y cantidad de los compuestos de C, N y $\mathrm{P}$ que entran al reactor de lodos activados pueden verse afectadas por las operaciones unitarias que ocurren antes del reactor, en particular por la clarificación primaria. Por lo tanto, es importante determinar el efecto de la clarificación primaria en los compuestos de $\mathrm{C}, \mathrm{N}$ y $\mathrm{P}$ del agua residual y así estimar de forma adecuada las características del agua clarificada.

\subsubsection{Modelos de estado estacionario y modelos de simulación dinámica}

Para realizar la modelación matemática de los sistemas de tratamiento de aguas residuales, se han desarrollado dos tipos de modelos matemáticos; modelos de estado estacionario y modelos de simulación dinámica. Los modelos de estado estacionario se caracterizan por asumir caudales y cargas constantes, y son en general relativamente simples. Esta simplicidad hace que este tipo de modelos sean particularmente útiles para el diseño. En éstos, no se requiere tener una descripción completa de los parámetros del sistema, sino más bien están orientados a definir los parámetros de diseño más importantes respecto de los criterios de desempeño establecidos.

Por otra parte, los modelos dinámicos son mucho más complejos que los modelos en estado estacionario, y se caracterizan por modelar caudales y cargas variables, lo que implica que el tiempo sea considerado e incluido como un parámetro más. Los modelos de simulación dinámica por ende son útiles en la predicción de la respuesta, en función del tiempo, de un sistema de tratamiento de aguas residuales, sean estos sistemas existentes o propuestos. Sin embargo, su complejidad requiere la estimación de muchas más constantes cinéticas y estequiométricas junto con todos los parámetros de diseño del sistema.

Los modelos de estado estacionario son muy útiles para definir las condiciones iníciales requeridas para poder correr simulaciones dinámicas, por ejemplo, la definición de los volúmenes de los reactores, los caudales de recirculación interna $\left(\mathrm{Q}_{\mathrm{s}} \mathrm{y} \mathrm{Q}_{\mathrm{a}}\right)$ y de purga $\left(Q_{w}\right)$, los valores de las diferentes concentraciones en los reactores y la comparación de los resultados finales obtenidos en las simulaciones.

\subsection{CONDICIONES OPERATIVAS DE UN SISTEMA DE LODOS ACTIVADOS}

Básicamente todos los sistemas aerobios para el tratamiento de aguas residuales operan bajo los mismos principios, sean estos filtros percoladores, lagunas de aireación, reactores de estabilización por contacto, sistemas de aireación extendida, entre otros. Estos sistemas se diferencian solamente en las condiciones bajo las cuales las reacciones biológicas están obligadas a operar, llamadas condiciones operativas.

Un sistema de lodos activados se puede definir con base en los regímenes de mezcla, el tamaño y forma de las unidades, la cantidad y configuración de los reactores, los caudales de recirculación, el caudal de entrada y otras características incorporadas al sistema de forma deliberada, o simplemente presentes de forma inherente, inadvertida o inevitable. Mientras que la respuesta de los organismos está definida por la naturaleza de sus procesos biológicos, la respuesta de un sistema de lodos activados está gobernada por una combinación que involucra tanto al comportamiento microbiano, como a las características físicas que definen al sistema tales como las condiciones ambientales y las condiciones operativas.

\subsubsection{Regímenes de mezclado}

En un sistema de lodos activados los regímenes de mezclado en los reactores y en la línea de retorno de lodos forman parte de las condiciones operativas, por lo tanto tienen influencia en la respuesta del sistema y por ende deben ser tomados en cuenta. Existen dos tipos de regímenes de mezclado; completamente mezclado y flujo pistón (Figura 4.2).

En el régimen de flujo pistón, el reactor tiene usualmente la forma de un canal alargado. El afluente 
entra por uno de los extremos del canal, luego fluye a lo largo del eje longitudinal y es mezclado por aspersores de aire ubicados a lo largo de un lado del canal o por aireadores superficiales horizontales. Teóricamente cada elemento de volumen de líquido a lo largo del eje longitudinal no se mezcla con los elementos de volumen que se encuentran antes y después. La descarga al tanque clarificador tiene lugar en el extremo final del canal. Para poder inocular con organismos al agua residual afluente al reactor, los lodos concentrados del clarificador son recirculados al inicio del reactor. Esto crea un régimen de mezclado intermedio, desviándose de las condiciones teóricas de flujo pistón, y la magnitud de esta desviación va a depender de la relación de recirculación de lodos. Las plantas convencionales de lodos activados operan en el régimen de mezclado intermedio cuando se utilizan factores de recirculación que varían de 0.25 hasta 3 veces el caudal promedio en el afluente. Si el factor de recirculación es muy alto, el régimen de mezclado se aproxima al completamente mezclado.

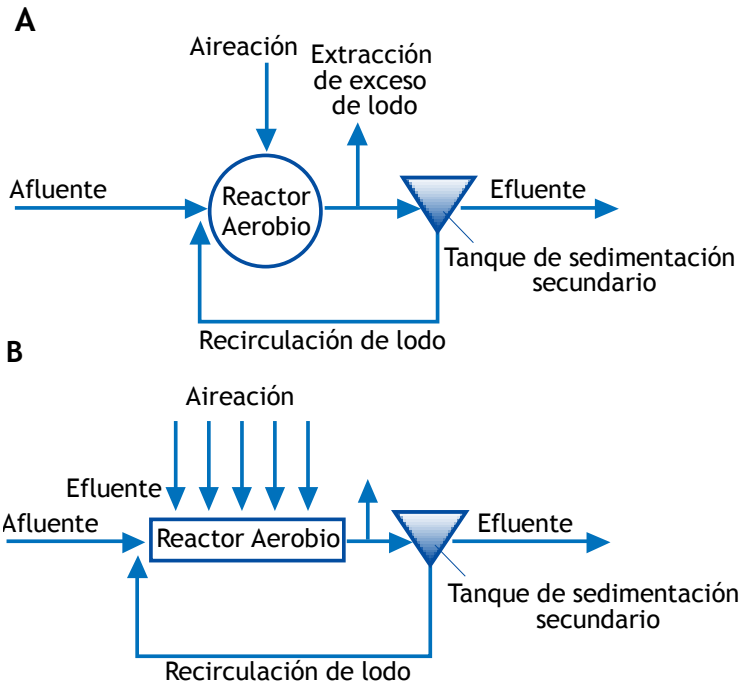

Figura 4.2 Sistemas de lodos activados con (A) reactor de régimen de mezcla completa, y $(B)$ reactor con régimen de flujo pistón

En el régimen de flujo pistón, el reactor tiene usualmente la forma de un canal alargado. El afluente entra por uno de los extremos del canal, luego fluye a lo largo del eje longitudinal y es mezclado por aspersores de aire ubicados a lo largo de un lado del canal o por aireadores superficiales horizontales. Teóricamente cada elemento de volumen de líquido a lo largo del eje longitudinal no se mezcla con los elementos de volumen que se encuentran antes y después. La descarga al tanque clarificador tiene lugar en el extremo final del canal. Para poder inocular con organismos al agua residual afluente al reactor, los lodos concentrados del clarificador son recirculados al inicio del reactor. Esto crea un régimen de mezclado intermedio, desviándose de las condiciones teóricas de flujo pistón, y la magnitud de esta desviación va a depender de la relación de recirculación de lodos. Las plantas convencionales de lodos activados operan en el régimen de mezclado intermedio cuando se utilizan factores de recirculación que varían de 0.25 hasta 3 veces el caudal promedio en el afluente. Si el factor de recirculación es muy alto, el régimen de mezclado se aproxima al completamente mezclado.

Un régimen de mezclado intermedio también se puede conseguir cuando dos o más reactores completamente mezclados se conectan en serie o cuando se utiliza aireación por pasos. En ésta última, el afluente se inyecta en una serie de puntos a lo largo del eje longitudinal del reactor de flujo pistón. Ambas configuraciones requieren de la recirculación del lodo clarificado del tanque clarificador secundario para inocular el agua residual que entra al reactor de flujo pistón.

La respuesta cinética promedio de un sistema de lodos activados incluyendo la masa de lodos, la producción diaria de lodos, la demanda diaria de oxígeno y la concentración de materia orgánica en el efluente, puede ser representada de forma bastante exacta cuando se asume que el sistema está completamente mezclado y que tanto el caudal afluente como la carga son constantes. Esto permite que el volumen del reactor, la masa de lodos purgada diariamente y la tasa promedio de utilización de oxígeno, puedan ser determinadas mediante el uso de fórmulas y ecuaciones relativamente simples. Las tasas máximas de utilización de oxígeno que surgen como producto de caudales y cargas cíclicas, pueden ser calculadas aplicando un factor relacionado con la tasa promedio de consumo de oxígeno. Estos factores han sido desarrollados a través de estudios de modelación simulando sistemas aerobios y anóxicos-aerobios operados bajo condiciones cíclicas y constantes de caudal y carga.

\subsubsection{Tiempo de retención de sólidos (TRS)}

En los esquemas de los sistemas de lodos activados (Figura 4.2), la purga de lodos se realiza directamente del reactor biológico. La práctica convencional es la de purgar los lodos directamente de la línea de 
recirculación del clarificador secundario. La purga de lodos realizada desde el reactor conduce a un método para el control del tiempo de retención de sólidos (TRS) o edad de lodos (en inglés Solids Retention Time, SRT) conocido como control hidráulico de la edad de lodos, el cual tiene varias ventajas respecto de la purga de lodos a través de la línea de recirculación.

La edad de lodos (TRS) en días, está definida por:

$T R S=\frac{\text { Masa de lodos en el reactor }}{\text { Masa de lodos purgados diariamente }}[\mathrm{d}]$

Cuando se purgan los lodos directamente del reactor biológico, las concentraciones en la purga y en el reactor son las mismas. Si se requiere, por ejemplo, una edad de lodos de 10 días, una décima parte del volumen del reactor es purgado a diario. Esto puede lograrse con un caudal de purga constante, $\mathrm{Q}_{\mathrm{w}}(\mathrm{l} / \mathrm{d})$, donde $\mathrm{Q}_{\mathrm{w}}$ es el volumen a purgar por día. Obteniendo:

$T R S=\frac{X_{t} V_{p}}{X_{t} Q_{W}}=\frac{V_{p}}{Q_{W}}$

donde:

$\mathrm{V}_{\mathrm{p}} \quad$ volumen del reactor biológico [1]

$\mathrm{Q}_{\mathrm{w}} \quad$ caudal de purga de lodos del reactor $[\mathrm{l} / \mathrm{d}]$

La ecuación 4.1 asume que la pérdida de sólidos en el efluente es despreciable y que la masa de lodos en los clarificadores secundarios es también despreciable respecto de la masa dentro del reactor biológico. Esta suposición es razonable cuando el sistema es operado a relaciones de recirculación elevadas $(\sim 1: 1)$ y la edad de lodos es mayor de 3 días aproximadamente (ver Sección 4.10).

\subsubsection{Tiempo de retención hidráulico nominal $\left(\mathrm{TRH}_{\mathrm{n}}\right)$}

En la teoría de lodos activados, el volumen del proceso por unidad de volumen del caudal de entrada se conoce como el tiempo de retención hidráulico nominal $\left(\mathrm{TRH}_{\mathrm{n}}\right)$, definido como:

$T R H_{n}=\frac{V_{p}}{Q_{i}}$

donde:

$\mathrm{TRH}_{\mathrm{n}}$ Tiempo de retención hidráulico nominal promedio [d]
$\mathrm{Q}_{\mathrm{i}} \quad$ Caudal diario promedio en el afluente $[\mathrm{l} / \mathrm{d}]$

Cuando el lodo de recirculación del clarificador secundario $\left(Q_{s}\right)$ y cualquier otra recirculación de licor mezclado que ingresa al reactor $\left(\mathrm{Q}_{\mathrm{a}}\right)$ se incluyen en el cálculo, el tiempo de retención se denomina, tiempo de retención hidráulico real, definido como:

$$
T R H_{a}=\frac{V_{p}}{Q_{i}+Q_{s}+Q_{a}}=\frac{T R H_{n}}{1+s+a}
$$

Donde:

$\mathrm{TRH}_{\mathrm{a}}$ tiempo de retención hidráulico real [d]

$\mathrm{s} \quad$ Relación de recirculación de lodos $\left(\mathrm{Q}_{\mathrm{s}} / \mathrm{Q}_{\mathrm{i}}\right)$

a Relación de recirculación del licor mezclado $\left(\mathrm{Q}_{\mathrm{a}} / \mathrm{Q}_{\mathrm{i}}\right)$

\subsubsection{Relación entre la edad de lodos y el tiempo de retención hidráulico}

De las definiciones dadas anteriormente, puede verse que hay dos parámetros que se relacionan con la variable tiempo en el sistema; $(i)$ la edad de lodos, la cual indica la cantidad de tiempo que el material particulado permanece en el reactor, y (ii) el tiempo de retención hidráulico nominal, el cual indica la cantidad de tiempo que el líquido y el material disuelto permanecen en el reactor. En sistemas de lodos activados que no cuentan con una remoción de sólidos de la fase acuosa mediante el uso de membranas o tanques de clarificación secundarios, como lo son los sistemas de lagunas aireadas, la edad de lodos y el tiempo de retención hidráulico nominal son iguales, es decir, la materia particulada y la materia soluble permanecen la misma cantidad de tiempo en el reactor. Cuando se incluye la separación o remoción de sólidos de la fase acuosa, los tiempos de retención se vuelven independientes y el TRS es mayor al $\mathrm{TRH}_{\mathrm{n}}$. Sin embargo, una edad de lodos alta está asociada a grandes masas de lodos en el reactor, lo que conduce a grandes volúmenes requeridos en el reactor $\left(\mathrm{V}_{\mathrm{p}}\right)$. Por lo tanto, aún con una separación de sólidos, a medida que el TRS aumenta, también lo hace el $\mathrm{TRH}_{\mathrm{n}}$. El vínculo entre el SRT y $\mathrm{HRT}_{\mathrm{n}}$ no es lineal ni proporcional, y depende de (i) la concentración de materia orgánica en el agua residual (DQO o $\left.\mathrm{DBO}_{5}\right)$ y (ii) la concentración de sólidos suspendidos totales (SST). En sistemas con remoción biológica de nutrientes, la edad de lodos es alrededor de 10 a 25 días, mientras que el tiempo de retención hidráulico nominal es del orden de 10 a 24 horas. 


\section{$4 \cdot 3$}

SIMPLIFICACIONES DEL MODELO

\subsubsection{Utilización completa de la materia orgánica biodegradable}

La diferencia entre un compuesto biodegradable y un no biodegradable está gobernada por la biomasa en el sistema y por la cantidad de tiempo que la biomasa tiene para degradar la materia orgánica. Se ha observado que la diferencia entre la concentración de la DQO soluble en el efluente para sistemas con bajos tiempos de retención hidráulico (2-3 h) y sistemas con tiempos altos (18-24h), es muy baja y del orden de 10 a $20 \mathrm{mgDQO} / 1$. Esto indica que la materia orgánica soluble lentamente biodegradable está presente normalmente en una concentración baja en aguas residuales municipales. Por este motivo, es razonable aceptar que la materia orgánica soluble en aguas residuales municipales se divide en dos grupos - la biodegradable, la cual comprende casi toda la materia rápidamente biodegradable, y la no biodegradable. Esto significa que incluso con tiempos de retención hidráulicos bajos, del orden unas pocas horas, hay una utilización o remoción total de la materia orgánica biodegradable dejando presente en el efluente solo la materia orgánica no biodegradable.

La materia orgánica particulada biodegradable, tanto suspendida como sedimentable (Xs), es en su mayoría lentamente biodegradable. Este material orgánico lentamente biodegradable (DQO $\left.{ }_{\mathrm{lb}}\right)$, sea sedimentable o no, se incorpora a la masa floculenta de lodos activados y se convierte en parte de los SSV de la masa de lodos en el reactor; la única ruta de salida para la materia orgánica particulada biodegradable no removida o degradada es a través de la purga de lodos $\left(\mathrm{Q}_{\mathrm{w}}\right)$. El tiempo disponible para la degradación de la $\mathrm{DQO}_{\mathrm{lb}}$ por los OHOs está por lo tanto relacionado al tiempo de retención de sólidos o edad de lodos del sistema. Aunque la descomposición de la materia orgánica particulada biodegradable toma mucho más tiempo que la de la materia orgánica soluble rápidamente biodegradable, esto es de poca importancia ya que el tiempo de retención de sólidos en el sistema (TRS) es mucho más largo que el tiempo de retención de líquidos $\left(\mathrm{TRH}_{\mathrm{n}}\right)$. Cuando las edades de lodo superan los 3 días a $20^{\circ} \mathrm{C}$ (o 4 días a $14^{\circ} \mathrm{C}$ ), la materia orgánica particulada lentamente biodegradable es totalmente removida.

Lo anterior ha sido verificado experimentalmente mediante trabajo de laboratorio. Con una edad de lodos corta, y por añadidura un tiempo de retención hidráulico corto, y con sistemas con edad de lodos alta y el consiguiente tiempo de retención hidráulico alto, se han obtenido rendimientos similares respecto de la fracción materia orgánica particulada ( $\mathrm{f}_{\mathrm{S}}$ us $)$ y soluble (fs'up) de la DQO. Como resultado, cuando la edad de lodos es mayor de 3 o 4 días, la concentración de materia orgánica biodegradable no consumida (o no degradada), tanto soluble $\left(\mathrm{S}_{\mathrm{s}}\right)$ como particulada $\left(\mathrm{X}_{\mathrm{s}}\right)$, tiende a ser muy baja. Bajo esta suposición se puede hacer entonces una simplificación importante para los modelos en estado estacionario y en simulaciones dinámicas. Así, las concentraciones de la materia orgánica soluble lentamente biodegradable y de la materia orgánica particulada muy lentamente biodegradable pueden considerarse despreciables en aguas residuales municipales promedio. No obstante, debe tenerse siempre en cuenta, que aunque lo anterior es razonable, la suposición de que toda la materia orgánica biodegradable es degradada puede no ser válida para otros tipos de agua residual y esta suposición va a estar condicionada, por ejemplo, por el tipo de industrias presentes en la cuenca dentro de la cual se planea diseñar un sistema de tratamiento de aguas. Cuando se hace una caracterización de este tipo de agua, cualquier material orgánico soluble y particulado no degradado en el sistema es implícitamente incluido con las fracciones no biodegradables solubles y particuladas respectivamente; esto es debido a que de esta manera es como se estructuran los modelos de lodos activados. Para los modelos en estado estacionario, debido a que toda la materia orgánica biodegradable es removida o degradada, se puede realizar una simplificación adicional: que no es necesario hacer una distinción entre la materia orgánica biodegradable ya sea soluble o particulada debido a ambas son transformadas finalmente en la biomasa de $\mathrm{OHO}$ medida en términos de SSV. Las ecuaciones del modelo de lodos activados en estado estacionario descritas a continuación se basan en esta simplificación.

\subsection{ECUACIONES DEL SISTEMA EN ESTADO ESTACIONARIO}

Una vez que se asume que toda la materia orgánica en el afluente, excepto la DQO soluble y no biodegradable, es utilizada por los $\mathrm{OHO}$ para formar nueva biomasa $\left(\mathrm{X}_{\mathrm{BH}}\right)$, o permanece en el sistema y se acumula como masa de lodos no biodegradable $\left(\mathrm{X}_{\mathrm{EH}}\right.$ and $\mathrm{X}_{\mathrm{I}}$ ), se puede concluir entonces que la masa de lodos producidos y la demanda de oxígeno asociada a la degradación de los compuestos orgánicos en el 
sistema son funciones estequiométricas de la carga diaria de la DQO; entre mayor sea la masa diaria de la DQO, mayor será la producción de lodos y la demanda de oxígeno para la degradación.

Las ecuaciones a continuación permiten calcular la masa de lodos generados y purgados diariamente en el reactor, la demanda diaria promedio de oxígeno y la concentración de la DQO en el efluente incluyendo la materia orgánica soluble no biodegradable por materia orgánica removida como una función de $(i)$ la carga orgánica total (DQO) por día $\left(\mathrm{FS}_{\mathrm{ti}}\right)$, (ii) las características del agua residual, esto es las fracciones no biodegradables solubles y particuladas de la DQO ( $\mathrm{f}_{\text {'us }}$ and $\mathrm{f}_{\mathrm{S}}$ 'up) y (iii) la edad de lodos (TRS). En la Tabla 4.1 se muestran las constantes cinéticas y estequiométricas, estas son el rendimiento específico $\left(\mathrm{Y}_{\mathrm{Hv}}\right)$, la tasa específica de pérdida de masa endógena $\left(b_{H}\right)$, la fracción no biodegradable de los OHOs $\left(\mathrm{f}_{\mathrm{H}}\right), \mathrm{y}$ la relación $\mathrm{DQO} / \mathrm{SSV}$ del lodo $\left(\mathrm{f}_{\mathrm{cv}}\right)$, así como también la dependencia correspondiente de los efectos de la temperatura.

\subsubsection{Para el afluente}

Los flujos (másicos) de entrada de materia orgánica total $\left(\mathrm{FS}_{\mathrm{ti}}, \mathrm{mgDQO} / \mathrm{d}\right)$, orgánica biodegradable $(\mathrm{FS} \mathrm{bi}$, $\mathrm{mgDQO} / \mathrm{d}$ ), orgánica suspendida no biodegradable (FX $\mathrm{Ivi}_{\mathrm{i}}, \mathrm{mgSSV} / \mathrm{d}$ ) y de sólidos suspendidos inorgánicos (SSI, FXIOi, mgSSI/d) están definidos como:

$F S_{t i}=Q_{i} S_{t i}$

$[\mathrm{mgDQO} / \mathrm{d}](4.4)$

$F S_{b i}=Q_{i} S_{b i}=Q_{i}\left(S_{S i}+X_{S i}\right) \quad[\mathrm{mgDQO} / \mathrm{d}](4.5 \mathrm{a})$

$F S_{b i}=Q_{i} S_{t i}\left(1-f_{S^{\prime} u s}-f_{S^{\prime} u p}\right) \quad[\mathrm{mgDQO} / \mathrm{d}](4.5 \mathrm{~b})$

$F S_{b i}=F S_{t i}\left(1-f_{S^{\prime} u s}-f_{S^{\prime} u p}\right) \quad[\mathrm{mgDQO} / \mathrm{d}](4.5 \mathrm{c})$
$F X_{I v i}=Q_{i} X_{I i}$
[mgSSV/d] (4.6a)
$F X_{I v i}=Q_{i} f_{S^{\prime} u p} S_{t i} / f_{c v}$
$[\mathrm{mgSSV} / \mathrm{d}](4.6 \mathrm{~b})$
$F X_{I v i}=F S_{t i} f_{S^{\prime} u p} / f_{c v}$
$[\mathrm{mgSSV} / \mathrm{d}](4.6 \mathrm{c})$
$F X_{I O i}=Q_{i} X_{I O i}$
$[\mathrm{mgSSI} / \mathrm{d}](4.7)$

\subsubsection{Para el sistema}

4.4.2.1 Masa de sólidos suspendidos volátiles (SSV) en el reactor

La masa de SSV de OHOs (MX $\left.\mathrm{BHv}_{\mathrm{BH}}, \mathrm{mgSSV}\right)$, de residuo endógeno $\left(\mathrm{MX}_{\mathrm{EHv}}, \mathrm{mgSSV}\right)$, de material orgánico no biodegradable $\left(\mathrm{MX}_{\mathrm{Iv}}, \mathrm{mgSSV}\right)$, y de sólidos suspendidos volátiles $\mathrm{SSV}\left(\mathrm{MX}_{\mathrm{v}}, \mathrm{mgSSV}\right)$ en el sistema están dados por:

$$
\begin{array}{ll}
M X_{B H v}=X_{B H v} V_{p} & {[\mathrm{mgSSV}](4.8 \mathrm{a})} \\
M X_{E H v}=X_{E H v} V_{p} & {[\mathrm{mgSSV}](4.8 \mathrm{~b})} \\
M X_{I v}=X_{I v} V_{p} & {[\mathrm{mgSSV}](4.8 \mathrm{c})} \\
M X_{v}=X_{v} V_{p} & {[\mathrm{mgSSV}](4.8 \mathrm{~d})} \\
M X_{B H v}=F S_{b i} \frac{Y_{H v} T R S}{\left(1+b_{H} T R S\right)}= & \\
=F S_{t i}\left(1-f_{S^{\prime} u s}-f_{S^{\prime} u p}\right) \frac{Y_{H v} T R S}{\left(1+b_{H} T R S\right)} &
\end{array}
$$

Tabla 4.1 Constantes cinéticas, estequiométricas y su dependencia de la temperatura para los OHOs, teniendo en cuenta la degradación de los compuestos orgánicos en un modelo de lodos activados en estado estacionario. (Marais y Ekama, 1976)

\begin{tabular}{lllll}
\hline Constante & Símbolo & Variación por temperatura & $\Theta$ & Valor estándar a 20 C \\
\hline Rendimiento (mgDQO/mgDQO) & $\mathrm{Y}_{\mathrm{H}}$ & Permanece constante & 1 & 0.67 \\
Rendimiento (mgSSV/mgDQO) & $\mathrm{Y}_{\mathrm{Hv}}$ & Permanece constante & 1 & 0.45 \\
Tasa de respiración endógena (1/d) & $\mathrm{bH}_{\mathrm{H}}$ & $\mathrm{bHT}_{\mathrm{H}}=\mathrm{b}_{\mathrm{H} 20} \theta^{\text {(T-20) }}$ & 1.029 & 0.24 \\
Fracción de residuo endógeno (-) & $\mathrm{fH}_{\mathrm{H}}$ & Permanece constante & 1 & 0.2 \\
Contenido de SSI en lo OHOs & $\mathrm{f}_{\mathrm{iOHO}}$ & Permanece constante & 1 & 0.15 \\
DQO/SSV (mgDQO/mgSSV) & $\mathrm{f}_{\mathrm{cv}}$ & Permanece constante & 1 & 1.48 \\
\hline
\end{tabular}




$$
\begin{aligned}
& M X_{E H v}=f_{H} b_{H} M X_{B H v} T R S= \\
& =F S_{b i} \frac{Y_{H v} T R S}{\left(1+b_{H} T R S\right)} f_{H} b_{H} T R S= \\
& =F S_{t i}\left(1-f_{S^{\prime} u s}-f_{S^{\prime} u p}\right) . \\
& \quad \frac{Y_{H v} T R S}{\left(1+b_{H} T R S\right)} f_{H} b_{H} T R S
\end{aligned}
$$

$$
\begin{aligned}
& M X_{I v}=\frac{F X_{I i}}{f_{c v}} T R S=F X_{I v i} T R S= \\
& =F S_{t i} \frac{f_{S^{\prime} u p}}{f_{c v}} T R S
\end{aligned}
$$

$$
M X_{v}=M X_{B H v}+M X_{E v}+M X_{I v}=
$$$$
=F S_{b i} \frac{Y_{H v} T R S}{\left(1+b_{H} T R S\right)}\left(1+f_{H} b_{H} T R S\right)
$$$$
+F X_{I v i} T R S=
$$$$
=F S_{t i}\left[\begin{array}{l}
\frac{\left(1-f_{S^{\prime} u s}-f_{S^{\prime} u p}\right) Y_{H v} T R S}{\left(1+b_{H} T R S\right)} \\
\left(1+f_{H} b_{H} T R S\right)+ \\
\frac{f_{S^{\prime} u p}}{f_{c v}} T R S
\end{array}\right]
$$

\subsubsection{Masa de sólidos suspendidos inorgánicos} (SSI) en el Reactor

Los sólidos suspendidos inorgánicos (SSI) en el afluente se acumulan en el reactor biológico de la misma forma que la materia orgánica particulada no biodegradable (Ec. 4.12), esto es la masa afluente de SSI en el reactor $\mathrm{FX}_{\mathrm{IO}}$ multiplicado por la edad de lodos (TRS), respectivamente:

$$
M X_{I O}=F X_{I O i} T R S
$$

$$
\mathrm{y} \text { : }
$$

$\mathrm{X}_{\mathrm{IOi}}$ concentración de SSI en el afluente [mgSSI/l]

Los SSI en el afluente solo comprenden una parte de los medidos en el reactor. Los $\mathrm{OHO}$ (y si están presentes también los organismos acumuladores de fósforo, PAO, por sus siglas en inglés, Phosphorus Accumulating Organisms) también contribuyen a la concentración de SSI. Para sistemas completamente aerobios o con nitrificación-desnitrificación, donde únicamente los OHOs forman parte de la biomasa activa, los $\mathrm{OHOs}$ contribuyen con un $10 \%$ de su masa (alrededor de 15\% como SSV) a los SSI (Ekama y Wentzel, 2004). Esta masa de SSI presente en los OHOs corresponde a sólidos disueltos intracelulares, los cuales precipitan como SSI cuando se hace la medición de los SST mediante secado de una muestra de lodo.

Por lo tanto, estrictamente, la contribución de los SSI por parte de los OHOs (y PAOs si presentes) a los SST debería ser menospreciada aun cuando esta es medida indirectamente en los resultados de una prueba de SST, porque estando estos sólidos disueltos dentro de las células, no aportan a la masa real de SSI en el clarificador secundario. No obstante, debido a que esta masa de SSI siempre se mide implícitamente en la medición analítica de SST, se seguirá utilizando de esta forma debido a que los procedimientos de diseño de clarificadores secundarios están basados históricamente en los SST medidos. Para sistemas completamente aerobios y sistemas con nitrificacióndesnitrificación, los rendimientos de masa de $\mathrm{OHO}$ como SSI son:

$$
\begin{aligned}
& M X_{I O}=F X_{I O i} S R T+f_{i O H O} M X_{B H v} \\
& M X_{I O}=F X_{I O i} S R T+f_{i O H O} f_{a v O H O} M X_{v} \\
& {[\mathrm{mgSSI} / \mathrm{d}](4.14 \mathrm{~b})}
\end{aligned}
$$

donde:

favOHо fracción de masa de los SSV que corresponde a $\mathrm{OHO}$ activos, (ver Sección 4.4.7)

$\mathrm{f}_{\mathrm{iOHO}} \quad$ contenido inorgánico en los OHO como SSV (0.15 mgSSI/mgOHOSSV)

Para sistemas con remoción biológica de fósforo (EBPR, por sus siglas en inglés Enhanced Biological Phosphorus Removal), los "SSI" de los PAOs deben incluirse. Para la asimilación de fósforo en sistemas con EBPR, la fracción fiPAO de los PAO es $1.30 \mathrm{mgSSI} / \mathrm{mg}$ PAOSSV, alrededor de 7 veces mayor que para los OHO. Por esta razón, para sistemas con EBPR la relación SSV/SST es significativamente más baja que para sistemas completamente aerobios o sistemas con nitrificación-desnitrificación.

\subsubsection{Masa de SST en el reactor}

La masa total de sólidos sedimentables (SST) (MX, mgSST) en el reactor es la suma de las masas de sólidos 
suspendidos orgánicos (volátiles) (SVV) e inorgánicos (SSI) en el reactor, respectivamente:

$M X_{t}=M X_{v}+M X_{I O}$

$[\mathrm{mgSST}](4.15)$

La relación $\mathrm{SSV} / \mathrm{SST}$ de los lodos $\left(\mathrm{f}_{\mathrm{i}}\right)$ es:

$f_{i}=\frac{M X_{v}}{M X_{t}}$

Si la concentración de SSI es desconocida, entonces la masa de SST en el reactor $\left(\mathrm{MX}_{\mathrm{t}}\right)$ puede ser calculada estimando la relación de SSV/SST $\left(\mathrm{f}_{\mathrm{i}}\right)$ del lodo:

$M X_{t}=M X_{v} / f_{i}$

$[\mathrm{mgSST}](4.17)$

donde:

$\mathrm{f}_{\mathrm{i}} \quad$ Relación de SSV/SST del lodo activado

\subsubsection{Demanda carbonácea de oxígeno}

La masa de oxígeno utilizada diariamente $\left(\mathrm{FO}_{\mathrm{c}}\right.$, $\mathrm{mgO}_{2} / \mathrm{d}$ ) está dada por:

$$
\begin{aligned}
& F O_{c}=F S_{b i}\left[\left(1-f_{c v} Y_{H v}\right)+\left(1-f_{H}\right) b_{H} \frac{Y_{H v} f_{c v} T R S}{\left(1+b_{H} T R S\right)}\right]= \\
& =F S_{t i}\left(1-f_{S^{\prime} u s}-f_{S^{\prime} u p}\right) \cdot\left[\begin{array}{l}
\left(1-f_{c v} Y_{H v}\right)+\left(1-f_{H}\right) b_{H} \cdot \\
\frac{Y_{H v} f_{c v} T R S}{\left(1+b_{H} T R S\right)}
\end{array}\right] \\
& \left.F \mathrm{mgO}_{2} / \mathrm{d}\right](4.18) \\
& {\left[\mathrm{mgO}_{2} / 1 . \mathrm{d}\right](4.19)}
\end{aligned}
$$

donde:

$\mathrm{O}_{\mathrm{c}} \quad$ Tasa de utilización de oxígeno carbonáceo (o usado en la oxidación de materia orgánica) $\left[\mathrm{mgO}_{2} \mathrm{l} / \mathrm{d}\right]$

De la Ec. 4.18, puede verse que la masa de oxígeno utilizada por los $\mathrm{OHO}$ por día $\left(\mathrm{FO}_{\mathrm{c}}\right)$ es la suma de dos términos. El primero $\left(1-\mathrm{f}_{\mathrm{cv}} \mathrm{Y}_{\mathrm{Hv}}\right)$ corresponde a la demanda de oxígeno para el crecimiento de los OHO. Este valor representa los electrones (DQO) que son utilizados en el proceso de crecimiento de los $\mathrm{OHO}$ para generar la energía a utilizar en la transformación de la materia orgánica en la creación de nueva biomasa (catabolismo). El balance de electrones utilizados (DQO, $f_{\mathrm{cv}} \mathrm{Y}_{\mathrm{Hv}}$ ) se conserva como nueva biomasa (anabolismo). Puede observarse que la demanda de oxígeno es proporcional a la materia orgánica biodegradable en el afluente y no cambia con la edad de lodos. Esto es debido a que toda la materia orgánica biodegradable del afluente se transforma en biomasa de OHOs. El segundo término corresponde a la demanda de oxígeno debido a la respiración endógena, la cual aumenta a medida que la edad de lodos aumenta. El incremento en la demanda carbonácea de oxígeno $\left(\mathrm{FO}_{\mathrm{c}}\right)$ con la edad de lodos se debe al incremento en los requerimientos de oxígeno de la respiración endógena. Este incremento es debido a que entre mayor sea el tiempo que permanece la masa de OHO SSV en el reactor, mayor es la cantidad de masa que se degrada mediante el proceso de respiración endógena, y mayor es la cantidad de $(i)$ electrones transferidos al oxígeno, (ii) carbono transformado en $\mathrm{CO}_{2}$ y (iii) energía perdida en forma de calor.

De lo anterior se puede entonces concluir que el crecimiento es el proceso biológico mediante el cual la materia orgánica biodegradable presente en el afluente o agua residual se transforma en masa de SSV como OHO (anabolismo) con una transferencia asociada de electrones al oxígeno, y una pérdida de energía en forma de calor (catabolismo). Por otra parte, la respiración endógena corresponde al proceso mediante el cual los componentes biodegradables de los organismos se degradan vía catabolismo a $\mathrm{CO}_{2}$ con una demanda de oxígeno adicional y pérdida de energía en forma de calor. Los electrones transferidos al oxígeno resultan en una menor acumulación de SSV en el reactor si se compara con la materia orgánica particulada no biodegradable. Todos los electrones de este material orgánico permanecen en el reactor como SSV y no son transferidos al oxígeno. Por esta razón, el rendimiento de la materia orgánica no biodegradable es en efecto 1 .

\subsubsection{Volumen del reactor y tiempo de retención}

Conociendo la masa total de sólidos sedimentables en el reactor $\left(\mathrm{MX}_{\mathrm{t}}\right)$, el volumen del reactor se determina utilizando un valor específico para la concentración de sólidos suspendidos del licor mezclado (SSLM, X $\mathrm{X}_{\mathrm{t}}$ ) (Sección 4.6):

$V_{p}=M X_{t} / X_{t}$

$\left[1, \mathrm{~m}^{3}\right.$ o $\left.\mathrm{Ml}\right](4.20)$

Para un volumen de reactor conocido $\left(\mathrm{V}_{\mathrm{p}}\right)$, el tiempo de retención hidráulico nominal, $\left(\mathrm{TRH}_{\mathrm{n}}\right)$ se encuentra con el caudal promedio de diseño $\left(Q_{i p}\right)$ utilizando la Ec. 4.2 . 


\subsubsection{Irrelevancia del TRH}

Las ecuaciones para el diseño descritas anteriormente conducen a la importante conclusión de que el tiempo de retención hidráulico $\left(\mathrm{TRH}_{\mathrm{n}}\right)$ es irrelevante para el diseño de un sistema de lodos activados. La masa de sólidos sedimentables volátiles (SSV) en el reactor es función principalmente de la carga diaria de DQO que entra al reactor y de la edad de lodos. De una manera similar, la masa de SST en el reactor es principalmente función de la carga diaria de DQO y SSI en el reactor y de la edad de lodos. Consecuentemente, en lo que concierne a la producción de lodos en el reactor, no importa si la carga de DQO (y SSI) por día proviene de un caudal bajo y una concentración alta $(\mathrm{Q}<, \mathrm{DQO}>$, $\mathrm{SSI}>$ ) o si por lo contrario proviene de un caudal alto y una concentración baja $(\mathrm{Q}>, \mathrm{DQO}<, \mathrm{SSI}<)$. Dado unos flujos másicos $\mathrm{FS}_{\mathrm{ti}}$ (y $\mathrm{FX}_{\mathrm{IOi}}$ ) iguales en ambas condiciones, la masa de SSV y SST permanecerá virtualmente idéntica. Sin embargo, el tiempo de retención hidráulica será diferente para cada caso, siendo el TRH más largo en el primero y más corto en el segundo, respectivamente. Es por esta razón que el tiempo de retención hidráulica puede considerarse circunstancial a la carga de DQO (y SSI), la masa de SSV (y SST) y el caudal diario - es decir, no sirve para el propósito de diseñar un sistema de lodos activados.

Criterios de diseño para el cálculo del volumen de un reactor de lodos activados basados únicamente en tiempos de retención hidráulica deben ser usados con precaución debido a que implícitamente incorporan características específicas del agua residual típicas de la región para la cual estos métodos fueron desarrollados.

\subsubsection{Concentración de DQO en el efluente}

En un sistema de lodos activados bajo condiciones normales de operación donde la edad de lodos sea superior a 5 días (con el fin de garantizar nitrificación y remoción biológica de nutrientes), la naturaleza de la materia orgánica en el afluente con aguas residuales municipales es tal, que la concentración de la DQO en el efluente no interviene en el diseño del sistema. La materia orgánica soluble rápidamente biodegradable es completamente utilizada en muy poco tiempo $(<2$ horas), y la materia orgánica particulada, sea esta biodegradable o no biodegradable, se incorpora a la masa de lodos y sedimenta con el mismo en los tanques clarificadores secundarios. Consecuentemente, la concentración en el efluente de la DQO incluye virtualmente toda la materia orgánica soluble no biodegradable del afluente, más la DQO de las partículas de lodos que escapan con el efluente debido a la operación imperfecta de los clarificadores secundarios. De este modo, la concentración de la DQO filtrada y no filtrada en el efluente, Ste, están dadas por:

$$
\begin{aligned}
& S_{t e}=S_{\mathrm{Ie}} \\
& \quad \text { filtrada }] \\
& \begin{array}{l}
S_{t e} \\
\quad=S_{I e}+f_{c v} X_{v e} \\
\quad \text { filtrada] }
\end{array}
\end{aligned}
$$$$
\text { [mgDQO/1 }
$$

Donde:

$\mathrm{S}_{\text {Ie }} \quad$ DQO no biodegradable en el efluente $=\mathrm{S}_{\mathrm{Ii}}=$ fS'us $\mathrm{S}_{\mathrm{ti}}[\mathrm{mgDQO} / \mathrm{l}]$

$\mathrm{X}_{\mathrm{ve}} \quad \mathrm{SSV}$ en el efluente $[\mathrm{mgSSV} / \mathrm{l}]$

$\mathrm{f}_{\mathrm{cv}} \quad$ Relación de DQO/SSV de los SSV [1.48 $\mathrm{mgDQO} / \mathrm{mgSSV}]$

En la mayoría de los casos, las concentraciones de SSV y SST en el efluente son muy bajas para ser medidas de forma confiable con pruebas de laboratorio de SSV y SST tradicionales. Métodos alternativos para la medición de concentraciones bajas de sólidos en el efluente han sido desarrolladas; en el caso de los SSV, a través de la medición de la concentración de la DQO filtrada y no filtrada, esto es usando la Ec. 4.21, y para los SST, a través de la turbidez una vez se ha obtenido una curva de calibración turbidez vs. SST, para el lodo activado en estudio (Wahlberg et al., 1994).

$$
X_{v e}=\left(S_{t e(\text { unfilt })}-S_{\text {te(filt })}\right) / f_{c v}
$$

\subsubsection{Balance de masa de la DQO (o balance de electrones)}

En el sistema de lodos activados, la DQO debe en teoría, conservarse de tal forma que en estado estacionario, el flujo másico de DQO que sale del sistema debe ser igual al flujo másico de DQO que entra el sistema para un intervalo de tiempo definido. Los electrones $\left(\mathrm{e}^{-}\right)$de la DQO de la materia orgánica en el afluente son (i) retenidos en la materia orgánica particulada y soluble no biodegradable, (ii) transformados en masa de OHO y por ende conservados en otro tipo de materia orgánica, o (iii) transferidos al oxígeno para formar agua. En general, el balance de DQO (o e $)$ en un sistema de lodos activados en estado estacionario está dado por la Ec. 4.23, donde:

$\mathrm{S}_{\mathrm{te}} \quad$ concentración total de la DQO soluble en el efluente [mgDQO/l] 
$\mathrm{X}_{\mathrm{V}} \quad$ concentración de los SSV en el reactor biológico [mgSSV/l]

$\mathrm{O}_{\mathrm{c}} \quad$ tasa de utilización de oxígeno carbonáceo (para degradación de la materia orgánica) en el reactor $\left[\mathrm{mgO}_{2} / \mathrm{l} . \mathrm{h}\right]$

$\left[\begin{array}{l}\text { Flujo de } D Q O\left(e^{-}\right) \\ \text {en la salida }\end{array}\right]=\left[\begin{array}{l}\text { Flujo de DQO }\left(e^{-}\right) \\ \text {en la entrada }\end{array}\right]$
$\left[\begin{array}{l}\text { Flujo de } D Q O \\ \text { soluble en el } \\ \text { efluente }\end{array}\right]+\left[\begin{array}{l}\text { Flujo de DQO } \\ \text { soluble en la purga } \\ \text { de lodos }\end{array}\right]+$
$+\left[\begin{array}{l}\text { Flujo de DQO } \\ \text { particulada en la } \\ \text { purga de lodos }\end{array}\right]+\left[\begin{array}{l}\text { Flujo de oxígeno utilizado } \\ \text { por los OHO para la } \\ \text { deg radación de DQO }\end{array}\right]=$
$=\left[\begin{array}{l}\text { Flujo de DQO } \\ \text { en la entrada }\end{array}\right]$

$Q_{e} S_{t e}+Q_{w} S_{t e}+Q_{w} X_{v} f_{c v}+V_{p} O_{c}=Q_{i} S_{t i}$

En la Ec. 4.23, los primeros dos términos representan la materia orgánica que sale del sistema a través del efluente y la purga de lodos, el tercer término representa la materia orgánica particulada que sale del sistema a través de la purga de lodos, y el cuarto término representa la masa de oxígeno utilizada por los OHOs para degradar la materia orgánica biodegradable. Estableciendo:

$\left(Q_{e}+Q_{w}\right) S_{t e}=Q_{i} S_{t e}=F S_{t e}$

$Q_{w} X_{v}=V_{p} X_{v} / T R S=M X_{v} / T R S=F X_{v}$

$V_{p} O_{c}=F O_{c}$

$Q_{i} S_{t i}=F S_{t i}$

Así, el balance masa de la DQO está dado por:

$F S_{t e}+f_{c v} M X_{v} / T R S+F O_{c}=F S_{t i}$

donde:

FS $\quad$ DQO orgánica soluble saliendo del sistema a través del efluente y la purga de lodos $[\mathrm{mgDQO} / \mathrm{d}]$

$\mathrm{f}_{\mathrm{cv}} \mathrm{MX}_{\mathrm{v}} / \mathrm{TRS}$ DQO orgánica particulada saliendo del sistema mediante la purga de lodos $[\mathrm{mgDQO} / \mathrm{d}]$

$\mathrm{FO}_{\mathrm{C}}$ masa de oxígeno utilizada por los OHOs para la degradación de la materia orgánica biodegradable, toda la proveniente del afluente a través del proceso de crecimiento y una parte proveniente de la biomasa de
OHOs a través del proceso de respiración endógena. $\left[\mathrm{mgO}_{2} / \mathrm{d}\right]$

El balance de masa de la DQO es una herramienta importante a la hora de evaluar (i) los datos medidos en sistemas experimentales (Ekama et al., 1986), (ii) los resultados calculados para el diseño utilizando el modelo en estado estacionario y (iii) los resultados calculados por modelos de simulación dinámica. La aplicación del balance de masa de la DQO para sistemas de lodos activados con nitrificación y desnitrificación se presenta en el Capítulo 5.

\subsubsection{Fracción activa de lodos}

La masa activa de SSV $\left(\mathrm{MX}_{\mathrm{BHv}}\right)$ en un reactor corresponde a la masa viva de OHOs que realiza el proceso de degradación de la materia orgánica. Las otras dos masas de sólidos orgánicos, $\mathrm{MX}_{\mathrm{EHv}}$ y $\mathrm{MX}_{\mathrm{Iv}}$, son inactivas $\mathrm{y}$ no biodegradables, $\mathrm{y}$ no cumplen ninguna función en lo que concierne al proceso de biodegradación en el sistema. Se nombran independientemente para diferenciar su origen; $\mathrm{MX}_{\mathrm{Iv}}$ corresponde a la materia orgánica particulada no biodegradable en el afluente mientras que $\mathrm{MX}_{\mathrm{EHv}}$ a la materia orgánica particulada producida en el reactor a través del proceso de respiración endógena. La fracción activa de $\mathrm{OHO}$ de los sólidos volátiles del reactor $\mathrm{f}_{\mathrm{av}}$ está dada por,

$f_{a v}=\frac{M X_{B H v}}{M X_{v}}$

[mgOHO SSV/mgSSV] (4.25)

Substituyendo el valor de $\mathrm{MX}_{\mathrm{BHv}} \mathrm{y} \mathrm{MX}_{\mathrm{v}}$ por las Ecs. 4.9 y 4.12 y reorganizando los términos se obtiene:

$\frac{1}{f_{a v}}=1+f_{H} b_{H T} T R S+\frac{f_{S^{\prime} u p}\left(1+b_{H T} T R S\right)}{f_{c v} Y_{H v}\left(1-f_{S^{\prime} u p}-f_{S^{\prime} u s}\right)}$

donde:

$\mathrm{f}_{\mathrm{av}} \quad$ Fracción activa de OHO de la masa de SSV

Si la masa total de sólidos suspendidos totales (SST) se utiliza como base para determinar la fracción activa, la fracción activa de la masa de lodos con respecto del SST, fat, se define como:

$$
f_{a t}=f_{i} f_{a v}
$$

donde:

$\mathrm{f}_{\mathrm{a}}$ fracción activa de OHO de la masa de SST $\mathrm{f}_{\mathrm{i}} \quad$ relación de SSV/SST del lodo activado 
Las fracciones activas $f_{a v} o f_{a t}$ dan una indicación de la estabilidad del lodo de purga, la cual está relacionada con la materia orgánica biodegradable remanente en la masa de lodo. La única materia orgánica biodegradable en la masa de SSV corresponde a los OHOs, los cuales en términos del modelo en estado estacionario equivalen a un $80 \%\left(1-\mathrm{f}_{\mathrm{H}}\right)$ de la masa de OHOs. Por ende, entre mayor sea la fracción activa, mayor será la proporción de materia orgánica biodegradable remanente en la masa de lodos, y mayor será el contenido energético remanente en la misma (Sección 4.11). Para que un lodo activado se considere estabilizado, la materia orgánica utilizable que permanece en el lodo debe ser lo suficientemente baja de tal forma que no genere olores por medio de la actividad biológica adicional. Los lodos a utilizar como acondicionadores de suelos necesitan haber sido estabilizados debido a que su principal función es aportar nutrientes y su contenido de materia orgánica no biodegradable al suelo (Korentajer, 1991). Los lodos no estabilizados utilizados en suelos destinados a la agricultura conducen a una demanda alta de oxígeno no deseable, producto de la actividad orgánica residual.

\subsubsection{Diseño en estado estacionario}

Las ecuaciones de diseño descritas anteriormente constituyen el punto de partida para el diseño aerobio o anóxico-aerobio de sistemas de lodos activados. Estas ecuaciones aplican tanto a sistemas con un solo reactor completamente mezclado, como también a sistemas más complejos con múltiples reactores anóxicosaerobios, para remoción biológica de nutrientes. Cuando se incluye la remoción biológica de fósforo, las anteriores ecuaciones no dan un resultado adecuado para estimación de las masas de SSV y SST en el sistema. En este tipo de sistemas, un segundo grupo de organismos heterótrofos, los PAOs los cuales tienen una estequiometría y cinéticas diferentes, necesitan ser incluidos para tener en cuenta la masa adicional de SSV y SST producida por masa de DQO utilizada. La inclusión de los PAOs en el modelo en estado estacionario se discute en el Capítulo 7.

Para sistemas más complejos, que incluyen zonas anóxicas-aerobias, las anteriores ecuaciones sirven de base si las suposiciones hechas en la derivación de las mismas aplican. Asumiendo que este sea el caso, los efectos de la nitrificación (Capítulo 5) y nitrificacióndesnitrificación (Capítulo 5) y las demandas de oxígeno asociadas pueden formularse como ecuaciones adicionales a las descritas anteriormente. El enfoque "simplificado" descrito se basa en la suposición de que toda la materia orgánica biodegradable es completamente removida y transformada por los microorganismos. Esto ha sido confirmado a través de la buena correlación obtenida entre la respuesta media de sistemas más complejos anóxicos-aerobios predicha por modelos cinéticos complejos (y validada experimentalmente) con los valores obtenidos mediante el proceso básico y las ecuaciones adicionales para incluir la nitrificación y desnitrificación. Estos buenos resultados obtenidos de la comparación entre el modelo simplificado en estado estacionario y modelos cinéticos de simulación más complejos, como el ASM1, fueron demostrados por Sötemann et al. (2006) para sistemas aerobios y sistemas con nitrificacióndesnitrificación (incluyendo digestión aerobia). De hecho, estos modelos simplificados en estado estacionario pueden formar la base para cálculos "manuales" para (i) definir y confirmar la información básica e inicial del diseño y (ii) revisar los resultados de modelos de simulación dinámica.

Otras suposiciones en las cuales se basa el modelo en estado estacionario son que (i) la masa activa de $\mathrm{OHO}$ que forma parte del agua residual afluente es despreciable en comparación con la que crece dentro del reactor, (ii) no hay pérdida de sólidos en el efluente del clarificador secundario, (iii) el balance de agua se conserva, (iv) se obtiene un balance del 100\% del balance de la DQO y (v) la pérdida de masa activa de $\mathrm{OHO}$ se modela mediante el proceso de respiración endógena. Es importante entender estas suposiciones y tomarlas en cuenta en el modelo para conocer sus limitaciones. Respecto a la suposición de la remoción total de la materia orgánica biodegradable, si este no llegara a ser el caso, entonces la masa de lodos producidos diariamente sería mayor y la demanda de oxígeno sería menor a los valores estimados por las ecuaciones básicas. La razón para estas desviaciones yace en la cinética de la degradación de la materia lentamente biodegradable - si, por ejemplo, la fracción aerobia de la masa de lodos es muy baja (Capítulo 5), la materia orgánica particulada biodegradable es utilizada solo parcialmente y la materia orgánica particulada biodegradable residual (Xs) se acumula en el sistema en forma de SSV adicionales a la materia orgánica particulada no biodegradable. Al mismo tiempo, la demanda carbonácea de oxígeno se reduce debido a que se utiliza una menor cantidad de materia orgánica biodegradable. Es claro que para estas situaciones, los resultados del modelo de simulación van a desviarse de los resultados del modelo en estado estacionario. De hecho, estas desviaciones deberían ser 
evaluadas e inspeccionadas con cautela ya que pueden indicar la posibilidad de resultados erróneos por parte del modelo de simulación.

\subsubsection{Procedimiento de diseño en estado estacionario}

El procedimiento de cálculo para diseñar un sistema para una edad de lodos requerida consta de los pasos descritos a continuación.

Seleccione las características del agua residual fs'up y fs'us las cuales representen adecuadamente las fracciones solubles y particuladas no biodegradables de la DQO del agua residual.

Posteriormente, calcule:

1) $\mathrm{FX}_{\mathrm{Ivi}}($ Ec. 4.6) y FXIOi (Ec. 4.7)

2) $\mathrm{FS}_{\text {ti }} \mathrm{y} / \mathrm{o} \mathrm{FS}_{\mathrm{bi}}($ Ec. 4.4 o 4.5 )

3) Seleccione la edad de lodos (TRS)

4) $\mathrm{MX}_{\mathrm{BHv}}$ (Ec. 4.9), MXEHv (Ec. 4.10), MX $\mathrm{X}_{\mathrm{Iv}}$ (Ec. 4.11), $\mathrm{MX}_{\mathrm{v}}\left(\right.$ Ec. 4.12), $\mathrm{MX}_{\mathrm{IO}}$ (Ec. 4.14), $\mathrm{MX}_{\mathrm{t}}$ (Ec. 4.15) o seleccione la fracción $\mathrm{f}_{\mathrm{i}}, \mathrm{MX}_{\mathrm{t}}$ (Ec. 4.17)

5) $\mathrm{FO}_{\mathrm{c}}\left(\right.$ Ec. 4.18) y $\mathrm{O}_{\mathrm{c}}$ (Ec. 4.19)

6) $\mathrm{V}_{\mathrm{p}}($ Ec. 4.20)

7) $\mathrm{TRH}_{\mathrm{n}},($ Ec. 4.2)

8) $\mathrm{S}_{\text {te }}($ Ec. 4.21$)$

En este procedimiento de diseño la DQO en el afluente y sus características van a estar gobernadas por el flujo específico de agua residual. La selección de los valores de las fracciones de DQO particulada y soluble no biodegradable son simples pero no por ello triviales. Cada una tiene un impacto en el diseño en áreas específicas. La fracción soluble no biodegradable de la DQO (f'us) tienen una influencia despreciable en los parámetros de diseño del reactor biológico, como son la producción de lodos y la demanda de oxígeno, pero tiene un marcada influencia en la concentración de la DQO en el efluente $\left(S_{\mathrm{te}}\right)$. En contraste, la fracción particulada no biodegradable de la DQO ( $f_{S}$ 'up no tiene influencia en la concentración de la DQO en el efluente $\left(\mathrm{S}_{\mathrm{te}}\right)$, pero si una marcada influencia en la tasa específica de producción de lodos (kgSSV producida/carga en kgDQO) y en el volumen específico del rector $\left(\mathrm{m}^{3} /\right.$ carga diaria de $\left.\mathrm{kgDQO}\right)$. Entre mayor sea $\mathrm{f}_{\text {S'up, }}$ mayores serán estos valores, y entre mayor sea la edad de lodos la influencia de fs'up se hace más notoria. El parámetro del sistema que debe ser seleccionado es la edad de lodos. La edad de lodos a utilizar va a depender de los requerimientos específicos de la planta de tratamiento de aguas residuales, tales como la calidad en el efluente, esto es, remoción de DQO orgánica únicamente, nitrificación, remoción de nitrógeno, remoción biológica de fósforo, - y las unidades para tratamiento de lodos proyectadas, lo que va a depender de si existe o no una clarificación primaria y de la estabilidad del lodo activado de purga, entre otras. Por esta razón la especificación de la edad de lodos, constituye una decisión muy importante en el diseño y requiere de consideraciones especiales (Sección 4.11).

\subsection{EJEMPLO DE DISEÑO}

El procedimiento desarrollado anteriormente para un sistema completo de lodos activados se demuestra con el uso de un ejemplo numérico. Asumiendo condiciones constantes de flujo y carga orgánica, se muestran a continuación los cálculos de los requerimientos de volumen del reactor, demanda carbonácea diaria de oxígeno, y producción diaria de lodos para un agua residual cruda y clarificada (Tabla 4.2).

\subsubsection{Efectos de la temperatura}

En la Tabla 4.1, la única constante cinética en el modelo de degradación de materia orgánica (DQO) en estado estacionario para aplicación en un sistema completo de lodos activados que se ve afectada por la temperatura es la tasa específica de respiración endógena $b_{H}$. Para esta constante, por cada grado centígrado que decrece la temperatura, el valor se reduce en un $3 \%$ (esto es $\theta_{\mathrm{bH}}=1.029$ ). La tasa a $14^{\circ} \mathrm{C}$ tiene un valor de $0.202 / \mathrm{d}$, mientras que a $22^{\circ} \mathrm{C}$ el valor es $0.254 / \mathrm{d}$. El efecto de la reducción en esta tasa cuando la temperatura decrece es que a bajas temperaturas la producción diaria de lodos se incrementa de forma marginal y la demanda carbonácea de oxígeno promedio disminuye de forma marginal. La diferencia en la producción de lodos $(\mathrm{kgSSV} / \mathrm{d})$ y la demanda de oxígeno $\left(\mathrm{kgO}_{2} / \mathrm{d}\right)$ es menor al $5 \%$ para un cambio de temperatura de 8 grados (de 14 a $22^{\circ} \mathrm{C}$ ). Consecuentemente, la demanda carbonácea promedio de oxígeno debería ser calculada para la temperatura máxima, y el volumen del reactor y la producción de lodos para la temperatura mínima, de tal forma que se puedan calcular los máximos valores de estos parámetros. 
Tabla 4.2 Características del agua residual cruda y clarificada utilizadas en el ejemplo de diseño

\begin{tabular}{|c|c|c|c|c|}
\hline Parámetros & Símbolo & Unidades & Agua cruda & Agua clarificada \\
\hline Caudal afluente & $\mathrm{Q}_{\mathrm{i}}$ & $\mathrm{Ml} / \mathrm{d}$ & 15 & 14.93 \\
\hline Concentración total de la DQO en el afluente & $\mathrm{S}_{\mathrm{ti}}$ & $\mathrm{mgDQO} / 1$ & 750 & 450 \\
\hline Fracción no biodegradable y particulada de la DQO & fs'up & & 0.15 & 0.04 \\
\hline Fracción no biodegradable y soluble de la DQO & fs'us & & 0.07 & 0.12 \\
\hline Fracción orgánica no biodegradable y soluble de $\mathrm{N}$ & $\mathrm{f}_{\mathrm{N}}$ 'ous & & 0.03 & 0.035 \\
\hline Concentración de NTK en el afluente & $\mathrm{N}_{\mathrm{ti}}$ & $\mathrm{mgN} / 1$ & 60 & 51 \\
\hline Concentración total de $\mathrm{P}$ en el afluente & $\mathrm{P}_{\mathrm{ti}}$ & $\mathrm{mgP} / 1$ & 15 & 12.75 \\
\hline Relación de NTK/DQO & $\mathrm{f}_{\mathrm{ns}}$ & $\mathrm{mgN} / \mathrm{mgDQO}$ & 0.08 & 0.117 \\
\hline Relación de P/DQO & $\mathrm{f}_{\mathrm{ps}}$ & $\mathrm{mgP} / \mathrm{mgDQO}$ & 0.02 & 0.028 \\
\hline Temperatura (máxima y mínima) & $\mathrm{T}_{\max }, \mathrm{T}_{\min }$ & ${ }^{\circ} \mathrm{C}$ & $14-22$ & $14-22$ \\
\hline $\mathrm{pH}$ & - & & 7.5 & 7.5 \\
\hline Alcalinidad $\mathrm{H}_{2} \mathrm{CO}_{3}$ en el afluente & Alki & $\mathrm{mg} / 1$ como $\mathrm{CaCO}_{3}$ & 250 & 250 \\
\hline SSI en el afluente & $\mathrm{X}_{\mathrm{IOi}}$ & $\operatorname{mgSSI} / 1$ & 47.8 & 9.5 \\
\hline SSV/SST del lodo activado & $\mathrm{f}_{\mathrm{i}}$ & $\mathrm{mgSSV} / \mathrm{mg} \mathrm{SST}$ & 0.75 & 0.83 \\
\hline
\end{tabular}

\subsubsection{Cálculos para la degradación de materia orgánica}

Este ejemplo de diseño demuestra el efecto de la temperatura y la edad de lodos en $(i)$ la masa de lodos como SST en el sistema ( $\left.\mathrm{MX}_{\mathrm{t}}, \mathrm{kgSST}\right)$, (ii) la demanda carbonácea diaria promedio de oxígeno $\left(\mathrm{FO}_{\mathrm{c}}, \mathrm{kgO}_{2} / \mathrm{d}\right)$, (iii) las fracciones activas de lodos respecto de los SSV y SST (fav and $f_{a t}$ ) y (iv) la masa de lodos como SST, purgados diariamente $\left(\mathrm{FX}_{\mathrm{t}}, \mathrm{kgSST} / \mathrm{d}\right)$. Estos parámetros son calculados para un agua residual cruda y clarificada a 14 y $22^{\circ} \mathrm{C}$ para edades de lodos que varían desde 3 hasta 30 días.

Masa de DQO tratada $/ \mathrm{d}=\mathrm{FS}_{\mathrm{ti}}=\mathrm{Q}_{\mathrm{i}} \mathrm{S}_{\mathrm{ti}} \mathrm{kgDQO} / \mathrm{d}$ Masa biodegradable de la DQO tratada $/ \mathrm{d}=\mathrm{FS}_{\mathrm{bi}}=(1-$ fs'up-fs'us) $\mathrm{S}_{\mathrm{ti}}$

Masa de materia orgánica particulada que ingresa al sistema como $\mathrm{mgSSV} / \mathrm{d}=\mathrm{FX}_{\mathrm{Ivi}}=\mathrm{FS}_{\mathrm{ti}} \mathrm{f}_{\mathrm{s}}$ 'up $/ \mathrm{f}_{\mathrm{cv}}$

Por consiguiente para el agua cruda:

$\mathrm{FS}_{\mathrm{ti}}=15 \mathrm{Ml} / \mathrm{d} \cdot 750 \mathrm{mgDQO} / 1=11,250 \mathrm{kgDQO} / \mathrm{d}$

$\mathrm{FS}_{\mathrm{bi}}=(1-0.07-0.15) 11250=8,775 \mathrm{kgDQO} / \mathrm{d}$

$\mathrm{FX}_{\mathrm{Ivi}}=0.15 \cdot 11,250 / 1.48=1,140 \mathrm{kgSSV} / \mathrm{d}$

$\mathrm{FX}_{\mathrm{IOi}}=15 \mathrm{Ml} / \mathrm{d} \cdot 47.8=717 \mathrm{kgSSI} / \mathrm{d}$

y para el agua clarificada:

$\mathrm{FS}_{\mathrm{ti}}=15 \mathrm{Ml} / \mathrm{d} \cdot 450 \mathrm{mgDQO} / 1=6,750 \mathrm{kgDQO} / \mathrm{d}$

$\mathrm{FS}_{\mathrm{bi}}=(1-0.117-0.04) \cdot 6750=5,690 \mathrm{kgDQO} / \mathrm{d}$

$\mathrm{FX}_{\mathrm{Ivi}}=0.04 \cdot 6,750 / 1.48=182.4 \mathrm{kgSSV} / \mathrm{d}$

$\mathrm{FX}_{\mathrm{IOi}}=15 \mathrm{Ml} / \mathrm{d} \cdot 9.5=142.5 \mathrm{kgSSI} / \mathrm{d}$

De las Ecs. 4.12 y 4.17, las masas de sólidos volátiles $\left(\mathrm{MX}_{\mathrm{v}}\right)$ y totales $\left(\mathrm{MX}_{\mathrm{t}}\right)$ en el sistema para el agua cruda:

$$
\begin{array}{ll}
\mathrm{MX}_{\mathrm{v}}=8,775 \frac{0.45 \cdot \mathrm{TRS}}{\left(1+\mathrm{b}_{\mathrm{HT}} \mathrm{TRS}\right)} \cdot & \\
\left(1+0.2 \mathrm{~b}_{\mathrm{HT}} \mathrm{TRS}\right)+1,140 \cdot \mathrm{TRS} & {[\mathrm{kgSSV}]} \\
\mathrm{MX}_{\mathrm{IO}}=717 \mathrm{TRS}+0.15 \mathrm{f}_{\mathrm{avOHO}} \mathrm{MX}_{\mathrm{v}} & {[\mathrm{kgSSI}]} \\
\mathrm{MX}_{\mathrm{t}}=\mathrm{MX}_{\mathrm{v}} / 0.75 \text { o } \mathrm{MX}_{\mathrm{IO}}+\mathrm{MX}_{\mathrm{i}} & {[\mathrm{kgSST}]} \\
\text { y para el agua clarificada: } &
\end{array}
$$

$$
\begin{array}{ll}
\mathrm{MX}_{\mathrm{v}}=5,690 \frac{0.45 \cdot \mathrm{TRS}}{\left(1+\mathrm{b}_{\mathrm{HT}} \cdot \mathrm{TRS}\right)} \cdot & \\
\left(1+0.2 \mathrm{~b}_{\mathrm{HT}} \cdot \mathrm{TRS}\right)+182.4 \cdot \mathrm{TRS} & {[\mathrm{kgSST}]} \\
\mathrm{MX}_{\mathrm{IO}}=142.5 \mathrm{TRS}+0.15 \mathrm{f}_{\text {avOHO MXV }} & {[\mathrm{kgSSI}]} \\
\mathrm{MX}_{\mathrm{t}}=\mathrm{MX}_{\mathrm{v}} / 0.83 \text { or } \mathrm{MX}_{\mathrm{IO}}+\mathrm{MX}_{\mathrm{i}} & {[\mathrm{kgSST}]}
\end{array}
$$

De la Ec. 4.18, la demanda carbonácea diaria promedio de oxígeno para el agua cruda es:

$$
\mathrm{FO}_{\mathrm{c}}=8,775\left[(0.334)+0.533 \frac{\mathrm{b}_{\mathrm{HT}} \cdot \mathrm{TRS}}{\left(1+\mathrm{b}_{\mathrm{HT}} \cdot \mathrm{TRS}\right)}\right]
$$

$\left[\mathrm{kgO}_{2} / \mathrm{d}\right]$ 
y para el agua clarificada:

$$
\begin{array}{r}
\mathrm{FO}_{\mathrm{c}}=5,690\left[(0.334)+0.533 \frac{\mathrm{b}_{\mathrm{HT}} \cdot \mathrm{TRS}}{\left(1+\mathrm{b}_{\mathrm{HT}} \cdot \mathrm{TRS}\right)}\right] \\
{\left[\mathrm{kgO}_{2} / \mathrm{d}\right]}
\end{array}
$$

De las Ecs. 4.26 y 4.27, la fracción activa con respecto de los SSV ( $\left.f_{a v}\right)$ y los SST ( $\left.f_{a t}\right)$ para el agua cruda:

$$
\begin{aligned}
\mathrm{f}_{\mathrm{av}}=1 /\left[1+0.2 \mathrm{~b}_{\mathrm{H}} \cdot \mathrm{TRS}+0.289\left(1+\mathrm{b}_{\mathrm{HT}} \cdot \mathrm{TRS}\right)\right] \mathrm{y}, \\
\mathrm{f}_{\mathrm{at}}=0.75 \mathrm{f}_{\mathrm{av}}
\end{aligned}
$$

y para el agua clarificada:

$$
\begin{gathered}
\mathrm{f}_{\mathrm{av}}=1 /\left[1+0.2 \mathrm{~b}_{\mathrm{H}} \mathrm{TRS}+0.142\left(1+\mathrm{b}_{\mathrm{HT}} \mathrm{TRS}\right)\right] \mathrm{y}, \\
\mathrm{f}_{\mathrm{at}}=0.83 \mathrm{f}_{\mathrm{av}}
\end{gathered}
$$

De la definición de la edad de lodos (Ec. 4.1), la masa de lodos secundarios como SSV y SST producidas (o purgadas) por día $\left(\mathrm{FX}_{\mathrm{t}}\right)$ para el agua residual es:

$$
\begin{aligned}
& \mathrm{FX}_{\mathrm{t}}=\mathrm{Q}_{\mathrm{w}} \mathrm{X}_{\mathrm{t}}=\mathrm{MX}_{\mathrm{t}} / \mathrm{TRS} \\
& \mathrm{FX}_{\mathrm{t}}=\frac{8,775}{0.75} \frac{0.45}{\left(1+\mathrm{b}_{\mathrm{HT}} \mathrm{TRS}\right)}\left(1+0.2 \mathrm{~b}_{\mathrm{HT}} \mathrm{TRS}\right)+\frac{1140}{0.75} \\
& {[\mathrm{kgSST} / \mathrm{d}]}
\end{aligned}
$$

y para el agua clarificada:

$$
\begin{aligned}
& \mathrm{FX}_{\mathrm{t}}=\frac{5,690}{0.83} \frac{0.45}{\left(1+\mathrm{b}_{\mathrm{HT}} \mathrm{TRS}\right)}\left(1+0.2 \mathrm{~b}_{\mathrm{HT}} \mathrm{TRS}\right)+\frac{142.8}{0.83} \\
& {[\mathrm{kgSST} / \mathrm{d}]}
\end{aligned}
$$

La masa de SSV purgados/producidos por día $\left(\mathrm{FX}_{\mathrm{v}}\right)$ es simplemente la multiplicación de $f_{i}$ por la masa de SST purgados por día,

$$
\mathrm{FX}_{\mathrm{v}}=\mathrm{f}_{\mathrm{i}} \mathrm{FX}_{\mathrm{t}} \quad[\mathrm{kgSSV} / \mathrm{d}]
$$

Substituyendo el valor de $\mathrm{b}_{\mathrm{HT}}$ a $14^{\circ} \mathrm{C}$ (esto es $0.202 / \mathrm{d}$ ) y a $22^{\circ} \mathrm{C}$ (esto es $0.254 / \mathrm{d}$ ) en las ecuaciones anteriores permite el cálculo de $\mathrm{MX}_{\mathrm{v}}, \mathrm{MX}_{\mathrm{t}}, \mathrm{FO}_{\mathrm{c}}, \mathrm{f}_{\mathrm{av}}, \mathrm{f}_{\mathrm{at}}$, $\mathrm{FX}_{\mathrm{t}}$ y $\mathrm{FX}_{\mathrm{v}}$ para edades de lodos de 3 y 30 días. Los resultados se pueden ver en la Figura 4.3. De estas figuras, la masa de lodos en el reactor (como SST o SSV), la demanda carbonácea promedio de oxígeno, la masa de SST producidos por día $(\mathrm{kgSST} / \mathrm{d})$ y la fracción activa (respecto de los SSLM o SSVLM) son afectados solamente de forma marginal por el cambio de temperatura. Para estos parámetros, en lo que concierne al diseño, los efectos de temperatura no juegan un rol determinante. No obstante, el tipo de agua residual afluente, esto es, cruda o clarificada, si tiene un efecto considerable. El tratamiento del agua residual cruda resulta en una mayor producción de lodos, una demanda de oxígeno más alta y una fracción activa más baja en el lodo respecto del tratamiento del agua clarificada.

La diferencia en los efectos de utilizar agua residual cruda y clarificada depende enteramente de la eficiencia de los clarificadores primarios. Las diferencias aparentes observadas en la Figura 4.3 surgen de la remoción de alrededor de un $40 \%$ de la DQO en los clarificadores primarios - entre mayor sea esta eficiencia de remoción de la DQO, mayor será la diferencia entre los parámetros del agua residual cruda y clarificada.

Los resultados para una edad de lodos de 20 días se encuentran en la Tabla 4.3. De la Ec. 4.20, para la misma concentración de SST en el reactor, el volumen del sistema es proporcional a la masa de lodos que contiene. Como consecuencia, para una misma concentración de SST, el volumen de un reactor que trate un agua residual clarificada va a ser solo el $33 \%$ de un reactor que depure el agua cruda a una edad de lodos de 20 días. Adicionalmente, la planta que trate el agua clarificada requiere solo el $63 \%$ del oxígeno utilizado en la plata que depure el agua cruda. Sin embargo, la fracción activa de los lodos respecto de los SST en la plata con agua residual clarificada es $43 \%$, el cual es demasiado alto para poder descargar directamente en los lechos de secado, mientras que la planta con agua cruda el valor de la fracción activa es de $23 \%$.

Como se puede observar, la opción de tratar agua residual cruda o clarificada requiere sopesar las ventajas y desventajas de cada sistema, esto es, para agua clarificada, reactores de menor volumen y menor consumo de oxígeno, pero con el manejo adicional de los lodos primarios y secundarios y su respectiva estabilización, y para el agua cruda, reactores de mayor volumen, mayor consumo de oxígeno y mayor producción de lodos secundarios, pero sin la necesidad de manejar lodos primarios. Estos aspectos se evalúan en mayor detalle en la sección 4.11 a continuación. 
Tabla 4.3 Valores de diseño del sistema de lodos activados para una edad de lodos de 20 días para un agua residual cruda y clarificada a 14 y $22^{\circ} \mathrm{C}$ utilizadas en el ejemplo

\begin{tabular}{|c|c|c|c|c|c|}
\hline \multirow{2}{*}{$\begin{array}{l}\text { Parámetros del sistema } \\
\text { Temperatura del agua }\end{array}$} & \multicolumn{2}{|l|}{ Unidades } & \multicolumn{2}{|c|}{ Agua cruda } & \multirow{2}{*}{$\frac{\text { Agua clarificada }^{1}}{22}$} \\
\hline & ${ }^{\circ} \mathrm{C}$ & 14 & 22 & 14 & \\
\hline Masa de SSV, $\mathrm{MX}_{\mathrm{V}}$ & kgSSV & 51,122 & 48,982 & 21,918 & 20,537 \\
\hline Masa de SST, MXt & $\operatorname{kgSST}$ & 68,162 & 65,309 & 26,408 & 24,743 \\
\hline Masa de $\mathrm{O}_{2}, \mathrm{FO}_{\mathrm{c}}$ & $\mathrm{kgO}_{2} / \mathrm{d}$ & 6,679 & 6,837 & 4,313 & 4,415 \\
\hline Fracción activa, $\mathrm{f}_{\mathrm{av}}$ & & 0.306 & 0.265 & 0.461 & 0.408 \\
\hline Fracción activa, $\mathrm{f}_{\text {at }}$ & & 0.23 & 0.199 & 0.383 & 0.339 \\
\hline Purga, $\mathrm{FX}_{\mathrm{v}}$ & $\mathrm{kgSSV} / \mathrm{d}$ & 2,556 & 2,449 & 1,096 & 1,027 \\
\hline Purga, $F_{\mathrm{t}}$ & $\mathrm{kgSST} / \mathrm{d}$ & 3,408 & 3,265 & 1,320 & 1,237 \\
\hline DQO en el efluente, $S_{\text {te }}$ & $\mathrm{mg} / 1$ & 52.5 & 52.5 & 52.5 & 52.5 \\
\hline \multicolumn{6}{|c|}{ Balance de masa de la DQO } \\
\hline \multicolumn{2}{|c|}{ Soluble en el Qe, MSte (Saliendo)kgDQO/d } & 743 & 743 & 766 & 766 \\
\hline \multicolumn{2}{|c|}{ Oxígeno utilizado $\mathrm{FO}_{\mathrm{c}}$ (Saliendo)kgDQO/d } & 6,679 & 6,837 & 4,313 & 4,415 \\
\hline \multicolumn{2}{|c|}{ DQO soluble en el $\mathrm{Q}_{\mathrm{w}}($ Saliendo) $\mathrm{kgDQO} / \mathrm{d}$} & 45 & 17 & 45 & 17 \\
\hline \multicolumn{2}{|c|}{$\begin{array}{l}\text { DQO de los SSV en el } Q_{w} \mathrm{kgDQO} / \mathrm{d} \\
\text { (Saliendo) }\end{array}$} & 3,783 & 3,625 & 1,622 & 1,520 \\
\hline DQO total entrando & $\mathrm{kgDQO} / \mathrm{d}$ & 11,249 & 11,249 & 6,718 & 6,718 \\
\hline DQO total saliendo ${ }^{1}$ & $\mathrm{kgDQO} / \mathrm{d}$ & 11,250 & 11,250 & 6,718 & 6,718 \\
\hline \multicolumn{2}{|c|}{ Balance de masa de la DQO (\%) } & 100 & 100 & 100 & 100 \\
\hline
\end{tabular}

1 Para el agua residual clarificada, basado en un caudal afluente de $14.93 \mathrm{Ml} / \mathrm{d}$ para poder tener en cuenta el flujo de lodos primarios de 725 $\mathrm{m}^{3} / \mathrm{d}(0.5 \%$ del caudal promedio diario $)$

\subsubsection{Balance de masa de la DQO}

Aplicando el balance de masa de la DQO con la Ec. 4.24 a las aguas del ejemplo produce:

1) DQO soluble en el efluente y purga de lodos,

$$
\left(\mathrm{Q}_{\mathrm{e}}+\mathrm{Q}_{\mathrm{w}}=\mathrm{Q}_{\mathrm{i}}\right): \mathrm{FS}_{\mathrm{te}}=\mathrm{S}_{\mathrm{ti}} \mathrm{Q}_{\mathrm{i}}=\mathrm{f}_{\mathrm{S}^{\prime} \mathrm{us}} \mathrm{S}_{\mathrm{ti}} \mathrm{Q}_{\mathrm{i}}
$$

$[\mathrm{kgDQO} / \mathrm{d}]$

2) DQO particulada (lodo activado) en la purga,

$$
\left(Q_{w}\right): F S_{X v}=f_{c v} M X_{v} / T R S \quad[\mathrm{kgDQO} / \mathrm{d}]
$$

donde, $M X_{v}$ está dado por la Ec. 4.12

3) Oxígeno utilizado para la degradación carbonácea, $\mathrm{FO}_{\mathrm{c}}, \mathrm{kgO}_{2} / \mathrm{d}$ y dado por la Ec. 4.18 .

4) Masa de DQO entrando al sistema,

$$
\mathrm{FS}_{\mathrm{ti}}=\mathrm{S}_{\mathrm{ti}} \mathrm{Q}_{\mathrm{i}} \quad[\mathrm{kgDQO} / \mathrm{d}]
$$

Los sistemas de lodos activados que operan a edades de lodos elevadas (por ejemplo de 30 días, Tabla 4.4), permiten la culminación casi completa del proceso de respiración endógena, permitiendo el tratamiento no solo del agua residual en el reactor, sino también la estabilización aerobia de los lodos, obteniendo así fracciones activas bajas, lo que a su vez permite que el lodo activado pueda descargarse directamente en los lechos de secado sin necesidad de un tratamiento previo adicional. El tratamiento del agua residual cruda en un sistema de aireación extendida, evita el tratamiento de lodos adicional, el cual toma lugar en el mismo reactor biológico, pero a su vez requiere reactores de mayor tamaño y una utilización elevada de oxígeno. En contraste, el tratamiento del agua clarificada con edades de lodos bajas (de alta tasa, por ejemplo de 8 días, Tabla 4.4) resulta en un sistema de lodos activados con un reactor pequeño y un bajo consumo de oxígeno, pero como consecuencia produce un lodo primario y un lodo de purga muy activo, los cuales deben ser estabilizados mediante un tratamiento aerobio o anaerobio adicional para reducir el contenido de materia orgánica biodegradable remanente en el lodo. A edades muy bajas de lodos, el objetivo de los sistemas de lodos activados es tratar solamente el agua residual, requiriendo que los lodos generados sean estabilizados en un reactor aerobio o anaerobio adicional. Independiente del enfoque adoptado (aireación extendida o de alta tasa) para una planta de tratamiento de aguas residuales en particular, el balance de masa de la DQO debe cumplirse no solo en el sistema de lodos activados, sino también en el sistema de tratamiento de lodos. 
A

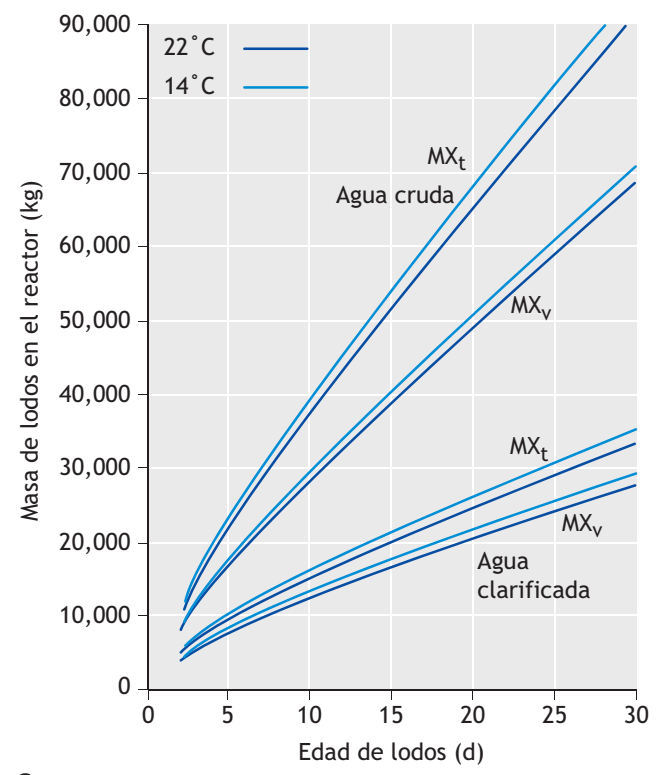

C

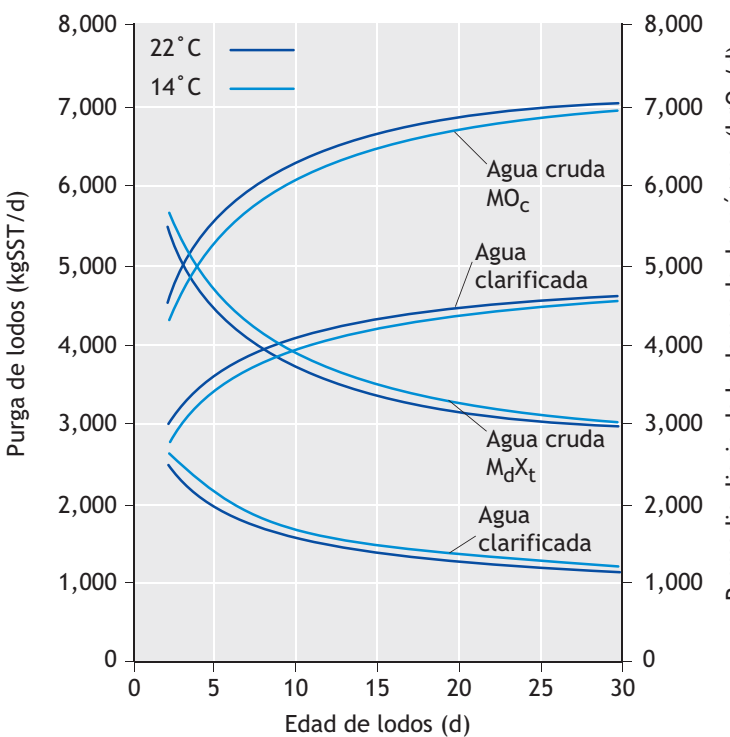

B

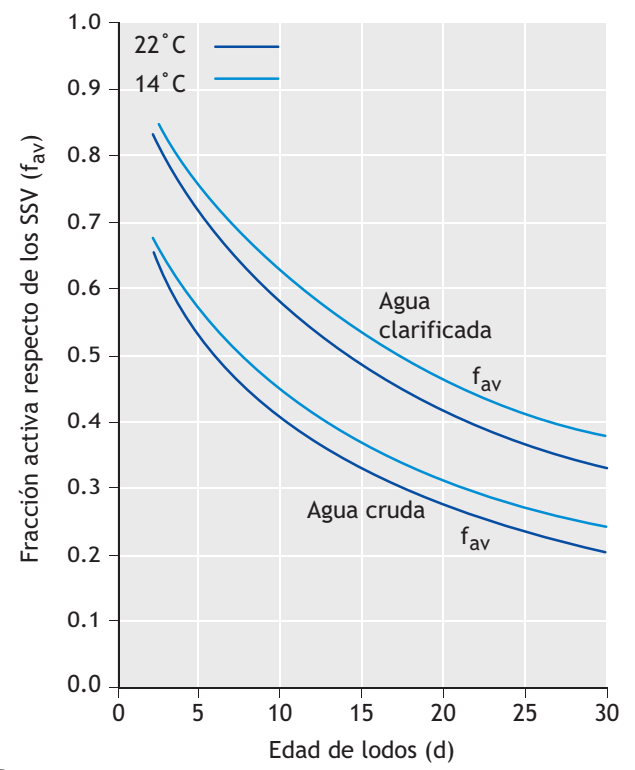

D

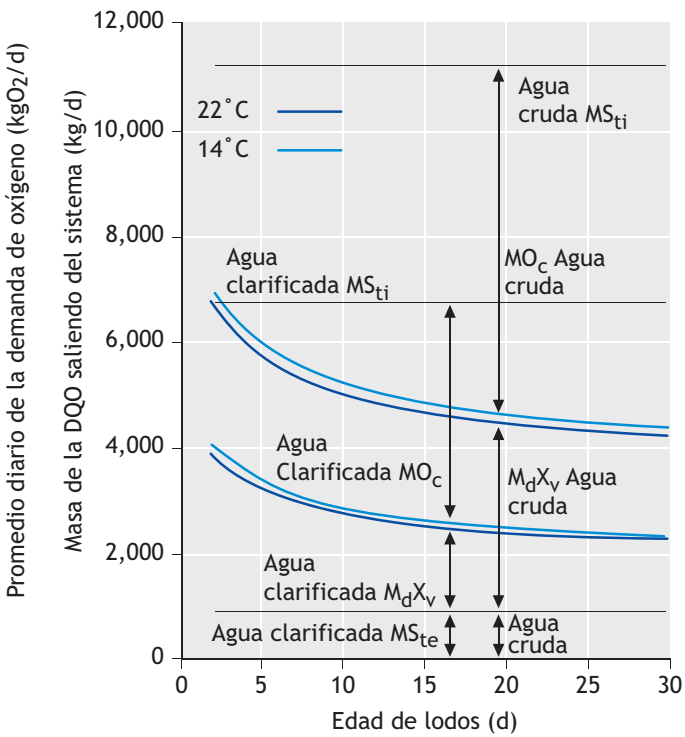

Figuras 4.3 Masa de lodos $M X_{t}(k g S S T)$ y $M X_{v}(k g S S V)$ (A), fracción activa del lodo respecto de los SSV (fav) (B), demanda de oxígeno carbonácea promedio $\mathrm{FO}_{\mathrm{c}}(\mathrm{kgO} / \mathrm{d}$ ) y masa de lodos producida por día (kgSST/d) (C) y el balance de masa de la DQO (D) contra la edad de lodos para el ejemplo utilizando agua residual cruda y clarificada a $14^{\circ} \mathrm{C}$ y $22^{\circ} \mathrm{C}$. Las constantes cinéticas y estequiométricas , y las características del agua residual se encuentran en las Tablas 4.2 y 4.3 
Tabla 4.4 Comparación de la producción de lodos, estabilidad (biodegradabilidad de la DQO remanente) y demanda de oxígeno tratando el agua residual cruda y clarificada para una edad de lodos baja y alta utilizando los datos definidos en el ejemplo

\begin{tabular}{llll}
\hline Parámetros & Unidades & Agua cruda & Agua clarificada \\
\hline Temperatura & ${ }^{\circ} \mathrm{C}$ & 14 & 14 \\
Edad de lodos & $\mathrm{d}$ & 30 & 8 \\
Concentración de lodos en el reactor & $\mathrm{mgSST} / \mathrm{l}$ & 4,000 & 4,000 \\
Volumen del reactor & $\mathrm{m}^{3}$ & 23,769 & 3,544 \\
Demanda de oxígeno & $\mathrm{kgO} / \mathrm{d}$ & 6,944 & 3,758 \\
SST del lodo primario & $\mathrm{kgSST} / \mathrm{d}$ & 0 & 3,335 \\
SSV del lodo primario & $\mathrm{kgSSV} / \mathrm{d}$ & 0 & 2,468 \\
DQO del lodo primario & $\mathrm{kgDQO} / \mathrm{d}$ & 0 & 4,531 \\
DQO biodegradable remanente & $\%$ & 0 & 68.5 \\
SST del lodo secundario & $\mathrm{kgSST} / \mathrm{d}$ & 3,169 & 1,772 \\
SSV del lodo secundario & $\mathrm{kgSSV} / \mathrm{d}$ & 2,377 & 1,471 \\
DQO del lodo secundario & $\mathrm{kgDQO} / \mathrm{d}$ & 3,518 & 2,177 \\
Fracción activa respecto de los SSV & $\mathrm{kgOHO} \mathrm{SSV/kgSSV}$ & 0.235 & 0.662 \\
DQO biodegradable remanente & $\%$ & 18.8 & 53 \\
Lodo total como SST & $\mathrm{kgSST} / \mathrm{d}$ & 3,169 & 5,107 \\
Lodo total como SSV & $\mathrm{kgSSV} / \mathrm{d}$ & 2,377 & 3,939 \\
Lodo total como DQO & $\mathrm{kgDQO} / \mathrm{d}$ & 3,518 & 6,708 \\
DQO biodegradable remanente & $\%$ & 18.8 & 63.5 \\
\hline
\end{tabular}

\subsection{REQUERIMIENTOS DE VOLUMEN DEL REACTOR}

Una vez que la masa de lodos en el reactor ha sido determinada considerando una edad de lodos y una carga orgánica de DQO por día, el volumen del reactor se puede determinar seleccionando una concentración específica de $\operatorname{SST}\left(\mathrm{X}_{\mathrm{t}}\right)$ a la cual se desea operar el sistema. Definido el volumen, el tiempo de retención hidráulico nominal, o el tiempo de aireación para sistemas completamente aerobios, puede determinarse con la Ec. 4.2. El tiempo de retención hidráulico por ende no interviene en el procedimiento de diseño y es una consecuencia de la masa de lodos en el reactor y de la concentración de SST. Este punto ya ha sido mencionado anteriormente pero cabe hace mención una vez más para hacer énfasis en que aún existen métodos de diseño que se basan en el tiempo de retención hidráulico o en el tiempo de aireación como parámetro básico de diseño. Estos métodos pueden conducir a resultados erróneos en el cálculo del volumen del reactor y deben utilizarse con cautela.

Comparemos, a manera de ejemplo, dos plantas operando a una edad de lodos determinada, ambas recibiendo la misma carga orgánica en $\mathrm{kgDQO} / \mathrm{d}$ pero la primera con una concentración alta de DQO y un caudal bajo, y la segunda con una concentración baja y una carga alta. Para estas condiciones, si el diseño se basara en el tiempo de retención hidráulica, es claro que la primera planta tendría un volumen mucho menor que la segunda, a pesar de que la masa de lodos en ambos reactores sería la misma. Adicionalmente, la primera planta podría presentar una concentración muy elevada de SST lo cual podría causar problemas en los clarificadores secundarios. Por lo tanto, si es el único parámetro de diseño considerado o el principal, el tiempo de retención hidráulico es un criterio inapropiado para diseñar y comparar los volúmenes de diferentes plantas de tratamiento, inclusive bajo condiciones operativas similares.

La Figura 4.4 muestra los requerimientos de volumen del reactor del ejemplo resuelto previamente para diferentes edades de lodos teniendo en cuenta el agua residual cruda y clarificada obtenida de las Ecs. 4.4 a 4.17 y 4.20 . El volumen del reactor puede ser determinado también a partir de la carga equivalente de DQO per cápita o población equivalente (PE). La Figura 4.4 muestra el volumen por población equivalente tomando como base una carga de 0.10 kgDQO/PE.d para el agua residual cruda. Por lo tanto, para tratar el agua residual cruda del ejemplo con una edad de lodos de 20 días y una concentración de sólidos de $4 \mathrm{kSST} / \mathrm{m}^{3}$, se requiere un volumen de reactor de 
145 1/PE o $1.45 \mathrm{~m}^{3} / \mathrm{kgDQO}$ descargados diariamente a la planta. Los requerimientos de volumen para un agua clarificada también se muestran en la Figura 4.4, considerando la fracción de DQO que se remueve en la clarificación primaria (40\% para el agua residual clarificada del ejemplo de diseño). Utilizando la misma figura, se observa que para tratar un agua residual clarificada con una edad de lodos de 20 días y una concentración de sólidos de $4 \mathrm{kgSST} / \mathrm{m}^{3}$, se requiere un volumen de reactor de $0.55 \mathrm{~m}^{3} / \mathrm{kgDQO}$ de agua cruda entrando a la planta por día, o 55 1/PE.

Carga del agua residual cruda $=0.10 \mathrm{~kg} \mathrm{DQO} / \mathrm{PE} . \mathrm{d}$ $40 \%$ de remoción de la DQO en el clarificador primario

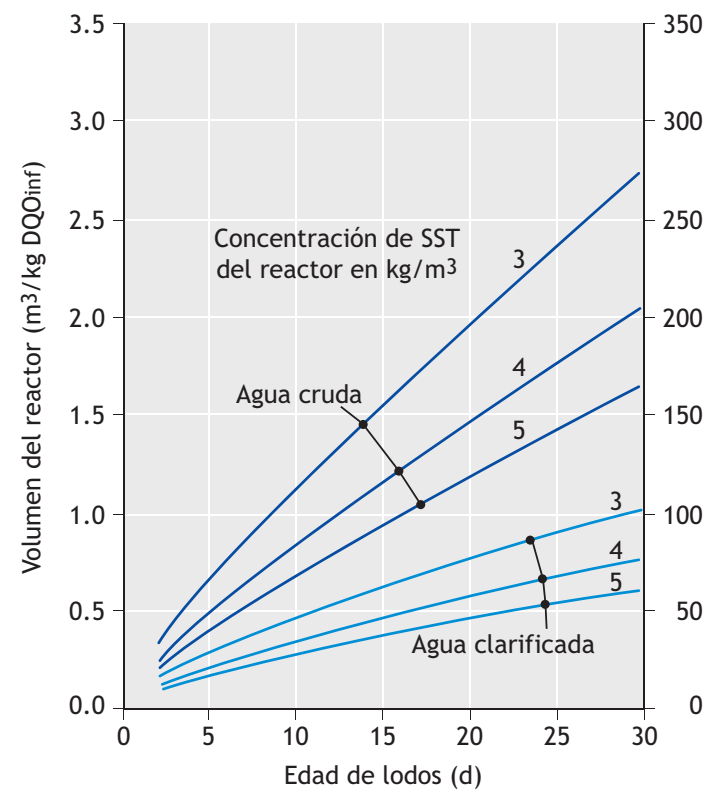

Figura 4.4 Requerimientos de volumen del reactor en $\mathrm{m}^{3} / \mathrm{kg}$ de carga de la DQO del agua residual cruda por día contra la edad de lodos para diferentes concentraciones promedio de SST teniendo en cuenta agua cruda y clarificada (asumiendo una remoción del $40 \%$ de la DQO en el clarificador primario). Los requerimientos de volumen en I/población equivalente $(\mathrm{PE})$ se muestran en el eje vertical derecho basados en una contribución de la DQO al agua cruda de $0.10 \mathrm{~kg}$ DQO/persona equivalente.

Comparando los requerimientos de volumen para los dos tipos de agua residual, cruda y clarificada respectivamente, se puede observar que haciendo uso de una clarificación primaria, se puede obtener una reducción considerable en el volumen del reactor del orden del $62 \%$ para el agua residual del ejemplo y una edad de lodos de 20 días.

\subsection{DETERMINACIÓN DE LA CONCENTRACIÓN DE SÓLIDOS SUSPENDIDOS TOTALES (SST)}

La selección de la concentración de sólidos operativa en el reactor puede realizarse de forma empírica basándose en experiencias pasadas que documenten el tratamiento de aguas residuales de características similares, o seleccionando los valores recomendados por guías de diseño, como las sugeridas por Metcalf and Eddy (1991). Por ejemplo, para este último en sistemas convencionales (con clarificación primaria) se recomienda tomar un valor de 1,500 a 3,000 mgSST/1, y para sistemas de aireación extendida (sin clarificación primaria) se recomiendan valores entre 3,000 y 6,000 $\mathrm{mgSST} / \mathrm{l}$. Las diferencias en la concentración de sólidos en un reactor tratando agua residual cruda y clarificada surgen debido a que $(i)$ el flujo de agua por $\mathrm{kg}$ de DQO en el reactor que depura agua cruda es considerablemente mayor que para el reactor que trata agua clarificada, y (ii) la capacidad de sedimentación del lodo en sistemas convencionales es más baja que en sistemas de aireación extendida. En un estudio realizado en Holanda con 45 plantas de tratamiento de aguas residuales, Stofkoper and Trentelman (1981), encontraron valores más altos del Índice volumétrico de lodos diluidos (IVLd $_{\mathrm{d}}$, en inglés Diluted Sludge Volume Index, $D S V I$ ) en sistemas con clarificación primaria que en sistemas que depuraban agua cruda de manera directa (Ekama and Marais, 1986).

El efecto de la carga del agua residual y la capacidad de sedimentación de los lodos, al igual que otro factores como la relación de caudal pico $\mathrm{f}_{\mathrm{q}}$, definido como el cociente entre el caudal pico $\left(\mathrm{Q}_{\max }\right)$ y el caudal promedio en temporada seca $\left(\mathrm{Q}_{\mathrm{p}, \mathrm{min}}\right)$, las características del agua residual y el lodo activado ( $\mathrm{f}_{\mathrm{S}}$ 'up, $\mathrm{f}_{\mathrm{S}}$ 'us, $\mathrm{f}_{\mathrm{i}}$ ), y los costos constructivos, pueden ser considerados para determinar la concentración de sólidos en el reactor mediante un análisis de minimización de costos constructivos (Hörler, 1969; Dick, 1976; Riddell et al., 1983; Pincince et al., 1995). En este tipo de análisis, los costos de construcción de los reactores y los clarificadores secundarios se determinan en función de la concentración de sólidos del reactor. La concentración bajo la cual los costos combinados de construcción de los reactores y los clarificadores secundarios producen un costo mínimo, correspondiendo a la concentración de diseño. 


\subsubsection{Costo del reactor biológico}

Una vez establecidas las características del agua residual y el lodo activado ( $\mathrm{f}_{\mathrm{S}}$ 'up, $\mathrm{f}_{\mathrm{S}}$ 'us, $\mathrm{f}_{\mathrm{i}}$ ), la edad de lodos y la carga de materia orgánica (como DQO) en el reactor $\left(\mathrm{MS}_{\mathrm{ti} \text { Reactor }}\right)$, la masa de SST en el reactor $\left(\mathrm{MX}_{\mathrm{t}}\right)$ puede ser determinada utilizando las Ecs. 4.15 o 4.17, y permanece constante. Por ejemplo, para el agua residual cruda del ejemplo de diseño, con una edad de lodos de 20 días y temperatura de $14{ }^{\circ} \mathrm{C}, \mathrm{MX}_{\mathrm{t}}=68,162$ $\mathrm{kgSST}$. El volumen del reactor en función de la concentración de sólidos $\mathrm{X}_{\mathrm{t}}$ se puede determinar mediante la ecuación 4.20:

$\mathrm{V}_{\mathrm{p}}=\mathrm{MX}_{\mathrm{t}} / \mathrm{X}_{\mathrm{t}}=\frac{68,162}{\mathrm{X}_{\mathrm{t}}}$

$\left[\mathrm{m}^{3}\right]$

donde:

$\mathrm{X}_{\mathrm{t}} \quad$ concentración en el reactor $\left[\mathrm{kgSST} / \mathrm{m}^{3}\right]$

Para estimar el costo del rector a partir del volumen, es necesario utilizar funciones empíricas que relacionen los costos constructivos y el volumen. Este tipo de relaciones siguen la forma:

$$
\text { Costo }_{\text {Reactor }}=C_{R}\left(V_{p}\right)^{P_{R}}
$$

donde:

$C_{R}, P_{R}$ son constantes correspondientes a un diseño de reactor específico.

\subsubsection{Costo del clarificador secundario}

Basándose en la teoría del flujo (en inglés, Flux Theory), Ekama et al. (1997) demostraron que con una relación de recirculación de lodos por encima de un valor mínimo crítico, el área superficial de los clarificadores secundarios es función únicamente de la concentración de sólidos en el reactor $\left(\mathrm{X}_{\mathrm{t}}\right)$ y la capacidad de sedimentación del lodo. Si la concentración de sólidos aumenta o si la sedimentación se deteriora, el área superficial requerida por los clarificadores secundarios aumenta. Por lo tanto, mientras el tamaño del reactor biológico disminuye a medida que $X_{t}$ se incrementa, el área de los clarificadores secundarios aumenta. Por consiguiente, los costos de construcción de los clarificadores secundarios aumentan con el incremento en $\mathrm{X}_{\mathrm{t}}$.

Para determinar el área superficial de los clarificadores secundarios es necesario especificar dos parámetros, (i) la capacidad de sedimentación o sedimentabilidad del lodo y (ii) el factor de caudal pico
$\mathrm{f}_{\mathrm{q}}=\mathrm{Q}_{\max } / \mathrm{Q}_{\mathrm{p} \text {,min. }}$ La teoría de flujo unidimensional (1D) idealizado requiere definir o estimar la capacidad de sedimentación del lodo en función de los valores de $\mathrm{V}_{0}$ y $r_{\text {hin }}$ que definen la velocidad en la zona de sedimentación $\left(\mathrm{V}_{\mathrm{s}}, \mathrm{m} / \mathrm{h}\right)$ versus la concentración de sólidos $\left(\mathrm{X}_{\mathrm{t}}, \mathrm{kgSST} / \mathrm{m}^{3}\right)$ :

$$
\mathrm{V}_{\mathrm{s}}=\mathrm{V}_{0} \exp \left(-\mathrm{r}_{\text {hin }} \mathrm{X}_{\mathrm{t}}\right)
$$

Los valores para $\mathrm{V}_{0}$ y $\mathrm{r}_{\text {hin }}$ no se encuentran disponibles de forma directa, y de manera estricta deben ser determinados in situ para cada lodo activado. Sin embargo, existen diferentes fórmulas que relacionan el valor de estos parámetros con parámetros más simples que estiman la capacidad de sedimentación del lodo, incluyendo, el índice volumétrico de lodos (IVL), el índice volumétrico de lodos agitado ( $\mathrm{IVL}_{\mathrm{a}}$ ) y el índice volumétrico de lodos diluidos $\left(\mathrm{IVL}_{\mathrm{d}}\right)$ (ver Ekama et al., 1997). Estos parámetros son estudiados con mayor detalle en el Capítulo 12 del presente libro. Como se ha mencionado, existen variaciones considerables entre las diferentes relaciones, por lo cual la selección para cada planta de tratamiento de aguas residuales requiere de una estimación cuidadosa. Para este ejemplo, las relaciones desarrolladas por Ekama y Marais (1986) son:

$I V L_{a 3.5}=0.67 I V L_{d}$

$[\mathrm{ml} / \mathrm{g}](4.29)$

$V_{0} / r_{\text {hin }}=67.9 \exp \left(-0.016 I V L_{a 3.5}\right)$

$\left[\mathrm{kgSST} / \mathrm{m}^{2} \cdot \mathrm{h}\right](4.2 \mathrm{~b})$

$r_{\text {hin }}=0.88-0.393 \log \left(V_{0} / r_{\text {hin }}\right)$

$\left[\mathrm{m}^{3} / \mathrm{kgSST}\right](4.29)$

$V_{0}=\left(V_{0} / r_{\text {hin }}\right) r_{\text {hin }}$

$[\mathrm{m} / \mathrm{h}](4.2 \mathrm{~d})$

Con base en la teoría de flujo 1D, la velocidad máxima ascendente en el clarificador o sedimentador secundario $\left(\mathrm{q}_{\mathrm{i}, \mathrm{P}}\right)$, dependiente del caudal pico del efluente y está definida por:

$q_{i, p}=V_{s}$ at $X_{t}=V_{0} \exp \left(-r_{\text {hin }} X_{t}\right)$

$[\mathrm{m} / \mathrm{h}](4.30)$

donde:

qi,máx velocidad máxima ascendente en el clarificador secundario $[\mathrm{m} / \mathrm{h}]$ 
$q_{i, \max }=Q_{i, \max } / A_{C S}=$

$f_{q} Q_{i, p} / A_{C S}$

$[\mathrm{m} / \mathrm{h}](4.3 \mathrm{~b})$

Después de calibrar la teoría de flujo 1D utilizando datos de eficiencia medidos en clarificadores secundarios de plantas en operación, Ekama y Marais (2004) encontraron que la máxima carga permisible de lodos (SLR $\mathrm{kgSST} / \mathrm{m}^{2}$.h, Sludge loading rate, por sus siglas en inglés) es del orden del $80 \%$ del valor obtenido mediante la teoría de flujo 1D. Esta reducción parece ser una consecuencia de las desviaciones en las condiciones hidrodinámicas reales presentes en clarificadores secundarios comparadas con el modelo unidimensional idealizado, el cual no toma en cuenta la presencia de flujos horizontales de líquidos y sólidos, la existencia de turbulencia, cortos circuitos y corrientes de densidad (Ekama et al., 1997).

Considerando el factor de reducción del $80 \%$ $(1 / 0.80)$, el área superficial de un clarificador secundario $\left(\mathrm{A}_{\mathrm{CS}}\right)$ en función de la concentración $\mathrm{X}_{\mathrm{t}}$ es:

$$
A_{C S}=\frac{1000 f_{q} Q_{i, p} / 24}{0.8 V_{0} \exp \left(-r_{\text {hin }} X_{t}\right)}
$$

donde:

$\mathrm{Q}_{\mathrm{i}, \mathrm{p}} \quad$ caudal promedio $[\mathrm{Ml} / \mathrm{d}]$

Las relaciones entre los costos de construcción de clarificadores secundarios y el diámetro $(\phi[\mathrm{m}])$ para clarificadores circulares de una profundidad determinada toman la forma de:

$$
\text { Costo }_{\text {Clarificadbr Secundario }}=C_{C S}(\phi)^{P_{C S}}
$$

donde:

$\mathrm{C}_{\mathrm{CS}}, \mathrm{P}_{\mathrm{CS}}$ constantes correspondientes a un diseño de clarificador específico

\subsubsection{Costo total}

El costo total del sistema reactor/clarificador secundario es la suma de los costos de las unidades individuales. La Figura 4.5 muestra resultados cualitativos para el ejemplo de diseño utilizando agua residual cruda y agua residual clarificada sin tener en cuenta que el volumen del reactor y el diámetro del clarificador secundario pueden tener restricciones en cuanto a su tamaño máximo o mínimo. Para plantas a escala real, el reactor biológico y/o el clarificador secundario pueden ser reemplazados por varias unidades de igual tamaño que garantizan que las dimensiones de las unidades se encuentren dentro de los rangos establecidos.

Análisis de costos como el descrito anteriormente, generalmente indican que el rango de concentración en un reactor biológico para la generación de costos mínimos es mayor para $(i)$ aguas residuales con carga orgánica elevada $\left(\mathrm{DBO}_{5}, \mathrm{DQO}\right),(\mathrm{ii})$ edades de lodos más altas y (iii) aguas residuales crudas que para aguas clarificadas, debido a que estos tres cambios aumentan el tamaño del reactor relativo al tamaño del clarificador secundario. Sin embargo, es menor para (iv) factores de caudal pico elevados $\left(f_{q}\right)$ y $(v)$ lodos con una baja
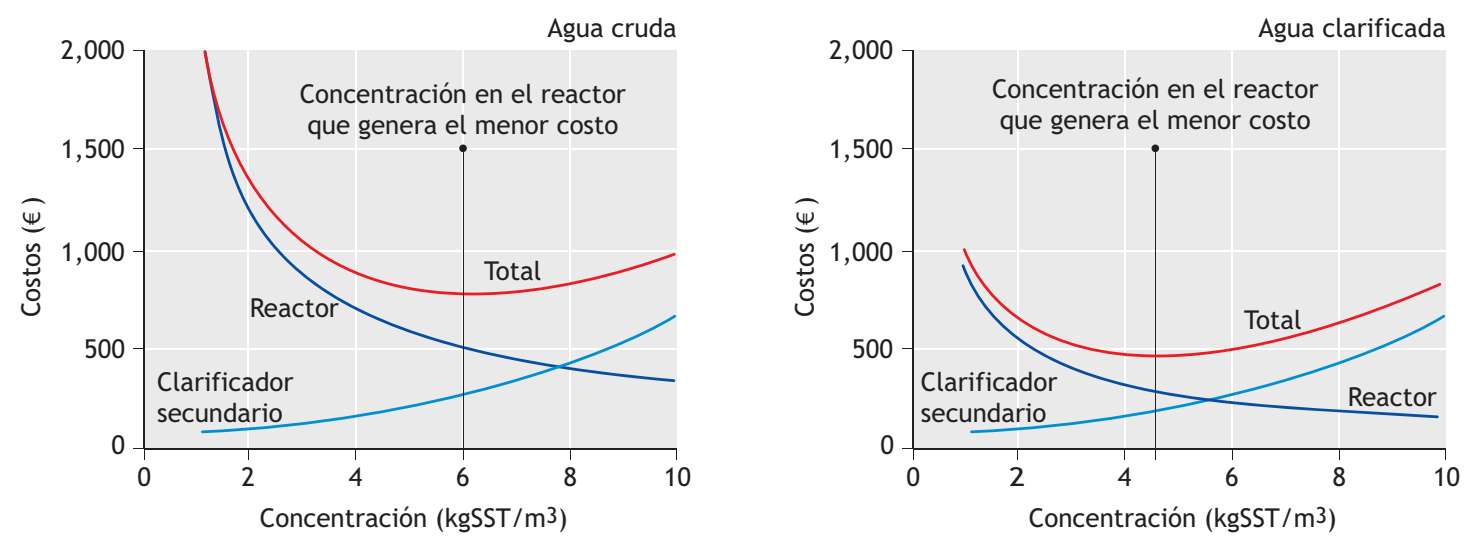

Figura 4.5 Costos del reactor, costos del clarificador secundario y costos totales para la estimación de la concentración de lodos en el reactor que genera el costo mínimo. Para el reactor y el clarificador del ejemplo de diseño, utilizando (A) el agua residual cruda y (B) agua residual clarificada 
sedimentabilidad, debido a que estos dos factores incrementan el tamaño del clarificador secundario con relación al tamaño del reactor biológico.

Por los motivos anteriores, un valor óptimo de concentración aplicable a cualquier sistema no puede especificarse. En países con aguas residuales de baja carga y plantas de tratamiento con edades bajas de lodos (por ejemplo Norteamérica), la concentración del reactor tiende a ser baja $(2,000-3,000 \mathrm{mgSST} / \mathrm{l})$ mientras que en países con aguas residuales de carga elevada y plantas de tratamiento con edades de lodos altas (por ejemplo Sudáfrica), la concentración en el reactor tiene a ser alta $(4,000-6,000 \mathrm{mgSST} / \mathrm{l})$.

\subsection{DEMANDA CARBONACEA DE OXÍGENO}

\subsubsection{Condiciones de estado estacionario (promedios diarios)}

La demanda carbonácea promedio de oxígeno por $\mathrm{kg}$ de carga de DQO en el reactor $\left(\mathrm{FO}_{\mathrm{c}} / \mathrm{FS}_{\text {tiReactor }}\right.$ ) se calcula utilizando la Ec. 4.18. Para edades de lodos mayores a 15 días, el aumento en $\mathrm{FO}_{\mathrm{c}} / \mathrm{FS}_{\text {tiReactor }}$ es pequeño con un aumento adicional en la edad de lodos tanto para aguas crudas como clarificadas. La diferencia de la $\mathrm{FO}_{\mathrm{c}} / \mathrm{FS}_{\text {tiReactor }}$ para aguas crudas y clarificadas es alrededor del 10\%, siendo mayor para el agua clarificada. Esto se debe a que en comparación con el agua residual cruda, la mayor parte de la materia orgánica total (DQO) en el agua residual clarificada es biodegradabale. Para las aguas residuales del ejemplo, con una edad de lodos de 20 días, la $\mathrm{FO}_{\mathrm{c}} / \mathrm{FS}_{\mathrm{ti} \text { Reactor }}$ es $0.604 \mathrm{kgO}_{2} / \mathrm{kgDQO}$ para agua cruda and 0.653 $\mathrm{kgO}_{2} / \mathrm{kgDQO}$ para agua clarificada.

A pesar de que la diferencia en la $\mathrm{FO}_{\mathrm{c}} / \mathrm{FS}_{\text {tiReactor }}$ entre aguas crudas y clarificadas es pequeña, la diferencia para la demanda de oxígeno por kg de DQO en la planta es grande (Figura 4.3C). Para aguas clarificadas, está dada por $0.653 \cdot(1-0.40)$ para un $40 \%$ de remoción de DQO en los clarificadores primarios. Esto resulta en un consumo de $0.38 \mathrm{kgO}_{2} / \mathrm{kgDQO}$ en la planta. Para el agua cruda la demanda permanece igual a 0.604 $\mathrm{kgO}_{2} / \mathrm{kgDQO}$ en la planta, lo que hace que la demanda de oxígeno para el agua clarificada sea $37 \%$ más baja que para el agua cruda. Claramente se puede observar que la clarificación primaria conduce a un ahorro significativo en los costos energéticos por aireación. Debido a que los clarificadores primarios remueven alrededor del 30 al 50\% de la carga de DQO en el afluente, la demanda carbonácea de oxígeno para aguas clarificadas es generalmente un 30 a 50\% más baja que para aguas residuales crudas.

La demanda carbonácea de oxígeno corresponde únicamente al oxígeno necesario para la oxidación de la materia orgánica en el afluente (DQO) y el proceso de respiración endógena asociado por parte de los OHOs. En sistemas con remoción de nitrógeno, una cantidad adicional de oxígeno es requerida para el proceso de nitrificación, el cual corresponde a la oxidación biológica del amoníaco a nitrato realizada por organismos autótrofos nitrificantes (organismos oxidantes de amonio AOO, Ammonia Oxidizing Organisms, por sus siglas en inglés). No obstante, mediante el proceso de desnitrificación, el cual corresponde a la reducción biológica del nitrato a gas nitrógeno por medio de los organismos facultativos heterótrofos, algunos de los compuestos orgánicos biodegradables son utilizados con nitrato como aceptor de electrones, para lo cual no se requiere oxígeno adicional. Por ende, el proceso de desnitrificación conduce a una reducción en la demanda de oxígeno. La demanda total de oxígeno para un sistema con remoción de nitrógeno corresponde a la suma de la demanda carbonácea y la demanda para nitrificación menos la demanda ahorrada en el proceso de desnitrificación. Los procedimientos para el cálculo de la demanda de oxígeno por nitrificación y el oxígeno ahorrado por la desnitrificación se presentan en el Capítulo 5. Las ecuaciones presentadas para el cálculo de la demanda carbonácea de oxígeno están basadas en que toda la materia orgánica biodegradable es utilizada con oxígeno como aceptor de electrones, esto es para sistemas completamente aerobios.

\subsubsection{Condiciones cíclicas (dinámicas) diarias}

Debido a la naturaleza cíclica de la carga orgánica en un reactor, la demanda carbonácea de oxígeno varía de manera concomitante durante el día. La carga de NTK en el reactor también varía a lo largo del día de una forma similar a la carga orgánica. Generalmente, las cargas de DQO y de NTK en el reactor aumentan por la mañana debido a incrementos tanto en el caudal como en la concentración de DQO y NTK llegando a valores picos alrededor del mediodía. De ahí en adelante, las cargas de DQO y NTK disminuyen alcanzando un mínimo en horas de la noche, normalmente de 2 a 4 de la madrugada, debido a una diminución en el caudal y en la concentración de DQO y NTK.

La relación entre la carga pico y promedio, y la carga pico y mínima, así como el momento del día en 
el que ocurren, va a depender del sistema urbano al cual sirve la planta de tratamiento. Factores inherentes al sistema urbano en particular incluyen el tamaño de la población, el tamaño y distribución en la cuenca y la actividad industrial en la misma. Generalmente, entre más pequeño sea un sistema, menores serán los caudales y las cargas de DQO y NTK, pero mayor será la relación entre el caudal pico y el promedio, y menor será la relación entre el caudal mínimo y el promedio. Debido a que la carga de NTK, su variación a lo largo del día y el proceso de nitrificación tienen una marcada influencia en los valores pico y promedio de la demanda total de oxígeno, en el Capítulo 5 se presentan métodos empíricos para estimar la demanda pico de oxígeno a partir de la demanda promedio para sistemas con nitrificación completamente aerobios.

En sistemas completamente aerobios con una edad de lodos mayor a 3 días y una temperatura mayor a 14 ${ }^{\circ} \mathrm{C}$, es muy probable que ocurra el proceso de nitrificación. Adicionalmente, el límite de validez del modelo de lodos activados en estado estacionario es de alrededor de 3 días, debido a que con una edad de lodos menor, no se puede garantizar la completa utilización de toda la materia orgánica biodegradable. Por estas razones, el desarrollo de una expresión empírica que relacione la demanda pico de oxígeno con la demanda promedio en sistemas completamente aerobios sin nitrificación no se puede desarrollar.

\subsection{PRODUCCIÓN DIARIA DE LODOS}

La masa de lodos producida diariamente en un sistema de lodos activados es igual a la masa de lodos activados purgados diariamente a través del caudal de purga y se denomina purga de lodos (WAS, Waste Activaded Sludge, por su sigla en inglés). De la definición de la edad de lodos (ver Ec. 4.1), la masa de lodos como SST producidos diariamente $\mathrm{FX}_{\mathrm{t}}$ está dada por el cociente entre la masa de lodos en el sistema $\mathrm{MX}_{\mathrm{t}}$ y la edad de lodos, esto es:

$F X_{t}=M X_{t} / T R S$

$[\mathrm{mgSST} / \mathrm{d}](4.33)$

Substituyendo las ecuaciones 4.12 y 4.17 por $\mathrm{MX}_{\mathrm{t}}$ y simplificando la expresión, se obtiene el lodo producido por día por mg de DQO en el reactor, esto es

$$
\begin{aligned}
& \frac{F X_{t}}{F S_{t i}}=\frac{1}{f_{i}}\left[\begin{array}{l}
\frac{\left(1-f_{S^{\prime} u s}-f_{S^{\prime} u p}\right) Y_{H v}}{\left(1+b_{H} T R S\right)} \cdot \\
\left(1+f_{H} b_{H} T R S\right)+\frac{f_{S^{\prime} u p}}{f_{c v}}
\end{array}\right] \\
& \text { [mgSST/d por } \mathrm{mgDQO} / \mathrm{d}](4.34)
\end{aligned}
$$

La Figura 4.6 muestra la masa total de lodos (SST) producida por unidad de carga en kgDQO por día en el reactor biológico contra la edad de lodos para las aguas residuales cruda y clarificada utilizadas en el ejemplo de diseño. Se puede observar que la masa de lodos producida en el sistema de lodos activados (por unidad de carga de DQO en el reactor) disminuye a medida que la edad de lodos aumenta tanto para el agua cruda como para el agua clarificada, pero la tasa de decrecimiento es despreciable para una edad de lodos mayor a 20 días. El tratamiento de agua clarificada resulta en una producción menor de lodo secundario por unidad de carga de DQO que en el tratamiento de agua cruda. Esto es debido a que la fracción particulada no biodegradable de la DQO ( $\mathrm{f}_{\mathrm{S}}$ 'up) y el contenido de materia inorgánica $\left(\mathrm{X}_{\mathrm{IOi}} / \mathrm{S}_{\mathrm{ti}}\right)$ en clarificada es considerablemente menor que en el agua residual cruda.

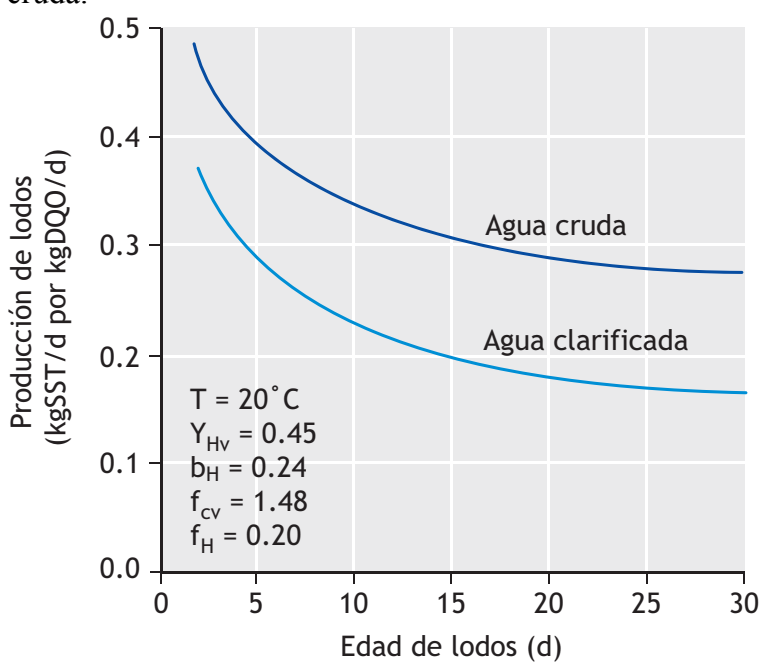

Figura 4.6 Producción diaria de lodos en kgSST/d por carga en $\mathrm{kgDQO} / \mathrm{d}$ en el reactor biológico utilizado en el ejemplo para agua residual cruda y clarificada a $14^{\circ} \mathrm{C}$

Los efectos de la temperatura en la producción de lodos son pequeños - la producción de lodos a $14^{\circ} \mathrm{C}$ es alrededor de $5 \%$ mayor que a $22^{\circ} \mathrm{C}$, una diferencia menor a la incertidumbre en la estimación de las características del agua residual fs'up y la relación $\mathrm{SSV} / \mathrm{SST}\left(\mathrm{f}_{\mathrm{i}}\right)$ del lodo si la concentración de SSI en el afluente $\left(\mathrm{X}_{\mathrm{IO}}\right)$ no es medida. 
Aunque la producción de lodos secundarios en sistemas que depuran agua clarificada es menor que cuando se trata un agua residual cruda, la masa total de lodos en un sistema para agua clarificada es mayor debido a que la producción total de lodos incluye tanto al lodo primario como al secundario; mientras que en plantas que depuran aguas residuales crudas, solamente se produce lodo secundario.

En un sistema para agua residual cruda, el lodo primario es tratado en el reactor de lodos activados. Del balance de la DQO, entre más oxígeno se utilice en el sistema, menor será la producción de lodos y menor será la fracción activa del lodo (Figura 4.3B,C). Por consiguiente, debido a que la demanda carbonácea de oxígeno es mucho mayor cuando se realiza el tratamiento de un agua cruda, la producción total de lodos es mucho menor que en un sistema que trate un agua clarificada.

Generalizando la anterior observación y tomando en cuenta la fracción activa del lodo de purga como un indicador de la materia orgánica biodegradable remanente en el lodo, existen dos enfoques a la hora de diseñar una planta de tratamiento de lodos activados (Tabla 4.4). Los enfoques u objetivos son: (i) tratar el agua residual clarificada con una baja edad de lodos (alrededor de 8 días) - lo cual resulta en un sistema de lodos activados muy pequeño con una baja demanda de oxígeno y una alta producción de lodos con un alto contenido energético, esto es con un alto contenido de materia orgánica biodegradable en el lodo primario y secundario, los cuales a su vez requieren de un tratamiento de estabilización adicional antes de su disposición final, ó, (ii) tratar el agua residual cruda a una edad de lodos alta (alrededor de 30 días) - lo cual resulta en un sistema muy grande de lodos activados con una alta demanda de oxígeno y una baja producción de lodos con un bajo contenido energético, esto es sin producción de lodo primario y con un contenido de materia orgánica remanente bajo (fracción activa baja) en el lodo secundario, el cual no requiere de una estabilización adicional antes de su disposición final.

La producción diaria de lodo primario y secundario corresponde a la masa de lodos que requiere un método de tratamiento, manejo y disposición final. El tratamiento y disposición final de los lodos de purga en sistemas de tratamiento de aguas residuales con remoción biológica de nutrientes no debe verse como un proceso independiente en el diseño de un sistema de lodos activados. De hecho, todos los procesos unitarios de la planta de tratamiento, desde el bombeo inicial del agua cruda, hasta la disposición final de los lodos, deben verse como parte de un sistema integrado, donde el diseño de una unidad depende las unidades que la preceden, y a su vez influye y puede afectar el diseño de las unidades que se encuentran a continuación.

\subsection{DISEÑO Y CONTROL DEL SISTEMA}

El parámetro fundamental en el diseño y control de un sistema de lodos activados es la edad de lodos (o tiempo de retención de sólidos), el cual dicta la masa de lodos a ser purgada del sistema diariamente. La edad de lodos puede y debe reemplazar completamente el uso de la relación alimento-microorganismos $(\mathrm{F} / \mathrm{M}$, por sus siglas en inglés Food-to-Microorganisms ratio, en $\mathrm{kg}$ de carga de DBO o DQO por día por kg de SSLM SSVLM en el reactor) también expresada de forma equivalente como el factor de carga, como parámetros de referencia y control. Esto es particularmente necesario en sistemas donde se requiere llevar a cabo la nitrificación. La edad de lodos puedes fijarse mediante un procedimiento de control simple, siempre y cuando el sistema haya sido diseñado de forma adecuada. Este procedimiento de control es además operacionalmente más práctico y confiable que los métodos de control basados en la relación F/M o factor de carga, las cuales buscan controlar la masa de lodos en el sistema ajustando la concentración de los SSLM en el reactor a un valor específico.

\subsubsection{Sistema controlado por la masa de lodos}

El procedimiento de control más comúnmente utilizado en el sistema de lodos activados implica mantener la concentración de SSLM a un valor determinado dentro del reactor. En el mejor de los casos, esta concentración se específica en el diseño, y en el peor de los casos, la concentración se establece a partir de la experiencia del comportamiento operacional de la planta. Para este último caso la concentración usualmente corresponde a la que puede ser mantenida en el sistema gracias a los clarificadores secundarios. Este enfoque solo permite el control de la masa de lodos en el sistema, pero no permite el control de la edad de lodos. De hecho, en algunas situaciones, el parámetro controlado no es la masa de lodos en el reactor a través de la medición directa de la concentración de lodos, sino a través del volumen sedimentado después de 30 minutos en un recipiente cilíndrico de 1 litro. $\mathrm{Si}$ el volumen sedimentado es mayor que un cierto valor, por ejemplo 
$450 \mathrm{ml} / 1$, entonces el lodo se purga hasta que se obtenga nuevamente este valor. Esta metodología fue desarrollada con el fin de obviar la necesidad de medir directamente la concentración de lodos en el reactor, y de esta forma, la concentración en el reactor varía de acuerdo a la sedimentabilidad del lodo medida a través del IVL.

Antes de que la nitrificación se convirtiera en un requerimiento en los sistemas de tratamiento, este enfoque garantizaba que los lodos fueran retenidos en el sistema y al mismo tiempo mantenía una concentración baja de sólidos suspendidos en el efluente. No obstante, con este método no se tiene control sobre la relación $\mathrm{F} / \mathrm{M}$, la masa de lodos, la concentración de lodos en el reactor o la edad de lodos, lo cual presenta un panorama inaceptable cuando se requiere que exista nitrificación en el sistema. Si bien la nitrificación es un proceso simple a tener en cuenta en el diseño de una planta de tratamiento (garantizando una edad de lodos lo suficientemente larga y una provisión suficiente de oxígeno), es un proceso que impone un régimen de control completamente diferente en la operación del sistema, donde se requiere que la edad de lodos se mantenga en un valor fijo.

Para poder mantener la relación $\mathrm{F} / \mathrm{M}$ o el factor de carga dentro de los límites deseados, en un sistema donde son utilizados como parámetros de control, es necesario medir no solamente la concentración del reactor de forma regular, sino además también la carga diaria de $\mathrm{DBO}_{5}$ o DQO. Esto implica la ejecución de muestreos y pruebas de laboratorio en el afluente para medir la concentración de la $\mathrm{DBO}_{5}$ o de la $\mathrm{DQO}$, junto con la medición de los patrones de variación de flujo diarios y así poder determinar la carga diaria de $\mathrm{DBO}_{5}$ o DQO. Para poder controlar la edad de lodos, es necesario hacer mediciones de la concentración de SSLM y de la masa de lodos purgados diariamente. El lodo de purga es usualmente extraído de la línea de recirculación del clarificador secundario para beneficiarse del lodo ya concentrado. Sin embargo, la concentración de lodos en la línea de recirculación varía de forma notoria a lo largo del día con los cambios cíclicos de flujo que llega a la planta de tratamiento (Figuras 4.7 y 4.8 ).

Por esta razón, para conocer la masa de lodos purgada a través de la línea de recirculación, es necesario medir la concentración en la línea, el caudal de purga y la duración de la misma cada vez que se realiza una purga. Para conocer el factor de carga o la edad de lodos, se requieren numerosos muestreos y mediciones para conocer las concentraciones en el afluente y/o en el reactor y en la línea de recirculación. Si bien este procedimiento es manejable para plantas de gran tamaño, donde la capacidad técnica es suficiente y adecuada, en plantas pequeñas el valor de la edad de lodos y del factor de carga son usualmente desconocidos. Como consecuencia, el proceso de nitrificación ocurre de forma esporádica, parcial, o inclusive puede llegar a detenerse durante periodos en los que el lodo tiene una baja sedimentabilidad, porque esto puede resultar en una purga excesiva de lodos con el objetivo práctico (según el operador) de reducir la acumulación de lodos en el sedimentador secundario lo que conduce a edades de lodos bajas.

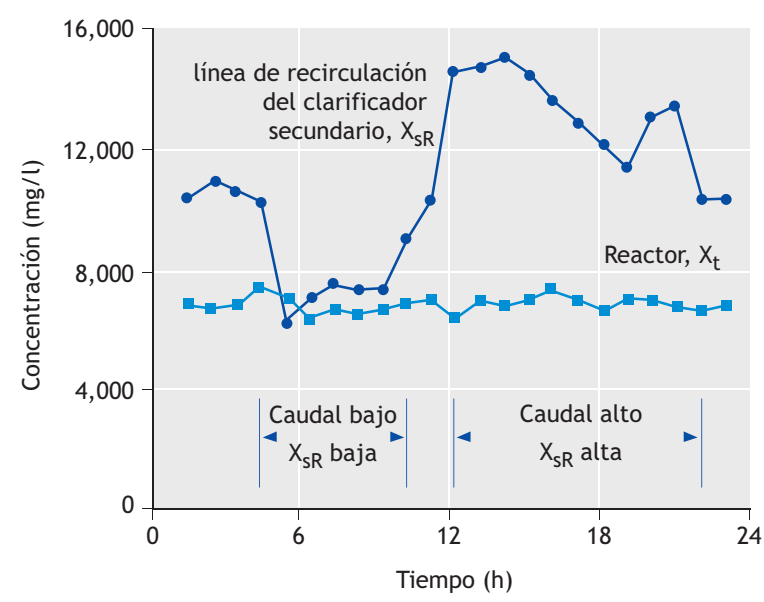

Figura 4.7 Datos experimentales de una planta de tratamiento de aguas residuales a escala real ilustrando como a lo largo del día la concentración dentro del reactor biológico permanece virtualmente constante a pesar de las grandes variaciones de concentración en la línea de recirculación del clarificador secundario (adaptado de Nicholls, 1975)

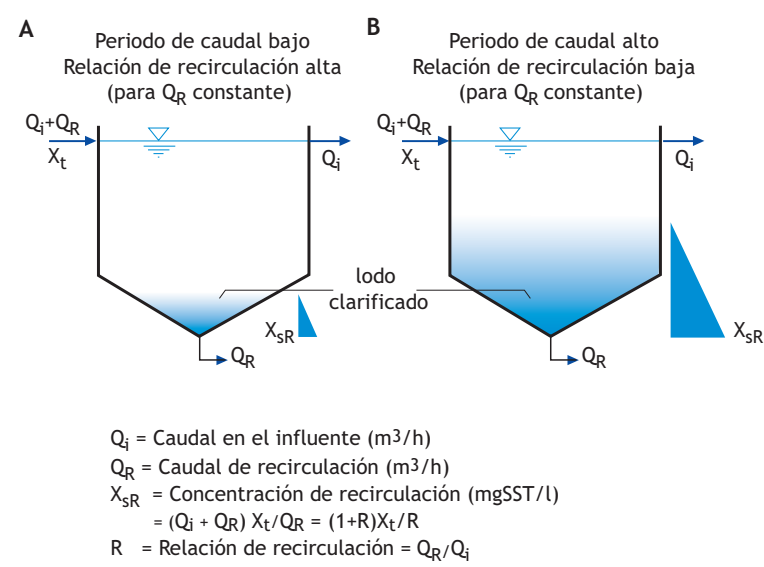

Figura 4.8 Impacto en la concentración de lodos $\left(\mathrm{X}_{\mathrm{SR}}\right)$ y en la relación de recirculación en un clarificador secundario, manteniendo un caudal de recirculación constante $\left(Q_{R}\right)$ para (A) periodos de caudal bajo y (B) periodos de caudal alto 
Aun en la situación en que la concentración es monitoreada y controlada con equipos automatizados, tales como la medición en línea de la concentración en el reactor y la purga automática de lodos, no es posible garantizar el control de la edad de lodos. Utilizando un control de la concentración para mantener un valor determinado a lo largo del año y con una carga orgánica estable en la planta de tratamiento (asumiendo que no hay más desarrollos urbanos), la edad de lodos disminuye durante el invierno porque la producción de lodos por $\mathrm{kg}$ de carga de DQO aumenta con una disminución en la temperatura, como consecuencia de una menor tasa de respiración endógena. Aunque esta disminución es relativamente pequeña, disminuir la edad de lodos es precisamente lo contrario que debería hacerse en época invernal si es que se desea que el sistema pueda mantener una concentración baja de amoníaco en el efluente. Esto tiene particular relevancia en plantas operadas a edades de lodos muy cercanas al valor mínimo requerido para la nitrificación (Capítulo 5), lo cual es una práctica común en países desarrollados donde se trata de maximizar la capacidad de la planta por las limitaciones en el espacio disponible para la inclusión de extensiones. Si se aplica un control sobre la concentración del reactor y adicionalmente la carga orgánica aumenta progresivamente, lo cual es una situación común en países con economías emergentes donde el desarrollo urbano está limitado por la capacidad de la planta, la edad de lodos disminuye de forma progresiva con el paso del tiempo. Esta situación llevará de forma inevitable a que en un día frío de invierno, el proceso de nitrificación se detenga por completo.

En plantas de tratamiento donde la nitrificación es un requisito, no solo se debe controlar la edad de lodos sino que además los clarificadores secundarios no pueden continuar llevando a cabo el doble rol de clarificadores y espesadores del lodo de purga. Para poder obtener un lodo de purga concentrado, la relación del caudal de recirculación debe ser bajo $(<0.25: 1)$, lo que resulta en tiempos de retención de lodos elevados en los clarificadores secundario (Figura 4.8).

Los elevados tiempos de retención de lodos estimulan a su vez el proceso de desnitrificación en los clarificadores secundarios produciendo lodos flotantes en la superficie de los clarificadores, especialmente en verano cuando la temperatura del agua residual es alta $\left(>20^{\circ} \mathrm{C}\right.$ ). Inclusive en regiones tropicales (donde se encuentran la mayoría de las economías emergentes) puede presentarse la situación de que un sistema de lodos activados no pueda ser operado sin que ocurra la nitrificación, inclusive a edades de lodo muy bajas. Por este motivo, diversos problemas de lodos flotantes debido a la desnitrificación pueden presentarse en sistemas donde la nitrificación no es requerida. Este es el caso de una planta de tratamiento de aguas residuales en Brasilia (Figura 4.9), la cual operaba con una relación de recirculación baja $(0.25: 1)$ y donde el proceso de nitrificación ocurría inclusive con una edad de lodos de tan solo 3 días, sufriendo de problemas de lodo flotante en repetidas ocasiones. Si la edad de lodos era reducida para detener el proceso de nitrificación (con TRS $<3$ días), la remoción de DQO se deterioraba considerablemente. Si la nitrificación ocurre de manera inevitable, es necesario proveer al reactor de zonas apropiadas anóxicas para garantizar la desnitrificación, y adicionalmente aumentar la relación de recirculación de lodos $(\sim 1: 1)$ para minimizar la presencia de lodo flotante.

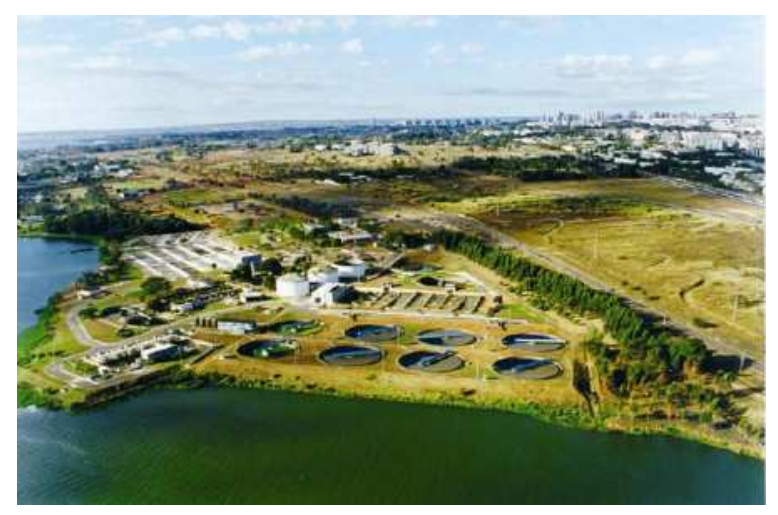

Figura 4.9 Una de las dos plantas de tratamiento de aguas residuales de Brasilia, Brasil (foto: R. Brummer)

Una vez que la nitrificación puede ocurrir, ya sea de forma intencional como un requerimiento de diseño o inevitable por las circunstancias del sistema, es claro que los clarificadores secundarios no pueden usarse para concentrar el lodo de purga. Si una unidad adicional es requerida para este proceso (concentrando el lodo del reactor o del clarificador secundario), es preferible entonces realizar la purga de lodos directamente del reactor biológico y así aprovechar las ventajas que ofrece el control hidráulico de la edad de lodos. El control hidráulico es simple, requiere de un número reducido de pruebas de laboratorio y permite el control casi exacto de la edad de lodos, lo que garantiza una nitrificación estable a lo largo del año. Este mecanismo de control se recomienda para sistemas de lodos activados donde se requiere llevar a cabo la 
nitrificación, inclusive si se cuenta con sistemas sofisticados para el control de la concentración de lodos en el reactor.

\subsubsection{Sistema controlado por la edad de lodos (Control Hidráulico)}

El control hidráulico de lodos fue propuesto e inicialmente e implementado de forma generalizada por Garret en 1958, y se basa en un método de "aireación modificada de aguas residuales" implementado por Setter et al. (1945). Si en un sistema se específica una edad de lodos de 10 días, una décima parte $(1 / 10)$ del volumen del reactor debe ser purgada a diario; de forma análoga si se requiere una edad de lodos de 20 días, una veinteava parte $(1 / 20)$ del volumen debe ser purgada diariamente, esto es $\mathrm{Q}_{\mathrm{w}}=\mathrm{V}_{\mathrm{p}} / \mathrm{TRS}$ (Ec. 4.1). Para plantas con niveles bajos de soporte técnico, se pueden instalar lechos de secado (de desaguado) o un clarificador adicional independiente a los clarificadores secundarios donde el agua de purga sea descargada. Para plantas con un mayor nivel de soporte técnico se recomienda el uso de una unidad de flotación por aire disuelto (DAF, por sus siglas en inglés Dissolved Air Flotation) (Bratby, 1978), la cual a su vez minimiza la liberación de fósforo en lodos de sistemas con remoción biológica de fósforo (Pitman, 1999). El sobrenadante se regresa al reactor biológico y el lodo concentrado se bombea a las unidades de tratamiento y disposición final de lodos de la planta. Este procedimiento permite establecer de forma bastante acertada la edad de lodos requerida debido a que la concentración del licor mezclado no varía de forma significativa durante el día (Figura 4.7).

Un aspecto importante del control hidráulico de la edad de lodos es que independiente del caudal tratado en la planta, mientras se siga purgando diariamente una fracción fija del volumen del reactor, la edad de lodos permanecerá estable. Si la carga de DQO por día que recibe la planta permanece constante, la concentración de los lodos permanecerá constante de forma automática. Por otra parte, si la carga de DQO aumenta, la concentración de los lodos aumentará automáticamente preservando la edad de lodos establecida inicialmente. De esta forma, monitoreando la concentración en el reactor y sus cambios para una edad de lodos fija, se puede conseguir una medida indirecta de los cambios a largo plazo en la carga de DQO que llega a la planta. Con el paso del tiempo la concentración en el reactor puede incrementarse indicando que la carga orgánica recibida en la planta está aumentando. El control hidráulico de la edad de lodos resulta muy fácil para el operador de la planta, ya que solo es necesario asegurarse que las canaletas y tuberías permanezcan libres de obstrucciones y conserven el caudal establecido. Bajo estas condiciones la concentración de sólidos del licor mezclado ni siquiera tiene que ser medida con una alta periodicidad.

El procedimiento de control hidráulico permite el ajuste de la edad de lodos simplemente cambiando el volumen de lodos purgados diariamente. Si por ejemplo la edad de lodos se reduce de 25 a 20 días, el efecto completo de los cambios se hará aparente solo después de que transcurra un tiempo de alrededor de la mitad de la nueva edad de lodos aplicada (es de decir, después de alrededor del 10 días). Gracias a esto, la biomasa tiene la oportunidad de adaptarse de forma gradual a los cambios en las relaciones F/M y factores de carga.

El control hidráulico de la edad de lodos es de particular relevancia en plantas de tratamiento con edades de lodos superiores a 5 días debido a que para estas plantas, la masa de lodos en los clarificadores secundarios corresponde a una fracción relativamente pequeña de la masa total del sistema. Con una edad de lodos inferior a 5 días la masa de lodos en los clarificadores secundarios puede volverse apreciable con respecto a la masa total del sistema, especialmente cuando la sedimentabilidad del lodo es baja (IVLD $>150$ $\mathrm{ml} / \mathrm{g}$ ). Cuando la masa de lodos en los clarificadores secundarios es apreciable, el control hidráulico debe tener esto en cuenta y la eficacia del método va a estar ligada a la ejecución de pruebas de laboratorio adicionales.

La aplicación del control hidráulico de la edad de lodos aumenta la responsabilidad que recae sobre el diseñador y la disminuye sobre el operario de la planta, quien muchas veces debe recurrir a su ingenio para operar los procesos biológicos de una manera forzada e improvisada dentro de las limitaciones del diseño, para así poder obtener la mejor calidad en el efluente posible. Se vuelve entonces esencial que el diseñador calcule de la forma más exacta la masa de lodos y así proporcionar un volumen suficiente al reactor biológico bajo las cargas orgánicas de diseño y de esta forma permitir que se obtenga la concentración de lodos en el reactor a la edad de lodos de diseño o deseada.

Adicionalmente, el área superficial de los clarificadores secundarios, la relación de recirculación de lodos y la capacidad de aireación deben 
dimensionarse acorde a las características particulares del agua residual y la edad de lodos definidas para el sistema. Si estos aspectos se toman en cuenta de forma adecuada, el control hidráulico de la edad de lodos de la planta se simplifica, cumpliendo con los requerimientos de sólidos y pruebas del IVL.

El control hidráulico de la edad de lodos hace que parámetros como el factor de carga y la relación $\mathrm{F} / \mathrm{M}$ sean redundantes y a la vez introduce una actitud completamente diferente hacia el control del sistema de lodos activados. Este enfoque es eminentemente práctico y permite establecer la edad de lodos deseada para garantizar nitrificación a lo largo de todo el año. Cuando la nitrificación es indispensable, el control de la edad de lodos se hace necesario, y la forma más fácil y práctica de hacerlo es a través del control hidráulico. Por otra parte, cuando se utiliza el control hidráulico, el tipo de fallas que se presentan en la operación del sistema son completamente diferentes a los problemas que se presentan con el control de sólidos. Con el control de la masa de sólidos la planta falla debido a la ausencia de nitrificación y el aumento de la concentración de amoníaco en el efluente, el cual es un componente disuelto, no visible y difícil de remover por otros medios. Con el control de la edad de lodos la planta falla de forma más evidente, presentando lodos sobre los vertederos del efluente de los clarificadores secundarios. Esto hace que en plantas de tratamiento con niveles bajos de capacidad técnica sea más probable la toma de acciones correctivas.

\subsection{SELECCIÓN DE LA EDAD DE LODOS}

La selección de la edad de lodos es la decisión fundamental más importante en el diseño de un sistema de lodos activados. La elección de la edad de lodos para una planta depende de varios factores, algunos de los cuales se mencionan en la Tabla 4.5, tales como la estabilidad del sistema, la sedimentabilidad del lodo, la conveniencia o no de descargar los lodos de purga directamente en lechos de secado, y lo más importante de todo, la calidad requerida en el efluente, estos es, la remoción de la carga orgánica únicamente, la necesidad de nitrificación, o de remover nitrógeno y fósforo. Varios de estos factores ya se han discutido anteriormente y no serán repetidos. A continuación solo se incluirán algunos comentarios adicionales sobre la Tabla 4.5.

\subsubsection{Edad de lodos baja (1 a 5 días)}

4.11.1.1 Plantas convencionales

Este tipo de plantas son operadas de un modo convencional, esto es usando una configuración en flujo pistón, pero también incluye sistemas modificados como de estabilización por contacto, aireación por pasos, alimentación por pasos entre otras. Plantas con edades de lodo bajas han sido ampliamente utilizadas en Europa y Norteamérica antes de que la remoción de nitrógeno (y fósforo) se convirtiera en un requerimiento adicional. Su objetivo principal es la remoción de la carga orgánica (DQO), para la cual una edad de lodos entre 1 y 3 días es suficiente. $\mathrm{Su}$ capacidad de remoción oscila comúnmente entre 75 y $90 \%$ y está sujeta a las características del agua residual, la operación de la planta en cuestión (particularmente el manejo de la transferencia del lodo entre el reactor y los clarificadores secundarios), y la eficiencia de los clarificadores secundarios. Debido a que la actividad predadora de los protozoos sobre las bacterias que nadan libremente está limitada por edades de lodos bajas, el componente no sedimentable del lodo activado floculento es alto, lo que causa turbidez y niveles altos de DQO en el efluente (Chao and Keinath, 1979; Parker et al., 1971).

La Tabla 4.5 asume que plantas operando con una edad de lodos baja no nitrifican en condiciones normales. Esto es cierto para regiones ubicadas en latitudes elevadas con climas templados donde la temperatura del agua residual es generalmente menor a $20^{\circ} \mathrm{C}$. Sin embargo, en regiones de baja latitud y tropicales donde la temperatura del agua residual puede exceder 25 y $30^{\circ} \mathrm{C}$, los sistemas que operan a una edad de lodos baja presentan procesos de nitrificación, de hecho, sería difícil impedir que ocurran. Bajo estas condiciones, lo mejor es aceptar la nitrificación como un proceso inevitable y diseñar el sistema considerando el desarrollo de este proceso. Adicionalmente sería ventajoso incluir una zona anóxica primaria (con una fracción de masa anóxica entre $\sim 15-20 \%$, ver Capítulo $5)$ en el sistema con el fin de desnitrificar una porción considerable del nitrato generado. Aun cuando el sistema no requiera la remoción de nitrógeno, la inclusión de la desnitrificación aumenta la edad mínima requerida de lodos para alcanzar la nitrificación, reduce la demanda de oxígeno, recupera alcalinidad y reduce el riesgo de flotación de lodos y concentraciones altas de DQO en el efluente debido a la desnitrificación (no deseada) en el fondo de los clarificadores secundarios. 
Tabla 4.5 Algunas consideraciones a tener en cuenta en la selección de la edad de lodos en un sistema de lodos activados

\begin{tabular}{|c|c|c|c|}
\hline Edad de lodos & Baja (1 a 5 días) & Intermedia (10 a 15 días) & Alta (>20 días) \\
\hline Tipo & $\begin{array}{l}\text { Alta tasa, alimentación } \\
\text { por pasos, } \\
\text { Lagunas de aireación, } \\
\text { Estabilización por } \\
\text { contacto } \\
\text { Sistemas con uso de } \\
\text { oxígeno puro }\end{array}$ & $\begin{array}{l}\text { Similar a los sistemas de alta tasa } \\
\text { pero incluyendo nitrificación y } \\
\text { algunas veces desnitrificación. } \\
\text { Sistemas con remoción biológica } \\
\text { de nutrientes }\end{array}$ & $\begin{array}{l}\text { Aireación extendida } \\
\text { Zanjas de oxidación de múltiples } \\
\text { canales - Orbal }{ }^{\circledR} \\
\text { Carousel } \\
\text { Sistemas con remoción biológica } \\
\text { de nutrientes }\end{array}$ \\
\hline Objetivos & $\begin{array}{l}\text { Remoción de la DQO } \\
\text { únicamente }\end{array}$ & $\begin{array}{l}\text { Remoción de la DQO } \\
\text { Nitrificación } \\
\text { Remoción biológica de } \mathrm{N} \text { y/o } \\
\text { Remoción biológica de } \mathrm{P}\end{array}$ & $\begin{array}{l}\text { Remoción de la DQO } \\
\text { Remoción biológica de } \mathrm{N} \\
\text { Remoción biológica de } \mathrm{P}\end{array}$ \\
\hline $\begin{array}{l}\text { Calidad del } \\
\text { efluente }\end{array}$ & $\begin{array}{l}\text { DQO baja } \\
\text { Amoniaco alto } \\
\text { Nitratos altos }\end{array}$ & $\begin{array}{l}\text { DQO baja } \\
\text { Amoniaco bajo } \\
\text { Nitratos bajos } \\
\text { Fosfatos altos/bajos } \\
\text { Relativamente estable }\end{array}$ & $\begin{array}{l}\text { DQO baja } \\
\text { Amoniaco bajo } \\
\text { Nitratos bajos } \\
\text { Fosfatos bajos } \\
\text { Usualmente estable }\end{array}$ \\
\hline $\begin{array}{l}\text { Clarificación } \\
\text { primaria }\end{array}$ & Incluida generalmente & Incluida usualmente & Excluida usualmente \\
\hline $\begin{array}{l}\text { Calidad de lodos } \\
\text { activados }\end{array}$ & $\begin{array}{l}\text { Producción alta de lodos } \\
\text { Muy activos } \\
\text { Requieren estabilización }\end{array}$ & $\begin{array}{l}\text { Producción intermedia de lodos } \\
\text { Activos } \\
\text { Requieren estabilización }\end{array}$ & $\begin{array}{l}\text { Producción baja de lodos } \\
\text { Inactivos } \\
\text { No requieren estabilización }\end{array}$ \\
\hline $\begin{array}{l}\text { Demanda de } \\
\text { oxígeno }\end{array}$ & Muy baja & Alta debido a la nitrificación & $\begin{array}{l}\text { Muy alta debido a la nitrificación y } \\
\text { a la edad de lodos altas }\end{array}$ \\
\hline $\begin{array}{l}\text { Volumen del } \\
\text { reactor }\end{array}$ & Muy pequeño & Mediano a grande & Muy grande \\
\hline $\begin{array}{l}\text { Sedimentabilidad } \\
\text { del lodo }\end{array}$ & $\begin{array}{l}\text { Generalmente buena, } \\
\text { pero con presencia de } \\
\text { lodo filamentoso (como } \\
\text { S. natans, } 1701 \text {, } \\
\text { Thiothrix posiblemente) } \\
\text { debido a relaciones F/M } \\
\text { altas. }\end{array}$ & $\begin{array}{l}\text { Buena con una edad de lodos corta } \\
\text { y fracción de masa aerobia alta, } \\
\text { pero generalmente pobre debido a } \\
\text { la aparición de lodo filamentoso } \\
\text { (M. parvicella) debido a } \\
\text { relaciones F/M bajas. }\end{array}$ & $\begin{array}{l}\text { Puede ser buena con una fracción } \\
\text { de masa aerobia alta, pero } \\
\text { generalmente pobre debido a la } \\
\text { aparición de lodo filamentoso }(M . \\
\text { parvicella) debido a relaciones } \mathrm{F} / \mathrm{M} \\
\text { bajas. }\end{array}$ \\
\hline Operación & $\begin{array}{l}\text { Muy compleja debido a } \\
\text { las variaciones del } \\
\text { sistema de lodos } \\
\text { activados y los } \\
\text { requerimientos de } \\
\text { tratamiento de lodos } \\
\text { primarios y secundarios }\end{array}$ & $\begin{array}{l}\text { Muy compleja con remoción } \\
\text { biológica de nutrientes y los } \\
\text { requerimientos de tratamiento de } \\
\text { lodos primarios y secundarios }\end{array}$ & $\begin{array}{l}\text { Simple si no incluye tratamiento de } \\
\text { lodos primarios y secundarios, pero } \\
\text { complejo si se incluye remoción } \\
\text { biológica de nutrientes }\end{array}$ \\
\hline Ventajas & $\begin{array}{l}\text { Costos de capital bajos } \\
\text { Autosuficiente } \\
\text { energéticamente si } \\
\text { incluye digestión } \\
\text { anaerobia }\end{array}$ & $\begin{array}{l}\text { Buena remoción de } \mathrm{N}(\mathrm{y} \mathrm{P}) \text { a un } \\
\text { costo relativamente bajo. }\end{array}$ & $\begin{array}{l}\text { Buena remoción de } \mathrm{N}(\mathrm{y} \mathrm{P}) \\
\text { Sin producción de lodo primario y } \\
\text { con producción de lodo secundario } \\
\text { estable } \\
\text { Costos bajos para el manejo de } \\
\text { lodos }\end{array}$ \\
\hline Desventajas & $\begin{array}{l}\text { costos operativos altos, } \\
\text { calidad variable en el } \\
\text { efluente }\end{array}$ & $\begin{array}{l}\text { Sistema complejo y costos } \\
\text { elevados para el manejo de lodos }\end{array}$ & $\begin{array}{l}\text { Reactores de gran tamaño, alta } \\
\text { demanda de oxígeno, altos costos } \\
\text { de inversión inicial }\end{array}$ \\
\hline
\end{tabular}


La remoción biológica de fósforo puede ocurrir a una edad baja de lodos de entre 3 y 5 días - los PAOs son organismos heterótrofos con una tasa de crecimiento relativamente alta. Ante la ausencia de nitrificación, una zona no aireada se convertiría en unazona anaerobia (esto es sin presencia ni entrada de oxígeno o nitratos) y la remoción biológica del fósforo sería posible contando con la presencia en el afluente de materia orgánica rápidamente biodegradable y ácidos grasos de cadena corta.

El sistema Phoredox desarrollado por Barnard (1976) se basa originalmente en el uso de dos reactores, uno anaerobio y uno aerobio. La edad de lodos mínima para la remoción biológica de fósforo depende de la temperatura, aumentando a medida que la temperatura disminuye y está alrededor de 3 a 5 días de 14 a $20^{\circ} \mathrm{C}$ (Mamais et al., 1992). A esta temperatura, la edad de lodo mínima para nitrificación es menor que la requerida para la EBPR, de tal forma que la nitrificación no se lleva a cabo eliminando los efectos adversos que el nitrato tiene sobre el sistema con remoción (biológica) de fósforo. No obstante, en climas más cálidos la edad de lodos mínima para alcanzar nitrificación y EBPR es similar por lo que se debe garantizar una recirculación de nitrato al reactor anaerobio con la inclusión de zonas anóxicas adicionales, indispensables para el correcto funcionamiento de la remoción de fósforo (Burke et al. 1986). Si no se requiere remover fósforo biológicamente, la nitrificación modifica al sistema de dos reactores (no aireado-aireado) de un sistema de remoción de fósforo a un sistema de remoción de nitrógeno.

\subsubsection{Lagunas aireadas}

Las lagunas de aireación, diferentes de las lagunas de oxidación donde la oxigenación es suministrada por algas, son esencialmente sistemas de lodos activados de alta tasa ya que la demanda de oxígeno es completamente suministrada por aireadores. Existen dos tipos principales de lagunas aireadas, con biomasa en suspensión y facultativas. En las lagunas aireadas con biomasa en suspensión los aireadores aportan la energía suficiente por unidad de volumen para mantener el lodo en suspensión. En las lagunas facultativas el aporte de energía por parte de los aireadores es insuficiente y los sólidos sedimentan y se acumulan al fondo de la laguna. Los sólidos biodegradables presentes en la capa de lodo sedimentado se degradan anaeróbicamente, como sucede en las lagunas de oxidación.
La cinética de las lagunas aireadas con biomasa en suspensión se comporta como la de los sistemas de lodos activados de flujo directo y pueden ser modeladas como tales. El tiempo de retención hidráulico nominal y de retención de sólidos es el mismo, y los caudales de purga $\left(Q_{\mathrm{w}}\right)$ y efluente $\left(\mathrm{Q}_{\mathrm{e}}\right)$ son los mismos e iguales al caudal en el afluente $\left(\mathrm{Q}_{\mathrm{i}}\right)$. Por ende, el volumen de las lagunas aireadas por unidad carga de DQO es muy grande comparado con los sistemas convencionales con edades de lodos bajas, en los cuales el tiempo de retención hidráulica es aproximadamente 20 veces más bajo que la edad de lodos.

El efluente de una laguna de biomasa suspendida tiene la misma composición que el licor mezclado dentro de la laguna. La DQO removida del sistema como demanda de oxígeno es relativamente pequeña y por lo tanto la concentración de DQO en el efluente no es apropiada para descargar directamente en aguas superficiales (aguas naturales). De hecho, el principal objetivo de todas las plantas de tratamiento con edades de lodos bajas es la de actuar como floculadores asistidos biológicamente, los cuales transforman biológicamente la materia orgánica biodegradable soluble en el afluente en una masa de microorganismos sedimentables que a su vez permiten atrapar la materia orgánica particulada (biodegradable y no biodegradable) formando así un lodo que sedimente y permita una efectiva separación de los sólidos de la fase líquida. Mientras que en las plantas convencionales el lodo de purga es transferido al lugar de tratamiento y disposición final de lodos, en los sistemas de lagunas aireadas el efluente pasa a una segunda laguna, esto es a una laguna de oxidación o a una laguna aireada facultativa, donde el material particulado puede sedimentar rápidamente al fondo de la laguna y producir así un efluente relativamente libre de sólidos y con una baja concentración de DQO. El lodo que permanece en el fondo de la laguna se estabiliza de forma anaerobia.

Las lagunas aireadas se utilizan principalmente para el tratamiento de aguas residuales industriales de baja tecnología, donde las cargas orgánicas son altas y varían estacionalmente, y donde adicionalmente no se requiere la nitrificación. Sin embargo, el tratamiento de estas aguas en diferentes sistemas de digestión anaerobia se está convirtiendo en una práctica cada vez más común debido a los beneficios que se obtienen, como principalmente una mejor calidad del efluente, la posibilidad de recuperar energía y la reducción de la emisión de gases de invernadero. 


\subsubsection{Edad de lodos intermedia (10 a 15 días)}

En sistemas de lodos activados donde los estándares de calidad requieren bajas concentraciones de amoniaco libre y salino en el efluente, la edad de lodos va a estar gobernada por la nitrificación. Este proceso, que varía dependiendo de la temperatura, requiere de edades de lodo de 5 a 8 veces más grandes que para los procesos de remoción únicamente de materia orgánica (DQO). En zonas de clima templado donde la temperatura del agua residual puede descender de $14^{\circ} \mathrm{C}$, es muy probable que la edad de lodos no pueda ser menor de 10 ó 15 días, tomando en consideración la inclusión de zonas no aireadas adicionales para la desnitrificación (y EBPR). En este rango de edad de lodos, la concentración de DQO en el efluente deja de jugar un papel preponderante en el diseño. Para edades de lodo mayores a aproximadamente 4 días, la depredación de las bacterias por parte de los protozoos es elevada y las propiedades floculantes del lodo son buenas lo que permite una baja dispersión de las partículas. También es cierto que virtualmente toda la materia orgánica biodegradable y soluble es consumida y degradada, resultando en concentraciones de DQO (o DBO) constantes que se aproximan al valor alcanzable más bajo posible, es decir al valor de la concentración de DQO soluble no biodegradable. La concentración de amoníaco en el efluente también juega un papel menor en el diseño debido a que el proceso de nitrificación tiene una cinética tal que permite que una vez iniciada y con un suministro suficiente de oxígeno, llegue prácticamente a completarse (alcanzando una transformación completa de amoniaco a nitrato). Aun cuando los estándares de calidad requieran una concentración, de por ejemplo $<10 \operatorname{mgFSA}-\mathrm{N} / \mathrm{l}$, la concentración probable esperada en el efluente no será mayor que 2 o $4 \mathrm{mgN} / 1$ una vez que el proceso de nitrificación se lleve a cabo. Consecuentemente, la edad de lodos va estar fijada por los requerimientos de nitrificación y calidad en el efluente. El método de cálculo de la edad de lodos para lograr la nitrificación se describe en el Capítulo 5 Sección 5.1.7. Una vez que ha sido seleccionada una edad de lodos con un valor un $25 \%$ más alto que el mínimo requerido, la concentración de amoniaco libre y salino en el efluente se ve más afectado por las condiciones operativas del sistema que por el proceso de nitrificación en sí mismo. Esto incluye limitaciones en el suministro de oxígeno, variaciones en la carga de amoniaco en el afluente, pérdida no controlada de lodo y cambios en el $\mathrm{pH}$ del licor mezclado.

En aguas residuales con una alcalinidad baja, la nitrificación puede causar reducciones importantes en el $\mathrm{pH}$ del efluente, a menudo llegando a valores tan bajos como 5. Esto no solo causa problemas en el proceso de nitrificación en sí, pudiendo incumplir con las concentraciones máximas permitidas, sino que además produce efluentes agresivos los cuales pueden causar un daño considerable en superficies de concreto. Para reducir estos problemas y aprovechar las ventajas adicionales que ofrece la recuperación de oxígeno y alcalinidad, se recomienda incluir la desnitrificación siempre que exista la posibilidad de que la nitrificación ocurra en el sistema, aun cuando no se requiera remover nitrógeno. No obstante, cuando se requiere que exista nitrificación y la desnitrificación es adicionalmente incorporada al sistema, se requieren edades de lodo mayores de 10 a 15 días, lo que hace que estos sistemas pasen a categorizarse como sistemas con edades de lodos alta.

En plantas aerobias de lodos activados que realicen la nitrificación siempre existe la posibilidad de que la desnitrificación ocurra en los clarificadores secundarios. Este problema se agrava cuando el sistema de purga de lodos se realiza directamente de la línea de recirculación de lodos (ver Sección 4.10.1). Con relaciones de recirculación bajas, el tiempo de retención en los clarificadores secundarios es largo, lo que favorece la desnitrificación (Figura 4.8). Henze et al., (1993) estimaron que entre 6-8 y $8-10 \mathrm{mgN} / 1 \mathrm{de}$ nitratos desnitrificados en el clarificador secundario pueden causar lodos flotantes a 10 y $20{ }^{\circ} \mathrm{C}$, respectivamente. La concentración de nitratos desnitrificados aumenta con ( $i$ ) el aumento del tiempo de retención de lodos en los clarificadores secundarios, el cual depende de la relación de recirculación y de las condiciones de caudal pico, (ii) el aumento de la fracción activa en los lodos, (Figura 4.3B), (iii) el aumento en la temperatura y (iv) el aumento de la masa de material orgánico biodegradable no utilizado absorbidos por los flóculos de lodo activado, la cual es más alta a edades de lodos bajas y máxima en condiciones de carga pico (Ekama et al., 1997).

Lo anterior demuestra que para plantas donde se lleve a cabo el proceso de nitrificación, los clarificadores secundarios no deben servir el doble propósito de clarificadores y espesadores del lodo de purga, que el control hidráulico de la edad de lodos debería ser empleado y por último que la desnitrificación debe ser incluida (ver Sección 4.10). Estas modificaciones van a reducir el problema de flotación de lodos en los clarificadores, pero puede que 
no eliminen la causa real del problema, esto es, las elevadas concentraciones de nitratos en el licor mezclado.

A fin de que se reduzcan los costos constructivos en el sistema de lodos activados, es necesario reducir la edad de lodos. Adicionalmente, una reducción en la edad de lodos aumenta tanto la remoción de fósforo como la de nitrógeno por unidad de masa de carga orgánica (WRC, 1984; Wentzel et al., 1990) lo cual sería particularmente benéfico para aguas residuales a bajas temperatura $\left(10-15^{\circ} \mathrm{C}\right)$ donde se requiera nitrificar.

Para tratar de reducir la edad de lodos requerida para nitrificar, y por ende reducir el volumen del reactor por $\mathrm{m}^{3}$ de agua residual tratada, en diversos estudios y aplicaciones se han incluido medios de soporte dentro del reactor aerobio (Wanner et al., 1988; Sen et al., 1994). Las bacterias nitrificantes que crecen en el medio de soporte no están sujetas a la edad de lodos del licor mezclado o al tamaño de la fracción de masa aerobia con la consecuencia de que ambos parámetros pueden ser reducidos. No obstante, la efectividad de los medios de soporte no ha sido la esperada, obteniéndose bajas relaciones costo/beneficio.

La reducción de la edad de lodos a valores de 8 a 10 días ha sido obtenida de forma satisfactoria aplicando nitrificación externa (Bortone et al., 1996; Sorm et al., 1997; Hu et al., 2000) y este sistema ya ha comenzado a tener aplicación a escala real (Vestner and Günthert, 2001; Muller et al., 2006). Cuando se utiliza nitrificación externa, el proceso de nitrificación se remueve completamente del lodo activado en suspensión y es transferido a un medio de soporte externo como puede ser un filtro percolador. Con la nitrificación independiente de la remoción biológica de nutrientes del licor mezclado, las edades de lodo pueden reducirse hasta 8 a 10 días. Este tipo de reducción permite disminuir el volumen del reactor biológico por $\mathrm{Ml}$ de agua residual tratada a una tercera parte sin impactar de forma negativa la remoción biológica de nitrógeno o fósforo. Adicionalmente, cuando se compara con sistemas convencionales de remoción de nutrientes, la sedimentabilidad del lodo mejora significativamente $\left(\mathrm{IVL}_{\mathrm{d}} \sim 60-80 \mathrm{ml} / \mathrm{g}\right.$ ) lo cual incrementa aún más la capacidad del sistema (Hu et al., 2000).

Comparando plantas con edades de lodo intermedias con plantas de alta tasa, la demanda de oxígeno por $\mathrm{kg}$ DQO (incluyendo nitrificación) se duplica (excepto con nitrificación externa en cuyo caso se reduce a la mitad), el volumen del sistema es 3 a 4 veces más grande, la masa diaria de lodo de purga se reduce en un $40 \%$ y la fracción activa es mucho menor. Las plantas de tratamiento de agua con edades de lodo intermedias son mucho más estables que las de alta tasa, requiriendo equipos de control menos sofisticados y menor intervención por parte del operador (excepto con nitrificación externa) haciendo a este tipo de plantas las más aptas para aplicaciones generales.

Con edades de lodo intermedias, la fracción activa del lodo de purga es aún demasiado grande para permitir la descarga directa a lechos de secados y disposición final. Consecuentemente, es necesario incorporar a la planta de tratamiento de agua alguna forma adicional de estabilización para los lodos de purga antes de su disposición final, como por ejemplo digestión anaerobia o aerobia. Esta última tiene la ventaja de tener una operación más sencilla y si se opera a una concentración alta de SSLM $(>2 \%)$ con aireación intermitente, permite mantener concentraciones bajas de nitrógeno y fósforo en el licor del sobrenadante (Mebrahtu et al., 2008), pero con la desventaja de tener altos costos energéticos debido al suministro de oxígeno. Por otra parte, la digestión anaerobia tiene la gran ventaja de generar energía a través del biogás producido pero las desventajas de tener un nivel de complejidad en la operación elevado y unas concentraciones altas de nitrógeno y fósforo en el sobrenadante del sistema. Aun con la recuperación de energía producto de la digestión anaerobia de los lodos de purga, debido a la menor cantidad de lodo purgado en la planta de lodos activados y a la alta demanda de oxígeno por unidad de kg de carga DQO, la autosuficiencia energética no es posible en sistemas con edad de lodos intermedia. No obstante, en plantas grandes (con una población equivalente mayor a 500,000 ) donde tanto la supervisión técnica como la pericia de los operarios es de alto nivel, es posible que los gastos energéticos se vean reducidos gracias a la producción de biogás por parte de los digestores anaerobios y que a la vez justifican el nivel de inversión económica de su implementación. Esto último es particularmente cierto si los costos de la energía aumentan como lo han venido haciendo durante el transcurso de la última década.

Brink et al. (2007) encontraron que las emisiones de gases de invernadero $\left(\mathrm{CO}_{2}\right)$ por parte de dos plantas de tratamiento completamente diferentes tratando el mismo tipo de agua residual son virtualmente idénticos 
si el contenido de materia orgánica biodegradable remanente en el lodo de disposición final es la misma, viz ( $i$ ) una edad de lodos alta (30 días, Tabla 4.5) para un sistema de aireación extendida tratando agua residual cruda y (ii) una edad de lodos baja (8 días, Tabla 4.5) para un sistema de lodos activados tratando agua residual clarificada con digestión anaerobia de lodos primarios y digestión aerobia o anaerobia de lodos con combustión de gas metano.

\subsubsection{Edad de lodos alta (20 días o más)}

\subsubsection{Plantas aerobias}

Las plantas de tratamiento con edades de lodo elevadas son comúnmente conocidas como plantas de aireación extendida. El principal objetivo de este tipo de plantas es el de obviar el tratamiento de los lodos primarios y secundarios producidos por los clarificadores primarios y secundarios respectivamente. Por este motivo, este tipo de plantas tratan agua residual cruda y a su vez la edad de lodos asociada se escoge de tal forma que la fracción activa (o materia orgánica biodegradable remanente) del lodo de purga sea lo suficientemente baja para que sea posible disponer los lodos directamente en lechos de secado. La edad de lodos necesaria para producir un lodo suficientemente estabilizado como para no generar problemas de olores es incierto y va a depender de la temperatura y de las condiciones climáticas, esto es dependiendo de si el lodo puede o no secarse lo suficientemente rápido antes de que comience a oler. En cualquiera que sea el caso, este valor probablemente excede los 30 días.

Interesantemente, un estudio realizado sobre el contenido de materia orgánica biodegradable remanente en lodos de purga tratados por medio de diferentes procesos de estabilización, Samson y Ekama (2000) encontraron que la digestión aerobia de lodos activados producía el lodo estabilizado con el menor contenido de materia orgánica biodegradable residual (10\%) comparada con oxidación con aire húmedo (Zimpro) y con lodos primarios digeridos anaeróbicamente (25-60\%, Figura 4.10)

\subsubsection{Plantas aerobias-anóxicas}

Cuando la edad de lodos excede de 20 a 25 días, la nitrificación es inevitable y es recomendable incorporar desnitrificación en el sistema por las diferentes razones citadas anteriormente, sin riesgo de que la estabilidad del proceso de nitrificación se vea afectado gracias a la elevada edad de lodos. Adicionalmente, de ser necesario, el EBPR puede incluirse en el sistema con un costo adicional extra muy bajo. De hecho, la remoción biológica de nitrógeno y fósforo son significativamente mayores con agua residual cruda que con aguas clarificadas debido al alto contenido de carga orgánica. Para poder remover nitrógeno (y fósforo), el reactor se subdivide en una serie de zonas no aireadas (anóxicas y anaerobias) y aireadas, las cuales se pueden distribuir en una variedad de configuraciones diferentes.

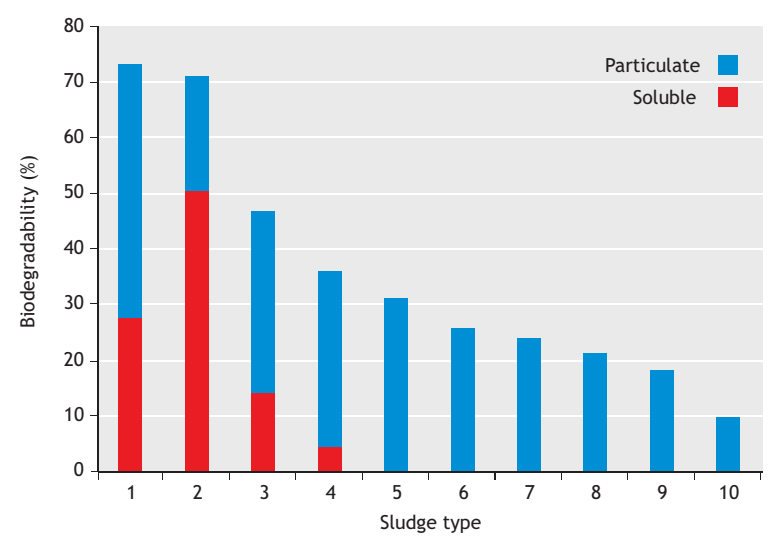

Figura $4.10 \%$ de materia orgánica biodegradable residual que permanece en lodos estabilizados producto del tratamiento de aguas residuales mediante diferentes tipos de sistemas de estabilización. Abreviaciones: Lodo primario (LP); ácidos grasos volátiles (VFA, por sus siglas en inglés Volatile Fatty Acids); lodo de purga (WAS, por sus siglas en inglés Waste Activated Sludge); flotación con aire disuelto (DAF, por sus siglas en inglés Dissolved Air Flotation). Leyenda: (1) Agua cruda no clarificada, (2) Humus de Zimpro ${ }^{\circledR}+$ LP - DQO soluble elevada, (3) LP digerido anaerobiamente + WAS - VFA elevado, (4) LP digerido anaerobiamente únicamente - elevados VFA, (5) LP digerido anaerobiamente únicamente, $1^{\text {ra }}$ etapa - bajo VFA, (6) Humus Zimpro ${ }^{\circledR}+$ LP - DQO soluble baja, (7) LP digerido anaerobiamente, $2^{\text {da }}$ etapa - bajo VFA, (8) WAS espesado por DAF, (9) LP digerido anaerobiamente + WAS, solo una etapa - VFA bajo y, (10) WAS digerido aerobiamente

En las configuraciones antes descritas, la desnitrificación se lleva a cabo en las zonas no aireadas pero mezcladas debido a que reciben licor mezclado de las zonas aireadas a través de recirculaciones internas para producir el proceso conocido como nitrificacióndesnitrificación. Los sistemas de nitrificacióndesnitrificación incluyen el Bardenpho de 4 etapas, que incorpora reactores anóxicos primarios y secundarios, el sistema modificado de Ludzack Ettinger (MLE), que incorpora un solo reactor anóxico primario, los sistemas Orbal, Carousel y zanjas de oxidación en las que las zonas anóxicas son creadas a lo largo de diferentes longitudes dentro del mismo canal del reactor, o en sistemas de aireación extendida con 
decantación intermitente (IDEA, por sus siglas en inglés intermittently decanted extended aeration). Si bien la incorporación de la desnitrificación impone limitaciones adicionales al diseño, en sistemas con edades de lodos elevadas estas limitaciones se vuelven mínimas siempre y cuando se suministre la aireación suficiente para garantizar una nitrificación eficiente bajo las diferentes condiciones esperadas (ver Capítulo $5)$.

\subsubsection{Plantas anaerobias-anóxicas-aerobias}

Cuando se requiere implementar un proceso de EBPR, un reactor anaerobio debe agregarse al inicio de la configuración del sistema y recibir el agua residual afluente pero con una mínima intrusión de oxígeno y nitrato por parte de las recirculaciones internas. Para lograr una buena remoción de $\mathrm{P}$ en un sistema con EBPR, es indispensable garantizar que no se descargue nitrato en la zona anaerobia, lo que constituye una condición adicional cuando se incluye la EBPR en sistemas de aireación extendida. El nivel de remoción obtenido a través de la EBPR va a depender de un número de factores, principalmente la concentración de DQO rápidamente biodegradable, la relación de TP/DQO y el nivel de exclusión de nitrato al que puede ser expuesto el reactor anaerobio, lo que depende de la relación de NTK/DQO en el afluente.

El lodo de purga de sistemas de aireación extendida que incluyen EBPR tiene el potencial de liberar concentraciones elevadas de P. Esto puede manejarse con el uso de lechos de desaguado/secado especialmente diseñados con arena para filtro sobre drenajes y vertederos de descarga, lo que permite al lecho de secado también operar como una unidad de drenado. Mientras se realiza la purga de lodos directamente a los lechos de secado, el drenaje subsuperficial y el caudal de desborde deben ser monitoreados, de tal forma que si por ejemplo la concentración de $\mathrm{P}$ llega a un valor de $5 \mathrm{mgP} / 1$, la purga de lodos y retorno del sobrenadante al inicio de la planta se detenga. El volumen relativamente pequeño de licor con un contenido elevado de $\mathrm{P}$ que drena de los lechos de secado inmediatamente después, es tratado químicamente o es usado como agua de irrigación en el lugar de la planta. La capacidad de desaguado de los lechos permite que una cantidad significativamente mayor de lodos sea descargada a estos que en el caso de lechos de secado convencionales sin drenajes.

\subsubsection{Factores predominantes aplicados al dimensionamiento de un sistema de lodos activados}

En la sección anterior se expusieron algunas de las consideraciones a tener en cuenta en la selección de la edad de lodos en un sistema de lodos activados, debido a que este es el parámetro de fundamental importancia en el diseño. La edad de lodos constituye el principal motor que gobierna la calidad del efluente y el dimensionamiento de un sistema de lodos activados. Generalmente, entre más exigentes sean los requerimientos de calidad en el efluente (y el lodo de purga) sobre un sistema de lodos activados, más alta será la edad de lodos, mayor será el tamaño del reactor biológico y mayor será la cantidad de características a determinar en el agua residual (Figura 4.11).

Para la remoción únicamente de materia orgánica, la edad de lodos del sistema es baja y por ende también el volumen del reactor. Esencialmente solo es necesario determinar la carga orgánica (DQO) y las fracciones no biodegradable y particulada (fS'up) y no biodegradable y soluble (fs'up). La carga orgánica y la concentración de DQO no biodegradable $y$ particulada afectan fuertemente la masa de lodos en el reactor y la producción diaria de lodos, mientras que la concentración de DQO no biodegradable y soluble determina la concentración esperada de la DQO filtrada en el efluente. La carga orgánica también fija la demanda diaria de oxígeno. Por último, las cargas hidráulicas máxima determinan el área superficial de los clarificadores secundarios.

Si se requiere que la nitrificación ocurra en el sistema, es necesario determinar un mayor número de características del agua residual. Las más importantes de estas son la tasa específica de crecimiento máxima de los organismos nitrificantes a una temperatura estándar de $20^{\circ} \mathrm{C}\left(\mu_{\mathrm{A} 20}\right)$ y la temperatura mínima del agua residual $\left(\mathrm{T}_{\mathrm{min}}\right)$, ambas de las cuales fijan la edad de lodos mínima para la nitrificación (TRS mín,NIT). La edad de lodos del sistema debe ser mayor que la mínima para garantizar la nitrificación y mientras mayor sea la relación entre la edad de lodos seleccionada y la

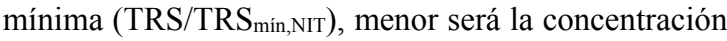
de amoníaco en el efluente y el sistema será más robusto y estable cuando existan fluctuaciones en las cargas de nitrógeno. Para sistemas con nitrificación también se requiere conocer la carga diaria de nitrógeno (tanto el NTK como el amoníaco libre y salino) de tal manera que se puedan determinar los componentes que forman parte del material nitrogenado en el afluente. 


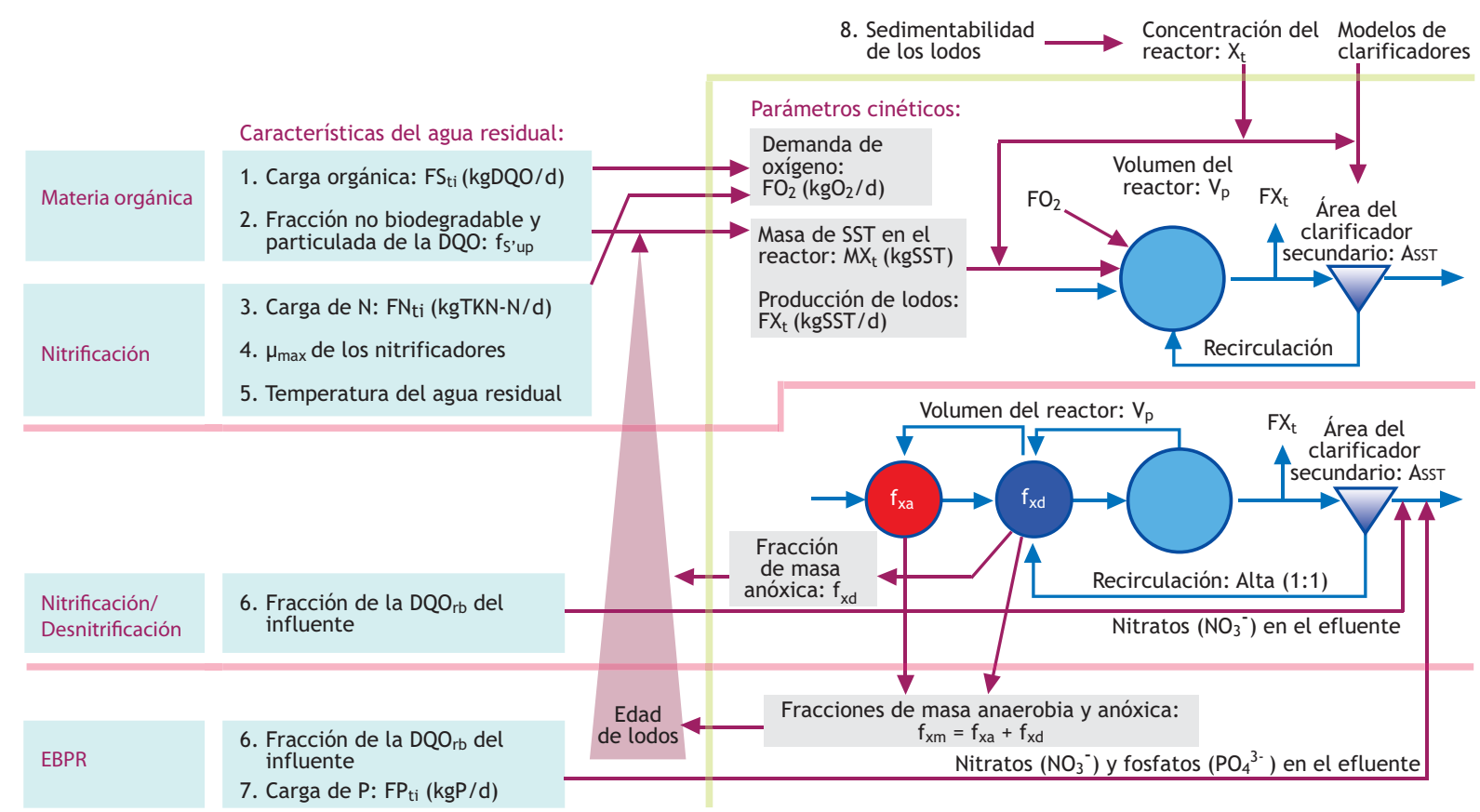

Figura 4.11 Características importantes del agua residual a tener en cuenta para diferentes sistemas de lodos activados e interrelaciones que afectan la edad de lodos y la calidad del efluente. Sistema con proceso completamente aerobio, nitrificación, nitrificacióndesnitrificación y EBPR

La tasa específica de crecimiento máximo de los nitrificantes se incluye dentro de las características del agua residual y no como una constante cinética del modelo debido a que este valor varía para diferentes tipos de agua residual.

Con la remoción biológica del nitrógeno (nitrificación/desnitrificación), una parte del reactor biológico (la fracción de masa anóxica $f_{x d}$ ) no sea airea de forma intencional. Entre mayor sea esta fracción, mayor será la cantidad de nitrato que puede ser desnitrificado pero al mismo tiempo mayor es el tiempo mínimo requerido para la edad de lodos, lo que a su vez resulta en reactores más grandes. También es necesario determinar características adicionales en el agua residual, incluyendo la concentración de $\mathrm{DQO}_{\mathrm{rb}}$ en el afluente. Una alta proporción de la DQO $\mathrm{rb}$ (hasta un $50 \%$ ) del nitrato desnitrificado en el reactor anóxico primario se lleva a cabo gracias a este componente, es por ello que si no se conoce la concentración de DQO $\mathrm{D}_{\mathrm{rb}}$, la concentración de nitratos en el efluente no puede ser calculada con exactitud.

En sistemas con EBPR, es necesario conocer la carga diaria de fósforo (tanto el fósforo total como el ortofosfato) en el agua residual de tal forma que los componentes que hacen parte del material fosfatado puedan ser estimados en el afluente. Adicionalmente, la estimación de la DQO rb es de vital importancia ya que establece los límites de remoción que pueden ser alcanzados. Si la concentración de $\mathrm{DQO}_{\mathrm{rb}}$ en el afluente no se determina, no es posible definir con exactitud la remoción biológica de fósforo. $\mathrm{La} \mathrm{DQO}_{\mathrm{rb}}$ en el afluente es una fuente indirecta de alimento para los PAOs, quienes son los encargados de mediar el proceso de EBPR. El propósito de la zona anaerobia, que recibe el agua residual afluente, es permitir que los PAOs tomen los productos de la fermentación de los ácidos grasos volátiles $(\mathrm{AGV})$ generados a partir de la DQO $\mathrm{rb}$. La presencia de nitrato (y/o oxígeno disuelto) en la zona anaerobia resulta en el uso de una parte de la DQO ${ }_{\mathrm{rb}}$ en el afluente por parte de los OHOs, lo cual reduce los productos de los AGV disponibles para los PAOs, y por ende reduce la remoción biológica de fósforo. La diferencia entre la concentración de fósforo en el afluente y la EBPR que puede alcanzarse, determina la concentración esperada en el efluente.

Para maximizar la EBPR es esencial mantener en niveles muy bajos la concentración de nitrato (y oxígeno disuelto) que entran a la zona anaerobia a través de las líneas de recirculación internas. Esta necesidad impone requisitos importantes en el nivel de desnitrificación requerido en las zonas anóxicas. Si la 
relación de NTK/DQO es muy alta, no es posible obtener bajas concentraciones de nitrato en las zonas anóxicas y puede ser necesaria la dosificación de metanol como fuente adicional de carbono. Altas remociones de nitrógeno en la zona anóxica requieren de grandes reactores anóxicos, los cuales junto con la zona anaerobia resultan en grandes fracciones de masa no aireada, que a su vez requieren de altas edades de lodos para garantizar la nitrificación. A menos que se apliquen estrategias específicas para mantener una edad de lodos baja, como es la implementación de procesos de nitrificación externa o la adición de medios de soporte en la zona aerobia para reducir la sensibilidad del sistema a las edades de lodo mínimas requeridas para nitrificación, los sistemas de EPBR con nitrificación/desnitrificación requieren edades de lodo elevadas, especialmente cuando las temperaturas mínimas son bajas.

Lo expuesto anteriormente demuestra como la determinación de las características del agua residual constituyen el aspecto más importante a la hora de modelar plantas de tratamiento de aguas residuales, sea utilizando modelos en estado estacionario o modelos de simulación dinámica. La incertidumbre en la estimación de las características de las aguas residuales (y la sedimentabilidad de los lodos) resulta en una incertidumbre comparable con la demanda de oxígeno, la producción de lodo, el volumen del reactor y la calidad final del efluente. Por este motivo se recomienda la aplicación de análisis de sensibilidad e incertidumbre a las características del agua y no a los parámetros cinéticos y estequiométricos de los modelos. De hecho, solo en ocasiones específicas deben cambiarse los parámetros de los modelos, a excepción quizás de la tasa específica máxima de crecimiento de los organismos nitrificantes, la cual como se mencionó anteriormente, es tratada como una característica del agua residual. La calibración a escala de laboratorio, escala piloto y escala real de las concentraciones en el efluente, la producción de lodo y la demanda de oxígeno, puede lograrse ajustando y modificando únicamente las características del agua residual, siempre y cuando los valores se ajusten a los balances de masa de agua, DQO, $\mathrm{N}$ y $\mathrm{P}$.

A menudo las predicciones dadas por los modelos no pueden ajustarse a los datos medidos debido a que estos no se ajustan a los balances de masa y los principios de continuidad. Solo cuando los datos recopilados se ajustan a las leyes de conservación de masa y la modificación de las características del agua residual no producen una buena correlación entre las predicciones del modelo y los datos de campo, es necesario ajustar los parámetros cinéticos y estequiométricos. No obstante, estos cambios deben realizarse con precaución y estar basados en el entendimiento de los procesos biológicos que se llevan a cabo en los sistemas, y no deben ajustarse de forma arbitraria solo porque, por ejemplo, hagan que el modelo se ajuste a los datos de las mediciones de la calidad del efluente del sistema.

\subsubsection{Comentarios generales}

En sistemas con remoción biológica de nutrientes, el control de la aireación es particularmente complejo bajo condiciones cíclicas de caudal y carga. Esto debido a que el sistema se ve afectado tanto por concentraciones de oxígeno disuelto bajas como altas. Concentraciones muy elevadas de oxígeno disuelto son innecesariamente costosas y resultan en la recirculación del oxígeno a las zonas anóxicas (y a las zonas anaerobias si se incluye remoción biológica de fósforo), de este modo reduciendo el potencial de remoción de nitrógeno (y fósforo); concentraciones muy bajas de oxígeno disuelto impactan negativamente la eficiencia de la remoción de nitrógeno y favorecen el desarrollo de lodos de baja sedimentabilidad. Aunque a lo largo de los años se han desarrollado sistemas adecuados para el control del oxígeno disuelto, el costo de proporcionar la capacidad de aireación en los reactores y el área superficial en los clarificadores secundarios cuando ocurren los caudales extremos, ha estimulado nuevas investigaciones en búsqueda de alternativas a las estrategias de control, como lo son la igualación y homogeneización de caudales y de cargas. Adicionalmente, la mayoría de las variaciones diurnas en las variables del sistema como la concentración de amoniaco, nitrato y fosfato, no son inducidas por los procesos biológicos sino por las variaciones en los regímenes de flujo. Para minimizar esta variación, se puede instalar un tanque de igualación antes del sistema de lodos activados de tal manera que la descarga de este tanque sea controlada para amortiguar las fluctuaciones de caudal y carga. La descarga del tanque es controlada por un microcomputador el cual calcula el caudal que mejor amortigua o regula el flujo proyectado para las siguientes 24 horas. Este método ha sido probado en la planta de tratamiento con remoción biológica de nutrientes de Goudkoppies (Johannesburgo, RSA) y ha revelado un gran potencial en la reducción de aireación y otros problemas asociados en plantas con remoción de nutrientes (Dold et al., 1982, 1984). 


\section{REFERENCIAS}

Barnard J.L. (1976) A review of biological phosphorus removal in the activated sludge process. Water $S A$ 2(3), 136-144.

Bratby J. (1978) Aspects of sludge thickening by dSSIolved-air flotation. Wat. Pollut. Control 77(3), 421-432.

Brink I.C., Wentzel M.C. and Ekama G.A. (2007) New developments in modelling waste water treatment processes - Using stoichiometry to build a plant wide mass balance based steady state WWTP model. Procs. $10^{\text {th }}$ IWA conference on Design, Operation and Economics of Large Wastewater Treatment Plants. Vienna, 9-13 Sept, 243-250.

Bortone G., Saltarelli R., Alonso V., Sorm R., Wanner J. and Tilche A. (1996) Biological anoxic phosphorus removal - The DEPHANOX process. Wat. Sci. Tech.34(1/2), 119-128.

Burke R.A., Wentzel M.C., Dold P.L., Ekama G.A. and Marais, G.v.R. (1989) Biological excess phosphorus removal in short sludge age activated sludge systems. Procs. 1st biennial WISA Conference, Cape Town, March.

Chao A.C. and Keinath T.M. (1979) Influence of process loading intensity on sludge clarification and settling characteristics. Wat. Res. 13(12), 1213-1224.

Dold P.L., Buhr H.O. and Marais G.v.R. (1982) Design and control of equalization tanks. Research Report No. W 42, Dept. of Civil Eng., Univ of Cape Town, Rondebosch, 7701, RSA.

Dold P.L., Buhr H.O. and Marais G.v.R. (1984) An equalization control strategy for activated sludge process control. Wat. Sci. Tech. 17 (Amsterdam), 221-234.

Dick R.I. (1976) Folklore in the design of final settling tanks. Journal WPCF 48(4), 633-644.

Ekama G.A., Dold P.L. and Marais G.v.R. (1986) Procedures for determining influent DQO fractions and the maximum specific growth rate of heterotrophs in activated sludge systems. Wat. Sci. Tech. 18(6), 91-114.

Ekama G.A. and Marais G.v.R. (1986) Sludge settleability and secondary settling tank design. Water Pollut. Control 85(2), 100-113.

Ekama G.A., Barnard J.L., Günthert F.W., Krebs P., McCorquodale J.A., Parker D.S., Wahlberg E.J. (1997) Secondary settling tanks: Theory, design, modelling and operation. IAWQ STR No 6, pp216, International Association on Water Quality, London.

Ekama G.A. and Marais P. (2004) Assessing the applicability of the 1D flux theory to full scale secondary settling tank design with a 2D hydrodynamic model. Wat. Res. 38(3), 495-506.

Ekama G.A. and Wentzel M.C. (2004) A predictive model for the reactor inorganic suspended solids concentration in activated sludge systems. Wat. Res. 38(19), 4093-4106.

Garrett M.T. (1958) Hydraulic control of activated sludge growth rate. Sew. and Ind. Waste 30, 253.

Henze M., Dupont R., Grau P. and De La Sola A. (1993)
Rising sludge in secondary settlers due to denitrification. Wat. Res. 27(2), 231-236.

Hörler A. (1969) Discussion of "Performance of (activated sludge) secondary settling tanks" by Pflanz P (1969) Procs. 4th IAWPR Conference, Prague, Ed. Jenkins SH, Pergamon Press, Oxford, 569-593.

$\mathrm{Hu}$ Z.R, Wentzel M.C. and Ekama G.A. (2000) External nitrification in biological nutrient removal activated sludge systems. Water SA 26(2), 225-238.

Korentajer L. (1991) A review of the agricultural use of sewage sludge: Benefits and potential hazards. Water SA 17(3), 189-196.

Mamais D. and Jenkins D. (1992) The effects of MCRT and temperature on enhanced biological phosphorus removal. Wat. Sci. Tech 26(5/6), 955-965.

Marais G.v.R. and Ekama G.A. (1976) The activated sludge process part 1 - Steady state behaviour. Water SA 2(4), 163-200.

Mebrahtu M.K. and Ekama G.A. (2008) Aerobic digestion of waste activated sludge from biological nutrient removal activated sludge systems. Procs $10^{\text {th }}$ biennial Water Institute of Southern Africa conference, Suncity, 18-21 May.

Metcalf and Eddy Inc. (1991) Wastewater Engineering: Collection, treatment, disposal and reuse, 3rd Edn., McGraw-Hill, New York.

Muller A.W., Wentzel M.C. and Ekama G.A. (2006) Estimation of nitrification capacity of rock media trickling filters in external nitrification BNR. Water $S A$ 32(5), 611-618.

Nicholls H.A. (1975) Internal Thesis Report, Dept. of Civil Eng., Univ. of Cape Town, Rondebosch, 7701, RSA.

Parker D.S, Kaufman W.J. and Jenkins D. (1971) Physical conditioning of activated sludge floc. Journal WPCF 43(9), 1817-1833.

Pincince A.B., Braley B.G., Sangrey K.H. and Reardon R.D. (1995) Minimizing costs of activated sludge systems: Application to the Deer Island treatment plant, Procs. 68th Annual WEF Conference and Exposition, Miami, 1, 693-699.

Pitman A.R. (1999) Management of biological nutrient removal plant sludges - Change the paradigms? Wat. Res. 33(5), 1141-1146.

Riddel M.D.R., Lee J.S. and Wilson T.E. (1983) Method for estimating the capacity of an activated sludge plant. Journal WPCF 55(4), 360-368.

Samson K.A. and Ekama G.A. (2000) An assessment of sewage sludge stability with a specific oxygen utilization rate (SOUR) test method. Wat. Sci. Tech. 42(9), 37-40.

Setter L.R., Carpenter W.T. and Winslow G.C. (1945) Practical application of modified sewage aeration. Sew. Works Jour. 17(4), 669-691

Sen D., Mitta P. and Randall C.W. (1994) Performance of fixed film media integrated in activated sludge reactors to enhanced nitrogen removal. Wat. Sci. Tech. 30(11), 13-24.

Sorm R., Bortone G., Saltarelli R., Jenicek P., Wanner J. and Tilche A. (1996) Phosphate uptake under anoxic conditions and fixed film nitrification in nutrient 
removal activated sludge system. Wat. Res. 30(7), 1573-1584.

Sötemann S.W., Wentzel M.C. and Ekama G.A. (2006) Mass balances based plant wide wastewater treatment plant models - Part 4: Aerobic digestion of primary and waste activated sludges. Water SA 32(3), 297-306.

Stofkoper J.A. and Trentelman C.C.M. (1982) Richtlijnen voor het dimensioneren van ronde nabezinktanks voor actiefslibinstallaties. $\mathrm{H}_{2} \mathrm{O}$ 15(14), 344-354.

Vestner R.J. and Gunthert F.W. (2001) Upgrading of trickling filters for biological nutrient removal with an activated sludge stage. GWF - Water • Wastewater 142(15), 39-46.
Wahlberg E.J., Keinath T.M. and Parker D.S. (1994) The influence of flocculation time on secondary clarification. Water Environ. Res. 66(6), 779-786.

Wanner J., Kucman K. and Grau P. (1988) Activated sludge process with biofilm cultivation. Wat. Res. 22(2), 207-215.

Wentzel M.C., Dold P.L., Ekama G.A. and Marais G.v.R. (1990) Biological excess phosphorus removal - Steady state process design. Water $S A$ 16(1), 29-48.

WRC (1984) Theory, Design and Operation of Nutrient Removal Activated Sludge Processes. Water Research CommSSIion, Private Bag X03, Gezina, 0031, RSA.

NOMENCLATURA

\begin{tabular}{|c|c|c|}
\hline Símbolo & Descripción & Unidades \\
\hline$a$ & Relación de recirculación del licor mezclado $\left(Q_{a} / Q_{i}\right)$ & - \\
\hline$A_{C S}$ & Área superficial del clarificador secundario & $\mathrm{m}^{2}$ \\
\hline$b_{H}$ & Tasa específica de respiración endógena de los OHOs & $\mathrm{d}^{-1}$ \\
\hline$C_{C S}$ & Constante de costo del clarificador secundario & - \\
\hline$C_{R}$ & Constante de costo del reactor biológico & - \\
\hline$f_{a}$ & Fracción de OHOs en el lodo activado & $\mathrm{mgSSV} / \mathrm{mgSSV}$ \\
\hline$f_{a t}$ & Fracción de OHOs en el lodo activado como SST & $\mathrm{mgSSV} / \mathrm{mgSST}$ \\
\hline$f_{a v}$ & Fracción de OHOs en el lodo como SSV & $\mathrm{mgSSV} / \mathrm{mgSSV}$ \\
\hline$f_{\text {avOHO }}$ & Fracción de OHOs en el lodo como SSV & $\mathrm{mgSSV} / \mathrm{mgSSV}$ \\
\hline$f_{c v}$ & Relación de DQO/SSV en el lodo & mgSSV/mgDQO \\
\hline$f_{H}$ & Fracción no biodegradable de los OHOs & $\mathrm{mgDQO} / \mathrm{mgDQO}$ \\
\hline$f_{i}$ & Relación de SSV/SST del lodo & $\mathrm{mgSSV} / \mathrm{mgSST}$ \\
\hline$f_{\mathrm{iOHO}}$ & Fracción de contenido inorgánico de los $\mathrm{OHOs}$ & $\mathrm{mgSSI} / \mathrm{mgDQO}$ \\
\hline$F O_{c}$ & Flujo diario de oxígeno utilizado & $\mathrm{mgO}_{2} / \mathrm{d}$ \\
\hline$f q$ & Factor de caudal pico $\left(\mathrm{Q}_{\max } / \mathrm{Q}_{\mathrm{i}, \mathrm{p}}\right)$ & $1 / 1$ \\
\hline$F S_{b i}$ & Flujo diario de DQO biodegradable en el afluente & $\mathrm{mgDQO} / \mathrm{d}$ \\
\hline$F S_{t e}$ & Flujo de DQO en el efluente & $\mathrm{g} \mathrm{DQO} / \mathrm{d}$ \\
\hline$F S_{t i}$ & Flujo de DQO total en el afluente & $\mathrm{mg} \mathrm{DQO} / \mathrm{d}$ \\
\hline$f_{\text {S'up }}^{\prime}$ & Fracción particulada no biodegradable de la DQO total en el afluente & - \\
\hline$f_{S^{\prime} u s}$ & Fracción soluble no biodegradable de la DQO total en el afluente & - \\
\hline$F S_{X v}$ & Flujo diario de materia orgánica particulada producida & $\mathrm{mg} \mathrm{DQO} / \mathrm{d}$ \\
\hline$F X_{I i}$ & Flujo diario de DQO particulada no biodegradable & $\mathrm{mgDQO} / \mathrm{d}$ \\
\hline$F X_{I O i}$ & Flujo diario de materia inorgánica particulada en el afluente & $\mathrm{mgSSI} / \mathrm{d}$ \\
\hline$F X_{I v i}$ & Flujo diario de de materia particulada no biodegradable como SSV en el afluente & $\mathrm{mgSSV} / \mathrm{d}$ \\
\hline$F X_{t}$ & Flujo diario de sólidos totales producidos & $\mathrm{mgSST} / \mathrm{d}$ \\
\hline$F X_{v}$ & Flujo diario de sólidos suspendidos volátiles producidos & $\mathrm{mgSSV} / \mathrm{d}$ \\
\hline$I V L$ & Índice volumétrico de lodos & $\mathrm{mL} / \mathrm{gSST}$ \\
\hline IVL $L_{a 3.5}$ & Índice volumétrico de lodos agitados a $3.5 \mathrm{~g} \mathrm{SST/L}$ & $\mathrm{mL} / \mathrm{gSST}$ \\
\hline$I V L_{d}$ & Índice volumétrico de lodos diluido & $\mathrm{ml} / \mathrm{gSST}$ \\
\hline$M X_{B H v}$ & Masa de OHOs en el reactor biológico & mgSSV \\
\hline$M X_{E H v}$ & Masa de residuo endógeno en el reactor biológico & $\operatorname{mgSSV}$ \\
\hline
\end{tabular}




\begin{tabular}{|c|c|c|}
\hline$M X_{I O}$ & Masa de materia inorgánica particulada en el afluente del reactor biológico & $\operatorname{mgSSI}$ \\
\hline$M X_{I v}$ & Masa de materia no biodegradable en el afluente del reactor biológico & mgSSV \\
\hline$M X_{t}$ & Masa de sólidos en el reactor biológico & $\operatorname{mgSST}$ \\
\hline$M X_{v}$ & Masa de sólidos suspendidos volátiles en el reactor biológico & mgSSV \\
\hline$O_{c}$ & Tasa de utilización de oxígeno para degradación de materia orgánica & $\mathrm{mgO}_{2} / 1 . \mathrm{d}$ \\
\hline$P_{C S}$ & Constante del exponente del costo del clarificador secundario & - \\
\hline$P_{R}$ & Constante del exponente del costo del reactor biológico & - \\
\hline$Q_{a}$ & Caudal de recirculación del licor mezclado & $1 / \mathrm{d}$ \\
\hline$Q_{e}$ & Caudal efluente & $1 / \mathrm{d}$ \\
\hline$Q_{i}$ & Caudal afluente & $1 / \mathrm{d}$ \\
\hline$Q_{i, m a ́ x}$ & Caudal pico o máximo en el clarificador secundario & $\mathrm{m}^{3} / \mathrm{h}$ \\
\hline$q_{i, m a ́ x}$ & Velocidad ascensional pico o máxima en el clarificador secundario & $\mathrm{m} / \mathrm{h}$ \\
\hline$Q_{i, p}$ & Caudal afluente promedio (bajo clima seco) & $1 / \mathrm{d}$ \\
\hline$Q_{s}$ & Caudal de recirculación de lodos & $1 / \mathrm{d}$ \\
\hline$Q_{w}$ & Caudal de purga de lodos & $1 / \mathrm{d}$ \\
\hline rhin & Constante de clarificación del lodo & $1 / \mathrm{g}$ \\
\hline$s$ & Relación de recirculación de lodos $\left(Q_{s} / Q_{i}\right)$ & - \\
\hline$S_{b i}$ & DQO biodegradable en el afluente & $\mathrm{mgDQO} / 1$ \\
\hline$S_{I e}$ & DQO soluble no biodegradable en el efluente & $\mathrm{mgDQO} / 1$ \\
\hline$S_{I i}$ & DQO soluble no biodegradable en el afluente & $\mathrm{mgDQO} / 1$ \\
\hline$S_{S}$ & DQO soluble rápidamente biodegradable & $\mathrm{mgDQO} / 1$ \\
\hline SSI & Sólidos suspendidos inorgánicos del lodo activado & $\operatorname{mgSSI} / 1$ \\
\hline$S_{t e}$ & DQO total en el efluente & $\mathrm{mgDQO} / 1$ \\
\hline$S_{\text {te(filt })}$ & DQO soluble en el efluente & $\mathrm{mgDQO} / 1$ \\
\hline$S_{\text {te(unfilt) }}$ & DQO total en el efluente & $\mathrm{mgDQO} / 1$ \\
\hline$S_{t i}$ & DQO total en el afluente & $\mathrm{mgDQO} / 1$ \\
\hline $\mathrm{TRH}_{a}$ & Tiempo de retención hidráulico actual & $\mathrm{d}$ \\
\hline $\mathrm{TRH}_{n}$ & Tiempo de retención hidráulico nominal & $\mathrm{d}$ \\
\hline$T R S$ & Tiempo de retención de sólidos o edad de lodo & $\mathrm{d}$ \\
\hline$V_{0}$ & Velocidad de sedimentación inicial & $\mathrm{m} / \mathrm{h}$ \\
\hline$V_{p}$ & Volumen del reactor biológico & 1 \\
\hline$V_{s}$ & Velocidad de sedimentación & $\mathrm{m} / \mathrm{h}$ \\
\hline$X$ & Materia particulada del lodo activado & $\mathrm{mgSST} / 1$ \\
\hline$X_{B H v}$ & Biomasa de OHOs & $\mathrm{mgSSV} / 1$ \\
\hline$X_{E H v}$ & Residuo endógeno de los OHOs en el lodo activado & $\mathrm{mgSSV} / 1$ \\
\hline$X_{I}$ & Materia no biodegradable del lodo activado en el afluente como DQO & $\mathrm{mgDQO} / 1$ \\
\hline$X_{I O i}$ & Concentración de inorgánicos en el afluente & $\mathrm{mgSSI} / 1$ \\
\hline$X_{I v}$ & Materia no biodegradable del lodo activado en el afluente como SSV & $\mathrm{mgSSV} / 1$ \\
\hline$X_{S}$ & DQO particulada lentamente biodegradable en el afluente & $\mathrm{mgDQO} / 1$ \\
\hline$X_{S i}$ & DQO particulada no biodegradable en el afluente & $\mathrm{mgDQO} / 1$ \\
\hline$X_{s R}$ & $\begin{array}{l}\text { Concentración de sólidos suspendidos en el lodo de recirculación del clarificador } \\
\text { secundario }\end{array}$ & $\mathrm{mgSST} / 1$ \\
\hline$X_{t}$ & Materia orgánica particulada del lodo activado & $\mathrm{mgSST} / 1$ \\
\hline$X_{v}$ & Materia orgánica del lodo activado & $\mathrm{mgSSV} / 1$ \\
\hline$X_{v e}$ & Materia orgánica (volátil) del lodo activado en el efluente & $\mathrm{mgSSV} / 1$ \\
\hline$Y_{H}$ & Rendimiento de los OHOS como DQO & $\mathrm{mgDQO} / \mathrm{mgDQO}$ \\
\hline$Y_{H v}$ & Rendimiento de los OHOS como SSV & $\mathrm{mgSSV} / \mathrm{mgDQO}$ \\
\hline
\end{tabular}




\section{ABREVIACIONES}

\begin{tabular}{|c|c|}
\hline Abreviación & Descripción \\
\hline$\overline{\mathrm{AGVs}}$ & Ácidos grasos volátiles \\
\hline BNR & Remoción biológica de nutrientes (biological nutrient removal, en inglés) \\
\hline $\mathrm{CP}$ & Clarificador primario \\
\hline $\mathrm{CS}$ & Clarificador secundario \\
\hline DBO & Demanda bioquímica de oxígeno \\
\hline DQO & Demanda química de oxígeno \\
\hline $\mathrm{DQO}_{\mathrm{lb}}$ & DQO lentamente biodegradable \\
\hline DQO $_{\mathrm{rb}}$ & DQO rápidamente biodegradable \\
\hline EBPR & Remoción biológica de fósforo (Enhanced biological phosphorus removal, en inglés) \\
\hline $\mathrm{F} / \mathrm{M}$ & Relación alimento-microorganismos (Food to microorganisms ratio, en inglés) \\
\hline IDEA & Aireación extendida decantada intermitentemente (Intermittently decanted extended aeration, en inglés) \\
\hline IVL & Índice volumétrico de lodos \\
\hline $\mathrm{IVL}_{\mathrm{a}}$ & Índice volumétrico de lodos agitados \\
\hline $\mathrm{IVL}_{\mathrm{d}}$ & Índice volumétrico de lodos diluidos \\
\hline NTK & Nitrógeno total de Kjeldahl \\
\hline OD & Oxígeno disuelto \\
\hline OHOs & Organismos heterotróficos ordinarios \\
\hline PAOs & Organismos acumuladores de fósforo (Phosphorus accumulating organisms, en inglés) \\
\hline $\mathrm{PE}$ & Población equivalente \\
\hline Qmáx & Caudal pico (incluyendo aguas lluvia) de aguas residuales \\
\hline Qp,mín & Caudal promedio (sin incluir aguas lluvia) de aguas residuales \\
\hline SS & Sólidos suspendidos \\
\hline SSI & Sólidos suspendidos inorgánicos (o fijos) \\
\hline SSLM & Sólidos suspendidos del licor mezclado \\
\hline SST & Sólidos suspendidos totales \\
\hline $\mathrm{SST}_{\mathrm{e}}$ & Sólidos suspendidos totales en el efluente \\
\hline SSV & Sólidos suspendidos volátiles \\
\hline SSVLM & Sólidos suspendidos volátiles del licor mezclado \\
\hline TRH & Tiempo de retención hidráulica \\
\hline TRS & Tiempo de retención de sólidos o edad de lodos \\
\hline WAS & Lodo de purga (Waste activated sludge, en inglés) \\
\hline Símbolos griegos & Explicación \\
\hline$\Theta_{b H}$ & $\begin{array}{l}\text { Coeficiente de Arrhenius para la corrección por temperatura de la tasa de respiración } \\
\text { endógena de los OHOs }\end{array}$ \\
\hline$\Phi$ & Diámetro del clarificador secundario \\
\hline
\end{tabular}




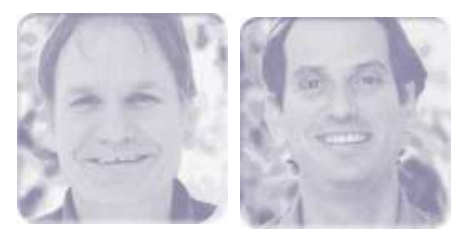

5

\section{Remoción Biológica de Nitrógeno}

\section{George A. Ekama y Mark C. Wentzel}

\subsection{INTRODUCCIÓN A LA NITRIFICACIÓN}

El término nitrificación describe el proceso biológico mediante el cual el amonio libre $\left(\mathrm{NH}_{3}\right)$ y salino $\left(\mathrm{NH}_{4}^{+}\right)$se oxidan a nitrito y subsecuentemente a nitrato. A manera de simplificación, la mayoría de las expresiones y ecuaciones utilizadas en este capítulo se expresarán en términos de $\mathrm{NH}_{4}{ }^{+}-\mathrm{N}$, el cual comprenderá tanto al amoniaco libre como al salino. El proceso de nitrificación se lleva a cabo por un grupo específico de organismos autotróficos (quimiolótrofos) con un comportamiento que difiere significativamente del de los organismos heterótrofos ordinarios (OHOs). Por ejemplo, mientras que los OHOs utilizan los mismos compuestos orgánicos como fuente de carbono y energía (catabolismo) para la síntesis de nueva biomasa (anabolismo), los organismos autotrófos nitrificantes utilizan como fuente de carbón al $\mathrm{CO}_{2}$ disuelto y como fuente de energía para la síntesis de nueva biomasa (anabolismo) a la energía liberada de la oxidación de amonio a nitrito y nitrito a nitrato (catabolismo). Esta diferencia causa que los organismos nitrificantes autótrofos posean coeficientes de crecimiento menores con valores de alrededor de una quinta parte que los $\mathrm{OHOs.}$

Los objetivos de este capítulo son los de repasar de forma breve la cinética de la nitrificación, resaltando los factores que afectan este proceso biológico, y exponer el procedimiento de diseño de un sistema de lodos activados aerobio que incluya el proceso de nitrificación. Se conoce que el proceso de nitrificación ocurre gracias a la actividad de dos grupos de bacterias autótrofas, los organismos oxidantes de amonio (AOOs, por sus siglas en inglés Ammonia oxidizing organisms) y los organismos oxidantes del nitrito (NOOs, por sus siglas en inglés Nitrite oxidizing organisms). Originalmente se pensaba que sólo las bacterias Nitrosomonas y Nitrobacter mediaban el proceso, pero recientes desarrollos en técnicas de identificación y clasificación molecular han mostrado que existen varios organismos nitrificantes, incluyendo bacterias del género Nitrospirae capaces de desempeñar tanto la oxidación de amonio a nitrito como de nitrito a nitrato, proceso conocido como oxidación completa de amonio (COMAMOX, por sus siglas en inglés Complete Ammonium Oxidation) (van Kessel et al., 2015; Daims et al., 2015).

De manera general, se considera que la nitrificación ocurre a través de dos pasos secuenciales de oxidación: (i) de amonio a nitrito debido a la actividad de los AOOs, y (ii) de nitrito a nitrato a través de la actividad de NOOs. Los organismos nitrificantes utilizan amonio y nitrito

() 2017 George A. Ekama. Tratamiento Biológico de Aguas Residuales: Principios, Modelación y Diseño. Eds. M. Henze, M.C.M. van Loosdrecht, G.A. Ekama y D. Brdjanovic. Eds. (versión en español) C.M. López Vázquez, G. Buitrón Méndez, H.A. García, F.J. Cervantes Carrillo. ISBN (versión impresa): 9781780409139, ISBN (e-Book): 9781780409146. Publicado por IWA Publishing, London, UK. 
principalmente para la generación de energía (catabolismo), pero una parte del amonio también se utiliza anabólicamente para la síntesis de nuevas células. Sin embargo, la cantidad de amonio que se utiliza para la síntesis celular corresponde a una fracción prácticamente despreciable ( $1 \%$ como máximo) del total de amonio convertido a nitrato por lor organismos nitrificantes. Consecuentemente, en los modelos en estado estacionario usualmente tienden a ignorarse los requerimientos de nitrógeno de los organismos nitrificantes y simplemente se consideran como catalizadores biológicos del proceso de nitrificación. El uso de este enfoque estequiométrico simplifica la descripción de la cinética del proceso.

Las dos ecuaciones estequiométricas básicas formuladas a partir de las reacciones de reducciónoxidación (redox) involucradas en el proceso de nitrificación son:

$$
\begin{gathered}
\mathrm{NH}_{4}^{+}+\frac{3}{2} \mathrm{O}_{2}(\text { AOOs }) \rightarrow \mathrm{NO}_{2}^{-}+\mathrm{H}_{2} \mathrm{O}+2 \mathrm{H}^{+} \\
\mathrm{NO}_{2}+\frac{1}{2} \mathrm{O}_{2}(\mathrm{NOOS}) \rightarrow \mathrm{NO}_{3}^{-}
\end{gathered}
$$

Estequiométricamente, los requerimientos de oxígeno para las reacciones son respectivamente $3 / 2 \cdot 32 / 14=3.43$ y $1 / 2 \cdot 32 / 14=1.14 \mathrm{mgO}_{2} / \mathrm{mgN}$ (también escrito como $\mathrm{mgO}_{2} / \mathrm{mgNH}_{4}{ }^{+}-\mathrm{N}$ ). Por ende, la reacción completa para la conversión de amonio a nitrato (ambos expresados como $\mathrm{N}$ ), requiere $2 \cdot 32 / 14=4.57 \mathrm{mgO}_{2} / \mathrm{mgN}$. Tomando en cuenta el amonio requerido para la síntesis de masa celular de los organismos nitrificantes, los requerimientos de oxígeno por $\mathrm{mg}$ de $\mathrm{NH}_{4}{ }^{+}-\mathrm{N}$ nitrificado es ligeramente inferior, con valores reportados del orden de $4.3 \mathrm{mgO}_{2} / \mathrm{mgNH}_{4}{ }^{+}-\mathrm{N}$. Este enfoque se utiliza en modelos de simulación como el ASM1 (por sus siglas en inglés, Aerobic Sludge Model 1, Henze et al., 1987) y es una de las razones por las cuales se presentan pequeñas diferencias entre los resultados arrojados por modelos estequiométricos en estado estacionario y por modelos más complejos de simulación dinámica.

\subsection{CINÉTICA DE LA NITRIFICACIÓN}

\subsubsection{Crecimiento}

Para poder hacer una formulación del comportamiento de los organismos nitrificantes es necesario entender la cinética biológica básica del crecimiento de los AOOs. La tasa de conversión de amonio a nitrito, realizada por la actividad de los AOOs, es generalmente mucho más lenta que la tasa de conversión de nitrito a nitrato realizada por los NOOs. Por esta razón, en la mayor parte de las plantas de tratamiento de aguas residuales municipales, cualquier nitrito generado se oxida rápidamente a nitrato. Como consecuencia, la concentracion de nitrito que se observa en el efluente de la mayoría de las plantas de tratamiento de aguas residuales que no presentan ningún tipo de inhibición de la actividad de los NOOs es generalmente baja $(<1 \mathrm{mgN} / 1)$.

Para definir un modelo en estado estacionario y teniendo en cuenta que la tasa que limita el proceso de nitrificación es la conversión de amonio a nitrito, entonces solo es necesario considerar la cinética de los AOOs.

Experimentos realizados por Downing et al. (1964), mostraron que la tasa de nitrificación puede describirse con la ecuación de Monod. De hecho, la cinética de Monod fue utilizada para modelar el proceso de nitrificación antes de ser utilizada en la modelación de la cinética de la degradación de la materia orgánica por parte de los organismos heterótrofos. La exitosa aplicación al proceso de nitrificación impulsó a Lawrence y McCarty (1972) a aplicarla al proceso de lodos activados. Monod estableció que (i) la masa generada de organismos es una fracción constante de la masa de substrato utilizado (amonio en este caso) y (ii) la tasa específca de crecimiento (la tasa de crecimiento por unidad de masa de los organismos por unidad de tiempo) está relacionada con la concentración de substrato a la cual están expuestos los organismos.

$\operatorname{De}(i)$ :

$M \triangle X_{B A}=Y_{A} M \Delta N_{a}$

donde

$\mathrm{M} \Delta \mathrm{X}_{\mathrm{BA}}$ masa generada de organismos nitrificantes [mgSSV]

$\mathrm{M} \Delta \mathrm{N}_{\mathrm{a}} \quad$ masa de amonio (como nitrógeno) utilizado [mgN]

$\mathrm{Y}_{\mathrm{A}} \quad$ Coeficiente estequiométrico de rendimiento de los organismos nitrificantes [mgSSV/mgN]

Tomando los cambios sobre un intervalo de tiempo $t$ $\mathrm{y}$ asumiendo que los cambios son muy pequeños, se 
puede escribir la ecuación previa de la siguiente manera:

$$
\frac{d X_{B A}}{d t}=Y_{A}\left[-\frac{d N_{a}}{d t}\right] \quad[\mathrm{mgAOO}-\mathrm{SSV} / \mathrm{d} . \mathrm{d}]
$$

Monod desarrolló la siguiente relación, conocida comúnmente como la ecuación de Monod:

$$
\mu_{A}=\frac{\mu_{A m} N_{a}}{K_{n T}+N_{a}} \quad[\mathrm{mgSSV} / \mathrm{mgSSV} . \mathrm{d}]
$$

donde:

$\mathrm{N}_{\mathrm{a}} \quad$ concentración de amonio en la masa líquida [mgN/l]

$\mu_{\mathrm{A}}$ tasa específica de crecimiento a una concentración determinada de amonio $\left(\mathrm{N}_{\mathrm{a}}\right)$ [mgAOO-SSV/mgAOO-SSV.d]

$\mu_{\mathrm{Am}}$ tasa específica máxima de crecimiento [mgAOO-SSV/mgAOO-SSV.d]

$\mathrm{K}_{\mathrm{n}} \quad$ constante de saturación media, (la concentración bajo la cual $\mu_{\mathrm{A}}=1 / 2 \mu_{\mathrm{Am}}$ ) [mgN/l]

Las constantes de Monod para la tasa específica máxima de crecimiento $\mu_{\mathrm{Am}}$ y el coeficiente de saturación media (también llamado coeficiente de afinidad) $\left(\mathrm{K}_{\mathrm{n}}\right)$ para los AOOs son sensibles a los cambios en temperatura, generalmente disminuyendo proporcionalmente con el descenso de la temperatura. El subíndice ' $\mathrm{T}$ ' adicional en los símbolos utilizados hace referencia a la temperatura en ${ }^{\circ} \mathrm{C}$.

La tasa de crecimiento está dada por el producto de la tasa específica de crecimiento y la concentración de AOOs $\left(\mathrm{X}_{\mathrm{BA}}\right)$ :

$$
\begin{array}{r}
\frac{d X_{B A}}{d t}=\mu_{A T} X_{B A}=\frac{\mu_{A m T} N_{a}}{K_{n T}+} N_{a} X_{B A} \\
{[\mathrm{mgAOO-SSV/1.d]}}
\end{array}
$$

La tasa de conversión de amonio se puede definir combinando las ecuaciones 5.3 y 5.5 , obteniendo:

$\frac{d N_{a}}{d t}=-\frac{1}{Y_{A}} \frac{\mu_{A m T} N_{a}}{K_{n T}+N_{a}} X_{B A} \quad[\mathrm{mgN} / \mathrm{l} . \mathrm{d}]$

Debido a que en los modelos en estado estacionario se acepta que la nitrificación es un proceso estequiométrico, es decir los organismos nitrificantes actúan solamente como catalizadores del proceso, la tasa de formación de nitrato es igual a la tasa de conversión de amonio libre y salino, dando como resultado:

$$
\begin{array}{ll}
\frac{d N_{n}}{d t}=-\frac{d N_{a}}{d t}= & \\
=\frac{1}{Y_{A}} \frac{\mu_{A m T} N_{a}}{K_{n T}+N_{a}} X_{B A} & {\left[\mathrm{mgNO}_{3}-\mathrm{N} / \mathrm{l} . \mathrm{d}\right]}
\end{array}
$$

donde:

$\mathrm{N}_{\mathrm{n}} \quad$ concentración de nitrato $\left(\mathrm{mgNO}_{3}-\mathrm{N} / \mathrm{l}\right]$

La tasa de utilización de oxígeno asociada a la nitrificación está basada en el requerimiento calculado anteriormente de $4.57 \mathrm{mgO}_{2} / \mathrm{mgNH}_{4}{ }^{+}-\mathrm{N}$, con lo cual se puede estimar el consumo de oxígeno requerido para oxidar cierta concentración de amonio $\mathrm{N}_{\mathrm{a}}$ a nitrato $\mathrm{N}_{\mathrm{n}}$ :

$O_{n}=4.57 \frac{d N_{a}}{d t}=4.57 \frac{d N_{n}}{d t} \quad\left[\mathrm{mgO}_{2} / 1 . \mathrm{d}\right]$

Al igual que en la ecuación 5.7, la ecuación 5.8 asume que la conversión estequiométrica de amonio libre y salino a nitrato resulta en una ligera sobreestimación de la producción de nitrato y por ende en el consumo de oxígeno calculado. Esto es debido a que un cierto porcentaje del amonio consumido por los organismos nitrificantes se usa para la síntesis celular (1\%). Basado en la fórmula empírica $\mathrm{C}_{5} \mathrm{H}_{7} \mathrm{O}_{2} \mathrm{~N}$ usada para describir la masa celular de un organismo, Brink et al. (2007) demostraron que por $1 \mathrm{mgNH}_{4}{ }^{+}-\mathrm{N}$ asimilado, se producen $0.99 \mathrm{mgN}$ como nitrato y $0.076 \mathrm{mgAOO}-\mathrm{SSV}$ con una utilización de $4.42 \mathrm{mgO}_{2} / \mathrm{mgNH}_{4}{ }^{+}-\mathrm{N}$.

La aplicación de la cinética del crecimiento de Monod al proceso de nitrificación por parte de Downing et al. (1964) es probablemente una de las aplicaciones más exitosas de investigación en microbiología y cinética microbiana aplicada al tratamiento de aguas residuales, tanto así que hoy en día la cinética de Monod se utiliza comúnmente para describir muchos procesos biológicos en términos de las concentraciones limitantes de nutrientes. La cinética del crecimiento de Monod requiere el conocimiento de 3 constantes, el rendimiento $\left(\mathrm{Y}_{\mathrm{A}}\right)$, la tasa específica máxima de crecimiento $\left(\mu_{\mathrm{Am}}\right)$ y el coeficiente de saturación media $\left(\mathrm{K}_{\mathrm{n}}\right)$.

El rendimiento de las bacterias nitrificantes representa la masa neta de organismos producida por unidad de masa de substrato (nitrógeno) utilizado. Desde 1960, cuando el modelo de nitrificación fue desarrollado, se observó que el coeficiente de rendimiento varia dependiendo de las condiciones de crecimiento. Sin 
embargo, Downing et al. (1964) establecieron que si bien la variabilidad de $\mathrm{Y}_{\mathrm{A}}$ resultaba en diferentes concentraciones de SSV, esto no debería afectar la determinación experimental de la tasa específica máxima de crecimiento, siempre y cuando se utilizaran valores consistentes $\mu_{\mathrm{Am}}$ y $\mathrm{Y}_{\mathrm{A}}$. Esto se debe a que $\mu_{\mathrm{Am}}$ se obtiene de una tasa específica máxima de nitrificación, $\mathrm{K}_{\mathrm{Am}}$ expresado en $\mathrm{mgNH}_{4}{ }^{+}-\mathrm{N}$ nitrificado por mg AOO-SSV por día, la cual es igual a $\mu_{\mathrm{Am}} / \mathrm{Y}_{\mathrm{A}}$. Si se selecciona un valor de $\mathrm{Y}_{\mathrm{A}}$ bajo, el valor de $\mu_{\mathrm{Am}}$ será tambén bajo $\mathrm{y}$ viceversa. Por ello, para evitar confusiones en la determinación experimental de $\mu_{\mathrm{Am}}$, se adopta un valor típico de $\mathrm{Y}_{\mathrm{A}}=0.10 \mathrm{mgSSV} / \mathrm{mgNH}_{4}{ }^{+}-\mathrm{N}$ ó 0.15 $\mathrm{mgDQO} / \mathrm{mgNH}_{4}{ }^{+}-\mathrm{N}$ en los modelos en estado estacionario y de simulación dinámica de plantas de tratamiento de aguas residuales municipales.

\subsubsection{Cinética del crecimiento}

La Figura 5.1 muestra la relación entre la tasa específica de crecimiento $\left(\mu_{\mathrm{A}}\right)$, la utilización del sustrato específico $\left(\mathrm{NH}_{4}{ }^{+}\right)$o tasa de nitrificación $\left(\mathrm{K}_{\mathrm{A}}\right)$, y la concentración de amonio libre y salino en la fase líquida descrito por la ecuación de Monod (Ec. 5.4).

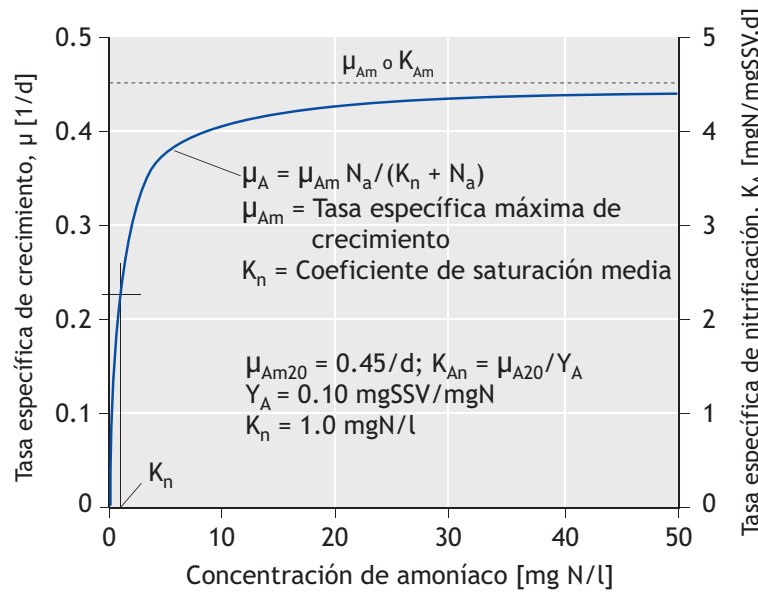

Figura 5.1 Descripción de la tasa específica de crecimiento y nitrificación de los organismos nitrificantes a $20^{\circ} \mathrm{C}$ usando la ecuación de Monod

En la Figura 5.1, los valores seleccionados son $\mu_{\mathrm{Am} 20}=$ $0.45 \mathrm{~d}^{-1}, \mathrm{Y}_{\mathrm{A}}=0.10 \mathrm{mg}$ AOO-SSV formado por $\mathrm{mg} \mathrm{NH}_{4}{ }^{+}-$ $\mathrm{N}$ nitrificado y $\mathrm{K}_{\mathrm{n} 20}=1.0 \mathrm{mgN} / 1$, resultando en $\mathrm{K}_{\mathrm{Am}}=4.5$ $\mathrm{mgNH}_{4}{ }^{+}-\mathrm{N} / \mathrm{mgAOO}-\mathrm{SSV}$.d. Un aspecto interesante es que debido a que $\mathrm{K}_{\mathrm{n}}$ es tan bajo $\left(\sim 1 \mathrm{mg} \mathrm{NH}{ }_{4}{ }^{+}-\mathrm{N} / \mathrm{l}\right)$, la tasa de nitrificación alcanza virtualmente su valor máximo a concentraciones superiores a $2 \mathrm{mgNH}_{4}{ }^{+}-\mathrm{N} / \mathrm{l}$. Sin embargo, a concentraciones menores a $2 \mathrm{mgN} / \mathrm{l}$, la tasa disminuye rápidamente aproximándose a cero. Esto implica que cuando la nitrificación se lleva a cabo, se realiza de forma casi completa (siempre y cuando se cumplan otros requisitos descritos a continuación) pero la concentración de amonio dificílmente se aproximará a cero.

\subsubsection{Respiración endógena}

Generalmente se acepta que todos los organismos experimentan una cierta pérdida de biomasa debido a los requerimientos energéticos de mantenimiento $o$ respiración endógena. Este comportamiento se manifiesta cuando la biomasa ha utilizado completamente el sustrato externo, por lo que su masa (en términos de SSV) disminuye mientras continua consumiendo oxígeno. Este proceso se denomina respiración endógena. Diferentes tipos de organismos muestran diferentes tasas de respiración endógena. Para los OHOs, es alta y del orden de $\mathrm{b}_{\mathrm{H} 20}=0.24 \mathrm{~d}^{-1}$, mientras que para los AOO es baja con valores de $\mathrm{b}_{\mathrm{A} 20}=0.04 \mathrm{~d}^{-1}$. Para el caso de los AOOs, el proceso de respiración endógena se modela de forma similar a la de los OHOs:

$\frac{d X_{B A}}{d t}=-b_{A T} X_{B A} \quad[\mathrm{mgAOO}-\mathrm{SSV} / \mathrm{l} . \mathrm{d}]$

donde:

b tasa específica de respiración endógena para los organismos nitrificantes a $\mathrm{T}^{\circ} \mathrm{C},[\mathrm{mgAOO}-$ $\mathrm{SSV} / \mathrm{mgAOO}-\mathrm{SSV} . \mathrm{d}]$

\subsection{CINÉTICA DEL PROCESO}

El sistema más básico o elemental de lodos activados modelado para el proceso de nitrificación corresponde a un reactor completamente mezclado con control hidráulico de la edad de lodos (ver Figura 4.2). Este sistema bajo condiciones en estado estacionario proporciona la información necesaria para el diseño de un sistema que lleve a cabo el proceso de nitrificación. La solución principal del modelo en estado estacionario es la determinación de la concentración de amonio en el efluente $\left(\mathrm{N}_{\mathrm{ae}}\right)$. Esta solución forma la base del análisis del comportamiento del proceso de nitrificación y arroja la información requerida para el diseño y control del proceso en sistemas de lodos activados. Esta información es a la vez la base para entender el modelado del proceso de nitrificación en modelos dinámicos de simulación de lodos activados como el ASM1. 


\subsubsection{Concentración de amonio en el efluente}

Efectuando un balance de la masa de organismos nitrificantes $\mathrm{M} \Delta \mathrm{X}_{\mathrm{BA}}$ sobre un sistema completamente mezclado en estado estacionario (Figura 4.2), se obtiene:

$$
\begin{aligned}
& M \Delta X_{B A}=\frac{\Delta X_{B A}}{\Delta t} V_{p}= \\
& =\frac{\mu_{A m T} N_{a}}{K_{n T}+N_{a}} X_{B A} V_{p}-b_{A T} X_{B A} V_{p}-X_{B A} Q_{W}
\end{aligned}
$$

[mgAOO-SSV]

donde:

$\mathrm{V}_{\mathrm{p}} \quad$ volumen del reactor [1]

Qw $\quad$ caudal de purga de lodos del reactor [1/d]

Dividiendo por $\mathrm{V}_{\mathrm{p}}$ se obtiene,

$$
\frac{\Delta X_{B A}}{\Delta t}=\frac{\mu_{A m T} N_{a}}{K_{n T}+N_{a}} X_{A T}-b_{A T} X_{B A}-\frac{Q_{W}}{V_{p}} X_{B A}
$$

Bajo condiciones en estado estacionario (carga y caudal constante) $\Delta \mathrm{X}_{\mathrm{BA}} / \Delta \mathrm{t}$ es igual a cero y de la Ec. 4.1: $\mathrm{Q}_{\mathrm{W}} / \mathrm{V}_{\mathrm{p}}=\mathrm{TRS}$. Reemplazando estas expresiones y resolviendo para la concentración de amonio en el reactor $\left(\mathrm{N}_{\mathrm{a}}\right)$, que por la definición de un reactor completamente mezclado es igual a la concentración en el efluente $\left(\mathrm{N}_{\mathrm{ae}}\right)$, la expresión generada es:

$N_{\mathrm{a}}=N_{\mathrm{ae}}=\frac{K_{n T}\left(b_{A T}+1 / T R S\right)}{\mu_{A m T}-\left(b_{A T}+1 / T R S\right)} \quad[\mathrm{mgN} / \mathrm{l}]$

De la ecuación 5.11, puede notarse que las concentraciones de amonio en el reactor $\left(\mathrm{N}_{\mathrm{a}}\right)$ y en el efluente $\left(\mathrm{N}_{\mathrm{ae}}\right)$ son independientes del coeficiente estequimétrico de crecimiento $\left(\mathrm{Y}_{\mathrm{A}}\right)$ y de la concentración de amonio en el afluente. Utilizando $\mu_{\mathrm{Am} 20}=0.33 \mathrm{~d}^{-1}, \mathrm{~K}_{\mathrm{n} 20}$ $=1.0 \mathrm{mgN} / 1$ a $20^{\circ} \mathrm{C}$, y tomando $\mathrm{b}_{\mathrm{AT}}=0.04 \mathrm{~d}^{-1}$ (ver Tabla 5.1), la Figura 5.2 muestra un gráfico de las concentraciones de $\mathrm{N}_{\mathrm{ae}}$ en función de la edad de lodos (TRS). Para edades de lodo altas, $\mathrm{N}_{\mathrm{ae}}$ es bajo a edades del lodo mayores a 4 días. Por debajo de este valor, $\mathrm{N}_{\mathrm{ae}}$ aumenta rápidamente $\mathrm{y}$ en términos de la ecuación 5.11 puede exceder la concentración de amonio libre y salino en el afluente $\left(\mathrm{N}_{\mathrm{ai}}\right)$. Lógicamente esto no es real ni factible ya que el valor $\mathrm{N}_{\mathrm{a}}$ no puede exceder el valor de $\mathrm{N}_{\mathrm{ai}}$, por lo que en la Ec. $5.11 \mathrm{~N}_{\mathrm{a}}=\mathrm{N}_{\mathrm{ai}}$ a edades del lodo demasiado cortas por debajo de las cuales la nitrificación no ocurre. Substituyendo $\mathrm{N}_{\text {ai }}$ por $\mathrm{N}_{\mathrm{a}}$ en la ecuación 5.11 y resolviendo para TRS, se obtiene la edad de lodos mínima requerida para que ocurra el proceso de nitrificación $\left(\mathrm{TRS}_{\mathrm{m}}\right)$, edad debajo de la cual teóricamente el proceso de nitrificación cesa:

$$
T R S_{m}=\frac{1}{\left(1+\frac{K_{n T}}{N_{\mathrm{ai}}}\right) \mu_{A m T}-b_{A T}}
$$

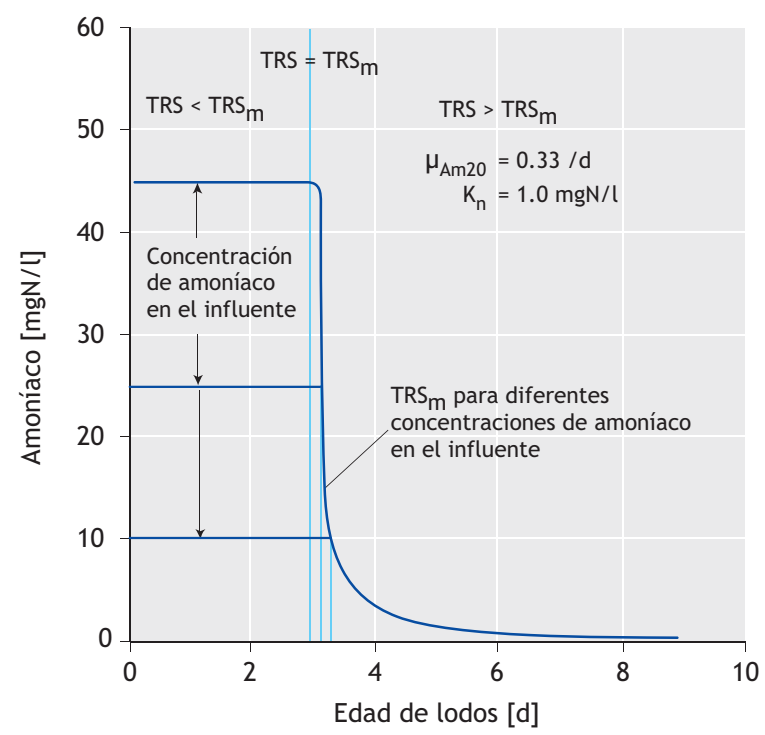

Figura 5.2 Concentración de amonio en el efluente en función de la edad de lodos para el modelo de nitrificación en estado estacionario

Esta ecuación indica que la edad de lodos depende ligeramente de la magnitud de $\mathrm{N}_{\mathrm{ai}}$ (Figura 5.2): entre mayor sea $\mathrm{N}_{\mathrm{ai}}$ el valor de $\mathrm{TRS}_{\mathrm{m}}$ será ligeramente menor.

El efecto de $\mathrm{N}_{\mathrm{ai}}$ en el valor de $\mathrm{TRS}_{\mathrm{m}}$ es muy pequeño debido a que la magnitud de $\mathrm{K}_{\mathrm{nT}}$ es muy baja con relación al valor de $\mathrm{N}_{\mathrm{ai}}(<5 \%)$. Por esta razón para valores de $\mathrm{N}_{\mathrm{ai}}$ $>20 \mathrm{mgN} / \mathrm{l}$ (y tomando en cuenta que raras ocasiones el valor de $\mathrm{N}_{\mathrm{ai}}$ es menor a esta concentración), y observando que $\mathrm{K}_{\mathrm{n} 20} \sim 1 \mathrm{mgN} / \mathrm{l}$, entonces el cociente de $\mathrm{K}_{\mathrm{nT}} / \mathrm{N}_{\mathrm{ai}}$ tiende a ser despreciable con respecto a la unidad. Así, substituyendo $\mathrm{K}_{\mathrm{nT}} / \mathrm{N}_{\mathrm{ai}}$ por cero en la Ecuación 5.12, se obtiene:

$$
T R S_{m}=\frac{1}{\mu_{A m T}-b_{A T}} \quad[\mathrm{~d}]
$$

Para todas las consideraciones prácticas, y tomando en cuenta la incertidumbre que existe en el valor de $\mu_{\mathrm{Am}}$, la Ec. 5.13 define adecuadamente la edad de lodos mínima para que ocurra el proceso de nitrificación. Conceptualmente, la Ec. 5.13 establece que si la tasa neta de crecimiento de los organismos nitrificantes (el inverso de la tasa específica máxima neta de crecimiento, $\mu_{\mathrm{Am}}$ $\mathrm{b}_{\mathrm{A}}$ ) es más lenta que la tasa de purga de los organismos nitrificantes (a través del caudal de purga de lodos), entonces los organismos no tienen el tiempo suficiente 
para crecer dentro del sistema y por ende el proceso de nitrificación no puede llevarse a cabo. A edades de lodo menores que la edad mínima requerida para nitrificación, los organismos son "lavados" o "desechados" del sistema y por esto son llamadas también edades de lodo de "lavado". Este concepto puede aplicarse a cualquier grupo de organismos dentro de un reactor biológico, y define la edad de lodos debajo de la cual un proceso biológico no puede ocurrir porque los organismos encargados de mediar el proceso no pueden crecer debido a que el tiempo de retención de sólidos es menor al tiempo que requieren para crecer y desarollarse, por lo que no pueden ser mantenidos en el sistema.

El valor virtualmente constante del $\mathrm{TRS}_{\mathrm{m}}$ para diferentes concentraciones de amonio libre y salino en el afluente (asumiendo valores fijos de $\mu_{\mathrm{AmT}}$ y $\mathrm{b}_{\mathrm{AT}}$ ), y el rápido incremento de la concentración de amonio (libre y salino) en el efluente para edades de lodos ligeramente superiores a $\mathrm{TRS}_{\mathrm{m}}$, se deben a un valor muy bajo de la constante de saturación media de los organismos nitrificantes $\left(\mathrm{K}_{\mathrm{n} 20}\right)$. Esta característica hace que a medida que se incrementa la edad de lodos (cuando TRS $>\mathrm{TRS}_{\mathrm{m}}$ ) también se incrementa la eficiencia del proceso de nitrificación. Esto puede ocurrir siempre y cuando el amonio libre y salino sea el factor limitante, y por consiguiente que el resto de los requerimientos se cumplan, como por ejemplo que la cantidad de oxígeno suministrada sea suficiente. Consecuentemente, bajo condiciones en estado estacionario y con una edad de lodos creciente, cinéticamente se esperaría que en un sistema de lodos activados no ocurra el proceso de nitrificación y que inicie y se lleve a cabo de forma virtualmente completa una vez que la edad de lodos sea mayor al mínimo requerido para la nitrificación (TRS > $\mathrm{TRS}_{\mathrm{m}}$ ). De manera inversa, a medida que la edad de lodos disminuye, se esperaría que en un sistema de lodos activados se lleve a cabo el proceso de nitrificación de manera completa y que de forma repentina el proceso se detenga en el momento en el cual la edad de lodos sea menor que la edad de lodos mínimo de la nitrificación $\left(\mathrm{TRS}<\mathrm{TRS}_{\mathrm{m}}\right)$.

Este comportamiento puede ocurrir en plantas de lodos activados donde después de muchos años de que el sistema nitrifica de forma virtualmente completa, repentinamente durante un peridod invernal, el sistema detiene completamente el proceso de nitrificación y produce unas concentraciones elevadas de amonio libre y salino en el efluente. Siempre que el suministro de oxígeno no sea un factor limitante, lo que sucede en este tipo de situaciones es que con el paso de los años la carga orgánica (DQO) en el sistema aumenta y para poder mantener la concentración de SSV en el reactor al nivel requerido por los diseños convencionales, el caudal de purga de lodos $\left(\mathrm{Q}_{\mathrm{w}}\right)$ también aumenta, reduciendo la edad de lodos TRS. De continuar esta tendencia, en combinación con las bajas temperaturas invernales, la edad de lodos TRS podría caer por debajo de la edad de lodos mínimo requerida por el proceso de nitrificación $\mathrm{TRS}_{\mathrm{m}}$. Esta situación puede evitarse cuando se realiza un control hidráulico de la edad de lodos, proceso en el cual un volumen constante del reactor es purgado diariamente para poder mantener una edad de lodos constante. No obstante, dependiendo de la sedimentabilidad del lodo en el reactor, el clarificador secundario puede sobrecargarse a medida que la concentración de SST del reactor aumenta durante el tiempo (ver Capítulo 4, Sección 4.10). Un operador de una planta de tratamiento puede elegir el modo en que un sistema de lodos activados falle a medida que aumenta la carga orgánica - lo cual no tiene porque suceder con el proceso de nitrificación y por ende con el de remoción de nitrógeno.

\subsection{FACTORES QUE AFECTAN EL PROCESO DE NITRIFICACIÓN}

De la discusión anterior, puede observarse que existen un número de factores que afectan el proceso de nitrificación, la edad de lodos mínima necesaria para lograrlo y la concentración de amonio libre y salino en el efluente de un sistema de lodos activados, estos incluyen:

1) Tasa específica máxima de crecimiento de los organismos nitrificantes $\mu_{\mathrm{Am} 20}$ : esta "constante" cinética varía considerablemente entre diferentes tipos de agua residual.

2) Temperatura: a medida que esta variable disminuye, disminuye también la tasa $\mu_{\mathrm{Am} 20}$ y aumenta el coeficiente $\mathrm{K}_{\mathrm{n} 20}$.

3) Presencia de zonas no aireadas en el reactor: este factor afecta a los AOOs ya que son organismos aerobios estrictos y solo pueden crecer en condiciones aerobias.

4) Concentración de oxígeno disuelto (OD): la cinética de Monod al asumir que la concentración de amonio libre y salino constituye el nutriente limitante del crecimiento de los AOOs, implica que el suministro de oxígeno es adecuado y suficiente.

5) Condiciones de flujo y cargas cíclicas: debido a que el amonio libre y salino se encuentra en disolución (tanto en el reactor como en el efluente), la concentración del mismo se ve afectada por el tiempo de residencia hidráulico real; la mayor parte de amonio no 
nitrificado durante el tiempo de residencia hidráulico real escapa con el efluente.

6) $\mathrm{pH}$ : el valor de $\mu_{\mathrm{Am} 20}$ es afectado considerablemente por un $\mathrm{pH}$ menor a 7 ó superior a 8 .

Estos 6 factores se discuten en mayor detalle en los siguientes párrafos.

\subsubsection{Características del afluente}

El valor de la tasa específica máxima de crecimiento de los organismos nitrificantes $\mu_{\mathrm{AmT}}$ ha mostrado ser bastante específico con respecto a las características del agua residual, variando inclusive entre diferentes muestras de una misma fuente $u$ origen. Esta característica es tan pronunciada que $\mu_{\mathrm{AmT}}$ no debería ser clasificada como una constante cinética, sino como una característica más del agua residual. Este efecto parece ser causado por la naturaleza inhibitoria de alguna(s) substancia(s) presentes en el afluente. Pero no debido a un problema de toxicidad, ya que se han observado altas eficiencias en el proceso de nitrificación (al aumentar la edad de lodos) aún con valores bajos de $\mu_{\mathrm{AmT}}$. Lo más probable es que substancias inhibitorias estén presentes en los caudales de aguas residuales municipales que tienen aportes industriales importantes. En general, entre mayor sea el aporte o la contribución industrial, más bajo tiende a ser el valor de $\mu_{\mathrm{AmT}}$, pero los compuestos químicos que causan esta disminución de $\mu_{\mathrm{AmT}}$ no han sido aún claramente determinados.

Se ha adoptado una temperatura estándar de $20^{\circ} \mathrm{C}$ para reportar el valor medio de la tasa $\mu_{\mathrm{Am}}$ con respecto al efecto de la temperatura. Así mismo, se han reportado diferentes valores de $\mu_{\mathrm{Am} 20}$ entre 0.30 y $0.75 \mathrm{~d}^{-1}$ para aguas residuales municipales. Estos dos valores límites o extremos tienen un efecto significativo en la magnitud de la edad de lodos mínima requerida para llevar a cabo la nitrificación. Si se consideran estos valores extremos, dos sistemas de tratamiento podrían tener edades de lodos mínimas $\left(\mathrm{TRS}_{\mathrm{m}}\right)$ que difieran entre si hasta en un $250 \%$. Resulta claro que debido al estrecho vínculo entre la edad de lodos y $\mu_{\mathrm{AmT}}$ es necesario estimar el valor de $\mu_{\mathrm{AmT}}$ experimentalmente si se desea alcanzar un diseño óptimo. En casos donde no existen datos experimentales, es necesario seleccionar un valor de $\mu_{\mathrm{AmT}}$ bajo para garantizar la nitrificación en el sistema. Si una vez que la planta inicia su operación el valor real de $\mu_{\mathrm{AmT}}$ es mayor al seleccionado, tanto la edad de lodos como el volumen del reactor serán mayores de los requeridos. No obstante, la inversión destinada a la construcción de un reactor con un volumen más grande del necesario no se pierde ya que en el futuro la planta de tratamiento podrá tratar una carga orgánica más alta con una edad de lodos más baja. Procedimientos experimentales para la determinación de $\mu_{\mathrm{AmT}}$ se pueden encontrar en literatura especializada, por ejemplo en WRC (1984).

La tasa de respiración endógena $b_{n 20}$ se considera constante para todo tipo de aguas residuales municipales con un valor estimado de $0.04 \mathrm{~d}^{-1}$. El efecto de $\mathrm{b}_{\mathrm{n} 20}$ es tan pequeño que no hay necesidad de discutir detalladamente los diferentes factores que afectan su valor. Por otra parte, se tiene poca información sobre los efectos de agentes inhibidores en el valor de $\mathrm{K}_{\mathrm{nT}}$; a pesar de esta falta de información es bastante probable que el valor de $\mathrm{K}_{\mathrm{nT}}$ aumente en presencia de estos agentes.

\subsubsection{Temperatura}

Las "constantes" cinéticas $\mu_{\mathrm{AmT}}, \mathrm{K}_{\mathrm{nT}}$ y $\mathrm{b}_{\mathrm{AT}}$ son altamente sensibles a los cambios de temperatura, siendo las dos primeras más sensibles que la tercera (Tabla 5.1). Los efectos causados por las variaciones de la temperatura pueden estimarse con las siguientes expresiones:

$$
\begin{aligned}
& \mu_{A m T}=\mu_{A m 20}\left(\theta_{n}\right)^{(T-20)} \\
& K_{n T}=K_{n 20}\left(\theta_{n}\right)^{(T-20)} \\
& b_{A T}=b_{A 20}\left(\theta_{b}\right)^{(T-20)}
\end{aligned}
$$$$
\text { [mgN/1] }
$$

donde:

$\theta_{\mathrm{n}} \quad$ coeficiente de Arrhenius de sensibilidad por temperatura para la nitrificación $=1.123$

Tabla 5.1 Constantes cinéticas y estequimétricas típicas y coeficientes de temperatura para los organismos oxidantes de amoníano (AOOs) aceptadas en la mayor parte de los modelos de lodos activados

\begin{tabular}{lllll}
\hline Constante cinética & Símbolo & Unidad & $\mathrm{A} 20^{\circ} \mathrm{C}$ & $\Theta$ \\
\hline Rendimiento & $\mathrm{Y}_{\mathrm{A}}$ & $\mathrm{mgSSV} / \mathrm{mgNH}_{4}{ }^{+}-\mathrm{N}$ & 0.10 & 1.00 \\
Tasa de respiración endógena & $\mathrm{b}_{\mathrm{A}}$ & $1 / \mathrm{d}, \mathrm{d}^{-1}$ & 0.04 & 1.029 \\
$\begin{array}{l}\text { Coeficiente de saturación media } \\
\begin{array}{l}\text { Tasa específica máxima de } \\
\text { crecimiento }\end{array}\end{array} \mathrm{K}_{\mathrm{n}}$ & $\mathrm{mgNH} 4+-\mathrm{N} / 1$ & 1.0 & 1.123 \\
\hline
\end{tabular}


$\theta_{\mathrm{b}}$

coeficiente de Arrhenius de sensibilidad por temperatura para la respiración endógena en el proceso de nitrificación $=1.029$

En particular, el efecto de la temperatura en $\mu_{\mathrm{AmT}}$ es alto. Por cada $6^{\circ} \mathrm{C}$ que disminuye la temperatura, el valor de $\mu_{\text {AmT }}$ se reduce a la mitad, lo que significa que la edad de lodos mínima para nitrificación se duplica. Es por esta razón que el diseño de un sistema que lleve a cabo el proceso de nitrificación debe hacerse considerando la temperatura mínima esperada en el sistema. La sensibilidad de la temperatura de $\mathrm{K}_{\mathrm{nT}}$ es también alta, duplicándose o disminuyendo a la mitad por cada $6{ }^{\circ} \mathrm{C}$ de incremento o reducción. Esto no afecta la edad de lodos mínima, pero si afecta la concentración de amonio libre y salino presente en el efluente; entre mayor sea el valor de $K_{n}$, mayor será la concentración de amonio en el efluente para TRS $>T_{\text {TRS }}$. No obstante, a mayor temperatura, el mayor valor de $\mu_{\mathrm{AmT}}$ compensa el efecto de un valor más alto de $\mathrm{K}_{\mathrm{nT}}$ de tal forma que el efecto neto en la concentración de amonio en el efluente disminuirá al incrementar la temperatura.

\subsubsection{Zonas no aireadas}

El efecto que las zonas no aireadas tienen en el proceso de nitrificación puede definirse o delinearse a partir de las siguientes premisas o consideraciones:

1) Los organismos nitrificantes son aerobios estrictos $y$ solo pueden crecer en las zonas aireadas del sistema.

2) La pérdida de masa endógena de los organismos nitrificantes ocurre en todo el sistema: tanto en zonas aerobias como en zonas no aeradas (anóxicas o anaerobias).

3) La proporción de los organismos nitrificantes en los SSV de las zonas aireadas y no aireadas es similar en todo el sistema de tal forma que las fracciones de masa de lodo de las diferentes zonas también reflejan la distribución de las masas de los organismos nitrificantes.

Con base en las premisas anteriores, se puede demostrar que si una fracción $\mathrm{f}_{\mathrm{xt}}$ de la masa total no es aireada, es decir la fracción aireada corresponde a 1- $\mathrm{f}_{\mathrm{xt}}$; la concentración de amonio en el efluente está dada por:

$N_{\mathrm{ae}}=\frac{K_{n T}\left(b_{A T}+1 / T R S\right)}{\mu_{A m T}\left(1-f_{x t}\right)-\left(b_{A T}+1 / T R S\right)} \quad[\mathrm{mgN} / \mathrm{l}]$

La Ecuación 5.15 es idéntica en estructura a la Ecuación 5.11, aceptando que la fracción de masa no aireada $\left(f_{\mathrm{xt}}\right)$ reduce el valor de $\mu_{\mathrm{AmT}}$ a $\mu_{\mathrm{AmT}}{ }^{*}\left(1-f_{\mathrm{xt}}\right)$, lo cual se desprende de las consideraciones (1) a (3) descritas anteriormente. El enfoque de utilizar una fracción de masa de lodos es compatible con la cinética del proceso de nitrificación de modelos de simulación dinámica de lodos activados tales como el ASM1 y ASM2 (Henze et al., 1987, 1995). En estos modelos el crecimiento de los organismos nitrificantes tiene lugar únicamente en la zona aerobia, mientras que el proceso de respiración endógena ocurre en todas las zonas del sistema de tratamiento. Sin embargo, cabe resaltar que esta consideración no es compatible con los métodos de diseño basados en la edad del lodo aerobio (WEF 1998; Metcalf y Eddy 1991), ya que esos métodos de diseño asumen que tanto los procesos de crecimiento como los de respiración endógena de los organismos nitrificantes ocurren únicamente en la zona aerobia. Estas diferencias explican las diferencias existentes entre los resultados arrojados por los modelos ASM y los modelos basados en la edad de lodos aerobia para el proceso de nitrificación.

Siguiendo el mismo enfoque y las mismas consideraciones postuladas y reflejadas en la Ecuación 5.13, se puede demostrar que la edad de lodos mínima requerida para lograr la nitrificación $\left(\mathrm{TRS}_{\mathrm{m}}\right)$ en un sistema de nitrificación-desnitrificación que cuenta con fracciones de masa no aireadas, $\mathrm{f}_{\mathrm{xt}}$, está dado por:

$$
T R S_{m}=\frac{1}{\mu_{A m T}\left(1-f_{x t}\right)-b_{A T}}
$$

De forma alterna, si se especifica la edad de lodos (TRS), entonces la fracción de la masa de lodos aerobios mínima $\left(1-f_{\mathrm{xt}}\right)$ que debe garantizarse para que el proceso de nitrificación se lleve a cabo se obtiene reemplazando TRS por $\mathrm{TRS}_{\mathrm{m}} \mathrm{y} \mathrm{f}_{\mathrm{xm}}$ por $\mathrm{f}_{\mathrm{xt}}$ en la Ecuación 5.16. Resolviendo para $\left(1-f_{\mathrm{xm}}\right)$ se obtiene:

$\left(1-f_{x m}\right)=\left(b_{A T}+1 / T R S\right) / \mu_{A m T}$

ó, de manera equivalente, de la Ecuación 5.17 la fracción de la masa de lodos no aireada máxima $f_{x m}$ que permita mantener la nitrificación para una edad de lodos determinada TRS es:

$f_{x m}=1-\left(b_{A T}+1 / T R S\right) / \mu_{A m T}$

Para una edad de lodos específica, el valor de diseño de la fracción de la masa de lodos aerobia mínima requerida $\left(1-f_{x m}\right)$ debe ser siempre considerablemente mayor que el valor dado por la Ec. 5.18, debido a que el 
proceso de nitrificación se vuelve inestable y la concentración de amonio en el efluente aumenta cuando el valor de $f_{\mathrm{xm}}$ del sistema se acerca al dado por la Ec. 5.18. Esta situación crítica se incrementa debido a las fluctuaciones y condiciones cíclicas tanto del caudal como de la carga o concentración de amoniaco en el afluente (discutido previamente). En consecuencia, para asegurar que se alcance una concentración baja de amonio en el efluente, la tasa específica máxima de crecimiento de los organismos nitrificantes $\mu_{\mathrm{AmT}}$ debe reducirse utilizando un factor de seguridad $\left(\mathrm{S}_{\mathrm{f}}\right)$ para obtener el valor mínimo de diseño de la fracción de la masa de lodos aerobia de la Ec. 5.18:

$\left(1-f_{x m}\right)=\left(b_{A T}+1 / T R S\right) /\left(\mu_{A m T} / S_{\mathrm{f}}\right)$

De forma alterna, la fracción máxima de la masa de lodos no aireada correspondiente para el diseño se obtiene de la ecuación 5.19A, y está dada por:

$f_{x m}=1-S_{\mathrm{f}}\left(b_{A T}+1 / T R S\right) / \mu_{A m T}$

La Figura 5.3, con ayuda de las ecuaciones que describen la sensibilidad por temperatura del proceso de nitrificación (Ec. 5.14) y la Ec. 5.19, muestra para una temperatura de $14^{\circ} \mathrm{C}$ la fracción máxima de masa de lodos no aireada permitida $\left(\mathrm{f}_{\mathrm{xm}}\right)$ para un valor $\mathrm{S}_{\mathrm{f}}=1.25 \mathrm{y}$ valores de $\mu_{\mathrm{Am} 20}$ en un rango de 0.25 a 0.50 . Como se puede observar, el valor de $\mathrm{f}_{\mathrm{xm}}$ es muy sensible al valor de $\mu_{\text {AmT. }}$. A menos que se seleccione una fracción de masa de lodos aireada $\left(1-f_{x m}\right)$ lo suficientemente alta, el proceso de nitrificación no se llevará a cabo y por consiguiente no será posible la remoción de nitrógeno por medio de la desnitrificación. De hecho, la selección de la fracción máxima de la masa de lodos no aireada necesaria para lograr una nitrificación casi completa que permita alcanzar el nivel de remoción de $\mathrm{N}$ requerido, constituye la decisión más importante en el diseño de un sistema de lodos activados con remoción biológica de nutrientes debido a que esta definirá la edad de lodos, y para una concentración de SSLM, también el volumen del reactor.

De la Ec. 5.15 y 5.19, se puede demostrar que para un caudal constante y una carga de amonio constante (condiciones en estado estacionario):

$N_{a e}=K_{n T} /\left(S_{f}-1\right) \quad[\mathrm{mgN} / 1]$

Si en la Ec. 5.20 para la temperatura mínima del agua residual se selecciona un valor de $\mathrm{S}_{\mathrm{f}}$ de, por ejemplo 1.25 o mayor, la concentración de amonio en el efluente $\left(\mathrm{N}_{\mathrm{ae}}\right)$ será menor a $2 \mathrm{mgNH}_{4}{ }^{+}-\mathrm{N} / 1$ a $14^{\circ} \mathrm{C}$ para $\mathrm{K}_{\mathrm{n} 20}=1.0 \mathrm{mgN} / 1$. Consecuentemente, el diseño de un sistema debe considerar siempre, en la medida de lo posible, la temperatura promedio esperada más baja para la selección de la edad de lodos y de la fracción de masa aireada (aerobia). Si esto es posible y utilizando un valor de $\mathrm{S}_{\mathrm{f}}=1.25$, la Ec. 5.20 indica que la concentración de amonio en el efluente será menor a $2 \mathrm{mgN} / 1$ a la temperatura más baja $\left(14{ }^{\circ} \mathrm{C}\right.$ en este ejemplo) y alrededor de $1 \mathrm{mgN} / 1$ a $20^{\circ} \mathrm{C}$. Así, no es estrictamente necesario realizar un cálculo explícito de $\mathrm{N}_{\mathrm{ae}}$ utilizando la Ecuación 5.15 ya que es posible obtener una nitrificación casi completa si se selecciona un $\mathrm{S}_{\mathrm{f}}$ adecuado. Claramente la selección de valores apropiados para $\mu_{\mathrm{Am} 20}$ y $\mathrm{S}_{\mathrm{f}}$ tienen consecuencias importantes en la concentración de amonio libre y salino en el efluente, y en la economía de un sistema de lodos activados con nitrificación y desnitrificación.

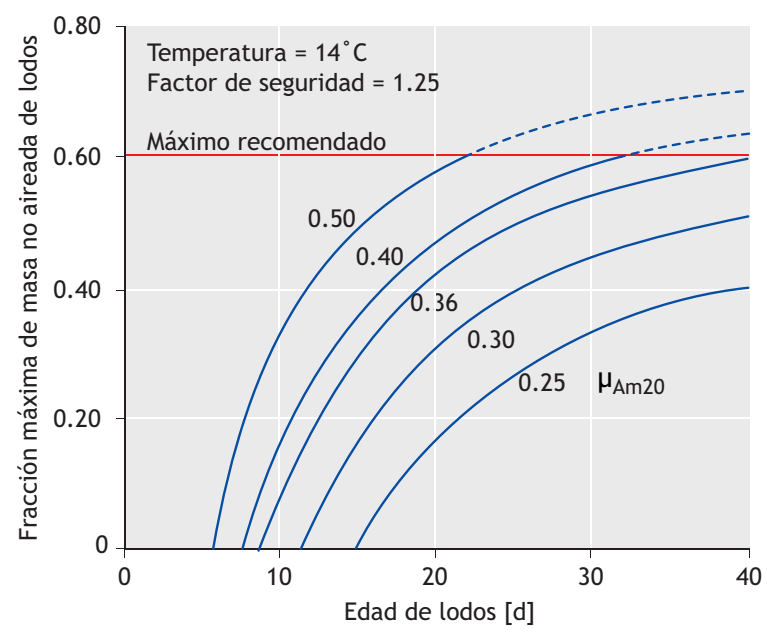

Figura 5.3 Fracción máxima de masa no aireada requerida para garantizar el proceso de nitrificación en función de la edad de lodos para diferentes tasas específicas máximas de crecimiento

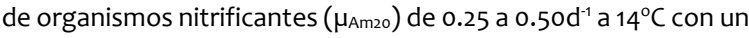
factor de seguridad $\mathrm{S}_{\mathrm{f}}=1.25$

\subsubsection{Fracción máxima permisible de masa no aireada}

Las ecuaciones descritas anteriormente permiten tomar las dos decisiones más importantes en el diseño de un sistema de lodos activados con nitrificacióndesnitrificación, la selección de la fracción máxima de masa de lodos no aireada y la edad de lodos para asegurar una nitrificación casi completa. Evidentemente de la Figura 5.3, para $\mu_{\mathrm{Am} 20}>0.50$ la fracción de masa no aireada a $14{ }^{\circ} \mathrm{C}$ puede llegar a valores de hasta $0.70 \mathrm{con}$ una edad de lodos de 40 días. Esta fracción de masa no aireada parece también aceptable si se tiene un TRS de 
10 días o mayor para una temperatura de $20^{\circ} \mathrm{C}$. No obstante, existen consideraciones adicionales que limitan la selección del valor de la fracción máxima de masa no aireada y la edad de lodos, las cuales incluyen:

1) Experimentos a escala de laboratorio en sistemas con nitrificación-desnitrificación y remoción biológica de fósforo (EBPR, por sus siglas Enhanced Biological Phosphorus Removal) han mostrado que para fracciones de masa no aireada mayores a 0.40 , la presencia de lodo filamentoso puede convertirse en un problema, en particular a bajas temperaturas $\left(<16^{\circ} \mathrm{C}\right)$. Sistemas que operan con una fracción de masa no aireada menor a 0.30 tienden a generar lodos con buena sedimentabilidad. (Musvoto et al., 1994; Ekama et al.,1999; Tsai et al., 2003).

2) En el diseño de plantas de tratamiento con requerimientos elevados de remoción de nitrógeno y fósforo, la fracción de la masa no aireada de lodos requiere usualmente de valores altos $(>40 \%)$. Si el valor de $\mu_{\mathrm{Am} 20}$ es bajo $\left(<0.40 \mathrm{~d}^{-1}\right.$, el cual es un valor usual cuando no se cuenta con información suficiente sobre el valor de $\mu_{\mathrm{Am} 20}$ ) la magnitud de la $f_{\mathrm{xm}}$ necesaria solo puede obtenerse con una edad de lodos elevada (ver Figura 5.3). Por ejemplo, si $\mu_{\mathrm{Am} 20}=0.35 \mathrm{~d}^{-1}$, con $\mathrm{S}_{\mathrm{f}}=1.3$ a $\mathrm{T}_{\min }=14^{\circ} \mathrm{C}$ y $\mathrm{f}_{\mathrm{xm}}=0.45$ (Ec. $5.19 \mathrm{~b}$ ) se requiere una edad de lodos de 25 días mientras que para $f_{x m}=0.55$ se necesita una edad de lodos de 37 días. Para una edad de lodos alta, se requiere un volumen de reactor mayor; y al aumentar el TRS de 25 a 37 días se incrementa el volumen del reactor en un $40 \%$ mientras que $\mathrm{f}_{\mathrm{xm}}$ solo aumentó en un $22 \%$. Adicionalmente, para la misma concentración de fósforo en la masa de lodos, la remoción de fósforo se ve reducida a medida que la edad de lodos aumenta debido a que la purga diaria de lodos disminuye a medida que la edad de lodos se incrementa. Consecuentemente, para valores bajos de $\mu_{\mathrm{Am} 20}$, el aumento en la remoción de nitrógeno y fósforo que puede lograrse aumentando la fracción de masa de lodos no aireada por encima de $0.50-0.60$, no resulta económica debido a los grandes volúmenes requeridos para los reactores, e inclusive pueden ser contraproducentes en lo que concierne a la remoción de fósforo. Una edad de lodos de 30 días probablemente se acerca al límite de practicidad económica de un sistema y bajo esta condición para un valor bajo de $\mu_{\mathrm{Am} 14}=0.16$, la fracción máxima de la masa de lodos no aireada es alrededor de 0.50 . Para valores más altos de $\mu_{\mathrm{Am} 14}$, la edad de lodos que permite una fracción de masa no aireada de 50\% disminuye de forma significativa, resaltando las ventajas que tendría el determinar experimentalmente el valor de $\mu_{\mathrm{Am} 20}$ de tal forma que se pueda corroborar si un valor elevado es aceptable.

3) La necesidad de definir un límite superior para el valor de la fracción de masa no aireada es esencial para el modelado experimental y teórico de sistemas con remoción de nutrientes. Experimentalmente a $20{ }^{\circ} \mathrm{C}$ con $\mathrm{TRS}=20$ días, si $\mathrm{f}_{\mathrm{xm}}>0.70$, la masa de lodos generados se incrementa de forma pronunciada. Teóricamente, esto ocurre para una $\mathrm{f}_{\mathrm{xm}}>0.60 \mathrm{a} \mathrm{T}=$ $14^{\circ} \mathrm{C}$ y TRS $=20$ días. La razón de esto es que para valores tan elevados de $f_{x m}$, la exposición del lodo a condiciones aerobias se vuelve insuficiente para utilizar la materia orgánica particulada y biodegradable atrapada en el mismo (lodo). Esto lleva a una disminución de la masa activa y la demanda de oxígeno, y a un incremento del material orgánico no degradado atrapado en la masa de lodos. Cuando esto sucede, el sistema continúa funcionando pero con una reducción de la remoción de DQO, lo que hace que el sistema se comporte como un reactor de estabilización por contacto, es decir con una floculación biológica con degradación mínima de materia orgánica. Este estado crítico ocurre con valores menores de $f_{x m}$ a medida que la temperatura se disminuye y la edad de lodos se reduce.

De la discusión anterior se puede establecer que la fracción de la masa no aireada no debe ser mayor a $60 \%$, como lo indica la Figura 5.3, e inclusive se recomendaría limitarlo a un máximo de $50 \%$, a menos que exista una razón muy específica para utilizar fracciones no aeradas más grandes.

\subsubsection{Concentración de oxígeno disuelto (OD)}

Concentraciones elevadas de OD, de hasta valores de 33 $\mathrm{mgO}_{2} / 1$, no parecen afectar las tasas de nitrificación de forma significativa. Sin embargo, concentraciones bajas de OD reducen el valor de la tasa de nitrificación. Para tener en cuenta este efecto, Stenstrom y Poduska (1980) sugieren la siguiente fórmula:

$$
\mu_{A, O}=\mu_{A m, T} \frac{O_{2}}{K_{o}+O_{2}}
$$

donde:

$\mathrm{O}_{2} \quad$ concentración de oxígeno disuelto en la fase líquida $\left[\mathrm{mgO}_{2} / 1\right]$ 
$\mathrm{K}_{0} \quad$ constante de saturación media $\left[\mathrm{mgO}_{2} / 1\right]$

$\mu_{\mathrm{Am} 20} \quad$ tasa específica máxima de crecimiento $\left[\mathrm{d}^{-1}\right]$

$\mu_{\mathrm{AO}}$ tasa específica de crecimiento a una concrentración específica de oxígeno en mg/l. $\left[\mathrm{d}^{-1}\right]$

$\mathrm{El}$ valor de $\mathrm{K}_{\mathrm{O}}$ varía entre 0.3 y $2 \mathrm{mgO}_{2} / 1$, es decir que para valores de oxígeno disuelto por debajo de Ko la tasa de crecimiento diminuye a menos de la mitad de la tasa. El amplio rango de valores de $\mathrm{K}_{\mathrm{O}}$ se debe probablemente a las diferencias que existen en la concentración de OD en la masa líquida y en los flóculos donde se lleva a cabo el consumo de oxígeno. En consecuencia, el valor de $\mathrm{K}_{\mathrm{O}}$ depende del tamaño de los flóculos, la intensidad de mezclado y la tasa de difusión de oxígeno dentro del flóculo. Además, en un reactor a escala real, la concentración de OD varía a lo largo del volumen del reactor debido a las entradas puntuales de oxígeno al sistema (con aireación mecánica) y a la imposibilidad de lograr una mezcla completa de forma instantánea. Por estas razones, no es posible establecer un valor mínimo de oxígeno que pueda aplicarse de forma generalizada debido a que los requerimientos de cada reactor van a estar condicionados a las condiciones específicas bajo las cuales operan. En reactores con aireación de burbujas, se recomienda usar comúnmente un valor mínimo de OD de $2 \mathrm{mg} / \mathrm{L}$ para asegurar que el proceso de nitrificación se lleve a cabo.

Bajo caudales y cargas cíclicas se dificulta alcanzar un suministro adecuado de oxígeno que se ajuste a la demanda y a un límite inferior de OD requerido (Capítulo 4, Sección 4.8.2). En lugares donde los caudales de aguas de lluvia son cortos, una alternativa práctica para facilitar el control de la concentración de OD en el reactor es mediante el uso de tanques ecualizadores. De hecho, la mayor parte de las variaciones son una consecuencia directa de la variación diaria (y sobretodo diurna) del caudal, mientras que una variación despreciable se debe a las tasas cinéticas o a los procesos biológicos, especialmente en reactores con una edad alta de lodos. Ante la ausencia de tanques ecualizadores, se puede incrementar la edad de lodos a valores significativamente mayores que el mínimo necesario para la nitrificación, es decir aumentando efectivamente el factor de seguridad $\mathrm{S}_{\mathrm{f}}$. Esto ayudará a disminuir los efectos de las demandas pico de oxígeno.

\subsubsection{Caudales y cargas cíclicas}

Se conoce de forma tanto experimental como teórica a través del uso de modelos de simulación, que bajo condiciones cíclicas de caudal y de carga la eficiencia de nitrificación de un sistema de lodos activados disminuye con respecto a las condiciones en estado estacionario. Diferentes estudios de simulación han demostrado que durante períodos de caudales y/o cargas pico no es posible oxidar todo el amonio disponible (inclusive si los organismos nitrificantes alcanzan su tasa máxima de crecimiento), y por ende se vierte una concentración mayor de amonio con el efluente. Esto a su vez reduce la masa de organismos nitrificantes en el sistema. Esto implica que las variaciones diurnas de cargas y caudales causan un efecto similar o equivalente al que se obtiene cuando se reduce la edad de lodos del sistema. Así, la concentración promedio de amonio en el efluente de un sistema expuesto a condiciones cíclicas es mayor que la concentración promedio de un sistema operado bajo condiciones constantes o estables de carga y caudal (condiciones en estado estacionario).

Los efectos adversos de las variaciones diurnas de caudal se intensifican a medida que la fracción de la amplitud de la variación de los caudales y las cargas aumenta, y se reducen a medida que el factor de seguridad $\left(\mathrm{S}_{\mathrm{f}}\right)$ aumenta. Estudios de simulación sobre el efecto de la variación diurna de caudales muestran una tendencia consistente entre la concentración máxima con respecto a la concentración promedio de amonio libre y salino en el efluente (en estado estacionario) y la edad de lodos del sistema respecto de la edad de lodos mínima requerida para nitrificación $\left(\mathrm{TRS} / \mathrm{TRS}_{\mathrm{m}}\right)$. Para $\mu_{\mathrm{Am} 20}=$ $0.45 \mathrm{~d}^{-1}$ (y las otras constantes presentadas en la Tabla 5.1), las Figuras 5.4 y 5.5 muestran la máxima concentración de amonio libre y salino en el efluente (el valor promedio no se muestra) en función de la edad de lodos del sistema respecto a la edad de lodos mínima requerida para la nitrificación $\left(\mathrm{TRS} / \mathrm{TRS}_{\mathrm{m}}\right)$ para un reactor completamente aerobio recibiendo un caudal y carga cíclica que varía en forma sinusoidal y en fase, con amplitudes de $0.25,0.50,0.75,1.00$ y 0.0 (estado estacionario) a $14^{\circ} \mathrm{C}$ (Figura 5.4) y $22^{\circ} \mathrm{C}$ (Figura 5.5).

Por ejemplo, a $14^{\circ} \mathrm{C}$ (Figura 5.4), si la edad de lodos del sistema es dos veces la edad de lodos mínima para nitrificación, la máxima concentración de amonio libre y salino en el efluente resultante es ocho veces mayor que el valor de la concentración en estado estacionario. De la Figura 5.4, se obtiene el valor en estado estacionario de $0.8 \mathrm{mgN} / \mathrm{l}$ de tal forma que el máximo esperado es $8 \cdot 0.8$ $=6.4 \mathrm{mgN} / 1$.

De las Figuras 5.4 y 5.5 , se puede observar claramente que ha medida que la variación diurna es mayor y la temperatura es menor, mayor es el valor de la 
concentración maxima (y promedio) de amonio en el efluente. Este efecto puede compensarse incrementando el valor de $\mathrm{S}_{\mathrm{f}}$, el cual tiene el efecto de incrementar la edad de lodos o disminuir la fracción de masa no aireada del sistema. Esto a su vez tiene un impacto importante en la calidad del efluente y en la sostenibilidad económica del sistema.

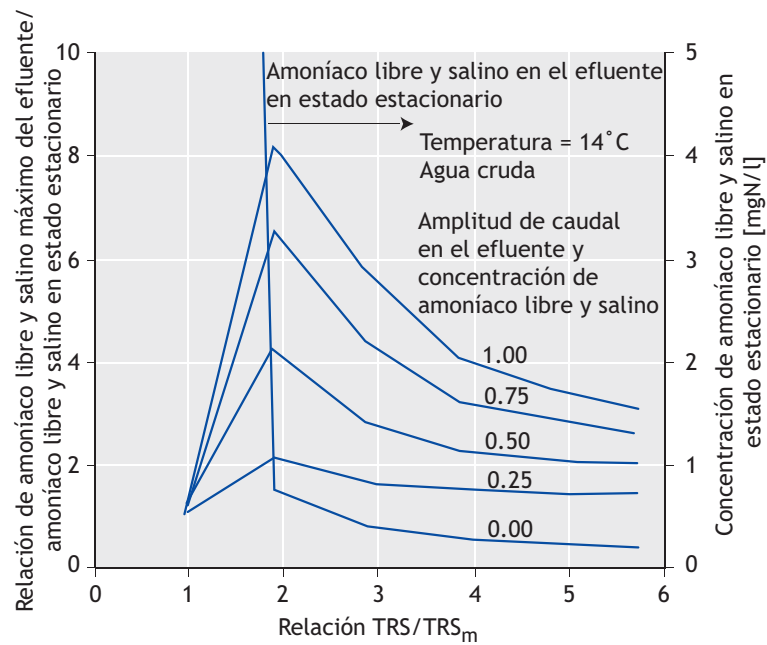

Figura 5.4 Relación de la máxima concentración de amonio (libre y salino) en el efluente y la concentración en estado estacionario en función de la relación entre la edad de lodos y la edad de lodos mínima para nitrificación para el caudal afluente y la amplitud de concentración de amonio (en fase) de 0.0 (estado estacionario) $0.25,0.50,0.75$ y $1.0 \mathrm{a} 14^{\circ} \mathrm{C}$.

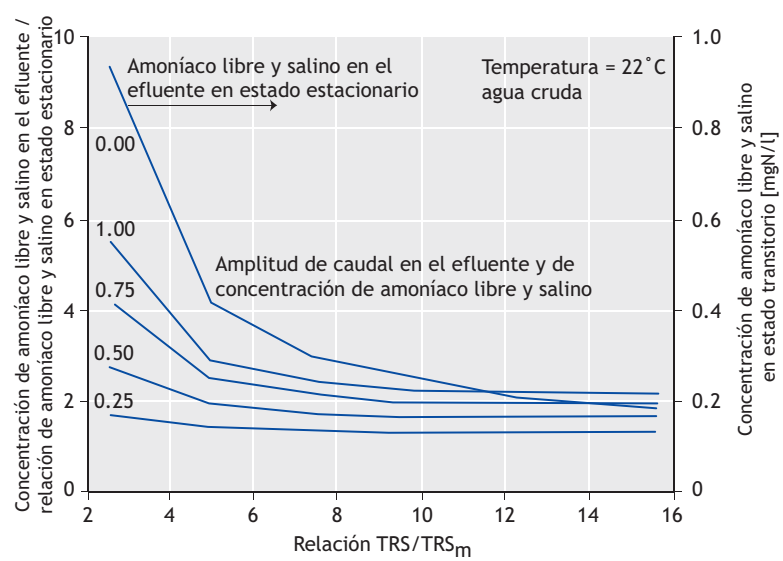

Figura 5.5 Relación de la máxima concentración de amonio (libre y salino) en el efluente y la concentración en estado estacionario, en función de la relación de la edad de lodos y la edad de lodos mínima para nitrificación para el caudal afluente y la amplitud de concentración de amonio (en fase) de 0.0 (estado estacionario) $0.25,0.50,0.75$ y 1.0 a $22^{\circ} \mathrm{C}$

La selección del valor de $\mu_{\mathrm{Am}}$ es esencial para el diseño y operación del sistema. Si el valor de $\mu_{\mathrm{Am}}$ seleccionado es mayor al real, aún con un factor de seguridad de 1.25 a 1.35 , la concentración de amonio en el efluente puede fluctuar, reduciendo la eficiencia del proceso. Por lo tanto, se recomienda seleccionar valores conservadores de $\mu_{\mathrm{Am}}$ (bajos) y de $\mathrm{S}_{\mathrm{f}}$ (altos) para asegurar la estabilidad de la nitrificación y bajas concentraciones de amonio en el efluente.

\subsection{6 $\mathrm{pH}$ y alcalinidad}

Fuera de un rango de $\mathrm{pH} 7-8$, la tasa $\mu_{\mathrm{Am}}$ es muy sensible a los cambios de $\mathrm{pH}$ del licor mezclado. Parece ser que tanto del ion hidrógeno o protón $\left(\mathrm{H}^{+}\right)$como el ion hidroxilo $\left(\mathrm{OH}^{-}\right)$tienen un efecto inhibitorio a medida que sus respectivas concentraciones se incrementan. Esto ocurre cuando el $\mathrm{pH}$ aumenta por encima de 8.5 (aumento de iones $\mathrm{OH}^{-}$) o disminuye por debajo de 7.0 (aumento de iones $\mathrm{H}^{+}$). Las tasas óptimas de nitrificación se encuentran entre $7.0<\mathrm{pH}<8.5$ con una disminución abrupta fuera de este rango.

De las ecuaciones generales de la nitrificación (Ecuación 5.1A), se observa que el proceso de nitrificación libera protones lo cual disminuye la alcalinidad del licor mezclado. Por cada $1 \mathrm{mgNH}_{4}{ }^{+}-\mathrm{N}$ que se nitrifica se consumen $2 \cdot 50 / 14=7.14 \mathrm{mg}$ de alcalinidad (como $\mathrm{CaCO}_{3}$ ). Basados en el equilibrio químico del carbonato (Loewenthal and Marais, 1977), se pueden desarrollar ecuaciones que relacionen el $\mathrm{pH}$ y la alcalinidad a cualquier concentración de dióxido de carbono. Estas relaciones se muestran en la Figura 5.6.

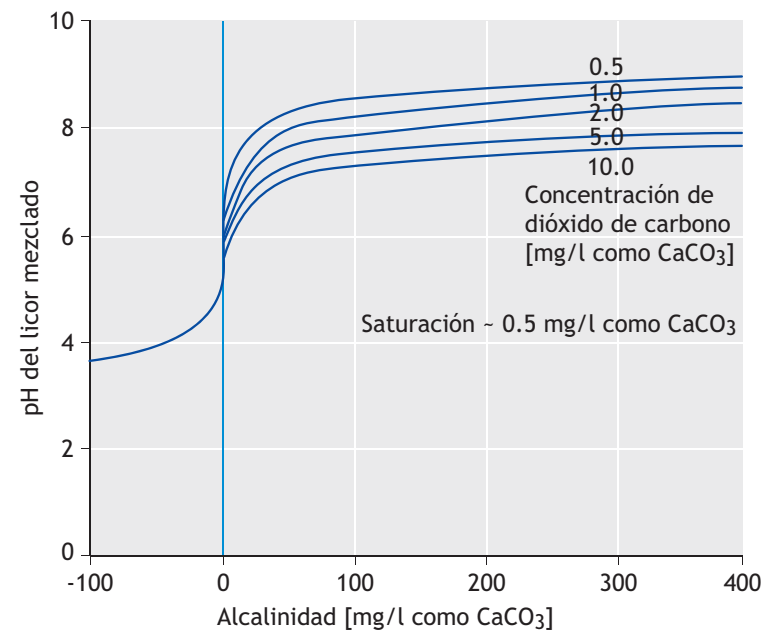

Figura $5.6 \mathrm{pH}$ del licor mezclado en función de la alcalinidad para diferentes concentraciones de dióxido de carbono

Cuando la alcalinidad cae por debajo de $40 \mathrm{mg} / \mathrm{l}$ como $\mathrm{CaCO}_{3}$, independientemente de la concentración de dióxido de carbono, el pH se vuelve inestable y decrece. Generalmente, esto ocasiona una caída en la eficiencia del proceso de nitrificación, efluentes agresivos con el 
concreto y la posibilidad de que se formen flóculos filamentosos (de pobre sedimentabilidad) (Jenkins et al., 1993).

Para un agua residual en particular, el efecto de la nitrificación en el $\mathrm{pH}$ puede evaluarse rápidamente de la siguiente forma. Por ejemplo, si el agua residual tiene una alcalinidad de $200 \mathrm{mg} / 1$ como $\mathrm{CaCO}_{3}$ y la producción esperada de nitrato es $24 \mathrm{mgN} / 1$, entonces la alcalinidad esperada del efluente va a ser $(200-7.17 * 24)=29 \mathrm{mg} / \mathrm{l}$ como $\mathrm{CaCO}_{3}$. De la Figura 5.6 se observa que el efluente tendrá un $\mathrm{pH}<7.0$.

Aguas residuales con baja alcalinidad se encuentran comúnmente en poblaciones donde el suministro de agua potable proviene de áreas abundantes en rocas o piedras sedimentarias. Un enfoque práctico a la hora de tratar este tipo de aguas residuales es el de (1) dosificar cal, ó mejor aún (2) crear una zona anóxica para desnitrificar una parte del nitrato producido. A diferencia de la nitrificación, la desnitrificación consume protones lo que equivale a generar alcalinidad. Debido a que el nitrato es un aceptor de electrones, puede demostrarse que por cada $\mathrm{mg}$ de nitrato desnitrificado, se produce un aumento de 1 - 50/14 = 3.57 mg de alcalinidad como $\mathrm{CaCO}_{3}$. Por ende, al incorporar el proceso de desnitrificación en un sistema con nitrificación, la pérdida neta de alcalinidad se reduce a valores que generalmente mantienen el valor de la alcalinidad por encima de $40 \mathrm{mg} / \mathrm{l}$ y como consecuencia el $\mathrm{pH}$ por encima de 7.0. En el ejemplo anteriormente descrito, donde se espera que la alcalinidad del sistema se reduzca a $29 \mathrm{mg} / 1$ como $\mathrm{CaCO}_{3}$, si el 50\% del nitrato se desnitrifica, la ganancia en alcalinidad sería de $(0.5 \cdot$ $24 \cdot 3.57)=43 \mathrm{mg} / 1$ como $\mathrm{CaCO}_{3}$ y resultaría en una alcalinidad en el sistema de $(29+43)=72 \mathrm{mg} / \mathrm{l}$ como $\mathrm{CaCO}_{3}$. Bajo estas circunstancias el $\mathrm{pH}$ del sistema se mantendrá por encima de 7.0. Para aguas con baja alcalinidad es por lo tanto imperativo que se incluya el proceso de desnitrificación en las plantas con nitrificación, aun si los requerimientos técnicos no exijan la remoción de nitrógeno. La incorporación de zonas no aireadas tiene influencia en la edad de lodos del sistema bajo la cual se lleva a cabo la nitrificación, por lo que debe tenerse en cuenta el efecto de las zonas anóxicas (o no aireadas) en la selección de la edad de lodos de un sistema con nitrificación-desnitrificación (Ver Sección 5.4.4).

En sistemas de lodos activados que tratan aguas residuales con una alcalinidad adecuada y capacidad de amortiguamiento suficiente, el efecto del $\mathrm{pH}$ en el proceso de nitrificación no es crítico y no requiere cuantificarse debido a que la reducción de $\mathrm{pH}$ puede limitarse u obviarse completamente incluyendo zonas anóxicas y por ende asegurando la recuperación de la alcalinidad a través del proceso de desnitrificación. No obstante, en aguas con una baja capacidad de amortiguamiento, o con un contenido alto de nitrógeno en el afluente (como son los licores producto de la digestión anaerobia), la interacción entre los procesos biológicos, $\mathrm{pH}$ y nitrificación constituye el punto más importante para la remoción de nitrógeno en un sistema de lodos activados. Por lo tanto, es esencial incluir el efecto del $\mathrm{pH}$ en la tasa de nitrificación para este tipo de aguas residuales y así poder cuantificar esta importante interacción.

De la Ecuación 5.4, la tasa específica de crecimiento de los AOOs $\left(\mu_{\mathrm{A}}\right)$ es función tanto de $\mu_{\mathrm{Am}}$ como de $K_{n}$. En los párrafos anteriores se demostró que la edad de lodos mínima tiene una alta dependiencia de $\mu_{\mathrm{AmT}}$, y que el $\mathrm{TRS}_{\mathrm{m}}$ solo es ligeramente influenciado por $\mathrm{K}_{\mathrm{nT}}$. Sin embaergo, a TRS $>>\mathrm{TRS}_{\mathrm{m}}$, la concentración de amonio en el efluente $\left(\mathrm{N}_{\mathrm{ae}}\right)$, aunque baja, es relativamente más alta que $K_{n T}$ : por ejemplo si $K_{n T}$ se duplica, la concentración de amonio en el efluente también se duplicará (Ec. 5.15). Por lo tanto, el valor de $\mathrm{K}_{\mathrm{nT}}$ gobierna la concentración de amonio en el efluente una vez que se lleva a cabo el proceso de nitrificación cuando TRS $>>$ $\mathrm{TRS}_{\mathrm{m}}$.

Se han realizado varios estudios con el fin de entender el efecto del $\mathrm{pH}$ en el valor de $\mu_{\text {Аmт }}$. Estas investigaciones generalmente no han logrado analizar por separado el efecto de $\mu_{\mathrm{AmT}}$ y $K_{\mathrm{nT}}$, de tal forma que la mayor parte de la información disponible se enfoca en $\mu_{\mathrm{AmT}}$. Casi no existe información respecto al efecto del $\mathrm{pH}$ en $\mathrm{K}_{\mathrm{nT}}$. El uso de modelos cuantitativos en la evaluación del efecto del $\mathrm{pH}$ sobre $\mu_{\mathrm{Am}}$ se ha visto obstaculizado por la dificultad de medir con precisión los efectos del pH en el proceso de nitrificación. Existen estudios que han demostrado que el valor de $\mu_{\mathrm{Am}}$ puede expresarse como un porcentaje del valor máximo obtenido a un $\mathrm{pH}$ óptimo. Aceptando este enfoque y ausmiendo que $\mu_{\mathrm{Am}}$ es máximo y permanece constante a un $\mathrm{pH}$ en el rango de $7.2<\mathrm{pH}$ $<8.0$, pero que disminuye a medida que el $\mathrm{pH}$ cae por debajo de 7.2 (Downing et al., 1964; Loveless and Painter 1968; Sötemann et al., 2005) diversos autores han formulado la siguiente expresión de la relación $\mu_{\mathrm{A}}-\mathrm{pH}$ (válida para $5.0<\mathrm{pH}<7.2$ ):

$\mu_{A m p H}=\mu_{A m 7.2} \theta_{n s}{ }^{(p H-7.2)}$ 
donde:

$\theta_{\text {ns }} \quad$ coeficiente de sensibilidad para $\mathrm{pH}=2.35$

Para valores de $\mathrm{pH}>8.0$ se ha observado que el valor

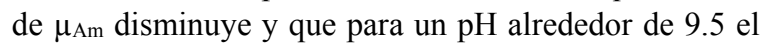
proceso de nitrificación cesa (Malan and Gouws, 1966; Wild et al., 1971; Antoniou et al., 1990). En consecuencia, para $\mathrm{pH}>7.2$, Sötemann et al. (2005) propusieron la Ec. 5.22b para modelar el declive del valor de $\mu_{\mathrm{Am}}$ desde $\mathrm{pH}>7.2$ hasta 9.5 como una función de $\mu_{\mathrm{Am} 7.2}$ utilizando la cinética de inhibición siguiente:

$$
\mu_{A m p H}=\mu_{A m 7.2} K_{I} \frac{K_{\max }-p H}{K_{\max }+K_{I I}-p H}
$$

donde:

$\begin{array}{ll}\mathrm{K}_{\mathrm{I}} & 1.13 \\ \mathrm{~K}_{\max } & 9.5 \\ \mathrm{~K}_{\mathrm{II}} & \approx 0.3\end{array}$

El efecto del $\mathrm{pH}$ en el valor $\mu_{\mathrm{Am}}$ puede modelarse mediante la combinación de las Ecuaciones 5.22a y $5.22 \mathrm{~b}$, la cual se muestra en la Ec. 5.22c y en la Figura 5.7. Puede verse que en el rango de $\mathrm{pH}$ entre 7.2 y 8.3 , el cambio de $\mu_{\mathrm{AmpH}}$ es pequeño, con $\mu_{\mathrm{AmpH}} / \mu_{\mathrm{Am} 7.2}>0.9$ :

$$
\mu_{A m p H}=\mu_{A m 7.2} 2.35^{(p H-7.2)} K_{I} \frac{K_{\max }-p H}{K_{\max }+K_{I I}-p H}
$$

donde:

$$
\text { para } \mathrm{pH}>7.2: \quad 2.35^{(\mathrm{pH}-7.2)}=1,
$$$$
\text { para } \mathrm{pH}<7.2: \quad K_{I} \frac{K_{\max }-p H}{K_{\max }+K_{I I}-p H}=1
$$

$$
\text { y para } \mathrm{pH}>9.5: \quad \quad \quad \mu_{\mathrm{AmpH}}=0 .
$$

En la Figura 5.7 se muestran también datos experimentales recopilados de la literatura con el fin de analizar el perfil generado con la Ecuación 5.22c. A pH bajo (<7.2), los datos de Wild et al. (1971) y Antoniou et al. (1990) se ajustan a la ecuación de forma razonable. Existen muy pocos datos para $\mathrm{pH}>8.5$, pero los pocos datos proporcionados por Antoniou et al. (1990) muestran un ajuste razonable con la Ecuación 5.22c.

En consecuencia, la Ec. $5.22 \mathrm{c}$ es válida para calcular el valor de $\mu_{\mathrm{AmpH}}$ en el rango de $\mathrm{pH}$ de 5.5 a 9.5. De la Ec. 5.22c, la edad mínima para nitrificación $\left(\mathrm{TRS}_{\mathrm{m}}\right)$ a diferentes valores de $\mathrm{pH}$, temperatura $(\mathrm{T}) \mathrm{y}$ fracción de masa no aireada $\left(f_{\mathrm{xm}}\right)$ está dada por:

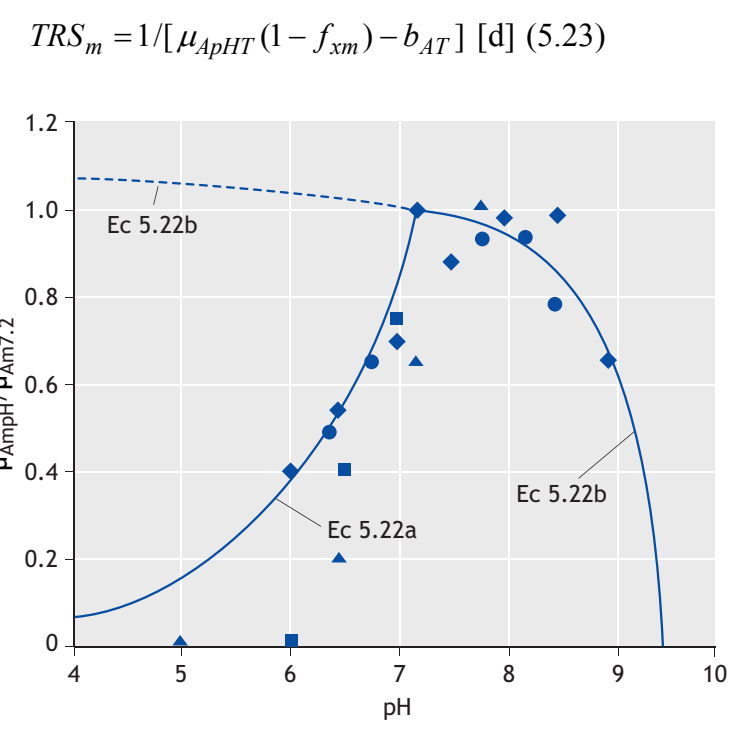

Figura 5.7 Tasa específica máxima de crecimiento de los organismos nitrificantes en función del pH de la fase líquida. La predicción del modelo está descrita por la línea continua. Los datos discretos proceden de Malan y Gouws (1966); Downing et al. (1964); Wild et al. (1971); y Antoniou et al. (1990)

El problema de la nitrificación con aguas residuales de baja alcalinidad es que el $\mathrm{pH}$ resultante del proceso no se puede calcular ya que depende de las interacciones entre el grado de nitrificación, la pérdida de alcalinidad, el $\mathrm{pH}$ у $\mu_{\text {Арнт. }}$ Para poder investigar esta interacción, Sötemann et al. (2005) integró al modelo biológico cinético ASM1 para el carbono (C) y la remoción de nitrógeno, un modelo mixto químico cinético de ácidos/bases débiles de dos fases (líquido-gas) para poder así extender la aplicación del ASM1 en situaciones donde sea importante estimar el valor del $\mathrm{pH}$ en los reactores biológicos. Esta integración, la cual incluyó la generación de $\mathrm{CO}_{2}\left(\mathrm{y} \mathrm{N}_{2}\right)$ gaseoso producto de los procesos biológicos y de su volatización debido a la aireación, también toma en cuenta entre otras cosas el efecto del $\mathrm{pH}$ en los organismos nitrificantes. En la simulación de un sistema de lodos activados con nitrificación-desnitrificación, con una edad de lodos alta y con un alcalinidad en el afluente $\left(\mathrm{H}_{2} \mathrm{CO}_{3}\right)$ decreciente, cuando la alcalinidad cayó por debajo de alrededor de 50 $\mathrm{mg} / \mathrm{l}$ como $\mathrm{CaCO}_{3}$ el pH del reactor aerobio llegó a un valor de 6.3. Esto retardó severamente el proceso de nitrificación y causó que la edad de lodos mínima del sistema $\left(\right.$ TRS $_{\mathrm{m}}$ ) se incrementara hasta la edad de lodos de operación del sistema. La simulación confirmó esta conclusión previa de que en un tratamiento de aguas residuales con baja alcalinidad: (1) la edad de lodos mínima para nitrificación $\left(\mathrm{TRS}_{\mathrm{m}}\right)$ varía con la temperatura y el $\mathrm{pH}$ del reactor y (2) para una alcalinidad 
baja en el efluente $\left(<50 \mathrm{mg} / 1\right.$ como $\left.\mathrm{CaCO}_{3}\right)$ la nitrificación se vuelve inestable y sensible a las condiciones de cargas dinámicas. Esto último puede resultar en un incremento en la concentración de amonio en el efluente, limitando la remoción de nitrógeno y reduciendo la eficiencia de la nitrificación. Si la alcalinidad en el efluente es menor a $50 \mathrm{mg} / \mathrm{l}$, debe dosificarse cal en el afluente para aumentar el $\mathrm{pH}$ del reactor y estabilizar los procesos de nitrificación y remoción de nitrógeno.

\subsection{REQUERIMIENTOS DE NUTRIENTES PARA LA PRODUCCIÓN DE LODOS}

Todo el material biológico y una parte de los compuestos orgánicos no biodegradables contienen nitrógeno $(\mathrm{N})$ y fósforo (P). La masa orgánica de lodos (SSV) que se acumula en el reactor biológico comprende la fracción activa de organismos $\left(\mathrm{X}_{\mathrm{BH}}\right)$, el residuo endógeno $\left(\mathrm{X}_{\mathrm{EH}}\right)$ y el material orgánico particulado no biodegradable $\left(\mathrm{X}_{\mathrm{I}}\right)$, cada uno de los cuales contiene N y P. De pruebas de laboratorio de nitrógeno total Kjeldhal (NTK) y SSV se ha encontrado que el contenido de $\mathrm{N}$ (contenido de $\mathrm{N}$ por $\mathrm{mg}$ de SSV, f, $\mathrm{mgN} / \mathrm{mgSSV}$ ) oscila entre 0.09 y 0.12 con un valor promedio de aproximadamente 0.10 $\mathrm{mgN} / \mathrm{mgSSV}$ en lodos activados. De forma similar, de pruebas de fósforo total y SSV, el contenido de $\mathrm{P}$ en sistemas de lodos activados aerobios puros y lodos activados anóxicos (contenido de $\mathrm{P}$ por $\mathrm{mg}$ de SSV, $\mathrm{f}_{\mathrm{p}}$, $\mathrm{mgP} / \mathrm{mgSSV}$ ) varía en un rango de 0.01 y 0.03 con un valor promedio de $0.025 \mathrm{mgP} / \mathrm{mgSSV}$. El modelo en estado estacionario muestra que las proporciones relativas de organismos activos $\left(\mathrm{X}_{\mathrm{BH}}\right)$, residuo endógeno $\left(\mathrm{X}_{\mathrm{EH}}\right)$ y materia orgánica particulada no biodegradable $\left(\mathrm{X}_{\mathrm{I}}\right)$ varían con la edad de lodos. Sin embargo, se ha encontrado que el valor de $f_{n}$ de los SSV permanece relativamente constante alrededor de $0.10 \mathrm{mgN} / \mathrm{mgSSV}$. Esto indica que el contenido de $\mathrm{N}$ de los organismos activos $\left(\mathrm{X}_{\mathrm{BH}}\right)$, del residuo endógeno $\left(\mathrm{X}_{\mathrm{EH}}\right)$ y de la materia orgánica particulada no biodegradable $\left(\mathrm{X}_{\mathrm{I}}\right)$ son cercanos a un mismo valor. Si lo anterior no fuera cierto y variaran de forma significativa, se observaría que el valor de $f_{n}$ cambiaría de una forma consistente con la edad de lodos. De manera similar, para sistemas completamente aerobios, los contenidos de $\mathrm{P}$ de los tres componentes del lodo activado son aproximadamente similares e iguales a $0.025 \mathrm{mgP} / \mathrm{mgSSV}$.

\subsubsection{Requerimientos de nitrógeno}

La masa de N (o P) que se incorpora diariamente a la masa de lodos se calcula mediante un balance de $\mathrm{N}$ sobre el sistema de lodos activados completamente mezclado (Figura 4.2) bajo condiciones en estado estacionario:

Masa de NTK saliente $=$ Masa de NTK entrante

Masa de NTK entrante $=Q_{i} \mathrm{~N}_{\mathrm{ti}}=\mathrm{FN}_{\mathrm{ti}}[\mathrm{mgN} / \mathrm{d}]$

Masa de NTK saliente $=$ Masa de NTK $Q_{e}$ y $Q_{w}$

$=N_{\mathrm{te}} Q_{\mathrm{e}}+\mathrm{N}_{\mathrm{te}} \mathrm{Q}_{\mathrm{w}}+\mathrm{f}_{\mathrm{n}} X_{\mathrm{v}} \mathrm{Q}_{\mathrm{w}}$

Teniendo en cuenta que $Q_{w}+Q_{e}=Q_{i}$ y que $Q_{w}=V_{p} / T R S$ se obtiene:

$Q_{i} N_{t e}=Q_{i} N_{t i}-f_{n} X_{v} V_{p} / T R S$

del cual:

$N_{t e}=N_{t i}-f_{n} M X_{v} /\left(Q_{i} \cdot T R S\right) \quad[\mathrm{mgN} / \mathrm{l}]$

donde:

$\mathrm{N}_{\mathrm{te}} \quad$ concentración de NTK en el efluente $[\mathrm{mgN} / \mathrm{l}]$

El último término en la Ecuación 5.24 se denomina $\mathrm{N}_{\mathrm{s}}$ y corresponde a la concentración de NTK en el afluente en $\mathrm{mgN} / \mathrm{l}$ que se incorpora a la masa de lodos (ya sea por requerimientos metabólicos de $\mathrm{N}$ para sintetizar más biomasa o presentes en la materia particulada no biodegradable) y que es removido del sistema en la purga de lodos como masa de lodo particulado $\left(\mathrm{Q}_{\mathrm{w}}\right)$ :

$N_{s}=f_{n} M X_{v} /\left(Q_{i} \cdot T R S\right) \quad[\mathrm{mgN} / \mathrm{l}]$

Del balance de masa del N, la fracción de nitrógeno no incluye el nitrógeno en disolución en el lodo purgado. La concentración de NTK soluble en el caudal de purga es igual a la concentración de NTK en el efluente $\left(\mathrm{N}_{\mathrm{te}}\right)$, la cual corresponde al nitrógeno soluble en forma de amonio $\left(\mathrm{N}_{\mathrm{ae}}\right)$ y nitrógeno orgánico soluble no biodegradable ( $\left.\mathrm{N}_{\text {ouse }}\right)$. Por lo tanto, de la Ecuación 5.24, y asumiendo que los organismos nitrificantes no pueden crecer en el sistema por lo que la nitrificación de amonio a nitrato no se lleva a cabo, la concentración de NTK en el efluente $\left(\mathrm{N}_{\mathrm{te}}\right)$ está dada por:

$N_{t e}=N_{t i}-N_{s}$

$[\mathrm{mgN} / \mathrm{l}]$

De la Ecuación 5.24, bajo condiciones diarias promedio, la concentración de $\mathrm{N}$ en el afluente requerida para el crecimiento microbiano y para su incorporación en la masa de lodos es igual al contenido de $\mathrm{N}$ de la masa de lodos (SSV) purgado diariamente dividido por el caudal afluente. Substituyendo la Ecuación 4.12, que relaciona la masa de lodos (SSV) en el reactor $\left(\mathrm{MX}_{\mathrm{v}}\right)$ a la carga orgánica promedio que ingresa al reactor $\left(\mathrm{FS}_{\mathrm{ti}}\right)$, 
cancelando $\mathrm{Q}_{\mathrm{i}} \mathrm{y}$ dividiendo a ambos lados de la expresión por $\mathrm{S}_{\mathrm{ti}}$, se obtiene una expresión que indica la concentración de $\mathrm{N}$ requerido por caudal afluente para la producción de lodos por carga orgánica:

$$
\begin{aligned}
& \frac{N_{s}}{S_{t i}}=f_{n}\left[\frac{\left(1-f_{S^{\prime} u s}-f_{S^{\prime} u p}\right) Y_{H v}}{\left(1+b_{H} T R S\right)}\left(1+f_{H} b_{H} T R S\right)+\frac{f_{S^{\prime} u p}}{f_{c v}}\right] \\
& \quad[\mathrm{mgN} / \mathrm{mgDQO}]
\end{aligned}
$$

El NTK en el afluente incluye al amonio y al nitrógeno presente en los compuestos orgánicos solubles y particulados de naturaleza biodegradable y no biodegradable. La materia orgánica no biodegradable, alguna de la cual contiene nitrógeno orgánico, no se degradada en el sistema de lodos activados. El nitrógeno orgánico soluble no biodegradable en el afluente $\left(\mathrm{N}_{\text {ousi }}\right)$ sale del sistema junto con el efluente (y en los caudales de purga de lodos). La materia orgánica particulada no biodegradable es atrapada en la masa de lodos del reactor y por ende el nitrógeno orgánico asociado a este material sale del sistema por medio de la purga diaria de lodos (SSV). El nitrógeno contenido en el material orgánico biodegradable ( $\mathrm{N}_{\text {obsi }}$ and $\mathrm{N}_{\text {obpi }}$ ) es liberado como amonio libre y salino cuando estos compuestos son degradados. Esta producción de amonio libre y salino se suma al contenido del reactor que viene del afluente. Una parte del amonio libre y salino en el reactor es consumido por los OHOs para formar más biomasa. Una parte de la biomasa de OHOs en el reactor se pierde a través del proceso de respiración endógena. El nitrógeno asociado con la fracción biodegradable de la masa de OHOs se libera como amonio libre y salino dentro del reactor pero el nitrógeno no biodegradable del residuo endógeno permanece como nitrógeno orgánico ligado a los SSV del residuo endógeno.

Debido a estas interacciones es posible que la concentración de amonio libre y salino del efluente en un sistema de lodos activados sin nitrificación, sea mayor que la concentración en el afluente. Esto sucede cuando el contenido de NTK en el afluente incluye a una fracción elevada de nitrógeno orgánico biodegradable (una circunstancia común en varias aguas residuales industriales). Si las condiciones son favorables para el proceso de nitrificación, la concentración neta de amonio libre y salino en el reactor puede estar disponible para la nitrificación, así como también para el crecimiento de los organismos presentes en el sistema.

A menos que sea asimilado por los OHOs en el proceso de crecimiento o nitrificado, el amonio libre y salino permanece inalterado y sale del sistema con el efluente. De esta forma, en ausencia de nitrificación, la concentración de amonio en el efluente $\left(\mathrm{N}_{\mathrm{ae}}\right)$ está dada por:

$$
\begin{array}{r}
N_{a e}=N_{a i}+N_{o b s i}+N_{o b p i}-\left(N_{s}-N_{o u p i}\right) \\
{[\mathrm{mgN} / 1]}
\end{array}
$$

y la concentración de NTK en el efluente $\left(\mathrm{N}_{\mathrm{te}}\right)$ está dada por:

$$
N_{\text {te }}=N_{\text {ouse }}+N_{a e} \quad[\mathrm{mgN} / \mathrm{l}]
$$

El mismo enfoque puede utilizarse para los requerimientos de fósforo en la producción de lodos. Aceptando que el contenido de $\mathrm{P}$ en el lodo activado de un sistema completamente aerobio sin remoción biológica adicional de $\mathrm{P}$ es $0.025 \mathrm{mgP} / \mathrm{mgSSV}$, la concentración total de $\mathrm{P}$ en el efluente $\left(\mathrm{P}_{\mathrm{te}}\right)$ es:

$P_{t e}=P_{t i}-P_{s}$

[mgP/l]

donde:

$\frac{P_{s}}{S_{t i}}=f_{p} \frac{M X_{v}}{Q_{i} T R S}=\frac{f_{p} N_{s}}{f_{n} S_{t i}} \quad\left[\mathrm{mgP} / 1_{\text {afluente }}\right]$

\subsubsection{Remoción de N (y P) por medio de la producción de lodos}

La Figura 5.8 muestra un gráfico de la las Ecuaciones 5.27 y 5.31 contra la edad de lodos para $\mathrm{f}_{\mathrm{n}}=0.10$ $\mathrm{mgN} / \mathrm{mgSSV}$ y $\mathrm{f}_{\mathrm{p}}=0.025 \mathrm{mgP} / \mathrm{mgSSV}$ para las aguas residuales cruda y clarificada del ejemplo. Es evidente que se requieren mayores concentraciones de NTK y fósforo total para la producción de lodo en aguas residuales crudas que en aguas residuales clarificadas. Esto se debe a que se producen mayores cantidades de lodo por mg de carga de DQO en el reactor a una edad de lodo determinada con aguas residuales crudas (ver Capítulo 4, Sección 4.9). Adicionalmente, los requerimientos de $\mathrm{N}$ y $\mathrm{P}$ disminuyen a medida que la edad de lodos aumenta debido a que la producción neta de lodo disminuye con un incremento en la edad de lodos. Generalmente para edades de lodo mayores de 10 días, la remoción de $\mathrm{N}$ del agua residual atribuible a la producción neta de lodos es menor a $0.025 \mathrm{mgN} / \mathrm{mgDQO}$ en el reactor. A medida que las relaciones de NTK/DQO en el afluente para aguas domésticas están en el rango de 0.07 a 0.13 (Figura 5.8), es claro que solo una fracción menor del NTK del afluente (A en la Figura 5.8) se 
remueve incorporándose a la masa de lodos. La remoción adicional de $\mathrm{N}$ (B en la Figura 5.8) se obtiene transfiriendo el $\mathrm{N}$ disuelto en la fase líquida a la fase gaseosa a través de la nitrificación autotrófica y las desnitrificación heterotrófica, la cual transforma el nitrato en gas nitrógeno en los reactores anóxicos (no aireados). Los detalles de la desnitrificación heterotrófica se presentan en secciones posteriores.

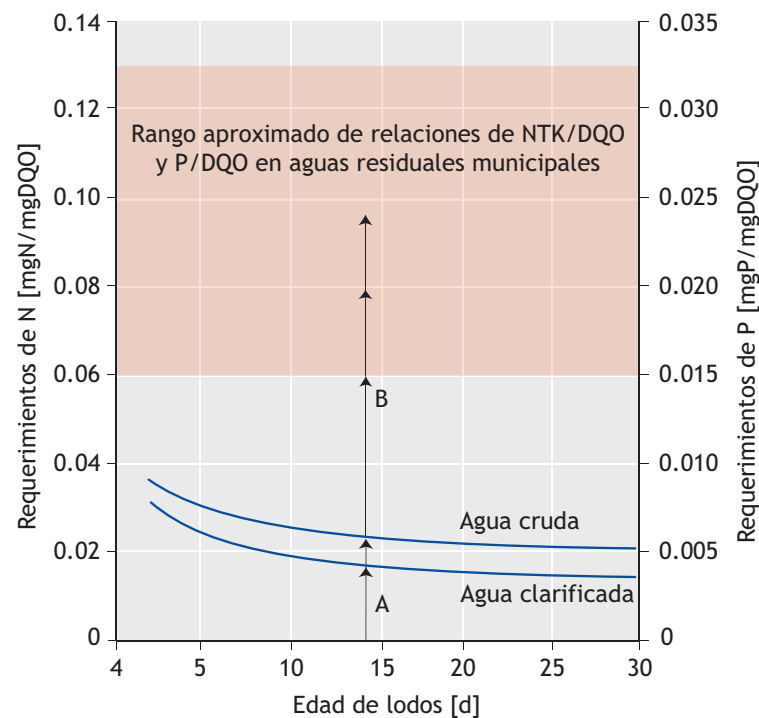

Figura 5.8 Requerimientos mínimos aproximados de nutrientes (nitrógeno y fósforo) como NTK en $\mathrm{mgN} /$ lafluente $_{\text {y fósforo total en }}$ $\mathrm{mgP} / \mathrm{l}_{\text {afluente }}$ por $\mathrm{mgDQO} / \mathrm{I}$ de carga orgánica en el reactor de lodos activados en función de la edad de lodos para las aguas residuales crudas y clarificadas a $20^{\circ} \mathrm{C}$ del ejemplo de diseño. Se incluyen los rangos promedio de la relación de concentración de NTK/DQO y fósforo-total/DQO en aguas residuales municipales.

De la Figura 5.8 se puede observar que la remoción normal de fósforo debido a su incorporación en la masa biológica de lodos está limitada a alrededor de 0.006 y $0.004 \mathrm{mgP} / \mathrm{mdDQO}$ para aguas residuales crudas y clarificadas respectivamente, alcanzando una remoción de fósforo total de alrededor del 20 al $25 \%$ en aguas residuales municipales promedio. Ya que la transformación de ortofosfato (disuelto) a la fase gaseosa no es posible, para poder incrementar la remoción de fósforo de la fase líquida una cantidad de ortofosfato adicional necesita ser incorporada a la masa de lodos. Esto puede lograrse de dos formas (i) químicamente y/o (ii) biológicamente.

Con la remoción química se dosifican sales de hierro o aluminio (sulfatos o cloruros) en el afluente (precipitación), en el reactor de lodos activados (precipitación simultánea), o en el efluente final (postprecipitación). La desventaja de la remoción química de fósforo es que incrementa significativamente (i) la salinidad del agua residual tratada, (ii) la producción de lodos debido a los sólidos inorgánicos que se forman y (iii) la complejidad y el costo de la planta de tratamiento.

Con la remoción biológica de fósforo, las condiciones ambientales en el reactor biológico se diseñan de tal forma que un grupo específico de organismos heterotróficos (llamados organismos acumuladores de fósforo, PAOs por sus siglas en inglés, Phosphorus accumulating organisms) crezcan en el reactor de lodos activados. Mediante la acumulación intracelular de polifosfatos, estos organismos tienen un contenido mucho más alto de $\mathrm{P}$ que los organismos heterotróficos ordinarios (OHOs), alcanzando hasta $0.38 \mathrm{mgP} / \mathrm{mgPAO}$ SSV (Wentzel et al., 1990). Entre mayor sea el número de PAOs que crecen en el reactor, mayor será el contenido promedio de fósforo en la masa de lodos (SSV) y por ende mayor será la remoción de fósforo a través de la purga de lodos. Con una masa significativa de PAOs presente en el reactor biológico, el contenido promedio de fósforo en los SSV de la masa de lodos se puede incrementar de $0.025 \mathrm{mgP} / \mathrm{mgSSV}$ en sistemas aerobios hasta $0.10 \mathrm{o}$ incluso $0.15 \mathrm{mgP} / \mathrm{mgSSV}$ en sistemas con remoción biológica de $\mathrm{N}$ y $\mathrm{P}$. La ventaja de remover el fósforo biológicamente comparado con una remoción química es que $(i)$ la salinidad del agua residual tratada no se incrementa, (ii) la producción de lodos solo aumenta entre un 10 y $15 \%$, (iii) el sistema es menos complejo de operar y (iv) menos costoso. Una desventaja de la remoción biológica de fósforo es que, siendo un proceso biológico, es menos fiable y más variable que la remoción química. Los procesos biológicos que median la remoción de $\mathrm{P}$ y $\mathrm{N}$ en sistemas de lodos activados y las diferentes configuraciones de reactores disponibles para efectuar el proceso se describen en el Capítulo 7.

\subsection{CONSIDERACIONES DE DISEÑO}

Las ecuaciones cinéticas que describen las interacciones entre el amonio libre y salino y el nitrógeno orgánico son complejas y han sido desarrolladas para los modelos de simulación de lodos activados ASM1 y ASM2 siguiendo el enfoque de crecimiento-muerte-regeneración. No obstante, para condiciones en estado estacionario se puede desarrollar un modelo simple de nitrificación teniendo en cuenta la cinética del proceso de nitrificación y los requerimientos de nitrógeno para la producción de lodos, asumiendo que (i) todo el material orgánico es utilizado en el reactor y ( $i$ i) se cumple un balance de masa del NTK sobre el sistema de lodos activados. Este modelo es adecuado para el diseño en estado estacionario 
y de él se pueden desarrollar gráficos de respuesta del sistema tratando el agua residual cruda y clarificada del ejemplo de diseño. La respuesta detallada del sistema puede determinarse a través de modelos de simulación dinámica una vez que se tiene ( $i$ ) el diseño del sistema de lodos activados incluyendo la edad de lodos, volúmenes y zonas en los reactores, y los caudales y relaciones de recirculación, y (ii) las concentraciones en estado estacionario a utilizar como condiciones iniciales en los modelos de simulación.

En el diseño de un sistema de lodos activados con nitrificación es necesario calcular $(i)$ las concentraciones de amonio libre y salino y nitrato en el efluente, y (ii) la demanda de oxígeno necesario para nitrificación.

\subsubsection{Concentración de NTK en el efluente}

El NTK filtrado presente en el efluente $\left(\mathrm{N}_{\mathrm{te}}\right)$ incluye el amonio libre y salino $\left(\mathrm{N}_{\mathrm{ae}}\right)$ y el nitrógeno orgánico soluble no biodegradable $\left(\mathrm{N}_{\text {ouse }}\right)$. Una vez que se han seleccionado los valores de $\mu_{\mathrm{Am} 20}, \mathrm{f}_{\mathrm{xt}}$, TRS y $\mathrm{S}_{\mathrm{f}}$, las ecuaciones que describen estas concentraciones son:

1) Amonio libre y salino en el efluente $\left(\mathrm{N}_{\mathrm{ae}}\right)$ : $\mathrm{N}_{\mathrm{ae}}$ está dado por la Ecuación 5.15, la cual aplica únicamente si $\mathrm{TRS}>\mathrm{TRS}_{\mathrm{m}}$ y $\mathrm{S}_{\mathrm{f}}>1.0$.

2) Concentración de nitrógeno orgánico soluble biodegradable $\left(\mathrm{N}_{\text {obse }}\right)$ : La materia orgánica biodegradable (tanto la soluble como la particulada) son descompuestas por los OHOs liberando el nitrógeno ligado orgánicamente como amonio libre y salino. En el modelo en estado estacionario se asume que todo el material orgánico biodegradable es degradado. Por ende, la concentración de nitrógeno orgánico soluble biodegradable en el efluente $\left(\mathrm{N}_{\mathrm{obse}}\right)$ es cero.

3) Concentración de nitrógeno orgánico soluble no biodegradable ( $\mathrm{N}_{\text {ouse }}$ ): Al no ser biodegradable, esta concentración de nitrógeno orgánico fluye a través del sistema de lodos activados y sale con el efluente de tal forma que la concentración en el efluente $\left(\mathrm{N}_{\text {ouse }}\right)$ es igual a la concentración en el afluente $\left(\mathrm{N}_{\text {ousi }}\right)$ :

$$
N_{\text {ouse }}=N_{\text {ousi }}
$$

donde:

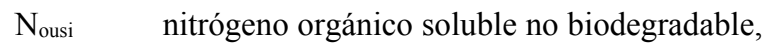
$\operatorname{mgOrgN-N} / 1=\mathrm{f}_{\mathrm{N}}$ 'ous $\mathrm{N}_{\mathrm{ti}}$ donde $\mathrm{f}_{\mathrm{N}}$ 'ous es la fracción de nitrógeno orgánico no biodegradable del NTK en el afluente $\left(\mathrm{N}_{\mathrm{ti}}\right)$.
Estas dos concentraciones de NTK en el efluente $\left(\mathrm{N}_{\mathrm{ae}}\right.$ y Nouse) son solubles y por ende escapan con el efluente (y en la purga de lodos). El NTK soluble (filtrado) en el efluente $\left(\mathrm{N}_{\mathrm{te}}\right)$ está dado por su suma, obteniendo:

$N_{t e}=N_{a e}+N_{\text {ousi }} \quad$ [NTK filtrado]

Si la muestra del efluente no se ha filtrado, la concentración de NTK en el efluente será mayor debido a la concentración adicional de NTK en los SSV en el efluente, dando como resultado:

$N_{t e}=N_{a e}+N_{\text {ouse }}+f_{n} X_{v e} \quad[\mathrm{NTK}$ no filtrado $]$

donde:

$\mathrm{X}_{\mathrm{ve}} \quad$ concentración de SSV en el efluente [mgSSV/l]

$\mathrm{f}_{\mathrm{n}} \quad$ contenido de $\mathrm{N}$ de los $\mathrm{SSV} \sim 0.1$

[mgOrgN-N/mgSSV]

\subsubsection{Capacidad de nitrificación}

Haciendo un balance de masa, para un sistema que opera con TRS $>\mathrm{TRS}_{\mathrm{m}}$, la concentración de nitrato producido en el sistema $\left(\mathrm{N}_{\mathrm{ne}}\right)$ con respecto del caudal afluente está dado por la concentración de NTK en el afluente $\left(\mathrm{N}_{\mathrm{ti}}\right)$ menos el NTK soluble en el efluente $\left(\mathrm{N}_{\mathrm{te}}\right)$ y menos la concentración de NTK del afluente que se incorpora a la masa de lodos purgados diariamente $\left(\mathrm{N}_{\mathrm{s}}\right)$, obteniendo:

$N_{n e}=N_{c}=N_{t i}-N_{t e}-N_{s}$

La concentración $\mathrm{N}_{\mathrm{s}}$ se determina de la masa de nitrógeno que se incorpora a la masa de SSV diariamente (Ec. 5.27). La masa de SSV en el reactor $\left(\mathrm{MX}_{\mathrm{v}}\right)$ estrictamente no necesita incluir la masa de los organismos nitrificantes debido a que su aporte a la masa total de microorganismos es, como se mencionó anteriormente, despreciable $(<2-4 \%)$.

En la Ec. 5.35, $\mathrm{N}_{\mathrm{c}}$ define la capacidad de nitrificación de un sistema de lodos activados. La capacidad de nitrificación $\left(\mathrm{N}_{\mathrm{c}}\right)$ es la masa de nitrato producido mediante el proceso de nitrificación en $\mathrm{mgNO}_{3}-\mathrm{N} / \mathrm{l}$. En la Ec. 5.27, la concentración de NTK en el efluente $\left(\mathrm{N}_{\mathrm{te}}\right)$ depende de la eficiencia en el proceso de nitrificación. En el cálculo de la fracción máxima de masa de lodos no aireada $\left(f_{x m}\right)$ para una edad de lodos determinada, si el factor de seguridad $\left(\mathrm{S}_{\mathrm{f}}\right)$ se seleccionó entre 1.25 y $1.35 \mathrm{a}$ la temperatura mínima de operación $\left(\mathrm{T}_{\min }\right)$, la eficiencia esperada para la nitrificación es alta $(>95 \%)$ y $\mathrm{N}_{\mathrm{ae}}$ será, en la mayoría de los casos, menor a 1-2 mgN/1. 
Adicionalmente, utilizando $\mathrm{S}_{\mathrm{f}}>1.25$ a $\mathrm{T}_{\min }, \mathrm{N}_{\mathrm{ae}}$ es virtualmente independiente tanto de la configuración del sistema como de la subdivisión de la masa de lodos en fracciones aireadas y no aireadas. En consecuencia, para el diseño de un sistema, utilizando $\mathrm{S}_{\mathrm{f}}>1.25, \mathrm{~N}_{\mathrm{te}}$ tiende a tener un valor alrededor de 3 a $4 \mathrm{mgN} / 1$ siempre y cuando se tenga certeza que el valor actual de $\mu_{\mathrm{Am} 20}$ no es menor que el valor seleccionado para el diseño y que existe una capacidad de aireación suficiente, de tal forma que la nitrificación no sea inhibida por un suministro insuficiente de oxígeno. Una vez que se aceptan los valores calculados de $f_{x m}$ y la edad de lodos (TRS) a la temperatura más baja esperada $\left(\mathrm{T}_{\min }\right)$, se puede tener la seguridad de que a temperaturas más altas la eficiencia de nitrificación aumenta al igual que el factor de seguridad $\left(\mathrm{S}_{\mathrm{f}}\right)$ obteniendo en verano con temperaturas máximas $\left(\mathrm{T}_{\max }\right)$ una concentración $\mathrm{N}_{\mathrm{te}}$ más baja, de aproximadamente $2-3 \mathrm{mgN} / 1$.

Dividiendo la Ec. 5.35 por la concentración total de DQO en el afluente $\left(\mathrm{S}_{\mathrm{ti}}\right)$, se obtiene la capacidad de nitrificación por $\mathrm{mgDQO}$ aplicado al reactor biológico, $\mathrm{N}_{\mathrm{c}} / \mathrm{S}_{\mathrm{ti}}$ :

$$
N_{c} / S_{t i}=N_{t i} / S_{t i}-N_{t e} / S_{t i}-N_{s} / S_{t i}
$$

donde:

$\mathrm{N}_{\mathrm{c}} / \mathrm{S}_{\mathrm{ti}}$ capacidad de nitrificación por mgDQO aplicada al sistema de lodos activados [mgN/mgDQO].

$\mathrm{N}_{\mathrm{ti}} / \mathrm{S}_{\mathrm{ti}} \quad$ relación de NTK/DQO en el agua residual afluente.

$\mathrm{N}_{\mathrm{s}} / \mathrm{S}_{\mathrm{ti}} \quad$ nitrógeno requerido para la producción de lodos por mgDQO aplicado (de la Ec. 5.27).

La relación de la capacidad de nitrificación y la concentración de DQO en el afluente $\left(\mathrm{N}_{\mathrm{c}} / \mathrm{S}_{\mathrm{ti}}\right)$ de un sistema puede estimarse de forma aproximada evaluando cada uno de los términos en la Ecuación 5.36 de la siguiente forma:

$\mathrm{N}_{\mathrm{ti}} / \mathrm{S}_{\mathrm{ti}} \quad$ Esta relación corresponde a una característica del agua y puede obtenerse de las mediciones de concentración de NTK y DQO en el afluente - varía de 0.07 a 0.10 para aguas residuales municipales crudas y de 0.10 a 0.14 para aguas residuales clarificadas.

$\mathrm{N}_{\mathrm{te}} / \mathrm{S}_{\mathrm{ti}} \quad$ Siempre y cuando las condiciones para una nitrificación eficiente se cumplan a la temperatura más baja ( $\left.\mathrm{T}_{\mathrm{mí}}\right)$, el NTK en el efluente a $\mathrm{T}_{\text {mín }}\left(\mathrm{N}_{\mathrm{te}}\right)$ se mantendrá bajo en valores de $\sim 2-3 \mathrm{mgN} / \mathrm{l}$, es decir que para concentraciones de DQO en el afluente $\left(\mathrm{S}_{\mathrm{ti}}\right)$ entre 1,000 y $500, \mathrm{~N}_{\mathrm{te}} / \mathrm{S}_{\mathrm{ti}}$ variará entre $0.005 \mathrm{y}$ 0.010. Con $\mathrm{T}_{\max }, \mathrm{N}_{\text {te }}$ será igual a $1-2 \mathrm{mgN} / 1$ hacienda más baja la relación de $\mathrm{N}_{\mathrm{te}} / \mathrm{S}_{\mathrm{ti}}$.

$\mathrm{N}_{\mathrm{s}} / \mathrm{S}_{\mathrm{ti}} \quad$ Obtenido de la Ec. 5.27.

La Figura 5.9 muestra una representación gráfica de la importancia relativa de las relaciones descritas anteriormente para la capacidad de nitrificación, $\mathrm{N}_{\mathrm{c}} / \mathrm{S}_{\mathrm{t}}$, a $14^{\circ} \mathrm{C}$ (Figura 5.9A) y a $22^{\circ} \mathrm{C}$ (Figura 5.9B). Estas figuras fueron obtenidas graficando $\mathrm{N}_{\mathrm{c}} / \mathrm{S}_{\mathrm{ti}}$ contra la edad de lodos para relaciones seleccionadas de NTK/DQO $\left(\mathrm{N}_{\mathrm{ti}} / \mathrm{S}_{\mathrm{ti}}\right)$ en el afluente de $0.07,0.08$ y 0.09 para las aguas residuales crudas del ejemplo teniendo en cuenta una remoción en la clarificación primaria de $40 \%$ y $15 \%$ para la DQO y NTK, respectivamente, obteniendo relaciones de NTK/DQO de $0.113,0.127$ y 0.141 para el agua residual clarificada. Adicionalmente, se muestran las edades de lodo mínimas para nitrificación para diferentes valores $0.0,0.2,0.4$ y 0.6 de la fracción de masa de lodos no aireada y para el $\mu_{\mathrm{Am} 20}$ de ejemplo con un valor de 0.45 $\mathrm{d}^{-1}$. Para una fracción de masa de lodos no aireada en particular, los valores graficados de $\mathrm{N}_{\mathrm{c}} / \mathrm{S}_{\mathrm{ti}}$ son únicamente válidos a edades de lodo mayores que la correspondiente edad de lodo mínima. Finalmente, estas figuras muestran las magnitudes relativas de los tres términos que afectan la capacidad de nitrificación contra la edad de lodos y la temperatura.

1) Temperatura: Para poder lograr una nitrificación completa a $14^{\circ} \mathrm{C}$ (para una $\mathrm{f}_{\mathrm{xm}}$ seleccionada), la edad de lodos requerida es más del doble que para una temperatura de $22^{\circ} \mathrm{C}$. La capacidad de nitrificación correspondiente por mg de DQO en el afluente a $14^{\circ} \mathrm{C}$ muestra una reducción marginal con respecto al caso a $22^{\circ} \mathrm{C}$ debido a que la producción de lodos a $14^{\circ} \mathrm{C}$ es ligeramente mayor que a $22^{\circ} \mathrm{C}$ producto de la reducción en la tasa de respiración endógena de los OHOs.

2) Edad de lodos: Para una relacción determinada de NTK/DQO en el afluente $\left(\mathrm{N}_{\mathrm{ti}} / \mathrm{S}_{\mathrm{ti}}\right)$, la capacidad de nitrificación $\left(\mathrm{N}_{\mathrm{c}} / \mathrm{S}_{\mathrm{ti}}\right)$ aumenta con un incremento en la edad de lodos debido a que el $\mathrm{N}$ requerido para la producción de lodos disminuye con la edad de lodos, lo que hace que más amonio libre y salino esté disponible para la nitrificación. Sin embargo, el aumento es marginal para TRS $>10$ días.

3) La relación de NTK/DQO en el afluente $\left(\mathrm{N}_{\mathrm{ti}} / \mathrm{S}_{\mathrm{ti}}\right)$ : Es claro que tanto para el agua residual cruda como para la clarificada, para una edad de lodos específica, la capacidad de nitrificación $\left(\mathrm{N}_{\mathrm{c}} / \mathrm{S}_{\mathrm{ti}}\right)$ es muy sensible a cambios en la relación de NTK/DQO en el afluente. 
Un aumento de 0.01 en $\mathrm{N}_{\mathrm{ti}} / \mathrm{S}_{\mathrm{ti}}$ ocasiona un incremento de 0.01 en $\mathrm{N}_{\mathrm{c}} / \mathrm{S}_{\mathrm{ti}}$. Para una misma relación de $\mathrm{N}_{\mathrm{ti}} / \mathrm{S}_{\mathrm{ti}}$, la capacidad de nitrificación $\left(\mathrm{N}_{\mathrm{c}} / \mathrm{S}_{\mathrm{ti}}\right)$ para un agua residual cruda es menor que para un agua clarificada debido a que se produce más lodo (SSV) por unidad de carga de DQO en un agua cruda que en un agua clarificada ya que la fracción paticulada no biodegradable de la DQO (fs'up) en un agua cruda es mayor que en una clarificada. Aparte de esta diferencia, un incremento en la relación de NTK/DQO en el afluente resulta en un incremento similar para la concentración de nitrato (capacidad de nitrificación) por mg de DQO del afluente. Esta situación disminuye la posibilidad, o hace que sea muy complicado obtener una desnitrificación completa utilizando la materia orgánica del agua residual como donante de electrones. Estos conceptos serán más claros más adelante cuando se describa el proceso de desnitrificación. Debido a que la clarificación primaria aumenta la relación de NTK/DQO en el afluente, la remoción de $\mathrm{N}$ a través del proceso de nitrificación-desnitrificación es siempre menor con un agua residual clarificada que con un agua residual cruda. No obstante, esta disminución en la remoción de $\mathrm{N}$ tiene la ventaja de requerir un reactor biológico de menor tamaño y una demanda de oxígeno más pequeña, lo que finalmente resulta en un ahorro en costos de construcción del reactor y de aireación.

\subsection{EJEMPLO DE DISEÑO DE UN SISTEMA CON NITRIFICACIÓN}

A continuación se presenta el diseño de un sistema de lodos activados con nitrificación. Con el fin de poder comparar los resultados obtenidos en el Capítulo 4 con el sistema diseñado sólo para la remoción de materia orgánica (DQO), el sistema de lodos activados con nitrificación se diseña para los mismos caudales y características del agua residual (ver Capítulo 4, Sección 4.5). Las características del agua residual cruda y clarificada se muestran en la Tabla 4.3 y las características adicionales necesarias para el diseño con nitrificación se muestra en la Tabla 5.2.

\subsubsection{Efecto de la nitrificación en el pH del licor mezclado}

Una consideración inicial importante es el possible efecto del $\mathrm{pH}$ del licor mezclado en el valor de $\mu_{\mathrm{Am} 20}$. El proceso de nitrificación consume alcalinidad (a razón de 7.14 $\mathrm{mg} / \mathrm{l}$ como $\mathrm{CaCO}_{3}$ por cada $\mathrm{mg}$ de amonio libre y salino convertido a nitrato) (sección 5.4.6). Si la alcalinidad en el afluente es insuficiente, el $\mathrm{pH}$ puede caer por debajo de 7.0 causando una reducción en el valor de $\mu_{\mathrm{Am} 20}$ (Ec. $5.22)$.

La relación de NTK/DQO del agua residual cruda es $0.08 \mathrm{mgN} / \mathrm{mgDQO}$ (Tabla 5.2). Con una tasa $\mu_{\mathrm{Am} 20}$ relativamente baja e igual a $0.45 \mathrm{~d}^{-1}$, la edad de lodos requerida para asegurar la nitrificación $\left(\mathrm{S}_{\mathrm{f}}=1.3\right)$ a una temperatura mínima de $14^{\circ} \mathrm{C}$ debe ser igual o mayor a 7 días en un proceso puramente aerobio $\left(f_{\mathrm{xm}}=0.0\right)($ Ec.

Tabla 5.2 Características del agua residual cruda y clarificada, requeridas para el cálculo de la concentración de nitrógeno en el efluente en sistemas de lodos activados con nitrificación

\begin{tabular}{|c|c|c|c|c|}
\hline Característica del agua residual afluente & Símbolo & Unidad & Agua cruda & Agua clarificada $^{1}$ \\
\hline Concentración de NTK & $A_{n t i}$ & mano/1 & 60 & 51 \\
\hline Relación de concentración de NTK/DQO & fin & & 0.08 & 0.113 \\
\hline Fracción de $\mathrm{NH}_{4}{ }^{+}$ & $\mathrm{f}_{\mathrm{N}}{ }^{\prime} \mathrm{a}$ & & 0.75 & 0.88 \\
\hline $\begin{array}{l}\text { Fracción soluble, no biodegradable de la fracción } \\
\text { orgánica de nitrógeno }\end{array}$ & $\mathrm{f}_{\mathrm{N} \text { 'ous }}$ & & 0.03 & 0.034 \\
\hline Contenido de nitrógeno de los SSV & $f_{n}$ & & 0.1 & 0.1 \\
\hline $\mathrm{pH}$ & & & 7.5 & 7.5 \\
\hline Alcalinidad & Alc & $\mathrm{mg} / \mathrm{l}$ como $\mathrm{CaCO}_{3}$ & 200 & 200 \\
\hline $\begin{array}{l}\text { Tasa específica máxima de crecimiento de los } \\
\text { AOOs a } 20^{\circ} \mathrm{C}\end{array}$ & $\mu_{\mathrm{Am}}$ & & 0.45 & 0.45 \\
\hline Caudal & $\mathrm{Q}_{\mathrm{i}}$ & $\mathrm{Ml} / \mathrm{d}$ & 15 & 15 \\
\hline
\end{tabular}

${ }^{1}$ Las características del agua residual clarificada deben seleccionarse/calcularse de tal forma que sea consistentes con las características del agua residual cruda y con el balance de masa sobre los clarificadores primarios, por ejemplo, las concentraciones de componentes solubles deben ser las mismas tanto en el agua cruda como en el agua clarificada. 

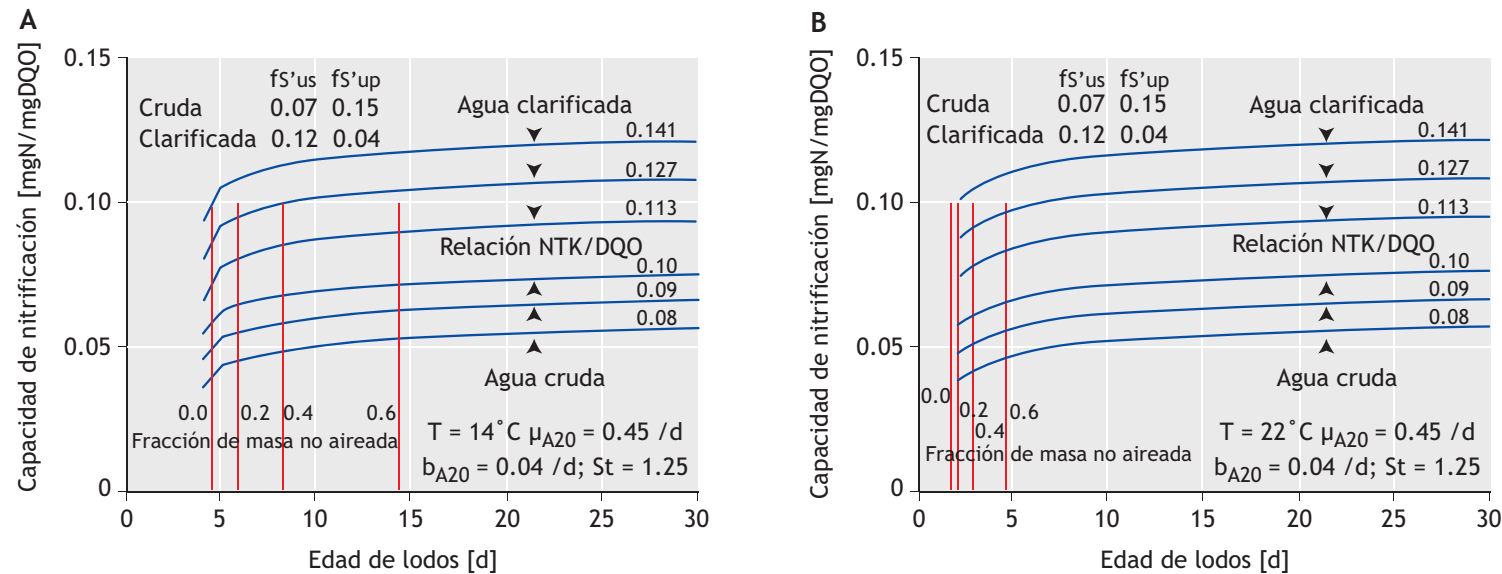

Figuras 5.9 Capacidad de nitrificación por mg de DQO suministrado al reactor biológico en función de la edad de lodos a diferentes relaciones de concentraciones de TKN/DQO en el afluente para aguas crudas y sedimentadas a $14^{\circ} \mathrm{C}(\mathrm{A})$ y $22^{\circ} \mathrm{C}$ (B). Las líneas verticales muestran las edades de lodo mínimas (TRS $\mathrm{m}$ ) requeridas para llevar a cabo el proceso de nitrificación con un factor de seguridad $\mathrm{S}_{\mathrm{f}}=1.25$ con fracciones no aireadas en el sistema de 0.0, $0.2,0.4$ y 0.6

5.19). A esta edad de lodos, la capacidad de nitrificación es alrededor de $0.037 \mathrm{mgN} / \mathrm{mgDQO}$ para una relación de NTK/DQO de $0.08 \mathrm{mgN} / \mathrm{mgDQO}$ (Figura 5.9A). Por ende, la concentración de nitrato producida (por litro de afluente) será alrededor de $0.037 \cdot 750=28 \mathrm{mgN} / 1$. Esto causa una reducción en la alcalinidad de $7.14 \cdot 28=200$ $\mathrm{mg} / \mathrm{l}$ como $\mathrm{CaCO}_{3}$. Si la alcalinidad en el afluente es de tan solo $200 \mathrm{mg} / 1$, la alcalinidad del licor mezclado puede caer por debajo de $40 \mathrm{mg} / \mathrm{l}$, causando que el $\mathrm{pH}$ disminuya por debajo de 7.0 (Figura 5.6). Un valor bajo de $\mathrm{pH}(<7.0)$ genera una nitrificación incompleta $\mathrm{e}$ inestable y produce un efluente agresivo, que con el paso de los años puede causar daños considerables a las superficies de concreto de la planta de tratamiento (ver Sección 5.4.6).

Esta estimación simple puede alertar tempranamente al diseñador sobre los posibles efectos adversos de un diseño propuesto. Continuando con este ejemplo, es necesario considerar el diseño de un sistema con nitrificación-desnitrificación para recuperar una parte de la alcalinidad y poder mantener un $\mathrm{pH}$ aproximadamente neutro. Si una cantidad de tan sólo $12 \mathrm{mgN} / 1$ de nitrato (la mitad aproximadamente) se desnitrificara en un reactor anóxico, la alcalinidad del efluente podría permanecer por encima de $50 \mathrm{mg} / \mathrm{l}$. Una relación alta de NTK/DQO acompañada de una alcalinidad baja en el afluente, son indicadores confiables de los problemas que podrían ocurrir en sistemas con nitrificación enteramente aerobios.

\subsubsection{Edad de lodos mínima requerida para nitrificación}

Con el fin de demostrar la nitrificación en condiciones puramente aerobias, en este ejemplo se acepta que la alcalinidad del afluente es suficientemente alta para mantener una alcalinidad en el efluente por encima de 50 $\mathrm{mgCaCO}_{3} / 1$. No se realizará ningún ajuste de $\mathrm{pH}$ para la tasa $\mu_{\mathrm{Am} 20}$. El ajuste por temperatura de las constantes cinéticas de los organismos nitrificantes se muestra en la Tabla 5.3.

Para un sistema completamente aerobio $\left(f_{\mathrm{xm}}=0.0\right)$ con $\mu_{\mathrm{Am} 20}=0.45 \mathrm{~d}^{-1}$ y $\mathrm{S}_{\mathrm{f}}=1.3$, la edad de lodos mínima para nitrificación $\left(\mathrm{TRS}_{\mathrm{m}}\right)$ se encuentra utilizando la Ecuación 5.19:

$$
\begin{aligned}
& T R S_{m}=S_{f} /\left(\mu_{A m T}-b_{A T}\right)= \\
& =2.5 \text { dias a } 22^{\circ} C\left(1.9 \text { dias con } S_{f}=1.0\right) \\
& =6.9 \text { dias a } 14^{\circ} \mathrm{C}\left(5.3 \text { dias con } S_{f}=1.0\right)
\end{aligned}
$$

Es claro entonces que para asegurar la nitrificación a lo largo del año para una tasa de $\mu_{\mathrm{Am} 20}$ relativamente baja

Tabla 5.3 Ajuste por temperatura de las constantes cinéticas del proceso nitrificación

\begin{tabular}{lllll}
\hline Constante & $20^{\circ} \mathrm{C}$ & $\theta$ & $22^{\circ} \mathrm{C}$ & $14^{\circ} \mathrm{C}$ \\
\hline$\mu_{\text {Am20 }}$ & 0.45 & 1.123 & 0.568 & 0.224 \\
$\mathrm{k}_{\text {n20 }}$ & 1 & 1.123 & 1.26 & 0.5 \\
$\mathrm{~b}_{\mathrm{A} 20}$ & 0.04 & 1.029 & 0.0425 & 0.034 \\
\hline
\end{tabular}


e igual a $0.45 \mathrm{~d}^{-1}$, la edad de lodos en un sistema completamente aerobio debe ser aproximadamente de 7 a 10 días.

\subsubsection{Concentración de $\mathrm{N}$ en el agua residual cruda}

La concentración de NTK en el agua residual cruda a afluente es de $60 \mathrm{mgN} / 1$ (Tabla 5.2). Aceptando que la fracción de amonio libre y salino en el NTK del afluente $\left(\mathrm{f}_{\mathrm{N}}\right.$ 'a) es igual a 0.75 y que la fracción de nitrógeno orgánico soluble no biodegradable ( $\mathrm{f}_{\mathrm{N}}$ 'ous) es de 0.03 para el agua residual cruda, la concentración de amonio en el afluente $\left(\mathrm{N}_{\mathrm{ai}}\right)$ se puede estimar como:

$\mathrm{N}_{\mathrm{ai}}=\mathrm{f}_{\mathrm{N}}{ }_{\mathrm{a}} \mathrm{N}_{\mathrm{ti}}=0.75 \cdot 60=45 \mathrm{mgN} / \mathrm{l}$

y la concentración de nitrógeno orgánico soluble no biodegradable $\left(\mathrm{N}_{\text {ousi }}\right)$ como

$\mathrm{N}_{\text {ousi }}=\mathrm{f}_{\mathrm{N}}{ }^{\prime \text { ous }} \mathrm{N}_{\mathrm{ti}}=0.03 \cdot 60=1.80 \mathrm{mgN} / 1$

Adicionalmente aceptando que el contenido de nitrógeno de la materia orgánica particulada no biodegradable en el afluente $\left(f_{n}\right)$ es igual a 0.10 $\mathrm{mgN} / \mathrm{mgSSV}$, entonces la concentración de nitrógeno orgánico asociado al componente orgánico particulado no biodegradable $\left(\mathrm{N}_{\text {oupi }}\right)$ es:

$\mathrm{N}_{\text {oupi }}=\mathrm{f}_{\mathrm{n}} \mathrm{fS}_{\mathrm{S}}{ }_{\text {up }} \mathrm{S}_{\mathrm{ti}} / \mathrm{f}_{\mathrm{cv}}=0.10(0.15 \cdot 750) / 1.48=7.6 \mathrm{mgN} / 1$

Por ende, la concentración de nitrógeno orgánico biodegradable en el afluente $\left(\mathrm{N}_{\mathrm{obi}}\right)$, tanto soluble como particulado $\left(\mathrm{N}_{\mathrm{obi}}=\mathrm{N}_{\mathrm{obsi}}+\mathrm{N}_{\mathrm{obpi}}\right)$ que se convierte en amoniaco está dado por:

$\mathrm{N}_{\mathrm{obi}}=60(1-0.75-0.03)-7.6=5.6 \mathrm{mgN} / \mathrm{l}$

\subsubsection{Concentración de $\mathrm{N}$ en el agua residual clarificada}

Siguiendo el procedimiento descrito anteriormente con el agua residual clarificada, para $\mathrm{f}_{\mathrm{N}}{ }^{\prime} \mathrm{a}=0.83$ y $\mathrm{f}_{\mathrm{N}}{ }^{\prime}$ ous $=0.034$ (ver Tabla 5.2) se obtiene:

$$
\begin{aligned}
& \mathrm{N}_{\mathrm{ti}}=51.0 \mathrm{mgN} / 1 \\
& \mathrm{~N}_{\mathrm{ai}}=0.88 \cdot 51.0=45.0 \mathrm{mgN} / 1 \\
& \mathrm{~N}_{\text {ousi }}=0.035 \cdot 51.0=1.80 \mathrm{mgN} / 1 \\
& \mathrm{~N}_{\text {oupi }}=0.10(0.04 \cdot 450) / 1.48=1.2 \mathrm{mgN} / 1 \\
& \mathrm{~N}_{\text {obi }}=51.0-45.0-1.8-1.2=3.0 \mathrm{mgN} / 1
\end{aligned}
$$

Debido a que el agua residual clarificada es producida a partir del agua cruda, las concentraciones de los componentes en solución deben ser las mismas. Al mismo tiempo debido a que las concentraciones de DQO y NTK cambian con la clarificación primaria, las fracciones de los componentes solubles aumentan con la clarificación primaria.

\subsubsection{Comportamiento del proceso de nitrificación}

El modelo en estado estacionario parte de la premisa que toda la materia orgánica biodegradable es degradada, y que todo el contenido de nitrógeno dentro de la misma es liberado como amonio. Por esta razón, la concentración de nitrógeno orgánico biodegradable en el efluente ( $\left.\mathrm{N}_{\text {obse }}\right)$ es cero.

De la Ec. 5.32, el nitrógeno orgánico soluble no biodegradable en el efluente es (para el agua cruda y clarificada):

$$
N_{\text {ouse }}=N_{\text {ousi }}=1.8 \quad[\mathrm{mgN} / \mathrm{l}]
$$

La concentración de amonio disponible para el proceso de nitrificación ( $\left.\mathrm{N}_{\mathrm{an}}\right)$ es igual a la concentración de NTK en el afluente $\left(\mathrm{N}_{\mathrm{ti}}\right)$ menos la concentración de nitrógeno requerido para la producción de lodos $\left(\mathrm{N}_{\mathrm{s}}\right)(\mathrm{Ec}$. 5.27) y menos la concentración de nitrógeno orgánico soluble en el efluente ( $\left.\mathrm{N}_{\text {ouse }}\right)$, obteniendo así:

$$
N_{a n}=N_{t i}-N_{s}-N_{\text {ouse }} \quad[\mathrm{mgN} / 1]
$$

Si la edad de lodos del sistema es menor que la mínima requerida para nitrificación $\left(\mathrm{TRS}<\mathrm{TRS} \mathrm{S}_{\mathrm{m}}\right.$ ), el proceso de nitrificación no se lleva a cabo y la concentración de nitrato en el efluente $\left(\mathrm{N}_{\text {ne }}\right)$ es cero. $\mathrm{Al}$ mismo tiempo la concentración de amonio en el efluente $\left(\mathrm{N}_{\mathrm{ae}}\right)$ es igual al nitrógeno disponible para nitrificación $\left(\mathrm{N}_{\mathrm{an}}\right.$, Ec. 5.38). Si por otra parte TRS $>\mathrm{TRS}_{\mathrm{m}}$, con $\mathrm{S}_{\mathrm{f}}=$ 1.0, la mayor parte del amonio libre y salino se nitrifica a nitrato y la concentración de nitrato en el efluente $\left(\mathrm{N}_{\mathrm{ne}}\right)$ se puede calcular como la diferencia entre $\mathrm{N}_{\mathrm{an}}$ (Ec. 5.38); y la concentración de amonio libre y salino se calcula con la Ec. 5.15. Tanto para TRS $<\mathrm{TRS}_{\mathrm{m}}$ como para TRS $>$ $\mathrm{TRS}_{\mathrm{m}}$, la concentración de NTK en el efluente $\left(\mathrm{N}_{\mathrm{te}}\right)$ es la suma de la concentración de amoníaco en el efluente con la concentración de nitrógeno orgánico soluble no biodegradable $\left(\mathrm{N}_{\mathrm{te}}=\mathrm{N}_{\mathrm{ae}}+\mathrm{N}_{\text {ouse }}\right)$.

Para TRS $<\mathrm{TRS}_{\mathrm{m}}$, la nitrificación no se lleva a cabo de tal forma que la concentración de nitrato en el efluente 
$\left(\mathrm{N}_{\mathrm{ne}}\right)$ es cero:

$$
N_{n e}=0.0
$$

y la concentración de amonio en el efluente $\left(\mathrm{N}_{\mathrm{ae}}\right)$ es:

$$
N_{a e}=N_{a n}=N_{t i}-N_{s}-N_{\text {ouse }} \quad[\mathrm{mgN} / 1]
$$

La concentración de NTK en el efluente $\left(\mathrm{N}_{\mathrm{te}}\right)$ es:

$$
N_{\text {te }}=N_{\text {ae }}+N_{\text {ouse }}
$$$$
[\mathrm{mgN} / 1]
$$

Dado que la nitrificación no ocurre (TRS $<\mathrm{TRS}_{\mathrm{m}}$ ), la masa de lodo de organismos nitrificantes $\left(\mathrm{MX}_{\mathrm{A}}\right)$ y la demanda de oxígeno para nitrificación $\left(\mathrm{FO}_{\mathrm{n}}\right)$ son iguales a cero:

$$
\begin{array}{ll}
M X_{A}=0 & {[\mathrm{mgSSV}]} \\
F O_{n}=0 & {\left[\mathrm{mgO}_{2} / \mathrm{d}\right]}
\end{array}
$$

Utilizando la Ec. 5.15, a medida que la edad de lodos se incrementa, $\mathrm{N}_{\mathrm{ae}}$ tiene un valor inicialmente negativo (lo cual es por supuesto imposible) y luego tiende a ser mayor que $\mathrm{N}_{\text {an }}$ (lo que tampoco es posible). Para edades de lodo ligeramente superiores a TRS $\mathrm{m}$, la concentración $\mathrm{N}_{\mathrm{ae}}$ cae por debajo de $\mathrm{N}_{\mathrm{an}}$. A partir de esta edad de lodos la nitrificación se lleva a cabo y para cualquier incremento adicional (por pequeño que sea) de la edad de lodos, el valor de $\mathrm{N}_{\mathrm{ae}}$ disminuye rápidamente aproximándose a valores bajos $(<4 \mathrm{mgN} / \mathrm{l})$.

Por ende para TRS $>\mathrm{TRS}_{\mathrm{m}}$ :

La concentración de amonio en el efluente $\left(\mathrm{N}_{\mathrm{ae}}\right)$ es:

$$
N_{\mathrm{ae}}=\frac{K_{n T}\left(b_{A T}+1 / T R S\right)}{\mu_{A m T}\left(1-f_{x t}\right)-\left(b_{A T}+1 / T R S\right)} \quad[\mathrm{mgN} / 1]
$$

la concentración de NTK en el efluente $\left(\mathrm{N}_{\mathrm{te}}\right)$ es:

$$
N_{\text {te }}=N_{\text {ae }}+N_{\text {ouse }}
$$$$
[\mathrm{mgN} / \mathrm{l}]
$$

y la concentración de nitrato en el efluente $\left(\mathrm{N}_{\mathrm{ne}}\right)$ es:

$$
N_{n e}=N_{a n}-N_{a e}=N_{t i}-N_{s}-N_{t e} \quad[\mathrm{mgN} / \mathrm{l}]
$$

La masa de organismos nitrificantes se puede calcular de forma análoga a la concentración de organismos heterotróficos activos (ver Ec. 4.9), como:

$$
M X_{A}=F N_{n e} Y_{A} T R S /\left(1+b_{A T} T R S\right) \quad[\mathrm{mgSSV}]
$$

donde:

$\mathrm{FN}_{\text {ne }} \quad$ masa de nitrato generada diariamente $=\left(\mathrm{Q}_{\mathrm{e}}+\mathrm{Q}_{\mathrm{w}}\right) \mathrm{N}_{\mathrm{ne}}=\mathrm{Q}_{\mathrm{i}} \mathrm{N}_{\mathrm{ne}}[\mathrm{mgN} / \mathrm{d}]$

La demanda de oxígeno para nitrificación es simplemente $4.57 \mathrm{mgO} / \mathrm{mgN}$ multiplicado por la masa de nitrato producido diariamente:

$F O_{n}=4.57 F N_{n e}$

$\left[\mathrm{mgO}_{2} / \mathrm{d}\right] \quad(5.43 \mathrm{~b})$

Reemplazando las concentraciones de $\mathrm{N}$ en el afluente para el agua residual cruda y clarificada, y los valores de las constantes cinéticas a $14^{\circ} \mathrm{C}$ en las Ecs. 5.38 a 5.43, se pueden calcular los resultados para diferentes edades de lodo. En la Figura 5.10A se muestran las diferentes concentraciones de $\mathrm{N}$ del sistema a diferentes edades de lodos para el agua cruda y residual a $14^{\circ} \mathrm{C}$. En la Figura 5.10C se muestra la masa de los organismos nitrificantes (como un porcentaje de la masa de SSV en el reactor) y la demanda de oxígeno para nitrificación para el agua residual cruda y clarificada a $14^{\circ} \mathrm{C}$. Los cálculos se repiten para las aguas residuales a $22^{\circ} \mathrm{C}$ los cuales se muestran en las Figuras 5.10B y 5.10D.

Las Figuras 5.10A y 5.10B muestran que cuando la edad de lodos es al menos $25 \%$ mayor que la edad de lodos mínima requerida para la nitrificación, el proceso de nitrificación se lleva a cabo de forma virtualmente completa (para las condiciones en estado estacionario). Además, al comparar los resultados del agua residual cruda y clarificada, existen pequeñas diferencias entre la demanda de oxígeno para nitrificación y las concentraciones en el efluente de amoniaco, nitrato y NTK. Esto se debe a que: ( $i$ ) el clarificador primario remueve solo una pequeña fracción del NTK del afluente, y (ii) el agua clarificada produce menos lodos, por lo que el amonio libre y salino disponible para nitrificación tanto en el agua residual cruda como en la clarificada es similar. Una vez que ocurre la nitrificación, la temperatura tiene un efecto mínimo en las concentraciones de nitrógeno en el efluente. Sin embargo, pequeñas variaciones en la temperatura producen cambios significativos en la edad de lodos mínima requerida para nitrificación.

A TRS $<$ TRS $_{m}$ (Figuras 5.10A y 5.10B) a medida que la edad de lodos se incrementa y alcanza a $\mathrm{TRS}_{\mathrm{m}}$ las concentraciones de amonio $\left(\mathrm{N}_{\mathrm{ae}}\right)$ y NTK en el efluente $\left(\mathrm{N}_{\mathrm{te}}\right)$ aumentan al mismo tiempo que $\mathrm{N}_{\mathrm{s}}$ disminuye. Para 

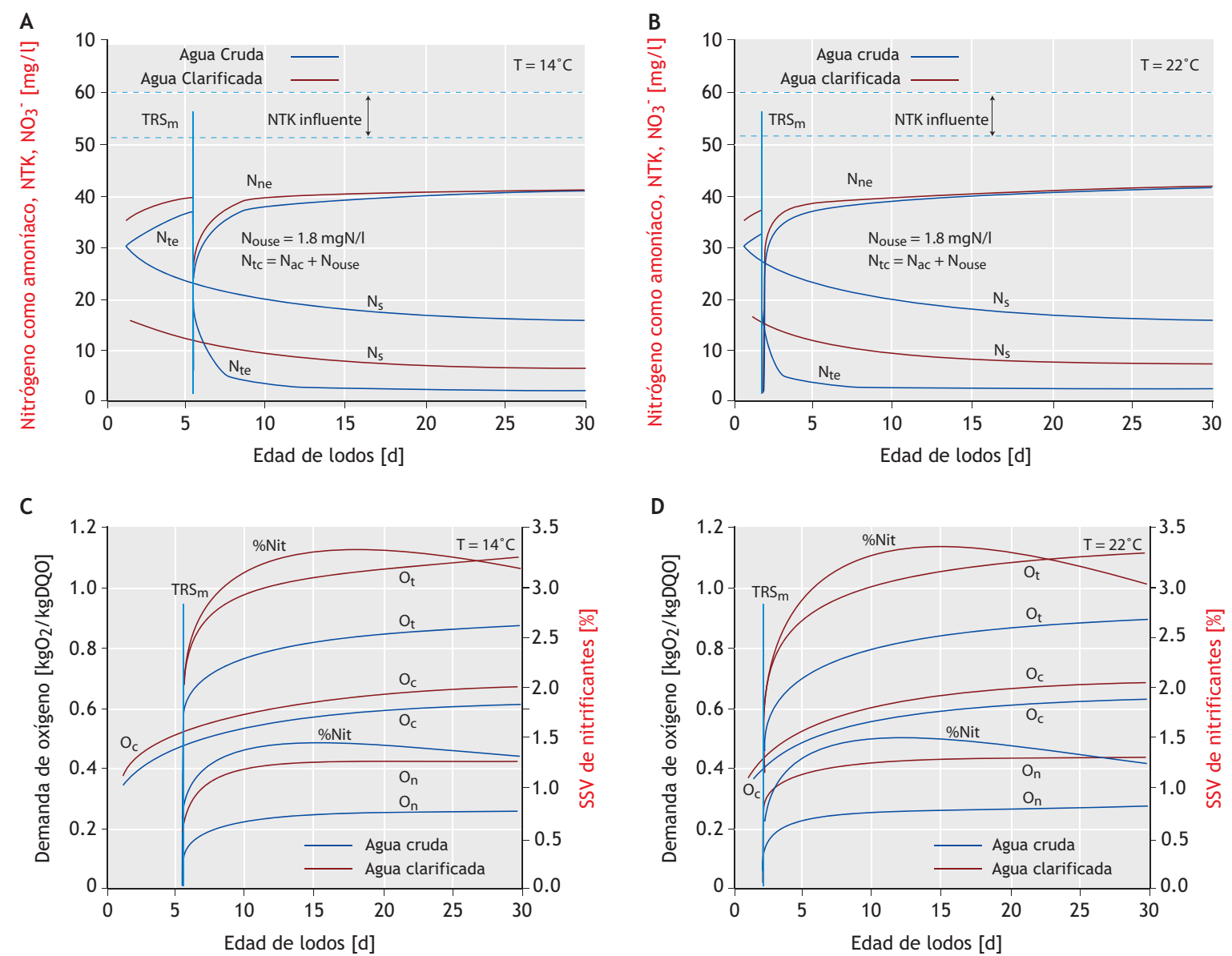

Figuras 5.10 Concentraciones en el efluente de amonio $\left(\mathrm{N}_{\mathrm{ae}}\right)$, NTK $\left(\mathrm{N}_{\mathrm{te}}\right)$, nitrato $\left(\mathrm{N}_{\mathrm{ne}}\right)$ y nitrógeno requerido para la generación de lodos $\left(\mathrm{N}_{\mathrm{s}}\right)$ a diferentes edades de lodos a $(\mathrm{A}) 14^{\circ} \mathrm{C}$ y (B) $22^{\circ} \mathrm{C}$; y demanda de oxígeno requerida para la nitrificación ( $\mathrm{O}_{\mathrm{n}}$ ), oxígeno para la remoción de materia orgánica $\left(\mathrm{O}_{c}\right)$ y oxígeno requerido total $\left(\mathrm{O}_{\mathrm{t}}\right)$ en $\mathrm{kgO}_{2} / \mathrm{kgDQO}$ y \% de masa de organismos nitrificantes (expresados en SSV) en función de la edad de lodos a (C) $14^{\circ} \mathrm{C}$ y (D) $22^{\circ} \mathrm{C}$ para el agua residual cruda y clarificada en el ejemplo de diseño

TRS $>$ TRS $_{\mathrm{m}}, \mathrm{N}_{\mathrm{ae}}$ decrece por debajo de $2 \mathrm{mgN} / \mathrm{l}$; y para TRS $>1.3 \cdot$ TRS $_{\mathrm{m}}$, la concentración de NTK en el efluente es inferior $4 \mathrm{mgN} / \mathrm{l}$. El aumento en la concentración de nitrato $\left(\mathrm{N}_{\mathrm{ne}}\right)$ al aumentar la edad de lodos a TRS > $1.3 \cdot \mathrm{TRS}_{\mathrm{m}}$ se debe a que existen menores requerimientos de nitrógeno para la producción de lodos $\left(\mathrm{N}_{\mathrm{s}}\right)$. Así, en sistemas con remoción biológica de nutrientes, un aumento en la edad de lodos aumenta la capacidad de nitrificación (ver Sección 5.5.2) y las concentraciones de nitrato que deben desnitrificarse son mayores para lograr la misma remoción de nitrógeno.

Las Figuras $5.10 \mathrm{C}$ y $5.10 \mathrm{D}$ muestran que la demanda de oxígeno para nitrificación aumenta rápidamente una vez TRS $>$ TRS $_{m}$, pero una vez se tiene un TRS > $1.3 \cdot \mathrm{TRS}_{\mathrm{m}}$ el incremento en la demanda de oxígeno es marginal e independiente de la temperatura o el tipo de agua residual, por ejemplo, para edades de lodo de $10 \mathrm{y}$
30 días se requieren respectivamente alrededor de 2,600 a $2,900 \mathrm{kgO}_{2} / \mathrm{d}$ para el proceso de nitrificación. Esta demanda de oxígeno para nitrificación representa un incremento de $42 \%$ y $65 \%$ sobre la demanda de oxígeno carbonácea (DQO) para el agua residual cruda y clarificada. No obstante, la demanda total de oxígeno para tratar el agua residual clarificada equivale a solamente el $75 \%$ de la necesaria para tratar el agua residual cruda.

Para que la nitrificación pueda proceder sin que sea inhibida por falta de oxígeno, es importante que el equipo de aireación esté diseñado adecuadamente para poder suministrar la demanda total de oxígeno; el crecimiento de los organismos heterotróficos generalmente prevalece sobre el crecimiento de los organismos nitrificantes cuando el suministro de oxígeno es insuficiente. Esto se debe a que los organismos heterotróficos pueden crecer 
en concentraciones de oxígeno de 0.5 a $1.0 \mathrm{mgO}_{2} / 1$ mientras que los organismos nitrificantes requieren concentraciones entre 1 y $2 \mathrm{mgO}_{2} / 1$.

De la misma forma, la masa de organismos nitrificantes aumenta rápidamente cuando TRS $>\mathrm{TRS}_{\mathrm{m}}$, a la vez que la concentración de amonio libre y salino disminuye rápidamente una vez que TRS $>\mathrm{TRS}_{\mathrm{m}}$. Bajo estas condiciones, el porcentaje de organismos nitrificantes es ligeramente mayor a $14^{\circ} \mathrm{C}$ que a $22^{\circ} \mathrm{C}$ debido a la baja tasa de respiración endógena $\mathrm{y}$ es aproximadamente el mismo porcentaje a edades de lodo de 10 días (alrededor de $420 \mathrm{kgSSV}$ ) y de 30 días (940 $\mathrm{kgSSV}$ ). Similitudes que prevalecen tanto para las aguas crudas como las clarificadas. Al comparar la masa de lodos de los organismos nitrificantes con la de los organismos heterotróficos en las Figuras 5.10C y 5.10D, aun con aguas residuales clarificadas con relaciones elevadas de NTK/DQO, la masa de nitrificantes comprende menos del $4 \%$ de la masa de SSV y por esta razón no se tiene en cuenta de manera estricta en la determinación de la concentración de SSV en reactores de lodos activados que tratan aguas residuales domésticas.

Es necesario recordar que si bien la clarificación primaria reduce solo una fracción menor del NTK, la reducción de la DQO afluente es significativa (del orden del $15 \%$ y $40 \%$ para el ejemplo de diseño). Aunque el agua residual clarificada tiene una concentración de NTK menor que la del agua cruda, la concentración de nitrato en el efluente no refleja esta diferencia. Esto se debe a que la remoción de $\mathrm{N}$ para la producción de lodos es menor para aguas residuales clarificadas que para aguas crudas. Consecuentemente la concentración de nitrato para aguas clarificadas es prácticamente la misma que para aguas crudas, aunque para aguas residuales con características diferentes puede ser mayor que el agua cruda.

Por otro lado, el potencial de desnitrificación, el cual corresponde a la máxima remoción posible de $\mathrm{N}$ a través de la desnitrificación utilizando la materia orgánica en el agua residual como donante de electrones, es altamente dependiente de la concentración de DQO en el afluente $\mathrm{y}$, como se mencionó anteriormente, esta concentración se reduce significativamente en la clarificación primaria. Esto puede conducir a una situación en la que es posible obtener una remoción casi completa de nitrato tratando aguas residuales crudas pero incompleta con aguas residuales clarificadas. Por consiguiente, la diferencia en la remoción de DQO y NTK en los clarificadores primarios juega un papel importante en el diseño de sistemas con remoción biológica de nutrientes.

\subsection{REMOCIÓN BIOLÓGICA DE NITRÓGENO MEDIANTE DESNITRIFICACIÓN HETERÓTROFA}

\subsubsection{Interacción entre la nitrificación y la remoción de nitrógeno}

La nitrificación es un prerequisito de la desnitrificación, y sin ésta la remoción biológica de nitrógeno no sería posible. Una vez que ocurre la nitrificación, es posible llevar a cabo la remoción biológica de nitrógeno mediante desnitrificación y debería ser incluida en los sistemas de tratamiento aun cuando la remoción de $\mathrm{N}$ no sea un requerimiento (ver Capítulo 4, Sección 4.11) incorporando de forma intencional zonas no aireadas dentro del reactor. Debido a que los organismos nitrificantes son aerobios estrictos, la nitrificación no se lleva a cabo en las zonas no aireadas, por lo que para compensar esta situación es necesario incrementar la edad de lodos del sistema. Para sistemas completamente aerobios y un agua residual a $14^{\circ} \mathrm{C}$, una edad de lodos de 5-7 días puede ser suficiente para efectuar una nitrificación completa, tomando en cuenta el requerimiento de que la concentración de amonio libre y salino en el efluente sea baja inclusive bajo condiciones cíclicas de caudal y carga $\left(\mathrm{S}_{\mathrm{f}}>1.3\right)$. Para sistemas aerobios-anóxicos, puede requerirse una edad de lodos de 15 a 20 días cuando se utiliza una fracción de masa no aireada de 50\% (Figura 5.3). Por consiguiente, para plantas de tratamiento donde se requiere remover $\mathrm{N}$, la edad de lodos tiende a ser invariablemente alta debido a (i) la incertidumbre en el valor de $\mu_{\mathrm{Am} 20}$, (ii) la necesidad de zonas no aireadas y ( iii) la necesidad de garantizar que el proceso de nitrificación se lleve a cabo a las temperaturas mínimas promedio de invierno $\left(\mathrm{T}_{\min }\right)$. Para plantas donde la nitrificación tiene altas probabilidades de ocurrir pero que no es una obligación (como por ejemplo, en regiones con temperaturas medias anuales superiores a $20-22{ }^{\circ} \mathrm{C}$ ), la incertidumbre en el valor de $\mu_{\mathrm{Am} 20}$ merece menos importancia y las zonas no aireadas pueden ser menores, resultando en edades de lodo bajas de entre 3 y 6 días. Aun bajo estas circunstancias las zonas no aireadas deberían ser incorporadas a los sistemas para poder obtener los beneficios de la desnitrificación en el caso de que la nitrificación se lleve a cabo. Cuando no hay nitrificación la zona no aireada se convierte en anaerobia (sin entrada de oxígeno disuelto o nitrato) en vez de anóxica, y las probabilidades de que ocurra una remoción biológica de fósforo (EBPR) adicional pueden ser altas. Debido a que la EBPR no es 
un requisito su desempeño no merece ninguna atención adicional, y tome o no lugar carece de importancia debido a que no afecta demasiado el comportamiento del sistema. Con una EBPR parcial, la producción de lodos por carga de DQO aumenta ligeramente $(<5 \%)$, y tanto la relación de SSV/SST como la demanda de oxígeno disminuyen (alrededor de un 5\%). No obstante, la EBPR puede ocasionar problemas de precipitación de minerales en las instalaciones de tratamiento de lodos en los casos en que el lodo de purga sea tratado en digestores anaerobios.

\subsubsection{Beneficios de la desnitrificación}

En el diseño de sistemas completamente aerobios (discutido anteriormente), se sugirió que aun cuando la nitrificación no es obligatoria pero si posible, deberían incorporarse zonas no aireadas al sistema para poder así favorecerse de los beneficios de la desnitrificación. Estos beneficios incluyen: (i) la reducción de la concentración de nitrato en el reactor, aminorando el problema de la generación de lodos flotantes en clarificadores secundarios (Capítulo 4, Sección 4.11), (ii) la recuperación de alcalinidad y (iii) la reducción de la demanda de oxígeno. Con respecto al punto (iii), bajo condiciones anóxicas, el nitrato puede ser utilizado como aceptor de electrones por los OHOs para la degradación de la materia orgánica en vez del oxígeno disuelto. El nitrato es equivalente en oxígeno a $2.86 \mathrm{mgO}_{2} / \mathrm{mgNO}_{3}-\mathrm{N}$ lo que significa que $1 \mathrm{mg}$ de $\mathrm{NO}_{3}-\mathrm{N}$ desnitrificado a $\mathrm{N}_{2}$ gaseoso tiene la misma capacidad para aceptar electrones que $2.86 \mathrm{mg}$ de oxígeno. En la nitrificación a nitrato, el amonio libre y salino libera 8 electrones $\left(\mathrm{e}^{-}\right) / \mathrm{mol}$ y el nitrógeno cambia su estado de oxidación (e $\left.\mathrm{e}^{-}\right) \mathrm{de}-3 \mathrm{a}+5$.

En la desnitrificación a $\mathrm{N}_{2}$, el nitrato acepta $5 \mathrm{e}^{-/} \mathrm{mol}$ y así el nitrógeno cambia su estado de oxidación ( $\left.\mathrm{e}^{-}\right) \mathrm{de}+5$ a 0 . Debido a que se consumen $4.57 \mathrm{mgO}_{2} / \mathrm{mg} \mathrm{NH}_{4}{ }^{+}-\mathrm{N}$ para la nitrificación, la equivalencia en oxígeno del nitrato en el proceso de desnitrificación a $\mathrm{N}_{2}$ es $5 / 8 \cdot 4.57$ $=2.86 \mathrm{mgO} / \mathrm{mgNO}_{3}-\mathrm{N}$ (Ver Tabla 5.4). Así, por cada 1 $\mathrm{mg}$ de $\mathrm{NO}_{3}-\mathrm{N}$ desnitrificado a $\mathrm{N}_{2}$ en la zona anóxica, (durante el cual se utilizan alrededor de $2.86 /\left(1-\mathrm{Y}_{\mathrm{COD}}\right)=$ $8.6 \mathrm{mgDQO})$ se requieren $2.86 \mathrm{mg}$ menos de oxígeno en la zona aerobia. Si se requieren $4.57 \mathrm{mgO} / \mathrm{mgNO}_{3}-\mathrm{N}$ de amonio libre y salino para formar $1 \mathrm{mg}$ de nitrato, y en el proceso de desnitrificación a $\mathrm{N}_{2}$ gaseoso se "recuperan" $2.86 \mathrm{mgO}_{2} / \mathrm{mgNO}_{3}-\mathrm{N}$, se puede recuperar un máximo de $2.86 / 4.57$ o $5 / 8=0.63$ de la demanda de oxígeno para nitrificación. La Tabla 5.4 muestra una comparación de las reacciones de nitrificación y desnitrificación.

En la práctica bajo condiciones normales de operación la recuperación de oxígeno para nitrificación por medio de la desnitrificación alcanza alrededor de 50\% (ver Figura 5.11). Por esta razón, si existe la posibilidad de que ocurra la nitrificación en el sistema, es siempre benéfico incluir la desnitrificación de tal forma que se pueda recuperar alcalinidad y oxígeno.

Tabla 5.4 Comparación del proceso de nitrificación y desnitrificación en el reactor biológico de un sistema de lodos activados

\begin{tabular}{|c|c|c|c|c|}
\hline & & Nitrificación & \multicolumn{2}{|c|}{ Desnitrificación } \\
\hline Forma química: & & Amonio $\left(\mathrm{NH}_{4}^{+}\right)$ & \multicolumn{2}{|c|}{ Nitrato $\left(\mathrm{NO}_{3}{ }^{-}\right)$} \\
\hline Función: & & Donante de electrones & \multicolumn{2}{|c|}{ Aceptor de electrones } \\
\hline Reacción media: & & Oxidación & \multicolumn{2}{|c|}{ Reducción } \\
\hline Organismos: & & Autotróficos & \multicolumn{2}{|c|}{ Heterotróficos } \\
\hline Condiciones: & & Aerobias & \multicolumn{2}{|c|}{ Anóxicas } \\
\hline Compuesto: & $\mathrm{NH}_{4}^{+}$ & $\mathrm{N}_{2}$ & $\mathrm{NO}_{2}^{-}$ & $\mathrm{NO}_{3}^{-}$ \\
\hline Estado de oxidación & -3 & 0 & +3 & +5 \\
\hline \multicolumn{5}{|c|}{ Nitrificación (oxidación) } \\
\hline
\end{tabular}

Pérdida neta
$5 \mathrm{e}^{-} \mathrm{de} \mathrm{N}=2.86 \mathrm{mgO}_{2} / \mathrm{mgN}$

Nitrificación: $4.57 \mathrm{mgO}_{2} / \mathrm{mgNH}_{4}-\mathrm{N}$ nitrificado a $\mathrm{NO}_{3}-\mathrm{N}$

Desnitrificación: $2.86 \mathrm{mgO}_{2}$ recuperados por cada $\mathrm{mg} \mathrm{NO}_{3}-\mathrm{N}$ desnitrificados a $\mathrm{N}_{2}$ gaseoso

Así, la desnitrificación permite como máximo una recuperación de 62.5\% (5/8 o 2.86/4.57) de la demanda de oxígeno 


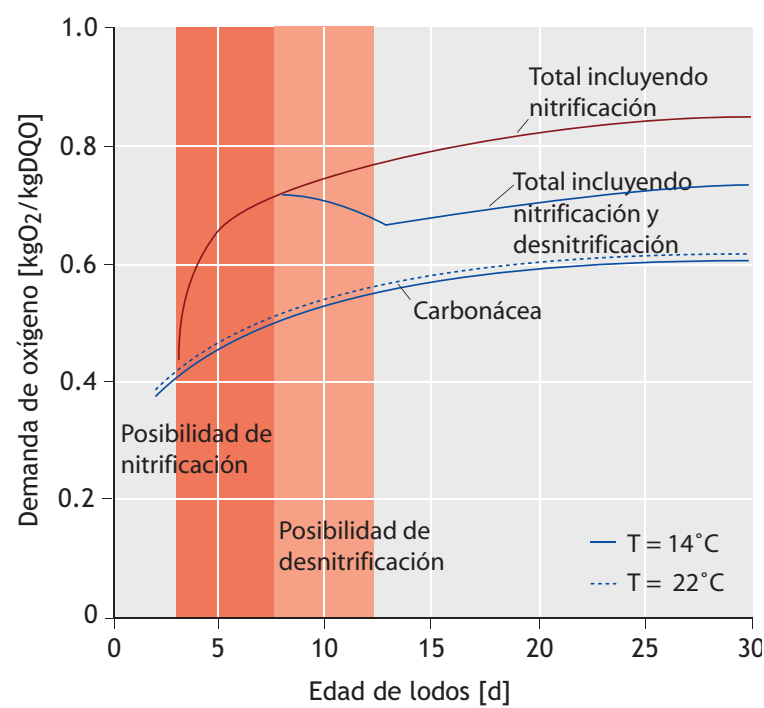

Figura 5.11 Demanda de oxígeno para la remoción de materia orgánica, demanda de oxígeno total incluyendo nitrificación y demanda total incluyendo nitrificación y desnitrificación por unidad de carga de DQO en el reactor biológico a diferentes edades de lodos del agua residual para el ejemplo de diseño

Con respecto al oxígeno, si el suministro es insuficiente para suplir los requerimientos combinados de remoción de carga orgánica y nitrificación, aparecerán zonas anóxicas dentro del reactor aerobio. Si el oxígeno es insuficiente, la fracción de masa aerobia en el reactor "aerobio" variará de acuerdo a las variaciones diarias de la carga de DQO y NTK en la planta. Bajo condiciones mínimas de carga, el suministro de oxígeno podría ser suficiente y la nitrificación podría llevarse a cabo de forma completa, pero durante cargas pico, el suministro de oxígeno será insuficiente y la nitrificación puede inhibirse (de forma parcial o completa) y la desnitrificación solo se llevará a cabo usando el nitrato acumulado en el sistema. Esta práctica se utiliza en procesos de nitrificación-desnitrificación dentro de un solo reactor como son las zanjas de oxidación y los sistemas de tipo carrusel.

\subsubsection{Remoción de nitrógeno por medio de la desnitrificación}

En sistemas con remoción biológica de nitrógeno, el $\mathrm{N}$ se remueve transfiriéndolo de la fase líquida tanto a la fase sólida como a la fase gaseosa. Alrededor del $20 \%$ del N en el afluente se incorpora a la masa de lodos (Figura 5.8), pero la mayor parte de $\mathrm{N}$, alrededor del $75 \%$ se remueve por transferencia a la fase gaseosa a través del proceso de nitrificación-desnitrificación cuando se alcanza una desnitrificación completa (Figura 5.12). En la nitrificación el $\mathrm{N}$ permanece en la fase líquida ya que se oxida de amonio a nitrato. Durante la desnitrificación se tranfiere del líquido a la fase gaseosa y escapa a la atmósfera. Si se logra una desnitrificación completa, una fracción relativamente pequeña del NTK en el afluente $(\sim 5 \%)$ permanece en la fase líquida y escapa como nitrógeno total (NTK + nitratos) en el efluente.

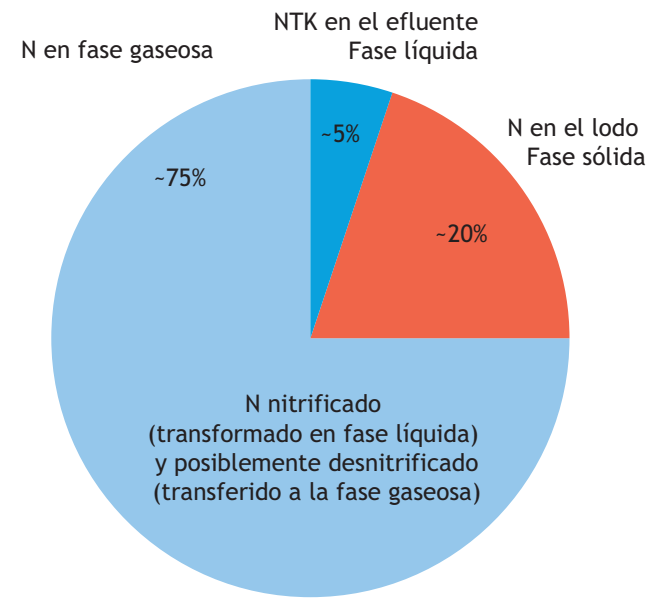

Figura 5.12 Trayectorias de conversión, remoción y salida de nitrógeno en un sistema de lodos activados con nitrificación y desnitrificación

Para las condiciones aerobias, el problema de los diseñadores es el de calcular la masa aceptora de electrones de oxígeno requerido por los OHOs (y los AOOs) para la utilización de una masa conocida de materia orgánica donante de electrones (material orgánico y amonio) disponible. Para las condiciones anóxicas, el problema es el opuesto. En este caso se debe calcular la masa de DQO (donantes de electrones) que es requerida para desnitrificar una masa conocida de nitrato (aceptor de electrones). Si la cantidad de donantes de electrones (DQO) disponibles no es suficiente, entonces no se puede lograr una desnitrificación completa. El cálculo de de la remoción de nitrógeno se enfoca esencialmente en lograr o alcanzar un balance entre los aceptores de electrones y los donantes (DQO) tomando en consideración ( $i$ ) la cinética y biología de la desnitrificación y (ii) los parámetros de operación del sistema (como son las relaciones de recirculación y el tamaño de los reactores anóxicos) bajo los cuales se lleva a cabo el proceso de desnitrificación.

Los donantes de electrones (o DQO o energía) para la desnitrificación pueden ser (i) internos ó (ii) externos al sistema de lodos activados. Los internos consideran los donantes de electrones presentes en el sistema mismo, en el agua residual afluente o los que se generan dentro del reactor biológico por los mismos organismos presentes en el lodo activado. Los donantes externos provienen de materia orgánica dosificada de forma controlada en las 
zonas anóxicas para promover la desnitrificación, e incluyen la adición de metanol, acetato, melazas, etc. (Monteith et al., 1980). El procedimiento de desnitrificación que se describe en las siguientes secciones se enfoca en el uso de donantes internos (DQO presente en el afluente o generada por los mismos organismos), pero los principios son lo suficientemente generales para incluir también fuentes de donantes de electrones externos.

\subsubsection{Cinética de la desnitrificación}

Existen tres fuentes internas de donantes de electrones, dos provienen del agua residual y una proviene de la misma masa de lodos activados. Las dos presentes en el agua residual corresponden a las dos formas principales de material orgánico, como son la materia orgánica rápidamente biodegradable $\left(\mathrm{DQO}_{\mathrm{rb}}\right)$ y la materia orgánica lentamente biodegradable (DQO $\left.\mathrm{D}_{\mathrm{lb}}\right)$. La tercera forma es también materia orgánica lentamente biodegradable, pero esta es generada por la biomasa presente en el reactor de lodos activados a través del proceso de muerte y lisis de la masa de organismos (también conocido como pérdida de masa endógena o respiración endógena). Esta $\mathrm{DQO}_{\mathrm{lb}}$ autogenerada se utiliza en la misma forma que la DQO pero se aborda de manera separada debido a que tanto la fuente como la tasa de suministro son diferentes a las presentes en el afluente. Sobretodo porque los $\mathrm{OHOs}$ degradan la DQO $\mathrm{rb}$ y DQO ${ }_{\mathrm{lb}}$ (en el afluente o autogenerada) siguiendo mecanismos diferentes.

Los diferentes mecanismos de degradación de la DQO $_{\mathrm{rb}}$ y la DQO $\mathrm{lb}$ conducen a diferentes tasas de utilización de la DQO. La DQO $r$ corresponde a la materia orgánica soluble que puede pasar directamente a través de la pared celular de los microorganismos y está conformada por compuestos simples y pequeños, por ejemplo azúcares y ácidos grasos de cadena corta (como ácido acético y propionico). En consecuencia, la DQO puede ser utilizada a una tasa de remoción relativamente alta, la cual no varía de forma significativa para los principales aceptores finales de electrones (oxígeno o nitrato) (Ekama et al., 1996). Los modelos de simulación utilizan la ecuación de Monod para modelar la tasa de utilización de la $\mathrm{DQO}_{\mathrm{rb}}$ por los OHOs tanto para condiciones aerobias como anóxicas. La DQO largos compuestos de materia orgánica particulada $\mathrm{o}$ coloidal los cuales son demasiados grandes para entrar al microorganismo de manera directa. Esta materia orgánica debe degradarse (hidrolizarse) a compuestos más pequeños en las capas de substancias extracelulares que rodean a los organismos, los cuales pueden posteriormente ser transferidos dentro del organismo y utilizados.

La tasa de hidrólisis extracelular de la DQO $\mathrm{lb}_{\mathrm{b}}$ es lenta y constituye el paso limitante en la utilización de la DQO $_{\mathrm{lb}}$. Esta tasa de hidrólisis es mucho más lenta bajo condiciones anóxicas que bajo condiciones aerobias alcanzando sólo alrededor de una tercera parte de la velocidad de hidrólisis aeróbia (Stern and Marais, 1974; van Haandel et al., 1981). Esto introduce un factor de reducción $(\eta)$ para la tasa de la hidrólisis de la DQOlb en la ecuación bajo condiciones anóxicas (Ec. 5.45, mostrada más adelante). Diferentes investigaciones han indicado que la utilización de DQOrb ocurre de forma simultánea a la hidrólisis de la DQOlb. Adicionalmente la tasa de $\mathrm{DOQ}_{\mathrm{rb}}$ es considerablemente más rápida (de 7 a 10 veces) que la tasa de hidrólisis de la DQOlb lo que hace que la tasa de desnitrificación con $\mathrm{DQO}_{\mathrm{rb}}$ del afluente sea mucho más rápida que con $\mathrm{DQO}_{\mathrm{lb}}$. Por consiguiente la $\mathrm{DQO}_{\mathrm{rb}}$ es la materia orgánica preferida para llevar a cabo la desnitrificación y entre más alto sea su contenido en el afluente respecto de la DQO total, mayor es la remoción de $\mathrm{N}$.

\subsubsection{Sistemas de desnitrificación}

Como resultado de los diferentes mecanismos de degradación y tasas de utilización de la DQO $\mathrm{Db}_{\mathrm{rb}}$ la DQOıb, la ubicación de la zona anóxica en el reactor biológico tiene un impacto significativo en la calidad de desnitrificación que se puede llevar a cabo. Existen muchas configuraciones para sistemas de una etapa que efectúen el proceso de nitrificación-desnitrificación pero desde el punto de vista de la fuente de donantes de electrones (en este caso sobretodo de la fuente de materia orgánica), estas pueden simplicarse a dos tipos básicos de desnitrificación o a combinaciones de éstas. Los dos tipos básicos que utilizan los donantes de electrones internos son $(i)$ la pos-desnitrificación, la cual utiliza materia orgánica autogenerada a través del proceso de respiración endógena y (ii) la pre-desnitrificación, la cual utiliza la materia orgánica presente en el agua residual afluente.

En el sistema con pos-desnitrificación (Figura 5.13A), el primer reactor es aerobio y el segundo es un reactor no aireado. El afluente entra al reactor aerobio donde se lleva a cabo el crecimiento aerobio de los organismos heterotróficos y los organismos nitrificantes. Si se cuenta con una edad de lodos lo suficientemente alta y una fracción de masa aerobia lo suficientemente grande, el proceso de nitrificación se lleva a cabo en el primer reactor. El licor mezclado del reactor aerobio pasa al reactor anóxico, también llamado reactor anóxico 
secundario, donde se mezcla por medio de agitadores. El efluente del reactor anóxico continua a los clarificadores secundarios desde donde el lodo sedimentado es recirculado al reactor aerobio.

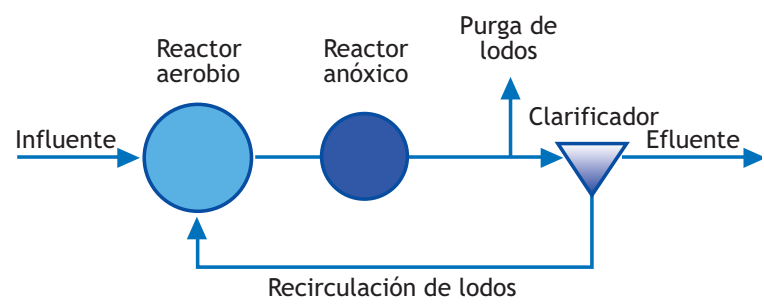

Figura 5.13A Sistema de remoción biológica de nitrógeno con pos-desnitrificación

La materia orgánica liberada por la masa de lodos cuando muere un microorganismo sirve como fuente de energía para la desnitrificación en el reactor anóxico. Sin embargo, la tasa a la que se libera esta energía es lenta, de tal forma que la tasa de desnitrificación es también lenta. Para poder obtener una reducción apreciable de nitrato la fracción de masa anóxica del sistema, es decir la fracción de masa de lodos en el sistema que se encuentra dentro del reactor anóxico, debe ser grande y esto puede causar, dependiendo de la edad de lodos, un cese de la nitrificación. Por ende, aunque teóricamente el sistema tiene el potencial para remover todo el nitrato, desde un punto de vista práctico esto no es posible ya que se requerirían fracciones de masa anóxica demasiado grandes al punto de que las condiciones para la nitrificación se dejarían de satisfacer, particularmente en el caso de bajas temperaturas $\left(<15^{\circ} \mathrm{C}\right)$. Adicionalmente, en el reactor anóxico la muerte y lisis de los microorganismos libera amonio, una parte del cual sale con el efluente reduciendo la remoción de nitrógeno total en el sistema. Para minimizar el contenido de amonio en el efluente, en algunas ocasiones se ubica un reactor de re-aireación entre el reactor anóxico y el clarificador secundario. En este reactor, el gas $\mathrm{N}_{2}$ es liberado del licor mezclado para evitar problemas de flotación de lodos en el clarificador secundario y el amonio es nitrificado a nitrato para poder cumplir con los estándares de descarga de amonio en el efluente, con el efecto indeseable de que la eficiencia de la remoción de nitrato del sistema se reduce y de que el nitrato presente en el clarificador secundario podría causar la flotación del manto lodos si este se llegara a desnitrificar en el fondo del clarificador secundario. Por estas razones, los sistemas con posdesnitrificación no se han aplicado de forma generalizada, a excepción de los casos en los que se utiliza en combinación con la dosificación de químicos.

\subsubsection{El sistema de Ludzack-Ettinger}

Ludzack and Ettinger (1962) fueron los primeros en proponer un sistema de lodos activados de una etapa con nitrificación-desnitrificación haciendo uso de la materia orgánica biodegradable del afluente como donante de electrones para el proceso de desnitrificación. El sistema propuesto consistía en dos reactores en serie, parcialmente separados el uno del otro. El agua residual afluente ingresaba al primer reactor, o reactor anóxico primario, el cual mantenía su estado mediante mezclado sin aireación. El segundo reactor era aireado y acá se llevaba a cabo la nitrificación. El efluente del reactor aerobio pasaba al clarificador secundario, del cual se sacaba una línea de recirculación de lodos que era devuelta al reactor aerobio. Debido a la mezcla en los reactores (anóxico y aerobio), se inducía un intercambio de los licores nitrificados y anóxicos. El nitrato que ingresaba al reactor anóxico primario se desnitrificaba a nitrógeno gaseoso. Ludzack y Ettinger reportaron que su sistema producía resultados variables de desnitrificación, debido probablemente a la falta de control en el proceso de intercambio de contenido de los reactores.

En 1973, Barnard propuso una mejora al sistema de Ludzack-Ettinger, separando completamente los reactores aerobio y anóxico, recirculando el lodo del clarificador secundario al reactor anóxico primario en vez de hacerlo al reactor aerobio, y adicionando una recirculación de licor mezclado del reactor aerobio al reactor anóxico primario (Figura 5.13B).

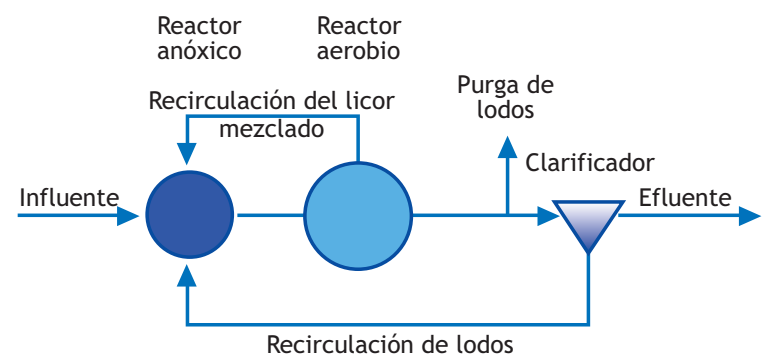

Figura 5.13B Sistema modificado de Ludzack-Ettinger para la remoción biológica de nitrógeno propuesto por Barnard (1973), incluyendo un solo reactor anóxico primario

Estas modificaciones, en particular la inclusión de la recirculación de licor mezclado, permitieron mejorar el control y la eficiencia de la remoción de nitrógeno. La $\mathrm{DQO}_{\mathrm{rb}} \mathrm{y}_{\mathrm{DQO}} \mathrm{lb}$ del afluente permiten obtener altas tasas de desnitrificación en el reactor anóxico primario alcanzando tasas de remoción de nitrato mucho más altas que con sistemas de pos-desnitrificación, aún cuando el reactor de pre-desnitrificación sea substancialmente más 
pequeño que en el sistema de pos-desnitrificación. Sin embargo, en este sistema, llamado el sistema Modificado de Ludzack-Ettinger (MLE), la remoción completa de nitrato no puede lograrse debido a que parte del flujo total del reactor aerobio no puede recircularse al reactor anóxico y sale del sistema a través del efluente. Para reducir la posibilidad de que ocurra la flotación del lodo en el clarificador secundario (debido a la desnitrificación del nitrato residual) la acumulación de lodos en el clarificador secundario necesita mantenerse al mínimo. Esto se puede lograr, manteniendo una alta tasa de recirculación de lodos igual al caudal medio del afluente (1:1).

\subsubsection{El sistema Bardenpho de 4 etapas}

Para eliminar la deficiencia que constituía una remoción incompleta de nitrato en el sistema MLE, Barnard (1973) propuso la inclusión de un reactor anóxico secundario en el sistema, conocido como el sistema Bardenpho de 4 etapas (Figura 5.13C). Barnard consideraba que la baja concentración de nitrato que salía del reactor aerobio al reactor anóxico secundario se desnitrificaría produciendo así un efluente final libre de nitratos. Adicionalmente Barnard incluyó un reactor de reaireación para remover el nitrógeno gas y nitrificar el amonio liberado durante el proceso de desnitrificación.

Si bien el sistema Bardenpho de 4 etapas tiene el potencial suficiente para alcanzar una remoción completa de nitrato, en la práctica esto no es posible excepto para aguas residuales municipales con una relación de NTK/DQO baja $<0.09 \mathrm{mgN} / \mathrm{mgDQO}$. La baja tasa de desnitrificación y la liberación de amonio (alrededor del $20 \%$ del nitrato desnitrificado) resultan en un uso subóptimo del tanque anóxico secundario. Como consecuencia de los requerimientos de las fracciones de masa de lodos aireada y no aireada como requerimiento para la nitrificación (ver Sección 5.4.3), es preferible excluir el reactor anóxico secundario (y el tanque de reaireación), aumentar el reactor anóxico primario e incrementar la tasa de recirculación interna del licor mezclado.

\subsubsection{Tasas de desnitrificación}

El proceso de desnitrificación y su comportamiento pueden explicarse de mejor manera en reactores operando en flujo pistón. No obstante, la explicación es igualmente válida para reactores completamente mezclados debido a que la cinética de desnitrificación es esencialmente de orden cero con respecto al nitrato (van Haandel et al., 1981; Ekama y Wentzel, 1999). Debido a los dos tipos de DQO biodegradable presentes en el agua residual afluente $\left(\mathrm{DQO}_{\mathrm{rb}}\right.$ y DQO $\left.\mathrm{lb}\right)$, la desnitrificación en el reactor anóxico primario ocurre en dos etapas (Figura 5.14A) - una etapa inicial rápida donde la tasa de desnitrificación es producto de la utilización simultánea de $\mathrm{DQO}_{\mathrm{rb}}$ y DQO $\mathrm{lb}\left(\mathrm{K}_{1}+\mathrm{K}_{2}\right)$ y una etapa más lenta donde la tasa específica de desnitrificación $\left(\mathrm{K}_{2}\right)$ es producto únicamente de la utilización de la DQO la autogenerada en el lodo debido a la muerte y lisis de los organismos.

En el reactor anóxico secundario ocurre una sola etapa de desnitrificación que es más lenta (Figura 5.14B, derecha), siendo esta tasa específica $\left(\mathrm{K}_{3}\right)$ alrededor de $2 / 3$ de la tasa lenta $\left(\mathrm{K}_{2}\right)$ en el reactor anóxico primario (Stern y Marais 1974; Van Haandel et al., 1981). En el reactor aerobio que precede al reactor anóxico secundario generalmente se consume toda la $\mathrm{DQO}_{\mathrm{rb}} \mathrm{y}$ la mayor parte de la $\mathrm{DQO}_{\mathrm{lb}}$ del afluente, de tal forma que la única DQO biodegradable que ingresa al reactor anóxico secundario corresponde a la $\mathrm{DQO}_{\mathrm{lb}}$ producida por la muerte y lisis de los microorganismos. La tasa de suministro de DQO la que dicta el valor de la tasa $\mathrm{K}_{3}$ y por esta razón es más

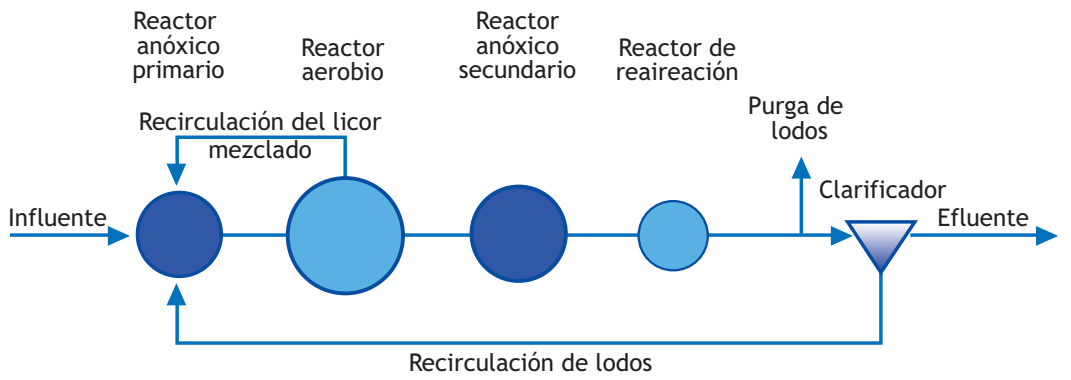

Figura 5.13C Sistema Bardenpho de 4 etapas para la remoción biológica de nitrógeno, incluyendo reactores anóxicos primario y secundario 
que lenta que la tasa $\mathrm{K}_{2}$. La Tabla 5.5 muestra valores típicos para las diferentes tasas $\mathrm{K}$ de desnitrificación.

La tasa $\mathrm{K}_{4}$ describe la desnitrificación que ocurre durante la digestión intermitentemente aireada (anóxicaaerobia) de lodos de purga (Warner et al., 1986). El valor de esta tasa es alrededor de dos terceras partes el valor de la tasa $\mathrm{K}_{3}$ (reactor anóxico secundario) (Tabla 5.5), pero es suficientemente alta para desnitrificar todo el nitrato generado en la digestión aerobia del lodo de purga si el ciclo de aireación es de al menos 4-6 horas siendo 50\% anóxico y $50 \%$ aerobio. Esta desnitrificación ofrece los mismos beneficios, como son: reducción en el consumo de alcalinidad, recuperación de oxígeno, mejoras en el control del pH, reducción en la dosificación de químicos (Dold et al., 1985) y un licor del sobrenadante de la deshidratación de lodos libre de nitrógeno. Una ventaja significativa si se tiene en cuenta el alto contenido de $\mathrm{N}$

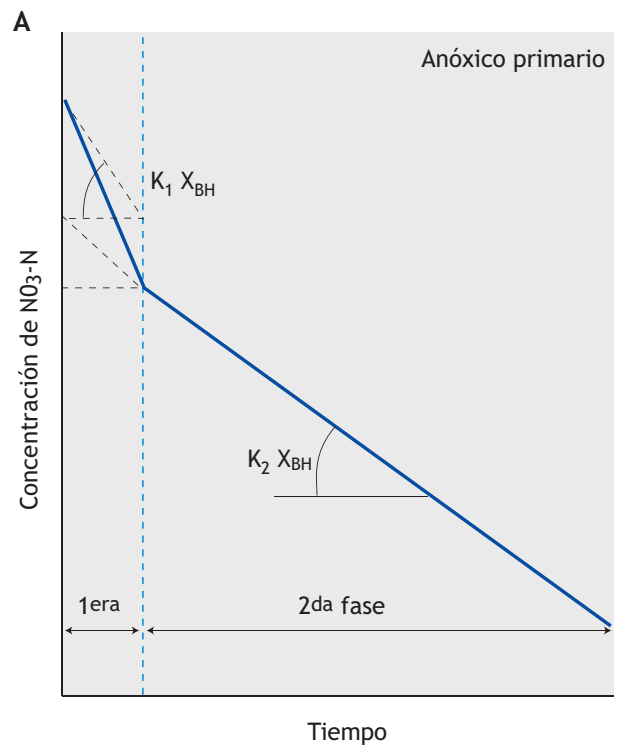

presente en los lodos de purga, sobretodo si el sobrenadante se recircula a la línea principal de tratamiento de la planta.

Los valores de las tasas específicas de desnitrificación, bajo condiciones de carga y caudal constantes pueden describirse con la cinética de la utilización de la materia orgánica rápidamente (DQOrb ó $\mathrm{S}_{\mathrm{S}}$ de acuerdo con los modelos ASM) y lentamente biodegradable (DQO $\mathrm{lb}$ ó $\mathrm{X}_{\mathrm{S}}$ según los modelos ASM) incluidas en modelos de simulación avanzados como el ASM1 (ver Capítulo 14, Sección 14.4). El uso de la materia orgánica rápidamente biodegradable se puede modelar con la ecuación de Monod.

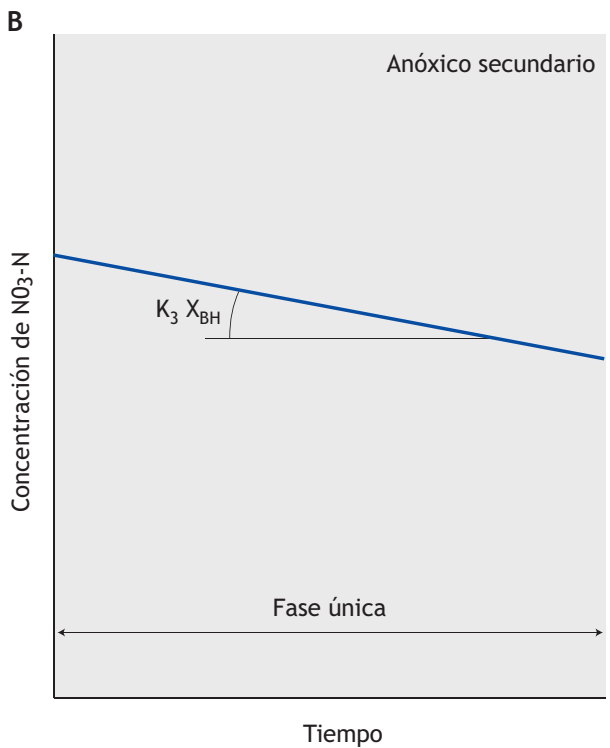

Figura 5.14 Perfiles de concentración de nitrato en función del tiempo en reactores en flujo pistón con (A) un reactor anóxico primario y (B) un reactor anóxico secundario, mostrando las tres fases de desnitrificación asociadas a las tasas $\mathrm{K}_{1}, \mathrm{~K}_{2}$ and $\mathrm{K}_{3}$. En el reactor anóxico primario, la rápida tasa inicial $\mathrm{K}_{1}$ es atribuible a la utilización de la $\mathrm{DQO}_{\mathrm{rb}}$ del afluente mientras que la segunda y más lenta tasa $\mathrm{K}_{2}$ a la utilización de la DQO secundario, la tasa $\mathrm{K}_{3}$ se atribuye únicamente a la utilización de la DQO

Tabla 5.5 Tasas de desnitrificación K y sus coeficientes de dependencia de la temperatura

\begin{tabular}{lllll}
\hline Símbolo & $20^{\circ} \mathrm{C}$ & $\theta$ & $14{ }^{\circ} \mathrm{C}$ & $22^{\circ} \mathrm{C}$ \\
\hline${ }^{\mathrm{a}} \mathrm{K}_{1,20}$ & 0.720 & 1.20 & 0.241 & 1.036 \\
${ }^{\mathrm{a}} \mathrm{K}_{2,20}$ & 0.101 & 1.080 & 0.064 & 0.118 \\
${ }^{\mathrm{a}} \mathrm{K}_{3,20}$ & 0.072 & 1.029 & 0.061 & 0.076 \\
${ }^{\mathrm{a}} \mathrm{K}_{4,20}$ & 0.048 & 1.029 & 0.040 & 0.051 \\
\hline
\end{tabular}

a Unidades: $\mathrm{mgNO}_{3}-\mathrm{N} / \mathrm{mgOHO}-\mathrm{SSV} . \mathrm{d}$ 
Así, para la tasa $\mathrm{K}_{1}$ :

$$
\begin{gathered}
K_{1}=\frac{\left(1-Y_{C O D}\right) f_{c v} \mu_{H}}{2.86 Y_{H}} \frac{S_{s}}{K_{s}+S_{s}} \\
{\left[\mathrm{mgNO}_{3}-\mathrm{N} / \mathrm{mgOHO}-\mathrm{SSV} . \mathrm{d}\right]}
\end{gathered}
$$

donde:

$$
\frac{S_{s}}{K_{s}+S_{s}} \approx 1
$$

En los reactores anóxicos, el término $\mathrm{S}_{\mathrm{s}} /\left(\mathrm{K}_{\mathrm{s}}+\mathrm{S}_{\mathrm{s}}\right)$ tiende a un valor cercano a 1 inclusive a concentraciones bajas de DQOrb (o Ss) debido a que la constante de saturación media $\left(\mathrm{K}_{\mathrm{s}}\right)$ es baja. Usando $\mathrm{Y}_{\mathrm{COD}}=0.67$ $\mathrm{mgDQO} / \mathrm{mgDQO}$ y $\mathrm{f}_{\mathrm{cv}}=1.48 \mathrm{mgDQO} / \mathrm{mgSSV}$ se obtiene, $\mathrm{K}_{1}=0.26 \mu_{\mathrm{H}} \mathrm{mgNO}_{3}-\mathrm{N} / \mathrm{mgOHO}-\mathrm{SSV} . \mathrm{d}$. Para alcanzar una tasa $\mathrm{K}_{1}=0.72 \mathrm{mgNO}_{3}-\mathrm{N} / \mathrm{mgOHOSSV} . \mathrm{d}$ (ver Tabla 5.5), el valor de $\mu_{\mathrm{H}}$ es $2.8 \mathrm{~d}^{-1}$, el cual está ubicado en el rango medio de las tasas observadas en sistemas de lodos activados. En investigaciones sobre la cinética de utilización de la $\mathrm{DQO}_{\mathrm{rb}}$ en selectores aerobios y anóxicos, Still et al. (1996) y Ekama et al. (1996) encontraron que los valores de $\mu_{\mathrm{H}}$ variaban entre $1.0 \mathrm{~d}^{-1}$ en sistemas de reactores completamentes mezclados y 4.5 $\mathrm{d}^{-1}$ en sistemas de reactores con selectores. Estos valores producen una tasa $\mathrm{K}_{1}$ de desnitrificación del orden de $0.26 \mathrm{mgNO}_{3}-\mathrm{N} / \mathrm{mgOHO}-\mathrm{SSV} . \mathrm{d}$ para sistemas completamente mezclados y del orden de $1.17 \mathrm{mgNO}_{3}$ N/mgOHO-SSV.d en selectores o tanques con flujo pistón (debido a la estimulación la biomasa de los OHOs).

Por otra parte, la utilización de la DQO $\mathrm{lb}_{\mathrm{b}}\left(\mathrm{X}_{\mathrm{S}}\right)$ se expresa en términos de la cinética de su hidrólisis usando una fórmula de superficie, la cual tiene la forma de una ecuación de Monod, con la diferencia de que la variable principal es el cociente de la DQO concentración de la biomasa activa de OHOs $\left(\mathrm{X}_{\mathrm{S}} / \mathrm{X}_{\mathrm{BH}}\right)$. De esta manera, las tasas $\mathrm{K}_{2}, \mathrm{~K}_{3}$ (y $\mathrm{K}_{4}$ ) se pueden calcular como:

$$
\begin{array}{r}
\mathrm{K}_{2}=\mathrm{K}_{3}=\mathrm{K}_{4}=\frac{\left(1-\mathrm{Y}_{\mathrm{COD}}\right) \mathrm{f}_{\mathrm{cv}}}{2.86 \mathrm{Y}_{\mathrm{H}}} \frac{\eta \mathrm{K}_{\mathrm{h}}\left(\mathrm{X}_{\mathrm{s}} / \mathrm{X}_{\mathrm{BH}}\right)}{\left[\mathrm{K}_{\mathrm{x}}+\left(\mathrm{X}_{\mathrm{s}} / \mathrm{X}_{\mathrm{BH}}\right)\right]} \\
{\left[\mathrm{mgNO}_{3}-\mathrm{N} / \mathrm{mgOHO} \text {-SSV.d }\right] \quad \text { (5.45) }}
\end{array}
$$

donde:

$\mathrm{X}_{\mathrm{S}} / \mathrm{X}_{\mathrm{BH}}$ es progresivamente más bajo en el reactor primario $\left(\mathrm{K}_{2}\right)$, seguido del secundario $\left(\mathrm{K}_{3}\right)$ y por último del sistema con digestión anóxica-aerobia $\left(\mathrm{K}_{4}\right)$

En los reactores anóxicos primarios y secundarios de flujo pistón bajo condiciones de carga y caudal constantes, la relación $\mathrm{X}_{\mathrm{S}} / \mathrm{X}_{\mathrm{BH}}$ cambia muy poco porque las tasas de hidrólisis anóxicas tienden a ser bajas. La razón por la cual $\mathrm{K}_{2}$ es mayor que $\mathrm{K}_{3}$ se debe a las diferentes relaciones $X_{\mathrm{s}} / \mathrm{X}_{\mathrm{BH}}$ que expresan el cociente de las concentraciones adsorbidas de materia orgánica lentamente biodegradable $\left(\mathrm{X}_{\mathrm{s}}\right)$ por la concentración de OHOs activos $\left(\mathrm{X}_{\mathrm{BH}}\right)$ en los diferentes reactores (Figura 5.15). Así, la relación $X_{S} / X_{B H}$ es más alta en un reactor anóxico primario debido a que la $\mathrm{DQO}_{\mathrm{lb}}$ adsorbida se origina tanto del afluente como de la muerte de OHOs. La relación es más baja en un reactor anóxico secundario porque la $\mathrm{DQO}_{\mathrm{lb}}$ proviene únicamente de la muerte de OHOs. Para las tasas de desnitrificación $\mathrm{K}_{2}$ and $\mathrm{K}_{3}$ no existe una relación simple y directa entre las tasas $\mathrm{K}$ y $\eta \mathrm{K}_{\mathrm{h}}$ debido a que $\mathrm{Xs} / \mathrm{X}_{\mathrm{BH}}$ es diferente para reactores anóxicos primarios y secundarios (y digestores aerobios) y varía con la edad de lodos y la fracción de masa no aireada.

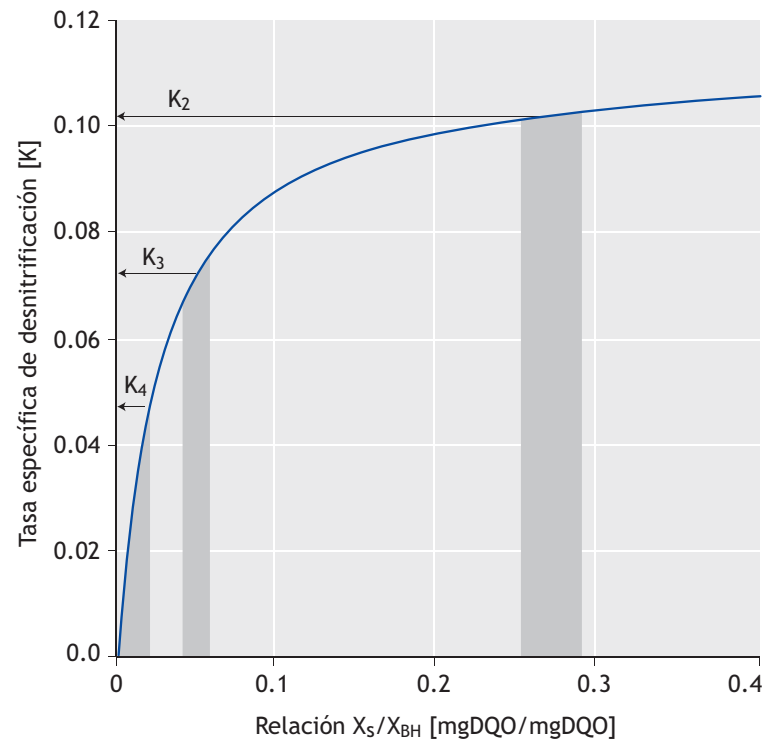

Figura 5.15 Tasa específica de desnitrificación (K) a diferentes relaciones de concentración de materia orgánica lentamente biodegradable por concentración de biomasa activa de $\mathrm{OHOs}$ $\left(\mathrm{X}_{\mathrm{S}} / \mathrm{X}_{\mathrm{BH}}\right)$, mostrando las tasas específicas de desnitrificación primaria anóxica $\left(\mathrm{K}_{2}\right)$, secundaria anóxica $\left(\mathrm{K}_{3}\right)$ y de digestión anóxica-aerobia $\left(\mathrm{K}_{4}\right)$

Las "constantes" de desnitrificación $\mathrm{K}_{1}, \mathrm{~K}_{2}, \mathrm{~K}_{3}$ y $\mathrm{K}_{4}$ no tienen una explicación cinética directa; son relativamente constantes porque son el resultado de una combinación de reacciones cinéticas que varían muy poco a edades de lodo de 10 a 30 días (Figura 5.15).

Por otra parte, la temperatura si tiene un efecto en las tasas de desnitrificación $(\mathrm{K})$ pero una vez que éstas han sido ajustadas por los efectos de la temperatura, muestran 
muy poca variación para diferentes edades de lodo (van Haandel et al., 1981). A través de observaciones experimentales y desde el punto de vista de la teoría cinética, puede concluirse que es aceptable usar valores de $\mathrm{K}_{2}$ y $\mathrm{K}_{3}$ constantes para diseños en estado estacionario. De hecho, este es el procedimiento que se sigue para estimar la desnitrificación potencial $\left(\mathrm{D}_{\mathrm{p}}\right)$ de un reactor anóxico bajo cargas y caudales constantes.

La tasa $\mathrm{K}_{1}$ puede cambiar significativamente debido a que la tasa de utilización de la DQO rb puede cambiar de forma apreciable dependiendo del los regímenes de mezclado del reactor anóxico o aerobio (Ekama et al., 1986,1996 and Still et al., 1996). No obstante, esta variación no afecta significativamente el diseño de un sistema con nitrificación-desnitrificación debido a que en condiciones normales, los reactores primarios son lo suficientemente grandes para permitir una completa utilización de la $\mathrm{DQO}_{\mathrm{rb}}$ aun cuando la tasa de utilización $\left(\mu_{\mathrm{H}}\right)$ sea baja. De hecho, el procedimiento de diseño de desnitrificación se basa en que toda la $\mathrm{DQO}_{\mathrm{rb}}$ es utilizada en el reactor anóxico primario lo cual implica que existan tanto una fracción mínima de masa anóxica primaria $\left(\mathrm{f}_{\mathrm{x} 1 \mathrm{~min}}\right)$ como una relación de recirculación $a$ mínima $\left(\mathrm{a}_{\mathrm{min}}\right)$. Estos conceptos también pueden aplicarse al diseño de selectores (Ekama et al., 1996). El modelo de simulación también ha sido aplicado a reactores de digestión anóxica-aerobia de lodos de purga. En estos casos, se encontró que el modelo predice con precisión el comportamiento tanto de los digestores aerobios como de los anóxicos-aerobios bajo condiciones constantes y cíclicas de carga y caudal, lo que permitió validar la tasa específica de desnitrificación $\mathrm{K}_{4}$ (Warner et al., 1986). Es importante resaltar que no fue necesario hacer ningún ajuste significativo al valor de las constantes cinéticas.

\subsubsection{Potencial de desnitrificación}

La concentración de nitrato (por litro de caudal afluente $\left.\mathrm{Q}_{\mathrm{i}}\right)$ que un reactor anóxico puede desnitrificar biológicamente se conoce como el potencial de desnitrificación del reactor. Se llama potencial debido a que si se consigue o no, depende de la carga de nitrato en los reactores anóxicos. Si se recicla una cantidad baja de nitrato a los reactores anóxicos, la totalidad del nitrato recirculado se desnitrifica, pero la remoción actual de nitrato, es decir el desempeño de la desnitrificación, es más bajo que el potencial que puede alcanzar. En este caso, la desnitrificación está limitada por el sistema (o por la recirculación). Un incremento en las relaciones de recirculación produce un incremento en la carga de nitrato al reactor anóxico y por ende también en la desnitrificación. Cuando las relaciones de recirculación son tales que la carga de nitrato en los reactores anóxicos iguala al potencial de desnitrificación del reactor, se obtiene un sistema de desnitrificación con desempeño óptimo y las relaciones de recirculación alcanzan sus valores óptimos. En este punto, las concentraciones de nitrato en el reactor anóxico y en su efluente son cero y por ende las más bajas posibles. Aumentar las tasas de recirculación por encima de los valores óptimos hace que la concentración de nitrato en el efluente del reactor anóxico aumente por encima de cero, pero esto no mejora el desempeño de la desnitrificación ya que esta está limitada por la biología (o por la cinética de los procesos). Bajo estas circunstancias se logra obtener el máximo potencial de desnitrificación de los reactores anóxicos, pero cualquier incremento en la concentración de nitrato hace que éste no pueda ser desnitrificado dadas las condiciones particulares del agua residual. Más aún, los aumentos en las relaciones de recirculación por encima de los valores óptimos no son económicamente viables debido a que generan costos innecesarios de bombeo e introducen en los reactores anóxicos una cantidad adicional innecesaria de oxígeno disuelto, la cual ocasiona una reducción no deseada del desempeño de la desnitrificación y conlleva a un aumento de la concentración de nitrato en el efluente. En consecuencia, el principio de la desnitrificación gira alrededor de $(i)$ calcular el potencial de desnitrificación de los reactores anóxicos, (ii) ajustar la carga de nitrato que llega a los reactores anóxicos con un valor igual al potencial de desnitrificación, y (iii) calcular las relaciones de recirculación asociadas con esta condición. De esta forma, las relaciones de recirculación calculadas para el licor mezclado pueden alcanzar los valores óptimos.

De la discusión anterior es clara la importancia que tienen el cálculo de la carga de nitrato y el potencial de desnitrificación en el diseño de un sistema con desnitrificación. La carga de nitrato se calcula mediante la capacidad de nitrificación, la cual corresponde a la concentración de nitrato por caudal afluente $\left(\mathrm{Q}_{\mathrm{i}}\right)$ generada por el proceso de nitrificación (Sección 5.6.2, Ec. 5.35). Anteriormente se mostró que la capacidad de nitrificación ( $\left.\mathrm{N}_{c}, \mathrm{mgN} / \mathrm{l}_{\text {influent }}\right)$ es aproximadamente proporcional a la concentración de NTK en el afluente $\left(\mathrm{N}_{\mathrm{ti}}\right)$. El potencial de desnitrificación se calcula de forma separada para la utilización de DQO $\mathrm{rb}_{\mathrm{rb}} \mathrm{DQO}_{\mathrm{lb}}$. La DQO da lugar a una tasa rápida de desnitrificación por lo que se puede asumir que toda es consumida en el reactor anóxico primario. De hecho, este es uno de los objetivos de diseño. En consecuencia, la contribución de la DQO $\mathrm{rb}$ al potencial de desnitrificación puede considerarse que es simplemente el componente catabólico de su capacidad 
de donar electrones a los nitratos. Por esta razón, se puede asumir que en la utilización completa de la DQO ${ }_{\mathrm{rb}}$ afluente, una proporción fija $\left(1-Y_{\mathrm{H}}\right)$ de los electrones de la $\mathrm{DQO}_{\mathrm{rb}}$ (componente catabólico) es donada al $\mathrm{NO}_{3}{ }^{-}$ reduciéndolo a $\mathrm{N}_{2}$. Por ende, conociendo el valor de la $\mathrm{DQO}_{\mathrm{rb}}$ en el afluente $\mathrm{y}$ asumiendo que se utiliza completamente, el potencial de desnitrificación de la DQO $r$ se puede calcular como:

$$
\begin{array}{r}
D_{p 1 D Q O r b}=f_{S b^{\prime} s} S_{b i}\left(1-f_{c v} Y_{H v}\right) / 2.86 \\
{\left[\mathrm{mgNO}_{3}-\mathrm{N} / \mathrm{l}_{\text {afluente }}\right]}
\end{array}
$$

donde:

$\mathrm{D}_{\mathrm{p} 1 \mathrm{DQOrb}}$ potencial de desnitrificación en el reactor anóxico primario para la $\mathrm{DQO}_{\mathrm{rb}}$ en afluente

$\mathrm{S}_{\mathrm{bi}} \quad \mathrm{DQO}$ biodegradable en el afluente [mgDQO/l]

$\mathrm{fS}_{\mathrm{S}}$ ' bs fracción de $\mathrm{DQO}_{\mathrm{rb}}$ de la $\mathrm{S}_{\mathrm{bi}}$

$\mathrm{Y}_{\mathrm{Hv}}$ rendimiento de los $\mathrm{OHOs}=0.45$ [mgSSV/mgDQO]

2.86 equivalencia del nitrato en $\mathrm{mg}$ de oxígeno, $\mathrm{mg}$ $\mathrm{O}_{2} / \mathrm{mgNO}_{3}^{-}$

Por otra parte, la DQO $\mathrm{lb}_{\mathrm{lb}}$, contribuye como substrato al proceso de desnitrificación tanto en los reactores anóxicos primarios como en los secundarios. Los potenciales de desnitrificación de la $\mathrm{DQO}_{\mathrm{lb}}$ se formulan con base en las tasas respectivas de desnitrificación $\mathrm{K}_{2} \mathrm{y}$ $\mathrm{K}_{3}$. Estas tasas $\mathrm{K}$ son una simplificación de las ecuaciones cinéticas que describen la utilización de la DQO ${ }_{\mathrm{lb}}$ presente en el afluente y/o presente por acción de la muerte y lisis de los organismos, y se basan en la cinética biológica fundamental incorporada a modelos de simulación de lodos activados como el ASM1 (van Haandel et al., 1981; Henze et al., 1987). Las tasas K definen la tasa de desnitrificación como $\mathrm{mgNO}_{3}-\mathrm{N}$ desnitrificado diariamente por mgOHO-SSV de masa en el reactor anóxico. Para poder determinar la contribución de la $\mathrm{DQO}_{\mathrm{lb}}$ al potencial de desnitrificación, es necesario calcular la masa de OHO-SSV producida por caudal afluente y la proporción de esta masa en los reactores anóxicos primarios y/o secundarios, para finalmente multiplicarlos por las tasas $\mathrm{K}_{2} \mathrm{y} / \mathrm{o} \mathrm{K}_{3}$ respectivamente.

Del modelo de lodos activados en estado estacionario para la remoción de materia orgánica (Capítulo 4, Sección 4.4.2.1), la masa de OHOs en el sistema $\left(\mathrm{MX}_{\mathrm{v}}\right)$ se calcula a partir de la carga de DQO biodegradable (Ec. 4.9). De esta masa $M X_{B H v}$, una fracción $f_{x 1} y / o f_{x 3}$ está(n) continuamente presente(s) en los reactores anóxicos primario $y / 0$ secundario, donde $f_{x 1} y / 0 \quad f_{x 3}$ son, respectivamente, las fracciones de masa anóxicas primaria y secundaria. La masa de OHO-SSV en los reactores anóxicos primarios y secundarios se puede calcular como:

$$
\begin{array}{r}
f_{x 1} M X_{B H v} / Q_{i}=f_{x 1} S_{b i} Y_{H v} T R S /\left(1+b_{H} T R S\right) \\
{[\mathrm{mgOHO}-\mathrm{SSV} / \mathrm{l}]}
\end{array}
$$

para un reactor anóxico primario,

$\mathrm{y}$,

$$
\begin{array}{r}
f_{x 3} M X_{B H v} / Q_{i}=f_{x 3} S_{b i} Y_{H v} T R S /\left(1+b_{H} T R S\right) \\
{[\mathrm{mgOHO}-\mathrm{SSV} / 1]}
\end{array}
$$

para un reactor anóxico secundario.

Multiplicando estas masas por sus respectivas tasas $\mathrm{K}$ produce los potenciales de desnitrificación primario y secundario atribuibles a la DQO ${ }_{\mathrm{lb}}\left(\mathrm{D}_{\mathrm{p} 1 \mathrm{DQOlb}}, \mathrm{D}_{\mathrm{p} 3 \mathrm{DQOlb}}\right)$ :

$$
\begin{aligned}
& D_{p 1, D Q O l b}=K_{2} f_{x 1} M X_{B H} / Q_{i}= \\
& =K_{2} f_{x 1} S_{b i} Y_{H v} T R S /\left(1+b_{H} T R S\right)
\end{aligned}
$$

$D_{p 3, D Q O l b}=K_{3} f_{x 3} S_{b i} Y_{H v} T R S /\left(1+b_{H} T R S\right)$

Este enfoque es válido debido a que las tasas $\mathrm{K}_{2}$ y $\mathrm{K}_{3}$ son continuas para el tiempo de residencia de lodos total en los reactores anóxicos, siempre y cuando la concentración de nitrato no llegue a cero (Figura 5.14). Combinando los componentes de DQO $\mathrm{rb}$ y DQO $\mathrm{lb}$ el potencial total de desnitrificación para los reactores anóxicos primarios y secundarios se puede obtener como:

$$
\begin{aligned}
& D_{p 1}=D_{p 1, D Q O r b}+D_{p l, D Q O l b} \\
& =f_{S b^{\prime} s} S_{b i}\left(1-f_{c v}\right) / 2.86+S_{b i} K_{2} f_{x l} f_{c v} T R S /\left(1+b_{H} T R S\right) \\
& =S_{b i}\left\{f_{S b^{\prime} s}\left(1-f_{c v}\right) / 2.86+K_{2} f_{x l} f_{c v} T R S /\left(1+b_{H} T R S\right)\right\} \\
& \quad\left[\mathrm{mgN} / 1_{\text {afluente }}\right] \\
& \mathrm{y}, \\
& D_{p 3}=D_{p 3, D Q O r b}+D_{p 3, D Q O l b} \\
& =0+S_{b i} K_{3} f_{x 3} Y_{H v} T R S /\left(1+b_{H} T R S\right)
\end{aligned}
$$

$$
\left[\mathrm{mgN} / \mathrm{l}_{\text {afluente }}\right]
$$

En las Ecuaciones 5.49 y 5.50 , las tasas $\mathrm{K}_{2}, \mathrm{~K}_{3}$ y bH son sensibles a los cambios de temperatura, disminuyendo a medida que la temperatura disminuye. La sensibilidad por temperatura de estas tasas ha sido determinada y se define en las Tablas 5.5 y 4.2. De las Ecuaciones 5.49 y 5.50 , se puede observar que los 
potenciales de desnitrificación son directamente proporcionales a la concentración de DQO biodegradable $\left(\mathrm{S}_{\mathrm{bi}}\right)$ en el agua residual. Esto es algo esperado porque del mismo modo que la demanda de oxígeno está directamente relacionada con la carga de DQO, también lo está la demanda de nitrato (la cual es llamada potencial de desnitrificación) ya que tanto el oxígeno como el nitrato actúan como aceptores de electrones para las reacciones de degradación de materia orgánica. Para un mismo tamaño de reactor, el reactor anóxico primario tiene un potencial de desnitrificación mucho más alto (alrededor de 2 a 3 veces más) que el reactor anóxico secundario debido a que (i) $\mathrm{K}_{2}$ es más grande que $\mathrm{K}_{3}$, y (ii) la $\mathrm{DQO}_{\mathrm{rb}}$ tiene una contribución apreciable al potencial de desnitrificación en el reactor anóxico primario. Por esta razón, la $\mathrm{DQO}_{\mathrm{rb}}$ debe calcularse con exactitud para estimar de manera confiable la remoción de nitrógeno que puede obtenerse. Para un agua residual municipal normal con una fracción de $\mathrm{DQO}_{\mathrm{rb}}\left(\mathrm{f}_{\mathrm{Sb}} \mathrm{s}\right)$ cercana a $25 \%$ (con respecto a la DQO biodegradable) y dependiendo de la temperatura y del tamaño del reactor anóxico primario, la $\mathrm{DQO}_{\mathrm{rb}}$ contribuye entre $1 / 3$ y $1 / 2$ al potencial de desnitrificación $\mathrm{D}_{\mathrm{p} 1}$. En un sistema con un alto grado de remoción de $\mathrm{N}$, entre $1 / 4$ y $1 / 3$ parte de la demanda carbonácea de oxígeno puede ser cubierta o reemplazada por la desnitrificación, la cual reduce la demanda carbonácea de oxígeno en el reactor aerobio en la misma cantidad. Como se mencionó anteriormente, esta reducción representa alrededor de la mitad del oxígeno requerido para producir nitrato en el proceso de nitrificación (ver Figura 5.11).

De la Ecuación 5.54, la contribución de la $\mathrm{DQO}_{\mathrm{rb}}$ en el afluente al potencial de desnitrificación de los reactores anóxicos secundarios es cero. Esto se debe a que toda la $\mathrm{DQO}_{\mathrm{rb}}$ es utilizada o en los reactores primarios anóxicos $\mathrm{o}$ en los reactores aerobios precedentes. No obstante, el término de la DQO $\mathrm{P}_{\mathrm{rb}}$ ha sido incluido en la $\mathrm{D}_{\mathrm{p} 3}$ (Ec. 5.50) considerando un posible evento en el cual se dosifique una fuente adicional externa de carbono para mejorar el proceso desnitrificación, como puede ser metanol, ácido acético o aguas residuales con una carga alta. El cálculo de

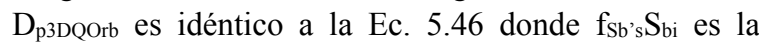
concentración de $\mathrm{DQO}$ en $\mathrm{mgDQO} / \mathrm{l}$ de la materia orgánica dosificada en el afluente. Sin embargo, se debe resaltar que el valor de YHv es significativamente menor a $0.56 \mathrm{mgSSV} / \mathrm{mgDQO}$ cuando se utiliza metanol.

El enfoque de la fracción de masa de lodos descrito anteriormente es válido debido a que la fracción de masa de SSV $\left(\mathrm{MX}_{\mathrm{v}}\right)$ o de SST $\left(\mathrm{MX}_{\mathrm{t}}\right)$ que corresponde a la masa de OHOs $\left(\mathrm{MX}_{\mathrm{BHv}}\right)$ es constante para unas características específicas del agua residual y una edad de lodos definida, y es igual a la fracción activa ( $f_{a t}$ o $f_{a v}$ - Ecs. 4.26 y 4.27) y muy similar en los reactores anóxicos y aerobios del sistema. Por lo tanto, las fracciones de masa (de lodo) aerobia y anóxica son iguales, independientemente de si se calculan utilizando los SSV, SST o las masas de OHOs; por ejemplo, en un sistema MLE con un volumen anóxico y aerobio de 3,000 y 6,000 $\mathrm{m}^{3}$, respectivamente, un valor muy cercano a $1 / 3$ de las masas de SSV y SST de los OHOs del sistema se encuentran en el reactor anóxico, y por ende, la fracción de masa anóxica es 0.33 .

\subsubsection{Fracción de masa anóxica primaria mínima}

En la Ec. 5.49, se asume que la desnitrificación inicial rápida siempre se lleva a cabo de forma completa, es decir que el tiempo de retención en el reactor anóxico primario es siempre mayor que el tiempo requerido para utilizar toda la $\mathrm{DQO}_{\mathrm{rb}}$ del afluente. Esto se debe a que en la Ec. 5.49, la desnitrificación se expresa en términos estequiométricos en lugar de cinéticos, es decir, se obtiene la concentración de nitrato removido por la tasa $\mathrm{K}_{1}$ una vez que se garantiza un tiempo suficiente para lograr el proceso. Teniendo en cuenta el tiempo de retención actual $\left(t_{1}\right)$ necesario para completar la $1^{\text {era }}$ fase de la desnitrificación (Figura 5.14 $\left.4^{\mathrm{a}}\right)$, y que $\mathrm{t}_{1} /(\mathrm{a}+\mathrm{s}+1)$ es el tiempo de retención hidráulico nominal mínimo necesario para alcanzarla, entonces se puede demostrar que la fracción de masa (de lodos) anóxica primaria mínima necesaria para remover toda la $\mathrm{DQO}_{\mathrm{rb}}$ en el afluente con una tasa $\mathrm{K}_{1}$ en $\mathrm{mgNO}_{3}-\mathrm{N} / \mathrm{mgOHOSSV}$.d es:

$f_{x 1 \mathrm{~min}}=\frac{f_{S b^{\prime} s}\left(1-f_{c v} Y_{H v}\right)\left(1+b_{H T} T R S\right)}{2.86 K_{1 T} Y_{H v} T R S}$

Substituyendo los valores de las constantes cinéticas en la Ec. 5.51, se obtiene una $\mathrm{f}_{\mathrm{x} 1 \mathrm{~min}}<0.08$ con un TRS $>$ 10 días a una temperatura de $14^{\circ} \mathrm{C}$. En la práctica, este valor es mucho menor que el requerido para la mayor parte de reactores anóxicos primarios de tal forma que la Ec. 5.51 es válida para la mayoría de los casos. La Ecuación 5.51 también sirve para dimensionar selectores anóxicos una vez que la tasa $K_{1}\left(0 \mu_{H}\right)$ ha sido seleccionada adecuadamente (Ver Sección 5.8.6, Ec. 5.44).

\subsubsection{Influencia de la desnitrificación en la demanda de oxígeno y en el volumen del reactor}

Del enfoque de diseño para la nitrificación (Ec. 5.19) y la desnitrificación (Ecs. 5.49 y 5.50), puede observarse que 
el diseño para la remoción de $\mathrm{N}$ se hace enteramente basado en las fracciones de masa de lodo y por ende no es necesario que el volumen del reactor se conozca de antemano. El volumen del reactor se obtiene de forma idéntica a como se obtiene para un sistema completamente aerobio (Capítulo 4, Sección 4.7), es decir, se puede calcular una vez que se defina la concentración de SST en el reactor $\left(\mathrm{X}_{\mathrm{t}}\right)$. El volumen del reactor obtenido de esta forma se subdivide proporcionalmente en las fracciones de masa anóxica primaria y/o secundaria calculadas. Consecuentemente, el diseño para la remoción de nitrógeno se ajusta e integra dentro del diseño de un sistema aerobio para remoción de carga orgánica y para una concentración de SST en el reactor y una edad de lodos determinada, un sistema completamente aerobio y un sistema anóxico-aerobio para remoción de $\mathrm{N}$, tienen un mismo volumen de reactor.

Diversas investigaciones indican que existen varios factores que influyen en la masa de lodos generada por un sistema para una edad de lodos y una carga diaria promedio de DQO determinada. Uno de estos factores es la exposición alternada bajo condiciones aerobias y anóxicas. Sin embargo, desde el punto de vista del diseño, la influencia relativa de estos factores respecto a la incertidumbre en la carga orgánica (DQO), la fracción de DQO particulada no biodegradable y su respectiva variación diaria y estacional, no es lo suficientemente grande y por ende no se considera en el procedimiento descrito anteriormente. Desde el punto de vista del diseño, la única diferencia significativa entre un sistema aerobio y un sistema anóxico-aerobio es la demanda de oxígeno, y esta diferencia debe tenerse en cuenta para poder realizar un diseño económico (Figura 5.11).

\subsection{DESARROLLO Y DEMOSTRACIÓN DEL PROCEDIMIENTO DE DISEÑO}

En las secciones anteriores se concluyó que las características del agua residual afluente que necesitan determinarse de forma precisa son la relación NTK/DQO y la fracción de $\mathrm{DQO}_{\mathrm{rb}}$. Estos parámetros tienen una influencia importante en la capacidad de nitrificación y en el potencial de desnitrificación, respectivamente, y por ende en el desempeño de la remoción de $\mathrm{N}$ y la concentración mínima de nitrato en el efluente que puede alcanzarse mediante el proceso de desnitrificación biológica.

El efecto de estas características del agua residual en el proceso de diseño se demuestra a continuación mediante la utilización de un ejemplo con un agua residual cruda y una clarificada a diferentes concentraciones de NTK y fracciones de DQO $_{\mathrm{rb}}$.

El diseño para la remoción biológica de $\mathrm{N}$ se desarrolla continuando y extendiendo los cálculos iniciados con el agua residual cruda y clarificada del ejemplo anterior. Las características del agua residual se muestran en las Tablas 4.3 y 5.2. La única característica adicional requerida para el diseño que incluye el proceso de desnitrificación es la fracción de DQO $\mathrm{rb}$ del afluente (f $f_{S b}$ 's), la cual tiene un valor de 0.25 y de 0.385 con respecto a la DQO biodegradable $\left(\mathrm{S}_{\mathrm{bi}}\right)$ para el agua cruda y la clarificada, respectivamente. Los resultados obtenidos hasta el momento para la remoción de materia orgánica (DQO) y nitrificación se muestran en la Tabla 5.6.

\section{5-9.1 Revisión de los cálculos previos}

Dadas las características del agua residual cruda ( $\mathrm{f}_{\text {s'up }}=$ $0.15 \mathrm{mgDQO} / \mathrm{mgDQO}$, fs'us $=0.07 \mathrm{mgDQO} / \mathrm{mgDQO}$, $\mathrm{T}_{\min }=14^{\circ} \mathrm{C}, \mathrm{S}_{\mathrm{ti}}=750 \mathrm{mgDQO} / 1-$ ver Tabla 4.3$) \mathrm{y}$ una edad de lodos de 20 días, y aceptando que el contenido de nitrógeno en los sólidos volátiles $\left(\mathrm{f}_{\mathrm{n}}\right)$ es 0.10 $\mathrm{mgN} / \mathrm{mgSSV}$, el nitrógeno requerido para la producción de $\operatorname{lodos}\left(\mathrm{N}_{\mathrm{s}}\right)$ es igual a $17.0 \mathrm{mgN} / 1$ (Ec. 5.27).

De la Sección 5.7.5, la concentración de nitrógeno orgánico soluble biodegradable y no biodegradable del efluente $\left(\mathrm{N}_{\text {obse }}\right.$ y $\mathrm{N}_{\text {ouse, Ec. }}$ 5.37) es 0.0 y $1.80 \mathrm{mgN} / 1$, respectivamente. De la Ec. 5.15 la concentración de amonio en el efluente $\left(\mathrm{N}_{\mathrm{ae}}\right)$ es $2.0 \mathrm{mgN} / \mathrm{l}$. La concentración de NTK en el efluente $\left(\mathrm{N}_{\mathrm{te}}\right)$ es igual a la suma de $\mathrm{N}_{\text {ouse }} \mathrm{y} \mathrm{N}_{\mathrm{ae}}\left(\right.$ Ec. 5.33 ) y por ende $\mathrm{N}_{\mathrm{te}}=3.8 \mathrm{mgN} / \mathrm{l}$ (Tabla 5.6).

La capacidad de nitrificación $\left(\mathrm{N}_{\mathrm{c}}\right)$ se estima con la Ec. 5.35 y para el agua residual cruda del ejemplo $\left(\mathrm{N}_{\mathrm{ti}}=48.0\right.$ $\mathrm{mgN} / \mathrm{l} ; \mathrm{NTK} / \mathrm{DQO}=0.08 \mathrm{mgN} / \mathrm{mgDQO})$ a $14^{\circ} \mathrm{C}$ es igual a $48.0-17.0-3.8=39.2 \mathrm{mgN} / 1$.

La demanda de oxígeno para nitrificación $\left(\mathrm{FO}_{\mathrm{n}}\right)$ se calcula de la Ec 5.43:

$$
\begin{aligned}
& \mathrm{FO}_{\mathrm{n}} \quad=4.57 \cdot \mathrm{N}_{\mathrm{c}} \cdot \mathrm{Q}_{\mathrm{I}}=4.57 \cdot 39.2 \cdot 1,510^{6} \mathrm{mgO}_{2} / \mathrm{d} \\
& =2687 \mathrm{kgO}_{2} / \mathrm{d}
\end{aligned}
$$

y la masa de organismos nitrificantes expresados en términos de SSV en el reactor se obtiene de la Ec. 5.42:

$$
\mathrm{MX}_{\mathrm{A}}=0.1 \cdot 20 /(1+0.034 \cdot 20) \cdot 39.2 \cdot 15 \cdot 10^{6}
$$$$
=702 \mathrm{kgSSV}
$$ 
Tabla 5.6 Resumen de los cálculos para el diseño de sistemas con remoción de DQO y nitrificación con edad de lodos de 20 días y temperaturas de $14^{\circ} \mathrm{C}$ y $22^{\circ} \mathrm{C}$ para el agua residual cruda y clarificada del ejemplo de diseño (ver Tablas 4.3 y 5.2 para las características del agua residual)

\begin{tabular}{|c|c|c|c|c|c|c|}
\hline \multirow{2}{*}{$\begin{array}{l}\text { Parámetro } \\
\text { Características del agua residual }\end{array}$} & \multirow[t]{2}{*}{ Símbolo } & \multirow[t]{2}{*}{ Unidad } & \multicolumn{2}{|c|}{ Agua cruda } & \multicolumn{2}{|c|}{ Agua clarificada } \\
\hline & & & & & & \\
\hline Caudal afluente & $\mathrm{Q}_{\mathrm{i}}$ & $\mathrm{Ml} / \mathrm{d}$ & 15.00 & & 14.93 & \\
\hline Concentración de la DQO en el afluente & $\mathrm{S}_{\mathrm{ti}}$ & $\mathrm{mgDQO} / 1$ & 750 & & 450 & \\
\hline Concentración de NTK en el afluente & $\mathrm{N}_{\mathrm{ti}}$ & $\mathrm{mgN} / 1$ & 60 & & 51 & \\
\hline Relación de NTK/DQO & $\mathrm{f}_{\mathrm{ns}}$ & $\mathrm{mgNTK} / \mathrm{mgDQO}$ & 0.080 & & 0.113 & \\
\hline Fracción de $\mathrm{DQO}_{\mathrm{rb}}$ & $f_{S b}$ 's & $\mathrm{mgDQO} / \mathrm{mgDQO}$ & 0.25 & & 0.385 & \\
\hline Temperatura del agua residual & $\mathrm{T}$ & ${ }^{\circ} \mathrm{C}$ & 14 & 22 & 14 & 22 \\
\hline \multicolumn{7}{|l|}{$\begin{array}{l}\text { Remoción de material orgánica (carbonácea) } \\
\text { (Capítulo 4) }\end{array}$} \\
\hline Masa de DQO no biodegradable en el afluente & $\mathrm{FS}_{\mathrm{bi}}$ & $\mathrm{kgDQO} / \mathrm{d}$ & 8,775 & 8,775 & 5,664 & 5,664 \\
\hline Masa residual de DQO biodegradable & $\mathrm{FS}_{\mathrm{b}}$ & $\mathrm{kgDQO} / \mathrm{d}$ & 0 & 0 & 0 & 0 \\
\hline Masa activa de microorganismos & $\mathrm{MX}_{\mathrm{BH}}$ & kgSSV & 15,659 & 12,984 & 10,107 & 8,381 \\
\hline Residuo de masa endógena & $\mathrm{MX}_{\mathrm{EH}}$ & kgSSV & 12,663 & 13,198 & 8,174 & 8,519 \\
\hline Masa orgánica no biodegradable & $\mathrm{MX}_{\mathrm{I}}$ & kgSSV & 22,804 & 22,804 & 3,649 & 3,649 \\
\hline Masa de sólidos suspendidos volátiles & $\mathrm{MX}_{\mathrm{v}}$ & kgSSV & 51,126 & 48,986 & 21,930 & 20,549 \\
\hline Masa de sólidos suspendidos totales & $\mathrm{MX}_{\mathrm{t}}$ & $\operatorname{kgSST}$ & 68,168 & 65,315 & 26,421 & 24,757 \\
\hline Fracción activa $-\mathrm{SSV}$ & $\mathrm{f}_{\mathrm{av}}$ & & 0.306 & 0.265 & 0.461 & 0.408 \\
\hline Fracción activa $-\mathrm{SST}$ & $f_{a v}$ & & 0.230 & 0.199 & 0.383 & 0.339 \\
\hline Masa de la demanda carbonácea de oxígeno & $\mathrm{FO}_{\mathrm{c}}$ & $\mathrm{kgO}_{2} / \mathrm{d}$ & 6,679 & 6,838 & 4,311 & 4,413 \\
\hline Masa de nitrógeno para la producción de lodos & $\mathrm{FN}_{\mathrm{s}}$ & $\mathrm{kgN} / \mathrm{d}$ & 255.6 & 244.9 & 109.7 & 102.7 \\
\hline Masa de SST purgada & $\mathrm{FX}_{\mathrm{t}}$ & $\mathrm{kgSST} / \mathrm{d}$ & 3,408 & 3,266 & 1,321 & 1,238 \\
\hline \multicolumn{7}{|l|}{ Nitrificación (Sección 5.6) } \\
\hline Fracción permisible de masa no aireada & $f_{x m}$ & & 0.534 & 0.80 & 0.534 & 0.80 \\
\hline Fracción de masa no aireada de diseño & $f_{x t}$ & & 0.534 & 0.534 & 0.534 & 0.534 \\
\hline Factor de seguridad & $\mathrm{S}_{\mathrm{f}}$ & & 1.25 & 2.88 & 1.25 & 2.88 \\
\hline Nitrógeno orgánico biodegradable en el efluente & Nobe & $\mathrm{mgN} / 1$ & 0.0 & 0.0 & 0.0 & 0.0 \\
\hline $\begin{array}{l}\text { Nitrógeno orgánico soluble no biodegradable en } \\
\text { el efluente }\end{array}$ & $\mathrm{nN}_{\text {ouse }}$ & $\mathrm{mgN} / 1$ & 1.80 & 1.80 & 1.80 & 1.80 \\
\hline Concentración de amonio en el efluente & $\mathrm{N}_{\mathrm{ae}}$ & $\mathrm{mgN} / 1$ & 2.0 & 0.7 & 2.0 & 0.7 \\
\hline Concentración de NTK en el efluente & $\mathrm{N}_{\mathrm{te}}$ & $\mathrm{mgN} / 1$ & 3.8 & 2.5 & 3.8 & 2.5 \\
\hline Concentración de $\mathrm{N}$ en la producción de lodos & $\mathrm{N}_{\mathrm{s}}$ & $\mathrm{mgN} / 1$ & 17.0 & 16.3 & 7.4 & 6.9 \\
\hline Capacidad ed nitrificación & $\mathrm{N}_{\mathrm{c}}$ & $\mathrm{mgN} / 1$ & 39.2 & 41.2 & 39.9 & 41.6 \\
\hline Masa de organismos nitrificantes & $\mathrm{MX}_{\mathrm{A}}$ & kgSSV & 702 & 669 & 711 & 673 \\
\hline Demanda de oxígeno de la nitrificación & $\mathrm{FO}_{\mathrm{n}}$ & $\mathrm{kgO}_{2} / \mathrm{d}$ & 2,685 & 2,824 & 2,719 & 2,840 \\
\hline Demanda total de oxígeno & $\mathrm{FO}_{\mathrm{t}}$ & $\mathrm{kgO}_{2} / \mathrm{d}$ & 9,364 & 9,661 & 7,030 & 7,254 \\
\hline
\end{tabular}

En la Tabla 5.6 se encuentran los cálculos de $\mathrm{N}_{\mathrm{s}}, \mathrm{N}_{\mathrm{ae}}, \mathrm{N}_{\mathrm{te}}$, $\mathrm{N}_{\mathrm{c}}, \mathrm{FO}_{\mathrm{n}}$ y $\mathrm{MX}_{\mathrm{A}}$ descritos anteriormente, para el agua residual cruda y clarificada a temperaturas de 14 y $22^{\circ}$.

Debido a que en el proceso de diseño se busca reducir la concentración de nitrato en el efluente tanto como sea posible, se disminuye el consumo de la alcalinidad del agua residual. Asumiendo que el $80 \%$ del nitrato que se forma es desnitrificado, el cambio en la alcalinidad de
$\mathrm{H}_{2} \mathrm{CO}_{3}=-7.14 \mathrm{~N}_{\mathrm{c}}+3.57$ (nitrato desnitrificado) $=-7.14$ $\cdot 39.2+3.57 \cdot 0.80 \cdot 39.2=\quad-168 \mathrm{mg} / \mathrm{l} \mathrm{como} \mathrm{CaCO}_{3}$. Con una alcalinidad de $\mathrm{H}_{2} \mathrm{CO}_{3}$ igual a $250 \mathrm{mg} / 1$ como $\mathrm{CaCO}_{3}$ la alcalinidad en el effluente $\left(\mathrm{H}_{2} \mathrm{CO}_{3}\right)=250-168$ $=82 \mathrm{mg} / \mathrm{l}$ como $\mathrm{CaCO}_{3}$, la cual como se puede observar en la Figura 5.6, se mantiene un $\mathrm{pH}$ por encima de 7.0 (ver Sección 5.4.6). 


\subsubsection{Selección de la fracción de la masa de lodos no aireada}

En sistemas con remoción de nitrógeno, la fracción de masa (de lodos) anóxica máxima disponible para la desnitrificación $\left(f_{x d m}\right)$ puede calcularse como la fracción de masa no aireada máxima $\left(\mathrm{f}_{\mathrm{xm}}\right)$ a la temperatura mínima, es decir:

$f_{x d m}=f_{x m}$

donde $f_{x m}$ se obtiene de la Ec. 5.19 para un TRS, $\mu_{\text {AmT }} y$ temperatura $T_{\min }$ seleccionada.

Esto se debe a que en sistemas con remoción de $\mathrm{N}$ no se puede considerar la fracción de la masa de lodos no aireados para el reactor anaerobio. En sistemas con remoción de $\mathrm{N}$ y $\mathrm{P}$ una parte de la masa de lodos no aireada (0.12-0.25) se necesita para que el reactor anaerobio estimule la remoción biológica de fósforo. Esta fracción de masa de lodos anaerobia $\left(f_{x a}\right)$ no puede ser utilizada para la desnitrificación. Para que la EBPR sea tan alta como sea posible, no debe existir ninguna recirculación de nitrato al reactor anaerobio para evitar que ocurra el proceso de desnitrificación dentro del reactor anaerobio. Por consiguiente, para demostrar el comportamiento del proceso de desnitrificación y el desarrollo mostrado a continuación, se acepta que la fracción de la masa de lodos no aireada máxima $\left(f_{\mathrm{xm}}\right)$ disponible para una edad de lodos de 20 días es enteramente anóxica, es decir $\mathrm{f}_{\mathrm{xdm}}=\mathrm{f}_{\mathrm{xm}}=0.534$.

\subsubsection{Desempeño de sistema MLE para desnitrificación}

5·9·3.1 Relación de recirculación del licor mezclado (a) óptima

En el sistema MLE, toda la fracción de masa anóxica se encuentra en un reactor anóxico primario, es decir $f_{x 1}$ $=f_{x d m}=f_{x m}$. El potencial de desnitrificación del reactor anóxico primario $\mathrm{D}_{\mathrm{p} 1}$ se calcula con la Ec. 5.49, es decir, para el agua residual cruda y clarificada del ejemplo a $14^{\circ} \mathrm{C}$ y $f_{x m}=f_{x d m}=f_{x 1}=0.534, D_{p 1}=52.5 \mathrm{mgN} / 1$. Los valores de $\mathrm{D}_{\mathrm{p} 1}$ para el agua cruda y clarificada del ejemplo a 14 y $22^{\circ} \mathrm{C}$ se encuentran en la Tabla 5.7.

En el sistema MLE, si la concentración de nitrato en la salida del reactor anóxico es cero, entonces la concentración de nitrato en el reactor aerobio (Nnar) es igual a $\mathrm{Nc} /(\mathrm{a}+\mathrm{s}+1)$. Esto significa que es igual a la capacidad de nitrificación en $\mathrm{mgN} / \mathrm{l}$ diluida con el caudal total (que no tiene nitrato) que entra al reactor aerobio el cual es $(\mathrm{a}+\mathrm{s}+1)$ veces el caudal afluente, donde $a$ y s son las relaciones de recirculación del licor mezclado y de lodos respectivamente (con respecto al caudal promedio $\mathrm{Q}_{\mathrm{i}}$ ). Aceptando que no existe desnitrificación en los clarificadores secundarios (la cual debe minimizarse de cualquier forma debido a los problemas de lodos flotantes), las concentraciones de nitrato en el efluente y a la salida del reactor aerobio (Nnar and Nne, respectivamente) son igual y pueden estimarse como:

$N_{n e}=N_{n a r}=\frac{N_{c}}{(a+s+1)}$

Conociendo el valor de $\mathrm{N}_{\text {ne }}$ y $\mathrm{N}_{\text {nar, }}$, y tomando en cuenta la concentración de OD en las recirculaciones $a$ y $\mathrm{s}$, es decir $\mathrm{O}_{\mathrm{a}}$ y $\mathrm{O}_{\mathrm{s}} \mathrm{mgO}_{2} / 1$, respectivamente, la carga equivalente de nitrato en el reactor anóxico primario $\left(\mathrm{N}_{\text {nlp }}\right)$ debido a las recirculaciones $a$ y $s$ esta dado por:

$N_{n l p}=\left[N_{n a r}+\frac{O_{a}}{2.86}\right] a+\left[N_{n e}+\frac{O_{s}}{2.86}\right] s$

La desnitrificación óptima, es decir, la que produce la concentración más baja de nitrato en el efluente, se obtiene cuando la carga equivalente de nitrato en la zona anóxica es igual al potencial de desnitrificación del reactor anóxico, $\mathrm{D}_{\mathrm{p} 1}=\mathrm{N}_{\mathrm{nlp}}$, obteniendo:

$D_{p 1}=\left[\frac{N_{c}}{(a+s+1)}+\frac{O_{a}}{2.86}\right] \cdot a+\left[\frac{N_{c}}{(a+s+1)}+\frac{O_{s}}{2.86}\right] \cdot s$

Resolviendo la Ec. 5.55 para $a$ se puede obtener la expresión para determinar la relación de la recirculación $a$ que garatiza que el reactor anóxico primario reciba una carga que se ajuste exactamente a su potencial de desnitrificación con nitrato y oxígeno disuelto presentes.

Este valor de $a$ se puede considerar óptimo dado que permite alcanzar el valor más bajo de $\mathrm{N}_{\mathrm{ne}}$ (concentración de nitrato en el efluente de la planta) y se puede calcular como:

$\mathrm{a}_{\text {opt }}=\left[-B+\sqrt{B^{2}+4 A C}\right] /(2 A)$

donde:

$\begin{array}{ll}\mathrm{A} & \mathrm{O}_{\mathrm{a}} / 2.86 \\ \mathrm{~B} & \mathrm{~N}_{\mathrm{c}}-\mathrm{D}_{\mathrm{p} 1}+\left\{(\mathrm{s}+1) \mathrm{O}_{\mathrm{a}}+\mathrm{s} \mathrm{O}_{\mathrm{s}}\right\} / 2.86 \\ \mathrm{C} & (\mathrm{s}+1)\left(\mathrm{D}_{\mathrm{pp}}-\mathrm{s} \mathrm{O}_{\mathrm{s}} / 2.86\right)-\mathrm{s} \mathrm{N}_{\mathrm{c}} \\ \mathrm{y} & \\ N_{\text {ne min }}= & N_{\text {ne aopt }}=\frac{N_{c}}{\left(a_{\text {opt }}+s+1\right)} \quad[\mathrm{mgN} / \mathrm{l}]\end{array}$ 
Tabla 5.7 Resumen de los calculos de diseño de un sistema modificado de Ludzack-Ettinger (MLE) para la remoción de nitrógeno en un sistema con y temperaturas de $14^{\circ} \mathrm{C}$ y $22^{\circ} \mathrm{C}$ para el agua residual cruda y clarificada del ejemplo de diseño (ver Tablas 4.3 y 5.2 para las características del agua residual)

\begin{tabular}{|c|c|c|c|c|c|c|}
\hline \multirow{2}{*}{$\begin{array}{l}\text { Parámetro } \\
\text { Características de las aguas residuales }\end{array}$} & \multirow[t]{2}{*}{ Símbolo } & \multirow[t]{2}{*}{ Unidad } & \multicolumn{2}{|c|}{ Agua cruda } & \multicolumn{2}{|c|}{ Agua clarificada } \\
\hline & & & & & & \\
\hline Caudal afluente & $\mathrm{Q}_{\mathrm{i}}$ & $\mathrm{Ml} / \mathrm{d}$ & 15.00 & & 14.93 & \\
\hline Concentración de DQO en el afluente & $\mathrm{S}_{\mathrm{ti}}$ & $\mathrm{mgDQO} / 1$ & 750 & & 450 & \\
\hline Concentración de NTK en el afluente & $\mathrm{N}_{\mathrm{ti}}$ & $\mathrm{mgN} / 1$ & 60 & & 51 & \\
\hline Relación de NTK/DQO & $\mathrm{f}_{\mathrm{ns}}$ & $\mathrm{mgNTK} / \mathrm{mgDQO}$ & 0.080 & & 0.113 & \\
\hline Fracción de $\mathrm{DQO}_{\mathrm{rb}}$ & $f_{S b}$ 's & $\mathrm{mgDQO} / \mathrm{mgDQO}$ & 0.25 & & 0.385 & \\
\hline Temperatura del agua residual & & ${ }^{\circ} \mathrm{C}$ & 14 & 22 & 14 & 22 \\
\hline \multicolumn{7}{|l|}{ Características de diseño del sistema MLE } \\
\hline Fracción de masa anóxica primaria & $f_{x 1}$ & & 0.534 & 0.534 & 0.534 & 0.534 \\
\hline Potencial de desnitrificación & $\mathrm{D}_{\mathrm{p} 1}$ & $\mathrm{mgN} / 1$ & 52.5 & 71.5 & 40.1 & 52.4 \\
\hline Fracción de masa anóxica primaria mínima & $\mathrm{f}_{\mathrm{x} 1, \min }$ & & 0.068 & 0.019 & 0.105 & 0.029 \\
\hline OD en la recirculación del licor mezclado $a$ & $\mathrm{O}_{\mathrm{a}}$ & $\mathrm{mgO}_{2} / 1$ & 2.0 & 2.0 & 2.0 & 2.0 \\
\hline OD en la recirculación de lodos $s$ & $\mathrm{O}_{\mathrm{s}}$ & $\mathrm{mgO}_{2} / 1$ & 1.0 & 1.0 & 1.0 & 1.0 \\
\hline Relación de recirculación de lodos & $\mathrm{s}$ & & 1.0 & 1.0 & 1.0 & 1.0 \\
\hline \multicolumn{2}{|c|}{ Desempeño: bajo la relación NTK/DQO del ejemplo } & & 0.080 & 0.080 & 0.113 & 0.113 \\
\hline Relación de recirculación óptima & aopt & & 21.6 & 44.1 & 6.5 & 17.9 \\
\hline Concentración de nitrato en el efluente a aopt & $\mathrm{N}_{\text {ne,aopt }}$ & $\mathrm{mgN} / 1$ & 1.7 & 0.9 & 4.7 & 2.1 \\
\hline Relación de recirculación práctica & aprac & & 5.0 & 5.0 & 5.0 & 5.0 \\
\hline Concentración de nitrato en el efluente a aprac & $\mathrm{N}_{\text {ne,aprac }}$ & $\mathrm{mgN} / 1$ & 5.6 & 5.9 & 5.7 & 5.9 \\
\hline Oxígeno recuperado por la desnitrificación & $\mathrm{FO}_{\mathrm{d}}$ & $\mathrm{kgO}_{2} / \mathrm{d}$ & 1,440 & 1,515 & 1,458 & 1,524 \\
\hline Demanda total neta de oxígeno & $\mathrm{FO}_{\mathrm{td}}$ & $\mathrm{kgO}_{2} / \mathrm{d}$ & 7,924 & 8,147 & 5,572 & 5,730 \\
\hline $\begin{array}{l}\text { Desempeño: bajo la relación NTK/DQO } \\
a_{\text {opt }}=a_{\text {prac }}=5: 1 \text { (balanceado) }\end{array}$ & & & 0.104 & 0.132 & 0.119 & 0.148 \\
\hline Concentración de nitrato en el efluente a $a_{o p t}$ & $\mathrm{~N}_{\text {ne,aopt }}$ & $\mathrm{mgN} / 1$ & 8.1 & 11.3 & 6.0 & 8.1 \\
\hline Concentración de NTK en el efluente & $\mathrm{N}_{\mathrm{te}}$ & $\mathrm{mgN} / 1$ & 4.3 & 3.6 & 3.9 & 3.0 \\
\hline Nitrógeno total en el efluente & & $\mathrm{mgN} / 1$ & 12.4 & 14.9 & 9.9 & 11.1 \\
\hline$\%$ de remoción de nitrógeno & & & 84.1 & 84.9 & 81.5 & 83.3 \\
\hline Demanda de oxígeno para nitrificación & $\mathrm{FO}_{\mathrm{n}}$ & $\mathrm{kgO}_{2} / \mathrm{d}$ & 3,894 & 5,411 & 2,884 & 3,862 \\
\hline Oxígeno recuperado por la desnitrificación & $\mathrm{FO}_{\mathrm{d}}$ & $\mathrm{kgO}_{2} / \mathrm{d}$ & 2,089 & 2,902 & 1,547 & 2,072 \\
\hline Demanda total neta de oxígeno & $\mathrm{FO}_{\mathrm{td}}$ & $\mathrm{kgO}_{2} / \mathrm{d}$ & 8,485 & 9,346 & 5,648 & 6,204 \\
\hline
\end{tabular}

Con $\mathrm{a}=$ aopt, la Ec. 5.57 es válida para $\mathrm{N}_{\text {ne }} \mathrm{y}$ permite el cálculo del valor mínimo posible de $\mathrm{N}_{\text {ne. }}$ Cuando a $\leq$ $\mathrm{a}_{\text {opt }}$, la Ec. 5.57 también es válida debido a que la premisa en la que se basa la Ec. 5.56 es válida, es decir, $\mathrm{N}_{\mathrm{nl}} \leq \mathrm{D}_{\mathrm{p} 1}$ o de forma equivalente, la concentración de nitrato es igual a cero a la salida del reactor anóxico.

Sin embargo, cuando a $>$ apt, esta premisa deja de cumplirse y $\mathrm{N}_{\text {ne }}$ aumenta a medida que la relación de recirculación $a$ aumenta, debido a que flujo y carga de oxígeno se incrementa proporcionalmente con la tasa de recirculación a y por consiguiente cada vez ingresa más oxígeno disuelto al reactor anóxico. Para a $>$ aopt, $\mathrm{N}_{\mathrm{ne}}$ puede calcularse como la diferencia entre la carga equivalente de nitrato en el reactor anóxico (la cual es la suma de la capacidad de nitrificación $\mathrm{N}_{\mathrm{c}} \mathrm{y}$ el equivalente en nitrato de la concentración de oxígeno respecto del caudal afluente) y el potencial de desnitrificación, usando la siguiente expresión:

$$
N_{n e}=N_{c}+\frac{a O_{a}}{2.86}+\frac{s O_{s}}{2.86}-D_{p 1} \quad[\mathrm{mgN} / 1]
$$

Debido a que $\mathrm{N}_{\mathrm{c}}, \mathrm{D}_{\mathrm{p} 1}, \mathrm{O}_{\mathrm{s}}$ y $\mathrm{O}_{\mathrm{a}}$ se asumen constantes, el incremento de $\mathrm{N}_{\text {ne }}$ es lineal, con una pendiente $\mathrm{O}_{\mathrm{a}} / 2.86$ $\mathrm{mgN} / 1$, para un incremento en $\mathrm{a}_{\text {opt }}$.

Cuando $\mathrm{a}=$ aopt, ambas Ecuaciones 5.57 y 5.58 resultan en la misma concentración de $\mathrm{N}_{\text {ne }}$. 
Tomando una edad de lodos de diseño de 20 días, la cual permite una fracción de masa de lodos no aireada máxima $\left(\mathrm{f}_{\mathrm{xm}}\right)$ de 0.534 , en las páginas siguientes se muestra el comportamiento del proceso de desnitrificación del sistema MLE con un ejemplo desplegado para un agua residual cruda y una clarificada a $14^{\circ} \mathrm{C}$ y $22^{\circ} \mathrm{C}$. En los cálculos, la concentración de oxígeno disuelto en las recirculaciones $a$ y $s\left(\mathrm{O}_{\mathrm{a}}\right.$ y $\left.\mathrm{O}_{\mathrm{s}}\right)$ son 2 y $1 \mathrm{mgO}_{2} / 1$ respectivamente, y la relación de recirculación $\mathrm{s}$ es 1:1. Esta relación de recirculación $\mathrm{s}$ se establece usualmente considerando un valor que permita una operación satisfactoria de los clarificadores secundarios. Los detalles sobre la teoría, diseño, modelación y operación de clarificadores secundarios presentados por Ekama et al. (1997) están descritos en el Capítulo 12.

Reemplazando los valores de la capacidad de nitrificación $\left(\mathrm{N}_{\mathrm{c}}\right)$ y el potencial de desnitrificación $\left(\mathrm{D}_{\mathrm{p} 1}\right)$ (Tablas 5.5 y 5.7) en las Ecuaciones 5.56 y 5.57, se obtiene en valor óptimo de la recirculación del licor mezclado $\left(\mathrm{a}_{\mathrm{opt}}\right)$ y la concentración mínima de nitrato en el efluente $\left(\mathrm{N}_{\text {ne aopt }}\right)$, por ejemplo, para el agua residual a $14^{\circ} \mathrm{C}$ del ejemplo, se obtiene:

$$
\begin{array}{ll}
\mathrm{A} & =2 / 2.86=0.70 \\
\mathrm{~B} & =39.6-40.1+\{(1+1) 2+11\} / 2.86 \\
\mathrm{y} & =+1.52 \\
\mathrm{C} & =(1+1)(40.1-11 / 2.86)-139.6=+39.61
\end{array}
$$

Lo que resulta en $\mathrm{a}_{\mathrm{opt}}=6.5$ y $\mathrm{N}_{\text {nemin }}=4.7 \mathrm{mgN} / \mathrm{l}$. La Tabla 5.7 muestra los resultados anteriores así como los valores del ejemplo para el agua residual cruda y clarificada a $14^{\circ} \mathrm{C}$ y $22^{\circ} \mathrm{C}$. Los resultados en la Tabla 5.7 muestran que para todos los 4 casos a apt es mayor a 5. A pesar de que los cálculos incluyen la descarga de OD al reactor anóxico, relaciones de recirculación mayores a 5 o 6 no son económicamente viables. Una pequeña disminución en el valor de $\mathrm{N}_{\text {ne }}$ alcanzada a relaciones de circulación mayores de 5:1 no justifica los costos adicionales de bombeo.

La Figura 5.16 ilustra esta situación para el agua residual cruda (Figura 5.16A) y clarificada (Figura $5.16 \mathrm{~B})$ a $14^{\circ} \mathrm{C}$ y $22^{\circ} \mathrm{C}$ graficando los valores de $\mathrm{N}_{\text {ne }}$ contra las relaciones de recirculación utilizando las Ecuaciones 5.57 y 5.58. Para el agua residual clarificada (Figura $5.16 \mathrm{~B}) \mathrm{a} 14^{\circ} \mathrm{C}$ y s $=1: 1$, para valores de $\mathrm{a}<\mathrm{a}_{\text {opt }}$, el reactor anóxico está subutilizado debido una carga baja de nitrato y OD, y a medida que la relación de recirculación $a$ aumenta hasta el valor de aopt, también lo hace la carga de nitrato la cual aumenta hacia el potencial de desnitrificación del reactor anóxico. Inicialmente, $\mathrm{N}_{\mathrm{ne}}$ disminuye rápidamente para pequeños incrementos en el valor de $a$, pero a medida que $a$ aumenta, la reducción en el valor dede $\mathrm{N}_{\text {ne }}$ disminuye. $\mathrm{A} 14^{\circ} \mathrm{C}$ con $\mathrm{a}=\mathrm{a}_{\mathrm{opt}}=6.5$, las relaciones de recirculación $a$ y $s$, descargan en el reactor anóxico una carga de nitrato equivalente a su potencial de desnitrificación permitiendo así la obtención de $\mathrm{N}_{\text {nemin }}=\mathrm{N}_{\text {neaopt }}=4.7 \mathrm{mgN} / 1$. Con $\mathrm{a}=\mathrm{a}_{\mathrm{opt}}=6.5$, la mayor parte del potencial de desnitrificación del reactor anóxico se utiliza para la desnitrificación y por ende resulta en la concentración de nitrato en el efluente mínima ( $\left.\mathrm{N}_{\text {neaopt }}\right)$. Esto se muestra en la Figura 5.17A y 5.17B para el agua residual cruda y clarificada a $14^{\circ} \mathrm{C}$. Para el agua residual clarificada (Figura 5.17B), con a aopt $=6.5$, el 88\% de la carga equivalente de nitrato (es decir $(\mathrm{a}+\mathrm{s}) \mathrm{N}_{\text {nemin }}=35.2$ $\mathrm{mgN} / 1$ de un potencial $\mathrm{D}_{\mathrm{p} 1}=40.1 \mathrm{mgN} / \mathrm{l}$ ) es nitrato y por lo tanto $88 \%$ de la desnitrificación potencial del reactor anóxico se utiliza para la desnitrificación y el $12 \%$ restante para la remoción de OD. Entre más elevado sea el valor de la recirculación $a$, mayor será la proporción del potencial de desnitrificación utilizado para la remoción de $\mathrm{OD} . \mathrm{A} 14^{\circ} \mathrm{C}$, para $\mathrm{a}>\mathrm{a}_{\mathrm{opt}}$, la carga equivalente de nitrato excede el potencial de desnitrificación y a medida que el valor de $a$ aumenta, también aumenta $\mathrm{N}_{\text {ne }}$ debido al incremento del flujo de $\mathrm{OD}$ al reactor anóxico. De la Ecuación 5.58, con $\mathrm{a}=15$, $\mathrm{N}_{\text {ne }}=10.6 \mathrm{mgN} / 1$ y $27 \%$ del potencial de desnitrificación es requerido para remover el OD, dejando solo $73 \%$ para la desnitrificación (Figuras 5.16B y 5.17B).

Para el agua residual clarificada a $22^{\circ} \mathrm{C}$ y $\mathrm{s}=1: 1$ (Figura 5.16B), el gráfico de $\mathrm{N}_{\mathrm{ne}}$ contra $a$ es similar al obtenido a una temperatura de $14^{\circ} \mathrm{C}$ hasta un valor de $a=$ 6.5. Esto se debe a que $\mathrm{N}_{\mathrm{c}}$ a $14^{\circ} \mathrm{C}$ y $22^{\circ} \mathrm{C}$ para el agua residual cruda y clarificada es casi la misma (39.9 y 41.6 $\mathrm{mgN} / 1$ a $14^{\circ} \mathrm{C}$ y $22^{\circ} \mathrm{C}$ respectivamente, ver Tabla 5.6). Sin embargo, a $22^{\circ} \mathrm{C}$, el potencial de desnitrificación es significativamente mayor que a $14^{\circ} \mathrm{C}\left(40.1 \mathrm{mgN} / 1\right.$ a $14^{\circ} \mathrm{C}$ y $52.4 \mathrm{mgN} / 1$ a $22^{\circ} \mathrm{C}$, ver Tabla 5.7) de tal manera que se requiere un $\mathrm{a}_{\mathrm{opt}}$ más elevado $\left(\mathrm{a}_{\mathrm{opt}}=17.9\right)$ a $22^{\circ} \mathrm{C}$ que a $14^{\circ} \mathrm{C}$ para poder descargar en el reactor anóxico una carga de nitratos similar a su potencial de desnitrificación. Por consiguiente a $22^{\circ} \mathrm{C}$, a medida que la recirculación $a$ aumenta por encima del valor de 6.5 , $\mathrm{N}_{\text {ne }}$ continua disminuyendo hasta que alcanza a $\mathrm{a}_{\mathrm{opt}}=$ 17.9. El aumento en el valor de $a$ de 6.5 a 17.9 reduce $\mathrm{N}_{\mathrm{ne}}$ de 4.9 a 2.1, es decir una diferencia de solo $2.8 \mathrm{mgN} / 1$. Esta pequeña disminución en $\mathrm{N}_{\mathrm{ne}}$ no justifica el incremento asociado a los costos de bombeo para 

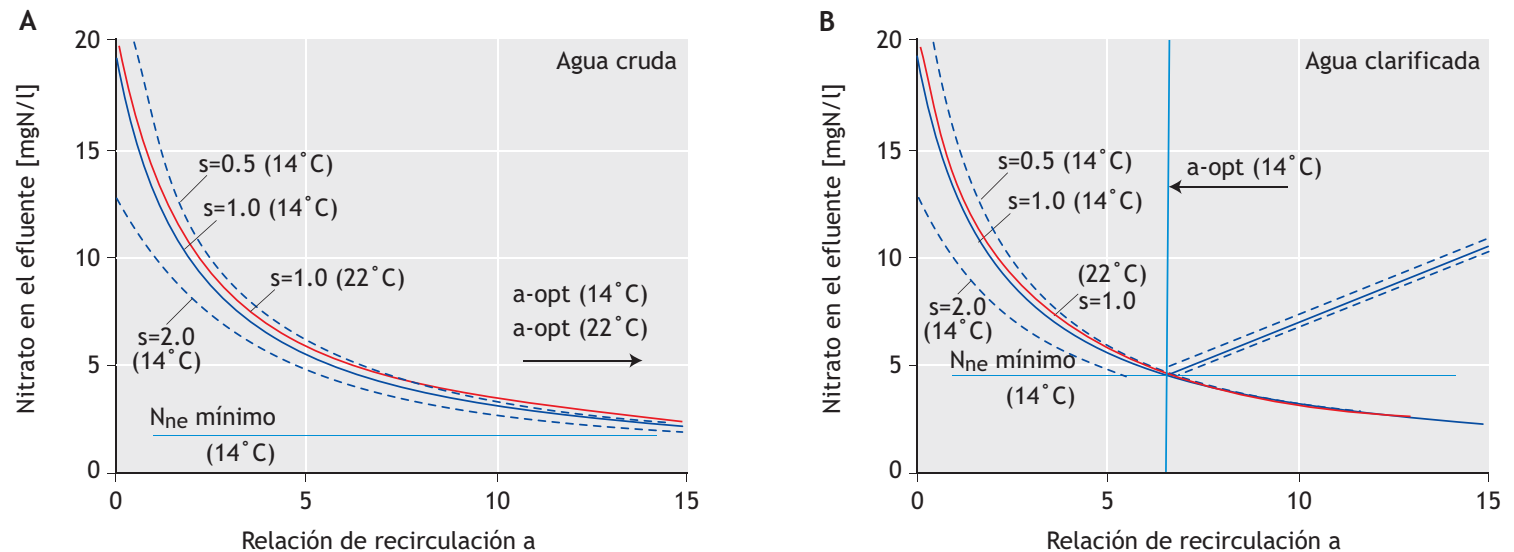

Figura 5.16 Concentración de nitrato en el efluente contra relación de recirculación del licor mezclado a para el agua residual (A) cruda y (B) clarificada del ejemplo de diseño teniendo en cuenta una relación de recirculación de lodos $s=1: 1$ a $14^{\circ} \mathrm{C}$ (línea azul) y $22^{\circ} \mathrm{C}$ (línea roja) y para $s=0.5: 1$ y $2.0: 1$ a $14^{\circ} \mathrm{C}$ (líneas punteadas)

producirla. Consecuentemente por razones de economía, la relación de recirculación $a$ se limita en la práctica (aprac) a un valor máximo de alrededor 5:1, el cual fija la concentración de nitrato en el efluente a un valor mínimo práctico entre 5 y $10 \mathrm{mgN} / 1$ para un sistema MLE dependiendo de la relación NTK/DQO en el afluente.

Para el procedimiento de diseño establecido hasta ahora, es claro que lo que se busca es balancear la carga equivalente de nitrato con el potencial de desnitrificación escogiendo una relación de recirculación apropiada. Para unos parámetros de diseño del sistema definidos (edad de lodos, fracción de masa anóxica, relación de recirculación de lodos, etc.) y unas características del agua residual (temperatura, fracción de DQO rápidamente biodegradable, relación de NTK/DQO etc.), el potencial de desnitrificacción del sistema MLE es constante. Con todo los parámetros y características definidas y fijas, el desempeño del sistema de desnitrificación está controlado por la relación de recirculación $a$, y este desempeño es óptimo cuando la relación de recirculación $a$ se ajusta a su valor óptimo $\mathrm{a}_{\text {opt }}$. Para un valor de a $<$ apt, el desempeño es inferior al óptimo debido a que la carga de nitrato es menor que el potencial de desnitrificación (Figura 5.17); para $\mathrm{a}=\mathrm{a}_{\mathrm{opt}}$, el desempeño es óptimo debido a que la carga equivalente de nitrato es igual al potencial de desnitrificación; y para a $>$ a apt, el desempeño puede considerarse también subóptimo debido a que en este caso la carga equivalente de nitrato es mayor que el
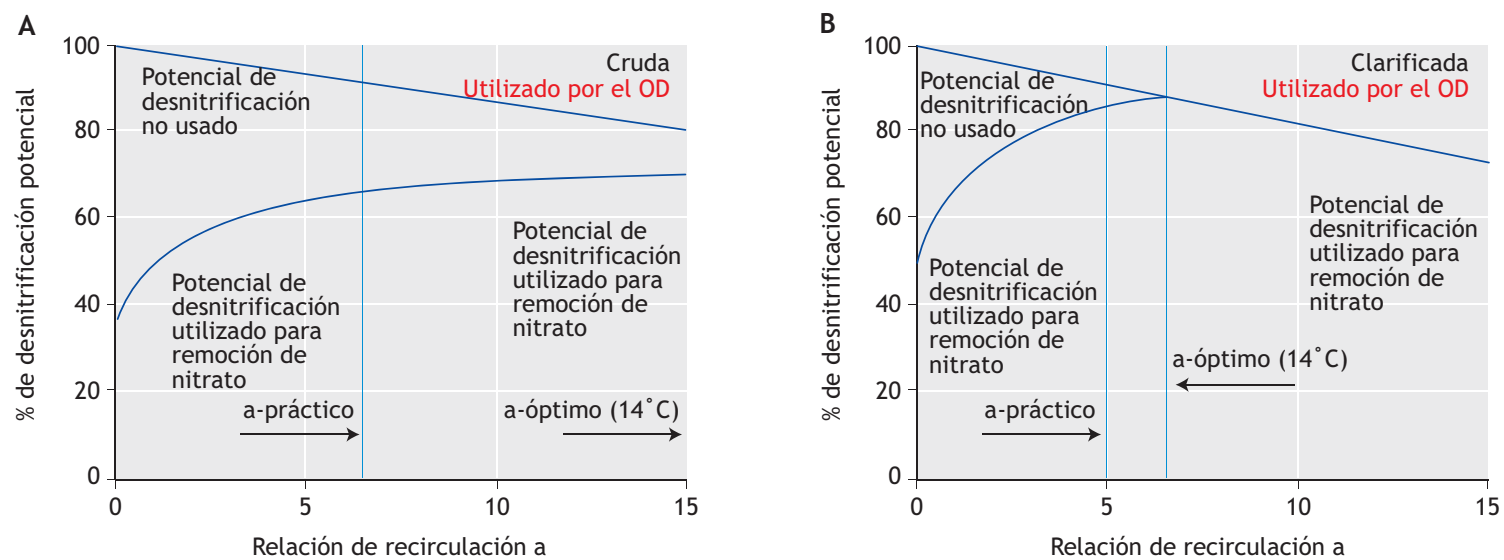

Figura 5.17\% de desnitrificación potencial no utilizada, utilizada por el oxígeno en las recirculaciones y usada para la desnitrificación en función de la relación de recirculación a del ejemplo de diseño para (A) un agua residual cruda y (B) clarificada, con relaciones de recirculación de lodos $s$ de $1: 1$ a $14^{\circ} \mathrm{C}$ 
potencial de desnitrificación y una mayor cantidad de OD que el necesario es recirculado de vuelta al reactor anóxico reduciendo la desnitrificación efectiva (ver Figuras 5.16 y 5.17).

Si el límite práctico para $a$ se ajusta a un valor de alrededor $\mathrm{a}_{\text {prac }}=5: 1 \mathrm{y} \mathrm{a}_{\mathrm{opt}}$ es apreciablemente mayor, entonces una proporción significativa del potencial de desnitrificación del reactor anóxico no se utiliza (Figura 5.17). Existen dos opciones para hacer frente a esta situación: (1) cambiar el diseño, es decir reducir la edad de lodos (TRS) y/o la fracción de masa de lodos no aireada $\left(f_{\mathrm{xm}}\right)$ o, (2) no modificar el diseño del sistema $\left(\mathrm{TRS}=20 \mathrm{~d}\right.$ y $\left.\mathrm{f}_{\mathrm{xm}}=0.534\right)$ y mantener el potencial de desnitrificación no utilizado como reserva para tener un factor de seguridad adicional en contra de los cambios en las características del agua residual. Por ejemplo, esa reserva puede ser utilizada para (i) contrarestar algún incremento en la carga orgánica la cual requiere una reducción en la edad de lodos, (ii) reducir los efectos causados por algún incremento en la relación NTK/DQO del afluente, la cual carga al reactor anóxico con nitrato con relaciones de recirculación más bajas, o (iii) disminuir alguna caída en el potencial de desnitrificación de los reactores anóxicos causado por una reducción en la fracción de DQOrb.

\subsubsection{Sistema MLE balanceado}

Con la opción (1) descrita anteriormente, la fracción de masa de lodos anóxica $\left(f_{x 1}\right)$ se reduce para eliminar el potencial de desnitrificación no usado. La disminución de $f_{x 1}$ aumenta la fracción de masa aerobia y por ende el factor de seguridad para la nitrificación $\left(\mathrm{S}_{\mathrm{f}}\right)$.

Para mantener el mismo $S_{f}$, y con un valor de $\mu_{\mathrm{Am} 20} \mathrm{y}$ $\mathrm{T}_{\text {min }}$ determinados, la edad de lodos del sistema puede reducirse a un valor que produzca un valor de $f_{x 1}$ que a la vez sea igual a la fracción de masa no aireada máxima $\left(f_{x m}\right)$ permitida (es decir, $f_{x 1}=f_{x m}$ ). Un sistema MLE con una edad de lodos (TRS) y una concentración NTK en el afluente $\left(\mathrm{N}_{\mathrm{ti}}\right)$ en el cual $\mathrm{f}_{\mathrm{x} 1}=\mathrm{f}_{\mathrm{xm}} \mathrm{y}$ aopt $=$ aprac (por ejemplo $5: 1$, de tal manera que este $a_{\text {prac }}$ recircula y por consiquiente carga al reactor anóxico exactamente con su potencial de desnitrificación. Este sistema se conoce como un sistema MLE balanceado.

Este enfoque de diseño para el sistema MLE fue propuesto por Haandel et al. (1982) y produce el diseño más económico de un reactor de lodos activados, es decir, con el TRS más bajo y por ende con un reactor de menor volumen, cumpliendo con la tasa más alta de desnitrificación para un valor de recirculación $a$ fijado a un valor práctico máximo. Las Figuras 5.18 y 5.19 muestran la relación de NTK/DQO en el afluente, $\mathrm{f}_{\mathrm{xm}}=$ $\mathrm{f}_{\mathrm{x} 1}, \mathrm{f}_{\mathrm{x} 1 \mathrm{~min}}, \mathrm{~N}_{\mathrm{ne}} \mathrm{y}$ el porcentaje de remoción de $\mathrm{N}\left(\% \mathrm{~N}_{\mathrm{rem}}\right)$ contra la edad de lodos con un sistema MLE balanceado para el agua residual cruda y clarificada del ejemplo de diseño a $14^{\circ} \mathrm{C}$ y $22^{\circ} \mathrm{C}$, respectivamente.

La edad de lodos que genera un balance en el sistema MLE para unas características determinadas del agua residual y un aprac no puede calcularse directamente. Es más fácil calcular la concentración de NTK en el afluente para un rango de edades de lodo y escoger aquella edad que mejor se ajusta a la concentración de NTK en el agua residual afluente $\left(\mathrm{N}_{\mathrm{ti}}\right)$. El procedimiento para calcular $\mathrm{N}_{\mathrm{ti}}$ en un sistema MLE balanceado es el siguiente: De los parámetros de diseño $\mu_{\mathrm{Am} 20}, \mathrm{~T}_{\min } \mathrm{y} \mathrm{S}_{\mathrm{f}} \mathrm{y}$ una edad de lodos seleccionada, se calcula $f_{x m}$ de la Ec. 5.19. Siempre que $f_{x m}>f_{x 1 \min }$ (Ec. 5.51), $f_{x 1}$ se ajusta igual a $f_{x m}$. Conociendo $\mathrm{f}_{\mathrm{x} 1} \mathrm{y}$ las características del agua, $\mathrm{D}_{\mathrm{p} 1}$ se calcula de la Ec. 5.49. Este $D_{p 1}$ y un valor seleccionado para aprac se reemplazan en la Ec. 5.55, la cual ajusta la carga equivalente de nitrato en el reactor anóxico igual al potencial de desnitrificación y por ende $\mathrm{a}_{\mathrm{opt}}=\mathrm{a}_{\text {prac. }}$. Con $\mathrm{D}_{\mathrm{p} 1} \mathrm{y} a$ definidos, $\mathrm{N}_{\mathrm{c}}$ se calcula con la Ec. 5.55. Una vez que se conoce el valor de $\mathrm{N}_{\mathrm{c}}, \mathrm{N}_{\mathrm{ti}}$ se calcula con $\mathrm{N}_{\mathrm{ti}}=\mathrm{N}_{\mathrm{te}}$ $+\mathrm{N}_{\mathrm{s}}+\mathrm{N}_{\mathrm{c}}$ (Ec. 5.35), donde $\mathrm{N}_{\mathrm{te}}=\mathrm{N}_{\text {ouse }}+\mathrm{N}_{\mathrm{ae}}$ (Ec. 5.33) y $\mathrm{N}_{\mathrm{ae}}$ está dado por la Ec. 5.21 debido a que con un $\mathrm{S}_{\mathrm{f}}$ fijo, la relación TRS- $f_{x m}$ también es fija. Con $\mathrm{N}_{\mathrm{c}}$ y $\mathrm{N}_{\mathrm{ti}}$ conocidos, la concentración de nitrato en el efluente $\left(\mathrm{N}_{\mathrm{te}}\right)$ y el porcentaje de remoción de nitrógeno $\left(\% \mathrm{~N}_{\mathrm{rem}}\right)$ se pueden encontrar con la Ec. 5.57 y con $\% \mathrm{~N}_{\text {rem }}=100\left(\mathrm{~N}_{\mathrm{ti}}\right.$ - $\left.\left(\mathrm{N}_{\mathrm{ne}}+\mathrm{N}_{\mathrm{te}}\right)\right)$, respectivamente. Este cálculo se repite para diferentes edades de lodo. La edad de lodos más baja permitida es aquella que lleva a que $f_{x 1}=f_{x m}=f_{x 1 m i n}$. En la Figura 5.18 para el agua residual a $14^{\circ} \mathrm{C}$ (Figura $\left.5.18^{\mathrm{a}}, \mathrm{C}\right)$, puede verse que $\mathrm{f}_{\mathrm{x} 1}\left(=\mathrm{f}_{\mathrm{xm}}\right)$ aumenta de alrededor de 0.09 con un TRS $=8 \mathrm{~d}$ (bajo la cual $\mathrm{f}_{\mathrm{xm}}$ es ligeramente mayor que $f_{x 1 \min }$ ) a 0.60 con un TRS $=26 \mathrm{~d}$ (bajo la cual $\mathrm{f}_{\mathrm{xm}}$ es igual al límite superior impuesto). A medida que $\mathrm{f}_{\mathrm{x} 1}$ aumenta, también aumenta la relación de NTK/DQO en el afluente de 0.061 con TRS $=8 \mathrm{~d}$, hasta 0.115 con $\mathrm{TRS}=26 \mathrm{~d}$. Con un aumento en la relación de NTK/DQO la capacidad de nitrificación $\left(\mathrm{N}_{\mathrm{c}}\right)$ aumenta $\mathrm{y}$ consecuentemente $\mathrm{N}_{\text {ne }}$ aumenta de alrededor de 3.2 $\mathrm{mgN} / 1$ con $\mathrm{TRS}=8 \mathrm{~d}$, hasta $9.3 \mathrm{mgN} / 1$ con $\mathrm{TRS}=26 \mathrm{~d}$. Esto se debe a que las relaciones de recirculación se mantienen en 5:1 y 1:1, respectivamente (ver Ec. 5.58). El procentaje de remoción de nitrógeno, el cual incluye el $\mathrm{N}$ removido a través de la purga de lodos $\left(\mathrm{N}_{\mathrm{s}}\right)$, disminuye de forma marginal de 85 a $82 \%$ a medida que la relación de NTK/DQO en el afluente y la edad de lodos aumentan para el sistema MLE balanceado. 

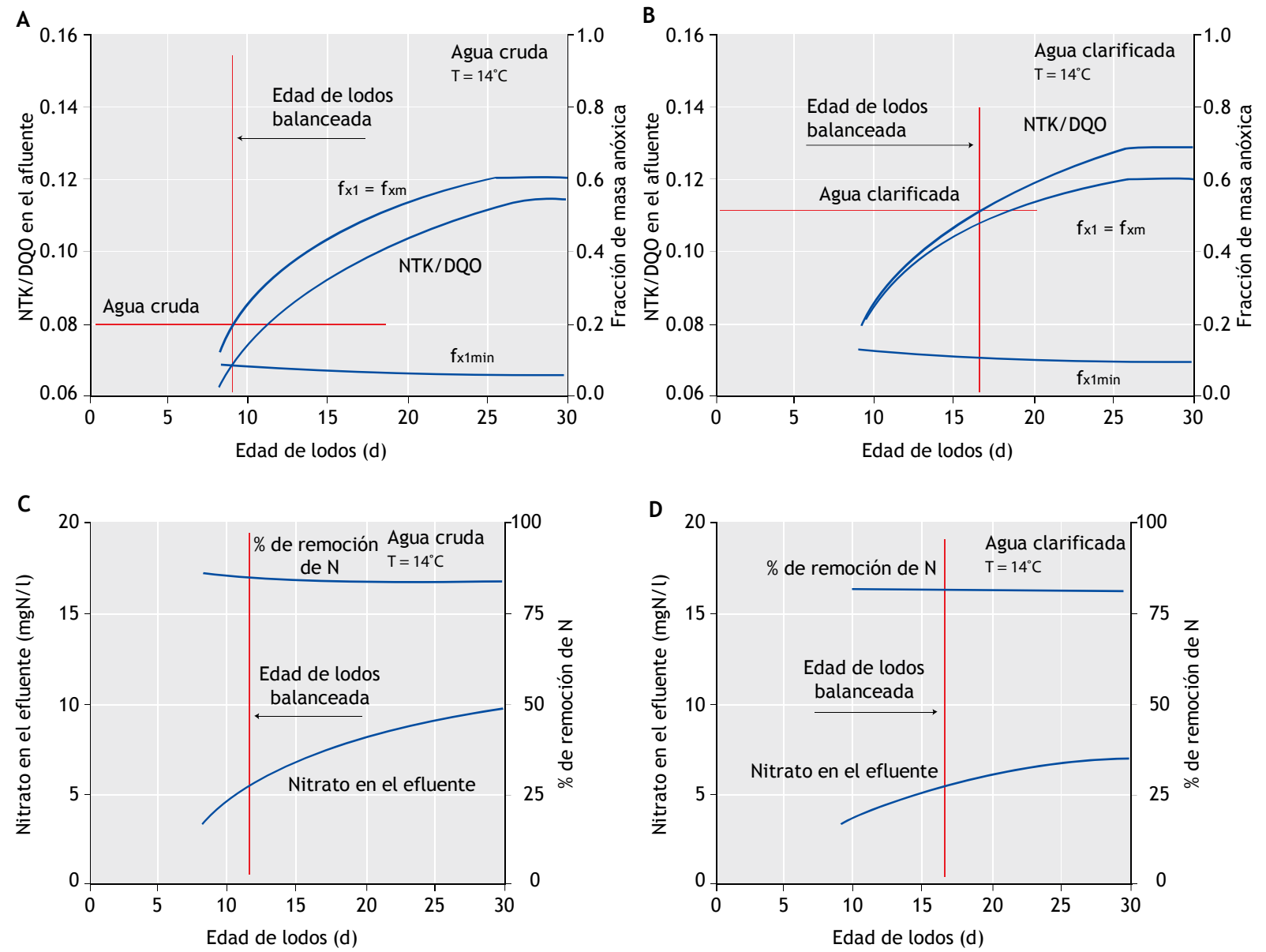

Figura 5.18 (A y B) Relación de NTK/DQO en el afluente, fracción de lodos máxima de la zona no aireada, fracción de la zona primaria anóxica y fracción mínima de la zona primaria anóxica contra la edad de lodos y (C y D) concentración en el efluente de nitrato y porcentaje de remoción de nitrógeno en función de la edad de lodos para un sistema MLE con un límite práctico para la relación de recirculación a de 5:1 utilizando el agua residual ( A y C) cruda y (B y D) clarificada del ejemplo de diseño a $14^{\circ} \mathrm{C}$

Para el agua clarificada a $14^{\circ} \mathrm{C}$ (Figura 5.18B, D) los resultados son similares a los obtenidos con el agua residual cruda para la relación de NTK/DQO en el afluente, $f_{\mathrm{x} 1}$ y $f_{\mathrm{x} 1 \min }$. Para el agua clarificada, el $\mathrm{N}_{\mathrm{ne}}$ es ligeramente menor, aumentando de alrededor de 3.2 a 6.7 $\mathrm{mgN} / 1$ para 8 y 26 días de TRS; adicionalmente el porcentaje de remoción de $\mathrm{N}$ es inferior, de alrededor de $78 \%$ debido principalmente a la menor remoción de $\mathrm{N}$ a través de la purga de lodos $\left(\mathrm{N}_{\mathrm{s}}\right)$. No obstante, debe recordarse que la relación de NTK/DQO y la fracción de $\mathrm{DOQ}_{\mathrm{rb}}$ es mayor en el agua residual clarificada que en el agua cruda que la produjo (relación de NTK/DQO igual a 0.113 y $0.080 \mathrm{mgN} / \mathrm{mgDQO}$, y fracción de $\mathrm{DQO}_{\mathrm{rb}}\left(\mathrm{f}_{\mathrm{sb}}\right.$ 's) igual a 0.25 y 0.385 para el agua residual clarificada y cruda respectivamente). Por consiguiente a $14^{\circ} \mathrm{C}$, mientras que un agua residual cruda puede ser tratada en un sistema MLE balanceado con un TRS $=11 \mathrm{~d}$ (Figura 5.18A), la edad de lodos necesaria para tratar el agua residual clarificada en un sistema MLE balanceado es de aproximadamente 17 días (Figura 5.18B). La Tabla 5.8 muestra una comparación entre los sistemas MLE balanceados para el agua residual cruda y clarificada. 
Tabla 5.8 Comparación del sistema balanceado MLE tratando el agua residual cruda y clarificada del ejemplo de diseño a $14^{\circ} \mathrm{C}$

\begin{tabular}{|c|c|c|c|c|}
\hline Parámetro & Símbolo & Unidad & Agua cruda & Agua clarificada \\
\hline Relación de NTK/DQO en el afluente & & & 0.080 & 0.113 \\
\hline Fracción de $\mathrm{DQO}_{\mathrm{rb}}$ en el afluente & $\mathrm{f}_{\mathrm{Sb}}$ 's & & 0.25 & 0.385 \\
\hline Fracción de masa no aireada & $f_{x m}$ & & 0.306 & 0.485 \\
\hline Fracción de masa anóxica & $f_{x 1}$ & & 0.306 & 0.485 \\
\hline Fracción de masa anóxica mínima & $f_{x 1 \min }$ & & 0.079 & 0.108 \\
\hline Relación de recirculación $a\left(\mathrm{a}_{\mathrm{prac}}=\mathrm{a}_{\mathrm{opt}}\right)$ & $\mathrm{a}$ & & $5: 1$ & $5: 1$ \\
\hline Edad de lodos & TRS & $\mathrm{d}$ & 11 & 17 \\
\hline Nitrato en el efluente & $\mathrm{N}_{\mathrm{ne}}$ & $\mathrm{mgN} / 1$ & 5.1 & 5.7 \\
\hline Concentración de NTK en el efluente & $\mathrm{N}_{\mathrm{te}}$ & $\mathrm{mgN} / 1$ & 4.3 & 4.1 \\
\hline Nitrógeno total en el efluente $\left(\mathrm{N}_{\mathrm{ne}}+\mathrm{N}_{\mathrm{te}}\right)$ & & $\mathrm{mgN} / 1$ & 9.4 & 9.8 \\
\hline Volumen del reactor a $4.5 \mathrm{gSST} / 1$ & & $\mathrm{~m}^{3}$ & 9,484 & 5,264 \\
\hline Demanda carbonácea de $\mathrm{O}_{2}$ & $\mathrm{FO}_{\mathrm{c}}$ & $\mathrm{kgO}_{2} / \mathrm{d}$ & 6,156 & 4,251 \\
\hline Demanada de $\mathrm{O}_{2}$ para nitrificación & $\mathrm{FO}_{\mathrm{n}}$ & $\mathrm{kgO}_{2} / \mathrm{d}$ & 2,492 & 2,685 \\
\hline $\mathrm{O}_{2}$ recuperado & $\mathrm{FO}_{\mathrm{d}}$ & $\mathrm{kgO}_{2} / \mathrm{d}$ & 1,327 & 1,437 \\
\hline Demanda total de $\mathrm{O}_{2}$ & $\mathrm{FO}_{\mathrm{td}}$ & $\mathrm{kgO}_{2} / \mathrm{d}$ & 7,321 & 5,499 \\
\hline$\% \mathrm{~N}$ removido & & & 84.3 & 80.9 \\
\hline Masa de SST purgados & $\mathrm{FX}_{\mathrm{t}}$ & & 3,880 & 1,394 \\
\hline Fracción activa respecto de los SST & $f_{\text {at }}$ & & 0.316 & 0.414 \\
\hline
\end{tabular}

De la Tabla 5.8 puede verse que $\mathrm{N}_{\text {ne }}$ es $\sim 0.6 \mathrm{mgN} / 1$ mayor para el agua residual clarificada, pero el volumen del reactor y la demanda total de oxígeno es significativamente menor comparada con la del agua residual cruda. Por consiguiente, desde el punto de vista de un sistema de lodos activados, el tratamiento de un agua residual clarificada es comparativamente más económico que el tratamiento de un agua residual cruda para una calidad del efluente comparable. Además, ambos sistemas requieren de un tratamiento de lodos; para el agua cruda debido a que con una edad de lodos de $11 d$, el lodo purgado no es estable (fracción activa $\mathrm{f}_{\text {at }}$ elevada) y para el agua clarificada, el lodo primario necesita ser estabilizado. El lodo de purga con una edad de $11 \mathrm{~d}$ puede estabilizarse por medio de una digestión anóxica-aerobia la cual permite que el $\mathrm{N}$ liberado en la digestión se nitrifique y desnitrifique (Warner et al., 1986; Brink et al., 2007) y el lodo primario puede estabilizarse por medio de una digestión anaerobia para beneficiarse de la producción de biogás. La elección de tratar un agua cruda o clarificada por ende no depende tanto de la calidad del efluente o de la economía misma del sistema de lodos activados, sino de la economía global de la planta de tratamiento de aguas residuales incluyendo el tratamiento de los lodos. Debido a que la temperatura del agua ( $\left.\mathrm{T}_{\min }\right)$ gobierna el diseño del sistema de lodos activados (y el tratamiento de lodos), los resultados para el sistema MLE balanceado a $22^{\circ} \mathrm{C}$ no son particularmente relevantes para regiones de climas templados. Sin embargo, en regiones tropicales y ecuatoriales, donde el tratamiento de aguas residuales se ha vuelto un tema de interés creciente, si se pueden encontrar temperaturas elevadas en el agua residual. Por este motivo y con el propósito de ilustrar los diferentes resultados para el sistema MLE balanceado, la Figura 5.19 muestra los resultados para el agua residual cruda y clarificada.

Comparado con el sistema a $14^{\circ} \mathrm{C}$, el límite superior para $\mathrm{f}_{\mathrm{xm}}=0.60$ se alcanza con una edad de lodos de tan solo 7 días a $22^{\circ} \mathrm{C}$, y por lo tanto se pueden tratar aguas residuales con relaciones de NTK/DQO significativamente mayores para edades de lodo similares. Estas relaciones mayores de NTK/DQO resultan en un valor de $\mathrm{N}_{\text {ne }}$ mayor, el cual para el agua residual cruda aumenta de 3 a $13 \mathrm{mgN} / 1$ y para el agua residual clarificada de 3 a $9 \mathrm{mgN} / 1$ para incrementos en la edad de lodos de 4 a 30 días. Si la $\mathrm{T}_{\min }$ fuese de $22^{\circ} \mathrm{C}$, el agua residual cruda y clarificada del ejemplo de diseño podría tratarse con una edad de lodos de 3 y 4 días, de manera correspondiente, resultando en valores de $\mathrm{N}_{\text {ne }}$ de 5 y $6.5 \mathrm{mgN} / 1$, respectivamente. Esto refuerza la conclusion de la Sección 5.8.1 de que en climas tropicales y ecuatoriales, es bastante probable que en las plantas de lodos activados se lleve a cabo el proceso de nitrificación inclusive a edades de lodo cortas (1 a 2 días) y por ende los sistemas deberían diseñarse para que incluyan el proceso de desnitrificación por razones 

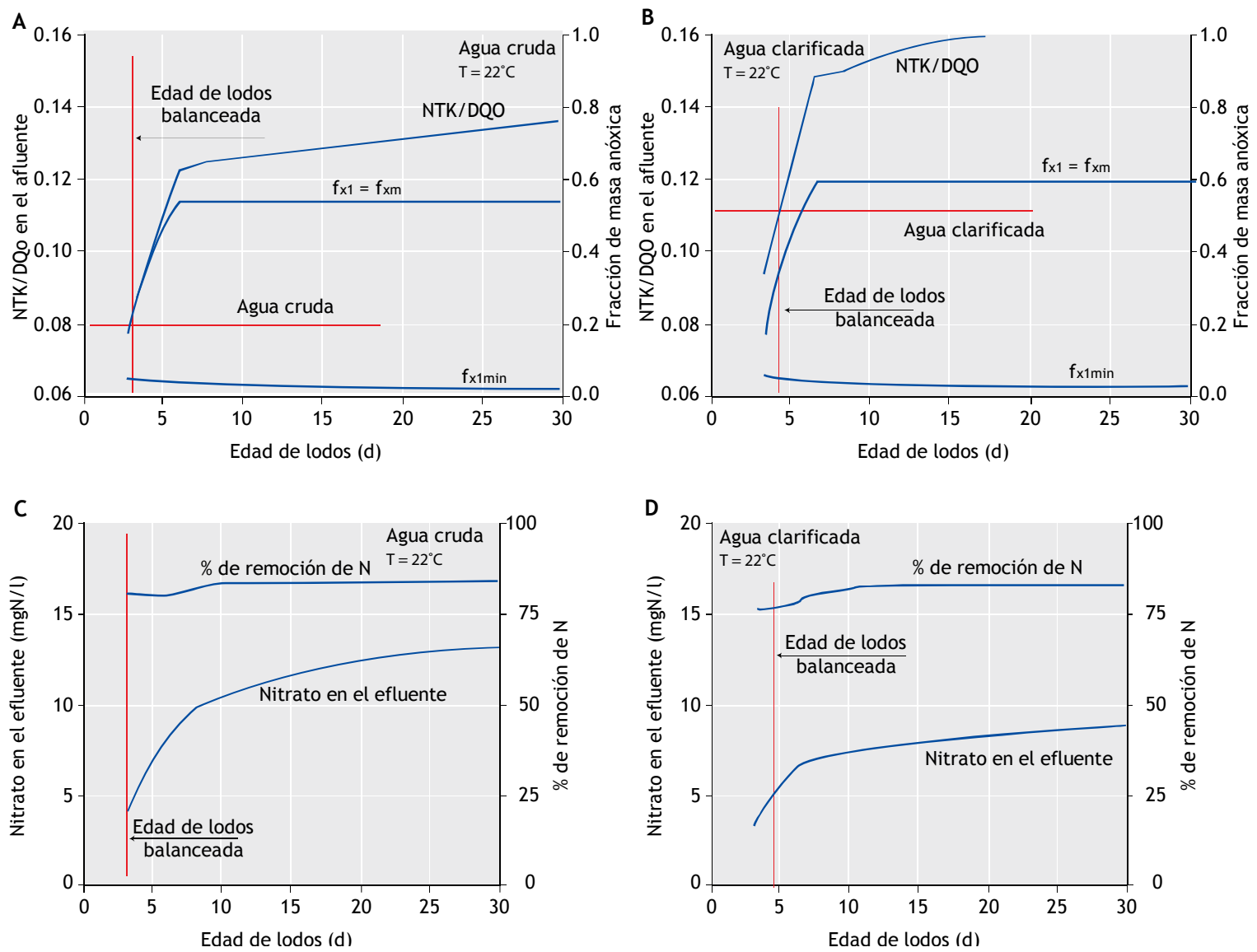

Figura 5.19 (A) Relación de NTK/DQO en el afluente contra edad de lodos, (B) fracciones de masa no aireada máxima (fxm), anóxica primaria ( $\mathrm{fx} 1$ ) y anóxica primaria mínima (fx1min) contra edad de lodos y (C y D) concentración de nitrato y \% de remoción de nitrógeno contra edad de lodos, para un sistema MLE balanceado con una relación de recirculación de licor mezclada a de 5:1 para el agua residual (A y C) cruda, (B y D) clarificada del ejemplo de diseño a la temperatura de $22^{\circ} \mathrm{C}$

operativas aun si se cumplen las condiciones de calidad en el efluente.

\subsubsection{Efecto de la relación de concentración de NTK/DQO en el afluente}

Cuando el potencial de desnitrificación no utilizado en el reactor anóxico se mantiene como reserva como un factor de seguridad (Opción 2), la edad de lodos y la fracción de masa de lodos anóxica no se cambian. Para esta situación es útil realizar un análisis de sensibilidad para ver la influencia de diferentes condiciones en la relación de NTK/DQO en el afluente y de la fracción de DQO ${ }_{\text {rb }}$ sobre la relación de recirculación $a$ y sobre la concentración de nitrato en el efluente. Continuando con el diseño para el agua residual cruda y clarificada del ejemplo, para una edad de lodos fija a 20 días y una fracción de masa no aireada (anóxica) de 0.534, la Figura 5.20 muestra un gráfico de la relación de recirculación $a$ óptima $\left(\mathrm{a}_{\mathrm{opt}}\right)$ y la concentración de nitrato en el efluente mínima $\mathrm{N}_{\text {nemin }}$ para relaciones de recirculación $s$ de $0.5,1.0$ y 2.0 contra la relación de NTK/DQO en el afluente de 0.06 a 0.16 , para el agua residual cruda (A y C), clarificada (B y D) a $14^{\circ} \mathrm{C}$ (A y B) y $22^{\circ} \mathrm{C}(\mathrm{C} \mathrm{y} \mathrm{D})$.

De la Figura 5.20, puede verse que a medida que la relación de NTK/DQO en el afluente aumenta, $\mathrm{a}_{\mathrm{opt}}$ disminuye y $\mathrm{N}_{\text {neaopt }}$ aumenta. Las líneas $\mathrm{a}_{\text {opt }}-\mathrm{N}_{\text {neaopt }}$ en la Figura 5.20 muestran el desempeño del sistema de desnitrificación cuando el potencial de desnitrificación del reactor anóxico se utiliza por completo, es decir, el desempeño del sistema de desnitrificación es igual a su potencial de desnitrificación y la concentración de nitrato es la más baja posible. Adicionalmente, para grandes incrementos en la relación de recirculación de $\operatorname{lodos} s$ (de 0.50:1 a 1.0:1 o 1.0:1 a 2.0:1) a apt disminuye pero $\mathrm{N}_{\text {neaopt }}$ no cambia debido a que el $\mathrm{OD}$ en las recirculaciones $a$ y $s$ no difieren mucho en la influencia que tienen sobre el reactor anóxico. Por consiguiente, tiene poca importancia cual recirculación lleva la carga 
de nitrato al reactor anóxico. Mientras el reactor anóxico reciba una concentración de nitratos con un valor cercano a su potencial de desnitrificación, se obtendrá la misma concentración mínima en el efluente (Nneaopt) para a apt. Las líneas a apt- $\mathrm{N}_{\text {neaopt }}$ por consiguiente indican el desempeño del sistema cuando la desnitrificación potencial del reactor anóxico se utiliza enteramente (Figura 5.17B), es decir el desempeño del sistema de desnitrificación es igual a su potencial. Un mejor desempeño de la desnitrificación no es posible de alcanzar - la desnitrificación está limitada por la cinética y la biomasa (y por ende también el sistema) alcanza su máxima capacidad de remoción posible (para una tasa de desnitrificación $\mathrm{K}_{2}$ ).

La Figura 5.20 muestra con las líneas $\mathrm{a}_{\text {prac }} \mathrm{y} \mathrm{N}_{\text {neprac }}$ usando la Ec. 5.57 el desempeño de la desnitrificación en el sistema a medida que aumenta la relación
NTK/DQO en el afluente operando a una relación de recirculación $a$ práctica ( $\mathrm{aprac}_{\mathrm{p}}$ ) de 5:1. Puede observarse que $\mathrm{N}_{\text {neaprac }}$ aumenta linealmente con un aumento en la relación de NTK/DQO. Para relaciones bajas de NTK/DQO en el afluente, aprac es considerablemente menor que $\mathrm{a}_{\text {opt }} \mathrm{y}$ el desempeño de la desnitrificación en el sistema es más baja que su potencial de desnitrificación. Eso es evidente en el hecho que $\mathrm{N}_{\text {neaprac }}$ es mayor que $\mathrm{N}_{\text {neaopt. }} \mathrm{A}$ medida que la relación NTK/DQO se incrementa, $a_{\text {opt }}$ disminuye hasta que $\mathrm{a}_{\text {opt }}$ $=$ aprac $=5.0: 1$. Para el agua residual a $14^{\circ} \mathrm{C}$ (Figura $5.20^{\mathrm{a}}$ ), esto sucede a una relación de NTK/DQO en el afluente de 0.104. Este valor corresponde a la relación de NTK/DQO en el afluente que balancea el sistema MLE para las condiciones de diseño seleccionadas (edad de lodos de 20 días, $\mathrm{f}_{\mathrm{xm}}=0.534$ y $\mathrm{a}_{\text {prac }}=5: 1$ para el agua residual cruda del ejemplo a $14^{\circ} \mathrm{C}$ ). Para relaciones de NTK/DQO en el afluente $>0.104$, la
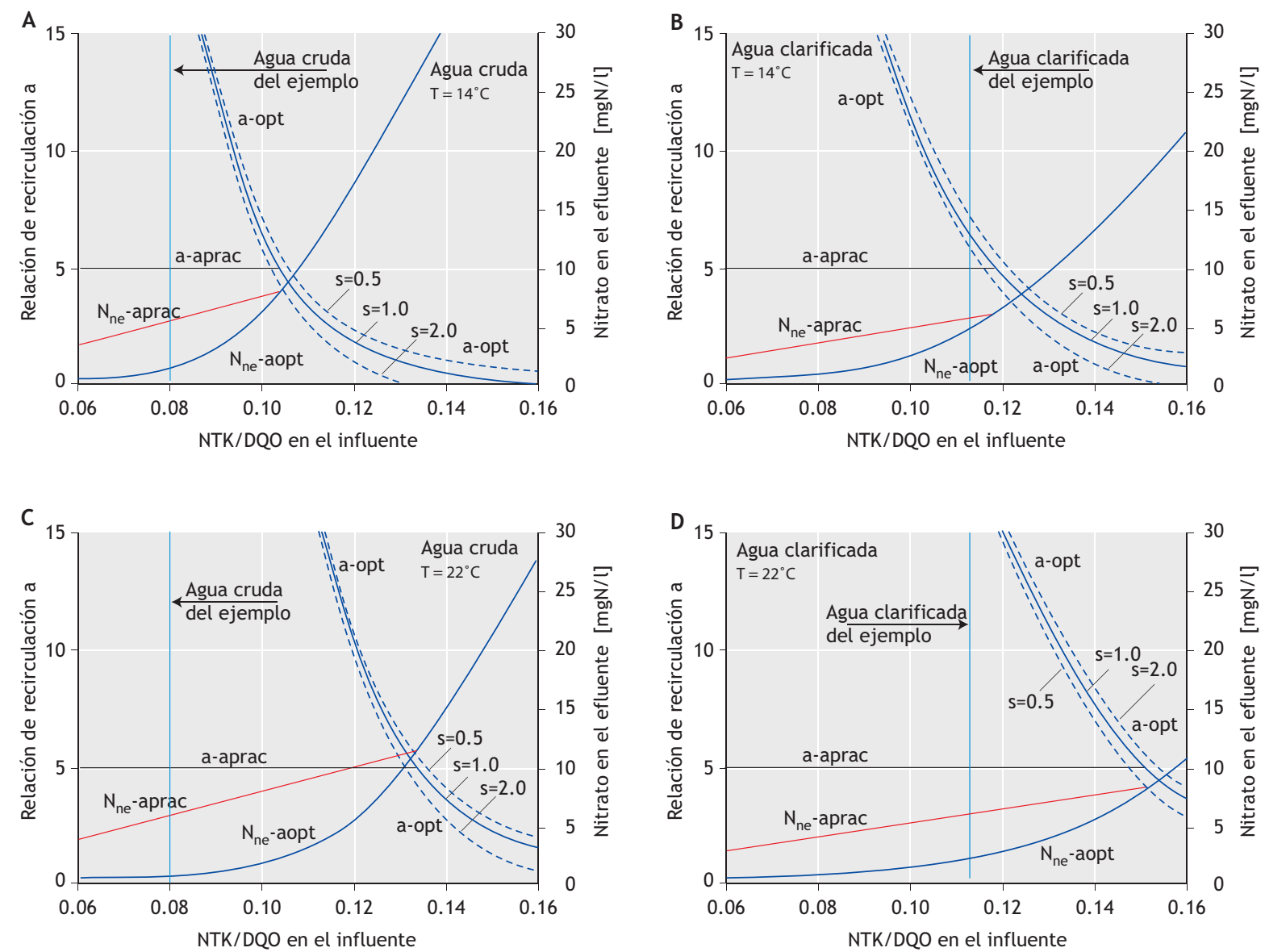

Figura 5.20 Relación de recirculación óptima ( $\mathrm{a}_{\mathrm{opt}}$ ), límite superior práctico ( $\left.\mathrm{a}_{\mathrm{prac}}=5: 1\right)$ y concentración de nitrato en el efluente con aopt

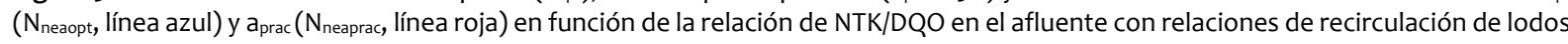
$s$ de 1:1 para el agua residual ( $\mathrm{A}$ y C) cruda y (B y D) clarificada con temperaturas de (A y B) $14{ }^{\circ} \mathrm{C}$ y (C y D) $22^{\circ} \mathrm{C}$. Las figuras también muestran la relación de recirculación óptima $a$ (aopt) para relaciónes de recirculación de lodos de 0.5:1 y 2:1 (líneas punteadas) 
relación de recirculación $a$ debería ajustarse a $\mathrm{a}_{\mathrm{opt}}$, la cual utiliza completamente el potencial de desnitrificación del reactor y es ahora menor que $\mathrm{a}_{\text {prac }}=5: 1$. Por esta razón para valores de $\mathrm{a}_{\text {prac }}$ iguales a $5: 1$, el potencial de desnitrificación completo del reactor anóxico solo puede utilizarse cuando la relación de NTK/DQO en el afluente es mayor de 0.104.

Esta misma conclusión puede obtenerse de la Figura 5.18A con una edad de lodos de 20 días $\left(f_{\mathrm{xm}}=0.534\right.$, $\mathrm{NTK} / \mathrm{DQO}=0.104)$. Por lo tanto para relaciones de NTK/DQO en el afluente menores a 0.104, cuando aprac $<\mathrm{a}_{\text {opt }}$, el desempeño del sistema de desnitrificación es menor que su potencial de desnitrificación debido a que no todo el potencial de desnitrificación del reactor es utilizado. Una vez que la relación NTK/DQO aumenta por encima del valor que equilibra o balancea al sistema MLE, a a es $<$ aprac y el valor de la recirculación $a$ debería ajustarse al valor de a opt para poder lograr obtener la concentración más baja de nitrato en el efluente $\left(\mathrm{N}_{\text {neaopt }}\right)$. Para estas relaciones de NTK/DQO en el afluente, el potencial de desnitrificación del reactor anóxico se utiliza completamente y las líneas $\mathrm{a}_{\text {opt }}-\mathrm{N}_{\text {neaopt }}$ indican el desempeño del sistema.

La Figura 5.20 es bastante útil ya que combina el desempeño de la desnitrificación en el sistema (líneas $a_{\text {prac }}-\mathrm{N}_{\text {neaprac}}$ ) y el potencial de desnitrificación (líneas $\mathrm{a}_{\text {opt }}-\mathrm{N}_{\text {neaopt }}$ ) en el mismo diagrama para relaciones de NTK/DQO en el afluente crecientes para un agua residual y un diseño en particular (TRS $=20$ días y $\mathrm{f}_{\mathrm{xm}}$ $=0.534)$. El punto de intersección entre la línea recta de $\mathrm{N}_{\text {neprac }} \mathrm{y}$ la línea curva de $\mathrm{N}_{\text {neaopt, }}$ por ejemplo para $\mathrm{a}_{\mathrm{opt}}=$ $a_{\text {prac }}=5: 1$, indica la relación de NTK/DQO en el afluente para el sistema MLE balanceado con la relación de recirculación $\mathrm{a}_{\text {prac }}=5: 1$ seleccionada. $\mathrm{La}$ Tabla 5.7 muestra el desempeño del sistema para las relaciones de NTK/DQO que balancean al sistema con una de edad de lodos de $20 \mathrm{~d} \mathrm{y}_{\mathrm{xm}}=0.534 \mathrm{a} 14^{\circ} \mathrm{C} \mathrm{y} 22^{\circ} \mathrm{C}$ para el agua residual cruda y clarificada del ejemplo de diseño.

De la Tabla 5.7 y la Figura 5.20A, para el agua residual a $14^{\circ} \mathrm{C}$, el sistema MLE (con edad de lodos de $20 \mathrm{~d}$ y $\mathrm{f}_{\mathrm{xm}}=0.534$ ) con una relación de recirculación de $5: 1$ puede mantener la concentración de nitrato en el efluente por debajo de $8.1(\mathrm{~N}$ total $=12.4) \mathrm{mgN} / 1$ para relaciones de NTK/DQO en el afluente por debajo de $0.104\left(\mathrm{~N}_{\mathrm{ti}}=78.0 \mathrm{mgN} / \mathrm{l}\right)$. Para el agua clarificada a $14^{\circ} \mathrm{C}$ (Figura 5.20B), el sistema MLE con una relación de recirculación de 5:1 puede mantener la concentración de nitrato en el efluente por debajo de
$11.3(\mathrm{~N}$ total $=14.9) \mathrm{mgN} / 1$ para relaciones de $\mathrm{NTK} / \mathrm{DQO}$ en el afluente de hasta $0.132\left(\mathrm{~N}_{\mathrm{ti}}=59.4\right.$ $\mathrm{mgN} / \mathrm{l})$. De manera similar, de las Figuras 5.20C,D, con agua residual cruda y clarificada a $22^{\circ} \mathrm{C}$, el sistema MLE con una relación de recirculación de 5:1 puede mantener las concentraciones de nitrato en el efluente por debajo de 6.0 y $8.1 \mathrm{mgN} / 1(\mathrm{~N}$ total $=9.9$ y 11.1 $\mathrm{mgN} / \mathrm{l})$, respectivamente, para relaciones de $\mathrm{NTK} / \mathrm{DQO}$ en el afluente de hasta $0.119\left(\mathrm{~N}_{\mathrm{ti}}=89.3\right.$ $\mathrm{mgN} / \mathrm{l})$ y $0.148\left(\mathrm{~N}_{\mathrm{ti}}=66.6 \mathrm{mgN} / \mathrm{l}\right)$. Estos resultados muestran que el sistema MLE que trata un agua residual clarificada produce valores de $\mathrm{N}_{\text {ne }}$ menores (del orden de 2-3 mgN/l) que cuando trata agua residual cruda a relaciones de NTK/DQO en el afluente considerablemente mayores. No obstante, debe tenerse en cuenta que $(i)$ las concentraciones de NTK en el afluente (indicadas anteriormente) para el agua residual cruda son considerablemente mayores que para el agua residual clarificada y (ii) un agua residual clarificada con una relación de NTK/DQO de $0.119\left(14^{\circ} \mathrm{C}\right)$ o 0.148 $\left(22^{\circ} \mathrm{C}\right)$ produciría un agua residual cruda con una relación de $\mathrm{NTK} / \mathrm{DQO}$ en el afluente considerablemente menor a $0.104\left(14^{\circ} \mathrm{C}\right)$ y 0.132 $\left(22^{\circ} \mathrm{C}\right)$.

\subsubsection{Diagrama de sensibilidad del sistema MLE}

En la Figura 5.20, el desempeño de la desnitrificación en el sistema para un valor seleccionado de $a_{\text {prac }}=5 \mathrm{se}$ combina con el potencial de desnitrificación del sistema para $\mathrm{a}=\mathrm{a}_{\text {opt }} \mathrm{y}$ diferentes valores de la relación de NTK/DQO y un único valor de la fracción de $\mathrm{DQO}_{\mathrm{rb}}$ en el afluente. Este diagrama de sensibilidad puede extenderse incluyendo nuevas líneas de $\mathrm{N}_{\text {neaopt }}$ para otras fracciones de $\mathrm{DQO}_{\mathrm{rb}}$. Un diagrama de sensibilidad del sistema es útil en la fase de diseño para así poder evaluar el desempeño de la desnitrificación bajo

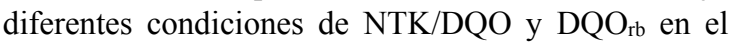
afluente. Estas dos características del agua residual que pueden variar considerablemente durante la vida útil de la planta de tratamiento, tienen un impacto mayor en el desempeño de la remoción de $\mathrm{N}$ en el sistema.

La Figura 5.21 combina el potencial de desnitrificación y el desempeño del sistema para diferentes relaciones de NTK/DQO en el afluente y diferentes fracciones de $\mathrm{DQO}_{\mathrm{rb}}$. Para los parámetros de diseño establecidos $\left(T R S=20 d, f_{x d m}=f_{x m}=0.534, s=\right.$ 1.0) las líneas curvas (azul oscuro) indican los valores de $\mathrm{N}_{\text {neaopt }}$ cuando el reactor anóxico está cargado a su potencial de desnitrificación, es decir, $\mathrm{N}_{\text {ne }}$ para $\mathrm{a}=\mathrm{a}_{\mathrm{opt}}$ 
para diferentes valores de la relación de NTK/DQO (de 0.06 a 0.16), y diferentes valores de la fracción de DQO $_{\mathrm{rb}}($ de 0.10 a 0.35 ) para el agua residual cruda $\mathrm{y}$ clarificada a $14^{\circ} \mathrm{C}$ (Figura 5.21A,B) y $22^{\circ} \mathrm{C}$ (Figura 5.21 C,D). Las mismas líneas $\mathrm{N}_{\text {neaopt }}$ están indicadas en las Figuras $5.20^{\mathrm{a}}$ y $\mathrm{C}$ para el agua residual cruda con una fracción de $\mathrm{DQO}_{\mathrm{rb}}\left(\mathrm{f}_{\mathrm{Sb}}\right.$ 's $)=0.25$. Estas líneas $\mathrm{N}_{\text {neaopt }}$ son calculadas con las Ecuaciones 5.56 y 5.57. Las líneas rectas en la Figura 5.21 indican los valores de $\mathrm{N}_{\text {neaprac }}$ para valores de la recirculación $a$ fijados a los valores indicados y variándolos desde 0.0:1 hasta 10.0:1. Estas líneas rectas de $\mathrm{N}_{\text {neaprac }}$ indican el desempeño del sistema para una relación de recirculación $a$ seleccionada y se calculan con la ayuda de la Ec. 5.57 del valor de la capacidad de nitrificación para una relación de NTK/DQO, una relación de recirculación $s$ de 1.0:1 y una relación de recirculación $a$ seleccionada.

Las líneas $\mathrm{N}_{\text {neaprac }}$ para $\mathrm{a}=\mathrm{a}_{\text {prac }}=5: 1$ son las mismas que las líneas punteadas mostradas en la Figura 5.20. En los puntos de intersección de las líneas rectas $\mathrm{N}_{\text {neaprac }}$ y las líneas curvas $\mathrm{N}_{\text {neaopt, }}$ el desempeño del sistema es igual al potencial de desnitrificación y representa a los diseños de sistemas MLE balanceados $\left(\mathrm{a}_{\mathrm{opt}}=\mathrm{a}_{\mathrm{prac}}\right)$. Por
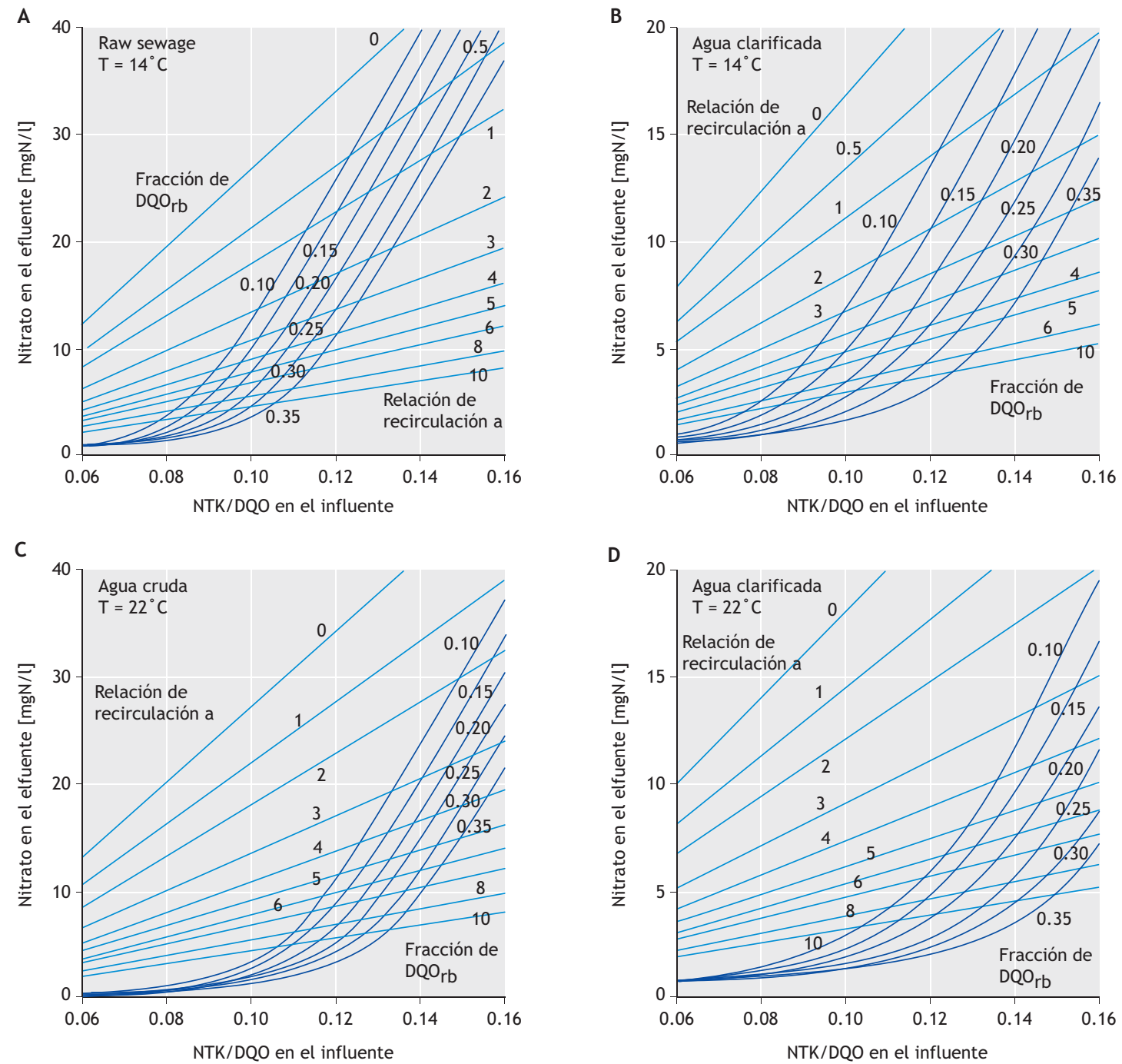

Figura 5.21 Concentración de nitrato en el efluente en función de la relación de concentración de NTK/DQO en el afluente para fracciones de materia orgánica rápidamente biodegradable $\left(\mathrm{DQO}_{\mathrm{rb}}\right)$ de $0.10,0.15,0.20,0.25,0.30$ y 0.35 , y relaciones de recirculación del licor mezclado $a$ desde o hasta 10 para el agua residual ( $A$ y C) cruda y (B y D) clarificada del ejemplo de diseño a (A y B) $14^{\circ} \mathrm{C}$ y $\left(C\right.$ y D) $22^{\circ} \mathrm{C}$ 
ejemplo, para el agua residual cruda a $14^{\circ} \mathrm{C}$, con a $=$ 5.0:1 y fsb's $=0.25$, la relación de NTK/DQO debe ser igual a 0.104 para alcanzar un diseño óptimo $\left(\mathrm{a}_{\mathrm{opt}}=5: 1\right.$ y para esta relación de NTK/DQO, $\mathrm{N}_{\mathrm{ne}}=8.1 \mathrm{mgN} / \mathrm{l}$ ). Esta es la relación de NTK/DQO que balancea al sistema MLE operando a TRS $=20 \mathrm{~d} \mathrm{y} \mathrm{x}_{\mathrm{xm}}=0.534$ (ver Figura 5.18A, C).

Para relaciones de NTK/DQO $<0.104$, a apt aumenta por encima de 5:1, pero si se mantiene fijo a $5: 1 \mathrm{a}=$ $\left.a_{\text {prac }}=5: 1\right)$ el valor de $N_{\text {ne }}$ contra NTK/DQO lo indica la línea recta $\mathrm{N}_{\text {neaprac }}$ con $\mathrm{a}=5: 1$. Para relaciones de NTK/DQO $>0.104$, a opt disminuye por debajo de 5:1, y el valor de $\mathrm{N}_{\text {ne }}$ contra NTK/DQO está indicado por la línea curva $\mathrm{N}_{\text {neaopt }}$ (azul oscuro). El valor de $\mathrm{a}_{\text {opt }}$ para una relación NTK/DQO determinada está indicado por el valor de la recirculación $a$ del punto de intersección entre la relación de NTK/DQO vertical en el afluente y la línea curva $\mathrm{N}_{\text {neaopt, }}$ por ejemplo, para el agua cruda del ejemplo de diseño $\left(\mathrm{f}_{\mathrm{bs}}=0.25\right)$ a $14^{\circ} \mathrm{C}($ Figura 5.21A) con una relación NTK/DQO de 0.12 , se obtiene $\mathrm{a}_{\mathrm{opt}}=$ 2:1 y $\mathrm{N}_{\text {ne }}$ igual $16.0 \mathrm{mgN} / 1$.

La utilidad de la Figura 5.21 es que permite evaluar el desempeño de un sistema MLE para una edad de lodos y una fracción de masa anóxica seleccionadas para diferentes valores de relación de NTK/DQO en el afluente y fracción de $\mathrm{DQO}_{\mathrm{rb}}$ teniendo en cuenta un límite superior de la relación de recirculación $a$ igual a $\mathrm{a}_{\text {prac. }}$ Para el agua residual cruda del ejemplo a $22^{\circ} \mathrm{C}$ con una fracción de $\mathrm{DQO}_{\mathrm{rb}}\left(\mathrm{f}_{\mathrm{Sb}}\right.$ 's) igual a 0.10 (Figura 5.21C), la relación de NTK/DQO en el afluente debe ser mayor a 0.113 para que el valor de $a$ sea $<6.0: 1$. Si $a$ se fija a un valor de $a_{\text {prac }}=6.0: 1$ y la relación de NTK/DQO es $<0.113$, entonces la carga de nitrato está por debajo de la capacidad del reactor anóxico y no se puede alcanzar el potencial de desnitrificación. El desempeño del sistema para relaciones de NTK/DQO en el afluente $<0.113$ lo indica la línea recta $\mathrm{N}_{\text {ne }}$ para un valor de $\mathrm{a}=5: 1$. Para una relación de NTK/DQO igual a 0.113 , la línea recta de $\mathrm{N}_{\text {ne }}$ con $\mathrm{a}=6: 1$ corta a la línea curva $\mathrm{N}_{\text {neaopt }}\left(\mathrm{a}=\mathrm{a}_{\mathrm{opt}}=6: 1\right)$ y el desempeño del sistema es entonces igual al potencial de desnitrificación. Si $a$ se mantiene a un valor de 6:1 para una relación de NTK/DQO $>0.113$, entonces el reactor anóxico se encuentra sobrecargado con nitrato y como consecuencia no se puede alcanzar una desnitrificación óptima debido a la carga innecesariamente alta de OD en el reactor anóxico (similar a lo mostrado en la Figura 5.16B para a $>6.7$ ). Por esta razón, la relación de recirculación $a$ debe reducirse a a apt para relaciones de NTK/DQO en el afluente $<0.113$, donde $\mathrm{a}_{\mathrm{opt}}$ está indicado por el valor de $a$ a lo largo de la línea curva $\mathrm{N}_{n e}$, la cual representa cuando el desempeño del sistema iguala su potencial de desnitrificación. Por ejemplo, si la relación NTK/DQO es igual 0.12 , entonces $\mathrm{a}=\mathrm{a}_{\mathrm{opt}}=$ 4:1 y esta relación de recirculación carga el reactor anóxico con una concentración de nitratos similar a su potencial de desnitrificación resultando en un $\mathrm{N}_{\text {ne }}$ de $12.0 \mathrm{mgN} / 1$. Por lo tanto, para relaciones de NTK/DQO $>0.113$, el desempeño del sistema y $\mathrm{N}_{\text {ne }}$ se indica por la línea curva $\mathrm{N}_{\mathrm{ne}}$ siempre y cuando la relación de recirculación $a$ se ajuste al valor aopt, el cual se indica por la línea de la relación de recirculación $a$ que pasa a través del punto de intersección de la línea vertical de la relación NTK/DQO y la línea curva de $\mathrm{N}_{\mathrm{ne}}$.

De lo anterior puede observarse que solamente en la línea curva $\mathrm{N}_{\mathrm{ne}}$ para una fracción determinada de $\mathrm{DQO}_{\mathrm{rb}}$, el desempeño del sistema es igual al potencial de desnitrificación y la a opt que produce estos está indicada por la línea de la relación de recirculación $a$ que pasa a través del punto de intersección de la línea vertical de la relación de NTK/DQO y la línea curva $\mathrm{N}_{\text {ne. Esta línea curva }} \mathrm{N}_{\mathrm{ne}}$ (para la cual $\mathrm{a}=\mathrm{a}$ opt) marca el límite entre las condiciones de sobrecarga y aquellas que reciben una carga inferior a la óptima en el reactor anóxico. En la región por encima de la línea curva $\mathrm{N}_{\mathrm{ne}}$ el reactor anóxico recibe una carga subóptima (a la izquierda de $\mathrm{a}_{\mathrm{opt}}$ en las Figuras 5.16 y 5.17) y el desempeño del sistema $\left(\mathrm{N}_{\mathrm{ne}}\right)$ para una relación particular de NTK/DQO se indica por el punto de intersección entre la línea vertical de la relación de NTK/DQO y la línea recta de la relación de recirculación $a$. En la región por debajo de la línea curva $\mathrm{N}_{\text {ne, }}$ el reactor anóxico se encuentra sobrecargado (a la derecha de aopt en las Figuras 5.16 y 5.17). Los valores de $\mathrm{N}_{\text {ne }}$ obtenidos de esta región no son válidos, pero si la relación de recirculación $a$ se reduce a $\mathrm{a}_{\mathrm{opt}}$ (es decir, el valor de $a$ en el punto de intersección entre la línea vertical de la relación de NTK/DQO y la línea curva $\mathrm{N}_{\mathrm{ne}}$ ), entonces los valores de $\mathrm{N}_{\mathrm{ne}}$ vuelven a ser válidos nuevamente. Por consiguiente, los valores de $\mathrm{N}_{\text {ne }}$ del desempeño del sistema indicados en la Figura 5.21 son solo válidos en o por encima de la línea curva $\mathrm{N}_{\text {ne }}$ que marca el límite. De la Figura 5.21 puede verse

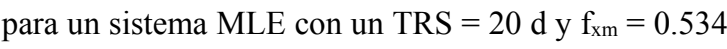
y una relación de recirculación a limitada a 5:1 (por razones de economía), entonces el sistema se encuentra mejor equipado para tratar aguas residuales con relaciones de NTK/DQO elevadas, dependiendo de la fracción de DQO $\mathrm{rb}_{\mathrm{rb}} ;>0.091$ para $\mathrm{fsb}_{\mathrm{sb}}=0.10 \mathrm{y}>0.117$ para $\mathrm{f}_{\mathrm{Sb}}$ 's $=0.35$. Esto sucede debido a que con un único reactor primario anóxico, el sistema MLE no es capaz 
de producir una concentración baja de nitrato en el efluente $(<4$ a $6 \mathrm{mgN} / \mathrm{l})$ si la relación de recirculación se limita a 5.0:1.

Si no se requiere obtener una concentración baja de nitrato en el efluente para relaciones bajas de NTK/DQO, entonces puede optarse por el diseño de un sistema MLE balanceado reduciendo la edad de lodos como se demostró en las Figuras 5.18 y 5.19. Si, por otra parte, es importante para el diseño obtener concentraciones bajas de nitrato en el efluente para relaciones bajas de NTK/DQO, entonces esto puede lograrse con relaciones de recirculación elevadas $\left(\mathrm{a}_{\mathrm{opt}}>\right.$ aprac) en sistemas MLE o mediante la inclusión de un reactor anóxico secundario a relaciones bajas de recirculación. La incorporación de un reactor anóxico secundario (y el correspondiente reactor de reaireación, ver Sección 5.8.5) resulta en un sistema Bardenpho de 4 etapas (Figura 5.13C). No obstante, debido a que la tasa de desnitrificación $\mathrm{K}_{3}$ es tan baja y a que debe reducirse en al menos un 20\% adicional para tener en cuenta el amonio liberado durante la desnitrificación endógena (el cual se nitrifica nuevamente en el reactor de reaireación), la remoción neta adicional de nitrato que se obtiene en un reactor anóxico secundario es muy baja. Esta remoción es tan baja que los reactores anóxicos secundarios normalmente no se incluyen en los sistemas de remoción de $\mathrm{N}$, excepto cuando las relaciones de NTK/DQO son inusualmente bajas. Los reactores anóxicos secundarios generalmente se incluyen en un sistema cuando la dosificación de metanol es necesaria para poder obtener concentraciones muy bajas de nitrógeno total en el efluente $(<5 \mathrm{mgN} / \mathrm{l})$

\subsection{VOLUMEN DEL SISTEMA Y DEMANDA DE OXÍGENO}

\subsubsection{Volumen del sistema}

Una vez que se ha determinado la subdivisión de la masa de lodos en fracciones anóxicas y aerobias, que garantiza la remoción de $\mathrm{N}$ requerida, la masa actual de lodos en el sistema necesita ser calculada para así poder determinar los volúmenes de los diferentes reactores. La masa de lodos, totales (SSLM) o volátiles (SSVLM), en los sistemas con remoción de $\mathrm{N}$ para unas características del agua residual y una edad de lodos seleccionada, es igual que para los sistemas completamente aerobios (remoción de DQO). Por lo tanto, las ecuaciones presentadas en el Capítulo 4, Sección 4.4.2, también aplican a sistemas con remoción de N. Para el ejemplo del agua residual cruda y clarificada, los parámetros de diseño del sistema MLE se enumeran en la Tabla 5.9. La masa de SSLM en el sistema a una edad del lodo de 20 días a $14^{\circ} \mathrm{C}$ es de 68,168 y $26,422 \mathrm{kgSST}$, respectivamente para el agua residual cruda y clarificada. Seleccionando una concentración de SSLM de 4,500 mg/l $\left(4 \mathrm{~kg} / \mathrm{m}^{3}\right)$ (ver Capítulo 4, Sección 4.7) el volumen de los sistemas diseñados para tratar un agua residual cruda y clarificada es de $15,148 \mathrm{~m}^{3}$ y $5,781 \mathrm{~m}^{3}$, respectivamente. Debido a que la masa de lodos en los sistemas con remoción de $\mathrm{N}$ se encuentra uniformemente distribuida dentro del sistema, es decir cada reactor en el sistema tiene la misma concentración de SSLM, la fracción de volumen que corresponde a cada reactor es igual a su correspondiente fracción de masa de lodos. Para el agua residual cruda y clarificada del ejemplo a $14^{\circ} \mathrm{C}$, el volumen de los reactores anóxicos es $0.534 \cdot 15,148=8,089 \mathrm{~m}^{3}$ y $0.534 \cdot 5,871$ $=3,135 \mathrm{~m}^{3}$, respectivamente. El tiempo de retención hidráulico nominal y actual de los reactores anóxicos y los reactores aerobios se puede calcular dividiendo los volúmenes de los reactores por el caudal nominal (afluente) y total que circula a través de éstos (Ecs. 4.2 y 4.3 - Tabla 5.9). Tenga en cuenta que el tiempo de retención nominal de un reactor es una consecuencia de la masa de lodos generada por la carga de DQO afluente, la concentración seleccionada de SSLM y la fracción de masa de lodos - el tiempo de retención por si mismo no tiene influencia en la cinética ni en el diseño de un sistema con nitrificación y desnitrificación (ver Capítulo 4, Sección 4.4.4).

\subsubsection{Demanda diaria total promedio de oxígeno}

La demanda total de oxígeno en un sistema con remoción de nitrógeno es la suma de la que se requiere para la degradación de la materia orgánica (DQO) y para la nitrificación menos la recuperada en el proceso de desnitrificación. La demanda diaria promedio de oxígeno para $(i)$ la remoción de la carga orgánica $\left(\mathrm{FO}_{\mathrm{c}}\right)$ se obtiene de la Ec. 4.18 (ver Capítulo 4, Sección 4.4.2.4) y (ii) para la nitrificación $\left(\mathrm{FO}_{\mathrm{n}}\right)$ se obtiene de la Ec. 5.43 (ver Capítulo 5, Sección 5.7.5). Estas demandas de oxígeno para el sistema MLE con una de edad de lodos de 20 días para el agua residual cruda y clarificada del ejemplo de diseño a $14^{\circ} \mathrm{C}$ es igual a 9,364 y $7,030 \mathrm{kgO}_{2} / \mathrm{d}$ (Tabla 5.9).

El oxígeno recuperado a través de la desnitrificación $\left(\mathrm{FO}_{\mathrm{d}}\right)$ se puede calcular como 2.86 veces la masa de nitrato desnitrificado (Sección 5.8.2) donde el flujo de nitrato desnitrificado es igual al producto del caudal 
promedio diario afluente $\left(\mathrm{Q}_{\mathrm{i}}\right)$ y la concentración de nitrato desnitrificado. La concentración de nitrato desnitrificado se obtiene de la diferencia entre la capacidad de nitrificación $\left(\mathrm{N}_{\mathrm{c}}\right)$ y la concentración de nitrato en el efluente:

$F O_{d}=2.86\left(N_{c}-N_{n e}\right) Q_{i} \quad\left[\mathrm{mgO}_{2} / \mathrm{d}\right] \quad(5.62)$

Del desempeño de la desnitrificación del sistema MLE en la Tabla 5.9, el oxígeno recuperado gracias al proceso de desnitrificación para el agua residual cruda y clarificada del ejemplo de diseño a $14^{\circ} \mathrm{C}$ es igual 1,440 y 1,458 $\mathrm{kgO}_{2} / \mathrm{d}$ (Tabla 5.9).

Para el agua residual cruda, la Tabla 5.9 muestra que (i) la demanda de oxígeno usado para la nitrificación $\left(\mathrm{FO}_{\mathrm{n}}\right)$ es alrededor de $40 \%$ de la requerida para la remoción de DQO $\left(\mathrm{FO}_{\mathrm{c}}\right)$, (ii) alrededor del 55\% de $\mathrm{FO}_{\mathrm{n}}$ puede recuperarse incorporando el proceso de desnitrificación al sistema, (iii) la demanda de oxígeno adicional producto de incorporar la nitrificación y desnitrificación es solo $20 \%$ de la requerida para remover la materia orgánica (DQO) únicamente, y $(i v)$ el efecto de la temperatura en la demanda total de oxígeno es marginal - menor al 3\% (ver también la Figura 5.11).

Para el agua residual clarificada, la Tabla 5.9 muestra que (i) la demanda de oxígeno para nitrificación es alrededor del $63 \%$ de la requerida para la remoción de DQO, (ii) alrededor del 54\% de la demanda de oxígeno para nitrificación puede recuperarse a través del proceso de desnitrificación, (iii) la demanda adicional de oxígeno producto de la incorporación de la nitrificación y desnitrificación en el sistema es alrededor de $30 \%$ de la requerida para la remoción de DQO únicamente, y (iv) el efecto de la temperatura en la demanda total de oxígeno es marginal

Tabla 5.9 Detalles del sistema MLE para el tratamiento del agua residual cruda y clarificada del ejemplo de diseño con edad de lodos 20 días, una temperatura de $14^{\circ} \mathrm{C}$ y una masa de fracción no aireada de 0.534

\begin{tabular}{|c|c|c|c|c|}
\hline Parámetros & Símbolo & Undad & Agua cruda & Agua clarificada \\
\hline Relación de NTK/DQO en el afluente & & & 0.080 & 0.113 \\
\hline Fracción de DQOrb en el afluente & fsb's & & 0.25 & 0.385 \\
\hline Masa de fracción no aireada & $f_{x m}$ & & 0.534 & 0.534 \\
\hline Masa de fracción anóxica & $f_{x 1}$ & & 0.534 & 0.534 \\
\hline Fracción anóxica mínima & $f_{x 1 \min }$ & & 0.068 & 0.105 \\
\hline Relación de recirculación $a\left(\mathrm{a}_{\mathrm{prac}}=\mathrm{a}_{\mathrm{opt}}\right)$ & & & $5: 1$ & $5: 1$ \\
\hline Edad de lodos & TRS & $\mathrm{d}$ & 20 & 20 \\
\hline Nitrato en el efluente & $\mathrm{N}_{\mathrm{ne}}$ & $\mathrm{mgN} / 1$ & 5.16 & 5.7 \\
\hline Concentración de NTK en el efluente & $\mathrm{N}_{\mathrm{te}}$ & $\mathrm{mgN} / 1$ & 3.8 & 3.8 \\
\hline Nitrógeno total en el efluente $\left(\mathrm{N}_{\mathrm{ne}}+\mathrm{N}_{\mathrm{te}}\right)$ & & $\mathrm{mgN} / 1$ & 9.4 & 9.5 \\
\hline Volumen del sistema a $4.5 \mathrm{gSST} / 1$ & & $\mathrm{~m}^{3}$ & 15,148 & 5,871 \\
\hline Voluemn anóxico & & $\mathrm{m}^{3}$ & 8,089 & 3,135 \\
\hline Tiempo de residencia hidráulico nominal & $\mathrm{TRH}_{\mathrm{n}}$ & $\mathrm{h}$ & 24.2 & 9.4 \\
\hline $\begin{array}{l}\text { Tiempo de residencia hidráulico nominal } \\
\text { en la zona aerobia }\end{array}$ & $\mathrm{TRH}_{\mathrm{n}}{ }^{\mathrm{AER}}$ & $\mathrm{h}$ & 11.2 & 4.4 \\
\hline $\begin{array}{l}\text { Tiempo de residencia hidráulico real } \\
\text { en la zona aerobia }\end{array}$ & $\mathrm{TRH}_{\mathrm{a}}{ }^{\mathrm{AER}}$ & $\mathrm{h}$ & 1.60 & 0.63 \\
\hline $\begin{array}{l}\text { Tiempo de residencia hidráulico nominal } \\
\text { en la zona anóxica }\end{array}$ & $\mathrm{TRH}_{\mathrm{n}}{ }^{\mathrm{AX}}$ & $\mathrm{h}$ & 12.9 & 5.0 \\
\hline $\begin{array}{l}\text { Tiempo de residencia hidráulico real } \\
\text { en la zona anóxica }\end{array}$ & $\mathrm{TRH}_{\mathrm{a}}{ }^{\mathrm{AX}}$ & $\mathrm{h}$ & 1.85 & 0.72 \\
\hline Demanda carbonácea de $\mathrm{O}_{2}$ & $\mathrm{FO}_{\mathrm{c}}$ & $\mathrm{kgO}_{2} / \mathrm{d}$ & 6,679 & 4,311 \\
\hline Demanada de $\mathrm{O}_{2}$ para nitrificación & $\mathrm{FO}_{\mathrm{n}}$ & $\mathrm{kgO}_{2} / \mathrm{d}$ & 2,685 & 2,719 \\
\hline $\mathrm{O}_{2}$ recuperado & $\mathrm{FO}_{\mathrm{d}}$ & $\mathrm{kgO}_{2} / \mathrm{d}$ & 1,440 & 1,458 \\
\hline Demanda total de $\mathrm{O}_{2}$ & $\mathrm{FO}_{\mathrm{td}}$ & $\mathrm{kgO}_{2} / \mathrm{d}$ & 7,924 & 5,572 \\
\hline$\% \mathrm{~N}$ removido & & & 84.4 & 81.4 \\
\hline Masa de SST purgados & $\mathrm{M} \Delta \mathrm{X}_{\mathrm{t}}$ & & 3,408 & 1,321 \\
\hline Fracción activa respecto de los SST & $f_{a t}$ & & 0.230 & 0.383 \\
\hline
\end{tabular}


-menor al 3\%-con respecto a la temperatura más baja.

Comparando la demanda de oxígeno para el agua residual cruda y clarificada, la demanda total de oxígeno para la última es alrededor de $30 \%$ menor que para la primera. Este ahorro es posible debido a que la sedimentación primaria remueve entre el 35 y $45 \%$ de la DQO del agua residual cruda. Adicionalmente, para el agua residual clarificada, la demanda de oxígeno de la nitrificación ocupa una mayor proporción del total consumido, y además, una menor parte de la demanda de oxígeno de la nitrificación puede recuperarse mediante la desnitrificación comparado con el agua residual cruda. Estos efectos se deben a que las relaciones de NTK/DQO son más altas para aguas residuales clarificadas.

Una vez que se conoce la demanda total diaria promedio de oxígeno, la demanda total pico de oxígeno puede estimarse aproximadamente utilizando una regla simple de diseño (Musvoto et al., 2002). De un gran número de simulaciones realizadas utilizando el modelo ASM1, se encontró que para un factor de seguridad de nitrificación $\left(\mathrm{S}_{\mathrm{f}}\right)$ superior a 1.25-1.35, la amplitud relativa o incremento relativo de la demanda total máxima de oxígeno es una fracción que corresponde a $1 / 3$ de la amplitud relativa de la demanda total de oxígeno de la carga de DQO y NTK en el afluente $\left(\mathrm{Q}\left(\mathrm{S}_{\mathrm{ti}}+4.57 \mathrm{~N}_{\mathrm{ti}}\right)\right)$. Por ejemplo, para el caso del agua residual cruda, si el potencial de la demanda total pico de oxígeno en el afluente se obtiene a una hora del día en el que el caudal afluente, y las concentraciones de DQO y NTK son $25 \mathrm{Ml} / \mathrm{d}, 1,250$ $\mathrm{mgDQO} / 1$ y $90 \mathrm{mgN} / 1$ respectivamente - es decir, 25 • $(1,250+4.57 \cdot 90)=41,532 \mathrm{kgO}_{2} / \mathrm{d}$, y la demanda total promedio de oxígeno es $15 \cdot(750+4.57 \cdot 60)=15,363$ $\mathrm{kgO}_{2} / \mathrm{d}$, entonces la amplitud relativa del potencial de la demanda total de oxígeno en el afluente es (41,532 $15,363) / 15,363=1.70$; por ende, la amplitud relativa de la demanda total de oxígeno es aproximadamente $0.33 \cdot 1.70=0.56$. De la Tabla 5.9 la demanda total diaria promedio de oxígeno es $7,924 \mathrm{kgO}_{2} / \mathrm{d}$ y por lo tanto la demanda pico de oxígeno es igual a $(1+0.56)$ - $7,924=12,378 \mathrm{kgO}_{2} / \mathrm{d}$.

Al igual que con todas las reglas simplificadas de diseño, la regla descrita anteriormente debe usarse con cautela y discreción, y donde sea posible, es mejor determinar la demanda total pico de oxígeno a través del uso de modelos de simulación de lodos activados. Se recomienda enfáticamente que los resultados de los modelos de simulación dinámica se comparen con los resultados obtenidos del modelo en estado estacionario y en caso de que se observen diferencias apreciables, es necesario que se establezcan las fuentes y razones de las mismas. Esta es una buena forma de encontrar errores en los modelos de simulación dinámica y los modelos en estado estacionario.

\subsection{DISEÑO, OPERACIÓN Y CONTROL DEL SISTEMA}

Debido a que el modelo en estado estacionario para la nitrificación es compatible y está completamente integrado al modelo para la remoción de carga orgánica, todas las consideraciones de diseño, operación y control descritas en el Capítulo 4, en las Secciones 4.9 a 4.11 para un sistema de lodos completamente aerobio, aplican igualmente a los sistemas con nitrificación-desnitrificación. 


\section{REFERENCIAS}

Antoniou P., Hamilton J., Koopman B., Jain R., Holloway B. Lyberatos G. and Svoronos SA. (1990) Effect of temperature and $\mathrm{pH}$ on the effective maximum specific growth rate of nitrifying bacteria. Wat. Res. 24(1), 97-101.

Barnard J.L. (1973) Biological denitrification. Water Pollut. Control 72(6), 705-720.

Brink I.C., Wentzel M.C. and Ekama G.A. (2007) A plant wide stoichiometric steady state WWTP model. Procs. $10^{\text {th }}$ IWA Specialized conference Design, Operation and Economics of large WWTP, Vienna, 9-13 sept, 243-250.

Dold P.L., Ekama G.A. and Marais G.v.R. (1985) pH control and cost savings in aerobic digestion. Procs. IAWPRC specialized seminar on wastewater systems control, Houston, April. In Advances in Water Pollution Control: Instrumentation and Control of Water and Wastewater and Transport Systems. (Ed. R.A.R. Drake), pp 375-382. Pergamon Press, Oxford.

Downing A.L., Painter H.A. and Knowles G. (1964) Nitrification in the activated sludge process. J. Proc. Inst. Sewage Purif., 130-153.

Ekama G.A., Dold P.L. and Marais G.v.R. (1986) Procedures for determining influent DQO fractions and the maximum specific growth rate of heterotrophs in activated sludge systems. Wat. Sci. Tech.18(6), 91-114.

Ekama G.A., Wentzel M.C., Casey T.G. and Marais G.v.R. (1996) Filamentous organism bulking in nutrient removal activated sludge systems. Paper 3: Stimulation of the selector effect under AOOSxic conditions. Wat. SA, 22(2), 119-126.

Ekama G.A., Casey T.G., Wentzel M.C. and Marais G.v.R. (1996) Filamentous organism bulking in nutrient removal activated sludge systems. Paper 6: Review, evaluation and consolidation of results. Wat. $S A$ 22(2) 147-152.

Ekama G.A., Barnard J.L., Guenthert F.W., Krebs P., McCorquodale J.A., Parker D.S. and Wahlberg E.J. (1997) Secondary settling tanks: Theory, design, modelling and operation. IAWQ STR No 6, pp216, International Association on Water Quality, London.

Ekama G.A. and Wentzel M.C. (1999) Denitrification kinetics in biological $\mathrm{N} \& \mathrm{P}$ removal activated sludge systems treating municipal wastewaters. Wat. Sci. Tech. 39(6), 69-77.

Henze M., Grady C.P.L., Gujer W., Marais G.v.R. and Matsuo T. (1987). Activated sludge model No.1. IAWPRC Scientific and Technical Reports No 1, International Association on Water Pollution Research and Control, IAWPRC, London, ISSN 1010-707X. 33pp.

Henze M., Gujer W., Mino T., Matsuo T., Wentzel M.C and Marais, G.v.R. (1995) Activated sludge model No.2, IAWQ Scientific and Technical Report No 3. IAWQ, London. ISSN 1025-0913, 32pp.

Jenkins D., Daigger G.T. and Richard M.G. (1993) Manual on the causes and control of activated sludge bulking and foaming. 2nd Edition, Lewis Publishers, Chelsea, MI., USA.

Lawrence and McCarty (1972) Unified basis for biological treatment design and operation. J. Sanit. Eng. Div. ASCE 96(SA3) 757-778.

Loewenthal R.E. and Marais G.v.R. (1977) Carbonate chemistry of aquatic systems: Theory and application. Ann Arbor Science, Michigan, USA.

Loveless J.E. and Painter H.A. (1968) The influence of metal ion concentration and $\mathrm{pH}$ value in the growth of Nitrosomonas strain isolated from activated sludge. J. Gen. Micro. 521 -14.

Ludzack F.J. and Ettinger M.B. (1962) Controlling operation to minimize activated sludge effluent nitrogen. JWPCF 34 920-931.

Malan W.N. and Gouws E.P. (1966) Geaktiveerde slyk vir rioolwatersuiwering op Bellville. Research report, Council for Scientific and Industrial Research, Nov. 1966.

Metcalf \& Eddy (1991) Wastewater engineering: Treatment, disposal, reuse. McGrw-Hill Intnl Series, New York.

Monteith H.D., Bridle T.R., Sutton P.M. (1980) Industrial waste carbon sources for biological denitrification. Prog. Wat. Tech, 12(Tor) 127- 141.

Musvoto E.V., Samson K., Taljard M., Fawcett K. and Alexander W.V. (2002) Calculation of peak oxygen demand in the design of full scale nitrogen removal activated sludge plants. Wat $S A$, Special Edn Wisa 2002, 56-60.

Musvoto E.V., Casey T.G., Ekama G.A., Wentzel M.C. and Marais G.v.R. (1994) The effect of incomplete denitrification on AOOSxic-aerobic (low F/M) filament bulking in nutrient removal activated sludge systems. Wat. Sci. Tech. 29(7) 295-299.

Sötemann S.W., Musvoto E.V., Wentzel M.C. and Ekama G.A. (2005) Integrated chemical, physical and biological processes modelling Part 1 - AOOSxic aerobic $\mathrm{C}$ and $\mathrm{N}$ removal in the activated sludge system. Wat. SA (4) 529-544.

Stenstrom M.K. and Poduska R.A. (1980) The effect of dissolved oxygen concentration on nitrification. Wat. Res. 14(6) 643-649.

Stern L.B. and Marais G.v.R (1974) Sewage as the electron donor in biological denitrification. Research Report W7, Dept. of Civil Eng., Univ. of Cape Town, Rondebosch, 7701, Cape, RSA.

Still D.A., Ekama G.A. Wentzel M.C. Casey T.G. and Marais G.v.R. (1996) Filamentous organism bulking in nutrient removal activated sludge systems. Paper 2: Stimulation of the selector effect under aerobic conditions. Wat. SA, 22(2), 97-118.

Tsai M-W. Wentzel M.C. and Ekama G.A. (2003) The effect of residual ammonia concentration under aerobic conditions on the growth of Microthrix parvicella in biological nutrient removal plants. Wat. Res. 37(12) 3009-3015. 
van Haandel A.C., Dold P.L. and Marais G.v.R (1982) Optimization of nitrogen removal in the single sludge activated sludge process. Wat. Sci. Tech. 14443.

van Haandel A.C. Ekama G.A. and Marais G.v.R. (1981) The activated sludge process part 3 -Single sludge denitrification. Wat. Res. 15 1135-1152.

van Kessel M.A.H.J., Speth D.R., Albertsen M., Nielsen P.H., Op den Camp H.J.M., Kartal B., Jetten M.S.M., Lücker S. (2015) Complete nitrification by a single microorganism. Nature 528(7583): 555-559.

Daims H., Lebedeva E.V., Pjevac P., Han P., Herbold C., Albertsen M., Jehmlich N., Palatinszky M., Vierheilig J., Bulaev A., Kirkegaard R.H., von Bergen M., Rattei T., Bendinger B., Nielsen P.H., Wagner M. (2015) Complete nitrification by Nitrospira bacteria. Nature 528(7583): 504-509.

Warner A.P.C., Ekama G.A. and Marais G.v.R. (1986) The activated sludge process Part 4 -Application of the general kinetic model to AOOSxic-aerobic digestion of waste activated sludge. Wat. Res. 20(8), 943-958.

WEF (1998) Design of Municipal WWTP, 4th Edn., Water Environment Federation (WEF) Manual of Practice MOP 8, WEF, Alexandria, VA, American Society of Civil Engineers (ASCE) Manual and Report on Engineering Practice No 76, ASCE Vol 3, ASCE, Reston.

Wentzel M.C., Ekama G.A., Dold P.L. and Marais G.v.R. (1990) Biological excess phosphorus removal steady state process design. Wat. SA 16(1) 29-48

Wild H.E., Sawyer C.N. and McMahon T.C. (1971) Factors affecting nitrification kinetics. J. Water Pollut. Control Fed., September.

WRC (1984) Theory, design and operation of nutrient removal activated sludge processes. Published by the Water Research Commission, Private Bag X03, Gezina, 0031, South Africa. 


\section{NOMENCLATURA}

\begin{tabular}{|c|c|c|}
\hline Símbolo & Descripción & Unidades \\
\hline $\mathrm{a}$ & $\begin{array}{l}\text { Relación de recirculación del licor mezclado desde el reactor aerobio } \\
\text { hasta el reactor anóxico primario }\end{array}$ & \\
\hline Alk & Alcalinidad respecto de una solución de $\mathrm{H}_{2} \mathrm{CO}_{3}$ de referencia & $\mathrm{mg} / \mathrm{l}$ as $\mathrm{CaCO}_{3}$ \\
\hline $\mathrm{a}_{\min }$ & $\begin{array}{l}\text { Relación de recirculacuión a mínima para utilizar toda la } \mathrm{DQO}_{\mathrm{rb}} \\
\text { en el reactor anóxico primario }\end{array}$ & \\
\hline aopt & $\begin{array}{l}\text { Relación de recirculación } a \text { óptima desde el reactor aerobio } \\
\text { hasta el reactor anóxico primario }\end{array}$ & \\
\hline aprac & Relación de recirculación $a$ máxima aplicable de forma práctica & \\
\hline $\mathrm{b}_{\mathrm{A} 20}$ & Tasa específica de respiración endógena a $20^{\circ} \mathrm{C}$ para los organismos nitrificantes & $/ \mathrm{d}$ \\
\hline $\mathrm{b}_{\mathrm{AT}}$ & Tasa específica de respiración endógena a $\mathrm{T}^{\circ} \mathrm{C}$ para organismos nitrificantes & $/ \mathrm{d}$ \\
\hline $\mathrm{b}_{\mathrm{H}}$ & Tasa específica de respiración endógena de los OHOs & $/ \mathrm{d}$ \\
\hline bн20 & Tasa específica de respiración endógena a $20^{\circ} \mathrm{C}$ para los $\mathrm{OHOs}$ & $/ \mathrm{d}$ \\
\hline bнт & Tasa específica de respiración endógena a $\mathrm{T}^{\circ} \mathrm{C}$ para los $\mathrm{OHOs}$ & $/ \mathrm{d}$ \\
\hline $\mathrm{D}_{\mathrm{p}}$ & Potencial de desnitrificación & $\mathrm{mgN} / \mathrm{l}$ \\
\hline $\mathrm{D}_{\mathrm{p} 1}$ & Potencial de desnitrificación anóxica primaria & $\mathrm{mgN} / 1$ \\
\hline De1DQOrb & Potencial de desnitrificación anóxica primaria debido a DQO $\mathrm{rb}$ & $\mathrm{mgN} / \mathrm{l}$ \\
\hline $\mathrm{D}_{\mathrm{p} 1 \mathrm{DQOlb}}$ & Potencial de desnitrificación anóxica primaria debido a $\mathrm{DQO}_{\mathrm{lb}}$ & $\mathrm{mgN} / 1$ \\
\hline $\mathrm{D}_{\mathrm{p} 3}$ & Potencial de desnitrificación anóxica secundaria & $\mathrm{mgN} / \mathrm{l}$ \\
\hline $\mathrm{D}_{\mathrm{p} 3 \mathrm{DQO} \mathrm{rb}}$ & Potencial de desnitrificación anóxica secundaria debido a $\mathrm{DQO}_{\mathrm{rb}}$ dosificada & $\mathrm{mgN} / \mathrm{l}$ \\
\hline $\mathrm{D}_{\mathrm{p} 3 \mathrm{DQOlb}}$ & Potencial de desnitrificación anóxica secundaria debido a DQOıb dosificada & $\mathrm{mgN} / 1$ \\
\hline$f_{\text {at }}$ & Fracción de OHOs en el lodo como SST & $\mathrm{mgSSV} / \mathrm{mgSST}$ \\
\hline$f_{a v}$ & Fracción de OHOs en el lodo como SSV & $\mathrm{mgSSV} / \mathrm{mgSSV}$ \\
\hline $\mathrm{f}_{\mathrm{cv}}$ & Relación de DQO/SSV del lodo & $\mathrm{mgSSV} / \mathrm{mgDQO}$ \\
\hline$f_{H}$ & Fracción no biodegradable de los OHOs & $\mathrm{mgDQO} / \mathrm{mgDQO}$ \\
\hline$f_{n}$ & Contenido de nitrógeno de los SSV & $\mathrm{mgN} / \mathrm{mgSSV}$ \\
\hline $\mathrm{f}_{\mathrm{N}}{ }^{\prime} \mathrm{a}$ & Relación de amonio/NTK en el afluente & $\mathrm{mgN} / \mathrm{mgN}$ \\
\hline $\mathrm{f}_{\mathrm{N} \text { 'ous }}$ & $\begin{array}{l}\text { Fracción de NTK en el afluente que corresponde a nitrógeno soluble } \\
\text { y orgánico no biodegradable }\end{array}$ & \\
\hline $\mathrm{FN}_{\mathrm{a}}$ & Masa diaria (flujo) de amonio libre y salino como nitrógeno utilizado & $\mathrm{mgN} / \mathrm{d}$ \\
\hline $\mathrm{FN}_{\mathrm{ne}}$ & Masa diaria (flujo) de nitrato como nitrógeno producido en la nitrificación & $\mathrm{kgNO}_{3}-\mathrm{N} / \mathrm{d}$ \\
\hline $\mathrm{f}_{\mathrm{ns}}$ & Relación de concentración de NTK/DQO del agua residual & $\mathrm{mgN} / \mathrm{mgDQO}$ \\
\hline $\mathrm{FN}_{\mathrm{S}}$ & Masa diaria (flujo) de nitrógeno requerido para la producción de lodo & $\mathrm{kgN} / \mathrm{d}$ \\
\hline $\mathrm{FO}_{\mathrm{c}}$ & Masa diaria (flujo) de oxígeno requerido para la remoción de material orgánica (DQO) & $\mathrm{kgO}_{2} / \mathrm{d}$ \\
\hline $\mathrm{FO}_{\mathrm{d}}$ & $\begin{array}{l}\text { Masa diaria (flujo) de oxígeno requerido recuperado mediante } \\
\text { el proceso de desnitrificación }\end{array}$ & $\mathrm{kgO}_{2} / \mathrm{d}$ \\
\hline $\mathrm{FO}_{\mathrm{n}}$ & Masa diaria (flujo) de oxígeno requerido para nitrificación & $\mathrm{kgO}_{2} / \mathrm{d}$ \\
\hline $\mathrm{FO}_{\mathrm{td}}$ & $\begin{array}{l}\text { Flujo total de oxígeno requerido por día (flux) menos la cantidad } \\
\text { de oxígeno recuperada mediante la desnitrificación }\end{array}$ & $\mathrm{kgO}_{2} / \mathrm{d}$ \\
\hline $\mathrm{f}_{\mathrm{p}}$ & Contenido de fósforo de los SSV & $\mathrm{gP} / \mathrm{mgSSV}$ \\
\hline fsb's & Fracción de DQO $\mathrm{rb}$ respecto de la DQO biodegradable en el afluente & \\
\hline f'up & Fracción particulada no biodegradable de la DQO total en el afluente & \\
\hline $\mathrm{f}_{\text {S'us }}^{\prime}$ & Fracción soluble no biodegradable de la DQO total en el afluente & \\
\hline $\mathrm{FS}_{\mathrm{b}}$ & Flujo de DQO biodegradable saliendo del reactor & $\mathrm{kgDQO} / \mathrm{d}$ \\
\hline $\mathrm{FS}_{\mathrm{bi}}$ & Flujo de DQO biodegradable presente en el afluente & $\mathrm{kgDQO} / \mathrm{d}$ \\
\hline$f_{x 1}$ & Fracción anóxica primaria de la masa de lodos & \\
\hline
\end{tabular}


$f_{x 1 \text { min }}$

$\mathrm{f}_{\mathrm{x} 3}$

$\mathrm{FX}_{\mathrm{A}}$

$f_{x d m}$

$f_{x m}$

$f_{\mathrm{xt}}$

$\mathrm{FX}_{\mathrm{t}}$

$\mathrm{K}_{1}$

$\mathrm{K}_{2}$

$\mathrm{K}_{3}$

$\mathrm{K}_{4}$

$\mathrm{K}_{\mathrm{A}}$

$\mathrm{K}_{\mathrm{Am}}$

$\mathrm{K}_{\mathrm{h}}$

$\mathrm{K}_{\mathrm{I}}$

$\mathrm{K}_{\text {II }}$

$\mathrm{K}_{\max }$

$\mathrm{K}_{\mathrm{n}}$

$\mathrm{K}_{\mathrm{n} 20}$

$\mathrm{K}_{\mathrm{nT}}$

$\mathrm{K}_{\mathrm{o}}$

$\mathrm{K}_{\mathrm{S}}$

$\mathrm{K}_{\mathrm{x}}$

$\mathrm{MX}_{\mathrm{A}}$

$\mathrm{MX}_{\mathrm{BHv}}$

$\mathrm{MX}_{\mathrm{EHv}}$

$\mathrm{MX}_{\mathrm{Iv}}$

$\mathrm{MX}_{\mathrm{t}}$

$\mathrm{MX}_{\mathrm{v}}$

$\mathrm{N}_{\mathrm{a}}$

$\mathrm{N}_{\mathrm{ae}}$

$\mathrm{N}_{\mathrm{ai}}$

$\mathrm{N}_{\text {an }}$

$\mathrm{N}_{\mathrm{c}} / \mathrm{S}_{\mathrm{ti}}$

$\mathrm{N}_{\mathrm{c}}$

$\mathrm{N}_{\mathrm{n}}$

$\mathrm{N}_{\text {nar }}$

$\mathrm{N}_{\text {ne }}$

$\mathrm{N}_{\text {neaopt }}$

$\mathrm{N}_{\text {neaprac }}$

$\mathrm{N}_{\text {nlp }}$

Nobe

$\mathrm{N}_{\text {obi }}$

$\mathrm{N}_{\text {obpi }}$

Nobse
Fracción anóxica primaria mínima de la masa de lodos

Fracción anóxica secundaria de la masa de lodos

Masa diaria (flujo) generada de organismos nitrificantes

Fracción anóxica máxima de la masa de lodos

Fracción no aireada máxima de la masa de lodos

Fracción no aireada de la masa total de lodos en el reactor

Masa diaria (flujo) de SST purgados del reactor

Tasa específica de desnitrificación rápida incial en el reactor anóxico primario

Tasa específica de desnitrificación secundaria en el reactor anóxico primario

Tasa espećifica de desnitrificación en el reactor anóxico secundario

Tasa específica de desnitrificación en un digestor in anóxico-aerobio

Tasa específica de nitrificación

Tasa específica máxima de nitrificación

Tasa específica máxima de consumo de DQOıb por parte de los OHOs bajo condiciones aerobias

Coeficiente de sensibilidad del $\mathrm{pH}$ para el proceso de nitrificación

Coeficiente de sensibilidad del $\mathrm{pH}$ para el proceso de nitrificación

Coeficiente de sensibilidad del pH para el proceso de nitrifiación

Constante de saturación media de los organismos nitrificantes

Constante de saturación media a $20{ }^{\circ} \mathrm{C}$ de los organismos nitrificantes

Constante de saturación media a $\mathrm{T}^{\circ} \mathrm{C}$ de los organismos nitrificantes

Constante de saturación media para el oxígeno disuelto

Constante de saturación media para la utilización de DQO $\mathrm{rb}$

Constante de saturación media para la utilización de DQO $\mathrm{lb}$

Masa de organismos nitrificantes en el reactor

Masa de biomasa de OHOs en el reactor

Masa de residuo endógeno en el reactor

Masa de materio orgánica no biodegradable del afluente en el reactor

Masa de SST en el reactor

Masa de matria orgánica del lodo activado en el reactor

Concentración de amonio en el licor mezclado

Concentración de amonio en el efluente

Concentración de amonio en el afluente

Concentración de amonio por litro en el afluente disponible para nitrificación

Capacidad de nitrificación por mg de DQO aplicada al reactor

Capacidad de nitrificación

Concentración de nitrato

Concentración de nitrato en el reactor aerobio

Concentración de nitrato en el efluente

Concentración de nitrato en el efluente con recirculación $a_{\text {opt }}$

Concentración de nitrato en el efluente con recirculación $a_{\text {prac }}$

Concentración de nitrato equivalente recirculado al reactor anóxico primario

Nitrógeno orgánico biodegradable residual en el efluente

Nitrógeno orgánico biodegradable en el afluente

Nitrógeno orgánico particulado biodegradable en el afluente

Nitrógeno organico soluble biodegradable en el efluente
$\mathrm{mgSSV} / \mathrm{d}$

$\mathrm{kgSST} / \mathrm{d}$

$\mathrm{mgNO}_{3-}$

$\mathrm{N} / \mathrm{mgOHOSSV} . \mathrm{d}$

$\mathrm{mgNO}_{3}-$

$\mathrm{N} / \mathrm{mgOHOSSV} . \mathrm{d}$

$\mathrm{mgNO}_{3}-$

$\mathrm{N} / \mathrm{mgOHOSSV} . \mathrm{d}$

$\mathrm{mgNO}_{3}-$

N/mgOHOSSV.d

mgN/mgSSV.d

$\mathrm{mgN} / \mathrm{mgSSV}$.d

mgDQO/mgDQO.d

$\mathrm{mgN} / 1$

$\mathrm{mgN} / 1$

$\mathrm{mgN} / 1$

$\mathrm{mgO} / 1$

$\mathrm{mgDQO} / 1$

mgDQO/mgDQO.d

mgSSV

kgSSV

kgSSV

kgSSV

$\mathrm{mgSST} / 1$

$\mathrm{gSSV} / 1$

$\mathrm{mgN} / 1$

$\mathrm{mgN} / 1$

$\mathrm{mgN} / 1$

$\mathrm{mgN} / 1$

$\mathrm{mgN} / \mathrm{mgDQO}$

$\mathrm{mgN} / 1$

$\mathrm{mgN} / 1$

$\mathrm{mgN} / 1$

$\mathrm{mgN} / 1$

$\mathrm{mgN} / \mathrm{l}$

$\mathrm{mgN} / \mathrm{l}$

$\mathrm{mgN} / 1$

$\mathrm{mgN} / 1$

$\mathrm{mgN} / 1$

$\mathrm{mgN} / 1$

$\mathrm{mgN} / 1$ 


\begin{tabular}{|c|c|c|}
\hline $\mathrm{N}_{\text {obsi }}$ & Nitrógeno orgánico soluble biodegradable en el afluente & $\mathrm{mgN} / 1$ \\
\hline $\mathrm{N}_{\text {oupi }}$ & Nitrógeno orgánico particulado no biodegradable en el afluente & $\mathrm{mgN} / 1$ \\
\hline $\mathrm{N}_{\text {ouse }}$ & Nitrógeno orgánico soluble no biodegradable en el efluente $\left(=\mathrm{N}_{\text {ousi }}\right)$ & $\mathrm{mgN} / 1$ \\
\hline $\mathrm{N}_{\text {ousi }}$ & Nitrógeno orgánico soluble no biodegradable en el afluente & $\mathrm{mgN} / 1$ \\
\hline $\mathrm{N}_{\mathrm{s}}$ & Concentración de nitrógeno en el afluente requerido para producción de lodo & $\mathrm{mgN} / 1$ \\
\hline $\mathrm{N}_{\mathrm{s}} / \mathrm{S}_{\mathrm{ti}}$ & $\begin{array}{l}\text { Relación de } \mathrm{N} \text { requerido para producción de lodos y concentración de DQO } \\
\text { en el fluente }\end{array}$ & $\mathrm{mgN} / \mathrm{mgDQO}$ \\
\hline $\mathrm{N}_{\mathrm{te}} / \mathrm{S}_{\mathrm{ti}}$ & Relación de NTK/DQO en el efluente & $\mathrm{mgN} / \mathrm{mgDQO}$ \\
\hline $\mathrm{N}_{\mathrm{te}}$ & Concentración de NTK en el efluente & $\mathrm{gN} / 1$ \\
\hline $\mathrm{N}_{\mathrm{ti}}$ & Concentración de NTK en el afluente & $\mathrm{gN} / 1$ \\
\hline $\mathrm{N}_{\mathrm{ti}} / \mathrm{S}_{\mathrm{ti}}$ & Relación de concentración de NTK/DQO en el afluente & $\mathrm{mgN} / \mathrm{mgDQO}$ \\
\hline $\mathrm{O}$ & Concentración de oxígeno disuelto en el licor mezclado & $\mathrm{mgO}_{2} / 1$ \\
\hline $\mathrm{O}_{\mathrm{a}}$ & Concentración de oxígeno disuelto en la recirculación $a$ & $\mathrm{mgO}_{2} / 1$ \\
\hline $\mathrm{O}_{\mathrm{c}}$ & $\begin{array}{l}\text { Tasa de utilización de oxígeno para la degradación } \\
\text { de la materia orgánica carboneacea }\end{array}$ & $\mathrm{mgO}_{2} / \mathrm{l} . \mathrm{h}$ \\
\hline $\mathrm{O}_{\mathrm{n}}$ & Tasa de utilización de oxígeno para nitrificación & $\mathrm{mgO}_{2} / \mathrm{l} . \mathrm{h}$ \\
\hline $\mathrm{O}_{\mathrm{s}}$ & Concentración de oxígeno disuelto en la recirculación $s$ & $\mathrm{mgO}_{2} / 1$ \\
\hline $\mathrm{O}_{\mathrm{t}}$ & Tasa de utilización de oxígeno total & $\mathrm{mgO}_{2} / \mathrm{l} . \mathrm{h}$ \\
\hline $\mathrm{P}_{\mathrm{s}}$ & Concentración de fósforo en el afluente requerida para la producción de lodo & $\mathrm{mgP} / 1$ \\
\hline $\mathrm{P}_{\mathrm{te}}$ & Concentración total de fósforo en el efluente & $\mathrm{mgP} / 1$ \\
\hline $\mathrm{P}_{\mathrm{ti}}$ & Concentración total de fósforo en el afluente & $\mathrm{mgP} / 1$ \\
\hline$Q_{e}$ & Caudal efluente & $1 / \mathrm{d}$ \\
\hline $\mathrm{Q}_{\mathrm{i}}$ & Caudal afluente & $1 / \mathrm{d}$ \\
\hline $\mathrm{Q}_{\mathrm{w}}$ & Caudal de purga de lodos del reactor & $1 / \mathrm{d}$ \\
\hline $\mathrm{S}$ & $\begin{array}{l}\text { Relación de recirculación de lodos desde el clarificador secundario } \\
\text { hasta el reactor anóxico primario }\end{array}$ & \\
\hline $\mathrm{S}_{\mathrm{bi}}$ & Concentración de DQO biodegradable en el afluente & $\mathrm{mgDQO} / 1$ \\
\hline $\mathrm{S}_{\mathrm{f}}$ & $\begin{array}{l}\text { Factor de seguridad para la tasa específica máxima de crecimiento } \\
\text { de los organismos nitrificantes }\end{array}$ & \\
\hline $\mathrm{S}_{\mathrm{S}}$ & Concentración de DQO rápidamente biodegradable (DQO $\mathrm{rb})$ & $\mathrm{mgDQO} / 1$ \\
\hline TRS & Tiempo de residencia de sólidos o edad de lodos & $\mathrm{d}$ \\
\hline $\mathrm{TRS}_{\mathrm{m}}$ & Edad de lodos mínima requerida para nitrificación & $\mathrm{d}$ \\
\hline $\mathrm{S}_{\mathrm{ti}}$ & Concentración total de DQO en el afluente & $\mathrm{mgDQO} / \mathrm{l}$ \\
\hline $\mathrm{T}$ & Temperatura & ${ }^{\circ} \mathrm{C}$ \\
\hline $\mathrm{t}_{1}$ & Duración (tiempo de residencia actual) de la primera fase de nitrificación & $\mathrm{d}$ \\
\hline$t_{1}(a+s+1) d$ & Duración (tiempo de residencia nomina) de la primera fase de nitrificación & $\mathrm{d}$ \\
\hline $\mathrm{T}_{\max }$ & Temperatura máxima del agua residual & ${ }^{\circ} \mathrm{C}$ \\
\hline $\mathrm{T}_{\min }$ & Temperatura mínima del agua residual & ${ }^{\circ} \mathrm{C}$ \\
\hline $\mathrm{TRH}_{\mathrm{n}}$ & Tiempo de residencia hidráulico nominal & $\mathrm{h}$ \\
\hline $\mathrm{TRH}_{\mathrm{n}}{ }^{\mathrm{AER}}$ & Tiempo de residencia hidráulico nominal en la zona aerobia & $\mathrm{h}$ \\
\hline $\mathrm{TRH}_{\mathrm{a}}^{\mathrm{AER}}$ & Tiempo de residencia hidráulico real en la zona aerobia & $\mathrm{h}$ \\
\hline $\mathrm{TRH}_{\mathrm{n}}{ }^{\mathrm{AX}}$ & Tiempo de residencia hidráulico nominal en la zona anóxica & $\mathrm{h}$ \\
\hline $\mathrm{TRH}_{\mathrm{a}} \mathrm{AX}^{-1}$ & Tiempo de residencia hidráulico real en la zona anóxica & $\mathrm{h}$ \\
\hline $\mathrm{V}_{\mathrm{p}}$ & Volumen del reactor & 1 \\
\hline $\mathrm{X}_{\mathrm{BHi}}$ & Concentración de SSV como OHOs por litro de caudal afluente en el reactor & $\mathrm{mgOHOSSV} / 1$ \\
\hline $\mathrm{X}_{\mathrm{BHv}}$ & Concentración de biomasa de OHOs & $\mathrm{mgSSV} / 1$ \\
\hline $\mathrm{X}_{\mathrm{EHv}}$ & Residuo endógeno de los OHOs en el lodo activado & $\mathrm{mgSSV} / 1$ \\
\hline$X_{I}$ & Materia orgánica no biodegradable presente en el afluente & $\mathrm{mgSSV} / 1$ \\
\hline
\end{tabular}




\begin{tabular}{lll}
$\mathrm{X}_{\mathrm{S}} / \mathrm{X}_{\mathrm{BH}}$ & Relación de concentración de $\mathrm{DQO}$ เь $/ \mathrm{OHO}$ & $\mathrm{mgDQO} / \mathrm{mgDQO}$ \\
$\mathrm{X}_{\mathrm{S}}$ & Concentración de DQO $\mathrm{lb}$ & $\mathrm{ngDQO} / \mathrm{l}$ \\
$\mathrm{X}_{\mathrm{t}}$ & Concentración de SST en el reactor & $\mathrm{mgSST} / \mathrm{l}$ \\
$\mathrm{X}_{\mathrm{v}}$ & Concentración de material orgánico del lodo activado dentro del reactor & $\mathrm{mg} \mathrm{SSV} / 1$ \\
$\mathrm{X}_{\mathrm{ve}}$ & Materia particulada volátil en el efluente & $\mathrm{mg} \mathrm{SSV} / \mathrm{l}$ \\
$\mathrm{Y}_{\mathrm{A}}$ & Tasa de rendimiento de los organismos nitrificantes & $\mathrm{mgSSV} / \mathrm{mgFSA}$ \\
$\mathrm{Y}_{\mathrm{H}}$ & Rendimiento de los OHOs en términos de la DQO $\left(=\mathrm{f}_{\mathrm{cv}} \mathrm{Y}_{\mathrm{Hv}}\right)$ & $\mathrm{mgDQO} / \mathrm{mgDQO}$ \\
$\mathrm{Y}_{\mathrm{Hv}}$ & Rendimiento de los OHOs en términos de los SSV & $\mathrm{mgSSV} / \mathrm{mg} \mathrm{DQO}$ \\
\hline
\end{tabular}

\begin{tabular}{ll}
\hline Abreviación & Descripción \\
\hline AGVs & Ácidos grasos volátiles \\
AOOSs & Organismos oxidantes del amonio \\
CP & Clarificador primario \\
CS & Clarificador secundario \\
DQO & Demanda química de oxígeno \\
DQOlb & DQO lentamente biodegradable \\
DQOrb & DQO rápidamente biodegradable \\
EBPR & Remoción biológica aumentada de fósforo \\
NOOs & (Enhanced biological phosphorus removal, en inglés) \\
NTK & Organismos oxidantes de nitrito \\
OD & Nitrógeno total de Kjeldahl \\
OHOs & Oxígeno disuelto \\
PAOs & Organismos heterotróficos ordinarios \\
SS & Organismos acumuladores de fósforo \\
SSI & (Phosphorus accumulating organisms, en inglés) \\
SSLM & Sólidos suspendidos \\
SST & Sólidos suspendidos inorgánicos inertes (o fijos) \\
SSV & Sólidos suspendidos del licor mezclado \\
SSVLM & Sólidos suspendidos totales \\
TRH & Sólidos suspendidos volátiles \\
TRS & Sólidos suspendidos volátiles del licor mezclado \\
WAS & Tiempo de residencia hidráulica \\
\hline
\end{tabular}




\begin{tabular}{|c|c|c|}
\hline \multicolumn{2}{|c|}{ Símbolos griegos Explicación } & nidades \\
\hline$\eta$ & \multicolumn{2}{|l|}{ Factor de reducción para la utilización de DQO } \\
\hline$\theta_{\mathrm{b}}$ & \multicolumn{2}{|l|}{$\begin{array}{l}\text { Coeficiente Arrhenius de dependencia de la temperatura para la respiración } \\
\text { endógena }\end{array}$} \\
\hline$\theta_{\mathrm{n}}$ & \multicolumn{2}{|l|}{ Coeficiente Arrhenius de dependencia de la temperatura para nitrificación } \\
\hline$\theta_{\mathrm{ns}}$ & \multicolumn{2}{|l|}{ Coeficiente de dependencia del pH para nitrificación } \\
\hline$\mu_{\mathrm{A}}$ & Tasa específica de crecimiento de los organismos nitrificantes & $/ \mathrm{d}$ \\
\hline$\mu_{\mathrm{A} 20}$ & Tasa específica de crecimiento a $20^{\circ} \mathrm{C}$ para los organismos nitrificantes & $/ \mathrm{d}$ \\
\hline$\mu_{\mathrm{Am}}$ & Tasa máxima de crecimiento específico de los organismos nitrificantes & $/ \mathrm{d}$ \\
\hline$\mu_{\mathrm{Am} 20}$ & Tasa máxima de crecimiento específico a $20^{\circ} \mathrm{C}$ de los organismos nitrificantes & $/ \mathrm{d}$ \\
\hline$\mu_{\mathrm{Am} 7.2}$ & Tasa máxima de crecimiento específico a $\mathrm{pH}=7.2$ de los organismos nitrificantes & $/ \mathrm{d}$ \\
\hline$\mu_{\mathrm{AmpH}}$ & Tasa máxima de crecimiento específico a $\mathrm{pH}$ de los organismos nitrificantes & $/ \mathrm{d}$ \\
\hline$\mu_{\mathrm{AmpHT}}$ & $\begin{array}{l}\text { Tasa máxima de crecimiento específico a pH y temperatura } \mathrm{T}^{\circ} \mathrm{C} \text { de los } \\
\text { organismos nitrificantes }\end{array}$ & $/ \mathrm{d}$ \\
\hline$\mu_{\mathrm{AmT}}$ & Tasa máxima de crecimiento específico a $\mathrm{T}^{\circ} \mathrm{C}$ de los organismos nitrificantes & $/ \mathrm{d}$ \\
\hline$\mu_{\mathrm{AO}}$ & Tasa de crecimiento específico a $0 \mathrm{mgO} / 1$ de los organismos nitrificantes & $/ \mathrm{d}$ \\
\hline$\mu_{\mathrm{AT}}$ & Tasa máxima de crecimiento a $\mathrm{T}^{\circ} \mathrm{C}$ de los organismos nitrificantes & $/ \mathrm{d}$ \\
\hline$\mu_{\mathrm{H}}$ & Tasa máxima de crecimiento de los OHOs & $/ \mathrm{d}$ \\
\hline 2.86 & Equivalencia del nitrato con respecto al oxígeno para la aceptación de electrones & $\mathrm{mgO}_{2} / \mathrm{mgNO}_{3}-\mathrm{N}$ \\
\hline 4.57 & Requerimiento de oxígeno para la nitrificación de amonio a nitrato & $\mathrm{mgO}_{2} / \mathrm{mgFSA}-\mathrm{N}$ \\
\hline
\end{tabular}


Planta de tratamiento de aguas residuals de Koortenoord en los Paises Bajos: los reactors de lodos activados están cubiertos y el aire recolectado de su interior es posteriormente tratado. (Foto: Hoogheemraadschap Schieland en de Krimpenerwaard)

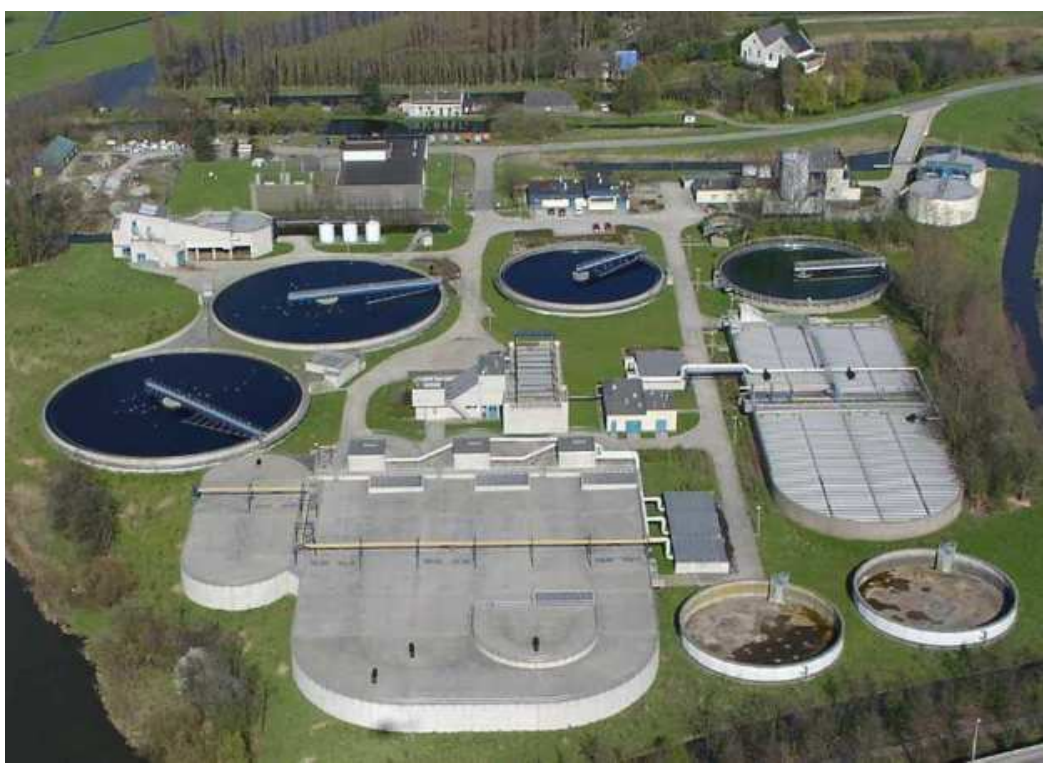




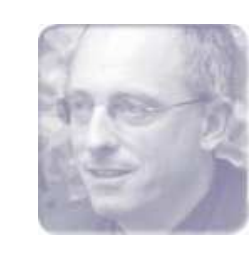

\section{6}

\section{Remoción Innovadora de Nitrógeno}

\section{Mark C.M. van Loosdrecht}

\subsection{INTRODUCCIÓN}

Los sistemas de lodos activados han sido usados exitosamente para eliminar carbono durante casi un siglo. En décadas pasadas la eliminación de nutrientes en el proceso de lodos activados ha sido explorada, evaluada y llevada a la práctica. Una preocupación creciente por proteger el ambiente ha propiciado la implementación continua de estándares cada vez más altos en los efluentes de las plantas de tratamiento. Esta situación ha impulsado los esfuerzos para mejorar la calidad de los efluentes, especialmente en cuanto a eliminación de nitrógeno. De esta manera, existen plantas de tratamiento que deberán mejorarse y requerirán ser ampliadas para cumplir con los nuevos estándares. Por lo tanto, en la última década han crecido las investigaciones enfocadas a desarrollar nuevas tecnologías para optimizar las plantas de tratamiento sin la necesidad de expandir los volúmenes existentes.

El tratamiento en las líneas de proceso internas con concentraciones elevadas de amonio tiene un gran potencial para la optimización de las plantas de tratamiento. Las líneas de agua interna (especialmente del agua de retorno proveniente del digestor de lodos) contribuyen con cerca del 10 al 30\% de la carga total de nitrógeno $(\mathrm{N})$ en una planta de tratamiento. En plantas grandes con tratamiento de lodo centralizados esta contribución es especialmente elevada.

Las líneas de agua que se originan de efluentes de digestores y de las instalaciones de tratamiento de lodos son llamadas líneas secundarias. Debido a que están altamente concentradas con amonio, se requieren volúmenes de tanque relativamente pequeños para el tratamiento de estas aguas. Además, es posible reducir los tiempos de residencia de sólidos (TRS, o también conocido en la literatura como SRT por sus siglas en inglés Sludge Retention Time) ya que a mayor temperatura, mayor es también la tasa de crecimiento máximo de los microorganismos, y generalmente las líneas secundarias tienen altas temperaturas $\left(20-35^{\circ} \mathrm{C}\right)$ comparadas con las de la línea de tratamiento principal. Por lo anterior, la eliminación de amonio de las líneas secundarias por medio de procesos físicos o biológicos puede conducir a un mejoramiento importante de la calidad final del efluente. Al final, si las líneas secundarias son tratadas de manera separada, el proceso 
puede dimensionarse con la finalidad de disminuir la carga en lugar de diseñarse para alcanzar una alta calidad del efluente, ya que el efluente puede descargarse a la línea principal de tratamiento de agua. Todos estos factores permiten el diseño de diversos y eficientes procesos que traten los efluentes del tratamiento de lodo.

A pesar de que este capítulo está enfocado principalmente al tratamiento de efluentes de digestores de lodos ubicados en plantas de tratamiento de aguas municipales, los métodos discutidos también pueden aplicarse al tratamiento de otras aguas residuales con concentraciones elevadas de nitrógeno, por ejemplo aguas industriales y lixiviados de efluentes de digestores anaerobios en general. Numerosos procesos y tecnologías han sido estudiadas y surgieron en el mercado de los lodos activados durante los últimos años: SHARON $^{\circledR}$-un sistema para eliminar $\mathrm{N}$ vía nitrito (Hellinga et al., 1998), Anammox- un proceso de eliminación de $\mathrm{N}$ completamente autótrofo (Mulder et al., 1995), $\mathrm{CANON}^{\circledR}$ - una combinación de nitritación y oxidación anaerobia de amonio (Third et al., 2001), y $\mathrm{BABE}^{\circledR}$ - bio-aumentación mejorada en procesos discontinuos (Salem et al., 2002), etc.

Se han evaluado diversos procesos físicos y químicos para el tratamiento de las líneas secundarias. No obstante, los procesos fisicoquímicos han sido generalmente menos favorables que los procesos biológicos, ya que comúnmente sus costos son significativamente mayores. Por ejemplo, los costos para aplicar un proceso SHARON $^{\circledR}$ con metanol para corregir el $\mathrm{pH}$ se estimaron en alrededor de 0.9-1.4 euros por $\mathrm{kg} \mathrm{N}$ eliminado para las plantas de tratamiento de aguas residuales de los Países Bajos (STOWA 1996), mientras que los procesos fisicoquímicos fueron entre 5 y 9 veces más costosos. Esto se debe principalmente a las diferencias en los costos de inversión y mano de obra. Finalmente, una limitación de los procesos físicos en plantas de tratamiento de aguas municipales es la necesidad de instalar diferentes unidades de operación y mantenimiento comparadas con los biológicos, lo que repercute en las necesidades de capacitación de los operadores en una planta de tratamiento.

El proceso físico más usado para tratar las aguas residuales que contienen amonio es la liberación del gas mismo (conocido también como stripping). Después de un incremento del $\mathrm{pH}$, el amonio puede ser extraído y recuperado. Este proceso puede ser más eficiente incrementando la temperatura, usando vapor en lugar de aire. Cuando existe energía disponible de residuos cerca del sitio, esto podría ser una opción viable en caso de que no haya otro uso para el vapor. El incremento de $\mathrm{pH}$ causará la precipitación de carbonatos, lo cual puede ser prevenido por medio de la acidificación del agua y la liberación del dióxido de carbono $\left(\mathrm{CO}_{2}\right)$ en un pretratamiento. Sin embargo, esta solución incrementa el uso de químicos y el número de pasos adicionales del proceso, lo que contribuye a una producción mayor de lodo químico en la planta.

La precipitación de fosfato de magnesio y amonio (MAP, por su siglás en inglés Magnesium Ammonium Phosphate), conocida también como estruvita, es otra opción para recuperar nitrógeno $(\mathrm{N})$ y fósforo $(\mathrm{P})$. Generalmente, la relación $\mathrm{P} / \mathrm{N}$ en el agua es tal que los fosfatos pueden ser eliminados sin ninguna adición de químicos. Sin embargo, para eliminar el amonio es necesario agregar fosfato de magnesio. Además, en este caso, los carbonatos tendrán que ser eliminados primero, de otra manera terminarán en el precipitado de la estruvita. La adición de fosfato de magnesio puede ser minimizado eliminando el amonio del lodo de la estruvita por medio de un tratamiento térmico. El amonio se volatilizará y podrá ser eliminado, mientras que el fosfato de magnesio y la estruvita pueden ser reusados.

La recuperación de amonio es usualmente una razón para aplicar métodos físicos. El problema es que se recupera una cantidad relativamente pequeña de amonio comparada con el uso total de amonio, por ejemplo como fertilizante. Además, estas tecnologías en general requieren de más energía que las usadas en procesos de nitrificación/desnitrificación $\mathrm{y}$ en la producción industrial de amonio. Debido a todos estos factores, el tratamiento biológico de líneas secundarias con altas cargas de nitrógeno ha sido la mejor opción viable.

\subsection{IMPACTO DE LOS PROCESOS EN LÍNEAS SECUNDARIAS}

La carga de nitrógeno en una línea secundaria es típicamente alrededor de $10-30 \%$ de la carga total de nitrógeno en el afluente. En las plantas donde se trata lodo externo (por ejemplo de otras plantas de tratamiento), esta fracción se incrementa significativamente. No obstante, este flujo equivale comúnmente a sólo el 1\% (o menos) del flujo de entrada. Las concentraciones de nitrógeno en el efluente de la planta de tratamiento dependen de su remoción en el tren principal del proceso. Si el amonio no es removido en el tren principal de tratamiento, entonces cada kilogramo de amonio eliminado en la línea secundaria va a ayudar a 
obtener un kilogramo menos de amonio en el efluente de la planta de tratamiento. Sin embargo, cabe mencionar que la disminución de nitrato no es equivalente a la carga eliminada en la línea secundaria de proceso. Esto dependerá considerablemente de las condiciones del sitio, pero generalmente variará en un rango de disminución de la carga equivalente del 40 al $70 \%$ del N eliminado en el proceso de la línea secundaria.

Los procesos para las líneas secundarias son especialmente útiles cuando las plantas requieren ampliarse debido al incremento de los estándares en el efluente o a un aumento en la carga. Así, con la construcción de tanques pequeños adicionales o la adición de pequeños volúmenes a los reactores, pueden disminuirse las concentraciones en el efluente. Una ventaja adicional es que existe la posibilidad de construir el reactor adicional de forma independiente al tren principal de proceso; así el trabajo de construcción es más simple que cuando los tanques existentes requieren ampliarse.

La aplicación de procesos para líneas secundarias también cambia la actitud de los operadores hacia el tratamiento y manejo de lodos. Como ejemplo se tiene a la planta de tratamiento de aguas residuales de Rotterdam en donde un reactor SHARON ${ }^{\circledR}$ fue instalado en 1998. En sus inicios, la carga de nitrógeno tratada era de 500 $\mathrm{kg} / \mathrm{d}$, pero debido a que fue redituable eliminar nitrógeno en un reactor para la línea secundaria, los operadores empezaron a optimizar la producción y el manejo de lodos. Ocho años después del arranque del sistema, la carga de nitrógeno en la línea secundaria fue de $700 \mathrm{~kg} / \mathrm{d}$, mientras que la carga total en la planta no cambió. No sólo se eliminó de manera adicional nitrógeno en la línea secundaria, sino que también se digirió el lodo en exceso y la producción de metano se incrementó. Lo anterior muestra que después de un tiempo la adición de procesos a las líneas secundarias puede ser incluso más rentable en casos donde el proceso de operación tiende a incrementar la carga en los digestores (por ejemplo mediante la aplicación de espesadores de lodo primario y secundario).

\subsection{EL CICLO DEL NITRÓGENO}

La detección de nuevos organismos está incrementando la complejidad del ciclo del nitrógeno (Figura 6.1). Tradicionalmente éste es descrito por procesos de nitrificación (el amonio es oxidado a nitrato vía nitrito), desnitrificación (conversión de nitrato o nitrito a nitrógeno molecular), y fijación de $\mathrm{N}$ atmosférico. Desde el punto de vista de la ingeniería de proceso, sería mejor eliminar al nitrato de este ciclo. Recientemente se ha encontrado que microorganismos 'aerobios' convencionales que oxidan el amonio pueden también usar otras vías en sus procesos.

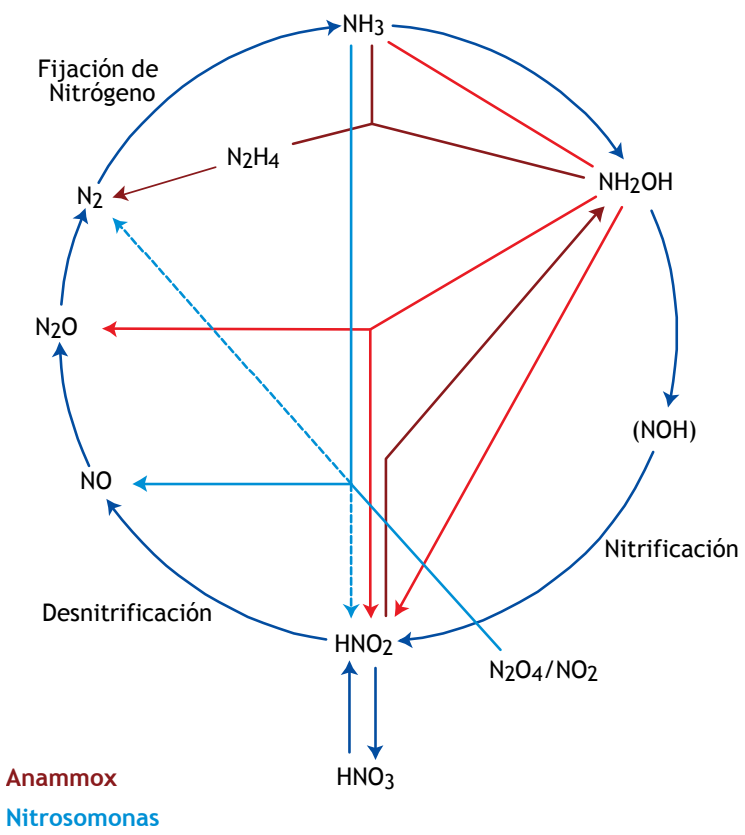

Nitrosomonas

Figura 6.1 El ciclo del nitrógeno

Cuando el oxígeno es limitante (condiciones microaerofílicas) las Nitrosomonas pueden combinar hidroxilamina con nitrito generando óxido nitroso (Bock, 1995). Este proceso fue descrito como una desamonificación aerobia (Hippen et al., 1997). Bajo condiciones anóxicas y en presencia de nitrito $\left(\mathrm{NO}_{2}{ }^{-}\right)$los microorganismos pueden convertir amonio de $\mathrm{NO}_{2}^{-}$a monóxido de nitrógeno (NO) gas (Schmidt et al. 2002). Ambas conversiones permiten la eliminación de amonio de la fase líquida, aunque claramente esto no es deseable ya que los productos finales son tóxicos o bien son gases que contribuyen fuertemente al efecto invernadero. Además, un nuevo grupo microbiano ha sido descubierto: las bacterias anaerobias oxidadoras de amonio o bacterias Anammox (Mulder et al., 1995). Éstas oxidan amonio a nitrógeno molecular $\left(\mathrm{N}_{2}\right)$ usando nitrito como aceptor de electrones bajo condiciones anóxicas. Aunque este 'atajo' en el ciclo del $\mathrm{N}$ fue descubierto recientemente, se demostró que las bacterias Anammox se encuentran fácilmente en los sistemas naturales. Se estima que el $50 \%$ o más de la desnitrificación en la naturaleza es llevada a cabo por ellas. 
El incremento de temperatura y concentración, por ejemplo en el caso de efluentes de digestores, permite numerosas alternativas para la eliminación biológica de nutrientes. Primeramente, existen mejores opciones para frenar la nitrificación al llegar a nitrito, ahorrando oxígeno y fuente de carbono. Incluso es posible tener una eliminación autótrofa completa de $\mathrm{N}$ cultivando bacterias Anammox. Además, la línea de agua cargada de $\mathrm{N}$ proveniente del tratamiento de lodos puede ser usada para cultivar bacterias nitrificantes en las líneas secundarias, las cuales son inoculadas en la línea principal del proceso. Esto permite operar el proceso aerobio principal del tren de tratamiento de agua con un TRS sub-óptimo o inferior al TRS mínimo requerido para alcanzar una nitrificación completa y satisfactoria.

El gran número de procesos existentes para tratar efluentes provenientes del tratamiento de lodos dificulta a veces una apropiada selección de la tecnología. Sin embargo, la selección del proceso será siempre específica para cada caso y dependerá principalmente de las limitaciones en la planta de tratamiento. Por ejemplo, si la capacidad de aireación en la planta de tratamiento es limitante, entonces la eliminación de amonio va a ser el tratamiento más adecuado. Por otro lado, si el incremento en la capacidad de desnitrificación es el objetivo, entonces la eliminación de $\mathrm{N}$ o la bio-aumentación pueden ser métodos apropiados. En caso de que una planta de tratamiento esté limitada por la edad del lodo, entonces sólo la bio-aumentación sería apropiada. También, la elección del tratamiento usando nitrato o nitrito depende de las condiciones locales y de la composición de la línea de agua secundaria.

Pero más allá de la ingeniería de procesos, existen otros aspectos que también deben considerarse, como el periodo de arranque, los riesgos de una falla, la flexibilidad del proceso, etc. La pregunta inicial es si la nitrificación o desnitrificación son limitantes en el tren principal del proceso (Figura 6.2). Si la nitrificación es limitada por el TRS, o si la desnitrificación es limitada por el tiempo de retención anóxico, entonces la bioaumentación es la mejor opción. En caso de limitación de espacio en la desnitrificación, la bio-aumentación permite la disminución del volumen aireado y el incremento del volumen anóxico en el proceso de lodos activados del tren principal. Sin embargo, si la aireación (nitrificación) o la DQO (desnitrificación) es limitante, entonces los procesos basados en la nitrificación pueden aplicarse. Además de la diferencia en el potencial de bioaumentación, la principal diferencia es que en la bioaumentación se tiene que completar la nitrificación porque de otra manera sólo las bacterias oxidadoras de amonio van a incrementarse, ocasionando que potencialmente se acumule nitrito en el efluente de la planta de tratamiento.

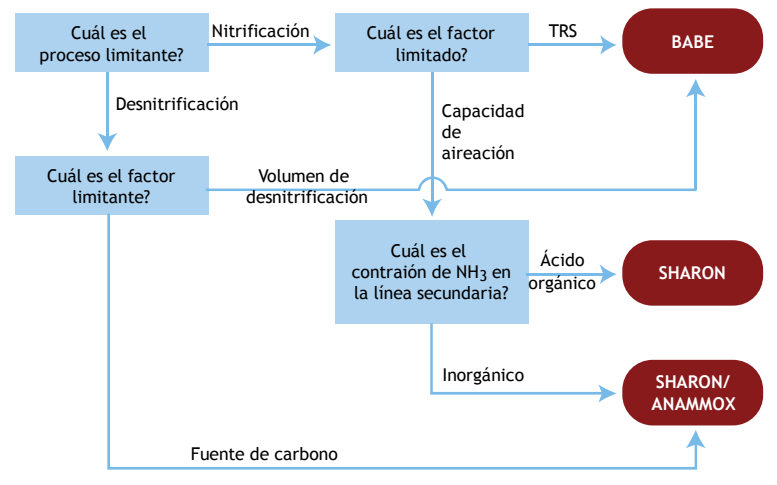

Figura 6.2 Diagrama para la selección del proceso de tratamiento en la línea secundaria

Además, se debe poner especial atención al contraión del amonio ya que, por naturaleza, el contraión después de una digestión anaerobia normal se convertirá en bicarbonato, el cual puede proporcionar el 50\% de la alcalinidad requerida para la eliminación de N. El restante debe provenir de la desnitrificación (ya sea por la adición de metanol o usando la DQO del lodo de recirculación en el proceso de bio-aumentación). El control del $\mathrm{pH}$ que se realiza añadiendo directamente alcalinidad es menos viable económicamente que el empleo de metanol combinado con la desnitrificación.

Por supuesto, el proceso de desnitrificación Anammox también puede ser usado para controlar el $\mathrm{pH}$. No obstante, en ciertos casos los tratamientos en la línea secundaria crean un contraión diferente para el amonio. Por ejemplo, si en el procesamiento de lodo se usan sales de hierro para mejorar la deshidratación, el cloruro será el contraión, creando una mayor necesidad para controlar la alcalinidad. En estos casos sería sensato cambiar el tratamiento de lodos. Si se emplea la deshidratación de lodos, usualmente los ácidos grasos formarán el contraión dominante. En tales casos, no hay necesidad de aplicar el proceso Anammox ya que hay suficiente DQO en la línea secundaria.

La desnitrificación no es realmente necesaria cuando el proceso en la línea secundaria es instalado para reducir la carga de amonio en el efluente de la planta. El efluente nitrificado de la línea secundaria puede ser vertido al inicio a la planta de tratamiento donde se desnitrificará inmediatamente. Sin embargo, la desnitrificación es una manera económicamente efectiva para controlar el $\mathrm{pH}, \mathrm{y}$ comúnmente es empleada para ello. Debido a que las 
líneas secundarias operan a altas concentraciones y temperaturas, no es necesaria una retención de lodos cuando se emplea nitrificación/desnitrificación. La retención de lodos ayudaría a emplear un reactor más pequeño (de 2 a 4 veces más pequeño dependiendo de la concentración de amonio), pero causará una operación más complicada y una inversión más alta para los trabajos mecánicos. La nitrificación y desnitrificación pueden ocurrir en un sistema de dos tanques (uno aireado y otro anóxico con una recirculación alta) o bien un sistema de un sólo tanque (con periodos alternados de aireación). El sistema de un tanque es más barato de construir, pero la inversión en el equipo de aireación será más cara debido a que no se usa durante parte del tiempo, mientras que el oxígeno total suministrado deberá ser el

mismo que en el sistema de dos tanques. También, el proceso de control es diferente. Por ejemplo, el punto de control (o set-point) del oxígeno disuelto en un sistema de dos tanques y de un tanque no será el mismo. En el primero propiciará un régimen en estado estacionario en ambos tanques, mientras que en el arreglo de un solo tanque existirá una mayor flexibilidad del control del proceso debido a las condiciones dinámicas intrínsecas.

La selección del proceso se ilustra más adelante usando el ejemplo de la planta de tratamiento de aguas residuales (PTAR) Beverwijk en los Países Bajos. Esta planta tiene una capacidad para 320,000 habitantes equivalentes (P.E.) con una carga de $\mathrm{N}$ del tratamiento de lodo (digestión metanogénica y una deshidratación térmica de lodo) de $1,200 \mathrm{kgN} / \mathrm{d}$. De acuerdo con la nueva legislación, el total de $\mathrm{N}$ en el efluente no puede exceder los $10 \mathrm{mg} / \mathrm{L}$ y como mínimo debe eliminar el
$75 \%$ del $\mathrm{N}$ total. Por lo tanto, la planta de tratamiento necesitó ser ampliada para satisfacer los nuevos límites. La eliminación del contenido de $\mathrm{N}$ en la línea secundaria fue suficiente para cumplir con los estándares requeridos. La pregunta fue cuál de los procesos para las líneas secundarias era, en este caso, la mejor opción. Se comparó la bio-aumentación $\left(\mathrm{BABE}^{\circledR}\right)$, la nitrificacióndesnitrificación (SHARON ${ }^{\circledR}$ ) y un proceso combinado nitritación-Anammox. En la línea secundaria el contraión del amonio $\left(\mathrm{NH}_{4}^{+}\right)$fue acetato (lo cual es normal después de una deshidratación térmica de lodos). Los experimentos en laboratorio muestran que el reactor $\mathrm{SHARON}^{\circledR}$ con 1 día de TRS en la parte aerobia puede llevar a cabo la nitrificación y desnitrificación vía nitrito sin corrección de $\mathrm{pH}$ con una eficiencia $>90 \%$ (Schemen et al., 2003).

Pero más allá de los factores exclusivamente técnicos, existen otros aspectos que en este caso, como en muchos otros, son importantes. Estos aspectos pueden ser el uso de la energía, la administración y manejo del proyecto, la construcción, etc., los cuales son desglosados en la matriz de decisión de la Tabla 6.1 (Schemen et al., 2003). Claramente existe una amplia variedad de criterios de decisión, los cuales pueden cambiar dependiendo del caso específico de cada planta. Además, cada aspecto en la toma de decisiones tiene una importancia y ponderación diferente, que depende a su vez de las condiciones locales. En este caso se calculó el puntaje total de cada sistema. Basado en esta matriz de decisión, la tecnología SHARON $^{\circledR}$ fue seleccionada para ser aplicada para el tratamiento de la línea secundaria de la PTAR Beverwijk (Figura 6.4).

Tabla 6.1 Matriz de decisión para seleccionar el tratamiento de la línea secundaria de la PTAR Beverwijk

\begin{tabular}{|c|c|c|c|c|}
\hline Criterio & Ponderación (\%) & $\mathrm{BABE}^{\circledR}$ & SHARON $^{\circledR}$ & SHARON $^{\circledR} /$ Anammox \\
\hline Costos operativos & 27 & + & ++ & + \\
\hline $\begin{array}{l}\text { Eficiencia de eliminación } \\
\text { de } \mathrm{N}\end{array}$ & 5 & ++ & ++ & + \\
\hline Demanda de energía & 15 & - & 0 & ++ \\
\hline Emisión de olores & 1 & + & + & + \\
\hline Tiempo de ejecución & 20 & + & + & -- \\
\hline $\begin{array}{l}\text { Administración y } \\
\text { dirección del proyecto }\end{array}$ & 1 & + & ++ & ++ \\
\hline Construcción & 1 & 0 & 0 & 0 \\
\hline Flexibilidad & 10 & - & + & ++ \\
\hline Innovación & 10 & + & + & ++ \\
\hline Riesgo de falla & 10 & + & + & - \\
\hline Total & 100 & 3.5 & 4.1 & 3.5 \\
\hline
\end{tabular}

Nota: $++=5 ;+=4 ; 0=3 ;-=2 ;--=1 \quad$ Máximo 5 puntos 


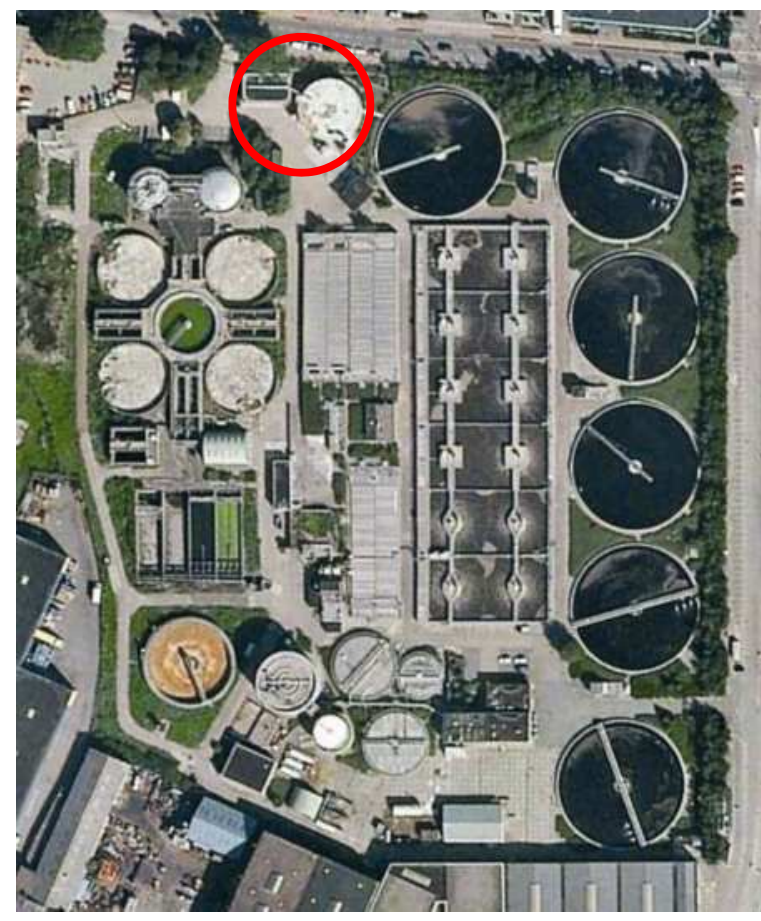

Figura 6.4 PTAR Beverwijk, el círculo rojo muestra el área usada para el proceso $\mathrm{SHARON}^{\circledast}$ tratando $1,200 \mathrm{kgN}$ por día

\subsection{ELIMINACIÓN DE N MEDIANTE NITRITO}

Desde hace varios años las tecnologías de nitritacióndesnitritación han sido consideradas como promisorias. Durante la nitritación (también conocido como nitrificación parcial) el amonio es convertido a nitrito mientras que se evita su oxidación a nitrato. Las ecuaciones estequiométricas para la nitrificación y desnitrificación son descritas abajo.

Eliminación convencional de amonio:

Nitritación ( $1^{\text {er }}$ paso de la nitrificación):

$\mathrm{NH}_{4}^{+}+1.5 \mathrm{O}_{2} \rightarrow \mathrm{NO}_{2}^{-}+\mathrm{H}_{2} \mathrm{O}+2 \mathrm{H}^{+}$

Nitratación (2 $2^{\text {do }}$ paso de la nitrificación):

$\mathrm{NO}_{2}^{-}+0.5 \mathrm{O}_{2} \rightarrow \mathrm{NO}_{3}^{-}$

Nitrificación:

$\mathrm{NH}_{4}^{+}+2 \mathrm{O}_{2} \rightarrow \mathrm{NO}_{3}^{-}+\mathrm{H}_{2} \mathrm{O}+2 \mathrm{H}^{+}$

Desnitrificación:

$\mathrm{NO}_{3}^{-}+4 \mathrm{~g} \mathrm{DQO}+\mathrm{H}^{+} \rightarrow 0.5 \mathrm{~N}_{2}+1.5 \mathrm{~g}$ lodo

En resumen:

$\mathrm{NH}_{4}^{+}+2 \mathrm{O}_{2}+4 \mathrm{~g} \mathrm{DQO} \rightarrow 0.5 \mathrm{~N}_{2}+\mathrm{H}_{2} \mathrm{O}+\mathrm{H}^{+}+$$$
+1.5 \mathrm{~g} \text { lodo }
$$

Eliminación de amonio basada en la nitritación $\left(\mathrm{SHARON}^{\circledR}\right)$ :

Nitritación ( $1^{\text {er }}$ paso de la nitrificación):

$\mathrm{NH}_{4}^{+}+1.5 \mathrm{O}_{2} \rightarrow \mathrm{NO}_{2}^{-}+\mathrm{H}_{2} \mathrm{O}+2 \mathrm{H}^{+}$

Desnitritación:

$\mathrm{NO}_{2}^{-}+2.4 \mathrm{~g} \mathrm{DQO}+\mathrm{H}^{+} \rightarrow 0.5 \mathrm{~N}_{2}+0.9 \mathrm{~g}$ lodo

Resumiendo:

$\mathrm{NH}_{4}^{+}+1.5 \mathrm{O}_{2}+2.4 \mathrm{~g} \mathrm{DQO} \rightarrow 0.5 \mathrm{~N}_{2}+\mathrm{H}_{2} \mathrm{O}+\mathrm{H}^{+}+$

$$
+0.9 \mathrm{~g} \text { lodo }
$$

La reducción en los requerimientos de oxígeno significa que el proceso demanda $25 \%$ menos aireación. La reducción del nitrito a nitrógeno molecular requiere $40 \%$ menos fuente de carbono. Ciertamente, ésta es una disminución importante en el costo cuando hay una baja relación $\mathrm{C} / \mathrm{N}$ en el agua residual, ya que en estos casos se requiere la adición de una fuente externa de carbono (como donador de electrones) como el metanol. Al final, la cantidad de lodo producido en un proceso basado en la nitritación es aproximadamente $40 \%$ menor.

La conversión biológica vía nitrito se puede forzar usando principalmente dos estrategias: $(i)$ creando fuertes condiciones de selección para favorecer el crecimiento de las bacterias oxidadoras de amonio y (ii) previniendo la oxidación del nitrito ya sea manteniendo la concentración de oxígeno baja o bien operando a niveles sub-óptimos de $\mathrm{pH}$, así como de concentraciones sub-óptimas de nitrito o amonio.

La primera condición o factor de selección usada es la temperatura. La oxidación de amonio es más sensible a cambios de temperatura que la oxidación de nitrito (Hellinga et al., 1998). A temperaturas por encima de $20^{\circ} \mathrm{C}$, aproximadamente, los organismos oxidantes de amonio tienen una mayor tasa de crecimiento que los organismos oxidantes de nitrito. El proceso SHARON ${ }^{\circledR}$ hace uso de las diferentes tasas de crecimiento a temperaturas altas mediante la selección de un TRS que se encuentre entre los requerimientos para la oxidación de amonio y de nitrito. Otras estrategias de selección importantes son las concentraciones elevadas de compuestos como amonio, nitrito o de sal en el reactor. Los organismos oxidantes de nitrito tienen una menor tolerancia y no pueden crecer en estas condiciones. Esto es especialmente relevante para las aguas residuales industriales.

También, como se mencionó anteriormente la segunda opción para prevenir la oxidación de nitrito es 
manteniendo la concentración de oxígeno baja o bien operando a niveles sub-óptimos de $\mathrm{pH}$, así como de concentraciones de nitrito o amonio. Generalmente en este caso, la oxidación de nitrito se inhibirá parcialmente. Así, combinando la inhibición (débil) por la presencia de nitrito con el proceso de desnitritación, es posible obtener una conversión total de nitrito. Debido a que bajo este esquema la desnitrificación se llevará a cabo a partir del nitrito, los organismos oxidantes de nitrito son privados de su sustrato y en consecuencia son eliminados del sistema.

A concentraciones bajas de oxígeno el nitrito y el nitrato son producidos dependiendo de la limitación de oxígeno. La concentración óptima por acumulación de nitrito en este tipo de procesos será menor para biopelículas delgadas, flóculos más pequeños o cargas bajas (Hao et al., 2002). Sin embargo, si sólo se emplea una concentración baja de oxígeno, el nitrato también se formará (Picioreanu et al., 1997). La Figura 6.3 ilustra el comportamiento durante la formación de nitrito/nitrato a diferentes concentraciones de oxígeno disuelto en una biopelícula, tal y como fue observado experimentalmente por Garrido et al. (1997) y explicado teóricamente por Picioreanu et al. (1997).

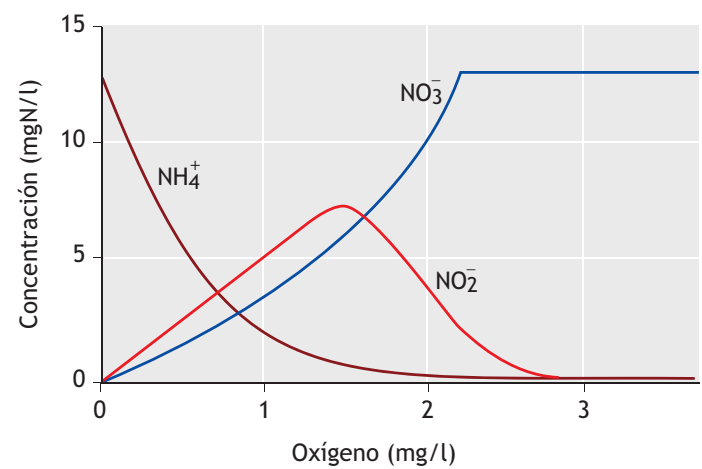

Figura 6.3 Efecto del oxígeno en la acumulación de NO2-N en una biopelícula.

La única manera de que la conversión pueda ser completamente vía nitrito es evitando la oxidación de nitrito mediante la competencia simultánea por nitrito y oxígeno. Esto requiere de una asociación directa de la nitritación y la desnitritación. Existen algunos casos en los que se usa una recirculación alta entre los reactores aerobios y anóxicos (Van Benthum et al., 1998) o donde se incluye una desnitrificación en la parte más baja del sistema (Kuai et al., 1998; Hao et al., 2002).

El proceso SHARON ${ }^{\circledR}$ (Hellinga et al., 1998) fue el primer método que fue desarrollado y llevado a escala completa para tratar aguas con altas concentraciones de amonio usando nitrito como intermediario (Figura 6.4). SHARON significa Monoreactor para la eliminación de Amonio a Alta Tasa vía Nitrito (por sus siglas en inglés Single-reactor system for High Activity Ammonium Removal Over Nitrite. El proceso aprovecha la elevada temperatura de la línea secundaria, permitiendo tasas de crecimiento específicas altas, haciendo posible la operación sin retención de lodos (Hellinga et al. 1998; Mulder et al. 2001). El proceso se basa en que el crecimiento máximo de las bacterias oxidantes de amonio es mayor que el de las oxidantes de nitrito a temperaturas elevadas. El TRS es relativamente corto (alrededor de 1 día) con el fin de seleccionar solamente las bacterias oxidantes de amonio sin permitir el crecimiento de las que oxidan nitrito.

El TRS relativamente corto requerido (de 1 día) significa que es posible operar el proceso sin retención de biomasa. El lodo producido se descarga en el efluente, lo cual no representa un problema porque el efluente es enviado al inicio del tren principal de proceso de la PTAR. En caso de que se retenga la biomasa, el tiempo de aireación se convertirá en el factor limitante para el diseño del reactor debido a la elevada cantidad de oxígeno que se requiere adicionar. Al final, el balance económico que determine y compare el volumen del reactor y el equipo de retención de biomasa es el que establecerá cuál es la opción más apropiada. En la práctica, se estima que a concentraciones mayores a 0.4 $0.5 \mathrm{gN} / 1$ un sistema sin retención de biomasa es más barato y requiere menos mantenimiento.

Una diferencia primordial entre reactores que operan con o sin retención de biomasa es su respuesta ante cambios en la concentración del afluente. En sistemas basados en la retención de biomasa la carga de lodo es importante para la conversión. El sistema tendrá que ser diseñado con base en los picos de las cargas tratadas. En un sistema $\sin$ retención de biomasa la tasa de crecimiento es el factor de diseño. Las tasas fluctuantes de carga provocarán concentraciones variantes de lodo en el reactor y en consecuencia mantendrán la concentración en el efluente constante e independiente de las concentraciones en el afluente.

El proceso de desnitrificación en el reactor SHARON $^{\circledR}$ es usualmente empleado para controlar el $\mathrm{pH}$ (Hellinga et al., 1998). Usar metanol o desechos orgánicos para producir alcalinidad a través de la desnitrificación es más económico que agregar alcalinidad mediante bicarbonatos o hidróxidos. No hay un requerimiento directo para la desnitrificación 
completa ya que el proceso para la línea secundaria no tiene restricciones en el efluente. El principal objetivo es eliminar grandes cantidades de nitrógeno. Para la desnitrificación de efluentes comunes, provenientes de digestores de lodos, la desnitrificación para el control del pH implica una eliminación de alrededor del 95\%.

Como fue mencionado anteriormente, el control de $\mathrm{pH}$ es el aspecto primordial a considerar durante el diseño de procesos de nitritación-desnitritación para efluentes de digestores. El pH se mantiene por medio de la liberación de $\mathrm{CO}_{2}$ del líquido. Esto sugiere que tanques altos (arriba de 4-5 metros de profundidad de agua) tendrían que ser diseñados para una correcta liberación de $\mathrm{CO}_{2}$ en lugar de enfocarse al suministro de $\mathrm{O}_{2}$. También es preferible mantener un $\mathrm{pH}$ donde el equilibrio de bicarbonato sea dirigido hacia $\mathrm{CO}_{2}$, por ejemplo debajo o alrededor de 7.0 , a pesar de que para las bacterias nitrificantes el crecimiento óptimo sea de 7.5-8.0. Un control efectivo del proceso puede ser preferentemente basado en mediciones de $\mathrm{pH}$. Ambos, la nitrificación excesiva y la desnitrificación limitada, van a conducir rápidamente al descenso de $\mathrm{pH}$, mientras que demasiada desnitrificación conducirá a un incremento del $\mathrm{pH}$. La respuesta del $\mathrm{pH}$ es muy sensible debido a que, en general, el sistema será operado bajo condiciones donde difícilmente se mantendrá un efecto tampón o buffer. Una conversión de $7 \mathrm{mg}$ de $\mathrm{N}$-amoniacal generará $1 \mathrm{mM}$ de protones o un descenso de $\mathrm{pH}$ a un valor de 3 ante la ausencia de una solución amortiguadora. Por ello cambios leves de las conversiones tendrán un impacto significativo en el nivel de $\mathrm{pH}$.

La nitrificación y desnitrificación son reacciones exotérmicas; esto significa que el proceso de conversión tiene un impacto significativo en la temperatura del reactor. La Figura 6.5 brinda un panorama de los factores que influyen en la temperatura del reactor. $\mathrm{NO}$ es necesario un control preciso de la temperatura; sin embargo, es preferible operar el proceso a temperaturas mayores a $25^{\circ} \mathrm{C}$ y menores a $40^{\circ} \mathrm{C}$.

El costo del proceso SHARON ${ }^{\circledR}$ es principalmente influenciado por factores operacionales, energéticos y por la fuente de carbono, tal y como lo describe la Figura 6.6. Los costos de inversión son relativamente bajos debido al diseño y simple operación del reactor.

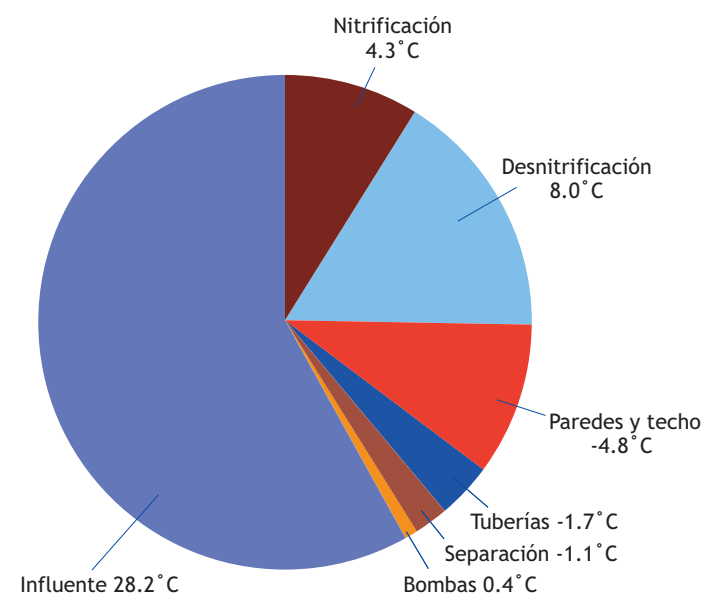

Figura 6.5 Impacto de diversos factores en el balance de calor de un reactor SHARON $^{\circledast}$ a escala completa, PTAR Dokhaven en Róterdam

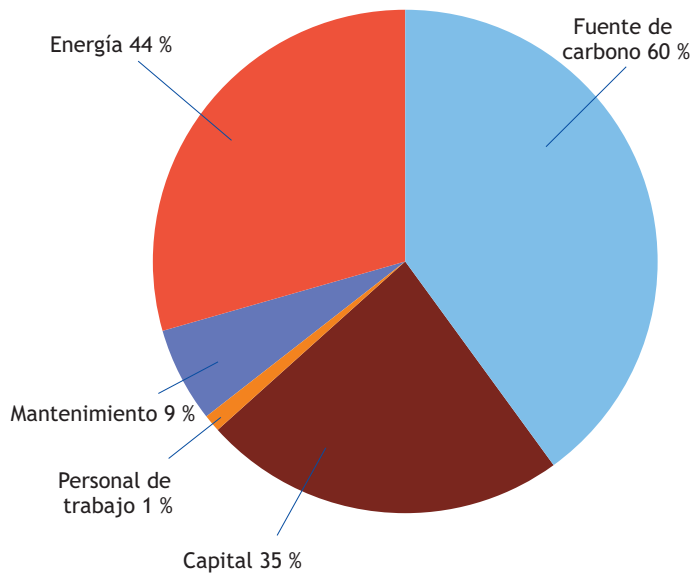

Figura 6.6 Costo de instalación del tratamiento de eliminación de $\mathrm{N}$ en línea secundaria usando un proceso SHARON ${ }^{\circledast}$

\subsection{OXIDACIÓN ANAEROBIA DE AMONIO}

Anammox es un proceso completamente autótrofo para eliminar N. Este término es un acrónimo que proviene del inglés ANAerobic AMMonium OXidation, lo cual se traduce como Oxidación Anaerobia de Amonio. Este proceso microbiano fue descubierto en los 80's (Mulder et al., 1989) y posteriormente en los 90's empezó a estudiarse su uso en tratamiento de aguas residuales. En efecto, la conversión Anammox es un tipo de atajo en el ciclo del nitrógeno. Este proceso convierte amonio directamente a nitrógeno molecular en condiciones anaerobias utilizando nitrito como aceptor de electrones. Las bacterias Anammox usan $\mathrm{CO}_{2}$ como fuente de carbono al igual que las bacterias nitrificantes convencionales. Para más detalles acerca del 
descubrimiento y aplicación del Anammox, es posible remitirse a la revisión científica realizada por Kuenen (2008).

Las ventajas de usar Anammox para eliminar nitrógeno son evidentes. No hay necesidad de usar una fuente externa de carbono, sólo el 50\% del amonio debe ser oxidado a nitrito y existe un rendimiento bajo de biomasa (o producción de lodo). Cuando el proceso Anammox es acoplado con el proceso de nitrificación parcial (nitritación), la conversión total puede ser vista como una oxidación directa de amonio a nitrógeno molecular. Las ecuaciones de las reacciones para los procesos de eliminación de nitrógeno convencionales y Anammox son:

Eliminación convencional de amonio:

Nitrificación:

$\mathrm{NH}_{4}^{+}+2 \mathrm{O}_{2} \rightarrow \mathrm{NO}_{3}^{-}+\mathrm{H}_{2} \mathrm{O}+2 \mathrm{H}^{+}$

Desnitrificación:

$\mathrm{NO}_{3}^{-}+4 \mathrm{~g} \mathrm{COD}+\mathrm{H}^{+} \rightarrow 0.5 \mathrm{~N}_{2}+1.5 \mathrm{~g}$ lodo

Resumen:

$$
\begin{array}{r}
\mathrm{NH}_{4}^{+}+2 \mathrm{O}_{2}+4 \mathrm{gCOD} \rightarrow 0.5 \mathrm{~N}_{2}+\mathrm{H}_{2} \mathrm{O}+\mathrm{H}^{+}+ \\
+1.5 \mathrm{~g} \text { lodo }
\end{array}
$$

\section{SHARON ${ }^{\circledR} /$ Anammox:}

Nitritación ( $1^{\text {er }}$ paso de la nitrificación):

$\mathrm{NH}_{4}^{+}+1.5 \mathrm{O}_{2} \rightarrow \mathrm{NO}_{2}^{-}+\mathrm{H}_{2} \mathrm{O}+2 \mathrm{H}^{+}$

Oxidación Anaerobia de Amonio:

$\mathrm{NH}_{4}^{+}+\mathrm{NO}_{2}^{-} \rightarrow \mathrm{N}_{2}+2 \mathrm{H}_{2} \mathrm{O}$

Resumen:

$\mathrm{NH}_{4}^{+}+0.75 \mathrm{O}_{2} \rightarrow 0.5 \mathrm{~N}_{2}+1.5 \mathrm{H}_{2} \mathrm{O}+\mathrm{H}^{+}$

Los menores requerimientos de energía y de donador de electrones (o fuente de carbono) hacen que el proceso Anammox contribuya fuertemente a incrementar la sustentabilidad de las operaciones del tratamiento del agua residual. La Tabla 6.2 muestra una comparación de parámetros indicadores entre la eliminación de nitrógeno por medio de la desnitrificación convencional y el proceso Anammox. En el proceso convencional, aproximadamente 4.7 toneladas de $\mathrm{CO}_{2}$ son liberados por tonelada de nitrógeno eliminado, mientras que en el proceso SHARON ${ }^{\circledR} /$ Anammox esto es de sólo 0.7. La reducción en las emisiones de $\mathrm{CO}_{2}$ es un incentivo adicional para la aplicación de Anammox en la industria. En las Tablas 6.3 y 6.4 se muestra un análisis comparativo del impacto de emplear Anammox a escala completa en lugar de tecnologías convencionales para plantas de tratamiento municipales e industriales, respectivamente.

Actualmente, el proceso Anammox se aplica sobre todo a temperaturas altas (ej. efluente de digestores). Sin embargo, debido a que las bacterias responsables se pueden encontrar fácilmente en la naturaleza, no existe una limitación real para su aplicación normal en PTARs que eliminen N. La aplicación de eliminación autótrofa de nitrógeno en una PTAR "normal" hace deseable la maximización de la producción de lodo (ej. por medio de sedimentación primaria y floculación), lo que incrementa la producción de metano en el digestor de lodos. Lo anterior permite mejorar de manera importante la eficiencia energética del sistema.

Las bacterias Anammox forman un grupo distinto en el mundo microbiano (Figura 6.7). Las reacciones catabólicas (que generan la energía) ocurren en un compartimento interno con una membrana celular (Anammoxozoma), a diferencia de otras bacterias en las que esta membrana no existe y la energía es generada en la membrana externa. Anammox tiene a la hidracina como intermediario. El rol exacto de la hidroxilamina sigue en debate; aunque puede ser que el NO en lugar de la hidroxilamina sea el intermediario. Aunque las bacterias desnitrificantes usan al $\mathrm{N}_{2} \mathrm{O}$ como intermediario, este compuesto está ausente en la fisiología de Anammox, por lo que este gas de invernadero no lo producen las bacterias Anammox.

Tabla 6.2 Comparación entre el sistema de eliminación convencional de $\mathrm{N}$ y el proceso SHARON ${ }^{\circledast} /$ Anammox.

\begin{tabular}{llrr}
\hline Concepto & Unidad & Tratamiento convencional & SHARON $^{\circledR} /$ Anammox $^{-}$ \\
\hline Energía & $\mathrm{kWh} / \mathrm{kgN}$ & 2.8 & 1.0 \\
Metanol & $\mathrm{kg} / \mathrm{kgN}$ & 3.0 & 0 \\
Producción de lodos & $\mathrm{kgVSS} / \mathrm{kgN}$ & $0.5-1.0$ & 0.1 \\
${\text { Emisión de } \mathrm{CO}_{2}}$ & $\mathrm{~kg} / \mathrm{kgN}$ & $>4.7$ & 0.7 \\
Costo Total $^{1}$ & $€ / \mathrm{kgN}$ & $3.0-5.0$ & $1.0-2.0$ \\
\hline
\end{tabular}

${ }^{1}$ Los costos totales incluyen tanto los costos de operación como el costo de capital inicial 
Tabla 6.3 Impacto del proceso Anammox en la eliminación de N en PTARs municipales: Comparación entre desnitrificación convencional y proceso Anammox en los Países Bajos (capacidad de tratamiento total 25 millones de P.E.)

\begin{tabular}{llccc}
\hline Concepto & Unidad & Convencional & $\begin{array}{c}\text { Pre-tratamiento, } \\
\text { Tratamiento anaerobio, } \\
\text { Anammox }\end{array}$ & Diferencia \\
\hline Producción de energía $\left(\mathrm{CH}_{4}\right)$ & $\mathrm{MW}$ & 0 & 40 & 40 \\
Emisión de $\mathrm{CO}_{2}$ & $\mathrm{kton} / \mathrm{año}$ & 400 & 6 & 394 \\
Consumo de energía & $\mathrm{MW}$ & 80 & 41 & 39 \\
Producción de lodos & $\mathrm{ktonSSV} /$ año & 370 & 270 & 100 \\
\hline
\end{tabular}

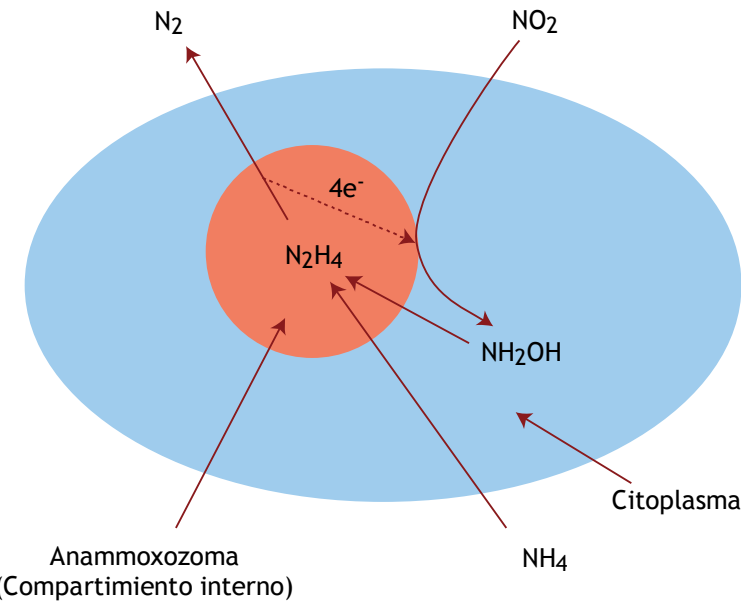

(Compartimiento interno)

Figura 6.7 Metabolismo Anammox

El rendimiento celular de Anammox es similar al de las bacterias nitrificantes. Cierta cantidad de nitrato es producido en el proceso de crecimiento de Anammox debido a la oxidación de nitrito a nitrato, lo cual compensa la reducción de $\mathrm{CO}_{2}$ a materia orgánica celular. Así, la generación anóxica de nitrato es un parámetro usado para medir el crecimiento y la actividad de Anammox.

El principal problema de los organismos Anammox es su tasa de crecimiento relativamente baja $\left(0.069 \mathrm{~d}^{-1}\right.$, Van de Graaf et al., 1996), aunque ésta no es un parámetro que limite la alta capacidad del reactor. Aproximadamente una eliminación de $5-10 \mathrm{kgN} / \mathrm{m}^{3} . \mathrm{d}$ es alcanzada sin dificultad debido al hecho de que los organismos fácilmente se inmobilizan a sí mismos en biopelículas compactas o gránulos, permitiendo un contenido muy alto de biomasa en el reactor. El lodo Anammox tiene una coloración rojiza característica (Figura 6.8).

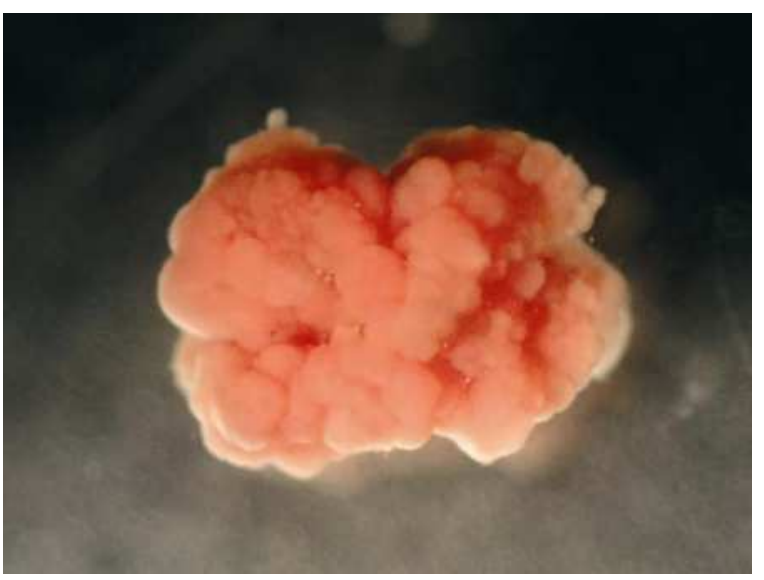

Figure 6.8 Típico lodo granular Anammox (foto: Water Board Hollandse Delta)

El sistema requiere nitrito para tener una eliminación efectiva de amonio; el nitrato no puede ser usado por los organismos Anammox. El proceso necesita por lo tanto un primer paso de nitritación. Una estrategia directa y sencilla es combinar el proceso Anammox con un proceso SHARON ${ }^{\circledR}$ o similar (Van Dongen et al., 2001). Es por ello que el proceso Anammox es precedido por el

Tabla 6.4 Impacto del proceso Anammox en la eliminación de N en PTARs industriales: Comparación entre desnitrificación convencional y proceso Anammox en los Países Bajos (capacidad de tratamiento total industrial 21 ktonDQO/año y 2 ktonN/año)

\begin{tabular}{llccc}
\hline Concepto & Unidad & Convencional & $\begin{array}{c}\text { Pre-tratamiento, } \\
\text { Tratamiento anaerobio, } \\
\text { Anammox }\end{array}$ & Diferencia \\
\hline Producción de energía $\left(\mathrm{CH}_{4}\right)$ & $\mathrm{MW}$ & 0 & 2 & 2 \\
Emisión de $\mathrm{CO}_{2}$ & $\mathrm{kton} /$ año & 30 & 6 & 24 \\
Consumo de energía & $\mathrm{MW}$ & 2.3 & 0.3 & 2 \\
Producción de lodos & ktonSSV /año & 30 & 4 & 26 \\
\hline
\end{tabular}


reactor SHARON ${ }^{\circledR}$ donde sólo se lleva a cabo una nitrificación parcial.

El reactor $\mathrm{SHARON}^{\circledR}$ trabaja en condiciones de tiempo de residencia hidráulico (TRH) de 1 día, temperatura de $25-40^{\circ} \mathrm{C}$ y $\mathrm{pH}=6.6-7.0$. Sin un control de $\mathrm{pH}$ en el reactor, se puede obtener una mezcla que contenga $50 \%$ de amonio y $50 \%$ de nitrito en el efluente del reactor SHARON ${ }^{\circledR}$. Esto se debe al hecho de que en el efluente de un digestor normal el contraión de amonio es bicarbonato. Cuando el 50\% del amonio es oxidado, se usa todo el carbonato amortiguador (buffer), y el proceso se inhibe a sí mismo debido al descenso de $\mathrm{pH}$. La primer aplicación de la tecnología SHARON $^{\circledR} /$ Anammox a escala completa fue en la PTAR Dokhaven en Róterdam, Países Bajos (470,000 P.E., carga de $\mathrm{N}$ de $830 \mathrm{~kg} / \mathrm{d}$, van der Star et al., 2007, Figura $6.9)$.

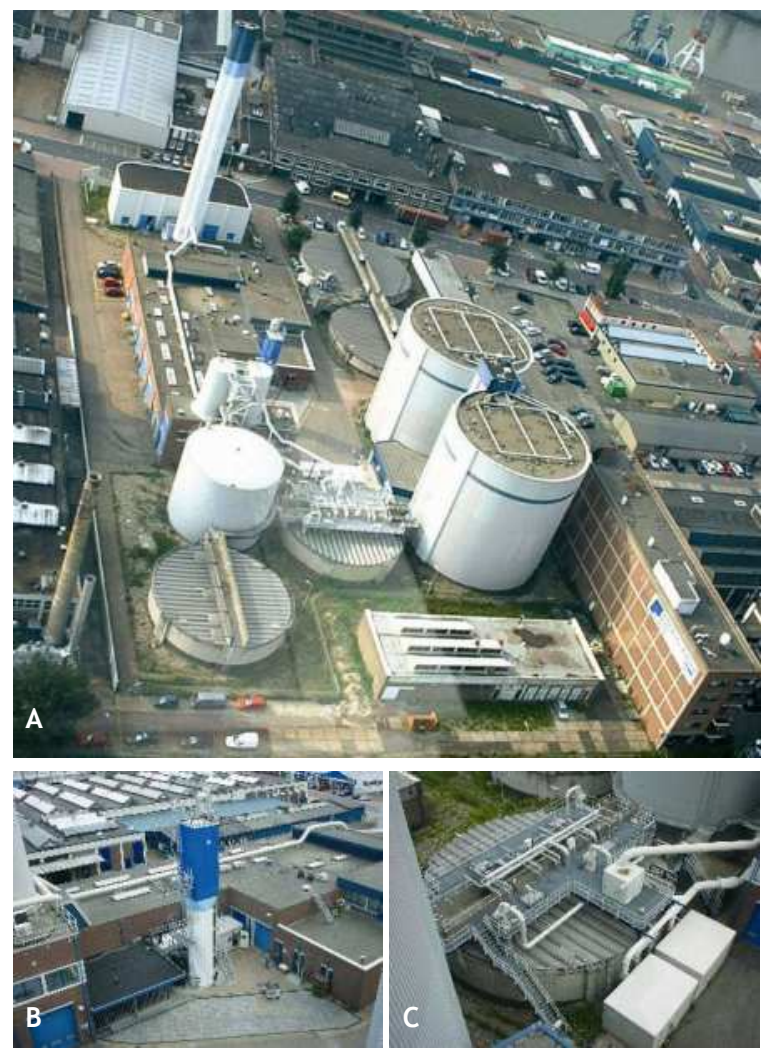

Figure 6.9 Vista aérea de las instalaciones de la PTAR Dokhaven (A) tratamiento de lodos y proceso Anammox, (B) proceso SHARON $^{\circledast}(C)$ reactores vistos desde la parte algo del digestor de lodos (foto: Water Board Hollandse Delta)

El tipo de recirculación interna del reactor usada en el proceso Anammox en Róterdam se ha adaptado especialmente para el uso de lodo granular. El compartimento inferior es una cama de lodos, la cual está mezclada completamente gracias al funcionamiento de un sistema airlift impulsado por la producción de nitrógeno molecular y el cual es recolectado en la parte alta de este compartimento inferior. De esta manera, se puede mantener la concentración de nitrito en un nivel bajo en todo el reactor independientemente de las concentraciones altas del afluente. El compartimento superior también contiene lodo y es principalmente utilizado para alcanzar una concentración baja en el efluente debido a sus características de flujo pistón.

La nitritación y el proceso Anammox pueden ser combinados en un sólo reactor. En este caso, se requiere la inmobilización de la biomasa debido a la tasa de crecimiento relativamente baja de las bacterias Anammox. En este sistema, no se puede aplicar el criterio de supresión y lavado de los organismos oxidantes de nitrito para prevenir la oxidación de nitrito. Sin embargo, tanto el oxígeno como el nitrito son factores limitantes y hacen que las bacterias Anammox ganen la competencia contra las bacterias odixantes de nitrito existentes en el proceso de eliminación de N (Hao et al., 2002).

El método más fácil es operar la biopelícula o el lodo granular basado en el proceso autótrofo de oxidación de amonio bajo condiciones de limitación de oxígeno tales que aproximadamente el $50 \%$ del amonio pueda ser oxidado. Si la biopelícula es estable, automáticamente la población Anammox se desarrollará en la parte más profunda de la biopelícula como se ilustra en la Figura 6.10 .

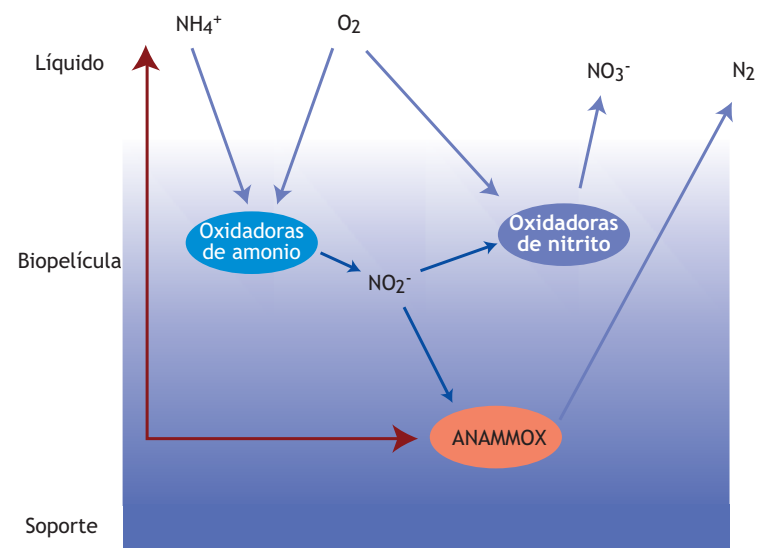

Figura 6.10 Representación esquemática de los procesos autótrofos de eliminación de $\mathrm{N}$ en biopelículas.

Este proceso ha sido observado espontáneamente en varias ocasiones (Siegrist et al., 1998). Sin embargo, éste ha tenido diversos acrónimos en la literatura, como: Nitrificación-desnitrificación autótrofa bajo condiciones 
limitadas de oxígeno $\left(\mathrm{OLAND}^{\circledR}\right.$, por sus siglas en inglés Oxygen Limited Aerobic Nitrification-Denitrification, Kuai et al. 1998), Desamonificación aerobia (Hippen et al., 1997) y eliminación completa autotrófa de nitrógeno vía nitrito $\left(\mathrm{CANON}^{\circledR}\right.$, por sus siglas en inglés Completely Autotrophic Nitrogen removal Over Nitrite, Strous, 2000; Sliekers et al., 2002). Los primeros dos nombres sugieren una desnitrificación bajo condiciones aerobias, lo cual no es correcto; por lo tanto, se sugiere que $\mathrm{CANON}^{\circledR}$ sea usado para describir de manera general este proceso. Efectivamente, los primeros dos nombres se relacionan con la suposición original de que la desnitrificación es realizada principalmente por las bacterias Nitrosomonas (Figura 6.1); sin embargo, después se demostró claramente que las bacterias Anammox eran las responsables de esta conversión (Peynaert et al., 2003; Helmer et al., 2001). Durante este tiempo, diversos procesos basados en las bacterias Anammox fueron propuestos en la literatura. Van der Star et al. (2007) realizó una revisión general y propuso la manera de nombrar uniformemente estos procesos, como se muestra en la Tabla 6.5.

\subsection{BIO-AUMENTACIÓN}

El principal criterio de diseño para una planta de tratamiento nitrificante es el TRS aerobio requerido, el cual se incrementa considerablemente en climas fríos. Por medio de la adición de bacterias nitrificantes al sistema de lodos activados es posible disminuir el TRS requerido. Esto puede ser usado como una opción para incrementar la capacidad, permitiendo que los sistemas desnitrifiquen cargas más altas o reduciendo el espacio requerido en las plantas nitrificadoras para utilizarlo para procesos de desnitrificación. La bio-aumentación puede ser realizada cultivando lodo nitrificante externamente, aunque esto tiene dos desventajas potenciales. El tipo de bacterias nitrificantes añadidas podrían no ser las óptimas para una planta de tratamiento en específico, ya que podrían sufrir de depredación por los protozoarios presentes en el lodo activado. Por lo tanto, es de sumo interés producir bacterias nitrificantes en un reactor continuamente inoculado con lodo del reactor aerobio principal y alimentado con efluente del digestor. De esta manera las bacterias nitrificantes que crezcan en el lodo son las mismas que ya existen en el sistema; ellas proliferarán dentro del lodo floculento y por lo tanto no

Tabla 6.5 Opciones y nombres para los sistemas de eliminación de nitrógeno que involucran procesos Anammox

\begin{tabular}{|c|c|c|c|c|}
\hline Nombre del proceso & Fuente & nitrito & Nombres alternativos del proceso & Primera referencia \\
\hline $\begin{array}{l}\text { Reactor doble para } \\
\text { nitritación y Anammox } \\
\text { (Fux et al., 2001) }\end{array}$ & $\mathrm{NH}_{4}^{+}$ & Nitritación & $\begin{array}{l}\text { SHARON }{ }^{\mathrm{a}, \mathrm{b}}-\text { Anammox } \\
\text { OLAND de dos etapas } \\
\text { Desamonificación de dos etapas }\end{array}$ & $\begin{array}{l}\text { Van Dongen et al. (2001) } \\
\text { Wyffels et al. }(2004) \\
\text { Treta et al. }(2004)\end{array}$ \\
\hline $\begin{array}{l}\text { Monoreactor para } \\
\text { nitritación-Anammox }\end{array}$ & $\mathrm{NH}_{4}^{+}$ & Nitritación & $\begin{array}{l}\text { Desamonificación aerobia } \\
\text { OLAND }^{c} \\
\text { CANON }^{d} \\
\text { Desamonificación aerobia/anóxica } \\
\text { Desamonificación } \\
\text { SNAPe } \\
\text { DEMON } \\
\text { DIB }^{f, g}\end{array}$ & $\begin{array}{l}\text { Hippen et al. (1997) } \\
\text { Kuai and Verstraete (1998) } \\
\text { Third et al. (2001) } \\
\text { Hippen } \text { et al. }(2001) \\
\text { Seyfried } \text { et al. }(2001) \\
\text { Lieu } \text { et al. (2005) } \\
\text { Wett (2006) } \\
\text { Ladiges et al. (2006) }\end{array}$ \\
\hline $\begin{array}{l}\text { Monoreactor para } \\
\text { desnitrificación-Anammox }\end{array}$ & $\mathrm{NO}_{3}^{-}$ & Desnitrificación & $\begin{array}{l}\text { Anammox }^{\mathrm{h}} \\
\text { DEAMOX }^{\mathrm{i}} \\
\text { DENAMMOX }^{\mathrm{j}}\end{array}$ & $\begin{array}{l}\text { Mulder et al. (1995) } \\
\text { Kalyuzhnyi et al. (2006) } \\
\text { Pathak and Kazama (2007) }\end{array}$ \\
\hline
\end{tabular}

\footnotetext{
a Por sus siglas en inglés Sustainable High rate Ammonium Removal Over Nitrate; el nombre se refiere a la nitritación donde la oxidación de nitrito es evitada mediante la selección de un tiempo de residencia y la operación a temperatura elevada.

b En ocasiones la nitrificación-desnitrificación vía nitrito es denominado con este término.

c Por sus siglas en inglés Oxygen-Limited Autotrophic Nitrification Denitrification.

d Por sus siglas en inglés Completely Autotrophic Nitrogen removal Over Nitrate

e Por sus siglas en inglés Single-stage Nitrogen removal using the Anammox and Partial nitritation

f El nombre se refiere al proceso de desamonificación en un SBR con control de $\mathrm{pH}$.

g Por sus siglas en inglés Deammonification in Interval-aerated Biofilm systems.

h Es el sistema donde el Anammox fue encontrado originalmente. El proceso completo fue originalmente nombrado como Anammox.

i Por sus siglas en inglés DEnitrifying AMmonium OXidation; este nombre se refiere a la desnitrificación que utiliza sulfuro como donador de electrones.

j Por sus siglas en inglés Denitrification-Anammox process; este nombre se refiere a la desnitrificación que utiliza materia orgánica como donador de electrones.
} 
serán depredadas por los protozoarios. Además, la carga de $\mathrm{N}$ a la planta de tratamiento decrecerá.
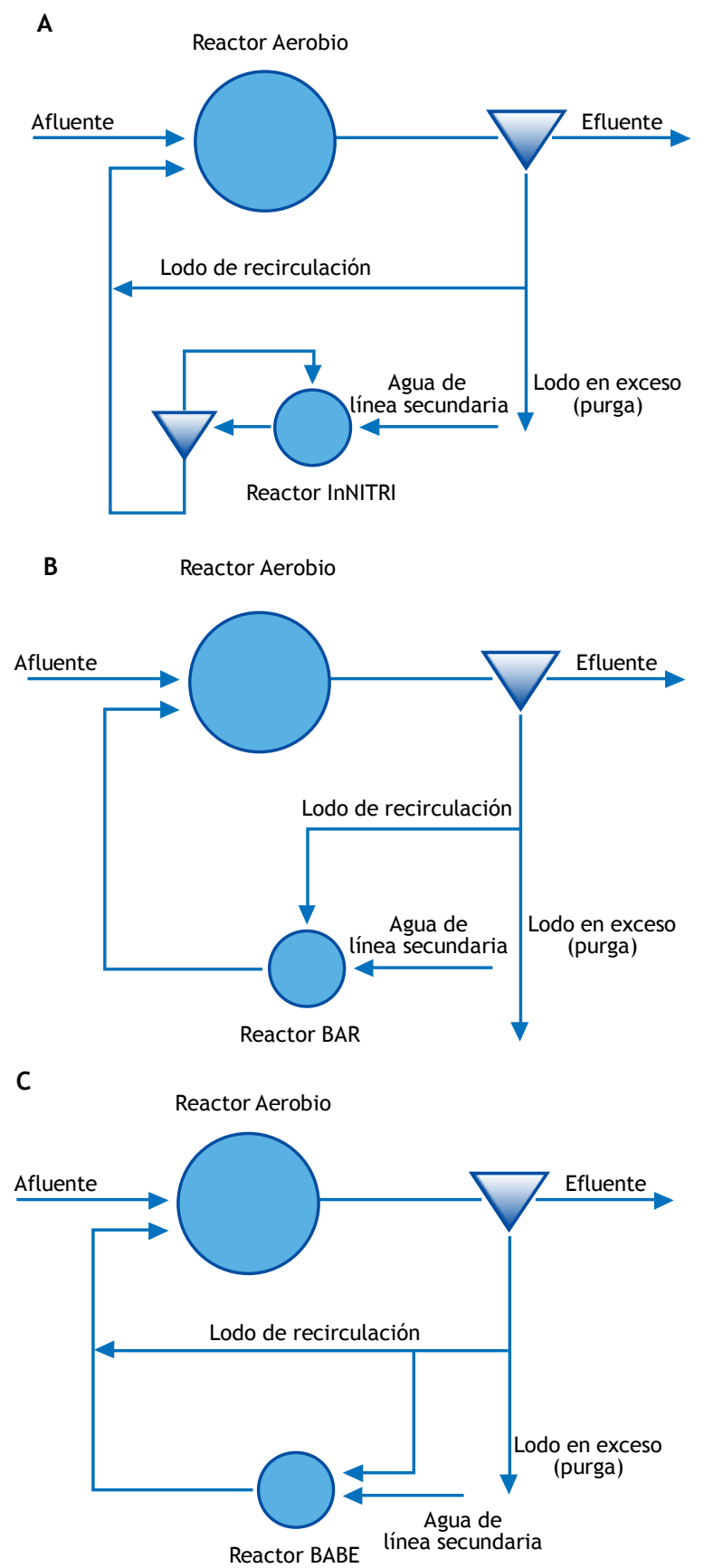

Figura 6.11 Esquemas de diferentes procesos de bioaumentación: (A) InNITRI ${ }^{\oplus}$, (B) BAR ${ }^{\oplus}$, and (C) BABE ${ }^{\oplus}$

Han existido tres diferentes propuestas para integrar un proceso de bio-aumentación. El primero es el proceso InNITRI $^{\circledR}$ (Kos, 1998), en el cual las bacterias nitrificantes son producidas en el efluente del digestor (Figure 6.11A). La formación del flóculo es obtenida mediante la retención de biomasa. Este proceso conlleva el riesgo de que una población microbiana nitrificante producida por bio-aumentación no sea adecuada y que la aplicación de un TRS más alto que el óptimo no sea deseable ya que esto disminuye la producción de lodo/nitrificantes.

Las otras dos opciones de tratamiento usan el lodo de recirculación como inóculo para el proceso. En estos casos no hay necesidad de retener los lodos ya que las bacterias provienen de la línea de lodo sedimentado y recirculado. La desnitrificación se requiere con el fin de mantener un nivel adecuado de $\mathrm{pH}$ en el reactor de la línea secundaria. Aquí la DQO requerida para la desnitrificación puede ser derivada de la DQO del lodo de recirculación. El proceso $\mathrm{BAR}^{\circledR}$ (Bio-aumentación por Regeneración; Novak et al., 2003) es derivado de un proceso donde el lodo de recirculación es aireado para mineralizar el lodo. Mediante la adición del efluente del digestor al reactor, las bacterias nitrificantes se producirán en el reactor $\mathrm{BAR}^{\circledR}$ (Figura 6.11B).

Una desventaja es que el reactor tendrá la misma temperatura baja que el proceso de lodos activados. Por lo tanto, resulta más ventajoso tomar sólo una fracción del lodo de recirculación y mezclarlo con el efluente caliente del digestor en una relación 1:1 (Figura 6.11C). Debido al incremento de temperatura y a la disminución en la carga de lodo, el tanque puede ser más compacto. Esta última tecnología ha sido nombrada proceso $\mathrm{BABE}^{\circledR}$ (Bio-aumentación mejorada en un tanque operado en discontinuo, en inglés Bio Augmentation Batch Enhanced; Zilverentant, 1999) ya que el proceso original es un tipo de reactor que opera cíclicamente.

El proceso $\mathrm{BABE}^{\circledR}$ ha sido desarrollado y diseñado completamente basado en simulaciones de modelos. Esto fue posible ya que el proceso no depende de bacterias desconocidas, pero sí en aquellas que eliminan el nitrógeno de manera convencional. Es por ello que modelos de lodos activados existentes y probados pueden ser aplicados (Salem et al., 2003 a, b). Los diseños basados en modelos se requieren también debido a la complejidad de los procesos y al ahorro en costos. Este proceso tiene muchas variables de diseño que pueden ser optimizadas ya que el reactor de líneas secundarias afecta la nitrificación en el proceso de la línea principal y viceversa. La nitrificación en la línea secundaria tiene que ser evaluada considerando la calidad del efluente en la planta principal. No es posible realizar un sistema adecuado a nivel laboratorio o piloto ya que la relación en volumen del reactor principal y el reactor de la línea secundaria es muy grande. 
El TRS mínimo se determina por la diferencia entre la tasa máxima de crecimiento de las bacterias nitrificantes menos su tasa de decaimiento. En el caso de la bioaumentación, la tasa máxima de crecimiento puede sumarse a la tasa específica de adición (cantidad de bacterias nitrificantes aumentadas por unidad de bacterias nitrificantes por unidad de tiempo). Otro enfoque diferente es considerar que en los procesos $\mathrm{BAR}^{\circledR}$ y $\mathrm{BABE}^{\circledR}$ el lodo en el reactor de la línea secundaria es una parte integral del lodo total; de esta manera el tiempo total efectivo de retención durante la aireación es prolongado. Sin embargo, para la evaluación del TRS mínimo se requiere considerar las diferentes concentraciones de lodo y temperaturas.

Las simulaciones del proceso $\mathrm{BABE}^{\circledR}$ han señalado numerosas características del proceso (Salem 2003 a, b). Una fracción más alta de amonio tratado en el reactor de líneas secundarias permite mejorar la calidad del efluente respecto a concentración de amonio. Este efecto es por supuesto sólo notorio cuando el TRS en el sistema es alrededor o menor que el TRS mínimo. El mayor impacto se observa a 50\% del TRS mínimo para nitrificación en la planta de lodos activados. El efecto de la temperatura en la nitrificación del sistema es menos fuerte e incluso a temperaturas muy bajas la concentración de amonio puede mantenerse baja en el efluente.

De manera global, este proceso tiene un mayor impacto en plantas de tratamiento con altas cargas. La eliminación adicional de amonio en el efluente del tren principal se debe a la eliminación de nitrógeno del efluente del digestor y de la bio-aumentación de bacterias nitrificantes en el reactor aerobio de la línea principal. El efecto de la bio-aumentación contribuye con un 50-70\% de la eliminación de nitrógeno adicional. En los sistemas con bajas cargas los procesos de bio-aumentación permiten un incremento en el espacio de desnitrificación de hasta un $10 \%$ del total del volumen de lodos activados.

Las simulaciones también revelan que no es necesario alcanzar un consumo máximo de $\mathrm{N}$ (mediante una bioaumentación máxima) en el proceso de líneas secundarias. Casi en cualquier caso hay una conversión óptima en el reactor de líneas secundarias arriba del cual el efluente del tratamiento principal no cambia más, mientras que el costo del tratamiento en la línea secundaria sigue incrementando. Además el tiempo de retención de la biomasa en el reactor de la línea secundaria debe optimizarse. Un incremento en el tiempo de retención permite una disminución en el nivel de amonio en el efluente del tren principal. Sin embargo, si la retención en el reactor $\mathrm{BABE}^{\circledR}$ se incrementa por encima de cierto tiempo óptimo, el efluente en la planta principal se deteriorará. Esto se debe al hecho de que al incrementar el tiempo de retención de la biomasa se va a permitir una menor carga de lodos y, por lo tanto, a la producción de lodos. Mientras que esto es generalmente ventajoso para una PTAR normal, no es deseable para un proceso de líneas secundarias, el cual supuestamente debe de producir lodo nitrificante.

Se llevó a cabo una evaluación basada en modelación para optimizar la PTAR Walcheren (140,000 P.E.) en los Países Bajos. Los resultados muestran que el área de los sistemas de tratamiento podrían reducirse hasta en un $50 \%$ si se adoptara la tecnología $\mathrm{BABE}^{\circledR}$ en vez de tecnologías convencionales (que podrían considerar la expansión de los volúmenes aerobios y anóxicos) (Salem et al., 2002). Un análisis de costos muestra que empleando la tecnología $\mathrm{BABE}^{\circledR}$ para el mejoramiento de una PTAR podría ahorrar alrededor de 115,000 euros por año. Existen importantes ahorros en los costos de construcción y algunos en la energía requerida. En este caso se asume que una desnitrificación completa en el reactor $\mathrm{BABE}^{\circledR}$ podría alcanzarse mediante la adición de metanol. Esto provoca costos adicionales debido a la compra de metanol y al lodo adicional generado. Construir un reactor $\mathrm{BABE}^{\circledR}$ ligeramente más grande permite el empleo significativo del sustrato endógeno del lodo de recirculación. Para cada planta el costo total de la optimización va a definir el diseño exacto del sistema.

En la PTAR Garmerwolde en los Países Bajos (300,000 P.E.) se llevó a cabo una evaluación a escala completa de la tecnología $\mathrm{BABE}^{\circledR}$. Este sistema de alta carga fue simulado con tres líneas paralelas: una que recibió la carga de $\mathrm{N}$ normal, una que fue operada sólo con eliminación de $\mathrm{N}$ en el efluente del digestor y otra línea que fue operada con bio-aumentación empleando la tecnología $\mathrm{BABE}{ }^{\circledR}$. El efecto de aumentación del proceso $\mathrm{BABE}^{\circledR}$ mejoró la tasa de nitrificación del lodo en casi $60 \%$ (Salem et al. 2003b), lo cual coincide con las predicciones del modelo. Debido al TRS de la planta, el proceso $\mathrm{BABE}^{\circledR}$ podría, en este caso, ser muy corto como para poder completar la nitrificación en invierno.

Una segunda aplicación a escala completa del proceso se llevó a cabo en la PTAR-Hertogenbosch, nuevamente en los Países Bajos (Figura 6.12). Esta planta fue operada a un TRS que brinda una buena calidad en el efluente en verano, pero no nitrifica en invierno. El agua de retorno del tratamiento de lodo contiene aproximadamente el $15 \%$ de la carga de $\mathrm{N}$ en la planta. El proceso $\mathrm{BABE}^{\circledR}$ 


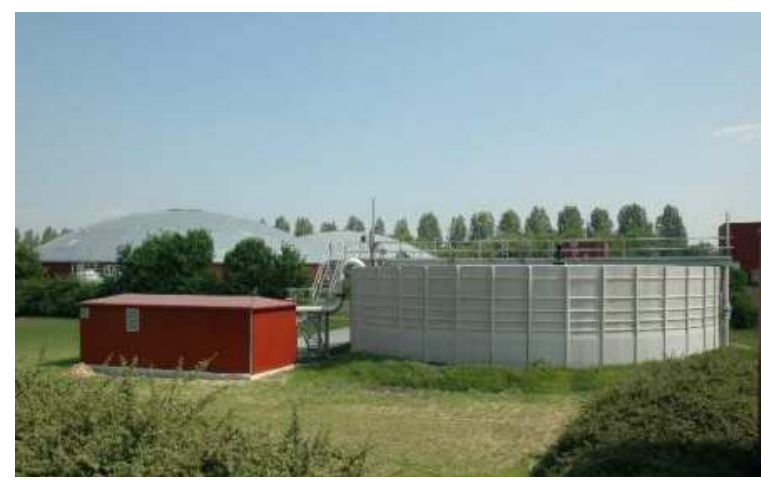

Figura 6.12 Aplicación a escala completa de la tecnología $\mathrm{BABE}^{\oplus}$ : PTAR Hertogenbosch en los Países Bajos (vista frontal: reactor de bio-aumentación; foto: DHV B.V.)

construido ocupó menos del 1\% del volumen total del procesos de lodos activados. Con esta implementación, la nitrificación pudo mantenerse durante los meses de invierno y además, se evitó la extensión del volumen de los reactores de lodos activados.

\subsection{CONCLUSIONES}

El aprovechamiento de las condiciones especiales del agua de lodo (por ejemplo respecto a la temperatura o concentraciones) permite el desarrollo de diferentes procesos, los cuales pueden efectivamente ser usados para mejorar la operación de las plantas de tratamiento. La elección del proceso es en gran parte influenciado por las condiciones locales. El análisis de las condiciones que son diferentes de lo 'normal' permite diseñar procesos innovadores que hacen uso y toman ventaja de estas condiciones particulares. 


\section{REFERENCIAS}

Bock E., Stüven R., Schmidt I., and Zart D. (1995) Nitrogen loss caused by denitrifying Nitrosomonas cells using ammonium or hydroxylamine as electron donors and nitrite as electron acceptor. Arch. Microbiol. 163, 16-20.

Garrido J.M., van Benthum W.A.J., van Loosdrecht M.C.M and Heijnen J.J. (1997) Influence of dissolved oxygen concentration on nitrite accumulation in a biofilm airlift suspension reactor. Biotech. Bioeng. 53, 168-178.

Hao X., Heijnen J.J. and van Loosdrecht M.C.M. (2002) Sensitivity analysis of a biofilm model describing a onestage completely autotrophic nitrogen removal (CANON) process. Biotech. Bioeng. 77(3), 266-277.

Hellinga C., Schellen A.A.J.C., Mulder J.W., van Loosdrecht M.C.M. and Heijnen J.J. (1998) The SHARON process: An innovative method for nitrogen removal from ammonium-rich wastewater. Wat. Sci. Tech. 37(9), 135-142.

Helmer C., Tromm C., Hippen A., Rosenwinkel K.H, Seyfried C.F. and Kunst S. (2001) Single stage biological nitrogen removal by nitritation and anaerobic ammonium oxidation in biofilm systems. Wat. Sci. Tech. 43(1), 311-320.

Hippen A., Rosenwinkel K.-H., Baumgarten G. and Seyfried C. F. (1997) Aerobic deammonification: a new experience in the treatment of wastewater. Wat. Sci. Tech. 35(10), 111-120.

Kos P. (1998) Short SRT (solids retention time) nitrification process/flowsheet. Wat. Sci. Tech. 38(1), 23-29.

Kuai L.P. and Verstraete W. (1998) Ammonium removal by the oxygen-limited autotrophic nitrificationdenitrification system. Appl. Env. Micr. 64, 4500-4506.

Kuenen J.G. (2008) Anammox bacteria: from discovery to application. Nature Reviews Microbiology 6(4), 320326.

Mulder A., Van De Graaf A.A., Robertson L.A., Kuenen J.G. (1995) Anaerobic ammonium oxidation discovered in a denitrifying fluidized bed reactor FEMS Microb. Ecology, 16 (3), 177-184.

Mulder J.W., Van Loosdrecht M.C.M., Hellinga C. and Van Kempen R (2001) Full scale application of the SHARON process for treatment of reject water of digested sludge dewatering. Wat. Sci. Tech. 43(11), 127-134.

Novák L., Wanner J., Kos M. (2003) A method for nitrification capacity improvement in an activated sludge process for biological wastewater treatment. $\mathrm{CZ}$ patent No. 291489

Pynaert K., Smets B. F., Wyffels S., Beheydt D., Siciliano S. D., and Verstraete W. (2003) Characterization of an Autotrophic Nitrogen-Removing Biofilm from a Highly Loaded Lab-Scale Rotating Biological Contactor. Appl. Env. Micr. 69, 3626-3635.

Picioreanu C., van Loosdrecht M.C.M. and Heijnen J.J. (1997) Modelling the effect of oxygen concentration on nitrite accumulation in a biofilm airlift suspension reactor. Wat. Sci. Tech. 36 (1), 147-156.

Salem S., Berends D., van Loosdrecht M.C.M. and Heijnen J.J. (2002). Model-based evaluation of a new upgrading concept for N-removal. Wat. Sci. Tech. 45(6), 169-176.
Salem S., Berends D., van Loosdrecht M.C.M. and Heijnen J.J. (2003a) Bio-augmentation by nitrification with return sludge. Wat. Res. 37(8), 1794-1804.

Salem S., Berends D.H.J.G., van der Roest H.F., van der Kuij R.J., and van Loosdrecht M.C.M (2003b) Full-scale application of the BABE process. Accepted for the IWA Conference on Design, Operation and Economics of Large Wastewater Treatment Plants Praha, September.

Schalk J., De Vries S., Kunen J.G. and Jetten M.S.M. (2000) Involvement of a novel hydroxylamine oxidoreductase in anaerobic ammonia oxidation. Biochemistry 39(18), 5405-5412.

Schemen R., van der Spoel H., Salem S. and van Kempen R. (2003) Unieke combinatie op rwzi Beverwijk. H2O 10,17-19.

Schmidt I., Hermelink C., de Pas-Schoonen K., Strous M., den Camp H.J.O., Kuenen J.G., and Jetten M.S.M. (2002) Anaerobic ammonia oxidation in the presence of nitrogen oxides (NOx) by two different lithotrophs. Appl. Env. Micr. 68(11), 5351-5357.

Siegrist H., Reithaar S., Koch G. and Lais P. (1998). Nitrogen loss in a nitrifying rotating contactor treating ammonia-rich wastewater without organic carbon. Wat. Sci. Tech. 38(8-9), 241-248.

Sliekers A.O., Derwort N., Campos Gomez. J.L., Strous M., Kuenen J.G. and Jetten M.S.M (2002) Completely autotrophic ammonia removal over nitrite in one reactor. Wat. Res. 36, 2475-2482.

Sliekers A.O., Third K.A., Abma W., Kuenen J.G. and Jetten M.S.M. (2003) CANON and Anammox in a gas-lift reactor. Fems Microbiology Letters 218, 339-344.

STOWA (1996) One reactor system for ammonia removal via nitrite, Report no 96-01, Utrecht.

Strous M. (2000) Microbiology of anaerobic ammonium oxidation. PhD thesis, Department of Biotechnology, the Technical university of Delft, The Netherlands.

Third K.A., Sliekers A.O., Kuenen J.G., Jetten M.S.M. (2001) The CANON system (completely autotrophic nitrogen-removal over nitrite) under ammonium limitation: Interaction and competition between three groups of bacteria. System. Appl. Microbio. 24, 588-596

Van Benthum W.A.J., Derissen B.P., Van Loosdrecht M.C.M. and Heijnen J.J. (1998) Nitrogen removal using nitrifying biofilm growth and denitrifying suspended growth in a biofilm airlift suspension reactor coupled to a chemostat. Wat. Res. 32, 2009-2018.

Van de Graaf A.A., Mulder A., de Bruijn P., Jetten M.S.M, Robertson L.A. and Kuenen J.G. (1996) Autotrophic growth of anaerobic ammonium oxidizing microorganisms in a fluidised bed reactor. Microbiology 142, 2187-2196.

Van der Star W.R.L., Abma W.R., Blommers D., Mulder J.W., Tokutomi T., Strous M., Picioreanu C., van Loosdrecht M.C.M. (2007) Startup of reactors for anoxic ammonium oxidation: Experiences from the first full-scale Anammox reactor in Rotterdam. Wat. Res. 41, 4149-4163. 
Van Dongen L.G.J.M., Jetten M.S.M. and van Loosdrecht M.C.M (2001) The combined SHARON/Anammox process: A sustainable method for $N$-removal from sludge water. STOWA, Utrecht.

Wett B. (2006) Solved upscaling problems for implementing deammonification reject water. Wat. Sci. Techn., 53(12), 121-128.
Zilverentant A. (1999) Process for the treatment of wastewater containing specific components e.g. ammonia. Patent PCT/NL99/00462,WO0005177.

\section{NOMENCLATURA}

\begin{tabular}{|c|c|}
\hline Abreviatura & Descripción \\
\hline SHARON & $\begin{array}{l}\text { Monoreactor para eliminación de amonio a alta tasa vía nitrito } \\
\text { (Single high activity ammonium removal over nitrate, en inglés) }\end{array}$ \\
\hline OLAND & $\begin{array}{l}\text { Nitrificación-desnitrificación autótrofa bajo condiciones limitadas de oxígeno } \\
\text { (Oxygen-limited autotrophic nitrification denitrification, en inglés) }\end{array}$ \\
\hline CANON & $\begin{array}{l}\text { Eliminación completa autótrofa de nitrógeno vía nitrato } \\
\text { (Completely autotrophic nitrogen removal over nitrate, en inglés) }\end{array}$ \\
\hline SNAP & Single-stage nitrogen removal using the Anammox and partial nitritation \\
\hline DIB & $\begin{array}{l}\text { Desmonificación en sistemas de biopelícula con inervalos aierados } \\
\text { (Deammonification in interval-aerated biofilm systems, en inglés) }\end{array}$ \\
\hline DEAMOX & $\begin{array}{l}\text { Oxidación de amonio desnitrificante } \\
\text { (Denitrifying ammonium oxidation, en inglés) }\end{array}$ \\
\hline DEA & $\begin{array}{l}\text { Proceso de Desnitrificación-Anammox } \\
\text { (Denitrification-Anammox process, en inglés) }\end{array}$ \\
\hline DEMON & Sistema de desmonificación \\
\hline BABE & Bio-aumentación mejorada en un tanque operado en modo discontinuo \\
\hline BAR & Bio-aumentación por regeneración \\
\hline TRH & Tiempo de residencia hidráulico \\
\hline TRS & Tiempo de residencia de sólidos \\
\hline PTAR & $\begin{array}{l}\text { Planta de tratamiento de aguas residuales (también conocidas como Plantas de tratamiento de riles o } \\
\text { Estaciones depuradoras de aguas residuales) }\end{array}$ \\
\hline
\end{tabular}









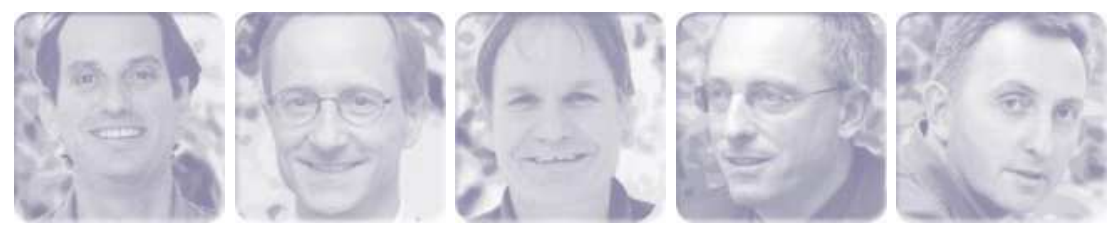

\title{
Remoción Biológica Aumentada de Fósforo
}

\author{
Mark C. Wentzel, Yves Comeau, George A. Ekama, \\ Mark C.M. van Loosdrecht y Damir Brdjanovic
}

El fósforo $(\mathrm{P})$ es el elemento clave a remover en las aguas residuales con el fin de limitar el crecimiento de plantas acuáticas y algas, controlando así la eutrofización. A diferencia del nitrógeno, el cual puede ser fijado de la atmósfera, la cual tiene un contenido de nitrógeno gas cercano al $80 \%$, el fósforo sólo proviene de lo que se vierte a los sistemas acuáticos (despreciando el aporte debido a la deposición atmosférica de P). Fuentes difusas de $\mathrm{P}$ como las que provienen de campos agrícolas son controladas de mejor manera mediante planes adecuados de fertilización, mientras que las fuentes puntuales de $\mathrm{P}$ como las que provienen de plantas de tratamiento de aguas residuales (PTAR) pueden ser removidas mediante procesos químicos o biológicos. Se están aplicando regulaciones más estrictas para remover $\mathrm{P}$ de aguas residuales con el fin de beneficiar al ambiente.

La remoción biológica aumentada de fósforo (EBPR, por sus siglas en inglés Enhanced Biological Phosphorus Removal) fue observada por primera vez a finales de los 50's. Durante las siguientes cinco décadas la comprensión, conceptualización y aplicación de esta tecnología ha evolucionado de observaciones incidentales iniciales a descripciones bioquímicas y matemáticas bien estructuradas, los cuales son aplicados en el diseño y control de plantas a escala completa. Estos desarrollos no provienen de un interés puramente científico sino casi enteramente del reconocimiento del rol pivotal que el $\mathrm{P}$ tiene en la eutrofización de ambientes acuáticos. Un reconocimiento que aunque lento fue iniciado en los 60s después de un incremento masivo de descargas de $\mathrm{P}$ en ambientes acuáticos dado desde 1950, lo cual impulsó la urgente necesidad de desarrollar medidas que limitaran eficientemente la descarga de P. Una de estas medidas fueron los sistemas EBPR.

El término remoción biológica aumentada de fósforo (EBPR) es usado en este capítulo para describir lo que es referido en la literatura como eliminación biológica de fósforo aumentada, remoción biológica de fósforo en exceso (BEPR, por sus siglas en inglés biological excess phosphorus removal) o a veces simplemente como

(ㄷ 2017 Mark C. Wentzel. Tratamiento Biológico de Aguas Residuales: Principios, Modelación y Diseño. Eds. M. Henze, M.C.M. van Loosdrecht, G.A. Ekama y D. Brdjanovic. Eds. (versión en español) C.M. López Vázquez, G. Buitrón Méndez, H.A. García, F.J. Cervantes Carrillo. ISBN (versión impresa): 9781780409139, ISBN (e-Book): 9781780409146. Publicado por IWA Publishing, London, UK. 
remoción biológica de fósforo (BPR, por sus siglas en inglés biological phosphorus removal), donde una biomasa tratadora de agua residual remueve fósforo por encima de los requerimientos anabólicos debido a la acumulación intracelular de reservas de polifosfato (poliP). Adicionalmente a la remoción de $\mathrm{P}$ debida a la síntesis celular, se puede llevar a cabo una precipitación química ya sea con químicos presentes en el agua residual o por adición en el sistema de tratamiento.

Una concentración baja del P total en el efluente puede ser alcanzada mediante la combinación de varios procesos como está indicado en la Tabla 7.1. Por ejemplo, para alcanzar $0.5 \mathrm{mgP} / \mathrm{l}$ en el efluente se puede emplear un sistema EBPR con filtración de arena, que puede ser precedido o no de una coagulación química (combinación E y D respectivamente). Además, la remoción biológica de fósforo combinada con una adición limitada de químicos puede alcanzar valores en el efluente por debajo de $0.1 \mathrm{mgP} / \mathrm{l}$, empleando coagulación y filtración principalmente con el fin de remover fosfato adherido a los sólidos suspendidos en el efluente.

En este capítulo el objetivo es presentar los mecanismos, entender el desarrollo práctico y establecer los lineamientos para el diseño de los sistemas EBPR. Con el fin de facilitar el desarrollo de los criterios de diseño en este libro, los conceptos presentados son aplicados a la fracción aerobia de los organismos acumuladores de fósforo (PAOs, por sus siglas en inglés Phosphorus accumulating organisms), los cuales sólo pueden usar oxígeno como aceptor de electrones para la producción de energía. Considerando que algunas PAOs desnitrificadores (DPAOs) existen y pueden tener un impacto significativo en el desempeño del proceso, su influencia es debidamente discutida más adelante.
Los sistemas con EBPR han generado gran interés considerando los beneficios potenciales de la remoción biólogica de fósforo, nitrógeno y materia orgánica en comparación con la remoción química. Por esta razón, se ha profundizado en el estudio de los mecanismos bioquímicos, la microbiología de los sistemas, la ingeniería de procesos, la optimización de PTARs y su modelación matemática. Como resultado, a lo largo de los años se han publicado de manera regular diversas revisiones sobre el desarrollo de sistemas EBPR (Marais et al., 1983; Arvin, 1985; Wentzel et al., 1991; Jenkins and Tandoi, 1991; van Loosdrecht et al., 1997; Mino et al., 1998; Blackall et al., 2002; Seviour et al., 2003; Oehmen et al., 2007).

\subsection{PRINCIPIOS DE LA REMOCIÓN BIOLÓGICA AUMENTADA DE FÓSFORO (EBPR)}

La remoción biológica aumentada de fósforo (EBPR) es la asimilación y remoción biológica de P por medio del uso de sistemas de lodos activados; sin embargo en los sistemas EBPR se remueve más fósforo de lo que sería removido por un sistema de lodos activados "normal" completamente aerobio. Lo anterior se debe a un requerimiento excedente al $\mathrm{P}$ "normal" para el crecimiento de lodos activados.

En un sistema completamente aerobio de lodos activados, la cantidad de P típicamente incorporado en la masa de lodos es cercana a $0.02 \mathrm{mgP} / \mathrm{mgSSV}(0.015$ $\mathrm{mgP} / \mathrm{mgSST}$ ). Por medio de una purga diaria de exceso de lodo, el fósforo es efectivamente removido (Figura 7.1). Esto puede dar una remoción de P de cerca del 15$25 \%$ del fósforo en muchas aguas residuales municipales.

Tabla 7.1 Combinaciones de procesos requeridos para obtener determinadas concentraciones de fósforo total en el efluente en descargas municipales (adaptado de Barnard and Steichen, 2007)

\begin{tabular}{|c|c|c|c|c|c|c|c|c|}
\hline \multirow[t]{2}{*}{ Proceso de tratamiento requerido } & \multicolumn{8}{|c|}{ Límite de $\mathrm{P}$ a alcanzar $(\mathrm{mgP} / \mathrm{l})$} \\
\hline & & $<1$ & & & & $<0.1$ & $<0.05$ & $<0.01$ \\
\hline Combinación & A & $\mathrm{B}$ & $\mathrm{C}$ & $\mathrm{D}$ & $\mathrm{E}$ & $\mathrm{F}$ & G & $\mathrm{H}$ \\
\hline Coagulación química & $\bullet$ & & $\bullet$ & & $\bullet$ & $\bullet$ & & \\
\hline EBPR (con clarificación final eficiente) & & $\bullet$ & $\bullet$ & $\bullet$ & $\bullet$ & $\bullet$ & $\bullet$ & $\bullet$ \\
\hline Post-coagulación & & & & & & & $\bullet$ & - \\
\hline Filtración de arena & & & & $\bullet$ & $\bullet$ & - & • & \\
\hline Adsorción & & & & & & & & $\bullet$ \\
\hline Filtración por membrana & & & & & & & & - \\
\hline
\end{tabular}






Figura 7.1 Observaciones del comportamiento de PAOs en un sistema EBPR (adaptado del Metcalf and Eddy, 2003)

En un sistema con EBPR, la cantidad de $P$ incorporado a la masa de lodos es incrementada del valor normal de $0.02 \mathrm{mgP} / \mathrm{mgSSV}$ a valores cercanos a 0.06-0.15 mgP/mgSSV (0.05-0.10 mgP/mgSST). Esto es alcanzado gracias a un sistema diseñado como tal o con modificaciones operacionales que lo estimulan, propiciando el crecimiento no sólo de organismos heterotróficos "ordinarios" presentes en los lodos activados, sino de organismos que pueden asimilar cantidades elevadas de $\mathrm{P}$ y almacenarlos internamente en largas cadenas llamadas polifosfatos (poliP). Genéricamente estos últimos organismos son llamados organismos acumuladores de fósforo (PAOs), en ocasiones también llamados organismos acumuladores de polifosfato. Los PAOs pueden incorporar hasta 0.38 $\mathrm{mgP} / \mathrm{mgSSV}$ (0.17 mgP/mgSST). En sistemas de remoción biológica de $\mathrm{P}$ tanto los PAOs como los organismos heterótrofos "ordinarios" (OHOs, por sus siglas en inglés ordinary heterotrophic organisms, los cuales no remueven $\mathrm{P}$ en exceso) coexisten. Entre más grande sea la proporción de PAOs que pueden ser estimulados para crecer en el sistema, mayor será el porcentaje de fósforo contenido en los lodos activados y en consecuencia mayor será el $\mathrm{P}$ que puede ser removido del afluente.

Por lo tanto, el reto en el diseño es incrementar la cantidad relativa de PAOs en comparación con los OHOs presentes en el lodo activado, ya que esto incrementará la capacidad de acumulación de $\mathrm{P}$ y por lo tanto la eficiencia de la remoción de fósforo. La relativa proporción de los dos grupos de organismos depende en gran medida de la fracción de DQO biodegradable del agua residual afluente que cada organismo asimila. Entre más elevada sea la proporción de DQO biodegradable en el afluente que los PAOs obtienen, mayor será la fracción de PAOs en el licor mezclado, mayor será el contenido de $\mathrm{P}$ en los lodos activados y también mayor será la eficiencia del sistema EBPR. Esto se muestra gráficamente en la Figura 7.2 .

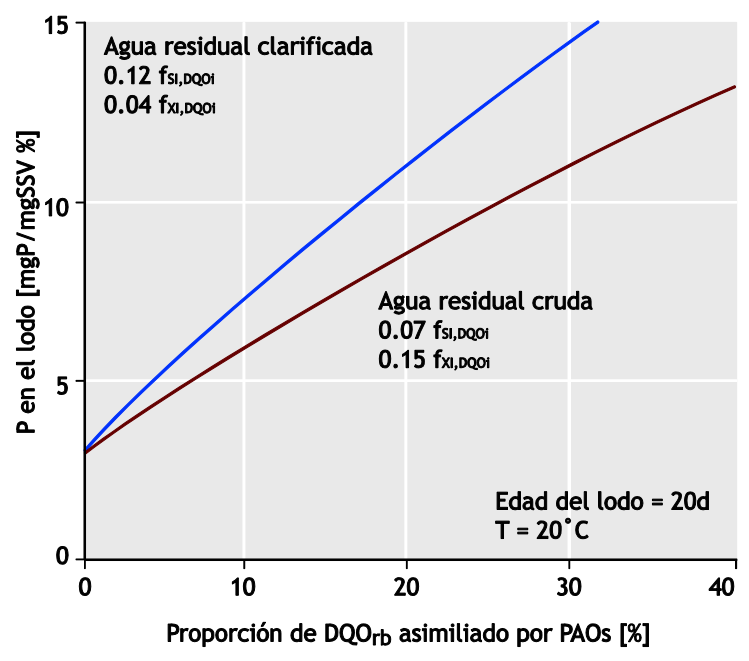

Figura 7.2 Porcentaje de P en SSV contra la proporción de DQO biodegradable (como \%) obtenido en PAOs.

Los procedimientos de diseño y operación son orientados hacia la maximización del crecimiento de PAOs. En un diseño apropiado de un sistema con EBPR, los PAOs pueden representar cerca del $40 \%$ de los organismos activos presentes ( $15 \%$ de los SSV u $11 \%$ de SST), y este sistema puede remover usualmente cerca de $10-12 \mathrm{mgP} / \mathrm{l}$ por cada $500 \mathrm{mgDQO} / \mathrm{l}$ afluente. Desde las primeras publicaciones reportadas de remoción mejorada de $\mathrm{P}$ en algunos sistemas de lodos activados, ha existido cierta controversia acerca de si el mecanismo es una precipitación de componentes inorgánicos aunque quizá mediado biológicamente, o se trata de una formación biológica y la acumulación de componentes de $\mathrm{P}$ en los organismos. El objetivo de este capítulo no es la discusión de la evidencia que soporta la naturaleza biológica de la remoción mejorada de $\mathrm{P}$, pero sí describir brevemente la teoría de la remoción biológica de $\mathrm{P}$ como es entendida por los autores y demostrar cómo esta teoría puede ser usada como un instrumento para diseñar la remoción biológica de $\mathrm{P}$ en sistemas de lodos activados.

Lo anterior no considera la precipitación de $\mathrm{P}$ debido a fenómenos químicos resultado de la acción biológica, ya que cambios en la alcalinidad y $\mathrm{pH}$ por ejemplo no están contemplados. Aunque ciertamente una precipitación inorgánica puede tener lugar, la remoción aumentada de $\mathrm{P}$ es principalmente entendida como un mecanismo biológico en los tratamientos para aguas municipales (diseñadas apropiadamente) con rangos normales de $\mathrm{pH}$, alcalinidad y concentraciones de calcio en el afluente. 


\section{$7 \cdot 3$}

MECANISMO DE LOS SISTEMAS DE EBPR

\subsubsection{Antecedentes}

Históricamente, diversos grupos de investigación han realizado importantes contribuciones para elucidar los mecanismos de los sistemas con EBPR, como Fuhs and Chen (1975), Nicholls y Osborn (1979), Rensink (1981), Marais et al. (1983), Comeau et al. (1986), Wentzel et al. (1986, 1991), van Loosdrecht et al. (1997), Mino et al. (1987, 1994, 1998), Kuba et al. (1993), Smolders et al. (1994a,b, 1995), Maurer et al. (1997), Seviour et al. (2003), Martin et al. (2006) y Oehmen et al. (2007). En esta sección se presenta una explicación de los conceptos básicos resaltando los modelos fundamentalistas más sofisticados para la remoción biológica de P. Una descripción más detallada de los mecanismos se puede encontrar en las referencias antes listadas.

\subsubsection{Microorganismos para la remoción biológica de $\mathrm{P}$}

El requerimiento básico de los sistemas EBPR es la presencia de organismos que puedan acumular una cantidad de $\mathrm{P}$ mayor a la requerida para los procesos metabólicos normales. Estos organismos estarán presentes en los sistemas de lodos activados y acumularán $\mathrm{P}$ en forma de polifosfato (poliP), almacenándolo en los llamados gránulos de volutina. En este capítulo todos los organismos acumuladores de poliP que presentan el comportamiento clásico observado en sistemas EBPR (es decir, presentan una liberación anaerobia de $\mathrm{P}$, asimilación aerobia de $\mathrm{P}$ y procesos asociados) son "agrupados" genéricamente como PAOs.

Los polifosfatos pueden ser acumulados por un amplio grupo de bacterias. En general pueden acumularlo como reserva de fosfato en relativamente pequeñas cantidades. Pero sólo pocos tipos de bacterias parecen ser capaces de tomar la energía almacenada como polifosfatos con el fin de asimilar los ácidos grasos volátiles (AGVs) y secuestrarlos como poli- $\beta$ hidroxialcanoatos (PHAs, por sus siglas en inglés poly- $\beta$ hydroxyalkanoates) en condiciones anaerobias (ausencia de un aceptor externo de electrones como oxígeno y nitrato).

En la investigación original de la microbiología de los sistemas con EBPR realizada con cultivos, se asumió erróneamente que los PAOs pertenecían a los géneros Acinetobacter (Fuhs and Chen, 1975; Buchan, 1983; Wentzel et al., 1986), Microlunatus phosphovorus (Nakamura et al., 1995), Lampropedia (Stante et al., 1997) o Tetrasphaera (Maszenan et al., 2000).
Recientemente, estudios en cultivos independientes han demostrado que Accumulibacter phosphatis, un miembro del género Rhodocyclus (un beta proteobacterium), es un PAO que puede crecer en cultivos enriquecidos hasta de un $90 \%$ de pureza (de acuerdo con las pruebas de hibridación fluorescente in situ o pruebas moleculares FISH) pero todavía no en cultivos axénicos o puros (Wagner et al., 1994; Hesselmann et al., 1999, Crocetti et al., 2000; Martin et al., 2006; Oehmen et al., 2007).

No obstante, la identificación del número exacto de organismos responsables en los sistemas con EBPR es de menor importancia, ya que aunque esto puede proveer información que ayude a detallar los modelos y procedimientos de diseño, éstas últmos no están basados en el comportamiento de organismos específicos sino en el desempeño observado de grupos de organismos identificados por su función, en este caso como PAOs.

\subsubsection{Prerequisitos}

Como fue mencionado anteriormente, para remover $\mathrm{P}$ en sistemas de lodos activados el crecimiento de organismos PAOs debe ser estimulado. Dos condiciones son esenciales para lograr esto: (i) una secuencia de reactores/condiciones anaerobio y después aerobio (o anóxico), y (ii) la adición o formación de AGVs en el reactor anaerobio.

\subsubsection{Observaciones}

Una vez cumplidos los prerequisitos para los sistemas con EBPR, las siguientes observaciones se han hecho a nivel de laboratorio, escala piloto y escala completa (Figura 7.3).

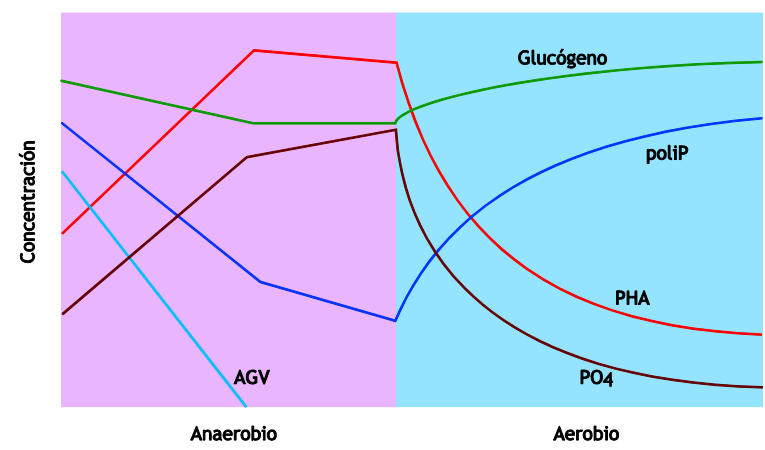

Figura 7.3 Diagrama esquemático que muestra el perfil de cambio en función del tiempo en cuanto a concentraciones de ácidos grasos volátiles (AGVs), fosfato $\left(\mathrm{PO}_{4}\right)$, polifosfato (poliP), poli-ß-hidroxialcanoato (PHA) y glucógeno a través de una secuencia de reactores anaerobio-aerobio en un sistema EBPR 
Bajo condiciones anaerobias los AGVs, el poliP intracelular y el glucógeno disminuyen; mientras que el fosfato soluble, $\mathrm{Mg}^{2+}, \mathrm{K}^{+}$y el PHA intracelular incrementan (Rensink, 1981; Hart and Melmed, 1982; Fukase et al., 1982; Watanabe et al., 1984; Arvin, 1985; Hascoet et al., 1985; Wentzel et al., 1985; Comeau et al., 1986, 1987; Murphy and Lötter, 1986; Gerber et al., 1987; Wentzel et al., 1988a; Satoh et al., 1992; Smolders et al., 1994a; Maurer et al., 1997).

Por otro lado, bajo condiciones aerobias el poliP intracelular y el glucógeno incrementan; mientras que el fosfato soluble, $\mathrm{Mg}^{2+}, \mathrm{K}^{+}$y PHA intracelular disminuyen (Fukase et al., 1984; Arvin, 1985; Hascoet et al., 1985; Comeau et al., 1986; Murphy and Lötter, 1986; Gerber et al., 1987; Wentzel et al., 1988a; Satoh et al., 1992; Smolders et al., 1994b; Maurer et al., 1997).

\subsubsection{Mecanismo de remoción biológica de $\mathrm{P}$}

Los PAOs y los organismos que no son capaces de acumular poliP, conocidos como organismos heterótrofos ordinarios (OHOs) presentan mecanismos bioquímicos muy distintos en el sistema EBPR. En una secuencia de reactores anaerobio/aerobio se considera que los AGVs entran al reactor anaerobio o bien son producidos en el mismo gracias a las bacterias fermentadoras.

\subsubsection{En el reactor anaerobio}

Las reacciones llevadas a cabo por los PAOs bajo condiciones anaerobias son ilustradas en un modelo bioquímico simplificado (Figura 7.4), el cual muestra explícitamente las fuentes de energía y carbono así como la manera en la que se utilizan (Figura 7.5) en un modelo cuantitativo proveniente de un cultivo enriquecido que usa acetato como única fuente de carbono, crecido con un tiempo de residencia de sólidos, o edad de lodos (TRS) de 8 días a $20^{\circ} \mathrm{C}$ (Figura 7.6).

Los OHOs no pueden utilizar AGVs debido a la ausencia de un aceptor de electrones externo que puede ser oxígeno o nitrato. Sin embargo, los PAOs pueden asimilar AGVs del medio y almacenarlos internamente uniéndolos en largas y complejas cadenas de carbono llamada poli- $\beta$-hidroxialcanoatos (PHAs). Los dos tipos de moléculas de PHA son el poli-ß-hidroxibutirato (PHB: 4 compuestos de carbono sintetizados con dos moléculas de acetato) y polihidroxivalerato (PHV: 5-C de Ac + Prop). El poli-ß-hidroximetilbutirato (PH2MB: 5-C from Ac + Prop) y el poli-ß-hidroximetilvalerato (PH2MV: 6-
C de dos Prop) pueden también estar presentes pero en menor cantidad.

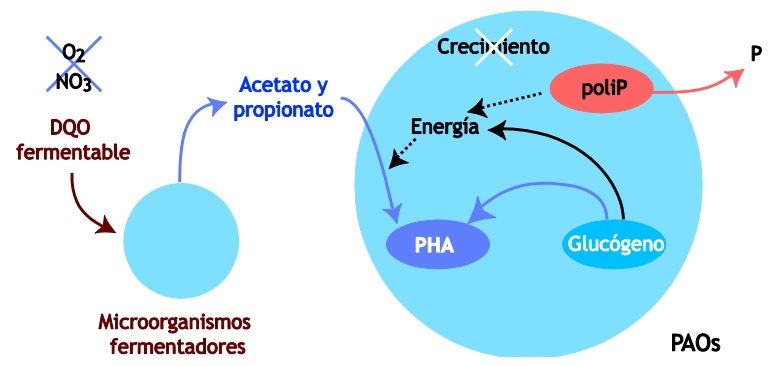

Figura 7.4 Modelo bioquímico simplificado para PAOs bajo condiciones anaerobias. Asimilación anaerobia de ácidos grasos volátiles (AGVs) provenientes del afluente u originados por la fermentación en el reactor anaerobio; almacenamiento de polihidroxialcanoatos (PHAs) asociado a la liberación de $\mathrm{P}$ realizada por PAOs

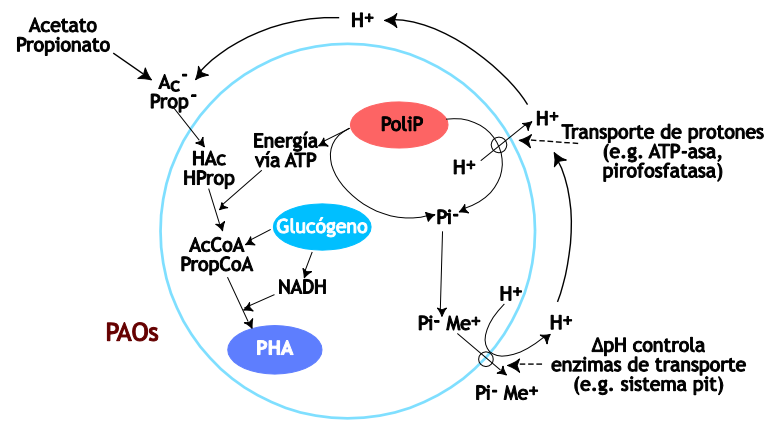

Figura 7.5 Modelo bioquímico para PAOs en condiciones anaerobias. La energía para la formación de ATP proviene principalmente de la degradación de polip mediante la energización de AMP, del transporte de protones por la enzima ATP-asa hasta cierto punto, y también de la degradación de glucógeno. Lo anterior proveé poder reductor en forma de $\mathrm{NADH}$ así como fuente de carbono que es almacenado como PHA. La degradación de polip genera una acumulación transitoria intracelular de fosfato inorgánico $(\mathrm{Pi})$ y metales (Me; por ejemplo magnesio)

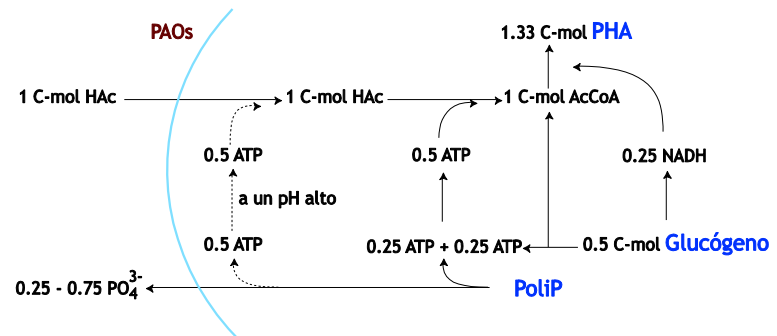

Figura 7.6 Modelo bioquímico cuantitativo para PAOs en condiciones anaerobias (adaptado de Smolders et al., 1994a). Los valores fueron obtenidos de un cultivo enriquecido crecido en acetato como única fuente de carbono a $20^{\circ} \mathrm{C}$ y con 8 días de TRS 
La formación de PHAs a partir de AGVs requiere energía para tres funciones: transporte activo de AGVs a través de la membrana celular, energización de los AGVs con la coenzima A (ej. acetilCoA) y generación de poder de reducción $(\mathrm{NADH})$ para la formación de PHA. La degradación de polifosfato está asociada con la formación de ADP a partir de AMP. Con la acción de la enzima fosfoquinasa, 2 moléculas de ADP son convertidas a ATP y AMP (van Groenestijn et al., 1987). Cuando el ATP es usado, los ortofosfatos son liberados y acumulados en el interior de la célula junto con los contra-iones del polifosfato (potasio y magnesio).

El flujo efluente de estos compuestos suele estar relacionado con el funcionamiento de una bomba de protones, la cual puede ayudar tanto en la asimilación del acetato como en la generación de una pequeña cantidad de ATP extra. Se ha observado (Smolders et al. 1994a) que los requerimientos de energía para la asimilación de acetato incrementa cuando se eleva el $\mathrm{pH}$. Esto puede estar asociado al hecho de que la energía para transportar acetato aumenta con el pH. El ATP es usado en gran parte para la energización del acetato y propionato en acetilCoA y propionil-CoA. La degradación del glucógeno es resultado de la formación de ATP, producción de NADH e intermediarios que son transformados en acetil-CoA (o propionil-CoA). Al final, acetil-CoA y propionil-CoA son almacenados como PHA (Comeau et al., 1986; Wentzel et al., 1986; Mino et al., 1998; Smolders et al., 1994a; Martin et al., 2006; Oehmen et al., 2007; Saunders, 2007).

Por lo tanto, en condiciones anaerobias los PAOs asimilan AGVs para su uso exclusivo, ya que los organismos heterótrofos ordinarios son incapaces de usar esta DQO. Para lograr lo anterior, una parte del poliP se consume y el $\mathrm{P}$ es liberado al medio. Para estabilizar las cargas negativas del poliP, los cationes $\mathrm{Mg}^{2+}, \mathrm{K}^{+} \mathrm{y}$ algunas veces $\mathrm{Ca}^{2+}$ forman complejos con éste. Cuando el poliP es consumido y el $\mathrm{P}$ es liberado, los cationes $\mathrm{Mg}^{2+} \mathrm{y} \mathrm{K}^{+}$principalmente son liberados en una relación de aproximadamente 1:0.33:0.33 de $\mathrm{P}: \mathrm{Mg}^{2+}: \mathrm{K}^{+}$(Comeau et al., 1987; Brdjanovic et al., 1996; Pattarkine and Randall, 1999).

\subsubsection{En el reactor aerobio subsecuente}

En presencia de oxígeno (o de nitrato en condiciones anóxicas) como aceptor de electrones externo, los PAOs utilizan PHA almacenado como fuente de carbono y de energía para su mantenimiento energético y la formación de nuevas células, así como también para la regeneración del glucógeno consumido en la fase anaerobia (Figuras 7.7 y 7.8 ).

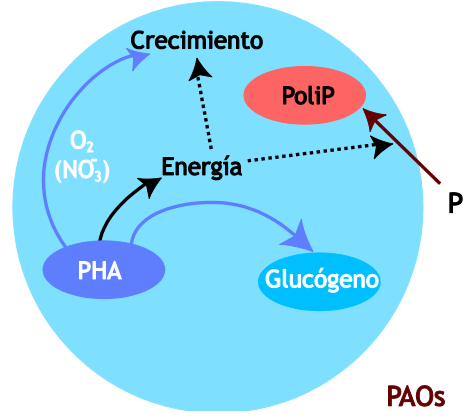

Figura 7.7 Modelo bioquímico simplificado de los PAOs en condiciones aerobias (o anóxicas)

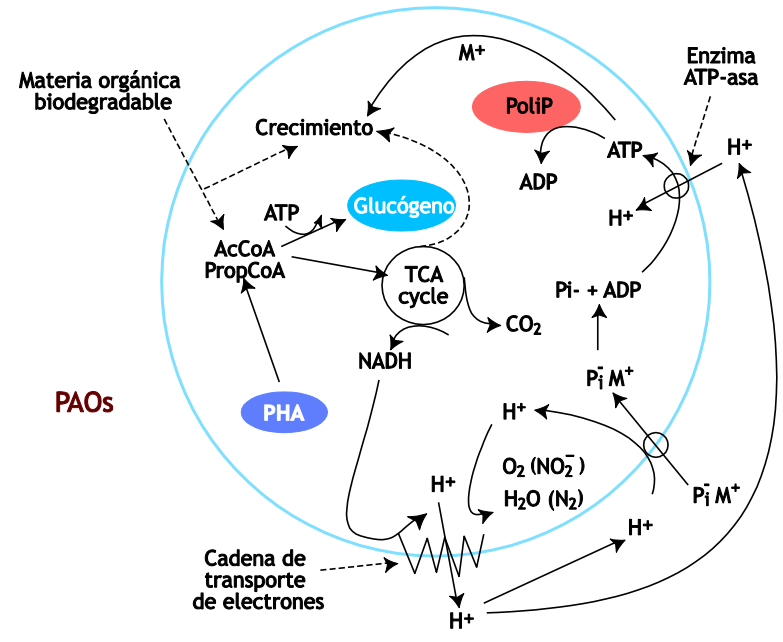

Figura 7.8 Modelo bioquímico para PAOs en condiciones aerobias o anóxicas (adaptado de Comeau et al. 1986). Para fines de diseño se considera que las reservas de PHA almacenadas, vía acetil-CoA y propionil-CoA son la fuente de carbono disponible para el crecimiento de PAOs en el reactor aerobio/anóxico; la materia orgánica biodegradable externa no puede ser usada. El ciclo de Krebs o de los ácidos tricarboxílicos (TCA por sus siglas en inglés Tricarboxylic acid cycle) es usado para producir intermediarios de carbono para crecimiento, generación de energía (ej. ATP) y producción de poder reductor (ej. NADH). El $\mathrm{NADH}$ en presencia de un aceptor de electrones como oxígeno o nitrato es usado después para expulsar protones. A través de la cadena de transporte de electrones, la cual crea una fuerza motriz de protones que transporta fosfato $\left(\mathrm{Pi}^{\mathrm{i}}\right)$ con cationes metálicos $\left(\mathrm{M}^{+}\right)$y síntetiza ATP; este último permite el crecimiento de PAO y almacenamiento de poliP.

El PHA almacenado es también usado como fuente de energía para capturar $\mathrm{P}$ del medio y regenerar el poliP en las nuevas células. Lo anterior permite que el $\mathrm{P}$ capturado sea mayor que el liberado en el reactor anaerobio, dando una remoción neta de $\mathrm{P}$ en la fase 
líquida. Junto a la captura de $\mathrm{P}$, los cationes $\mathrm{Mg}^{2+}$ y $\mathrm{K}^{+}$ también son asimiliados ya que funcionan como contraiones para el polímero de polifosfato cargado negativamente, en una relación molar de aproximadamente 1:0.33:0.33 de $\mathrm{P}: \mathrm{Mg}^{2+}: \mathrm{K}^{+}$.

Los PAOs con poliP almacenado son removidos del sistema en el reactor aerobio (donde la concentración de poliP almacenado internamente en los PAOs es la más elevada a lo largo del sistema) por medio de la purga de lodos en exceso (la purga que proviene de la corriente de lodos de retorno es posible, pero no se deseable para lograr el control hidráulico de la edad de lodos, ver Capítulo 4).

En estado estacionario, la masa de PAOs (con poliP almacenado) purgada diariamente equivale a la masa de los nuevos PAOs generados por día (con poliP almacenado), es decir que para una determinada edad de lodos, carga y operación del sistema, la masa de PAOs en los reactores biológicos permanece constante. En consecuencia, al no existir una acumulación o pérdida de PAOs la relación $\mathrm{P} / \mathrm{SSV}$ permanece prácticamente constante. La masa celular nueva de los PAOs formados depende de la masa de sustrato (PHA) que hayan almacenado estos microorganismos. En consecuencia, la remoción aumentada de $\mathrm{P}$ obtenida dependerá de la masa almacenada de PHA en el reactor anaerobio.

Mediante el control del almacenamiento de PHA en un cultivo enriquecido de PAOs en un reactor discontinuo sequencial anaerobio-anerobio a escala de laboratorio, Brdjanovic, et al., (1998a) explicó dos escenarios comunes en los que se ha observado incrementos en la concentración de $\mathrm{P}$ en el efluente de la PTAR. La primera ocurre regularmente después de los fines de semana, el cual es un fenómeno conocido como 'Monday P-peaks' por su término en inglés; y la segunda ocurre después de eventos de lluvias fuertes. En los dos escenarios anteriores se observa un aumento de $\mathrm{P}$ en el efluente debido al agotamiento del PHA almacenado en las células durante los periodos prolongados de aireación. Considerando este fenómeno de almacenamiento dual, Brdjanovic y colaboradores sugirieron más adelante que el glucógeno no puede reemplazar al PHA en el proceso de asimilación de $\mathrm{P}$ bajo condiciones aerobias, ya que el glucógeno sólo es usado para mantenimiento.

\subsubsection{Modelo cuantitativo anaerobio-aerobio de PAO}

En la Figura 7.9 se muestra un modelo cuantitativo para PAOs en condiciones anaerobias-aerobias, el cual fue planteado tomando como base un cultivo enriquecido de PAOs operado a un TRS de 8 días, pH 7.0 y empleando acetato como única fuente de carbono (Smolders et al., 1994a,b). Bajo condiciones anaerobias, el acetato afluente es asimilado por los PAOs con energía que proviene de la degradación de poliP y glucógeno, lo cual resulta en la formación de PHB (o PHA) y la producción de $\mathrm{CO}_{2}$. Bajo condiciones aerobias, el oxígeno es consumido para sintetizar poliP, glucógeno y biomasa, y para lograr el mantenimiento celular. Estos procesos

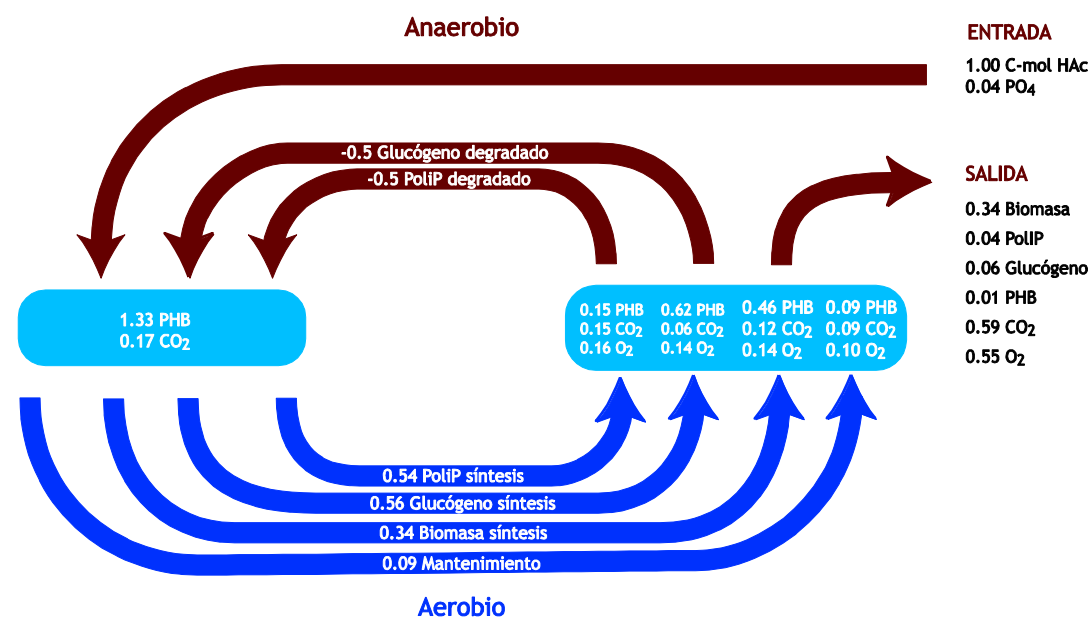

Figura 7.9 Modelo cuantitativo para PAOs en condiciones anaerobio y aerobias (adaptado de Smolders et al., 1994b). Cada C-mol de acetato corresponde a 0.5 moles de acetato. Por lo tanto en el caso del acetato, 1 C-mol corresponde a 32 gDQO. Todas las concentraciones de los compuestos de carbono son expresados en unidades de C-mol. 
aerobios resultan en la formación de poliP y la generación de $\mathrm{CO}_{2}$. Cuando la biomasa se purga para mantener un determinado TRS, finalmente se obtiene que cada C-mol de acetato permite remover 0.04 moles de $\mathrm{P}$ en forma de poliP.

\subsubsection{DQO fermentable y DQO lentamente biodegradable}

Como fue indicado anteriormente, bajo condiciones anaerobias los PAOs pueden almacenar únicamente AGVs ( $\left.\mathrm{S}_{\mathrm{AGV}}\right)$. Sin embargo, en algunas aguas residuales que contienen una baja concentración de $\mathrm{AGVs}$ se puede remover $\mathrm{P}$ de manera significativa, lo cual está relacionado con la presencia de $\mathrm{DQO}$ rápidamente biodegradable $\left(\mathrm{S}_{\mathrm{S}}\right)$ que está compuesto tanto de $\mathrm{S}_{\mathrm{AGV}}$ como de DQO fermentable $\left(\mathrm{S}_{\mathrm{F}}\right)$ (Siebritz et al., 1983; Wentzel et al., 1985; Nicholls et al., 1985; Pitman et al., 1988; Wentzel et al., 1990; Randall et al., 1994). Así, se considera que los $\mathrm{AGVs}$ provenientes del afluente y aquellos fermentados del $S_{F}$ están disponibles para el almacenamiento anaeróbico de PAOs.

Se ha demostrado que aunque la DQO lentamente biodegradable $\left(X_{S}\right)$ puede ser hidrolizada en DQO rápidamente biodegradable $\left(\mathrm{S}_{\mathrm{S}}\right)$ bajo condiciones anaerobias, este proceso no está vinculado con la liberación anaerobia de fosfato. La aclaración anterior es de una importancia crucial ya que influirá en el diseño y operación de sistemas de remoción biológica de nutrientes, en el dimensionamiento y determinación del número de reactores anaerobios necesarios, así como en la decisión de incluir o no un clarificador primario para alcanzar una remoción de $\mathrm{P}$ deseable.

Para fines de diseño, en este capítulo se acepta la evidencia experimental que vincula los sistemas de EBPR con el Ss, y por ende una conversión significativa de $\mathrm{X}_{S}$ a AGVs se considera poco probable. En consecuencia, cuando ocurre una producción de AGVs, ésta será principalmente a partir de la DQO rápidamente biodegradable $\left(\mathrm{S}_{\mathrm{S}}\right)$. Una excepción a esta consideración ocurre cuando existe una fermentación del lodo primario cuyo efluente es alimentado al reactor anaerobio, lo cual favorece la hidrólisis de $\mathrm{X}_{\mathrm{S}}$ en $\mathrm{S}_{\mathrm{S}} \mathrm{y}$ subsecuentemente en AGVs.

\subsubsection{Funciones de la zona anaerobia}

A partir de la descripción de los mecanismos anteriormente mencionados, la zona anaerobia tiene dos funciones cuando el afluente es un agua residual doméstica "normal": (i) Estimular la conversión de DQO fermentable $\left(\mathrm{S}_{\mathrm{F}}\right)$ en AGVs por medio de la fermentación facultativa acidogénica de los organismos heterótrofos.

(ii) Permitir a los PAOs secuestrar los AGVs, asimilándolos y almacenándolos como PHA. En efecto este proceso permite a los PAOs atrapar y almacenar sustrato bajo condiciones en las que no hay un aceptor de electrones externo (condiciones anaerobias) y por lo tanto no son disponibles para los OHOs. De esta manera los PAOs no tienen que competir por el sustrato, lo cual sí ocurriría si estuvieron en condiciones donde hay un aceptor externo de electrones disponible (anóxico/aerobio).

De los dos procesos mencionados, el primero es el más lento y el que determina el tamaño del reactor anaerobio. Pero en caso de que la fermentación del lodo primario se implemente en la planta de tratamiento, el primer proceso no limita el tamaño del reactor anaerobio, por lo que puede reducirse.

\subsubsection{Influencia de la recirculación del oxígeno y el nitrato en el reactor anaerobio}

Tal y como fue observado en numerosas investigaciones (Barnard, 1976; Venter et al., 1978; Rabinowitz and Marais, 1980; Hascoet and Florentz, 1985), la recirculación de oxígeno y/o nitrato al reactor anaerobio causa un detrimento del sistema EBPR ya que los OHOs son capaces de usar la DQO fermentable como fuente de energía y carbono cuando hay un aceptor externo de electrones como el oxígeno y el nitrato.

Por cada $1 \mathrm{mgO}_{2}$ recirculado al reactor anaerobio 3 mgDQO son consumidos, y por cada $1 \mathrm{mgN}$ de nitrato reciclado $8.6 \mathrm{mgDQO}$ son consumidos; asumiendo que la fuente de carbono disponible es DQO fermentable y ésta es consumida por los OHOs. Si se considera un rendimiento neto de $0.67 \mathrm{mgDQO}$ por cada $\mathrm{mgDQO}$ consumido para producción de lodos producido, entonces el restante $0.33 \mathrm{mgDQO}$ sirve para producir energía usando oxígeno, por lo que se obtiene una relación de 3 mg DQO de $\mathrm{S}_{\mathrm{F}}$ por cada $\mathrm{mg} \mathrm{O}_{2}$ consumido. De igual manera, considerando que $1 \mathrm{mg}$ de nitrato es el equivalente a $2.86 \mathrm{mg}$ de oxígeno, se obtiene una relación de $8.6 \mathrm{mg}$ de $\mathrm{DQO}$ consumido por $\mathrm{mg} \mathrm{NO}_{3}-\mathrm{N}$ reducido.

Por lo tanto, cuando hay intrusión de oxígeno y/o nitrato la cantidad de AGVs generada y liberada a la solución es reducida debido a que la DQO rápidamente biodegradable $\left(\mathrm{DQO}_{\mathrm{rb}}\right.$ ) es consumida por OHOs en lugar de ser convertida a AGVs. Así mismo, existe una 
competencia entre PAOs y OHOs por los AGVs restantes; los PAOs los secuestrarán mientras que los OHOs los metabolizarán. En consecuencia, la recirculación de oxígeno y/o nitrato causa un detrimento en la liberación, asimilación y remoción neta de $\mathrm{P}$ debido a que la masa de AGVs disponible para su almacenamiento por PAOs disminuye.

Por lo tanto, prevenir la recirculación de oxígeno y nitrato al reactor anaerobio es una de las estrategias más importantes en el diseño y operación para los sistemas EBPR (Siebritz et al., 1989).

\subsubsection{Desnitrificación realizado por PAOs}

El nivel de desnitrificación acoplado a la remoción de $\mathrm{P}$ realizado por PAOs parece ser muy variable (Ekama and Wentzel, 1999). Se han reportado desde remociones de $\mathrm{P}$ cercanas a cero (Clayton et al., 1989,1991) hasta remociones en condiciones anóxicas que dominan sobre la aerobia (Sorm et al., 1996). La evidencia experimental sugiere que la magnitud de la asimilación anóxica de $\mathrm{P}$ es influenciada por la fracción de masa anóxica y la carga de nitrato al reactor anóxico en relación con su potencial de desnitrificación (Hu et al., 2001, 2002).

La remoción anóxica de $\mathrm{P}$ no parece alcanzar la misma eficiencia que la remoción aerobia de $\mathrm{P}$ (Ekama and Wentzel, 1999) y dicho proceso se encuentra aún bajo investigación. Por ello, desde un punto de vista de diseño, en el cual la maximización de la remoción de $\mathrm{P}$ es una prioridad, en este capítulo no se hace demasiado énfasis en la asimilación anóxica de $\mathrm{P}$ y por consiguiente no está incluida en el diseño. Sin embargo, debe enfatizarse que debido a la acumulación anaerobia de DQO $_{\mathrm{rb}}$ por PAOs, la cinética de desnitrificación cambia cuando un reactor anaerobio está incluido en el sistema.

\subsubsection{Relación entre DQO afluente y lodo}

Las relaciones descritas anteriormente entre la DQO afluente y las diversas masas orgánicas de lodo (activa, endógena e inerte) se muestran en la Figura 7.10.

\subsection{OPTIMIZACIÓN Y DESARROLLO DE SISTEMAS CON EBPR}

En esta sección, primeramente se discuten los conceptos de optimización de EBPR y después se revisa el desarrollo de los principales sistemas de lodos activados con EBPR en un contexto histórico.

\subsubsection{Principios para la optimización de EBPR}

Un panorama general de los principios para optimizar la remoción de fósforo vía biológica y química se presentan en la Figura 7.11. Ciertas configuraciones o procesos basados en estos principios están identificados con nombres específicos y serán descritos abajo. Los principios de optimización de sistemas EBPR pueden ser agrupados en seis categorías:

(i) La intrusión de oxígeno al reactor anaerobio debe ser minimizada. Para este propósito, mezcladores tipo vórtice, cascadas y caídas aguas arriba, bombas tipo tornillo y bombas air-lift deben ser evitados.

(ii) La entrada de nitrato y nitrito al reactor anaerobio debe ser minimizado, para lo cual se desarrollaron diversos procesos. Por ejemplo, la configuración anaerobia-aerobica (ej. A/O) puede ser mejorada insertando un reactor anóxico en el cual el lodo aerobio sea recirculado para desnitrificar (ej. configuraciones $\mathrm{A}^{2} / \mathrm{O}$ y Phoredox modificada). También, la recirculación de lodo activado del clarificador secundario puede ser desnitrificado en un reactor anóxico localizado en la línea secundaria de lodos (ej. configuración JHB) o bien aguas abajo de la zona anaerobia desde donde hay a su vez otra recirculación interna al reactor anaerobio (ej. configuración UCT). Dicho reactor anóxico puede ser dividido en dos, en el primer compartimento se desnitrifica el lodo para ser recirculado al reactor anaerobio y en el segundo compartimento se lleva a cabo la recirculación interna del reactor aerobio para llevar a cabo la desnitrificación del tren de agua (ej. configuración MUCT). La adición de una segunda zona anóxica, aguas abajo del reactor aerobio es otra manera de reducir la concentración de nitrato tanto en el efluente como en el lodo de recirculación (ej. configuración Bardenpho modificado).

(iii) La asimilación de AGVs por los PAOs en el reactor anaerobio debe ser maximizada. La fermentación del lodo primario es una manera eficiente de incrementar el contenido de AGVs en el afluente aunque esto también contribuye a incrementar la carga de materia orgánica y de amonio al sistema de lodos activados. El acetato de sodio o los residuos industriales fermentables pueden ser adicionados directamente al reactor anaerobio. El tiempo de retención hidráulico del reactor anaerobio puede ser incrementado para favorecer la fermentación in situ del afluente o para adicionar materia orgánica fermentable. 


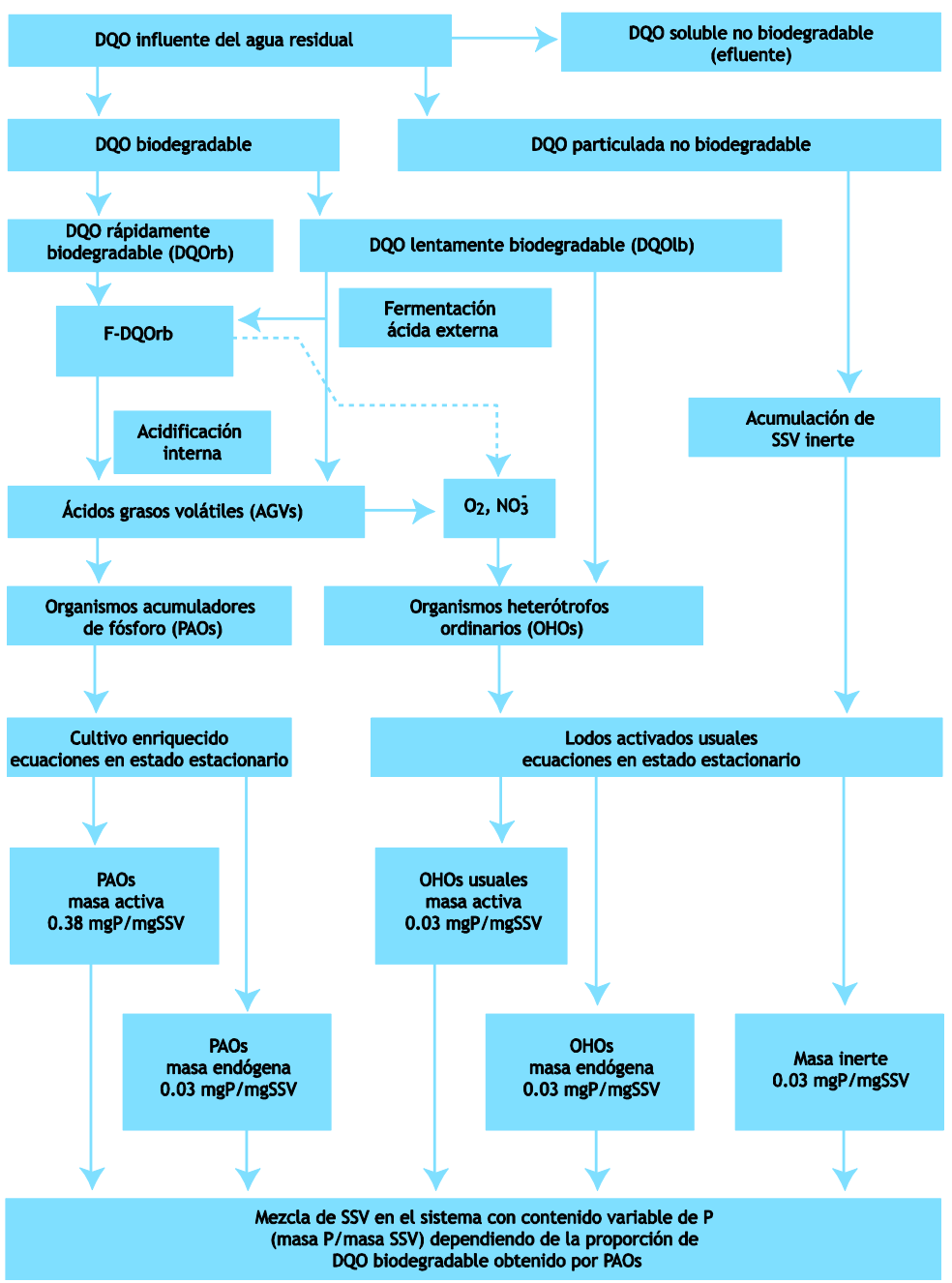

Figura 7.10 Diagrama esquemático que muestra los productos de varias fracciones de la DQO afluente en relación con las masas activa, endógena e inerte en el lodo.

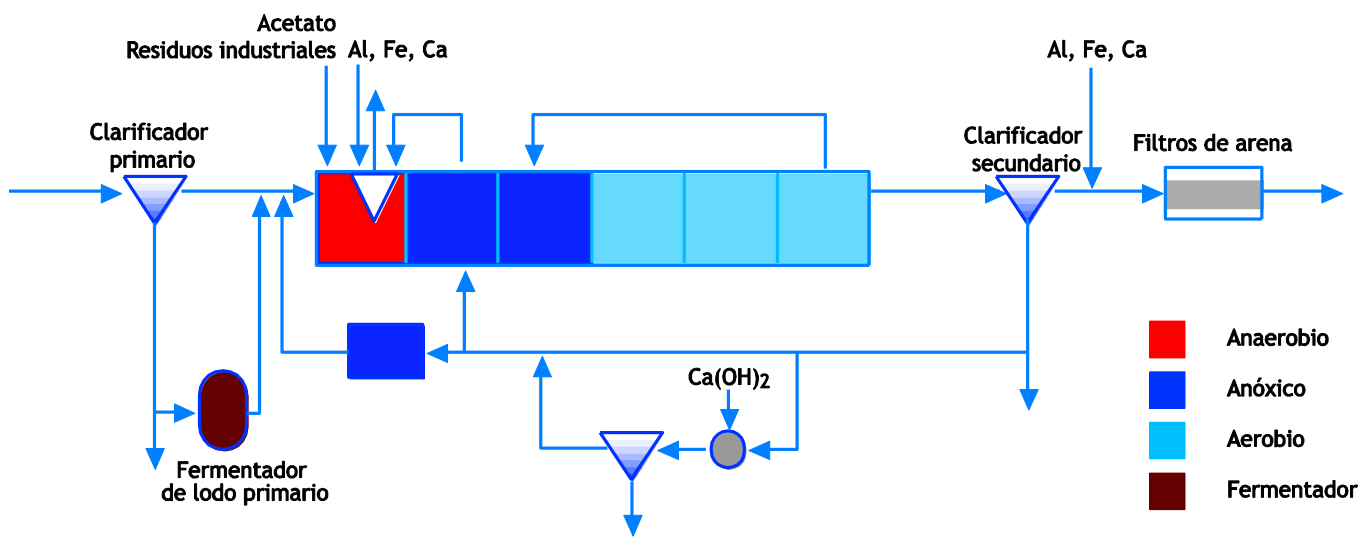

Figura 7.11 Panorama general de la optimización de los procesos de remoción de P y sistemas EBPR 
(iv) El fósforo particulado efluente debe ser minimizado por medio de una remoción eficiente de los sólidos suspendidos totales. El contenido de fósforo particulado puede alcanzar valores tan altos como $18 \%$ de gP/gSST en cultivos enriquecidos. Con un contenido típico del 5\%, cada $10 \mathrm{mgSST} / 1$ en el efluente contribuye a $0.5 \mathrm{mgP} / \mathrm{l}$. Por lo tanto una clarificación secundaria eficiente que evite la flotación de lodo debido a la desnitrificación en sedimentador, filtros de arena o incluso en la ultrafiltración (en un bioreactor de membrana) significa una reducción en la concentración del SST efluente.

(v) El fósforo soluble efluente debe ser minimizado. Además de la optimización del proceso EBPR, se puede adicionar coagulantes químicos como hierro (ej. $\mathrm{FeCl}_{3}$ ), sales de aluminio (ej. alumbre) o calcio (ej. cal) en el tren principal para su pre-, co-, o postprecipitación; ya sea en el clarificador primario, en el proceso de lodos activados o aguas abajo del clarificador secundario respectivamente.

(vi) La extracción del sobrenadante del tanque anaerobio o la remoción de lodo de la línea de recirculación de lodo y su coagulación puede también propiciar una disminución del fósforo soluble efluente (ej. proceso BCFS $^{\circledR}$; van Loosdrecht et al., 1998). También puede realizarse un proceso en la línea secundaria mediante la precipitación con cal del fosfato liberado anaeróbicamente. Una liberación de fosfato más eficiente puede ser alcanzada en el tanque de la línea secundaria mediante la derivación de cierta cantidad de afluente que contenga DQO rápidamente biodegradable (ej. proceso PhoStrip ${ }^{\circledR}$ ). En caso de que una digestión anaerobia o aerobia sea realizada con lodo secundario de purga, prácticamente todo el polifosfato degradará y el fosfato se liberará al medio. Una recuperación de fósforo en forma de estruvita $\left(\mathrm{MgNH}_{4} \mathrm{PO}_{4}\right)$ o hidroxiapatita $\left(\mathrm{Ca}_{10}\left(\mathrm{PO}_{4}\right)_{6}(\mathrm{OH})_{2}\right), \quad$ los cuales pueden ser usados como fertilizadores, es también una manera de reducir la carga de fosfato soluble que regresa al proceso de lodos activados y eventualmente al efluente.

(vii) La asimilación de fósforo por síntesis celular puede ser maximizada. Aunque el tiempo de retención de sólidos (TRS) es un factor más limitado que otros usados para optimizar la eficiencia de un sistema EBPR, el mantener un TRS tan bajo como sea posible ayuda a incrementar la remoción de fósforo por síntesis celular. Otro beneficio de reducir el TRS es que los PAOs degradan en una menor medida sus reservas de poliP para mantenimiento celular.

\subsubsection{Descubrimiento}

La remoción mejorada de $\mathrm{P}$ en los sistemas de lodos activados fue observado por primera vez y de manera independiente por dos grupos de investigación, Srinath et al., (1959) en India y Alarcon (1961) en Estados Unidos de America. Aunque ambos grupos demostraron la remoción de $\mathrm{P}$ en experimentos por lote bajo condiciones aerobias, no se propuso una explicación del por qué los lodos en ciertas plantas mostraban una remoción aumentada de $\mathrm{P}$ y en otras no, o si la remoción era un fenómeno biológico o bien físico/químico.

Srinath et al., (1959) observó que la deficiencia de oxígeno en una zona aguas arriba de un tanque de aireación en flujo pistón estaba asociado con la proliferación de concentraciones altas de fosfato y que este "problema" podía solucionarse incrementando la aireación. Dichas observaciones iniciaron la investigación de sistemas EBPR, que al final culminaron en la implementación a escala completa de la tecnología EBPR. A lo largo de los siguientes 40 años, un número de procesos y configuraciones fueron desarrollados y se presentan a continuación en la Figura 7.12 (A - H).

\subsubsection{Sistema PhoStrip ${ }^{\circledR}$}

La primer investigación estructurada del fenómeno de remoción de P fue realizado por Levin y Shapiro (1965), quienes demostraron la naturaleza biológica de la remoción en sistemas con EBPR mediante estudios extensivos realizados sobre el efecto de la concentración de oxígeno, pH e inhibidores. Más adelante, en experimentos discontinuos de dos muestras de licor mezclado recirculado, una aireada y la otra no, la aireada mostró asimilación de P mientras que en la no aireada se detectó una liberación de P. Shapiro et al. (1967) observó que la liberación de $\mathrm{P}$ en experimentos discontinuos anaerobios los procesos de liberación de $\mathrm{P}$ bajo condiciones anaerobias podrían ser revertidos a un proceso de remoción de $\mathrm{P}$ si el licor mezclado se aireaba nuevamente. Levin (1965) utilizó el fenómeno de liberación de $\mathrm{P}$ bajo condiciones anaerobias y la remoción de $\mathrm{P}$ bajo condiciones aerobias para patentar el primer sistema comercial de remoción de $\mathrm{P}$, el proceso PhoStrip (Figura 7.12G, comercializado por Biospherics, USA). 

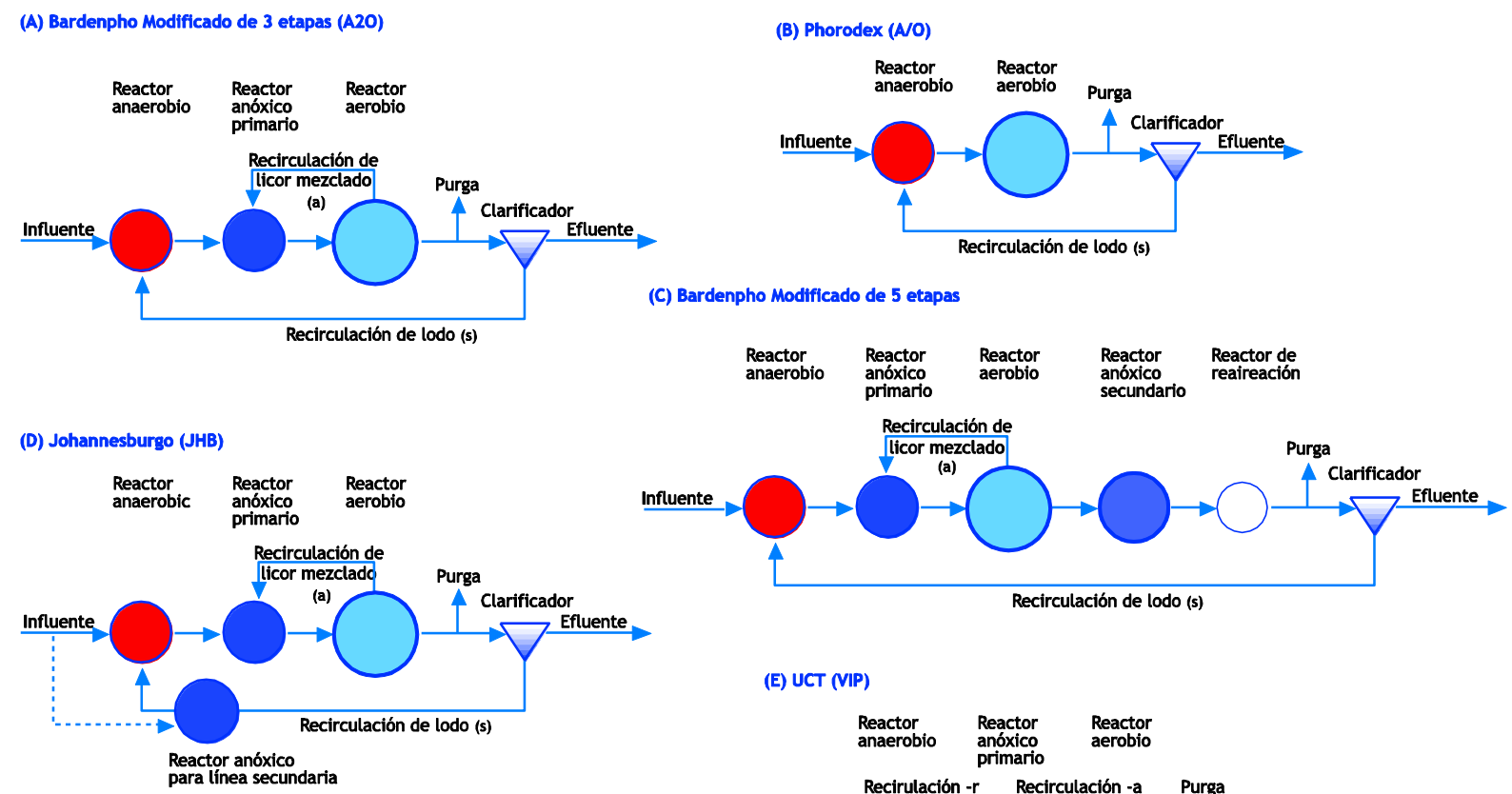

(E) UCT (VIP)

(F) UCT Modificado (MUCT) $\begin{array}{llll}\text { Reactor } & \text { Reactor } & \text { Reactor } & \text { Reactor } \\ \text { anaerobio } & \text { anóxico } & \text { ańxico } & \text { aerobio }\end{array}$
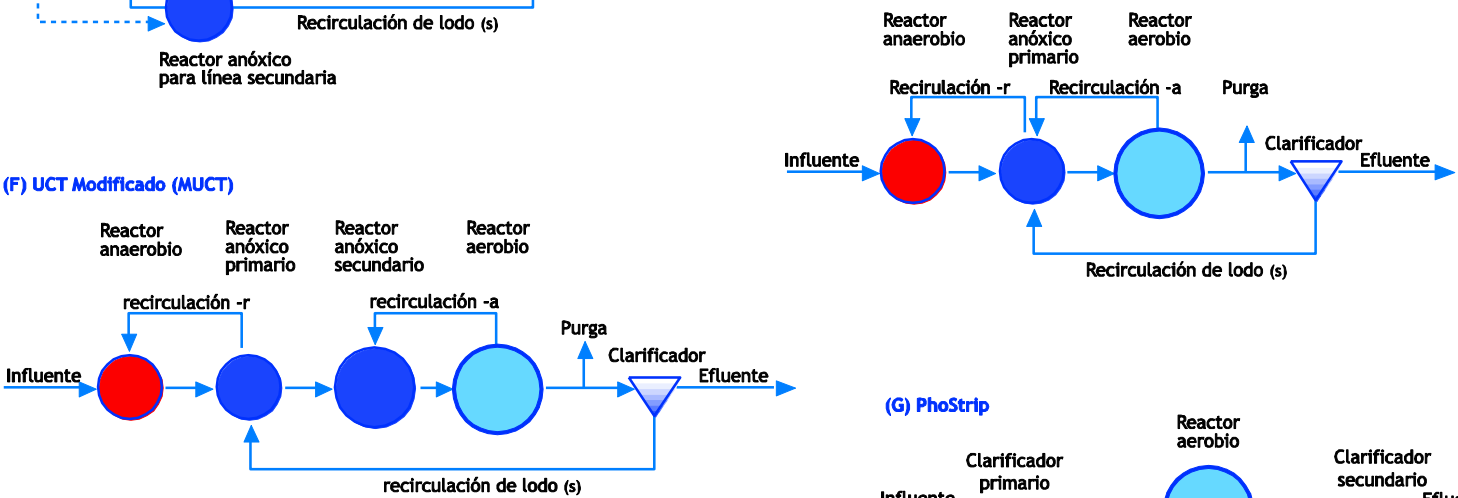

(H) BCFS
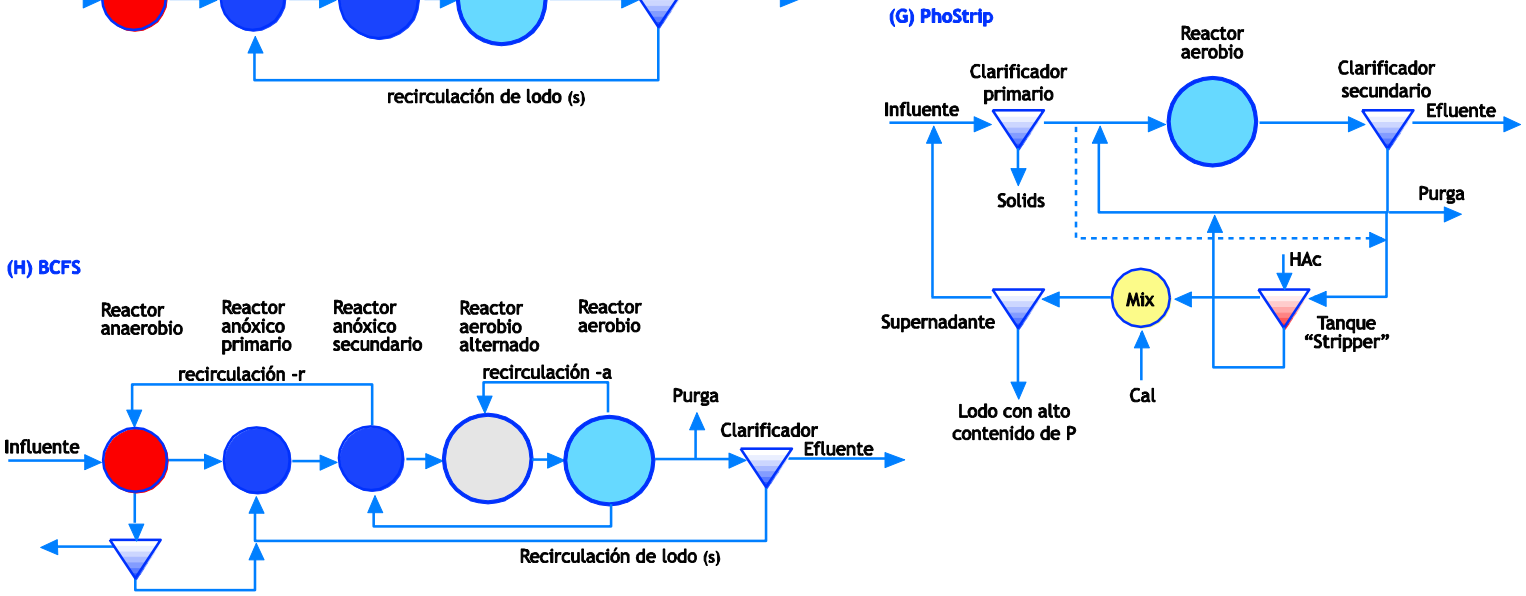

Figura 7.12 Configuraciones para sistemas de EBPR: (A) Bardenpho Modificado de 3 etapas ( $\left.\mathrm{A}^{2} \mathrm{O}\right)$, (B) Phoredox (A/O), (C) Bardenpho Modificado de 5 etapas, (D) Johannesburgo (JHB), (E) UCT (VIP), (F) MUCT (UCT Modificado), (G) PhoStrip, y (H) BCFS

Levin et al. (1972) describió este sistema de la siguiente manera: "El proceso está basado en el descubrimiento de que la aireación del licor mezclado puede inducir a que los microorganismos de los lodos activados asimilen una cantidad mayor de fósforo disuelto del requerido para crecer. Si el suministro de aire cesa y se permite a los organismos del lodo consumir todo el oxígeno disuelto, el fósforo previamente asimilado será liberado a la fase líquida. Sin embargo, cuando la aireación es reactivada, los microorganismos vuelven a tomar fósforo disuelto del medio". El proceso PhoStrip consiste en un tanque de aireación con clarificador, del cual se deriva un proceso en línea secundaria. Parte de de la línea de lodos del clarificador (típicamente 10-30\% del caudal afluente) se conduce a un tanque anaerobio "stripping" donde el lodo sedimenta 
y el P es liberado. El lodo que ha liberado el fósforo es recirculado al tren principal de lodos activados, mientras que al sobrenadante se le realiza una dosificación química (usalmente de cal) en un tanque precipitador con el fin de secuestrar, sedimentar y purgar el P que había sido liberado previamente. El sobrenadante del tanque precipitador es recirculado ya sea al caudal afluente o al efluente de la línea principal.

El proceso PhoStrip combina la remoción química y biológica, se aplica a sistemas que no requieren desnitrificación y es un proceso para la línea secundaria. Modificaciones posteriores del proceso PhoStrip incluyen a) la adición de una parte del caudal afluente al tanque "stripper" para promover la liberación de $\mathrm{P}$ (PhoStrip II; Levin and Della Sala, 1987), b) la remoción del P liberado del lodo mediante la recirculación del sobrenadtante a un tanque liberador de fósforo (Meganck, 1987) y c) la inclusión de un tanque anóxico aguas arriba del tanque de aireación con el fin de recircular el licor mezclado del tanque aerobio al anóxico y aplicar así el principio del proceso PhoStrip en la nitrificación de plantas de tratamiento. Debido a que los sistemas PhoStrip incluyen remoción química de $\mathrm{P}$, el diseño de este sistema no será considerado en este capítulo. En el proceso BCFS, la liberación biológica de P que ocurre en el tanque "stripper" está implícita en el tanque anaerobio del sistema de lodos activados (van Loosdrecht et al., 1998).

\subsubsection{Bardenpho Modificado}

Aunque a principios de los 70s el fenómeno de remoción biológica de $\mathrm{P}$ había sido observado en un número de plantas a escala completa (Vacker et al., 1967; Scalf et al., 1969; Witherow, 1970; Milbury et al., 1971), y el primer sistema EBPR comercial (PhoStrip) había sido desarrollado, existía poca confianza de que los sistemas EBPR fueran tecnologías con aplicación potencial práctica. Mulbarger (1970) fue muy lejos al afirmar que "el diseño de plantas de tratamiento de lodos activados especializadas para un alto nivel de remoción de $\mathrm{P}$ deben ser evitadas y debe considerarse un efecto adicional positivo cuando esto ocurre". Sin embargo, de las investigaciones realizadas a mitad de la década de los 70s (Fuhs and Chen, 1975; Barnard, 1974a,b, 1975a,b, 1976a,b) una conclusión emergió y permitió que los sistemas con EBPR se explotaran ampliamente: la remoción biológica de $\mathrm{P}$ es estimulada cuando los organismos del lodo activado están sujetos a una secuencia de condiciones anaerobias y aerobias. Sin embargo, el diseño y la operación de la fase anaerobia es la que presenta problemas mayores.

En una investigación microbiológica, Fuhs y Chen (1975) concluyeron que los fenómenos ocurridos en los sistemas EBPR son mediados ya sea por un sólo grupo de organismos o por diversos grupos de organismos relacionados estrechamente. Ellos afirmaron que Acinetobacter es el principal género implicado y concluyeron que "las condiciones anaerobias que preceden a las aerobias en tratamiento de aguas residuales podrían estar relacionadas con la existencia de Acinetobacter spp. Durante la anaerobiosis, esta flora podría tender a producir compuestos como etanol, acetato y succinato, los cuales sirven como fuente de carbono para Acinetobacter spp.". Fuhs y Chen no cuantificaron las "condiciones anaerobias" ni desarrollaron métodos prácticos para la implementación de los sistemas con EBPR.

El primer sistema con EBPR en el tren principal fue desarrollado por Barnard (1974a, b, 1975, 1976a, b) y Nicholls (1975). Barnard (1975), mientras investigaba la respuesta de nitrificación/desnitrificación en el sistema Barderpho de 4 etapas que él desarrolló para este propósito, observó que el sistema removió $\mathrm{P}$ en exceso. Barnard (1974) postuló que "el requerimiento esencial para la remoción de fósforo en un sistema biológico es que, durante alguna etapa antes de la etapa final del proceso, el lodo o el licor mezclado pase a través de una etapa anaerobia durante la cual los fosfatos pueden o no ser liberados, seguido por una etapa aireada durante la cual los fosfatos serán removidos por los organismos o serán precipitados como resultados del cambio de potencial redox".

De acuerdo con las observaciones de Barnard (1974), Nicholls (1975) experimentó a escala completa los sistemas de lodos activados de Alexandra y Olifantsvlei (Johannesburg, South Africa). Él instaló zonas anaerobias en diferentes partes de los dos sistemas de lodos activados y concluyó que "una buena remoción de fosfato puede ser esperado de un sistema Bardenpho modificado (es decir un Bardenpho de 4 etapas) cuando un tanque anaerobio es localizado al inicio del sistema de lodos activados".

Barnard (1976), en postulaciones más detalladas que desarrolló en 1974 concluyó que la masa de los organismos "debe pasar a través de una fase anaerobia donde la demanda de oxígeno exceda el suministro tanto de oxígeno o nitrato..." Él propuso la instalación de un 
reactor anaerobio antes de la entrada de la planta para "permitir que el licor mezclado se vuelva anaerobio a través de la acción del agua residual afluente ". Bernard llamó a este principio el método "Phoredox", y lo aplicó al sistema Bardenpho de 4 etapas (entre otros), al cual incluyó un reactor anaerobio antes del reactor anóxico primario. De esta manera el reactor anaerobio recibe el afluente y la línea de recirculación de lodos de los clarificadores secundarios. Esta configuración fue nombrada como Bardenpho Modificado de 5 etapas (Figura 7.12C). Barnard también propuso que cuando la remoción de nitrógeno no es altamente requerida, el segundo reactor anóxico y los reactores de reaireación pueden excluirse, resultando así el sistema Bardenpho Modificado de 3 etapas (Figura 7.12A). Esta configuración también ha sido llamada como sistema anaerobio/anóxico/aerobio $\left(\mathrm{A}^{2} \mathrm{O}\right)^{1}$.

Para explicar el fenómeno de remoción aumentada o mejorada de P, Barnard (1976) hipotetizó que la liberación de $\mathrm{P}$ en sí misma no estimula la remoción de $\mathrm{P}$, sólo indica que se ha alcanzado un potencial redox bajo en el reactor anaerobio, y es éste potencial redox bajo lo que estimula la remoción biológica de P. Barnard (1976) reconoció las dificultades asociadas con la medida del potencial redox, y propuso que la medida de la liberación de $\mathrm{P}$ en la zona anaerobia pueda servir como un sustituto para indicar que las condiciones necesarias para una remoción mejorada de $\mathrm{P}$ prevalecen.

De acuerdo con la hipótesis de Barnard, el nitrato recirculado al reactor anaerobio del sistema Bardenpho Modificado de 5 etapas determina hasta cierto grado el nivel en el cual el potencial redox que puede ser disminuido. En consecuencia, se puede esperar que el nitrato recirculado influencíe adversamente en la remoción mejorada de $\mathrm{P}$, como fue observado previamente por Barnard (1975).

Barnard (1976) aparentemente aceptó que la configuración Bardenpho Modificada debe reducir de manera suficiente el nitrato, de manera que la recirculación de lodos no interfiera en el mantenimiento del potencial redox bajo, necesario para la liberación de $\mathrm{P}$ en el reactor anaerobio. Él consideró que como contrapeso a la intrusión de nitrato se puede incrementar

${ }^{1}$ La nomenclatura original de Barnard para los reactores anaerobio y anóxico fue adoptado en este capítulo. De esta manera, Anóxico: condición en la cual el nitrato está presente pero no el oxígeno, Anaerobio: condición en la cual ni el nitrato ni el oxígeno están presentes. Estas definiciones son inadecuadas aparentemente cuando se intenta comparar las condiciones de dos reactores del mismo tamaño, uno completamente mezclado y otro en flujo pistón. el tiempo de retención en el reactor anaerobio. Para el diseño de dicho reactor, Barnard (1976) sugirió un tiempo de retención nominal de una hora. En esta etapa no existía un método racional disponible para predecir la remoción de fósforo y nitrógeno. En el diseño, las remociones fueron estimadas en gran parte de la experiencia obtenida durante la operación de los experimentos.

El trabajo de Barnard, en el que se desarrolló un sistema que incorporó los requerimientos esenciales para sistemas con EBPR aunque éstos no fueron completamente entendidos, estimularon la investigación extensiva en este fenómeno con el fin de obtener experiencia acerca de su comportamiento, delinear de manera más precisa los factores que influencían en los sistemas con EBPR, y desarrollar criterios para su diseño.

\subsubsection{Sistemas Phoredox o anaerobio/óxico $(\mathrm{A} / \mathrm{O})$}

En el sistema Barderpho Modificado, la configuración desarrollada por Barnard para sistemas con EBPR estuvo fuertemente influenciada por los requerimientos legales para la nitrificación en Sudáfrica. En caso de la que nitrificación no sea requerida, decrece la necesidad de tener zonas anóxicas para desnitrificar y edades de lodo altas para asegurar la nitrificación. Estos aspectos fueron reconocidos por Barnard (1976), quien aplicó el método "Phoredox" para un sistema de lodos activados sin nitrificación. La configuración para este sistema incluye un reactor anaerobio que recibe el afluente y la recirculación de lodos, seguido por un reactor aerobio (Figura 7.12B). La edad de lodos y el tanque aerobio son diseñados y controlados para prevenir la nitrificación, aplicando por ejemplo edades de lodo bajas y cargas altas a la planta. Este sistema ha sido conocido en Sudáfrica como Phoredox.

Timmerman (1979) propuso un sistema anaerobio/óxico (A/O) que es esencialmente lo mismo que el sistema Phoredox. La configuración básica $\mathrm{A} / \mathrm{O}$ es idéntica a la de Phoredox, pero en el A/O se propuso específicamente que las zonas anaerobias y aerobias sean divididas en compartimentos para obtener una

Por ejemplo, un reactor anaerobio completamente mezclado no tendrá nitrato en el reactor; mientras que un reactor de flujo pistón puede contener nitrato en una porción considerable alo largo de la longitud del reactor, y ser entonces parcialmente "anóxico" y parcialmente "anaerobio". Desafortunadamente el concepto de Barnard no indica la intensidad de estas condiciones. 
configuración de reactores en serie que se acerque a condiciones de flujo pistón.

Aunque propuesto conceptualmente en 1976, los requerimientos para la nitrificación en Sudáfrica han prevenido la implementación de los sistemas Phoredox o A/O. El desempeño del sistema bajo las condiciones de Sudáfrica han sido investigados a escala laboratorio por Burke et al. (1986), quien encontró dificultades en prevenir la nitrificación a temperatura de $20^{\circ} \mathrm{C}$ incluso en edades de lodo menores a 3 días con una fracción de masa no aireada del $50 \%$.

El sistema como A/O ha encontrado una aplicación más amplia en EUA y ha sido estudiado por numerosos investigadores obteniendo resultados mixtos (Hong et al., 1983; Kang et al., 1985a, etc.).

\subsubsection{Efecto del nitrato en sistemas EBPR}

Los requerimientos legales para la nitrificación en Sudáfrica centran la atención en sistemas de remoción de nutrientes (por ejemplo nitrógeno y fósforo) más que en remoción de fósforo únicamente. En consecuencia, un esfuerzo considerable en las investigaciones se ha centrado en evaluar el sistema Bardenpho Modificado. Investigaciones recientes de los sistemas Bardenpho Modificados de 3 y 5 etapas (McLaren and Wood, 1976; Nicholls, 1978; Simpkins and McLaren, 1978; Davelaar et al., 1978; and Osborn and Nicholls, 1978) coinciden en el que nitrato recirculado al reactor anaerobio tiene un efecto negativo en la remoción biológica de $\mathrm{P}$, y por lo tanto la medición de nitrato en la recirculación al reactor anaerobio puede ser crucial para determinar el éxito de la liberación y remoción de $\mathrm{P}$ en un sistema nitrificador. Sin embargo, ninguna de las investigaciones brindó un modelo confiable para predecir la desnitrificación con el fin de cuantificar el nitrato recirculado.

Marais y su grupo (Stern and Marais, 1974; Martin and Marais, 1975; Wilson and Marais, 1976; Marsden and Marais, 1977) reconocieron la importancia de cuantificar la remoción de nitrato. Para obtener la información sobre la magnitud y la cinética de desnitrificación, ellos reemplazaron los reactores completamente mezclados en un sistema Bardenpho de 4 etapas por medio de reactores de flujo pistón y midieron el nitrato a lo largo del reactor en condiciones de caudal y carga constante.

Sus descubrimientos en la cinética de la desnitrificación son revisadas en el Capítulo 5. Con respecto a la relevancia de la remoción de $\mathrm{P}$, ellos encontraron que no era posible incrementar la zona anóxica en el sistema con el fin de asegurar una concentración baja de nitrato en el efluente y en la línea de recirculación. Si para una edad de lodos y temperatura fija, la fracción de masa no aireada del lodo era incrementada más allá de cierta magnitud, el sistema dejaría de nitrificar. Ellos recomendaron que la fracción máxima de masa anóxica permisible fuera determinada por la tasa específica de crecimiento máxima para las bacterias nitrificadoras a la temperatura y edad de lodos más baja que el sistema tendría que operar. Limitar la fracción de masa anóxica (para asegurar la nitrificación) necesariamente limita la magnitud de la desnitrificación alcanzable. Cuando el grupo de Marais operó a una fracción no aireada que permitió la nitrificación, la desnitrificación fue incompleta y el nitrato efluente fue elevado.

Considerando los descubrimientos en la cinética de desnitrificación, Rabinowitz y Marais en 1977 comenzaron a estudiar la remoción de $\mathrm{P}$ usando el sistema Bardenpho Modificado tratando agua residual municipal de la ciudad de la Ciudad del Cabo. Ellos seleccionaron el sistema Bardenpho Modificado de 3 etapas (Figura 7.12A) como la configuración básica, prefiriéndola sobre la de 5 etapas (Figura 7.12C) ya que en primera, el origen del agua residual no permitió que la fracción no aireada fuera mayor al $40 \%$ a $14^{\circ} \mathrm{C}$ para una edad de lodo de 20 días cuando se mantenía una nitrificación eficiente; y en segunda, considerando que el reactor anaerobio no puede contribuir con la desnitrificación potencial, el sistema de 5 etapas no puede reducir el nitrato a cero para la relación medida de NTK/DQO en el agua residual. En consecuencia (como se discutió previamente en el Capítulo 5), el volumen del reactor anóxico secundario fue añadido al anóxico primario para obtener la remoción máxima de nitrato y por lo tanto la mínima concentración de nitrato en la línea de lodos recirculada. Los descubrimientos de esta investigación (Rabinowitz and Marais, 1980) pueden ser resumidos de la siguiente manera:

(i) Cuando la concentración de nitrato en el efluente (y en la línea de lodos recirculada) fue baja, usualmente se observó una liberación y remoción mejorada de P. Ésta última disminuyó de manera no proporcional cuando el nitrato en la línea secundaria incrementó. Un comportamiento similar fue observado en investigaciones previas (Barnard, 1975b; Simpkins and McLaren, 1978). 
(ii) Con diferentes lotes de agua residual que tienen el mismo DQO afluente, con la misma concentración de nitrato en la línea de lodos recirculada, un lote de agua residual dio relativamente una alta liberación de $\mathrm{P}$ y también una alta remoción biológica de $\mathrm{P}$ mientras que en el siguiente lote no existió (o hubo poca) liberación de $\mathrm{P}$ y remoción mejorada de $\mathrm{P}$. La razón de este comportamiento no fue aparente en los experimentos.

En la configuración de Bardenpho Modificado de 3 etapas la remoción de $\mathrm{P}$ fue insatisfactoria; el sistema no presentó una remoción aumentada de $\mathrm{P}$ en un periodo largo de tiempo, y cuando esta remoción fue obtenida, generalmente tendió a ser baja e inconsistente debido a los efectos de (i) y /o (ii) mencionados anteriormente. Se encontró que incrementar la fracción de masa anaerobia durante los periodos de baja remoción de $\mathrm{P}$ era contraproducente ya que esto sólo se podría hacer a expensas de la fracción anóxica, lo cual a su vez incrementaría la concentración de nitrato en la recirculación.

Finalmente se concluyó que para las aguas residuales usadas en las investigaciones experimentales, el sistema Bardenpho Modificado no pareció ser adecuado para la remoción aumentada de P. Esto no implicó que el sistema no fuera adecuado para otras aguas residuales, pero la investigación sacó a la luz que habían reestricciones no conocidas anteriormente, las cuales podían impedir una remoción eficiente de $\mathrm{P}$ :

(i) Para que una nitrificación completa se lleve a cabo a una edad de lodo determinada considerando una temperatura mínima, es necesario establecer un límite superior en la fracción de masa no aireada.

(ii) La limitación de la fracción de masa no aireada a su vez limita la concentración de nitrato que puede ser removido. Para el sistema Bardenpho Modificado de 5 etapas, si el nitrato generado es mayor que el potencial de desnitrificación, el nitrato va a aparecer en el efluente y va a ser reciclado al reactor anaerobio. Para el sistema Bardenpho Modificado de 3 etapas, una completa desnitrificación no es posible, y el nitrato siempre va a estar presente en la recirculación al reactor anaerobio. Recircular el nitrato en ambos sistemas influenciará de manera adversa la remoción de P.

\subsubsection{Sistema de la Universidad de La Ciudad del Cabo (UCT; VIP)}

En una revisión de los esfuerzos que se realizaron sin éxito para obtener una remoción biológica consistente de $\mathrm{P}$ en un sistema Bardenpho Modificado, Rabinowitz y Marais (1980) llegaron a la conclusión de que sin importar otros factores que pueden afectar la remoción de $\mathrm{P}$, el nitrato recirculado al reactor anaerobio parecía tener un impacto importante. Su efecto negativo en el reactor anaerobio fue después demostrado por Hascoet y Florentz (1985), entre otros.

Si el nitrato en la línea de recirculación al reactor anaerobio se mantiene a una concentración baja, entonces se espera alcanzar un sistema con EBPR estable. La principal complicación para obtener esta estabilidad en el sistema Bardenpho Modificado es que el nitrato descargado al reactor anaerobio está directamente vinculado con la concentración de nitrato en el efluente. Si por alguna razón la concentración de nitrato en el efluente incrementa mientras que la DQO se mantiene constante, por ejemplo en caso de que la relación NTK/DQO afluente incremente, el sistema ofrece pocas opciones para reducir esto por métodos operacionales. El único medio disponible en la operación es reducir la recirculación de lodos, pero esto es una opción riesgosa debido a que la sedimentabilidad del licor mezclado en estas plantas tiende a ser más baja que en los sistemas puramente aerobios. Por este motivo, Rabinowitz y Marais (1980) investigaron otras configuraciones que podrían proteger al reactor anaerobio de una intrusión de nitrato, independizando así el reactor anaerobio de la concentración de nitrato en el efluente. Lo anterior derivó en el desarrollo del sistema de la Universidad de la Ciudad del Cabo (UCT, Figura 7.12E).

En el sistema UCT, el lodo recirculado $s$ es descargado al reactor anóxico primario. Una recirculación posterior permite (recirculación $r$ ) extraer licor mezclado del reactor anóxico primario y conducirlo al reactor anaerobio. El licor mezclado es también recirculado del reactor aerobio al reactor anóxico (recirculación a). Mediante la manipulación de la relación de recirculación $a$, el nitrato en el reactor anóxico puede ser controlado para ser cero, y por lo tanto no se recirculará nitrato al reactor anaerobio. Así, las condiciones anaerobias en el reactor pueden ser mantenidas independientemente de la concentración de nitrato efluente y aunque la relación de NTK/DQO afluente a la planta varíe. Esta condición, aunque deseable, se alcanza en el sistema UCT a costa de (i) volumen del reactor anaerobio; para mantener una 
fracción de lodo en el reactor anaerobio igual a la existente en el sistema Bardenpho Modificado, el volumen del reactor anaerobio en el sistema UCT debe ser incrementado en una proporción $(1+\mathrm{r}) / \mathrm{r}$, y (ii) la incapacidade de alcanzar una desnitrificación completa tal y como se discute el efecto de la recirculación en la eficiencia de remoción de nitrógeno (Capítulo 5).

Experimentos de la configuración UCT a escala laboratorio usando el agua residual de la Ciudad del Cabo mostraron mejoría en la eficiencia del sistema EBPR tanto en magnitud como en confiabilidad, comparado con lo que se había obtenido en el sistema Barderpho Modificado. Sin embargo, tal vez el logro más importante desde el punto de vista de la investigación fue que en el sistema UCT fue posible eliminar el impacto negarivo que tenía el nitrato recirculado al reactor anaerobio en la remoción de $\mathrm{P}$, por lo que otros factores que influenciaban en el sistema EBPR pudieron ser estudiados más fácilmente (Siebritz et al., 1982). A partir de los datos experimentales, los efectos de estos otros factores se volvieron evidentes: $(i)$ para la misma DQO afluente un lote de agua residual presenta mayor remoción de $\mathrm{P}$ que el otro, esto fue observado tentativamente, pero no había sido explícitamente identificado debido al efecto del nitrato, y (ii) la magnitud de la remoción biológica de $\mathrm{P}$ pareció estar vinculada a algunas características del agua residual, todavía no identificadas.

Una variación del sistema UCT fue propuesto, llamado la Planta de la Inciativa de Virginia (VIP, por sus siglas en inglés Virginia Initiative Plant, Daigger et al., 1987). La configuración básica para este sistema es idéntico al de UCT con excepción de dos puntos: (i) se usan series múltiples de reactores completamente mezclados y (ii) el sistema es operado a una edad de lodo corta, de 5 a 10 días.

\subsubsection{Sistema UCT Modificado}

La experiencia con el sistema UCT (Siebritz et al., 1980, 1982) indicó algunos problemas en cuanto al control.

La relación de licor mezclado recirculado (recirculación $a$ ) necesita ser controlado cuidadosamente para que el reactor anóxico primario sea simplemente

\footnotetext{
${ }^{2}$ Aunque desde el punto de vista de remoción de $\mathrm{N}$ y $\mathrm{P}$ no es necesario un control cuidadoso de la recirculación $a$, la presencia de nitrato y/o nitrito en el efluente del reactor anóxico secundario ha sido vinculado con el problema de la aparición de lodo filamentoso debido a la baja relación F/M (por sus siglas en inglés food/microorganism) en sistemas de remoción de nutrientes (Casey
}

sub-cargado con nitrato y evitar descargar nitrato en el reactor anaerobio. En una operación a escala completa este control cuidadoso de la relación de recirculación $a$ no es posible debido a la incertidumbre en la relación NTK/DQO, particularmente bajo condiciones de caudal y carga cíclicos.

Para simplificar la operación del sistema UCT, se propuso una alternativa en la que no fuera necesaria un control cuidadoso de la recirculación $a$. Esto conllevó a una modificación del sistema UCT llamado UCT Modificado (Figura 7.12F). En éste último el reactor anóxico es subdividido en dos reactores, en el primero se tiene una fracción de lodo de alrededor de 0.10 y en la segunda se tiene la fracción de lodo anóxico disponible de acuerdo al balance. En el primer reactor anóxico se recibe la recirculación de lodo (s) y se deriva la recirculación-r que va al reactor anaerobio. La recirculación $a$ mínima es aquella en la cual se introduce sólo el nitrato necesario al segundo reactor anóxico para cargarlo hasta su potencial de desnitrificación. Una recirculación mayor al mínimo no removerá nitrato adicional, sólo introducirá más nitrato del que puede ser removido en el reactor y por lo tanto el nitrato aparecerá en el efluente. No tiene mayor impacto llegar a este punto ( $\mathrm{c}>\mathrm{a}_{\mathrm{min}}$ ), simplemente el nitrato en el reactor aerobio se mantendrá constante. En consecuencia, se puede incrementar la recirculación $a$ a cualquier valor mayor a $\mathrm{a}_{\min }$, para dar el tiempo de retención requerido sin afectar al reactor anóxico primario, prescindiendo así de un control cuidadoso de la recirculación $a^{2}$.

No obstante, esta ventaja obtenida tiene un costo (WRC, 1984): La relación máxima de NTK/DQO que da cero nitrato al reactor anaeobio es reducido de \pm 0.14 en el sistema UCT a \pm 0.11 en el sistema UCT Modificado. Sin embargo, una relación NTK/DQO de 0.11 $\mathrm{mgN} / \mathrm{mgDQO}$ está presente en la mayor parte de las aguas residuales municipales crudas y clarificadas. Además, si la planta se diseña de manera que la recirculación $r$ pueda ser tomada ya sea del reactor anóxico primario o anóxico secundario, el sistema puede ser operado ya sea con una configuración UCT o UCT Modificada, como mejor convenga.

et al., 1992, 1993a,b, 1994). Por lo tanto, para restringir la aparición de lodo filamentoso es necesario controlar cuidadosamente la recirculación $a$, lo cual efectivamente eliminaría la ventaja del MUCT sobre el sistema UCT. En sistemas BCFS, el IVL (índice volumétrico de lodos) es 100-120, por lo que o este problema no existe o el control redox es realmente efectivo. 


\subsubsection{Sistema Johannesburgo (JHB)}

Tomando en cuenta lo reportado por Barnard (1976) acerca de la influencia adversa del nitrato recirculado en el reactor anaerobio del sistema Bardenpho Modificado de 5 etapas, Osborn and Nicholls (1978) propusieron en un estudio a escala piloto en las plantas de Johannesburgo (Johannesburg Northern Works) modificar la configuración Bardenpho Modificado de 5 etapas moviendo la zona anóxica secundaria del tren principal y reposicionándolo en la línea de recirculación de lodos. El resultado fue un sistema de 4 etapas (anóxico, anaerobio, anóxico y aerobio) que fue conocido como sistema Johannesburgo (JHB) (Burke et al., 1986; Nicholls et al., 1987).

Mediante el reposicionamiento del reactor anóxico secundario en la línea de recirculación de lodos en el sistema JHB (Figura 7.12D), la masa de nitrato que necesita ser removida en el reactor anóxico secundario para dar cero nitrato en la descarga al reactor anaerobio es reducido a $\mathrm{s} /(1+\mathrm{s})$ veces en comparación con el sistema Bardenpho Modificado de 5 etapas. Esto es, para proteger el reactor anaerobio de la recirculación de nitrato, en el sistema JHB sólo el nitrato en la recirculación $s$ tiene que ser removido mientras en el sistema Bardenpho Modificado de 5 etapas se tiene que remover el nitrato en la recirculación $s$ más el que se encontraba en el efluente.

También, mediante el posicionamiento del reactor anóxico en la recirculación $s$, la concentración de lodo en el reactor secundario anóxico en el sistema JHB es incrementado por un factor de $(1+\mathrm{s}) / \mathrm{s}$ comparado con el reactor secundario anóxico del sistema Bardenpho Modificado de 5 etapas, permitiendo así la reducción del tamaño del reactor para alcanzar la misma fracción de masa anóxica. Sin embargo, a diferencia de sistema Bardenpho Modificado de 5 etapas, el sistema JHB (así como el UCT) no pueden alcanzar una desnitrificación completa. El sistema JHB no tiene el inconveniente del sistema UCT respecto al incremento del volumen anaerobio por la misma fracción de masa; sin embargo la desnitrificación se lleva a cabo a una tasa más baja que en el reactor anóxico primario del UCT, por lo que la protección al reactor anaerobio del nitrato sólo puede ser alcanzado con una relación de NTK/DQO afluente más baja, aunque gran parte de las aguas residuales caerán en el rango de operación de los sistemas JHB. Investigaciones extensivas a escala completa del comportamiento del sistema JHB han sido reportados (Nicholls et al., 1987; Pitman et al., 1988; Pitman, 1991).

\subsubsection{Remoción biológica-química de fósforo (sistema BCFS $^{\circledR}$ )}

Una adaptación posterior del sistema UCT Modificado fue desarrollada a finales del siglo XX en los Países Bajos. Este sistema llamado BCFS ${ }^{\circledR}$ (Figura 7.12H) fue desarrollado para dar soporte al proceso biológico mediante la liberación de fosfato y su recuperación potencial en el tren primario, estabilizando las propiedad de sedimentación del lodo y optimizando el control de la remoción de nitrógeno. En este sistema una tercera recirculación fue incluida, del reactor aerobio al reactor anóxico primario, con el fin de maximizar la desnitrificación y ser capaz de airear el reactor anóxico secundario durante los picos de caudal. De esta manera ambos, amonio y nitrato pueden ser mejor controlados a valores bajos en el efluente (amonio típicamente debajo de $0.5 \mathrm{gN} / 1$ y nitrato alrededor de $5-8 \mathrm{mgN} / \mathrm{l})$. Los caudales de recirculación son controlados por un electrodo simple redox operados con un regulador de frecuencia o flujo (van Loosdrecht et al., 1998). La compartimentación contribuye a estabilizar un bajo índice volumétrico de lodos (IVL, alrededor de $120 \mathrm{ml} / \mathrm{g}$ ) (Kruit et al., 2002). Una remoción biológica de fósforo puede ser alcanzada por medio de la adición de precipitantes al reactor anaerobio. Debido a que la concentración de fosfato es alta en este tanque, los precipitantes son usados eficientemente. Sin embargo, la dosificación de químicos debe ser realizado cuidadosamente. Mucha precipitación hará que los fosfatos no estén disponibles para el uso de los PAOs y por lo tanto la eficiencia del sistema EBPR se deterioraría.

Un factor a considerar es que las PTARs responderán rápidamente a los cambios en la adición de químicos mientras que en la remoción biológica de $\mathrm{P}$ esta respuesta puede tomar varios días sino es que semanas. En un proceso BCFS una pequeña mampara es colocada al final del flujo pistón del tanque anaerobio. El lodo sedimenta de regreso al tanque y un sobrenadante claro puede obtenerse para la precipitación de fosfato. El P puede entonces ser recuperado (Barat and van Loosdrecht, 2006) y se evitará que el lodo químico se acumule en el lodo activado, el cual limitaría la capacidad total en la planta al reducir la edad de lodo.

Con el fin de construir eficientemente todos los tanques en estos sistemas complejos de remoción biológica de nutrientes, es posible cambiar la construcción de tanques rectangulares a un tanque circular dividido en diferentes a las para las zonas aerobia/anóxica/anaerobia. De esta manera la cantidad de 
concreto requerido es minimizado ya que las paredes internas requieren mucho menos refuerzo que las paredes externas de la construcción (ver Figura 11.1).

\subsection{DESARROLLO DE UN MODELO PARA SISTEMAS CON EBPR}

\subsubsection{Primeros desarrollos}

La conceptualización del sistema Bardenpho Modificado de 5 etapas (Barnard, 1976), el cual fue el primer sistema de EBPR con nitrificación-desnitrificación (NDEBPR) en el tren principal, se basó principalmente en el reconocimiento de $(i)$ la necesidad de una secuencia anaerobio/aerobio de reactores, y (ii) la influencia adversa del nitrato recirculado en la zona anaerobia. Los procedimientos de diseño fueron basados en estimaciones empíricas para dimensionar la desnitrificación y los reactores anaerobios en términos del tiempo de retención hidráulico nominal; el dimensionamiento del reactor anaerobio pareció estar vinculado con la caída del potencial redox debajo de un determinado valor crítico. No existía un método racional para predecir la remoción de $\mathrm{N}$ y $\mathrm{P}$; en el diseño las remociones eran estimadas principalmente a partir de la experiencia ganada en sistemas similares a los propuestos.

\subsubsection{DQO rápidamente biodegradable}

Buscando una explicación de los diferentes patrones de comportamiento de la liberación de $\mathrm{P}$ y su remoción aumentada a escala laboratorio en sistemas UCT Modificados y MLE (por sus siglas en inglés Modified Ludzack Ettinger), Siebritz et al., (1980,1982) aplicó en sistemas con EBPR el concepto de DQO rápidamente biodegradable (DQO $\mathrm{rb}$, ver Sección 7.3.6), el cual había sido desarrollado para estudiar proceso aerobios y de desnitrificación (Dold et al., 1980). Se observó que la única diferencia evidente entre la configuración UCT Modificado y MLE era la concentración de DQO $\mathrm{Pb}_{\mathrm{rb}}$ disponible para los microorganismos en el reactor anaerobio $\left(\mathrm{S}_{\mathrm{AGV}}\right)$. En el reactor anaerobio del sistema UCT Modificado, la concentración máxima de DQOrb $\left(\mathrm{S}_{\mathrm{AGV}}\right)$ es alcanzada cuando el nitrato no se recircula al reactor anaerobio. En contraste, en el sistema MLE se recircula suficiente nitrato al reactor anóxico con el fin de utilizar toda la $\mathrm{DQO}_{\mathrm{rb}}$, por lo que $\mathrm{S}_{\mathrm{AGV}}=0$. Por lo tanto, los diferentes patrones de comportamiento de los procesos serían consistentemente descritos si se asume que la concentración de $\mathrm{DQO}_{\mathrm{rb}}$ en el reactor anaerobio (Ss) disponible para los microorganismos es el parámeto clave que determina si existirá liberación y posteriormente una captura de $\mathrm{P}$.

A partir del presente entendimiento de los sistemas con $\mathrm{EBPR}$, el parámetro $\mathrm{S}_{\mathrm{AGV}}$ es teórico y no puede ser medido - la DQO $\mathrm{rb}$ disponible para los microorganismos del reactor anaerobio no equivale a la concentración de $\mathrm{S}_{\mathrm{AGV}}$ debido a la conversión de DQO fermentable a AGVs realizada por los OHOs y al almacenamiento de AGVs por PAOs (ver Sección 7.3.6).

\subsubsection{Modelo paramétrico}

Una investigación extensiva que Siebritz et al., (1983) realizó a lo largo de un año para validar la hipótesis de la $\mathrm{DQO}_{\mathrm{rb}}$ estableció que la liberación de $\mathrm{P}$ parece ser inducida cuando la $\mathrm{DQO}_{\mathrm{rb}}$ en el reactor anaerobio $\left(\mathrm{S}_{\mathrm{S}}\right)$ excede los $25 \mathrm{mg} / 1$, la liberación y posterior remoción de $P$ incrementa a medida que $\left(\mathrm{S}_{\mathrm{AGV}}-25\right)$ incrementa. Es decir, la remoción de $\mathrm{P}$ tuvo una relación lineal con la concentración de $\mathrm{DQO}_{\mathrm{rb}}$ en el reactor anaerobio. Lo anterior abrió camino para buscar y cuantificar otros factores que afectan la liberación y remoción mejorada de P. Se concluyó que los sistemas con EBPR dependían de tres factores $(i)\left(\mathrm{S}_{\mathrm{AGV}}-25\right)$, (ii) la fracción de lodo en el sistema que pasa a través del reactor anaerobio y (iii) el tiempo neto que el lodo es retenido en el reactor anaerobio.

Se hipotetizó que en caso de que alguno de los anteriores fuera cero el sistema de EBPR no funcionaría. Empíricamente estos tres factores fueron combinados en un solo factor que mide la propensión del sistema para remover $\mathrm{P}$. El contenido de $\mathrm{P}$ en la biomasa activa de lodo puede encontrarse en función de dicho factor.

Investigaciones posteriores mostraron que en los sistemas Bardenpho Modificado y UCT (y JHB que aún no era considerado), así como sus respectivas recirculaciones e interacciones con el tiempo de retención anaerobio, los factores (ii) y (iii) descritos arriba pueden ser combinados en un sólo parámetro, por lo que los tres parámetros anteriormente listados pueden ser reducidos a dos parámetros clave $(i)\left(\mathrm{S}_{\mathrm{AGV}}-25\right)$ y, (ii) la fracción de masa anaerobia, definida como (masa de lodo en el reactor anaerobio)/(masa total de lodo en el sistema).

Basado en estas observaciones, el sistema con EBPR se formuló empíricamente en términos de dos parámetros clave y también de la masa de lodo (activa, endógena e 
inerte) purgada por día, dando lugar a un modelo paramétrico.

Posteriormente, pruebas extensivas de los conceptos incluidos en el modelo paramétrico verificaron de manera general la utilidad del modelo. Usando el sistema UCT a escala laboratorio, estos conceptos fueron evaluados a diferentes edades de lodo, temperaturas, fracciones de masa anaerobia y concentraciones de DQO afluente en las cuales la fracción de DQO ${ }_{\mathrm{rb}}$ en el afluente (agua residual municipal no sediementada) fue enriquecida con la adición de glucosa o acetato. Todos estos experimentos dieron resultados consistentes con las predicciones basadas en el concepto de DQO $_{\mathrm{rb}}$ utilizado en el modelo paramétrico.

En un proyecto de investigación conjunto entre el Consejo de la Ciudad de Johannesburgo (Johannesburg City Council) en Goudkoppies y Northern Works, un análisis a escala completa de los sistemas usando estos conceptos dio una explicación consistente cuando se obtuvo una alta o baja remoción de $\mathrm{P}$ (Nicholls et al., 1982). Por lo tanto, el modelo paramétrico permitió por primera vez un enforque cuantitativo del diseño de las PTARs con remoción de $\mathrm{N}$ y $\mathrm{P}$, y brindó los fundamentos para evaluar el desempeño de las plantas existentes (Ekama et al., 1983). Para un estudio más detallado acerca del modelo paramétrico, el lector es referido al WRC (1984).

\subsubsection{Comentarios sobre el modelo paramétrico}

El modelo paramétrico descrito anteriormente fue desarrollado a partir de los datos experimentales de sistemas que fueron operados en las siguientes condiciones:

- Concentración afluente de DQO: 250-800 mgDQO/1

- DQO rápidamente biodegradable: 70-220 mgDQO/l

- Por lo tanto la fracción $\mathrm{f}_{\mathrm{ts}}:$ 0.12-0.27 mgDQO ${ }_{\text {rb }} / \mathrm{mgDQO}_{\text {total }}$

- Relación NTK/DQO: 0.09-0.14 mgN/mgDQO

- Edad de lodo: 13 y 25 días

- Temperatura: $14^{\circ} \mathrm{C}$ y $20^{\circ} \mathrm{C}$

- Fracción de masa anaerobia: 0.10-0.20 $\mathrm{gSSV}_{\mathrm{AN}} / \mathrm{gSSV}_{\mathrm{sys}}$

Las observaciones realizadas bajo estas condiciones formaron la base para estructurar y formular la manera de estimar la remoción aumentada de P, las ecuaciones derivadas fueron calibradas con datos experimentales.
Una comparación de las predicciones teóricas y las mediciones experimentales mostraron una buena correlación. Sin embargo, a pesar de la evidente utilidad del modelo paramétrico éste sigue siendo empírico, pues relaciona parámetros observables pero no brinda ninguna explicación del por qué éstos son importantes y es independiente de cualquier hipótesis formal de los mecanismos biológicos que dirigen estos procesos. De manera que la aplicación del modelo paramétrico debe limitarse estrictamente a los rangos de los parámetros del sistema y las características de agua residual indicadas anteriormente. Se requería entonces de un modelo con más fundamentos.

Hasta aquél momento la descripción del sistema de EBPR con nitrificación-desnitrificación (NDEBPR) no consideraba la presencia de ningún organismo en específico. El modelo paramétrico incluso considera al lodo activado como un todo, con cierta propensión para remover P. Se hipotetizó que la variación dentro de los diferentes sistemas con EBPR se debe a los cambios en la propensión del lodo de remover $\mathrm{P}$, causado por cambios en la concentración de DQO $_{\mathrm{rb}}$ afluente, la fracción de masa anaerobia y/o la descarga de nitrato al reactor anaerobio. Sin embargo, investigaciones paralelas en las ciencias naturales identificaron grupos específicos de organismos que tienen cierta propensión de almacenar altas cantidades de $\mathrm{P}$ en forma de polifosfatos (poliP). Esto permitió cambiar el enfoque de la modelación de la EBPR en los sistemas con NDEBPR, considerando que en el lodo existen grupos específicos de organismos que participan en la remoción biológica de $\mathrm{P}$, genéricamente conocidos como organismos poliP (Wentzel et al., 1986), organismos bio-P (Comeau et al., 1986) u organismos acumuladores de fósforo (PAOs; IAWPRC Task Group, 1991).

\subsubsection{Cinética de los sistemas con NDEBPR}

Wentzel et al., (1988a) inició el desarrollo de un modelo general que describe el comportamiento de un sistema con NDEBPR. Se asumió que en un sistema con NDEBPR que trata aguas residuales municipales se podría desarrollar un cultivo mixto categorizado en tres grupos $(i)$ organismos heterótrofos capaces de acumular poliP, nombrados como organismos acumuladores de fósforo (PAOs), (ii) organismos heterótrofos que no son capaces de acumular poliP, nombrados organismos heterótrofos ordinarios (OHOs), y (iii) organismos autótrofos que participan en la nitrificación, nombrados organismos nitrificantes (ANOs, por sus siglas en inglés Autotrophic nitrifying organisms). 
Wentzel et al. $(1985,1988)$ reconoció que el desarrollo de un modelo de lodos activados para describir el comportamiento de los sistemas con NDEBPR requeriría la inclusión de estos tres grupos de organismos y la descripción de sus interacciones. Con respecto a los OHOs y ANOs, ellos aceptaron el modelo de nitrificación- desnitrificación (ND) a estado estacionario descrito anteriormente y el modelo cinético general ND (Dold et al., 1991) (Capítulos 4 y 5). Dichos modelos requirieron ser extendidos para incorporar el comportamiento de PAOs y así incluir los tres grupos de organismos

Para alcanzar este objetivo, las características cinéticas y estequiométricas de los PAOs en el lodo activado requirieron ser establecidos. De los intentos de obtener información respecto a las características de los PAOs usando licor mezclado de los sistemas NDEBPR tratando aguas residuales municipales, Wentzel et al., (1988) concluyó que en los sistemas de cultivos mixtos el comportamiento de los OHOs tiende a dominar y enmascarar el comportamiento de los PAOs. Por ello se intentó aislar las características de los PAOs mediante el crecimiento enriquecido de PAOs en un sistema de lodos activados de cultivo mixto. En un cultivo enriquecido ( $i$ ) el crecimiento de PAOs es favorecido hasta el punto en el que estos se convierten en el organismo dominante primario y su comportamiento domina la respuesta del sistema, y (ii) el crecimiento de organismos competidores, así como la predación u otros tipos de interacciones son reducidas pero no excluídas.

Wentzel et al., (1988a) propuso obtener un cultivo enriquecido de PAOs tomando licor mezclado de un cultivo mixto de un sistema con NDEBPR, seleccionando un sustrato y estableciendo las condiciones ambientales que favorecería más el crecimiento y enriquecimiento de los PAOs.

\subsubsection{Cultivos enriquecidos de PAOs}

\section{7·5.6.1 Desarrollo de un cultivo enriquecido}

Usando los modelos bioquímicos, Wentzel et al., (1988a) identificó las condiciones que serían necesarias en un sistema de lodos activados con NDEBPR para producir un cultivo enriquecido de PAOs. Estas fueron (i) la secuencia anaerobio/aerobio con una adecuada fracción de masa anaerobia; (ii) la alimentación al reactor

${ }^{3} \mathrm{El}$ procedimiento API $20 \mathrm{NE}$ ha sobre-estimado la ocurrencia de Acinetobacter spp. debido a la técnica empleada (Venter et al., 1989) y la selección del cultivo (e.g. Wagner et al., 1994). Sin embargo, para el desarrollo de modelos de diseño y simulación, una anaerobio usando acetato como sustrato con un adecuado balance de macro- y micronutrientes, en particular $\mathrm{Mg}^{2+}$, $\mathrm{K}^{+}$y en menor grado $\mathrm{Ca}^{2+}$; y (iii) un control de $\mathrm{pH}$ en el reactor aerobio.

Empleando las configuraciones UCT y el Bardenpho Modificado de 3 etapas, con una edad de lodos que varía de 7.5 a 20 días, se desarrollaron cultivos enriquecidos de PAOs en los cuales una proporción mayor al $90 \%$ de los organismos cultivados aerobicamente fueron identificados como Acinetobacter spp., siguiendo el procedimiento API (por sus siglas en inglés Analytical Profile Index) $20 \mathrm{NE}^{3}$. Los resultados de los cultivos enriquecidos indicaron que sí se alcanzaron concentraciones signficativas de PAOs. Por ejemplo, en el sistema UCT (fracción de masa anaerobia 15\%, edad de lodo de 10 días y alimentación de acetato a 500 $\mathrm{mgDQO} / \mathrm{l})$ se obtuvo una liberación de fosfato de $\approx 253$ $\mathrm{mgP} / \mathrm{l}$, captura de fosfatos de $\approx 314 \mathrm{mgP} / \mathrm{l}$ y una remoción neta de $\mathrm{P}$ de $\approx 61 \mathrm{mgP} / \mathrm{l}$. Esta remoción fue mucho mayor que la observada en cultivos mixtos de sistemas de NDEBPR con agua municipal afluente de $500 \mathrm{mgDQO} / \mathrm{l}$, dando una liberación de fosfato de $\approx 45 \mathrm{mg} / \mathrm{l}$, asimilación de fosfato de $\approx 57 \mathrm{mg} / \mathrm{l}$ y remoción neta de $\mathrm{P}$ de $\approx 12$ $\mathrm{mgP} / \mathrm{l}$. El cultivo enriquecido del licor mezclado en la zona aerobia mostró una remoción de $\approx 0.38$ $\mathrm{mgP} / \mathrm{mgLMSSV}$ con una relación SSV/SST de $\approx 0.46$ $\mathrm{mgSSV} / \mathrm{mgSST}$, lo cual fue mucho mayor que en el sistema de cultivo mixto donde se tuvo una relación $\mathrm{P} / \mathrm{LMSSV}$ de $\approx 0.1$ y una fracción SSV/SST de $\approx 0.75$. La baja relación SSV/SST de los sistemas de cultivo enriquecido se debe a las altas cantidades de poliP que están asociados con sus contra-iones y son almacenados por los PAOs (Ekama and Wentzel, 2004).

\subsubsection{Modelo cinético de los cultivos enriquecidos}

De las observaciones experimentales de cultivos enriquecidos operando en condiciones estacionarias, y otros experimentos por lote en los cuales el licor mezclado fue purgado del sistema y sujeto a una amplia variedad de condiciones, Wentzel et al., (1989a) dilucidó las características y cinética de la biomasa activa de PAO. Dos características de los PAOs en los cultivos enriquecidos fueron de particular interés:

(i) Poca propensión a desnitrificar, por lo que este proceso no se incluyó en el modelo de PAO (la baja capacidad de desnitrificación de los PAOs tuvo

exacta identificación de PAOs en cultivos enriquecidos es poco relevante ya que los modelos están basados en observaciones experimentales cuantitativas. 
implicaciones en la modelación de las desnitrificación en el cultivo mixto de sistemas NDEBPR, como se mencionará más adelante).

(ii) Una tasa extremadamente baja de decaimiento endógeno, $0.04 \mathrm{mgSSVa} / \mathrm{mgSSVa}$ d, la cual es mucho menor que la de los $\mathrm{OHOs}$ en un sistema aerobio de lodos activados, que corresponde a $0.24 \mathrm{mgSSVa} / \mathrm{mgSSV}$ a.d (McKinney and Ooten, 1969; Marais and Ekama, 1976). Una observación similar fue realizada por Wentzel et al., (1985) en estudios de cultivo mixto de sistemas con NDEBPR tratando aguas municipales; donde se observó a partir de gráficas de captura contra liberación de fosfato de lodos de diferentes edades que, para una liberación de fosfato dada, la asimilación de fosfato fue relativamente insensible a la edad del lodos. Para explicar esta observación, Wentzel et al., (1985) propuso que los PAOs "sufren poca o ninguna pérdida de masa endógena”. El alto valor de la tasa específica de pérdida de masa endógena en los cultivos de OHOs ha sido atribuido a la alta tasa de predación y recrecimiento, formulada como muerte por regeneración en el modelo cinético ND de Dold et al., (1980). El bajo valor de la tasa específica de pérdida de masa endógena en los cultivos enriquecidos con PAOs y las observaciones de Wentzel et al., (1985) llevaron a la conclusión (Wentzel et al., 1989a) de que los PAOs no son predadores en el mismo grado que los OHOs. De esta manera, en la modelación del decaimiento endógeno de PAOs, Wentzel et al., (1989a) usó el enfoque clásico de respiración endógena, con excepción de aquellas condiciones donde un aceptor de electrones externo no está disponible.

Tomando en cuenta lo anterior Wentzel et al., (1989a) desarrolló un modelo conceptual para el comportamiento de los PAOs en cultivos enriquecidos incorporando las características, procesos y componentes identificados como importantes en la investigación experimental. Usando el modelo conceptual como base, Wentzel et al., (1989a) formuló matemáticamente las tasas del proceso y sus interacciones estequiométricas, desarrollando así un modelo cinético de los cultivos enriquecidos con PAOs. Como fue recomendado por el grupo IAWPRC Task Group (Henze et al., 1987), este modelo fue presentado en forma de matriz con las constantes cinéticas y estequiométricas, siendo cuantificados con una variedad de procedimientos experimentales (Wentzel et al., 1989b). Así, el modelo de PAOs integrado con la simulación de OHOs y ANOs dio como resultado el modelo conocido como UCTPHO (Wentzel et al., 1992). Usando estas constantes, se aplicó el modelo cinético para simular diversos experimentos con cultivos enriquecidos, obteniendo una buena correspondencia entre los datos observados y simulados (Figuras 7.13 a 7.15). El modelo fue después aplicado para simular el comportamiento en condiciones estacionarias de las configuraciones UCT y Bardenpho Modificado de 3 etapas, obteniendo nuevamente buenas correlaciones (Wentzel et al., 1989b).
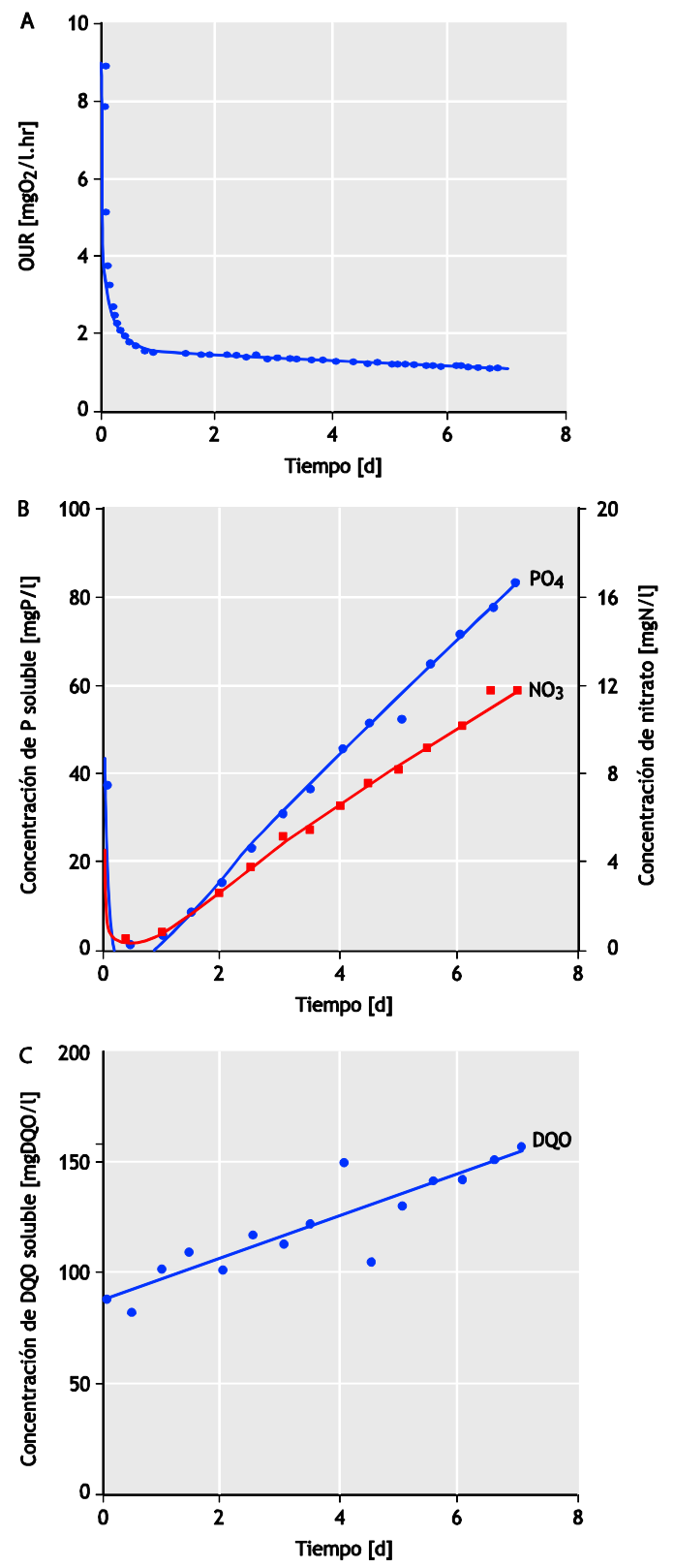

Figura 7.13 Observaciones y simulaciones experimentales de (A) tasa de utilización de oxígeno (OUR), (B) fósforo soluble total $\left(\mathrm{PO}_{4}\right)$, nitrato $\left(\mathrm{NO}_{3}\right)$ y (C) DQO filtrada a lo largo del tiempo con digestión por lote de un licor mezclado de un cultivo enriquecido (basado en Wentzel et al., 1989a) 

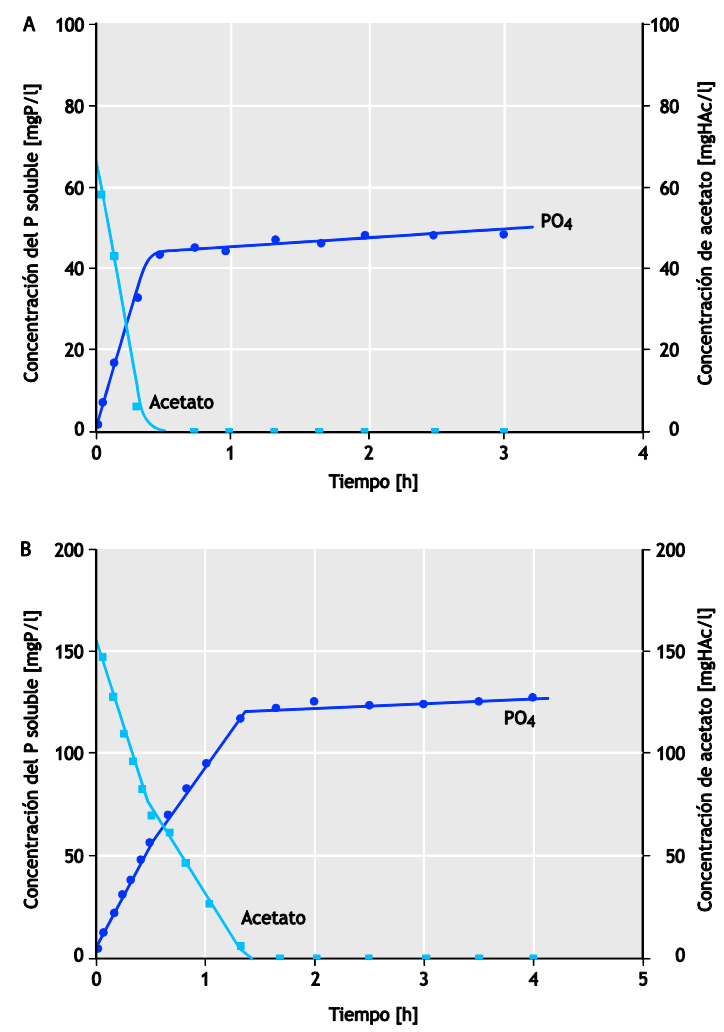

Figura 7.14 Observaciones y simulaciones experimentales de la fósforo soluble total $\left(\mathrm{PO}_{4}\right)$ y perfiles de concentración de acetato a lo largo del tiempo con adición anaerobia de (A) 0.11 mgDQO acetato/mgSSV y (B) $0.265 \mathrm{mgDQO} / \mathrm{mgSSV}$ a un licor mezclado purgado de un cultivo enriquecido Bardenpho (basado en Wentzel et al., 1989b)

\subsubsection{Modelo simplificado de cultivos enriquecidos en estado estacionario}

Wentzel et al. (1990) simplificó el modelo cinético para cultivos enriquecidos y desarrolló un modelo en estado estacionario para cultivos enriquecidos en condiciones de caudal y carga constantes. De un análisis de la cinética de los procesos en condiciones estacionarias, se encontró que muchos procesos se llevaban a cabo de forma completa; estas relaciones cinéticas no cumplían más una función y entonces podían ser reemplazadas por relaciones estequiométricas. Por ejemplo:

- Las fracciones de masa anaerobia usadas en los cultivos enriquecidos fueron suficientes para asegurar que todo el acetato (usado como sustrato) fuera secuestrado en la zona anaerobia, por lo que no resultó necesario incorporar la cinética del almacenamiento de acetato.
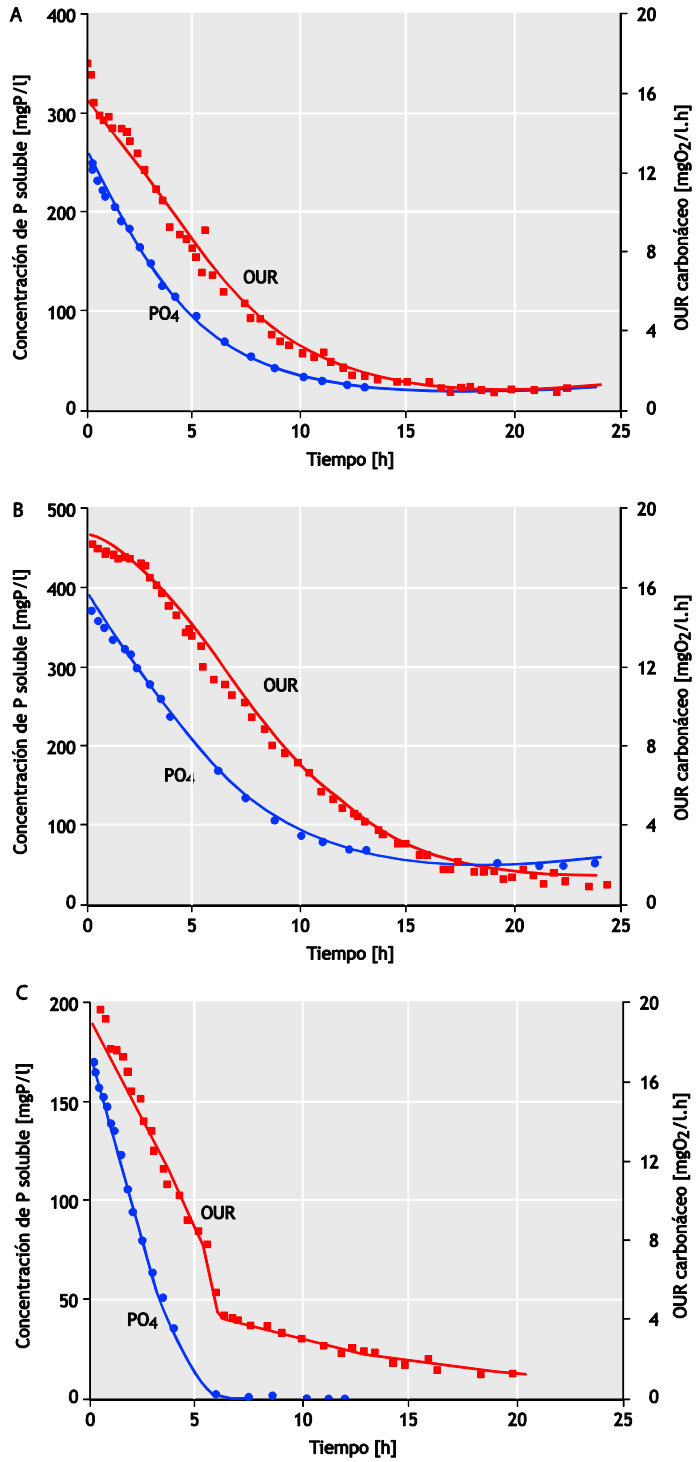

Figura 7.15 Observaciones y simulaciones experimentales de fósforo soluble total $\left(\mathrm{PO}_{4}\right)$, perfiles de tasa de utilización de oxígeno (OUR) carbonáneo a lo largo del tiempo en aireación seguida de adición anaerobia de acetato de (A) 0.207 $\mathrm{mgDQO} / \mathrm{mgSSV}$, (B) $0.363 \mathrm{mgDQO} / \mathrm{mgSSV}$ y (C) 0.22 $\mathrm{mgDQO} / \mathrm{mgSSV}$ de licor mezclado purgado de un cultivo enriquecido Bardenpho. La concentración de $\mathrm{PO} 4$ llegó a cero durante el curso de este último experimento (C). (basado en Wentzel et al., 1989b).

- Prácticamente todo el sustrato secuestrado en la zona anaerobia fue posteriormente utilizado en la zona aerobia, por lo que tampoco resultó necesario incroporar la cinética de la utilización de PHA ni almacenamiento de poliP. 
Se observó que estas simplificaciones implicaron que para una edad de lodo específica existiera una relación constante entre la masa de acetato alimentado con el sistema y la masa de PAOs formada con el poliP almacenado. Posteriormente se hizo una suposición que simplificó el modelo en estado estacionario:

- Los requerimientos de energía para la liberación de P durante el mantenimiento anaerobio es siempre pequeño comparado con la que se requiere para almacenar AGVs; por lo que no fue necesario incorporar la cinética de liberación de fosfato para el mantenimiento anaerobio.

Ellos racionalizaron más adelante que las simplificaciones y suposiciones implicaron que bajo un estado estacionario el contenido de poliP en los PAOs del lodo activado es constante, de $0.38 \mathrm{gP} / \mathrm{gSSV}$ PAO, e independiente de la edad de lodo. Lo que varía es la proporción relativa de PAOs (con poliP almacenado) en el lodo activado. Tomando en cuenta las simplificaciones y suposiciones, Wentzel et al., (1990) desarrolló algunas ecuaciones para cultivos enriquecidos en condiciones estacionarias, calculando la masa endógena y activa de PAO, la liberación de fosfato, así como la captura y remoción debido a estas masas. Estas ecuaciones dieron los medios para cuantificar la población de PAOs en un sistema de NDEBPR con cultivo mixto en el que se trata agua municipal.

\subsubsection{Cultivos mixtos en estado estacionario de sistemas con NDEBPR \\ 7.5.7.1 Modelo de cultivos mixtos en estado estacionario}

Habiendo desarrollado el modelo en estado estacionario para sistemas de cultivos mixtos, Wentzel et al., (1990) lo extendió para incorporar cultivos mixtos de PAOs y OHOs presentes en sistemas con NDEBPR que reciben agua doméstica como afluente. Esta extensión probó ser posible ya que (i) los cultivos enriquecidos más que cultivos puros fueron usados para establecer las características cinéticas y estequiométricas de PAOs. En cultivos enriquecidos, los PAOs presentes en cultivos mixtos de lodo activado fueron favorecidos pero ninguna especie fue aislada artificialmente (como en los cultivos puros), (ii) los organismos competidores y predadores no fueron artificialmente excluidos (como en los cultivos

\footnotetext{
${ }^{4} \mathrm{~A}$ partir de simulaciones posteriores usando el modelo de cultivo mixto en condiciones estacionarias, se encontró que si los PAOs fueran sujetos a una tasa alta de predación no sería posible obtener una elevada eficiencia de remoción de $\mathrm{P}$ en el cultivo mixto del
}

puros) por lo que los PAOs fueron sujetos a las mismas presiones de selección en cultivos enriquecidos que en cultivos mixtos, (iii) los PAOs fueron también sujetos a las mismas condiciones presentes en cultivos mixtos de sistemas de lodo activado (ej. secuencia anaerobio/aerobio, TRS altos > 5 días, etc.), (iv) los PAOs mostraron los mismos patrones de comportamiento en cultivos enriquecidos que en cultivos mixtos (ej. liberación/captura de $\mathrm{P}$, acumulación de PHA/poliP, etc.). De hecho, el comportamiento aunque "magnificado" de los cultivos enriquecidos comparado con los cultivos mixtos fue un criterio usado para establecer que los cultivos se habían enriquecido correctamente.

Un aspecto que emergió cuando se extendió el modelo fue la diferencia de la pérdida de masa endógena entre el cultivo enriquecido de PAOs y el lodo activado aerobio "normal" (OHO). Como fue mencionado anteriormente, la alta tasa de decaimiento endógeno en cultivos con OHOs ha sido atribuido a la alta tasa de predación y recrecimiento, formulado como muerte regenerativa en el modelo cinético ND de Dold et al., (1980). La baja tasa de decaimiento endógeno de PAOs en los cultivos enriquecidos llevaron a Wentzel et al., (1989a) a concluir que los PAOs no eran predadores al mismo grado que los OHOs, y en adoptar un enfoque de respiración endógena en la modelación de la pérdida de masa endógena de $\mathrm{PAO}^{4}$.

La baja tasa de depredación en los PAOs, y el hecho de que los PAOs y OHOs esencialmente no compiten por el mismo sustrato, implica que las poblaciones PAO y OHO actúan prácticamente de manera independiente uno del otro en cultivos mixtos "normales" de sistemas con NDEBPR. Desarrollando el modelo, Wentzel et al., (1990) consideró que el análisis de los dos grupos poblacionales podría hacerse de manera separada. Sin embargo, se identificaron dos interacciones relevantes en el reactor anaerobio para incluise en el modelo:

(i) En muchas aguas municipales "normales" el contenido de acetato y otros AGVs es pequeño o no está presente (Wentzel et al., 1988b). Wentzel et al., (1985) mostró que en el reactor anaerobio el componente de $\mathrm{DQO}_{\mathrm{rb}}$ en el afluente es convertido a AGVs por medio de una fermentación ácida que efectuan los OHOs, mediante el cual los AGVs

sistema NDEBPR. La velocidad de muerte de PAOs sería tan alto que una masa significativa de estos organismos no podría acumularse en el sistema, por lo que la eficiencia del EBPR sería cercana a cero. 
quedan disponibles para su acumulación por los PAOs. La tasa de conversión es mucho más lenta que la tasa de almacenamiento de PHA, por lo tanto la tasa de conversión controla la tasa de acumulación. Así, la masa de sustrato AGVs que se está disponible para los PAOs en el reactor anaerobio es determinada por la cinética de conversión mediada por OHOs. El trabajo de Meganck et al., (1985) y de Brodisch, (1985) reafirmó esta hipótesis acerca de esta conversión, ya que demostraron que en los sistemas anaerobio/aerobio se desarrollan organismos que en el reactor anaerobio convierten los azúcares y compuestos similares en AGVs.

(ii) $\mathrm{Si}$ el nitrato (u oxígeno) es recirculado al reactor anaerobio, la $\mathrm{DQO}_{\mathrm{rb}}$ es utilizada preferentemente por los OHOs si hay nitrato (u oxígeno) como aceptor de electrones externo, reduciendo en consecuencia la masa de $\mathrm{DQO}_{\mathrm{rb}}$ convertida a AGVs.

Wentzel et al., (1985) tomó en cuenta los puntos mencionados anteriormente y formuló un modelo cinético de conversión de $\mathrm{DQO}_{\mathrm{rb}}$ a AGVs, y por lo tanto del almacenamiento de dichos AGVs. Posteriormente Wentzel et al., (1990) retomó este modelo de conversión pero tuvo la precaución de incluir situaciones donde los AGVs están presentes en el afluente acotando lo siguiente:

- La DQO $\mathrm{rb}_{\mathrm{rb}}$ necesita subdividirse en dos fracciones, AGVs/DQO rb (ej. acetato) y DQO fermentable/DQO ${ }_{\text {rb }}$ (ej. glucosa). Ambas fracciones serían medidas como $\mathrm{DQO}_{\mathrm{rb}}$ en el bioensayo convencional (ej. Ekama $e t$ al., 1986; Wentzel et al., 1995) y en los experimentos de filtración (ej. Dold et al., 1986; Mamais et al., 1993; Mbewe et al., 1995), por ejemplo:

$D Q O_{r b}=A G V s+D Q O_{\text {fermentable }}$

o, en símbolos

$S_{S}=S_{A G V}+S_{F}$

- La tasa de almacenamiento de AGVs es tan rápida que todo el AGV afluente es secuestrado por los PAOs en el reactor anaerobio para una fracción de masa anaerobia mayor al $10 \%$ y una edad de lodo mayor a 10 días (esto puede ser verificado de la cinética de almacenamiento).

- La DQO fermentable es convertida a AGVs por los OHOs en el reactor anaerobio, y los AGVs resultantes están disponibles para almacenamiento en los PAOs. El modelo para la conversión esta dado por Wentzel et al., (1985).

Esta teoría dio a Wentzel et al. (1990) los medios para calcular la masa del sustrato (AGVs del afuente y la conversión de DQO fermentable) secuestrado por los PAOs en el reactor anaerobio. Sabiendo la masa de sustrato secuestrado por los PAOs, se pudo calcular la masa de sustrato remanente disponible para los OHOs. En efecto, Wentzel et al. (1990) dividió la DQO biodegradable afluente en dos fracciones, una eventualmente para ser utilizada por los PAOs y otra para ser utilizada por los OHOs. Debido a la independencia de acción de estos dos grupos de organismos, ellos pudieron usar:

(i) El modelo simplificado de un cultivo enriquecido de PAOs en estado estacionario para calcular la masa de PAOs activa y endógena formada del sustrato asimilado, y de la liberación, captura y remoción de $P$ mediada por estas masas.

(ii) El modelo de lodos activados en estado estacionario (Marais and Ekama, 1976; WRC, 1984; Capítulo 4) empleado para calcular las biomasas de $\mathrm{OHO}$ activas y endógenas formadas del sustrato remanente, la tasa de conversión de DQO fermentable a AGVs en el reactor anaerobio, los SSV inertes acumulados del afluente, los requerimientos de $\mathrm{P}$, y por lo tanto la remoción de $\mathrm{P}$ asociada con las biomasas activa, endógena e inerte. Se debe aclarar que en el modelo de lodos activados, el decaimiento endógeno es simulado usando el enfoque clásico de respiración endógena. Este enfoque es más simple y bajo condiciones de estado estable brinda resultados muy cercanos al cálculo de regeneración por muerte.

La remoción total de $\mathrm{P}$ para el sistema fue calculado mediante la suma de remociones individuales de $\mathrm{P}$.

Wentzel et al., (1990) comparó la habilidad de predicción del modelo con EBPR de un cultivo mixto en estado estacionario contra las observaciones realizadas en 30 sistemas con NDEBPR a escala laboratorio a lo largo de seis años. Las configuraciones fueron Phoredox, Bardenpho Modificado de 3 etapas, UCT, UCT Modificado y Johannesburgo con una edad de lodos que varió de 3 a 28 días. En esta evaluación, el nitrato medido en la recirculación a la zona anaerobia fue usado para estimar la remoción de DQO fermentable en la zona anaerobia por los OHOs usando nitrato como aceptor externo de electrones. $\mathrm{La}$ DQO fermentable remanente estuvo disponible para la 
conversión a AGVs en el reactor anaerobio, para su posterior almacenamiento como PHA por los PAOs. Las gráficas de las Figuras 7.16 a 7.18 muestran los valores calculados respecto a los medidos en cuanto a la liberación de $\mathrm{P}$, remoción de $\mathrm{P}$ y concentración de SSV, los cuales mostraron una buena correlación.

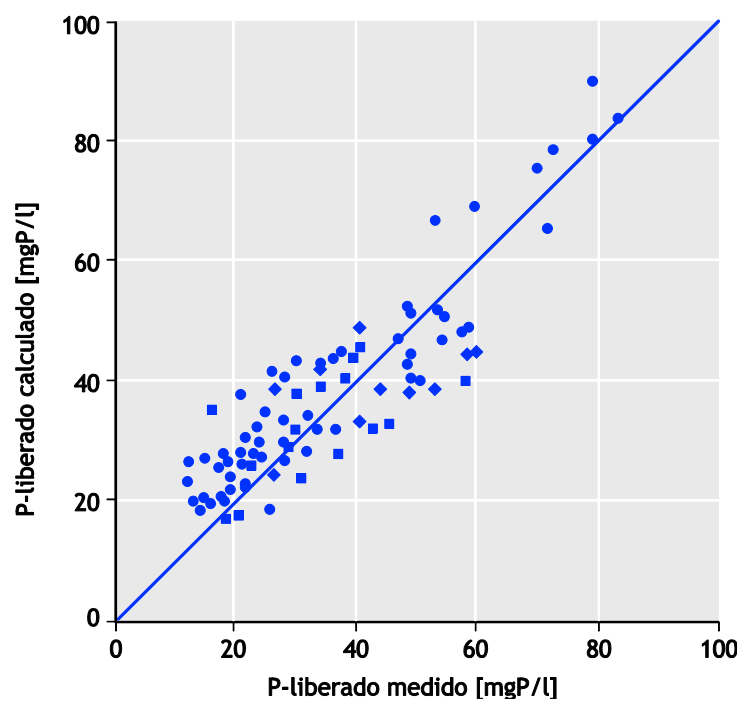

Figura 7.16 Liberación de $\mathrm{P}$ calculada contra medida en diferentes configuraciones de sistemas EBPR con TRS de 3 a 28 días (basado en Wentzel et al., 1990)

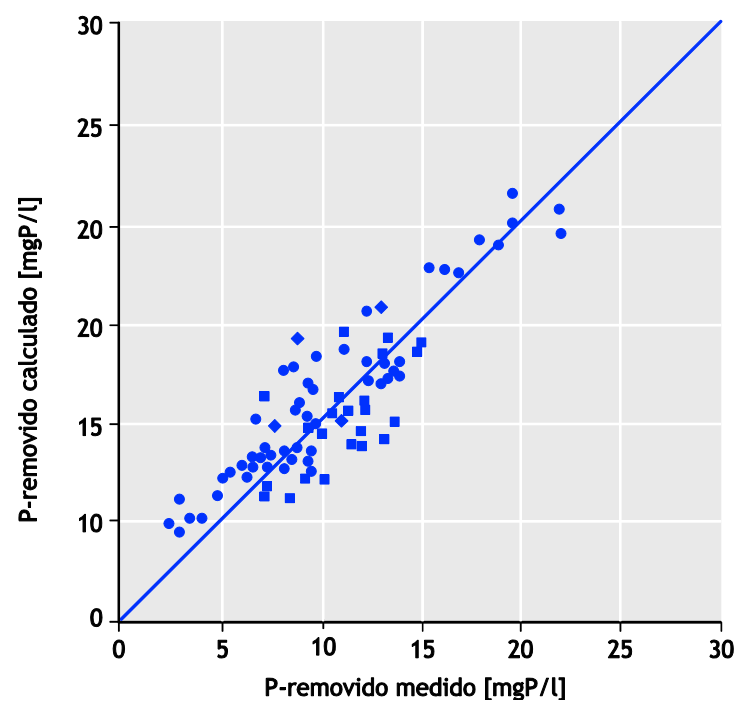

Figura 7.17 Remoción de P calculado contra medido en diferentes configuraciones de sistemas EBPR con TRS de 3 a 28 días (basado en Wentzel et al., 1990)

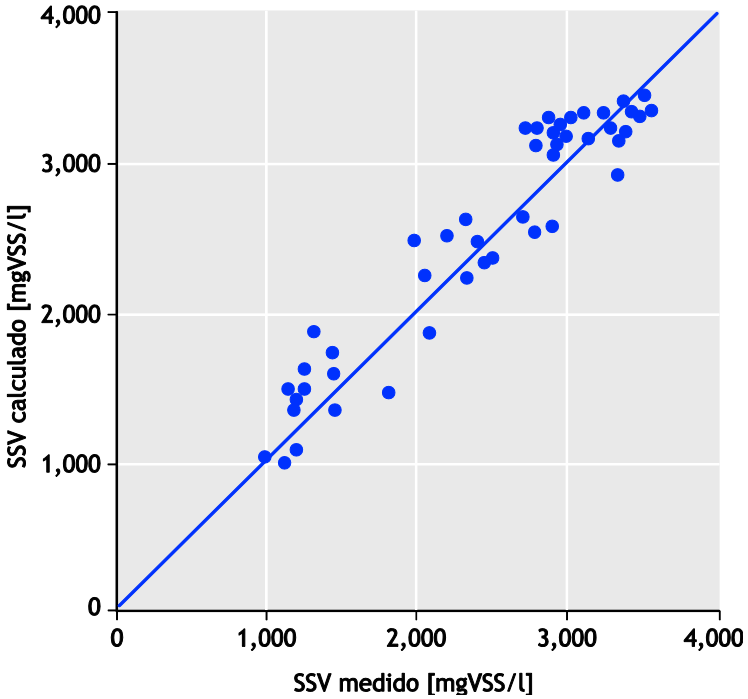

Figura 7.18 Concentración de SSV calculada contra medida en diferentes configuraciones de sistemas EBPR con TRS de 3 a 28 días (basado en Wentzel et al., 1990)

\subsubsection{Incorporación de aspectos de la desnitrificación en modelos para cultivos mixtos en estado estacionario}

En las predicciones de la concentración de $\mathrm{P}$ en configuraciones operando en un régimen estacionario empleando el modelo para cultivo mixto (Figuras 7.16 a 7.18), necesariamente el nitrato recirculado al reactor anaerobio necesita ser conocido, y así es como está disponible para observaciones experimentales en sistemas con NDEBPR. Claramente, para completar el modelo la desnitrificación tiene que ser incorporada en el modelo de cultivo mixto en condiciones estacionarias, un aspecto que estaba omitido hasta esta fase. Una posibilidad para lograr esto fue estimar el nitrato en la recirculación del reactor anaerobio usando la teoría de desnitrificación para el modelo ND en condiciones estacionarias (Ekama et al., 1983; WRC, 1984, Capítulo 5). Datos experimentales indicaron que el modelo ND en condiciones estacionarias predijo de manera muy precisa la desnitrificación en sistemas con NDEBPR. Sin embargo, con el desarrollo de la teoría para sistemas EBPR se evidenció una incosistencia de la aplicación del modelo ND a sistemas NDEBPR en condiciones estacionarias:

Los cultivos enriquecidos en los estudios de Wentzel et al., (1989a) indicaron que los PAOs que cultivó no desnitrificaban. Esto implicó que la $\mathrm{DQO}_{\mathrm{rb}}$, convertida a AGVs por OHOs y secuestrada por PAOs en el reactor anaerobio no estuvo disponible para la desnitrificación en 
el reactor anóxico primario en el sistema de NDEBPR. Esto a su vez implicó que la magnitud de la desnitrificación en el reactor anóxico primario del sistema con NDEBPR necesitaba ser significativamente más pequeña que el reactor anóxico primario del sistema ND. Sin embargo, observaciones experimentales en sistemas con NDEBPR indicaron que esto no era así, y que aproximadamente la misma magnitud de desnitrificación era alcanzada. Lo anterior implicó que la cinética de desnitrificación para sistemas ND necesitaron ser adaptados o modificados para su aplicación en sistemas con NDEBPR.

Usando reactores anóxicos en flujo pistón y experimentos por lote, Clayton et al., $(1989,1991)$ inició una investigación experimental de la cinética de desnitrificación en sistemas con NDEBPR. Se encontró que para sistemas de NDEBPR:

- En el reactor anóxico primario, (i) la alta tasa de desnitrificación asociada con la $\mathrm{DQO}_{\mathrm{rb}}$ fue muy baja o ausente, (ii) la tasa baja de desnitrificación asociada con la DQO $\mathrm{lb}_{\mathrm{b}}$ fue aproximadamente 2.5 veces de la tasa medida en el reactor anóxico primario de sistemas ND.

- En el reactor anóxico secundario, la tasa de desnitrificación fue aproximadamente 1.5 veces la tasa medida en reactores anóxicos secundarios de sistemas ND.

De un extensivo cuestionamiento acerca de las causas, Clayton et al. $(1989,1991)$ concluyó que el aumento en la tasa de desnitrificación se debió a:

- Desnitrificación por PAOs - para los sistemas investigados, las mediciones de PHA y $\mathrm{P}$ indicaron que los PAOs no desnitrifican.

- Modificación del agua residual en la zona anaerobia - el agua residual que no haya pasado a través de la zona anaerobia induce la misma respuesta de desnitrificación que un agua residual que haya pasado a través de la zona anaerobia.

Estas observaciones llevaron a Clayton et al. (1989, 1991) a concluir que el incremento en la tasa se debía a la de un aumento en la tasa de hidrólisis de DQO reactores anóxicos de sistemas con NDEBPR debido a alguna estimulación en el lodo activado, aparentemente inducidos por la presencia del reactor anaerobio en estos sistemas.

\subsection{MODELO DE CULTIVOS MIXTOS EN ESTADO ESTACIONARIO}

\subsubsection{Principios del modelo}

El principio fundamental del modelo de cultivo mixto en condiciones en estado estacionarias consiste en dividir el lodo activado en tres diferentes grupos:

1. ANOs, los organismos nitrificantes

2. OHOs, los organismos heterótrofos ordinarios y

3. PAOs, los organismos acumuladores de fósforo

Después, conociendo el contenido de $\mathrm{P}$ en las diferentes fracciones del lodo (activo, endógeno e inerte) correspondientes a cada grupo poblacional, la remoción de P para cada fracción puede ser calculada. Finalmente la remoción de $\mathrm{P}$ en el sistema puede ser obtenida por medio de la suma de las remociones de $\mathrm{P}$ individuales.

Los procedimientos para la cuantificación de los ANOs que se presentaron en el Capítulo 5 pueden utilizarse sin modificaciones en cuanto a la nitrificación y desnitrificación de sistemas con EBPR. Pero la fracción de masa no aireada $\left(\mathrm{f}_{\mathrm{AN}}\right)$ sí debe ser extendida para incluir tanto los reactores anóxicos como anaerobios. Debido a la relativamente pequeña contribución que los ANOs hacen a la masa de lodo $(<3 \%)$, la remoción de $\mathrm{P}$ debido a este grupo poblacional puede ser despreciado.

Con respecto a los OHOs y PAOs, el principio es separar la DQO biodegradable entre los dos grupos poblacionales y calcular las masas que resultan de las dos fracciones de DQO (Figuras 7.10 y 7.19). Una vez conocido el contenido de $\mathrm{P}$ en cada masa, la remoción de $\mathrm{P}$ puede ser calculado. Los procedimientos para la cuantificación de OHOs (incluida la masa inerte) han sido presentados en el Capítulo 4; estos pueden ser aplicados para sistemas de EBPR con nitrificación y desnitrificación, pero necesitan ser modificados para considerar la reducción de DQO biodegradable debido al almacenamiento de DQO por los PAOs, como se muestra más adelante. En esta sección, los procedimientos serán presentados para la cuantificación de PAOs y OHOs, así como para dividir la DQO biodegradable entre PAOs y OHOs.

La relación entre el flujo de los componentes de DQO biodegradable afluente, su destino en el sistema de tratamiento, y la biomasa activa producida, es ilustrada en la Figura 7.20 y explicada en las siguientes secciones. La biomasa de lodo está compuesta por fracciones 


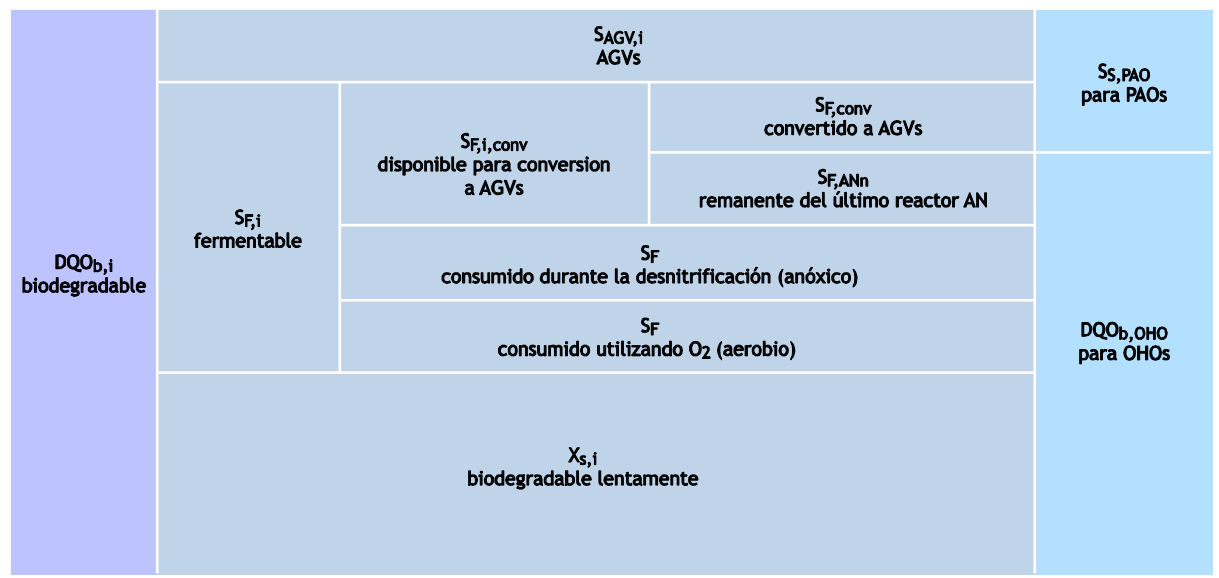

Figura 7.19 División de la DQO biodegradable afluente entre PAOs y OHOs

particuladas activas e inactivas. Las fracciones activas incluyen componentes de biomasa de PAOs, OHOs y otras biomasas como las de los organismos nitrificantes, los cuales no necesitan ser calculados en este ejemplo de diseño. Los componentes inactivos incluyen partículas inertes provenientes del afluente (orgánicos e inorgánicos), así como residuos particulados endógenos generados debido al decaimiento celular.

\begin{tabular}{|c|c|c|c|}
$\begin{array}{c}\text { Componente } \\
\text { afluente } \\
\text { [gDQO/m }\end{array}$ & $\begin{array}{c}\text { Flujo de } \\
\text { componente } \\
\text { afluente } \\
\text { [gDQO/d] }\end{array}$ & $\begin{array}{c}\text { Biomasa activa } \\
\text { producida } \\
\text { (parcial) } \\
\text { [gSSVa/d] }\end{array}$ & $\begin{array}{c}\text { Biomasa activa } \\
\text { presente en el } \\
\text { sistema de tratamiento } \\
\text { [gSSVa] }\end{array}$ \\
\hline$X_{S, i} Q_{i}=F X_{S, i} \frac{Y_{O H O}}{\left(1+b_{O H O, T} T R S\right)}=Y_{O H O, o b s} F X_{S, i}=M X_{O H O} / T R S$ \\
\hline $\begin{array}{c}\text { Caudal } \\
\text { afluente } \\
{\left[\mathrm{m}^{3} / \mathrm{d}\right]}\end{array}$ & $\begin{array}{c}\text { Coeficiente de } \\
\text { rendimiento } \\
\text { observado } \\
\text { [(gSSVa/gDQO }\end{array}$ & $\begin{array}{c}\text { Tiempo de } \\
\text { residencia } \\
\text { de sólidos } \\
\text { [d] }\end{array}$ \\
\hline
\end{tabular}

Figura 7.20 Relaciones entre los componentes afluentes, flujo, así como biomasa producida y presente en el sistema

\subsubsection{Ecuaciones másicas}

\subsubsection{PAOs}

Biomasa activa:

$$
M X_{P A O}=\frac{Y_{P A O}}{\left(1+b_{P A O, T} T R S\right)} F S_{S, P A O} T R S
$$

donde:

MXPAO masa activa de los PAO [gSSVa]

$Y_{\mathrm{PAO}} \quad$ rendimiento celular de los PAOs

$$
\text { [gSSVa/gDQO] }
$$

FSs,PAO masa de sustrato almacenado diariamente por los PAOs en el reactor anaerobio [gDQO/d]
ВРAO,T tasa específica de decaimiento endógeno PAO a temperatura T [gSSVe/gSSV.d]

TRS edad de lodo [d]

Masa endógena:

$M X_{E, P A O}=f_{X E, P A O} b_{P A O, T} M X_{P A O} T R S$

donde:

MXE,PaO masa endógena PAO [gSSVe]

$\mathrm{f}_{\mathrm{XE}, \mathrm{PAO}} \quad$ fracción de residuo endógeno particulado de PAOs [gSSVe/gSSVa]

\subsubsection{OHOS}

Biomasa activa:

$M X_{\mathrm{OHO}}=\frac{Y_{\mathrm{OHO}}}{\left(1+b_{\mathrm{OHO}, \mathrm{T}} T R S\right)} F D Q O_{b, \mathrm{OHO}} T R S$

donde:

МХоно biomasa activa $\mathrm{OHO}$ [gSSVa]

$\mathrm{FDQO}_{\mathrm{b}, \mathrm{OHO}}$ masa de sustrato biodegradable disponible por día para OHOs [gDQO/d]

$=\mathrm{FDQO}_{\mathrm{b}, \mathrm{i}}-\mathrm{FS}_{\mathrm{S}, \mathrm{PAO}}$

FDQO $_{b, \mathrm{i}} \quad$ masa de DQO biodegradable afluente por día $[\mathrm{gDQO} / \mathrm{d}]$

$=\mathrm{FDQO}_{\mathrm{i}}\left(1-\mathrm{f}_{\mathrm{SI}}-\mathrm{f}_{\mathrm{XI}}\right)$

Үоно rendimiento de OHOs [gSSVa/gDQO]

bоно,т tasa específica de decaimiento endógeno de $\mathrm{OHO}$ a temperatura $\mathrm{T}\left[\mathrm{d}^{-1}\right]$

Masa endógena:

$$
M X_{E, \mathrm{OHO}}=f_{X E, \mathrm{OHO}} b_{\mathrm{OHO}, \mathrm{T}} M X_{\mathrm{OHO}} T R S
$$


donde:

$\mathrm{MX}$ E,оно masa de residuo endógeno en el sistema [gSSVe]

fXE,OHO fracción de residuo endógeno particulado de OHOs [gSSVe/gSSVa]

\subsubsection{Masa inerte}

Materia orgánica inerte del afluente que se acumula en el sistema:

$$
M X_{I}=\frac{f_{X I, D Q O, i} F D Q O_{i} T R S}{f_{C V}}
$$

donde:

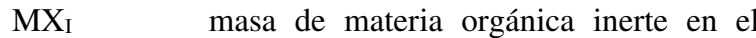
sistema que proviene del afluente [gSSVi]

$f_{X I, D Q O}$,i fracción de DQO afluente que es particulado inerte

$\mathrm{FDQO}_{\mathrm{i}} \quad$ masa diaria de DQO total afluente

\subsubsection{División de DQO biodegradable entre PAOs y OHOs}

De los mecanismos de EBPR (Sección 7.3), sólo el sustrato AGVs puede ser almacenado por los PAOs en el reactor anaerobio. De esta manera, la $\mathrm{DQO}_{\mathrm{rb}}$ afluente $\left(\mathrm{S}_{\mathrm{S}, \mathrm{i}}\right)$ necesita ser subdividida en dos fracciones, llamadas AGVs $\left(S_{A G V, i}\right)$ y DQO fermentable $\left(S_{F, i}\right)$. Por lo que, $S_{S, i}$ $=\mathrm{S}_{\mathrm{AGV}, \mathrm{i}}+\mathrm{S}_{\mathrm{F}, \mathrm{I}}$

Los $\mathrm{AGV}$ s en el afluente $\left(\mathrm{S}_{\mathrm{AGV}, \mathrm{i}}\right)$ están directamente disponibles para su almacenamiento por los PAOs en el reactor anaerobio. Wentzel et al. (1985) demostró que el componente fermentable $\left(\mathrm{S}_{\mathrm{F}, \mathrm{i}}\right)$ es convertido a AGVs en el reactor anaerobio por los $\mathrm{OHOs,}$, produciendo AGVs adicionales que están disponibles para su almacenamiento por PAOs. La tasa de conversión es mucho menor que la tasa de almacenamiento, por lo que la tasa de conversión controla la tasa de almacenamiento de los AGVs generados. Por lo tanto, la masa del sustrato AGV que se vuelve disponible en el reactor anaerobio es gobernada por la cinética de conversión y por la masa del sustrato AGV presente en el afluente. Si hay AGVs presentes en el afluente, se puede asumir que todos estos AGVs se pueden almacenar en el reactor anaerobio por los PAOs.

\subsubsection{Cinética de conversión de orgánicos fermentables a AGVs}

El modelo de conversión propuesto por Wentzel et al. (1985) hipotetiza que:
- Sólo la DQO fermentable $\left(\mathrm{S}_{\mathrm{F}}\right)$ puede ser convertida a un compuesto adecuado para su almacenamiento en los PAOs (ej. AGVs). El tiempo requerido para convertir la DQO lentamente biodegradable $\left(\mathrm{X}_{\mathrm{S}}\right)$ a AGVs se asume como despreciable (ver Sección 7.3.6.1) comparado con el tiempo de residencia del licor mezclado en el reactor anaerobio.

- La conversión es mediada por la masa de OHOs en el reactor anaerobio.

- Todos los AGVs generados de la conversión de DQO fermentable son inmediatamente almacenados por los PAOs.

- Toda la DQO fermentable no convertida a AGVs en el reactor anaerobio es utilizada subsecuentemente por el metabolismo de los OHOs.

- La tasa de conversión de la DQO fermentable se puede obtener como:

$\frac{d S_{F, A N}}{d t}=-k_{F, T} S_{F, A N} X_{O H O, A N}$

donde:

$\mathrm{dS}_{\mathrm{F}, \mathrm{AN}} / \mathrm{dt}$ tasa de conversión de compuestos orgánicos fermentables [gDQO $\mathrm{m}^{3} / \mathrm{d}$ ]

$\mathrm{k}_{F, \mathrm{~T}} \quad$ tasa de fermentación de primer orden a una temperatura T. A $20^{\circ} \mathrm{C}=0.06$ [ $\left.\mathrm{m}^{3} / \mathrm{gSSV} . \mathrm{d}\right]$

$\mathrm{S}_{\mathrm{F}, \mathrm{AN}} \quad$ concentración de DQO fermentable en el reactor anaerobio $\left[\mathrm{gDQO} / \mathrm{m}^{3}\right]$

$\mathrm{X}_{\mathrm{OHO}, \mathrm{AN}}$ concentración de $\mathrm{OHOs}$ en el reactor anaerobio $\left[\mathrm{gSSVa} / \mathrm{m}^{3}\right]$

- Todos los AGVs presentes en el afluente del reactor anaerobio serán almacenados inmediatamente por PAOs.

\subsubsection{Efecto de la recirculación de nitrato u oxígeno}

Si el nitrato u oxígeno entran al reactor anaerobio a través de la recirculación o con el afluente, la conversión de DQO fermentable a AGVs se complica. Se asume que el oxígeno o nitrato que entre al reactor anaerobio será utilizado como aceptor de electrones por los OHOs, los cuales usarán la DQO $\mathrm{O}_{\mathrm{rb}}\left(\mathrm{S}_{\mathrm{s}}\right)$ como donante de electrones (sustrato). No es claro qué sustrato, la DQO fermentable o los AGVs afluente, será usado de manera preferente como donante de electrones. Para la modelación de cultivos mixtos en condiciones estacionarias se asume que la DQO fermentable afluente servirá como donante de electrones. Esto implica que los AGVs generados por 
la conversión no son más liberados sino metabolizados directamente por los OHOs, hasta que el oxígeno o el nitrato se agotan. En el modelo de conversión esto puede ser ajustado por medio de la reducción de la cantidad de DQO fermentable para conversión, como sigue:

$$
\begin{aligned}
& S_{F, i, c o n v}=S_{F, i}-8.6\left(s S_{N O 3, s}+S_{N O 3, i}\right) \\
& -3.0\left(s S_{O 2, s}+S_{O 2, i}\right)
\end{aligned}
$$

donde:

$\mathrm{S}_{\mathrm{F}, \mathrm{i}, \mathrm{conv}}$

DQO fermentable disponible para conversión por volumen de afluente $\left[\mathrm{gDQO} / \mathrm{m}^{3}\right.$ ]

$\mathrm{S}_{\mathrm{F}, \mathrm{i}} \quad$ DQO fermentable afluente $\left[\mathrm{gDQO} / \mathrm{m}^{3}\right.$ ]

$\mathrm{s} \quad$ factor de recirculación de lodos al reactor anaerobio basado en el caudal afluente

$\mathrm{S}_{\mathrm{NO3,s}} \quad$ concentración de nitrato en la línea de recirculación de lodo al reactor anaerobio $\left[\mathrm{gNO}_{3}-\mathrm{N} / \mathrm{m}^{3}\right]$

So2,s concentración de oxígeno en la línea de recirculación de lodo al reactor anaerobio $\left[\mathrm{gO}_{2} / \mathrm{m}^{3}\right]$

$\mathrm{S}_{\mathrm{NO} 3, \mathrm{i}} \quad$ concentración de nitrato en el afluente al reactor anaerobio $\left[\mathrm{gNO}_{3}-\mathrm{N} / \mathrm{m}^{3}\right.$ ]

$\mathrm{S}_{\mathrm{O} 2, \mathrm{i}} \quad$ concentración de oxígeno en el afluente al reactor anaerobio $\left[\mathrm{O}_{2} / \mathrm{m}^{3}\right]$

8.6 masa de DQO removida por unidad de nitrato desnitrificado $\left[\mathrm{gDQO} / \mathrm{gNO}_{3}-\mathrm{N}\right]$;

$2.86 /\left(1-\mathrm{f}_{\mathrm{CV}} \cdot \mathrm{Y}_{\mathrm{OHO}-\mathrm{SSV}}\right)=$ $2.86 /(1-1.48 \cdot 0.45)=8.6$

3.0 Masa de DQO removida por unidad de oxígeno utilizado $\left[\mathrm{gDQO} / \mathrm{gO}_{2}\right]$;

$$
1 /\left(1-\mathrm{f}_{\mathrm{CV}} \cdot \mathrm{Y}_{\mathrm{OHO}} \mathrm{Ssv}\right)=
$$$$
1 /(1-1.48 \cdot 0.45)=3.0
$$

\subsubsection{Ecuaciones de conversión en condiciones de estado estacionario}

Las ecuaciones en estado estacionario para la conversión de DQO fermentable a AGVs pueden ser desarrolladas aplicando las Eqs. 7.7 y 7.8 en el balance de masa del reactor anaerobio (n) de una serie de $n$ reactores anaerobios de igual volumen. Estos rendimientos permiten calcular en la ecuación la concentración de la DQO efluente del reactor anaerobio (n):

$$
S_{F, A N n}=\frac{S_{F, i, \text { conv }} /(1+s)}{\left[1+k_{F, T} \frac{f_{A N}}{N} \frac{M X_{O H O}}{Q_{i}(1+s)}\right]^{n}}
$$

donde:

$\mathrm{S}_{\mathrm{F}, \mathrm{ANn}} \quad$ concentración de DQO fermentable en el efluente del reactor anaerobio (n) $\left[\mathrm{gDQO} / \mathrm{m}^{3}\right.$ ]

$\mathrm{f}_{\mathrm{AN}} \quad$ fracción de masa anaerobia [gSSV/gSSV]

$\mathrm{N}$ número total de reactores anaerobios en serie de igual volumen $\mathrm{n}=1,2 \ldots . \mathrm{N}$

MXоно masa de OHOs en todo el sistema de NDEBPR [gSSVa]

$\mathrm{Q}_{\mathrm{i}} \quad$ caudal afluente $\left[\mathrm{m}^{3} / \mathrm{d}\right]$

La Ec. 7.9 permite calcular la DQO fermentable convertida en $\mathrm{AGV}$ en una serie de $n$ número de reactores anaerobios, por ejemplo:

$F S_{F, C O N V}=Q_{i}\left[S_{F, i, c o n v}-(1+s) S_{F, A N n}\right]$

donde:

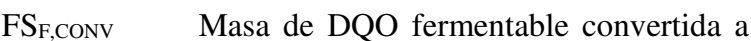
$\mathrm{AGV}$ en los reactores anaerobios por día $[\mathrm{gDQO} / \mathrm{d}]$

Sin embargo, para calcular la $S_{\mathrm{F}, \mathrm{ANn}}$, el término $\mathrm{MX}$ оно/ $\mathrm{Q}_{\mathrm{i}}$ necesita ser determinado.

Ahora, $\mathrm{MX}_{\mathrm{оно}}$ son sintetizados de la masa total de DQO biodegradable afluente menos la masa de DQO almacenadas por los PAOs. De los mecanismos de EBPR y la hipótesis de conversión, todos los AGVs generados por conversión y todos los AGVs en el afluente son almacenados por los PAOs, por lo tanto la masa de DQO

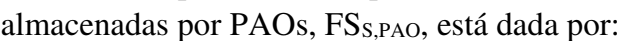

$$
\begin{aligned}
F S_{S, P A O} & =F S_{F, C O N V}+Q_{i} S_{A G V, i} \\
F S_{S, P A O} & =Q_{i}\left[S_{F, i, c o n v}-(1+s) S_{F, A N n}\right] \\
& +Q_{i} S_{A G V, i}
\end{aligned}
$$

donde:

$\mathrm{FS}_{\mathrm{S}, \mathrm{PAO}}$ masa diaria de $\mathrm{S}_{\mathrm{S}}$ almacenada por los PAOs $[\mathrm{gDQO} / \mathrm{d}]$

La DQO disponible para OHOs es la DQO biodegradable no almacenada por los PAOs:

$$
F D Q O_{b, \text { ОНО }}=F D Q O_{b, i}-F S_{S, P A O}
$$

donde:

FDQO para los OHOs al día [gDQO/d] 
De esta manera, como se mencionó anteriormente la ecuación para estimar la masa ordinaria de los organismos heterótrofos considera la reducción de DQO disponible:

$$
M X_{\mathrm{OHO}}=\frac{Y_{\mathrm{OHO}}}{\left(1+b_{\mathrm{OHO}, \mathrm{T}} T R S\right)} F D Q O_{b, \mathrm{OHO}} T R S
$$

La producción de OHOs puede ser también expresado como la masa sintetizada por volumen de afluente mediante la sustitución de las Eqs. 7.12 y 7.13 en Ec. 7.14a y dividiéndolo entre el caudal afluente:

$$
\begin{aligned}
\frac{M X_{O H O}}{Q_{i}}= & \frac{Y_{H}}{\left(1+b_{O H O, T} T R S\right)} \cdot \\
& \cdot\left[\left(D Q O_{b, i}-S_{F, i, \text { conv }}+(1+s) S_{F, A N n}+S_{V F A, i}\right)\right] \\
& \cdot T R S
\end{aligned}
$$

donde:

$\mathrm{MX}_{\mathrm{OHO}} / \mathrm{Q}_{\mathrm{i}}$ concentración equivalente de $\mathrm{OHOs}$ producidos por volumen de afluente $\left[\mathrm{gSSVa} / \mathrm{m}^{3}\right]$

Las Eqs. 7.9 y 7.14a necesitan ser resueltas simultáneamente para calcular la concentración de DQO fermentable $\left(\mathrm{S}_{\mathrm{F}, \mathrm{ANn}}\right)$ que sale del último reactor anaerobio $(\mathrm{ANn})$. El siguiente procedimiento iterativo puede ser usado:

- Asumir que $\mathrm{S}_{\mathrm{F}, \mathrm{ANn}}=0 \mathrm{mgDQO} / \mathrm{l}$.

- Calcular MXоно usando Ec. 7.14a.

- Usar el valor calculado para MXоно, y calcular $\mathrm{S}_{\mathrm{F}, \mathrm{ANn}}$ de la Ec. 7.9.

- Recalcular MXоно usando el valor $\mathrm{S}_{\mathrm{F}, \mathrm{ANn}}$ calculado.

- Repetir los dos últimos pasos hasta que $\mathrm{S}_{\mathrm{F}, \mathrm{ANn}} \mathrm{y}$ МХоно sean constantes.

Se pueden derivar ecuaciones similares para simular el comportamiento de PAOs desnitrificantes (DPAOs) para condiciones anóxicas. La interacción con PAOs estrictamente aerobios y desnitrificadores ordinarios requere que la cinética de consumo de sustrato y almacenamiento de cada grupo de microorganismos sea considerada, lo cual es una tarea que puede ser ejecutada mejor usando modelos computacionales que pueden ser programados y ahora están comercialmente disponibles.

\subsubsection{Implicaciones de la teoría de conversión}

La teoría de conversión planteada anteriormente permite calcular la masa de AGVs generada por los OHOs por día. Considerando que todos los AGVs, ya sean producto de la conversión o provenientes del afluente, son almacenados por los PAOs, la masa de sustrato disponible para OHOs es la DQO biodegradable remanente. La DQO biodegradable afluente es dividida en dos fracciones, una para ser utilizada por PAOs y la otra para ser usada por OHOs. Debido a la independencia de acción entre los dos grupos de organismos las ecuaciones establecidas anteriormente (Ec. 7.1 a 7.3) pueden ser aplicadas para calcular la biomasa activa y endógena de PAO, y las ecuaciones del Capítulo 4 para calcular la biomasa activa, endógena e inerte de $\mathrm{OHO}$, debidamente modificadas de las Eqs. 7.4 a 7.6. De esta forma, conociendo el contenido de $\mathrm{P}$ de cada fracción, la remoción de $\mathrm{P}$ debido a cada una de estas puede ser calculada (ver a continuación).

\subsubsection{Liberación de $\mathrm{P}$}

La cuantificación de la liberación de P por parte de los PAOs como resultado del almacenamiento de AGVs no es necesaria para diseñar sistemas EBPR en estado estacionario, pero sí sirve para obtener información útil. De los mecanismos de remoción de $\mathrm{P}$ (Sección 7.3), por cada mol de AGV almacenado por los PAOs, se considera que un mol de $\mathrm{P}$ es liberado (tomando en cuenta que esta relación depende del pH) con el fin de dar la energía necesaria para polimerizar y almacenar los AGVs como PHA. De esta manera, la liberación de P se obtiene como:

$F S_{P O 4, \text { rel }}=f_{P O 4, \text { rel }} F S_{S, P A O}$

donde:

FSPO4,rel masa de P liberada al día por los PAOs $[\mathrm{gP} / \mathrm{d}]$

f $\mathrm{PO4, \text {rel }} \quad$ relación de $\mathrm{P}$ liberado/AGV asimilado $=1.0 \mathrm{molP} / \mathrm{molDQO}$

$=0.5 \mathrm{gP} / \mathrm{gDQO}$

o, en unidades de concentración:

$S_{P O 4, \text { rel }}=f_{P O 4, \text { rel }} \frac{F S_{S, P A O}}{Q_{i}}$

donde:

SPO4,rel P liberado $\left[\mathrm{gP} / \mathrm{m}^{3}\right.$ de afluente $]$ 
S $\mathrm{S}, \mathrm{PAO} \quad$ concentración de $\mathrm{DQO}_{\mathrm{rb}}$ almacenada por los PAOs $\left[\mathrm{gDQO} / \mathrm{m}^{3}\right]$

\subsubsection{Remoción de P y concentración en el efluente de $P$ total}

La remoción de $\mathrm{P}$ es calculada para las fracciones individuales de lodo, la remoción total de $\mathrm{P}$ se obtiene de la suma de remociones individuales de P.

PAOs

$\triangle P P A O=f_{P, P A O} \frac{M X_{P A O}}{T R S} \frac{1}{Q_{i}}$

donde:

$\triangle$ PिAO remoción de $\mathrm{P}$ por PAOs $\left[\mathrm{gP} / \mathrm{m}^{3}\right]$

$f_{P, P A O} \quad$ fracción de $\mathrm{P}$ en la biomasa activa $\mathrm{PAO}=0.38 \mathrm{gP} / \mathrm{gSSVa}$

OHOs

$\triangle \mathrm{P}_{\text {ОНО }}=f_{P, \text { ОНО }} \frac{M X_{\text {ОНО }}}{T R S} \frac{1}{Q_{i}}$

donde:

$\Delta$ Роно remoción de $\mathrm{P}$ por OHOs $\left[\mathrm{gP} / \mathrm{m}^{3}\right]$

$\mathrm{f}_{\mathrm{P}, \mathrm{OHO}} \quad$ fracción de $\mathrm{P}$ en la biomasa activa de los $\mathrm{OHOs}=0.03 \mathrm{gP} / \mathrm{gSSVa}$

Masa de residuo endógeno (de cualquier biomasa incluidos PAOs y OHOs)

$\Delta P_{X E}=f_{P, X E} \frac{\left(M X_{E, P A O}+M X_{E, O H O}\right)}{T R S} \frac{1}{Q_{i}}$

donde:

$\Delta \mathrm{P}_{\mathrm{XE}} \quad$ remoción de $\mathrm{P}$ debido a la masa de residuo endógeno $\left[\mathrm{gP} / \mathrm{m}^{3}\right]$

$\mathrm{f}_{\mathrm{P}, \mathrm{XE}}$ fracción de $\mathrm{P}$ en la masa inerte $[\mathrm{gP} / \mathrm{gSSVe}]=0.03 \mathrm{gP} / \mathrm{gSSVe}$

Masa inerte afluente

$\Delta P_{X I}=f_{P, X I} \frac{M X_{I, i}}{T R S} \frac{1}{Q_{i}}$

donde:

$\Delta \mathrm{P}_{\mathrm{XI}} \quad$ remoción de $\mathrm{P}$ debido a la masa inerte afluente $\left[\mathrm{gP} / \mathrm{m}^{3}\right]$

$\mathrm{f}_{\mathrm{P}, \mathrm{XI}} \quad$ fracción de $\mathrm{P}$ en la masa inerte [gP/gSSVi] $=0.03 \mathrm{gP} / \mathrm{gSSVi}$

La remoción potencial de $\mathrm{P}$ total en el sistema, despreciando la precipitación química de fósforo (típicamente debido a las sales de aluminio, calcio o hierro presentes en el afluente o adicionados al sistema) es:

$\Delta P_{S Y S, P O T}=\Delta P_{P A O}+\Delta P_{O H O}+\Delta P_{X E}+\Delta P_{X I}$

donde:

$\Delta \mathrm{P}_{\text {SYS,POT }} \quad$ remoción potencial de $\mathrm{P}$ total en el sistema $\left[\mathrm{gP} / \mathrm{m}^{3}\right]$

La remoción real de $\mathrm{P}$ en el sistema será el valor más bajo entre la remoción potencial de $\mathrm{P}$ y el P total afluente.

$\Delta P_{S Y S, A C T}=\min \left(\Delta P_{S Y S, P O T} ; T_{P, i}\right)$

donde:

$\Delta \mathrm{P}_{\text {SYS,ACT }}$ remoción real total de $\mathrm{P}$ en el sistema $\left[\mathrm{gP} / \mathrm{m}^{3}\right]$

Cualquier sólido suspendido en el efluente contribuye a incrementar la concentración de fósforo particulado en el efluente

$X_{P, e}=f_{P, S S T} S S T_{e}$

donde:

$\mathrm{f}_{\mathrm{P}, \mathrm{SST}} \quad$ contenido promedio de $\mathrm{P}$ en el lodo activado $\left[\mathrm{gP} / \mathrm{m}^{3}\right]$

$\mathrm{SST}_{\mathrm{e}} \quad$ concentración de sólidos suspendidos totales en el efluente $\left[\mathrm{gSST} / \mathrm{m}^{3}\right]$

La concentración de $\mathrm{P}$ total en el efluente es calculado mediante la sustracción de la remoción actual de $\mathrm{P}$ total del sistema y sumando el P particulado contribuido por los sólidos suspendidos en el efluente

$T_{P, e}=T_{P, i}-\Delta P_{S Y S, A C T}+X_{P, e}$

donde:

$\mathrm{T}_{\mathrm{P}, \mathrm{i}} \quad$ Concentración de $\mathrm{P}$ total en el afluente $\left[\mathrm{gP} / \mathrm{m}^{3}\right]$

$\mathrm{T}_{\mathrm{P}, \mathrm{e}} \quad$ Concentración de $\mathrm{P}$ total en el efluente $\left[\mathrm{gP} / \mathrm{m}^{3}\right]$

\subsubsection{Masa de lodos como SSV y SST, y contenido de $\mathrm{P}$ en los SST}

\subsubsection{Masa de lodo SSV}

La masa de lodos como SSV en el sistema se puede calcular de la misma manera que para los sistemas anóxicos/aerobios, mediante la suma de las contribuciones individuales de las fracciones de SSV, obteniendo: 


$$
\begin{aligned}
M X_{S S V} & =M X_{P A O}+M X_{O H O} \\
& +M X_{E, P A O}+M X_{E, O H O}+M X_{I} \\
M X_{S S V} & =V_{p} S S V
\end{aligned}
$$

donde:

MXssv Masa SSV en el sistema [gSSV]

SSV Concentración SSV en el sistema $\left[\mathrm{gSSV} / \mathrm{m}^{3}\right.$ ]

$\mathrm{V}_{\mathrm{P}} \quad$ Volumen del sistema de proceso $\left[\mathrm{m}^{3}\right]$

Para los sistemas aerobios y anóxicos/aerobios, la masa de lodo (SST) en el sistema es calculado de los SSV por medio de la relación SSV/SST. Sin embargo, para las fracciones de licor mezclado de PAOs, la relación SSV/SST diferirá sustancialmente de los valores de las fracciones de OHOs. Esto es debido al alto valor de poliP inorgánico almacenado internamente por los PAOs, asociados a sus contra-iones. Los contra-iones son requeridos para neutralizar las cargas negativas en el poliP, estabilizándolo de esta manera. Estos contraiones son principalmente $\mathrm{Mg}^{2+}$ y K${ }^{+}$, y en menor medida $\mathrm{Ca}^{2+}$ (Fukase et al., 1982; Arvin et al., 1985; Comeau et al., 1986; Wentzel et al., 1989a).

\subsubsection{Masa de lodo SSF}

Los sólidos suspendidos fijos (inorgánicos) provienen de varias fuentes (Ekama and Wentzel, 2004):

- Componentes intracelulares de la biomasa activa que contienen sales, los cuales permanecen como residuos inorgánicos cuando se realiza una combustión a $550^{\circ} \mathrm{C}$. Se considera una fracción de $0.15 \mathrm{gSSF} / \mathrm{gSSV}$ a para los OHOs. Los organismos nitrificantes tienen una fracción similar que puede ser despreciada ya que normalmente estos microorganismos representan menos del $2 \%$ de la biomasa;

- Los PAOs que contienen tanto la fracción estándar de $0.15 \mathrm{gSSF} / \mathrm{gSSV}$ a más los poliP y contraiones catiónicos que contribuyen considerablemente al contenido de SSF en los PAOs. Para los PAOs aerobios con un contenido de $38 \%$ de $\mathrm{gP} / \mathrm{gSSVa}$, Ekama and Wentzel (2004) reportan un contenido de $\mathrm{SSF}$ de $1.30 \mathrm{gSSF} / \mathrm{gSSVa}$;

- Se considera que los residuos orgánicos endógenos e inertes no contienen inorgánicos como sales, ya que estos se disuelven después de la lisis celular;
- Se considera que la materia orgánica particulada lentamente biodegradable tampoco contiene inorgánicos;

- El SSF afluente se acumula en el lodo activado;

- La precipitation de minerales y disolución de SSF son despreciables. Sin embargo, si se lleva a cabo precipitación química, la acumulación de minerales en el lodo debe considerarse;

Por lo tanto, la masa de lodos de SSF en el sistema se puede expresar como:

$$
\begin{aligned}
M X_{S S F}= & f_{S S F, \text { OHO }} M X_{O H O}+f_{S S F, P A O} M X_{P A O} \\
& +F X_{S S F, i} T R S
\end{aligned}
$$

donde:

MX $X_{\text {sSF }} \quad$ masa de sólidos suspendidos fijos en el sistema $[\mathrm{gSSF}]$

fSSF,OHо fracción de SSF en la biomasa activa de OHOs

$=0.15 \mathrm{gSSF} / \mathrm{gSSVs}$ (dando un fvт,оно de $0.87 \mathrm{gSSV} / \mathrm{gSST}$ )

fFSS,PAO fracción de SSF en la biomasa activa de PAOs

$=1.30 \mathrm{~g} \mathrm{SSF} / \mathrm{gSSV}$ s para PAOs aerobios (dando un fVt,PAO de $0.44 \mathrm{gSSVa} / \mathrm{gSST}$ )

$\mathrm{FX}_{\mathrm{FSS}, \mathrm{i}} \quad$ masa diaria de SSF afluente [gSSF/d]

\subsubsection{Masa de lodos (SST) y relación de SSV/SST}

La masa de SST en el sistema está dada por la suma de los SSV y los SSF:

$M X_{S S T}=M X_{S S V}+M X_{S S F}$

$M X_{S S T}=V_{p} X_{S S T}$

donde:

MXSsT sólidos suspendidos totales en el sistema [gSST]

y la relación de los SSV contra los SST en el lodo:

$f_{V T}=\frac{M X_{S S V}}{M X_{S S T}}$

donde:

$\mathrm{f}_{\mathrm{VT}} \quad$ relación SSV/SST para el lodo. 


\subsubsection{Contenido de P en los SST}

El contenido de fósforo promedio en la biomasa se calcula considerando lo que cada masa contribuye a los SST. La fracción de P en los SSF puede variar de manera significativa dependiendo de las sales de aluminio, hierro y calcio presentes ya sea en el afluente o adicionadas al sistema para lograr una precipitación química del fósforo.

$$
\begin{aligned}
f_{P, S S T}= & \frac{\frac{f_{P, O H O} M X_{O H O}}{f_{V T}}}{M X_{S S T}} \\
+ & \frac{\frac{f_{P, X E}\left(M X_{E, O H O}+M X_{E, P A O}\right)}{f_{V T}}}{M X_{S S T}} \\
+ & \frac{\frac{f_{P, X I} M X_{I, i}}{f_{V T}}}{M X_{S S T}}+\frac{\frac{f_{P, P A O} M X_{P A O}}{f_{V T, P A O}}}{M X_{S S T}} \\
+ & \frac{f_{P, S S F, i} M X_{S S F}}{M X_{S S T}}
\end{aligned}
$$

donde:

fP,SST fracción de $\mathrm{P}$ en los sólidos suspendidos totales $[\mathrm{gP} / \mathrm{gSST}]$

f $\mathrm{P}, \mathrm{SSF} \quad$ fracción de $\mathrm{P}$ en los sólidos suspendidos fijos o inorgánicos $[\mathrm{gP} / \mathrm{gSSF}]$

$=0.02 \mathrm{gP} / \mathrm{gSSF}$ (valor propuesto que requiere de corrección si hay una presencia significativa de coagulantes de $\mathrm{P}$, como son las sales de $\mathrm{Al}, \mathrm{Fe}, \mathrm{o} \mathrm{Ca}$ ).

\subsubsection{Requerimiento de volumen de proceso}

Como fue descrito en el Capítulo 4, los requerimientos de volumen de proceso son determinados a partir de la masa de lodo en el sistema y la selección de la concentración de lodo deseada, ya sea en términos de SST o SSV:

$$
V_{P}=M X_{S S T} / X_{S S T, O X}
$$

donde:

$\mathrm{V}_{\mathrm{P}} \quad$ volumen del reactor $\left[\mathrm{m}^{3}\right]$

$\mathrm{X}_{\mathrm{TSS}, \mathrm{OX}} \quad$ concentración seleccionada de SST para el reactor aerobio $\left[\mathrm{gSST} / \mathrm{m}^{3}\right]$

o, de forma alterna:
$V_{P}=M X_{S S V} / X_{S S V, O X}$

donde:

Xssv,ox concentración seleccionada de SSV para el reactor aerobio $\left[\mathrm{gSSV} / \mathrm{m}^{3}\right]$

El requerimiento de volumen de proceso $\left(\mathrm{V}_{\mathrm{P}}\right)$ es el volumen efectivo; es decir, el volumen que sería requerido si el lodo tuviera una concentración uniforme en todo el sistema. En algunas configuraciones de NDEBPR esto no es así ya que las concentraciones de lodo varían en las diferentes zonas. Por ejemplo, la concentración de lodo en la zona anaerobia en la configuración UCT/MUCT se reduce en un factor s/(1+ s) comparado con otras zonas (anóxica y aerobia). En estos casos el volumen debe ser ajustado para tomar en cuenta esto.

\subsubsection{Requerimientos de nitrógeno para la producción de lodo}

La forma de la ecuación para calcular los requerimientos de nitrógeno para la producción de lodo es:

$F N_{\text {sintesis }}=f_{N, S S V} M X_{S S V} / T R S$

donde:


producción de lodo [gN/d]

$\mathrm{f}_{\mathrm{N}, \mathrm{SSV}} \quad$ contenido de nitrógeno en el lodo $=0.10 \mathrm{gN} / \mathrm{gSSV}$

Sin embargo, el término MXssv en el sistema con EBPR necesita considerar los cambios en los constituyentes de SSV, los cuales son calculados usando la Ec. $7.24 \mathrm{a}$.

El requerimiento de nitrógeno para la producción de lodo expresado en base a la concentración afluente es:

$N T K_{i, \text { sintesis }}=F N_{\text {sintesis }} / Q_{i}$

\subsubsection{Demanda de oxígeno}

\subsubsection{Demanda carbonácea de oxígeno}

La demanda carbonácea de oxígeno $\left(\mathrm{FO}_{2, \mathrm{C}}\right)$ está dada por la suma de las demandas de oxígeno de los PAOs y los OHOs. Desde el punto de vista del balance de masa de la DQO, cualquier DQO removida que no es convertida a biomasa o residuo endógeno es consumida para producción de energía. Por ejemplo, 1 unidad de DQO 
biodegradable (DQOb; como $\mathrm{S}_{\mathrm{VFA}}$ ) removida producirá ( $f_{\mathrm{CV}} \cdot \mathrm{Y}_{\mathrm{PAO}}$ ) unidades de $\mathrm{X}_{\mathrm{PAO}}$ con la energía obtenida de la respiración de $\left(1-\mathrm{f}_{\mathrm{CV}} \bullet \mathrm{Y}_{\mathrm{PAO}}\right)$ unidades de DQOb. El factor $\mathrm{f}_{\mathrm{CV}}$ (gDQO-biomasa activa/gSSV-biomasa activa) es usada para convertir las unidades de Y biomasa activa/gDQO-sustrato en gDQO-biomasa activa/gDQO-sustrato. Por lo tanto, 1 unidad de DQO equivale a $\left(\mathrm{f}_{\mathrm{CV}} \cdot \mathrm{Y}_{\mathrm{PAO}}+1-\mathrm{f}_{\mathrm{CV}} \cdot \mathrm{Y}_{\mathrm{PAO}}\right)$ y el balance de DQO se mantiene.

\section{Demanda de oxígeno para PAOs}

La demanda de oxígeno para PAOs proviene de la respiración, la cual brinda energía para la síntesis de biomasa y para la respiración endógena.

$$
\begin{aligned}
F O_{2, P A O} & =F O_{2, P A O \text { sintesis }} \\
& +F O_{2, \text { PAO respiración_endógena }} \\
F O_{2, P A O}= & \left(1-f_{C V} Y_{P A O}\right) F S_{S, P A O} \\
& +f_{C V}\left(1-f_{E, P A O}\right) b_{P A O, T} M X_{P A O}
\end{aligned}
$$

o más explícitamente, como una función de la masa diaria de sustrato almacenada por PAOs

$$
\begin{aligned}
F O_{2, P A O} & =F S_{S, P A O}\left[\left(1-f_{C V} Y_{P A O}\right)\right] \\
& +\left[\begin{array}{c}
f_{C V}\left(1-f_{X E, P A O}\right) b_{P A O, T} \\
\cdot \frac{Y_{P A O}}{\left(1+b_{P A O, T} T R S\right)} T R S
\end{array}\right]
\end{aligned}
$$

donde:

$\mathrm{FO}_{2, \mathrm{PAO}}$ masa diaria de oxígeno consumido por PAOs $\left[\mathrm{gO}_{2} / \mathrm{d}\right]$

$\mathrm{f}_{\mathrm{CV}}$ relación DQO/SSV en el lodo [gDQO/gSSV]

Demanda de oxígeno por OHOs

De la misma manera, para OHOs:

$$
\begin{aligned}
\mathrm{FO}_{2, \mathrm{OHO}}= & F \mathrm{O}_{2, \mathrm{OHO} \text { síntesis }} \\
& +\mathrm{FO}_{2, \mathrm{OHO} \text { respiración_endógena }} \\
\mathrm{FO}_{2, \mathrm{OHO}}= & \left(1-f_{\mathrm{CV}} Y_{\mathrm{OHO}}\right) F D Q O_{b, \mathrm{OHO}} \\
& +f_{\mathrm{CV}}\left(1-f_{\mathrm{E}, \mathrm{OHO}}\right) b_{\mathrm{OHO}, \mathrm{T}} \mathrm{MX} \mathrm{OHO}_{\mathrm{OHO}}
\end{aligned}
$$

o más explícitamente, como una función de la masa diaria de sustrato almacenada por OHOs

$$
\begin{aligned}
\mathrm{FO}_{2, \mathrm{OHO}}= & F D Q O_{b, \mathrm{OHO}}\left[\left(1-f_{\mathrm{CV}} \mathrm{Y}_{\mathrm{OHO}}\right)\right] \\
& +\left[\begin{array}{l}
f_{\mathrm{CV}}\left(1-f_{\mathrm{XE}, \mathrm{OHO}}\right) \\
b_{\mathrm{OHO}, T} \frac{Y_{\mathrm{OHO}}}{\left(1+b_{\mathrm{OHO}, \mathrm{T}} T R S\right)} T R S
\end{array}\right]
\end{aligned}
$$

donde:

$\mathrm{FO}_{2, \mathrm{OHO}}$ masa diaria de oxígeno consumido por OHOs $\left[\mathrm{gO}_{2} / \mathrm{d}\right]$

Demanda total de oxígeno

La demanda carbonácea de oxígeno en $\mathrm{gO}_{2} / \mathrm{d}$ es:

$\mathrm{FO}_{2, \mathrm{C}}=\mathrm{FO}_{2, \mathrm{PAO}}+\mathrm{FO}_{2, \mathrm{OHO}}$

donde:

$\mathrm{FO}_{2, \mathrm{C}}$ masa diaria de demanda carbonácea de oxígeno $\left[\mathrm{gO}_{2} / \mathrm{d}\right]$

Ahora, la Ec. $7.31 \mathrm{~b}$ puede ser simplificada $\left[\mathrm{gO}_{2} / \mathrm{d}\right]$ asumiendo que:

$\mathrm{Y}_{\mathrm{PAO}} \approx \mathrm{Y}_{\mathrm{OHO}}$,

$\left(\mathrm{FS}_{\mathrm{F}, \mathrm{PAO}}+\mathrm{FDQO}_{\mathrm{b}, \mathrm{OHO}}\right) \approx \mathrm{FDQO}_{\mathrm{b}, \mathrm{i}}$

$\mathrm{f}_{\mathrm{XE}, \mathrm{PAO}}(0.20) \approx \mathrm{f}_{\mathrm{XE}, \mathrm{OHO}}(0.25)$

$$
\begin{aligned}
F O_{2, c}= & \left(1-f_{C V} Y_{O H O}\right) F D Q O_{b, i} \\
& +f_{C V}\left(1-f_{X E, O H O}\right) \\
& \left(b_{P A O, T} M X_{P A O}+b_{O H O, T} M X_{O H O}\right)
\end{aligned}
$$

\subsubsection{Demanda de oxígeno para nitrificación}

Considerando el cambio en los requerimientos de nitrógeno en la producción de lodo (FN $\mathrm{Fíntesis})$ y en la capacidad de nitrificación $\left(\mathrm{NIT}_{\mathrm{c}}\right)$, la demanda de oxígeno para la nitrificación $\mathrm{FO}_{2, \mathrm{NIT}}$ se puede calcular de acuerdo con el Capítulo 5.

\subsubsection{Demanda total de oxígeno}

Para sistemas EBPR no nitrificantes, la demanda de oxígeno total $\mathrm{FO}_{2, \mathrm{t}}$ es dada por $\mathrm{FO}_{2, \mathrm{c}}$, mientras que para un sistema $\mathrm{EBPR}$ nitrificante $\mathrm{FO}_{2, \mathrm{~T}}$ es dada por la suma de $\mathrm{FO}_{2, \mathrm{C}}$ y $\mathrm{FO}_{2, \mathrm{~N}}$. Incluir la nitrificación en un sistema EBPR necesariamente se traduce en que la desnitrificación debe también ser incluida. El efecto de la nitrificación y desnitrificación en la demanda total de oxígeno será explicada más adelante.

$F O_{2, T}=F O_{2, C}+F O_{2, N I T}$

donde: 
$\mathrm{FO}_{2, \mathrm{~T}} \quad$ Masa diaria de la demanda total de oxígeno $\left[\mathrm{gO}_{2} / \mathrm{d}\right]$.

\subsection{EJEMPLO DE DISEÑO}

\subsubsection{Procedimiento para un diseño en condiciones estacionarias}

El procedimiento para el diseño de un sistema con EBPR en condiciones estacionarias se muestra en la Figura 7.21. Primero, el agua residual necesita ser caracterizada en términos del caudal y el flujo másico diario de DQO, nitrógeno, fósforo, sólidos inorgánicos y concentración de oxígeno. A continuación se selecciona una configuración de tratamiento, la cual operará a una edad de lodos (TRS) y una temperatura definida, utilizando las constantes cinéticas y estequiométricas apropiadas. Después, la DQO $r$ afluente es dividida entre los PAOs y OHOs, lo cual permite el cálculo de la capacidad de remoción de $\mathrm{P}$ en el sistema y de la producción de biomasa (y del residuo endógeno) en términos de los SSV. A partir de la estimación total de SSV y SST, se puede calcular el volumen de proceso del bioreactor, así como los requerimientos de nitrógeno y oxígeno.
Finalmente, se realiza un balance de DQO para comprobar los cálculos.

\subsubsection{Información base}

El agua residual cruda (sin clarificación primaria) a tratar tiene una composición similar a la presentada en los Capítulos 4 y 5 respecto a remoción de materia orgánica y nitrógeno respectivamente. Las fracciones de la DQO afluente se resumen en las Tablas 7.2 y 7.3. Un caudal de $15 \mathrm{Ml} / \mathrm{d}$ es seleccionado para un fácil manejo de las unidades. La DQO total en el afluente es $750 \mathrm{~g} / \mathrm{m}^{3}$ y el fósforo total afluente es $17 \mathrm{~g} / \mathrm{m}^{3}$. El fraccionamiento de la DQO afluente se ilustra en la Figura 7.22. Los parámetros cinéticos y estequiométricos se presentan en la Tabla 7.4.

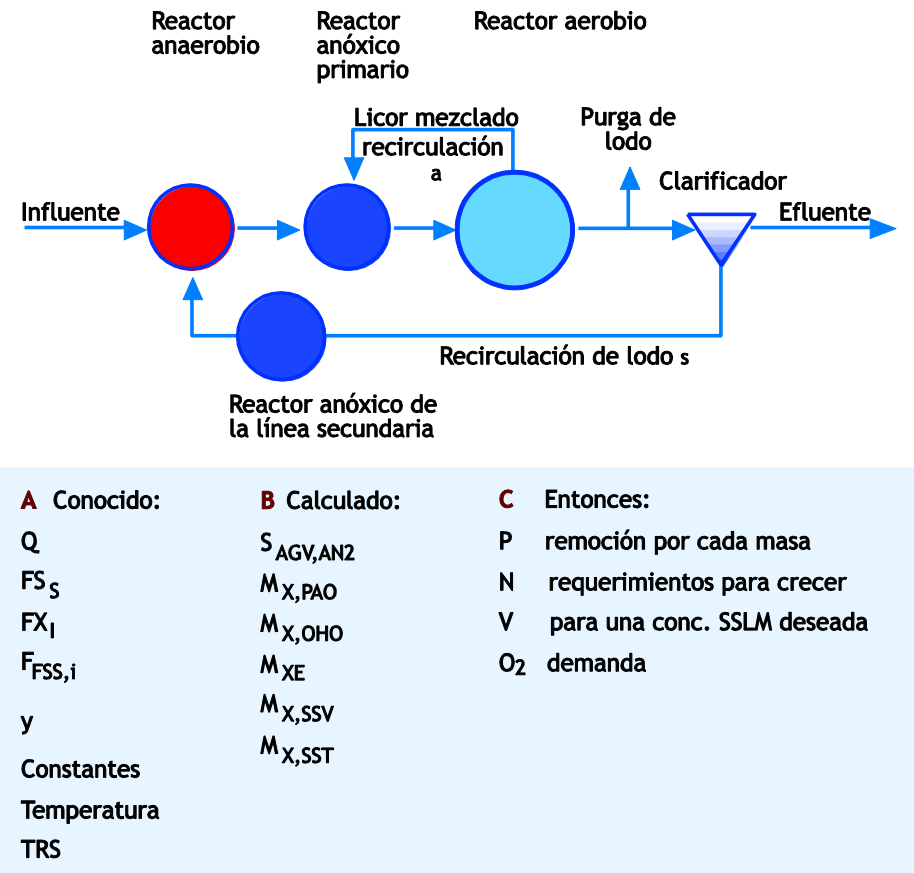

Figura 7.21 Panorama general del procedimiento de diseño del sistema EBPR. Se ilustra la configuración Johannesburgo. el reactor anaerobio está dividido en dos compartimentos (no señalado en el dibujo). 
Tabla 7.2 Características del afluente para el ejemplo de diseño del sistema EBPR (agua residual cruda)

\begin{tabular}{|c|c|c|c|c|}
\hline Descripción & Símbolo & Valor & Unidades & Cálculos \\
\hline Caudal afluente & $\mathrm{Q}_{\mathrm{i}}$ & 15 & $\mathrm{Ml} / \mathrm{d}$ & \\
\hline DQO total & $\mathrm{DQO}_{\mathrm{i}}$ & 750 & $\mathrm{gDQO} / \mathrm{m}^{3}$ & \\
\hline \multicolumn{5}{|l|}{ Concentraciones de DQO } \\
\hline rápidamente biodegradable & $\mathrm{S}_{\mathrm{s}, \mathrm{i}}$ & 146 & $\mathrm{gDQO} / \mathrm{m}^{3}$ & $=750 \cdot 0.195$ \\
\hline ácidos grasos volátiles & $\mathrm{S}_{\mathrm{AGV}, \mathrm{i}}$ & 22 & $\mathrm{gDQO} / \mathrm{m}^{3}$ & $=146 \cdot 0.15$ \\
\hline fermentable & $\mathrm{S}_{\mathrm{F}, \mathrm{i}}$ & 124 & $\mathrm{gDQO} / \mathrm{m}^{3}$ & $=146-22$ \\
\hline lentamente biodegradable & $\mathrm{X}_{\mathrm{S}, \mathrm{i}}$ & 439 & $\mathrm{gDQO} / \mathrm{m}^{3}$ & $=750 \cdot(1-0.195-0.07-0.15)$ \\
\hline soluble inerte & $\mathrm{S}_{\mathrm{Ii}}$ & 53 & $\mathrm{gDQO} / \mathrm{m}^{3}$ & $=750 \cdot 0.07$ \\
\hline particulado inerte & $\mathrm{X}_{\mathrm{I}, \mathrm{i}}$ & 113 & $\mathrm{gDQO} / \mathrm{m}^{3}$ & $=750 \cdot 0.15$ \\
\hline Nitrato & $\mathrm{S}_{\mathrm{NO} 3, \mathrm{i}}$ & 0 & $\mathrm{gN} / \mathrm{m}^{3}$ & \\
\hline $\mathrm{O}_{2}$ disuelto & $\mathrm{S}_{\mathrm{O} 2, \mathrm{i}}$ & 0 & $\mathrm{gO}_{2} / \mathrm{m}^{3}$ & \\
\hline $\mathrm{P}$ total & $\mathrm{T}_{\mathrm{p}, \mathrm{i}}$ & 17.0 & $\mathrm{gP} / \mathrm{m}^{3}$ & \\
\hline SS Fijos (inorgánicos) & $\mathrm{XSSF}, \mathrm{i}_{\mathrm{i}}$ & 49 & $\mathrm{gSSF} / \mathrm{m}^{3}$ & \\
\hline Fracción de P en el SSF afluente & $\mathrm{fP}_{\mathrm{PSSF}, \mathrm{i}}$ & 0.02 & $\mathrm{gP} / \mathrm{gSSF}$ & \\
\hline Alcalinidad & $\mathrm{S}_{\mathrm{ALK}}$ & 250 & $\mathrm{gCaCO}_{3} / \mathrm{m}^{3}$ & \\
\hline
\end{tabular}

El proceso de EBPR seleccionado (Tabla 7.5) corresponde a una configuración de Johannesburgo, la cual es operada a $14^{\circ} \mathrm{C}$, con 2 zonas anaerobias, un TRS de 20 días, una fracción de masa anerobia de 0.10, una relación de recirculación de lodos de 0.75 con respecto al caudal afluente, una relación de recirculación del reactor aerobio al anóxico (a) de 1.5, una recirculación de lodo (s) entrando a la zona anaerobia sin oxígeno disuelto pero con una concentración de $0.5 \quad \mathrm{gNO}_{3}-\mathrm{N} / \mathrm{m}^{3}$, una concentración de sólidos suspendidos totales en el efluente de $5 \mathrm{~g} / \mathrm{m}^{3}$ y una concentración de diseño del licor mezclado de $4,000 \mathrm{gSST} / \mathrm{m}^{3}$.

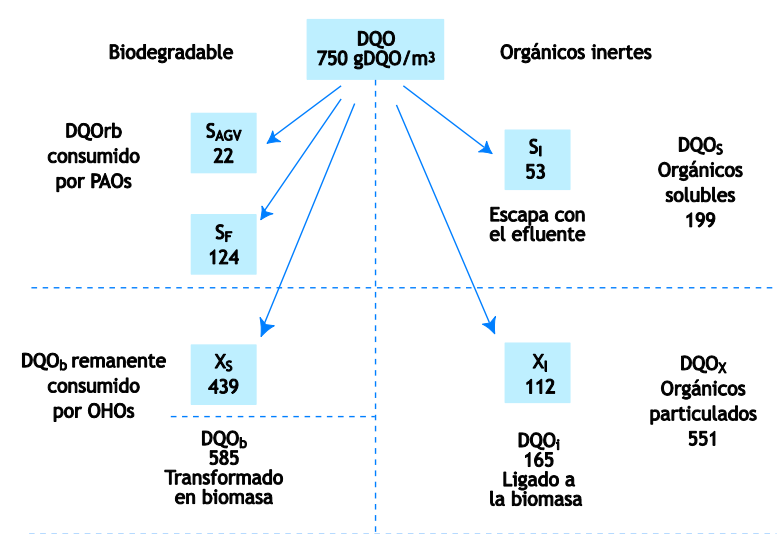

Figura 7.22 Fraccionamiento de DQO afluente para el ejemplo de diseño del sistema con EBPR

\subsubsection{Cálculos}

Continuando con el mismo procedimiento presentado en la sección 7.6, los cálculos detallados se muestran en la Tabla 7.6 y en las siguientes páginas. Cada paso es presentado con los símbolos, valores, unidades,

Tabla 7.3 Fracciones de DQO en el agua residual cruda del ejemplo de diseño EBPR

\begin{tabular}{|c|c|c|c|}
\hline Descripción & Símbolo & Fracciones de DQO & Unidades \\
\hline Tipo de agua residual & & Cruda & \\
\hline \multicolumn{4}{|l|}{ Fracciones de DQO } \\
\hline Fracción de DQO $\mathrm{rb}$ & fSS,DQOi & 0.195 & $\mathrm{~g} / \mathrm{gDQOt}$ \\
\hline Fracción de $\mathrm{S}_{\mathrm{VFA}}$ en $\mathrm{DQO}_{\mathrm{rb}}$ & $\mathrm{f}_{\mathrm{SAGV}, \mathrm{SSi}}$ & 0.15 & $\mathrm{~g} / \mathrm{gDQO}$ ss \\
\hline Fracción de DQO soluble inerte & $\mathrm{fSI}_{\mathrm{SI} D Q O i}$ & 0.07 & g/gDQOt \\
\hline Fracción de DQO particulada inerte & $f_{X I, D Q O i}$ & 0.15 & $\mathrm{~g} / \mathrm{gDQOt}$ \\
\hline
\end{tabular}


definiciones de símbolos, ecuaciones usadas para calcular un parámetro dado y los cálculos con los valores numéricos para cada parámetro. Al final, el balance de masa en términos de DQO se realiza para validar los cálculos. Cabe resaltar que en el paso 3.2, la DQO fermentable en el efluente de último reactor anaerobio se calcula iterativamente.

Tabla 7.4 Parámetros cinéticos y estequiométricos para el ejemplo de diseño del sistema EBPR

\begin{tabular}{|c|c|c|c|c|}
\hline \multicolumn{2}{|c|}{ Parámetro } & Símbodo & Valor & Unidades \\
\hline \multirow{11}{*}{$\begin{array}{l}\stackrel{\widetilde{U}}{U} \\
:\end{array}$} & $\mathrm{OHO}$ & & & \\
\hline & Tasa de fermentación de primer orden a temperatura de $20^{\circ} \mathrm{C}$ & $\mathrm{k}_{\mathrm{F} \_20}$ & 0.06 & $\mathrm{~m}^{3} / \mathrm{gSSV} . \mathrm{d}$ \\
\hline & Coeficiente por temperatura $\mathrm{kF}_{\mathrm{F}, \mathrm{T}}$ & $\theta_{\mathrm{kF}}$ & 1.029 & \\
\hline & Tasa de fermentación de primer orden a temperatura $\mathrm{T}^{(\mathrm{a})}$ & $\mathrm{kF}_{-} \mathrm{T}$ & 0.051 & $\mathrm{~m}^{3} / \mathrm{gSSV} . \mathrm{d}$ \\
\hline & Tasa específica de decaimiento endógeno para $\mathrm{OHOs} \mathrm{a} 20^{\circ} \mathrm{C}$ & bоно_20 & 0.24 & gSSVe /gSSV.d \\
\hline & Coeficiente de temperatura para bоно,т & $\theta_{\mathrm{bOHO}}$ & 1.029 & \\
\hline & Tasa específica de decaimiento endógeno para OHOs a $\mathrm{T}$ & bоно_T & 0.202 & gSSVe /gSSV.d \\
\hline & $P A O$ & & & \\
\hline & Tasa específica de decaimiento endógeno para PAOs a $20^{\circ} \mathrm{C}$ & bPAO_20 & 0.04 & gSSVe /gSSV.d \\
\hline & Coeficiente de temperatura para $\mathrm{b}_{\mathrm{PAO}, \mathrm{T}}$ & $\theta_{\mathrm{bPAO}}$ & 1.029 & \\
\hline & Tasa específica de decaimiento endógeno para PAOs a T & bPAO_T & 0.034 & gSSVe /gSSV.d \\
\hline \multirow{20}{*}{ 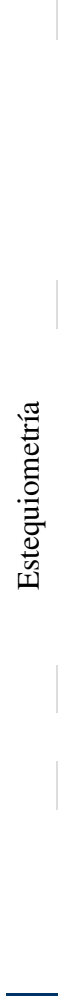 } & $\mathrm{OHO}$ & & & \\
\hline & Rendimiento de biomasa para $\mathrm{OHOs}$ & YPAO & 0.45 & gSSVa/gDQO \\
\hline & Fracción de residuo endógeno de OHOs & fXE_OHO & 0.20 & gSSVe/gSSVa \\
\hline & Fracción de $\mathrm{P}$ en la biomasa activa de $\mathrm{OHO}$ & fР_OHO & 0.03 & $\mathrm{gP} / \mathrm{gSSVa}$ \\
\hline & Fracción de $\mathrm{P}$ en la masa endógena (OHO y PAO) & $\mathrm{fP}_{-} \mathrm{XE}$ & 0.03 & $\mathrm{gP} / \mathrm{gSSVe}$ \\
\hline & Fracción de sólidos suspendidos fijos (inorgánicos) de OHOs & fSSF_OHO & 0.15 & $\mathrm{gSSF} / \mathrm{gSSVa}$ \\
\hline & PAO & & & \\
\hline & Rendimiento de biomasa para PAOs & $\mathrm{Y}_{\mathrm{PAO}}$ & 0.45 & gSSVa/gDQO \\
\hline & Fracción de residuo endógeno de PAOs & $\mathrm{f}_{\mathrm{XE} \_\mathrm{PAO}}$ & 0.25 & gSSVe/gSSVa \\
\hline & Fracción de P en la biomasa de PAO & $f_{P \_P A O}$ & 0.38 & $\mathrm{gP} / \mathrm{gSSVa}$ \\
\hline & Fracción de $\mathrm{P}$ en la masa endógena (OHO y PAO) & $\mathrm{fP}_{-} \mathrm{XE}$ & 0.03 & $\mathrm{gP} / \mathrm{gSSVe}$ \\
\hline & Relación SSV/SST en la biomasa activa de PAO & fVt_PAO & $0.46^{(\mathrm{b})}$ & $\mathrm{gSSV} / \mathrm{gSST}$ \\
\hline & Relación de P-liberado/ AGV-consumido & fPO4_REL & 0.50 & $\mathrm{gP} / \mathrm{gDQO}$ \\
\hline & Fracción de sólidos suspendidos fijos (inorgánicos) de PAOs & fSSF_PAO & 1.30 & $\mathrm{gSSF} / \mathrm{gSSVa}$ \\
\hline & Inertes & & & \\
\hline & Fracción de $\mathrm{P}$ en la masa inerte & $\mathrm{fP}_{-} \mathrm{XI}$ & 0.03 & $\mathrm{gP} / \mathrm{gSSVi}$ \\
\hline & General & & & \\
\hline & Relación DQO/SSV en el lodo & $f_{C V}$ & 1.48 & gDQO/gSSV \\
\hline & $\begin{array}{l}\text { Relación SSV/SST para biomasa activa y endógena de OHOs } \\
\text { Masa endógena e inerte de PAO }\end{array}$ & fvT & $0.80^{(\mathrm{b})}$ & $\mathrm{gSSV} / \mathrm{gSST}$ \\
\hline & Contenido de nitrógeno en la biomasa activa & $\mathrm{f}_{\mathrm{N}}, \mathrm{sSV}$ & 0.10 & $\mathrm{gN} / \mathrm{gSSVa}$ \\
\hline
\end{tabular}

(a) $\quad \mathrm{k}_{\mathrm{T}}=\mathrm{k}_{20} \bullet \theta^{(\mathrm{T}-20) ;}$ por ejemplo: $\mathrm{k}_{\mathrm{F}, 14}=0.060 \cdot 1.029^{(14-20)}=0.051$

(b) Estos valores no son requidos si los SSF son calculados usando la Ec. $7.24 \mathrm{c}$ 
Table 7.5 Características del sistema biológico para el ejemplo de diseño del sistema con EBPR (configuración de Johannesburgo)

\begin{tabular}{|c|c|c|c|}
\hline Descripción & Símbolo & Valor & Unidades \\
\hline Temperatura & $\mathrm{T}$ & 14 & ${ }^{\circ} \mathrm{C}$ \\
\hline Número de zonas anaerobias & $\mathrm{n}$ & 2 & reactores \\
\hline Tiempo de residencia de sólidos o edad de lodos & TRS & 20 & $\mathrm{~d}$ \\
\hline Fracción de masa anaerobia & $f_{\mathrm{AN}}$ & 0.10 & $\mathrm{gSSV} / \mathrm{gSSV}$ \\
\hline Relación de recirculación de lodo con base al caudal afluente & $\mathrm{s}$ & 0.75 & $\mathrm{~m}^{3} \cdot \mathrm{d} / \mathrm{m}^{3} \cdot \mathrm{d}$ \\
\hline Relación de recirculación del reactor aerobio al anóxico & a & 1.5 & $\mathrm{~m}^{3} \cdot \mathrm{d} / \mathrm{m}^{3} \cdot \mathrm{d}$ \\
\hline Recirculación de $\mathrm{O}_{2}$ disuelto en el lodo & $\mathrm{So} 2, \mathrm{~s}$ & 0 & $\mathrm{gO}_{2} / \mathrm{m}^{3}$ \\
\hline Concentración de nitrato en la recirculación de lodo & $\mathrm{S}_{\mathrm{NO} 3, \mathrm{~s}}$ & 0.5 & $\mathrm{gNO}_{3}-\mathrm{N} / \mathrm{m}^{3}$ \\
\hline Sólidos suspendidos totales en el efluente & $\mathrm{SST}_{\mathrm{ef}}$ & 5 & $\mathrm{gSST} / \mathrm{m}^{3}$ \\
\hline Concentración de diseño de SST en el reactor aerobio & $\mathrm{X}_{\text {sST,ox }}$ & 4,000 & $\mathrm{gSST} / \mathrm{m}^{3}$ \\
\hline
\end{tabular}

Tabla 7.6 Cálculos detallados del ejemplo de diseño del sistema EBPR

1. Configuración del sistema

Configuración de Johannesburgo operada a $14^{\circ} \mathrm{C}$

2. Composición del afluente y de la recirculación de lodo (de tablas anteriores)

$\mathrm{Q}_{\mathrm{i}} \quad 15 \quad \mathrm{Ml} / \mathrm{d} \quad$ Caudal afluente

2.1 Concentraciones del afluente

Datos del afluente y del bioreactor

\begin{tabular}{|c|c|c|c|}
\hline DQO $_{\mathrm{i}}$ & 750 & $\mathrm{gDQO} / \mathrm{m}^{3}$ & concentración afluente de DQO total \\
\hline $\mathrm{Ss}, \mathrm{i}_{\mathrm{N}}$ & 146 & $\mathrm{gDQO} / \mathrm{m}^{3}$ & concentración afluente de DQOrb \\
\hline $\mathrm{S}_{\mathrm{AGV}, \mathrm{i}}$ & 22 & $\mathrm{gDQO} / \mathrm{m}^{3}$ & concentración afluente de AGVs \\
\hline $\mathrm{S}_{\mathrm{F}, \mathrm{i}}$ & 124 & $\mathrm{gDQO} / \mathrm{m}^{3}$ & concentración afluente de DQO fermentable \\
\hline $\mathrm{X}_{\mathrm{S}, \mathrm{i}}$ & 439 & $\mathrm{gDQO} / \mathrm{m}^{3}$ & concentración afluente de DQO lentamente biodegradable \\
\hline $\mathrm{DQO}_{\mathrm{b}, \mathrm{i}}$ & 585 & $\mathrm{gDQO} / \mathrm{m}^{3}$ & concentración afluente de DQO biodegradable $\left(\mathrm{S}_{\mathrm{S}, \mathrm{i}}+\mathrm{X}_{\mathrm{S}, \mathrm{i}}\right)$ \\
\hline $\mathrm{S}_{\mathrm{I}, \mathrm{i}}$ & 53 & $\mathrm{gDQO} / \mathrm{m}^{3}$ & concentración afluente de DQO soluble inerte \\
\hline $\mathrm{X}_{\mathrm{I}, \mathrm{i}}$ & 113 & $\mathrm{gDQO} / \mathrm{m}^{3}$ & concentración afluente de DQO particulado inerte \\
\hline $\mathrm{S}_{\mathrm{NO}, \mathrm{i}}$ & 0 & $\mathrm{gNO}_{3}-\mathrm{N} / \mathrm{m}^{3}$ & concentración afluente de nitrato \\
\hline $\mathrm{S}_{\mathrm{O} 2, \mathrm{i}}$ & 0 & $\mathrm{gO}_{2} / \mathrm{m}^{3}$ & concentración afluente oxígeno disuelto \\
\hline XssF,i & 49 & $\mathrm{gSSF} / \mathrm{m}^{3}$ & $\begin{array}{l}\begin{array}{l}\text { concentración afluente de } \\
\text { (inorgánicos) }\end{array}\end{array}$ \\
\hline $\mathrm{T}_{\mathrm{P}, \mathrm{i}}$ & 17 & $\mathrm{gP} / \mathrm{m}^{3}$ & concentración afluente $\mathrm{P}$ total \\
\hline \multicolumn{4}{|c|}{ 2.2 Flujo afluente usado en los cálculos (= Qi • concentración afluente del compuesto) } \\
\hline FDQO $_{\mathrm{i}}$ & 11250 & $\mathrm{kgDQO} / \mathrm{d}$ & flujo afluente diario de DQO total \\
\hline $\mathrm{FS}_{\mathrm{S}, \mathrm{i}}$ & 2194 & $\mathrm{kgDQO} / \mathrm{d}$ & flujo afluente diario de DQOrb \\
\hline $\mathrm{FS}_{\mathrm{AGV}, \mathrm{i}}$ & 329 & $\mathrm{kgDQO} / \mathrm{d}$ & flujo afluente diario de AGVs \\
\hline $\mathrm{FS}_{\mathrm{F}, \mathrm{i}}$ & 1865 & $\mathrm{kgDQO} / \mathrm{d}$ & flujo afluente diario de DQO fermentable \\
\hline $\mathrm{FDQO}_{\mathrm{b}, \mathrm{i}}$ & 8775 & $\mathrm{kgDQO} / \mathrm{d}$ & flujo afluente diario de DQO biodegradable $\left(\mathrm{S}_{\mathrm{S}, \mathrm{i}}+\mathrm{X}_{\mathrm{S}, \mathrm{i}}\right)$ \\
\hline $\mathrm{FX}_{\mathrm{I}, \mathrm{i}}$ & 1688 & $\mathrm{kgDQO} / \mathrm{d}$ & flujo afluente diario de DQO particulado inerte \\
\hline $\mathrm{FX}, \mathrm{sSF}, \mathrm{i}$ & 735 & $\mathrm{kgSSF} / \mathrm{d}$ & flujo afluente diario de sólidos suspendidos fijos (inorgánicos) \\
\hline \multicolumn{4}{|c|}{ 2.3 Características del lodo reciclado } \\
\hline $\mathrm{s}$ & 0.75 & $\mathrm{~m}^{3} \cdot \mathrm{d} / \mathrm{m}^{3} \cdot \mathrm{d}$ & Factor de recirculación de lodo basado en el caudal afluente \\
\hline $\mathrm{S}_{\mathrm{O} 2, \mathrm{~s}}$ & 0 & $\mathrm{gO}_{2} / \mathrm{m}^{3}$ & $\mathrm{O}_{2}$ disuelto en la recirculación de lodos \\
\hline $\mathrm{S}_{\mathrm{NO} 3, \mathrm{~s}}$ & 0.5 & $\mathrm{gNO}_{3}-\mathrm{N} / \mathrm{m}^{3}$ & Concentración de nitrato en el lodo recirculado \\
\hline
\end{tabular}




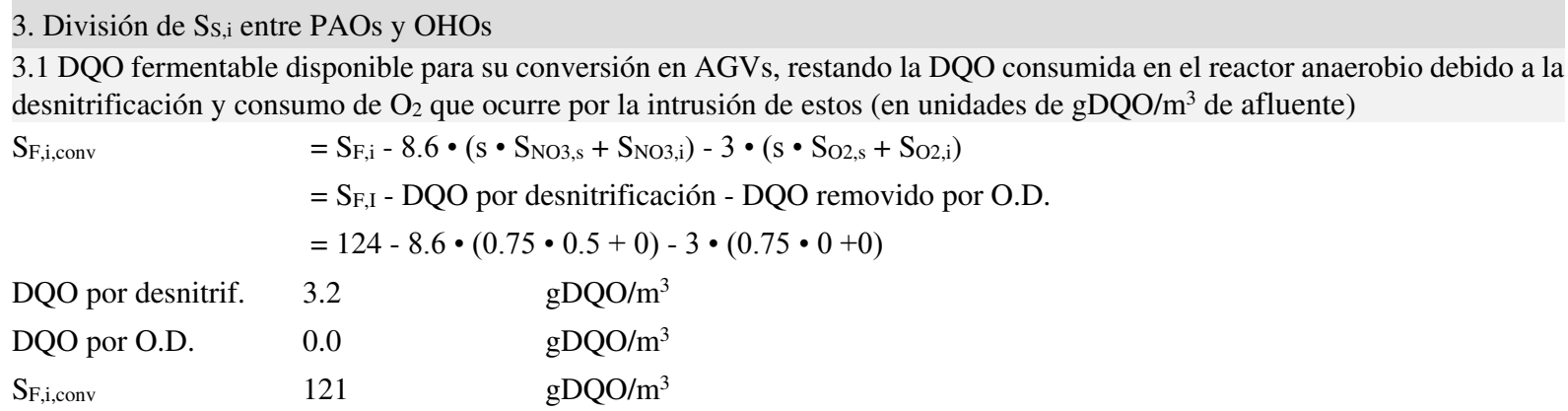

3.2 DQO fermentable remanente o residual presente en el efluente del último reactor anaerobio

$\mathrm{n}$

$\operatorname{del} 2^{\text {nd }}$ reactor $\mathrm{AN}$

cálculos realizados iterativamente

a- supone un valor inicial_1 de $\mathrm{S}_{\mathrm{F}, \mathrm{ANn}}=0$. Este valor es usado para calcular $\mathrm{MX}$ Оно

b- establecer el MХоно calculado como el valor inicial_2

c- repetir los pasos a- y b- hasta que el valor inicial_2 $\mathrm{S}_{\mathrm{F}, \mathrm{ANn}}$ iguale el $\mathrm{S}_{\mathrm{F}, \mathrm{ANn}}$ calculado

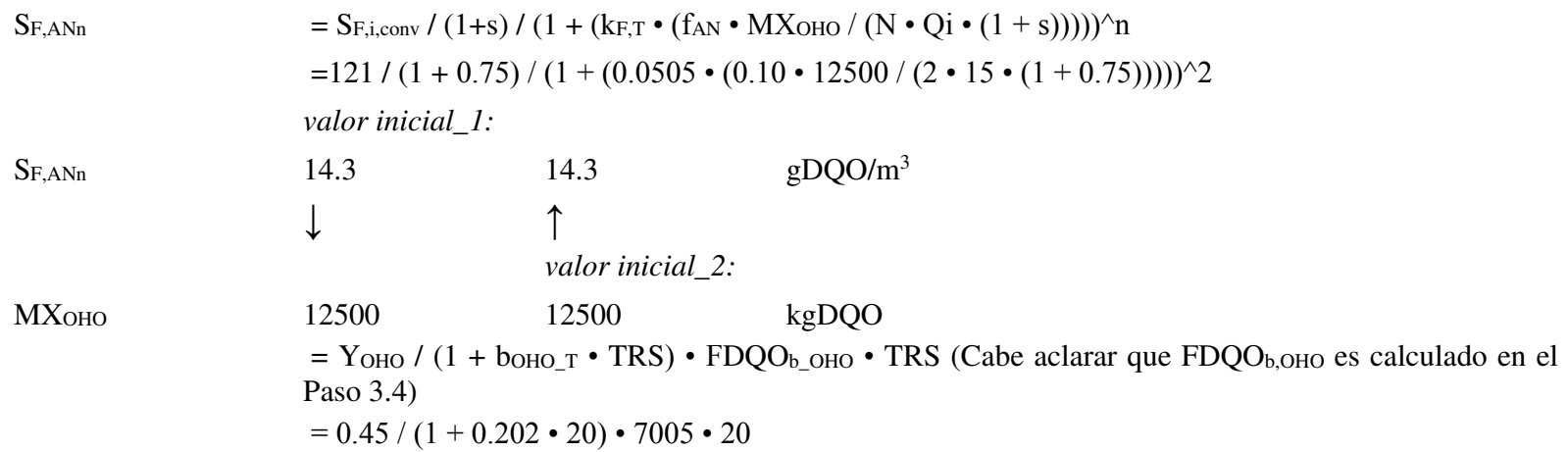

3.3 AGVs almacenados por los PAOs

\begin{tabular}{|c|c|}
\hline FSs,PAO & $\begin{array}{l}=\mathrm{Q}_{\mathrm{i}} \cdot\left(\mathrm{S}_{\mathrm{F}, \mathrm{i}, \mathrm{conv}}-(1+\mathrm{s}) \cdot \mathrm{S}_{\mathrm{F}, \mathrm{ANn}}\right)+\mathrm{Q}_{\mathrm{i}} \cdot \mathrm{S}_{\mathrm{AGV}, \mathrm{i}} \\
=1 \cdot(121-(1+0.75) \cdot 14.3)+1 \cdot 22\end{array}$ \\
\hline $\mathrm{FS}_{\mathrm{S}, \mathrm{PAO}}$ & kgDQO/d \\
\hline
\end{tabular}

3.4 DQO biodegradable remanente disponible para los OHOs

$\begin{array}{ll}\text { FDQO }_{\mathrm{b}, \mathrm{OHO}} & =\mathrm{FDQO}_{\mathrm{b}, \mathrm{i}}-\mathrm{FS}_{\mathrm{S}, \mathrm{PAO}} \\ & =8775-1770 \\ \text { FDQO }_{\mathrm{b}, \mathrm{OHO}} & 7005 \quad \mathrm{kgDQO} / \mathrm{d}\end{array}$

4. Ecuaciones para cálculo de biomasa (SSV)

Corresponde a la masa biomasa presente en el sistema, sintetizada a partir de la DQO afluente (en g/d) considerando el efecto acumulativo del TRS $[(\mathrm{g} / \mathrm{d}) \cdot \mathrm{d}=\mathrm{g}$ en el sistema $]$

4.1 PAOs

Biomasa activa

YPAO

$0.45 \quad \mathrm{gSSVa} / \mathrm{gDQO}$

$\mathrm{Y}_{\mathrm{PAO}, \mathrm{obs}}=\mathrm{Y}_{\mathrm{PAO}} /\left(1+\mathrm{b}_{\mathrm{PAO}, \mathrm{T}} \cdot \mathrm{TRS}\right)$

$=0.45 /(1+0.034 \cdot 20)$

YPAO,obs $\quad 0.269 \mathrm{gSSVa} / \mathrm{gDQO}$

$\mathrm{MX}_{\mathrm{PAO}}=\mathrm{Y}_{\mathrm{PAO}, \mathrm{obs}} \cdot \mathrm{FS}_{\mathrm{S}, \mathrm{PAO}} \cdot \mathrm{TRS}$

$=0.269 \cdot 1770 \cdot 20$

MXPAO $\quad 9517 \quad$ kgSSVa en el sistema 
Masa endógena

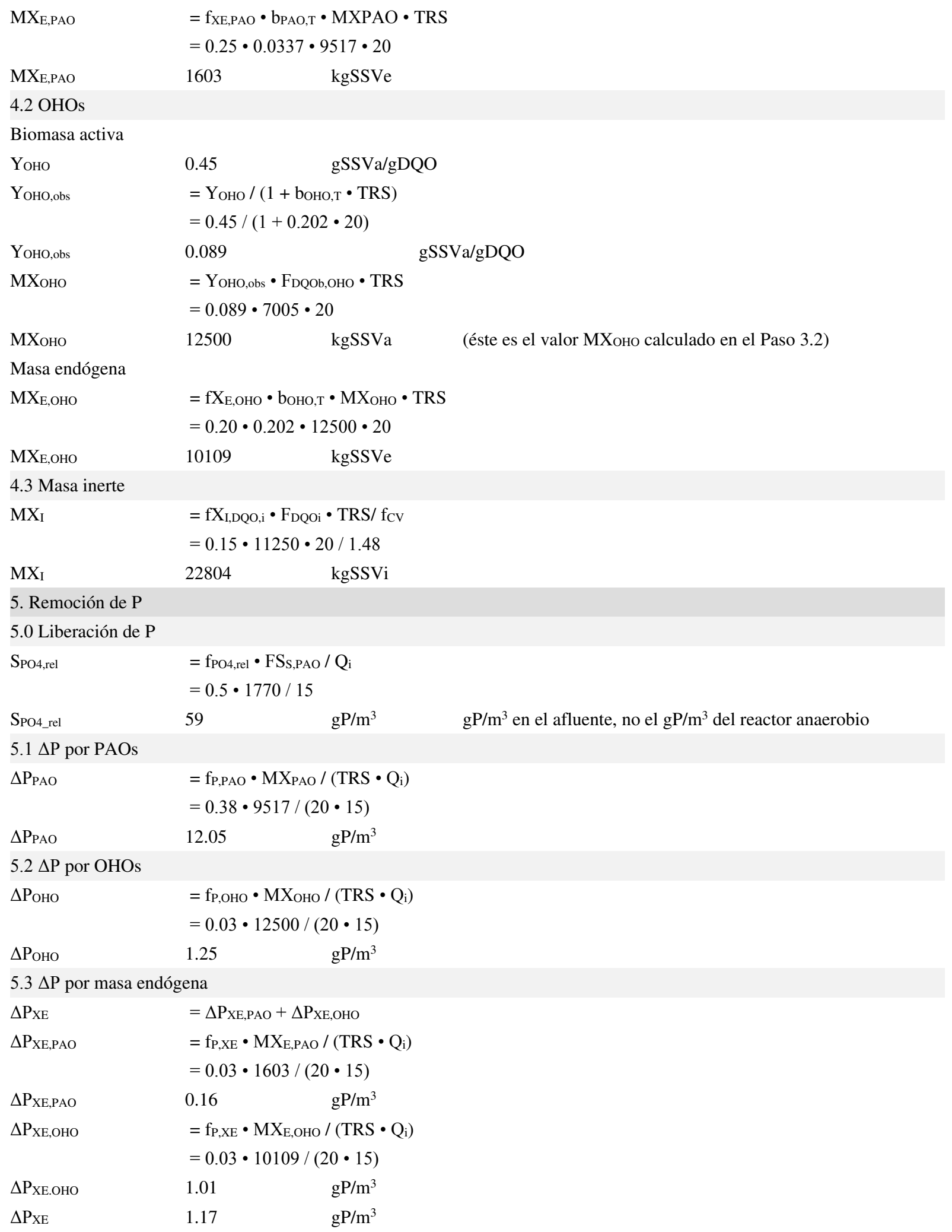


$5.4 \Delta \mathrm{P}$ por masa inerte afluente

$\begin{array}{llr}\Delta \mathrm{P}_{\mathrm{XI}} & =\mathrm{f}_{\mathrm{P}, \mathrm{XI}} \bullet \mathrm{MX}_{\mathrm{I}} /\left(\mathrm{TRS} \cdot \mathrm{Q}_{\mathrm{i}}\right) \\ & =0.03 \cdot 22804 /(20 \bullet 15) \\ \Delta \mathrm{P}_{\mathrm{XI}} & 2.28 & \mathrm{gP} / \mathrm{m}^{3}\end{array}$

$5.5 \Delta \mathrm{P}$ por precipitación química de $\mathrm{P}$ debido a la presencia de sales en el afluente o su adición en el sistema

No considerado

5.6 Remoción potencial de P total

$\Delta \mathrm{P}_{\mathrm{SYS}, \mathrm{POT}}=\Delta \mathrm{P}_{\mathrm{PAO}}+\Delta \mathrm{P}_{\mathrm{OHO}}+\Delta \mathrm{P}_{\mathrm{XE}}+\Delta \mathrm{P}_{\mathrm{XI}}$

$=12.05+1.25+1.17+2.28$

$\Delta \mathrm{P}_{\text {SYS,POT }} \quad 16.76 \quad \mathrm{gP} / \mathrm{m}^{3}$

5.7 Remoción de P actual total

$\mathrm{TP}, \mathrm{i}$

$17.0 \quad \mathrm{gP} / \mathrm{m}^{3}$

$\Delta \mathrm{P}_{\text {SYS }, \mathrm{ACT}}=\min \left(\Delta \mathrm{P}_{\mathrm{SYS}, \mathrm{POT}} ; \mathrm{T}_{\mathrm{p}, \mathrm{i}}\right)$

$=\min (16.76 ; 17.0)$

$\triangle P_{\text {SYS,ACT }} \quad 16.8 \quad \mathrm{gP} / \mathrm{m}^{3}$

5.8 $\mathrm{P}$ particulado en el efluente

Para calcular después Paso 6.5 donde el contenido de P en SST es calculado

$\mathrm{X}_{\mathrm{P}, \mathrm{e}}$

$=\mathrm{f}_{\mathrm{P}, \mathrm{TSS}} \cdot \mathrm{SST}_{\mathrm{e}}$

$=0.124 \cdot 5$

$\mathrm{X}_{\mathrm{P}, \mathrm{e}}$

$0.6 \mathrm{gP} / \mathrm{m}^{3}$

5.9 P total efluente

$\mathrm{T}_{\mathrm{p}, \mathrm{e}}$

$=\mathrm{T}_{\mathrm{p}, \mathrm{i}}-\Delta \mathrm{PSYS}, \mathrm{ACT}+\mathrm{X}_{\mathrm{P}, \mathrm{e}}$

$=17.0-16.8+0.6$

$\mathrm{T}_{\mathrm{p}, \mathrm{e}}$

0.9

$\mathrm{gP} / \mathrm{m}^{3}$

6. SSV y SST

6.1 SSV y fracción activa

MX

$=\mathrm{MX}_{\mathrm{PAO}}+\mathrm{MX}$

$=9517+12500$

MX bio

$22017 \quad \mathrm{kgSSV}$

MXvss

$=\mathrm{MX}_{\mathrm{PAO}}+\mathrm{MX} \mathrm{OHO}+\mathrm{MX}_{\mathrm{E}_{-} \mathrm{PAO}}+\mathrm{MX}_{\mathrm{E}_{-} \mathrm{OHO}}+\mathrm{MX}_{\mathrm{I}}$

$=9517+12500+1603+10109+$

22804

MXvss $56533 \quad \mathrm{kgSSV}$

fbio,Vss $\quad=$ MXbio / MXSSV

$=22017 / 56533$

$f_{\text {bio,VSS }} \quad 39 \%$

6.2 SSF

MXSSF

$=\mathrm{f}_{\mathrm{SSF}, \mathrm{OHO}} \cdot \mathrm{MX} \mathrm{XHO}_{\mathrm{OH}}+\mathrm{f}_{\mathrm{SSF}, \mathrm{PAO}} \cdot \mathrm{MX} \mathrm{PAO}_{\mathrm{P}}+\mathrm{F}_{\mathrm{X}, \mathrm{SSF}, \mathrm{i}} \cdot \mathrm{TRS}$

$=0.15 \cdot 12500+1.3 \cdot 9517+735 \cdot 20$

MXSSF

28947

$\mathrm{kgSSF}$

$6.3 \mathrm{SST}$

MXSST

$=\mathrm{MX}_{\mathrm{SSV}}+\mathrm{MX}_{\mathrm{SSF}}$

$=56533+28947$

MXssT

85479

kgSST 


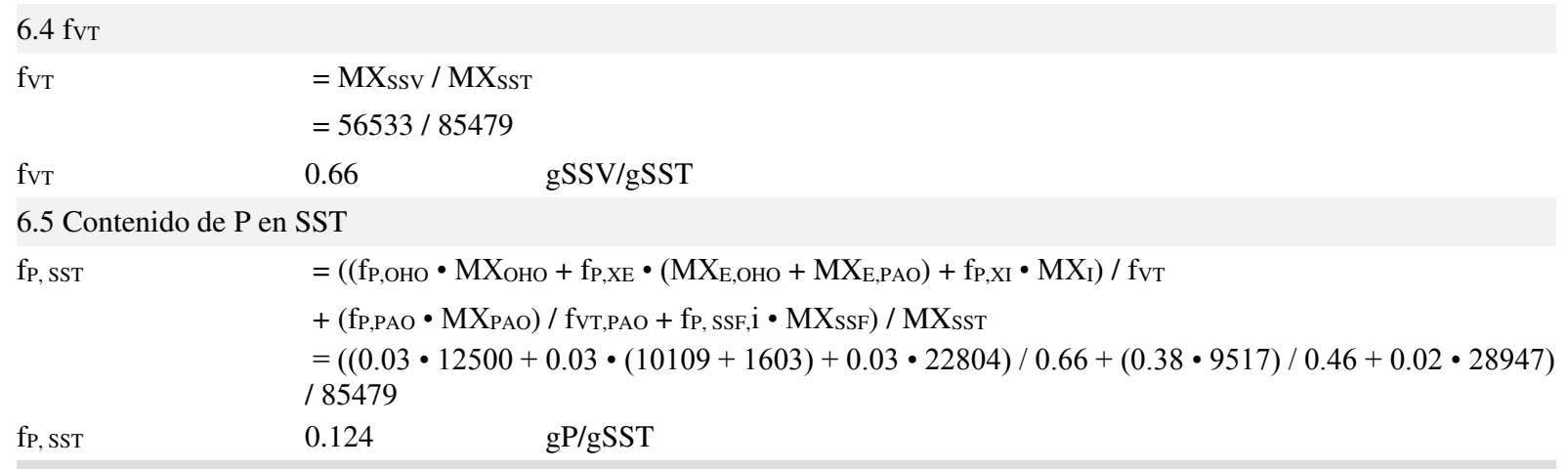

7. Volumen de proceso (basado en SST, aunque también puede estar basado en SSV)

Es importante mencionar que el caudal afluente necesita ser apropiado

$\begin{array}{lll}\text { X }_{\text {SST,OX }} & 4000 \quad \mathrm{gSST} / \mathrm{m}^{3} \\ V_{\mathrm{P}} & =\text { MXsst } / \text { Xsst,OX } \\ & =85479 / 4000 \\ \mathrm{~V}_{\mathrm{P}} & 21370 & \mathrm{~m}^{3}\end{array}$

El volumen en la zona anaerobia (dividida en dos secciones) depende de la fracción de masa anaerobia

$\begin{array}{lll}\mathrm{V}_{\mathrm{p}, \mathrm{AN}} & =\mathrm{f}_{\mathrm{AN}} \mathrm{V}_{\mathrm{p}} & \\ & =0.10 \cdot 21370 \\ \mathrm{~V}_{\mathrm{p}, \mathrm{AN}} & 2137 & \\ & & \mathrm{~m}^{3}\end{array}$

Las fracciones de masa anóxica y aerobia, y por lo tanto el volumen en dichas zonas, deben ser estimadas de acuerdo con el procedimiento presentado en el Capítulo 5 de remoción de nitrógeno y en Ramphao et al. (2005), donde las ecuaciones que relacionan las fracciones de volumen con las fracciones de masa de acuerdo con los factores de recirculación son dados para varias configuraciones de reactores, incluyendo JHB. Usando una estimación de las fracciones de masa aerobio y anóxico de 0.45 cada una, el volumen $\left(\mathrm{m}^{3}\right)$ para cada zona es cercano a: AN1: 1,060, AN2: 1,060, AX: 7,000, OX: 10,500, AX-RAS: 1,750, para un volumen total de 21,370 $\mathrm{m}^{3}$. Cabe notar que esta aproximación preliminar no considera que la concentración del lodo en la zona RAS - anóxica es 2.3 veces más concentrada que en la zona del tren principal $((1+r) / r)$ lo cual resulta en cerca de un tercio de la masa anóxica que está en la zona RAS- anóxica y en menor requerimiento del volumen de proceso.

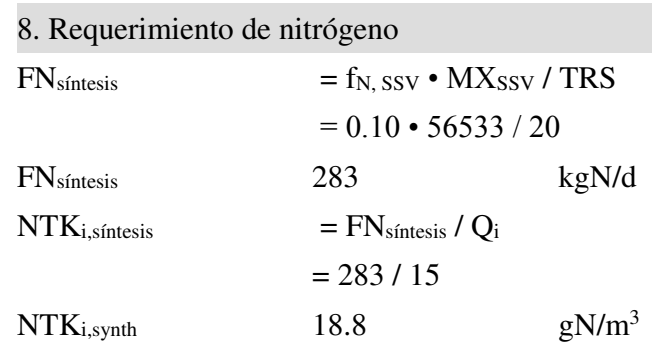

9. Demanda de oxígeno (D.O.)

D.O. de PAOs para síntesis celular y respiración endógena

\begin{tabular}{|c|c|}
\hline $\mathrm{FO}_{2, \mathrm{PAO}}$ & $=\mathrm{FO}_{2, \mathrm{PAO}, \text { síntesis }}+\mathrm{FO}_{2, \mathrm{PAO}, \text { endo }}$ \\
\hline \multirow[t]{2}{*}{$\mathrm{FO}_{2, \mathrm{PAO}, \text { síntesis }}$} & $=\mathrm{FS}_{\mathrm{S}, \mathrm{PAO}} \cdot\left(1-\mathrm{f}_{\mathrm{CV}} \cdot \mathrm{Y}_{\mathrm{PAO}}\right)$ \\
\hline & $=1770 \bullet(1-1.48 \cdot 0.45)$ \\
\hline $\mathrm{FO}_{2, \mathrm{PAO} \text {,sínteis }}$ & 591 \\
\hline \multirow[t]{2}{*}{$\mathrm{FO}_{2, \mathrm{PAO}, \text { endo }}$} & $\left.=\mathrm{FS}_{\mathrm{S}, \mathrm{PAO}} \cdot \mathrm{f}_{\mathrm{CV}} \bullet\left(1-\mathrm{f}_{\mathrm{XE}, \mathrm{PAO}}\right) \cdot \mathrm{b}_{\mathrm{PAO}, \mathrm{T}} \cdot \mathrm{Y}_{\mathrm{PAO}, \mathrm{obs}} \cdot \mathrm{TRS}\right)$ \\
\hline & $=1770 \cdot 1.48 \cdot(1-0.25) \cdot 0.0337 \cdot 0.268 \cdot 20$ \\
\hline $\mathrm{FO}_{2, \mathrm{PAO} \text {,endo }}$ & 355.9 \\
\hline $\mathrm{FO}_{2, \mathrm{PAO}}$ & $\mathrm{kgO}_{2} / \mathrm{d}$ \\
\hline
\end{tabular}

D.O. de OHOs para síntesis celular y respiración endógena

$\mathrm{FO}_{2, \mathrm{OHO}}=\mathrm{FO}_{2, \mathrm{OHO} \text {, síntesis }}+\mathrm{FO}_{2, \mathrm{OHO} \text {,endo }}$ 


\begin{tabular}{|c|c|c|c|c|c|}
\hline $\mathrm{FO}_{2, \mathrm{OHO}, \text { síntesis }}$ & \multicolumn{5}{|c|}{$=\mathrm{FDQO}_{\mathrm{b}_{-} \mathrm{OHO}} \bullet\left(1-\mathrm{f}_{\mathrm{CV}} \cdot \mathrm{Y}_{\mathrm{OHO}}\right)$} \\
\hline $\mathrm{FO}_{2, \mathrm{OHO}, \text { synth }}$ & \multicolumn{5}{|l|}{2340} \\
\hline $\mathrm{FO}_{2, \mathrm{OHO}, \text { endo }}$ & \multicolumn{5}{|c|}{$=\mathrm{FDQO}_{\mathrm{b}, \mathrm{OHO}} \cdot \mathrm{f}_{\mathrm{CV}} \bullet\left(1-\mathrm{f}_{\mathrm{XE}, \mathrm{OHO}}\right) \cdot \mathrm{b}_{\mathrm{OHO}, \mathrm{T}} \cdot \mathrm{Y}_{\mathrm{OHO}, \mathrm{obs}} \cdot \mathrm{TRS}$} \\
\hline $\mathrm{FO}_{2, \mathrm{OHO}, \text { endo }}$ & \multicolumn{5}{|l|}{2992} \\
\hline $\mathrm{FO}_{2, \mathrm{OHO}}$ & 5332 & \multicolumn{4}{|l|}{$\mathrm{kgO}_{2} / \mathrm{d}$} \\
\hline \multicolumn{6}{|c|}{ D.O. total (carbonácea) } \\
\hline $\mathrm{FO}_{2, \mathrm{C}}$ & \multicolumn{5}{|c|}{$\begin{array}{l}=\mathrm{FO}_{2, \mathrm{PAO}}+\mathrm{FO}_{2, \mathrm{OHO}} \\
=947+5332\end{array}$} \\
\hline \multicolumn{2}{|c|}{ o en una forma simplificada: } & \multicolumn{4}{|l|}{$\mathrm{kgO}_{2} / \mathrm{d}$} \\
\hline $\mathrm{FO}_{2, \mathrm{C}}$ & \multicolumn{5}{|c|}{$\begin{array}{l}=\left(1-\mathrm{f}_{\mathrm{CV}} \bullet \mathrm{Y}_{\mathrm{OHO}}\right) \cdot \mathrm{FDQO}_{\mathrm{b}, \mathrm{i}}+\mathrm{f}_{\mathrm{CV}} \bullet\left(1-\mathrm{fX}_{\mathrm{E}, \mathrm{OHO}}\right) \cdot\left(\mathrm{b}_{\mathrm{PAO}, \mathrm{T}} \bullet \mathrm{MX}_{\mathrm{PAO}}+\mathrm{b}_{\mathrm{OHO}, \mathrm{T}} \bullet \mathrm{MX} \text { ОHO }\right) \\
=(1-1.48 \cdot 0.45) \cdot 9775+1.48 \cdot(1-0.20) \bullet(0.0337 \cdot 9517+0.202 \cdot 12500)\end{array}$} \\
\hline $\mathrm{FO}_{2, \mathrm{C}}$ & 6303 & \multicolumn{4}{|l|}{$\mathrm{kgO}_{2} / \mathrm{d}$} \\
\hline \multicolumn{6}{|c|}{ Verificación del balance de masa de la DQO } \\
\hline \multicolumn{6}{|l|}{ Entrada } \\
\hline $\mathrm{FDQO}_{\mathrm{i}}$ & & 11250 & $\mathrm{kgDQO} / \mathrm{d}$ & $100 \%$ & ENTRADA \\
\hline \multicolumn{6}{|l|}{ Salida } \\
\hline \multicolumn{6}{|c|}{ Demanda de $\mathrm{O}_{2}$ por síntesis y respiración endógena } \\
\hline FOc & & 6,279 & $\mathrm{kgDQO} / \mathrm{d}$ & $55.8 \%$ & \\
\hline \multicolumn{6}{|c|}{ Solubles inertes que escapan en el efluente } \\
\hline $\mathrm{FS}_{\mathrm{I}, \mathrm{i}}$ & & 788 & $\mathrm{kgDQO} / \mathrm{d}$ & $7.0 \%$ & \\
\hline \multirow[t]{2}{*}{ Lodo } & gSSV & $\mathrm{gDQO} /$ & & & \\
\hline & \multicolumn{5}{|c|}{$\left(=\mathrm{gSSV} \bullet \mathrm{fCV}_{\mathrm{CV}} / \mathrm{TRS}=\mathrm{gSSV} \bullet 1.48 / 20=\mathrm{gSSV} \bullet 0.0740\right)$} \\
\hline MX & 9,517 & 704 & $\mathrm{kgDQO} / \mathrm{d}$ & $6.3 \%$ & \\
\hline МХоно & 12,500 & 925 & $\mathrm{kgDQO} / \mathrm{d}$ & $8.2 \%$ & \\
\hline MX & 22,017 & 1,629 & kgDQO/d & $14.5 \%$ & \\
\hline $\mathrm{MX}_{\mathrm{E}, \mathrm{PAO}}$ & 1,603 & 119 & $\mathrm{kgDQO} / \mathrm{d}$ & $1.1 \%$ & \\
\hline $\mathrm{MX}_{\mathrm{E}, \mathrm{OHO}}$ & 10,109 & 748 & kgDQO/d & $6.6 \%$ & \\
\hline MXI & 22,804 & 1,688 & kgDQO/d & $15.0 \%$ & \\
\hline MXendo+inert & 34,516 & 2,554 & $\mathrm{kgDQO} / \mathrm{d}$ & $22.7 \%$ & \\
\hline $\mathrm{MX}_{\mathrm{TOT}}$ & 56,533 & 4,183 & kgDQO/d & $37.2 \%$ & \\
\hline & Suma: & 11250 & kgDQO/d & $100 \%$ & SALIDA \\
\hline & $\Delta($ Entrada-Salida $)$ & 0 & kgDQO/d & $0 \%$ & \\
\hline
\end{tabular}

El cierre del balance de masa de la DQO al $100 \%$ indica que toda la DQO afluente está considerada en los cálculos de la demanda de oxígeno y la producción del lodo. Del balance de masa de DQO y de las condiciones de diseño del ejemplo se puede rastrear la manera en la que se removió la DQO afluente, en este caso: $56 \%$ fue oxidado con el oxígeno, $7 \%$ escapó en el efluente como materia soluble inerte y $37 \%$ se convirtió en lodo activado. El lodo está compuesto por 39\% (1,629/4,183) de biomasa activa y $61 \%(2,554 / 4,183)$ de materia particulada inactiva, del cual el $40 \%(1,688 / 4,183)$ es afluente inerte y $21 \% \quad((119+748) / 4,183)$ residuo endógeno, todo lo anterior en términos de DQO. Un resumen de los resultados del diseño del sistema EBPR se presenta en la Tabla 7.7 a continuación. 
Tabla 7.7 Resumen de los resultados para el diseño del sistema con EBPR (configuración de Johannesburgo)

\begin{tabular}{|c|c|c|c|}
\hline Descripción & Parámetro & Unidades & Valor \\
\hline \multicolumn{4}{|l|}{ 1. afluente y bioreactor } \\
\hline Tipo de agua residual & cruda/clarificada & & cruda \\
\hline Temperatura & $\mathrm{T}$ & ${ }^{\circ} \mathrm{C}$ & 14 \\
\hline Caudal de agua afluente & $\mathrm{Q}_{\mathrm{i}}$ & $\mathrm{Ml} / \mathrm{d}$ & 15 \\
\hline DQO total en el afluente & DQO $_{i}$ & $\mathrm{gDQO} / \mathrm{m}^{3}$ & 750 \\
\hline DQO rápidamente biodegradable en el afluente & $\mathrm{S}_{\mathrm{S}, \mathrm{i}}$ & $\mathrm{gDQO} / \mathrm{m}^{3}$ & 146 \\
\hline DQO biodegradable en el afluente & $\mathrm{DQO}_{\mathrm{b}, \mathrm{i}}$ & $\mathrm{gDQO} / \mathrm{m}^{3}$ & 585 \\
\hline P total afluente & $\mathrm{T}_{\mathrm{Pi}}$ & $\mathrm{gP} / \mathrm{m}^{3}$ & 17 \\
\hline Tiempo de residencia de sólidos (edad de lodos) & TRS & $\mathrm{d}$ & 20 \\
\hline Factor de recirculación de lodo & $\mathrm{s}$ & $\mathrm{m}^{3} \cdot \mathrm{d} / \mathrm{m}^{3} \cdot \mathrm{d}$ & 0.75 \\
\hline Factor de recirculación de licor mezclado & a & $\mathrm{m}^{3} \cdot \mathrm{d} / \mathrm{m}^{3} \cdot \mathrm{d}$ & 1.5 \\
\hline Concentración de nitrato en la recirculación de lodo & $\mathrm{S}_{\mathrm{NO} 3, \mathrm{~s}}$ & $\mathrm{gN} / \mathrm{m}^{3}$ & 0.5 \\
\hline \multicolumn{4}{|l|}{ 2. Porción de $\mathrm{S}_{\mathrm{S}, \mathrm{i}}$ para PAOs y de DQOb,i para OHOs } \\
\hline Concentración de DQO fermentable en el último reactor anaerobio & $\mathrm{S}_{\mathrm{F}, \mathrm{ANn}}$ & $\mathrm{gDQO} / \mathrm{m}^{3}$ & 14.3 \\
\hline Flujo de $\mathrm{S}_{\mathrm{S}, \mathrm{i}}$ para PAOs & $\mathrm{FS}_{\mathrm{S}, \mathrm{PAO}}$ & $\mathrm{kgDQO} / \mathrm{d}$ & 1,770 \\
\hline Flujo de $\mathrm{DQO}_{\mathrm{b}, \mathrm{i}}$ para $\mathrm{OHOs}$ & FDQOb,OHо & $\mathrm{kgDQO} / \mathrm{d}$ & 7,000 \\
\hline \multicolumn{4}{|l|}{ 3. Sistema de biomasa (SSV) } \\
\hline Masa de PAOs & MXPAO & kgSSV & 9,520 \\
\hline Masa de residuo endógeno de PAOs & MXE,PAO & kgSSV & 1,600 \\
\hline Masa de OHOs & МХОНО & kgSSV & 12,500 \\
\hline Masa de residuo endógeno de OHOs & МХЕ,оно & kgSSV & 10,110 \\
\hline Masa de orgánicos inertes del afluente & MXI & kgSSV & 22,800 \\
\hline \multicolumn{4}{|l|}{ 4. Remoción de P } \\
\hline Liberación de $\mathrm{PO}_{4}$ & SPO4_rel & $\mathrm{gP} / \mathrm{m}^{3}$ & 59.0 \\
\hline Remoción de P por PAOs & $\Delta$ РРAO & $\mathrm{gP} / \mathrm{m}^{3}$ & 12.1 \\
\hline Remoción de $\mathrm{P}$ por OHOs & $\Delta \mathrm{P}_{\text {оно }}$ & $\mathrm{gP} / \mathrm{m}^{3}$ & 1.3 \\
\hline Remoción de P por residuo endógeno & $\Delta \mathrm{P}_{\mathrm{XE}}$ & $\mathrm{gP} / \mathrm{m}^{3}$ & 1.2 \\
\hline Remoción de $\mathrm{P}$ por $\mathrm{X}_{\mathrm{I}}$ & $\Delta \mathrm{PXI}_{\mathrm{X}}$ & $\mathrm{gP} / \mathrm{m}^{3}$ & 2.3 \\
\hline Remoción potential de $\mathrm{P}$ en el sistema & $\Delta \mathrm{P}_{\mathrm{SYS}, \mathrm{POT}}$ & $\mathrm{gP} / \mathrm{m}^{3}$ & 16.8 \\
\hline Remoción real de $\mathrm{P}$ en el sistema & $\Delta \mathrm{P}_{\mathrm{SYS}, \mathrm{ACT}}$ & $\mathrm{gP} / \mathrm{m}^{3}$ & 16.8 \\
\hline $\mathrm{P}$ particulado efluente (proveniente de $\mathrm{SST}_{\mathrm{e}}$ ) & $\mathrm{X}_{\mathrm{P}, \mathrm{e}}$ & $\mathrm{gP} / \mathrm{m}^{3}$ & 0.6 \\
\hline P total afluente & $\mathrm{T}_{\mathrm{Pi}}$ & $\mathrm{gP} / \mathrm{m}^{3}$ & 17.0 \\
\hline P total efluente & $\mathrm{T}_{\mathrm{Pe}}$ & $\mathrm{gP} / \mathrm{m}^{3}$ & 0.9 \\
\hline \multicolumn{4}{|l|}{ 5. Sólidos suspendidos volátiles y totales (SSV y SST) en el sistema } \\
\hline Masa de biomasa activa & MX bio & kgSSVa & 22,000 \\
\hline Masa de SSV & $\mathrm{MX}_{\mathrm{SSV}}$ & kgSSV & 56,500 \\
\hline Relación de SSVa/SSV & $f_{\text {bio, }}$ SSV & gSSVa/gSSV & 0 \\
\hline Masa de SS fijos o inertes & MXssF & $\mathrm{kgSSF}$ & 28,900 \\
\hline Masa de SST & MXsst & $\operatorname{kgSST}$ & 85,500 \\
\hline Relación de SSV/SST & $f_{V T}$ & $\mathrm{gSSV} / \mathrm{gSST}$ & 0.66 \\
\hline
\end{tabular}


Fracción de P en SST

fP, SST

$\mathrm{gP} / \mathrm{gSST}$

0.12

6. Volumen total en el bioreactor

Volumen del bioreactor

$V_{P}$

$\mathrm{m}^{3}$

21,400

7. Requerimiento de $\mathrm{N}$

Requerimento de $\mathrm{N}$ para síntesis celular

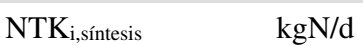

18.8

8. Demanda de oxígeno

Flujo de demanda de $\mathrm{O}_{2}$ para PAOs

$\mathrm{FO}_{2, \mathrm{PAO}} \quad \mathrm{kgO}_{2} / \mathrm{d} \quad 947$

Flujo de demanda de $\mathrm{O}_{2}$ para $\mathrm{OHOs}$

$\mathrm{FO}_{2, \mathrm{OHO}}$

$\mathrm{kgO}_{2} / \mathrm{d}$

5,330

Flujo de demanda de $\mathrm{O}_{2}$ carbonáceo

$\mathrm{FO}_{2, \mathrm{C}}$

$\mathrm{kgO}_{2} / \mathrm{d}$

6,280

DQO salida/DQO entrada

Balance de DQO

$\mathrm{gDQO} / \mathrm{gDQO}$

$100.0 \%$

Caudal en $\mathrm{m}^{3} / \mathrm{d}$ y flujo másico en $\mathrm{g} / \mathrm{d}$

Para caudales mayores de 1,000, los flujos pueden ser en unidades de $\mathrm{kg} / \mathrm{d}$

\subsection{INFLUENCIA DE LA EBPR EN EL SISTEMA}

\subsubsection{Influencia en los sólidos suspendidos totales y volátiles, y en la demanda de oxígeno}

El modelo de los sistemas con EBPR presentados anteriormente permite el cálculo de los sólidos suspendidos volátiles (SSV) y totales (SST) en el licor mezclado (Eqs. 7.23 y 7.24, respectivamente), así como de la demanda carbonácea de oxígeno (Ec. 7.31). En la Figura 7.23 se compara el comportamiento de un agua residual cruda y clarificada respectivamente a lo largo de diversas edades de lodo, graficando las masas SSV y SST generadas, así como de la demanda carbonácea de oxígeno por kgDQO en el bioreactor, con y sin EBPR. El sistema con EBPR graficado cuenta con dos reactores anaerobios en serie, una fracción de biomasa anaerobia total $\left(f_{A N}\right)$ de $15 \%$ y no tiene recirculación de nitrito al reactor anaerobio; está operado al $20^{\circ} \mathrm{C}$.

De esta comparación se sugiere que la adición de la EBPR al sistema de lodos activados incrementa ligeramente la concentración de SSV, aproximadamente de un 5 a $12 \%$ y de 15 a $25 \%$ para aguas residuales crudas y clarificadas respectivamente (dependiendo de la edad de lodos). Este incremento en SSV se debe a la disminución del decaimiento endógeno/muerte celular en los PAOs $\left(0.04 \mathrm{~d}^{-1}\right.$ a $\left.20^{\circ} \mathrm{C}\right)$ comparado con los $\mathrm{OHOs}$ $\left(0.24 \mathrm{~d}^{-1}\right.$ a $\left.20^{\circ} \mathrm{C}\right)$. Sin embargo, la concentración de SST se incrementa sustancialmente, aproximadamente de 20 a $25 \%$ y de 45 a $55 \%$ para agua residual cruda y clarificada, respectivamente (dependiendo de la edad de lodos). Este incremento en la producción de SST se debe a las altas cantidades de poliP inorgánico almacenado y los cationes inorgánicos asociados necesarios para estabilizar las cadenas de poliP -principalmente $\mathrm{Mg}^{2+} \mathrm{y}$ $\mathrm{K}^{+}$(Fukase et al., 1982; Arvin et al., 1985; Comeau et al., 1986; Wentzel et al., 1989a; Ekama and Wentzel, 2004). El alto contenido inorgánico en la biomasa de los PAOs causa que la relación SSV/SST sea mucho más baja que aquella presente en los OHOs, $0.46 \mathrm{mgSSV} / \mathrm{mgSST}$ comparado con 0.75 a $0.85 \mathrm{mgSSV} / \mathrm{mgSST}$.
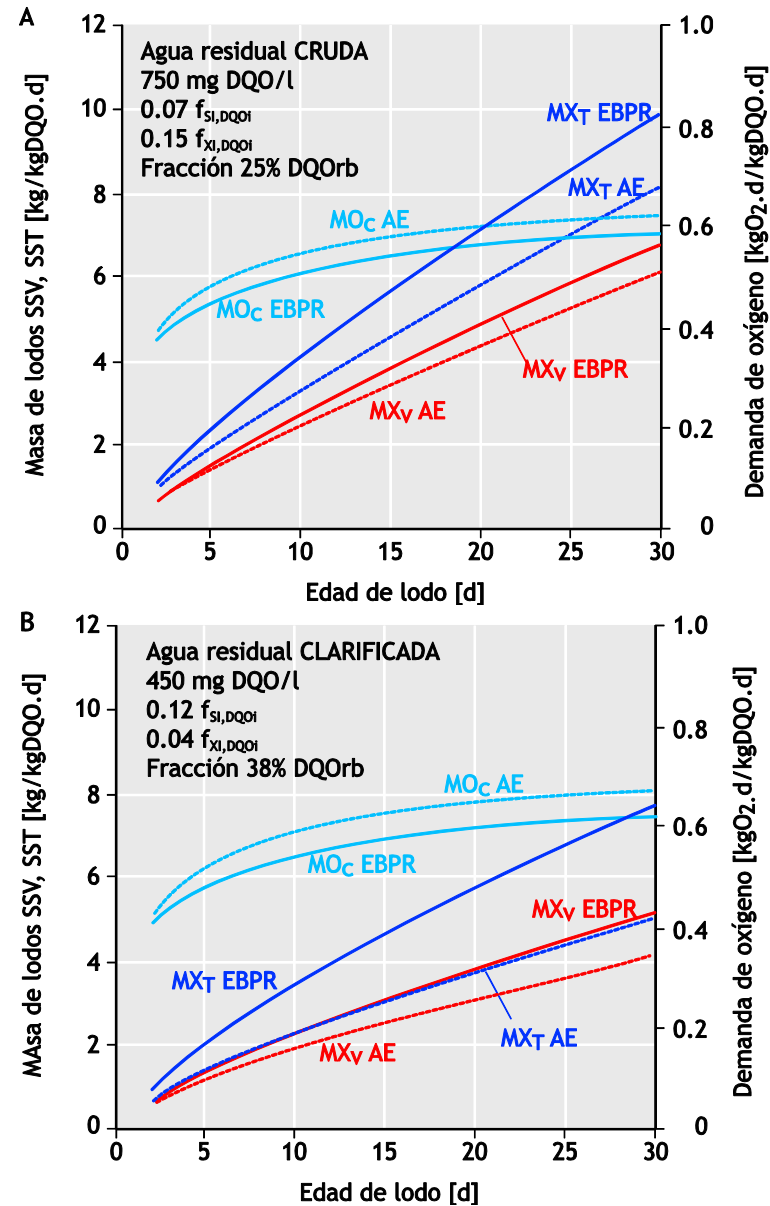

Figura 7.23 Masas aproximadas de sólidos suspendidos volátiles $\left(M X_{V}\right)$, sólidos suspendidos totales $\left(M X_{T}\right)$ y demanda carbonácea de oxígeno $\left(\mathrm{MO}_{\mathrm{c}}\right)$ por cada kg de DQO descargado en el reactor biológico completamente aerobio y un sistema de remoción biológica de $\mathrm{P}$ (EBPR), tratando (A) agua cruda y (B) clarificada. 
Por lo tanto, entre más alta sea la fracción PAO en el licor mezclado, mayor será el EBPR y menor la relación SSV/SST. El incremento de la concentración de los SST cuando se incluye en un sistema la EBPR necesita ser tomado en cuenta en el diseño del volumen del reactor (Ec. 7.27) y en el cálculo de la producción de lodo. Además, se debe asegurar una concentración suficiente de dichos cationes en el afluente debido a los requerimientos de cationes inorgánicos que estabilizan el poliP; de otra manera el EBPR se vería afectado adversamente (Wentzel et al., 1988; Lindrea et al., 1994). Por otro lado, debido a que la masa de SSV generada por $\mathrm{kg}$ de carga de DQO es mayor cuando hay un sistema con EBPR que cuando no lo hay, la demanda de oxígeno con EBPR es en consecuencia menor, cerca de 5-6\% y 8-9\% para un agua residual cruda y clarificada respectivamente (dependiendo de la edad de lodos, Figura 7.23).

Aunque la diferencia en la producción de SSV entre un sistema con EBPR y uno sin remoción de P es menor, los componentes de las fracciones de lodo en los dos sistemas difieren significativamente. Esto puede ser fácilmente demostrado comparando la composición (\%) de la masa SSV generada en sistemas que tienen EBPR con aquellos que no lo tienen. Para ilustrar lo anterior, la composición (\%) de la masa de SSV se muestra en la Figura 7.24 para sistemas a $20^{\circ} \mathrm{C}$ con y sin EBPR tratando aguas residuales con características como las ya mostradas. Se observa que el sistema EBPR tiene una menor cantidad de biomasa activa de $\mathrm{OHO}$ que un sistema que no es un EBPR, pero el sistema EBPR tiene una concentración significativa de biomasa activa de PAO.

\subsubsection{Relación P/SSV}

Un parámetro frecuentemente usado para evaluar el desempeño de un sistema de EBPR en un lodo activado es la relación P/SSV (o P/SST) en el licor mezclado. En la Figura 7.26 se grafica la relación P/SSV calculada para un sistema con dos reactores anaerobios en serie y la caracterización del agua residual mostrada contra la edad de lodo. Se asume una descarga de nitrato igual a cero al reactor anaerobio.

En la Figura 7.25 se observar que a medida que la edad de lodo en el sistema incrementa, la relación P/SSV también aumenta hasta que se llega a una edad de lodos de 10 días. Un aumento posterior en la edad de lodos causa una disminución de la relación P/SSV. El aumento inicial de P/SSV con la edad de lodo puede ser descrita como un incremento en la biomasa activa de $\mathrm{OHO}$ debido a un incremento de la edad de lodo. Esto produce una conversión más eficiente de la DQO fermentable a AGVs en el reactor anaerobio y con ello un aumento de la biomasa activa de PAOs (con un contenido de P asociado de $0.38 \mathrm{mgP} / \mathrm{mgSSV}$ ). La disminución de P/SSV puede deberse al efecto de la respiración endógena de los PAOs.
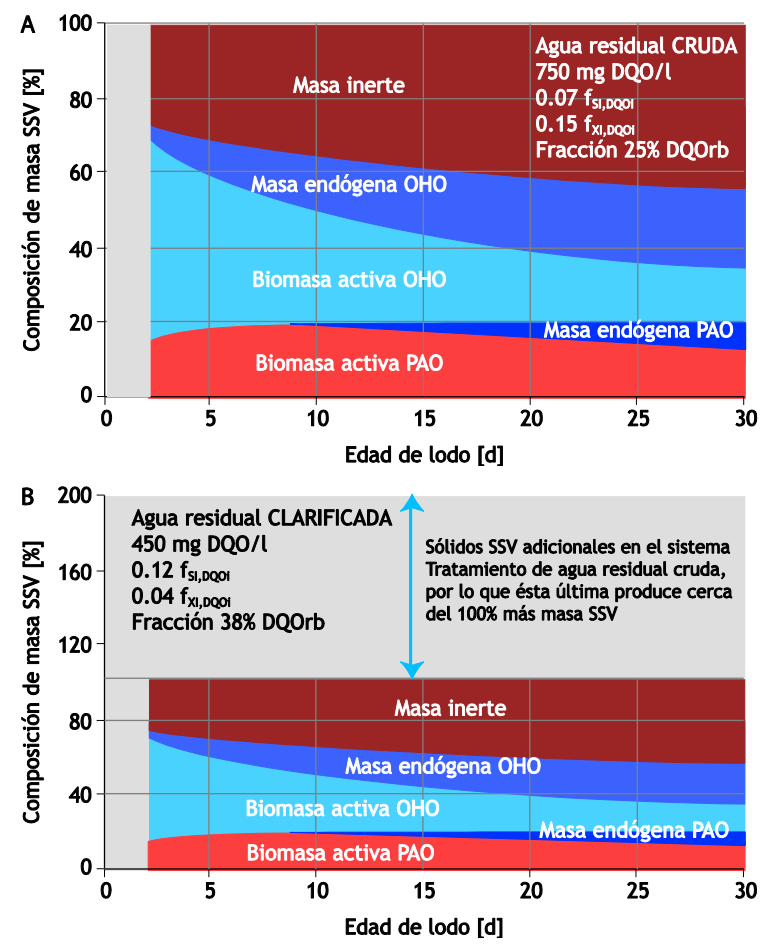

Figura 7.24 Composición (\%) de masa SSV para sistemas con EBPR tratando (A) agua cruda y (B) agua clarificada

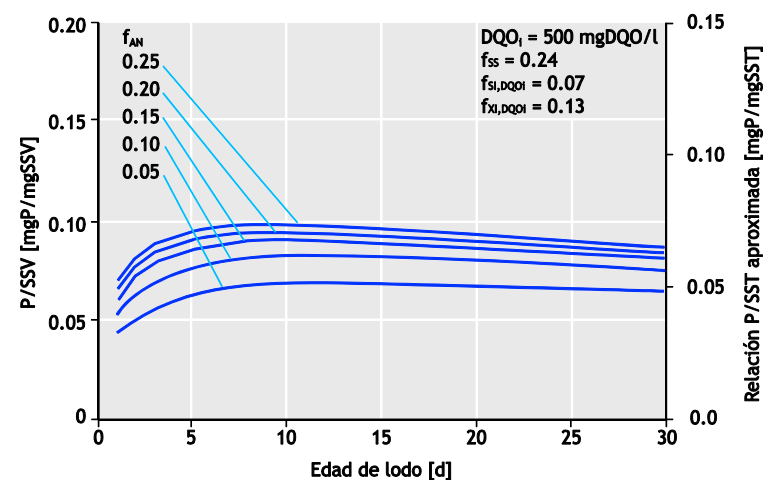

Figura 7.25 Relaciones estimadas de fósforo y sólidos suspendidos volátiles ( $P / S S V)$ y totales $(P / S S T)$ en el licor mezclado contra edad de lodo, en sistemas de EBPR con varias fracciones de masa anaerobia $\left(f_{A N}\right)$ tratando agua residual con las características mostradas 
Esto sugiere que la relación P/SSV es consecuencia de la selección de los parámetros fundamentales de diseño, que son la edad de lodos y la fracción de masa anaerobia. Además, el contenido de $\mathrm{P}$ en los SSV es también una función de las características del agua residual (ej. fracción $\left.\mathrm{DQO}_{\mathrm{rb}}\right)$. En consecuencia, la relación P/SSV no puede ser usada directamente como un parámetro de diseño básico de manera confiable; podría ser establecida en el diseño sólo si primero se obtiene experimentalmente usando los paramétros de diseño seleccionados para el agua residual a tratar.

\subsection{FACTORES QUE AFECTAN LA MAGNITUD DE LA REMOCIÓN DE P}

\subsubsection{Descarga nula de nitrato y oxígeno al reactor anaerobio}

En esta sección se analiza la influencia de los principales parámetros de diseño en la magnitud de la remoción de $\mathrm{P}$, usando un modelo de cultivo mixto en condiciones estacionarias y asumiendo una descarga nula de nitrato y oxígeno. Estos parámetros son:

- Edad de lodos (TRS).

- Fracción de masa (de lodos) anaerobia (f $\left.\mathrm{f}_{\mathrm{AN}}\right)$.

- DQO total afluente $\left(\mathrm{DQO}_{\mathrm{i}}\right)$.

- Número de reactores anaerobios (n).

- Agua residual cruda o clarificada.

\subsubsection{Edad del lodo y fracción de masa de lodo anaerobio}

En la Figura 7.26 se grafica la remoción de P y la relación $\mathrm{P}$ removida/ $\mathrm{DQO}_{\mathrm{i}}$ contra la edad de lodo, para un reactor anaerobio de una etapa con $\mathrm{f}_{\mathrm{AN}}$ of $0.05 ; 0.10 ; 0.15 ; 0.20$ y 0.25 . En los cálculos se asumió las características de un agua residual municipal típica que no ha sido clarificada, con una DQO total afluente de $250 \mathrm{mgDQO} / \mathrm{l}$, asumiendo que no hay entrada de nitrato en el reactor anaerobio y con un factor de recirculación al reactor anaerobio de 1:1. La gráfica muestra lo siguiente:

- El efecto del TRS en la remoción de P es complejo. Para un TRS $<3$ días la remoción de $\mathrm{P}$ incrementa conforme aumenta la TRS. Sin embargo, para una TRS > 3 días, la remoción de $\mathrm{P}$ disminuye cuando la TRS aumenta. La razón de esto es que un incremento de la TRS causa un incremento de la biomasa $\mathrm{OHO}$ en el sistema, lo que a su vez causa un incremento de la conversión de la DQO fermentable y, por lo tanto, un incremento de la liberación y captura de P. Sin embargo un incremento de la TRS también ocasiona un deterioro de la captura de $\mathrm{P}$ debido a la disminución de la biomasa activa PAO (y su contenido de $\mathrm{P}$ asociado) purgada diariamente. Con un TRS $<3 d$, el primer efecto domina la remoción de $\mathrm{P}$, mientras que a un TRS $>3 \mathrm{~d}$ el segundo efecto domina, elevando la forma de la curva. El segundo efecto, que es una disminución de la biomasa activa de PAO y OHO cuando incrementa el TRS, será afectado de manera crucial por el decaimiento endógeno de PAOs. Si el decaimiento endógeno de PAOs $\left(0.04 \mathrm{~d}^{-1}\right)$ fuera el mismo que el de OHOs $(0.24$ $\left.\mathrm{d}^{-1}\right)$ no se obtendría un sistema EBPR.

- El efecto de $\mathrm{f}_{\mathrm{AN}}$ en la remoción de P es también mostrado en la Figura 7.26. Un incremento de $\mathrm{f}_{\mathrm{AN}}$ aumenta la remoción de $\mathrm{P}$ para un TRS determinado. Esto se debe a la elevación de la conversión de la DQO fermentable cuando hay una fracción de masa anaerobia mayor. Sin embargo, el mejoramiento de la remoción de $\mathrm{P}$ disminuye cada que se incremente la $\mathrm{f}_{\mathrm{AN}}$ debido a que dicha conversión cinética es de primer orden. Como se muestra en la gráfica, en un reactor anaerobio de una etapa se debe seleccionar una $\mathrm{f}_{\mathrm{AN}}$ alrededor de 0.15 ya que aplicar una $\mathrm{f}_{\mathrm{AN}}>$ 0.20 solo conlleva a un incremento modesto de $\mathrm{P}$.

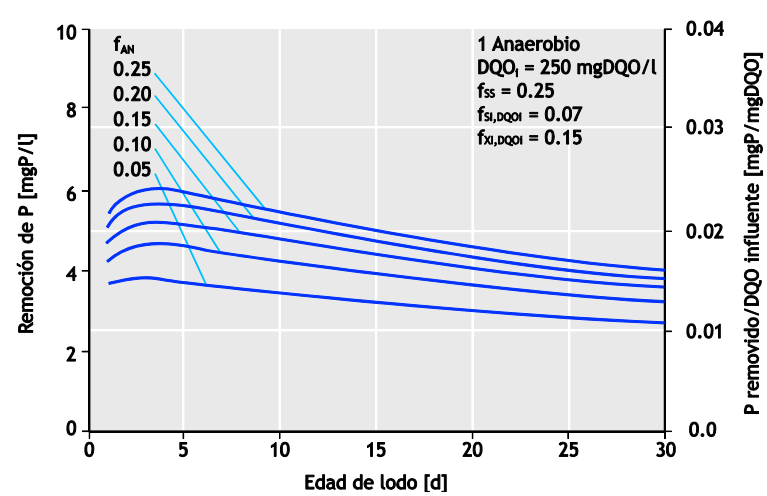

Figura 7.26 Remoción de $\mathrm{P}$ estimado contra la edad de lodo para diferentes fracciones de masa anaerobia $\left(f_{A N}\right)$, en un reactor anaerobio de una etapa que trata agua residual no clarificada con una DQO total de $250 \mathrm{mgDQO} / \mathrm{l}$.

\subsubsection{DQO afluente}

Las Figuras 7.27 y 7.28 son gráficas similares a la Figura 7.26 ya dada, excepto en que la $\mathrm{DQO}_{\mathrm{i}}$ es $500 \mathrm{mgDQO} / \mathrm{l}$ y $1,000 \mathrm{mgDQO} / \mathrm{l}$ respectivamente. Para ayudar a comparar las diferencias entre la DQO afluente, el segundo eje "y" (derecha) es dado como P removido/ DQO $_{i}$. Una comparación de las Figuras 7.26, 7.27 y 7.28, sugiere que con el incremento de $\mathrm{DQO}_{\mathrm{i}}$, la eficiencia de la remoción de $\mathrm{P}$ (y por lo tanto la $\mathrm{P}$ removida/ $\mathrm{DQO}_{\mathrm{i}}$ ) incrementa. 
Esto es debido al incremento en la magnitud de la concentración de DQO fermentable (fracción DQO afluente constante como fss $=0.25$ ), y la conversión de

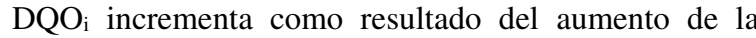
biomasa $\mathrm{OHO}$.

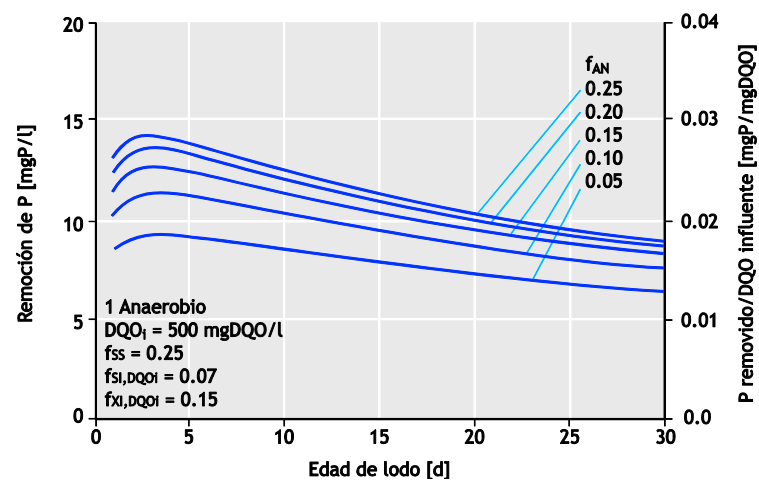

Figura 7.27 Remoción de P estimado contra la edad de lodo para diferentes fracciones de masa anaerobia $\left(f_{A N}\right)$, en un reactor anaerobio de una etapa que trata agua residual no clarificada con una DQO total de $500 \mathrm{mgDQO} / \mathrm{l}$.

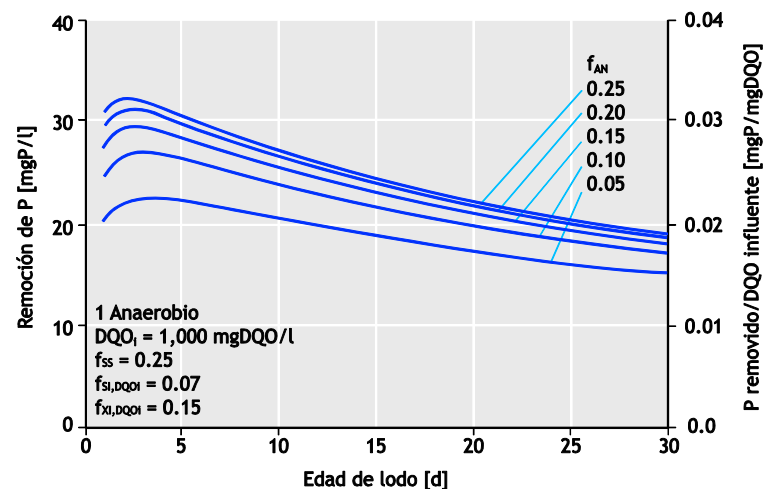

Figura 7.28 Remoción de P estimado contra la edad de lodo para diferentes fracciones de masa anaerobia $\left(f_{A N}\right)$, en un reactor anaerobio de una etapa que trata agua residual no clarificada con una DQO total de $1,000 \mathrm{mgDQO} / \mathrm{l}$.

\subsubsection{Subdivisión de $\mathrm{f}_{\mathrm{AN}}$}

El efecto de subdividir el reactor anaerobio es mostrado en la Figura 7.29. La gráfica es similar a la Figura 7.27, pero con la zona anaerobia subdividida en dos reactores iguales. Comparando el comportamiento de la remoción de P en las Figuras 7.27 y 7.29, una operación en serie de la zona anaerobia incrementa de manera significativa la remoción de P. Esta mejora es debido al incremento de la conversión de DQO fermentable cuando hay una operación de reactores anaerobios en serie, como resultado de la naturaleza de primer orden de la conversión cinética. Una comparación (no mostrada) entre reactores anaerobio de una etapa y en serie de dos y cuatro tanques indica que la principal mejora ocurre de un reactor de una etapa a uno de dos en serie. Para el diseño, al menos dos reactores en serie de igual tamaño deben ser usandos.

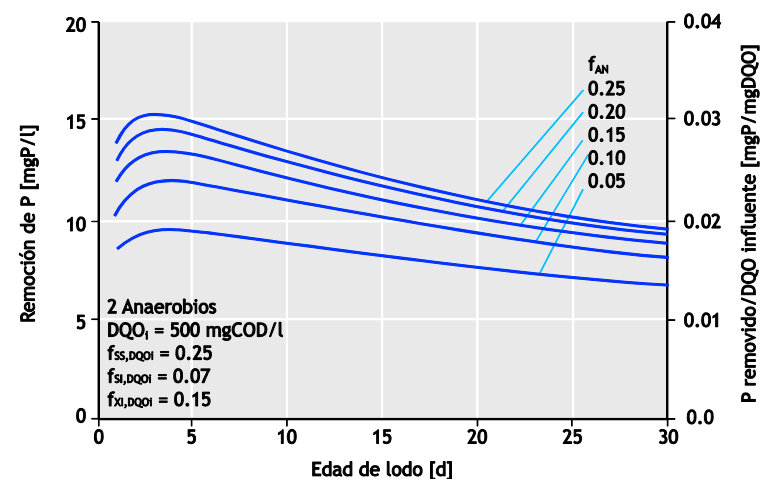

Figura 7.29 Remoción de P estimada contra la edad del lodo para varias fracciones de masa anaerobia $\left(f_{A N}\right)$, para un sistema de reactor anaerobio de dos etapas en serie que trata agua residual no clarificada con una DQO total de $500 \mathrm{mgDQO} / \mathrm{l}$, con las características descritas (ver Figura 7.27 para un sistema con reactor de una sola etapa)

\subsubsection{Agua residual afluente clarificada y no clarificada}

El efecto de la clarificación del agua residual en la remoción de $\mathrm{P}$ es ilustrado en la Figura 7.30, donde la remoción de $\mathrm{P}$ se grafica contra la edad de lodo para varios valores de $\mathrm{f}_{\mathrm{AN}}$, para un agua residual con una $\mathrm{DQO}_{\mathrm{i}}$ de $1,000 \mathrm{mgDQO} / \mathrm{l}$ y sujeto a una clarificación primaria para dar una agua residual clarificada de una concentración de $600 \mathrm{mgDQO} / \mathrm{l}$. Comparando la remoción de $\mathrm{P}$ para el agua residual originalmente sin clarificar (Figura 7.28) con el agua clarificada (Figura 7.30), es evidente que la clarificación reduce la remoción de $\mathrm{P}$ en el sistema. Esta reducción se debe a la disminución de la masa de DQO biodegradable que entra al sistema de lodos activados lo que causa una reducción de la DQO fermentable convertida y en la masa de OHOs generada. Sin embargo, la remoción de $\mathrm{P}$ por afluente de DQO que entra al reactor biológico es mayor que en el agua residual clarificada que en el no clarificada. Lo anterior se puede observar en las Figuras 7.28 y 7.30, comparando la $\mathrm{P}$ removida/DQO $\mathrm{D}_{\mathrm{i}}$ en el eje derecho de las ordenadas. Esto se eleva debido a que la relación $\mathrm{S}_{\mathrm{S}, \mathrm{i}} / \mathrm{DQO}_{\mathrm{i}}$ es mayor para agua residual clarificada $\left(\mathrm{f}_{\mathrm{SS}}=\right.$ 0.38 ) que para el agua no clarificada ( $f_{S s}=0.25$, cabe mencionar que se asume que el $\mathrm{S}_{\mathrm{Si}}$ no es removido en el clarificador. Aunque en estricto sentido esto no es correcto, la remoción de $\mathrm{S}_{\mathrm{Si}}$ en los clarificadores parecer ser mínima). 


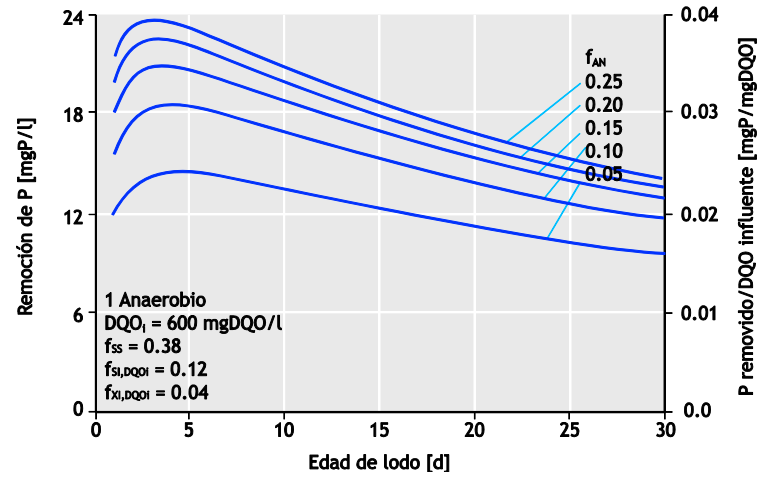

Figura 7.30 Remoción de P estimada contra la edad del lodo para varias fracciones de masa anaerobia $\left(f_{A N}\right)$, para un sistema de reactor anaerobio de una etapa que trata agua residual clarificada con una DQO total de $600 \mathrm{mgDQO} / \mathrm{l}$, con las característica descritas (ver Figura 7.28 para el agua residual originalmente sin clarificar)

\subsubsection{TRS aerobio mínimo requerido para una buena EBPR}

En el sistema con EBPR el comportamiento de las tres fuentes de almacenamiento en las células (PHA, poliP y glucógeno es altamente dinámico y determinado por su conversión durante la fase anaerobia y aerobia (o anóxica). El contenido de PHA en la biomasa depende de la concentración de biomasa en el reactor. La concentración de biomasa puede ser fácilmente controlada por la manipulación de la carga del sustrato y el TRS. Mientras que la producción anaerobia de PHA depende de la carga de sustrato en el sistema, el consumo aerobio de PHA depende del nivel de PHA dentro de la biomasa y en la cinética de los cuatro procesos que utilizan PHA. El PHA formado bajo condiciones anaerobias debe ser consumido durante la fase aerobia. De otra manera, el nivel de PHA en las célculas incrementará hasta que un máximo nivel es alcanzado. A partir de ese momento, la captura de sustrato bajo condiciones anaerobias no ocurrirá, lo cual deteriorá el sistema con EBPR.

En los sistemas de lodos activados diseñados para la remoción de materia orgánica y nitrógeno, el TRS está directamente vinculado con la tasa de crecimiento de los microorganismos; el TRS mínimo requerido corresponde con la tasa máxima de crecimiento $\left(\mathrm{TRS}_{\operatorname{mín}}=1 / \mu_{\text {máx }}\right)$. Sin embargo, en los sistemas con EBPR donde los compuestos almacenados juegan un papel importante en el metabolismo de la bacteria, la determinación de la

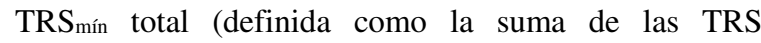
mínimamente requeridas en la fase anaerobio y aerobia: $\mathrm{TRS}_{\text {mín }}{ }^{\mathrm{TOTAL}}=\mathrm{TRS}_{\text {mín }}{ }^{\mathrm{AN}}+\mathrm{TRS}_{\text {mín }}{ }^{\mathrm{AER}}$ ) depende de las tasas del proceso cinético y de un número de condiciones de proceso, notablemente del tiempo requerido para la conversión anaerobia de $\mathrm{DQO}_{\mathrm{rb}}$ a PHA, el tiempo requerido para el consumo de PHA en condiciones aerobias o anóxicas, la tasa específica de carga de sustrato por unidad de biomasa, y el contenido máximo de PHA en la célula. Debido a que la remoción anóxica de fósforo no está bien estudiada, en este diseño se asume que el crecimiento sólo ocurre bajo condiciones aerobias, y por ello únicamente los procesos de EBPR aerobios (y por lo tanto sólo el TRS mín $^{\text {AER }) ~ s o n ~ c o n s i d e r a d o s ~ e n ~ e s t e ~}$ capítulo. No existe un tiempo mínimo de oxidación aerobia por debajo del cual el PHA producido anaerobicamente pueda no ser oxidado. El modelo para la predicción del TRS aerobio mínimo requerido como una función de los parámetros de proceso fue desarrollado y comparado con datos experimentales usados para evaluar diversos aspectos operacionales del sistema con EBPR en un SBR (Brdjanovic et al., 1998b). El modelo probado fue capaz de describir los procesos satisfactoriamente (Figura 7.31).

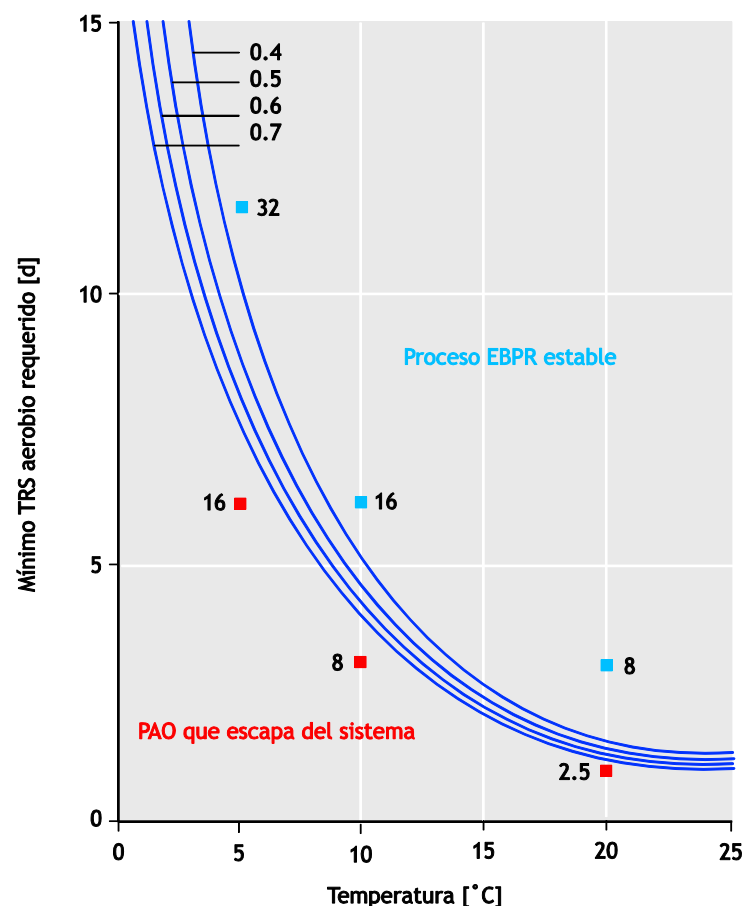

Figura 7.31 TRS aerobio mínimo requerido como una función de la capacidad máxima de almacenamiento de PHA en un cultivo enriquecido (0.4 - 0.7 gDQO-PHA/gDQO- biomasa activa) y de la temperatura. Los símbolos indican el TRS aerobio de diferentes sistemas SBR a escala de laboratorio (Smolders et al., 1994C, Brdjanovic et al., 1998b). Los números al lado de los rectángulos ndican el TRS total de los sistemas. Una buena EBPR fue alcanzada en en los TRS marcados en azul, mientras que los EBPR fallaron en los TRS marcados en rojo debido a que fueron muy cortos 


\subsubsection{Influencia de la fracción $\mathrm{DQO}_{\mathrm{rb}}$ afluente}

Asumiendo una descarga cero de nitrato en el reactor anaerobio, el efecto de la fracción $\mathrm{DQO}_{\mathrm{rb}}$ afluente con respecto a la DQO biodegradable $\left(\mathrm{f}_{\mathrm{SS}}=\mathrm{S}_{\mathrm{S}, \mathrm{i}} / \mathrm{DQO}_{\mathrm{b}, \mathrm{i}}\right)$ es ilustrada en el Figura 7.32 donde las remociones teóricas de $\mathrm{P}$ son graficadas contra fss para un sistema con dos reactores anaerobios en serie, un TRS de 20 días y $\mathrm{f}_{\mathrm{AN}} \mathrm{y}$ características del agua residual como se muestran. Esto sugiere que para una $\mathrm{f}_{\mathrm{AN}}$ seleccionada, cuando la fracción $\mathrm{DQO}_{\mathrm{rb}}$ ( $\mathrm{f}_{\mathrm{ss}}$ ) incrementa la remoción de $\mathrm{P}$ también incrementa. En el diseño, una opción para mejorar la remoción de $\mathrm{P}$ es adicionando $\mathrm{DQO}_{\mathrm{rb}}$ al afluente, por ejemplo por medio de una fermentación ácida del lodo primario (Pitman et al. 1983; Barnard 1984; Osborn et al. 1989).

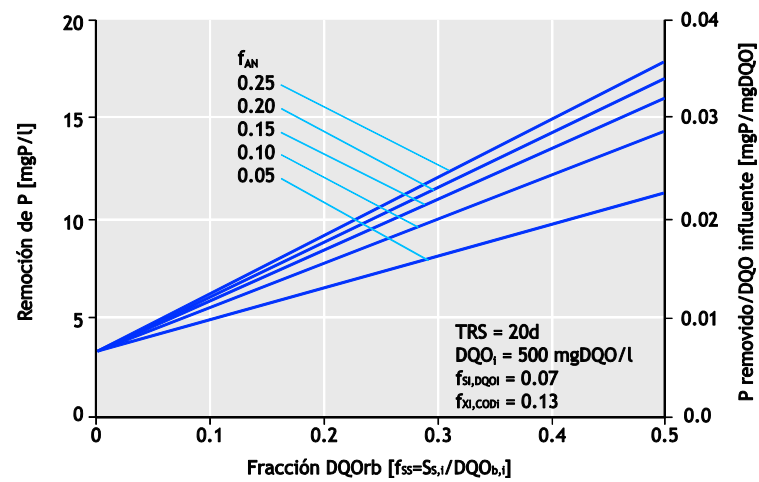

Figura 7.32 Remoción de $\mathrm{P}$ estimada contra la $\mathrm{DQO}$ rápidamente biodegradable (DQOrb, Ss,i) como una fracción de la DQO biodegradable $\left(\mathrm{DQO}_{\mathrm{b}, \mathrm{i}}\right)$ DQO $\left(\mathrm{f}_{\mathrm{ss}}=\mathrm{S}_{\mathrm{s}, \mathrm{i}} / \mathrm{DQO}_{\mathrm{b}, \mathrm{i}}\right)$ para varias fracciones de biomasa anaerobia $\left(f_{A N}\right)$ para un sistema de dos reactores anaerobios en serie con $20 d$ de edad de lodo, tratando agua residual no clarificada de $500 \mathrm{mgDQO} / \mathrm{l}$, con las característica antes descritas.

\subsubsection{Influencia de la recirculación de nitrato y oxígeno en el reactor anaerobio}

La influencia de la recirculación de nitrato al reactor anaerobio se ilustra en la Figura 7.33 donde las remociones teóricas de $\mathrm{P}$ son graficadas contra la concentración de nitrato recirculado en un sistema de dos reactores anaerobios en serie, con un radio de recirculación 1:1, 20 días de TRS y $\mathrm{f}_{\mathrm{AN}}$ y las características del agua residual mostradas. Esto indica que la recirculación de nitrato tiene un efecto negativo marcado en la magnitud de la remoción de $\mathrm{P}$ (de acuerdo con numerosas observaciones experimentales). A medida que la concentración de nitrato recirculado al reactor anaerobio incrementa, la remoción de $\mathrm{P}$ decrece, como se explica a continuación.

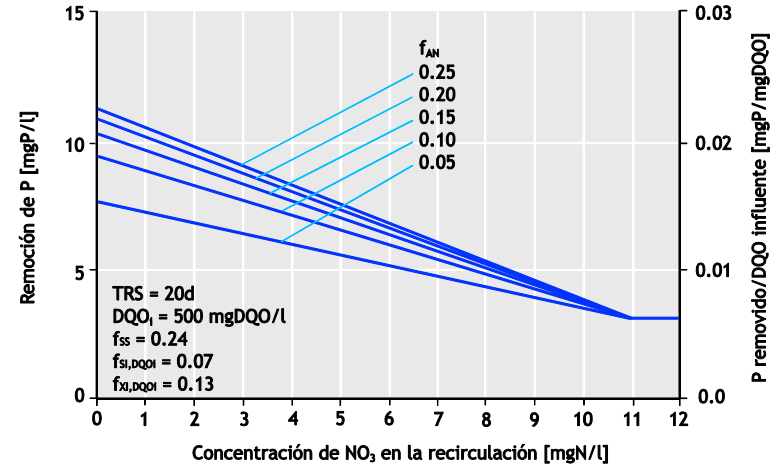

Figura 7.33 Remoción de P estimada contra concentración de nitrato en la recirculación del reactor anaerobio (radio de recirculación 1:1) para varias fracciones de biomasa anaerobia $\left(f_{A N}\right)$, para un sistema de dos reactores anaerobios en serie con $20 \mathrm{~d}$ de edad de lodo, que trata agua residual no clarificada de $500 \mathrm{mgDQO} / \mathrm{l}$, con las característica antes descritas.

Si el oxígeno y/o nitrato es recirculado al reactor anaerobio, los OHOs no transforman más la DQO fermentable en AGVs, porque son capaces de utilizarlo directamente como fuente de energía y carbono usando oxígeno o nitrato como aceptor externo de electrones. Por cada $1 \mathrm{mgO}_{2}$ y $1 \mathrm{mgNO}_{3}-\mathrm{N}$ recirculado al reactor anaerobio, 3.0 y $8.6 \mathrm{mgDQO}$, respectivamente, son utilizados. Consecuentemente, permitir que el oxígeno y/o nitrato entren al reactor anaerobio reduce la masa disponible de AGVs para su almacenamiento por PAOs, y en consecuencia esto reduce la liberación, captura y remoción de $\mathrm{P}$.

De la Figura 7.33, cuando la concentración de nitrato en la recirculación excede cerca de $11 \mathrm{mgN} / \mathrm{l}$, la remoción de $\mathrm{P}$ permanece constante a cerca de $3 \mathrm{mgP} / \mathrm{l}$; para esta condición toda la $\mathrm{DQO}_{\mathrm{rb}}$ afluente para esta agua residual es desnitrificada por los OHOs resultando en que no hay liberación de AGVs, y no hay DQO disponible para PAOs y por lo tanto la EBPR no se lleva a cabo en el sistema - la remoción de $\mathrm{P}$ obtenida se debe a la purga de lodo "normal" con un contenido de P metabólico (0.03 $\mathrm{mgP} / \mathrm{mgSSV}$ ). Si la concentración de $\mathrm{DQO}_{\mathrm{rb}}$ afluente incrementa o disminuye, la masa de nitrato recirculado que consume completamente la DQO ${ }_{\mathrm{rb}}$ también incrementará o disminuirá en consecuencia (teniendo en cuenta que la relación de recirculación permanece constante).

De lo anterior es claro que una de las principales guías en cualquier diseño de un sistema con EBPR es minimizar la intrusión de oxígeno y la recirculación de nitrato en el reactor anaerobio. En condiciones donde la nitrificación es obligatoria, diferentes configuraciones han sido desarrolladas específicamnete para prevenir esto 
por medio de la incorporación de una desnitrificación completa, o pasando la recirculación de lodo a través de zonas anóxicas antes de ser descargado al reactor anaerobio.

\subsubsection{Influencia de la temperatura en sistemas con EBPR}

Con la aplicación de la modelación matemática de los procesos biológicos, el rol de los coeficientes de temperatura adquiere mayor importancia. Los modelos matemáticos que incluyen el proceso de EBPR en un sistema lodos activados, como el Modelo de Lodos Activado No. 2 (ASM2, por su siglas en inglés Activated Sludge Model) (Henze et al., 1994), el Modelo de lodos Activados de la Universidad de la Ciudad del Cabo (UCTPHO; Wentzel et al., 1992) o el modelo metabólico de sistemas EBPR (Modelo TUDP; Smolders et al., 1994) se basan en coeficientes estequiométricos y cinéticos válidos en un rango estrecho de temperaturas o para una sola temperatura dada. En el ASM2, los coeficientes de proceso están definidos para dos diferentes temperaturas $\left(10\right.$ y $\left.20^{\circ} \mathrm{C}\right)$. En este modelo, los coeficientes estequiométricos son independientes de la temperatura, mientras que los coeficientes cinéticos son afectados por los cambios de temperatura. Los procesos en el ASM2 son clasificados en cuatro grupos basados en sus dependencas de temperatura (cero, baja, media y alta dependencia). En muchos coeficientes fueron asignados valores idénticos a 10 y $20^{\circ} \mathrm{C}$. Esto fue justificado por la escasez de datos disponibles y por la baja sensibilidad de ciertos parámetros a las variaciones de temperatura. En esta clasificación, se considera que los procesos de EBPR tienen un bajo grado de dependencia a la temperatura en comparación con otros procesos incorporados en ASM2. El ASM2 es en general recomendado para aplicarse en el tratamiento de aguas residuales con lodos activados a temperaturas entre 10 y $25^{\circ} \mathrm{C}$, los autores del modelo ASM2 son cuidadosos sobre la aplicabilidad del modelo por fuera de este rango.

De manera similar, el modelo UCTPHO tiene parámetros de proceso establecidos para una temperatura de $20^{\circ} \mathrm{C}$. Para otras temperaturas de operación, el ajuste de los valores se lleva a cabo considerando la temperatura de entrada y las constantes de temperatura de Arrhenius. En el modelo metabólico todos los parámetros son determinados a $20{ }^{\circ} \mathrm{C}$, pero no hay información disponible respecto a sus dependencias por temperatura. Se ha sugerido que el impacto de la temperatura en PAOs puede ser modelado con los mismos coeficientes que se usan para los organismos heterótrofos. Sin embargo, debido a las grandes diferencias en cuanto al metabolismo de los productos de almacenamiento, esta consideración puede ser errónea. Debido a que las PTARs municipales (incluidas aquellas con sistemas de EBPR), pueden manejar temperaturas de licor mezclado tan bajas como $5^{\circ} \mathrm{C}$, o tan altas como $35^{\circ} \mathrm{C}$, existe una fuerte necesidad de estudiar sistemáticamente el impacto de la temperatura en sistemas con EBPR, lo cual también debería considerar los requerimientos específicos de los modelos matemáticos y su aplicaciones en diferentes climas.

Hace algunos años se pensaba que los microorganismos Acinetobacter sp. eran los responsables de la remoción biológica aumentada de $\mathrm{P}$, y en consecuencia, gran parte de la investigación científica respecto al impacto de la temperatura estaba relacionada con esta bacteria en particular. Sin embargo, fue demostrado después que Acinetobacter tiene un rol muy limitado en el fenómeno de EBPR (Wagner et al., 1994), y por lo tanto, la información del metabolismo de $\mathrm{P}$ de Acinetobacter tiene menor relevancia.

Existen diversas publicaciones que reportan los efectos de la temperatura en la eficiencia de EBPR (considerando la diferencia entre la calidad del afluente y el efluente) usando lodos activados, aunque con resultados inconsistentes. Mejoras en la eficiencia de sistemas con EBPR a temperaturas más elevadas (en un rango de $20-37^{\circ} \mathrm{C}$ ) fueron observadas por Jones et al., (1987); Yeoman et al., (1988); McClintock et al., (1993) and Converti et al., (1995). En contraste, una buena o comparativamente mejor eficiencia en la remoción de $\mathrm{P}$ a temperaturas más bajas (en un rango de $5-15^{\circ} \mathrm{C}$ ) fue reportado por Sell et al., (1981); Kang et al., (1985b); Krichten et al., (1985); Barnard et al., (1985); Vinconneau et al., (1985) and Florentz et al., (1987). Sin embargo, cuando la cinética de los procesos de EBPR fueron estudiados, dichas inconsistencias no existían. Un aumento en la tasa de liberación de $\mathrm{P}$ y/o de captura de $\mathrm{P}$ a temperaturas más elevadas fueron reportados por Shapiro et al., (1967), Boughton et al., (1971), Spatzierer et al., (1985), and Mamais and Jenkins, (1992). Adicionalmente a las tasas de liberación y captura de P, Mamais y Jenkins, (1992) también reportaron un incremento en las tasa de crecimiento y consumo de sustrato cuando la temperatura aumenta $\left(10-33^{\circ} \mathrm{C}\right)$. Los diferentes resultados de los efectos de la temperatura en los sistemas de EBPR con lodos activados pueden ser explicados mediante el uso de diferentes sustratos, lodo activado y métodos de medición. 
La temperatura tiene influencía en una variedad de procesos en los sistemas de lodos activados (lisis, fermentación, nitrificación, etc.), los cuales pueden influir en los procesos de EBPR. Estos efectos complican la determinación del efecto de la temperatura en la EBPR. Adicionalmente, muchos de los descubrimientos presentados en el párrafo anterior están basados en un enfoque tipo caja negra, y se compara las concentraciones de P afluente y efluente en la PTAR a diferentes temperaturas del agua residual. En ese tiempo no había disponibilidad de un estudio estructurado del efecto de la temperatura en la estequiometría y la cinética de los procesos de EBPR bajo condiciones específicas de laboratorio. Todos estos factores explican los diferentes resultados contradictorios obtenidos en el pasado, los cuales son difíciles de interpretar correctamente.

El efecto de la temperatura en la estequiometría de los procesos de EBPR no habían sido estudiados en gran detalle en los 80's hasta que Brdjanovic et al., (1997, 1998c) llevó a cabo un estudio sistemático del efecto de los cambios de temperatura en la estequiometría y en la cinética en sistemas tanto anaerobios como aerobios. Este estudio incluyó experimentos para investigar los efectos a corto plazo (horas) de los cambios de temperatura en la fisiología de los sistemas con EBPR, y a largo plazo (semanas) de los cambios de temperatura en la ecología de los sistemas con EBPR. Cultivos enriquecidos de PAOs alimentados con un agua residual sintética fueron utilizados en un reactor discontinuo secuencial (SBR) bajo condiciones controladas de laboratorio. Los principales resultados de este trabajo son resaltados más adelante.

\subsubsection{Efecto de la temperatura en la fisiología de la EBPR}

El lodo que contribuye a la remoción de $\mathrm{P}$ fue enriquecido en un sistema anaerobio-aerobio, alimentado con acetato, en un reactor discontinuo secuencial (SBR) a $20^{\circ} \mathrm{C}$. La conversión de los compuestos relevantes para la remoción biológica de fósforo fue estudiado a 5, 10, 20 y $30^{\circ} \mathrm{C}$ en lotes separados durante un periodo de pocas horas. Se encontró que la estequiometría de los procesos anaerobios no era sensible a los cambios de temperatura, mientras que sí se observaron efectos en la estequiometría aerobia. En contraste, la temperatura tiene una fuerte influencia en la cinética de los procesos bajo condiciones anaerobias así como aerobias. La tasa de liberación anaerobia de $\mathrm{P}$ (o captura de acetato) muestra su valor máximo a $20^{\circ} \mathrm{C}$. Sin embargo, un incremento continuo fue observado en el intervalo de $5-30^{\circ} \mathrm{C}$ para las tasas de conversión bajo condiciones aerobias. Basado en estos experimentos, los coeficientes de temperatura paras las diferentes reacciones fueron calculados. Se encontró un coeficiente general de temperatura $\theta$ para condiciones anaerobias y aerobias de 1.078 y 1.057 (válido en los rangos de $\quad 5^{\circ} \mathrm{C} \leq \mathrm{T} \leq 20^{\circ} \mathrm{C} \quad$ y $\quad 5^{\circ} \mathrm{C} \leq \mathrm{T} \leq 30^{\circ} \mathrm{C}$ ), respectivamente.

\subsubsection{Estudios de procesos y ecología molecular}

La conversión en estado estacionario de compuestos relevantes fue estudiada en un reactor con EBPR a 20, $30,20,10$ y $5^{\circ} \mathrm{C}$. Dentro del estudio de este proceso, se aplicaron dos métodos (microscopía electrónica: EM, y electroforesis en gel con gradiente de desnaturalización en seco (DDGGE, por sus siglas en inglés dry denaturing gradient gel electrophoresis)) para investigar la composición de la comunidad bacteriana del lodo responsable de la remoción biológica de $\mathrm{P}$ a diferentes temperaturas (el método FISH no estaba disponible en el tiempo que se realizó el estudio). Los coeficientes de temperatura para las conversiones metabólicas obtenidas en los experimentos de temperatura a largo plazo fueron similares a los coeficientes de temperatura observados en los experimentos de corto plazo (horas) $(\theta=1.085$ y $\theta$ $=1.078$, respectivamente). La temperatura tuvo un impacto moderado en la tasa de los procesos aerobios de captura de $\mathrm{P}(\theta=1.031)$ durante los experimentos a largo plazo. Sin embargo, se observó un fuerte efecto de la temperatura en otros procesos metabólicos de la fase aerobia, como el consumo de PHA $(\theta=1.163)$, consumo de oxígeno $(\theta=1.090)$ y crecimiento $(\theta>1.110)$. Diferentes coeficientes de temperatura fueron obtenidos para la fase aerobia en los experimentos a largo y corto plazo, probablemente debido al cambio en la estructura de la población. Este cambio fue también visto en los estudios de ecología molecular. Los diferentes coeficientes de temperatura encontrados para la captura de $\mathrm{P}$ comparados con otros procesos metabólicos de la fase aerobia resalta que en procesos tan complejos como los de EBPR, es peligroso dar conclusiones rápidas sólo a partir de parámetros fácilmente medibles (como el fosfato). Esta consideración puede fácilmente subestimar la dependencia de la temperatura en otros procesos metabólicos de la fase aerobia de la EBPR.

Meijer (2004) incorporó los coeficientes de temperatura obtenidos en los estudios de Brdjanovic et al. $(1997,1998 \mathrm{c})$ en el modelo TUDP. Este modelo extendido (combinación del ASM1 y TUDP) fue exitosamente aplicado para la expansión de una PTAR municipal ubicada en Surat, India (temperatura del lodo activado $28^{\circ} \mathrm{C}$; Brdjanovic et al., 2007) y en el tratamiento de un efluente industrial (temperatura del 
lodo activado $34^{\circ}$; Pinzon et al., 2007). Recientemente en el estudio de la competencia entre organimos acumuladores de fósforo (PAOs) y los organismos acumuladores de glucóneo (GAOs por sus siglas en inglés, Glycogen accumulating organisms), LopezVazquez et al., (2008b,c) repitió los experimentos originales de Brdjanovic et al., (1997, 1998c) y extendió el modelo TUDP con coeficientes para dos temperaturas adicionales, $15^{\circ} \mathrm{C}$ y $35^{\circ} \mathrm{C}$ respectivamente. En general, este estudio confirmó los resultados de Brdjanovic et al. (1997, 1998c) para un rango de temperatura de 5-30 ${ }^{\circ} \mathrm{C}$.

\subsection{DESNITRIFICACIÓN EN SISTEMAS CON NDEBPR}

\subsubsection{Antecedentes}

En algunos países, la legislación respecto a las concentraciones máximas de amoníaco en los efluentes requiere que la nitrificación sea incorporada en el sistema de lodos activados con EBPR. En un modelo de cultivo mixto para EBPR a condiciones estables, el nitrato recirculado al reactor anaerobio requiere ser conocido considerando la influencia adversa del nitrato recirculado a reactor anaerobio en la remoción de P. De hecho, una de las principales guías en cualquier procedimiento de diseño de remoción de $\mathrm{P}$ es la prevención de intrusión del nitrato recirculado. Esto puede lograrse previniendo la nitrificación en una configuración simple como Phoredox o en sistemas A/O, pero esta opción no es posible en algunos países. De igual manera, una cuantificación confiable y precisa de la desnitrificación en sistemas con NDEBPR es esencial para el diseño de sistemas con remoción de $\mathrm{P}$, adicional al diseño de la remoción de $\mathrm{N}$.

Un enfoque que ha sido usado para cuantificar la desnitrificación en sistemas con NDEBPR consiste en estimar la desnitrificación utilizando los conceptos teóricos y los procedimientos que describen los procesos de nitrificación-desnitrificación (ND), establecidos en el Capítulo 5 (WRC 1984). Datos experimentales han indicado que este enfoque predice la desnitrificación observada de forma satisfactoria (Nicholls, 1982). Sin embargo, de los mecanismos de sistemas con EBPR y del desarrollo de la teoría cinética de la EBPR, se evidencía una inconsistencia al utilizar este enfoque: La DQO $\mathrm{Db}_{\mathrm{rb}}$ parece ser usada dos veces; en el reactor anaerobio donde se producen los AGVs que son capturados y almacenados como PHA por los PAOs, y en el reactor anóxico primario para la desnitrificación. Esta situación solo puede ser posible si los PAOs realizan el proceso de desnitrifrificación utilizando gran parte de los AGVs (almacenados internamente como PHA en el reactor anaerobio aguas arriba) como donante de electrones en el reactor anóxico aguas abajo, lo cual implica que la principal captura de $\mathrm{P}$ debe darse en el reactor anóxico primario y no en el reactor aerobio. Aunque este comportamiento no fue observado anteriormente en algunos sistemas con NDEBPR a escala laboratorio y los trabajos realizados con cultivos enriquecidos en la Universidad de la Ciudad del Cabo, sí fue demostrado claramente por Vlekke et al. (1987), Kuba et al. (1996), $\mathrm{Hu}$ et al. (2007) e integrado en el Modelo de Lodos Activados 2d: ASM2d (por sus siglas en inglés Activated Sludge Model 2d, Henze et al., 1999).

Mientras que el modelo ASM2d simula la utilización de PHA por los PAOs en condiciones anóxicas, éste no modela el cambio en el comportamiento de la EBPR cuando hay captura anóxica de $\mathrm{P}$ - la remoción de $\mathrm{P}$ declina hasta un tercio de la tasa original (Ekama and Wentzel, 1999). El modelo ASM2d permite que la captura de $\mathrm{P}$ comience en el reactor anóxico, pero predice una remoción de $\mathrm{P}$ igual a que si la captura de $\mathrm{P}$ se hubiera llevado a cabo sólo en el reactor aerobio. Algunas modificaciones en modelos posteriores han buscado simular el fenómeno anterior, por ejemplo $\mathrm{Hu}$ et al. (2007)

\subsubsection{Desnitrificación potencial en sistemas con NDEBPR}

La desnitrificación potencial es la cantidad máxima de nitrato que puede ser removido biológicamente en los reactores anóxicos. Las investigaciones experimentales respecto a la cinética del proceso de desnitrificación en sistemas con NDEBPR indicaron que la formulación desarrollada para sistemas con ND puede ser aplicada en sistemas con NDEBPR. Los procedimientos establecidos en el Capítulo 5 para desarrollar las ecuaciones que permiten calcular la desnitrificación potencial en sistemas con ND pueden también utilizarse en sistemas con NDEBPR. Cabe mencionar que el símbolo prima (') es añadido a la tasa específica de desnitrificación para indicar que el valor del parámetro es diferente entre el sistema con ND (sin símbolo prima) y el sistema con NDEBPR (con símbolo prima) (Clayton et al., 1991; Ekama and Wentzel, 1999).

$d \mathrm{NO}_{3} / d t=-K_{T}^{\prime} X_{\mathrm{OHO}}\left[\mathrm{mg} \mathrm{NO}_{3}{ }^{-\mathrm{N}} / \mathrm{l} . \mathrm{d}\right]$

$\mathrm{dNO}_{3} / \mathrm{dt} \quad$ tasa de desnitrificación [ $\mathrm{mg} \mathrm{NO}_{3}{ }^{-} \mathrm{N} / \mathrm{l}$.d]

$\mathrm{K}^{\prime}{ }_{\mathrm{T}} \quad$ tasa específica de desnitrificación a una temperatura $\mathrm{T}$ para sistemas con NDEBPR [mgNO ${ }_{3}^{-} \mathrm{N} / \mathrm{mg}$ SSVa.d] 


\subsubsection{Desnitrificación potencial en el reactor anóxico primario}

La desnitrificación en el reactor anóxico primario se realiza mediante la utilización de cualquier $\mathrm{DQO}_{\mathrm{rb}}$ que entra al reactor anaerobio, y la DQO procedimientos para determinar la cantidad de DQO $\mathrm{Db}_{\mathrm{rb}}$ que entra del reactor anaerobio al reactor anóxico primario han sido establecidos en la Sección 7.6.3.3., donde $S_{F, A N n}$ es la concentración de DQO fermentable en el efluente del reactor anaerobio, y $\mathrm{S}_{\mathrm{F}, \mathrm{ANn}}(1+$ relación de recirculación) la masa por litro de afluente. Estos procedimientos toman en cuenta la utilización de $\mathrm{DQO}_{\mathrm{rb}}$ en el reactor anaerobio debido al almacenamiento llevado a cabo por los PAOs (ya sea directamente o después de la conversión) o debido a la respiraciónaerobia/desnitrificación realizada por los OHOs. De esta manera, el potencial de desnitrificación en el reactor anóxico primario $\left(\mathrm{D}_{\mathrm{p} 1}\right)$ puede expresarse como:

$D_{p 1}=S_{F, A N n}(1+r)\left(1-f_{c v} Y_{O H O}\right) / 2.86+{ }^{\left[\mathrm{mgN} / \mathrm{l}_{\mathrm{inf}}\right]}$
$K^{\prime}{ }_{2 T} X_{\text {OHO }} T R H_{n p}$

donde:

$\mathrm{D}_{\mathrm{p} 1}$

potencial de desnitrificación en el reactor anóxico primario $\left[\mathrm{mgN} / \mathrm{l}_{\text {inf }}\right]$

$\mathrm{K}_{2 \mathrm{~T}}$ tasa específica de desnitrificación en el reactor anóxico primario del sistema con NDEBPR usando DQOlb a temperatura T y $\sim 0.23 \mathrm{mgNO}_{3}{ }^{-} \mathrm{N} / \mathrm{mgSSV}$ a.d (Clayton $e t$ al., 1991; Ekama and Wentzel, 1999) la cual es $~ 2.5$ veces más que en los sistemas ND $\left(\mathrm{K}_{2 \mathrm{~T}}\right)$

$\mathrm{TRH}_{\mathrm{np}}$ tiempo de residencia hidráulico nominal del proceso [d]

Continuando con los procedimientos establecidos en el Capítulo 5, la Ec. 7.33 puede ser modificada o simplificada para dar:

$$
\begin{aligned}
D_{p 1}= & S_{F, A N n}(1+r)\left(1-f_{c V} Y_{O H O}\right) / 2.86 \\
& +\frac{f_{A X 1} K^{\prime}{ }_{2 T}\left(D Q O_{b, i}-S_{s, P A O}\right) Y_{O H O} T R S}{\left(1+b_{O H O, T} T R S\right)}
\end{aligned}
$$

o,

$$
D_{p 1}=\alpha+f_{A X 1} K_{2 T}^{\prime} \beta
$$

donde:

$\mathrm{f}_{\mathrm{AX} 1} \quad$ fracción de masa en el reactor primario anóxico
$\alpha=S_{F, A N n}(1+r)\left(1-f_{c v} Y_{O H O}\right) / 2.86$

$\beta=\frac{\left(D Q O_{b, i}-S_{S, P A O}\right) Y_{O H O} T R S}{\left(1+b_{O H O, T} T R S\right)}$

En la Ec. 7.34 se asume que la desnitrificación que utiliza la $\mathrm{DQO}_{\mathrm{rb}}$ del reactor anaerobio [ $\left.\mathrm{S}_{\mathrm{F}, \mathrm{ANn}}(1+\mathrm{r})\right]$, representada por la tasa inicial rápida $\left(\mathrm{K}_{2 \mathrm{~T}}{ }^{\mathrm{T}}\right)$, es siempre completa, es decir que se asume que el tiempo de retención actual en el reactor anóxico primario es mayor que el tiempo requerido para utilizar la $\mathrm{DQO}_{\mathrm{rb}}$. Así como en los sistemas con ND, una ecuación puede ser desarrollada para determinar la fracción de masa mínima en el reactor anóxico primario $\mathrm{f}_{\mathrm{AX} 1 \mathrm{~m} i ́ n}$ necesaria para consumir la DQO $\mathrm{rb}$ :

$f_{A X 1 \text { min }}=\frac{S_{F, A N n}(1+r)\left(1-f_{C V} Y_{\text {OHO }}\right)\left(1+b_{\text {OHO }, T} T R S\right)}{\left(\mathrm{DQO}_{\mathrm{b}, \mathrm{i}}-S_{S, P A O}\right) 2.86 K_{1 T}^{\prime} Y_{\text {OHO }} T R S}$

$f_{A X 1 \text { min }}=\alpha /\left(\beta K_{1 T}^{\prime}\right)$

Donde $\mathrm{K}_{1 \mathrm{~T}}$ es la tasa inicial rápida de desnitrificación en el reactor anóxico primario del sistema con DNEBPR utilizando la $\mathrm{DQO}_{\mathrm{rb}}$ a $\mathrm{T}^{\circ} \mathrm{C}$, y es igual a la tasa $\left(\mathrm{K}_{1 \mathrm{~T}}\right)$ que existe en el sistema con ND.

Sustituyendo los valores de las constantes en la Ec. 7.36 y asumiendo que el $80 \%$ de la $\mathrm{DQO}_{\mathrm{rb}}$ afluente es capturada por los PAOs en el reactor anaerobio, $\mathrm{f}_{\mathrm{AX} 1 \mathrm{mín}}<$ 0.02 para TRS $>10$ días a $14^{\circ} \mathrm{C}$ con $\mathrm{DQO}_{\mathrm{b}, \mathrm{i}}=800$ $\mathrm{mgDQO} / 1$ y $\mathrm{f}_{\mathrm{ss}}=0.24$. Este valor de fracción de masa anóxica cercano a 0.02 es mucho menor que los valores prácticos para reactores anóxicos primarios, por lo que las ecuaciones Eqs. 7.34 y 7.35 serán válidas para la mayoría de los casos.

Sin embargo, la Ec. 7.34 no está libre de complicaciones. Para poder calcular la desnitrificación potencial en el reactor anóxico primario $\left(\mathrm{D}_{\mathrm{p} 1}\right)$, se requiere conocer la concentración de la $\mathrm{DQO}_{\mathrm{rb}}$ en el efluente del reactor anaerobio $\left(\mathrm{S}_{\mathrm{F}, \mathrm{ANn}}\right)$. Para calcular $\mathrm{S}_{\mathrm{F}, \mathrm{ANn}}$, se requiere saber la concentración de nitrato recirculado al reactor anaerobio, lo cual a su vez requiere de $\mathrm{D}_{\mathrm{p} 1}$. Este aspecto se discute con más detalle en la Sección 7.10.3.2 a continuación. 
7.10.3.2 Desnitrificación potencial del reactor anóxico secundario

La desnitrificación potencial del reactor anóxico secundario $\left(\mathrm{D}_{\mathrm{p} 3}\right)$ se encuentra siguiendo los principios establecidos en el Capítulo 5, y se puede encontrar como:

$$
\begin{aligned}
D_{p 3} & =\frac{f_{A X 3} K^{\prime}{ }_{3 T}\left(D Q O_{b, i}-S_{S, P A O}\right) Y_{O H O} T R S}{\left(1+b_{O H O, T} T R S\right)} \\
D_{p 3} & =f_{A X 3} K_{3 T}^{\prime} \beta
\end{aligned}
$$

donde:

$\mathrm{f}_{\mathrm{AX} 3}$ fracción de masa del reactor secundario anóxico

$\mathrm{K}_{3 \mathrm{~T}} \quad$ tasa específica de desnitrificación en el reactor secundario anóxico a temperatura T y $\sim 0.10 \mathrm{mgNO}_{3}{ }^{-} \mathrm{N} / \mathrm{mgSSV}$ a.d (Clayton et al., 1991; Ekama and Wentzel, 1999) es decir alrededor de 1.5 veces más alto que en los sistemas con ND $\left(\mathrm{K}_{3 \mathrm{~T}}\right)$

La Ec. 7.37 puede aplicarse a reactores secundaros anóxicos situados tanto en tren principal de agua (por ejemplo la configuración Bardenpho Modificada de 5 etapas) como en la línea de recirculación de lodos (por ejemplo el proceso JHB). Sin embargo, para poder aplicar la Ec. 7.37 a reactores anóxicos secundarios ubicados en la línea de recirculación, se debe tener cuidado a la hora de evaluar $\mathrm{f}_{\mathrm{AX} 3}$, ya que la concentración del licor mezclado se incrementa en un factor de $(1+\mathrm{s}) / \mathrm{s}$ en los reactores anóxicos ubicados en la línea $\mathrm{s}$ de recirculación de lodos con respecto de los reactores ubicados en el tren principal.

Entre más altas sean las tasas de desnitrificación K’ $2 \mathrm{~T}$ y K' ${ }_{3 \mathrm{~T}}$ en los sistemas con NDEBPR comparado con los sistemas con ND, más alto será el valor de $\eta$ en el proceso de hidrólisis/crecimiento de los OHOs qque utilizan la $\mathrm{DQO}_{\mathrm{lb}}$ en condiciones anóxicas en los modelos ASM2 y ASM2d.

\subsubsection{Principios del procedimiento de diseño de desnitrificación para sistemas con NDEBPR}

En sistemas con NDEBPR, el diseño está orientado a alcanzar en un sistema lodos activados de una etapa los siguientes objectivos:

1. Remoción de DQO,

2. Remoción de N (nitrificación/desnitrificación) y

\section{Remoción de P (EBPR).}

Algunos conflictos pueden surgir entre estos objetivos, en particular en la remoción de $\mathrm{N}$ y $\mathrm{P}$, por ejemplo la masa no aireada requerida de los reactores anóxicos (remoción de $\mathrm{N}$ ) y los reactores anaerobios (remoción de P). En cada diseño, se necesita evaluar cuáles son las prioridades para el tratamiento para encontrar el punto óptimo de operación del sistema.

En algunos países, el diseño de sistemas con NDEBPR usualmente se enfoca en la EBPR, dando a la desnitrificación un papel secundario, debido a los límites máximos establecidos por la legislación para la concentración de $\mathrm{P}$ en el efluente, y sólo en casos seleccionados las concentraciones de nitrato están también limitadas en el efluente. De esta manera, en estas situaciones el principio fundamental de diseño de la desnitrificación para sistemas con NDEBPR es asegurar que el reactor anaerobio se proteja del nitrato en las líneas de recirculación. Este principio fundamental determinará la selección de la configuración del sistema (Barderpho Modificado de 5 etapas, JHB y UCT/MUCT considerados en este capítulo) y brinda los procedimientos para poder dimensionar los reactores anóxicos.

Cuando se selecciona una configuración de un sistema con EBPR, es necesario establecer si se puede alcanzar una desnitrificación completa. Para las características del agua residual, como son la concentración de NTK y la DQO afluente $\left(\mathrm{NTK}_{\mathrm{i}}\right.$ and $\left.\mathrm{DQO}_{\mathrm{i}}\right)$, la tasa específica máxima de crecimiento de las bacterias nitrificantes a $20^{\circ} \mathrm{C}\left(\mu_{\mathrm{NITmax} 20}\right)$ y la temperatura promedio mínima de agua, la fracción máxima de lodo no aireado $\left(\mathrm{f}_{\mathrm{Xmax}}\right)$ y la capacidad de nitrificación $\left(\mathrm{NIT}_{\mathrm{c}}\right.$ ) pueden calcularse para una edad de lodos seleccionada (TRS) siguiendo los principios establecidos en el Capítulo 5. Esta $\mathrm{f}_{\mathrm{Xmax}}$ necesita dividirse entre las fracciones de masa anaerobia (para la EBPR) y anóxica (para la desnitrificación). En consecuencia, la fracción máxima de masa (de lodos) anóxica ( $\left.f_{X d m a ́ x}\right)$ es la diferencia entre la fracción máxima de masa no aireada ( $\mathrm{f}_{\mathrm{Xmax}}$ ) y la fracción de lodo anaerobio seleccionada $\left(\mathrm{f}_{\mathrm{AN}}\right)$, de manera que:

$f_{X d \max }=f_{X \text { max }}-f_{A N}$

donde:

fXdmax fracción máxima de masa anóxica

$\mathrm{f}_{\mathrm{Xmax}} \quad$ fracción máxima de masa no aireada 
El valor de fXmáx se puede calcular con la Eq (5.19), para una edad de lodos, $\mu_{\text {NITmáx } 20,}, \mathrm{~S}_{\mathrm{f}}$ y $\mathrm{T}_{\text {min }}$ seleccionados (ver Capítulo 5).

El valor de $f_{X d m a ́ x}$ puede después subdividirse entre las fracciones de lodo anóxico primario y secundario (f $f_{\mathrm{AX} 1 \mathrm{y}}$ $\left.f_{\mathrm{AX} 3}\right)$ y esta división fija el potencial de desnitrificación de estos dos reactores $\left(D_{\mathrm{p} 1}\right.$ y $\left.D_{\mathrm{p} 3}\right)$ y por lo tanto también del sistema. Si el potencial de desnitrificación del sistema excede la capacidad de nitrificación (esto es $\mathrm{D}_{\mathrm{p} 1}+\mathrm{D}_{\mathrm{p} 3}>$ $\mathrm{NIT}_{\mathrm{c}}$ ) entonces es posible una desnitrificación completa y el reactor anóxico secundario se sitúa en el tren principal, como en la configuración Bardenpho Modificado de 5 etapas. Si una desnitrificación completa no es posible, en la configuración Bardenpho Modificado de 5 etapas existirá nitrato en el efluente y retornará al reactor anaerobio en la recirculación $s$. De esta manera, el reactor anóxico secundario se mueve a la línea secundaria de lodos, como en el sistem JHB, en el cual el potencial de desnitrificación del reactor anóxico secundario $\left(\mathrm{D}_{\mathrm{p} 3}\right)$ debe exceder la carga de nitrato y oxígeno que se envía en la recirculación de lodos $s$. Si este requerimiento no es alcanzado, el nitrato "escapará" del reactor anóxico de la línea secundaria y entrará al reactor anaerobio. En este escenario, debido a que el potencial de desnitrificación del reactor anóxico primario $\left(D_{\mathrm{p} 1}\right)$ es mayor que en el reactor anóxico secundario $\left(D_{\mathrm{p} 3}\right)$ para fracciones de masa similares, el reactor anóxico secundario resulta en una utilización ineficiente de la fracción de masa anóxica, y la fracción de masa anóxica secundaria se consiera parte del reactor anóxico primario, como en el sistema UCT/MUCT. Alternativamente, si se requiere una concentración muy baja de nitrato en el efluente, es posible utilizar un reactor anóxico secundario donde se adicione metanol.

\subsubsection{Analisis de la desnitrificación en sistemas con NDEBPR}

El análisis del comportamiento de la desnitrificación en sistemas con NDEBPR es esencialmente el mismo que para sistemas con ND (ver Capítulo 5) excepto en:

- La fracción de masa para desnitrificación (fXdmáx) para un sistema con NDEBPR se encuentra con la la Ec. 7.38, mientras que $f_{X d m a ́ x}$ para el sistema con ND se puede calcular con la Ec. 5.56. Por lo tanto, para la misma fracción máxima de masa no aireada (f $f_{X m a ́ x}$ ), un sistema con NDEBPR tiene una fracción de masa más baja que un sistema con ND. La diferencia entre estas fracciones es igual a $\mathrm{f}_{\mathrm{AN}}$.
- Las tasas específicas de desnitrificación para sistemas con ND ( $\mathrm{K}_{2}$ y $\mathrm{K}_{3}$, Capítulo 5) deben substituirse con las tasas medidas para sistemas con NDEBPR (K' ${ }_{2 \mathrm{~T}}$ y K' ${ }_{3 т}$, Sección 7.10.2).

- El potencial de desnitrificación de los reactores anóxicos primarios y secundarios para sistemas con ND debe modificarse con respecto del Capítulo 5 por las Eqs. 7.34 y 7.37 (para un sistema con NDEBPR) con el fin de considerar el almacenamiento de DQO por parte de los PAOs en el reactor anaerobio, y la inconsistenet y no bien estudiada participación de los PAOs en el proceso de desnitrificación.

El objetivo del modelo simplificado en estado estacionario presentado a continuación es el de obtener un estimado de la relación de recirculación $a$ con el fin de cargar el reactor anóxico hasta su potencial de desnitrificación. Un análisis detallado de los sistemas con EBPR puede realizarse con la ayuda de programas de simulación. Considerando lo anterior, a continuación se desarrollan las ecuaciones necesarioas para el cálculo de la desnitrificación en un sistema UCT.

\subsubsection{Sistema UCT}

En el sistema UCT el comportamiento de la desnitrificación es muy similar al observado en un sistema MLE, de tal forma que considerando el efecto de la incorporación de un reactor anaerobio, las ecuaciones de diseño y los procedimientos desarrollados para el sistema MLE pueden ser adaptados rápidamente para la aplicación en el sistema UCT.

En esta aplicación, los siguientes principios son de importancia:

- Debido a que una desnitrificación completa no es posible, toda la fracción de masa anóxica disponible se utiliza en el reactor anóxico primario.

- La relación de recirculación $a$ determina la división de nitrato entre el reactor anóxico primario y el efluente. La relación de recirculación se selecciona de tal manera que la carga equivalente de nitrato al reactor anóxico primario realizada por medio de la recirculaciones $a$ y $s$ carguen al reactor jsutamente a su potencial de desnitrificación.

Considerando lo anterior, a continuación se desarrollan las ecuaciones de diseño para el sistema UCT:

- Potencial de desnitrificación $\left(D_{p l}\right)$ : el potencial del reactor anóxico primario $\left(D_{\mathrm{p} 1}\right)$ se encuentra 
empleando la Ec. 7.34 con $f_{\mathrm{AX} 1}=f_{X d m a ́ x}$, de manera que:

$$
D_{p 1}=\alpha+f_{x d \max } K_{2 T}^{\prime} \beta
$$

- Concentración de nitrato en el efluente $\left(S_{N O 3, e}\right)$ : Si la concentración de nitrato en el efluente del reactor anóxico primario es cero, entonces:

$$
S_{N O 3, e}=N I T_{c} /(a+s+1)
$$

- Relación óptima de recirclación a $\left(a_{\text {opt }}\right)$ : Debido a las similitudes entre los sistemas MLE y UCT, es posible desarrollar una ecuación para la recirculación aopt del sistema UCT siguiendo el mismo procedimiento que para el sistema MLE: de esta manera $\mathrm{a}_{\mathrm{opt}}$ es la recirculación $a$ que carga al reactor anóxico primario justo hasta su potencial de desnitrificación $\left(\mathrm{D}_{\mathrm{p} 1}\right)$. A partir de una balance de masa del reactor anóxico primario, la carga de nitrato equivalente al reactor $\left(\mathrm{FS}_{\mathrm{NO} 3, \mathrm{AX} 1} / \mathrm{Q}_{\mathrm{i}}\right)$ está dada por:

$$
\begin{aligned}
& \frac{F S_{N O 3, A X 1}}{Q_{i}}=s\left[S_{N O 3, e}+\frac{S_{O 2, s}}{2.86}\right]+ \\
& a\left[S_{N O 3, e}+\frac{S_{O 2, a}}{2.86}\right]
\end{aligned}
$$

donde:

$\mathrm{S}_{\mathrm{O} 2, \mathrm{y}}$ y $\mathrm{S}_{\mathrm{O} 2, \mathrm{a}}$ son las concentraciones de $\mathrm{O}_{2}$ disuelto en las recirculaciones $s$ y $a$, respectivamente.

Igualando la Ec. 7.41 con el valor obtenido de cálculo del potencial de desnitrificación de la Ec. 7.39, reemplazando a por $\mathrm{a}_{\mathrm{opt}} \mathrm{y}$ resolviendo para $\mathrm{a}_{\mathrm{opt}}$, se obtiene:

$a_{\text {opt }}=\left[-B+\sqrt{B^{2}-4 A C}\right] /(2 A)$

donde:

$$
\begin{array}{ll}
\mathrm{A} & \mathrm{S}_{\mathrm{O} 2, \mathrm{a}} / 2.86 \\
\mathrm{~B} & \mathrm{NIT}_{\mathrm{c}}-\mathrm{D}_{\mathrm{p} 1}+\left\{(\mathrm{s}+1) \mathrm{S}_{\mathrm{O} 2, \mathrm{a}}+\mathrm{s} \mathrm{S}_{\mathrm{O} 2, \mathrm{~s}}\right\} / 2.86 \\
\mathrm{C} & \mathrm{s} \mathrm{NITC}-(\mathrm{s}+1)\left(\mathrm{D}_{\mathrm{p} 1-\mathrm{s}} \mathrm{S}_{\mathrm{o}, \mathrm{s}, \mathrm{s}} / 2.86\right)
\end{array}
$$

Si se tiene que a = a apt, la Ec. 7.42 dará el valor mínimo de $\mathrm{S}_{\mathrm{NO} \text {,e }}$ que se puede alcanzar. La Ec. 7.42 es válida siempre que $a$ sea menor o igual a aopt, ya que la suposición de la Ec. 7.42, es decir que la concentración de nitrato en el efluente del reactor anóxico primario es cero, solo se cumple cuando a $\leq$ aopt. Si el sistema es operado con a > $\mathrm{a}_{\mathrm{opt}}$, la carga de nitrato equivalente que llega al reactor anóxico primario por medio de las recirculaciones $a$ y $s$ excede el potencial de desnitrificación y entonces el nitrato se recircula al reactor anaerobio por medio de la recirculación $r$, deteriorando la eficiencia de remoción de $\mathrm{P}$ en el sistema con EBPR. Adicionalmente, si el nitrato "escapa" del reactor anóxico primario, entonces la concentración de nitrato en su efluente no es igual a cero, y en consecuencia la Ec. 7.40 para calcular la concentración de nitrato en el efluente $\left(\mathrm{S}_{\mathrm{NO} 3, \mathrm{e}}\right)$ no es válida.

\subsubsection{Máxima concentración de nitrato recirculado al reactor anaerobio}

Los procedimientos de diseño para la desnitrificación en las secciones previas han sido desarrolladas asumiendo que se aplican las altas tasas de desnitrificación $\mathrm{K}^{\prime 2}$ г $\mathrm{y}$ $\mathrm{K}^{\prime}{ }_{3 \mathrm{~T}}$, es decir que el sistema exhibe EBPR. Sin embargo, la recirculación de nitrato y oxígeno en el reactor anaerobio tiene un efecto negativo en el proceso de EBPR. En casos donde hay una cantidad de nitrato u oxígeno recirculado tal que toda la DQO fermentable es consumida por desnitrificación, no existirá materia orgánica remanente para convertir a AGVs. En este caso, en la Ec. 7.8 se fija $S_{\mathrm{F}, \mathrm{i}, \mathrm{conv}}=0 \mathrm{y}$ al resolver $\mathrm{S}_{\mathrm{NO}, \mathrm{s}} \mathrm{se}$ obtiene:

$S_{N O 3, s}=\left[\left\{\frac{S_{F, i}}{8.6}-\frac{\left(s S_{O 2, s}+S_{O 2, i}\right)}{2.86}\right\}-S_{N O 3, i}\right] / s$

Esta concentración de nitrato efectivamente establece la cantidad máxima de nitrato que puede ser recirculada al reactor anaerobio usando las ecuaciones desarrolladas este capítulo las cuales permanecen válidas. Si a esta concentración de $\mathrm{S}_{\mathrm{NO} 3, \text { s, }}$ hay alguna cantidad de AGVs presentes en el afluente, se seguirá obteniendo una remoción biológica de $\mathrm{P}$ (EBPR).

Si se excede la concentración de $\mathrm{S}_{\mathrm{NO} 3, \mathrm{~s}}$, se produce una competencia entre los PAOs y los OHOs por los AGVs (para su almacenamiento y desnitrificación, respectivamente) y un modelo cinético es requerido para determinar el comportamiento del sistema y las ecuaciones desarrolladas en este capítulo dejan de ser válidas para esta situación.

\subsection{ORGANISMOS ACUMULADORES DE GLUCÓGENO (GAOs)}

Los organismos acumuladores de glucógeno (GAOs) tienen un metabolismo que es muy similar al de los 
PAOs: estos también son capaces de almacenar materia orgánica rápidamente biodegradable (principalmente AGVs) como PHA bajo condiciones anaerobias y utilizan este compuesto intracelular como fuente de carbono y energía en condiciones aerobias (Figura 7.34).

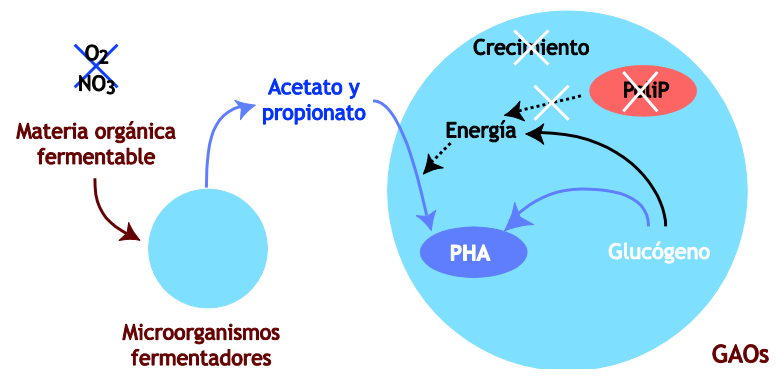

Figura 7.34 Modelo bioquímico simplificado del metabolismo anerobio de los GAOs

Sin embargo, a diferencia de los PAOs, los GAOs sólo disponen del glucógeno intracelular para obtener por medio de la glucólisis su fuente de carbono y energía, la cual a su vez sirve para el almacenamiento de AGVs en forma de PHA (Filipe et al., 2001a; Zeng et al., 2003). En consecuencia, los GAOs no muestran la liberación típica de $\mathrm{P}$ en condiciones anaerobias y la subsecuente captura de $\mathrm{P}$ en condiciones aerobias. Por lo tanto, desde la perspectiva del proceso de EBPR, los GAOs son microorganismos indeseables ya que son capaces de asmilar AGVs en condiciones anaerobias, competiendo con los PAOs por la misma fuente de carbono, sin contribuir a la remoción de $\mathrm{P}$.

Diferentes condiciones operacionales y ambientales han sido identificadas como factores importantes para entender la dinámica de la competencia entre PAOs y GAOs, como son: el compuesto usado como fuente de carbono (acetato y/o propionato), el $\mathrm{pH}$, la temperatura y la relación de $\mathrm{P}_{\text {afluente }} / \mathrm{DQO}$.

El compuesto utilizado como fuente de carbono juega un rol importante en la competencia entre PAOs y GAOs ya que diferentes cepas de PAOs y GAOs identificadas hasta el momento tienen diferentes preferencias, afinidades y tasas de asimilación de sustrato. Candidatus Accumulibacter phosphatis, una especie de PAO conocida (de aquí en adelante referido como Accumulibacter) (Crocetti et al., 2000), tiene una afinidad similar para la captura tanto de acetato como de propionato, siendo capaz de asimilarlo a tasas similares (Oehmen et al., 2005b, 2006a). Candidatus Competibacter phosphatis (de aquí en adelante referido como Competibacter e identificado como GAO potencial; Crocetti et al., 2002) es capaz de asimilar acetato tan rápido como la Accumulibacter pero no puede almacenar propionato (Oehmen et al., 2005b,2006a). Otra especie de GAO, perteneciente al grupo alfaproteobacteria (de aquí en adelante referido como alfaproteobacteria-GAO; Wong et al., 2004; Meyer et al., 2006), presenta una alta afinidad y preferencia por el propionato más que por el acetato, siendo capaz de asimilar propionato tan rápido como la Accumulibacter pero asimilando el acetato a una tasa del orden de $50 \%$ de la tasa de consumo de propionato (Oehmen et al., 2005b, 2006b).

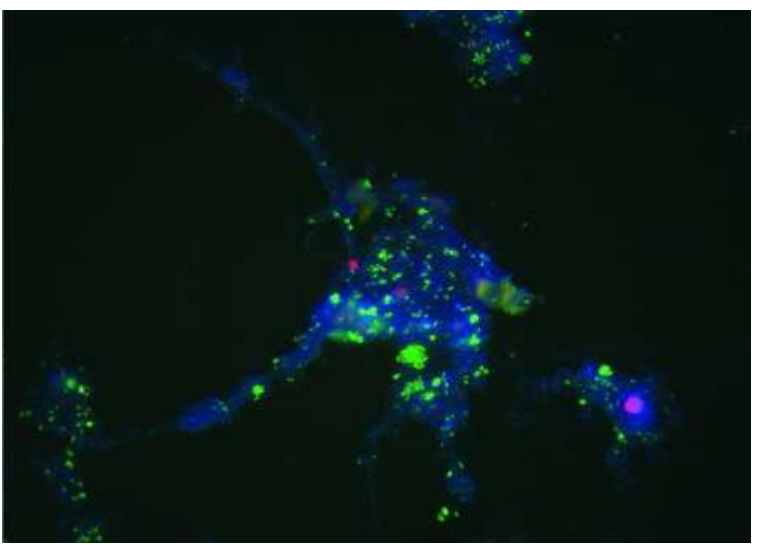

Figura 7.35 Distribución poblacional bacterial por FISH de una PTAR a escala completa. Organismos acumuladores de fósforo: verde (sonda PAOmix); Organismos acumuladores de glucógeno (sonda GAOmix): rojo; eubacteria (sonda EUB338 mix): azul. (Lopez-Vazquez et al., 2008a)

Como se mencionó anteriormente, los PAOs (Accumulibacter) tienen la misma preferencia por el acetato que por el propionato y pueden almacenar ambas especies de AGVs a una tasa similar, mientras que los GAOs (Competibacter y alfa-proteobacteria-GAO) no son capaces de utilizar acetato y propionato con la misma eficiencia que la Accumulibacter. Estas observaciones han sido usadas para proponer y desarrollar estrategias y medidas de control a favor de los PAOs sobre los GAOs a través de la alternancia de la fuente de carbono afluente (entre acetato y propionato; Oehmen et al., 2006a; Lu et al., 2006) o buscando un afluente con una adecuada relación de acetato/propionato la cual sea más favorable para el desarrollo de los PAOs (Lopez-Vazquez et al., 2008c).

El pH tiene una influencia importante en el metabolismo anaerobio de los PAOs y los GAOs. A niveles más altos de $\mathrm{pH}(>7.0)$, la energía requerida (ATP) para el transporte de sustrato a través de la membrana celular se incrementa (Smolders et al., 1995; 
Filipe et al., 2001a). Esto resulta en un alto grado de utilización del poliP y el glucógeno almacenados intracelularmente. Diversas publicaciones han descrito la predominancia de los PAOs y, por lo tanto, la estabilidad del desempeño de los procesos de EBPR a niveles altos de $\mathrm{pH}(\mathrm{pH}>7.25)$ y la prevalencia de los GAOs a niveles bajos de $\mathrm{pH}(\mathrm{pH}$ < 7.25; Filipe et al., 2001a, 2001b; Schuler and Jenkins, 2002; Oehmen et al., 2005a). Estas observaciones sugieren que con valores elevados de $\mathrm{pH}$ puede que la hidrólisis del glucógeno sea el proceso metabólico limitante en los GAOs, o que los PAOs tiene ventajas metabólicas sobre los GAOs debido a que no sólo cuentan con la ruta glucolítica sino también con la hidrólisis del poliP (Filipe et al., 2001a).

La temperatura tiene un impacto mayor en la competencia y prevalencia de los PAOs y los GAOs en los sistemas de lodos activados. A temperaturas moderadas y bajas $\left(<20{ }^{\circ} \mathrm{C}\right)$ los PAOs tienden ser los microorganismos dominantes y cuentan con considerables ventajas metabólicas sobre los GAOs mientras que lo opuesto ocurre a temperaturas más altas $\left(>20^{\circ} \mathrm{C}\right.$ ). Esto puede ser explicado considerando que a temperaturas más bajas de $20{ }^{\circ} \mathrm{C}$, los PAOs tienen tasas de crecimiento más altas que los GAOs (Lopez-Vazquez et al., 2008b, 2008d) y menores requerimientos de mantenimiento anaerobio (Lopez-Vazquez et al., 2007), lo cual potencialmente limita la ocurrencia de GAOs en los sistemas de tratamiento de agua residual operados a bajas temperaturas (Lopez-Vazquez et al., 2008a). Sin embargo a temperaturas mayores de $20{ }^{\circ} \mathrm{C}$ los GAOs tienen tasas de consumo de sustrato más elevadas que los PAOs (Whang and Park, 2006; Lopez-Vazquez et al., 2007) favoreciendo su ocurencia cuando se tratan aguas residuales cálidas $\left(>20^{\circ} \mathrm{C}\right)$. No obstante, la aplicación de niveles altos de $\mathrm{pH}$ parece dar ventajas competitivas a los PAOs a pesar de las temperaturas elevadas en el lodo activado (Whang et al., 2007; Lopez-Vazquez et al., 2008c).

La relación de $\mathrm{P}_{\text {afluente }} / \mathrm{DQO}$ (o $\mathrm{P}_{\text {afluente }} / \mathrm{AGV}$ ) ha sido identificada como otro factor importante en la competencia entre los PAOs y los GAOs. Ya que el metabolismo anaerobio de los PAOs involucra la utilización de poliP para la captura y el almacenamiento de AGVs como PHA, una carencia de fósforo en el afluente por un periodo extendido de tiempo puede causar la disminución de las reservas intracelulares de poliP, resultando en la pérdida de su fuente de energía para capturar AGVs, lo cual a su vez resulta en la proliferación de los GAOs. Por lo tanto, una baja relación de $\mathrm{P}_{\text {afluente}} / \mathrm{DQO}$ (alrededor de $0.006 \mathrm{gPO}_{4}-\mathrm{P} / \mathrm{gDQO}$ ) es típicamente utilizada para el cultivo de GAOs en sistemas a escala laboratorio, mientras que relaciones altas $(\geq 0.04$ $\left.\mathrm{g} \mathrm{PO}_{4}-\mathrm{P} / \mathrm{gDQO}\right)$ son usadas cuando se estudian cultivos enriquecidos de PAOs (Smolders et al., 1995; Liu et al., 1997; Schuler and Jenkins, 2003).

\subsection{CONCLUSIONES Y PERSPECTIVAS}

La remoción biológica aumentada de fósforo (EBPR) ha sido desarrollada para ayudar a controlar la eutrofización por medio de la remoción de fósforo de las aguas residuales, evitando el uso de sustancias químicas. El alto contenido de fósforo en la biomasa purgada de los procesos con EBPR hace posible la recuperación del fósforo por medio de la formación de estruvita (fosfato doble de magnesio y amonio: $\mathrm{MgNH}_{4} \mathrm{PO}_{4}$ ), especialmente cuando un digestor anaerobio es usado, o como hidroxiapatita $\left(\mathrm{Ca}_{10}(\mathrm{PO} 4)_{5}(\mathrm{OH})_{2}\right)$ cuando no existe una cantidad suficiente de amonio.

En algunos cuerpos de agua de alta sensibilidad, se han promulgado límites máximos permisibles muy bajos para la descarga de fósforo (y nitrógeno), en ocasiones por debajo de $0.1 \mathrm{~g}$ de $\mathrm{P}$ total por $\mathrm{m}^{3}$. Para poder alcanzar de forma consistente niveles tan bajos de $\mathrm{P}$ en los efluentes, es necesario emplear coagulantes y sistemas filtración o ultrafiltración.

Los organismos acumuladores de fósforo (PAOs) aún no han sido aislados en cultivos puros. Sin embargo para entender los mecanismos bioquímicos de su metabolismo anaerobio, anóxico y aerobio se han empleado cultivos enriquecidos en donde más del $90 \%$ de la biomasa activa son PAOs. A partir de estos estudios ha sido posible derivar los principios para la optimización de los procesos y se han desarrollado modelos matemáticos para el análisis de diseños en condicones estacionarias, los cuales a su vez se han incorporado en programas de software para poder así estudiar diferentes escenarios y facilitar el diseño, optimización y desarrollo de sistemas con EBPR. El efecto del nitrato en las recirculaciones de lodo (o recirculaciones internas), y el efecto de los cambios dinámicos en las cargas (como son las sobrecargas de materia orgánica después del fin de semana o la adición de descargas industriales) puede cuantificarse de una mejor manera través de dichos programas computacionales.

Los desarrollos futuros en el campo van a venir de un mejor entendimiento de los mecanismos bioquímicos de los PAOs, los GAOs y lso organismos filamentosos para poder así proponer estrategias prácticas de control que 
favorezcan la prevalencia de los PAOs. Estudios con cultivos puros de PAOs y GAOs pueden ser eventualmente alcanzados. Consecuentemente, Una vez se tenga una mejor comprensión de los procesos

\section{REFERENCIAS}

Alarcon G.O. (1961) Removal of phosphorus from sewage. Unpublished Master, John Hopkins University, Baltimore.

Arvin E. (1985) Biological removal of phosphorus from wastewater. CRC Crit. Rev. Env. Control 15, 25-64.

Barat R., van Loosdrecht M.C.M. (2006) Potential phosphorus recovery in a WWTP with the BCFS $^{\circledR}$ process: Interactions with the biological process. Wat. Res. 40(19), 3507-3516.

Barnard J.L. (1974a) Cut P and N without chemicals. Water Wastes Eng. 11, 33-36.

Barnard J.L. (1974b) Cut P and N without chemicals. Water Wastes Eng. 11, 41-44.

Barnard J.L. (1975a) Biological nutrient removal without the addition of chemicals. Wat. Res. 9, 485-490.

Barnard J.L. (1975b). Nutrient removal in biological systems. Water Pollut. Control 74(2), 143-154.

Barnard J.L. (1976) A review of biological phosphorus removal in the activated sludge process. Water SA. 2, 136-144.

Barnard J.L. (1976) Nutrient removal in biological systems. Water Pollut. Control 74, 143-154.

Barnard J.L., and Steichen M.T. (2007). Optimizing BPR plant operations for achieving sustainable low effluent phosphorus. Proceedings of the Nutrient Removal - The State of the Art, Specialty Conference, Baltimore, MD, pp. 903-926, Eds Water Environment Federation and International Water Association.

Barnard J.L., Stevens G.M. and Leslie P.J. (1985). Design strategies for nutrient removal plant. Wat. Sci. Techn. 17(11/12), 233-242.

Blackall L.L., Crocetti G., Saunders A.M., and Bond P.L. (2002) A review and update of the microbiology of enhanced biological phosphorus removal in wastewater treatment plants. Antonie Van Leeuwenhoek Int. J. General Molec. Microbiol. 81(1-4), 681-691.

Bortone G., Saltarelli R., Alonso V., Sorm R., Wanner J., and Tilche A. (1996) Biological anoxic phosphorus removal - The Dephanox process. Wat. Sci. Tech. 34(12), 119-128

Boughton W.H., Gottfried R.J., Sinclair N.A. and Yall I. (1971) Metabolic factors affecting enhanced phosphorus uptake by activated sludge. Applied Microbiology. 22., 571-577.

Brdjanovic D., Hooijmans C.M., van Loosdrecht M.C.M., Alaerts G.J., Heijnen J.J. (1996). The dynamic effects of potassium limitation on biological phosphorus removal. Wat. Res. 30(10), 2323-2328.

Brdjanovic D., van Loosdrecht M.C.M., Hooijmans C.M., Alaerts G.J. and Heijnen J.J. (1997). Temperature Effects on Physiology of Biological Phosphorus bioquímicos fundamentales, los modelos paramétricos y metabólicos pueden ser mejorados y desarrollados, lo cual permitirá la creación de modelos computacionales más precisos y procesos de EBPR más robustos.

Removal Systems. J. Env. Eng., ASCE. 123(2), 144154.

Brdjanovic D., Slamet A., van Loosdrecht M.C.M., Hooijmans C.M., Alaerts G.J. and Heijnen J.J. (1998a) Impact of excessive aeration on biological phosphorus removal from wastewaters. Wat. Res., 32(1), 200-208.

Brdjanovic D., van Loosdrecht M.C.M., Hooijmans C.M., Alaerts G.J. and Heijnen J.J. (1998b) Minimal aerobic sludge retention time in biological phosphorus removal systems. Biotechn. and Bioeng., 60(3), 326-332.

Brdjanovic D., Logemann S., van Loosdrecht M.C.M., Hooijmans C.M., Alaerts G.J. and Heijnen J.J. (1998c). Influence of temperature on biological phosphorus removal: process and molecular ecology study. Wat. Res. 32(4), 1035-1048.

Brdjanovic D., Moussa, M.S., Mithaiwala M., Amy G., and van Loosdrecht M.C.M. (2007). Use of Modeling for Optimization and Upgrade of a Tropical Wastewater Treatment Plant in a Developing Country. Wat. Sci. Tech. 56(7), 21-31.

Brodisch, K.E.U. (1985) Interaction of different groups of microorganisms in biological phosphate removal. Wat. Sci. Tech. 17(11/12), 89-97.

Buchan L. (1983) Possible biological mechanism of phosphorus removal. Wat. Sci. Tech. 15(3/4), 87-103.

Burke R., Dold P.L., and Marais G. (1986) Biological excess phosphorus removal in short sludge age activated sludge systems. Research Report No. W58, University of Cape Town, S.A.

Clayton J.A., Ekama G.A., Wentzel M.C., and Marais G.V.R. (1991) Denitrification kinetics in biological nitrogen and phosphorus removal activated-sludge systems treating municipal wastewaters. Wat. Sci. Tech. 23(4-6), 1025-1035.

Converti A., Rovatti M. and Borghi del M. (1995) Biological removal of phosphorus from wastewaters by alternating aerobic and anaerobic conditions. Wat. Res. 29(1), 263269.

Comeau Y., Hall K.J., Hancock R.E.W., and Oldham W.K. (1986) Biochemical model for biological enhanced phosphorus removal. Wat. Res. 20, 1511-1521.

Comeau Y., Rabinowitz B., Hall K.J., and Oldham W.K. (1987) Phosphorus release and uptake in enhanced biological phosphorus removal from wastewater. $J$. Water Pollut. Control Fed., 59, 707-715.

Crocetti G.R., Banfield J.F., Keller J., Bond P.L. and Blackall L.L. (2002) Glycogen accumulating organisms in laboratory-scale and full-scale wastewater treatment processes. Microbiology 148, 3353-3364.

Crocetti G.R., Hugenholtz P., Bond P.L., Schuler A., Keller J., Jenkins D., and Blackall L.L. (2000) Identification of polyphosphate-accumulating organisms and design of 
16S rRNA-directed probes for their detection and quantitation. Appl. Environ. Microbiol. 66(3), 11751182.

Daigger G.T., Randall C.W., Waltrip G.D., Romm E.D., and Morales L.M. (1987) Factors affecting biological phosphorus removal for the VIP process, a high-rate University of Cape Town process. Paper presented at the IAWPRC Biological Phosphate Removal from Wastewater, Rome.

Davelaar D. (1978) Biological removal of phosphorus from wastewater in a nitrifying/denitrifying activated sludge system. M.Sc. Thesis, Agricultural University, Wageningen.

de Haas D.W., Wentzel M.C., and Ekama G.A. (2000) The use of simultaneous chemical precipitation in modified activated sludge systems exhibiting biological excess phosphate removal Part 1: Literature review. Water SA. 26(4), 439-452.

Dold P.L., Bagg W.K., and Marais G.V.R. (1986) Measurement of the readily biodegradable COD fraction (Sbs) in municipal wastewater by ultrafiltration. Research report no. W57 University of Cape Town, S.A.

Dold P.L., Ekama G.A., and Marais G.v.R. (1980) A general model for the activated sludge process. Progr. Wat. Technol. 12, 47-77.

Dold P.L., Wentzel M.C., Billing A.E., and Marais G.v.R. (1991) Activated sludge system simulation programs: Nitrification and nitrification / denitrification systems, Version 1 (UCTOLD, IAWPRC). WRC Report no. TT 52/91, Pretoria, S.A.

Ekama G.A., and Wentzel M.C. (1999) Denitrification kinetics in biological $\mathrm{N}$ and $\mathrm{P}$ removal activated sludge systems treating municipal wastewaters. Wat. Sci. Tech. 39(6), 69-77.

Ekama G.A., and Wentzel M.C. (2004) A predictive model for the reactor inorganic suspended solids concentration in activated sludge systems. Wat. Res. 38(19), 4093 4106.

Ekama G.A., Dold P.L., and Marais G.v.R. (1986) Procedures for determining influent COD fractions and the maximum specific growth rate of heterotrophs in activated sludge systems. Wat. Sci. Tech. 18, 91-114.

Ekama G.A., Siebritz I.P., and Marais G.v.R. (1983) Considerations in the process design of nutrient removal activated sludge processes. Wat. Sci. Tech. 15(3/4), 283318.

Filipe C.D.M., Daigger G.T. and Grady Jr C.P.L. (2001a) A metabolic model for acetate uptake under anaerobic conditions by glycogen-accumulating organisms: Stoichiometry, kinetics and effect of $\mathrm{pH}$. Biotech. Bioeng. 76(1), 17-31.

Filipe C.D.M., Daigger G.T., and Grady C.P.L. (2001b) pH as a key factor in the competition between glycogenaccumulating organisms and phosphorus-accumulating organisms. Water Environ. Res. 73(2), 223-232.

Florentz M, Caille D., Bourdon F., and Sibony J. (1987) Biological phosphorus removal in France. Wat. Sci. Techn. 19(4), 1171-1173.

Fuhs G.W., and Chen M. (1975) Microbiological basis of phosphate removal in the activated sludge process for the treatment of wastewater. Microbial Ecol. 2, 119-138.

Fukase T., Shibata M., and Miyaji Y. (1982) Studies on the mechanism of biological removal of phosphorus. Japan J. Water Pollut. Res. 5, 309-317.

Gerber A., Devilliers R.H., Mostert E.S., and Winter C.T. (1987) Interactions between phosphate, nitrate and organic substrate in biological nutrient removal processes. Wat. Sci. Tech. 19(1-2), 183-194.

Groenestijn J.W.v., Deinema M.H., and Zehnder A.J.B. (1987). ATP production from polyphosphate in Acinetobacter strain 210A. Arch. Microbiol., 148, 1419.

Gujer W. Henze M. (1991) Activated sludge modelling and simulation. Wat. Sci. Tech. 23(4-6), 1011-1023.

Hart M.A., and Melmed. L.N. (1982) Microbiology of nutrient removing activated sludge. Poster pres. Special in Seminar of the IAWPRC, Pretoria, S.A.

Hascoët M.C., and Florentz M. (1985) Influence of nitrates on biological phosphorus removal from wastewater. Water SA 11, 1-8.

Hascoët M.C., Florentz M., and Granger P. (1985) Biochemical aspects of enhanced biological phosphorus removal from wastewater. Wat. Sci. Tech. 17(11/12), 23 41.

Henze M., Gujer W., Mino T., Matsuo T., Wentzel M.C. and Marais G.v.R. (1994) Activated sludge model no.2. IAWQ Scientific and Technical Report No.3.

Henze M., Grady C.P.L.J., Gujer W., Marais G.v.R., and Matsuo T. (1987) Activated sludge model no.1. IAWPRC, Sci. and Technical Report No.1. International Association on Water Pollution Research and Control, London, U.K.

Henze M., Gujer W., Mino T., Matsuo T., Wentzel M.C., Marais G.V.R. and van Loosdrecht M.C.M. (1999) Activated sludge Model No.2d, ASM2d. Wat. Sci. Tech.39(1), 165-182.

Hesselmann R.P.X., Werlen C., Hahn D., van der Meer J.R., and Zehnder A.J.B. (1999). Enrichment, phylogenetic analysis and detection of a bacterium that performs enhanced biological phosphate removal in activated sludge. Systematic Appl. Microbiol., 22(3), 454-465.

Hong S.N., M.L. Spector R.P.S., and Galdieri J.V. (1983) Recent advances on biological nutrient control by the A/O process. Water Pollution Control Federation Research Symposium, Oct., Atlanta., GA.

Hu Z.R., Wentzel M.C., and Ekama G.A. (2001) External nitrification in biological nutrient removal activated sludge systems. Wat. Sci. Tech. 43(1), 251-260.

Hu Z.R., Wentzel M.C., and Ekama G.A. (2002) The significance of denitrifying polyphosphate accumulating organisms in biological nutrient removal activated sludge systems. Wat. Sci. Tech. 46(1/2), 129-138

Hu Z.R., Wentzel M.C., and Ekama G.A. (2007) A general kinetic model for biological nutrient removal activated sludge systems: Model development. Biotech. Bioeng. 98(6), 1242-1258.

Jenkins D., and Tandoi V. (1991) The applied microbiology of enhanced biological phosphate removal Accomplishments and needs. Wat. Res. 25(12), 14711478 . 
Jones P.H., Tadwalkar A.D., and Hsu C.L. (1987) Enhanced uptake of phosphorus by activated sludge - effect of substrate addition. Wat. Res. 21(5), 301-308.

Kang S.J., and Horvatin P.J. (1985a) Retrofit of a full scale municipal treatment plant at Pontiac, Michigan for biological phosphorus removal. Pres. Technol. Transfer Sem. BPR in Municipal Wastewater Treatment, Penticton, B.C., Canada.

Kang S.J ., Horvatin P.J., and Briscoe L. (1985b) Full-scale biological phosphorus removal using $\mathrm{A} / \mathrm{O}$ process in a cold climate. In Proc. Int. Conf. Management strategies for Phosphorus in the Environment. Selper Ltd., UK.

Krichten D.J., Hong S.N., and Tracy K.D. (1985) Applied biological phosphorus removal technology for municipal wastewater treatment by the $\mathrm{A} / \mathrm{O}$ process. In Proc. Int. Conf. Management strategies for Phosphorus in the Environment. Selper Ltd., UK

Kruit J., Hulsbeek J., Visser A. (2020) Bulking sludge solved?! Wat. Sci. Tech. 46 (1-2), 457-464.

Kuba T., and van Loosdrecht M.C.M. (1996) Phosphorus and nitrogen removal with minimal COD requirement by integration of denitrifying dephosphatation and nitrification in a two-sludge system. Wat. Res. 30(7), 1702-1710.

Kuba T., Murnleitner E., van Loosdrecht M.C.M., and Heijnen J.J. (1996) A metabolic model for biological phosphorus removal by denitrifying organisms. Biotech. Bioeng. 52, 685-695.

Kuba T., Smolders G., van Loosdrecht M.C.M. and Heijnen J.J. (1993) Biological phosphorus removal from wastewater by anaerobic-anoxic sequencing batch reactor Wat. Sci. Tech. 27(5-6), 241-252

Levin G.V., and Sala U.D. (1987) PhoStrip process - a viable answer to eutrophication of lakes and coastal sea waters in Italy. Advances in Water Pollution Control, Proc. Rome Specialist Conf. on Biological Phosphate Removal from Wastewater, Sept. 28-30.

Levin G.V., and Shapiro J. (1965) Metabolic uptake of phosphorus by wastewater organisms. J. Water Pollut. Control Fed. 37, 800-821.

Levin G.V., Topol G.J., Tarnay A.C., and Samworth R.B. (1972) Pilot plant tests of a phosphorus removal process. J. Water Pollut. Control Fed. , 44(10), 1940-1954.

Lindrea K.C., Pigdon S.P., Boyd B., and Lockwood G.A. (1994) Biomass characterization in a nitrificationdenitrification biological enhanced phosphorus removal (NDEBPR) plant during start-up and subsequent periods of good and poor phosphorus removal. Wat. Sci. Tech. 29(7), 91-100.

Liu W.T., Nakamura K., Matsuo T. and Mino T. (1997) Internal energy-based competition between polyphosphate- and glycogen-accumulating bacteria in biological phosphorus removal reactors-effect of $\mathrm{P} / \mathrm{C}$ feeding ratio. Wat. Res. 31(6), 1430-1438.

Lopez-Vazquez C.M., Song Y.I., Hooijmans C.M., Brdjanovic D., Moussa M.S., Gijzen H.J. and van Loosdrecht M.C.M. (2007) Short-term temperature effects on the anaerobic metabolism of glycogen accumulating organisms. Biotech. Bioeng. 97(3), 483495.
Lopez-Vazquez C.M., Hooijmans C.M., Brdjanovic D., Gijzen H.J. and van Loosdrecht M.C.M. (2008a) Factors affecting the microbial populations at full-scale Enhanced Biological Phosphorus Removal (EBPR) wastewater treatment plants in The Netherlands. Wat. Res. (in press), doi:10.1016/j.watres.2008.01.001.

Lopez-Vazquez C.M., Hooijmans C.M., Brdjanovic D., Gijzen H.J. and van Loosdrecht M.C.M. (2008b) Longterm temperature effects on the metabolism of glycogen accumulating organisms (in preparation).

Lopez-Vazquez C.M., Oehmen A., Zhiguo Y., Hooijmans C.M., Brdjanovic D., Gijzen H.J., van Loosdrecht M.C.M. (2008c) Modelling the competition between phosphorus- and glycogen accumulating organisms: Carbon, temperature and $\mathrm{pH}$ effects (in preparation).

Lopez-Vazquez C.M., Song Y.I., Hooijmans C.M., Brdjanovic D., Moussa M.S., Gijzen H.J. and van Loosdrecht M.C.M. (2008d). Temperature effects on the aerobic metabolism of glycogen accumulating organisms. Biotech. Bioeng. (in press). doi: 10.1002/bit.21892.

Lu H., Oehmen A., Virdis B., Keller J. and Yuan Z. (2006) Obtaining highly enriched cultures of Candidatus Accumulibacter phosphatis through alternating carbon sources. Wat. Res. 40(20), 3838-3848.

Mamais D. and Jenkins D. (1992). The effects of MCRT and temperature on enhanced biological phosphorus removal. Wat. Sci. Tech. 26(5-6), 955-965.

Mamais D., Jenkins D., and Pitt P. (1993) A rapid physicalchemical method for the determination of readily biodegradable soluble COD in municipal wastewater. Wat. Res. 27(1), 195-197.

Marais G.v.R., and Ekama G.A. (1976). The activated sludge process Part I - steady state behaviour. Water SA 2, 164-200.

Marais G.v.R., Loewenthal R.E., and Siebritz I.P. (1983). Review: Observations supporting phosphate removal by biological excess uptake. Wat. Sci. Tech. 15(3/4), 15-41.

Marsden M.G., and Marais G.v.R. (1977). The role of the primary anoxic reactor in denitrification and biological phosphorus removal. Research Report No.W19, Dept. of Civil. Eng., University of Cape Town, S.A.

Martin H.G., Ivanova N., Kunin V., Warnecke F., Barry K.W., McHardy A.C. Yeates C., He S.M., Salamov A. A., Szeto, E., Dalin E., Putnam N. H., Shapiro H.J., Pangilinan J.L., Rigoutsos I., Kyrpides N.C., Blackall L.L., McMahon K.D., Hugenholtz P. (2006) Metagenomic analysis of two enhanced biological phosphorus removal (EBPR) sludge communities. Nature Biotech. 24(10), 1263-1269.

Martin K.A.C., and Marais G.v.R. (1975) Kinetics of enhanced phosphorus removal in the activated sludge process. No. Research Report W14, Dept. of Civil Eng., University of Cape Town, S.A.

Maszenan A.M., Seviour R.J., Patel B.K.C., Schumann P., Burghardt J., Tokiwa Y., Stratton H. M. (2000) Three isolates of novel polyphosphate-accumulating Grampositive cocci, obtained from activated sludge, belong to a new genus, Tetrasphaera gen. nov., and description of two new species, Tetrasphaera japonica sp, nov and Tetrasphaera australiensis sp nov. Internat. J. 
Systematic Evolutionary Microbiol. 50, 593-603.

Maurer M., Abramovich D., Siegrist H., and Gujer W. (1999) Kinetics of biologically induced phosphorus precipitation in waste-water treatment. Wat. Res. 33(2), 484-493.

Maurer M., Gujer W., Hany R., and Bachmann S. (1997) Intracellular carbon flow in phosphorus accumulating organisms from activated sludge systems. Wat. Res. 31(4), 907-917.

McClintock S.A., Randall C.W. and Pattarkine V.M. (1993) "Effects of temperature and mean cell residence time on biological nutrient removal processes". Wat. Environ. Res. 65(5), 110-118.

McKinney R.E., and Ooten R.J. (1969) Concepts of complete mixing activated sludge. Proceedings of the 19th Sanitary Engineering Conference, University of Kansas, 32-59.

McLaren A.R., and Wood R.J. (1976) Effective phosphorus removal from sewage by biological means. Water $S A$ 2(1), 47-50.

Méganck M., Malnou D.P.L.F., Faup G.M. and Rovel J.M. (1985) The importance of the acidogenic microflora in biological phosphorus removal. Wat. Sci. Tech. 17(11/12), 199-212.

Meijer S.C.F. (2004) Theoretical and practical aspects of modelling activated sludge processes. PhD Thesis Delft University of Technology, ISBN 90-9018027-3.

Meyer R.L., Saunders A.M. and Blackall L.L. 2006. Putative glycogen accumulating organisms belonging to alphaproteobacteria identified through rRNA-based stable isotope probing. Microbiology-SGM 152, 419 429.

Milbury W.F., McCauley D., and Hawthorne C.H. (1971) Operation of conventional activated sludge for maximum phosphorus removal J. Water Pollut. Control Fed. 43, 1890-1901.

Mino T., Arun V., Tsuzuki Y., and Matsuo T. (1987). Effect of phosphorus accumulation on acetate metabolism in the biological phosphorus removal process. Paper presented at the IAWPRC Biological Phosphate Removal from Wastewater, Rome.

Mino T., Van Loosdrecht M.C.M., and Heijnen J.J. (1998) Microbiology and biochemistry of the enhanced biological phosphate removal process. Wat. Res. 32(11), 3193-3207.

Mino T., Wen-Tso L., Kurisu F., and Matsuo T. (1994). Modelling glycogen storage and denitrification capability of microorganisms in enhanced biological phosphate removal processes. Spec. conf. on modelling of wastewater treatment, Kollekolle, Denmark.

Mulbarger M.C. (1970) The Three Sludge System for Nitrogen and Phosphorus Removal. Proc. 44th Annual Conference of the Water Pollution Control Federation, San Francisco, CA.

Murphy M., and Lötter L.H. (1986) The effect of acetate on polyphosphate formation and degradation in activated sludge with particular reference to Acinetobacter calcoaceticus: A microscopic study. Water SA 12, 6366.

Nakamura K., Ishikawa S., and Kawaharasaki M. (1995) Phosphate-uptake and release activity in immobilized polyphosphate-accumulating bacterium Microlunatus phosphovorus strain NM-1. J. Ferment. Bioeng. 80(4), 377-382.

Nicholls H.A. (1975). Full scale experimentation on the new Johannesburg extended aeration plant. Water SA 1(3), 121-132.

Nicholls H.A. (1978). Kinetics of phosphorus transformations in aerobic and anaerobic environments. Prog. Wat. Tech. 10.

Nicholls H.A. (1982). Application of the Marais-Ekama activated sludge model to large plants. Wat. Sci. Tech. 14, 581-598.

Nicholls H.A. (1987). Improvement to the stability of the biological phosphate removal process at the Johannesburg Northern Works. Proc. BPR from Wastewaters, Rome. 261-272.

Nicholls H.A., and Osborn D.W. (1979) Bacterial stress: Prerequisite for biological removal of phosphorus. $J$. Water Pollut. Control Fed. 51, 557-569.

Nicholls H.A., Pitman A.R., and Osborn D.W. (1985) The readily biodegradable fraction of sewage: Its influence on phosphorus removal and measurement. Wat. Sci. Tech. 17(11/12), 73-87.

Oehmen A., Saunders A.M., Teresa Vives M.T., Yuan Z. and Keller J. (2006a) Competition between polyphosphate and glycogen accumulating organisms in enhanced biological phosphorus removal systems with acetate and propionate as carbon sources. J. Biotech. 123(1), 22-32.

Oehmen A., Vives M.T., Lu H., Yuan Z. and Keller J. (2005a) The effect of $\mathrm{pH}$ on the competition between polyphosphate-accumulating organisms and glycogenaccumulating organisms. Wat. Res. 39(15), 3727-3737.

Oehmen A., Yuan Z., Blackall L.L. and Keller J. (2005b) Comparison of acetate and propionate uptake by polyphosphate accumulating organisms and glycogen accumulating organisms. Biotech. Bioeng. 91(2), 162168.

Oehmen A., Zeng R.J., Saunders A.M., Blackall L.L, Keller J., and Yuan Z. (2006b) Anaerobic and aerobic metabolism of glycogen accumulating organisms selected with propionate as the sole carbon source. Microbiology 152(9), 2767-2778.

Oehmen A., Lemos P.C., Carvalho G., Yuan Z., Keller J., Blackall L.L., Reis M.A.M. (2007) Advances in enhanced biological phosphorus removal: From micro to macro scale. Wat. Res. 41(11), 2271-2300.

Osborn D.W., and Nicholls H.A. (1978) Optimisation of the activated sludge process for the biological removal of phosphorus. Prog. Wat. Tech. 10(1/2), 261-277.

Pattarkine V.M., Randall C.W. (1999) The requirement of metal cations for enhanced biological phosphorus removal by activated sludge. Wat. Sci. Technol. 40(2), $159-165$

Pinzon A., Brdjanovic D, Moussa M., Lopez-Vazquez C.M., Meijer S., Van Straaten H., Janssen A., Van Loosdrecht MCM, and Amy G. (2007) Modelling Oil Refinery Wastewater Treatment Plant. Environ. Technol., 29(11).

Pitman A.R. (1991) Design considerations for nutrient removal activated sludge plants. Wat. Sci. Tech. 23(4-6), 781-790. 
Pitman A.R., Vandalsen L., and Trim B.C. (1988) Operating experience with biological nutrient removal at the Johannesburg Bushkoppie works. Wat. Sci. Tech. 20(45), 51-62.

Rabinowitz B., and Marais G.v.R. (1980) Chemical and biological phosphorus removal in the activated sludge process. M.A.Sc. thesis, Univ. CapeTown, S.A., Res. Rep. No. W32.

Ramphao M.C., Wentzel M.C., Merritt R., Ekama G.A. Young and Buckley C.A. (2005) The impact of solidluiquid separation on design of biological nutrient removal activated sludge systems. Biotech. \& Bioeng., 89(6), 630-646

Randall A.A., Benefield L.D., and Hill W.E. (1994) The effect of fermentation products on enhanced biological phosphorus removal, polyphosphate storage, and microbial population dynamics. Wat. Sci. Tech. 30(6), 213-219.

Rensink J.H., Donker H.J.G.W., and Vries H.P.d. (1981). Biological P-removal in domestic wastewater by the activated sludge process. Proc. 5th Eur. Sewage and Refuse Symp. Munich

Satoh H., Mino T., and Matsuo T. (1992) Uptake of organic substrates and accumulation of polyhydroxyalkanoates linked with glycolysis of intracellular carbohydrates under anaerobic conditions in the biological excess phosphate removal processes. Wat. Sci. Tech. 26(5-6), 933-942.

Saunders A.M., Mabbett A.N., McEwan A.G., and Blackall L.L. (2007) Proton motive force generation from stored polymers for the uptake of acetate under anaerobic conditions. FEMS Microbiol. Lett. 274(2), 245-251.

Scalf M.R., Pfeffer F.M., Lively L.D., Witherow J.O., and Priesing C.P. (1969) Phosphate removal in Baltimore, Maryland. J. Sanitary Eng. Div. Am. Soc. Civil Eng., 95(SA5) 817-827.

Schuler A.J. Jenkins D. (2002) Effects of pH on enhanced biological phosphorus removal metabolisms. Wat. Sci. Tech. 46(4-5), 171-178.

Schuler A.J. and Jenkins D. (2003) Enhanced biological phosphorus removal from wastewater by biomass with different phosphorus contents, Part 1: Experimental results and comparison with metabolic models. Water Environ. Res. 75(6),485-498.

Sell R.L., Krichten D.J., Noichl O.J. and Hartzog D.G. (1981) Low temperature biological phosphorus removal. In $54^{\text {th }}$ WPCF Conference, Detroit.

Seviour R.J., Mino T., and Onuki M. (2003) The microbiology of biological phosphorus removal in activated sludge systems. FEMS Microbiol. Rev. 27(1), 99-127.

Shapiro J., Levin G.V., and G.H.Z. (1967) Anoxically induced release of phosphate in wastewater treatment. $J$. Water Pollut. Control Fed. 39, 1810-1818.

Siebritz I.P., Ekama G.A., and Marais G.v.R. (1980) Excess biological phosphorus removal in the activated sludge process at warm temperature climate. Proc. WasteTreatment Utilization. 2, 233-251, Pergamon Press, Toronto.

Siebritz I.P., Ekama G.A., and Marais G.v.R. (1982) A parametric model for biological excess phosphorus removal. Wat. Sci. Tech. 15(3/4), 127-152.

Simpkins M.J., and McLaren A.R. (1978) Consistent biological phosphate and nitrate removal in an activated sludge plant. Prog. Wat. Tech. 10(5/6), 433-442.

Smolders G.J.F., van der Meij J., van Loosdrecht M.C.M., and Heijnen J.J. (1994a) Model of the anaerobic metabolism of the biological phosphorus removal process: Stoichiometry and $\mathrm{pH}$ influence. Biotech. Bioeng. 43, 461-470.

Smolders G.J.F., van der Meij J., van Loosdrecht M.C.M., and Heijnen J.J. (1994b) Stoichiometric model of the aerobic metabolism of the biological phosphorus removal process. Biotech. Bioeng. 44(7), 837-848.

Smolders G.J.F., van Loosdrecht M.C.M. Heijnen J.J., Henze M. and Gujer W. (1994c). A metabolic model for the biological phosphorus removal process. Water Sci. Technol. 31(2), 79-93.

Smolders G.J.F., Meij J.v.d., Loosdrecht M.C.M.v., and Heijnen J.J. (1995) A structured metabolic model for anaerobic and aerobic stoichiometry and kinetics of the biological phosphorus removal process. Biotech. Bioeng. 47, 277-287.

Sorm R., Bortone G., Saltarelli R., Jenicek P., Wanner J., and Tilche A. (1996) Phosphate uptake under anoxic conditions and fixed-film nitrification in nutrient removal activated sludge system. Wat. Res. 30(7), 15731584.

Spatzierer G., Ludwig C., and Matsche N. (1985) Biological; phosphorus removal in combination with simultaneous precipitation. Wat. Sci. Tech. 17(11/12), 163-176.

Srinath E.G., Sastry C.A., and Pillai S.C. (1959) Rapid removal of phosphorus from sewage by activated sludge. Experientia 15, 339-340.

Stante L., Cellamare C.M., Malaspina F., Bortone G., and Tilche A. (1997) Biological phosphorus removal by pure culture of Lampropedia spp. Wat. Res. 31(6), 13171324.

Stern L.B., and Marais G.v.R. (1974) Sewage as the electron donor in biological denitrification Research Report No.W7, Dept. of Civil Eng., University of Cape Town, S.A.

Timmerman M.W. (1979) Biological phosphate removal from domestic wastewater using anaerobic/aerobic treatment. Development Ind. Microbiol.,20.

Vacker D., Connell C.H., and Wells W.N. (1967) Phosphate removal through municipal wastewater treatment at San Antonio, Texas. J. Water Pollut. Control Fed. 39, 750771.

van Loosdrecht M.C.M., Brandse F.A., and de Vries A.C. (1998) Upgrading of waste water treatment processes for integrated nutrient removal - The BCFS process. Wat. Sci. Tech. 37(9), 209-217.

van Loosdrecht M.C.M., Smolders G.J., Kuba T., and Heijnen J.J. (1997) Metabolism of micro-organisms responsible for enhanced biological phosphorus removal from wastewater - Use of dynamic enrichment cultures. Antonie Van Leeuwenhoek Int. J. Gen. Molec. Microbiol. 71(1-2), 109-116.

Venter S.L., Halliday J., and Pitman A.R. (1978) Optimisation of the Johannesburg Olifantsvlei extended 
aeration plant for phosphorus removal. Prog. Wat. Tech. 10(1/2), 279-292.

Viconneau J.C., Hascoet M.C. and Florentz M. (1985) The first application of biological phosphorus removal in France. In Proc. Int. Conf. Management Strategies for Phosphorus in the Environment, Selper Ltd. UK.

Vlekke G.J.F.M., Comeau Y., and Oldham W.K. (1988) Biological phosphate removal from wastewater with oxygen or nitrate in sequencing batch reactors. Environ. Tech. Lett. 9, 791-796.

Wagner M., Erhart R., Manz W., Amann R., Lemmer H., Wedi D., Schleifer K.H. (1994) Development of an rRNA-targeted oligonucleotide probe specific for the genus Acinetobacter and its application for in situ monitoring in activated sludge. Appl. Environ. Microbiol. 60(3), 792-800.

Watanabe A., Miya A., and Matsuo Y. (1984). Laboratory scale study on biological phosphate removal using synthetic waste water: Removal performance and the investigation of enhanced phosphorus accumulating organisms. IAWPRC, Newsletter of the Study Group on Phosphate Removal in Biological Sewage Treatment Processes 2(1), 40-43.

Wentzel M.C., Dold P.L., Ekama G.A., and Marais G.v.R. (1989a) Enhanced polyphosphate organism cultures in activated sludge systems 3 . Kinetic model. Water $S A$ 15(2), 89-102.

Wentzel M.C., Ekama G.A., Dold P.L., and Marais G.v.R. (1990). Biological excess phosphorus removal - Steadystate process design. Water SA 16(1), 29-48.

Wentzel M.C., Ekama G.A., Loewenthal R.E., Dold P.L., and Marais G.v.R. (1989b) Enhanced polyphosphate organism cultures in activated-sludge systems .2. Experimental behavior. Water SA 15(2), 71-88.

Wentzel M.C., L.H. Lötter Loewenthal R.E., and Marais G.v.R. (1986) Metabolic behaviour of Acinetobacter spp. in enhanced biological phosphorus removal - A biochemical model. Water SA 12, 209-224.

Wentzel M.C., Lotter L.H., Ekama G.A., Loewenthal R.E., and Marais G.v.R. (1991) Evaluation of biochemicalmodels for biological excess phosphorus removal. Wat. Sci. Tech. 23(4-6), 567-576.

Wentzel M.C., Marais G.v.R., Loewenthal R.E., and Ekama G.A. (1988) Enhanced polyphosphate organism cultures in activated-sludge systems 1. Enhanced culture development. Water SA 14(2), 81-92.

\section{AGRADECIMIENTOS}

Los autores agradecen a Carlos M. Lopez-Vazquez por su contribución en la Sección 7.11 respecto a los organismos acumuladores de glucógeno.
Wentzel M.C., Mbewe A., and Ekama G.A. (1995) Batch test for measurement of readily biodegradable COD and active organism concentrations in municipal wastewaters. Water SA 21(2), 117-124.

Wentzel M.C., Dold P.L., Ekama G.A., and Marais G.v.R. (1985) Kinetics of biological phosphorus release. Wat. Sci. Tech. 17(11/12), 57-71.

Wentzel M.C., Ekama G.A., and Marais G.v.R. (1992) Processes and modelling of nitrificationdenitrification biological excess phosphorus removal systems - a review. Wat. Sci. Tech. 25(6), 59-82

Whang L.M., Filipe C.D.M. and Park J.K. (2007) Modelbased evaluation of competition between polyphosphate- and glycogen-accumulating organisms. Wat. Res. 41(6), 1312-1324.

Whang L.M. and Park J.K. (2006) Competition between polyphosphate- and glycogen-accumulating organisms in enhanced biological phosphorus removal systems: Effect of temperature and sludge age. Wat. Environ. Res. 78(1), 4-11.

Whang L.M., and Park J.K. (2002) Competition between polyphosphate- and glycogen-accumulating organisms in biological phosphorus removal systems - effect of temperature. Wat. Sci. Tech. 46(1-2), 191-194.

Wilson D.E., and Marais G.v.R. (1976) Adsorption phase in biological denitrification. Research Report No.W11, Dept. of Civil Eng., University of Cape Town, S.A.

Witherow J.L. (1970). Phosphorus removal in activated sludge. Proc. $24^{\text {th }}$ Industrial Waste Conference, Purdue University, 1169.

Wong M.T., Tan F.M., Ng W.J. and Liu W.T. (2004) Identification and occurrence of tetrad-forming alphaproteobacteria in anaerobic-aerobic activated sludge processes. Microbiology-SGM 150, 3741-3748.

WRC (1984) Theory, design and operation of nutrient removal activated sludge processes. Water Research Commission, Pretoria, S.A.

Zeng R.J., van Loosdrecht M.C.M., Yuan Z. and Keller J. (2003) Metabolic model for glycogen-accumulating organisms in anaerobic/aerobic activated sludge systems. Biotech. Bioeng. 81(1), 92-105.

Yeoman S., Hunter M., Stephenson T., Lester J.N. and Perry R. (1988). An assessment of excess biological phosphorus removal during activated sludge treatment. Env. Tech. Lett. 9, 637-646. 
NOMENCLATURA

\begin{tabular}{|c|c|c|c|}
\hline $\begin{array}{l}\text { Nuevo símbolo } \\
\text { (Chapter } 7 \text { ) }\end{array}$ & $\begin{array}{l}\text { UCT Symbol } \\
\text { (Chapter } 4 \text { and } 5 \text { ) }\end{array}$ & Descripción & Unidades \\
\hline$a$ & $a$ & $\begin{array}{l}\text { Relación de recirculación del licor mezclado basado en el } \\
\text { caudal afluente }\end{array}$ & $\mathrm{m}^{3} \cdot \mathrm{d} / \mathrm{m}^{3} \cdot \mathrm{d}$ \\
\hline$a_{o p t}$ & $a_{\text {opt }}$ & Relación de recirculación a que da la mínima $\mathrm{N}_{\mathrm{ne}}$ & $\mathrm{m}^{3} \cdot \mathrm{d} / \mathrm{m}^{3} \cdot \mathrm{d}$ \\
\hline ьоно & $b_{H}$ & Tasa específica de decaimiento endógeno para OHOs & gSSVe/gSSV.d \\
\hline bоно,т & $b_{B H}$ & $\begin{array}{l}\text { Tasa específica de decaimiento endógeno para OHOs a } \\
\text { temperatura } \mathrm{T}\end{array}$ & gSSVe/gSSVe.d \\
\hline bPAO & & Tasa específica de decaimiento endógeno para PAOs & gSSVegSSVe.d \\
\hline$b_{P A O, T}$ & $b_{G T}$ & $\begin{array}{l}\text { Tasa específica de decaimiento endógeno para PAOs a } \\
\text { temperatura } \mathrm{T}\end{array}$ & gSSVe/gSSVe.d \\
\hline$D Q O_{b}$ & & Concentración de DQO biodegradable & $\mathrm{gDQO} / \mathrm{m}^{3}$ \\
\hline$D Q O_{b, i}$ & & Concentración de DQO biodegradable en el afluente & $\mathrm{gDQO} / \mathrm{m}^{3}$ \\
\hline$D Q O_{b, \mathrm{OHO}}$ & & Concentración de DQO biodegradable disponible para OHOs & $\mathrm{gDQO} / \mathrm{m}^{3}$ \\
\hline$D_{P I}$ & & Desnitrificación potencial del reactor anóxico primario & $\mathrm{gNO}_{3}-\mathrm{N} / \mathrm{m}^{3}$ afluente \\
\hline$D_{P 3}$ & & Desnitrificación potencial del reactor anóxico secundario & $\mathrm{gNO}_{3}-\mathrm{N} / \mathrm{m}^{3}$ afluente \\
\hline$f_{A N}$ & $f_{x a}$ & Fracción de masa anaerobia & gSSV/gSSV \\
\hline$f_{A X I}$ & $f_{X 1}$ & Fracción de masa del reactor anóxico primario & $\mathrm{gSSV} / \mathrm{gSSV}$ \\
\hline$f_{A X 1, \min }$ & & Fracción mínima de masa del reactor anóxico primario & gSSV/gSSV \\
\hline$f_{A X 3}$ & $f_{X 3}$ & Fracción de masa del reactor anóxico secundario & gSSV/gSSV \\
\hline$F D Q O_{b, i}$ & $F S_{b i}$ & Masa diaria de DQO biodegradable afluente & $\mathrm{gDQO} / \mathrm{d}$ \\
\hline$F D Q O_{b, \text { ОНО }}$ & $F S_{B H}$ & $\begin{array}{l}\text { Masa diaria de DQO biodegradable afluente disponible para } \\
\text { OHOs }\end{array}$ & gDQO/gDQO \\
\hline$F D Q O_{i}$ & $F S_{t i}$ & Masa diaria de DQO afluente & gDQO/d \\
\hline$f_{C V}$ & $f_{c v}$ & Relación DQO/SSV ratio en el lodo & gDQO/gSSV \\
\hline$f_{S S F, O H O}$ & $f_{\text {iОНО }}$ & Contenido inorgánico en OHOs & gSSF/gSST \\
\hline$f_{S S F, P A O}$ & & Contenido inorgánico en PAOs & $\mathrm{gSSF} / \mathrm{gSST}$ \\
\hline$f_{N, S S V}$ & $f_{n}$ & Contenido de $\mathrm{N}$ en el lodo & $\mathrm{gN} / \mathrm{gSSV}$ \\
\hline$F N_{\text {sintesis }}$ & & Masa diaria de nitrógeno requerido para producción de lodo & $\mathrm{gN} / \mathrm{d}$ \\
\hline $\mathrm{FO}_{2, \mathrm{C}}$ & $F O_{c}$ & Masa diaria de demanda de oxígeno carbonáceo & $\mathrm{gO}_{2} / \mathrm{d}$ \\
\hline $\mathrm{FO}_{2, \mathrm{OHO}}$ & $F O_{H}$ & Masa diaria de oxígeno consumido por OHOs & $\mathrm{gO}_{2} / \mathrm{d}$ \\
\hline$F O_{2, P A O}$ & $F O_{G}$ & Masa diaria de oxígeno consumido por PAOs & $\mathrm{gO}_{2} / \mathrm{d}$ \\
\hline $\mathrm{FO}_{2, T}$ & $F O_{t}$ & Masa diaria de demanda total de oxígeno & $\mathrm{gO}_{2} / \mathrm{d}$ \\
\hline$f_{P, S S F}$ & & Fracción de P en los sólidos suspendidos fijos (inorgánicos) & $\mathrm{gP} / \mathrm{gSSF}$ \\
\hline$f_{P, S S F, i}$ & & Fracción de $\mathrm{P}$ en el SSF afluente & $\mathrm{gP} / \mathrm{gSSF}$ \\
\hline$f_{P, O H O}$ & $f_{X B H P}$ & Fracción de $\mathrm{P}$ en la biomasa activa $\mathrm{OHO}$ & $\mathrm{gP} / \mathrm{gSSVa}$ \\
\hline$f_{P, P A O}$ & $f_{X B G P}$ & Fracción de $\mathrm{P}$ en la biomasa activa $\mathrm{PAO}$ & $\mathrm{gP} / \mathrm{gSSVa}$ \\
\hline$f_{P, S S T}$ & $f_{p}$ & Contenido de $\mathrm{P}$ en los SST & $\mathrm{gP} / \mathrm{gSST}$ \\
\hline$f_{P, S S V}$ & $f_{p}$ & Contenido de $\mathrm{P}$ en los SSV & $\mathrm{gP} / \mathrm{gSSV}$ \\
\hline$f_{P, X E, \text { ОHO }}$ & $f_{X E G P}$ & Fracción de $\mathrm{P}$ en la masa endógena $\mathrm{OHO}$ & $\mathrm{gP} / \mathrm{gSSVe}$ \\
\hline$f_{P, X E, P A O}$ & & Fracción de $\mathrm{P}$ en la masa endógena $\mathrm{PAO}$ & $\mathrm{gP} / \mathrm{gSSVe}$ \\
\hline$f_{P, X I}$ & $f_{X I P}$ & Fracción de P en la masa inerte & $\mathrm{gP} / \mathrm{gSSVi}$ \\
\hline$f_{P O 4, \text { rel }}$ & $f_{\text {prel }}$ & Relación de P liberado/AGV asimilado & $\mathrm{gP} / \mathrm{gDQO}$ \\
\hline$F S_{F, C O N V}$ & & $\begin{array}{l}\text { Masa diaria de DQO fermentable convertido a AGVs en los } \\
\text { reactors anaerobios }\end{array}$ & $\mathrm{gDQO} / \mathrm{d}$ \\
\hline$f_{S I, D Q O i}$ & $f_{\text {S'us }}$ & Fracción de DQO soluble no biodegradable afluente & gDQO/gDQO \\
\hline$F S_{P O 4, r e l}$ & $M P_{r e}$ & Masa diaria de $\mathrm{P}$ liberado por PAOs & $\mathrm{gP} / \mathrm{d}$ \\
\hline
\end{tabular}




\begin{tabular}{|c|c|c|c|}
\hline$f_{S S, D Q O i}$ & $f_{S t} t^{\prime}$ & $\begin{array}{l}\text { Fracción de DQO rápidamente biodegradable respecto a la } \\
\text { DQO total afluente }\end{array}$ & gDQO/gDQO \\
\hline$f_{S S}$ & $f_{S b}{ }^{\prime} s$ & $\begin{array}{l}\text { Fracción de DQO rápidamente biodegradable respecto a la } \\
\text { DQO biodegradable afluente }\end{array}$ & gDQO/gDQO \\
\hline$F S_{S, P A O}$ & $M S_{\text {seq }}$ & $\begin{array}{l}\text { Masa diaria de DQO rápidamente biodegradable almacenada } \\
\text { por PAOs en el reactor anaerobio }\end{array}$ & $\mathrm{gDQO} / \mathrm{d}$ \\
\hline$F S_{A G V, i}$ & & Masa diaria de AGV afluente & $\mathrm{gDQO} / \mathrm{d}$ \\
\hline$f_{S A G V, S S i}$ & & Fracción de AGVs en la DQO rápidamente biodegradable & gDQO/gDQO \\
\hline$f_{V T}$ & $f_{V T H}$ & $\begin{array}{l}\text { Relación SSV/SST en la masa de OHO y PAOs (incluido masa } \\
\text { activa, endógena e inerte) }\end{array}$ & $\mathrm{gSSV} / \mathrm{gSST}$ \\
\hline$f_{V T, P A O}$ & $f_{V T G}$ & Relación SSV/SST para biomasa activa PAO & $\mathrm{gSSV} / \mathrm{gSST}$ \\
\hline$f_{X d m a x}$ & & Fracción máxima de masa anóxica & $\mathrm{gSSV} / \mathrm{gSSV}$ \\
\hline$f_{X E, O H O}$ & $f_{E H}$ & Fracción de residuo endógeno de OHOs & gSSVe/gSSVa \\
\hline$f_{X E, P A O}$ & $f_{E G}$ & Fracción de residuo endógeno de PAOs & gSSVe/gSSVa \\
\hline$F X_{F S S, i}$ & $M X_{I O i}$ & Masa diaria de inorgánicos afluente & $\mathrm{gSSF} / \mathrm{d}$ \\
\hline$f_{X I, D Q O i}$ & $f_{\text {S'up }}$ & Fracción de DQO particulado no biodegradable afluente & gDQO/gDQO \\
\hline$f_{X \max }$ & & Fracción máxima de masa no aireada & gSSV/gSSV \\
\hline$F X_{S, i}$ & & Masa diaria de DQO lentamente biodegradable afluente & gDQO/d \\
\hline$T R H_{n p}$ & $R_{h n}$ & Tiempo de retención hidráulico nominal promedio del proceso & $\mathrm{d}$ \\
\hline$K^{\prime} I T$ & & $\begin{array}{l}\text { Tasa específica de desnitrificación en el reactor anóxico } \\
\text { primario del sistema NDEBPR usando DQOrb a temperatura T }\end{array}$ & $\mathrm{gNO}_{3}{ }^{-} \mathrm{N} / \mathrm{gOHOSSV} . \mathrm{d}$ \\
\hline$K^{\prime}{ }_{2 T}$ & & $\begin{array}{l}\text { Tasa específica de desnitrificación en el reactor anóxico } \\
\text { primario del sistema NDEBPR usando DQOlb a temperatura T }\end{array}$ & $\mathrm{gNO}_{3}-\mathrm{N} / \mathrm{gOHOSSV} . \mathrm{d}$ \\
\hline$K_{3 T}^{\prime}$ & & $\begin{array}{l}\text { Tasa específica de desnitrificación en el reactor anóxico } \\
\text { secundario del sistema NDEBPR usando DQOlb a temperatura } \\
\mathrm{T}\end{array}$ & $\mathrm{gNO}_{3}{ }^{-} \mathrm{N} / \mathrm{gOHOSSV} . \mathrm{d}$ \\
\hline$k_{F, T}$ & $K_{C T}$ & Tasa constant de fermentación de primer orden a temperatura $\mathrm{T}$ & $\mathrm{m}^{3} / \mathrm{gOHOSSV} . \mathrm{d}$ \\
\hline$K_{T}^{\prime}$ & & $\begin{array}{l}\text { Tasa específica de desnitrificación de OHOs para un sistema } \\
\text { NDEBPR (') a temperatura T }\end{array}$ & $\mathrm{gNO}_{3}{ }^{-} \mathrm{N} / \mathrm{gOHOSSV} . \mathrm{d}$ \\
\hline$M X_{E, \text { ОHO }}$ & $M X_{E H}$ & Masa de residuo endógeno $\mathrm{OHO}$ en el sistema & gSSVe \\
\hline$M X_{E, P A O}$ & $M X_{E G}$ & Masa de residuo endógeno PAO en el sistema & gSSVe \\
\hline$M X_{S S F}$ & & Masa de sólidos suspendidos fijos (inorgánicos) en el sistema & gSSF \\
\hline$M X_{I}$ & $M X_{I}$ & $\begin{array}{l}\text { Masa de material organico inerte en el sistema, proveniente del } \\
\text { afluente }\end{array}$ & gSSV (or gSSVi) \\
\hline МХОно & $M X_{B H v}$ & Masa de OHOs en el sistema & gSSVa \\
\hline$M X P A O$ & $M X_{B G}$ & Masa de PAOs en el sistema & gSSVa \\
\hline$M X_{S S T}$ & & Masa de SST en el sistema & gSST \\
\hline$M X_{S S V}$ & $M X_{v}$ & Masa de sólidos suspendidos volátiles en el sistema & gSST \\
\hline$N$ & $n$ & Número de reactors anaerobios en serie & - \\
\hline$N$ & $N$ & $\begin{array}{l}\text { Número total de reactors anaerobios en serie de igual volumen } \\
\mathrm{n}=1,2 \ldots . \mathrm{N}\end{array}$ & - \\
\hline$N I T_{c}$ & $N_{c}$ & Capacidad de nitrificación en el bioreactor & $\mathrm{gNO}_{3}-\mathrm{N} / \mathrm{m}^{3}$ \\
\hline$Q_{i}$ & $Q_{i}$ & Caudal promedio diario de afluente & $\mathrm{m}^{3} / \mathrm{d}$ \\
\hline$Q_{i, a d w f}$ & $Q_{i, a d w f}$ & Caudal promedio diario durante periodo seco & $\mathrm{Ml} / \mathrm{d}$ \\
\hline$R$ & $r$ & $\begin{array}{l}\text { Relación de recirculación de licor mezclado del reactor aerobio } \\
\text { al anóxico (o anaerobio) basado en el caudal afluente }\end{array}$ & $\mathrm{m}^{3} \cdot \mathrm{d} / \mathrm{m}^{3} \cdot \mathrm{d}$ \\
\hline$S$ & $s$ & $\begin{array}{l}\text { Relación de recirculación de lodo activado basado en el caudal } \\
\text { afluente }\end{array}$ & $\mathrm{m}^{3} \cdot \mathrm{d} / \mathrm{m}^{3} \cdot \mathrm{d}$ \\
\hline$S_{A l k}$ & $S_{A l k}$ & Concentración de alcalinidad & $\mathrm{mgCaCO}_{3} / 1$ \\
\hline$S_{F}$ & $S_{F}$ & Concentración de materia orgánica fermentable & $\mathrm{gDQO} / \mathrm{m}^{3}$ \\
\hline
\end{tabular}




\begin{tabular}{|c|c|c|c|}
\hline$S_{F, A n n}$ & $S_{b s f}$ & $\begin{array}{l}\text { Concentración de materia orgánica fermentable en el reactor } \\
\text { anaerobio } \mathrm{n}^{\circ}\end{array}$ & $\mathrm{gDQO} / \mathrm{m}^{3}$ \\
\hline$S_{F, \text { conv }}$ & $S_{b s f i}^{\prime}$ & Materia orgánica fermentable convertida a AGV por volumen & $\mathrm{gDQO} / \mathrm{m}^{3}$ \\
\hline$S_{F, D E N I T}$ & & $\begin{array}{l}\text { Concentración de DQO fermentable consumido debido a } \\
\text { desnitrificación en el reactor anaerobio }\end{array}$ & $\mathrm{gDQO} / \mathrm{m}^{3}$ \\
\hline$S_{F, i}$ & $S_{b s f i}$ & Concentración de DQO fermentable en el afluente & $\mathrm{gDQO} / \mathrm{m}^{3}$ \\
\hline$S_{F, i, c o n v}$ & $S_{b s f i}^{\prime}$ & $\begin{array}{l}\text { SF,i disponible para conversion en AGVs por volume de } \\
\text { afluente }\end{array}$ & $\mathrm{gDQO} / \mathrm{m}^{3}$ \\
\hline$S_{F, O X I D}$ & & $\begin{array}{l}\text { Sustrato fermentable consumido por oxidación aerobia en el } \\
\text { reactor anaerobio }\end{array}$ & $\mathrm{gDQO} / \mathrm{m}^{3}$ \\
\hline$S_{I, i}$ & & $\begin{array}{l}\text { Concentración de materia orgánica soluble no biodegradable } \\
\text { en el afluente }\end{array}$ & $\mathrm{gDQO} / \mathrm{m}^{3}$ \\
\hline $\mathrm{S}_{\mathrm{NO}, e}$ & $N_{n e}$ & Concentración de nitrato efluente & $\mathrm{gNO}_{3}-\mathrm{N} / \mathrm{m}^{3}$ \\
\hline$S_{N O 3, i}$ & $N_{03 i}$ & Concentración de nitrato afluente (al reactor anaerobio AN) & $\mathrm{gNO}_{3}-\mathrm{N} / \mathrm{m}^{3}$ \\
\hline $\mathrm{S}_{\mathrm{NO}, \mathrm{s}}$ & $N_{03 r}$ & $\begin{array}{l}\text { Concentración de nitrato en la recirculación de lodo al reactor } \\
\text { anaerobio }\end{array}$ & $\mathrm{gNO}_{3}-\mathrm{N} / \mathrm{m}^{3}$ \\
\hline $\mathrm{SO} 2$ & $\mathrm{So} 2$ & Concentración de oxígeno disuelto & $\mathrm{gO}_{2} / \mathrm{m}^{3}$ \\
\hline $\mathrm{SO}, a$ & $O_{r}$ & $\begin{array}{l}\text { Concentración de oxígeno en la recirculación del reactor } \\
\text { anóxico al reactor anaerobio }\end{array}$ & $\mathrm{gO}_{2} / \mathrm{m}^{3}$ \\
\hline$S_{O 2, i}$ & $O_{i}$ & Concentración de oxígeno afluente & $\mathrm{gO}_{2} / \mathrm{m}^{3}$ \\
\hline$S_{O 2, s}$ & $N_{n s}$ & $\begin{array}{l}\text { Concentración de oxígeno en la recirculación de lodo al reactor } \\
\text { anaerobio }\end{array}$ & $\mathrm{gO}_{2} / \mathrm{m}^{3}$ \\
\hline$S_{P O 4, \text { rel }}$ & $P_{\text {rel }}$ & Concentración de P liberado & $\mathrm{gP} / \mathrm{m}^{3}$ \\
\hline$T R S$ & $R_{s}$ & Edad de lodo & $\mathrm{d}$ \\
\hline$S_{S, i}$ & $S_{S}$ & Concentración de DQOrb afluente & $\mathrm{gDQO} / \mathrm{m}^{3}$ \\
\hline$S_{S, P A O}$ & & Concentration de Ss almacenados por PAOs & $\mathrm{gDQO} / \mathrm{m}^{3}$ \\
\hline$S_{A G V}$ & $S_{A}$ & Concentración de ácidos grasos volátiles & $\mathrm{gDQO} / \mathrm{m}^{3}$ \\
\hline$S_{A G V, i}$ & $S_{b s a i}$ & Concentración de AGV afluente & $\mathrm{gDQO} / \mathrm{m}^{3}$ \\
\hline$T$ & $t$ & Tiempo & $\mathrm{h}$ \\
\hline$T$ & $T$ & Temperatura & ${ }^{\circ} \mathrm{C}$ \\
\hline$N T K$ & $N_{t}$ & Concentración de nitrógeno total Kjeldahl & $\mathrm{gN} / \mathrm{m}^{3}$ \\
\hline$N T K_{i, s y n t h}$ & & NTK afluente requerido para síntesis de biomasa & $\mathrm{gN} / \mathrm{m}^{3}$ \\
\hline$T_{\min }$ & $T$ & Temperatura mínima & ${ }^{\circ} \mathrm{C}$ \\
\hline$T_{P, e}$ & $P_{t}$ & Concentración de fósforo total efluente & $\mathrm{gP} / \mathrm{m}^{3}$ \\
\hline$T_{P, i}$ & $P_{t}$ & Concentración de fósforo total afluente & $\mathrm{gP} / \mathrm{m}^{3}$ \\
\hline SST & $X_{T S S}$ & Sólidos suspendidos totales & $\mathrm{gSST} / \mathrm{m}^{3}$ \\
\hline$V_{P}$ & $V_{p}$ & Volumen del proceso biológico (bioreactor) & 1 \\
\hline$S S V$ & $X_{v}$ & Concentración de SSV & $\mathrm{gSSV} / \mathrm{m}^{3}$ \\
\hline$X_{S S F, i}$ & & Concentración de sólidos suspendidos fijos afluente (SSF) & $\mathrm{gSSF} / \mathrm{m}^{3}$ \\
\hline$X_{I, i}$ & & Concentración de materia particulada inerte afluente & $\mathrm{gDQO} / \mathrm{m}^{3}$ \\
\hline Хоно & Хоно & Concentración de organismos heterótrofos ordinarios & $\mathrm{gDQO} / \mathrm{m}^{3}$ \\
\hline$X_{O H O, A N}$ & & Concentración de OHOs en el reactor anaerobio & $\mathrm{gDQO} / \mathrm{m}^{3}$ \\
\hline$X_{P A O}$ & $X_{P A O}$ & Concentración de organismos acumuladores de fósforo & $\mathrm{gDQO} / \mathrm{m}^{3}$ \\
\hline$X_{S}$ & $X_{S}$ & Concentración de DQOlb & $\mathrm{gDQO} / \mathrm{m}^{3}$ \\
\hline$X_{S, i}$ & & Concentración de DQOlb afluente & $\mathrm{gDQO} / \mathrm{m}^{3}$ \\
\hline$X_{S S T}$ & $X_{t}$ & Concentración de sólidos suspendidos totales en el reactor & $\mathrm{gSST} / \mathrm{m}^{3}$ \\
\hline$X_{S S T . O X}$ & & Concentración de SST deseada en el reactor aerobio & $\mathrm{gSST} / \mathrm{m}^{3}$ \\
\hline$X_{S S V}$ & & Concentración de sólidos suspendidos volátiles en el reactor & $\mathrm{gSSV} / \mathrm{m}^{3}$ \\
\hline$X_{S S V . O X}$ & & Concentración de SST seleccionada en el reactor aerobio & $\mathrm{gSSV} / \mathrm{m}^{3}$ \\
\hline$Y_{\mathrm{OHO}}$ & $Y_{H v}$ & Rendimiento de biomasa $\mathrm{OHO}$ & $\mathrm{gSSVa} / \mathrm{gDQ}$ \\
\hline
\end{tabular}




$\begin{array}{llll}\triangle P_{\text {OHO }} & \triangle P_{H} & \text { Remoción de P por OHOs } & \mathrm{gP} / \mathrm{m}^{3} \text { afluente } \\ \triangle P_{P A O} & \Delta P_{G} & \text { Remoción de P por PAOs } & \mathrm{gP} / \mathrm{m}^{3} \text { afluente } \\ \triangle P_{S Y S} & \Delta P_{T} & \text { Remoción total de P en el sistema } & \mathrm{gP} / \mathrm{m}^{3} \text { afluente } \\ \triangle P_{S Y S . A C T} & & \text { Remoción total real de P en el sistema } & \mathrm{gP} / \mathrm{m}^{3} \text { afluente } \\ \triangle P_{S Y S, P O T} & & \text { Remoción potencial de P en el sistema } & \mathrm{gP} / \mathrm{m}^{3} \text { afluente } \\ \triangle P_{X E} & - & \text { Remoción de P debido a la masa de residuo endógeno } & \mathrm{gP} / \mathrm{m}^{3} \text { afluente } \\ \triangle P_{X I} & \Delta P_{I} & \text { Remoción de P debido a la masa inerte } & \mathrm{gP} / \mathrm{m}^{3} \text { afluente }\end{array}$

\begin{tabular}{|c|c|}
\hline Abreviación & Descripción \\
\hline $\mathrm{A} / \mathrm{O}$ & Proceso anaerobio/aerobio \\
\hline $\mathrm{A}^{2} \mathrm{O}$ & Proceso anaerobio/ anóxico, aerobio \\
\hline AGV & Ácido graso volatil \\
\hline AN & Anaerobio \\
\hline ANO & $\begin{array}{l}\text { Organismos nitrificantes } \\
\text { (por sus siglas en inglés Autotrophic nitrifying organisms) }\end{array}$ \\
\hline $\mathrm{AX}$ & Anóxico \\
\hline $\mathrm{CS}$ & Clarificador secundario \\
\hline DDGGE & $\begin{array}{l}\text { Electroforesis en gel con gradiente de desnaturalización en seco } \\
\text { (por sus siglas en inglés Dry denaturing gradient gel electrophoresis) }\end{array}$ \\
\hline $\mathrm{DQO}_{\mathrm{rb}}$ & DQO rápidamente biodegradable \\
\hline $\mathrm{DQO}_{\mathrm{lb}}$ & DQO lentamente biodegradable \\
\hline e & Efluente \\
\hline EBPR & $\begin{array}{l}\text { Remoción biológica aumentada de fósforo } \\
\text { (por sus siglas en inglés Enhanced biological phosphorus removal) }\end{array}$ \\
\hline FISH & $\begin{array}{l}\text { Hibridación por fluorescencia in situ } \\
\text { (por sus siglas en inglés Fluorescence in situ hybridisation) }\end{array}$ \\
\hline Inf & Afluente \\
\hline SSVnb & Sólidos suspendidos volátiles no biodegradables o Sólidos suspendidos volátiles inertes \\
\hline JHB & Proceso de Johannesburgo \\
\hline MLE & $\begin{array}{l}\text { Proceso de Ludzack-Ettinger modificado } \\
\text { (por sus siglas en inglés Modified Ludzack-Ettinger process) }\end{array}$ \\
\hline MUCT & Proceso de UCT modificado \\
\hline ND & Nitrificación-Desnitrificación \\
\hline NDEBPR & Sistemas EBPR con nitrificación-denitrificación \\
\hline $\mathrm{OHO}$ & Organismos heterotróficos ordinarios \\
\hline OUR & Tasa de consumo de oxígeno \\
\hline PAO & $\begin{array}{l}\text { Organismo acumulador de fósforo } \\
\text { (por sus siglas en inglés Phosphate accumulating organism) }\end{array}$ \\
\hline PHA & Poli- $\beta$-hidroxialcanoato \\
\hline PHB & Poli- $\beta$-hidroxibutirato \\
\hline PHV & Poli- $\beta$-hidroxivalerato \\
\hline $\mathrm{PO}_{4}$ & Fosfato(s) \\
\hline NTK & Nitrógeno total Kjeldahl \\
\hline Ntot & Nitrógeno total \\
\hline Ptot & Fósforo total \\
\hline SBR & Reactor discontinuo secuencial \\
\hline SSI & Sólidos suspendidos inertes \\
\hline SSLM & Sólidos suspendidos del licor mezclado \\
\hline SST & Sólidos suspendidos totales \\
\hline SSV & Sólidos suspendidos volátiles \\
\hline
\end{tabular}


SSVa

SSVLM

SSVnb

TCA

TRH

TRS

UCT

VIP
Sólidos suspendidos volatiles activos

Sólidos suspendidos volátiles del licor mezclado

Sólidos suspendidos volátiles no biodegradables o Resíduo endógeno como sólidos suspendidos volátiles

Ciclo de los ácidos tricarboxílicos

Tiempo de residencia hidráulico

Tiempo de residencia de sólidos o edad del lodo

Proceso de la Universidad de la Ciudad del Cabo (Cape Town University)

Proceso de la iniciativa de Virginia

(por sus siglas en inglés Virginia initiative plant process)

\begin{tabular}{|c|c|c|c|}
\hline $\begin{array}{l}\text { Símbolos griegos } \\
\text { (Chapter } 7 \text { ) }\end{array}$ & $\begin{array}{l}\text { Símbolo UCT } \\
\text { (Chapter } 4 \text { and 5) }\end{array}$ & Descripción & Unidades \\
\hline$\alpha$ & & Constante alfa & \\
\hline$\beta$ & & Constante beta & \\
\hline$\mu_{\text {NITmax } 20}$ & $\mu_{A m 20}$ & $\begin{array}{l}\text { Tasa máxima de crecimiento específico para bacterias } \\
\text { nitrificantes a } 20^{\circ} \mathrm{C}\end{array}$ & $d^{-1}$ \\
\hline$\theta_{k F}$ & & Coeficiente de temperatura Arrhenius para $\mathrm{kF}$ & - \\
\hline$\eta$ & & $\begin{array}{l}\text { Factor de reducción para procesos aerobios de } \\
\text { hidrólisis/crecimiento utilizando } \mathrm{DQO}_{\mathrm{lb}} \text { en condiciones anóxicas }\end{array}$ & \\
\hline$\theta_{b O H O}$ & & Coeficiente de temperatura Arrhenius para bоно & - \\
\hline$\theta_{b P A O}$ & & Coeficiente de temperaturaArrhenius para bPAO & - \\
\hline
\end{tabular}




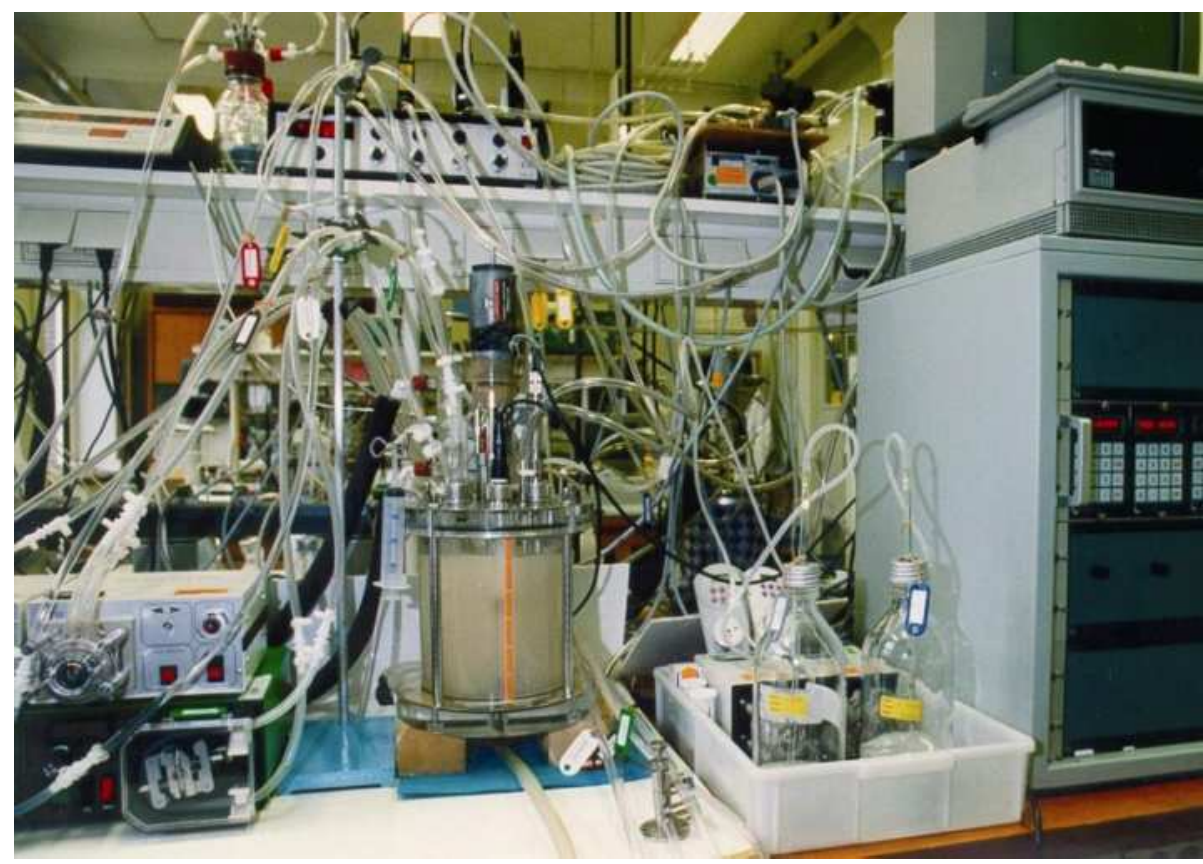

La investigación básica usando cultivos enriquecidos de PAOs en unos reactores discontinuos secuenciales (SBR) a escala laboratorio contribuyeron de manera significativa en el desarrollo de los modelos metabólicos (Foto: D. Brdjanovic) 


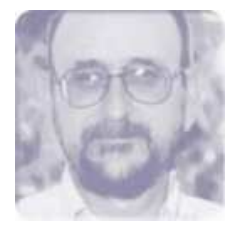

\section{8}

\section{Eliminación de Patógenos}

\section{Charles P. Gerba}

\subsection{INTRODUCCIÓN}

Aunque los seres humanos se exponen continuamente a una amplia gama de microorganismos que se encuentran en el ambiente, sólo una pequeña proporción de estos microbios son capaces de interactuar con el huésped, e iniciar una infección y/o enfermedad. Los microorganismos causantes de enfermedades se llaman patógenos. La infección es el proceso en el cual un microorganismo crece y se reproduce dentro o sobre el huésped. La infección no se traduce necesariamente en enfermedad, ya que es posible que el organismo crezca dentro o sobre el huésped, pero no producir la enfermedad. En el caso de las infecciones entéricas causadas por Salmonella (por ejemplo diarrea), sólo la mitad de las personas infectadas desarrollan signos clínicos de la enfermedad. Los microorganismos patógenos generalmente se originan a partir de un huésped infectado (ya sea humano $u$ otro animal) o directamente del medio ambiente.

Los microorganismos transmitidos por vía fecal-oral generalmente se conocen como patógenos entéricos, ya que infectan el tracto gastrointestinal. Ellos se caracterizan por ser estables en el agua y en los alimentos $y$, en el caso de las bacterias entéricas, son capaces de crecer fuera del huésped si existen las condiciones adecuadas ambientales (temperaturas cálidas y materia orgánica suficientes).

Las enfermedades transmitidas por medio del agua son aquellas que se transfieren a través de la ingesta de agua contaminada, la cual sirve como portador pasivo de algún agente infeccioso. Las enfermedades más comunes transmitidas a través del agua son cólera y fiebre tifoidea, las cuales frecuentemente han devastado zonas densamente pobladas a lo largo de la historia de la humanidad; $y$ que han sido controladas efectivamente por la protección de las fuentes de agua y por el tratamiento de suministros de agua contaminados. Algunas otras enfermedades causadas por bacterias, virus, protozoarios y lombrices parasitarias (helmintos) también pueden ser transmitidas por medio del agua potable contaminada. Sin embargo, es importante recordar que las enfermedades transmitidas por el agua se transfieren por la vía fecal-oral, de humano a humano o animal a 
humano, de modo que el agua potable es sólo una de las varias posibles fuentes de transmisión de los microorganismos.

Los microorganismos patógenos que son capaces de causar enfermedades son los virus, las bacterias y los protozoarios. Las lombrices o helmintos también son capaces de ser transmitidos por aguas residuales. Algunos de los patógenos entéricos más comunes que se encuentran en las aguas residuales se enlistan en las Tablas 8.1, 8.2 y 8.3.

Tabla 8.1 Clasificación de algunos protozoarios y helmintos transmitidos ambientalmente.

\begin{tabular}{l}
\hline Protozoos \\
\hline Grupo filogénico Apicomplexa \\
Ciclospora cayetanesis \\
Cryptosporidium parvum \\
Grupo filogénico Sarcomastigophora \\
Entamoeba histolytica \\
Giardia lamblia \\
\hline Helmintos \\
Grupo filogénico Nematoda \\
Ascaris lumbricoides \\
Necator americanus \\
Trichuris trichiura \\
Grupo filogénico Platyhelminthes \\
Clase Cestoidea \\
Taenia saginata \\
Clase Trematoda \\
Schistosoma mansoni
\end{tabular}

\subsection{TIPOS DE PATÓGENOS ENTÉRICOS}

\subsubsection{Virus}

Los virus están compuestos sólo de ácido nucleico (que contiene la información genética) rodeado por una capa protectora o cápside. Algunos virus también pueden tener una capa lipídica que rodea la capa de proteína. El ácido nucleico puede ser ácido ribonucleico (ARN) o bien, ácido desoxirribonucleico (ADN). Ellos no pueden crecer fuera del organismo huésped (por ejemplo bacterias, plantas o animales), pero no necesitan alimentos para sobrevivir. Debido a esto, son capaces de sobrevivir por largos períodos de tiempo, especialmente cuando existen bajas temperaturas en el ambiente. Los virus que infectan las bacterias se llaman bacteriófagos, y cuando un bacteriófago infecta a una bacteria coliforme se conoce como colífago. Los virus que crecen en el tracto intestinal en los humanos son conocidos como virus entéricos. Los virus entéricos suelen tener un huésped muy específico; por lo tanto, sólo infectan a los seres humanos. La ingesta de tan sólo unos pocos virus (1-10) puede causar una infección, comparado con las miles de bacterias entéricas que normalmente se ingieren.

Los virus entéricos humanos requieren el uso de cultivo de tejido animal (por ejemplo, células de riñón de mono) para aislarse y crecer en el laboratorio, haciéndolos mucho más costosos de estudiar que las bacterias entéricas.

Tabla 8.2 Virus entéricos y enfermedades asociadas

\begin{tabular}{|c|c|}
\hline Virus Entéricos & Enfermendad \\
\hline \multicolumn{2}{|l|}{ Enterovirus } \\
\hline Poliovirus & Parálisis \\
\hline Coxsackievirus & $\begin{array}{l}\text { Meningitis, enfermedades } \\
\text { cardiacas, diabetes } \\
\text { resfriado común, diarrea }\end{array}$ \\
\hline Echovirus & $\begin{array}{l}\text { Fiebre, sarpullido, meningitis, } \\
\text { diarrea. }\end{array}$ \\
\hline $\begin{array}{l}\text { Enterovirus } \\
\qquad(\text { tipos 68-100) }\end{array}$ & $\begin{array}{l}\text { Infección en los ojos, fiebre, } \\
\text { parálisis, meningitis }\end{array}$ \\
\hline Hepatitis virus A & Enfermedad hepática \\
\hline Reovirus & Desconocido \\
\hline Rotavirus & Diarrea \\
\hline Adenovirus & $\begin{array}{l}\text { Diarrea, infección en los ojos y } \\
\text { garganta, infecciones } \\
\text { respiratorias, obesidad }\end{array}$ \\
\hline Astrovirus & Diarrea \\
\hline Torovirus & Diarrea \\
\hline $\begin{array}{l}\text { Norovirus Calicivirus } \\
\text { Humanos } \\
\text { Sapprovirus }\end{array}$ & $\begin{array}{l}\text { Diarrea } \\
\text { Diarrea }\end{array}$ \\
\hline Hepatitis virus E & Enfermedad hepática \\
\hline Picobirnavirus & Diarrea \\
\hline Aichivirus & Diarrea \\
\hline
\end{tabular}

En la actualidad se conocen más de 160 virus entéricos que infectan a los seres humanos, con algunos otros nuevos que han sido descubiertos. Una amplia gama de virus entéricos causan diarrea. El rotavirus es una infección común en los niños menores de dos años, que causa una cantidad significativa de mortalidad en los países en desarrollo. Más de una docena de grandes brotes transmitidos a través del agua, tanto en niños como en adultos, han sido asociados con este virus. El Norovirus y su asociado Sapovirus son la causa principal de diarrea viral en el mundo. El Norovirus fue descubierto por primera vez durante un brote de gastroenteritis en Norwalk, Ohio en los Estados Unidos en 1968. Éste causa una enfermedad caracterizada por 
diarrea y vómitos que generalmente dura de 24 a 48 horas. No hay inmunidad a largo plazo y las personas pueden volver a infectarse una y otra vez. Es el virus más comúnmente asociado con los brotes de enfermedades transmitidas a través el agua. La hepatitis viral transmitida a través del agua es causada por el virus de hepatitis A (VHA) y el virus de hepatitis E (VHE). La hepatitis A y E son virus muy comunes en el mundo en desarrollo, donde cerca de un $90 \%$ de la población puede tener anticuerpos contra el VHA. El VHE se ha asociado con grandes brotes transmitidos a través del agua en Asia y África, pero no se han documentado brotes en los países desarrollados. El VHE puede causar tasas de mortalidad de entre el 20 y $30 \%$ en las mujeres embarazadas, durante un brote transmitido a través del agua. El VHE es el único virus entérico que parece utilizar animales como huéspedes, tales como cerdos y ciervos. El VHA es uno de los virus entéricos más resistentes a la inactivación por calor.

Los enterovirus han sido los virus entéricos más ampliamente estudiados en aguas residuales, ya que crecen más fácilmente en el laboratorio. Los enterovirus son miembros de la familia Picornaviridae que se encuentran entre los virus con ácido ribonucleico (ARN) más pequeños. "Pico" significa pequeño. Los enterovirus son virus icosaédricos de aproximadamente 27 a $32 \mathrm{~nm}$ de diámetro. Los enterovirus se dividen en varios grupos (Tabla 8.2). El ácido nucleico de los enterovirus se compone de ssARN. Estos son los virus detectados con más frecuencia en el agua residual contaminada. Sin embargo, su mayor prevalencia aparente puede estar asociada, en parte, con líneas de células disponibles para su propagación, porque muchos virus patógenos entéricos, tales como VHA, adenovirus entéricos, rotavirus, norovirus, y demás virus redondos pequeños son difíciles de cultivar en líneas celulares convencionales.

Los virus que pertenecen al género Enterovirus son capaces de causar una gran variedad de condiciones clínicas incluyendo fiebre, sarpullido, meningitis, enfermedades del corazón, parálisis, diabetes, diarrea, y trastornos mentales. En la actualidad hay cerca de 100 enterovirus conocidos, pero los más comúnmente estudiados son los coxsackie, ecovirus y poliovirus. Muchos de éstos son fácilmente aislados de aguas residuales y forman parte muy importante de los conocimientos sobre la efectividad del tratamiento de aguas residuales en la eliminación de virus. Las cepas de la vacuna de poliovirus han sido las más estudiadas, ya que pueden ser cultivadas en un par de días en el laboratorio, y el amplio uso anterior de vacunas vivas de poliovirus en el mundo lo han convertido en el enterovirus más comúnmente aislado.

Los adenovirus, a diferencia de los otros virus entéricos, tienen un genoma de ADN de doble tirante, lo que los hace más resistentes a la inactivación por desinfección con luz ultravioleta. Los adenovirus han sido generalmente aislados de aguas residuales en mayores concentraciones que los enterovirus más comúnmente estudiados. Por lo menos, 50 tipos de adenovirus humanos han sido identificados. Los adenovirus son generalmente asociados con infecciones del tracto respiratorio, pero también son capaces de causar infecciones de la garganta y en los ojos, y son una causa importante de diarrea en niños. Los adenovirus tipo 36 también se han asociado con la obesidad en animales y seres humanos. Debido a su genoma de ADN de doble tirante, es capaz de usar las enzimas de reparación en su huésped humano para reparar el daño causado por la luz UV, por lo que es el patógeno de transmisión hídrica más resistente a la desinfección con luz UV (Gerba et al., 2002). Los adenovirus se han asociado con brotes infecciosos en la nariz, ojos y garganta, transmitidos a través del agua en lugares recreativos. Varios brotes recientes en Europa sugieren que han sido transmitidos a través del agua potable (Divizia et al., 2004; Kukkula et al., 1997).

\subsubsection{Bacterias}

Las bacterias son organismos unicelulares rodeados por una membrana y una pared celular. Las bacterias que crecen en el tracto intestinal humano se conocen como bacterias entéricas. Los patógenos entéricos bacterianos generalmente no pueden sobrevivir durante periodos prolongados de tiempo en el ambiente. A diferencia de los virus entéricos, los patógenos entéricos bacterianos suelen infectar tanto a seres humanos como a animales. Así, las bacterias Salmonella infectan a humanos, pollos, ganado, reptiles, etc. Las bacterias se agrupan por su forma, tamaño, capacidad de fermentar varios tipos de nutrientes, necesidad de oxígeno, y por la tinción de Gram. Las bacterias se agrupan en Gram negativas y Gram positivas, lo cual es un reflejo de la composición química de su pared celular.

Las bacterias entéricas de mayor preocupación en aguas residuales son Salmonella, Campylobacter, Shigella, Vibrio, Cholerae y la enteropatógena Escherichia coli. (Tabla 8.3). Estas bacterias generalmente están asociadas con la diarrea. Salmonella 
es un grupo muy grande con forma de bacilo, son Gram negativas, y comprenden más de 2,000 serotipos conocidos. Todos estos serotipos son patógenos para los seres humanos y pueden causar una serie de síntomas desde una gastroenteritis leve hasta una enfermedad grave o la muerte. La Salmonella es capaz de infectar una gran variedad de animales tanto de sangre fría, como animales de sangre caliente. La fiebre tifoidea, causada por S. typhi y la fiebre paratifoidea, causada por $S$. paratyphi, normalmente se encuentran sólo en los seres humanos, aunque la $S$. paratyphi también se puede encontrar en animales domésticos en raras ocasiones. Salmonella es la bacteria patógena más comúnmente estudiada en las aguas residuales.

Tabla 8.3 Patógenos entéricos bacterianos encontrados en las aguas residuales.

Salmonella spp. >2400 Serotipos
Salmonella typhi
Salmonella paratyphi
Shigella spp.
Campylobacter jejuni
Vibrio cholerae
Cepas patógenas de Escherichia coli
Yersina entercolitica

La Escherichia coli es un bacilo Gram negativo encontrado en el tracto gastrointestinal de todos los animales de sangre caliente y se considera generalmente como un organismo inofensivo. Sin embargo, varias cepas son capaces de causar gastroenteritis; entre éstas están las enterotoxigénicas (ETEC) y enterohemorrágicas (EHEC). Estas cepas patógenas de $E$. coli se han asociado con brotes transmitidos a través del agua. E. coli enterotoxigénica es una causa importante de diarrea en las personas que viajan de los países industrializados para visitar países menos desarrollados, y también es una causa importante de diarrea en bebés y niños de los países menos desarrollados. Tras un período de incubación de 10 a 72 horas, los síntomas incluyen calambres, vómitos, diarrea (puede ser profusa), gran dolor articular y muscular y deshidratación. La duración de la enfermedad normalmente es menor a 3 o 5 días. Los brotes han sido asociados con el agua potable contaminada por desechos humanos. Las EHEC fueron descritas por primera vez en 1982 cuando se produjo una epidemia multiestatal en los Estados Unidos y se demostró que era debido a un serotipo específico conocido como E. coli O157: H7. Las infecciones por EHEC son ahora reconocidos por ser un problema importante en América del Norte, Europa y algunas zonas de América del Sur. La enfermedad suele incluir calambres severos y diarrea, que inicialmente es líquida pero se vuelve extremadamente sangrienta. La enfermedad suele ser autolimitada y dura un promedio de 8 días. Sin embargo, algunas de las víctimas, en particular los más jóvenes, desarrollan Síndrome Urémico Hemolítico (SUH), que produce insuficiencia renal y anemia hemolítica. Esta enfermedad puede tener como consecuencia la pérdida permanente de la función renal. Tanto los seres humanos y el ganado pueden ser una fuente para que el agua sea contaminada por este organismo. También se han producido brotes transmitidos a través del agua, tanto subterránea como en aguas no desinfectadas en lugares recreativos.

La Shigella está estrechamente relacionada con la $E$. coli. S. dysenteriae causa una enfermedad más grave y $S$. sonnei provoca los síntomas más leves. Es principalmente una enfermedad de los seres humanos. El organismo a menudo se encuentra en el agua contaminada con desechos humanos y se transmite por vía fecal-oral. No parece sobrevivir mucho tiempo en el medio ambiente.

Campylobacter jejuni es un bacilo curvo Gramnegativo y es la bacteria entérica generalmente más asociada con gastroenteritis en los Estados Unidos y el Reino Unido. Es principalmente una infección transmitida por el consumo de alimentos asociados con las aves de corral. Es relativamente frágil y sensible a la presión ambiental y no parece ser capaz de prolongar su sobrevivencia en el ambiente. Se ha asociado con brotes en aguas de lugares recreativos y agua potable.

El género Gram-negativo Vibrio contiene más de un miembro que es patógeno para los seres humanos. El miembro más famoso del género es todavía $V$. cholerae. El Cólera se transmite por la ingesta de alimentos y agua contaminados con materia fecal. El cólera sigue prevaleciendo en muchas partes de América Central, América del Sur, Asia y África

El serogrupo $V$. cholerae Ol incluye dos biotipos, cólera (clásica) y El Tor, cada uno de los cuales incluye organismos de los serotipos Inaba y Ogawa. Una enterotoxina similar es elaborada por cada uno de estos organismos, así que las enfermedades clínicas son similares. La infección asintomática es mucho más común que la enfermedad, pero los casos leves de diarrea también son comunes. En los casos graves no tratados, la muerte puede ocurrir dentro de un par de horas y la tasa de mortalidad sin tratamiento puede superar el 50\%. Esto es debido a una diarrea acuosa profusa descrita como 
heces de agua de arroz. El aspecto de agua de arroz es debido al derramamiento de la mucosa intestinal y las células epiteliales. Con el tratamiento adecuado, la tasa de mortalidad es inferior al $1 \%$. Los seres humanos son el único huésped natural conocido. Por lo tanto, el depósito de $V$. cholerae es humano, aunque pueden existir depósitos ambientales, al parecer en relación con los copépodos o fitoplancton. Vibrio cholerae es un organismo marino nativo y su potencial para la transmisión a los seres humanos está relacionado con una ecología compleja que controla su aparición y concentración en la cadena alimentaria marina (Lipp et al., 2002).

\subsubsection{Protozoarios}

Los protozoarios son animales unicelulares que frecuentemente de hecho tienen ciclos de vida muy complejos. Los protozoarios entéricos, transmitidos a través del agua, tienen una etapa de vida ambientalmente resistente llamado quiste $\mathrm{u}$ ovoquiste. Estos quistes $\mathrm{u}$ ovoquistes tienen paredes gruesas que se hacen muy resistentes a los desinfectantes. También son capaces de sobrevivir durante períodos prolongados de tiempo en el medio ambiente, especialmente a bajas temperaturas. Ellos son mucho más grandes que las bacterias y virus, y se pueden reducir considerablemente en número por filtración a través de medios granulares. La Giardia y el Criptosporidium han sido los protozoarios de mayor atención debido a que se asocian con un gran número de brotes de enfermedades transmitidas a través del agua en los países desarrollados. Como es el caso de los virus entéricos, se requiere un bajo número de quistes de Giardia y ovoquistes Criptosporidium para causar la infección.

La Giardia causa una infección muy común en los seres humanos. Ésta causa diarrea que puede durar de 7 a 10 días, pero la infección puede durar hasta seis meses sin tratamiento con episodios recurrentes de diarrea. Algunas personas pueden quedar crónicamente infectadas. Esto explica por qué es frecuentemente aislado de aguas residuales domésticas. Cuando los quistes de Giardia se incorporan al ambiente pueden sobrevivir durante períodos prolongados. Se ha documentado que los quistes de $G$. lamblia puden sobrevivir hasta 77 días a $8{ }^{\circ} \mathrm{C}$, y 4 días a $37^{\circ} \mathrm{C}$, en agua destilada (Bingham et al., 1979). Los quistes de Giardia son bastante resistentes a la desinfección con cloro, y los brotes se han asociado con suministros sin filtros clorados.

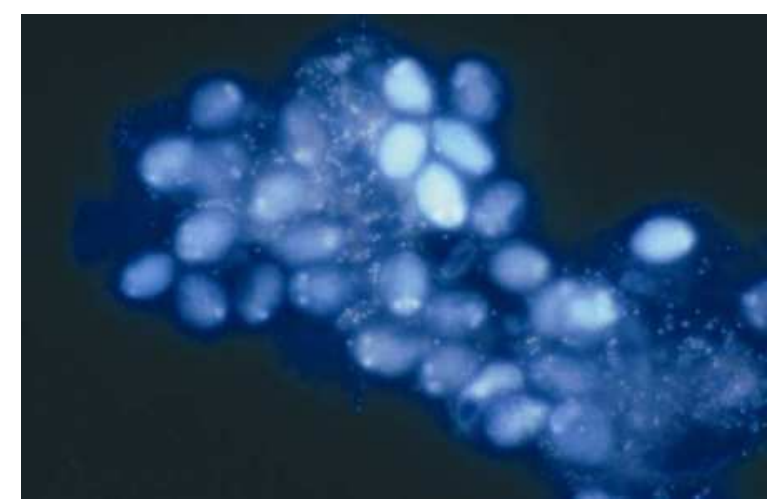

Figura 8.1 Flóculo de un efluente de aguas residuales llenado artificialmente con quistes de Giardia teñidas con DAPI. DAPI (4', 6-diamidino-2-fenilindol) es un indicador fluorescente que se une fuertemente al ADN (Foto: G. Medema).

El Criptosporidium también produce diarrea en los seres humanos, pero por lo general la infección sólo dura 5-7 días, a pesar de que es más grave que Giardia. En las aguas residuales los ovoquistes se producen generalmente en concentraciones menores (generalmente sólo $1-10 \%$ ) que los observados para la Giardia, probablemente debido a que éstos no se excretan tanto como la Giardia. Sin embargo, los ovoquistes de Criptosporidium son a menudo más comunes y en mayores concentraciones en las aguas superficiales que los quistes de Giardia, probablemente a causa del ganado bovino.

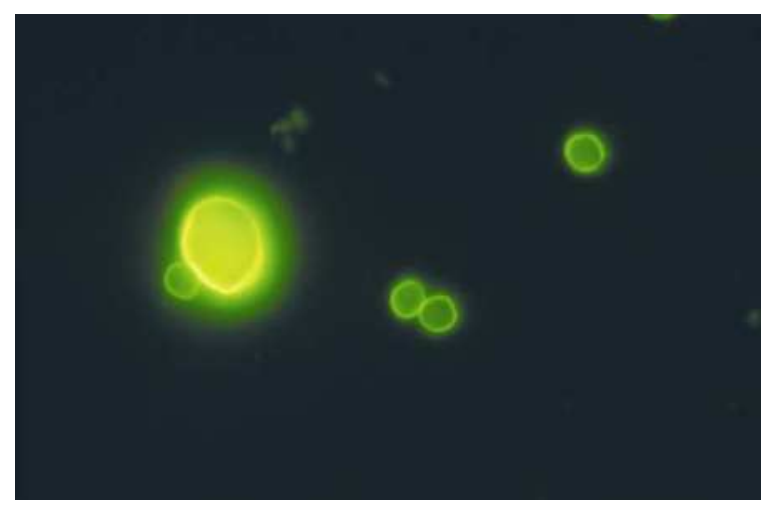

Figura 8.2 Ovoquistes de Cryptosporidium (círculos pequeños) y un quiste de Giardia (ovalado grande) que fueron teñidos con anticuerpos monoclonales con isotiocianato de fluoresceína (FITC) (Foto: G. Medema)

El C. parvum forma ovoquistes extremadamente resistentes que sobreviven a la desinfección con cloro, una práctica común en las plantas convencionales de tratamiento de agua. Es conocido como el patógeno de transmisión hídrica más resistente a la desinfección con cloro. También se ha encontrado que sobrevive durante semanas en aguas superficiales (Johnson et al., 1997). El 
C. parvum infecta principalmente el ganado, pero también infecta a los seres humanos. El C. hominis es una especie que infecta principalmente a los seres humanos (Nichols, 2008). Los brotes transmitidos a través del agua han sido causados por ambas especies. En algunos países, el C. hominis parece ser la especie que más comúnmente infecta a los seres humanos, mientras que en otros predomina el C. parvum.

La Entamoeba histolytica es causa de disentería amebiana (diarrea con sangre), y es la tercera causa más común de muerte por parásitos en el mundo. La prevalencia mundial supera los 500 millones de infecciones con más de 100.000 muertes cada año. Hay dos tamaños de quistes, pequeños $(5-9 \mu \mathrm{m})$ y grandes (10-20 $\mu \mathrm{m})$. Sólo el quiste más grande ha sido asociado con alguna enfermedad; el quiste más pequeño tiende a estar asociado con el estilo de vida de los comensales (los organismos se benefician del huésped, mientras que el huésped no se ve afectado). Cerca de $2-8 \%$ de las personas infectadas desarrollan disentería amebiana invasiva en la que los trofozoitos (forma amebiana) invaden activamente la pared intestinal, sangre e hígado. Este organismo es generalmente un problema en los países en desarrollo, donde el saneamiento es deficiente y se transmite a través de alimentos y agua contaminados. El organismo no es común en los países desarrollados y no se han producido brotes transmitidos por el agua en los Estados Unidos por más de 40 años. Entamoeba no es tan resistente a los desinfectantes como Giardia y Cryptosporidium y no parece sobrevivir mucho en el ambiente.

\subsubsection{Helmintos}

Los helmintos son lombrices capaces de parasitar seres humanos. Algunos helmintos se presentan en el tracto intestinal, y sus huevos (óvulos) se excretan en las heces y puede propagarse por las aguas residuales, el suelo o los alimentos. Sus huevos son capaces de prolongar la sobrevivencia en el ambiente (meses o años) y son bastante resistentes a los desinfectantes. Los helmintos de mayor atención incluyen nemátodos (Nematoda), las tenias (Cestoda) y trematodos (Trematoda).

Una causa importante de infecciones por nemátodos en los seres humanos en el mundo es Ascaris lumbricodes. Se estima que alrededor de 1.000.000 de personas pueden estar infectadas en todo el mundo, con la mayoría de las infecciones en las zonas tropicales y subtropicales. (Crompton, 1988). Sólo unos pocos óvulos necesitan ser ingeridos para causar la infección. Una mujer sola puede excretar 200.000 huevos por día cuando esta infectada. No hay depósitos animales conocidos. El ciclo de vida de este ascáride incluye una fase en la que las larvas migran a través de los pulmones y son ingeridas haciendo su camino a los intestinos. Los síntomas normalmente corresponden a la carga parasitaria, y una carga pesada de parásitos puede conducir a la obstrucción intestinal. Aunque la mayoría de las infecciones son leves, se estima que 20.000 personas mueren cada año por complicaciones y obstrucción intestinal (Freedman, 1992). Aunque los huevos son densos, y se eliminan fácilmente por sedimentación de las aguas residuales, son muy resistentes a la acción del cloro. Además, pueden sobrevivir durante períodos largos de tiempo en sedimentos lodosos y el suelo, y durante años bajo condiciones frías y húmedas.

Los tricocéfalos o Trichuris tichiura son otras lombrices parasitarias comunes de los seres humanos y es la tercera infección por nemátodos más común en humanos. El huevo debe ser depositado en el suelo y requiere 21 días en suelo húmedo, sombreado y cálido para ser infeccioso. Los huevos pueden sobrevivir hasta 18 meses en el suelo (Burden et al., 1976). La infección en humanos es a través de la ingesta de agua o tierra contaminada. Las lombrices causan diarrea, vómitos, anemia, y el apéndice inflamado.

Hay dos grupos principales de anquilostomas intestinales que infectan a las personas: el anquilostoma del mundo antiguo (Ancylostoma duodenale) y anquilostoma del nuevo mundo (Necator americanus). Estos sólo infectan a los seres humanos, habitan en el intestino delgado y se alimentan de sangre. También son la causa principal de la deficiencia de hierro en las zonas tropicales. Las larvas de estos organismos pueden sobrevivir hasta seis semanas en suelo húmedo, sombreado, arenoso o arcilloso. No sobreviven bien en suelo seco, temperaturas bajo cero y temperaturas superiores a $45^{\circ} \mathrm{C}$.

La tenia Taenia saginata es transmitida por productos de carne de res infectada, y es la lombriz solitaria más común en los humanos. El ganado se infecta al comer hierba o tierra contaminada con desechos humanos o heces. El organismo puede sobrevivir en el ambiente por semanas. En un estudio se encontró que sobrevive durante 16 días en las aguas residuales no tratadas y durante casi seis meses en la hierba (Jepson y Roth 1952). Los síntomas de la infección son dolor abdominal, dolor de cabeza, náuseas, diarrea y obstrucción intestinal. 


\subsection{PRESENCIA DE AGENTES PATÓGENOS EN LAS AGUAS RESIDUALES}

Los microorganismos que causan enfermedades están casi siempre presentes en cierto nivel en las aguas residuales domésticas. La razón es que los individuos infectados normalmente excretan un gran número de patógenos cuando se infectan. Incluso las personas que no están enfermas pueden excretar patógenos. Para la mayoría de los patógenos entéricos, de 10 a $75 \%$ de las personas que están infectadas se enferman. La concentración de rotavirus puede ser tan alta como $10^{10}$ por gramo de heces animales o de $10^{12}$ por cada $100 \mathrm{~g}$ de heces humanas (Tabla 8.4).

Tabla 8.4 Concentración de patógenos entéricos en heces.

\begin{tabular}{lc}
\hline Organismo & por gramo de heces \\
\hline $\begin{array}{c}\text { Parásitos protozoarios } \\
\text { Helmintos }\end{array}$ & $10^{6}-10^{7}$ \\
$\quad$ Ascaris & $10^{4}-10^{5}$ \\
Virus Entéricos & \\
Enterovirus & $10^{3}-10^{7}$ \\
Rotavirus & $10^{10}$ \\
Adenovirus & $10^{11}$ \\
Bacterias entéricas & \\
Salmonella spp. & $10^{4}-10^{10}$ \\
Shigella & $10^{5}-10^{9}$ \\
Bacterias indicadoras & \\
Coliformes & $10^{7}-10^{9}$ \\
Coliformes fecales & $10^{6}-10^{9}$ \\
\hline
\end{tabular}

Las personas infectadas pueden excretar patógenos entéricos por varias semanas o varios meses. La concentración de patógenos entéricos en aguas residuales varía dependiendo de varios factores:

- La incidencia de la infección en la comunidad. Entre más personas infectadas, más patógenos liberados en las aguas residuales. Así, en los países en desarrollo, a mayores tasas de enfermedades entéricas, mayores concentraciones de los agentes patógenos se pueden esperar en las aguas residuales.

- El nivel socioeconómico de la población. Este factor se relacionan con el nivel de las prácticas de educación e higiene, así como al acceso a la atención médica para tratar enfermedades infecciosas.

- La época del año. En los climas templados las infecciones por rotavirus llegan a su cumbre a principios del invierno, mientras que las infecciones por Criptosporidium tienen su punto más alto a principios de primavera y el otoño.
- $\quad$ El consumo de agua per cápita. Cuanto menor es el consumo de agua por persona, mayor es la concentración de agentes patógenos en las aguas residuales.

Por estas razones, las concentraciones de patógenos entéricos son mucho mayores en las aguas residuales en los países en desarrollo que en el mundo industrializado. Por ejemplo, la concentración de enterovirus observados en las aguas residuales en los Estados Unidos ha sido entre 10 y 1.000 por litro, mientras que concentraciones tan altas como 100.000 por litro se han observado en África y Asia (Leong, 1983).

\subsubsection{Organismos indicadores}

El examen de rutina de agua por la presencia de patógenos entéricos es a menudo una tarea tediosa, difícil, costosa y consume mucho tiempo. Por lo tanto, se utilizan organismos indicadores para evaluar la presencia de contaminación fecal y la eficacia de los procesos de tratamiento de aguas residuales. Desarrollado en el cambio del siglo pasado para evaluar la contaminación fecal, el concepto indicador depende del hecho de que ciertas bacterias no patógenas se producen en las heces de todos los animales de sangre caliente. Estas bacterias pueden ser fácilmente aisladas y cuantificadas por métodos simples. La detección de estas bacterias en el agua significa que la contaminación fecal se ha producido y sugiere que los patógenos entéricos también pueden estar presentes. Por ejemplo, las bacterias coliformes, que normalmente se producen en los intestinos de todos los animales de sangre caliente, se excretan en gran número en las heces. En el agua contaminada, las bacterias coliformes se encuentran en densidades aproximadamente proporcionales al grado de contaminación fecal. Dado que las bacterias coliformes son generalmente más resistentes que las bacterias que causan la enfermedad, su ausencia en el agua es un indicio de que el agua es bacteriológicamente segura para el consumo humano.

Los indicadores se han utilizado tradicionalmente para mostrar la presencia de patógenos entéricos; sin embargo, hoy reconocemos que rara vez hay una correlación directa entre los indicadores bacterianos y patógenos humanos (Ashbolt et al., 2001). Como tal, el uso de indicadores se define mejor por su finalidad prevista (Tabla 8.5). 
Tabla 8.5 Definiciones y ejemplos de microorganismos indicadores (modificado de Ashbolt et al., 2001)

\begin{tabular}{ll}
\hline Grupo & Definiciones y ejemplos \\
\hline $\begin{array}{l}\text { Indicador de } \\
\text { proceso }\end{array}$ & $\begin{array}{l}\text { Un grupo de organismos que demuestra } \\
\text { la eficacia de un proceso, tal como } \\
\text { bacterias heterótrofas totales o } \\
\text { coliformes totales para la desinfección } \\
\text { con cloro }\end{array}$ \\
$\begin{array}{l}\text { Indicador } \\
\text { fecal }\end{array}$ & $\begin{array}{l}\text { Un grupo de organismos que indican la } \\
\text { presen coliformes fecales o Escherichia coli }\end{array}$ \\
Organismos & $\begin{array}{l}\text { Un grupo o especie indicativo de la } \\
\text { presencia y comportamiento de } \\
\text { patógenos, respectivamente, tal como } E . \\
\text { modice o }\end{array}$ \\
& $\begin{array}{l}\text { coli como índice para Salmonella y } \\
\text { específicos colífagos masculinos como } \\
\text { modelos para los virus entéricos } \\
\text { humanos }\end{array}$ \\
\hline
\end{tabular}

Por lo tanto, los indicadores de proceso son utilizados para evaluar la eficacia de un proceso de tratamiento (por ejemplo, tratamiento de agua potable), mientras que los indicadores fecales indican la presencia de contaminación fecal. Un organismo índice (o modelo) representa la presencia y el comportamiento de un patógeno en un entorno dado.

La concentración de diversos indicadores en aguas residuales sin tratar se muestra en la Tabla 8.6.

Tabla 8.6 Niveles estimados de organismos indicadores en aguas residuales

\begin{tabular}{lc}
\hline Organismo & CFU por $100 \mathrm{ml}$ \\
\hline Coliformes & $10^{7}-10^{9}$ \\
Coliformes fecales & $10^{6}-10^{7}$ \\
Estreptococos fecales & $10^{5}-10^{6}$ \\
Enterococos & $10^{4}-10^{5}$ \\
Clostridium perfringens & $10^{4}$ \\
Estafilococo (coagulasa positivo) & $10^{3}$ \\
Pseudomonas aeruginosa & $10^{5}$ \\
Bacterias ácido-resistentes & $10^{2}$ \\
Colífagos & $10^{2}-10^{3}$ \\
Bacteroides & $10^{7}-10^{10}$ \\
\hline
\end{tabular}

\subsubsection{Indicadores bacterianos}

El grupo de coliformes, que incluye el género Escherichia, Citrobacter, Enterobacter, y Klebsiella, es relativamente fácil de detectar. En concreto, este grupo incluye todos los aerobios y anaerobios facultativos, Gram negativos, no formadores de esporas, bacterias en forma de bacilo que producen gas tras la fermentación de lactosa en los medios de cultivo establecidos dentro de las 48 horas a $35{ }^{\circ} \mathrm{C}$. El grupo de coliformes se ha utilizado como el parámetro estandarizado para la evaluación de la contaminación fecal en el agua de lugares recreativos y agua potable durante la mayor parte del siglo pasado.

La tasa de mortalidad de bacterias coliformes depende de la cantidad y el tipo de materia orgánica en el agua y su temperatura. Si el agua contiene concentraciones significativas de materia orgánica y tiene una temperatura elevada, las bacterias pueden aumentar en número. Este fenómeno se ha observado en aguas tropicales eutróficas, aguas que reciben efluentes de fábricas de papel, aguas residuales, sedimentos acuáticos y el suelo orgánico enriquecido (es decir, el lodo residual modificado) después de períodos de fuertes lluvias.

Aunque el total del grupo coliforme ha servido como el principal indicador de la contaminación del agua por muchos años, muchos de los organismos de este grupo no se limitan a las fuentes de materia fecal. Así, se han desarrollado métodos para restringir la enumeración de los coliformes que son más claramente de origen fecal, es decir, los coliformes fecales o coliformes termotolerantes. Estos organismos, que incluyen los géneros Escherichia y Klebsiella, se diferencian en el laboratorio por su capacidad para fermentar la lactosa con la producción de ácido y gas a $44.5^{\circ} \mathrm{C}$ en 24 horas. En general, esta prueba indica la presencia de coliformes fecales, sin que ello distinga entre contaminación humana y animal. La aparición frecuente de coliformes y bacterias coliformes fecales en aguas tropicales no contaminadas, y su capacidad de sobrevivir durante períodos largos de tiempo fuera del intestino en estas aguas, sugieren que estos organismos se producen de forma natural en las aguas tropicales (Toranzos 1991), y que se deben desarrollar nuevos indicadores para estas aguas.

La $E$. coli se utiliza comúnmente como un indicador, ya que fácilmente se puede distinguir de otros miembros del grupo coliforme fecal (por ejemplo, por la ausencia de ureasa y la presencia de $\beta$-glucuronidasa) y es más probable que indique la existencia de contaminación fecal. Los coliformes fecales también tienen algunas de las mismas limitaciones en el uso como las bacterias coliformes, por ejemplo, la regeneración y menor resistencia al tratamiento del agua que los virus y los protozoos. 
Los estreptococos fecales pertenecen a los géneros Enterococcus y Streptococcus (Gleeson y Gray, 1997). El género Enterococcus incluye todos los estreptococos que comparten ciertas propiedades bioquímicas y tienen una amplia gama de tolerancia a las condiciones adversas de crecimiento. Se diferencian de otros estreptococos por su capacidad para crecer en cloruro de sodio al $6.5 \%, \mathrm{pH}$ 9.6, y $45^{\circ} \mathrm{C}$, e incluyen Ent. avium, Ent. faecium, Ent. durans, Ent. faecalis, y Ent. gallinarium. En la industria del agua, el género se da a menudo como estreptococos para este grupo. Del género estreptococos, sólo $S$. bovis y $S$. equino se consideran como estreptococos fecales verdaderos. Estas dos especies de estreptococos se encuentran principalmente en los animales; Ent. faecalis y Ent. faecium son más específicos para el intestino humano. Se sugiere considerar que la presencia de coliformes fecales/estreptococos fecales $\mathrm{CF} / \mathrm{EF}$ en proporción de 4 o más indica la existencia de una contaminación de origen humano, mientras que una proporción por debajo de 0.7 es indicativo de contaminación animal (Geldreich y Kenner, 1969). Sin embargo, la validez de la relación $\mathrm{CF} / \mathrm{EF}$ ha sido cuestionada. Además, esta relación es válida sólo para una contaminación fecal reciente (de máximo 24 horas).

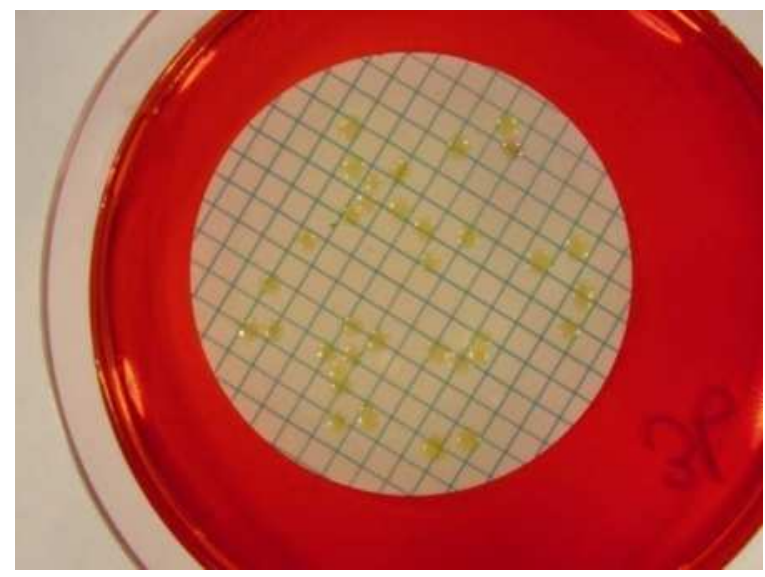

Figura 8.3 Colonias amarillas de Escherichia coli en agar laurilsulfato (Foto: H. Veenendaal)

Los estreptococos fecales son considerados, por tener ciertas ventajas sobre los coliformes y bacterias coliformes fecales, como indicadores porque ellos (Gleeson y Gray, 1997):

- rara vez se multiplican en el agua

- son más resistentes al estrés ambiental y la cloración que los coliformes

- generalmente persisten más tiempo en el medio ambiente.
Los enterococos han sido sugeridos como indicadores útiles para estimar el riesgo de gastroenteritis en los bañistas y por ello se han recomendado ciertos estándares de calidad del agua (Cabelli 1989).

La Clostridium perfringens es una bacteria anaerobia sulfito-reductora que forma esporas, es gram positiva, en forma de bacilo, y exclusivamente de origen fecal. Las esporas son muy resistentes al calor $\left(75^{\circ} \mathrm{C}\right.$ durante 15 minutos), persisten durante períodos largos en el ambiente, y son muy resistentes a los desinfectantes. Las esporas de este organismo son altamente resistentes lo que limita su utilidad como indicador. Sin embargo, se ha propuesto que podría ser usada como un indicador de una contaminación pasada, un trazador de indicadores menos resistentes, y un indicador de la eliminación de los parásitos protozoarios o virus durante el tratamiento de agua potable y aguas residuales (Payment y Franco, 1993). Otras bacterias anaerobias tales como Bifidobacterium y Bacteroides han sido propuestas como posibles indicadores. Esto debido a que algunos de los géneros Bifidobacterium se asocian principalmente con los seres humanos, los cuales potencialmente podrían ayudar a distinguir entre la contaminación humana y animal. Sin embargo, se necesitan mejores métodos y que sean más estandarizados para la detección de todas las bacterias anaerobias en el ambiente antes de que puedan ser detectadas adecuadamente de forma rutinaria.

\subsubsection{Bacteriófagos como indicadores}

Los bacteriófagos (o virus bacterianos) han sido propuestos como indicadores de contaminación fecal debido a su presencia constante en las aguas residuales tratadas. Estos organismos también han sido sugeridos como indicadores de contaminación viral. Esto es debido a que la estructura, morfología y tamaño, así como el comportamiento en el medio acuático de la mayoría de los bacteriófagos se parecen mucho a las características de los virus entéricos. Por estas razones, también se han utilizado ampliamente para evaluar la resistencia del virus a los desinfectantes, para evaluar el destino del virus durante el tratamiento de agua potable y aguas residuales, y como indicadores de aguas superficiales y subterráneas. El uso de bacteriófagos como indicadores de contaminación fecal se basa en el supuesto de que su presencia en muestras de agua indica la presencia de bacterias capaces de soportar la replicación del fago. Dos grupos de fagos han sido estudiados: el colífago somático, el cual infecta las cepas huéspedes de E. coli a través de las paredes celulares receptoras, y el colífago FARN específico, que infecta cepas de E. coli y bacterias 
relacionadas a través de la $\mathrm{F}+$ o pilus sexual. Una ventaja significativa de la utilización de colífagos es que puede ser detectado por técnicas sencillas y económicas que dan resultados en 8-18 horas. Tanto un método de chapado (el método de superposición de agar) y el método NMP (número más probable) se pueden utilizar para detectar colífagos en volúmenes que van de 1 a $100 \mathrm{ml}$. El colífago F-específico (fago masculino-específico) ha recibido el mayor grado de atención debido a que son similares en tamaño y forma a muchos de los virus entéricos patógenos humanos. Los colífagos f2, ФX174, MS-2, y 1-PRD son los más comúnmente utilizados como indicadores y para la evaluación de los desinfectantes. La presencia del colífago en grandes cantidades en las aguas residuales y su alta resistencia a la cloración contribuye a su consideración como un índice de contaminación de las aguas residuales y como indicadores potenciales de virus entéricos.

Los Bacteriófagos de Bacteroides fragilis también se han propuesto como posibles indicadores de virus humanos en el ambiente (Tartera y Jofre, 1987). Los Bacteroides spp. son anaerobios estrictos y son un componente importante de las heces humanas, por lo que los bacteriófagos activos contra estos organismos tienen el potencial de ser indicadores adecuados de contaminación viral. Los bacteriófagos que infectan a $B$. fragilis parecen ser exclusivamente de origen humano (Tartera y Jofre, 1987) y parecen estar presentes sólo en muestras ambientales contaminadas por heces fecales de origen humano. Esto puede ayudar a diferenciar la contaminación humana de la animal. Ellos están ausentes de los hábitats naturales, lo cual es una ventaja considerable sobre los colífagos, que se encuentran en las heces de los animales. No son capaces de multiplicarse en el ambiente (Tartera et al., 1989), y su tasa de descomposición en el medio ambiente parece ser similar a la de los virus entéricos humanos. Sin embargo, su huésped es una bacteria anaerobia que implica una metodología complicada y tediosa, lo que limita su idoneidad como organismo indicador rutinario.

\subsubsection{Normas y criterios para los indicadores}

Los indicadores bacterianos, tales como los coliformes, han sido utilizados para el desarrollo de normas de calidad del agua. Varios organismos gubernamentales han establecido normas para la calidad del agua y el uso de descargas de efluentes. Por ejemplo, en las descargas de aguas negras en los Estados Unidos no debe exceder los 200 coliformes fecales $/ 100 \mathrm{ml}$.
Los criterios y directrices son términos utilizados para describir las recomendaciones para los niveles aceptables de microorganismos indicadores. No son legalmente exigibles, pero sirven como guía indicando que existe un problema potencial en la calidad del agua. Idealmente, todas las normas deberían indicar que existe una amenaza inaceptable para la salud pública o que alguna relación existe entre la cantidad de enfermedades y el nivel de los organismos indicadores. Esta información es difícil de obtener debido a la implicación de costosos estudios epidemiológicos que a menudo son difíciles de interpretar a causa de factores de confusión. Un área de la epidemiología elabora criterios para su evaluación en diversos lugares como por ejemplo el de la práctica de la natación en lugares recreativos. Los estudios epidemiológicos realizados en Estados Unidos han demostrado una relación entre la natación asociada a gastroenteritis y las densidades de E. coli y enterococos. Sin embargo, no se encontró relación alguna con las bacterias coliformes (Cabelli, 1989). Se indicó que la media geométrica estándar de 35 enterococos por cada $100 \mathrm{ml}$ sea utilizada para las aguas marinas donde se llevan a cabo actividades acuáticas.

Tabla 8.7¥Promedios aritméticos y geométricos del número de bacterias en el agua

\begin{tabular}{ll}
\hline $\mathrm{NMP}^{a}$ & Logaritmo \\
\hline 2 & 0.30 \\
110 & 2.04 \\
4 & 0.60 \\
150 & 2.18 \\
1100 & 3.04 \\
10 & 1.00 \\
12 & 1.08 \\
$198=$ media aritmética & $1.46=\log \bar{x}$ \\
& antilogaritmo $\bar{x}=29$ \\
& $29=$ media aritmética \\
\hline
\end{tabular}

${ }^{a} \mathrm{NMP}$, número más probable

El uso de normas microbianas también requiere el desarrollo de métodos estándares y la garantía de la calidad o los planes de control de calidad para los laboratorios que realizan el monitoreo. El conocimiento de cómo tomar muestras y la frecuencia de la muestra también es importante. Toda esta información se suele definir en el reglamento cuando una norma se establece. Por ejemplo, la frecuencia de muestreo puede ser determinada por el tamaño (número de consumidores), de la entidad proveedora del agua. El muestreo debe proceder de forma aleatoria, de manera que el sistema entero sea caracterizado. Debido a la gran variabilidad en 
el número de indicadores en el agua, se pueden permitir algunas muestras positivas o tener niveles de tolerancia o pueden permitirse promedios. Por lo general, los promedios geométricos se utilizan en la elaboración de normas, debido a la frecuentemente sesgada distribución de los números de bacterias. Esto impide que la obtención de uno o dos valores altos sobreestimen los altos niveles de contaminación, lo cual puede ser el caso con medias aritméticas (Tabla 8.7).

Las medias geométricas se determinan con la siguiente fórmula:

$$
\begin{aligned}
& \log \bar{x}=\frac{\sum(\log x)}{N} \\
& \bar{x}=\operatorname{anti} \log (\log \bar{x})
\end{aligned}
$$

Donde:

$$
\begin{aligned}
N & \text { número de muestras } \\
\bar{x} & \text { promedio geométrico, y } \\
X & \text { número de organismos por volúmen de muestra. }
\end{aligned}
$$

Como puede verse, establecer normas y desarrollar criterios es un proceso difícil y no hay un estándar ideal. Es necesario en gran parte el juicio de científicos, funcionarios de salud pública, y la agencia reguladora.

\subsection{ELIMINACIÓN DE PATÓGENOS E INDICADORES POR PROCESOS DE TRATAMIENTOS DE AGUAS RESIDUALES}

\subsubsection{Lagunas}

Teniendo en cuenta los tiempos de retención suficientes, las lagunas de oxidación pueden permitir una reducción significativa en las concentraciones de patógenos entéricos, especialmente en los huevos de helmintos. Por esta razón, han sido ampliamente promovidas en los países en desarrollo como un método de bajo costo para la reducción de patógenos y para la reutilización de aguas residuales para el riego. Sin embargo, un inconveniente importante de los estanques es el potencial de que existan cortocircuitos debido a gradientes térmicos, incluso en sistemas de estanques múltiples diseñados con tiempos de retención largos (es decir, de 90 días). A pesar de que la cantidad de cortocircuitos pueda ser pequeña, a menudo se pueden encontrar niveles detectables de patógenos en el efluente de los estanques de oxidación.

La inactivación y/o eliminación de agentes patógenos en las lagunas de oxidación está controlada por un número de factores, incluyendo: temperatura, luz solar, $\mathrm{pH}$, bacteriófago, depredación por otros microorganismos, amoníaco, la actividad de las algas, la adsorción o la retención de sólidos sedimentables y el asentamiento de los organismos más grandes (helmintos y protozoos). Las bacterias indicadoras y las bacterias patógenas pueden removerse hasta un $90-99 \%$ o más, en función de los tiempos de retención (Tabla 8.8).

Oragui (2003) observó que en lagunas facultativas de dos metros de profundidad disminuyó la cantidad de rotavirus considerablemente en el primer metro de la laguna, con una pequeña diferencia encontrada para rotavirus en la capa inferior de 1-2 m. Se especula que el $\mathrm{pH}$ alto y los efectos tóxicos de amoníaco y sulfuro fueron responsables de la disminución de virus en esta capa.

Se ha demostrado que todos los tipos de lagunas de estabilización son efectivas en la eliminación de parásitos protozoarios, cuyo mecanismo de eliminación principal es la sedimentación, la cual está relacionada con el tiempo de retención hidráulica (Tabla 8.9), (Stott, 2003).

\begin{tabular}{|c|c|c|c|c|c|c|}
\hline \multirow{2}{*}{$\begin{array}{l}\text { Pasos para el } \\
\text { tratamiento }\end{array}$} & \multirow{2}{*}{$\begin{array}{l}\text { Coliformes } \\
\text { fecales } / 100 \mathrm{ml}\end{array}$} & \multirow[t]{2}{*}{ Rotavirus/l } & \multicolumn{2}{|c|}{ \% Eliminacion de cada paso } & \multicolumn{2}{|c|}{$\%$ Eliminación total } \\
\hline & & & Coliformes fecales & Rotavirus & Coliformes fecales I & Rotavirus \\
\hline Aguas negras & $6.12 \cdot 10^{4}$ & 11,300 & - & - & & \\
\hline Laguna anaerobia & $3.13 \cdot 10^{6}$ & 5,870 & 94.9 & 94.8 & - & - \\
\hline Laguna facultativa & $8.91 \cdot 10^{5}$ & 1,410 & 71.5 & 76.0 & - & - \\
\hline $1^{\text {era }}$ laguna & $1.50 \cdot 10^{6}$ & 187 & 83.2 & 86.7 & - & - \\
\hline $2^{\text {da }}$ laguna & $4.37 \cdot 10^{4}$ & 23.4 & 70.8 & 87.5 & - & - \\
\hline $3^{\text {era }}$ laguna & $1.41 \cdot 10^{3}$ & 3.9 & 96.8 & 83.3 & 99.95 & 99.96 \\
\hline
\end{tabular}
Los sistemas de un solo estanque son capaces de eliminar de 60 a 90\% de helmintos (Veerannan, 1977). Con sistemas de lagunas múltiples se pueden lograr niveles no

Tabla 8.8 Eliminación de coliformes fecales y rotavirus de aguas residuales y efluentes de lagunas (modificado por Oragui, 2003)

Notas: El tiempo de retención en cada laguna fue de cinco días. 
Tabla 8.9 Reporte de eliminación de helmintos y protozoos patógenos entéricos (modificado de Stott, 2003)

\begin{tabular}{lrr}
\hline Proceso de tratamiento & \multicolumn{2}{c}{ Eliminación del parásito (\%) } \\
\cline { 2 - 3 } & Huevos de helmintos & (oo)quistes de protozoos \\
\hline Sedimentación normal & $73(35-96)$ & $38(4-68)$ \\
Sedimentación asistida por compuestos químicos & $97(95->99.99)$ & $70(27-93)$ \\
Tanques sépticos & $94.7(85->99)$ & - \\
Filtro percolador & $60(5-90)$ & $77(5-93)$ \\
Lodos activados & $92(75->99)$ & $87(15->99.9)$ \\
Laguna aireada & $83(48->99)$ & $5(84-87)$ \\
Estanques de oxidación & $93(72-100)$ & $81(81(60-91)$ \\
Filtración (arena/multimedia) & $92(78-99.6)$ & $72(40-99)$ \\
Lagunas de Hyacinth/lemna & $>>99$ & $86(69-98)$ \\
Humedales artificiales con flujo superficial & $89(71->99)$ & $85(58-99.9)$ \\
Humedales artificiales con flujo subsuperficial & - & $80(32-99.8)$ \\
Residuos de lagunas de estabilización & $99(88->99)$ & $98(87->99)$ \\
Lagunas anaerobias & $<99$ & 99.99 \\
\hline
\end{tabular}

detectables de huevos. Varios autores han propuesto que los tiempos de retención de 11 a 20 días darían como resultado la eliminación de los huevos con el estándar de la Organización Mundial de la Salud de igual o menor de un huevo de nemátodo por litro.

Un modelo empírico simple para predecir la eliminación de huevos de nemátodos como una función del tiempo de retención hidráulica (TRH) fue propuesto por Ayres et al. (1992). Niveles de confianza menores al 95\% pueden utilizarse en el modelo para determinar el número y los tiempos de retención de las lagunas necesarios para reducir el nivel de huevos de parásitos en efluentes a igual o menor de un huevo de nemátodo por litro para riego restringido basado en las concentraciones iniciales de huevos de nemátodos en las aguas residuales crudas.

\section{$\%$ Eliminación de huevos nemátodos $=$ 100 [1-0.41exp(-0.49 TRH+0.0085TRH $\left.\left.{ }^{2}\right)\right]$}

Este modelo predice que la retención de 1-2 días en las lagunas eliminaría 75 a $84 \%$ de los huevos, de 3 a 5 días de retención eliminaría de 89.8 a $95.6 \%$ y la retención de 20 días eliminaría arriba de $99.9 \%$ de huevos. Los sistemas lagunares múltiples resultan en una mayor eliminación de huevos en comparación con un sistema de tratamiento convencional (como por ejemplo un sistema de lodos activados). Esto se debe a que la sedimentación es el principal mecanismo para la eliminación de los huevos de helmintos.

\subsubsection{Filtros percoladores}

Los filtros percoladores son generalmente menos eficaces en la eliminación de patógenos que los lodos activados convencionales. En los filtros percoladores, incluyendo la sedimentación primaria y secundaria, se puede esperar que se eliminen $92 \%$ de los huevos de parásitos, $77 \%$ de los quistes y ovoquistes (Stott, 2003). En una planta bien operada el filtro percolador eliminará $20-80 \%$ de las bacterias entéricas y la planta de tratamiento completa de 70 a $97 \%$ (Feachem et al., 1983). La combinación de la sedimentación y filtros percoladores han reportado una eliminación del 99.9\% de las especies de Campylobacter (Arimi et al., 1988). La eliminación de los virus entéricos fluctúa de 0 a $94 \%$, probablemente en función de lo bien que la planta está siendo operada (Leong, 1983).

\subsubsection{Lodos activados}

El tratamiento por lodos activados, como se explica en esta sección, incluye la sedimentación primaria, aireación y sedimentación secundaria. La eliminación de patógenos es muy variable en este proceso, y depende del tipo de organismo y tiempos de detención a través del proceso. Se cree que la mayoría de la eliminación es debido a la sedimentación y adsorción, o a la incorporación en los flóculos biológicos que se forman durante el proceso. La eliminación de todos los agentes patógenos va de 40 a $99 \%$.

La eliminación de patógenos es altamente variable en procesos de sedimentación primaria. Debido a su pequeño tamaño, se produce la eliminación de virus y 
Tabla 8.10 La eliminación de patógenos durante el tratamiento de aguas residuales por lodos activados

\begin{tabular}{|c|c|c|c|c|}
\hline & Virus entéricos & Salmonela & Giardia & Cryptosporidium \\
\hline $\begin{array}{l}\text { Concentración en las aguas } \\
\text { residuales (número por litro) }\end{array}$ & $10^{5}-10^{6}$ & $5,000-80,000$ & $9,000-200,000$ & $1-3,960$ \\
\hline \multicolumn{5}{|l|}{ Eliminación durante: } \\
\hline \multicolumn{5}{|l|}{ Tratamiento Primario ${ }^{a}$} \\
\hline \% Eliminación & $50-98.3$ & $95.8-99.8$ & $27-64$ & \multirow[t]{5}{*}{0.7} \\
\hline Número remanente $\mathrm{L}^{-1}$ & $1,700-500,000$ & $160-3,360$ & $72,000-146,000$ & \\
\hline \multicolumn{4}{|l|}{ Tratamiento Secundario $^{b}$} & \\
\hline \% Eliminación & $53-99.92$ & 98.65-99.996 & $45-96.7$ & \\
\hline Número remanente $\mathrm{L}^{-1}$ & $80-470,000$ & $3-1075$ & $6,480-109,500$ & \\
\hline \multicolumn{5}{|l|}{ Tratamiento terciario $^{c}$} \\
\hline \% Eliminación & 99.983-99.9999998 & 99.99-99.999999995 & 98.5-99.99995 & \multirow[t]{2}{*}{$2.7^{d}$} \\
\hline Número remanente $\mathrm{L}^{-1}$ & $0.007-170$ & $0.000004-7$ & $0.099-2,951$ & \\
\hline
\end{tabular}

${ }^{a}$ Sedimentación primaria y desinfección

${ }^{b}$ Sedimentación primaria, filtro percolador y lodos activados y desinfección

${ }^{c}$ Sedimentación primaria, filtro percolador y lodos activados, desinfección, coagulación, filtración y desinfección

${ }^{d}$ Sólo Filtración

bacterias durante este proceso. Generalmente, los huevos de helmintos se eliminan más eficazmente con un intervalo de remoción de 60 a 90\% (Stott, 2003). La eliminación de protozoarios es más variable y oscila entre 4 y $93 \%$. Lo mismo ocurre para las bacterias entéricas y viruses. La eliminación de virus entéricos va de 0 a $98 \%$ (Tabla 8.10; Leong, 1983). Las tasas de sedimentación para helmintos pueden variar entre las especies dependiendo de la gravedad específica y las dimensiones del parásito y la densidad del líquido. Así, los huevos de Ascaris y Trichuris se eliminarán más eficazmente que los huevos de quistes anquilostoma o protozoarios y ovoquistes. En un estudio de huevos de Ascaris y Trichuris estos se eliminaron a tasas del 96\% y $90 \%$, respectivamente, en comparación con las tasas de remoción de $80 \%$ para los huevos de anquilostoma (Stott, 2003). La eficiencia de la eliminación de bacterias e indicadores patógenos varían de 80 a $90 \%$ en el proceso de lodos activados (Bitton, 2005). Siendo la mayor parte de las bacterias eliminadas transferidas al lodo.

Muchos de los virus terminan en el lodo probablemente debido a la presencia de bacterias que tienen sitios de unión similares a las que se adhieren a los virus en el intestino humano (Sano et al., 2004). La inactivación de los virus también puede ocurrir durante el proceso. Glass y O'Brien (1980) encontraron que, después de 10 horas de ventilación, el $75 \%$ de los virus son inactivados y el 25\% se asocian con los flóculos del lodo que se formó. Así, la inactivación por si sola no es suficiente para remover la mayoría de los virus con un tiempo de retención de 6 a 12 horas. Los estudios han demostrado que de 90 a 99 por ciento de los enterovirus y rotavirus pueden ser eliminados en las plantas de lodos activados (Rao et al., 1977; Rao et al., 1986; Rose et al., 1996). Los colífagos también se eliminan en un grado similar (Safferman y Morris, 1976; Rose et al., 2001). Estudios sobre colífagos nativos mostraron que el $97 \%$ de ellos están sólidamente asociados a estanques ventilados (Ketratanakal y Ohgaki, 1989).

Bitton (2005) resumió que la eliminación de virus y bacterias se debía a tres factores principales:

- adsorción o encapsulación dentro de los sólidos del fango

- inactivación de virus por bacterias

- la ingesta por protozoarios y nemátodos pequeños.

La eliminación de helmintos en sistemas de lodos activados varía con la especie. Ascaris y Trichuris se eliminan en un 96 a 97\% y anquilostomas en un $88 \%$ (Bhaskaran et al., 1956). Se ha observado que Giardia se elimina de entre un 80 a 99\%; (Casson et al., 1990;. Mayer and Palmer, 1996). Los más pequeños ovoquistes de Criptosporidium pueden ser eliminados en un grado menor (80 a 96.8\%), (Chauret et al., 1999; Mayer y Palmer, 1996). Gennaccaro et al., (2003) observaron que el $40 \%$ de los ovoquistes todavía son viables después del tratamiento completo de los lodos activados y desinfección con cloro. Se ha reportado una eliminación $>97 \%$ para Entamoeba histolytica (Feachem et al., 1983). La mayor eliminación de quistes/ovoquistes ocurre predominantemente durante la sedimentación secundaria. Cuando tanto la sedimentación primaria como la secundaria se consideran en conjunto, se han logrado intervalos de eliminación de huevos de Ascaris 
del $97 \%$ a por debajo de los límites de detección. El proceso de lodos activados tiene poco efecto en la viabilidad de huevos de Ascaris y los protozoarios Giardia y Criptosporidium. La eliminación de los otros grupos de organismos entéricos se produce en gran medida por la unión a los flóculos y por sedimentación. Los virus, en particular, están estrechamente unidos a los lodos y por esa razón se encuentran concentraciones altas en el lodo. En general, los lodos activados, incluyendo la sedimentación primaria y secundaria pueden eliminar de 0 a $99.9 \%$ de las helimintos y protozoos patógenos.

\subsubsection{Biorreactores de membrana}

Los biorreactores de membrana combinan el tratamiento de lodos activados con los procesos de membrana, tales como microfiltración o ultrafiltración, con un biorreactor de crecimiento suspendido. Las membranas son normalmente sumergidas en el tanque de aireación. La mayoría de los estudios sobre la eliminación de patógenos y microorganismos indicadores se han limitado a plantas piloto.

Ottoson et al., (2006) compararon la eliminación de patógenos entéricos después del tratamiento mediante un biorreactor de membranas, lodos activados con desnitrificación seguido de filtración por arena, y el uso de un reactor anaerobio de flujo ascendente (UASB). El biorreactor de membrana eliminó los indicadores (E. coli, Enterococcus, y colífagos) más eficientemente que los otros dos tratamientos (Tabla 8.11).

Tabla 8.11 Indicadores y reducción de patógenos por parte de un biorreactor de membrana, lodos activados filtrados por arena y sistema de tratamiento anaerobio de lecho de lodos de flujo ascendente (Ottoson et al., 2006).

\begin{tabular}{lrr}
\hline Organismo & $\begin{array}{r}\text { Eliminación } \\
\left(\log _{10}\right)\end{array}$ & $\begin{array}{r}\text { Eliminación } \\
(\%)\end{array}$ \\
\hline E. coli & 4.97 & 99.99 \\
Enterococos & 4.52 & 99.99 \\
Esporas de C. perfringens & 3.04 & 99.9 \\
Colífagos somáticos & 3.08 & 99.9 \\
F-colífagos específicos & 3.78 & 99.9 \\
Enterovirus & 1.79 & 98.4 \\
Genomas Norovirus & 1.14 & 93 \\
Quistes de Giardia & $>3.52$ & $>99.98$ \\
Ooquistes de Cryptosporidium & $>1.44$ & $>96.4$ \\
\hline
\end{tabular}

El reactor eliminó $E$. coli en un $4.97 \log _{10}$, enterovirus en un $1.79 \log _{10}$ y los parásitos protozoarios por debajo de los límites inferiores de detección. Zhang y
Farahbakhsh (2007) también reportaron altas eliminaciones de coliformes fecales (debajo de la detección) y $5.8 \log _{10}$ de colífagos F-específicos.

\subsubsection{Reactores anaeróbicos}

El sistema de lecho de lodos de flujo ascendente o UASB es una forma de tratamiento anaerobio para aguas residuales generalmente diluidas. A menudo se utilizan en combinación con otros procesos de tratamiento (por ejemplo, lagunas depuradoras). La eliminación de patógenos no ha sido ampliamente estudiado para este proceso de tratamiento, pero la eficiencia de remoción parece ser bastante bajo para la mayoría de los agentes patógenos y organismos indicadores.

Se ha propuesto que la mayoría de la eliminación de huevos de helmintos en sistemas UASB se produce por filtración y agregación, ya que el aluente fluye hacia arriba a través de la capa de lodo, y la sedimentación no juega un papel importante debido a que las velocidades del flujo ascendente son más altas que las velocidades de sedimentación de los huevos (Dixo et al., 1995). La eliminación de los huevos de helmintos se reportó en un intervalo de 70 a $89.6 \%$ (Stott, 2003). Pant y Mitttal (2007) observaron una reducción promedio en UASB de $79 \%$ para coliformes fecales, $88 \%$ para Salmonella y Shigella, y $87 \%$ para Vibrio, que es mucho menor que la observada para el proceso de lodos activados.

\subsubsection{Humedales naturales y artificiales}

La eliminación de agentes patógenos en sistemas que contienen plantas, como las lagunas de aguas residuales/estanques de oxidación se relaciona con el tiempo de retención. Procesos como sedimentación, filtración, luz solar y los efectos antagónicos micro y macro flora son propensos a estar involucrados.

Las tasas de remoción en humedales artificiales se comparan favorablemente con las de estanques, aunque por lo general tienen un menor tiempo de retención (por lo general un mínimo de cinco días en lugar de 20 a 30 días en los estanques). Es probable que la eficiencia de sedimentación sea mejor en humedales construidos a causa de la presencia de plantas y la resuspensión es también menos probable. Los sistemas híbridos que incorporan los estanques con plantas acuáticas y de flujo subsuperficial pueden producir resultados para la eliminación de parásitos superior a la de los estanques con tiempos de retención similares (Kadlec y Knight, 1996; Gerba et al., 1999.). 
Debido a la presencia de animales (mamíferos pequeños, aves), que excretan bacterias fecales, la eliminación de bacterias indicadoras (es decir, coliformes fecales) suele ser muy variable, especialmente si se utilizan efluentes desinfectados de los lodos activados (Kadlec y Knight, 1996). Se ha informado que la concentración de coliformes fecales varían de 110 hasta 550 por $100 \mathrm{ml}$ en humedales naturales que no reciben efluentes de aguas residuales (Kadlec y Knight, 1996). Cuando los niveles de coliformes fecales y estreptococos son altas, típicas de aguas residuales $\sin$ tratar $o$ parcialmente tratadas que no han sido desinfectadas, la eficiencia de eliminación en humedales es casi siempre superior al 90 por ciento para coliformes y de más del 80 por ciento para estreptococos fecales. Las eliminaciones siguen una cinética de primer orden, siempre y cuando las poblaciones de las bacterias sean altas (Kadlec y Knight, 1996).

Se han estimado coeficientes de decaimiento de primer orden para coliformes totales de $0.86 \log _{10} /$ día para humedales de flujo sub-superficial (Gersberg et al., 1987) y de $0.74 \log _{10} /$ día en un humedal con flores de ciprés en Florida (Scheuerman et al., 1989). También en otro sistema de ciprés, se estimó un decaimiento de 0.70 $\log _{10} /$ día para coliformes fecales y $0.62 \log _{10} /$ día para estreptococos fecales. Gearhart et al., (1989) midieron un decaimiento de $0.29 \log _{10}$ /día para coliformes fecales en un humedal superficial en el sur de California.

Gersberg et al., (1989) reportaron una reducción del 96.1\% de Salmonella dentro de las 52 horas en Santee, California, y Scheuerman et al. (1989) reportaron un decaimiento de $0.91 \log _{10} /$ día en un entorno natural de cipreses en Florida.

Se encontró que la eliminación de los microorganismos en las lagunas de lemna estaba relacionada con el tamaño del organismo. Los quistes de Giardia se eliminaron más eficientemente que los ovoquistes de Cryptosporidium (98\% vs $89 \%$ de remoción, respectivamente) para un tiempo de retención de 9 días (Falabi et al., 2002). En el mismo estanque, las bacterias coliformes fecales fueron eliminadas en un $61 \%$ y los colífagos en un $40 \%$. Entre la turbiedad del afluente y la eliminación del parásito protozoario se encontró una correlación significativa $(\mathrm{p}=0.01)$.

En humedales naturales parece posible la eliminación de $>99 \%$ de los helmintos. Stott et al. (1999) evaluó cañaverales de 100 metros de longitud con números artificialmente altos de huevos de parásitos (100 a 500 huevos por litro) y, a menudo no se detectaron huevos en el efluente. La mayoría de los huevos aparentemente se asientan en los primeros 10 a 25 metros de los lechos de los sistemas.

El papel de las plantas en la eliminación de los huevos y ovoquistes/quistes no es del todo clara. En un sistema de flujo subsuperficial de vegetación mixta (cañas/arbustos/árboles) los quistes/ovoquistes se eliminaron en un $95 \%$ en comparación con el $82-92 \%$ en un sistema de subsuelo sin plantas (Quinonoez-Diaz et al., 2001). Sin embargo, en un humedal basado en gravilla en la vegetación de Egipto no tuvo ningún efecto aparente sobre la eliminación de helmintos (Stott et al., 1996).

Gersberg et al., (1989) reportó una reducción del 99\% en colífago MS-2 en un estudio de los humedales del subsuelo y el $91.5 \%$ en un humedal de flujo superficial.

\subsubsection{Tratamiento en suelos}

La aplicación al suelo de aguas residuales se considera otra forma de tratamiento. Aunque por lo general es un medio para mejorar la calidad del agua residual tratada en sistemas secundarios, también se utiliza para tratar efluentes primarios. El riego de los cultivos y la recolección de agua percolada resultante de los campos de drenaje o recuperación de los pozos puede ser considerado un medio de tratamiento. Una práctica común es el paso de las aguas residuales a través de pendientes de tierra de baja permeabilidad cubiertas de vegetación y la recuperación de las aguas residuales en la parte inferior de la pendiente. La infiltración en los suelos arenosos es, probablemente, la práctica más común para mejorar la calidad de las aguas residuales.

\subsubsection{Flujo terrestre}

Los sistemas de flujo terrestre permiten que el drenaje fluya por una distancia de por lo general 50 a 100 metros a lo largo de una pendiente vegetal de $2-8 \%$ y las aguas residuales resultantes son recogidas en una zanja. Los mecanismos principales de la eliminación de los microorganismos incluyen la sedimentación, la filtración a través de la vegetación, adsorción al suelo, y la desecación durante períodos de secado. El flujo terrestre no es muy eficaz en la eliminación de microorganismos. Cuando se aplican flujos primarios, los coliformes fecales sólo se reducen en aproximadamente $90 \%$, y la eliminación mínima se produce cuando se aplican los flujos secundarios. Chernicharo et al. (2001) recomiendan que un sistema de flujo terrestre con tasas 
de aplicación de 0.4 a $0.5 \mathrm{~m}^{3} / \mathrm{m} / \mathrm{h}$ y una longitud de la pendiente de 35 metros puede resultar en un $99 \%$ de eliminación de huevos de parásitos. Schaub et al. (1978) estudiaron la reducción de poliovirus y colífago f2 de las aguas residuales crudas, primarias y tratadas secundariamente distribuidas sobre $36 \mathrm{~m}$ de largo de pendientes cubiertas de hierba y una pendiente general de $3 \%$. El colífago f 2 se detectó dentro de 50 a 90 minutos en la parte inferior de la pendiente dependiendo de las tasas de carga hidráulica. Sólo el 30-60\% de los colífagos fueron eliminados y el $85 \%$ del poliovirus.

\subsubsection{Infiltración}

La infiltración de las aguas residuales tratadas se practica tanto como un medio para mejorar aún más la calidad de las aguas residuales para su reutilización y para recargar los acuíferos subterráneos. Por lo general, las aguas residuales se colocan en cuencas y se permite que se filtren lentamente a través del suelo, con períodos intermedios de humedecimiento y secado para evitar la obstrucción del suelo. La eliminación de patógenos es muy específica, dependiendo en gran medida de la naturaleza del suelo (la cantidad de arcilla) y factores climáticos (temperatura). Debido al gran tamaño de los óvulos, la Giardia y el Cryptosporidium pueden eliminarse efectivamente después del paso de las aguas residuales a través de unos pocos metros. Las bacterias también se eliminan por debajo de niveles no detectables. Los virus entéricos; sin embargo, a menudo pueden viajar distancias mucho mayores. Mientras que los organismos más grandes se separan por filtración, la eliminación de los virus depende de la adsorción a las partículas del suelo.

Los virus han sido los más estudiados debido a que tienen el mayor potencial para el movimiento a través del suelo. Los virus son capaces de transportarse en largas distancias a través de ciertos tipos de suelos (arenas, arcillas fracturadas) por cientos de metros (Yates y Gerba, 1998). Siendo partículas, el transporte de los virus se limita generalmente en los poros más grandes y puede viajar más rápido que los contaminantes químicos solubles en determinadas condiciones (McKay et al., 1993; Bales et al., 1989.). Por lo tanto, la ausencia de contaminación química (como por nitrato, materia orgánica y sales solubles) no se opone a la presencia de virus patógenos en las áreas afectadas por la aplicación al suelo de aguas residuales.

La sobrevivencia y el transporte de virus a través del suelo se rige por una serie de factores (temperatura, profundidad del agua subterránea, las tasas de carga hidráulica, el tipo de suelo, la presencia de la materia orgánica, $\mathrm{pH}$ ). La temperatura y la profundidad de la zona vadosa son probablemente los más importantes. Los virus pueden sobrevivir durante años en las aguas subterráneas a temperaturas inferiores a $10{ }^{\circ} \mathrm{C}$ (Kutz y Gerba, 1988), pero sólo unos pocos días a temperaturas superiores a $37^{\circ} \mathrm{C}$. Como la mayoría de los organismos, el transporte a través de la zona vadosa o insaturada reduce en gran medida el número de virus debido al mayor retraso en las interfases suelo-aire-agua, aunque algunos virus se mueven más fácilmente que otros a través de la zona vadosa (Chu et al., 2003). Hay una mayor retención en el suelo con contenido de arcilla en aumento, menor $\mathrm{pH}$ y concentraciones más bajas de materia orgánica soluble.

En general, se puede esperar una alta remoción de grandes cantidades de patógenos en sistemas de infiltración/extracción que brinden tiempos de retención suficientes en la profundidad del subsuelo, tengan una zona saturada adecuada y el uso de suelos bien estructurados que minimicen los flujos preferenciales. Con un adecuado funcionamiento se puede esperar una eliminación de más del $99.99 \%$ de todos los patógenos. Dado que estos sistemas dependen en gran medida de la eficiencia de los procesos naturales de eliminación, son menos propensos a ser afectados por fallos operativos a corto plazo.

\subsubsection{Tanques sépticos}

Los tanques sépticos tienen todavía un uso generalizado, incluso en países desarrollados. Los agentes patógenos no se eliminan eficazmente durante este proceso dado que los cortocircuitos pueden permitir el paso de algunos de los residuos con un limitado tiempo de retención en el tanque. La contaminación viral de las aguas subterráneas por tanques sépticos está bien documentada, y se han asociado con numerosos brotes epipemiológicos debido a la contaminación de las aguas subterráneas. Sin embargo, en las zonas con profundidad suficiente para las aguas subterráneas (por lo menos varios metros) y baja densidad (número por hectárea) pueden ser eficaces y con un impacto limitado sobre la calidad del agua subterránea.

La sedimentación en el tanque es el mecanismo principal de eliminación, por lo menos para los helmintos y parásitos protozoarios. Feacham et al., (1983) sugirieron que los tanques sépticos, con un tiempo de retención de 1-3 días, pueden reducir los agentes patógenos de 0 a $2 \log _{10}$. Lloyd y Fredrick (2000) 
reportaron la eliminación de helmintos de 99.95 a > 99.99\% para un sistema de emergencia OXFAM usando dos tanques en serie que ofrece sedimentación anaerobia y un tiempo de retención de 2-3 días. Sobre la base de una revisión de la literatura, Feacham et al., (1983) estimaron que un tanque séptico bien diseñado y a $>25$ ${ }^{\circ} \mathrm{C}$ podría reducir bacterias fecales indicadoras y Salmonella en un 50 a $95 \%$. La reducciones de virus es poco probable que superen el $50 \%$.

\subsubsection{Tratamiento terciario}

El tratamiento terciario se emplea a menudo con el propósito de mejorar aún más la calidad microbiana de procesos de tratamiento secundario. Esto es especialmente cierto si el agua residual se reutiliza o recicla para el riego de los cultivos alimentarios o de paisaje, con fines recreativos y de agua potable. Los procesos de tratamiento terciario que reducen el número de patógenos pueden incluir:

-filtración - medios de filtración rápidos o mixtos, filtración de arena lenta, microfiltración

-adición de productos químicos que coagulan para mejorar los procesos de floculación y filtración

-procesos de membranas -ultrafiltración; nanofiltración; ósmosis inversa

- retención en estanques o reservorios

- paso a través de los sistemas naturales - los humedales; tratamiento suelo-acuífero.

La mayoría de los tratamientos terciarios son muy eficaces en la reducción del número de helmintos y parásitos protozoarios porque involucran la filtración y retención que ayuda a la eliminación de estos microorganismos. En general, en los procesos de tratamiento terciario se eliminan más del $99 \%$ de los helmintos, y entre un 95 a $99 \%$ de los quistes y ovoquistes de protozoos. Debido a su pequeño tamaño, los virus son eliminados menos eficazmente por arena y por filtración en medios mixtos; la ultrafiltración o la ósmosis inversa son a menudo necesarias para llevarlos a niveles por debajo de detección (es decir, menos de un virus en 1,000 litros).

La reducción de patógenos por arena y por la filtración en medios mixtos puede ser muy variable en función del tamaño de grano y las tasas de carga hidráulica (Logan et al., 2001). En general, la filtración por arena es capaz de eliminar los helmintos por debajo del nivel de detección (Rose et al., 1996). Schwartzbrod et al. (1989) reportaron la reducción de helmintos de 900 huevos y 10 huevos por litro por filtración de arena. Rose et al. (1996) informaron que la filtración rápida es más eficaz para la eliminación de quistes de Giardia que para ovoquistes de Cryptosporidium. La eliminación de ambos organismos fue mayor del $98 \%$, aunque se detectaron ovoquistes de Cryptosporidium todavía en las aguas residuales. Los intervalos de eliminación por filtración rápida, incluyendo coagulación/floculación seguida por filtración en medios mixtos (grava, arena y carbón), varió desde 97.9 hasta 99\%. Reducciones significativas de bacterias entéricas ocurrieron con la coagulación. La mayor eliminación de virus parece ocurrir con las sales férricas $(99.5 \%)$, seguido de cal $(98.8 \%)$ y luego por el alumbre (95\%). Con la coagulación, floculación, sedimentación y filtración puede esperarse la eliminación de $99.9 \%$ o más de las bacterias y virus (Leong et al., 1983;. Rose et al., 1996.).

\subsubsection{Desinfección}

La desinfección de las aguas residuales tratadas se practica a menudo para reducir el nivel de microorganismos patógenos. Esto es especialmente cierto si se va a reciclar, reutilizar o para preservar aguas recreacionales. En algunos países desarrollados, como los Estados Unidos, se requiere la desinfección de los vertidos de aguas residuales tratadas. La temperatura tiene un efecto importante ya que controla la velocidad de las reacciones químicas. Por lo tanto, cuando la temperatura aumenta, la tasa de mortandad con un químico desinfectante aumenta.

El pH puede afectar a la ionización del desinfectante y la viabilidad del organismo. La mayoría de los organismos transmitidos por el agua se ven afectados negativamente por los niveles de $\mathrm{pH}$ por debajo de $3 \mathrm{y}$ por encima de 10. En el caso de halógenos tales como cloro, el pH controla la cantidad de $\mathrm{HOCl}$ (ácido hipocloroso) y $\mathrm{OCl}^{-}$(hipoclorito) en solución. El $\mathrm{HOCl}$ es más eficaz que el $\mathrm{OCl}^{-}$en la desinfección de microorganismos. Con el cloro, la CT (concentración de desinfectante por tiempo de contacto) aumenta con el $\mathrm{pH}$. La adhesión de organismos a superficies o partículas en el agua tales como arcillas y detritus orgánicos ayuda en la resistencia de los microorganismos a la desinfección. El material particulado puede interferir, por lo tanto, actuando y reaccionando químicamente con el desinfectante, neutralizando así la acción del desinfectante, o protegiendo físicamente al organismo del desinfectante (Stewart y Olson 1996). Las sustancias químicas disueltas que interfieren con la desinfección química incluyen compuestos orgánicos, compuestos 
nitrogenados inorgánicos y orgánicos, hierro, manganeso y sulfuro de hidrógeno.

Por lo general, la desinfección se lleva a cabo a través de la adición de un oxidante. El cloro es, por mucho, el desinfectante más común que se utiliza para el tratamiento de aguas residuales. Hay numerosos factores que controlan la eficacia o tasa de mortandad (o inactivación) de un microorganismo en las aguas residuales. En las aguas residuales, el amoníaco y la materia orgánica se combinan rápidamente para reducir el nivel de cloro libre, que es la forma más eficaz de inactivación del cloro en los microorganismos.

\subsubsection{Desinfección por cloro}

El cloro es un agente oxidante fuerte que, cuando se añade como un gas en agua, forma una mezcla de ácido hipocloroso $(\mathrm{HOCl})$ y ácido clorhídrico.

$\mathrm{Cl}_{2}+\mathrm{H}_{2} \mathrm{O}=\mathrm{HOCl}+\mathrm{HCl}$

En soluciones diluidas, existe poco $\mathrm{Cl}_{2}$ en solución. La acción del desinfectante se asocia con el $\mathrm{HOCl}$ formado. El Ácido hipocloroso se disocia de la siguiente manera:

$\mathrm{HOCl}=+\mathrm{H}^{+} \mathrm{OCl}$

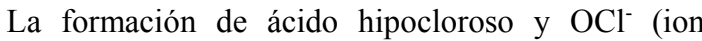
hipoclorito) depende del $\mathrm{pH}$ del agua. La cantidad de $\mathrm{HOCl}$ es mayor en valores de $\mathrm{pH}$ neutros y a más bajos niveles, lo que resulta en una mayor capacidad de desinfección del cloro en estos niveles de $\mathrm{pH}$. El cloro como $\mathrm{HOCl} \mathrm{u} \mathrm{OCl}^{-}$se define como cloro libre disponible. $\mathrm{HOCl}$ se combina con amoniaco y compuestos orgánicos para formar lo que se conoce como cloro combinado. Las reacciones de cloro con amoníaco y sustancias que contienen nitrógenos orgánicos son de gran importancia en la desinfección del agua.

Estas reacciones resultan en la formación de monocloramina, dicloramina, tricloramina, etc:

$$
\begin{gathered}
\mathrm{NH}_{3}+\mathrm{HOCl} \rightarrow \mathrm{NH}_{2} \mathrm{Cl}+\mathrm{H}_{2} \mathrm{O} \\
\text { Monocloramina } \\
\mathrm{NH}_{2} \mathrm{Cl}+\mathrm{HOCl} \rightarrow \mathrm{NHCl}_{2}+\mathrm{H}_{2} \mathrm{O} \\
\text { Dicloramina } \\
\mathrm{NHCl}_{2}+ \\
\mathrm{HOCl} \rightarrow \mathrm{NCl}_{3}+\mathrm{H}_{2} \mathrm{O} \\
\text { Tricloramina }
\end{gathered}
$$

Tales productos conservan el poder de desinfección del ácido hipocloroso, pero son mucho menos eficaces a una concentración dada de cloro.

El cloro libre es muy eficaz para la inactivación de microorganismos patógenos. En el tratamiento de agua potable, $1 \mathrm{mg} / 1 \mathrm{o}$ menos durante aproximadamente 30 minutos es generalmente suficiente para reducir significativamente el número de bacterias. La presencia de las sustancias que interfieren en las aguas residuales, reduce la eficacia de la desinfección por cloro, y se necesitan concentraciones relativamente altas de cloro (20-40 mg/l) (Bitton, 2005). Los virus entéricos y parásitos protozoarios son más resistentes al cloro que las bacterias (Tabla 8.12) y pueden ser encontrados en los chorros de aguas residuales secundarias después de las prácticas de desinfección normales. Cryptosporidium es muy resistente al cloro. Una concentración de cloro de 80 $\mathrm{mg} / \mathrm{l}$ es necesaria para causar $90 \%$ de inactivación después de un tiempo de contacto de 90-minutos (Korich et al., 1990). Las cloraminas son mucho menos eficientes que el cloro libre (alrededor de 50 veces menos eficiente) para la inactivación de virus (Tabla 8.13).

Los huevos de Ascaris son muy resistentes a los efectos de muchos desinfectantes químicos (Krishnaswami y Post, 1968), lo cual es probablemente debido a la impermeabilidad de la capa de la membrana de los huevos (Wharton, 1980).

Debido a la presencia de amoníaco en las descargas de aguas residuales, la mayor parte del cloro añadido se convierte en cloraminas. Esta demanda del cloro se debe cumplir antes de que el cloro libre esté disponible para la desinfección. Cuando el cloro es añadido, el residuo llega a un pico (formación de monocloramina principalmente) y después disminuye a un mínimo llamado el punto de quiebre. En el punto de quiebre, la cloramina se oxida a gas nitrógeno en una serie compleja de reacciones, que se resumen en la ecuación 8.9.

$2 \mathrm{NH}_{3}+3 \mathrm{HOCl} \rightarrow \mathrm{N}_{2}+3 \mathrm{H}_{2} \mathrm{O}+3 \mathrm{HCl}$

La adición de cloro más allá del punto de quiebre asegura la existencia de cloro libre residual. 
Tabla 8.12 Valores CT para la inactivación por cloro de microorganismos en el agua ( $99 \%$ de inactivación)a (Sobsey, 1989; Rose et al., 1997.)

\begin{tabular}{lrrr}
\hline Organismo & ${ }^{\circ} \mathrm{C}$ & $\mathrm{pH}$ & $C T$ \\
\hline Bacteria & & & \\
$\quad$ E. coli & 5 & 6.0 & 0.04 \\
$\quad$ E. coli & 23 & 10.0 & 0.6 \\
Virus & & & \\
$\quad$ Polio 1 & 5 & 6.0 & 1.7 \\
Echo 1 & 5 & 6.0 & 0.24 \\
Echo 1 & 5 & 7.8 & 0.56 \\
Echo 1 & 5 & 10.0 & 47.0 \\
Coxsackie B5 & 5 & 7.8 & 2.16 \\
$\quad$ Coxsackie B5 & 5 & 10.0 & 33.0 \\
$\quad$ Adenovirus 40 & 5 & 7.0 & 0.15 \\
Protozoos & & & \\
$\quad$ Quistes de G. lamblia & 5 & 8.0 & $119-192$ \\
$\quad$ Ooquistes Cryptosporidium & 25 & 7.0 & $>7200$ \\
\hline${ }^{a}$ En una agua destilada tamponada & & &
\end{tabular}

${ }^{a}$ En una agua destilada tamponada.

Tabla 8.13 valores CT para cloraminas en agua (99\% de inactivación) ${ }^{a}$ (adaptado de Sobsey, 1989; Rose et al., 1997.)

\begin{tabular}{lrrr}
\hline Organismo & ${ }^{\circ} \mathrm{C}$ & $\mathrm{pH}$ & $\mathrm{CT}$ \\
\hline Bacteria & & & \\
$\quad$ E. coli & 5 & 9.0 & 113 \\
Virus & & & \\
$\quad$ Polio 1 & 5 & 9.0 & 1420 \\
$\quad$ Hepatitis A & 5 & 8.0 & 592 \\
$\quad$ Colífago MS2 & 5 & 8.0 & 2100 \\
$\quad$ Rotavirus SA11 & 5 & 8.0 & 4034 \\
Protozoos & & & \\
$\quad$ G. muris & 5 & 7.0 & 1400 \\
$\quad$ Cryptosporidium & 25 & 7.0 & $>7200$ \\
\hline
\end{tabular}

${ }^{a}$ En un agua destilada tamponada

\subsubsection{Ozono}

El ozono $\left(\mathrm{O}_{3}\right)$, un potente agente oxidante, se puede producir al pasar una descarga eléctrica a través de una corriente de aire u oxígeno. El ozono es más caro de aplicar para el tratamiento de aguas residuales que la cloración, pero es más comúnmente usado en tratamiento de agua potable. El ozono no deja residuos en el agua. La efectividad del ozono como desinfectante no se ve afectada por el pH o el amoníaco. El ozono es un oxidante mucho más potente que el cloro (Tablas 8.12 y 8.14). Los ovoquistes de Cryptosporidium pueden ser inactivados por la capa de ozono, pero se requiere una CT de 1-3.

\subsubsection{Estimación de la eficacia de cloro y ozono}

En un esfuerzo para predecir el resultado de la desinfección, se han desarrollado varios modelos sobre la base de los datos experimentales. La principal teoría de desinfección usada hoy en día es todavía el modelo Chick-Watson, que expresa la tasa de inactivación de los microorganismos mediante una reacción química de primer orden.

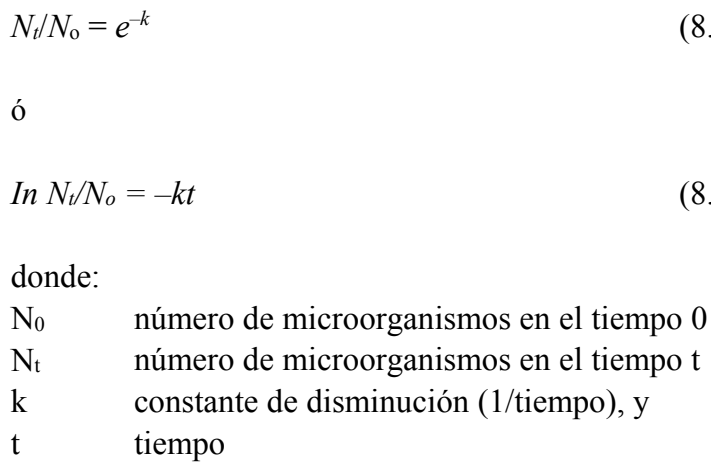

El logaritmo de la tasa de sobrevivencia $\left(\mathrm{N}_{\mathrm{t}} / \mathrm{N}_{0}\right)$ dibuja una línea recta en función del tiempo. Desafortunadamente, los datos de laboratorio y de campo a menudo se desvían de la cinética de primer orden. Antes de la inactivación, es posible observar curvas con forma de hombro en ciertos grupos de organismos o datos múltiples en sitios críticos. Las curvas de este tipo son comunes en la desinfección de bacterias coliformes por cloraminas. Las curvas que se extienden asintóticamente, vista a menudo con muchos desinfectantes, se puede explicar debido a la sobrevivencia de una subpoblación resistente como resultado de la protección de las sustancias que interfieren con la eficacia del los desinfectates (materia en suspensión en agua), aglutinación, o por resistencia conferida genéticamente.

En aplicaciones de agua, la eficacia del desinfectante se puede expresar como CT, donde $C$ es la concentración de desinfectante y $t$ el tiempo requerido para inactivar un cierto porcentaje de la población en condiciones específicas ( $\mathrm{pH}$ y temperatura). Típicamente, se usa un nivel de $99 \%$ de inactivación cuando se comparan los valores de CT. En general, cuanto menor sea el valor de CT, más eficaz será el desinfectante. El método de CT permite una comparación general de la eficacia del cloro, cloroaminas y ozono en agentes microbianos diferentes (Tablas 8.12 a la 8.14). Es utilizado por la industria del agua potable para determinar la cantidad de desinfectante que debe aplicarse durante el tratamiento para conseguir una reducción dada de microorganismos patógenos. La Tabla 8.12 muestra valores de CT de cloro para una 
variedad de microorganismos patógenos. El orden de resistencia al cloro y otros desinfectantes más usados para el tratamiento de agua es: quistes de protozoarios $>$ virus $>$ bacterias vegetativas.

Tabla 8.14 Valores de CT para la inactivación por ozono de microorganismos en el agua (99\% de inactivación) (Sobsey, 1989; Rose et al, 1997.)

\begin{tabular}{lrrr}
\hline Organismo & ${ }^{\circ} \mathrm{C}$ & $\mathrm{pH}$ & $\mathrm{CT}$ \\
\hline Bacteria & & & \\
$\quad$ E. coli & 1 & 7.2 & $0.006-0.02$ \\
Virus & & & \\
$\quad$ Polio 2 & 25 & 7.2 & 0.72 \\
$\quad$ Rota SA11 & 4 & $6.0-8.0$ & $0.019-0.064$ \\
$\quad$ Coxsackie B5 & 20 & 7.2 & $0.64-2.6$ \\
$\quad$ Adeno 40 & $5-7$ & 7.0 & \\
Protozoos & & & \\
$\quad$ G. lamblia & 5 & 7.0 & 0.53 \\
$\quad$ Cryptosporidum & 22 & & 3.5 \\
\hline
\end{tabular}

\subsubsection{Desinfección con luz ultravioleta}

El uso de desinfección por luz ultravioleta en aguas residuales ha incrementado su popularidad porque no es conocido por producir subproductos cancerígenos o tóxicos, y no hay necesidad de manejar o almacenar productos químicos tóxicos. Desafortunadamente tiene varias desventajas, incluyendo costos más elevados que los halógenos, ausencia de desinfectante residual, dificultad en la determinación de la dosis de UV, el mantenimiento y la limpieza de las lámparas de UV, y la fotorreactivación potencial de algunas bacterias entéricas (Bitton, 2005). Sin embargo, los avances en la tecnología UV están proporcionando un menor costo, lámparas más eficientes y más equipamiento fiable. La inactivación microbiana es proporcional a la dosis de UV, que se expresa en microvatios-segundo por centímetro cuadrado $\left(\mu \mathrm{W}-\mathrm{s} / \mathrm{cm}^{2}\right)$ o

UV dosis $=i t$

donde:

\section{i $\quad \mu W / \mathrm{cm}^{2} \quad y$ \\ t tiempo de exposición}

En la mayoría de los estudios de desinfección se ha observado que el logaritmo de la fracción sobreviviente de organismos es casi lineal cuando se representa en función de la dosis, en donde la dosis es el producto de la concentración y del tiempo (CT) para desinfectantes químicos o de la intensidad y el tiempo (IT) para UV. Una observación adicional es que una dosis constante produce una inactivación constante. Esto se expresa matemáticamente en la ecuación. 8.13.

$\log \frac{N_{\mathrm{s}}}{N_{\mathrm{i}}}=$ función $(I T)$

donde:

Ns densidad de organismos sobrevivientes (número/ $\mathrm{cm}^{3}$ ), $\mathrm{y}$

$\mathrm{N}_{\mathrm{i}}$ densidad inicial de los organismos antes de la exposición (número/ $\mathrm{cm}^{3}$ )

Debido a la relación logarítmica de inactivación microbiana frente a la dosis UV, es común describir la inactivación en términos de sobrevivencia, tal como se expresa en la ecuación. 8.14. Por ejemplo, si sobrevivió un organismo en 1,000 a la exposición a los rayos UV, el resultado sería un $-3 \log _{10}$ de sobrevivencia, o una reducción de $3 \log _{10}$.

$\log$ sobrevivencia $=\log \frac{N_{\mathrm{s}}}{N_{\mathrm{i}}}$

La determinación de la susceptibilidad de diversos microorganismos patógenos acuáticos es fundamental en la cuantificación de la dosis UV necesaria para la desinfección adecuada del agua. Los factores que pueden afectar a la dosis de UV incluyen aglutinación de células, sólidos en suspensión, turbidez, y la absorción UV. Experimentos para determinar la susceptibilidad de los microorganismos a luz UV descritos en la literatura a menudo se basan en la exposición de los microorganismos bajo condiciones optimizadas de desinfección por UV. Tales condiciones incluyen la filtración de los microorganismos que producen suspensiones de células monodispersas, uniformes y el uso de agua tamponada con baja turbidez y alta transmisión a $254 \mathrm{~nm}$. Por lo tanto, en realidad se necesitan las dosis más altas para lograr la misma cantidad de inactivación microbiana en sistemas a escala real.

La eficacia de la luz UV disminuye en los tratamientos de aguas residuales debido a la presencia de sustancias que afectan la transmisión de rayos UV en el agua. Como por ejemplo, de sustancias húmicas, 
compuestos fenólicos, sulfonatos de lignina, y el hierro férrico.

La materia en suspensión puede proteger a los microorganismos de la acción de la luz UV, por lo que la filtración de las aguas residuales es generalmente necesaria para una desinfección eficaz por luz UV.

En general, la resistencia de los microorganismos a la luz UV sigue el mismo patrón que la resistencia a los desinfectantes químicos; es decir, virus de doble cadena de $\mathrm{ADN}>$ colífagos MS-2 > esporas bacterianas $>$ virus entéricos de doble cadena $\mathrm{ARN}>$ virus entéricos de cadena normal de ARN > bacterias vegetativas (Tabla 8.15).

Tabla 8.15 dosis UV para matar microorganismos (Roessler y Severin, 1996; John et al 2003;. Gerba et al, 2002; Li et al, 2007)

\begin{tabular}{lr}
\hline Organismo & $\begin{array}{c}\text { Dosis ultravioleta }\left(\mu \mathrm{W}-\mathrm{s} / \mathrm{cm}^{2}\right) \\
\text { requirida para eliminar el } 90 \%\end{array}$ \\
\hline Campylobacter jejuni & 1,100 \\
Escherichia coli & $1,300-3,000$ \\
Klebsiella terrigena & 3,900 \\
Salmonella typhi & $2,100-2,500$ \\
Shigella dysenteriae & $890-2,200$ \\
Vibro cholerae & $650-3,400$ \\
Yersinia enterocolitica & 1,100 \\
Adenovirus & $23,600-56,000$ \\
Coxsackievirus & $11,900-15,600$ \\
Echovirus & $10,800-12,100$ \\
Poliovirus & $5,000-12,000$ \\
Hepatitis A & $3,700-7,300$ \\
Rotavirus SA11 & $8,000-9,900$ \\
Colífago MS-2 & 18,600 \\
Cryptosporidium & 3,000 \\
Giardia & 2,000 \\
Encephalitozoon intestinalis & 2,800 \\
\hline
\end{tabular}

La radiación ultravioleta daña el ADN o ARN microbiano en una longitud de onda de aproximadamente $260 \mathrm{~nm}$. Se provoca la dimerización de la timina, que bloquea la replicación del ácido nucleico y efectivamente inactiva los microorganismos. El sitio inicial del daño UV en los virus es el genoma, seguido por daño estructural a la capa de proteína del virus. Los virus de alto peso molecular con ADN o ARN de doble cadena, son más fáciles de inactivar que aquellos con bajo peso molecular de doble cadena. Del mismo modo, los virus con un solo ácido nucleico de alto peso molecular son más fáciles de inactivar que aquellos de bajo peso molecular con ácidos nucleicos de una cadena. Esto es probablemente debido a la densidad del objetivo que es mayor en los genomas más grandes. Sin embargo, los virus con genomas de doble cadena son menos susceptibles que aquellos con genomas de cadena sencilla debido a la capacidad de las enzimas de origen natural dentro de la célula huésped para reparar secciones dañadas del genoma de doble cadena, usando la hebra no dañada como una plantilla (Roessler y Severin, 1996).

Un fenómeno conocido como fotorreactivación se produce en algunas bacterias dañadas con luz UV cuando se exponen a longitudes de onda visibles entre 300 y 500 nm. El daño de la luz UV es reparado mediante la activación de una enzima de fotorreactivación, que se une y luego se divide por los atenuadores de timina en el ácido nucleico. El daño en el $\mathrm{ADN}$ también se puede reparar en la oscuridad por un mecanismo que extirpa pares de bases de pirimidina dimerizados y permite la reinserción de bases no dimerizadas por otras enzimas. La capacidad de regeneración de cualquier organismo depende del tipo de organismo. Los coliformes totales y fecales son capaces de fotorreactivar, pero los estreptococos fecales no lo son. Para evitar fotorreactivación, la dosis suficiente se debe aplicar o evitar ante la exposición de la luz solar directa.

\subsection{CONCLUSIONES}

De esta revisión, es evidente que aunque se puede alcanzar una eliminación importante de agentes patógenos entéricos mediante varios procesos de tratamiento de aguas residuales de uso común a nivel mundial, esta eliminación es muy variable y depende de la operación óptima del proceso. Por lo tanto, sin algún tipo de monitoreo microbiano el éxito de estos procesos es a menudo difícil de juzgar. Los indicadores o monitoreo de patógenos (por ejemplo, huevos de nemátodos en el caso de estanques de oxidación o lagunas) son necesarios para garantizar la mayor eliminación por el proceso.

Sin embargo, se debe de esperar siempre un cierto nivel de patógenos en las aguas residuales. A pesar de que algunos autores reportan $100 \%$ de eliminación de algunos patógenos en procesos de tratamiento, esta eliminación sólo refleja el límite de sus métodos de detección de los organismos en cuestión. Por lo tanto, es mejor comunicar que la eliminación es superior a cierto valor (por ejemplo, >99\%) para reflejar mejor el límite del método de detección. Sólo se puede esperar que una combinación de filtración (coagulación-filtros de ; ultrafiltración) con una desinfección adecuada pueda producir de manera regular aguas residuales con niveles indetectables de patógenos. 


\section{REFERENCIAS}

Ashbolt N.J., Grabow W.O.K. and Snozzi M. (2001) Indicators of microbial water quality, in Water Quality: Guidelines, Standards and Health, (L. Fewtrell and J. Bartram, Ed. IWA Publishing, London, pp. 289-315.

Arimi S.M., Fricker C.R. and Park R.W. (1988) Occurrence of "thermophilic" campylobacters in sewage and their removal by treatment processes. Epidemiol. Infect. 101, 279-286.

Ayres R.M., Alabaster G.P., Mara D.D. and Lee D.I. (1992) A design equation for human intestinal nematode egg removal in waste stabilization ponds. Wat. Res. 26, 863865.

Bales R.C., Gerba C.P., Grondin G.H. and Jensen S.L. (1989) Bacteriophage transport in sandy soil and fractured tuff. Appl. Env. Micr. 55, 2061-2067.

Bhaskaran T.R., Sampathkumaran M.A., Sur T.C. and Radhakrishban I. (1956) Studies on the effect of sewage treatment processes on the survival of intestinal parasites. Indian J. Med. Res. 44, 163-180.

Bingham A.K., Jarroll E. and Meyer E. (1979) Giardia spp.: Physical factors of excystation in vitro, and excystation vs. eosin exclusion as determinants of viability. Exp. Parasitol.

47 ,

284-291

Bitton G. (2005) Wastewater Microbiology, Third ed. Wiley-Liss, New York.

Burden D.J., Whitehead A., Green E.A., McFadzean J.A. and Beer R. (1976) The treatment of soil infected with human whip-worm Trichuris trichiura. J. Hyg. 77, 377382.

Cabelli V.J. (1989) Swimming-associated illness and recreational water quality criteria. Wat. Sci. Tech. 21, $13-21$.

Carraro E., Fea E., Salva S. and Grillo G. (2000) Impact of a wastewater treatment plant on Cryptosporidium oocyst and Giardia cysts occurring in a surface water. Wat. Sci. Tech. 41, 31-37.

Casson L.W., Sorber C.A., Sykora J.L., Gavaghan P.D., Shapiro M.A. and Jakubowski W. (1990) Giardia in waste-water - effect of treatment. J. Water Pollut. Control Fed. 62, 670-675.

Chauret C., Springthorpe S. and Sattar S. (1999) Fate of Cryptosporidium oocysts, Giardia cysts and microbial indicators during wastewater treatment and anaerobic sludge digestion. Canad. J. Microbiol. 45, 257-262.

Chernicharo C.A.L., da Silveira Cota R., Zerbini A.M., von Sperling M. and Novy de Castro L.H. (2001) Post- treatment of anaerobic effluents in an overland flow system. Wat. Sci. Tech. 44, 229-236.

Chu Y., Jin Y. and Yates M.V. (2003) Effect of soil properties on saturated and unsaturated virus transport through columns. J. Environ. Qual. 32, 2017-2025.

Crompton D.W.T. (1988) The prevalence of ascariasis. Parasitol. Today 4, 162-169.

Divizia M., Gabrieli R., Donia D., Macaluso A., Bosach A., Guix S., Sanchez G., Villena C., Pinto R. M., Palombi L., Buonuomo E., Cenko F., Leno L., Bebeci D., and Bino S. (2004) Waterborne gastroenteritis outbreak in Albania. Wat. Sci. Tech. 50, 57-61.

Dixo N.G.H., Gambrill M.P., Catunda P.F.C. and van Haandal A.C. (1995) Removal of pathogenic microorganisms from the effluent of an upflow anaerobic digester using waste stabilization ponds. Wat. Sci. Tech 31, 275-284.

Falabi J.A., Gerba C.P. and Karpiscak M.M. (2002) Giardia and Cryptosporidium removal from waste-water by a duckweed (Lemma gibba L.) covered pond. Lett. Appl. Microbiol. 34,384-387.

Feachem R.G., Bradley D., Garelick H. and Mara D.D. (1983) Sanitation and Disease, Wiley, New York.

Freedman D.O. (1992) Intestinal nematodes, in Infectious Diseases. Gorbach S.L., Barlett J.G. and Blacklow N. (Eds.)., Saunders, Philadelphia, pp. 2003-2008.

Geldreich E.E., and Kenner B.A. (1969) Comments on fecal streptococci in stream pollution. J J. Water Pollut. Control Fed. 41, R336-R341.

Gennaccaro A.L., McLayghlin M.R., Quintero-Betancourt W., Hoffman D. E. and Rose J. B. (2003) Infectious Cryptosporidium parvum oocysts in reclaimed effluent. Appl. Env. Micr. 69, 4983-4984.

Gerba C.P., Gramos D.M. and Nwachuku N. (2002) Comparative inactivation of enteroviruses and adenovirus 2 by UV light. Appl. Env. Micr. 68, 51675169.

Gerba C.P., Thurston J.A., Falabi J.A., Watt P. and Karpiscak M.M. (1999) Optimization of artificial wetland design for removal of indicator microorganisms and pathogenic protozoa. Wat. Sci. Tech. 40, 363-368.

Gearheart R.A., Klopp F. and Allen G. (1989) Constructed free surface wetlands to treat and receive wastewater; Pilot to full-scale, in Hammer, D. A. (Ed.). Constructed Wetlands for Wastewater Treatment: Municipal, Industrial and Agricultural, Lewis Publishers, Chelsea, Michigan. pp. 121-137. 
Gersberg R.M., Elkins B.V., Lyon S.R. and Goldman C.R. (1987) Survival of bacteria and viruses in municipal wastewaters applied to artificial wetlands in Reddy K. R. and Smith, W.H. (Eds.) Aquatic Plants for Water Treatment and Resource Recovery. Magnoia Publishing, Orlando. pp. 237-245.

Gersberg R.M., Gearhart R.A. and Ives M. (1989) Pathogen removal in constructed wetlands, in Hammer, D.A. (Ed.) Constructed Wetlands for Wastewater Treatment: Municipal, Industrial, and Agricultural. Lewis Publishers, Chelsea, Michigan. pp. 431-445.

Glass J.S. and O'Brien (1980) Enterovirus and coliphage inactivation during activated sludge treatment. Wat. Res. 14, 877-882.

Gleeson C., and Gray N. (1997) The Coliform Index and Waterborne Disease, E and FN Spon, London.

Jepsen A. and Roth H. (1952) Epizootiology of Cysticercus bovis-restance of the eggs of Tenia sageninata. Report 14. Vet. Cong. 22, 43-50.

John D.E., Nwachuku N., Pepper I.L. and Gerba C.P. (2003) Development and optimization of a quantitative cell culture infectivity assay for the microsporidium Encephalitozoon intestinalis and application to ultraviolet light inactivation. J. Microbiol. Methods. 52, 183-196.

Johnson D.C., Enriquez C.E., Pepper I.L., Davis T.L., Gerba C.P. and Pepper I.L. (1997) Survival of Giardia, Cryptosporidium, poliovirus and Salmonella in marine waters. Wat. Sci. Tech. 35, 261-268

Kadlec R.H. and Knight R.L. (1996) Treatment Wetlands. Lewis Publishers, Boca Raton, Florida.

Kertratanakul A. and Ohgaki S. (1989) Indigenous coliphages and RNA-F-specific coliphages associated with suspended solids in activated sludge process. Wat. Sci. Tech. 27, 257-260.

Korich D.G., Mead J.R., Madore M.S., Sinclair N.A., and Sterling C.R. (1990) Effect of zone, chlorine dioxide, chlorine, and monochloramine on Cryptosporidium parvum oocyst viability. Appl. Env. Micr. 56, 1423 1428.

Krishnaswami S.K. and Post F.J. (1968) Effects of chlorine on Ascaris (Nematoda) egg. Hlth. Lab. Sci. 5, 225-232.

Kukkula M., Arstila P., Klossner M.L., Maunula L., Bonsdorff and Jaatinen P. (1997) Waterborne outbreak of gastroenteritis. Scand. J. Infect. Dis. 29, 415-418.

Kutz S.M. and Gerba C.P. (1988) Comparison of virus survival in freshwater sources. Wat. Sci. Tech. 20,467471.

Leong L.Y.C. (1983) Removal and inactivation of viruses by treatment processes for potable water and wastewater - a review. Wat. Sci. Tech. 15, 91-114.
Li D., Craik S.A., Smith D.W. and Belosevic M. (2008) Survival of Giardia lamblia trophozoites after exposure to UV light. Fems Microbiology Letters 278, 56-61.

Lipp E.K., Huq A. and Colwell R.R. (2002) Effects of global climate on infectious disease: the cholera model. Clin. Microbiol. Rev. 15, 757-770.

Lloyd B.J. and Frederick G.L. (2000) Parasite removal by waste stabilization pond systems and its relationship between concentrations in sewage and prevalence in the community. Wat. Sci. Tech. 42, 375-386.

Logan A.J., Stevik T.K., Siegrist R.L. and Ronn R.M. (2001) Transport and fate of Cryptosporidium parvum oocysts in intermittent sand filters. Wat. Res. 35, 4359-4369.

Mayer C.L. and Palmer C.J. (1996) Evaluation of PCR, nested PCR and fluorescent antibodies for detection of Giardia and Cryptosporidium species in wastewater. Appl. Env. Micr. 62, 2081-2085.

McKay L.D., Cherry J.A., Bales R.C., Yahya M.T. and Gerba C.P. (1993) A field example of bacteriophage as tracers of fracture flow. Environ. Sci. Tech. 27, 10751079 .

Madore M.S., Rose J.B., Gerba C.P., Arrowood M.J. and Sterling C.R. (1987) Occurrence of Cryptosporidium oocysts in sewage effluents and selected surface waters. J. Parasitol. 73, 702-705.

Montgomery (1988) Water Treatment and Design. John Wiley \& Sons, New York.

Nichols G. (2008) Epidemiology. In: Fayer R. and Xiao L. (Eds.), Cryptosporidium and Cryptosporidiosis. Second edition. IWA Publishing, London, pp.79-118.

Oragui J. (2003) Viruses in feces, in Mara D. and Horan N. (Eds.). The Handbook of Water and Wastewater Microbiology. Academic Press, San Diego. pp.473-476.

Ottoson J., Hansen A., Bjorlenius B., Norder H. and Senstrom T. A. (2006) Removal of viruses parasitic protozoa and microbial indicators in conventional and membrane processes in a wastewater pilot plant. Wat. Res. 40, 1449-1457.

Pant A. and Mittal A.K. (2007) Monitoring of pathogencitity of effluents from the UASB based sewage treatment plant. Environ. Monit. Assess. 133, 43-51.

Payment P., and Franco E. (1993) Clostridium perfringens and somatic coliphages as indicators of the efficiency of drinking water treatment for viruses and protozoan cysts. Appl. Env. Micr. 59, 2418-2424.

Quinonez-Diaz M., Karpiscak M.M., Ellman E.D. and Gerba C.P. (2001) Removal of pathogenic and indicator microorganisms by a constructed wetland receiving untreated domestic wastewater. J. Environ. Sci. Hlth. Part A. 36, 1311-1320. 
Rao V.C., Lakhe S.B., Waghmare S.V. and Dube P. (1977) Virus removal in activated sludge sewage treatment. Prog. Wat. Tech. 9, 113-127.

Rao V.C., Metcalf T.G. and Melnick J.L. (1986) Removal of pathogens during wastewater treatment. In: Rehm, H. J. and Reed, C. (Eds.). Biotechnology, Vol. 8.VCH, Berlin.

Robertson L.J., Paton C.A., Campbell A.T., Smith P.G., Jackson M.H., Gilmore R.A., Black S.E., Stevenson D.A., and Smith H.V. (2000) Giardia cysts and Cryptsporidium oocysts at sewage treatment works in Scotland, UK. Wat. Res. 34, 2310-2322.

Rose J.B., Huffman D.E., Riley K., Farrah S.R., Lukasik J.O. and Hamann C.L. (2001) Reduction of enteric microorganisms at the Upper Occoquan Sewage Authority Water Reclamation Plant. Water Environ. Res. 73, 711-720.

Rose J.B., Dickson L.J., Farrah S.R. and Carnahan R.P. (1996) Removal of pathogenic and indicator microorganisms by a full-scale water reclamation facility. Wat. Res. 30, 2785-2797.

Rose J.B., Lisle J.T. and LeChevallier M. (1997) Waterborne Cryptosprodiosis: incidence, outbreaks and treatment strategies, in Fayer, R. (Ed.), "Cryptosporidium and Cryptosporodiosis." CRC Press, Boca Raton, Florida. pp. 93-109.

Roessler P.F., and Severin B.F. (1996) Ultraviolet light disinfection of water and wastewater, in Modeling Disease Transmission and Its Prevention by Disinfection (C.J. Hurst, ed.) Cambridge University Press, Cambridge, UK, pp. 313-368.

Safferman R.S. and Morris M.E. (1976) Assessment of virus removal by multi-stage activated sludge process. Wat. Res. 10, 413-42

Sano D., Matsuo T. and Omura T. (2004) Virus-binding proteins recovered from bacterial culture derived from activated sludge by affinity chromatography assay using a virus capsid peptide. Appl. Env. Micr. 70, 3434-3442.

Schaub S.A., Kenyon K.F., Bledsoe and Thomas R.E. (1978) Evaluation of the overland runoff mode of land application for virus removal in Mckim, (Ed.), State of Knowledge in Land Treatment of Wastewater. Cold Regions Research and Engineering Laboratory. Hanover, NH. pp. 245-252.

Scheuerman P.R., Bitton G. and Farrah S.R. (1989) Fate of microbial indicators and viruses in a forested wetland, in Hammer, D. A. (Ed.), Constructed Wetlands for Wastewater Treatment: Municipal, Industrial and Agricultural. Lewis Publishers, Chelsea, Michigan. pp. 657-663.
Schwartzbrod J., Stein J. L., Bouhoum K. and Baleux B. (1989) Impact of wastewater treatment $n$ helminth eggs. Wat. Sci. Tech. 21, 295-297.

Sobsey M.D. (1989) Inactivation of health-related microorganisms in water by disinfection processes. Wat. Sci. Tech. 21, 179-195.

Stewart M.H. and Olson B.H. (1996) Bacterial resistance to portable water disinfectants, in Hurst, C. H. (Ed.), Modeling Disease Transmission and Its Prevention by Disinfection. Cambridge University Press, pp. 140-192.

Stott R., Jenkins T., and Williams J. (1996) Pathogen removal and microbial ecology in gravel bed hydroponic treatment of wastewater. Research Monograph 4, Dept. of Civil Engineering, University of Portsmouth, UK.

Stott R., Jenkins T., Bahgat M. and Shalaby I. (1999) Capacity of constructed wetlands to remove parasite eggs from wastewaters in Egypt. Wat. Sci. Tech. 40, 117-198.

Stott R. (2003) Fate and behavior of parasites in wastewater treatment systems, in Mara D. and Horan N. (Eds.), The Handbook of Water and Wastewater Microbiology. Academic Press, San Diego. pp.491-521.

Tartera C., and Jofre J. (1987) Bacteriophage active against Bacteroides fragilis bacteriophage as indicators of the virological quality of water. Wat. Sci. Tech. 18, 16231637.

Tartera C., Lucena F., and Jofre J. (1989) Human origin of Bacteroides fragilis bacteriophage present in the environment. Appl. Env. Micr. 55, 2696-2701.

Toranzos G.A. (1991) Current and possible alternative indicators of fecal contamination in tropical waters: a short review. Environ. Toxicol. Water Qual. 6, 121-130.

Veerannan K.M. (1977) Effect of sewage treatment by stabilization pond method on the survival of intestinal parasites. Indian J. Environ. Hlth. 19, 100-106.

Wharton D.A. (1980) Naematode egg-shells. Parasitol. 81, 447-463.

Yates M.V. and Gerba, C.P. (1998) Microbial considerations in wastewater reclamation and reuse, in Asano, T. (Ed.), Wastewater Reclamation and Reuse. Technomic Publishing, Lancaster, PA. pp. 437-488.

Zhang K. and Farahbakhsh K. (2007) Removal of native coliphages and coliform bacteria from municipal wastewater by various wastewater treatment processes: implications to water reuse. Wat. Res. 41, 2816-2824. 


\section{NOMENCLATURA}

\begin{tabular}{lll}
\hline Símbolo & Descripción & Unidad \\
\hline$I$ & Intensidad & $\mu \mathrm{W} / \mathrm{cm}^{2}$ \\
$K$ & Constante de decaimiento & $1 / \mathrm{d}$ \\
$N$ & Número de muestras & \\
$N i$ & Densidad inicial del organismo antes de la exposición & númo $/ \mathrm{cm}^{3}$ \\
$N o$ & Número de organismo al tiempo 0 (inicial) & \\
$N S$ & Densidad de organismos sobrevivientes & número $/ \mathrm{cm}^{3}$ \\
$N t$ & Número de microorganismo al tiempo t & \\
$T$ & Tiempo de exposición & $\mathrm{h}$ \\
$T$ & Tiempo & $\mathrm{d}$ \\
$X$ & Número de microorganismos por volumen de muestra & \\
$\bar{x}$ & Media geométrica & \\
\hline
\end{tabular}

\begin{tabular}{ll}
\hline Abreviación & Descripción \\
\hline CT & Concentración de desinfectante con respecto al tiempo de contacto \\
ADN & Acido desoxirrubonulcelico \\
DAPI & 4 ',6-diamidino-2-fenilindol \\
EHEC & Cepas enterohemorrágicas \\
ETEC & Cepas enterotoxigénicas \\
CF & Coliformes fecales \\
FITC & Isotiocianato de fluoresceína \\
EF & Estreptococo fecal \\
VHA & Virus de hepatitis A \\
VHE & Virus de hepatitis E \\
TRH & Tiempo de retención hidráulico \\
SUH & Síndrome urémico hemolítico \\
NMP & Número más probable \\
ARN & Acido ribonocleico \\
UASB & Reactor anaerobio de flujo ascendente \\
UV & Radiación ultravioleta \\
\hline
\end{tabular}


La contaminación del agua potable por patógenos microbiológicos puede causar brotes de enfermedades y contribuir con la tasa de mortalidad de las enfermedades. Es importante resaltar que las enfermedades transmitidas por el agua se generan por la ruta oral-fecal, de humano a humano o de animales a humanos, así, el agua potable representa una de las muchas fuentes posibles de transmición. La contaminación del agua potable por las aguas residuales es un problema común en los países en desarrollo (foto: UNESCO-IHE archive)

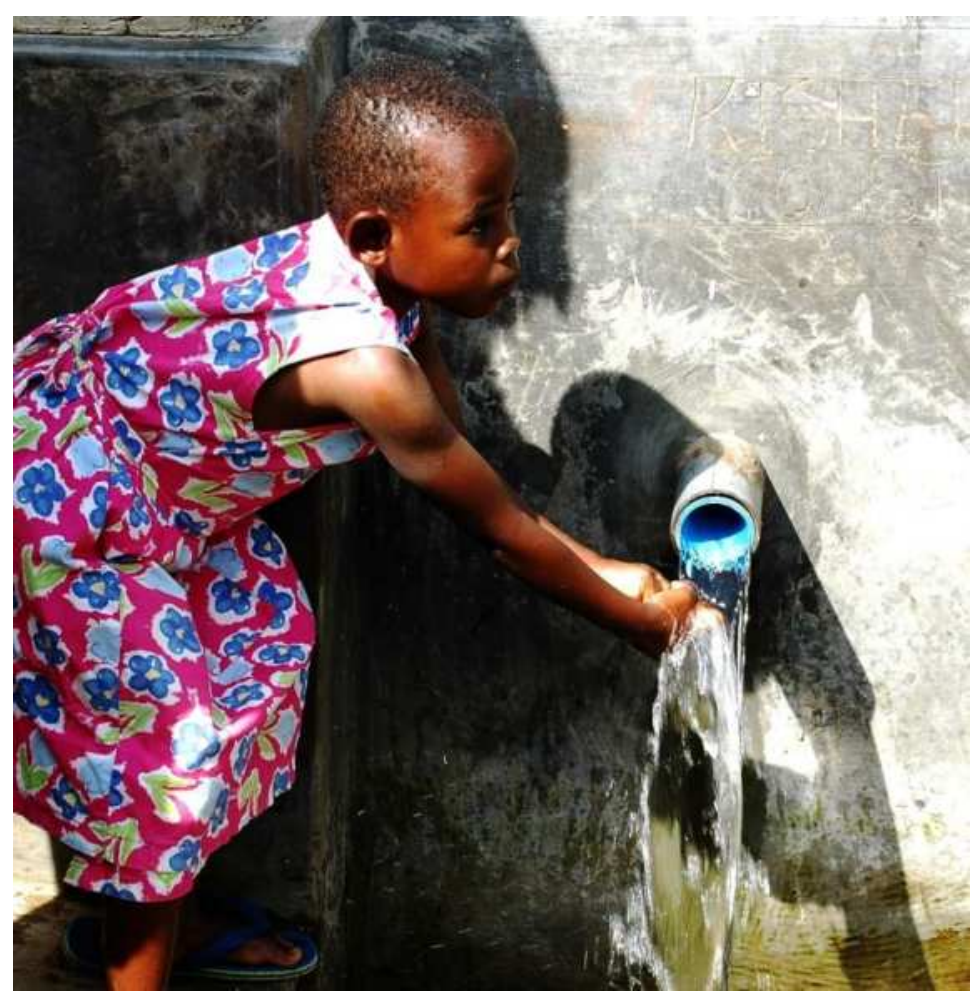




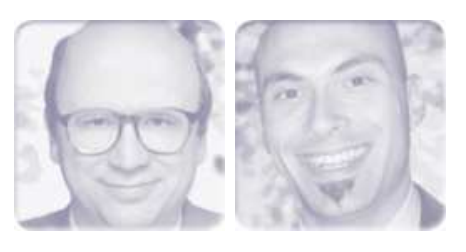

\section{9}

\section{Aireación y Mezclado}

\section{Michael K. Stenstrom y Diego Rosso}

\subsection{LA TECNOLOGÍA DE AIREACIÓN}

\subsubsection{Introducción}

La aireación es un proceso esencial en la mayoría de las plantas de tratamiento de aguas residuales. Involucra los costos más altos de consumo de energía, alcanzando hasta $75 \%$ del consumo total de energía de las plantas (Randon, 1995). Por esta razón, cuando se aplican prácticas de uso eficiente de energía, la operación eficiente de los sistemas de aireación es de crucial importancia. La Figura 9.1 muestra un esquema cualitativo del uso de energía en una planta de tratamiento de aguas residuales de tipo convencional.

Los sistemas de aireación transfieren el oxígeno de la atmósfera a las aguas residuales en los tanques de tratamiento biológico mediante (i) la agitación de la superficie del líquido con un mezclador o una turbina,

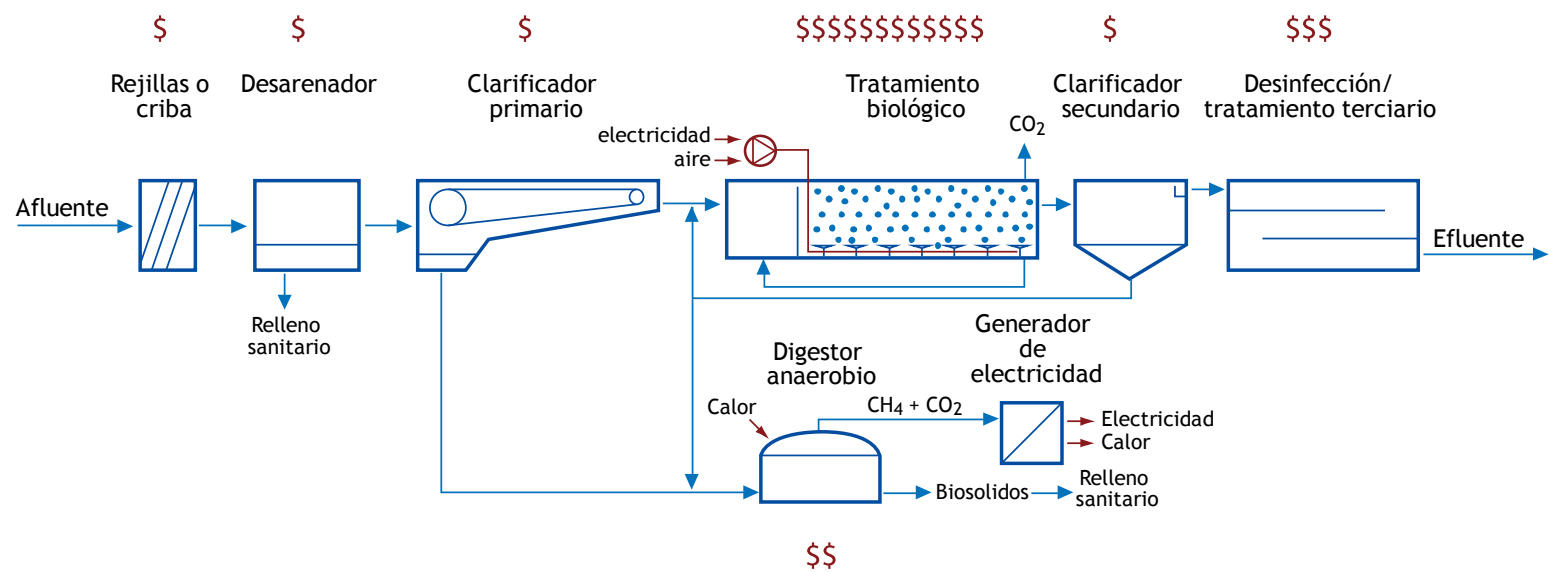

Figura 9.1 Esquema de una planta de tratamiento de aguas residuales el cual muestra una comparación cualitativa del consumo de energía en cada una de las fases o unidades de tratamiento. 
(ii) la liberación de aire a través de orificios macroscópicos o materiales porosos, ó (iii) a través del contacto directo del aire con el agua residual. Los sistemas de aireación de burbujas gruesas o de mayor tamaño crean gradientes de velocidad de relativamente mayor magnitud debido a las interfases gas-líquido mayores por lo que son conocidos como interfases de régimen de flujo rápido. Mientras que cuando los sistemas de aireación crean o hacen uso de burbujas pequeñas o finas se generan gradientes de velocidad que tienen interfases gas-líquido bajas conocidas como interfases de régimen de flujo lento (Rosso and Stenstroom, 2006a).

Cuando se analizan o determinan las características específicas de los sistemas de aireación es importante definir los parámetros de eficiencia. Esto es necesario para comparar las diferentes tecnologías, así como también para monitorear la operación de los sistemas de aireación. El parámetro más básico es la tasa de oxígeno transferida en agua limpia, definida como la tasa de transferencia de oxígeno (OTR por sus siglas en inglés Oxygen Transfer Rate-, $\left.\mathrm{kgO}_{2} / \mathrm{h}\right)$ :

$$
O T R=k_{L} a\left(D O-D O_{s a t}\right) V
$$

donde

$\mathrm{k}_{\mathrm{L}} \quad$ coeficiente de transferencia de masa líquidosuperficie $(/ \mathrm{h})$

DO concentración de oxígeno disuelto en agua $\left(\mathrm{kgO}_{2} / \mathrm{m}^{3}\right)$

$\mathrm{DO}_{\text {sat }}$ concentración de saturación de oxígeno disuelto en agua $\left(\mathrm{kgO}_{2} / \mathrm{m}^{3}\right)$

$\mathrm{V} \quad$ volumen de agua $\left(\mathrm{m}^{3}\right)$

El parámetro OTR cuantifica la capacidad del sistema de aireación, por ejemplo, la cantidad de oxígeno que puede suministrar al agua por unidad de tiempo. El OTR define la capacidad del sistema de aireación independientemente de su eficiencia concerniente a la transferencia de oxígeno; de esta manera, es necesario definir parámetros adicionales. El parámetro más común para describir la eficiencia energética es la eficiencia de aireación (AE por sus sigles en inglés - aeration efficiency-, $\mathrm{kgO}_{2} / \mathrm{kWh}$ ) definida como:

$$
A E=\frac{O T R}{P} \quad\left(\mathrm{kgO}_{2} / \mathrm{kWh}\right)
$$

donde

$\mathrm{P} \quad$ energía consumida por el sistema de aireación $(\mathrm{kW})$
En el caso de los sistemas de aireación sumergida (tales como los difusores de burbuja de aire fina o gruesa), la eficiencia de transferencia de oxígeno (OTE, por sus siglas en inglés - Oxygen Transfer Efficiency, \%) se puede definir como:

$$
O T E=\frac{\left(O_{2, e n t}-O_{2, s a l}\right)}{O_{2, e n t}}
$$

donde $\mathrm{O}_{2 \text {,ent }}$ y $\mathrm{O}_{2 \text {,sal }}$ representan los flujos de transferencia de masa de oxígeno que ingresan y egresan, respectivamente, de un volumen de agua. OTE proporciona una medida para medir la eficiencia absoluta del proceso de aireación. En ocasiones, el uso de este parámetro es más conveniente con respecto a otros porque permite comparar los sistemas de aireación sin tomar en cuenta la complicada operación de compresores y sopladores. Los sopladores generalmente son instalados por diferentes fabricantes o compañías, por lo que el diseño y especificaciones de los sistemas de aireación puede simplificarse si se utilizan diferentes parámetros para determinar la eficiencia del proceso de aireación (mediante el OTE) y del soplador.

Con la finalidad de evitar sesgos debidos a condiciones ambientales y de proceso específicos del sitio en cuestión, las pruebas base de aireación se deben llevar a cabo bajo condiciones estándares a $20^{\circ} \mathrm{C}$ y $1 \mathrm{~atm}$ bajo concentraciones nulas iniciales de oxígeno disuelto y de salinidad. De esta manera, los resultados generalmente se reportan en términos de la eficiencia de transferencia de oxígeno estándar (SOTE, \%), tasa de transferencia de oxígeno estándar ( $\left.\mathrm{SOTR}, \mathrm{kgO}_{2} / \mathrm{h}\right)$, ó eficiencia estándar de aireación ( $\mathrm{SAE}, \mathrm{kgO}_{2} / \mathrm{kWh}$ ).

Para la aplicación de las condiciones estándar a las condiciones específicas de un sitio de estudio se requiere el uso de parámetros empíricos y locales. El agua utilizada en el proceso contiene contaminantes disueltos y suspendidos que pueden causar diferencias con respecto al desempeño de los aireadores probados $\mathrm{u}$ operados con agua limpia. El parámetro que tiene el mayor impacto es el factor $\alpha$, el cual está definido como la relación que existe entre los coeficientes de transferencia de masa en el agua residual o de proceso y en agua limpia:

$$
\alpha=\frac{\left(k_{L} a\right)_{\text {agua residual }}}{\left(k_{L} a\right)_{\text {agua limpia }}}
$$

$$
\alpha=\frac{\alpha S O T E}{S O T E}
$$


donde

SOTE eficiencia de transferencia de oxígeno bajo condiciones estándar (\%)

aSOTE eficiencia de transferencia de oxígeno en el agua de proceso bajo condiciones estándar excluyendo el efecto causado por los contaminantes en el coeficiente de transferencia de masa (\%)

Los métodos necesarios para expresar los valores estándares bajo condiciones locales de proceso para diversas situaciones pueden encontrarse en diversos documentos (como por ejemplo, a presiones barométricas o temperaturas diferentes, entre otros parámetros). Existen diversos parámetros que pueden utilizarse para describir la operación de los sistemas de aireación. La Tabla 9.1 presenta varios de estos parámetros utilizados a lo largo de este capítulo.

Existen diversas opciones para describir o medir la energía de los sistemas de aireación (Tabla 9.2). El consumo de electricidad medido en los cables de suministro de energía eléctrica corresponde al consumo de energía real de los motores eléctricos utilizado por los aireadores o sopladores. Esta es la opción más utilizada e incluye todas las pérdidas de energía del sistema. En algunas ocasiones, se utiliza la energía producida o generada por un motor. A veces, se llega a utilizar la energía suministrada, lo cual está directamente relacionado con la energía real consumida durante el proceso de aireación. Es importante no confundir los diferentes parámetros utilizados para el consumo de energía o la energía generada para ser consistentes durante el diseño del proceso.

El consumo de electricidad medido en los cables conductores es el parámetro más utilizado debido a que es el que mejor describe el consumo real de energía. Cuando se utiliza este parámetro deben determinarse las eficiencias reales de los sopladores, motores o cajas de cambio. La energía proporcionada por los motores puede ser un parámetro conveniente de diseño si las especificaciones de los motores son proporcionadas por separado. Un error común en el diseño de los sistemas de aireación es el de confundir los diversos parámetros que se utilizan para describir y medir el consumo de generación de energía. Si no se especifica de otra manera, a lo largo de este capítulo cualquier referencia al consumo de energía estará relacionado con el consumo de electricidad medido en las líneas de suministro de energía eléctrica. La siguiente sección presenta una descripción de los sistemas de aireación comerciales.

Tabla 9.1 Resumen de todos los parámetros utilizados para definir y especificar las características de los sistemas de aireación

\begin{tabular}{|c|c|c|}
\hline Parámetro & Definición & Notas \\
\hline OTR & Tasa de transferencia de oxígeno en agua limpia & $=\mathrm{kLa}\left(\mathrm{DO}-\mathrm{DO}_{\mathrm{sat}}\right) \mathrm{V}$ \\
\hline SOTR & $\begin{array}{l}\text { Tasa de transferencia de oxígeno bajo condiciones estándar en agua } \\
\text { limpia }\end{array}$ & \\
\hline OTE & Eficiencia transferencia de oxígeno en agua limpia & $=\left(\mathrm{O}_{2, \text { ent }}-\mathrm{O}_{2, \text { sal }}\right) / \mathrm{O}_{2, \text { ent }}$ \\
\hline SOTE & $\begin{array}{l}\text { Eficiencia transferencia de oxígeno bajo condiciones estándar en agua } \\
\text { limpia }\end{array}$ & \\
\hline $\mathrm{AE}$ & Eficiencias de aireación en agua limpia & $=\mathrm{OTR} / \mathrm{P}$ \\
\hline SAE & Eficiencia de aireación bajo condiciones estándar en agua limpia & \\
\hline $\mathrm{k}_{\mathrm{La}}$ & Coeficiente de transferencia de masa a líquido-superficie & Medido en agua limpia \\
\hline$\square$ & $\begin{array}{l}\text { Factor alpha, relación entre la transferencia de masa en aguas residuales } \\
\text { y en agua limpia }\end{array}$ & $\begin{aligned} \mathrm{s} & =\alpha \mathrm{SOTE} / \mathrm{SOTE} \\
& =\mathrm{k}_{\mathrm{L}} \mathrm{a}_{\mathrm{agua}} \text { residual } / \mathrm{k}_{\mathrm{L}} \mathrm{a}_{\text {agua limpia }}\end{aligned}$ \\
\hline $\mathrm{F}$ & Factor de ensuciamiento o bloqueo & $=\alpha \mathrm{SOTE}_{\text {difusor nuevo }} / \alpha \mathrm{SOTE}_{\text {difusor usado }}$ \\
\hline$\alpha \mathrm{F}$ & Factor $\alpha$ para difusores usados & $=\alpha \mathrm{F}$ \\
\hline$\alpha \mathrm{SOTE}$ & $\begin{array}{l}\text { Eficiencia de transferencia de oxígeno bajo condiciones estándar en agua } \\
\text { de residual }\end{array}$ & \\
\hline$\alpha$ FSOTE & $\begin{array}{l}\text { Eficiencia de transferencia de oxígeno bajo condiciones estándar en agua } \\
\text { de residual para difusores usados }\end{array}$ & \\
\hline$\alpha \mathrm{SAE}$ & Eficiencia de aireación bajo condiciones estándar en agua residual & \\
\hline$\alpha \mathrm{FSAE}$ & $\begin{array}{l}\text { Eficiencia de aireación bajo condiciones estándar en agua residual para } \\
\text { difusores usados }\end{array}$ & \\
\hline
\end{tabular}

Las condiciones estándar se definen como aquellas llevadas a cabo a $20^{\circ} \mathrm{C}, 1 \mathrm{~atm}$, con cero salinidad y nula concentración de oxígeno disuelto en agua limpia. $\mathrm{P}=$ energía suministrada (por su sigle en inglés, power); $\mathrm{V}=$ volumen de agua. 
Tabla 9.2 Resumen de las eficiencias de aireación (AE) y eficiencias estándares de aireación (SAE) para aireadores superficiales comerciales

\begin{tabular}{|c|c|c|}
\hline $\begin{array}{l}\mathrm{SAE} \\
\left(\mathrm{kgO}_{2} / \mathrm{kWh}\right)\end{array}$ & $\begin{array}{l}\mathrm{AE} \\
\text { TRS Corto } \\
(@ 2 \mathrm{mgDO} / \mathrm{l})\end{array}$ & $\begin{array}{l}\mathrm{AE} \\
\text { TRS Largo } \\
(@ 2 \mathrm{mgDO} / \mathrm{l})\end{array}$ \\
\hline $\begin{array}{l}\text { Aireadores superficiales de } \text { alta }_{0.9-1.3} \\
\text { velocidad }\end{array}$ & $0.4-0.8$ & \\
\hline $\begin{array}{l}\text { Aireadores superficiales de baja }{ }_{1.5-2.1} \\
\text { velocidad }\end{array}$ & $0.7-1.5$ & \\
\hline Sistemas de burbuja gruesa & $0.3-0.7$ & 0.4-0.9 \\
\hline $\begin{array}{l}\text { Turbinas o jets de } \text { aireación }_{1.2-1.8} \\
\text { (burbuja fina) }\end{array}$ & $0.4-0.6$ & $0.6-0.8$ \\
\hline Difusores finos (burbuja fina) & $0.7-1.0$ & $2.0-2.6$ \\
\hline
\end{tabular}

\subsubsection{Aireadores superficiales}

Los aireadores superficiales pertenecen a la primera generación de tecnologías de transferencia de oxígeno. Típicamente, los aireadores superficiales se caracterizan por tener altos valores de OTR y bajos valores de SAE (en el rango de 0.9-2.1 $\mathrm{kgO}_{2} / \mathrm{kWh}$ ). Los aireadores superficiales agitan el líquido esparciéndolo como pequeñas gotas de agua creando una cresta de agua turbulenta que fluye a varios metros por segundo. Las gotas de agua que viajan a través de la cresta entran en contacto turbulento con el aire atmosférico y generalmente se oxigenan por lo menos hasta un valor medio de saturación. Tan pronto como las gotas de agua hacen contacto con la superficie líquida del tanque de aireación se mezclan con el agua del tanque creando un patrón de oxígeno disuelto típico de estos sistemas tal y como se ilustra en la Figura 9.2.

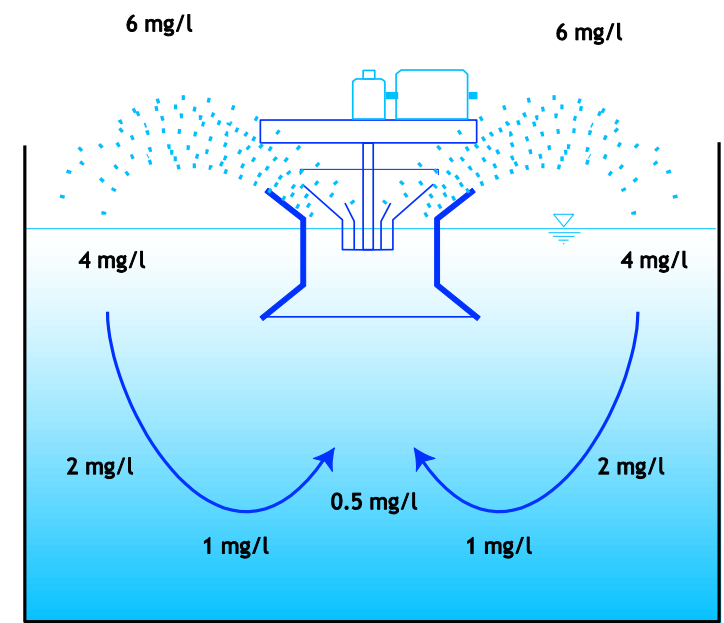

Figura 9.2 Esquema de los perfiles de oxígeno disuelto observados típicamente en tanques equipados con aireadores superficiales
Dado que ni aire ni oxígeno son suministrados por aireadores superficiales, el parámetro OTE no puede ser definido en estos sistemas. El movimiento del líquido también proporciona mezclado. En algunos casos, las características y especificaciones de los aireadores superficiales se defininen mediante la tasa o flujo de bombeo del líquido o en términos del parámetro OTR.

Los aireadores superficiales pueden tener dos configuraciones: de alta velocidad (por ejemplo de una sola velocidad) y de baja velocidad (con una caja de velocidades) (Figura 9.3). Los aireadores superficiales de alta velocidad rotan a velocidades de 900-1200 rpm. Y debido a que no tienen una caja de velocidades pueden ser fácilmente instalados y son más económicos. Por otra parte, la cresta que generan es altamente turbulenta, lo que resulta en la generación de aerosoles y la posible ruptura del floc de lodos activados. Los dos tipos de aireadores superficiales tienen un alto contacto del aire con el agua causando la evaporación del agua y por consiguiente su enfriamiento. En ciertas instalaciones, tales como en lagunas ubicadas en países con clima cálido 0 en plantas industriales, los aireadores superficiales pueden ser una buena elección para enfriar los efluentes. Para climas fríos no se recomienda la instalación de aireadores superficiales ya que el proceso de enfriamiento reduce la actividad biológica y durante el invierno pueden congelarse. En general, los aireadores superficiales de alta velocidad tienen SAE más bajos que los de baja velocidad (0.9-1.3 $\mathrm{kgO}_{2} / \mathrm{kWh}$ versus $1.5-2.1$ $\mathrm{kgO}_{2} / \mathrm{kWh}$, respectivamente).

La introducción de una caja de velocidades entre el motor eléctrico y el mezclador permiten que el aireador rote a velocidades más bajas (30-60 rpm). Esto está generalmente asociado a un incremento en los costos de inversión y a tiempos de compra y adquisición más largos 

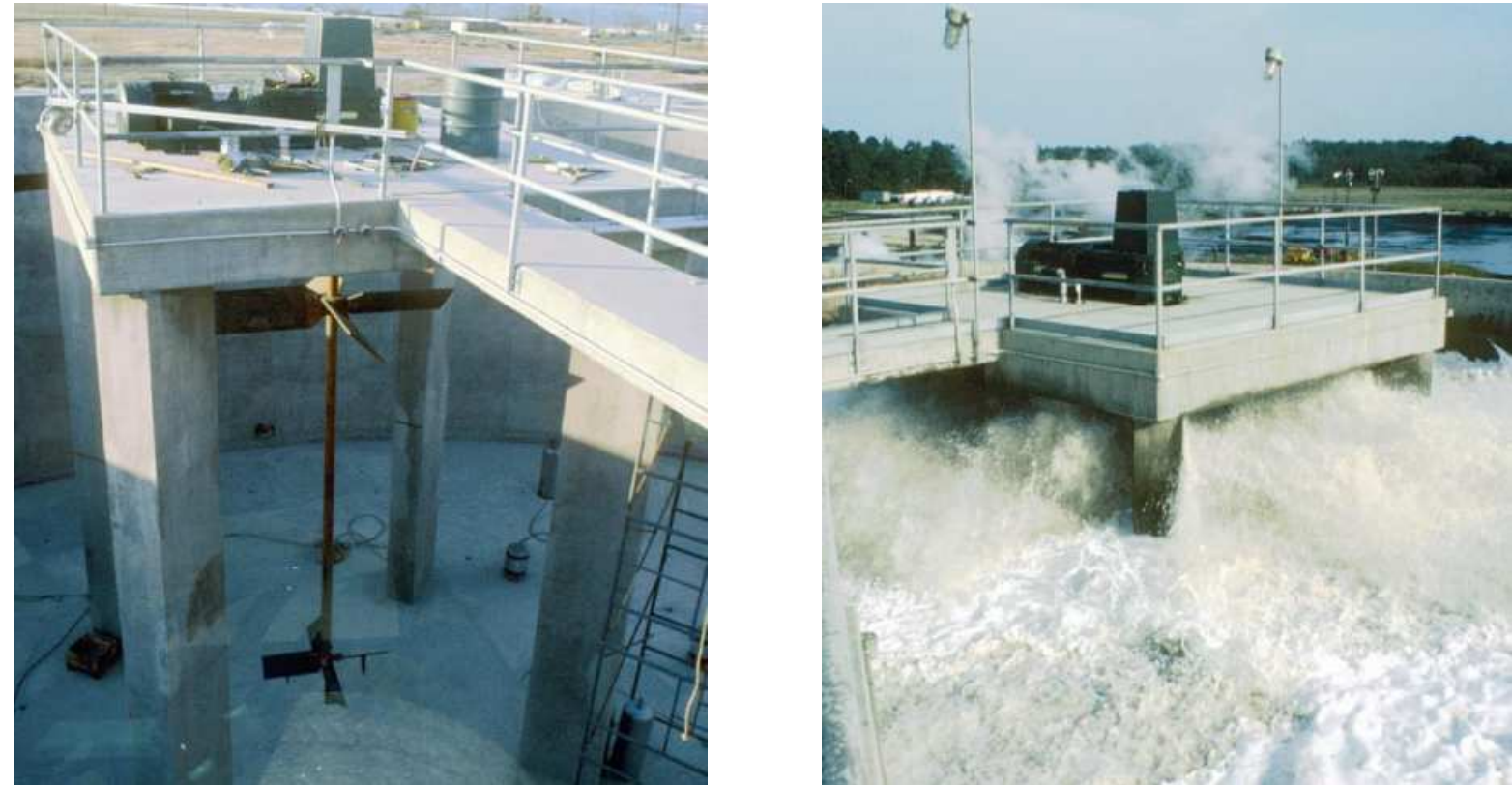

Figura 9.3 Aireador superficial de baja velocidad durante su instalación (izquierda) y en operación (derecha). La forma de las aspas del mezclador ubicado al fondo del tanque asegura que los sólidos no sedimenten. Las columnas del sistema estructural sobre el cual se apoya el aireador actúan también como mamparas para evitar la creación de vórtices (fotos: M.K. Stenstrom)

(principalmente debido a que la caja de velocidades se fabrica únicamente después de que el sistema ha sido adquirido). Sin embargo, los costos iniciales de inversión y los períodos de compra y adquisición más largos pueden ser recompensados con eficiencias de aireación más altas. La pérdida de calor y la formación de aerosoles son factores importantes y deben de ser cuidadosamente considerados cuando se seleccionan los sistemas de aireación. Sobre todo teniendo en cuenta que la generación de aerosoles y olores pueden ser altamente sensibles en zonas urbanas.

Los aireadores superficiales no pueden utilizarse en tanques profundos o lagunas si no cuentan con sistemas de mezclado que aseguren una mezcla eficiente en el fondo de estos sistemas (mediante tubos y mezcladores más profundos). Los tubos profundos pueden dirigir el flujo de agua ascendente hacia el aireador del fondo del tanque. Un mezclador profundo se monta en un eje más largo que lo ubica aproximadamente $1 \mathrm{~m}$ por encima del fondo del tanque. Rara vez se instalan mezcladores superficiales en sistemas con profundidades mayores a 4 o $5 \mathrm{~m}$ si no cuentan con tubos o mezcladores profundos.

Los fondos de lagunas o tanques de tierra deben ser protegidos contra la posible erosión causada por el líquido. Es común que mezcladores superficiales generen erosiones y huecos en tanques con fondo de tierra lo que favorece que rocas y piedras dañen los mezcladores y los sistemas estructurales. De manera adicional, en el caso de lagunas anchas pero poco profundas, la zona de acción o de influencia de los aireadores superficiales podría no alcanzar el perímetro de las lagunas creando potencialmente la formación de zonas con baja concentración de oxígeno disuelto.

Un tipo de aireador superficial que proporciona aireación y mezclado, así como también una velocidad horizontal al flujo de agua, es el mezclador superficial de cepillo o rotor. Generalmente este tipo de aireadores se pueden encontrar en diques de oxidación o carruseles (Figura 9.4). Este tipo de aireadores de baja velocidad tienen generalmente altos requerimientos específicos de energía (en otras palabras, cuentan con bajos SAE). Los altos requerimientos de energía se deben al hecho de que deben bombear y airear el líquido al mismo tiempo. Ello se debe también a la necesidad de recircular el líquido a lo largo de los diques de oxidación, mientras que en tanques con flujo pistón el agua fluye generalmente mediante la acción de la fuerza de gravedad. Dado que el agua es alrededor de tres órdenes de magnitud más densa que el aire, la mayor parte de la energía utilizada por los aireadores de cepillo se utiliza para bombear el líquido. De esta manera la eficiencia de los diques de oxidación con aireadores superficiales de cepillo puede mejorarse mediante el reemplazo de los aireadores por difusores de burbuja fina y mezcladores y bombas sumergibles de 

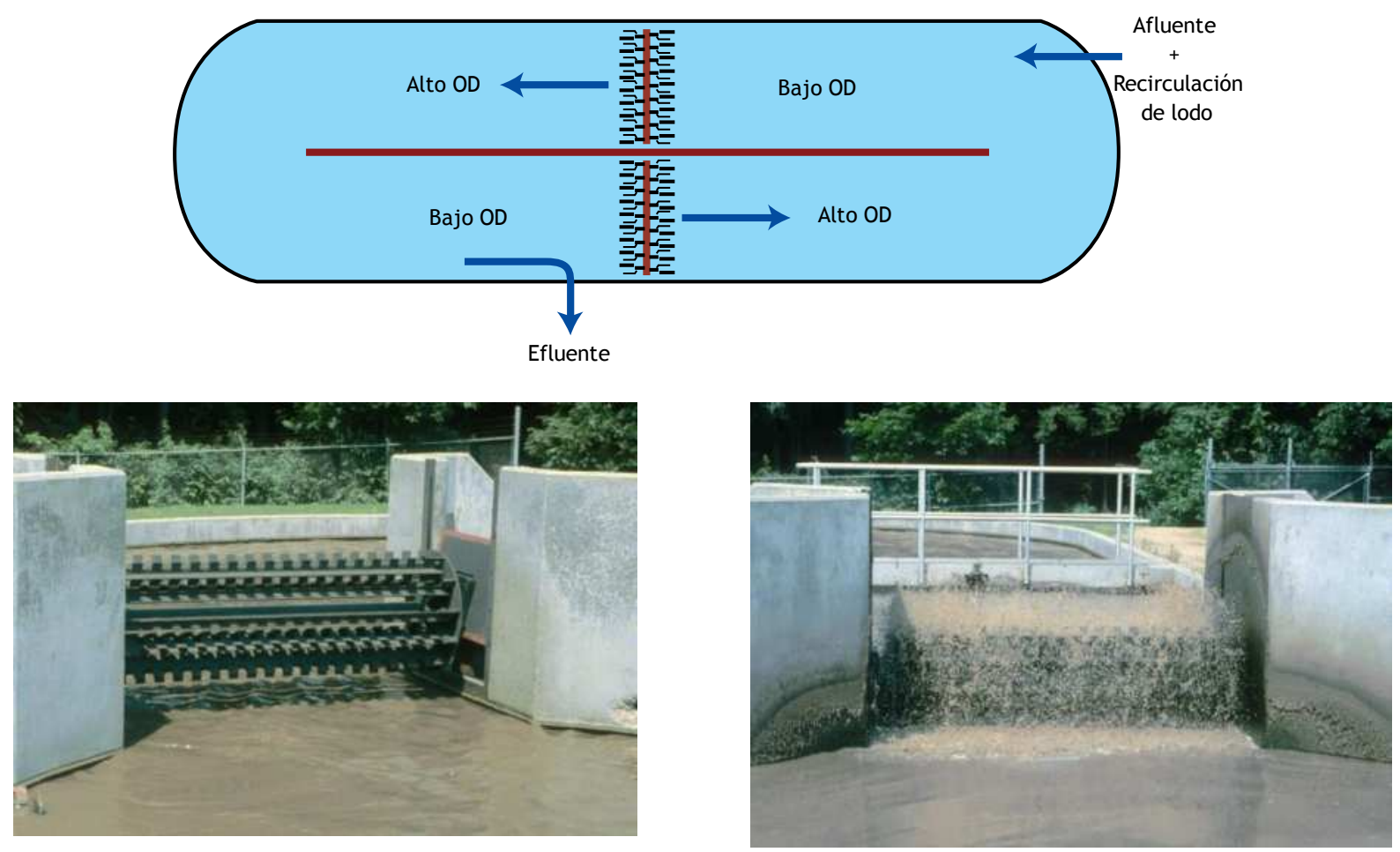

Figura 9.4 Dique de oxidación o carrusel (en la parte superior se muestra un esquema de flujo) equipado con mezcladores superficiales de cepillo durante un periodo de descanso (abajo a la izquierda) y durante su operación (abajo a la derecha). El eje del aireador está montado sobre rieles que permiten regular la energía proporcionada por el motor, así como también elevar el aireador por completo sobre la superficie libre del agua evitando obstruir el flujo del líquido durante las labores de mantenimiento o descanso (fotos: M.K. Stenstrom)

bajo consumo energético, permitiendo reducir significativamente el consumo de energía.

En raras ocasiones se instalan sistemas de aireación superficial de cepillo en lagunas aireadas de baja profundidad (Figura 9.5). La superficie del cepillo se monta sobre un elemento flotante, abierto en el centro, donde el aireador superficial lleva a cabo tanto el mezclado como la aireación. Este tipo de tecnología de aireación se selecciona en ciertas lagunas con la finalidad de reducir la operación y el mantenimiento, dado que el elemento flotante facilita las labores de mantenimiento y reparación.

También, de ser requerido, la estructura flotante permite reubicar el aireador alrededor de la laguna para prevenir la acumulación de lodo en el fondo.

\subsubsection{Sistemas de burbuja gruesa}

Todos los sistemas de burbuja grande o gruesa cuentan con orificios macroscópicos o perforaciones para liberar burbujas de aire generalmente de diámetros superiores a $50 \mathrm{~mm}$. Estas burbujas no son esféricas pero ligeramente alargadas u ovaladas. Las burbujas gruesas

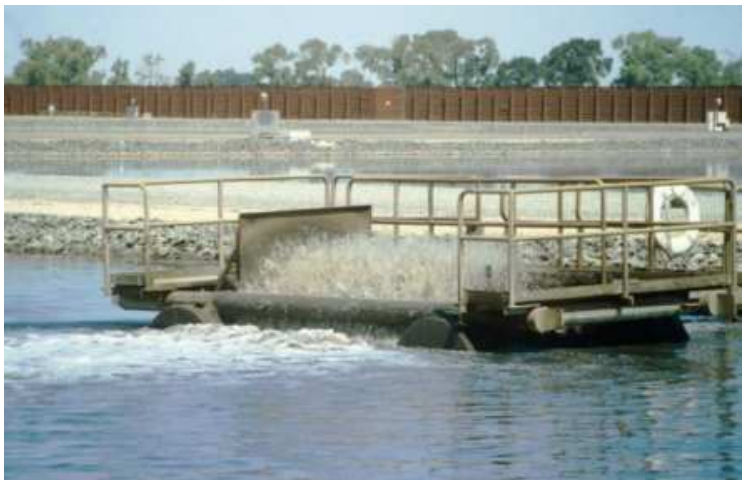

Figura 9.5 Mezclador superficial de cepillo montado sobre un elemento flotante dentro de una laguna de aireación (foto: M.K. Stenstrom)

inducen una mayor turbulencia y se caracterizan por tener una menor acumulación de surfactantes en la interfase. Por ello, tienen valores $\alpha$ superiores a los de sistemas de burbuja fina (Kessener y Ribbius, 1935; Rosso y Stenstrom 2006a). Los sistemas sumergidos, tales como los de burbuja gruesa, se instalan generalmente en el fondo de los tanques para optimizar su eficiencia. Antes, cuando los costos de energía eran menores, los difusores de burbuja gruesa eran generalmente instalados en línea a los lados de los tanques de flujo pistón (creando un 
efecto espiral), o en dos o más líneas (creando un flujo transversal). Estos sistemas requerían menos difusores, reduciendo los costos iniciales de inversión, pero tenían bajas eficiencias de aireación, y por consiguiente, requerían ser mejorados y actualizados.

Los difusores de burbuja gruesa tienen ventajas inherentes con respecto a otros sistemas. Por ejemplo, se ensucian menos y sufren menos de depósitos e incrustaciones. Lo anterior se debe al mayor tamaño y turbulencia de los orificios de descarga, haciéndolos menos susceptibles al bloqueo y taponamiento. Estos difusores tienen bajas eficiencias estándares de aireación (en el rango de 0.6-1.5 $\mathrm{kgO}_{2} / \mathrm{kWh}$ ) porque las burbujas de aire viajan rápidamente a través de la columna de agua, además de tener una menor relación superficievolumen.

Los difusores de burbuja gruesa tiene como principal ventaja la alcanzar altos valores de OTR dentro de un tanque con un volumen determinado. El flujo de aire no es limitado por el número de difusores u orificios. Estos sistemas de burbuja gruesa de alto flujo tienen bajos valores de SAE que son generalmente inversamente proporcionales a los valores de OTR. La obtención de alta transferencia de aire (es decir, altos valores de OTR) requieren altos flujos de aire que resultan en tiempos de retención cortos de las burbujas y áreas de transferencia más bajas. Los valores máximos de OTR que los sistemas de burbuja gruesa pueden alcanzar pueden ser más altos que los valores de sistemas de burbuja fina o aireadores superficiales pero generalmente estan limitados por la capacidad de los aireadores (y no debido a la superficie ocupada en el fondo de los tanques de aireación como regularmente ocurre con difusores de burbuja fina). De esta manera, una elección frecuentemente utilizada en sistemas de tratamiento de aguas residuales industriales altamente concentradas es la instalación de rejillas con varias líneas de difusores de burbuja gruesa. Para sistemas que no requieren altos valores de OTR por unidad de volumen, tales como en plantas municipales, los difusores de burbuja gruesa son una mala elección desde la perspectiva de la conservación de energía. Como consecuencia de los altos precios de la energía eléctrica en los años 1970, las plantas de tratamiento municipales equipadas con difusores de burbuja gruesa empezaron a reemplazarlos con difusores de burbuja fina.

Las Figuras 9.6 y 9.7 muestran dos modelos de difusores de burbuja gruesa disponibles a nivel comercial. En la Figura 9.6 se muestran dos tipos de rociadores, y un arreglo en cresta y otro en surco para difusores de burbuja gruesa. Los rociadores de la primera generación de difusores gruesos, son esencialmente pernos metálicos (los más antiguos) o de plástico (los más recientes) con uno o más orificios. El aire viaja a través del tubo principal, del tubo descendente y a través del rociador para finalmente ser liberado a través de los orificios. Los orificios están ubicados debajo de las tapas metálicas para favorecer la dispersión de las burbujas y prevenir que las burbujas asciendan de manera vertical en línea recta (como lo harían las perlas en un collar). Los sistemas de alta tasa pueden usar una rejilla formada por tubos, usualmente de plástico, con perforaciones de aproximadamente $5 \mathrm{~mm}$ de diámetro ubicados en intervalos de $0.5 \mathrm{~m}$ en la parte inferior en la dirección del fondo del tanque.
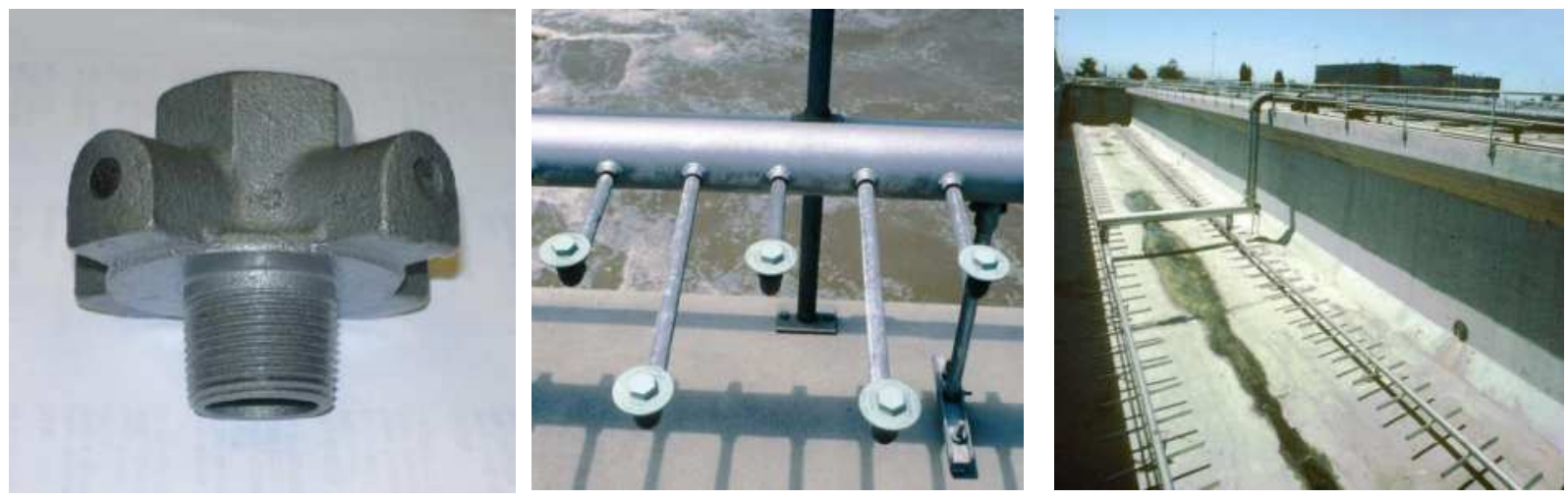

Figura 9.6 Rociadores de aire (izquierda) instalados en el fondo del tanque de un reactor de lodos activados (centro). A la derecha se muestra en detalle la instalación de los rociadores, espaciados alternadamente a una distancia más corta o más larga con respecto al tubo de suministro de aire principal con la finalidad de incrementar la distribución de aire (fotos: M.K. Stenstrom) 

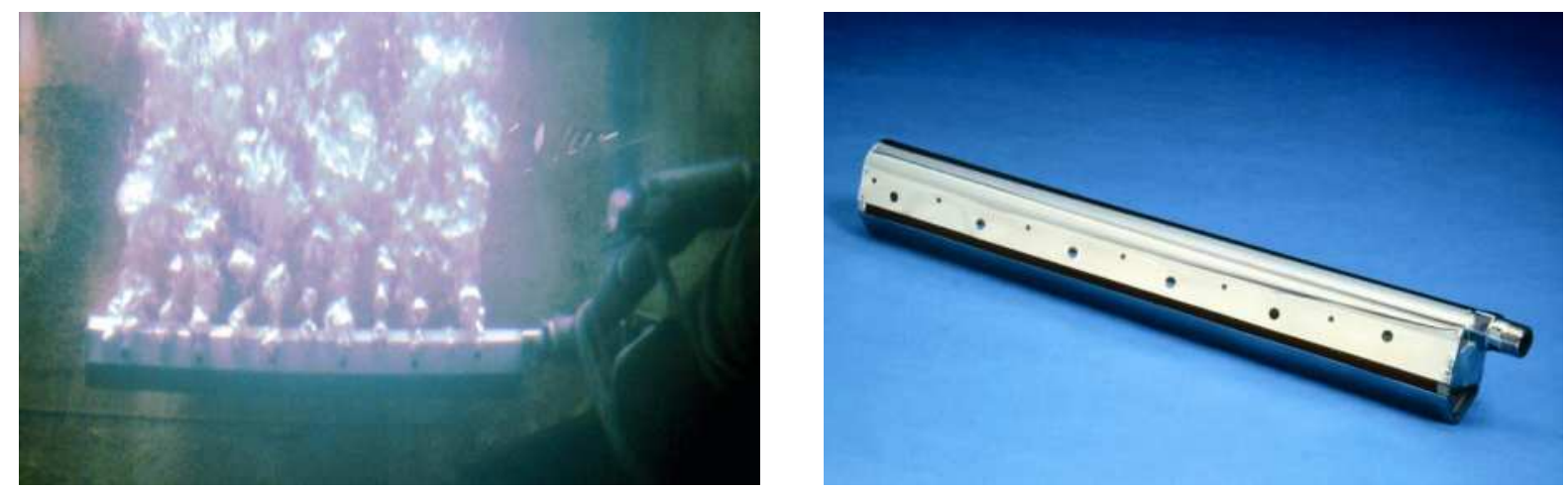

Figura 9.7 Un difusor de burbuja gruesa del tipo " alimentador de gallinas". A la derecha, se puede observar el modelo fuera del agua, el cual cuenta con orificios de dos tamaños y un espacio abierto. A la derecha, se muestra una fotografía debajo del agua de uno de estos difusores en operación en agua limpia. Nótese la alta turbulencia generada por las burbujas gruesas (fotos: M.K. Stenstrom)

\subsubsection{Sistemas de burbuja fina}

Las burbujas finas pueden ser producidas por diferentes tecnologías, ya sea mediante la liberación de aire a través de discos porosos, o mediante la dispersión mecánica de burbujas más grandes en burbujas más pequeñas (Figuras 9.8, 9.9, 9.10 y 9.11).

Las últimas tecnologías emplean turbinas sumergidas o difusores de jet que crean las burbujas finas, sin utilizar orificios aquellos, y en ambos casos energía mecánica es usada para disgregar las burbujas más grandes en burbujas más finas. Los sistemas de turbinas tienen valores de SAE más bajos (en el rango de 1.2-1.8
$\mathrm{kgO}_{2} / \mathrm{kWh}$ ) que los sistemas de difusores de burbuja fina. Los difusores de poro fino son un subconjunto de los sistemas de difusores de burbuja fina. Los difusores de poro fino crean las burbujas fijas mediante la liberación de aire compromido a través de orificios pequeños o poros de membranas o materiales porosos, tales como piedras cerámicas o plásticos porosos. Debido a su extendido uso en el sector municipal, este capítulo se enfoca en los difusores de poro fino.

Los difusores de poro fino son hasta el momento los difusores más utilizados comúnmente en los Estados Unidos y Europa. Tienen altos valores de SAE (en el
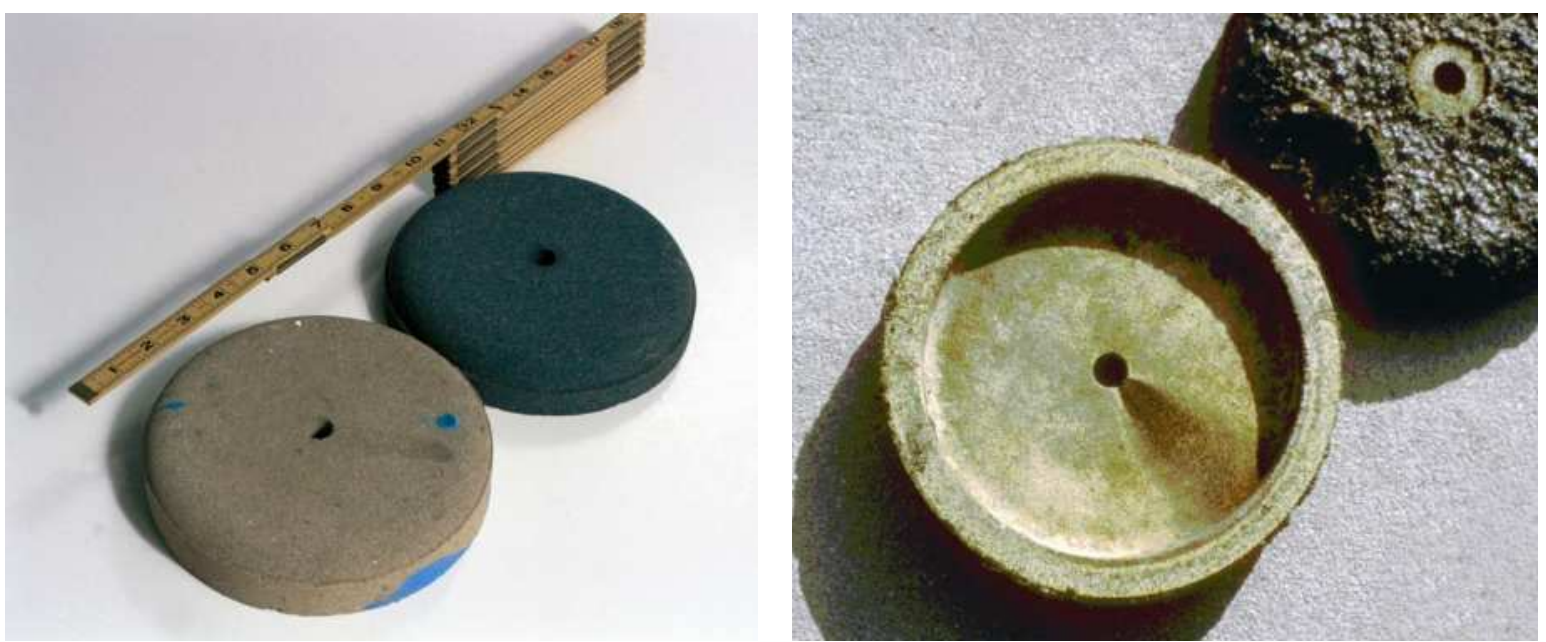

Figura 9.8 Primera generación de difusores de poro fino: domos o discos cerámicos. El aire es alimentado a través de un tubo o una conexión conectados a la ranura central del disco o domo, el cual es liberado a través de los poros. La fotografía de la derecha muestra un difusor después de un uso prolongado, se puede observar un deterioro considerable en la superficie externa causado por la acción de los microorganismos. La zona más obscura observada dentro del disco o domo muestra la posición de la tubería o conexión del sistema de suministro de aire y, debido a las manchas dejadas por los contaminantes, se puede notar la trayectoria de ciertas fugas del sistema de aireación (fotos: M.K. Stenstrom) 

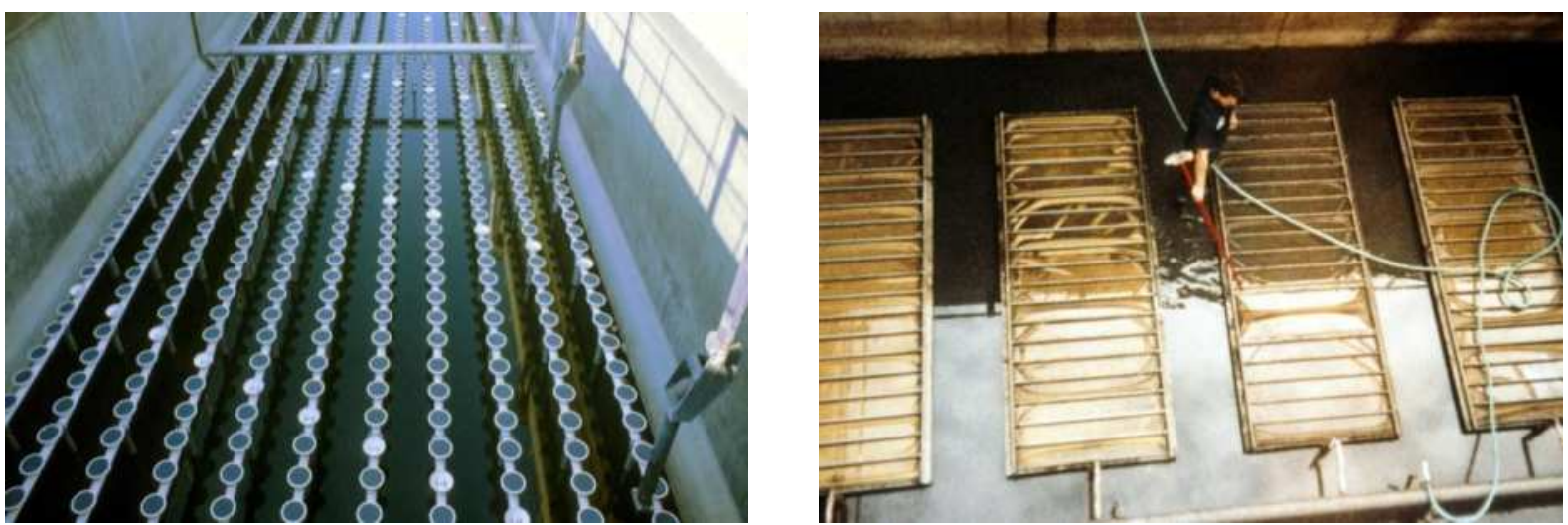

Figura 9.9 Ejemplos de instalaciones de difusores de poro fino ubicados en el fondo de dos tanques de aireación. A la izquierda, discos cerámicos. A la derecha, paneles de membrana (fotos: M.K. Stenstrom)

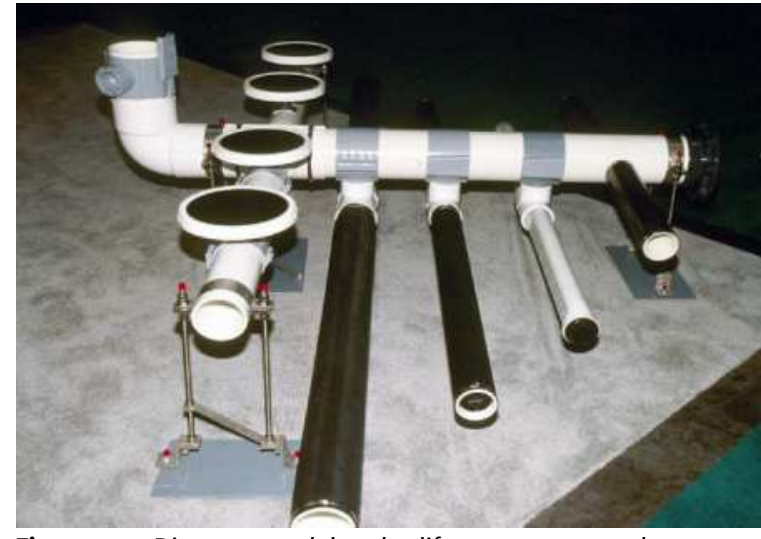

Figura 9.10 Diversos modelos de difusores presentados por un fabricante en una feria comercial. De izquierda a derecha: discos cerámicos y de membrana, tubos de membrana de dos geometrías, difusores de burbuja gruesa de plástico (en blanco) parecidos a los mostrados en la figura 9.9, y una membrana tubular montada directamente sobre la tubería principal de suministro de aire (Foto: M.K. Stenstrom)

rango de 3.6-4.8 $\mathrm{kgO}_{2} / \mathrm{kWh}$ ) y se utilizan comúnmente en las configuraciones instaladas en el fondo de los tanques de aireación, obteniendo la máxima ventaja de su eficiencia. Los sistemas de difusores de poro fino liberan o volatilizan menores cantidades de compuestos volátiles orgánicos debido a su alta eficiencia, lo cual favorece la utilización de bajos flujos de aire (Hsieh et al. 1993a,b). Por la misma razón, los difusores de poro fino también reducen las pérdidas de calor (Talati y Stenstrom 1990; Sedory y Stenstrom 1995).

Los difusores de poro fino tienen dos desventajas importantes: la primera es que requieren una limpieza periódica; y la segunda es un alto efecto negativo en la eficiencia de transferencia causada por los contaminantes presentes en las aguas residuales. Este factor o efecto se cuantifica comúnmente a través del factor $\alpha$ (el cual es una medida de relación existente entre las eficiencias de transferencia de masa en el agua residual con relación al agua limpia, o $\mathrm{K}_{\mathrm{L}} \mathrm{a}_{\mathrm{pw}} / \mathrm{K}_{\mathrm{L}} \mathrm{a}_{\mathrm{cw}}$ ). Los difusores de poro fino generalmente tienen coeficientes de transferencia $\alpha$ más bajos que los difusores de burbuja gruesa o los aireadores superficiales operados bajo condiciones operativas similares (Kessener y Ribbius, 1935; Stenstrom y Gilbert, 1981). Las diferencias observadas entre los diferentes coeficientes $\alpha$ fueron observados desde los años 1930 (Kessener y Ribbius, 1935), pero fueron un tanto olvidados hasta que la crisis energética de los años 1970 incrementaron el interés y la percepción en tecnologías energéticamente más eficientes. Antes de 1980, diversas plantas eran diseñadas con factores $\alpha$ de 0.8 , el cual era considerado como un valor universal para todos los sistemas de aireación operados bajo diversas condiciones operativas. Sin embargo, se ha observado que los diferentes métodos de aireación tienen diferentes coeficientes $\alpha$. Más aún, el valor inicial $\alpha$ de los difusores de poro fino se reduce progresivamente durante el tiempo de operación debido a la acumulación de depósitos, ensuciamiento o ruptura (Rosso y Stenstrom, 2006b).

Más aún, para sistemas de burbuja fina el factor $\alpha$ depende de las condiciones de proceso y operación tales como el tiempo de retención de sólidos (TRS, por sus siglas en inglés, solids retention time) o el flujo de aire (Rosso et al., 2005).

\subsection{SOPLADORES DE AIRE}

\subsubsection{Estado del arte}

Los sopladores de aire son compresores que operan a baja presión y que se utilizan en los sistemas de aireación sumergida, incluyendo las turbinas. Ciertos sistemas no utilizan sopladores y operan bajo succión; sin embargo, se utilizan principalmente para mezclado. 

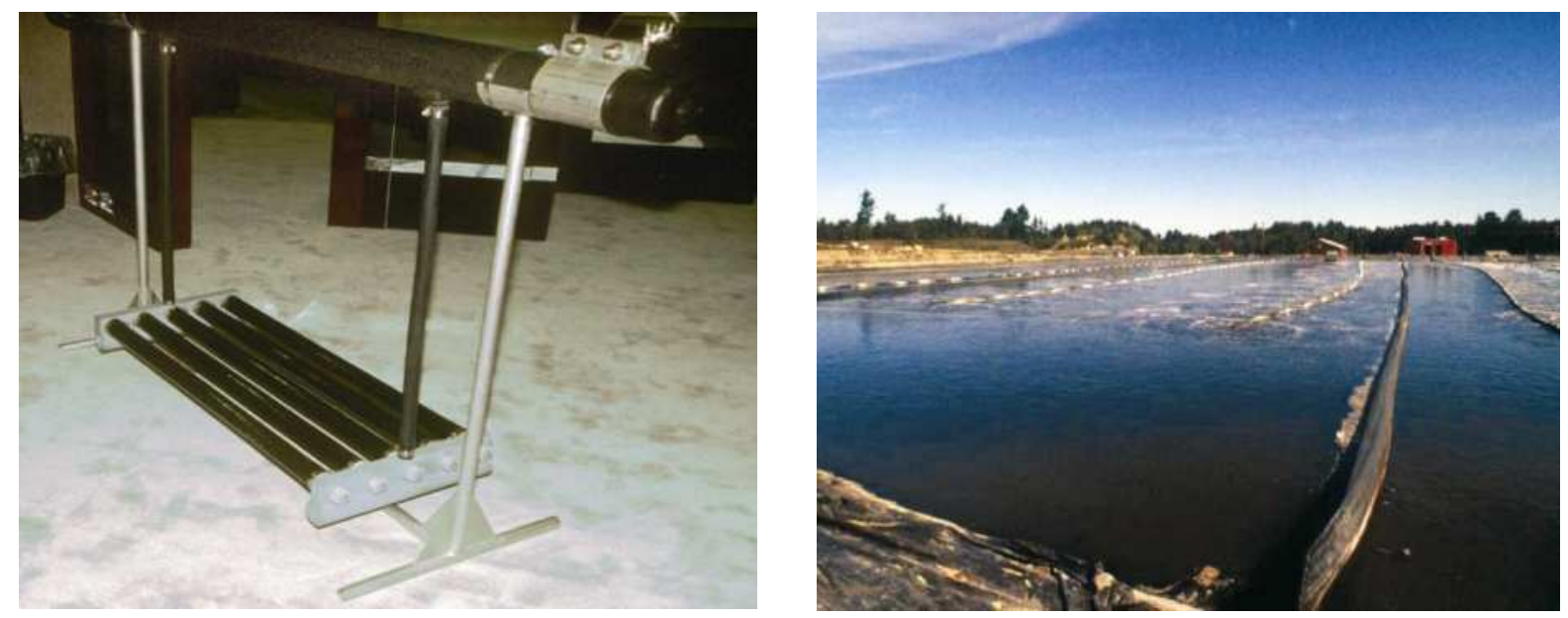

Figura 9.11 Aplicación de difusores de burbuja fina a una laguna aireada. Los tubos de suministro de aire (ubicados sobre el bastidor de difusores) distribuyen el aire a lo largo de la laguna, y las mangueras verticales transportan el aire de los tubos de suministro a los bastidores de los difusores (ubicados cerca del fondo de la laguna) (fotos: M.K. Stenstrom)

Los sopladores, debido a su limitada capacidad para regular su velocidad de operación, tienden a restringir o limitar los ahorros energéticos en las plantas de tratamiento. Los sopladores se clasifican en dos grupos: de desplazamiento positivo y centrífugo. Los sopladores de desplazamiento positivo generalemente operan bajo flujo constante, con presiones variables, mientras que los sopladores centrífugos operan a presión constante con flujo variable. Las ventajas y desventajas de estos sistemas se describen en la Tabla 9.3.

Los sopladores de desplazamiento positivo o centrífugo se pueden utilizar en plantas pequeñas, mientras que las plantas más grandes utilizan prácticamente sólo sopladores centrífugos. Antes de la llegada de los controladores de frecuencia variable (VFD, por sus siglas en inglés Variable Frequency Driver), las posibilidades de regular los flujos de los sopladores de desplazamiento positivo eran bajas. De manera alternativa, el flujo de aire producido por los sopladores tendía a ser regulado mediante la obstrucción del sistema de succión ó, en otras ocasiones, el exceso de flujo podría ser liberado a presiones reducidas. Obviamente, ninguna solución era $100 \%$ satisfactoria. Con la instalación de los VFD el flujo es proporcional a las revoluciones de los sopladores (con una pequeña fracción de pérdida debido a fricciones o deslizamientos), permitiendo la operación de los sistemas de aireación dentro de un amplio rango de velocidad que permite incrementar o reducir los flujos de aire generados.

\subsubsection{Sopladores centrífugos}

Los sopladores centrífugos succionan aire y lo conducen a lo largo del eje de rotación de su eje, proporcionándole velocidad al aire con una propela unida al eje principal. El aire se descarga continuamente de manera radial y su incremento en energía cinética es convertido en un incremento de presión al reducir la velocidad del aire a través del difusor. La Figura 9.12

Tabla 9.3 Resumen de las características principales de los sopladores de desplazamiento positivo y centrífugo

\begin{tabular}{|c|c|}
\hline Desplazamiento positivo & Centrífugos \\
\hline $\begin{array}{l}\text { - Más económicos a pequeña escala } \\
\text { - Ruidosos (las bajas frecuencias de operación relacionadas } \\
\text { con los lóbulos rotatorios son difíciles de disminuir). Los } \\
\text { sistemas de tres lóbulos contribuyen parcialmente a disminuir } \\
\text { este problema. } \\
\text { - La transferencia de vibraciones a tuberías, anclajes y soportes } \\
\text { son en algunas ocasiones problemáticos. } \\
\text { El motor se sobrecarga con presiones excesivas de descarga, } \\
\text { requiriendo una protección continua de los motores. }\end{array}$ & $\begin{array}{l}\text { - Económicos gran escala pero especialmente para } \\
\text { instalaciones grandes. } \\
\text { - También son ruidosos pero los sonidos de rotación de alta } \\
\text { frecuencia son más fáciles de controlar. } \\
\text { - La operación a flujos excesivos puede sobrecargar el motor, } \\
\text { y la operación a altas presiones puede causar vibraciones } \\
\text { excesivas, lo cual puede llevar a la destrucción del soplador. } \\
\text { Se sugiere la instalación de sistemas detección de flujo y } \\
\text { vibraciones para una operación segura y confiable. }\end{array}$ \\
\hline
\end{tabular}


muestra un par de sopladores centrífugos. Los sopladores centrífugos tradicionales no tienen la capacidad de incrementar o reducir los flujos, por lo cual tienen que ser operados a una velocidad de rotación constante. Las últimas tecnologías has permitido el desarrollo de sopladores centrífugos que tienen conductos de succión variable y los más modernos incluyen difusores con salida variable (Figuras 9.13 y 9.14). Con base en el ángulo de los conductos de succión, el flujo de aire puede ser regulado y el soplador puede regular el flujo. Sin embargo, los sopladores centrífugos tienen un rango óptimo de operación, y fuera de él la eficiencia se reduce.

\subsubsection{Sopladores de desplazamiento positivo}

Los sopladores de desplazamiento positivo (Figura 9.15) siguen un enfoque diferente a los centrífugos. En vez de impartir una velocidad continua al aire con un rotor para convertir la energía cinética en presión, el soplador de desplazamiento positivo comprime el aire dentro de una de sus válvulas y lo impulsa mediante la acción de sus émbolos. La Figura 9.15 ilustra el concepto.

Debido a la naturaleza del proceso, la compresión de los sopladores de desplazamiento positivo no es tan
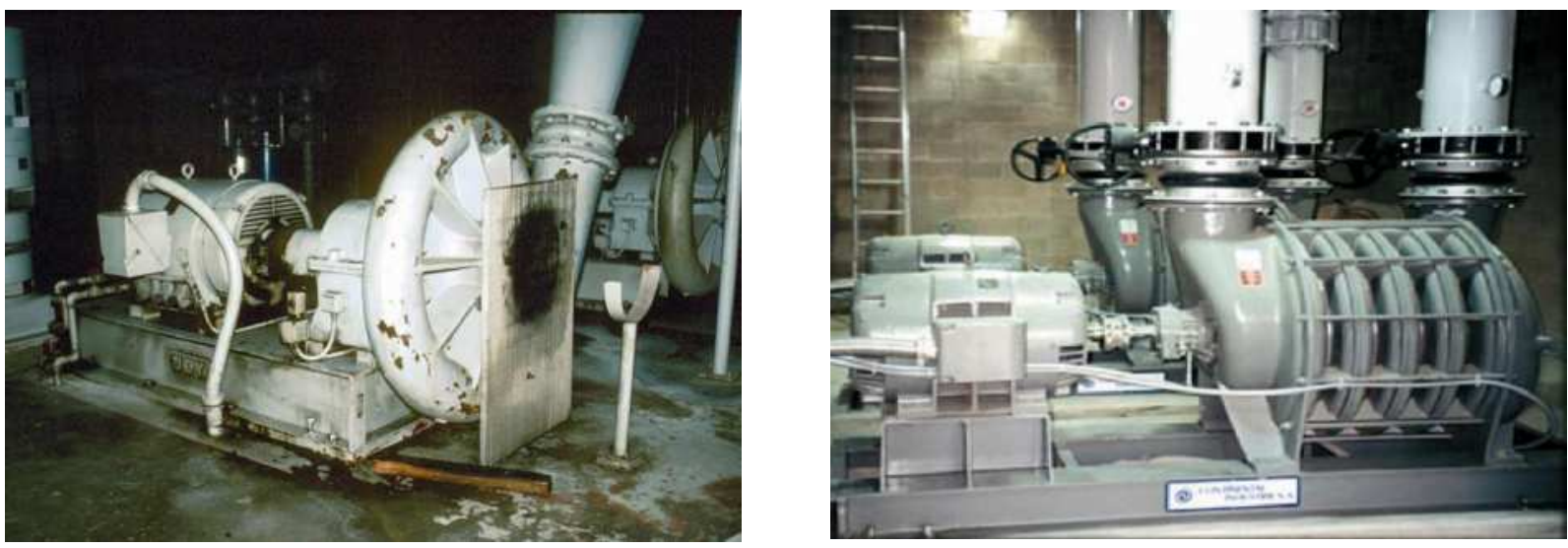

Figura 9.12 Sopladores centrífugos de una etapa (izquierda) y de múltiples etapas (derecha) (fotos: M.K. Stenstrom)

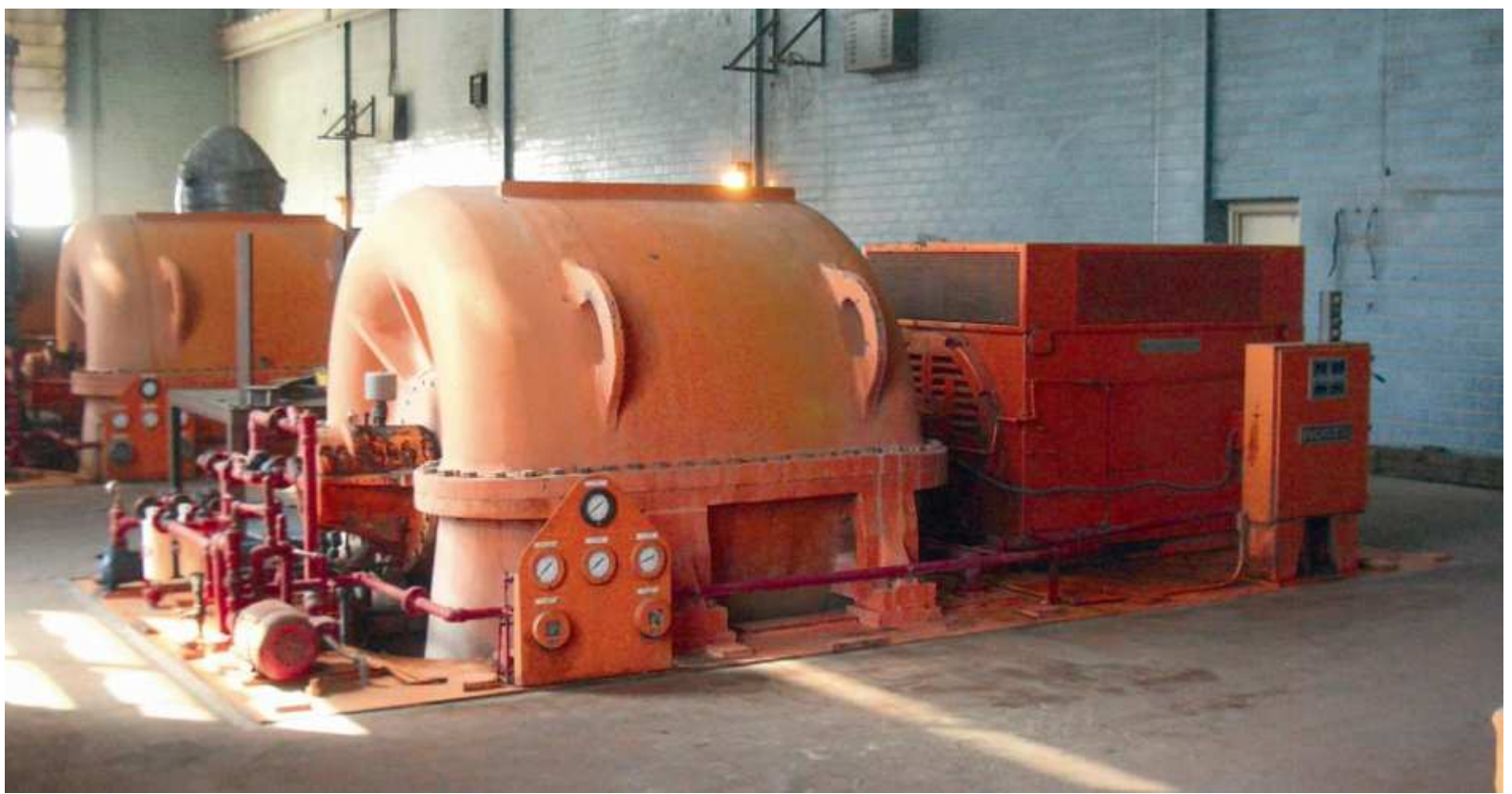

Figura 9.13 Sopladores centrífugos de múltiples etapas con conductos de succión variables instalados en una planta de tratamiento de aguas residuales de gran capacidad. La línea de referencia ilustra las grandes dimensiones del soplador, con una capacidad de consumo de $3500 \mathrm{~kW}, 4160 V A C$ y salidas de aproximadamente $26 \mathrm{Nm}^{3} / \mathrm{s}\left(\sim 1600 \mathrm{Nm}^{3} / \mathrm{min}\right)$ bajo condiciones óptimas de operación (foto: D. Rosso) 


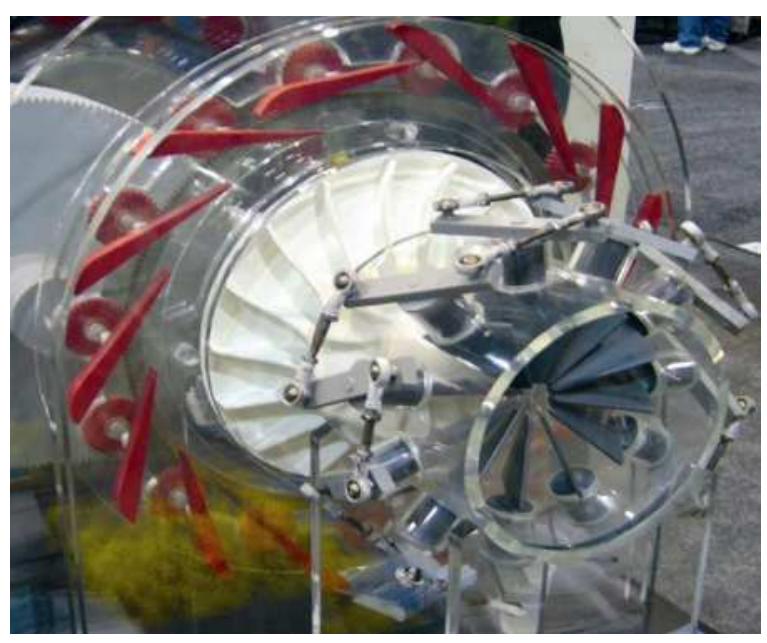

Figura 9.14 Modelo tridimensional de un soplador centrífugo de una etapa con sistemas de conductos variables de toma (en gris) y distribución (en color rojo) presentado en una feria comercial (foto: D. Rosso)

eficiente como la de los sistemas centrífugos, pero puede alcanzar altas presiones de salida para flujos de aire similares. También, el flujo de aire puede ser regulado al variar la velocidad de operación de los sopladores. Una desventaja de los sistemas de desplazamiento positivo es el ruido producido por la compresión, el cual puede ser fácilmente identificado como un sonido agudo de baja frecuencia.

\subsubsection{Reguladores de frecuencia}

Un regulador de frecuencia (VFD) es un sistema electrónico que permite el control de la frecuencia de la corriente alterna (AC, por sus siglas en inglés Alternating Current), controlando la velocidad de rotación del motor eléctrico que alimenta. Por ejemplo, si un motor eléctrico tiene una velocidad de $1800 \mathrm{rpm}$ con una frecuencia eléctrica de $60 \mathrm{~Hz}$ (similar a la utilizada en los Estados
Unidos), su velocidad puede ser reducida a $1200 \mathrm{rpm}$ al reducir la frecuencia a $40 \mathrm{~Hz}$.

Mediante la instalación de un VFD a un motor eléctrico, el motor puede operar a velocidades más altas o bajas con referencia a su rango de operación nominal, $\mathrm{y}$ puede ser encendido o detenido debido al menor sobrecalentamiento. Cuando los motores tradicionales encienden y arrancan, alrededor de $300 \%$ de la energía consumida es utilizada para alcanzar la velocidad de operación. Esto sobrecalienta el motor y limita la capacidad del motor para arrancar más de una vez en un cierto periodo de tiempo (por ejemplo, en intervalos de una hora). El alto consumo de energía requerido durante el arranque puede afectar el suministro de energía eléctrica, particularmente durante los periodos diurnos de alto consumo de energía. En plantas de tratamiento de aguas residuales los ciclos de consumo de agua en áreas urbanas conllevan a altos consumos de energía por la mañana o por la tarde que es cuando la electricidad tiene un mayor costo. Debido a ello, es esencial reducir el consumo de energía requerido para arrancar el motor.

\subsubsection{Sistemas de control}

Básicamente, las técnicas actuales de control de sistemas de aireación se basan en señales de retroalimentación proporcionadas por sensores de medición de concentración de oxígeno disuelto sumergidas en los tanques de aireación. La concentración de oxígeno disuelto es una consecuencia o efecto causado por la transferencia de oxígeno y también un indicador importante relacionado con las condiciones del proceso. Cuando la concentración de oxígeno es baja, el metabolismo bacteriano puede inhibirse. Cuando esto ocurre, la composición del lodo puede cambiar, reduciendo la eficiencia de tratamiento $\mathrm{y}$, en casos extremos, la falla del proceso (por ejemplo, generando lodo con características filamentosas). Por el contrario,
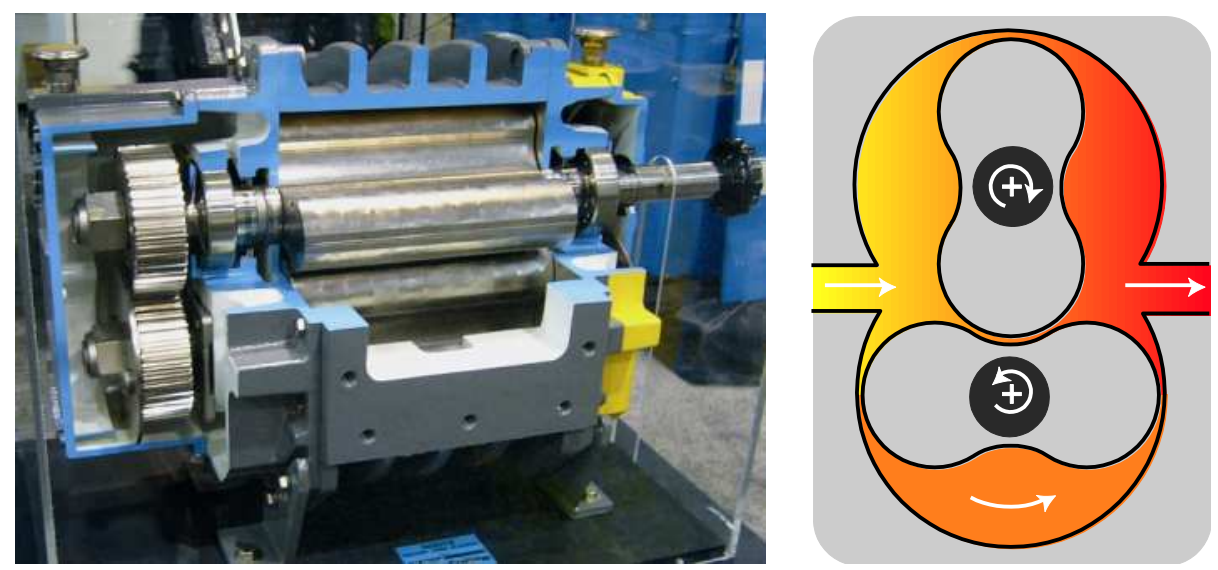

Figura 9.15 Fotografía y esquema de un soplador de desplazamiento positivo (fotos: D. Rosso) 
una alta concentración de oxígeno puede causar problemas en la eficiencia del proceso de desnitrificación (el cual requiere condiciones anóxicas) y consumir cantidades excesivas de energía (Ferrer, 1998; Serralta et $a l .$, 2002). Diversos estudios se han enfocado en mejorar el control de las concentraciones de oxígeno disuelto en los sistemas de tratamiento (Ferrer, 1998; Ma et al., 2004).

Diversas plantas de tratamiento cuentan con sopladores que puede generar descargas limitadas de presión antes de sobrecargar los motores. La contrapresión, llamada presión dinámica húmeda (DWP por sus siglas en inglés, Dynamic Wet Pressure), que requieren los difusores bloqueados puede llegar a ser demasiado alta impidiendo que algunos difusores no liberen aire, lo cual puede resultar en una distribución desigual o desbalanceada a lo largo del tanque. En algunas otras instalaciones, los sopladores pueden tener la capacidad de descargar la contrapresión DWP de los difusores bloqueados únicamente cuando operan fuera de su rango óptimo de eficiencia, resultando en mayores costos de energía y en un posible daño del soplador.

Para optimizar el consumo de energía de los sistemas de aireación, la mejor estrategia es suministrar la menor cantidad de aire que requiere el sistema de tratamiento, siempre y cuando se asegure el cumplimiento de las eficiencias de remoción necesarias. En este sentido, se sugiere adoptar un sistema en línea de bajo costo para la medición y monitoreo de los gases generados. Medir los gases generados por el sistema de tratamiento proporciona información precisa relacionada con la transferencia de oxígeno, y no simplemente la concentración de oxígeno disuelto, proporcionando una nueva herramienta para calcular de una manera más confiable los consumos energéticos. Además, la medición continua de estos parámetros ofrece una herramienta útil para monitorear una potencial disminución en la eficiencia de transferencia de oxígeno causada por el taponamiento y fallas de los difusores.

\subsubsection{Mejoras de los sopladores y recomendaciones}

Cuando se requiera mejorar la operación de los sopladores, se deben tomar en cuenta diversos factores. De manera inicial, se debe instalar un mayor número de sopladores al requerido. Esto permitirá llevar a cabo labores de operación y mantenimiento en turnos sin afectar la operación de la planta de tratamiento. Con la finalidad de evitar incrementos súbitos en los flujos de aire (que incrementan el consumo de energía) se recomienda instalar sopladores equipados con reguladores (por ejemplo, sopladores de desplazamiento positivo equipados con reguladores de frecuencia, o sopladores centrífugos equipados con entradas de aire con guías, difusores con salida, o reguladores de frecuencia). Estos sistemas permiten regular el flujo de aire dentro de su rango de operación, ajustándose a las variaciones de carga orgánica observadas en la planta de tratamiento. Cuando el flujo se incrementa y produce una demanda de aire más alta a la capacidad soplador, otro soplador debe activarse, tal y como se practica en los sistemas tradicionales. Los beneficios de los sistemas con flujo variable son su mayor flexibilidad y una transición más suave dentro de cierto rango de flujos de aire, facilitando una mejor administración de los costos de energía.

Un problema clásico que enfrentan los operadores e ingenieros de proceso es la operación desbalanceada de los sistemas de control de oxígeno disuelto. El problema básico radica en que el algoritmo de control puede considerar el soplador de una manera matemática un recurso infinito. El siguiente ejemplo puede explicar este fenómeno.

Una planta de tratamiento está compuesta de diversos tanques de aireación operados en paralelo. Cuando un tanque tiene una concentración de oxígeno baja, causada por un flujo desigual o inclusive un efecto aleatorio, el controlador induce que ese tanque requiere más aire y abre una válvula de aire, proporcionando más aire al tanque afectado. Idealmente, el soplador debe suministrar más aire, pero en realidad esto no ocurre. Por el contrario, el aire requerido es redireccionado del que le corresponde al tanque adjunto. Esto ocurre tanto por la caída de presión en el sistema de distribución de aire como por la naturaleza del soplador. La pérdida de aire del tanque adjunto origina que la concentración de oxígeno disuelto disminuya en ese tanque, y como consecuencia el controlador indica que se requiere más aire, el cual es tomado o redireccionado del que le corresponde a otros tanques. Al final, la caída en las concentraciones de oxígeno indican que todos los tanques requieren más aire y como respuesta el sistema de control enciende otro soplador. Dado que los sopladores tienen flujos de aire definidos, y no una distribución continua de los flujos de aire, el aire suministrado a todos los tanques se incrementará y la concentración de oxígeno disuelto subirá. Algún tanque alcanzará primero una alta concentración de oxígeno disuelto y el sistema de control responderá reduciendo el flujo de aire suministrado a ese tanque. Esto no reduce el flujo del soplador, sino que 
incrementa el flujo de aire suministrado a los otros tanques. Rápidamente todos los tanques alcanzarán una concentración alta de oxígeno disuelto y el sistema de control apagará el soplador adicional. Así, el ciclo iniciará una vez más y las concentraciones oxígeno disuelto se verán reducidas hasta que el soplador adicional se encienda una vez más y así el ciclo continuará.

El impacto directo que tiene una distribución de aire desbalanceada es un consumo excesivo de energía para arrancar y detener los sopladores, así como también un desgaste excesivo de estos sistemas. Cuando los operadores se muestran preocupados por el impacto que esto puede tener en la eficiencia de la planta, tienden a desactivar el sistema de control de oxígeno disuelto originando problemas tanto de aireación excesiva como limitada. Generalmente, los operadores optan por operar las plantas bajo condiciones excesivas de aireación con la finalidad de evitar el incumplimiento de la calidad de los efluentes tratados.

En conclusión, se puede decir que:

- La selección de los sistemas de sopladores de distribución y suministro de aire tienen un efecto considerable en el capital invertido y también consecuencias en los costos de operación de las plantas de tratamiento durante toda su vida útil.

- El mercado ofrece sopladores que cuentan con la capacidad de iniciar, arrancar y parar. Las tecnologías más avanzadas ofrecen sopladores centrífugos con canales variables de entrada o difusores de salida, sopladores de desplazamiento positivo, y reguladores de frecuencia.

- Los sistemas de control de oxígeno disuelto tienden a fallar con frecuencia, resultando en una distribución desigual del suministro de aire. Esto origina un mayor desgaste de los sistemas de aireación. En muchos casos, los operadores deciden fijar la operación del sistema en una concentración arbitraria para evitar el suministro desigual de aire, originando problemas de sobre aireación y un consumo excesivo de energía.

Las recomendaciones principales son:

- Los sopladores deben ser seleccionados con cuidado. Los sopladores que cuentan con la capacidad de arrancar y apagarse deben ser siempre considerados como una alternativa viable. Ya sea en diseños nuevos o cuando se actualicen las plantas existentes.

- Los costos de sopladores nuevos deben ser evaluados a través de un análisis económico que tome en cuenta los costos operativos de los sistemas tradicionales durante toda su vida útil. Dentro de este análisis, posibles incrementos en la demanda de aire deben ser considerados así como también las limitaciones que los sistemas tradicionales o convencionales pueden tener al respecto. Estas limitaciones pueden implicar una menor eficiencia operativa de los sopladores (incrementando los costos de energía) o la falta de capacidad de los sopladores para operar a mayores flujos de aire requeridos.

- Para mitigar el suministro de aire desbalanceado causado por los sistemas de control se requiren diversos cambios y ajustes. Primero, se deben de instalar sopladores que tengan una mayor capacidad para arrancar, detenerse y regular su velocidad de operación. Segundo, se debe de proporcionar un sistema de control inteligente que no considere el soplador como un recurso infinito. Esto requiere que el sistema de control esté equipado con un modelo para el soplador (específicamente considerando el flujo de aire en función de la curva de presión y el tiempo de arranque). Este modelo puede considerar diversos estados operativos de manera que la presión pueda estimarse y las válvulas de aire de todos los tanques se ajusten proporcionalmente.

\subsection{EFECTOS DE LAS CONDICIONES OPERATIVAS}

\subsubsection{El impacto del tiempo de retención de sólidos}

El tiempo de retención celular o tiempo de retención de sólidos (TRS) es el parámetro con mayor impacto en la eficiencia de aireación. El TRS está directamente relacionado con la concentración de la biomasa, y define los requerimientos de oxígeno. La eficiencia de aireación y $\operatorname{los}$ factores $\alpha$ (que definen la relación entre la transferencia de oxígeno en las aguas residuales y limpias) son más altos a tiempos de retención de sólidos más largos. Así, los procesos biológicos de remoción de nutrientes, típicamente operados a TRS largos, presentan eficiencias de aireación más altas. Más aún, los selectores anóxicos y anaerobios en plantas con remoción de nutrientes tienen efectos benéficos que van más allá de la remoción de nutrientes o mejores características de sedimentación. Al consumir la materia orgánica altamente biodegradable presente en las aguas residuales, los selectores remueven rápidamente sustancias surfactantes, las cuales tiene un impacto dramático en la reducción de la transferencia de oxígeno.

Diversos estudios (US EPA, 1989; Rosso et al., 2005) muestran que la eficiencia de transferencia de oxígeno es 
directamente proporcional al TRS del sistema, inversamente proporcional al flujo de aire por difusor, $y$ directamente proporcional a los parámetros geométricos (profundidad del difusor, número de difusores, y área cubierta por los difusores). La Figura 9.16 ilustra este concepto.
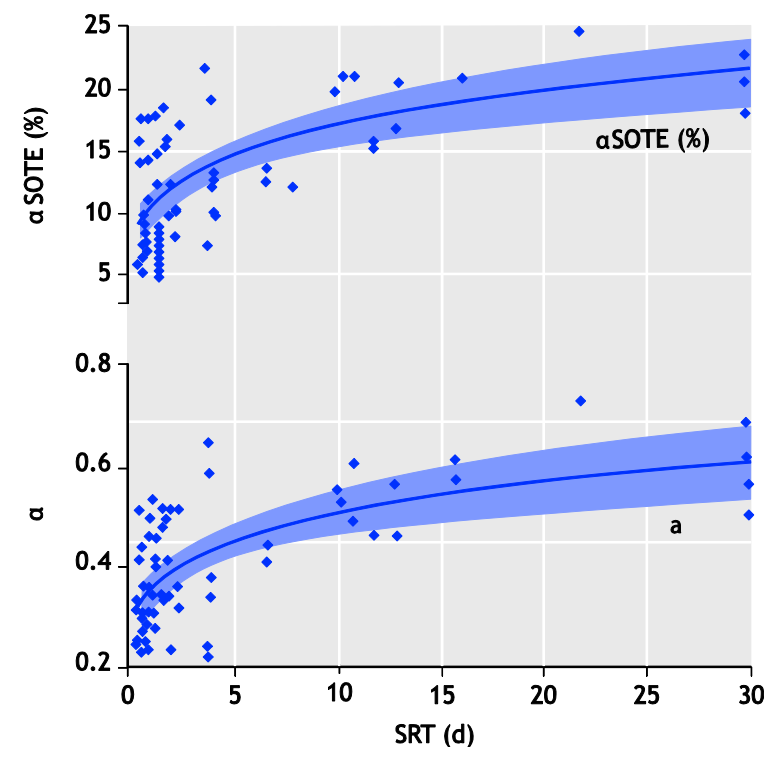

Figura 9.16 Efecto del TRS en $\alpha$ SOTE y $\alpha$. Las áreas sombreadas muestran los intervalos con $95 \%$ de confianza

El TRS define los requerimientos netos de oxígeno y está relacionado con el grado de tratamiento y de remoción de aquellos contaminantes que tienen a reducir la transferencia de oxígeno. Sistemas con TRS largos remueven o absorben los surfactantes en las fases iniciales del proceso, incrementando la eficiencia promedio de transferencia de oxígeno. Al extender el TRS se incrementan los requerimientos de oxígeno, mejorando la remoción de la materia orgánica biodegradable (Khan et al., 1998), y también incrementando la eficiencia de transferencia de oxígeno de todo el sistema. El incremento en los requerimientos de oxígeno causados por TRS más largos son parcial o totalmente compensados por los ahorros alcanzados al incrementar la eficiencia de transferencia de oxígeno.

El flujo de aire influye en el flujo dinámico de las burbujas: a mayor flujo de aire por difusor u orificio, más grandes las burbujas, creando una menor relación volumen-superficie y una mayor velocidad ascendente de las burbujas. El resultado es una menor área entre el gas y el líquido y un tiempo de residencia de las burbujas más corto, causando una reducción en la transferencia de oxígeno. La geometría afecta la eficiencia porque a mayor profundidad y cobertura de la superficie (entendiéndose esto último como la relación entre el el área cubierta por los difusores y el área total del tanque) se incrementa el tiempo de transferencia de oxígeno y el área superficial, incrementando la eficiencia de transferencia de oxígeno.

Además de estas ventajas, existe la evidencia cada vez mayor que los procesos que operan a TRS más largos tienen una mayor eficiencia de remoción de compuestos antropogénicos, como los farmacéuticos (Soliman et al., 2006; Goebel et al., 2007). Andersen et al. (2003) reportan remociones de 17 a-ethinilestradiol (EE3) de hasta $90 \%$ después de que la capacidad de una planta de tratamiento para remover nutrientes incrementó el TRS de la planta en alrededor de 11-13 días. En el futuro, la operación de plantas de tratamiento a TRS más largos será probablemente más común para incrementar la remoción de compuestos orgánicos en la medida en la cual se extienda el reuso del agua tratada.

\subsubsection{El rol de los selectores}

Casi todos los nuevos diseños de lodos activados utilizan selectores, ya sea anóxicos o anaerobios. El beneficio de los selectores en la reducción de organismos filamentosos (Harper y Jenkins, 2003) mejora el índice volumétrico de lodos y reduce la probabilidad de que se genere un lodo voluminoso de baja sedimentabilidad y disminuye la posible expansión de los mantos de lodo en los calificadores secundarios (Jang y Schuler, 2007). Parker et al. (2003) estudió 21 plantas de tratamiento que contaban con selectores anóxicos y anaerobios, y reportó que todas las plantas mostraron una mejoría después de la instalación de los selectores. $70 \%$ de las plantas que contaban con selectores anóxicos alcanzaron índices volumétricos de lodo (IVL) inferiores a los $200 \mathrm{ml} / \mathrm{g}$, mientras que $90 \%$ de las plantas con selectores anaerobios mostraron IVL menores de $150 \mathrm{ml} / \mathrm{g}$. Martins et al. (2004) reportó resultados similares y concluyeron que las plantas alcanzan una mejor operación cuando cuentan con selectores anaerobios. En algunos casos, la actividad de las bacterias acumuladoras de fósforo (PAO, por sus siglas en inglés, Poly-phosphate Accumulating Organismos) se incrementó inclusive cuando existían selectores estrictamente anóxicos, en los cuales las PAO mejoraron la estructura del floc y la densidad de la biomasa (Tampus et al., 2004). Más detalles sobre selectores pueden encontrar en el capítulo 11 de este libro.

Una ventaja de los selectores en la remoción o absorción de una fracción de la materia carbonacea, 
como por ejemplo la DQO rápidamente biodegradable (RBDQO), tal y como se ilustra en la Figura 9. 17.
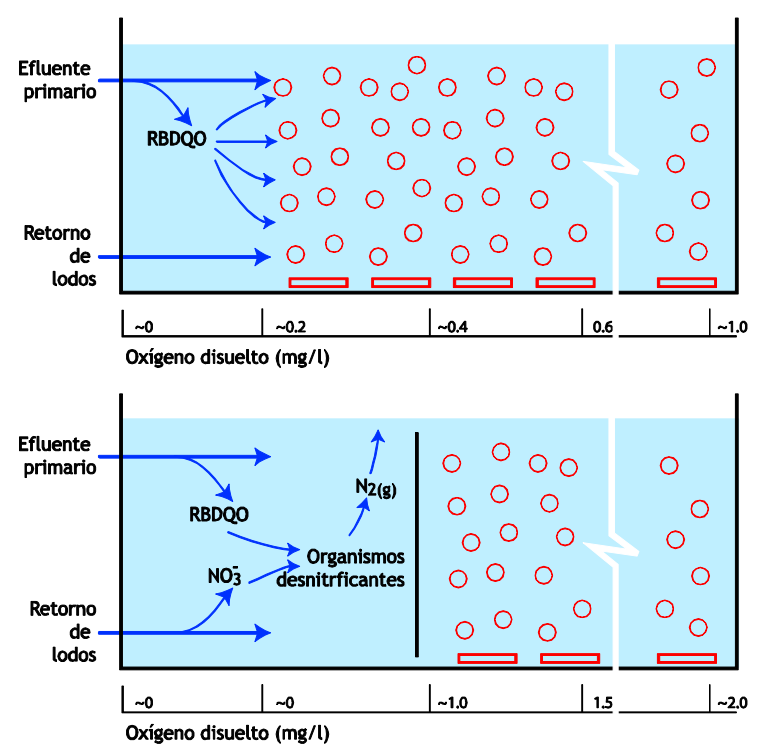

TRS más largos. Estos dos factores compensan la demanda adicional de oxígeno que se genera al operar las plantas a TRS más largos.

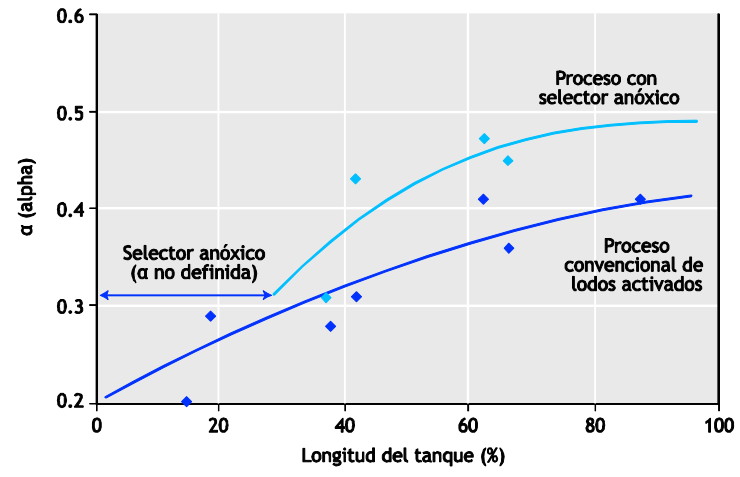

Figura 9.17 Representación esquemática del rol de los selectores en la remoción de la materia rápidamente biodegradable (mayormente surfactantes). La gráfica muestra las eficiencias de transferencia de oxígeno en función de la longitud del tanque y de los procesos de remoción. Los datos mostrados fueron medidos en una planta de tratamiento con dos trenes de tratamiento de lodos activados independientes con clarificadores independientes, tratando la misma agua residual

La RBDQO está parcialmente compuesta de agentes de superficie activa o surfactantes, que son típicamente descargados como ácidos volátiles, aceites, jabones y detergentes. Los surfactantes, debido a su naturaleza amfifílica, se acumulan en la interfase aire-agua de las burbujas ascendentes, reduciendo la eficiencia de transferencia de oxígeno. La remoción de la RBDQO puede mejorar la eficiencia de transferencia de oxígeno, reduciendo los costos de operación del proceso de aireación (Rosso y Stenstroom, 2006a).

Por estas y otras razones, los selectores anóxicos para nitrificación/desnitrificación (NDN) deben siempre ser evaluados como una alternativa para los tratamientos convencionales. Análisis previos demostraron que la operación de un sistema NDN puede tener costos operativos totales menores (aeración + disposición de los lodos - créditos de metano) que aquellos que operan sólo con nitrificación o convencionales (Rosso y Stenstroom, 2005). En climas cálidos, si los costos de un proceso convencional fueran utilizados como los costos de referencia normalizados (asignando un valor de1.0), los sistemas de desnitrificación tendrían un costo total de 1.13, y los NDN de 0.88. Los procesos NDN ofrecen un crédito en oxígeno debido a su naturaleza, y también a las más altas transferencias de oxígeno asociadas con los

\subsubsection{Ensuciamiento de los difusores, obstrucción y limpieza}

La eficiencia de transferencia de oxígeno de los difusores de poro fino se reduce de manera inevitable durante el tiempo (Figuras 9.18 y 9.19). Simultáneamente, la contrapresión (DWP) se incrementa, en algunos casos de manera dramática. Este incremento en DWP se debe al ensuciamiento y bloqueo u obstrucción de los poros de los difusores de cerámica (USEPA, 1989), o está asociado con un cambio permanente en las características de los orificios para membranas poliméricas (Kaliman et al., 2007). Ambos efectos causan una reducción en la eficiencia total del proceso y en el desperdicio de energía (Figura 9.20). Siempre se requiere limpiar los difusores para restaurar la eficiencia del proceso y reducir los costos de energía. Estudios llevados a cabo en 94 plantas muestran que la eficiencia se reduce con el tiempo y que la mayor caída ocurre en los primeros 24 meses de operación (Rosso y Stenstroom, 2006b). La caída en la eficiencia fue estimada e incluida en los análisis de costos, y la evaluación del valor presente fue comparado contra los costos de limpieza. La frecuencia de limpieza fue siempre mayor en casos de altas tasas de ensuciamiento 


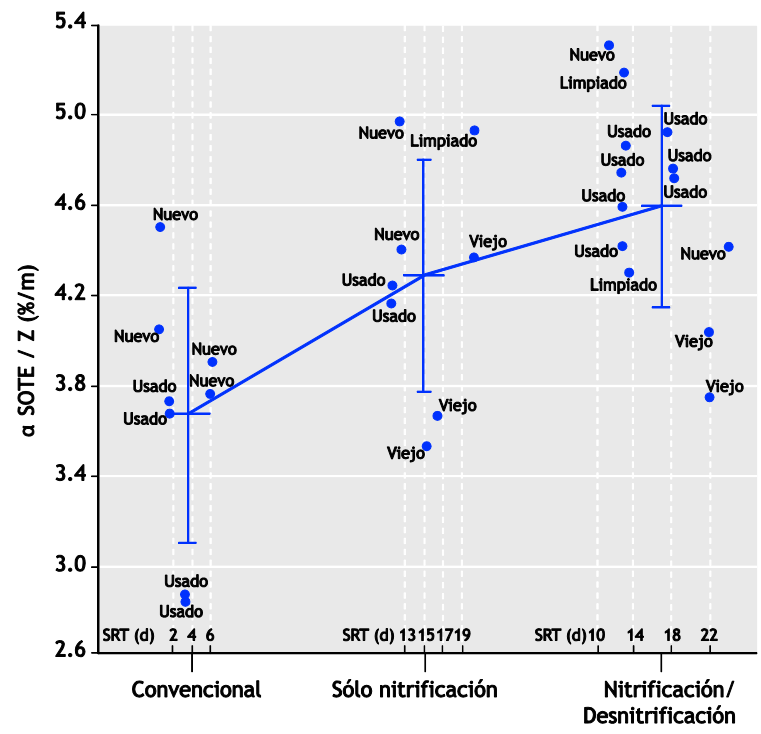

Figura 9.18 Eficiencia de transferencia de oxígeno normalizada a condiciones estándar para un grupo de plantas seleccionadas que operan con diferentes trenes de tratamiento. Las leyendas se refieren al estado de los difusores: NUEVO (menos de un mes de instalación), USADO (entre uno y 24 meses de operación), VIEJO (más de 24 meses en operación), y LIMPIADO (menos de un mes después de limpieza). La edad del difusor disminuye el incremento en la eficiencia causado por la modernización de la planta (por ejemplo de un sistema convencional a un proceso de nitrificación y nitrificación-desnitrificación -NDN)

y la frecuencia óptima mínima fue de nueve meses pero nunca más de 24 meses.

Debido a la naturaleza química y a la morfología de los materiales, los difusores pueden experimentar ensuciamiento y obstrucción dependiendo de las condiciones del proceso, calidad del agua, tipo difusores, y tiempo en operación (USEPA 1985, 1989). Como resultado, los difusores de poro fino necesitan ser limpiados de una manera rutinaria. La elección de la frecuencia de limpieza y el método determina la eficiencia al largo plazo y los beneficios de la utilización de la aireación mediante poros finos. Diversos métodos han sido utilizados para limpiar visores de poro fino que varían en cuanto a dificultad y costo. El método más simple es el de vaciar los tanques de aireación y lavar los difusores desde lo alto el tanque. Esta forma de limpieza es efectiva para remover el limo biológico acumulado y generalmente ayuda a recuperar al menos de manera parcial la efíciencia. En casos en los cuales depósitos inorgánicos (de sílice, carbonato de calcio, etc.) han causado el bloqueo y taponamiento, se requiere una limpieza ácida. El lavado manual con ácido clorhídrico en bajas concentraciones (entre 10-15 por ciento en peso)

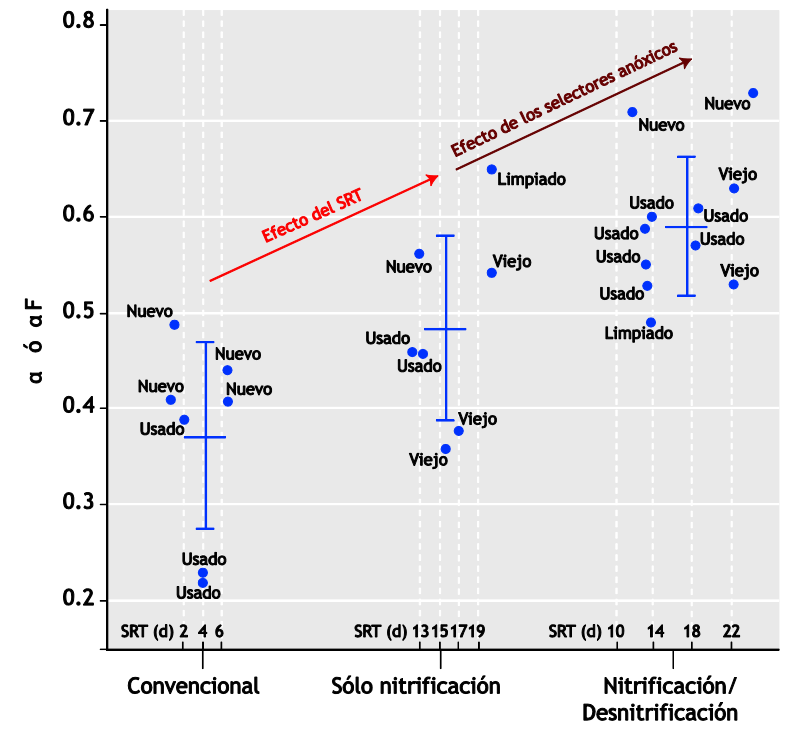

Figura 9.19 Evolución de los factores $\alpha \circ \alpha \mathrm{F}$ para plantas seleccionadas operando bajo diferentes esquemas de operación. Las leyendas se refieren al estado de los difusores: NUEVO (menos de un mes de instalación), USADO (entre uno y 24 meses de operación), VIEJO (más de 24 meses en operación), y LIMPIO (menos de un mes después de limpieza). Obsérvese el incremento en los factores $\alpha$ y $\alpha \mathrm{F}$ al incrementar el TRS, y un incremento adicional debido a instalación de los selectores anóxicos (el TRS promedio para los sistemas nitrificación y de nitrificación desnitrificación es el mismo).

es muy común. También una limpieza con un gas ácido utilizando ácido clorhídrico en gas o ácido acético inyectado en la línea de distribución de aire es factible (Schmit et al., 1989). Los resultados específicos dependerán del diseño de la planta y de las previsiones para la limpieza de los difusores (Rieth et al., 1990). Por ejemplo, es necesario contar con una capacidad instalada extra, períodos con bajas cargas o contar con la capacidad para modificar la operación de los sistemas con la finalidad de vaciar los tanques de aireación para llevar a cabo la limpieza (Figura 9.21). Esto generalmente es posible en plantas de tratamiento grandes, pero podría no ser factible en plantas pequeñas. De cualquier manera, existen costos directos asociados a la limpieza, tales como los costos de mano de obra, substancias o soluciones químicas, y reeemplazo de piezas averiadas. De esta manera, la elección del método de limpieza y frecuencia se debe manejar con cautela. 


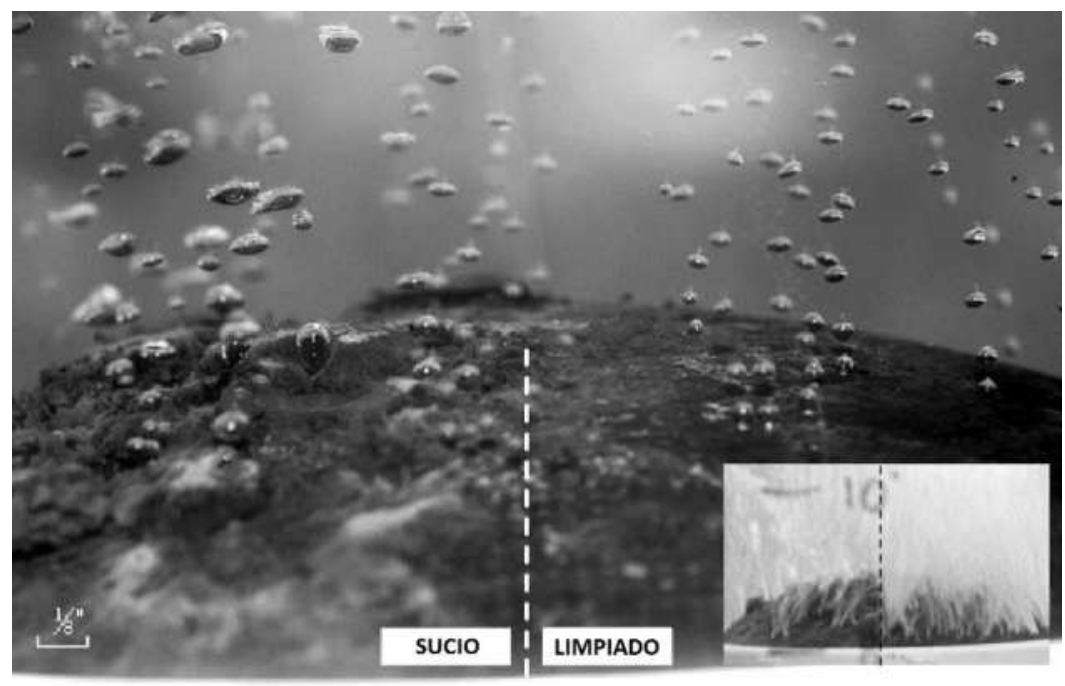

Figura 9.20 Difusor de membrana sucio tomado en una planta de tratamiento convencional después de dos años en operación, la mitad derecha de su superficie se limpió manualmente de manera mecánica. La diferencia en el número y tamaño de las burbujas generadas se debe al ensuciamiento causado por la bio-película formada en la mitad izquierda de la membrana. El aire liberado por los orificios en la mitad izquierda tiene que atravesar la bio película, y durante su trayectoria en el tiempo necesario para coalescer y formar menos burbujas pero más grandes con la desventaja que ello causa en la transferencia de oxígeno. En el semicuadro se muestra la membrana al flujo de aire de operación (foto: Shao-Yuan Ben Leu)
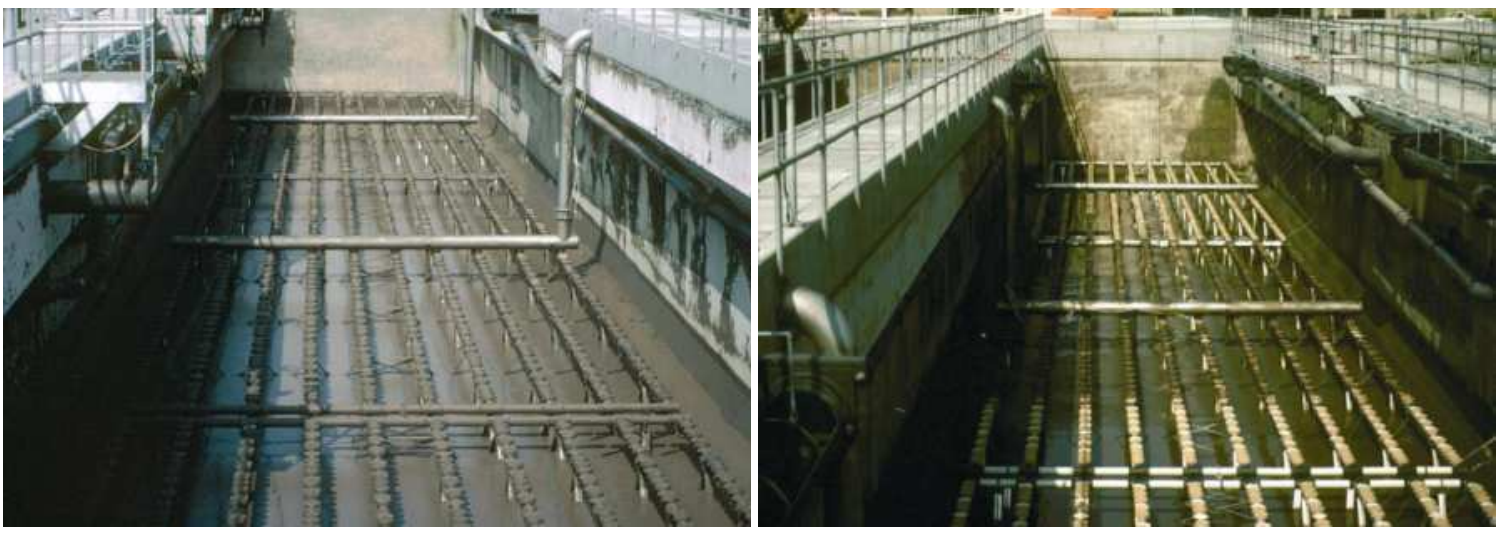

Figura 9.21 Tanque de aireación vacío equipado con domos cerámicos antes (izquierda) y durante (derecha) la limpieza con manguera desde lo alto el tanque. Los difusores con un color más claro que se puede observar en la parte baja de la figura de la derecha han sido limpiados (fotos: M.K. Stenstrom)

\subsubsection{Efectos de los surfactantes}

El tratamiento convencional, típicamente llevado a cabo a bajos TRS, tiene bajas concentraciones de biomasa, y ofrece menos oportunidades para que los sustratos disueltos sean rápidamente absorbidos por la biomasa. $\mathrm{La}$ operación a altos TRS tiene la ventaja de operar a altas concentraciones de biomasa. A TRS similares promedio, los sistemas de tratamiento que cuentan con selectores anaerobios o que llevan a cabo los procesos de nitrificación y desnitrificación tienen ventajas adicionales relacionadas con la remoción parcial o absorción en los selectores de la materia orgánica rápidamente biodegradable (RBDQO). Esto resulta benéfico por la reducción en los requerimientos de oxígeno (en el caso de los selectores anóxicos) y por la reducción en la acumulación de RBDQO sobre la superficie de las burbujas lo cual reduce de manera considerable la transferencia de oxígeno (Figuras 9.22 y 9.23) (Eckenfelder y Ford, 1968; Rosso y Stenstroom, 2006a). 


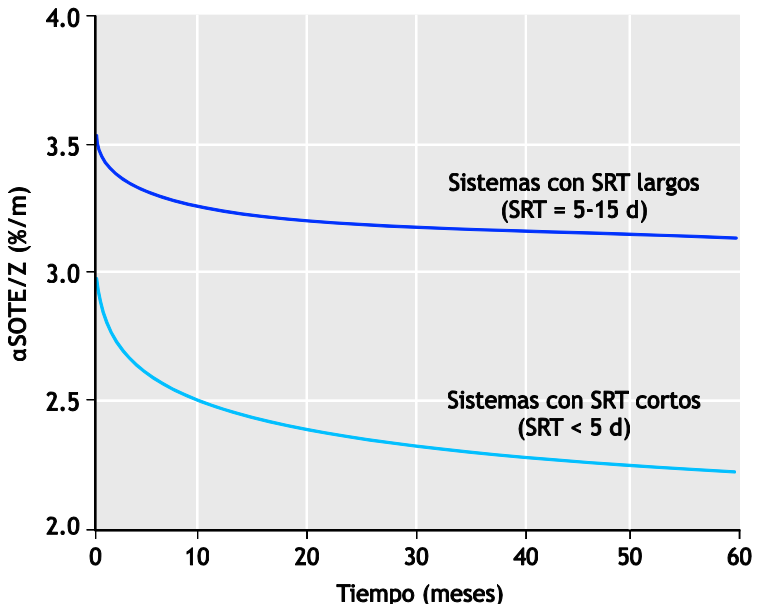

Figura 9.22 Tasas de su ensuciamiento para procesos de lodo activado operados a bajos y altos TRS. Las gráficas han sido generadas a partir del ajuste matemático de diversas bases de datos recolectados de 103 estudios de gases evacuados en 21 sistemas de tratamiento de aguas residuales

La RBDQO está parcialmente compuesta de agentes de superficie activos o surfactantes, los cuales son típicamente causados por la descarga de aceites, jabones y detergentes. Los surfactantes, debido a su naturaleza amfifilica, se acumulan en la interfase entre el aire y el agua de las burbujas que ascienden. La acumulación de surfactantes incrementa la rigidez de la interfase y reduce la circulación de los gases y consecuentemente la tasa de transferencia (Rosso y Stenstroom, 2006a). Hasta recientemente, el concepto intuitivo de "la obstrucción molecular" era considerada como la causa de la caída en la transferencia de masa. Este fenómeno es dominante para interfaces gas-líquido inactivas, con nulas velocidades de fluido interfaciales, cuando la difusión molecular a través de la película inactiva es el único

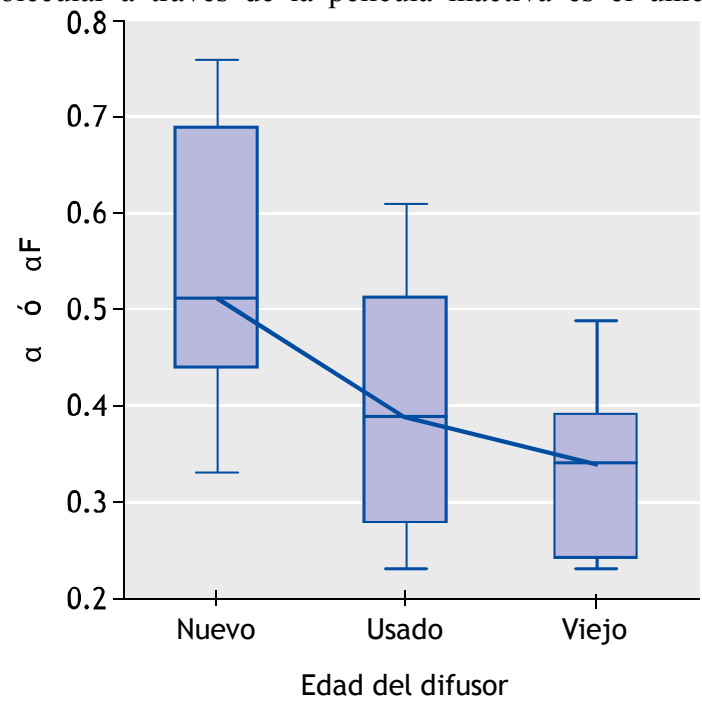

mecanismo de transporte, y las moléculas surfactantes a altas concentraciones pueden obstruir la difusión molecular de las moléculas de oxígeno a través de la interfase. Para interfaces en movimiento, el transporte turbulento a través de la interfase es el principal mecanismo que lleva a cabo la transferencia de masa, por dos razones: las tasas de intercambio y renovación interfacial y el área real cubierta por las moléculas de los surfactantes.

La Figura 9.24 contiene fotografías una resolución de $1 / 500$ " de burbujas gruesas y finas en la concentración de $50 \mathrm{mg} / \mathrm{l}$ de una solución de dodecil-sulfato de sodio, y muestra los patrones dinámicos de los flujos internos con ilustraciones. Las fotografías muestran que la gran mayoría de las burbujas tienen diámetros inferiores a 1 $\mathrm{mm}$. Pruebas llevadas a cabo en agua limpia sin surfactantes bajo condiciones análogas producen diámetros medios de burbujas de aproximadamente 4 $\mathrm{mm}$, más grandes que cualquier otra burbuja mostrada en la figura ubicada al centro del lado izquierdo en la Figura 9.24. En la Figura 9.24, una burbuja fina y una gruesa son resaltadas y el patrón de circulación interior está descrito a un lado. La acumulación de surfactante en la interfase de la burbuja fina ocurre en una magnitud mayor que en la burbuja gruesa, debido a que el tiempo de residencia hidráulico es mayor de que las moléculas de la sustancia surfactante tienen un mayor tiempo disponible para emigrar sobre la superficie. También, las burbujas más pequeñas tienen una velocidad entre facial mucho más pequeña y, una vez que los surfactante se han adherido a su superficie, sus extensiones hidrofóbicas que ingresan dentro de la burbuja reduce la circulación interna de los gases, actuando como barrera en un reactor mezclado.

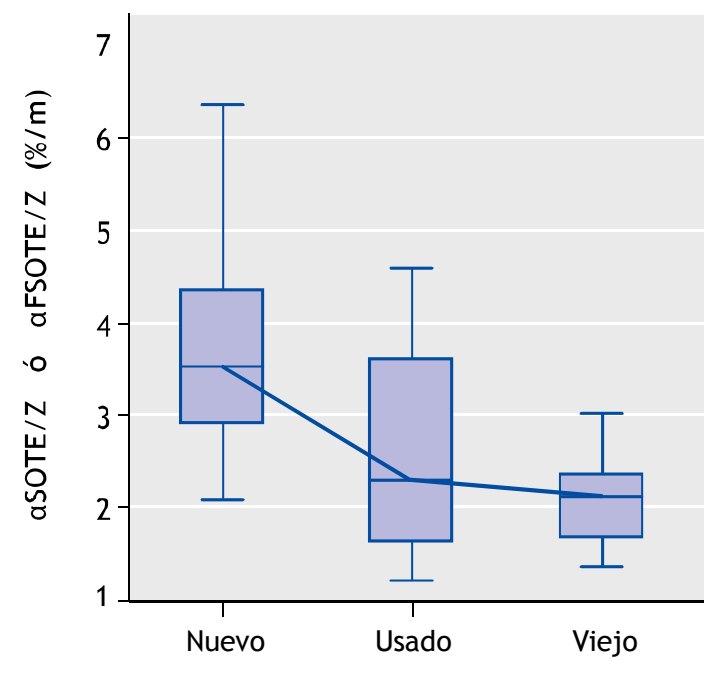

Edad del difusor

Figura 9.23 Reducción en la eficiencia en función del tiempo de operación: $\alpha \mathrm{F}$ a la izquierda, y $\alpha \mathrm{FSOTE} / \mathrm{Z}$ en la derecha. La línea continua muestra los valores promedio 


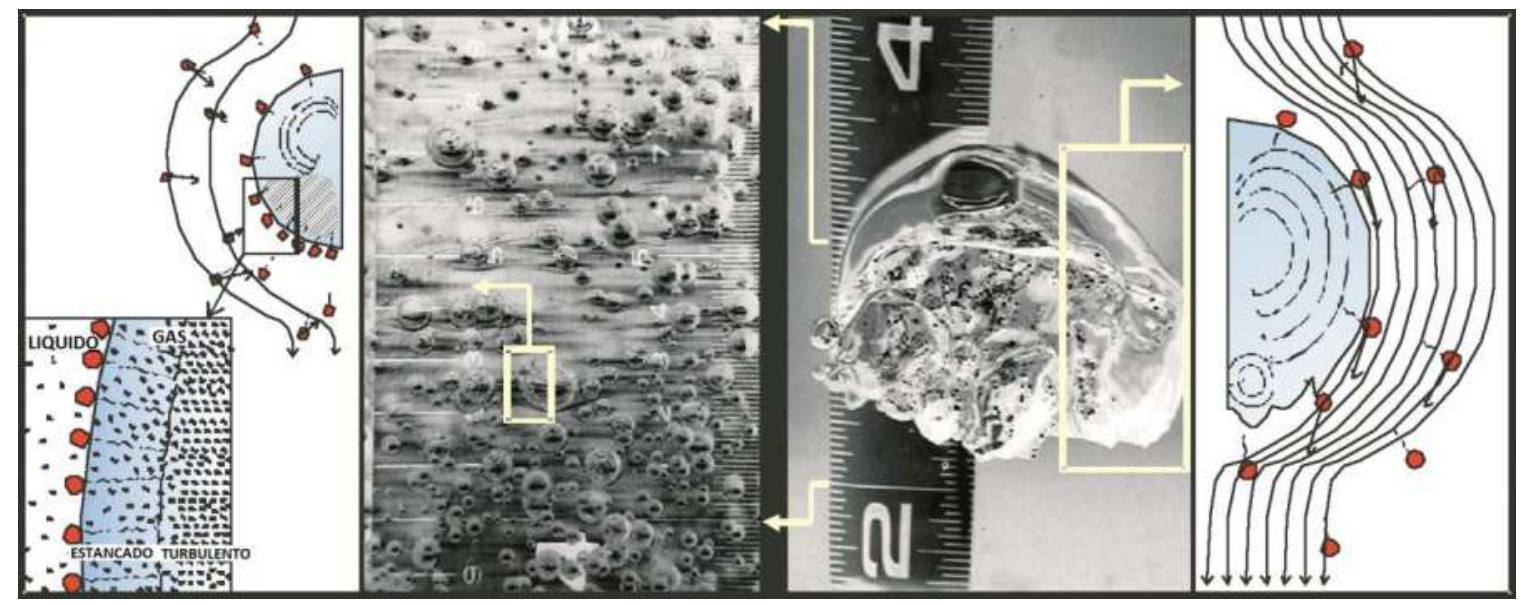

Figura 9.24 Comparación entre burbujas finas (izquierda) y gruesas (derecha) generadas por dos sistemas de aireación diferentes operados al mismo flujo de aire en la misma solución surfactante. Las ilustraciones a los extremos izquierdo y derecho muestran los diferentes mecanismos de acumulación interfacial en los dos casos. La escala está en pulgadas ( 1 pulgada = 25.4 mm), cada línea indica una subdivisión de $1 / 10$ pulgadas $(=2.54 \mathrm{~mm})$

Basados en los resultados de un análisis dimensional, las burbujas finas cubiertas con moléculas surfactantes han mostrado actuar como esferas sólidas, por ejemplo con una reducción severa en la circulación interna de los gases los cuales probaron ser la principal causa para la caída en la transferencia de gases (Rosso et al., 2005).

El efecto de los surfactantes puede ser parcialmente contrarrestado mediante el incremento del régimen de flujo (por ejemplo mediante burbujas gruesas). La Figura 9.25 muestra diversos valores de $\alpha$ en función del número de los Reynolds (Re) de las burbujas. A números de Reynolds bajos un ligero incremento en sus valores tienden a disminuir el valor de $\alpha$. Esto ocurre porque la burbuja ascendien como una esfera sólida. A valores altos de Re, los efectos de flotación y las fuerzas de arrastre son suficientes para favorecer la circulación interna en la burbuja. A valores de Re muy altos, prácticamente alcanzables sólo con burbujas gruesas, los efectos de los surfactantes son altamente contrarrestados, incrementando el factor $\alpha$ a expensas de la eficiencia de energía o a valores bajos de SAE. La Figura 9.25 muestra también el impacto de dos surfactantes diferentes, un impacto rápido con una alta difusividad (en una solución de dodecil sulfato de sodio, a.m.u. $\sim 10^{2}$ ), y un impacto lento con baja difusividad (en una solución de polivinilpirrolidona, a.m.u. $\sim 10^{4}$ ). El surfactante más rápido reprime más dramáticamente la tasa de transferencia por su mayor tasa de difusión y la mayor acumulación en la superficie de la burbuja.

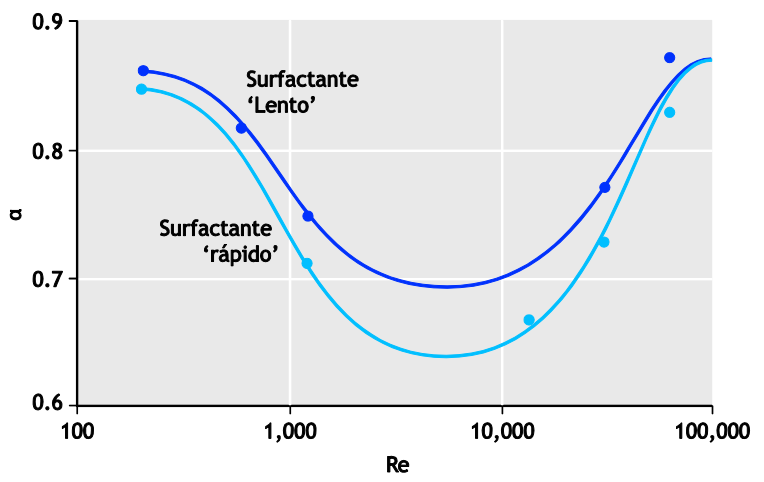

Figura 9.25 Efecto del régimen de flujo en los factores $\alpha$ de burbujas finas (con bajos Re) y burbujas gruesas (con altos Re) en dos soluciones que contienen surfactantes diferentes

Los altos niveles de turbulencia asociados a los aireadores de burbuja gruesa los hacen comportarse más como aireadores superficiales que como aireadores de burbuja fina. De esta manera, los aireadores de alta turbulencia pueden alcanzar mejores tasas de transferencia, pero a mayores consumos de energía y menores eficiencias de aireación.

\subsubsection{Monitoreo del desempeño del proceso de aireación}

Diversas pruebas en agua limpia (ASCE 2007) pueden ser ejecutadas para comparar diferentes equipos y configuraciones. Los resultados pueden reportarse en términos de la SOTE (\%), SOTR $\left(\mathrm{kgO}_{2} / \mathrm{h}\right)$, SAE $\left(\mathrm{kgO}_{2} / \mathrm{kWh}\right)$. Se debe poner especial cuidado cuando se reporte como SAE, ya que diferentes medidas del 
consumo de energía pueden hacerse. Generalmente, se recomienda determinar el consumo en la entrada total del sistema, ya que se incluyen el soplador, los acoplamientos, sistema de distribución y regulación, además de las ineficiencias del motor. Los estados de las pruebas llevadas a cabo en agua limpia pueden utilizarse como garantía para verificar el desempeño y pueden también crear un ambiente competitivo de ofertas entre diferentes fabricantes. La Figura 9.26 muestra una inagen de una prueba en agua limpia en paneles de membrana antes de su inicio.

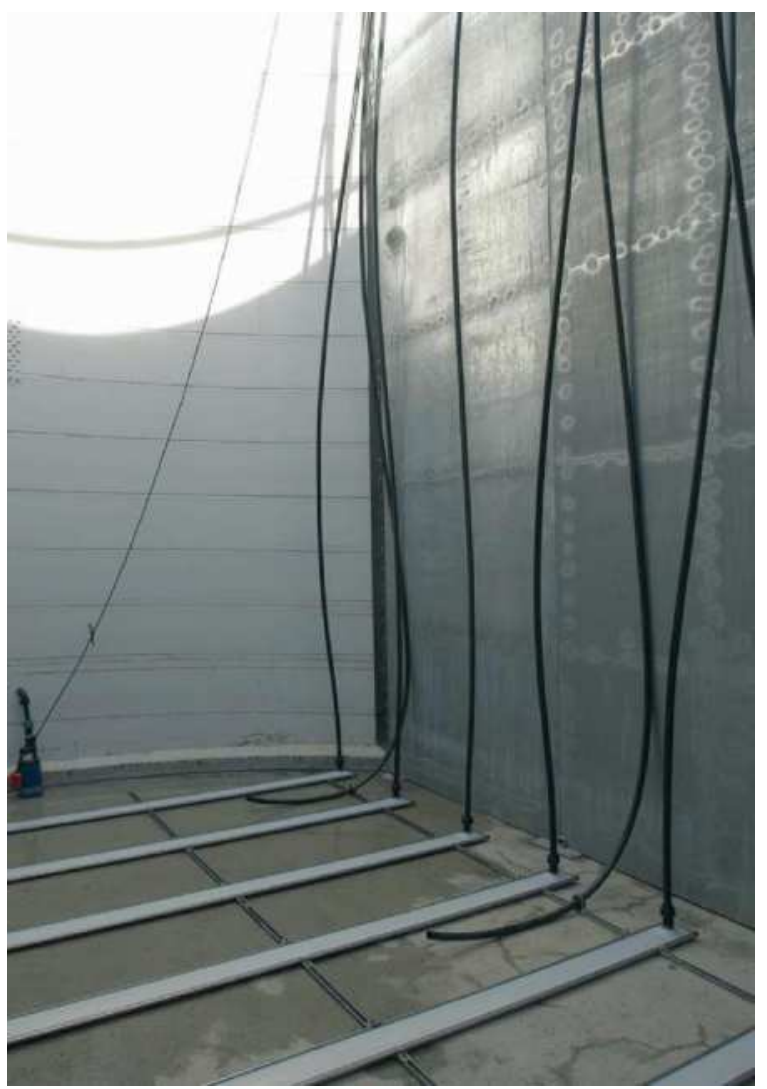

Figura 9.26 Difusores de poro fino (en este caso paneles de membrana) ubicados dentro de un tanque de $5 \mathrm{~m}$ de profundidad antes de llevar a cabo las pruebas en agua limpia (foto: M.K. Stenstrom)

Para otras condiciones del agua de proceso, los resultados pueden reportarse en términos de la OTE, OTR y AE, los cuales incluyen los impactos de las condiciones no estandarizadas. Para resultados concernientes al escape de los gases, es conveniente utilizar el $\alpha$ SOTE o el $\alpha$ SOTR. Estos dos parámetros están corregidos para todas las condiciones que difieren de las estándar excluyendo el factor $\alpha$. Lo anterior es posible porque las otras condiciones no estándar pueden ser fácilmente determinadas y corregidas. El factor $\alpha$, el cual expresa la relación entre los coeficientes de transferencia de masa en el agua de proceso en agua limpia, puede calcularse con base en los resultados de los gases generados si hay disponibles datos concernientes al agua limpia. En sistemas de aviación sucios o dañados, se utiliza un segundo parámetro, F, para definir el grado de ensuciamiento o daño. De esta manera, la eficiencia de un sistema de aireación de poro fino puede definirse mediante el $\alpha$ SOTE mientras que la eficiencia del sistema usado o dañado mediante el $\alpha$ FSOTE. El $\alpha$ SOTE y $\alpha$ SFSOTE se utilizan para definir las eficiencias de transferencia en aguas de proceso. Para comparar los resultados presentados aquí y aquellos bajo condiciones reales de operación, se deben de utilizar otras correcciones, tales como la concentración de oxígeno disuelto y la temperatura en el sitio.

Para definir de una manera más adecuada el desempeño de los aireadores, las técnicas de muestreo y prueba de las emisiones de gases han sido utilizadas de una manera excesiva para determinar las eficiencias de dirección difusa. Las pruebas de emisión de gases fueron desarrolladas por Redmon et al. (1983) en colaboración con la US EPA patrocinada por el Comité de Estandarización de Transferencia de Oxígeno de la ASCE. Este comité escribió un manual para la evaluación de difusores de poro fino (US EPA, 1989), una norma para transferencia de oxígeno en agua limpia, y guías para la ejecución de pruebas en aguas de proceso (US EPA, 1997). Esas publicaciones describen a detalle las pruebas en agua limpia y en las emisiones de gases (Figura 9.27). El principal impacto de las mejoras implementadas en los métodos de prueba son un incremento en la precisión y exactitud en el diseño y cuantificación de los sistemas de aireación. Estos métodos son aplicados ampliamente en los Estados Unidos (Redmon et al., 1983; Mueller y Stensel, 1990;

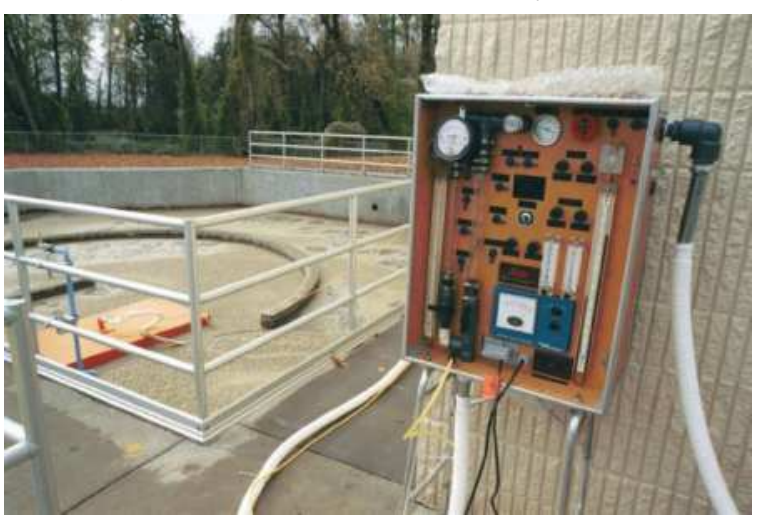

Figura 9.27 Mecanismo para la medición de las emisiones de gases (foto: M.K. Stenstrom) 
Iranpor et al., 2002) y en Europa (Kayser et al., 1979; Frey, 1991; Libra et al., 2002; Wagner et al., 2003; Guillot et al., 2005). El análisis de las emisiones también ha sido propuesto como un mecanismo de control adicional del sistema de aireación (Trillo et al., 2004).

\subsection{PRÁCTICAS SUSTENTABLES DE AIREACIÓN}

\subsubsection{Sistemas de aireación mecánicos simples para el tratamiento de aguas residuales}

Las lagunas de oxidación o estabilización son generalmente económicas y de baja intensidad energética, asumiendo que existe tierra disponible. Pueden también considerarse como un método de tratamiento en evolución, con una construcción inicial que utiliza únicamente la aireación natural, con la posibilidad de implementar una aireación artificial si la carga orgánica se incrementa. Aunque los sistemas lagunares han reducido su popularidad en las dos décadas pasadas debido a sus eficiencias de tratamiento modestas, sigue siendo altamente populares en áreas rurales. Adicionalmente, dado que se ha dado un mayor énfasis en la conservación y ahorro de energía así como también en evitar las emisiones de gases de invernadero, el diseño y operación de los sistemas lagunares debe de modificarse para secuestrar las emisiones de carbono a bajos consumos energéticos. Existe un sin número de referencias que detallan el diseño de las lagunas, y aunque son intrínsicamente simples, los principios de diseño son estrictos para asegurar una operación exitosa.

Las lagunas no aireadas pueden ser aeróbicas o facultativas dependiendo de la profundidad. La aireación natural en la superficie de las lagunas con concentraciones bajas de oxígeno varía desde aproximadamente 13 a $18 \mathrm{~kg} /$ ha.d. Las profundidades deben restringirse máximo 1 o $2 \mathrm{~m}$. Si la carga se incrementa, será necesario agregar aireadores superficiales o permitir que la laguna se convierta en anaerobia.

La aireación de lagunas generalmente se lleva a cabo mediante aireadores superficiales de alta velocidad, los cuales pueden ser instalados con una planificación y diseño simples. Los aireadores superficiales utilizados en estas aplicaciones típicamente operan en el rango más bajo de valores de SAE reportados previamente. Un aireador superficial grande será menos efectivo que diversos aireadores superficiales pequeños distribuidos sobre la superficie de la laguna aunque consuman la misma energía. Más aún, el uso de aireadores múltiples es preferible ya que permiten llevar a cabo con mayor flexibilidad las labores de mantenimiento sin grandes pérdidas en la eficiencia.

En años recientes en los Estados Unidos, sistemas de aireación sumergida han sido utilizados en lagunas. Esto tiene diferentes ventajas incluyendo menores pérdidas de calor durante el invierno así como también la capacidad de utilizar lagunas más profundas ahorrando la tierra disponible. La aireación sumergida puede ser proporcionada mediante tuberías de aire flotantes o parcialmente sumergidas ancladas al fondo de la laguna. Difusores de poro fino pueden montarse sobre las tuberías de aire utilizando mangueras con diámetros aproximados de $25 \mathrm{~mm}$. Este sistema también tiene la ventaja de que puede utilizarse en lagunas con fondos irregulares.

Existen ventajas y desventajas entre los requerimientos de mantenimiento de los dos métodos alternativos de aireación. Si se utilizan aireadores superficiales, el mantenimiento debe llevarse a cabo con botes o lanchas con personal capacitado para trabajar sobre estructuras flotantes. Si se utilizan difusores de poro fino, el mantenimiento de los sopladores siempre se lleva a cabo fuera de la laguna, pero el mantenimiento de los difusores tiene que ejecutarse dentro de la laguna. Finalmente, los difusores no se verán afectados por congelamiento durante los meses más fríos, lo cual es una de las mayores ventajas que afectan a los aireadores superficiales.

La Figura 9.28 muestra una laguna típica con un aireado superficial. Los requerimientos de energía son controlados mediante dos factores: la energía requerida para el mezclado y la requerida para la aireación. En energía mínima para el mezclado se encuentra en el rango de 1.5 to $1.75 \cdot 10^{-3} \mathrm{~kW} / \mathrm{m}^{3}$ pero el consumo típico de energía se encuentra alrededor de 8 to $10 \cdot 10^{-3} \mathrm{~kW} / \mathrm{m}^{3}$. La energía requerida para la aireación dependerá de la carga del afluente. El oxígeno requerido es de alrededor de 1.0 to $1.5 \mathrm{~kg} / \mathrm{kgBOD}_{5}$ dependiendo del tipo de agua residual y del grado esperado de tratamiento. Datos proporcionados por los fabricantes o valores de SAE previamente reportados pueden utilizarse para calcular la energía de aireación necesaria. Si se utilizan aireadores superficiales, datos proporcionados por los fabricantes pueden utilizarse para determinar la zona máxima de influencia, lo cual ayudará a controlar el espaciamiento y distribución de los aireadores. Finalmente, se recomienda tener un número mayor de aireadores al requerido para 


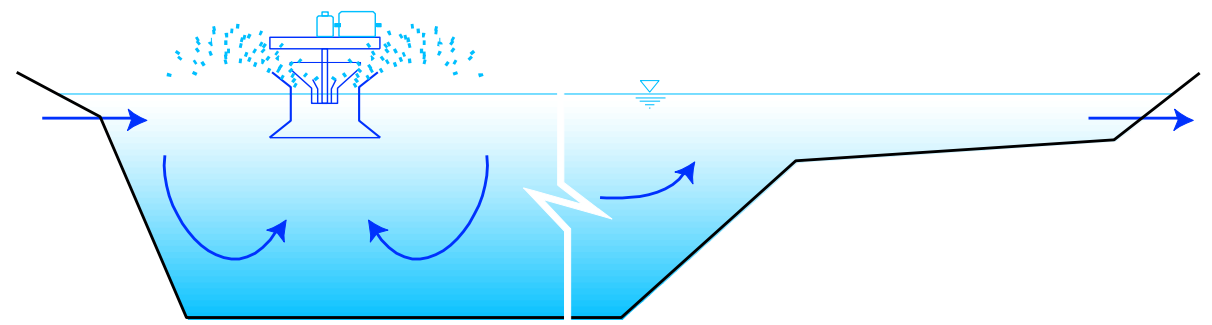

Figura 9.28 Diagrama longitudinal de una laguna aereada equipada con un aereador superficial

satisfacer la demanda durante periodos de operación bajo altas cargas.

Los últimos diseños de sistemas lagunares utilizan múltiples lagunas, con diversos flujos en paralelo a través de los sistemas lagunares (Figura 9.29) (Rich, 1980). Estos diseños usan una mera energía comparadas con los sistemas alternativos de lagunas porque la concentración de oxígeno disuelto puede variar desde valores bajos en las lagunas iniciales a valores muy altos en las últimas lagunas, los cuales en muchos casos podría requerir únicamente una aireación natural. Las lagunas pueden también utilizarse para acuacultura o producción de alimentos (Gordon et al., 1982).

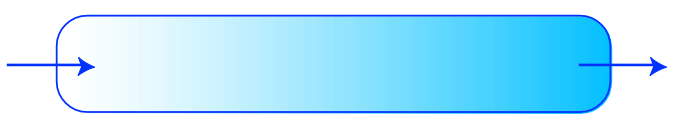

A

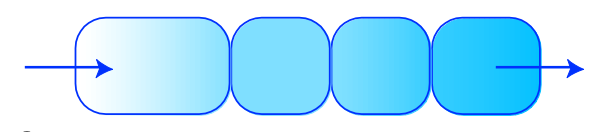

B

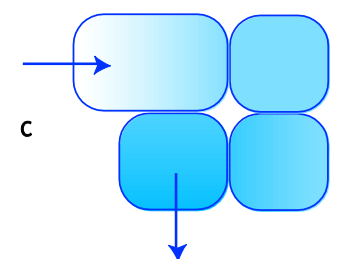

Figura 9.29 Esquema comparativo de sistemas de lagunas convencionales $(A)$ y múltiples $(B, C)$

\subsubsection{Estrategias para la conservación de energía}

Aquí se presentan tres casos de estudio llevados a cabo en una planta de tratamiento de aguas residuales municipales para mostrar la implementación de algunas posibles estrategias para la conservación de la energía.
Un resumen de las características de las plantas se presenta en la Tabla 9.4.

- Planta 1: Esta planta de tratamiento trata alrededor de $240000 \mathrm{~m}^{3} /$ día de aguas residuales generadas por una población equivalente a 800000 personas. Esta planta utilizan difusores cerámicos de disco para la aireación. Cuando se modernizó o actualizó con sistemas de poro fino, esta planta de tratamiento se convirtió después de 20 años de una planta de tratamiento de lodos activados convencional en una planta con tratamiento secundario con nitrificación y desnitrificación (NDN) para la remoción de amonio. Las pruebas de emisión de gases se aplicaron de manera continua durante los dos procesos para evaluar el ensuciamiento de los difusores.

- Planta 2: Los escenarios de operación y prueba de esta planta son similares a los de la primera: esta planta tiene discos cerámicos para la aireación y el proceso de tratamiento ha sido convertido de un sistema convencional a uno de NDN. La capacidad de esta planta es relativamente menor al de las otras dos: la población beneficiada es aproximadamente de 220000 personas y el flujo que trata esta planta es de $76000 \mathrm{~m}^{3} /$ día.

- Planta 3: Los difusores de poro fino utilizados en esta planta de tratamiento están hechos de EPDM (un monómero diano de etileno propileno), y esta planta no ha sido actualizada debido a que su capacidad ha sido excedida. De manera similar a la planta uno, la capacidad de esta planta es de $12500 \mathrm{~m}^{3}$ por día y la población beneficiada es de 880000 personas. Hasta la última prueba, los difusores en la mayoría de los tanques en esta planta (ocho de 10) no habían sido limpiados desde su instalación (8 años antes). 
Tabla 9.4 Datos de las plantas de tratamiento de aguas residuales evaluadas

\begin{tabular}{llll}
\hline Parámetro & Planta 1 & Planta 2 & Planta 3 \\
\hline Flujo volumétrico promedio (m/hour) & 10000 & 3150 & 12500 \\
$\mathrm{DBO}_{5}$ en el enfluente primario (mg/l) & 162 & 132 & 146 \\
Concentración de amonio en el enfluente primario (mg-N/l) & 28 & 25 & 28 \\
Número de tanques en operación & 18 & 6 & 10 \\
Proceso de tratamiento & $\mathrm{NDN}^{\mathrm{a}}$ & $\mathrm{NDN}$ & $\mathrm{CAS}^{\mathrm{b}}$ \\
Población beneficiada & 800000 & 220000 & 880000 \\
\hline
\end{tabular}

${ }^{\text {a }} \mathrm{NDN}=$ Proceso de nitrification/desnitrificación.

${ }^{\mathrm{b}} \mathrm{CAS}=$ Proceso convencional de lodos activados.

Las pruebas de emisión de gases se llevaron a cabo con base en la descripción de Redmon et al. (1983). El balance de masa entre el oxígeno añadido (20.95\% de fracción molar) y el flujo de emisiones de gases permite calcular el OTE, el cual fue estandarizado a $\alpha$ SOTE. Para cada prueba, se recolectaron datos de seis a ocho puntos de muestreo, distribuidos uniformemente sobre la superficie del tanque de aireación y presentados con base en los promedios ponderados de los flujos. Además, la OTR, en $\mathrm{kgO}_{2} / \mathrm{h}$, se calculó midiendo el flujo de las emisiones de gases y la caída de presión en los difusores se estimó con base en las mediciones determinadas en planta y las pruebas en agua limpia. Con la OTR y la pérdida de presión, los costos de aireación se determinaron mediante la función adiabática para sopladores (Metcalf y Eddy, 2003)

La Figura 9.30 muestra los efectos del ensuciamiento y el bloqueo o taponamiento en la eficiencia de aireación: $\alpha$ SOTE ha sido graficado en función del tiempo de operación después de la instalación de los difusores de poro fino. En la Figura 9.30a, el valor de $\alpha$ SOTE en todos los sistemas decrece con el tiempo de operación, pero la tasa de ensuciamiento o taponamiento varía dependiendo del tipo difusor y la operación de la planta. El valor numérico desplegado encima de cada dato corresponde al TRS. Puede observarse en que el ensuciamiento es extremadamente rápido cuando el TRS es corto: los difusores pierden casi el $50 \%$ de su $\alpha$ SOTE después de
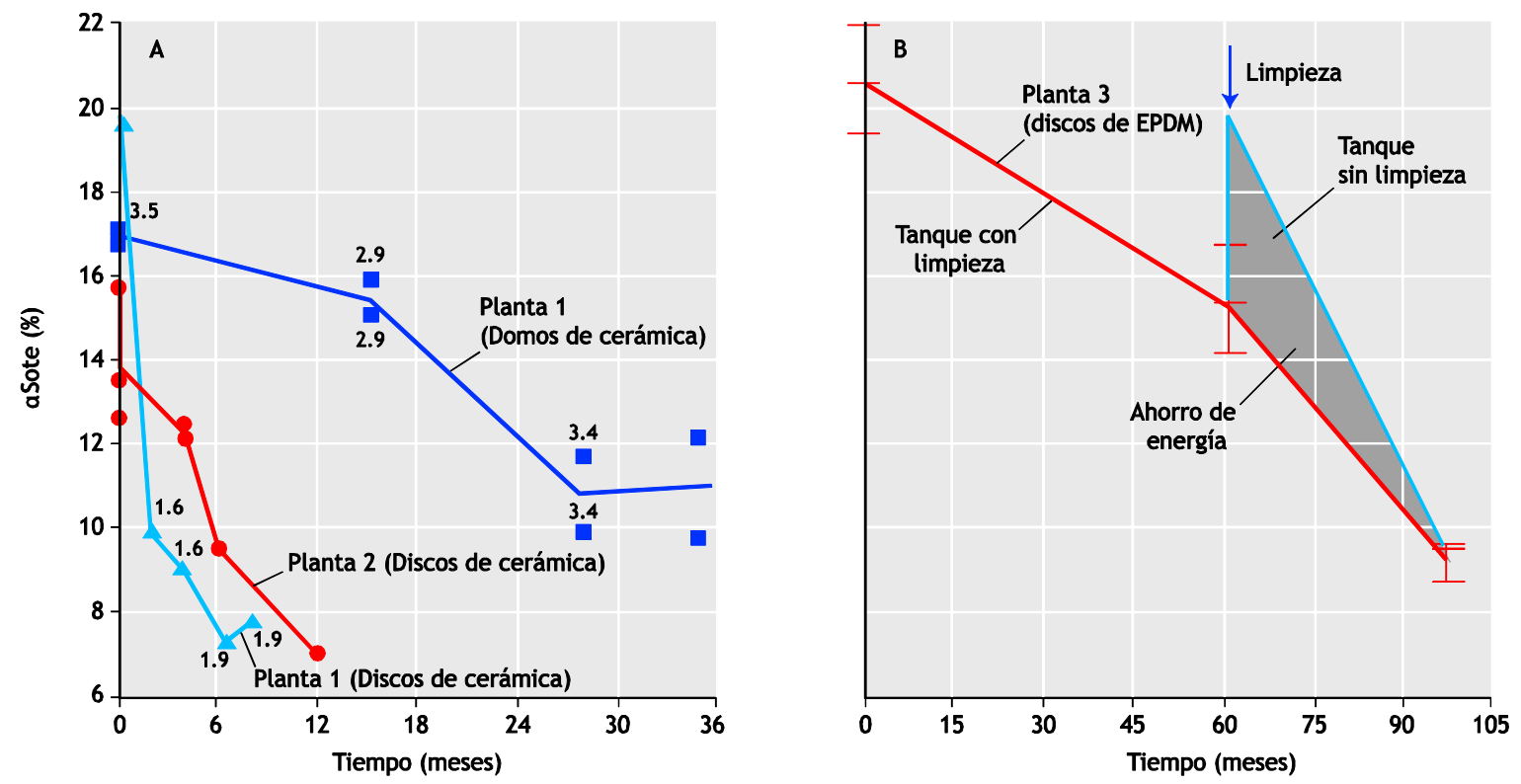

Figura 9.30 (A) Reducción en las eficiencias de aireación de difusores de poro fino. Dependiendo de los tipos de difusores y los procesos de operación, la tasa de ensuciamiento o bloqueo de los difusores depende de las condiciones locales. (B) La limpieza de los difusores ayudó considerablemente a recuperar la eficiencia de aireación, y los ahorros de energía pudieron ser calculados mediante la estimación de la diferencia entre los difusores con y sin limpieza (descrito en el texto). 
tres meses de operación. La Figura 9.30b muestra la recuperación de $\alpha$ SOTE después de la limpieza de los difusores. En la planta 3, sólo dos de los 10 tanques de aireación fueron vaciados y limpiados durante el periodo de pruebas. No se comparan con los tanques que no fueron limpiados, los tanques limpios tuvieron una aSOTE de $19.5 \%$ comparada con el $15.5 \%$ de los que no se limpiaron, un incremento de $4 \%$ o una mejora relativa de aproximadamente $30 \%$. Además, los ahorros de energía logrados por la limpieza de los difusores pueden ser estimados al integrar el área comprendida entre el incremento en la eficiencia de aireación de los difusores limpios con respecto a los sucios. Dicha área corresponde al área sombreada mostrada en la Figura $9.30 \mathrm{~b}$.

La Figura 9.31 muestra los costos de energía de aireación en tres plantas. Con base en su estado, ya sea limpio o sucio, los difusores fueron agrupados en tres columnas: en color blanco los instalados recientemente, en azul los que han sido limpiados, y en gris oscuro los sucios o bloqueados. Las líneas verticales ubicadas encima de cada columna muestran la deIVLación estándar de los resultados de las pruebas, y los costos de aireación de los diferentes procesos (convencionales o NDN) fueron graficados de manera separada para las plantas 1 y 2 . Se observaron mejoras considerables en el uso de energía cuando los difusores fueron limpiados, proporcionando un ahorro de energía estimado de aproximadamente $4.5 \mathrm{kWh} /$ año, o de $9900 \mathrm{~kW}$ hora por día en la planta 1.

La Figura 9.32 muestra los costos de aireación bajo diferentes procesos de tratamiento. El consumo total de energía de la planta 1 fue graficado en función del tiempo de retención de sólidos. Para comparar los diferentes procesos, las cargas orgánicas de tratamiento fueron estandarizadas utilizando la misma base: la OTR de los procesos convencionales fueron ajustados al nivel de los de NDN. Como resultado, los costos de aireación se reducen de manera exponencial con el TRS. A TRS cortos, las condiciones de aireación varían dramáticamente y se requiere más energía para bombeo debido al mayor ensuciamiento de los difusores (áreas en rojo). Los TRS largos proporcionan una mejor eficiencia de transferencia de oxígeno y hacen que los procesos NDN requieran menos aire para oxidar la misma cantidad de contaminantes. Esta observación confirmó las conclusiones obtenidas en estudios previos (Rosso y Stenstroom, 2006b) que concluyeron que tiempos de retención de sólidos más largos y ambientes anóxicos como los generados en los procesos NDN proporcionan una composición de bacterias más saludable que pueden contribuir a reducir el impacto negativo de la sustancias surfactantes en la transferencia de oxígeno (por ejemplo, contribuyendo a incrementar el factor $\alpha$ (Stenstroom et al., 1981). En estos casos, el análisis de las emisiones de gases sirve como una herramienta útil para la operación de la planta y el mantenimiento de los difusores.

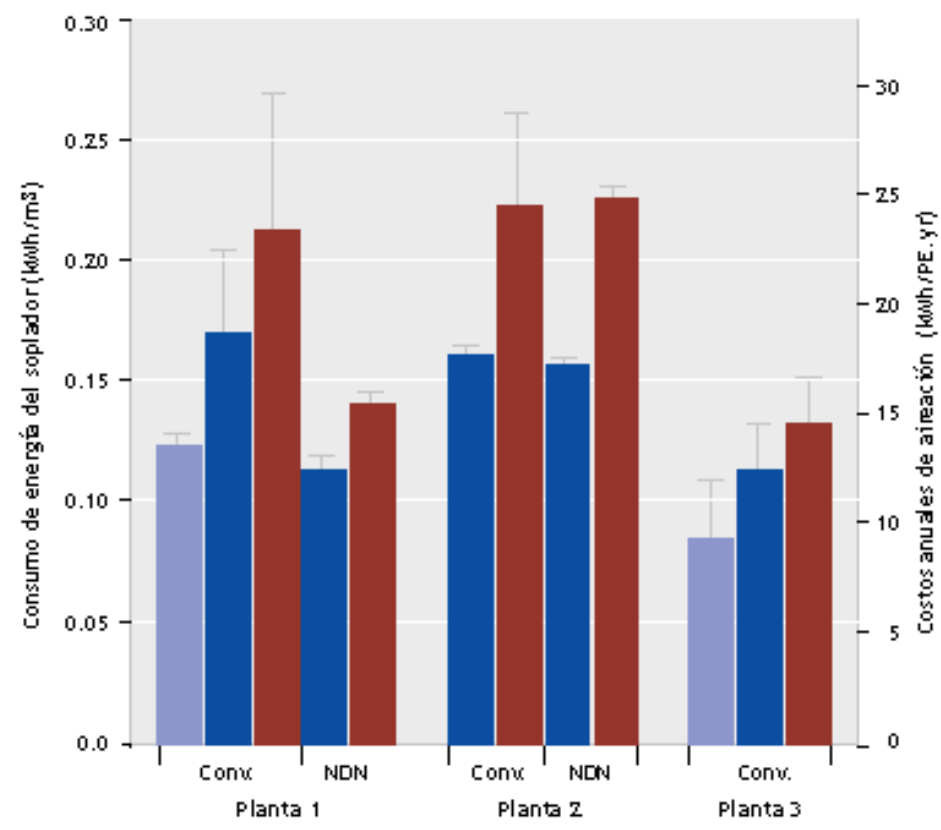

Figura 9.31 Consumo de energía de difusores de poro fino en diferentes plantas de tratamiento. Los costos de aireación fueron estandarizados considerando las cargas totales de demanda de oxígeno y la población beneficiada. 


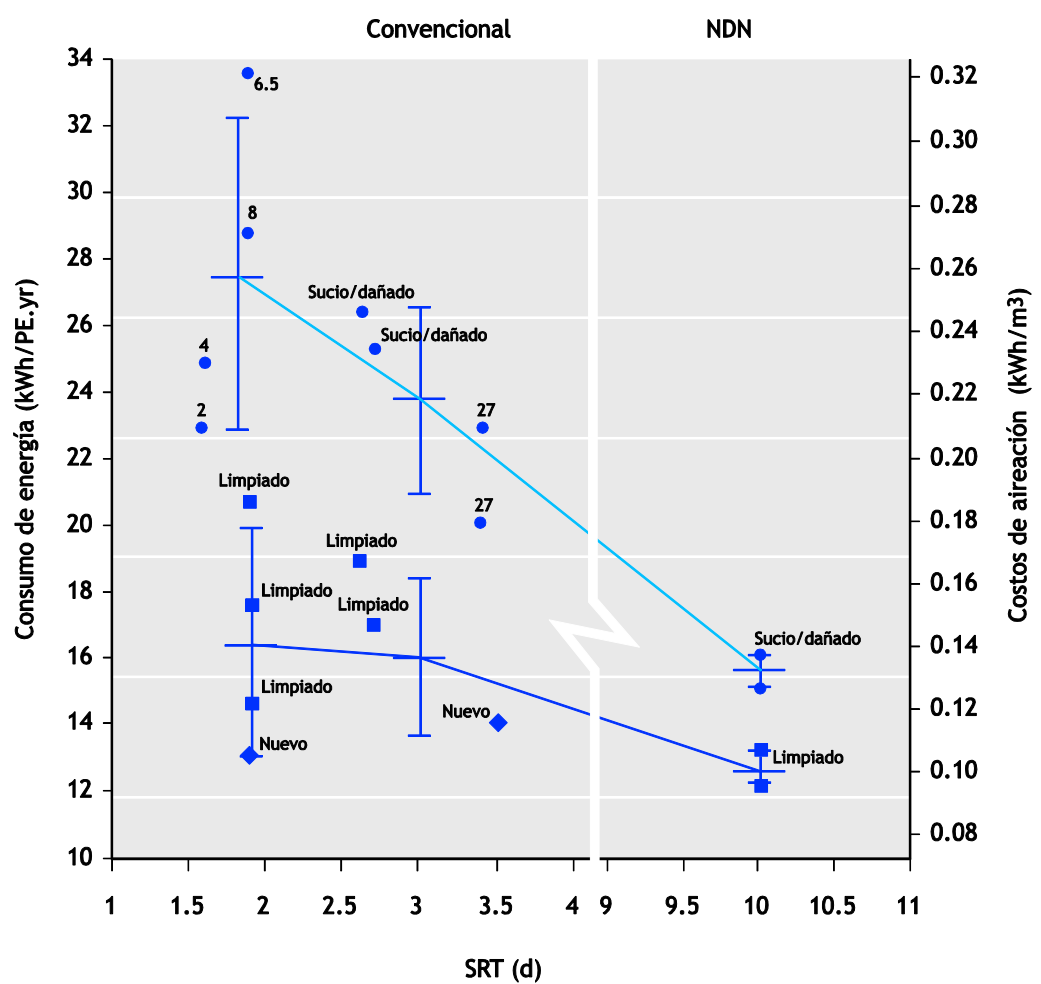

Figura 9.32 Costos de aireación de la Planta 1, se presentan en función del tipo de operación de la planta y del ensuciamiento del difusor: el ensuciamiento del difusor se redujo a TRS más largos

\subsection{REQUERIMIENTOS DE AIREACIÓN}

\subsubsection{Algoritmo de diseño}

Para aplicarlo descrito en este capítulo al diseño o modernización de una planta de tratamiento, se presentan dos ejemplos hipotéticos. Primero, como un ejemplo de diseño, se pueden implementar un algoritmo como el que se muestra en la Figura 9.33. Para una carga fija de agua residual a un TRS definido, la demanda de oxígeno se puede calcular de manera inicial como el OTR requerido (masa de $\mathrm{O}_{2}$ por unidad de tiempo):

OTR $=($ flujo de la planta - carga orgánica de la planta $)$ - exceso de lodo

El tamaño del tanque de aireación y la profundidad de los tanques se deben determinar con base en las restricciones de diseño y económicas concernientes. Luego entonces, se debe seleccionar el tipo de difusor y asumir un valor inicial para $\alpha$ SOTE. Basados en datos sobre los difusores proporcionados por los fabricantes se puede sugerir un rango de flujo de aire por difusor y, consecuentemente, el número total de difusores requerido puede determinarse. El $\alpha$ SOTE puede seleccionarse con base en información proporcionada por los fabricantes o utilizando valores disponibles en la literatura para $\alpha$. El flujo de aire requerido puede estimarse tomando en cuenta la tasa de consumo de oxígeno y la transferencia de oxígeno, lo cual permitirá calcular el flujo específico de aire. A continuación, el flujo específico de aire normalizado, $Q_{\mathrm{N}}$, puede calcularse con base en el flujo de aire requerido, el área del difusor, el número total de difusores y la profundidad del difusor, utilizando la ecuación 9.7. Una vez que se conoce $Q_{\mathrm{N}}$ y utilizando el TRS de operación de la planta, se puede estimar un valor de $\alpha$ SOTE más acorde a las condiciones locales de la planta utilizando la Figura 9.34.

$$
Q_{N}=\frac{A F R}{a N_{D} Z}
$$

donde:

AFR velocidad del flujo de aire $\left(\mathrm{m}^{3} / \mathrm{s}\right)$

a área efectiva de operación de los difusores $\left(\mathrm{m}^{2}\right)$

$\mathrm{N}_{\mathrm{D}} \quad$ número total de difusores (-)

$\mathrm{Z} \quad$ profundidad del difusor $(\mathrm{m})$ 


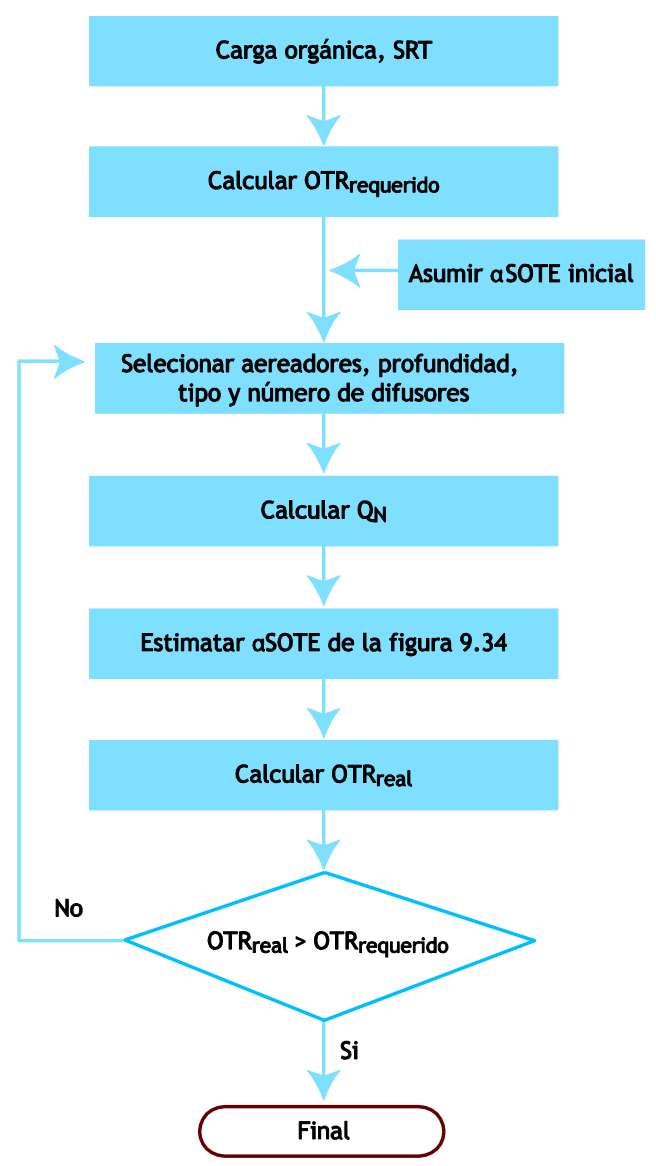

Figura 9.33 Diagrama de flujo para el diseño de un sistema de aireación

Una vez que se ha estimado un nuevo valor para $\alpha$ SOTE se debe de comparar contra el $\mathrm{v}$ alor de $\alpha$ SOTE previamente asumido. Si el nuevo valor difiere en más de $0.5 \%$ del valor inicialmente asumido, se debe repetir el mismo algoritmo de cálculo utilizando el nuevo $\alpha$ SOTE (estimando un nuevo flujo de aire y un flujo específico de aire hasta calcular un nuevo flujo de aire especifico normalizado, QN). Utilizando la Figura 9.34, se determinará un tercer valor para $\alpha$ SOTE que será comparado contra el segundo $\alpha$ SOTE calculado. Se recomienda repetir el algoritmo de cálculo hasta que los valores de $\alpha$ SOTE sean practicamente los mismos. Si los valores no convergen, se debe seleccionar un nuevo número de difusores o inclusive un tipo o tecnología diferente de difusores.

A continuación se muestra un ejemplo numérico. Dado un flujo de $0.875 \mathrm{~m}^{3} / \mathrm{s}$, con una carga de $180 \mathrm{mg} / 1 \mathrm{MLSS}$, y asumiendo unas tasas de crecimiento de $0.5 \mathrm{y}$ de decaimiento de $0.061 / \mathrm{d}$, el OTR requerido será de 9540
$\mathrm{kgO}_{2} /$ día. Considerando un tiempo de tensión hidráulico de cuatro horas, tres tanques con dimensiones cada uno de $90 \times 9 \times 5 \mathrm{~m}$ (longitud por ancho por profundidad) y una $\alpha$ SOTE inicial de $13.5 \%$, el flujo de aire será de $0.985 \mathrm{~m}^{3}$ por segundo. Tomando en cuenta para el diseño discos cerámicos de nueve pulgadas de diámetro (con un área efectiva de trabajo de $0.0373 \mathrm{~m}^{2}$ por difusor) con un flujo operativo por difusor de $7.87 \times 10-4 \mathrm{~m}^{3} / \mathrm{s}$, se requerirán 1250 difusores. Dados estos datos, es posible calcular un $Q_{\mathrm{N}}$ de 0.004152 1/s. Este valor, junto con un TRS de 8.7 días, nos permite calcular un nuevo valor de $\alpha$ SOTE de 11. 9\%. Usando este nuevo valor de $\alpha$ SOTE, un nuevo QN puede ser calculado en alrededor de 0.0051 $1 / \mathrm{s}$, y el algoritmo de diseño converge en $11.7 \%$ después de una iteración.

\subsubsection{Algoritmo para verificación y mejoramiento}

Un segundo ejemplo puede ser útil para ilustrar el incremento en la carga orgánica recibido en una planta, tal y como se muestra en la Figura 9.34.

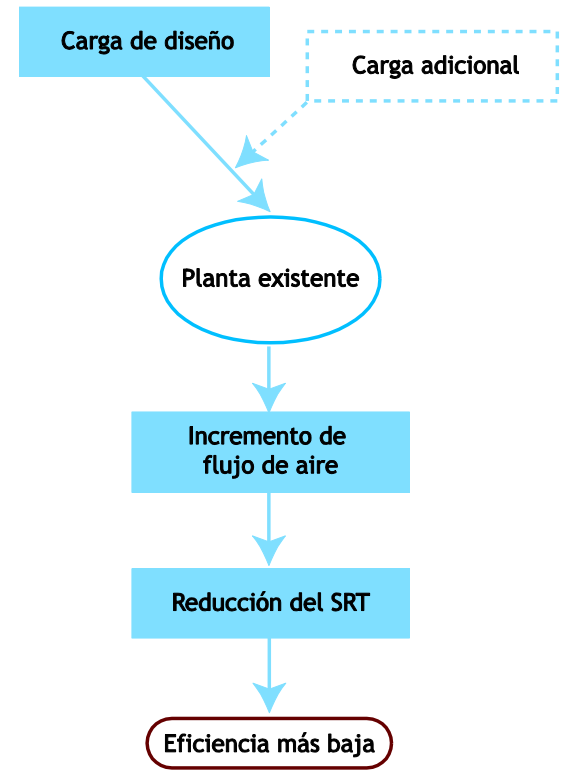

Figura 9.34 Diagrama de flujo para verificar/modernizar la operación de un tanque de aireación

El incremento de carga que ingresa la planta incrementa la demanda de oxígeno y, para suministrar una mayor carga de oxígeno, los aireadores deben operar a flujos de aire más altos. Esto causa un incremento en QN dado que el número de difusores y la geometría del tanque de aireación no cambian. Si la concentración de sólidos no se incrementa, entonces la planta operará a tiempos de retención de sólidos (TRS) más bajos. Como 
consecuencia, la eficiencia del proceso de aireación disminuirá debido al flujo de aire más alto y al tiempo de residencia de sólidos más corto.

La figura 9.35 presenta dos escenarios: el Punto I muestra el diseño inicial, el cual corresponde al utilizado en el ejemplo previo; el punto de diseño II muestra un incremento en la carga de 0.835 a $1.094 \mathrm{~m}^{3} / \mathrm{s}$, con una caída en $\alpha$ SOTE de 11.9 a 10.5\%. El incremento de 1.094 a $1.313 \mathrm{~m}^{3} / \mathrm{s}$ para el punto de diseño número III resulta en una caída adicional en la eficiencia a $9.5 \%$. El efecto directo de incrementar la carga será un incremento en el consumo de energía eléctrica por unidad de carga orgánica tratada. Este ejemplo muestra que, al incrementar la carga, existen causas que originan una menor eficiencia de aireación: el mayor flujo de aire y el menor tiempo de residencia de sólidos.

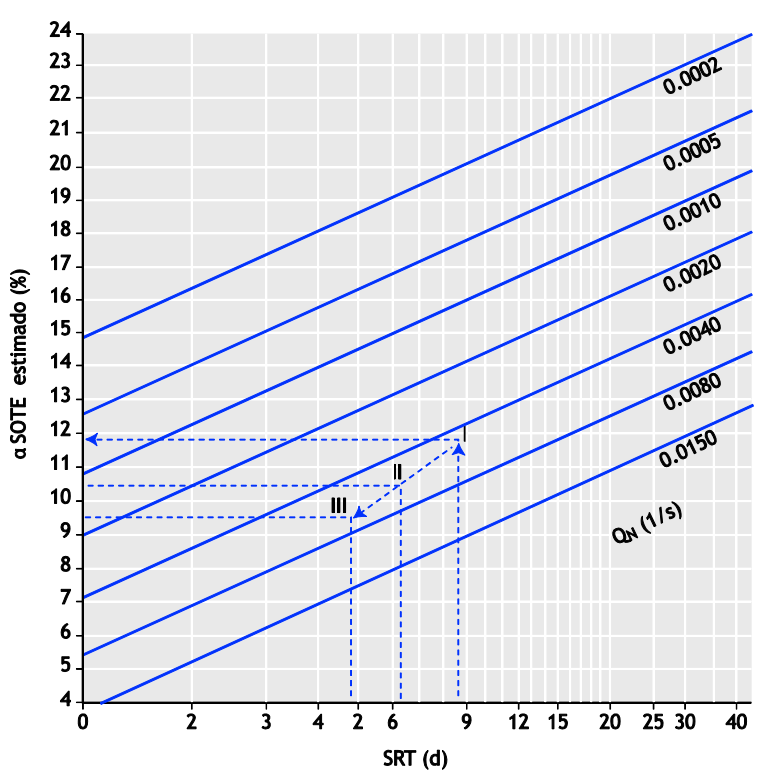

Figura 9.35 Gráfica de diseño y verificación. I: Flujo $=0.875 \mathrm{~m}^{3} / \mathrm{s}$ (ejemplo de diseño), $\mathrm{Q}_{\mathrm{N}}=0.0046 / \mathrm{s}, \mathrm{TRS}=8.7 \mathrm{~d}, \alpha \mathrm{SOTE} \mathrm{EST}_{\mathrm{S}}=11.9$ \%; II: Flujo $=1.094 \mathrm{~m}^{3} / \mathrm{s}, \mathrm{Q}_{\mathrm{N}}=0.0058 / \mathrm{s}$, TRS $=6.3 \mathrm{~d}, \alpha \mathrm{SOTE}_{\mathrm{EST}}=$ $10.5 \%$; III: Flujo $=1.313 \mathrm{~m}^{3} / \mathrm{s}, Q_{N}=0.0069 / \mathrm{s}$, TRS $=4.9 \mathrm{~d}, \alpha$ SOTE $_{\text {EST }}$ $=9.5 \%$ 


\section{REFERENCIAS}

Allbaugh T.A., Kang S.J. (1989) Fine Pore Diffuser Case History for Frankenmuth, Michigan, EPA/600/R94/100, U.S. Environmental Protection Agency, Washington, D.C.

American Society of Civil Engineers - ASCE (1984, 1991, 2007) Measurement of Oxygen Transfer in Clean Water, ASCE 2-91, American Society of Civil Engineers, New York.

American Society of Civil Engineers - ASCE (1997) Standard Guidelines for In-Process Oxygen Transfer Testing, ASCE 18-96, American Society of Civil Engineers 345 E. 47th St, New York.

Boyle W.C., Craven A., Danley W., Rieth M. (1989) Oxygen Transfer Studies at the Madison Metropolitan Sewerage District Facilities, EPA/600/R-94/096, U.S Environmental Protection Agency, Washington, D.C.

Cornel P., Wagner M., Krause S. (2002) Investigation of Oxygen Transfer Rates in Full Scale Membrane Bioreactors, Paper Reference No. e21291a; Darmstadt Technical University, Darmstadt.

Eckenfelder W.W., and Ford D.L. (1968) New concepts in oxygen transfer and aeration, in Advances in water quality improvement, University of Texas Press, 215236.

Ferrer J., (1998) Energy saving in the aeration process by fuzzy logic control. Wat. Sci. Tech. 38(3), 255-263.

Fisher M.J., Boyle W.C. (1999) Effect of Anaerobic and Aerobic Selectors on Oxygen Transfer in Water. Water Environ. Res. 71(1), 84-93.

Frey W. (1991) Comparison of aeration equipment under operating-conditions, Wat. Sci. Tech. 24(7), 43-45.

Gilbert R.G., Sullivan R.C. (1989) Off-Gas Analysis Results and Fine Pore Retrofit Case History for Hartford, Connecticut, EPA/600/R-94/105; U.S. Environmental Protection Agency, Washington, D.C.

Gillot S., Kies F., Amiel C., Roustan M., Héduit A. (2005) Application of the off-gas method to the measurement of oxygen transfer in biofilters, Chem. Eng. Sci. 60, 6336-6345.

Gordon M.S., Chapman D.J., Kawasaki L.Y., Tarifeño-Silva E., and Yu D.P. (1982) Aquacultural approaches to recycling of dissolved nutrients in secondarily treated domestic wastewaters - IV - Conclusions, design and operational considerations for artificial food chains, Wat. Res. 16, 67-71.

Harper W.F. and Jenkins D. (2003) The Effect of an Initial Anaerobic Zone on the Nutrient Requirements of Activated Sludge, Water Environ. Res.75(3), 216-224.

Hsieh C.C., Ro K.S., Stenstrom M.K. (1993a) Estimating Emissions of Twenty VOCs: Surface Aeration. J.Environ. Eng. Div. 119, 1077-1098.

Hsieh C.C., Babcock R.W., Stenstrom M.K. (1993b) Estimating Emissions of Twenty VOCs: Diffused Aeration, J. Environ. Eng. Div. 119, 1099-1118.

Iranpour R., Magallanes A., Zermeno M., Moghaddam O., Wilson J., Stenstrom M.K. (2000a) Assessment of Aeration System Performance Efficiency: Frequent
Sampling for Damage Detection. Water Environ. Res. 72 (3), 363-376.

Iranpour R., Magallanes A., Zermeno M., Varsh V., Abrishamci A., Stenstrom M.K. (2000b) Assessment of Aeration Basin Performance: Sampling Methods and Tank Coverage. Wat. Res. 34 (12), 3137-3152.

Iranpour R., Shao Y.J., Ahring B.K., Stenstrom M.K. (2002) Case Study of Aeration Performance under Changing Process Conditions. J. Environ. Eng. 128, 562-569.

Iranpour R., Stenstrom M.K. (2001) Relationship Between Oxygen Transfer Rate and Airflow for Fine-Pore Aeration under Process Conditions. Water Environ. Res. 73 (3), 266-275.

Kaliman A., Rosso D., Leu S.Y., Stenstrom M.K. (2007) Fine-pore aeration diffusers: accelerated membrane ageing studies, Wat. Res. in press.

Kayser R. (1979) Measurements of $\mathrm{O}_{2}$ Transfer in Clean Water and under Process Conditions, Prog. Wat. Tech.11 (3), 23-26.

Kessener H.J., Ribbius F.J. (1935) Practical Activated Sludge Research. J. Proc. Inst. Sewage Purif. 50-56.

Khan E., Babcock R.W., Suffet I.H., Stenstrom M.K. (1998) Method development for measuring biodegradable organic carbon in reclaimed and treated wastewaters. Wat. Environ. Res. 70, 1025-1032.

Libra J.A., Schuschardt A., Sahlmann C., Handschag J., Wiesmann U., Gnirss R. (2002) Comparison of the efficiency of large-scale ceramic and membrane aeration systems with the dynamic off-gas method, Wat. Sci. Tech. 46(4-5), 317-324.

Ma Y., Peng Y, Wang S. (2004) Feedforward-feedback control of dissolved oxygen concentration in a predenitrification system. Bioprocess Biosyst Eng. 27, 223.

Marx J.J. (1989) Fine Pore Diffuser System Evaluation for the Green Bay Metropolitan Sewerage District, EPA/600/R-94/093. U.S. Environmental Protection Agency, Washington, D.C.

Masutani G., Stenstrom M.K. (1990) Fine Pore Diffuser Fouling: The Los Angeles Studies. UCLA ENG, University of California: Los Angeles.

Metcalf and Eddy, Inc. (2003) Wastewater engineering. treatment and reuse. 4th ed., McGraw-Hill, New York.

Mueller J.A., Kim Y.K., Krupa J.J., Shkreli F.; Nasr S., Fitzpatrick B. (2000) Full-Scale Demonstration of Improvement in Aeration Efficiency. J.Environ.Eng. 126 (6), 549-555.

Mueller J.A., Saurer P.D. (1989) Case History of Fine Pore Diffuser Retrofit at Ridgewood, New Jersey, EPA/600/R-94/098. U.S. Environmental Protection Agency, Washington, D.C.

Mueller J.S., and Stensel H.D. (1990) Biologically enhanced oxygen transfer in activated sludge process. J. Water Pollut. Control Fed. 62(2), 193-203.

Parker D., Appleton R., Bratby J., and Melcer H. (2003) North American Performance Experience with Anoxic and Anaerobic Selectors for Activated Sludge Bulking Control. Proc. $9^{\text {th }}$ Specialized Conference on Design, 
Operation and Economics of Large Wastewater Treatment Plants, Prague.

Reardon D.J. (1995) Turning down the power, Civ. Eng. 65(8) 54-56.

Redmon D.T., Boyle W.C., Ewing L. (1983) Oxygen Transfer Efficiency Measurements in Mixed Liquor Using Off-Gas Techniques. J. Water Pollut. Control Fed. 55, 1338-1347.

Rieth M.G., Boyle W.C., and Ewing L. (1990) Effects of Selected Design Parameters on the Fouling Characteristics of Ceramic Diffusers, J. Water Pollut. Control Fed. 62 (7), 877-886.

Rosso D., and Stenstrom M.K. (2005) Comparative Economic Analysis of the Impacts of Mean Cell Retention Time and Denitrification on Aeration Systems. Wat. Res. 39, 3773-3780.

Rosso D., and Stenstrom M.K. (2006a) Surfactant effects on $\alpha$-factors in aeration systems. Wat. Res. 40, 1397-1404.

Rosso D., and Stenstrom M.K. (2006b) Economic Implications of Fine Pore Diffuser Aging. Wat. Environ. Res. 78, 810-815.

Rosso D., Iranpour R. and Stenstrom M.K. (2005). Fifteen Years of Off-gas Transfer Efficiency Measurements on Fine-Pore Aerators: Key Role of Sludge Age and Normalized Air Flux. Wat. Environ. Res. 77(3), 266273.

Rosso D., Huo D.L., and Stenstrom M.K. (2005) Effects of interfacial surfactant contamination on bubble gas transfer. Chem. Eng. Sci. 61, 5500-5514.

Rosso D., Larson L.E., and Stenstrom M.K. (2007) Aeration of large-scale municipal wastewater treatment plants: state of the art. Proc. Proc. 10th IWA Conference on Design, Operation and Economics of Large Wastewater Treatment Plants, Vienna.

Schmit F.L., Redmond D.T., Ewing L. (1989) In place gas cleaning of diffusion elements, U.S. Patent 4,889,620, December 26, 1989.

Sedory P.E., Stenstrom M.K. (1995) A Dynamic Model for the Prediction of Aeration Basin Temperature. J.Environ. Eng. Div. 121 (9), 609-618.

Serralta J., Ribess J., Seco A., Ferrer J. (2002) A supervisory control system for optimizing nitrogen removal and aeration energy consumption in wastewater treatment plants. Wat. Sci. Tech.. 45 (4-5), 309.

Soliman M.A., Pedersen J.A. and Suffet I.H. (2004). Rapid gas chromatography-mass spectrometry screening method for human pharmaceuticals, hormones, antioxidants and plasticizers in water. J. Chromatogr. A 1029, 223-227.

Stenstrom M.K., Andrews J.F. (1980) Cost Interactions in an Activated Sludge System. J.Environ. Eng. Div. 106 (EE4), 787-796.

Stenstrom M.K., Gilbert R.G. (1981) Effects of Alpha, Beta and Theta Factors in Design, Specification and Operations of Aeration Systems. Water Res. 15, 643654.
Stenstrom M.K., Vazirinejad H.O., Ng A. (1984) Economic Evaluation of Upgrading Aeration Systems. J. Water Pollut. Control Fed. 56(1), 20-26.

Talati S.N., Stenstrom M.K. (1990) Aeration Basin Heat Loss. J.Environ. Eng. Div. 116, 70-86.

Trillo I., Jenkins T.E., Redmon D., Hilgart T., and Trillo J. (2004) Implementation of Feedforward Aeration Control Using On-Line Offgas Analysis: The Grafton WWTP Experience. Proc. WEFTEC 2004, New Orleans.

U.S. Environmental Protection Agency - USEPA (1989) Fine Pore (Fine Bubble) Aeration Systems, EPA/625/189/023. U.S. Environmental Protection Agency, Cincinnati.

Wagner M., Cornel P, and Krause S. (2003) Comparison of different oxygen transfer testing procedures in full-scale membrane bioreactors, Wat. Sci. Tech. 47(12), 169-176.

Warriner R. (1989a) Oxygen Transfer Efficiency Surveys at the Jones Island Treatment Plants, 1985-1988, EPA/600/R-94/094. U.S. Environmental Protection Agency, Washington, D.C.

Warriner R. (1989b) Oxygen Transfer Efficiency Surveys at the South Shore Wastewater Treatment Plant, 19851987, EPA/600/R-94/099. U.S. Environmental Protection Agency, Washington, D.C.

Yunt F.W., and Stenstrom M.K. (1996) Aeration equipment evaluation - phase II: process water test results, $E P A$ Report 68-03-2906.

\section{AGRADECIMIENTOS}

Los autores de la versión orignal en inglés, agradecen a Shao-Yuan Ben Leu del Departamento de Ingeniería Civil de la UCLA, a An Kaliman de Songo Widya Engineering, y a Judy Libra de la Universidad Tecnológica de Cottbus. También agradecen a las instituciones públicas que colaboraron, incluyendo la Oficina de Saneamiento de la Ciudad de Los Angeles, los Distritos de Saneamiento del Condado de Los Angeles, los Distritos de Saneamiento del Condado de Orange, la Agencia Inland Empire Utilities, el Departamento de Obras Públicas de la Ciudad de Simi Valley, y las Autoridad de Agua y Saneamiento del Distrito de Columbia. Finalmente, dan las gracias a las compañías consultoras de ingeniería que nos apoyaron durante la ejecución de las campañas de pruebas, incluyendo HDR, Brown and Caldwell, Carollo Engineers, Montgomery Watson Harza y Metcalf and Eddy. 
NOMENCLATURA

\begin{tabular}{|c|c|c|}
\hline Símbolo & Descripción & Unidades \\
\hline $\mathrm{a}$ & Área efectiva de operación de los difusores & $\mathrm{m}^{2}$ \\
\hline $\mathrm{AE}$ & Eficiencia de aireación en agua limpia & $\mathrm{kgO}_{2} / \mathrm{kWh}$ \\
\hline AFR & Velocidad del flujo de aire & $\mathrm{m}^{3} / \mathrm{s}$ \\
\hline DO & Concentración de oxígeno disuelto en el agua & $\mathrm{kgO}_{2} / \mathrm{m}^{3}$ \\
\hline $\mathrm{DO}_{\text {sat }}$ & Concentración de saturación de oxígeno disuelto en el agua & $\mathrm{kgO}_{2} / \mathrm{m}^{3}$ \\
\hline $\mathrm{k}_{\mathrm{La}}$ & Coeficiente de transferencia de masas en el líquido & $1 / \mathrm{h}$ \\
\hline $\mathrm{K}_{\mathrm{L}} \mathrm{a}_{\mathrm{cw}}$ & Coeficiente de transferencia de masas para agua limpia & $1 / \mathrm{h}$ \\
\hline $\mathrm{K}_{\mathrm{L}} \mathrm{a}_{\mathrm{pw}}$ & Coeficiente de transferencia de masas para el agua residual o de proceso & $1 / \mathrm{h}$ \\
\hline $\mathrm{N}_{\mathrm{D}}$ & Número total de difusores & - \\
\hline OTE & Eficiencia de transferencia de oxígeno en agua limpia & $\%$ \\
\hline OTR & Tasa de transferencia de oxígeno en agua limpia & $\mathrm{kgO}_{2} / \mathrm{h}$ \\
\hline $\mathrm{P}$ & Energía consumida por el sistema de aireación & $\mathrm{kW}$ \\
\hline SAE & Eficiencia estándar de aireación & $\mathrm{kgO}_{2} / \mathrm{kWh}$ \\
\hline SOTE & $\begin{array}{l}\text { Eficiencia de transferencia de oxígeno bajo condiciones estándar en agua } \\
\text { limpia }\end{array}$ & $\%$ \\
\hline SOTR & Tasa de transferencia de oxígeno bajo condiciones estándar en agua limpia & $\mathrm{kgO}_{2} / \mathrm{h}$ \\
\hline $\mathrm{V}$ & Volumen de agua & $\mathrm{m}^{3}$ \\
\hline Z & Profundidad del difusor & $\mathrm{m}$ \\
\hline Abreviación & Descripción & \\
\hline $\mathrm{AC}$ & Corriente alterna & \\
\hline ASCE & Sociedad Estadounidense de Ingenieros Civiles (en inglés, American Society of & Civil Engineers) \\
\hline CAS & Proceso convencional de lodos activados & \\
\hline DWP & Presión dinámica húmeda o contra presión & \\
\hline EE3 & 17a-ethinylestradiol & \\
\hline EPA & Agencia de protección ambiental de los Estados Unidos (en inglés, Environmenta & 1 Protection Agency) \\
\hline EPDM & Hule de monómero de Etileno Propileno Dieno (en inglés, Ethylene propylene die & ne monomer rubber) \\
\hline $\mathrm{F}$ & Factor de ensuciamiento, bloqueo o falla de los difusores & \\
\hline MLSS & Concentración de sólidos suspendidos en el licor mezclado & \\
\hline NDN & Proceso de nitrificación/desnitrificación & \\
\hline PD & Desplazamiento positivo & \\
\hline RBCOD & $\begin{array}{l}\text { DQO rápidamente biodegradable como una mediad de la materia orgánica rápid } \\
\text { biodegradable }\end{array}$ & amente o fácilmente \\
\hline $\operatorname{Re}$ & Número de Reynolds & \\
\hline $\mathrm{rpm}$ & Revoluciones por minuto & \\
\hline TRS & Tiempo de retención de sólidos & \\
\hline IVL & Índice volumétrico de lodos & \\
\hline VFD & Regulador de frecuencias (VFD, por sus siglas en inglés Variable Frequency Dr & ivers) \\
\hline
\end{tabular}




\begin{tabular}{|c|c|c|}
\hline $\begin{array}{l}\text { Símbolos } \\
\text { griegos }\end{array}$ & Explicación & Unidades \\
\hline$\alpha$ & $\begin{array}{l}\text { Relación de la transferencia de masa en el agua residual o de proceso con } \\
\text { respecto a la transferencia de masa en agua limpia }\end{array}$ & \\
\hline$\alpha \mathrm{F}$ & Factor alfa utilizado para difusores usados & \\
\hline$\alpha \mathrm{FSAE}$ & $\begin{array}{l}\text { Eficiencia de aireación bajo condiciones estándar en agua de residual o de } \\
\text { proceso para difusores usados }\end{array}$ & $\%$ \\
\hline$\alpha$ FSOTE & $\begin{array}{l}\text { Eficiencia de transferencia de oxígeno bajo condiciones estándar en agua residual } \\
\text { o de proceso para difusores usados }\end{array}$ & $\%$ \\
\hline$\alpha \mathrm{SAE}$ & $\begin{array}{l}\text { Eficiencia de aireación bajo condiciones estándar en agua de residual o de } \\
\text { proceso }\end{array}$ & $\%$ \\
\hline aSOTE & Eficiencia de transferencia de oxígeno bajo condiciones estándar en agua residual & $\%$ \\
\hline
\end{tabular}

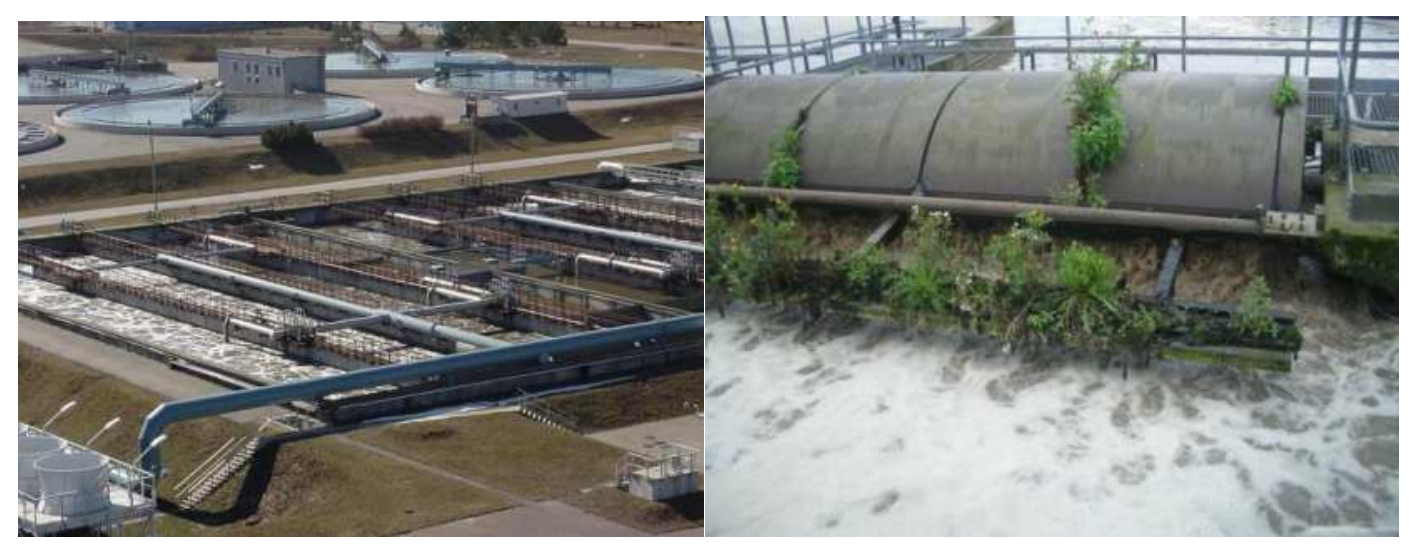

El proceso de aireación representa el costo de energía más alto en las plantas de tratamiento de aguas residuales, alcanzando desde 45 hasta $75 \%$ del consumo total de la energía en plantas de lodos activados convencionales y hasta $85 \%$ en reactores sumergidos de membrana. Tomando en cuenta su importancia para el desempeño total de la planta, son esenciales las labores de mantenimiento y operación de los sistemas de aireación. Las fotos ilustran dos enfoques de mantenimiento muy diferentes en dos plantas de tratamiento en Europa (fotos: D. Brdjanovic). 


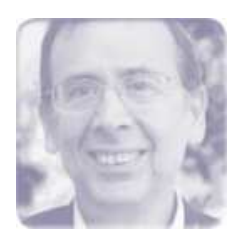

\section{0}

\section{Toxicidad}

\section{Jorge H. García Orozco}

\subsection{INTRODUCCIÓN}

El proceso de lodos activados ha sido y continúa siendo el sistema más aplicado para el tratamiento de aguas residuales domésticas e industriales aunque los procesos anaerobios, con mejor rendimiento energético, también se han hecho populares. Dado que los procesos biológicos emplean organismos vivos, están sujetos a trastornos por agentes inhibidores o tóxicos, requiriendo especial atención para garantizar que la eficiencia de los procesos ante la eventual presencia de estos agentes.

La inhibición es causada por agentes químicos o físicos, tales como $\mathrm{pH}$, temperatura, potencial de óxidoreducción del medio, etc. Por otra parte, muchas sustancias que están presentes en las aguas residuales ejercen efectos inhibitorios o tóxicos sobre los microorganismos de una planta de tratamiento de aguas residuales. Hasta ahora han surgido dos conceptos, inhibición y toxicidad. En el contexto del tratamiento biológico de aguas residuales, la inhibición se define como un trastorno del sistema enzimático de una célula viva o el daño directo a la estructura de la célula, resultando en la desaceleración de la actividad de las células. Cuando las reacciones bioquímicas inhibidas son vitales para la célula, entonces el agente se identifica como tóxico. El efecto de la toxicidad se manifiesta en los microorganismos inicialmente en una mayor dificultad para absorber los nutrientes, una disminución en la tasa de crecimiento y finalmente la muerte de la célula. Trasladando esto a los sistemas de tratamiento, se observa una menor tasa de degradación y generalmente, también se altera la actividad de la biomasa.

Un medio puede ser tóxico o no tóxico. Existe una continuidad, desde un medio que contiene un substrato fácilmente degradable, pasando por condiciones inhibitorias, hasta alcanzar condiciones muy tóxicas, en las que la célula muere después de un corto tiempo de exposición. Dependiendo de la concentración del agente tóxico y los antecedentes de exposición de las células a compuestos tóxicos, la célula puede experimentar alteraciones menores o morir. Cuando un microorganismo se somete a concentraciones crecientes de una sustancia tóxica, su actividad, la cual se mide por la tasa de degradación del substrato o la tasa de crecimiento, disminuye hasta que alcanza un punto en el que cesa toda la actividad. Este punto, es decir, el nivel 
de concentración de la sustancia tóxica, depende de la exposición previa del microorganismo al mismo compuesto. Las células tienen cierta capacidad de adaptación, pudiendo desarrollar en ocasiones una maquinaria enzimática tal que podría llegar a un punto en el cual el agente tóxico también podría ser utilizado como substrato, a menudo a expensas de mayores requerimientos energéticos. A medida que la adaptación avanza, el microorganismo es capaz de tolerar concentraciones más altas e inclusive desarrollarse. En este sentido, el tiempo de exposición es esencial. Existen exposiciones a corto y largo plazo, siendo esta última útil para la adaptación, especialmente si la concentración inicial es baja. De hecho, estas es una estrategia común utilizada para aclimatar la biomasa en ciertas aplicaciones sobretodo de índole industrial.

Al final, el tratamiento puede experimentar eficiencias de remoción más bajas y problemas en los procesos de sedimentación, afectando la calidad del efluente debido a la menor capacidad de la biomasa para sedimentar y, por consiguiente, esto resulta en la pérdida de sólidos a través del efluente. Como resultado, la toxicidad también afecta el efluente con el correspondiente impacto negativo en los cuerpos de agua receptores.

¿Cómo es posible que las aguas residuales domésticas, que generalmente componen la mayor parte de los afluentes de las plantas de tratamiento, tengan cierto grado de toxicidad? La respuesta es que, en la mayoría de nuestras ciudades con o sin planificación, los efluentes industriales se mezclan con los grandes volúmenes de la "inofensiva" y biodegradable agua residual doméstica. En años recientes, los parques industriales se han construido implementando algunas medidas de producción más limpia, evitando su descarga directa en los alcantarillados municipales y tratando los efluentes industriales. Sin embargo, es común que las aguas residuales urbanas sean recolectadas en sistemas combinados de alcantarillas, y también existe la posibilidad de que ocurra alguna descarga industrial accidental en la alcantarilla. Con esto en mente, se han desarrollado métodos y aplicaciones para explorar y tratar de cuantificar los efectos tóxicos que ocurren con mayor frecuencia en las plantas de tratamiento biológico de aguas residuales.

\subsection{DETERMINACIÓN DE LA TOXICIDAD}

Derivado de las enseñanzas de Paracelso (Philippus Aureolus Theophrastus Bombastus von Hohenheim), el médico medieval que inventó la química médica, muchas sustancias actuales pueden actuar tanto como substratos (alimentos) o como venenos si alcanzan dosis demasiado altas. Hablando del tratamiento biológico, somos muy conscientes de la capacidad que tienen los microorganismos para metabolizar muchos productos químicos (en particular, orgánicos). Sin embargo, la tasa de degradación de algunas de estas sustancias es extremadamente lenta y ocurre a expensas de una gran cantidad de energía metabólica, lo que a su vez disminuye o afecta el crecimiento de las células.

Si existe toxicidad, esto no significa necesariamente que el microorganismo morirá, pero sí que su actividad disminuirá. Como hemos visto, el incremento en los niveles de inhibición podría representarse como un camino continuo que conduce a la muerte. Puesto que en un sistema de tratamiento existen muchas especies, un cierto nivel de toxicidad afecta a los diversos microorganismos en diferente grado y manera. Por ejemplo, mientras que algunos son incapaces de adaptarse y eventualmente desaparecerán, otros podrán adaptarse y permanecer en el sistema. Como resultado, la composición de la población microbiana podría cambiar e inclusive los objetivos y el propósito de los procesos de tratamiento podrían redefinirse. Esto se puede aprovechar para controlar el funcionamiento del reactor; sin embargo, dado que la dinámica poblacional es un proceso lento, estos cambios serán solo útiles cuando se alcance otro estado estacionario. La toxicidad puede ser de tipo crónico (causada generalmente por bajas concentraciones de agentes tóxicos) o aguda (generada por altas concentraciones de compuestos tóxicos).

Existe una necesidad de desarrollar e implementar diversas herramientas que permitan detectar durante la etapa de diseño, así como $\mathrm{t}$ viene en choques de concentración o como una condición de tratamiento también durante la operación de un reactor biológico, la presencia de compuestos tóxicos y el grado de toxicidad que podría afectar a las comunidades microbianas. Así, en el presente capítulo se presentarán a continuación diversos métodos y técnicas para tratar de cuantificar la presencia de sustancias inhibitorias o tóxicas en el afluente y en el reactor de un proceso de tratamiento de aguas residuales.

\subsubsection{Respirometría}

La actividad de la biomasa disminuye bajo la presencia de sustancias inhibidoras. Un claro reflejo de la actividad en los procesos aerobios es la tasa de consumo de oxígeno, medida y expresada generalmente como la tasa 
de respiración. Por otra parte, en sistemas anaerobios la actividad biológica se ve reflejada en la producción de biogás (compuesto primordialmente por metano y dióxido de carbono).

La prueba de respirometría enfocada en la determinación y cuantificación de la presencia de substancias o compuestos inhibitorios y tóxicos se basa en evaluar la disminución de la tasa de respiración con respecto a la actividad observada cuando dichos compuestos o substancias están ausentes. Generalmente para expresar el grado de inhibición se utiliza la $\mathrm{CE}_{50}$ (concentración efectiva). La CE50 indica la concentración de la substancia o compuesto inhibidor al cual la velocidad de respiración corresponde al 50\% de la velocidad observada sin la presencia del inhibidor. Esta concentración se estima después de ejecutar varias pruebas a diferentes concentraciones de compuestos inhibidores, graficando una curva que exprese el porcentaje de inhibición en función de la concentración del compuesto inhibidor, e identificando la concentración a la cual ocurre un $50 \%$ de inhibición. En general, el comportamiento inhibitorio puede ser descrito a diversos CEx, donde $\mathrm{x}$ es cualquier porcentaje de inhibición, donde CEx depende, por supuesto, de la concentración de la substancia inhibidora.

Un protocolo reconocido para evaluar el grado de inhibición en procesos aerobios es la prueba de inhibición respirométrica de lodos activados o el método OCDE 209. Dado que la prueba requiere aireación, la guía de instrucciones advierte que la prueba es viable para sustancias con una solubilidad adecuada, una baja volatilidad y que su respuesta inhibidora cause una disminución de la tasa de respiración a medida que la concentración del inhibidor aumenta. De lo contrario los resultados deben ser cuidadosamente interpretados (Tabla 10.1).
La prueba es sensible al origen de los lodos, por ello es que se sugiere validar las pruebas de inhibición mediante la ejecución de una prueba adicional ejecutada después de la dosificación de un inhibidor conocido (3,5 diclorofenol). Debe tomarse en cuenta que esta prueba se considera una prueba de toxicidad aguda. Se han desarrollado y aplicado variantes para solucionar algunas limitaciones de este protocolo. Ricco et al. (2004), por ejemplo, agregaron un solo substrato (acetato) y también cambiaron el procedimiento de oxigenación usando oxígeno puro en vez de aire, evitando así la pérdida de sustancias volátiles de la muestra de agua.

Existen otros procedimientos alternativos que persiguen el mismo fin, como por ejemplo la norma ISO 8192-2006, la cual es una prueba para la inhibición del consumo de oxígeno en los lodos activados (para la remoción de carbono y amonio), que intenta estandarizar los procedimientos para permitir una evaluación comparativa.

\subsubsection{Bioluminiscencia (Microtox ${ }^{\circledR}$ )}

La bioluminiscencia es la prueba de referencia más ampliamente utilizada para la determinación de la toxicidad. En las pruebas con Microtox ${ }^{\circledR}$, se determina la actividad de un microorganismo marino bioluminiscente, Vibrio fischeri (Photobacterium phosphoreum), aunque también se han utilizado otras bacterias. El principio de esta prueba se basa en que la luminiscencia bacteriana está directamente ligada a la respiración por lo que, en presencia de una substancia inhibidora, la tasa de bioluminiscencia disminuye. Así, se mide la reducción de la luz emitida por el cultivo a diversas dosis de substancias inhibidoras y se compara con la luz emitida con soluciones estándares y pruebas en ejecutadas con blancos (sin la dosificación de inhibidores). El Microtox ${ }^{\circledR}$ mide la luz emitida por el cultivo a una longitud de onda de $490 \mathrm{~nm}$.

Tabla 10.1 Método 209 (OCDE), resumido.

\begin{tabular}{ll}
\hline Pasos & Procedimientos \\
\hline 1 & $\begin{array}{l}\text { Preparar el lodo de prueba y un alimento sintético basado en peptona, extracto de carne, urea y sales } \\
2\end{array}$ \\
Realizar la prueba de respiración a diferentes concentraciones del inhibidor. \\
Usar dos controles como la respiración base y calcular su promedio $\left(\mathrm{R}_{\text {prom }}\right)$.
\end{tabular}


La inhibición causada se calcula a partir de la intensidad de la luz con la siguiente fórmula:

$$
\% I=\left(\frac{\text { Pérdida de intensidad de luz }}{<\text { intensidad de luz inicial }}\right) \times 100
$$

Aunque la prueba tiene amplia aceptación, no se considera tan sensible como los bioensayos que utilizan, por ejemplo, Daphnia u organismos más grandes e incluso peces (Pimephales promelas). Sin embargo, su utilidad radica en que el procedimiento es relativamente simple y proporciona resultados relativamente rápidos comparados con otras pruebas para la detección de la toxicidad. Araujo et al. (2005) evaluaron el impacto de ciertas descargas industriales en el tratamiento de las aguas residuales usando un Microtox ${ }^{\circledR}$. Se observó que el efecto inhibidor de los efluentes industriales disminuyó en $93 \%$ después de pasar por la planta de tratamiento de aguas residuales, mientras que la remoción de la DQO alcanzó $83 \%$. Específicamente, la entrada de la planta de tratamiento mostró una $\mathrm{CE}_{50}$ de $2.12 \%$ y el efluente una $\mathrm{CE}_{50}$ igual a $47.8 \%$. El porcentaje indica el porcentaje del volumen de los efluentes industriales que causó $50 \%$ de inhibición al ser añadidos a un agua residual que no contenía substancias tóxicas.

\subsubsection{Otras pruebas de toxicidad}

Existen también varios métodos colorimétricos. Toxtrak $^{\circledR}$ es uno de ellos y se basa en la actividad redox de la resazurina. Esta substancia cambia de color azul a rosa cuando se reduce a resorufina durante su degradación. El ensayo se realiza con lodo de la planta de tratamiento en estudio o con biomasas comerciales (tales como cultivos liofilizados). Si existe toxicidad, disminuye la tasa de degradación y también disminuye la reducción de la resazurina. Los cambios se miden con base en las diferentes absorbancias de las muestras al compararlas con la absorbancia de una substancia utilizada como control (que mantiene la misma absorbancia). La prueba de absorbancia se lleva a cabo a una longitud de onda de $603 \mathrm{~nm}$, específica para el color azul. De esta manera, la inhibición se estima como:

$\% I=\left[1-\left(\frac{\Delta A_{s}}{\Delta A_{c}}\right)\right] \cdot 100$

donde $\Delta \mathrm{A}_{\mathrm{s}}$ y $\Delta \mathrm{A}_{\mathrm{c}}$, representan los cambios (disminución) en la absorbancia de la muestra y la absorbancia del control, respectivamente. En este caso, $\Delta$ indica la diferencia entre valor inicial y el valor final. El porcentaje de inhibición (\% I) es una medida relativa. Dado que existen sustancias tóxicas que aumentan la respiración, el valor de \% I podría ser negativo.

También existen productos comerciales que evalúan los efectos inhibidores y tóxicos en el proceso de nitrificación como un indicador de los sistemas de tratamiento biológico aerobios. Este principio se basa en que los organismos nitrificantes son más susceptibles a los entornos tóxicos que los organismos heterótrofos. Un ejemplo es el método $\mathrm{N}-\mathrm{Tox}^{\circledR}$, que afirma que en caso de que el proceso de nitrificación se vea afectado debido a la falta de oxígeno o a la presencia de una concentración excesiva de un compuesto inhibidor o tóxico, se produce un aumento en la concentración de $\mathrm{N}_{2} \mathrm{O}$ en la fase gaseosa. Dicho incremento en la concentración de $\mathrm{N}_{2} \mathrm{O}$ en la fase gaseosa puede ser detectado antes de que el agua residual ingrese en el reactor biológico, lo que permite contar con un cierto tiempo para tomar las medidas preventivas necesarias.

Con respecto a los sistemas anaerobios, se han desarrollado diferentes métodos para evaluar la toxicidad. Un ejemplo es la norma ISO 13641-1:2003 que consiste en la determinación de la inhibición de la producción de biogás de bacterias anaerobias. Esta prueba general se puede utilizar para evaluar la toxicidad de los compuestos, mezclas, efluentes y lodos, a través de la determinación de la producción de biogás (metano y dióxido de carbono) a partir de la digestión anaerobia de los lodos de aguas residuales. El método se puede aplicar a sustancias solubles, insolubles y volátiles. Sin embargo, debido a la gran variabilidad en composición de los lodos de las plantas de tratamiento, este tipo de prueba sufre de altos coeficientes de variación (OCDE 224, 2007)

\subsubsection{Medidores de toxicidad en línea}

En general, todos los ensayos presentados anteriormente tienen una desventaja: requieren mucho tiempo, comenzando con la determinación de los parámetros básicos, DQO y $\mathrm{DBO}_{5}$, comparado con los bioensayos mencionados en las secciones anteriores (bioluminiscencia y respirometría). Como se explicó en una sección anterior, se necesita una respuesta rápida para proteger los sistemas de tratamiento, así como para diseñar y proponer esquemas o estrategias de control y optimización. Al respecto, varios fabricantes ofrecen dispositivos comerciales para supervisar y controlar la toxicidad en la entrada de un tratamiento biológico. Estos 
dispositivos ofrecen un monitoreo continuo, con tiempos de respuesta de 3-15 minutos y un amplio rango en la determinación de la inhibición (de hasta 0 a 100\%). Generalmente, la técnica se basa en medir la actividad respirométrica (tasa de consumo de oxígeno) similar a una prueba rápida de la DBO. También están disponibles sistemas para usos más especializados basados en la luminiscencia o movilidad de algas (utilizando Daphnia), para aplicaciones en agua potable y efluentes de plantas de tratamiento. Estos dispositivos se pueden adaptar para elaborar estrategias de control simples, tales como el desvío de caudales de aguas que contengan compuestos tóxicos.

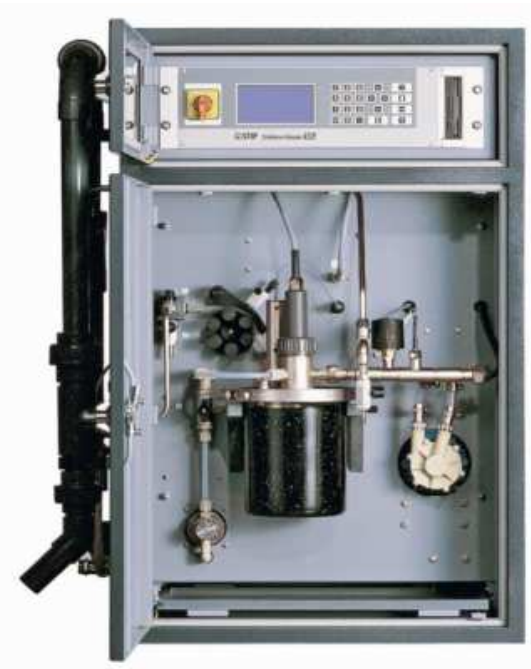

Figura 10.1 Toxímetro en línea (Foto: Endress+Hauser Conducta $\mathrm{GmbH}$ )

\subsection{MODELOS CINÉTICOS PARA LA DESCRIPCIÓN DE SUBSTRATOS TÓXICOS}

La primera evidencia de que existe toxicidad es una caída en la tasa de degradación. Los agentes químicos inhibidores y tóxicos pueden estar presentes en el afluente del sistema de tratamiento o ser un producto del metabolismo de la biomasa. La Figura 10.2 muestra un comportamiento típico observado cuando existen condiciones inhibitorias.

Las expresiones cinéticas que describen las transformaciones biológicas pueden describirse con la expresión de Michaelis-Menten (véase Capítulo 2). Esta expresión puede ampliarse y modificarse para describir el efecto de compuestos inhibidores que interfieren con las enzimas activas impidiéndoles la formación de ciertos productos. Las estructuras varían en la medida en que una enzima particular o el substrato afectan las reacciones. Más aún, cuando existe un efecto múltiple de diversos substratos que involucren varias especies microbianas, se usa un modelo no estructurado y no segregado, es decir, un modelo que agrupa todos los efectos de los componentes en uno solo y trata a todas las células como una sola comunidad. En estos casos, sólo se consideran los parámetros que pueden ser detectados en las expresiones cinéticas, las concentraciones de biomasa y el substrato, siguiendo un enfoque similar a los involucrados en la expresión de Monod.

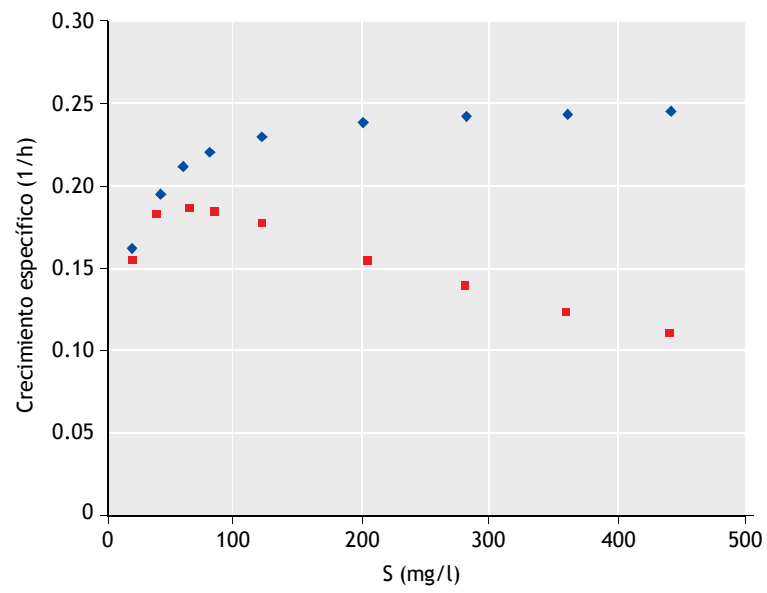

Figura 10.2 Degradación de fenol mostrando un efecto de inhibición causada por un substrato ( $($ ) (Goudar et al., 2000)

Muy a menudo, la sustancia inhibidora no puede distinguirse del resto, por lo que en este caso se utiliza una medida de concentración general, como por ejemplo la demanda química de oxígeno (DQO). Con esto en mente, se presentan a continuación los conceptos de los modelos de inhibición enzimática.

\subsubsection{Modelos de inhibición enzimática}

El mecanismo de cinética enzimática se basa en la unión del substrato a la enzima para producir un producto.

$E+S \leftrightarrow S^{*} \rightarrow P+E$

Donde E y S representan la enzima y el substrato, respectivamente: $\mathrm{S}^{*}$, un complejo activado, y $\mathrm{P}$ el producto. Dado que la segunda reacción se considera la reacción limitante (definido por $\mathrm{k}_{2}$ ); la unión del substrato a la enzima se considera en equilibrio. Este equilibrio se define por $\mathrm{k}_{1}$ (la reacción directa) y k-1 (una reacción inversa). 
El mecanismo antes descrito conlleva a la expresión cinética de Michaelis-Menten:

$$
r_{s}=\frac{r_{s}, \max S}{k_{s}+S}
$$

Aquí $\mathrm{k}_{\mathrm{s}}$ es una combinación de las constantes cinéticas para ambos pasos, $\mathrm{k}_{\mathrm{s}}=\left(\mathrm{k}_{-1}+\mathrm{k}_{2}\right) / \mathrm{k}_{1}$; ya que se asume que la descomposición del complejo activado es un proceso lento, $\mathrm{k}_{2}$ es pequeño $\mathrm{y}$ por lo tanto $\mathrm{k}_{\mathrm{s}}$ define aproximadamente el equilibrio o coeficiente de afinidad.

La capacidad para producir un producto, en el mecanismo descrito por la ecuación 10.3, se puede perder cuando existe una sustancia que interfiere en el mismo sitio específico de la enzima (inhibición competitiva) y/o en una posición diferente, previniendo la transformación del substrato en el producto (inhibición no competitiva). Otra posibilidad es que el inhibidor interactúe con el complejo activado (inhibición acompetitiva). Estos son los tipos esenciales de procesos de inhibición de las enzimas.

Las enzimas son moléculas catalíticas muy complejas y específicas que median todas las transformaciones biológicas. Las expresiones formuladas previamente se desarrollaron considerando un substrato específico y el efecto en su respectiva enzima. Sin embargo, en el tratamiento biológico existen múltiples transformaciones llevadas a cabo por diversas células en reacciones en serie. La suposición es que, independientemente de las múltiples reacciones que se llevan a cabo, siempre existe una reacción limitante que controla o limita la transformación en general y, por ello, se puede mantener o continuar con el uso y aplicación de los mecanismos enzimáticos descritos previamente.

\subsubsection{Inhibición competitiva}

En este primer tipo de inhibición, se asume que hay un inhibidor que se une a la enzima en el mismo lugar que el substrato, descrito como paso B en la ecuación 10.5.

$$
\begin{aligned}
& \left(\text { Paso A) } E+S \leftrightarrow S^{*} \rightarrow P+E\right. \\
& \left(\text { Paso B) } E+I \leftrightarrow I^{*}\right.
\end{aligned}
$$

La reacción (etapa B) no conduce al producto. Dado que el inhibidor (I) ocupa los mismos sitios que el substrato, el resultado es una afinidad modificada. Dicho efecto se ve reflejado en la disminución de la velocidad de la reacción directa (etapa A). En este caso la expresión cinética requerida para describir este mecanismo es:

$$
r_{s}=\frac{r_{\max } S}{k_{s}\left(1+\frac{I}{k_{i}}\right)+S}
$$

En la expresión anterior, aparece un nuevo parámetro que incorpora la inhibición enzimática en el modelo; $\mathrm{k}_{\mathrm{i}}$ representa la afinidad del inhibidor y es inversamente proporcional a la inhibición.

$$
\text { Inhibición }=\propto \frac{I}{k_{i}}
$$

10.3.1.2 Inhibición no competitiva

$$
\begin{aligned}
& \left(\text { Paso A)E+S } \leftrightarrow S^{*} \rightarrow P+E\right. \\
& \left(\text { Paso B) E+S ↔ } S^{*}+I \leftrightarrow S I^{*}\right. \\
& (\text { Paso } C) E+I \leftrightarrow I^{*}+S \leftrightarrow I S^{*}
\end{aligned}
$$

Ambos complejos activados, SI* y SE*, no producirán el producto. El inhibidor (I) no compite por el sitio activo; una vez unido en otro lugar de la enzima, cambia su composición y evita que el producto se forme. En este caso, puesto que no existe competencia entre el substrato y el inhibidor para los sitios activos, la afinidad del substrato no se modifica $\mathrm{y}$, como consecuencia, $\mathrm{k}_{\mathrm{s}}$ permanece constante; sin embargo, $r_{\text {máx }}$ disminuye en presencia de I. La expresión cinética puede ser descrita por:

$$
r_{s}=\frac{r_{\max } S}{\left(k_{s}+S\right)\left(1+\frac{I}{k_{i}}\right)}
$$

Diversos casos entran en esta categoría. El efecto de los metales en la desnitrificación (Gumaelis et al. 1996) sigue una ecuación de inhibición no competitiva, donde $\mathrm{k}_{\mathrm{i}}$ representa la concentración que resulta en un $50 \%$ de inhibición (en ese estudio cadmio con una concentración de $12 \mathrm{mg} / \mathrm{L}$ ). Este modelo también fue aplicado satisfactoriamente en la descripción del efecto de surfactantes no iónicos en el proceso de lodos activados (Carvalho et al., 2001).

Muchos de los compuestos tóxicos conocidos regulados por la Agencia de Protección del Ambiente de estados Unidos (US Environmental Protection Agency, EPA, RCRA) entran dentro de la categoría de inhibidores no competitivos (Bitton, 2005). 
10.3.1.3 Inhibición acompetitiva

$$
\begin{aligned}
& \left(\text { Paso A) } E+S \leftrightarrow S^{*} \rightarrow P+E\right. \\
& \left(\text { Paso B) } E+S \leftrightarrow S^{*}+I \leftrightarrow S I^{*}\right.
\end{aligned}
$$

Cuando ocurre una inhibición de tipo acompetitiva, el inhibidor se une al complejo activo formado por el substrato, bloqueando la formación del producto. Ambos parámetros se modifican por la presencia del inhibidor, existiendo una disminución de $\mathrm{k}_{\mathrm{s}} \mathrm{y} \mathrm{r}_{\max }$. De esta manera, la expresión cinética toma la siguiente forma:

$$
r_{s}=\frac{r_{\max } S}{k_{s}+S\left(1+\frac{I}{k_{i}}\right)}
$$

Estos mecanismos y sus ecuaciones cinéticas representan las formas "clásicas" de inhibición. La Figura 10.3 muestra una representación de Lineweaver-Burk de las tres situaciones típicas descritas anteriormente. Existen otras formas gráficas como la de Hanes $S / r_{\mathrm{s}}$ vs. S) y Eadie-Hofstee ( $r_{s} / S$ vs. $\left.r_{s}\right)$ que se pueden usar para estimar la misma información.

También existe el caso donde hay una mezcla de inhibiciones (inhibición mixta) que comparten características de los inhibidores competitivos y de los no competitivos. En este caso, ambos parámetros cambian, $r_{\max }$ disminuye $\mathrm{y}_{\mathrm{s}}$ aumenta, mientras que la afinidad neta disminuye.

Este modelo se describe de la siguiente manera:

$$
r_{s}=\frac{r_{\max } S}{k_{s}\left(1+\frac{I}{k_{i}}\right)+S\left(1+\frac{I}{k_{i}^{\prime}}\right)}
$$

La gráfica de Lineweaver-Burk para este caso se presenta en la Figura 10.4. Ver también la Tabla 10.2 para un resumen de estos modelos.

En el caso cuando $\mathrm{k}_{\mathrm{i}}$ es igual a $\mathrm{k}_{\mathrm{i}}{ }^{\prime}$, entonces la ecuación. 10.12 se convierte en el modelo no competitivo, ecuación 10.10 (Dixon y Webb, 1964).

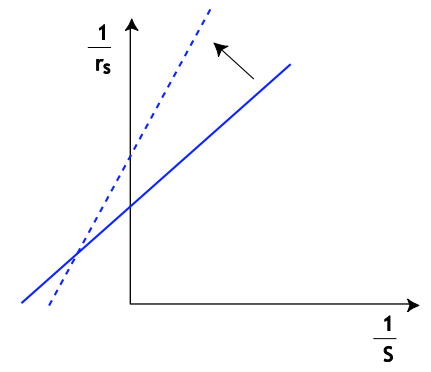

Figura 10.4 Modelo de inhibición mixto

Tabla 10.2 Resumen de los modelos de inhibición

\begin{tabular}{lll}
\hline Tipo de inhibición & $\mathrm{r}_{\max }$ & $\mathrm{k}_{\mathrm{s}}$ \\
\hline Competitiva & Sin efecto & Aumenta \\
No competitiva & Disminuye & Sin efecto \\
Acompetitiva & Disminuye & Disminuye \\
Mixta & Disminuye & Aumenta \\
\hline
\end{tabular}

\subsubsection{Inhibición constante}

Usando de los recíprocos de las principales variables de acuerdo con Lineweaver-Burk, la constante de inhibición se puede calcular usando las intersecciones de las gráficas correspondientes en presencia del inhibidor. La Tabla 10.3 resume las intersecciones de las gráficas.


Figura 10.3 Modelos clásicos de inhibición: competitivo (A), no competitivo (B) y acompetitivo (C). Las flechas indican la dirección en la cual la inhibición ocurre. 
Tabla 10.3 Intersecciones para las gráficas con inhibición de Lineweaver-Burk

\begin{tabular}{lcc}
\hline Tipo de inhibición & $\begin{array}{l}\text { Intersección en } \\
\text { el eje vertical }\end{array}$ & $\begin{array}{l}\text { Intersección en } \\
\text { el eje horizontal }\end{array}$ \\
\hline Competitivae & $\frac{1}{\mathrm{r}_{\max }}$ & $\frac{1}{\mathrm{k}_{\mathrm{s}}\left(1+\frac{\mathrm{I}}{\mathrm{k}_{\mathrm{i}}}\right)}$ \\
No competitiva & $\frac{\left(1+\frac{\mathrm{I}}{\mathrm{k}_{\mathrm{i}}}\right)}{\mathrm{r}_{\max }}$ & $\frac{1}{\mathrm{ks}_{\mathrm{s}}}$ \\
Acompetitiva & $\frac{\left(1+\frac{\mathrm{I}}{\mathrm{k}_{\mathrm{i}}}\right)}{\mathrm{r}_{\max }}$ & $\frac{\left(1+\frac{\mathrm{I}}{\mathrm{k}_{\mathrm{i}}}\right)}{\mathrm{ks}}$ \\
Mixta & $\frac{\left(1+\frac{\mathrm{I}}{\mathrm{k}_{\mathrm{i}}{ }^{\prime}}\right)}{\mathrm{r}_{\max }}$ & $\frac{\left(1+\frac{\mathrm{I}}{\mathrm{k}_{\mathrm{i}}{ }^{\prime}}\right)}{\mathrm{k}_{\mathrm{s}}\left(1+\frac{\mathrm{I}}{\mathrm{k}_{\mathrm{i}}}\right)}$ \\
\hline
\end{tabular}

Para estimar el parámetro de inhibición $\mathrm{K}_{\mathrm{i}}$ es posible emplear un procedimiento gráfico diferente, utilizando el gráfico de Lineweaver-Burk y una gráfica secundaria especial, dependiendo del tipo de modelo de inhibición que sea utilizado.

1) Paso 1. Llevar a cabo el experimento de degradación a diferentes concentraciones de substrato, manteniendo la concentración del inhibidor constante.

2) Paso 2. Graficar los datos en un gráfico de Lineweaver-Burk (1/ $\mathrm{r}_{\mathrm{s}}$ vs.1/S) para cada valor de la concentración del inhibidor, I.

3) Paso 3. La intersección vertical para cada concentración de I representa la $1 / \mathrm{r}_{\max }$ aparente. Es necesario anotar la pendiente de cada concentración I.

5) Paso 4a. Para el modelo de inhibición competitiva, graficar la pendiente contra I. La intersección con el eje I es-ki.

4) Paso 4b. Para una inhibición no competitiva, graficar el valor inverso de la $r_{\max }$ aparente en función de la concentración de inhibidor, I. De nuevo, la intersección del eje I representa $-\mathrm{k}_{\mathrm{i}}$.

En general, en cuanto al modelo mixto, $r_{\max }$ disminuye cuando $\mathrm{k}_{\mathrm{s}}$ aumenta, por lo tanto, se puede utilizar un procedimiento especial llamado gráfica de Dixon. En este caso, los experimentos de degradación se ejecutan midiendo $r_{s}$ a diferentes concentraciones del inhibidor, manteniendo la concentración de substrato, $\mathrm{S}$, constante. Después, el mismo precedimiento se repite a una concentración $S$ diferente. La inversa de $r_{s}$ se grafica contra I para las dos concentraciones de S evaluadas; la intersección de las líneas resultantes define ki cuando se analiza sobre el eje I (Dixon y Webb, 1964).

\subsubsection{Inhibición por el substrato}

El modelo que se muestra en la Figura 10.2 es típico de la inhibición por substrato. Como mecanismo de reacción se pueden emplear una secuencia de reacciones enzimáticas.

$\left(\right.$ Paso A) $E+S \leftrightarrow S^{*} \rightarrow P+E$

$($ Paso $B) E+S \leftrightarrow S^{*}+S \leftrightarrow S_{2}^{*}$

En este caso, el complejo $\left(\mathrm{S}_{2} *\right)$ no genera el producto (P). Esto puede verse como un caso especial de una inhibición no competitiva, por lo que el mismo substrato inactiva la enzima.

El modelo cinético se escribe de la siguiente forma:

$$
r_{s}=\frac{r_{\max } S}{k_{s}+S+\frac{S^{2}}{k_{i}}}
$$

Esta ecuación es conocida como ecuación de Andrews y como se ha mencionado, puede ser derivada como un caso especial de la ecuación 10.11. La ecuación tiene ciertas características, por ejemplo, la máxima velocidad se puede encontrar en un valor de substrato $\left(S_{\text {crit }}\right)$ dada por:

$S_{c r i t}=\left(k_{s} k_{i}\right)^{\frac{1}{2}}$

Hay muchos ejemplos y aplicaciones cuando se trata de substratos individuales. Uno común es la degradación de fenol, según lo reportado por Goudar et al. (2000) donde $\mu_{\max }=0.251 \mathrm{~h}^{-1}, \mathrm{k}_{\mathrm{s}}=0.011 \mathrm{~g} / \mathrm{L} \mathrm{y} \mathrm{k}_{\mathrm{i}}=0.348 \mathrm{~g} / \mathrm{L}$ (Figura 10.2).

\subsubsection{Inhibición por el producto}

Un ejemplo clásico de inhibición por el producto fue presentado por Aiba y colaboradores quienes describieron la inhibición por alcohol en la fermentación alcohólica de la glucosa. Empleando los resultados mostrados por la gráfica de Lineweaver-Burk, describieron el papel del alcohol como un inhibidor no competitivo ya que $\mathrm{r}_{\max }$ disminuye mientras $\mathrm{ks}_{\mathrm{s}}$ se mantiene sin cambios, para altas concentraciones de etanol. La expresión que los autores presentaron fue:

$$
r_{s}=\frac{r_{\max } S}{\left(k_{s}+S\right)\left(1+\frac{P}{k_{p}}\right)}
$$


La ecuación anterior representa un tipo de inhibición no competitiva.

En el caso del tratamiento anaerobio, Fukusaki et al. (1990) reportaron la inhibición por productos intermedios durante la fermentación de propionato a metano. Los inhibidores fueron el acetato y el hidrógeno. Ellos describieron el efecto de los dos inhibidores con el mismo modelo.

$$
r_{s}=\frac{r_{\max }}{1+\left(\frac{P}{k_{p}}\right)^{n}}
$$

Dependiendo de qué inhibidor se describe, los valores de los tres parámetros $\left(\mathrm{n}, \mathrm{r}_{\max } \mathrm{y} \mathrm{k}_{\mathrm{p}}\right.$ ) varían de manera dependiente. Esta ecuación representa otra situación de inhibición no competitiva.

La inhibición también puede ser causada por el mismo substrato que puede ejercer un efecto inhibidor. Por ejemplo, el propionato puede ejercer un efecto inhibidor sobre la producción de metano, efecto que puede describirse por medio de la ecuación de Andrews (Ec. 10.14) donde $S$ representa la concentración de propionato sin disociar. La conversión de propionato en acetato e hidrógeno puede ser descrito como:

$$
\mathrm{C}_{3} \mathrm{H}_{6} \mathrm{O}_{2}+2 \mathrm{H}_{2} \mathrm{O} \rightarrow \mathrm{C}_{2} \mathrm{H}_{4} \mathrm{O}_{2}+\mathrm{CO}_{2}+3 \mathrm{H}_{2}
$$

Por último, en esta sección, la premisa fundamental ha sido que los modelos obtenidos para la cinética enzimática pueden ser aplicados directamente a las cinéticas de degradación de substrato encontradas normalmente en los sistemas de tratamiento de aguas residuales, es decir, expresadas en términos de la concentración de substrato en $\mathrm{DQO}$ o $\mathrm{DBO}_{5}$.

\subsubsection{Otras expresiones cinéticas}

A través de los años, se han desarrollado otras expresiones cinéticas para describir el proceso de degradación en los sistemas de tratamiento. Algunas de estas expresiones se derivan de alguna manera desde las formas presentadas en la sección anterior.

Se han reportado una serie de expresiones cinéticas (Ríos, 2005) que pueden ser adaptadas para expresar la inhibición como la ecuación de Contois, una modificación de la ecuación de Grau y SiberEckenfelder:
Contois: $r_{s}=\frac{r_{\max } S}{\alpha X+S}$

Donde $\alpha$ es directamente proporcional a la inhibición.

Grau: $r_{s}=r_{\max }\left(\frac{S}{S_{0}}\right)^{n}$

donde, $\mathrm{n}<1$.

Siber-Eckenfelder: $r_{s}=r_{\max }\left(\frac{S}{S_{0}}-y\right)$

donde $y$ es una fracción no degradable del substrato que entra al sistema. Una $y$ más grande significa que el substrato será menos degradable, por lo tanto lo más probable es que $r_{\max }$ sea más pequeña.

\subsubsection{Inhibición por causas físicas}

Las dos variables más comunes dentro de un proceso, aparte de la concentración, son el $\mathrm{pH}$ y la temperatura del medio. Estos dos pueden llevar a condiciones inhibitorias graves ya que todos los sistemas biológicos son bastante limitados en su rango de operación. Las reacciones químicas en general pueden soportar o incluso necesitar grandes variaciones en la temperatura y presión para continuar operando a una tasa razonable o para llegar hasta que la reacción se complete o termine. Por el contrario, la biodegradación puede estar a lo sumo una docena de grados por encima o por debajo de la temperatura normal del cuerpo, $\mathrm{y}$ a estas temperaturas las enzimas pueden inactivarse.

Lo mismo puede decirse del $\mathrm{pH}$. Las moléculas orgánicas complejas que participan en todos los procesos biológicos reaccionan con el pH del medio, cambiando la configuración o polaridad, y por lo tanto, modificando su capacidad de reacción.

La inactivación que ocurre más allá de los límites puede ser reversible, por ejemplo en las moléculas biológicas, si la condición se corrige a tiempo. Sin embargo, cuando se trata de una comunidad microbiana, si el cambio es prolongado podríamos inducir un cambio en la composición de la comunidad, que podría adquirir unas características o capacidades diferentes. Por ejemplo, a distintas temperaturas se podría inducir la selección y crecimiento de microorganismos psicrofílicos, mesofílicos o termofílicos. 
Hay que reconocer que el efecto sobre la actividad microbiana de estos parámetros $(\mathrm{T}, \mathrm{pH})$ o de cualquier otro no son únicos en la naturaleza. Indicando que existen valores de estos parámetros en los que la actividad está en su nivel óptimo, pero fuera de estos valores, el sistema no funciona de manera óptima lo que podríamos interpretar como una inhibición.

\subsubsection{Temperatura}

Como en cualquier reacción química, la velocidad de reacción aumenta a medida que aumenta la temperatura, esto se debe al concepto de energía de activación. Las reacciones biológicas no son una excepción y por ello se puede aplicar la ecuación de Arrhenius. De esta manera, la constante de velocidad puede expresarse en función de la energía de activación y de la temperatura:

$$
k=A e^{-E \mathrm{a} / R T}
$$

donde:

$$
\begin{array}{ll}
\text { Ea } & \text { energía de activación } \\
R & \text { constante de la ley de gases } \\
A & \text { factor de frecuencia } \\
\text { T } & \text { temperatura absoluta }
\end{array}
$$

En tratamiento de aguas residuales se usa muy comúnmente una ecuación derivada de la anterior:

$$
k_{T}=k_{T_{O}} \theta^{\left(T-T_{O}\right)}
$$

donde:

$\theta \quad$ constante (típicamente entre 1.04 y 1.09)

$\mathrm{T}_{\mathrm{o}} \quad$ temperatura de referencia

Las ecuaciones 10.22 y 10.23 describen el efecto de la temperatura sobre las velocidades de reacción. A medida que la temperatura aumenta, la constante de velocidad también aumenta, aunque no puede incrementarse de manera indefinida. Así, poco después de alcanzar un valor máximo, las velocidades de las reacciones caen de manera súbita y las ecuaciones anteriores dejan de ser válidas.

Bailey y Ollis (1986) propusieron una expresión que combina la teoría del estado de transición y el equilibrio entre las enzimas activas e inactivas presentes en el sistema, dando lugar a la ecuación siguiente (Figura 10.5):

$r_{\max }=\frac{\beta T e^{-E / R T}}{1+e^{\Delta S / R} e^{-\Delta H / R T}}$ donde:

$\begin{array}{ll}\beta & \text { constante } \\ \mathrm{T} & \text { temperatura absoluta } \\ \Delta \mathrm{S} & \text { entropía de desactivación } \\ \Delta \mathrm{H} & \text { entalpía de desactivación }\end{array}$

La típica gráfica de Arrhenius, log (velocidad constante) frente a $1 / \mathrm{T}$, se puede utilizar para describir la dependencia de la temperatura. A bajas temperaturas, la pendiente de la curva se aproxima a $-\mathrm{E} / \mathrm{R}$. Mientras que a altas temperaturas, la aproximación de la pendiente es $(\Delta \mathrm{H}-\mathrm{E}) / \mathrm{R}$.

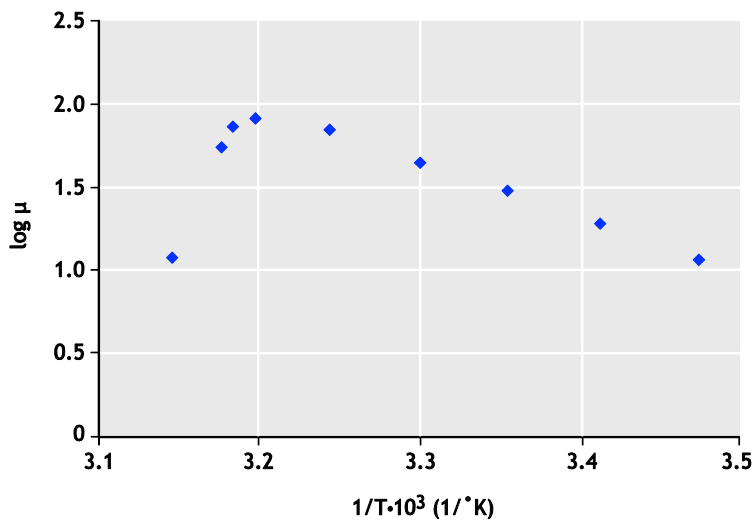

Figura 10.5 Efecto de la temperatura sobre la tasa de crecimiento de E. Coli (Bailey y Ollis, 1986).

Dado que la mayoría de los sistemas de tratamiento de aguas residuales municipales operan dentro de un rango de temperatura moderada o mesofílica (por ejemplo, entre 15 y $25^{\circ} \mathrm{C}$ ), generalmente no se alcanzan las temperaturas extremas. Por lo tanto, la única variación térmica de interés es generalmente el intervalo lineal de la gráfica de Arrhenius, que se caracteriza por la pendiente $-\mathrm{E} / \mathrm{R}$, que es en donde la temperatura aumenta. Antes de que el sistema falle y si se opera el proceso por un tiempo suficientemente largo a una temperatura cercana a la temperatura máxima, la población bacteriana existente podría adaptarse a la nueva temperatura o la población podría cambiar a un grupo bacteriano más adaptado.

\subsubsection{2 $\mathrm{pH}$}

La acidez de un medio altera las biomoléculas, y por lo tanto la actividad de los microorganismos. El intervalo óptimo para el proceso de lodos activados es un $\mathrm{pH}$ dentro de un intervalo de 7.0 a 7.5. Fuera de este rango la actividad biológica disminuye más o menos en la misma forma que con los cambios de temperatura. 
Algunos organismos son más susceptibles que otros a los cambios en el $\mathrm{pH}$, por ejemplo, las bacterias nitrificantes entran en esta categoría. Un ejemplo de las correcciones necesarias para las condiciones de crecimiento subóptimas es la ecuación 10.25 utilizada en un estudio exhaustivo de la nitrificación realizado por la EPA, USA (1973), el cual es válido para un $\mathrm{pH}<7.2$ :

$$
\mu_{N}=\mu_{N \max }[1-0.833(7.2-p H)]
$$

Dado que la tendencia del tratamiento biológico es que el $\mathrm{pH}$ disminuya cuando tiene lugar la nitrificación, existe una necesidad menor por investigar el efecto de los $\mathrm{pH}$ básicos en los sistemas biológicos. Sin embargo, Ko et al. (2001) utilizaron un tipo de modelo no competitivo para describir la inhibición causada por el nivel de $\mathrm{pH}$ en el sistema de lodos activados para los rangos de $\mathrm{pH}$ ácidos y básicos:

$$
\mu_{N}=\frac{\mu_{N \max }}{1+\frac{I}{k_{i}}}
$$

La concentración I del inhibidor es una concentración pseudo-tóxico definida como:

$I=\left(p H_{t h}-p H\right)^{2}$

La primera variable $\left(\mathrm{pH}_{\mathrm{th}}\right)$ representa el umbral de $\mathrm{pH}$ y se fija en 6.77 para el rango ácido, y a 7.80 para el rango básico. Dentro de este rango de valores de $\mathrm{pH}$ no existe inhibición. Los autores encontraron un $\mathrm{k}_{\mathrm{i}}=0.748$ en el rango ácido y un $\mathrm{k}_{\mathrm{i}}=1.194$ en el rango básico. El valor $\mathrm{k}_{\mathrm{i}}$ tiene la misma interpretación dada anteriormente; entre más pequeño es $\mathrm{k}_{\mathrm{i}}$, mayor es la inhibición.

\subsection{TRATAMIENTO DE EFLUENTES CON TOXICIDAD}

Las secciones anteriores describen la existencia de medios tóxicos, a través de la medición de sus efectos sobre la actividad de la biomasa. Algunos estudios hacen hincapié en los modelos de inhibición, mientras que otros hacen énfasis en los efectos de compuestos específicos. Sin embargo, la mayoría de los estudios de inhibición se han realizado con compuestos individuales. Más aún, la mayoría de las veces, ni siquiera es posible determinar qué tipo de toxinas llegan a las plantas de tratamiento, sobre todo en una planta municipal; por lo anterior, es importante la detección temprana de este tipo de compuestos en el agua residual antes de que ingresen a la planta. Debido a esto, las pruebas de toxicidad son un campo de desarrollo importante (para una perspectiva más amplia de este tema consultar Bitton, 2005).

Tomando como base la modificación del método OCDE 209, Volskay y Grady (1988) llevaron a cabo una investigación sobre la toxicidad encontrada en el sistema de lodos activados para algunos de los contaminantes prioritarios, es decir, aquellos que suponen un riesgo para el público general. Los autores encontraron que muchos de los compuestos evaluados mostraron concentraciones superiores de sus $\mathrm{CE}_{50}$ que las concentraciones normalmente encontradas en sistemas de tratamiento. Sin embargo, señalaron que no se tomó en cuenta el efecto sinérgico, ya que los experimentos de inhibición se realizaron con cada compuesto individualmente.

Cuando las concentraciones de contaminantes tóxicos en los sistemas de tratamiento son más bajos que su $\mathrm{CE}_{50}$, significa que el sistema se enfrenta cuando mucho a un $50 \%$ de inhibición; sin embargo, cualquier porcentaje de inhibición representa un problema para planta de tratamiento.

Hasta ahora, este capítulo se ha centrado en los efectos de la toxicidad sobre los microorganismos que intervienen en el tratamiento biológico de aguas residuales, sin embargo, la presencia de compuestos tóxicos impide llevar a cabo un tratamiento eficaz con lo que la descarga del efluente podría contener una gran concentración de estos compuestos y otras sustancias tóxicas presentes en las aguas residuales, causando un mayor impacto en el cuerpo de agua receptor. Dado que todavía hay impactos desconocidos debido a la exposición de los seres humanos y de la biota en general a las "bajas" concentraciones de los compuestos tóxicos en el agua, debe de prevalecer una actitud prudente. Esto favorece el desarrollo de estrategias preventivas, incluyendo el de evitar que estas sustancias ingresen en el sistema de tratamiento.

La Evaluación de la Reducción de la Toxicidad (TRE, Toxicity Reduction Evaluation) de la Agencia de Protección Ambiental de EE.UU. (EPA, 1999) es una de las estrategias preventivas diseñada para plantas de tratamiento de efluentes municipales, buscando la fuente a través del flujo de agua hasta identificar la fuente de la sustancia tóxica. Esto a menudo puede ser una tarea costosa, ya que requiere muchas pruebas de detección, que en última instancia pueden dar lugar a modificaciones de la planta de tratamiento que en muchos casos no pueden evitarse. 
Los objetivos de estudio de Evaluación de Reducción de Toxicidad son:

- Evaluar el funcionamiento y el desempeño de las plantas de tratamiento de aguas residuales municipales para identificar y corregir las deficiencias en el tratamiento que contribuyen a la presencia de compuestos tóxicos de los efluentes (por ejemplo, problemas operativos, aditivos químicos o tratamientos incompletos)

- Identificar los compuestos causantes de toxicidad de los efluentes

- Identificar la fuente de efluentes tóxicos (por ejemplo, origen industrial, comercial o doméstico)

- Evaluar, seleccionar y aplicar métodos o tecnologías de reducción de la toxicidad para el control de la toxicidad del efluente (incluyendo opciones de control de toxicidad en la planta o en un pre-tratamiento)

Después de que la sustancia(s) tóxica(s) o la fuente de la toxicidad ha(n) sido identificada(s), las medidas preventivas, pre-tratamiento o tratamiento pueden ser adaptadas para proteger el propio tratamiento o para evitar la toxicidad debida a la entrada de las aguas tóxicas en el sistema.

En estos casos, se recomienda implementar un enfoque de producción más limpia, con el fin de evitar o minimizar los compuestos tóxicos que puedan llegar a través del sistema de alcantarillado municipal. En muchos países desarrollados esto es un procedimiento obligatorio para actividades industriales, especialmente donde existe la combinación de productos químicos que resulte en una matriz compleja de compuestos. Conceptos tales como la sustitución de materiales, la segregación de corrientes, recirculación de flujos, y la minimización del consumo de agua deben ser incorporados en las prácticas normales de operación. Todas estas medidas reducen al mínimo los problemas y ahorran dinero a largo plazo. Un resumen de prevención de la contaminación industrial es presentado por Eckenfelder (2000), quien propone añadir una barrera (tratamiento) para cada tipo diferente de agente contaminante presente y el diseño de un sistema de tratamiento muy robusto.

Mediante una simulación por computadora, Ko et al. (2002) compararon algunas estrategias de pretratamiento, tales como: almacenamiento del afluente y reintroducción, alimentación por bloques, recirculación rápida de lodos y almacenamiento de lodos. La comparación se basó en la estrategia que obtendría un mejor tratamiento de los contaminantes en términos de
$\mathrm{DBO}_{5}$ y nitrógeno. Usando modelos de inhibición para los compuestos tóxicos aplicados a los microorganismos heterótrofos y nitrificantes, encontraron que el almacenamiento del afluente y la estrategia de reintroducción resultaron en un mejor tratamiento cuando el afluente estaba contaminado con una sustancia tóxica.

Esto implica que un método de detección temprana puede ser capaz de enviar el flujo de un afluente con compuestos tóxicos a una instalación de almacenamiento para posteriormente alimentarlo en el tratamiento a una velocidad pre-determinada. Esta tasa de re-introducción también debe basarse en las pruebas de inhibición, con el fin de obtener un buen funcionamiento de la planta; en este caso, el parámetro principal será el porcentaje del flujo almacenado con respecto al flujo principal del afluente.

Una estrategia de prevención inicial por supuesto es mejor que la implementación de acciones correctivas como las descritas anteriormente. Si se diseñara una planta de tratamiento para funcionar bajo cualquier circunstancia, esta sería una instalación costosa. Lo ideal sería que todos los choques de concentración y presencia de afluentes tóxicos se evitaran; sin embargo, en términos reales, esto no es posible, los accidentes ocurren y por lo tanto, como medida preventiva, se puede diseñar una planta de tratamiento de la manera más robusta posible.

\subsubsection{Operación de sistemas durante la inhibición}

A continuación, se presentan algunos casos de estudio en el que se encontraron condiciones inhibidoras a través de los valores de los parámetros fundamentales de la biodegradación y no a través del análisis del afluente. También, se presentan estrategias de tratamiento que se utilizan para hacer frente a las condiciones inhibitorias en el reactor de lodos activados. En general, se muestran dos situaciones contrastantes, una con características inhibitorias menores y otra con características muy inhibitorias. Ambos casos presentan aparentemente una operación estable con respecto a los resultados del tratamiento; sin embargo, en detalle, las diferencias observadas proporcionan una idea de las consecuencias causadas por la presencia de las substancias inhibidoras, a pesar de que prevalecía una situación aparentemente normal. 
10.4.1.1 Caso de estudio 1: Tratamiento de aguas residuales de la fabricación de productos químicos

Se presenta un ejemplo de dos reactores de lodos activados de escala de laboratorio que operan en paralelo alimentadas con un substrato artificial, uno de ellos enriquecido con $78 \mathrm{mg} / \mathrm{L}$ de un inhibidor conocido (2,4diclorofenol, DCF) (García, 1985). Ambos reactores fueron operados a varias cargas orgánicas, basadas en carbono orgánico total (COT). La carga orgánica $(\mathrm{F} / \mathrm{M})$ de $0.32 \mathrm{~d}^{-1}$ se utilizó para comparar los resultados. Con el fin de adsorber el DCF, se empleó carbón activado en polvo (CAP) el cual se añadió al reactor en una dosis de $50 \mathrm{mg} / \mathrm{L}$ basándose en la velocidad de alimentación. En estado estacionario, las concentraciones del inhibidor fueron de $0.8 \mathrm{mg} / \mathrm{L}$ e inferiores a $0.01 \mathrm{mg} / \mathrm{L}$ (la cual fue la concentración más baja encontrada en el reactor a la que se añadió carbono). Otros valores comparativos se muestran en la Tabla 10.4; los valores de substrato y por lo tanto, los valores específicos de los parámetros están basados en el COT. De esta manera, la suma del coeficiente de respiración y el coeficiente de rendimiento en términos de oxígeno no se sumarán.

El 2,4-diclorofenol es un inhibidor conocido y se alimentó a una concentración donde no se observó inhibición aparente a corto plazo: $79 \mathrm{mg} / \mathrm{L}$ en la alimentación. Esta concentración se decidió después de realizar pruebas respirométricas a diferentes concentraciones con biomasa no aclimatada. El criterio utilizado fue el de elegir una concentración tal que no causara efectos tóxicos evidentes. Puesto que la biomasa en el reactor tenía un período suficientemente largo de aclimatación, esta adaptación se usó como un factor de seguridad. Los datos, después de que se alcanzó el estado estacionario, se reportan en la Tabla 10.4.

El DCP es una substancia conocida que desacopla la fosforilación oxidativa, y por consiguiente resulta en un rendimiento de biomasa bajo y en un coeficiente de respiración más alto en el reactor, cuando el DCF no es capturado o removido por el carbón activado. Para llevar a cabo este estudio se asumió que en todo momento el reactor con CAP estuvo expuesto a una mejor inhibición debido a la adsorción del DCF en el CAP. Eckenfelder (2000) reportó una correlación inversa entre la dosis de carbono y la toxicidad usando un bioensayo para el efluente de un proceso PACT ${ }^{\circledR}$. Cuanto mayor sea la dosis de carbono menor es la toxicidad exhibida por el efluente. El experimento descrito aquí se ajusta al proceso PACT ${ }^{\circledR}$. Analizando la información se observa que la tasa de degradación específica $\left(\mathrm{r}_{\mathrm{s}}\right)$ es ligeramente mayor en el reactor con carbón activado debido que se expone a una menor inhibición; los parámetros estequiométricos también muestran el efecto más claramente.

La presencia de la sustancia inhibidora, aunque en una pequeña proporción con respecto al substrato de base, se pudo observar debido al cambio en los valores de ' $a$ ' $y$ ' $Y_{\mathrm{x}}$ ' y también por la velocidad de degradación, aunque con un menor porcentaje de cambio. El substrato en general, presentó una tasa de $1.9 \mathrm{mg} \mathrm{DQO} / \mathrm{mg}$ COT. Usando esta relación en los valores reportados en la Tabla 10.4 , es posible modificar la $a$ y $Y_{H}$ ' mediante el ajuste de las unidades básicas. Por lo tanto, la relación [a $\left.+\mathrm{Y}_{\mathrm{H}}{ }^{\prime}\right]$ se modifica consecuentemente como:

Reactor sin CAP:

$\mathrm{a}=0.80 / 1.9=0.42 \mathrm{mgO}_{2} / \mathrm{mg}$ DQO

$\mathrm{Y}_{\mathrm{H}}{ }^{\prime}=1.20 / 1.9=0.63 \mathrm{mgO}_{2} / \mathrm{mg}$ DQO

$\mathrm{a}+\mathrm{Y}_{\mathrm{H}}^{\prime}=1.05$

Reactor con CAP:

$\mathrm{a}=0.70 / 1.9=0.37 \mathrm{mgO}_{2} / \mathrm{mg}$ DQO

$\mathrm{Y}_{\mathrm{H}}{ }^{\prime}=1.25 / 1.9=0.66 \mathrm{mgO}_{2} / \mathrm{mg} \mathrm{DQO}$

$\mathrm{a}+\mathrm{Y}_{\mathrm{H}}{ }^{\prime}=1.03$

Tomando en consideración que estos datos son valores experimentales, la precisión de la aproximación es razonable. El reactor sin carbón activado degrada casi todo el substrato, incluyendo el DCF, cuya concentración en el efluente fue del orden de $1 \mathrm{mg} / \mathrm{L}$. La concentración de DCF en el reactor con carbón activado en polvo era menor que $0.01 \mathrm{mg} / \mathrm{L}$. Esta baja concentración podría atribuirse a la adsorción en el carbón activado, así como a la biodegradación. No se encontraron evidencias de la adsorción del DCF en la biomasa.

Tabla 10.4 Coeficientes estequiométricos en presencia de 2,4-diclorofenol sin y con carbón activado en polvo (CAP)

\begin{tabular}{|c|c|c|c|c|c|c|c|}
\hline & $\begin{array}{l}\mathrm{FM} \\
\left(\mathrm{d}^{-1}\right)\end{array}$ & $\begin{array}{c}r_{\mathrm{s}} \\
\left(\mathrm{d}^{-1}\right)\end{array}$ & $\begin{array}{c}\mathrm{X} \\
(\mathrm{mgSSV} / \mathrm{L})\end{array}$ & $\begin{array}{c}\text { SOUR } \\
\left(\mathrm{d}^{-1}\right)\end{array}$ & $\begin{array}{c}\mathrm{a} \\
\left(\mathrm{mgO}_{2} / \mathrm{mgCOT}\right)\end{array}$ & $\begin{array}{c}\mathrm{Y}_{\mathrm{x}} \\
(\mathrm{mg} \mathrm{SS} / \mathrm{mgCOT})\end{array}$ & $\begin{array}{c}\mathrm{Y}^{\prime}{ }_{\mathrm{x}} \\
\left(\mathrm{mgO}_{2} / \mathrm{mgCOT}\right)\end{array}$ \\
\hline Sin CAP & 0.32 & 0.29 & 1,700 & 0.31 & 0.80 & 0.72 & 1.20 \\
\hline Con CAP & 0.32 & 0.31 & 2,311 & 0.26 & 0.70 & 0.94 & 1.25 \\
\hline
\end{tabular}


10.4.1.2 Caso de estudio 2: Tratamiento de aguas residuales textiles

Alva-Urdanivia (1996) describe otro caso en el que agua que contiene dimetil-formamida (DMF, $\mathrm{C}_{3} \mathrm{H}_{7} \mathrm{NO}$ ) del lavado de gases en un proceso de fabricación de fibra acrílica, se trató en un proceso biológico (filtro percolador), pero fue difícil de estabilizar.

Se investigó el tratamiento biológico con DMF como substrato único usando microorganismos aclimatados y seleccionados previamente. Se encontraron buenas eficiencias de eliminación en sistemas en flujo discontinuo, en un experimento que duró 7 días. Otros esfuerzos en sistemas abiertos continuos han resultado en tratamientos con bajas eficiencias.

Otra metodología evaluada, consistió en un tratamiento combinado usando un efluente sintético doméstico como co-substrato junto con la DMF en un reactor aerobio operado de manera discontinua. Las aguas residuales domésticas se simularon con una solución de peptona-dextrosa. Se utilizaron dos reactores, uno con DMF a $800 \mathrm{mg}$ DQO/L, más la mezcla de peptona-dextrosa a $200 \mathrm{mg} \mathrm{DQO} / \mathrm{L}$, y un segundo con DMF como única fuente de carbono agregada a la misma concentración de $800 \mathrm{mg}$ DQO/L. La reacción de degradación de la DMF se puede escribir como se muestra a continuación:

$\mathrm{C}_{3} \mathrm{H}_{7} \mathrm{NO}_{2}+a \mathrm{O}_{2} \rightarrow \mathrm{Y}_{\mathrm{H}} \mathrm{C}_{5} \mathrm{H}_{7} \mathrm{NO}_{2}+\mathrm{NH}_{3}+\mathrm{CO}_{2}+\mathrm{H}_{2} \mathrm{O}$

La carga orgánica $\left(\mathrm{S}_{\mathrm{o}} / \mathrm{X} \theta_{\mathrm{h}}\right)$, basada en la DQO, se mantuvo cercana a 0.3 tanto como fue posible, el $\mathrm{pH}$ alrededor de 7.3 y la temperatura a $25^{\circ} \mathrm{C}$ en ambos reactores. Los valores medios de los parámetros estequiométricos obtenidos durante un período de cuatro meses se muestran en la Tabla 10.5; M1 representa el reactor con substrato combinado y M2 el alimentado sólo con DMF.

En este experimento se demostró que la DMF se puede degradar casi completamente en un sistema de tratamiento semi-continuo; este análisis fue monitoreado mediante cromatografía de gases. La DMF fue consumida en ambos sistemas. Sin embargo, en el reactor con un solo substrato (M2) la degradación fue ligeramente más rápida, pero quedó remanente un residuo no identificado, en términos de DQO, después de la desaparición de la DMF (Figura 10.6).

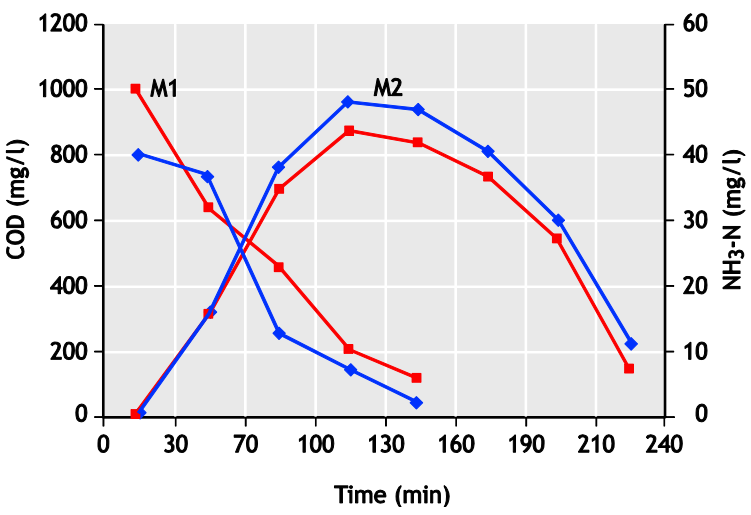

Figura 10.6 Nitrificación durante la degradación de DMF

El mayor consumo de oxígeno observado en M2 no se puede atribuir a la nitrificación, debido al exceso de nitrógeno contenido en la DMF, ya que en ambos reactores, el nivel de las especies de nitrógeno y el patrón de reacción fue casi el mismo (Figura 10.7). La nitrificación se inició cuando el carbono casi se había agotado.

En el caso de las tasas de respiración no ocurrió lo mismo. A pesar del hecho de que M1 tenía una concentración de carbono más alta, el consumo específico de oxígeno fue casi constante a lo largo de la degradación del carbono. Mientras que en M2, hubo un pico varias veces mayor en comparación con su reactor gemelo.

¿Podemos decir que la DMF causa un efecto tóxico si se consume casi en su totalidad? La respuesta es sí, si se comparan los valores de los parámetros con los valores comunes que se encuentran en el caso de las aguas residuales domésticas, donde el substrato es utilizado para el crecimiento y la generación de energía en un porcentaje de $67 \%$ y $33 \%$, respectivamente. Lo cual está más relacionado al reactor M1. Es importante denotar

Tabla 10.5 Efecto del co-substrato sobre los coeficientes estequiométricos

\begin{tabular}{lccccc}
\hline & $\begin{array}{c}\mathrm{X} \\
\left(\mathrm{d}^{-1}\right)\end{array}$ & $\begin{array}{c}\mathrm{X} \\
(\mathrm{mgSSV} / \mathrm{L})\end{array}$ & $\begin{array}{c}\mathrm{a} \\
\left(\mathrm{mgO}_{2} / \mathrm{mgDQO}\right)\end{array}$ & $\begin{array}{c}\mathrm{Y}_{\mathrm{H}} \\
\left(\mathrm{mgVSS} / \mathrm{mgDQO}^{\prime}\right.\end{array}$ & 0.71 \\
\hline M1 & 0.33 & 3,782 & 0.31 & 0 & 0.50 \\
M2 & 0.31 & 2,847 & 0.54 & 0.33 & 0.47 \\
\hline
\end{tabular}


que este cambio drástico en los valores de $a$ y $Y^{\prime}{ }_{H}$ fue debido a la adición de una pequeña proporción de un "buen" substrato, y a pesar de presentar, en general, una tasa de eliminación de la DQO similar, se observó una diferencia significativa en los parámetros estequiométricos y en las tasas de respiración.

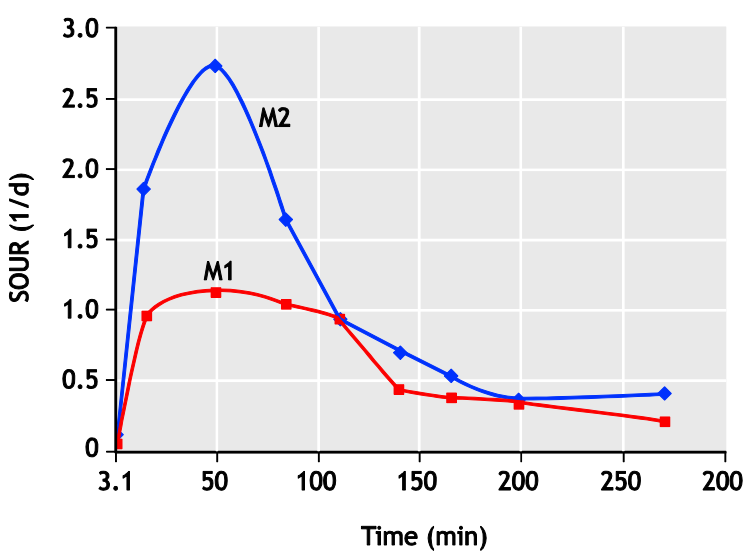

Figura 10.7 Respiración durante la degradación de DMF

Estos dos casos (DCF y DMF) difieren en un aspecto importante, en el primero, se puede considerar que la biomasa sufrió cambios menores en la composición, en comparación con un lodo activado convencional, mientras que en el último, los cambios en los parámetros pueden atribuirse al cambio en la biomasa. Este es un caso de adaptación a un medio hostil (M2), sin embargo, los rendimientos fueron comparables.

\subsubsection{Caso de estudio 3: Tratamiento de aguas residuales urbanas}

En los casos anteriores, hay una sustancia identificable que causa la inhibición, en el presente caso, se investiga una inhibición indefinida causada por la combinación de sustancias que se encuentran en drenajes donde están presentes aguas residuales domésticas e industriales. La naturaleza inhibidora de los efluentes industriales se elimina parcialmente a través de un tratamiento biológico, en función de la adaptación de la biomasa. Excepto por la presencia de choques de cargas sufridos por un sistema, se considera que la biomasa está bien adaptada cuando la planta de tratamiento ha estado recibiendo aguas residuales con una composición relativamente estable. Sin embargo, esta adaptación no significa que el tratamiento no fue inhibido, en mayor o menor grado. Como se describió anteriormente, un modo sencillo de evaluar el riesgo potencial de un inhibidor en el afluente del tratamiento biológico de aguas residuales, es el control de la relación $\mathrm{DBO}_{5} / \mathrm{DQO}$. A continuación se presentan dos casos donde el carácter inhibidor inherente de las aguas residuales se modifica a través de un pre-tratamiento por medio de ozonización de las aguas residuales.

1) El primer caso se basa en el estudio de Beltran et al. (2000), utilizando aguas residuales domésticas. Una etapa de pre-ozonización es aplicada para aumentar la relación de $\mathrm{DBO}_{5} / \mathrm{DQO}$ de 0.57 a 0.69 , aplicando una dosis de $30 \mathrm{mgO}_{3} / \mathrm{L}$ a las aguas residuales. Dos flujos paralelos, uno con un pre-tratamiento con ozono y el otro tal como se genera, se introdujeron a un proceso de lodos activados. A partir de los datos obtenidos se estimaron los parámetros reportados en la Tabla 10.6. Aunque el modelo de Grau no incluye explícitamente un término de inhibición, los valores de las constantes de velocidad indican que el sistema de tratamiento con pre-ozonización es más rápido que el reactor sin tratamiento previo. Esto es debido a que los valores reportados para el equivalente de oxígeno de la biomasa (b) son bastante bajos; la $Y_{H}^{\prime}$ se calculó mediante un balance utilizando los valores de las fracciones (entre paréntesis). En este experimento, se observa que el coeficiente de utilización de oxígeno (a) es menor en el caso de las aguas residuales pretratadas con ozono y el coeficiente de rendimiento de biomasa real $\left(Y_{H}\right)$ más alto. Esto indica un menor estrés en el caso del agua pre-ozonizada, es decir, con una condición menos tóxica.

2) En el segundo caso (Ríos, 2005), para una combinación de aguas residuales domésticas e industriales se encontró una relación $\mathrm{DBO}_{5} / \mathrm{DQO}$ promedio de 0.51 . Se empleó un pre-tratamiento de ozonización para disminuir el efecto inhibidor mostrado por la relación $\mathrm{DBO}_{5} / \mathrm{DQO}$, con la intención de hacer el afluente más degradable, con la premisa de

Tabla 10.6 Valores estimados de los parámetros biocinéticos

\begin{tabular}{|c|c|c|c|c|c|c|}
\hline Tratamiento & $\begin{array}{c}\mathrm{a} \\
\mathrm{mgO}_{2} / \mathrm{mgDQO}\end{array}$ & $\begin{array}{c}\mathrm{Y}_{\mathrm{H}} \\
\mathrm{mgSSV} / \mathrm{mgDQO}\end{array}$ & $\begin{array}{c}\mathrm{Y}_{\mathrm{H}^{\prime}} \\
\mathrm{mgO}_{2} / \mathrm{mgDQO}\end{array}$ & $\begin{array}{c}\mathrm{b} \\
\mathrm{mgO}_{2} / \mathrm{mgSSV}\end{array}$ & $\begin{array}{l}\mathrm{K}_{\mathrm{m}} \\
\mathrm{d}^{-1}\end{array}$ & $\begin{array}{c}\mathrm{k}^{1} \\
\mathrm{mgDQO} / \mathrm{mgSSV} . \mathrm{d}\end{array}$ \\
\hline Lodos activados & 0.58 & 0.33 & 0.42 & $0.45(1.27)$ & 0.097 & 2.2 \\
\hline $\begin{array}{l}\text { Ozonización + lodos } \\
\text { activados }\end{array}$ & 0.49 & 0.48 & 0.51 & $0.82(1.06)$ & 0.106 & 3.7 \\
\hline
\end{tabular}

${ }^{1} \mathrm{k}$ fue inspirada en el modelo cinético de Grau. 
que una pre-oxidación rompería estructuras moleculares complejas y tóxicas, incrementando la biodegradabilidad (Beltran et al., 2000). Después de la ozonización aplicada en un sistema semi-continuo, la relación $\mathrm{DBO}_{5} / \mathrm{DQO}$ aumentó a 0.69 en promedio, utilizando una dosis de $27 \mathrm{mgO}_{3} / \mathrm{L}$. De la misma manera, las dos aguas residuales, pre-ozonizadas y sin ozonizar, fueron alimentadas a reactores aerobios continuos (lodos activados, LA) con la misma carga orgánica para poder llevar a cabo una comparación. Los resultados mostraron diferencias interesantes en el tratamiento biológico de los dos sistemas utilizados en el estudio.

Después de la ozonización en el sistema semicontinuo (durante 10 minutos), la DQO disminuyó en un $13 \%$ con un incremento de alrededor de $13 \%$ de la $\mathrm{DBO}_{5}$, como se muestra en la Tabla 10.7. En este caso, la intención no era obtener un tratamiento completo basado en la aplicación de ozono, sino solo una rápida detoxificación del afluente. Después de que el estado estacionario se alcanzó en los dos reactores funcionando en paralelo, se obtuvieron los resultados resumidos en la Tabla 10.8 .

Hay varias observaciones que se pueden hacer como resultado de este estudio. En primer lugar, el crecimiento de la biomasa parece ser menor en el reactor con preozonización, a juzgar por las menores concentraciones de biomasa encontradas en este reactor. En segundo lugar, la $\mathrm{DQO}_{\text {y }} \mathrm{DBO}_{5}$ remanentes, son más bajas en el reactor alimentado con el afluente previamente pre-ozonizado, una señal de una tasa de degradación más rápida. En términos porcentuales, la $\mathrm{DQO}$ y $\mathrm{DBO}_{5}$ eliminadas son mayores en el reactor con pre-ozonización. Tomando en cuenta todos los datos, se calcularon los parámetros que se muestran en la Tabla 10.9.

El efecto sobre el coeficiente de rendimiento real $\left(Y_{H}\right)$ y el coeficiente de utilización de oxígeno $(a)$ difieren en este segundo caso con respecto a la situación analizada en el primero. Ambos parámetros son mayores en el sistema ozonizado, aunque en el caso del coeficiente de rendimiento la diferencia es mínima. Cuando el rendimiento se expresa en unidades de oxígeno, la tendencia es exactamente lo contrario de la que se encuentra en las otras situaciones, es decir, el tratamiento que se encuentra bajo estrés debido a la presencia de las sustancias tóxicas utiliza una mayor proporción de oxígeno. Una razón podría ser o estar relacionado con los valores del coeficiente de la tasa de decaimiento de la biomasa $\left(\mathrm{K}_{\mathrm{m}}\right)$ que se han observado; de alguna manera, el reactor con agua residual ozonizada muestra un valor más alto, que a su vez podría explicar el mayor consumo de oxígeno en este reactor. Esto se puede ver en la Tabla 10.10, donde se presentan las tasas de consumo de oxígeno total (RE) y el rendimiento observado. No se realizaron correcciones debidas a la presencia de las especies de nitrógeno.

Tabla 10.7 Efecto de la ozonización en la biodegradabilidad del afluente

\begin{tabular}{|c|c|c|c|c|c|c|}
\hline Lote & $\begin{array}{c}\text { DQO inicial } \\
(\mathrm{mg} / \mathrm{L})\end{array}$ & $\begin{array}{c}\text { DQO final } \\
(\mathrm{mg} / \mathrm{L})\end{array}$ & $\begin{array}{c}\mathrm{DBO}_{5} \text { inicial } \\
(\mathrm{mg} / \mathrm{L})\end{array}$ & $\begin{array}{c}\mathrm{DBO}_{5} \text { final } \\
(\mathrm{mg} / \mathrm{L})\end{array}$ & $\mathrm{DBO}_{5} / \mathrm{DQO}$ inicial & $\mathrm{DBO}_{5} / \mathrm{DQO}$ final \\
\hline 1 & 445 & 390 & 241 & 270 & 0.54 & 0.69 \\
\hline 2 & 450 & 378 & 234 & 265 & 0.52 & 0.70 \\
\hline
\end{tabular}

Tabla 10.8 Resumen del funcionamiento en el estado estacionario

\begin{tabular}{cccccccccc}
\hline Lote & Reactor & $\begin{array}{c}\theta_{\mathrm{h}} \\
(\mathrm{h})\end{array}$ & $\begin{array}{c}\theta_{\mathrm{x}} \\
(\mathrm{d})\end{array}$ & $\begin{array}{c}\mathrm{X} \\
(\mathrm{mg} / \mathrm{L})\end{array}$ & $\begin{array}{c}\mathrm{S}_{\mathrm{o}} \\
(\mathrm{mg} \mathrm{DQO} / \mathrm{L})\end{array}$ & $\begin{array}{c}\mathrm{S} \\
(\mathrm{mg} \mathrm{DQO} / \mathrm{L})\end{array}$ & $\begin{array}{c}\mathrm{S}_{\mathrm{o}} \\
(\mathrm{mg} \mathrm{DBO} / \mathrm{L})\end{array}$ & $\begin{array}{c}\mathrm{S} \\
(\mathrm{mg} \mathrm{DBO} / \mathrm{L})\end{array}$ & $\begin{array}{c}\mathrm{F} / \mathrm{M} \\
(\mathrm{mg} / \mathrm{mg})\end{array}$ \\
\hline \multirow{2}{*}{1} & $\mathrm{LA}$ & 20 & 14.1 & 1,310 & 445 & 125 & 241 & 30 & 0.41 \\
& $\mathrm{O}_{3}+\mathrm{LA}$ & & 14.5 & 1,165 & 390 & 84 & 270 & 20 & 0.40 \\
2 & $\mathrm{LA}$ & 15 & 8.9 & 1,233 & 450 & 142 & 234 & 44 & 0.58 \\
& $\mathrm{O}_{3}+\mathrm{LA}$ & & 9.2 & 1,044 & 378 & 92 & 265 & 35 & 0.58 \\
\hline
\end{tabular}

Tabla 10.9 Resumen de los parámetros estequiométricos y cinéticos

\begin{tabular}{|c|c|c|c|c|c|c|c|}
\hline Tratamiento & $\begin{array}{c}\mathrm{a} \\
\left(\mathrm{mg} \mathrm{O}_{2} / \mathrm{mg} \mathrm{DQO}\right)\end{array}$ & $\begin{array}{c}\mathrm{Y}_{\mathrm{H}} \\
(\mathrm{mg} \mathrm{SSV} / \mathrm{mg} \mathrm{DQO})\end{array}$ & $\begin{array}{c}\mathrm{Y}_{\mathrm{H}^{\prime}} \\
\left(\mathrm{mg} \mathrm{O}_{2} / \mathrm{mg} \mathrm{DQO}^{\prime}\right)\end{array}$ & $\begin{array}{c}\mathrm{b} \\
\left(\mathrm{mg} \mathrm{O}_{2} / \mathrm{mg} \mathrm{SSV}\right)\end{array}$ & $\begin{array}{c}\mathrm{K}_{\mathrm{m}} \\
\left(\mathrm{d}^{-1}\right)\end{array}$ & $\begin{array}{c}\mathrm{k}^{1} \\
\left(\mathrm{~d}^{-1}\right)\end{array}$ & $\alpha^{1}$ \\
\hline$\overline{\mathrm{LA}}$ & 0.39 & 0.44 & 0.66 & 1.51 & .060 & 3.8 & 1.07 \\
\hline $\mathrm{O}_{3}+\mathrm{LA}$ & 0.44 & 0.46 & 0.58 & 1.27 & .083 & 4.3 & 0.86 \\
\hline
\end{tabular}

${ }^{1} \mathrm{k}$ y $\alpha$ derivan del modelo cinético de Contois 
Tabla 10.10 Condiciones operacionales

\begin{tabular}{|c|c|c|c|c|}
\hline \multirow[b]{2}{*}{ Lote } & \multicolumn{2}{|c|}{ Lodos activados } & \multicolumn{2}{|c|}{ Ozonación + Lodos activados } \\
\hline & $\begin{array}{c}\mathrm{Y}_{\mathrm{obs}} \\
(\mathrm{mg} \mathrm{SSV} / \mathrm{mg} \mathrm{DQO})\end{array}$ & $\begin{array}{c}\mathrm{RE} \\
\left(\mathrm{mg} \mathrm{O}_{2} / \mathrm{mg} \mathrm{SSV} . \mathrm{d}\right)\end{array}$ & $\begin{array}{c}\mathrm{Y}_{\mathrm{obs}} \\
(\mathrm{mg} \mathrm{SSV} / \mathrm{mg} \mathrm{DQO})\end{array}$ & $\begin{array}{c}\mathrm{RE} \\
\left(\mathrm{mgO}_{2} / \mathrm{mg} \mathrm{SSV.d}\right)\end{array}$ \\
\hline 1 & 0.238 & 0.203 & 0.207 & 0.230 \\
\hline 2 & 0.286 & 0.245 & 0.258 & 0.322 \\
\hline
\end{tabular}

La inhibición presente en el reactor debido al afluente sin pre-tratamiento, se ve reflejada en las constantes cinéticas, en este caso, en los parámetros del modelo de Contois. El tratamiento con ozono muestra una mayor tasa de degradación constante y un índice de inhibición inferior, de acuerdo con este modelo.

A pesar de la diferencia del comportamiento mostrado en estos dos últimos casos, el punto a resaltar es que tanto los parámetros estequiométricos como los parámetros cinéticos reflejan situaciones en las que la inhibición está presente. Aunque se utilizaron diferentes modelos cinéticos, la constante de velocidad es consistentemente superior para el reactor con pre-ozonización, así como los valores observados de otros parámetros que indican que existió un comportamiento inhibitorio.

\subsection{OBSERVACIONES FINALES}

La inhibición no es una condición que se dá de manera repentina desde una ausencia total hasta que el sistema esté totalmente inhibido, sino que es un proceso continuo que causan que los sistemas de tratamiento se desvíen de su operación óptima, de su funcionamiento original al cual fue diseñado o incluso llegar a una falla completa. Con el tiempo, la biomasa presente en un proceso biológico se puede adaptar a ciertas condiciones inhibitorias, siendo capaz de recuperarse después de haber sido expuesta por primera vez a la sustancia tóxica. Esto no quiere decir que el efecto de la disminución del rendimiento desaparecería con el tiempo, pero si lo que la adaptación significa: la capacidad de sobrevivir bajo nuevas condiciones. Aunque el tratamiento puede continuar y producir un efluente de buena calidad, esto no significa necesariamente que las condiciones ambientales para la biomasa sean óptimas.

Los modelos cinéticos presentados en este capítulo para describir la inhibición de sistemas complejos de degradación, tales como los que se producen en el tratamiento biológico de aguas residuales, se han desarrollado sobre la base de mecanismos de cinética enzimática. Estos modelos fueron transcritos a situaciones relativamente más complejas como en los que se presentan múltiples substratos que interactúan con diversos consorcios de microorganismos. La suposición fundamental es que existe un paso limitante similar a las reacciones descritas por los mecanismos enzimáticos, que definen, por ejemplo, el tipo de inhibición encontrado en sistemas de tratamiento de este tipo. La mayor parte de los casos descritos en este capítulo siguen lo que se ha llamado el modelo no competitivo clásico, aunque, la ecuación de Andrews a menudo también llega a utilizarse. Otros modelos que llegan a utilizarse, son extensiones de los primeros modelos de lodos activados.

A medida que más compuestos refractarios se encuentran en el medio ambiente, la tendencia creciente (y necesaria) es la de capturarlos en la fuente en la cual se generan a través de medidas de producción más limpia y también mejorar los sistemas de tratamiento existentes, ya que muchos de estos compuestos no pueden ser eliminados por los tratamientos convencionales. Obviamente, hay que hacer una distinción entre los efluentes industriales y las aguas residuales domésticas, tanto en términos de la cantidad y de calidad. La dilución, que es principalmente una característica de las aguas residuales domésticas, usualmente provoca que la inhibición pase inadvertida, a menos que cause una especie de choque tóxico. Esto, a menudo, continúa generando una inhibición, debido a la falta de un sistema de alerta temprana y a la incapacidad del tratamiento convencional para eliminar eficazmente las sustancias tóxicas e inhibitorias, poniendo en riesgo continuo al ambiente acuático (así como a otros medios).

Desafortunadamente, las plantas de tratamiento regularmente no cuentan con sistemas de monitoreo y detección en línea eficaces. Se pueden aplicar diferentes procedimientos para disminuir las condiciones inhibitorias y mantener la estabilidad y el rendimiento del proceso de lodos activados; en las sociedades donde la situación económica lo permite. En muchos países (especialmente en los países en desarrollo) no se realiza el análisis periódico de la presencia de toxicidad en los efluentes de los sistemas de tratamiento. Los ensayos biológicos con algas, invertebrados y peces son los más 
sensibles, mientras que las pruebas de bio-luminiscencia o respirometría son más prácticas, especialmente cuando se refiere al afluente de la planta de tratamiento. El requerimiento de realizar la Prueba Total de Toxicidad del Efluente (WET, Whole Effluent Toxicity) ha sido impuesta en algunas plantas de tratamiento en los Estados Unidos por regulaciones de la EPA, lo cual es un buen ejemplo de cómo disminuir el impacto ambiental causado por los efluentes de las aguas residuales de las plantas de tratamiento. 


\section{REFERENCES}

Alva-Urdanivia R. (1996) Study of the biodegradation of Dimethyl Formamide. M Sc. Thesis, Instituto Tecnologico y de Estudios Superiores de Monterrey, Monterrey.

Araujo C.V.M., Nascimento R.B., Oliveira C.A., Strotmann U.J. and da Silva E.M. (2005) The use of Microtox ${ }^{\circledR}$ to assess the toxicity removal of industrial effluents from the industrial district of Camacari (BA, Brazil). Chemosphere 58(9), 1277-1281.

Bailey J.E. and Ollis D.F. (1986) Biochemical Engineering Fundamentals, $2^{\text {nd }}$ Edition. McGraw Hill, Book Co.

Beltran J.B., Garcia J.F. y Alvarez, P.M. (2000) Estimation of biological kinetic parameters from continuous integrated ozonation-activated sludge system treating domestic wastewater. Biotech. Progress 16, 10181024.

Bitton G. (2005) Wastewater Microbiology, $3^{\text {rd }}$ Edition. John Wiley \& Sons, Hoboken, N.J.

Bridié A.l., Wolf C.J.M. and Winter M. (1979) BOD and COD of some petrochemicals. Wat. Res. 13 627-630.

Carvalho G., Nopens I., Vanrolleghem P.A. and Pinheiro H.M. (2001) Modeling activated sludge acclimatization to a non-ionic surfactant. Wat. Sci. Tech. 43 (7), 9-17.

Dixon M. and E.C. Webb (1964) Enzymes, $2^{\text {nd }}$ Edition, Longmans. London.

Eckenfelder W.W. (2000) Industrial Water Pollution Control, $3^{\text {rd }}$ Edition. McGraw Hill Book Co., New York.

EPA (U.S. Environmental Protection Agency, 1973). Process Design Manual for Nitrogen Control, Office of Technology Transfer, Washington, D.C.

EPA (U. S. Environmental Protection Agency) (1999) Toxicity Reduction Evaluation Guidance for Municipal Wastewater Treatment Plants (EPA/833B-99/002). Office of Wastewater Management. Washington D.C.

Fukusaki S., Nishio N., Shobayashi M. and Nagai S. (1990) Inhibition of the fermentation of propionate to methane by hydrogen, acetate and propionate. Appl. Env. Micr. 56 (3), 719-723.

Garcia J.H. (1985) Stoichiometry of activated sludge in the presence of toxics. Presented at the XXV National Convention, Mexican Institute of Chemical Engineers, San Luis Potosi, October, 23-25. (In Spanish)

Goudar C.T., Ganji S.H., Pujar B.G. and Strevett K.A. (2000) Substrate inhibition kinetics of phenol degradation. Wat. Env. Res. 72 (1), 50-55.
Grau P., Dohanyos U. and Chudoba J. (1975) Kinetics of multi-component substrate removal by activated sludge. Wat. Res. 9, 637-642.

Gumaelis 1., Smith E.H. and Dalhammar G. (1996) Potential biomarker for denitrification of wastewaters: effects of process variables and cadmium toxicity. Wat. Res 30(12), 3025-3031.

ISO (International Standards Organisation) (2003) ISO 13641-1:2003. Determination of inhibition of gas production of anaerobic bacteria-Part 1 . General test. Geneva.

ISO (International Standards Organisation) (2006) ISO 8192-2006: Test for inhibition of oxygen consumption by activated sludge for carbonaceous and ammonium oxidation. Geneva.

Ko J.H, Choi K.S., Woo H.J., Lee H.I. and Kim C.W. (2001) Evaluation of $\mathrm{pH}$ inhibition on activated sludge by the pseudo toxic concentration (СРТ) concept model. Wat. Sci. Tech. 43 (7), 65-72.

Ko J.H., Woo H.J., Copp J.B., Kim S. and Kim C.W. (2002) Evaluation of several respiration-based activated sludge toxicity control strategies Wat. Sci. Tech. 45 (45), 143-150.

OECD (Organisation for Economic Cooperation and Development) (2007) OECD 224 Guideline. Determination of the inhibition of the activity of anaerobic bacteria-reduction of gas production from anaerobically digesting (sewage) sludge. Geneva.

Ricco G., Tomei M.C., Ramadori R. and Laera G. (2004) Toxicity assessment of common xenobiotic compounds on municipal activated sludge: comparison between respiratory and Microtox ${ }^{\circledR}$. Wat. Res. 38, 2103-2110.

Rios L.C. (2005) Effect of ozone pre-treatment on the activated sludge performance. M.Sc. Thesis, Instituto Tecnologico y de Estudios Superiores de Monterrey. Monterrey. (In Spanish).

Siber S. and Eckenfelder Jr. W. W. (1980) Effluent quality variation for multi-component substrates in the activated sludge process. Wat. Res. 14, 471-476.

Volskay V.T. and Leslie Grady Jr. C.P. (1988) Toxicity of selected RCRA compounds to activated sludge microorganisms. WPCF 60 (10), 1850-1856. 


\section{NOMENCLATURA}

\begin{tabular}{|c|c|}
\hline Símbolo & Descripción \\
\hline$a$ & Coeficiente de respiración / Coeficiente de uso de oxígeno \\
\hline$A$ & Factor de frecuencia \\
\hline$b$ & Equivalente en oxígeno de la biomasa \\
\hline$E a$ & Energía de activación \\
\hline$I$ & Intensidad de luz \\
\hline$I$ & Concentración del inhibidor \\
\hline$k, k_{m}$ & Coeficientes de la tasa de la degradación aerobia especificada en términos de oxidación de carbono \\
\hline$R$ & Constante de la ley de los gases \\
\hline$R_{\text {avg }}$ & Promedio de la respiración en la prueba control \\
\hline$R_{c}$ & Tasa de respiración a la concentración de la sustancia \\
\hline$r_{s}$ & Tasa de degradación específica \\
\hline$S$ & Concentración de propionato no disociado \\
\hline$S_{\text {crit }}$ & Valor del substrato al que se puede encontrar la máxima velocidad \\
\hline$T$ & Temperatura absoluta \\
\hline$T_{o}$ & Temperatura de referencia \\
\hline$Y_{H}$ & Rendimiento real medido de la biomasa \\
\hline$Y_{P}$ & Rendimiento del producto \\
\hline$\Delta A_{c}$ & Disminución de la absorbancia en el sistema o prueba control \\
\hline$\Delta A_{s}$ & Disminución de la absorbancia en la muestra \\
\hline$\Delta H$ & Entalpía de desactivación \\
\hline$\Delta S$ & Entropía de desactivación \\
\hline Abreviatura & Descripción \\
\hline DCF & Diclorofenol \\
\hline DMF & Dimetil-formamida \\
\hline $\mathrm{CE}$ & Concentración efectiva \\
\hline FM & Carga orgánica (Relación Alimento/Microorganismo) \\
\hline ISO & Organización internacional de normalización (International organization for standardization) \\
\hline OUR & Tasa de consumo de oxígeno (Oxygen utilization [uptake] rate) \\
\hline CAP & Carbono activado en polvo \\
\hline ThOD & Demanda teórica de oxígeno \\
\hline COT & Carbon orgánico total \\
\hline TRE & Evaluación de reducción de toxicidad (Toxicity reduction evaluation) \\
\hline WET & Prueba de toxicidad de efluente total (Whole Effluent Toxicity) \\
\hline Símbolos griegos & Explicación \\
\hline$\mu_{\max }$ & Tasa máxima de crecimiento \\
\hline$\beta$ & Constante \\
\hline$\underline{\theta}$ & Coeficiente de temperatura de Arrhenius \\
\hline
\end{tabular}




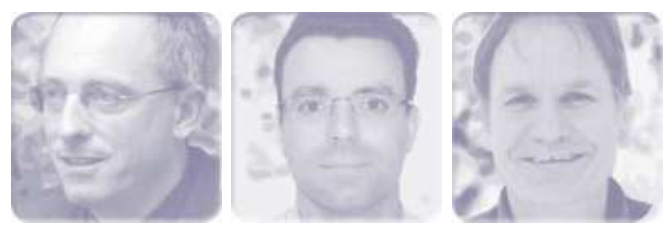

\section{Lodos filamentosos}

\section{Mark C.M. van Loosdrecht, Antonio M. Martins y George A. Ekama}

\section{$11.1 \quad$ INTRODUCCION}

El proceso por lodos activados es la tecnología más comúnmente utilizada para el tratamiento biológico de aguas residuales. Este sistema consiste en dos etapas, la bioquímica (tanque aireado) y la física (clarificador secundario). En el tanque de aireación son eliminados la materia orgánica, amoniaco $\mathrm{y}$ fosfato por los lodos activados. La cantidad de bacterias que son producidas en el agua residual es relativamente baja. Un afluente que contiene $500 \mathrm{mg}$ de DQO puede producir de 200 a 300 mg de sólidos suspendidos. Sin retención de biomasa, estos valores serían la concentración real de lodo en el proceso de tratamiento. Así mismo, la retención de biomasa es utilizada para incrementar la concentración de lodo en la etapa bioquímica. Las bacterias pueden formar flóculos que pueden ser separados del agua tratada mediante gravedad, lo cual resulta en una tecnología de separación amigable y económica. Una buena separación (sedimentación) y compactación (espesamiento) de los lodos activados en el clarificador secundario es una condición previa para garantizar una buena calidad en el efluente en este proceso. La separación se basa en la formación de flóculos compactos. La fuerza de gravedad relativamente baja hace necesario que el sedimentador se vuelva parte integral de la planta de tratamiento; además constituye fácilmente entre un 30 y 50\% del área total de la planta (Figura 11.1).

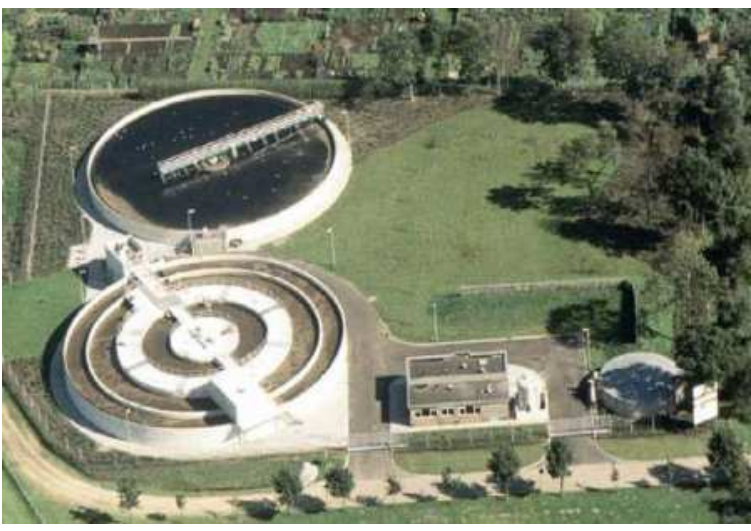

Figura 11.1 Planta para la eliminación biológica de nutrientes instalada en Holanda (proceso BCFS ${ }^{\oplus}$ ). Se muestra la importancia de la separación del lodo en el diseño del proceso. El diseño del sedimentador fue hecho de acuerdo a un IVL de $120 \mathrm{ml} / \mathrm{g}$ (foto: van Loosdrecht et al., 1998) 
La relación entre la sedimentación del lodo y el diseño del sedimentador se considera en detalle en el Capítulo 12. El índice de volumétrico de lodo (IVL) es utilizado como una medición empírica que asocia las características del lodo y el diseño del sedimentador (Ekama et al., 1986). Este valor puede obtenerse tras permitir que el lodo sedimente durante $30 \mathrm{~min}$ en una probeta de 1 litro. El volumen de la cama de lodos puede ser leído y dividido entre el contenido original de sólidos suspendidos de la muestra de lodo. De esta forma podemos obtener el volumen contenido en un gramo de lodo después de la sedimentación. El efecto del IVL sobre el tamaño del sedimentador es importante (Figura 11.2); por ejemplo, un incremento en el IVL de 100-150 $\mathrm{ml} / \mathrm{g}$ puede resultar en el diseño de un sedimentador que tenga casi el doble del área requerida.

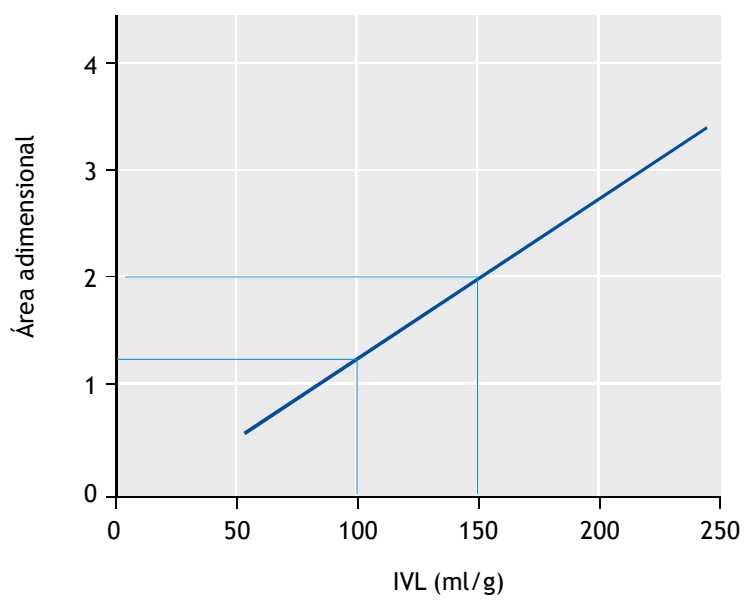

Figura 11.2 Relación entre el índice volumétrico del lodo y el área superficial requerida para un sedimentador, de acuerdo a las guías para el diseño de STOWA (STOWA, 1994)

La aparición de lodo voluminoso filamentoso (filamentous bulking sludge), o el incremento volumétrico del lodo, es un término que describe el crecimiento excesivo de bacterias filamentosas, un problema común y antiguo dentro del proceso de lodos activados (Donaldson, 1932). Cuando los flóculos del lodo se tornan filamentosos, se abultan y vuelven voluminosos y porosos, la capacidad de sedimentación disminuye y el lodo no sedimenta de manera eficiente. En la práctica, los lodos filamentosos están relacionados con un IVL alto. El valor crítico de IVL por el cual el lodo filamentoso se genera, dependerá fuertemente de las prácticas locales referentes al diseño y construcción de los sedimentadores. El lodo filamentoso se produce de manera general cuando los sólidos suspendidos no pueden ser mantenidos dentro del sedimentador; sin embargo, existen distintas formas de diseñar los sedimentadores. En Holanda, por ejemplo, se considera que el lodo es filamentoso cuando el valor del IVL es mayor a $120 \mathrm{ml} / \mathrm{g}$, y este valor se considera en las guías de diseño para sedimentadores. El esponjamiento del lodo es típicamente un parámetro operacional o problema empírico, por esta razón no existe un valor científico exacto para diferenciar entre un lodo filamentoso y uno que no lo es.

Los flóculos filamentosos, abultados y porosos sedimentan más lentamente por lo que requieren sedimentadores más grandes para ser mantenidos en el proceso y/o para prevenir la presencia de sólidos en el efluente. El crecimiento de bacterias filamentosas es especialmente perjudicial y ocasiona muchos problemas en la práctica, sobretodo de sedimentación. Las bacterias filamentosas a menudo no representan un grupo dominante en la planta de tratamiento, pero son suficientes fracciones volumétricas de $1 \%$ a $20 \%$ (Palm et al., 1980; Kappeler y Gujer, 1994b) para causar problemas graves de sedimentabilidad (Figura 11.3).
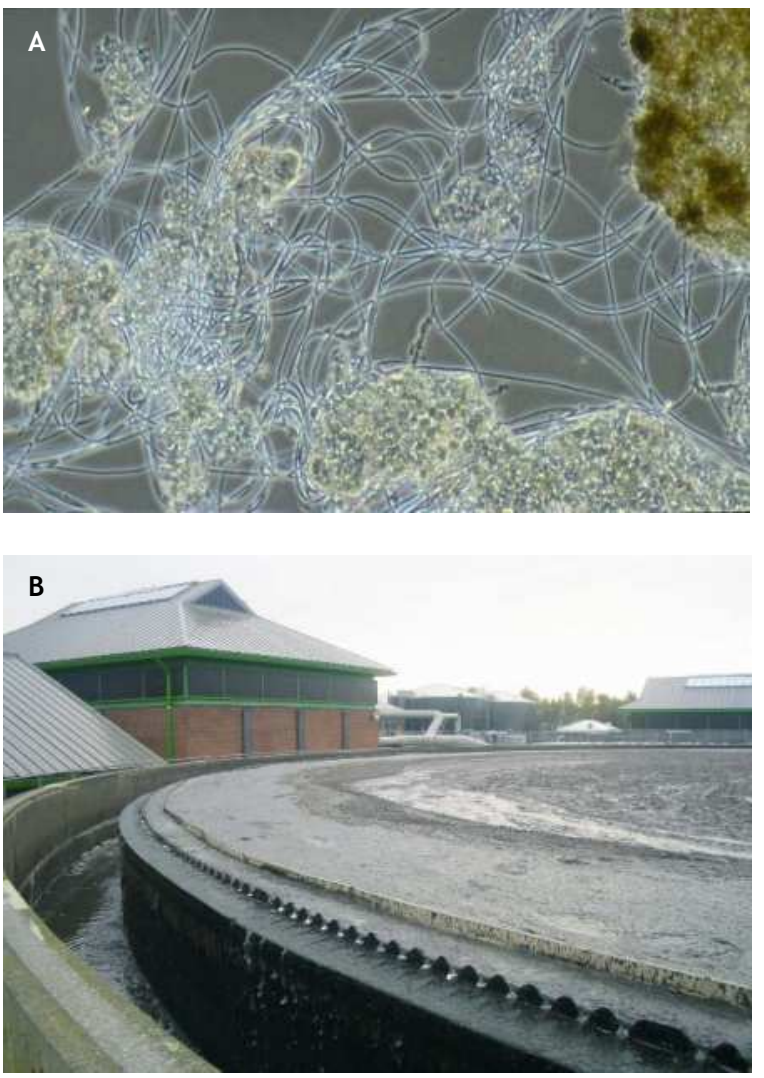

Figura 11.3 Problemas para el operador de una planta de tratamiento de aguas residuales: (A) lodo filamentoso, (B) lodos filamentosos saliendo de la planta junto con el efluente (fotos: D.H. Eikelboom y D. Brdjanovic) 
Los lodos filamentosos siguen siendo un problema durante la operación de las plantas de tratamiento de aguas residuales a pesar del gran número de investigaciones al respecto. Esto se debe a que existen muchas condiciones que permiten la proliferación de los organismos filamentosos. Muchas bacterias filamentosas no pueden crecer en cultivos puros, lo que impide un estudio detallado de estos organismos. El estado de la operación de la planta en la que se produce el esponjamiento del lodo por lo general es sólo marginalmente documentado.

Una de las razones por las cuales no se ha podido encontrar una solución general a la generación o aparición de lodos filamentosos puede ser la ausencia de un consenso acerca del punto o nivel exacto en el cual el problema debe ser abordado. El principal enfoque encontrado en la literatura tiene que ver con la identificación de bacterias filamentosas específicas (Eikelboom, 1975; 2000). Mediante el estudio y entendimiento de la ecología y la fisiología de las bacterias filamentosas, ya sea en cultivos puros o por la aplicación de técnicas in situ como la microautorradiografía (MAR), se podría esperar que se averigüe una solución para evitar la proliferación de ciertas bacterias filamentosas específicas. Un enfoque diferente es el de reconocer que la característica general es la morfología de la célula. Entender cómo la morfología de la célula microbiana afecta la ecología de la bacteria podría permitir encontrar una solución general independientemente de las especies involucradas (Chudoba et al., 1973a; Rensink, 1974). Dentro de este enfoque, la prevalencia de una clase específica de bacterias filamentosas es un problema secundario. El problema radica entonces en considerar que se requieren conocimientos de los procesos de ingeniería, así como microbiológicos, ya que la solución no puede obtenerse de manera aislada de uno de estos dos campos.

\subsection{ASPECTOS HISTÓRICOS}

La intención de este capítulo no es describir por completo la historia y desarrollo del sistema de lodos activados. Para esto, se invita al lector a revisar la literatura sugerida, por ejemplo, de Allemann y Prakasam (1983) o Albertson (1987). Nos limitaremos a destacar algunos de los aspectos históricos más importantes que han contribuido al entendimiento del problema de los lodos filamentoso.

El proceso de lodos activados fue desarrollado en Inglaterra a principios de 1900 (Ardern y Lockett, 1914).
Inicialmente, los sistemas operaban en ciclos discontinuos que incluían el llenado y vaciado, pero luego éstos se convirtieron rápidamente en sistemas de flujo continuo. A pesar de los constantes problemas de sedimentación, los sistemas de flujo continuo se popularizaron y propagaron por todo el mundo. Donaldson (1932) sospechaba que el retromezclado en los tanques aireados de flujo pistón, que cambia el comportamiento hidráulico y el régimen de sustrato hacia un modo completamente mezclado, era un factor importante que promovía el desarrollo de lodos filamentosos. Como una medida correctiva, Donaldson sugirió que el tanque aireado debía ser divido en compartimientos (por ejemplo, para promover un comportamiento similar al de un reactor de flujo pistón) para obtener una buena sedimentación del lodo. Sin embargo, los sistemas de lodos activados completamente mezclados y continuamente alimentados siguieron siendo del diseño preferido. Claramente los avances de la ingeniería civil prevalecieron por encima de las avances de la ingeniería de procesos durante la operación. La discusión sobre el efecto de los patrones o regímenes de alimentación en la sedimentación de lodo fue retomada en la década de los años 1970. Los estudios demostraron la ventaja de utilizar tanques compartimentalizados con un modelo de flujo pistón en lugar de sistemas completamente mezclados con alimentación continua (Chudoba et al., 1973b; Rensink, 1974; y muchos otros), confirmando las primeras recomendaciones de Donaldson (1932).

Pasveer (1959) regresó a la tecnología original de llenado y vaciado de Ardern y Lockett, desarrollando el sistema Pasveer o de fosas o diques de oxidación. Esto retomó la discusión sobre las ventajas de utilizar esos sistemas en el tratamiento municipal de aguas residuales. Los diques de oxidación de llenado y vaciado llegaron a ser populares en Europa durante poco tiempo, pero una vez más, casi todos los sistemas no tardaron en convertirse en fosas de oxidación de flujo continuo, complementadas con un sedimentador secundario y una recirculación de lodos. Durante la década de los años 1960 Pasveer demostró que un dique de oxidación con alimentación discontinua produce un lodo con una mejor capacidad de sedimentación en comparación con los sistemas completamente mezclados y continuamente alimentados (Pasveer, 1969).

En la década de los años 1970 Chudoba et al. (1973b) y Rensink (1974) desarrollaron el reactor selector, el cual llegó a ser la herramienta de ingeniería más utilizada para controlar el esponjamiento del lodo. Aunque el uso de 
selectores ha sido exitoso porque ha disminuido la aparición de lodos filamentosos en los sistemas de lodos activados, todavía existen algunos reportes que documentan su existencia.

\subsection{RELACION ENTRE MORFOLOGIA Y ECOFISIOLOGIA}

Una de las interrogantes más intrigantes y complejas acerca de los lodos filamentosos es si la morfología microbiana, fisiología y cinéticas del sustrato están relacionadas, y cómo contribuye esto a la mayor prevalencia de las bacterias filamentosas en los lodos activados. ¿Existe un mecanismo general que pueda explicar el crecimiento de bacterias filamentosas o es necesario identificar cada microorganismo filamentoso y describir su taxonomía, fisiología, morfología y cinética a fin de desarrollar estrategias para controlar la aparición de lodos filamentosos? ¿Es posible diseñar condiciones en el reactor que prevengan la proliferación de microorganismos filamentosos y aún así alcanzar biológicamente los efluentes de calidad requeridos? Aún cuando en algunas plantas nunca se ha observado la proliferación de lodos filamentosos, durante décadas los científicos, ingenieros y microbiólogos han fracasado en la búsqueda de respuestas para estas preguntas. Sin embargo, algunas relaciones que pueden inferirse serán brevemente discutidas más adelante.

\subsubsection{Enfoque microbiológico}

La falta de éxito en la búsqueda de una solución general para el control de los lodos filamentosos invita a muchos investigadores a mirar hacia las poblaciones microbianas para investigar las bacterias predominantes responsables. Las claves para la identificación (Eikelboom, 1977, 2000), basadas en la caracterización microscópica, fueron desarrolladas para detectar bacterias filamentosas.

Aún con muchas limitaciones, estos métodos de identificación proporcionaron una herramienta sistemática que permitió que con cierta confianza se identificaran microorganismos filamentosos. El siguiente paso fue encontrar relaciones predominantes entre estos microorganismos, su fisiología y condiciones operacionales (por ejemplo, la concentración de oxígeno disuelto (O.D.), relación sustrato/microorganismo (S/X), etc.), para definir estrategias específicas para su control (Jenkins et al., 1993a) (Tabla 11.1). La distribución de microorganismos filamentosos varía considerablemente entre las diferentes áreas geográficas (Martins et al. 2004a), y de acuerdo a la temporada. Se puede concluir que Microthrix parvicella y los Tipos 0092 y 0041/0675 son aparentemente el mayor morfotipo de microorganismos filamentosos, y los principales responsables de la pérdida de la capacidad de sedimentación observada en los sistemas de lodos activados para la eliminación biológica de nutrientes (EBN). Estos estudios también han mostrado que los casos supuestamente debidos a la abundancia de Microthrix parvicella, fueron más frecuentes en el invierno y primavera que en el verano y otoño (Kruit $e t$ al., 2002). También se confirmó que los morfotipos: Tipo 021N, Tipo 0961, Sphaerotilus natans y Thiothrix sp., pueden ser controlados mediante la introducción de etapas anaerobias y anóxicas, como típicamente se hace en los sistemas de remoción aumentada de fósforo y en sistemas con pre-desnitrificación (Ekama et al., 1996b). Sin embargo, estas condiciones parecen ser ineficientes para los microorganismos filamentosos dominantes encontrados en los sistemas biológicos para eliminación de nutrientes. Curiosamente, el morfotipo de bacterias filamentosas encontradas en los sistemas biológicos para la eliminación de nutrientes es Gram positivas, lo que implica que su superficie celular posiblemente hidrofóbica, puede fácilmente adsorber compuestos de baja solubilidad. No obstante, es incierto si los sistemas operados con baja carga también puedan enriquecer las bacterias Gram positivas que forman flóculos.

Durante la década de los años 1990 se introdujeron al tratamiento biológico de aguas residuales diversos métodos basados en el análisis del ADN y ARN (Capítulo 2). Estos métodos permitieron la correcta identificación de poblaciones de bacterias filamentosas. Por lo tanto, es aconsejable aplicar sondas genéticas específicas, cuando estén al alcance, para el estudio de las poblaciones de microorganismos que ocasionan los lodos filamentosos. Su aplicación de manera conjunta con la caracterización y definición de los lodos se consideran uno de los mayores desafíos para controlar la generación de lodos filamentosos en conjunto con el buen control y operación de las instalaciones (por ejemplo mediante el uso de selectores).

\subsubsection{Enfoque morfo-ecológico}

Las bacterias filamentosas crecen preferentemente en una o dos direcciones. Aparentemente este rasgo morfológico les provee ventajas a las bacterias filamentosas bajo condiciones limitadas por sustrato (por ejemplo ambientes resistentes a la difusión). Se prevé que estos organismos presentan una velocidad de crecimiento mayor hacia el exterior y por ello tienden a ganar la 
Tabla 11.1 Grupos propuestos de morfotipos de microorganismos filamentosos modelo (Wanner y Grau, 1989; Jenkins et al., 1993)

\begin{tabular}{|c|c|c|}
\hline Grupos & Características & Control \\
\hline \multicolumn{3}{|c|}{ I: Microorganismos en la zona de bajo O.D. } \\
\hline $\begin{array}{l}\text { Sphaerotilus natans, Tipo } 1701 \text {, } \\
\text { Haliscomenobacter hydrossis }\end{array}$ & $\begin{array}{l}\text { Utilizan sustratos rápidamente } \\
\text { biodegradables; crecen bien a bajas } \\
\text { concentraciones de O.D.; crecen en un } \\
\text { amplio rango de TRS. }\end{array}$ & $\begin{array}{l}\text { Selectores de flujo pistón aerobios, anóxicos o } \\
\text { anaerobios; aumento en el TRS; aumento en la } \\
\text { concentración de O.D. en el tanque de aeración } \\
(>1.5 \mathrm{mg} \mathrm{O} / 1) \text {. }\end{array}$ \\
\hline \multicolumn{3}{|c|}{ II: Microorganismos en la zona mixotrófica } \\
\hline Thiothrix sp. Tipo $021 \mathrm{~N}$ & $\begin{array}{l}\text { Utilizan sustratos rápidamente } \\
\text { biodegradables, especialmente ácidos } \\
\text { orgánicos de bajo peso molecular; TRS de } \\
\text { moderados a altos; capaces de oxidar el } \\
\text { sulfuro para almacenar gránulos de azufre; } \\
\text { elevados consumos de nutrientes bajo } \\
\text { deficiencia de estos. }\end{array}$ & $\begin{array}{l}\text { Selectores de flujo pistón aerobios, anóxicos o } \\
\text { anaerobios; adición de nutrientes eliminación } \\
\text { de sulfuro y/o altas concentraciones de ácidos } \\
\text { orgánicos (eliminación de condiciones } \\
\text { sépticas). }\end{array}$ \\
\hline \multicolumn{3}{|c|}{ III: Otros microorganismos de la zona aerobia } \\
\hline $\begin{array}{l}\text { Tipo 1851, Nostocoida limicola } \\
\text { spp. }\end{array}$ & $\begin{array}{l}\text { Utilizan sustratos rápidamente } \\
\text { biodegradables; TRS de moderados a altos. }\end{array}$ & $\begin{array}{l}\text { Selectores de flujo pistón aerobios, anóxicos o } \\
\text { anaerobios; TRS reducidos. }\end{array}$ \\
\hline \multicolumn{3}{|c|}{ IV: Microorganismos de la zona aerobia, anóxica, anaerobia } \\
\hline $\begin{array}{l}\text { Microthrix parvicella, Tipo } \\
\text { 0092, Tipo 0041/0675 }\end{array}$ & $\begin{array}{l}\text { Abundantes en sistemas anaerobios- } \\
\text { anóxicos-aerobios; TRS elevados; posible } \\
\text { crecimiento en sustratos particulados } \\
\text { hidrolizados. }\end{array}$ & $\begin{array}{l}\text { Aun incierto, pero las soluciones más } \\
\text { recomendadas son: instalar un colector para } \\
\text { eliminar sustratos particulados; mantener un } \\
\text { régimen de flujo pistón en todo el sistema; las } \\
\text { diferentes etapas (anaerobia/anóxica/aerobia) } \\
\text { deben ser bien definidas; mantener una } \\
\text { concentración de oxígeno relativamente alta en } \\
\text { la fase aerobia }\left(1.5 \mathrm{mg} \mathrm{O}_{2} / \mathrm{l}\right) \text { y una baja } \\
\text { concentración de amonio }(<1 \mathrm{mg} \mathrm{N} / \mathrm{l}) \mathrm{Kruit} \text { et } \\
\text { al. (2002), y bajos niveles de nitrato y nitrito } \\
\text { en el reactor anóxico antes del reactor aerobio } \\
\text { (Casey et al., 1999; Musvoto et al., 1994). }\end{array}$ \\
\hline
\end{tabular}

competencia debido a que pueden acceder fácilmente al sustrato que se encuentra en el líquido fuera de los flóculos (Martins et al., 2003a). Esto concuerda con algunos estudios que también relacionan el crecimiento excesivo de microorganismos filamentosos con la resistencia a la difusión de sustrato dentro de los flóculos biológicos (Pipes, 1967; Kappeler y Gujer, 1994a).

Dados estos puntos de vista, la morfología como tal aporta una ventaja ecológica para los microorganismos filamentosos. Esto también implica que las bacterias filamentosas pueden estar presentes dentro del flóculo bajo condiciones que no favorecen su crecimiento longitudinal y por ello sin causar la aparición de un lodo filamentoso. Pero, si los substratos fueran limitantes, entonces estas crecerán rápidamente de manera longitudinal fuera del flóculo. La presencia casi ubicua de microorganismos filamentosos en los lodos activados han llevado a pensar que éstos eran realmente la columna vertebral de los flóculos en los lodos activados (Jenkins et al., 1993a). Más aún, este tipo de estructura filamentosa podría promover la atracción de otras células a través de sus sustancias poliméricas extracelulares (SPE).

\subsection{IDENTIFICACION Y CARACTERIZACION DE BACTERIAS FILAMENTOSAS}

Generalmente se cree que las bases para entender y caracterizar la aparición de lodos filamentosos dependen de una apropiada identificación de las bacterias filamentosas involucradas. Esto es brevemente descrito a continuación.

\subsubsection{Comparación entre la caracterización microscópica y los métodos moleculares}

Algunos tipos de bacterias aún no están identificadas y no han sido reconocidas taxonómicamente. Por ello, estas bacterias no han sido documentadas en manuales estándares para la identificación microbiológica como el Manual de Bergey. Eikelboom $(1975,1977)$ desarrolló el primer código para identificar bacterias filamentosas en sistemas de lodos activados. Esta identificación esta 
principalmente basada en características morfológicas y en la respuesta de bacterias filamentosas en algunos ensayos de tinción microscópica. Los procedimientos, técnicas y códigos de identificación fueron compilados en un manual de investigación microscópica del lodo (Eikelboom, 2000), que junto con un manual parecido de Jenkins et al. (1993a, 2003), han sido utilizados como referencias mundiales para la identificación de bacterias filamentosas.

Aunque es muy utilizada, este tipo de identificación tiene sus limitaciones. Por ejemplo, muchas bacterias filamentosas (como los morfotipos Sphaerotilus natans, 1701, 0092 y 0961) pueden cambiar su morfología dependiendo de las condiciones ambientales, y aunque algunas de ellas pueden verse morfológicamente iguales, pueden probablemente variar de forma considerable en su fisiología y taxonomía. Por ejemplo, el morfotipo filamentoso Nostocoida limícola tiene varias bacterias filogenéticamente diferentes (Seviour et al., 2002), pertenecientes a los siguientes grupos: bacterias Gram positivas con bajo porcentaje molar de $\mathrm{G}+\mathrm{C}$, bacterias Gram positivas con alto porcentaje molar de $\mathrm{G}+\mathrm{C}$, Planctomicetos, bacterias verdes no azufradas y Protobacteria subclase alfa (Martins et al., 2004b). Esto también aplica para el morfotipo filamentoso Eikelboom Tipo 1863.

La identificación microscópica de bacterias filamentosas basada en la morfología requiere personal con experiencia y bien entrenado; de lo contrario se pueden hacer juicios erróneos. Además, alrededor de 40 nuevos morfotipos de bacterias filamentosas fueron recientemente identificadas en un estudio en sistemas de lodos activados en la industria, haciendo la identificación aun más compleja (Eikelboom y Geurkink, 2002). Debido a que la identificación microscópica es difícil y engañosa, las técnicas de identificación se han dirigido hoy en día hacia métodos moleculares. Los métodos moleculares basados en el análisis del ADN y ARN bacteriano se han desarrollado rápidamente. Para el estudio de lodos activados hay distintos métodos comúnmente usados. A fin de caracterizar la complejidad de una comunidad microbiana se puede utilizar el ARNr $16 \mathrm{~S}$ de las bacterias. Los detalles sobre este método no se consideran en este capítulo, pero se tratan de manera breve en el Capítulo 2.

\subsubsection{Fisiología de las bacterias filamentosas}

Como se ha mencionado, la mayoría de los organismos filamentosos no han sido bien caracterizados, principalmente debido a problemas para cultivarlos en laboratorio. Los recientes desarrollos que combinan la microautorradiografía con la hibridación in situ con fluorescencia (FISH) son promisorios para elucidar la fisiología exacta de las bacterias filamentosas. Sin embargo, no existe una relación obvia y evidente entre la morfología y fisiología de las bacterias filamentosas (Capítulo 2).

Un problema general radica en que los reportes fisiológicos antiguos, en los cuales se describen diversos morfotipos de bacterias filamentosas, sean comunes y coincidan en la descripción de bacterias filogenéticamente no relacionadas y con grandes diferencias fisiológicas. En consecuencia estos datos (por ejemplo del morfotipo 'Nostocoida limicola') podrían ser incorrectos. Por lo tanto, estos datos deben ser interpretados con cautela $\mathrm{y}$, en futuros estudios fisiológicos de bacterias, es necesario demostrar la taxonomía de los organismos estudiados.

Los pocos estudios fisiológicos llevados a cabo con cultivos puros de bacterias filamentosas quimiolitoautotróficas han mostrado que la mayoría de ellas parecen tener un metabolismo respiratorio estrictamente aerobio, con el oxígeno como aceptor final de electrones. A nuestro entender, sólo los morfotipos Tipo 0961, Tipo 1863, Tipo 1851 y Nostocoida limícola parecen ser capaces de desarrollar un metabolismo fermentativo y por lo tanto pueden tener ventajas competitivas en sistemas con etapas anaerobias. De cualquier manera, se cree que estos morfotipos son generalmente una minoría en los sistemas de lodos activados dentro del total de poblaciones microbianas y en general podrían no ser los responsables de la aparición de lodos filamentosos.

Algunas bacterias filamentosas (como Microthrix parvicella, Sphaerotilus natans, Thiotihrix spp., Tipo $021 \mathrm{~N}$ y Tipo 1851) son capaces de usar nitrato como aceptor de electrones, reduciéndolo sólo hasta nitrito. Sin embargo, la velocidad de consumo de sustrato y desnitrificación de las bacterias filamentosas hasta ahora analizadas (Tipo $021 \mathrm{~N}$ y Thiothrix spp.) es mucho más baja (más de 80 veces) que las bacterias que forman flóculos (Shao y Jenkins 1989). El Tipo 0092, una bacteria filamentosa dominante en muchos sistemas de lodos activados para la eliminación de nutrientes, parece ser incapaz de utilizar nitrato como aceptor de electrones. Además, parece ser que Microthrix parvicella no puede proliferar bajo condiciones anóxicas. Así, se han llegado a implementar zonas de contacto anóxico para controlar 
la generación de lodos filamentosos debido a la presencia del Tipo 021N y Sphaerotilus natans (Ekama et al., 1996a). De las bacterias más predominantes encontradas en sistemas de lodos activados para la eliminación de nutrientes, sólo los morfotipos Tipo 0092 y Microthrix parvicella han podido ser cultivadas en cultivos puros y se han encontrado serias dificultades para el aislamiento de esta última. Parece ser que Microthrix parvicella es el organismo dominante más problemático en los procesos de eliminación de nutrientes (Nielsen et al. 2002), sugiriendo que su comportamiento es demasiado parecido a las bacterias acumuladoras de fosfato o glucógeno. La principal diferencia es que éstas se especializan en el consumo de cadenas largas de ácidos grasos en lugar de ácidos grasos volátiles. Este organismo necesita reducir compuestos de azufre para la síntesis de proteínas y parece ser microaerofílico (Slijkhuis y Deinema 1988; Rossetti et al., 2005).

Cuando existen condiciones anóxicas o anaerobioanóxicas en la eliminación biológica de nutrientes, $M$. parvicella puede proliferar. Se ha observado que los selectores anóxicos no pueden controlar la aparición de lodos filamentosos ocasionados por $M$. parvicella bajo condiciones anóxicas-aerobias. Cuando en un sistema con selector el principal reactor es completamente aerobio, los lodos filamentosos ocasionados por $M$. parvicella pueden ser controlados, mientras que en un sistema con reactores anóxicos-aerobios no (Ekama et al., 1996a). Estas experiencias de laboratorio fueron confirmadas por Kruit et al. (2002) quienes estudiaron diversas plantas reales concluyendo que el principal criterio para prevenir la proliferación de $M$. parvicella es: tener etapas aireadas (O.D. > $1.5 \mathrm{mg} / \mathrm{L}$ ) y anóxicas (donde el oxígeno no es detectable) bien definidas.

Una hipótesis alterna para la proliferación de $M$. parvicella y bacterias filamentosas análogas fue propuesta por Casey et al. $(1992,1999)$. M. parvicella solo puede reducir nitrato a nitrito, mientras los heterótrofos normales realizan la desnitrificación completa, desde nitrato hasta nitrógeno molecular. A bajas concentraciones de oxígeno disuelto (que ocurren en la transición de la condición anóxica a la aerobia o en etapas de desnitrificación simultánea) las últimas enzimas de la ruta desnitrificante podrían ser inhibidas, lo que permite la formación de $\mathrm{N}_{2} \mathrm{O}$ o NO. Este último compuesto es potencialmente tóxico para las células microbianas. Dado que $M$. parvicella no puede producir NO y que no es sensible a las condiciones bajas de O.D., entonces puede por lo tanto proliferar en estos sistemas.

\subsection{TEORIAS ACTUALES PARA EXPLICAR LA APARICIÓN DE LODOS FILAMENTOSOS}

Se han formulado diversas hipótesis acerca del esponjamiento del lodo con la esperanza de encontrar una explicación general a este problema. Desafortunadamente, ninguna de ellas ha permitido encontrar una solución definitiva. Además, muchas de estas teorías aún carecen de verificación experimental. Sin embargo, estas forman la actual estructura teórica básica para acercarse y entender la aparición o generación de lodos filamentoso, por lo cual serán discutidas a continuación.

\subsubsection{Selección basada en la difusión}

Muchos investigadores han señalado que la morfología de las bacterias filamentosas ayuda en el consumo del sustrato cuando hay concentraciones bajas de nutrientes u oxígeno. Hasta principios de la década de los años 70 la competencia entre bacterias filamentosas y no filamentosas era basada en el hecho de que la relación superficie-volumen (S/V) es mayor en las bacterias filamentosas (Pipes, 1967). Especialmente a bajas concentraciones de sustrato, esta alta relación de $\mathrm{S} / \mathrm{V}$ representa una ventaja para los organismos, ya que la transferencia de masa hacia las células con una alta relación $\mathrm{S} / \mathrm{V}$ es supuestamente más fácil. A concentraciones más bajas de sustrato esto podría permitir una velocidad de crecimiento relativamente más alta.

En teorías más recientes se ha mencionado que los organismos filamentosos podrían penetrar fácilmente los flóculos hacia el exterior. Cuando los flóculos crecen a bajas concentraciones de sustrato se observa que las bacterias filamentosas tienen un alto consumo de sustrato en comparación con los formadores de flóculos al interior del mismo (Sezgin et al., 1978; Kappeler y Gujer, 1994a). Los microgradientes de concentraciones de sustrato presentes en los flóculos se han determinado teóricamente (Beccari et al., 1992) y experimentalmente en lodos floculentos. Martins et al. (2004c) ampliaron esta teoría comparando el crecimiento del flóculo con el de una biopelícula. van Loosdrecht et al. (1995) y Picioreanu et al. (1998) han postulado que a concentraciones de sustrato bajas se generan biopelículas abiertas y filamentosas; mientras que a altas concentraciones de sustrato se originan biopelículas compactas y ligeras. Ben-Jacob et al. (1994) mostraron que la morfología de las colonias de un cultivo puro también depende del microgradiente del sustrato, en donde a bajas concentraciones de sustrato la morfología 
es dominada por bacterias filamentosas. Por lo tanto, podría ser que a bajas concentraciones de sustrato un flóculo tienda a ser más abierto y filamentoso (Martins et al., 2003b) al ser dominado por bacterias filamentosas.

\subsubsection{Teoría de selección cinética}

Al igual que Donaldson (1932), Chudoba et al. (1973a) relacionaron las características de sedimentación con las características de mezclado del tanque de aireación del sistema de lodos activados. Utilizando una mezcla de cultivos con un sustrato definido bajo condiciones controladas en el laboratorio, Chudoba et al. (1973a) mostraron que los sistemas de aireación con bajos niveles de mezclado axial y altos microgradientes de concentraciones de sustrato a lo largo del sistema, suprimen el crecimiento de bacterias filamentosas y permiten el desarrollo de un lodo con buena capacidad de sedimentación. Estos autores concluyeron que la principal causa de la selección de microorganismos que forman flóculos en los cultivos puros es el macrogradiente de la concentración de sustrato en la parte inicial del sistema.

Basado en estos resultados, Chudoba et al. (1973b) formularon la teoría de formación cinética para explicar la aparición o supresión de bacterias filamentosas en sistemas de lodos activados. La explicación se fundamenta en el criterio de selección para el sustrato limitante soluble por parte de las bacterias filamentosas y las que forman los flóculos. Chudoba et al. (1973b) establecieron la hipótesis de que los microorganismos filamentosos (estrategas " $K$ ") son organismos de crecimiento lento con una velocidad máxima de crecimiento $\left(\mu_{\text {máx }}\right)$ y una constante de afinidad $\left(K_{s}\right)$ más bajas que las bacterias que forman los flóculos (estrategas "r") (Figura 11.4). En sistemas donde la concentración de sustrato es baja (típicamente $\mathrm{C}_{\mathrm{S}}<\mathrm{K}_{\mathrm{S}}$ ), teniendo sistemas completamente mezclados con alimentación continua, las bacterias filamentosas tienen una velocidad específica de crecimiento más alta que las bacterias floculentas, y de esta forma ganan la competencia por el sustrato. En sistemas en donde la concentración de sustrato es alta, como en reactores de flujo pistón $\mathrm{y}$ en reactores discontinuos secuenciales (SBR), las bacterias filamentosas son eliminadas ya que se espera que su velocidad de crecimiento sea más baja que las bacterias floculentas. Diversos estudios con cultivos puros de bacterias filamentosas (por ejemplo Sphaerotilus natans, Haliscomenobacter hydrossis, Tipo 1701, Tipo 021N, Microthrix parvicella) y floculentas (Arthrobacter globiformis, Zoogloea ramigera) apoyan esta teoría (van den Eynde et al., 1983). Es, sin embargo, cuestionable si estas bacterias floculentas son representativas de los sistemas de lodos activados. El uso de estudios y análisis moleculares ha mostrado que bacterias no dominantes han sido regularmente enriquecidas en el laboratorio a partir de la inoculación con lodos activados de plantas reales. Una técnica cuantitativa basada en MAR y FISH se desarrolló y aplicó recientemente para medir in situ la cinética de bacterias filamentosas (Candidatus Meganema perideroedes y Thiothrix sp.) (Nielsen et al., 2003). Este enfoque es prometedor y se deben incrementar los esfuerzos para extender y llevar a cabo estudios similares con otras bacterias filamentosas y no filamentosas.

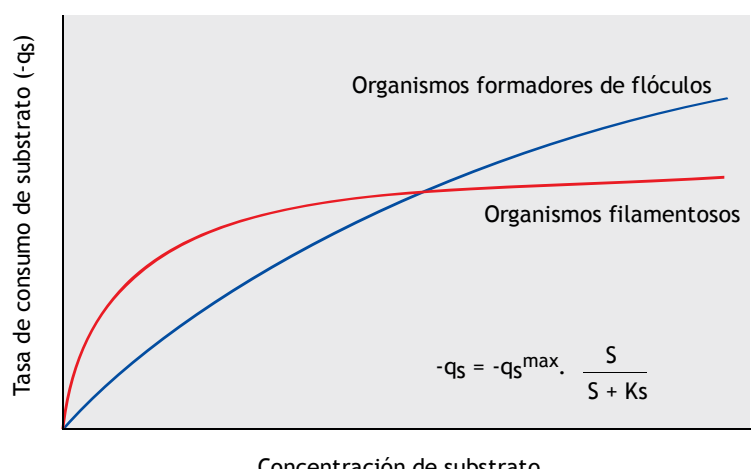

Figura 11.4 Relación entre la tasa de consumo de sustrato $\left(q_{\mathrm{s}}\right)$ y concentración de sustrato ( $\mathrm{S}$ ) para las bacterias filamentosas y formadoras de flóculos, de acuerdo con la teoría de selección cinética (Chudoba et al., 1973b)

Hasta ahora no se ha demostrado de manera inequívoca que las bacterias filamentosas tengan en general una velocidad de crecimiento más baja que otras bacterias presentes en el lodo. Además, no hay una explicación teórica del porqué la morfología de los organismos filamentosos se ve reflejada o incide en una velocidad de crecimiento más baja. El valor de $\mathrm{K}_{\mathrm{s}}$, generalmente bajo para las bacterias filamentosas tal y como se propone en la teoría de selección cinética, no ha sido aún demostrado para casos generales. Si Ks es visto como una propiedad de las enzimas que participan en el consumo del sustrato, no parece haber relación entre $\mathrm{K}_{\mathrm{S}}$ y la morfología de los organismos filamentosos. Sin embargo, si $\mathrm{K}_{\mathrm{S}}$ es visto como un parámetro de transferencia de masa aparente que describe la transferencia de masa hacia la célula, como en la hipótesis S/V de Pipes (1967) basada en la difusión, entonces si coincidiría con los principios de la teoría de selección cinética. En los flóculos el valor de Ks basado en las mediciones de líquido es de cualquier forma un coeficiente que aparente se puede ver afectado por la 
morfología del flóculo. Entre más sea la resistencia a la difusión (flóculos más densos y grandes), mayor será el valor de $\mathrm{K}_{\mathrm{S}}$ aparente medido (Beccari et al., 1992; Chu et al., 2003). Para los organismos filamentosos que se extienden desde el flóculo esto significaría que el Ks tendría un valor bajo comparado con las bacterias localizadas dentro del flóculo. Con base en lo anterior, podría ser que la teoría basada en la difusión (Pipes, 1967; Sezgin et al., 1978; Kappeler y Gujer, 1994a; Martins et al., 2004c) y la teoría de selección cinética (Chudoba et al., 1973b) sean dos caras de una misma moneda, y por lo tanto ambas posean la capacidad de describir el mismo fenómeno.

Un experimento que indica que ambas teorías sean potencialmente correctas fue llevado a cabo por Martins et al. (2008). Cuando el crecimiento bacteriano se realiza con almidón, la concentración del sustrato soluble es siempre baja. El producto de la hidrólisis (maltosa) es consumido directamente por las células para su crecimiento. En este caso hay un consumo de sustrato a bajas concentraciones, pero sin la formación de un gradiente de sustrato debido a que el almidón es hidrolizado dentro del flóculo y no en el líquido.

Bajo esta condición Martins et al. (2008) obtuvieron un lodo con buena capacidad de sedimentación (de acuerdo a la teoría basada en la difusión), y con flóculos que fueron principalmente formados por células de Nostocoida (de acuerdo a la teoría de selección cinética). Esta observación podría indicar que la competencia entre bacterias filamentosas y no filamentosas ha sido correctamente descrita por la teoría de selección cinética, pero la morfología del flóculo depende de la formación de un gradiente de difusión (Figura 11.5) de manera similar a como ocurre con los sistemas de biopelículas (van Loosdrecht et al., 1995).

\subsubsection{Teoría de la selección de almacenamiento}

Tradicionalmente se ha supuesto que los microorganismos filamentosos tienen la habilidad de almacenar sustrato cuando su concentración es alta. Esta habilidad les brinda presumiblemente una ventaja adicional sobre las bacterias no filamentosas en sistemas de lodos activados altamente dinámicos como los reactores de flujo pistón, los SBR y tanques selectores (Van den Eynde et al. 1983). Sin embargo, estudios recientes indican que los lodos filamentosos podrían tener una capacidad de almacenamiento similar o más alta que un lodo con buena capacidad de sedimentación (Beccari et al., 1998; Martins et al., 2003b).
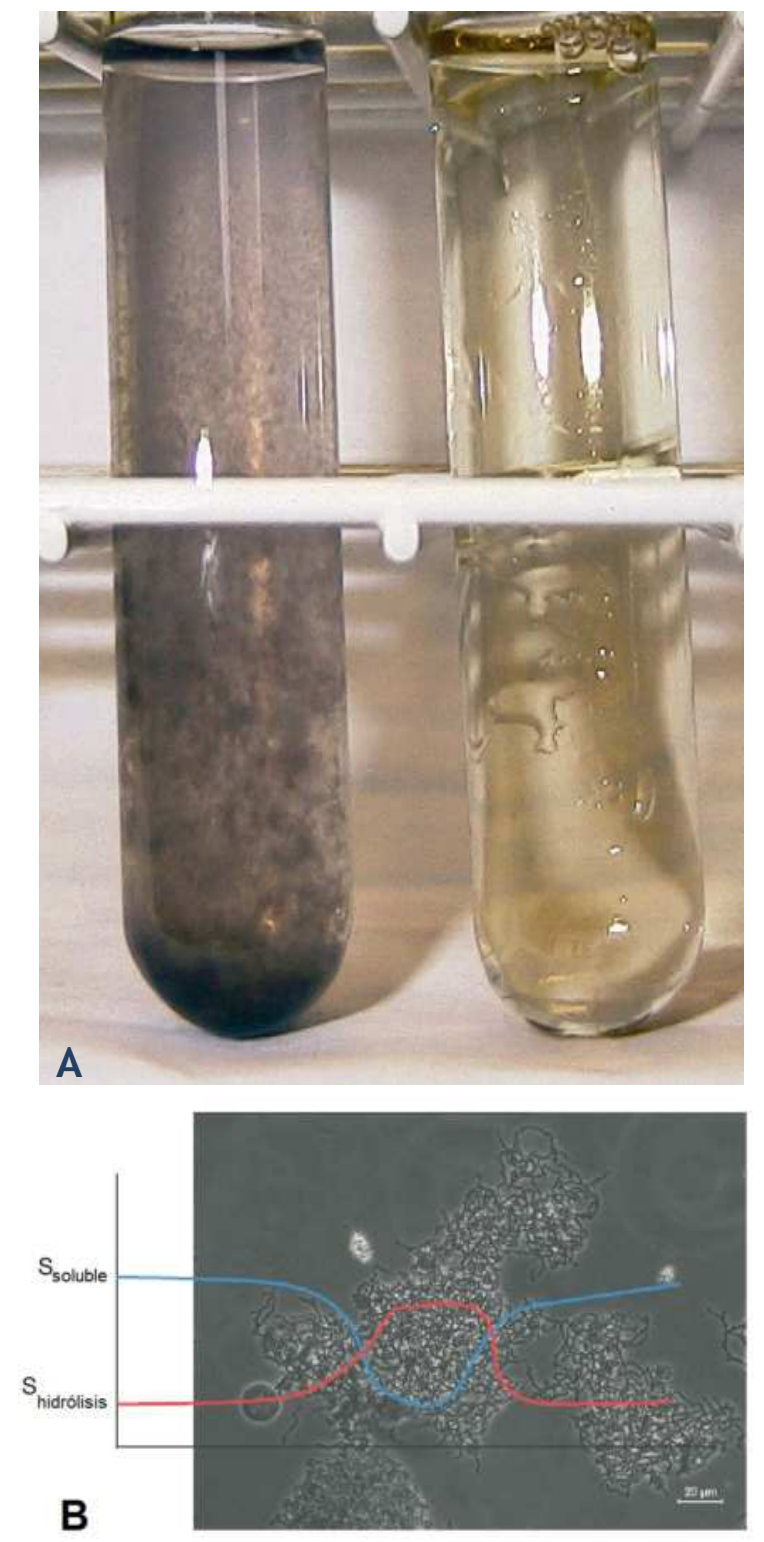

Figura 11.5 (A) Izquierda: lodo en presencia de almidón teñido de azul con yodo. Derecha: sobrenadante no teñido debido a la ausencia de almidón, (B) gráfica microscópica de un lodo floculento dominado por células de Nostocoida en un cultivo de lodos activados. La línea azul representa la concentración del sustrato soluble y la roja la concentración de sustrato de los productos de la hidrólisis (fotos: A.M. Martins)

En estudios con cultivos puros y mixtos también se muestra que algunas bacterias filamentosas, como Microthrix parvicella, pueden tener una alta capacidad de almacenamiento bajo diversas condiciones ambientales (aerobias, anóxicas y anaerobias) (Nielsen et al., 2002). El material almacenado puede ser metabolizado para la generación de energía o la producción de proteínas 
durante periodos de escasez de substrato, lo cual podría representar una gran ventaja selectiva para estos microorganismos al competir con otras bacterias filamentosas y no filamentosas. Así, la baja capacidad de sedimentación de las bacterias filamentosas no puede considerarse claramente como una regla absoluta para la selección de bacterias filamentosas. A pesar de que podría no ser un parámetro primario de selección, el almacenamiento y la regeneración (agotamiento) son procesos intrínsecos que juegan un papel clave en sistemas con selectores (van Loosdrecht et al., 1997). De este modo, éstos procesos deben considerarse en la descripción de los procesos metabólicos que tienen lugar en sistemas con lodos filamentosos y no filamentosos.

\subsection{ACCIONES CORRECTIVAS}

Existen básicamente dos estrategias que pueden ser utilizadas para controlar la proliferación de lodos filamentosos, por ejemplo los métodos específicos y los no específicos. Los métodos no específicos contemplan técnicas como la cloración, ozonación y aplicación de peróxido de hidrógeno. El principio de aplicación de estos métodos es muy simple: dado que las bacterias filamentosas se ubican en la parte externa del flóculo son más susceptibles a los agentes oxidantes que las bacterias formadoras del flóculo. Se debe tomar en cuenta que esta explicación está de acuerdo con la hipótesis basada en la difusión para la competencia de bacterias filamentosas. La cloración es ampliamente utilizada en Estados Unidos y los procedimientos para su implementación son bien conocidos (Jenkins et al., 1993b). Sin embargo, su aplicación en Europa es limitada debido a problemas ambientales relacionados con la potencial formación de sub-productos no deseados como los compuestos orgánicos halogenados. Otro aspecto negativo es que las bacterias de lento crecimiento, como las nitrificantes, requieren de mucho tiempo para recuperarse al verse afectadas por agentes oxidantes, lo que podría potencialmente afectar la calidad del efluente. Además, los métodos no específicos no eliminan las causas del crecimiento excesivo de los microorganismos filamentosos y su efecto es sólo momentáneo. Lo mismo aplica para métodos de control a corto plazo, como la redistribución de la biomasa de los clarificadores hacia el tanque de aireación y/o con el incremento en la velocidad de purga de lodo. Los métodos específicos son catalogados como preventivos y tienen el objetivo de favorecer el crecimiento de estructuras bacterianas floculentas a partir de estructuras bacterianas filamentosas. El reto es encontrar las condiciones ambientales adecuadas en una planta de tratamiento de lodos activados para poder alcanzar este objetivo. Debido a que el éxito de su aplicación podría suprimir el crecimiento de bacterias filamentosas permanentemente en sistemas de lodos activados, estos métodos podrían ser desarrollados y preferentemente adoptados.

Hasta ahora las acciones para prevenir la generación de lodos filamentosos no están basadas en el conocimiento de la fisiología y/o la cinética de un tipo específico de bacteria filamentosa. Esto, a pesar del gran énfasis en estudiar la identificación de las bacterias filamentosas presentes. Las acciones generales preventivas parecen coincidir en que los sustratos rápidamente biodegradables requieren ser consumidos a altas concentraciones. Esto significa que a la entrada del proceso de lodo activados es necesario generar las condiciones hidráulicas requeridas de tipo flujo pistón para que la DQO rápidamente biodegradable sea consumida, y sólo entonces puede utilizarse un tanque completamente mezclado. Si el oxígeno es consumido a bajas concentraciones, esto conduce como con la DQO rápidamente biodegradable, a la aparición de lodos filamentosos.

El efecto combinado de la concentración de oxígeno y la concentración de sustrato rápidamente biodegradable sobre las propiedades del lodo se presenta en la Figura 11.6. La concentración efectiva de sustrato debe estar en relación a la constante de afinidad del sustrato; de este modo, se utiliza la relación entre la velocidad instantánea del sustrato y la velocidad máxima. El contenido de oxígeno disuelto parece ser sólo relevante para el periodo donde el sustrato rápidamente biodegradable está disponible. El prerequisito de flujo pistón en la parte inicial del proceso de lodos activados ha resultado en el desarrollo de selectores para prevenir los lodos filamentosos. Las dos teorías antes descritas para explicar la proliferación de los lodos filamentosos $(\mathrm{S} / \mathrm{V}$ o de selección basada en la difusión, así como la teoría de selección cinética) apoyan este enfoque.

\subsubsection{Selectores}

Un selector puede definirse como la parte inicial de un reactor biológico, caracterizado por un número de dispersión bajo y por un macrogradiente adecuado de concentración de sustrato (Chudoba et al., 1973b; Rensink, 1974). También puede ser una pequeña zona inicial separada del reactor biológico que recibe el afluente y el flujo de la recirculación del lodo; y que tiene una alta velocidad de consumo de DQO rápidamente biodegradable, resultando en su eliminación 
prácticamente completa (Jenkins et al., 1993a). En los selectores, los microorganismos están sujetos a periodos con (abundancia) y sin (ayuno) sustratos externos. En esencia, un SBR con alimentación en pulsos o un SBR alimentado de forma estática representan un sistema de selector ideal.

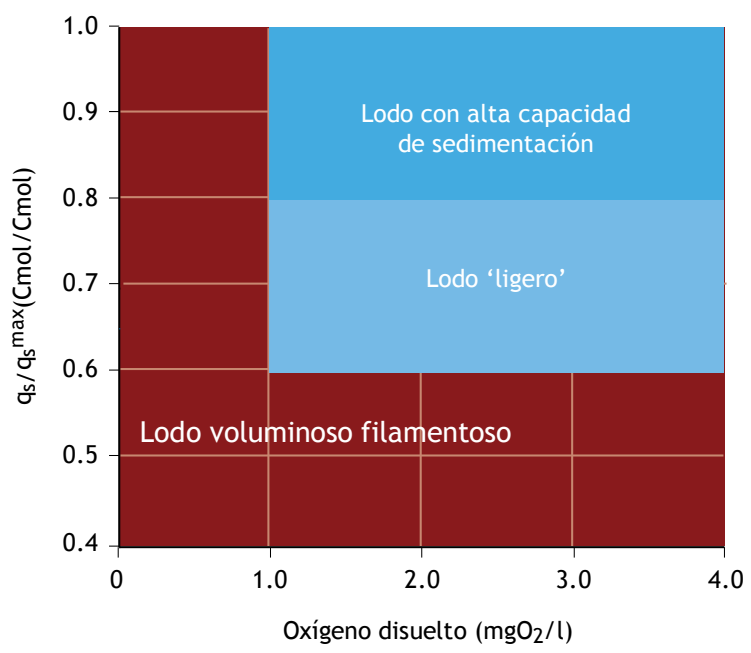

Figura 11.6 Efecto de la concentración de oxígeno y sustrato rápidamente biodegradable (expresado en términos de la velocidad de consumo específica observada de sustrato con relación a su velocidad máxima de consumo) sobre el tipo de lodo formado en el proceso de lodos activados (Martins et al. 2003b)

Se ha demostrado que en los sistemas antes descritos se puede producir un lodo aerobio granular, que es lo opuesto a un lodo filamentoso (Beun et al., 1999). En sistemas con selectores los microorganismos están sujetos a ambientes de altas velocidades de crecimiento y son capaces de acumular sustratos como productos de almacenamiento interno en sus células. Se requiere de un periodo suficientemente largo, después de un periodo sin sustrato externo disponible (baja velocidad de crecimiento o ambientes de escasez) para restablecer la capacidad de almacenamiento de las células (van Loosdrecht et al., 1997; Beun et al., 1999). Los selectores han sido adoptados rápidamente en sistemas reales de lodos activados y siguen siendo la tecnología más aplicada a nivel mundial para prevenir el fenómeno de los lodos filamentosos. Sin embargo, regularmente existen reportes sobre fallas de los selectores (Ekama et al., 1996b). No está claro si estas fallas son por causa de un mal diseño del tanque selector, o debido a ciertas condiciones transitorias en el sistema de tratamiento biológico, o bien a otros factores que de alguna manera afectan la dinámica poblacional, lo que podría otorgar ventajas competitivas a las bacterias filamentosas. Para el control de los lodos filamentosos ocasionados por $M$. parvicella, en procesos para la eliminación biológica de nutrientes, los selectores pueden presentar fallas (Eikelboom, 1994; Ekama et al., 1996b; Kruit et al., 2002) o podrían no ser suficientes (ver también previamente la sección sobre fisiología). A continuación se describirán brevemente los diferentes tipos de selectores y sus fallas potenciales. Un panorama general acerca del diseño de selectores puede encontrarse en la Tabla 11.2.

\subsubsection{Selectores aerobios}

A finales de la década de los años 80 sólo se requería llevar a cabo la eliminación de carbono orgánico en las plantas de tratamiento de aguas residuales en la mayoría de los países; y usualmente los sistemas completamente aireados con un patrón de alimentación completamente mezclado eran los preferidos. En los Estados Unidos, los sistemas eran principalmente de alta carga con un tiempo de retención de sólidos (TRS) menor a 5 días. Bajo estas condiciones la aparición de lodos filamentosos se atribuía principalmente al excesivo crecimiento de bacterias filamentosas Tipo 021N y Tipo 1701. En Europa y Sudáfrica se construyeron plantas de baja carga como los sistemas de diques de oxidación y los sistemas con aireación extendida. En la década de los años 90 se crearon en Estados Unidos y Europa regulaciones más rigurosas con respecto a la descarga de nutrientes, particularmente con relación a la descarga de amonio. A fin de cumplir con estos requerimientos, las plantas de tratamiento de aguas residuales tuvieron que ser remodeladas y ampliadas y se hicieron modificaciones para mejorar la capacidad nitrificante. Se mejoraron los sistemas de aireación, y para mantener a las bacterias nitrificantes en el sistema, el TRS se extendió generalmente por encima de los 10 días. Así, los sistemas de aireación intermitente llegaron a ser más comunes ya que permiten alcanzar cierto grado de desnitrificación. Bajo estas condiciones los lodos filamentosos eran principalmente debidos a la proliferación de los morfotipos Microthrix parvicella y Tipos 021N, 0041/0675 0092 y 0581. Estas observaciones llevaron a la definición del grupo de bacterias filamentosas de baja relación S/M (Jenkins et al., 1993). Para controlar la generación de lodos filamentosos se implementaron selectores aerobios con una pequeña zona de mezclado (aerobios o anóxicos) o zona de contacto (sin aireación) para suprimir el excesivo crecimiento del Tipo $012 \mathrm{~N}$, Thiothrix spp., Sphaerotilus natans, pero no siempre funcionó para controlar el crecimiento de Mcrothrix parvicella. 
Tabla 11.2 Guía para el diseño de selectores aerobios, anóxicos y anaerobios en sistemas de tratamiento de aguas residuales municipales

\begin{tabular}{|c|c|c|}
\hline Parámetro & Valor & Referencia \\
\hline \multicolumn{3}{|l|}{ Selectores aerobios } \\
\hline Número de compartimientos & $\geq 3$ & Jenkins et al. (1993a) \\
\hline Tiempo de contacto & $\begin{array}{l}10 \text { - } 15 \text { min., dependiendo de la carga, } \\
\text { temperatura y composición del agua residual (por } \\
\text { ejemplo: fracción de la DQO rápidamente } \\
\text { biodegradable). }\end{array}$ & Still et al. (1996) \\
\hline Tasa de carga de lodos & $\begin{array}{l}\left.12\left(1^{\mathrm{er}} \text { comp. }\right), 6\left(2^{\text {do }} \text { comp. }\right) \text { y } 3 \text { ( } 3^{\mathrm{er}} \text { comp. }\right) \mathrm{kg} \\
\text { DQO/kg SSLM.d }\end{array}$ & Jenkins et al. (1993a) \\
\hline Carga en los flóculos & 50 a 150 g DQO $/ \mathrm{kg} \mathrm{SST} \mathrm{(} 1^{\mathrm{er}}$ comp. $)$ & Kruit et al. (1994) \\
\hline Concentración de O.D. & $\begin{array}{l}\geq 2 \mathrm{mg} \mathrm{O}_{2} / 1 \text {, pero depende de la tasa de carga de } \\
\text { lodos, tasa de carga de flóculos y/o tasa de } \\
\text { consumo de sustrato. Se debe instalar un sensor en } \\
\text { el } 1^{\text {er }} \text { compartimiento }\end{array}$ & $\begin{array}{l}\text { Sezgin et al. (1978), Albertson (1987), } \\
\text { Martins et al. (2003b) }\end{array}$ \\
\hline \multicolumn{3}{|l|}{ Selectores anóxicos } \\
\hline Número de compartimentos & $\geq 3$ & Jenkins et al. (1993a) \\
\hline Tasa de carga de lodos & $\begin{array}{l}6\left(1^{\mathrm{er}} \text { comp. }\right), 3\left(2^{\text {do }} \text { comp. }\right) \text { y } 1.5\left(3^{\mathrm{er}} \text { comp. }\right) \mathrm{kg} \\
\text { DQO } / \mathrm{kg} \text { SSLM.d }\end{array}$ & Jenkins et al. (1993a) \\
\hline Tiempo de contacto & $45-60 \mathrm{~min}$ & Kruit et al. (2002) \\
\hline$\left(\mathrm{DQOFB} / \mathrm{NO}_{3}-\mathrm{N}\right)_{\text {consumido }}$ & $\begin{array}{l}\text { Usualmente alrededor de } 7-9 \mathrm{mg} \text { de } \mathrm{DQO} \\
\text { rápidamente biodegradable por } \mathrm{mg} \mathrm{NO}_{3}-\mathrm{N} \text {, } \\
\text { debido al almacenamiento de sustrato. }\end{array}$ & $\begin{array}{l}\text { Jenkins et al. (1993a), Ekama et al. } \\
\text { (1996a), Van Loosdrecht et al. (1997) }\end{array}$ \\
\hline \multicolumn{3}{|l|}{ Selectores anaerobios } \\
\hline Número de compartimientos & $\geq 3$, canales largos (relación largo-ancho $>10: 1$ ) & Albertson (1987), Kruit et al. (2002) \\
\hline Tiempo de contacto & $1-2 \mathrm{~h}$ & Kruit et al. (2002) \\
\hline$\left(\mathrm{DQO}_{\mathrm{AGV}+\text { fermentable }} / \mathrm{PO}_{4}-\mathrm{P}\right)_{\mathrm{i}}$ & $9-20 \mathrm{~g} \mathrm{DQO} / \mathrm{g} \mathrm{P}$ & $\begin{array}{l}\text { Wentzel et al. (1990), Smolders et al. } \\
\text { (1996) }\end{array}$ \\
\hline
\end{tabular}

El tiempo de contacto, un parámetro de diseño típico para los selectores, tiene un efecto no lineal e importante en la sedimentación del lodo (Martins et al., 2003a). Cuando el tiempo de contacto no es lo suficientemente largo, el sustrato soluble presente en la zona de contacto no es consumido por completo, y puede alcanzar el tanque de aireación principal. Por otro lado, cuando el tiempo de contacto es ligeramente más largo, la concentración del sustrato es baja, acercándose al nivel típico de los tanques completamente mezclados, favoreciendo el crecimiento de microorganismos filamentosos. El efecto de un tanque de contacto demasiado grande o pequeño sobre el índice de volumen de lodo (IVL) dificulta alcanzar un buen diseño (Figura 11.7).

En sistemas con patrones de alimentación altamente dinámicos, como la variación de la temperatura, las variaciones de flujo y carga en los sistemas de tratamiento de aguas residuales, no es fácil realizar un buen diseño y puede ser una razón plausible del por qué existen diversos reportes que documentan las fallas de los



Figura 11.7 Selector Aerobio (foto: M.C.M. van Loosdrecht)

tanques selectores aerobios. Por lo tanto, se espera que en la práctica sólo los sistemas con un comportamiento cercano al de un flujo pistón, como en canales largos (con una relación longitud-ancho superior a 10:1), tanques compartimentalizados o en SBR alimentados mediante pulsos, puedan garantizar un macrogradiente de sustratos alto $\mathrm{y}$ funcionar apropiadamente bajo condiciones 
altamente dinámicas. Además, una apropiada puesta a punto puede mejorar el desempeño de los sistemas de lodos activados que estén cinéticamente limitados (Scuras et al., 2001).

Se ha reconocido y verificado a través de diversos estudios la necesidad de mantener una concentración mínima de O.D. en función de la dinámica de la carga orgánica soluble o de la velocidad de consumo del sustrato en el tanque de aireación y en el selector aerobio; esto ha llevado a la formulación y propuesta de diagramas de trabajo específicos (Figura 11.5). Aunque el tiempo de contacto recomendado en un tanque selector aerobio es muy pequeño, la cantidad de oxígeno requerido es alrededor del 30\% de la DQO soluble eliminada (Jenkins et al., 1993a; Ekama et al., 1996a; Martins et al., 2003b). Esto resalta la importancia de suministrar suficiente oxígeno en el selector aerobio. Si un tanque selector aerobio compartimentalizado (flujo pistón) tiene una velocidad de aireación demasiada baja, los impactos sobre la sedimentación del lodo podrían ser peores que con un tanque selector completamente mezclado que haya sido sobredimensionado (Martins et al., 2003b). Además, el control de la aireación es muy importante y deben colocarse sensores en el primer compartimiento debido a que el consumo de oxígeno es muy alto (Tabla 11.2).

\subsubsection{Selectores no aireados}

Como en los selectores aerobios, toda la DQO rápidamente biodegradable debe ser eliminada en los reactores (selectores) anóxicos y anaerobios, a fin de prevenir su entrada a la etapa aerobia, que de ocurrir podría proporcionar una ventaja para las bacterias filamentosas (Kruit et al., 2002). Además, ni oxígeno ni nitrato deben estar presentes en el reactor anaerobio, y el primero de estos tampoco en el reactor anóxico. Los flujos de recirculación internos podrían introducir de manera no intencional cierto oxígeno a estos reactores. Además de la interrupción de la remoción biológica aumentada de fósforo (EBPR) y/o la actividad desnitrificante, el empeoramiento de las características de sedimentación del lodo pueden verse afectadas por la presencia de condiciones microaerofílicas en las etapas anaerobias y/o anóxicas, atribuidas a la difusión de oxígeno a través de la superficie del líquido (Plósz et al., 2003), o a la aireación de la corriente del lodo/líquido de recirculación por medio de las bombas o en vertedores.

\subsubsection{Selectores anóxicos}

El criterio para diseñar selectores anóxicos (Tabla 11.2) se basa principalmente en la relación de DQO rápidamente biodegradable en función del nitrato que ingresa al reactor (Ekama et al., 1996b). Dado que en los selectores una fracción importante de la DQO rápidamente biodegradable es convertida en productos de almacenamiento, se espera que la relación sea mayor que el rango típico requerido para llevar a cabo una desnitrificación directa (de alrededor de 7-9 mg de DQO rápidamente biodegradable por cada $\mathrm{mg} \mathrm{NO}_{3}-\mathrm{N}$ ). Se ha encontrado que el tipo de mezclado tiene una influencia baja o casi nula en comparación con los selectores aireados. Por lo tanto, los diseños de selectores anóxicos son en principio más estables con respecto a las variaciones de flujo y diseños específicos, siempre y cuando se mantenga un superávit de nitrato (Martins et al., 2004b). En sistemas a escala real es difícil balancear la carga de nitrato con la de la DQO rápidamente biodegradable, debido a las variaciones diarias y a que ocurre algún grado de desnitrificación en el clarificador secundario.

Se pueden esperar ciertos periodos con baja concentración de nitrato o condiciones anaerobias temporales en los selectores anóxicos. Estas condiciones no representan necesariamente un daño para las características de sedimentación del lodo debido a que en los selectores anóxicos una fracción importante de la DQO rápidamente biodegradable puede ser almacenada por organismos heterotróficos ordinarios (Beun et al., 2000), o utilizada por organismos acumuladores de fósforo (PAO, por sus siglas en inglés, poly-phosphate accumulating organisms), o bien por los organismos acumuladores de glucógeno (GAO, por sus siglas en inglés glycogen-accumulating organisms). Sin embargo, si la DQO rápidamente biodegradable no es removida por completo, podría llegar al tanque de aireación originando la producción de lodo filamentoso si el selector anóxico reduce su capacidad de almacenamiento (por ejemplo en sistemas completamente mezclados). En general, se requiere de un mayor número de investigaciones para elucidar los factores clave que afectan e influyen en la competencia entre estos microorganismos. Mientras tanto, para diseñar un selector anóxico confiable es aconsejable realizar primeramente estudios a nivel de planta piloto para después escalar los sistemas. Los esfuerzos por tener concentraciones de nitrato más bajas no impedirán la recirculación del lodo con bajo contenido de nitrato, limitando así el uso de selectores anóxicos. 


\subsubsection{Selectores anaerobios}

Bajo condiciones estrictamente anaerobias (por ejemplo en procesos tipo UCT) los sustratos solubles, principalmente los ácidos grasos volátiles y otros sustratos simples, son utilizados y en su mayoría almacenados. El diseño de selectores anaerobios se basa en la relación velocidad de consumo de DQO rápidamente biodegradable sobre la velocidad de liberación de fosforo, asegurándose que la DQO rápidamente biodegradable prácticamente no entre al principal tanque de aireación (Tabla 11.2). Estas condiciones fueron creadas en el sistema de lodos activados para promover el crecimiento de los PAO. Sin embargo, otro grupo de bacterias, conocidas como GAO, pueden crecer bastante bien en condiciones similares (Filipe et al., 2001). Ambos tipos de bacterias son capaces de utilizar sustratos solubles simples en las etapas anaerobias y almacenarlos en forma de polihidroxi-alcanoatos (PHA). La reserva de energía que permite el consumo y los mecanismos de almacenamiento es sin embargo diferente en ambos tipos de bacterias. El polifosfato es utilizado por los PAO y el glucógeno por los GAO. Esta diversidad metabólica permite tener una gran flexibilidad en los selectores anaerobios durante la eliminación de la carga orgánica, independientemente de que ocurra la eliminación de fósforo. Además, a pesar de la gran diversidad de los PAO y GAO, no han encontrado bacterias filamentosas abundantes que puedan proliferar bajo estas condiciones operativas.

Como resultado de la disponibilidad y consumo de DQO rápidamente biodegradable en los tanques anaerobios, los PAO y GAO se acumulan en el lodo y limitan el crecimiento de los microorganismos aerobios, ya que la DQO rápidamente biodegradable no llega a alcanzar la fase aerobia. Así, entre más sustrato es consumido en el tanque anaerobio, existe menos sustrato disponible en el tanque aerobio, y las características de sedimentación de los lodos activados se incrementan. Así mismo, los lodos ricos en PAO normalmente sedimentan mejor debido a que se agrupan densamente y almacenan polifosfato intracelular, en combinación con la precipitación química de fósforo, incrementando aún más la densidad del lodo. Las condiciones de mezclado en los selectores anaerobios, como en los selectores anóxicos, no parecen ser críticas. Por otro lado, el traslado de DQO hacia el tanque aireado es mucho menos perjudicial que bajo condiciones aerobias, lo que significa que el diseño de selectores anaerobios no es muy crítico (Martins et al., 2004a). En estudios recientes se ha confirmado el éxito de los selectores anaerobios para controlar los lodos filamentosos, aun cuando Microthrix parvicella es la bacteria filamentosa más dominante (Kruit et al., 2002). Sin embargo, no siempre se puede utilizar un selector anaerobio. Por ejemplo, su aplicación no se recomienda para flujos con residuos ricos en compuestos de azufre. Las condiciones anaerobias pueden favorecer la producción de compuestos reducidos de azufre, los cuales pueden ser usados en la etapa aerobia por bacterias filamentosas sulfo-oxidantes (Eikelboom, 2000).

En estudios recientes realizados en los Países Bajos se demostró que mediante la implementación de selectores de flujo pistón anaerobios y aerobios bien controlados se puede obtener un lodo con buena capacidad de sedimentación (IVL $<120 \mathrm{ml} / \mathrm{g}$ con valores comunes por debajo de $100 \mathrm{ml} / \mathrm{g}$ ) en sistemas biológicos a escala real para la eliminación de nutrientes (Kruit et al., 2002). Un factor potencialmente importante que permitió alcanzar una mejor sedimentación del lodo fue la introducción de un reactor aerobio, después de la etapa anóxica/aerobia, a fin de crear de forma simultánea una concentración baja de amonio (>1.5 mgO $2 / 1)$ (Kruit et al., 2002; Tsai et al., 2003). Un sistema de tratamiento basado en estas consideraciones es el concepto BCFS $^{\circledR}$ (Van Loosdrecht et al., 1998), el cual es exitosamente utilizado en doce plantas de Holanda.

\subsection{MODELOS MATEMATICOS}

Para el estudio de sistemas complejos, como los cultivos de lodos activados, en donde diversos factores actúan de forma conjunta, el modelado matemático puede ser una herramienta muy útil. Se han alcanzado grandes avances en este campo a pesar de la extrema complejidad de la dinámica poblacional de los lodos activados. Los Modelos de Lodos Activados (ASM, por sus siglas en inglés, Activated Sludge Model 1, 2, 2d y 3) publicados por el grupo de trabajo de la IWA sobre el Modelado Matemático para el diseño y operación del tratamiento biológico de aguas residuales, son un ejemplo de modelos útiles para estudiar la dinámica poblacional en el sistema de lodos activados. Dado que el conocimiento de la fisiología bacteriana crece con el tiempo, los modelos también son continuamente actualizados (Figura 11.8).

Un ejemplo es la incorporación de procesos de almacenamiento en ASM 3. Este es el primer intento para permitir el modelado del metabolismo del almacenamiento de polímeros y describir de una mejor forma las conversiones que ocurren en selectores. También, en modelos metabólicos recientemente 
desarrollados se provee una mejor conexión entre la cinética y la capacidad de almacenamiento (Beun et al., 2000), y esto contribuirá ciertamente a la descripción y modelado de los procesos metabólicos que ocurren en los selectores. A pesar del gran detalle de estos modelos, el crecimiento de las bacterias filamentosas y por lo tanto la generación de lodos filamentosos aún no pueden ser predichos.

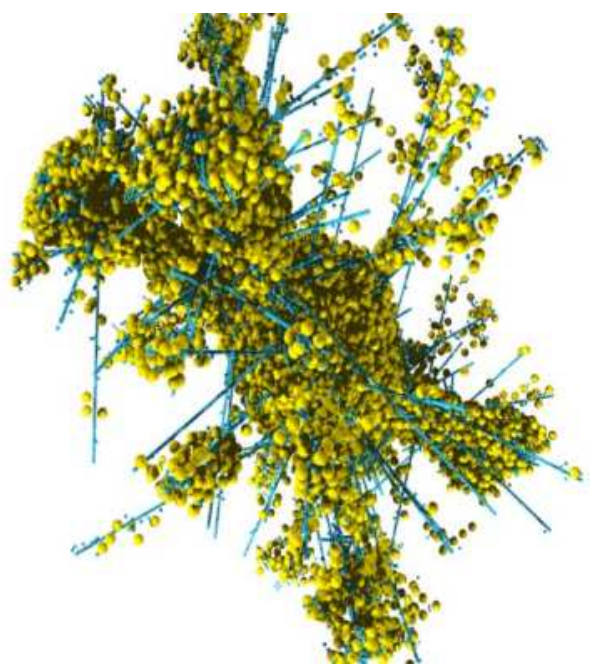

Figura 11.8 Estructura modelada de un flóculo con bacterias filamentosas y formadoras de flóculos (imagen: Martins et al., 2004c)

Los modelos que pueden predecir las características de sedimentación de los lodos activados están en fases tempranas de desarrollo. Algunos modelos existentes para predecir el desarrollo de bacterias filamentosas y no filamentosas consideran ya sea especies duales o grupos de organismos que compiten entre sí afectando la morfología de los flóculos (por ejemplo, organismos formadores de flóculos, filamentosas, filamentosas de bajo O.D., filamentosas de bajo $\mathrm{S} / \mathrm{X}$ ) para sustratos simples o para grupos de sustratos (DQO rápidamente biodegradable o DQO de lenta biodegradación) (Kappeler y Gujer, 1994a; Takács y Fleit, 1995). Estos modelos pueden ser básicamente agrupados en dos: uno considerando la cinética y fisiología bacteriana modelos biocinéticos; y el otro considerando tanto la fisiología, la cinética, como la morfología bacteriana. El transporte de difusión de sustratos al interior de los flóculos de los lodos activados es un mecanismo importante en la competencia entre bacterias formadoras de flóculos y bacterias filamentosas. Kappeler y Gujer (1994a) propusieron que la DQO rápidamente biodegradable puede favorecer el crecimiento de microorganismos filamentosos debido a la resistencia contra la difusión del sustrato en los flóculos biológicos.
Estos autores sugieren la integración de este comportamiento en modelos tradicionales ASM (Capitulo 14). Para modelar las diferencias en la resistencia a la difusión del sustrato, los coeficientes medios de saturación de la DQO rápidamente biodegradable de los microorganismos filamentosos fueron menores que aquellos de las bacterias no filamentosas o formadoras de flóculos. Este enfoque proporciona resultados cualitativos realistas. Sin embargo, aún no es posible predecir el IVL o las propiedades de sedimentación del lodo.

En estudios posteriores se tuvo en cuenta tanto la micromorfología del flóculo como las características de crecimiento orientadas de las bacterias filamentosas (crecimiento preferencial unidireccional) (Takács y Fleit, 1995). Este estudio fue el primero en combinar las características morfológicas con la fisiología de las bacterias filamentosas y no filamentosas. Tres grupos de microorganismos (formadores de flóculos, filamentosos de bajo O.D. y baja $\mathrm{S} / \mathrm{X}$ ) fueron considerados con los parámetros cinéticos siguiendo la tendencia indicada por la teoría de selección cinética, y se estimuló con diferentes escenarios de sustrato soluble y O.D. La estimulación de la estructura del flóculo activado bajo condiciones de difusión reguladas mostró, como era de esperarse, que las bacterias filamentosas predominaban en ambientes con sustratos solubles y limitaciones de O.D. Los autores no diferenciaron entre el efecto de los parámetros cinéticos y el efecto de la morfología celular como tal.

Recientemente, Martins et al. (2004c) adoptaron un modelo previo para predecir la morfología de una biopelícula (Picioreanu 1998) en los flóculos de los lodos activados. Se mostró que el gradiente de difusión es más importante para la morfología del flóculo que las diferencias en las constantes de afinidad entre los diferentes microorganismos, lo que apoya la teoría basada en el gradiente de difusión para la selección de bacterias filamentosas.

En resumen, el modelado puede ser utilizado para llevar a cabo una mejor evaluación del papel del crecimiento unidireccional de las bacterias filamentosas, junto con la alta capacidad de estas bacterias para crecer de acuerdo con el micro-gradiente de sustrato en los flóculos, bajo una gran variedad de parámetros cinéticos. En este sentido, se requieren más esfuerzos en investigación para entender el papel de la morfología bacteriana y la difusión, ya que los parámetros cinéticos como el coeficiente medio de saturación del sustrato 
intrínseco, la capacidad de almacenamiento y las velocidades de decaimiento, son todavía desconocidos. Esta clase de estudios puede permitir alcanzar un mejor entendimiento de la competencia entre bacterias filamentosas y no filamentosas en microambientes con gradientes regulados tal como los encontrados en sistemas de lodos activados.

\subsection{LODO GRANULAR}

Entendiendo que los lodos filamentosos, más que el lodo floculento, se produce cuando la DQO rápidamente biodegradable es eliminada bajo condiciones donde ocurren fuertes gradientes de sustrato, es posible entender que la formación de gránulos se presenta cuando estas condiciones son minimizadas (Beun et al., 1999). Efectivamente, de acuerdo con las morfologías del lodo, el lodo granular es el fenómeno opuesto a la aparición de los lodos filamentosos (Figura 11.9).

Para las biopelículas ya se había planteado la hipótesis de que su morfología depende de la relación entre la velocidad del transporte del sustrato y el crecimiento de la biomasa (van Loosdrecht et al., 1995; van Loosdrecht et al., 2002). Esto no sólo significa que el IVL va a mejorar al minimizar los gradientes de sustrato, sino que también la selección de organismos formadores de flóculos va a mejorar el IVL. Por lo tanto, siempre ha sido relativamente fácil generar un lodo granular anaerobio o un lodo granular nitrificante (Figura 11.10).

La aplicación de selectores anaerobios permite seleccionar ciertas bacterias (acumuladoras de fosfato o de glucógeno) con una velocidad máxima de crecimiento
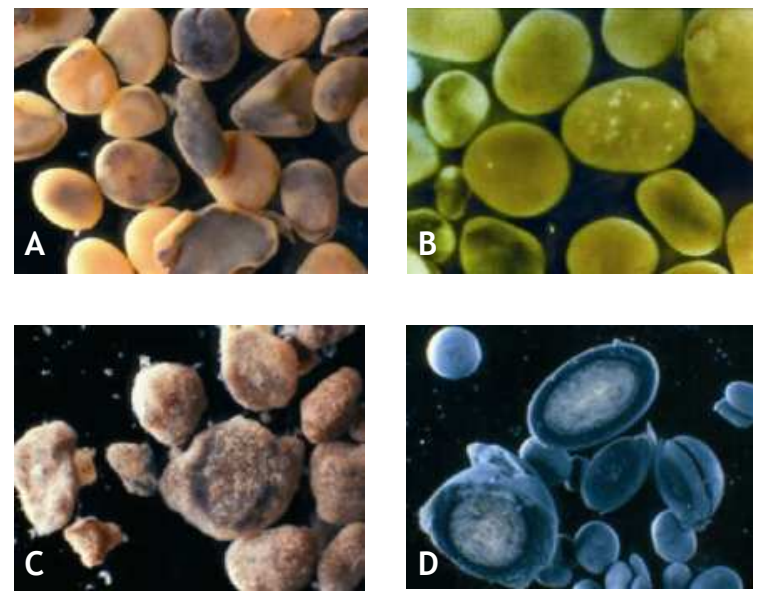

más baja que las bacterias heterotróficas ordinarias. Por lo tanto, los selectores anaerobios tienen una ventaja extra sobre los selectores aerobios. La selección de este tipo de condiciones también brinda la ventaja de favorecer la formación más estable de lodo aerobio granular (De Kreuk et al., 2004).

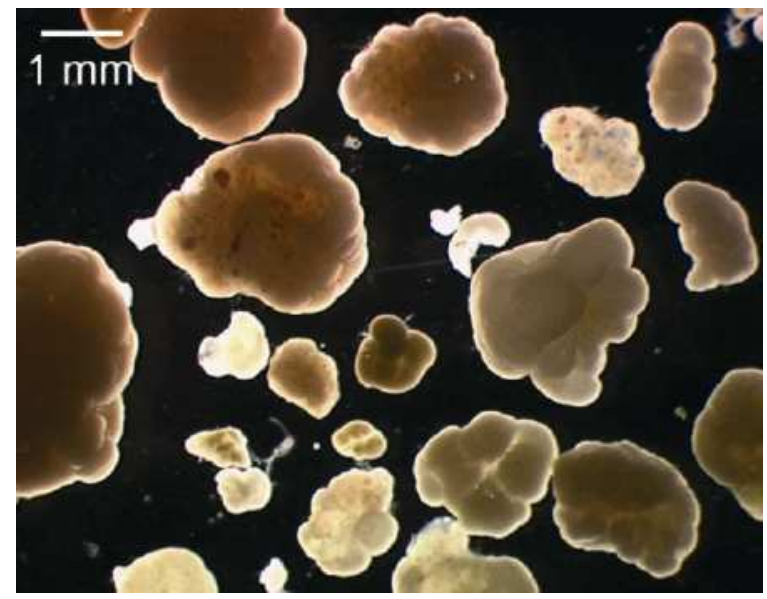

Figura 11.9 Lodo granular aerobio (foto: M.R. de Kreuk)

\subsection{CONCLUSIONES}

La proliferación de lodos filamentosos es uno de los principales problemas de los lodos activados. En la práctica, existe un nivel suficiente de conocimiento para entender al menos cómo controlar el problema. Por ejemplo, un sistema de lodos activados con remoción biológica de nutrientes diseñado para minimizar los problemas de la proliferación de lodos activados debe tomar en cuenta las siguientes características generales:

Figura 11.10 Variedades de lodo granular: (A) nitrificante, (B) heterotrófico, (C) desnitrificante, (D) metanogénico (fotos: Biothane B.V) y (E) Anammox (foto: Paques B.V.) 
(i) contar con un proceso de pretratamiento para la eliminación de sustratos complejos (por ejemplo lípidos), (ii) contar con reactores selectores de flujo pistón para crear un fuerte macrogradiente de concentración de sustrato a lo largo del sistema, (iii) crear etapas de flujo pistón anaerobias, anóxicas y aerobias bien definidas, y favorecer la exclusión de oxígeno de la etapa anóxica y de nitrato y oxígeno de la etapa anaerobia, (iv) evitar la aireación intermitente y las condiciones microaerofílicas, y por último, $(v)$ tener una buena aeración para mantener una alta concentración de O.D. ( $\left.>1.5 \mathrm{mgO}_{2} / \mathrm{L}\right)$ y una baja concentración de amonio $(<1 \mathrm{mg} \mathrm{N} / \mathrm{l})$ al final de la etapa aerobia.
Las ideas básicas han llevado incluso a procesos basados en el concepto opuesto a la proliferación de lodos filamentosos: el lodo granular. Aún sistemas bien diseñados existen problemas operacionales que pueden rápidamente originar lodos filamentosos.

Por lo tanto, siempre que los procesos básicos que gobiernan la morfología del lodo no se tengan completamente en cuenta, la declaración hecha por Albertson (1987): “a pesar de todo lo que aprendamos y entendamos acerca del lodo, este seguirá sufriendo de bacterias filamentosas", seguirá siendo válida.
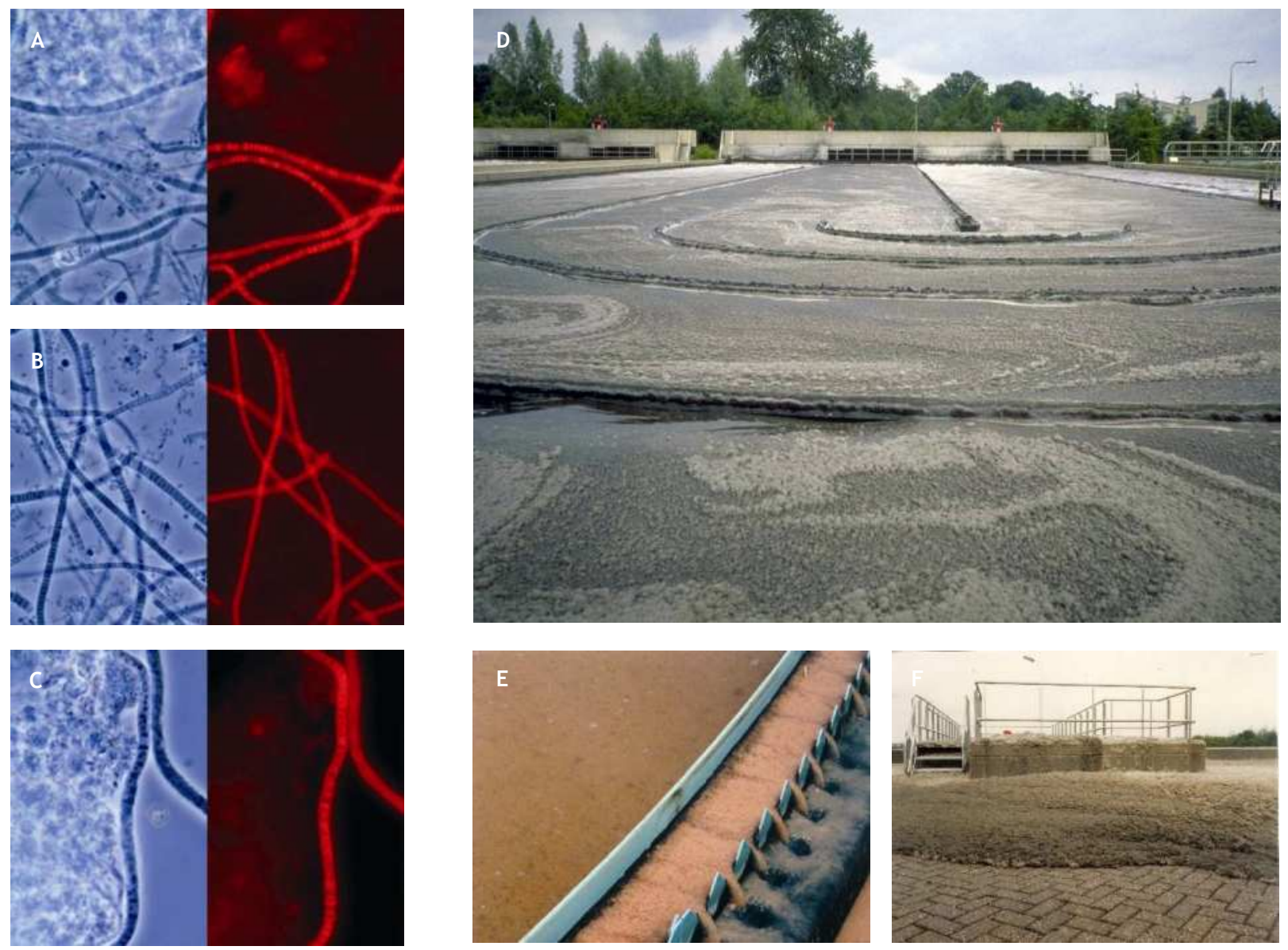

Imágenes FISH de especies filamentosas encontradas en plantas industriales de tratamiento de aguas residuales: (A) Alysiomicrobium bavaricum, (B) Meganema perideroedes y (C)Thiothrix sp. Manifestación extrema de lodos filamentosos (D) en el tanque de lodos activados, $(\mathrm{E})$ en el tanque de sedimentación secundaria, y $(\mathrm{F})$ vertido de lodos filamentosos de los reactores (fotos: Eikelboom, 2000, 2006; photo E: I. Takacs) 


\section{REFERENCES}

Albertson O.E. (1987) The control of bulking sludges: from the early innovators to current practice. J. Water Pollut. Control Fed. 59(4), 172-182.

Alleman J.E., Prakasam T.B.S. (1983) Reflections on seven decades of activated sludge history. J. Water Pollut. Control Fed. 55(5), 436-443.

Ardern E., Lockett W.T. (1914) Experiment on the oxidation of sewage without the aids of filters. J. Soc. Chem. Ind. 33, 523-539.

Beccari M., Di Pinto A.C., Ramadori R., Tomei M.C. (1992) Effect of dissolved oxygen and diffusion resistances on nitrification kinetics. Wat. Res. 26(8), 1099-1104.

Beccari M., Majone M., Massanisso P., Ramadori R. (1998) A bulking sludge with high storage response selected under intermittent feeding. Wat. Res. 32(11), 34033413.

Ben-Jacob E., Schochet O., Tenenbaum A., Cohen I., Czirók A., Vicsek T. (1994) Generic modelling of cooperative growth patterns in bacterial colonies. Nature 368(3), 4649.

Beun J.J., Hendriks A., Van Loosdrecht M.C.M., Morgenroth E., Wilderer P.A., Heijnen J.J. (1999) Aerobic granulation in a sequencing batch reactor. Wat. Res. 33(10), 2283-2290.

Beun J.J., Paletta F., Van Loosdrecht M.C.M., Heijnen J.J. (2000) Stoichiometry and kinetics of poly-B hydroxybutyrate metabolism under denitrifying conditions in activated sludge cultures. Biotech. Bioeng. 67, 379-389.

Casey T.G., Wentzel M.C., Loewenthal R.E., Ekama G.A., Marais, G.v.R. (1992) A hypothesis for the cause of low $\mathrm{F} / \mathrm{M}$ filament bulking in nutrient removal activated sludge systems. Wat. Res. 26(6), 867-869.

Casey T.G., Wentzel M.C., Ekama G.A. (1999) Filamentous organism bulking in nutrient removal activated sludge systems. Paper 11: A biochemical/microbiological model for proliferation of anoxic-aerobic (AA) filamentous organisms. Water SA 25(4), 443-451.

Chu K.H., Van Veldhuizen, H.M., Van Loosdrecht, M.C.M. (2003) Respirometric measurement of kinetic parameters: Effect of activated sludge floc size Wat. Sci. Tech. 48(8), 61-68.

Chudoba J., Ottová V., Madera V. (1973a) Control of activated sludge filamentous bulking - I. Effect of the hydraulic regime or degree of mixing in an aeration tank. Wat. Res. 7(9), 1163-1182.

Chudoba J., Grau P., Ottová V. (1973b) Control of activated sludge filamentous bulking - II. Selection of microorganisms by means of a selector. Wat. Res. 7(10), 1398-1406.

De Kreuk M.K., van Loosdrecht M.C.M. (2004) Selection of slow growing organisms as a means for improving aerobic granular sludge stability Wat. Sci. and Tech, 49(11-12), 9-17.

Donaldson W. (1932) Use of activated sludge increasing. Civ. Eng. 2(3), 167-169.
Eikelboom D.H. (1975) Filamentous organisms observed in activated sludge. Wat. Res. 9, 365-388.

Eikelboom D.H. (1977) Identification of filamentous organisms in bulking activated sludge. Prog. Wat. Tech. 8, 153-162.

Eikelboom D.H. (1994) The Microthrix parvicella puzzle, Wat. Sci. Tech. 29, 271-279.

Eikelboom D.H. (2000) Process control of activated sludge plants by microscopic investigation. IWA Publishing, London, UK.

Eikelboom D.H., Geurkink B. (2002) Filamentous microorganisms observed in industrial activated sludge plants. Wat. Sci. Tech. 46(1/2), 535-542.

Eikelboom D.H. (2006) Identification and control of filamentous micro-organisms in industrial waste water treatment plants, IWA Publishing, London, UK

Ekama G.A., Marais G.v.R. (1986) Sludge settleability and secondary settling tank design procedures. Water Pollut. Control 85(1), 101-113.

Ekama G.A., Wentzel M.C., Casey T.G., Marais G.v.R. (1996a) Filamentous organism bulking in nutrient removal activated sludge. Paper 3: Stimulation of the selector effect under anoxic conditions. Water SA 22(2), 119-126.

Ekama G.A. Wentzel M.C., Casey T.G., Marais G.v.R. (1996b) Filamentous organism bulking in nutrient removal activated sludge systems. Paper 6: review, evaluation and consolidation of results. Water $S A$ 22(2), 147-152.

Jenkins D., Richard M.G., Daigger G.T. (1993a) Manual on the causes and control of activated sludge bulking and foaming, 2nd ed. Michigan: Lewis Publishers, Inc.

Jenkins D., Richard M.G., Daigger G.T. (1993b) Manual on the Causes and Control of Activated Sludge Bulking, Foaming, and Other Solids Separations Problems, 3rd ed. Lewis Publishers, Inc.

Kappeler J., Gujer W. (1994a) Development of a mathematical model for "aerobic bulking". Wat. Res. 28(2), 303-310.

Kappeler J., Gujer W. (1994b) Verification and applications of a mathematical model for "aerobic bulking". Wat. Res. 28(2), 311-322.

Kruit J., Boley F., Jacobs L.J.A.M., Wouda T.W.M. (1994) Prediction of the $\mathrm{O} 2$ conditions in the selector. Wat. Sci. Tech. 29(7), 229-237.

Kruit J., Hulsbeek J., Visser A. (2002) Bulking sludge solved?! Wat. Sci. Tech. 46(1/2), 457-464.

Martins A.M.P., Van Loosdrecht M.C.M., Heijnen J.J. (2003a) Effect of feeding pattern and storage on the sludge settleability under aerobic conditions. Wat. Res. 37(11), 2555-2570.

Martins A.M.P., Van Loosdrecht M.C.M., Heijnen J.J. (2003b) Effect of dissolved oxygen concentration on the sludge settleability. Appl. Microbiol. Biotechnol. 62 (56), 586-593. 
Martins A.M.P., Heijnen J.J., Van Loosdrecht M.C.M. (2004a) Bulking Sludge in Biological Nutrient Removal Systems (2004) Biotech. Bioeng. 86(2), 125-135.

Martins A.M.P., Pagilla K., Heijnen J.J., van Loosdrecht M.C.M. (2004b) Filamentous bulking sludge - A critical review. Wat. Res. 38, 793-817.

Martins A.M.P., Picioreanu C., Heijnen, J.J., van Loosdrecht M.C.M. (2004c) Three-dimensional dualmorphotype species modeling of activated sludge floc. Environ. Sci. Tech. 38, 5632-5641.

Martins A.M.P., Karahan Ö, Van Loosdrecht M.C.M., Heijnen J.J. (2008) Effect of polymeric substrate on sludge settleability. Submitted to Wat. Res.

Musvoto E.V., Casey T.G., Ekama G.A., Wentzel M.C., Marais GvR. (1994) The effect of incomplete denitrification on anoxic-aerobic (low F/M) filament bulking in nutrient removal activated sludge systems Wat. Sci. Techn. 29 (7), 295-299.

Nielsen P.H., Roslev P., Dueholm T.E., Nielsen J.L. (2002) Microthrix parvicella, a specialized lipid consumer in anaerobic-aerobic activated sludge plants. Wat. Sci. Tech. 46(1-2), 73-80.

Nielsen J.L., Christensen D., kloppenborg M., Nielsen P.H. (2003) Quantification of cell-specific substrate uptake by probe-defined bacteria under in situ conditions by microautoradiography and fluorescence in situ hybridisation. Environ. Microb. 5(3), 202-211.

Palm J.C., Jenkins D., Parker D.S. (1980) Relationship between organic loading, dissolved oxygen concentration and sludge settleability in the completelymixed activated sludge process. J. Water Pollut. Control Fed. 52, 2484-2506.

Pasveer A. (1959) A contribution to the development in activated sludge treatment. J. Proc. Inst. Sewage Purif. 4, 436.

Pasveer A. (1969) A case of filamentous activated sludge. $J$. Water Pollut. Control Fed. 41(7), 1340-1352.

Picioreanu C., Van Loosdrecht M.C.M., Heijnen J.J. (1998) Mathematical modelling of biofilm structure with a hybrid differential-discrete cellular automaton approach. Biotech. Bioeng. 58, 101-116.

Pipes W.O. (1967) Bulking of activated sludge. Adv. Appl. Micr. 9, 185-234.

Plósz B., Jobbágy A., Grady C.P.L. (2003) Factors influencing deterioration of denitrification by oxygen entering an anoxic reactor through the surface. Wat. Res. 37, 853-863.

Rensink J.H. (1974) New approach to preventing bulking sludge. J. Water Pollut. Control Fed. 46(8), 1888-1894.

Rossetti S., Tomei M.C., Nielsen P.H., Tandoi V. (2005) "Microthrix parvicella", a filamentous bacterium causing bulking and foaming in activated sludge systems: A review of current knowledge FEMS Microb. Rev., 29(1), 49-64.

Scuras S.E, Jobbágy A., Grady Jr. C.P.L. (2001) Optimization of activated sludge reactor configuration: kinetic considerations. Wat. Res 35(18), 4277-4284.

Seviour R.J., Liu J.R., Seviour E.M., McKenzie C.A., Blackall L.L., Saint C.P. (2002) The "Nostocoida limcola" story: the phylogeny of this morphotype responsible for bulking in activated sludge. Wat. Sci. Tech. 46(1/2), 105-110.

Sezgin M., Jenkins D., Parker D.S. (1978) A unified theory of filamentous activated sludge bulking. J. Water Pollut. Control Fed. 50(2), 362-381.

Shao Y.-J., Jenkins D. (1989) The use of anoxic selectors for the control of low F/M activated sludge bulking. Wat. Sci. Tech. 21, 609-619.

Slijkhuis H. and Deinema M.H. (1988) Effect of environmental conditions on the occurrence of Microthrix parvicella in activated sludge, Wat. Res. 22, 825-828.

Smolders G.J.F., Van Loosdrecht M.C.M., Heijnen J.J. (1996) Steady-state analysis to evaluate the phosphate removal capacity and acetate requirement of biological phosphorus removing mainstream and sidestream process configurations. Wat. Res. 30(11), 2748-2760.

Still D.A, Ekama G.A., Wentzel M.C., Casey T.G. and Marais G.v.R. (1996) Filamentous organism bulking in nutrient removal activated sludge systems. Paper 2: Stimulation of the selector effect under aerobic conditions. Water SA 22(2), 97-118.

STOWA (1994) Selector design: the role of the influent characterization. Report 94-16 (in Dutch).

Takács I., Fleit E. (1995) Modelling of the micromorphology of the activated sludge floc: low DO, low F/M bulking. Wat. Sci. Tech. 31(2), 235-243.

Tsai M.-W., Wentzel M.C., Ekama G.A. (2003) The effect of residual ammonia concentration under aerobic conditions on the growth of Microthrix parvicella in biological nutrient removal plants. Wat. Res. 37(5), 3009-3015.

van den Eynde E., Geerts J., Maes B., Verachtert H. (1983) Influence of the feeding pattern on the glucose metabolism of Arthrobacter sp. and Sphaerotilus natans, growing in chemostat culture, simulating activated sludge bulking. Europ. J. Appl. Micr. Biotech. $17,35-43$

van Loosdrecht M.C.M., Eikelboom D., Gjaltema A., Mulder A., Tijhuis L., Heijnen J.J. (1995) Biofilm structures. Wat. Sci. Tech. 32(8), 35-43.

van Loosdrecht M.C.M., Pot M.A., Heijnen J.J. (1997) Importance of bacterial storage polymers in bioprocesses. Wat. Sci. Tech. l 35(1),41-47.

van Loosdrecht M.C.M., Brandse F.A., De Vries A.C. (1998) Upgrading of waste water treatment processes for integrated nutrient removal - the BCFS process. Wat. Sci. Tech.37(9), 209-217.

van Loosdrecht, M.C.M., Heijnen, J.J., Eberl, H., Kreft, J., Picioreanu, C. (2002) Mathematical modelling of biofilm structures. Antonie van Leeuwenhoek, Internat. J. Gen. Mol. Microb. 8, 245-256.

Wanner J., Grau P. (1989) Identification of filamentous organisms from activated sludge: a compromise between wishes, needs and possibilities. Wat. Res. 23(7), 883-891.

Wentzel M.C., Dold P.L., Ekama G.A., Marais G.v.R. (1990) Biological excess phosphorus removal - steady state process design. Water $S A$ 16(1), 29-48. 


\section{NOMENCLATURA}

\begin{tabular}{|c|c|c|}
\hline Símbolo & Descripción & Unidad \\
\hline$C_{S}$ & Concentración del sustrato en el líquido & $\mathrm{mg} \mathrm{DQO} / 1$ \\
\hline$K_{S}$ & Concentración de saturación media para la utilización de sustrato & $\mathrm{mg} \mathrm{DQO} / 1$ \\
\hline$q_{S}$ & Tasa de consumo de sustrato & $\mathrm{mg} \mathrm{DQO} / \mathrm{l} \cdot \mathrm{h}$ \\
\hline Abreviaturas & \multicolumn{2}{|l|}{ Descripción } \\
\hline ASM & \multicolumn{2}{|c|}{ Modelos de lodos activados (por sus siglas en inglés Activated Sludge Models) } \\
\hline $\mathrm{S} / \mathrm{V}$ & \multicolumn{2}{|l|}{ Relación superficie-volumen } \\
\hline DBO & \multicolumn{2}{|l|}{ Demanda bioquímica de oxígeno } \\
\hline DQO & \multicolumn{2}{|l|}{ Demanda química de oxígeno } \\
\hline SPE & \multicolumn{2}{|l|}{ Sustancias poliméricas extracelulares } \\
\hline FISH & \multicolumn{2}{|c|}{$\begin{array}{l}\text { Hibridación in situ con fluorescencia (por sus siglas en inglés, Fluourescence in situ } \\
\text { Hybridization) }\end{array}$} \\
\hline GAO & \multicolumn{2}{|c|}{$\begin{array}{l}\text { Organismo acumuladores de glucógeno (por sus siglas en inglés, Glycogen- } \\
\text { Accumulating Organisms) }\end{array}$} \\
\hline IWA & \multicolumn{2}{|l|}{ International Water Association } \\
\hline MAR & \multicolumn{2}{|l|}{ Microautorradiografía } \\
\hline SSLM & \multicolumn{2}{|l|}{ Sólidos suspendidos en el licor mezclado } \\
\hline $\mathrm{PAO}$ & \multicolumn{2}{|c|}{$\begin{array}{l}\text { Organismos acumuladores de fósforo (por sus siglas en inglés, Poly-phosphate- } \\
\text { Accumulating Organisms) }\end{array}$} \\
\hline PHA & \multicolumn{2}{|l|}{ Poli-hidroxi-alcanoatos } \\
\hline DQORB & \multicolumn{2}{|l|}{ DQO rápidamente biodegradable } \\
\hline TRS & \multicolumn{2}{|l|}{ Tiempo de retención de sólidos } \\
\hline IVL & \multicolumn{2}{|l|}{ Índice volumétrico del lodo } \\
\hline UCT & \multicolumn{2}{|l|}{ University of Cape Town } \\
\hline $\mathrm{AGV}$ & \multicolumn{2}{|l|}{ Ácidos grasos volátiles } \\
\hline
\end{tabular}




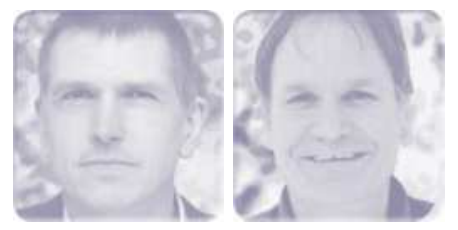

12

\section{Sedimentación Secundaria}

\section{Imre Takács y George A. Ekama}

\subsection{INTRODUCCIÓN}

La sedimentación secundaria o sedimentación final, en su nivel más fundamental, separa una fase sólida más pesada (la masa de lodo) de una fase líquida más ligera (agua tratada) por medio de la acción de la gravedad, por lo tanto, a menudo se denomina separación de fases sólido-líquido. El proceso se lleva a cabo por lo general en grandes tanques de concreto, llamados sedimentadores secundarios o clarificadores secundarios. Miles de libros, artículos de revistas e informes contienen una gran cantidad de información que se ha producido en el último medio siglo en relación con la teoría, el diseño y el funcionamiento de los tanques de sedimentación secundarios. El objetivo de este capítulo es ofrecer una visión general del proceso de sedimentación y su aplicación en la práctica, con especial énfasis en los aspectos prácticos, el diseño y el funcionamiento de estas unidades de separación de fases.

La sedimentación inducida por la acción de la gravedad también se aplica en otros procesos, como por ejemplo para la clarificación de las aguas residuales crudas en sedimentadores primarios, o para el espesamiento de los lodos de purga (para reducir el contenido de agua).
Además de la sedimentación por la acción de la gravedad, en los procesos de tratamiento de las aguas residuales se aplican otros métodos para la separación de los lodos activados, por ejemplo membranas o flotación. Estas aplicaciones y sus aspectos de ingeniería no se tratan en este capítulo (véase el capítulo 13 para sistemas de membranas).

\subsubsection{Objetivo de la sedimentación}

En los reactores de lodos activados, se produce una mezcla concentrada de biomasa o lodo y aguas residuales utilizada para el tratamiento biológico de aguas residuales. Una vez que se consigue el tratamiento biológico con una eficiencia suficiente, el lodo tiene que ser separado de las aguas residuales tratadas, las cuales se convierten en el efluente secundario. El lodo está formado por microorganismos (principalmente bacterias) y restos celulares en un rango de tamaño micrométrico, los cuales normalmente son difíciles de separar de la fase líquida. Sin embargo, los lodos floculan naturalmente y bajo condiciones adecuadas, forman fácilmente flóculos de uno a tres órdenes de magnitud mayores que las bacterias. Los flóculos, con una densidad ligeramente 
mayor que la del agua, pueden ser separados de las aguas residuales tratadas en los clarificadores. Dado que la diferencia de densidad entre la masa de lodo y el agua es pequeña, las velocidades de sedimentación son lentas y requieren tiempos de residencia hidráulica largos, típicamente del orden de horas. Esto, combinado con los grandes flujos de aguas residuales generados en las poblaciones, resulta en grandes estructuras visibles desde el espacio (Figura 12.1).

En una ciudad que cuente con un sistema centralizado de tratamiento de aguas residuales mediante lodos activados, por cada 1,000 personas se requiere un clarificador secundario con un área superficial aproximada de entre 5 a $15 \mathrm{~m}^{2}$, en función de los hábitos locales de consumo de agua.

\subsubsection{Funciones del tanque de sedimentación secundario}

Los sedimentadores secundarios desempeñan múltiples funciones en el tratamiento de las aguas residuales, siendo las tres principales: (i) la clarificación, produciendo un efluente con una cantidad mínima de sólidos, (ii) el espesamiento, concentrando el licor mezclado de los lodos activados (con una recirculación interna al tanque de lodos activados), y (iii) el almacenamiento de lodos, por lo general de forma temporal, en períodos con altas precipitaciones pluviales y por consiguiente altos caudales afluentes.

\subsubsection{Clarificación en los sedimentadores secundarios}

El efluente de un clarificador bien diseñado y operado generalmente contiene entre 5 y $15 \mathrm{mg} / \mathrm{L}$ de sólidos suspendidos. Teniendo en cuenta que el intervalo típico de la concentración de sólidos suspendidos en el licor mezclado (SSLM) se ubica entre 1500 y $3500 \mathrm{mg} / \mathrm{L}$, se espera que la eficiencia del clarificador se encuentre en un rango de entre $99 \%$ y $99.9 \%$. Hay dos factores clave para lograr los altos rendimientos de manera consistente: (i) un clarificador debe crear las condiciones que promuevan la floculación de lodos y la captura de pequeñas partículas dentro de los flóculos del lodo activado, y (ii) las condiciones de flujo en la zona de clarificación deben ser uniformes. Esto último en particular alrededor de los canales de salida del efluente y las paredes de los vertedores de salida, para reducir al mínimo el efecto provocado por las corrientes locales que pueden elevar el agua desde los mantos de lodo más profundos del clarificador (que contienen las

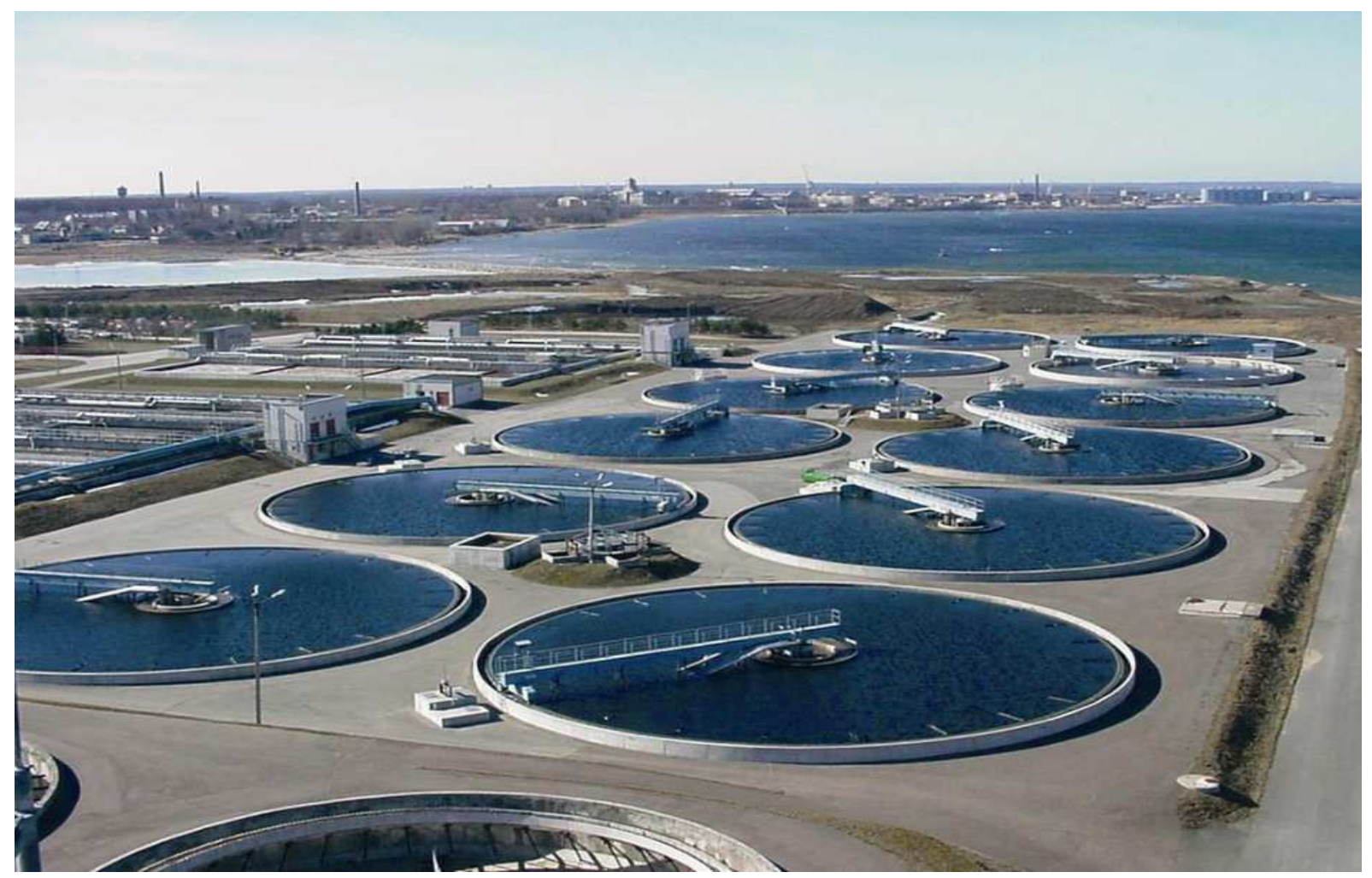

Figura 12.1 Los clarificadores secundarios son una de las estructuras más visibles de la Tierra desde el espacio (foto: D. Brdjanovic) 
concentraciones de sólidos más altas) hacia el efluente arrastrando los sólidos suspendidos. La sección 12.2 presenta un resumen de los aspectos de ingeniería requeridos para alcanzar una sedimentación secundaria satisfactoria. El contenido de sólidos suspendidos de una muestra de efluente contribuyen a las concentraciones de DBO (mayoritariamente), DQO y fósforo total (y en menor medida al nitrógeno total) del efluente. Debido a que los límites de concentración de sólidos imperantes en zonas sensibles son altamente estrictos, es importante mantener los sólidos de los efluentes a los niveles más bajos posibles. Incluso cuando el efluente secundario está sujeto a un tratamiento terciario (tales como tecnologías de filtración), un efluente clarificado bajo en sólidos en suspensión aumenta la vida útil y disminuye los costos de funcionamiento de las unidades terciarias.

\subsubsection{Espesamiento en los sedimentadores secundarios}

Los lodos sedimentados en el fondo del clarificador regresan al reactor de lodos activados de forma continua. A medida que existe una mayor concentración de sólidos en los lodos de la recirculación o lodos de retorno, menor será el flujo requerido de retorno. Un clarificador bien diseñado (siempre que el sistema biológico esté funcionando de manera óptima) generará sólidos altamente espesos (típicamente de $7-12 \mathrm{kgSST} / \mathrm{m}^{3}$ ) para el flujo de recirculación de sólidos. Si el rendimiento de espesamiento del clarificador no es óptimo, se requerirá que los flujos de la recirculación de lodos sean más altos en la operación diaria, lo que aumentará la energía empleada en el clarificador para la extracción de lodos e incrementará la entrada de SSLM debido al mayor flujo de recirculación. Si el flujo de retorno de lodos es demasiado alto, existe una mayor probabilidad de que el manto de lodos sea inestable (véase el párrafo siguiente).

\subsubsection{Depósito de lodo en sedimentadores secundarios}

En los sistemas de lodos activados típicos, la mayor parte de los lodos, en un momento dado, se encuentran en los biorreactores, pero hay un intercambio continuo de la masa de lodos entre los reactores y el clarificador. Un aumento repentino en el flujo del afluente o, la disminución en la capacidad de compactación de los lodos, tendrá como resultado el desplazamiento de algunos de los lodos del reactor hacia el clarificador, produciendo un lecho o manto de lodos muy elevado. Tomará tiempo y, potencialmente, la intervención del operador, para devolver al reactor la biomasa depositada en el lecho de lodo del clarificador. La funcionalidad que tienen los clarificadores para almacenar los lodos permite capturar los sólidos y retenerlos hasta que el mecanismo de recirculación del lodo puede hacer frente a la sobrecarga temporal de sólidos.

Hay conFiguraciones del clarificador y estrategias operativas que utilizan explícitamente la funcionalidad de la acumulación de lodo de un clarificador (véase, por ejemplo, el lecho filtrante en un clarificador de flujo vertical). Esto puede ser favorable para la calidad del efluente, pero se requiere un buen diseño y una operación cuidadosa para evitar el lavado o expulsión accidental del lecho o la presencia de altas concentraciones de sólidos en el efluente.

\subsection{CONFIGURACIONES DE LOS TANQUES DE SEDIMENTACIÓN}

Un sedimentador secundario bien diseñado debe proporcionar condiciones de reposo o movimiento muy lento en las aguas residuales tratadas para lograr la mayor compactación posible y una mejor clarificación. Al mismo tiempo, los factores económicos son altos ya que estas unidades son grandes, con costos de construcción significativos y el terreno que requieren es potencialmente grande y por consiguiente caro. El patrón de flujo dentro de un clarificador juega un papel importante en la mejora o pérdida de su rendimiento. El patrón de flujo es una consecuencia de la forma del clarificador, la posición y la conFiguración de las estructuras de entrada y salida del efluente, el mecanismo de remoción del lodo y deflectores (bafles) internos. En este capítulo se discutirán las características generales de los tres tipos más populares: clarificador de flujo radial, flujo horizontal y flujo vertical. Las investigaciones y experiencias operacionales en las instalaciones de gran escala han mostrado que no hay una diferencia significativa en el rendimiento de clarificadores que han sido bien diseñados, independientemente de su forma. La decisión de elegir uno u otro no es, por lo general, debido al rendimiento del proceso en el que será aplicado. Por lo que, el espacio disponible para su construcción, el fabricante $\mathrm{u}$ otras consideraciones de ingeniería determinarán la mejor opción para cada caso. Por ejemplo, si el espacio es limitado, los clarificadores rectangulares con la construcción de paredes comunes pueden ser los más adecuados. El acoplamiento con unidades existentes o la simplificación de operaciones (utilizando los mismos clarificadores con el que los operadores ya están familiarizados) también puede ser una consideración importante. 


\subsubsection{Clarificador circular con patrón de flujo radial}

Una de las formas más populares de clarificadores, debido a un diseño mecánico más sencillo, es el decantador circular (Figura 12.2).

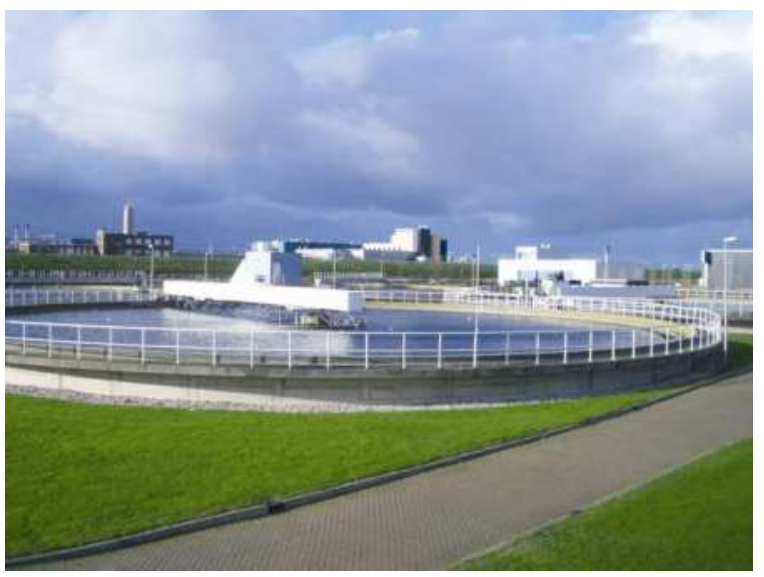

Figura 12.2 Clarificador circular (foto: D. Brdjanovic)

Las estructuras de alimentación y recolección del efluente pueden ser colocadas en diferentes lugares, pero el patrón de flujo en estas unidades, en general, es radial, lo que lleva a mayores velocidades lineales en el centro del clarificador, disminuyendo conforme se acercan hacia el perímetro. El licor mezclado normalmente se alimenta a un cilindro o campana circular ubicada en el centro que disminuye la velocidad del flujo. El diseño de la campana o cilindro debe ayudar a la floculación de la masa de lodo. Las estructuras de amortiguación que se abren en el clarificador ayudan a disipar la energía del líquido, proporcionando condiciones de reposo en el clarificador. El licor mezclado del reactor, debido a su mayor densidad, por lo general fluye hacia el perímetro justo por encima de la parte superior del manto de lodos. Con frecuencia un patrón de recirculación en forma de anillo u ovalo se desarrolla con el líquido que fluye hacia el centro, cerca de la superficie. El control de los patrones de flujo en los clarificadores se consigue normalmente mediante la colocación de estructuras de derivación de flujo o deflectores cerca de los puntos de entrada o salida. El efluente se extrae a través de vertedores múltiples en forma de $\mathrm{V}$, donde el agua vertida es recolectada a través de un canal. El vertedor debe estar nivelado, de tal manera que el flujo se distribuya de manera uniforme a lo largo de toda su longitud. El lodo sedimentado en el fondo del tanque es recolectado por el mecanismo de recirculación de lodo y/o es extraído de la tolva de lodos a través de la purga de lodos.

Los dos elementos mecánicos más habituales para recolectar los lodos son las barredoras y succionadoras. Usando la ventaja proporcionada por la forma circular, los dos mecanismos giran dentro del clarificador un par de veces por hora gracias a una unidad periférica que rueda en la pared exterior del clarificador.

Una ilustración conceptual de un clarificador alimentado por el centro, con un el sistema de salida de efluente periférico se muestra en la Figura 12.3. Las flechas azul marino representan el patrón de flujo general en el tanque, las flechas marrones indican la dirección del flujo de lodo, y las flechas azul claro se utilizan para mostrar la eliminación flujo de efluente clarificado a través de los canales del vertedor.

El diseño detallado de cada componente del clarificador, diseño hidráulico, estructurales y otros tipos de cálculos son necesarios, pero están más allá del objetivo de este texto.

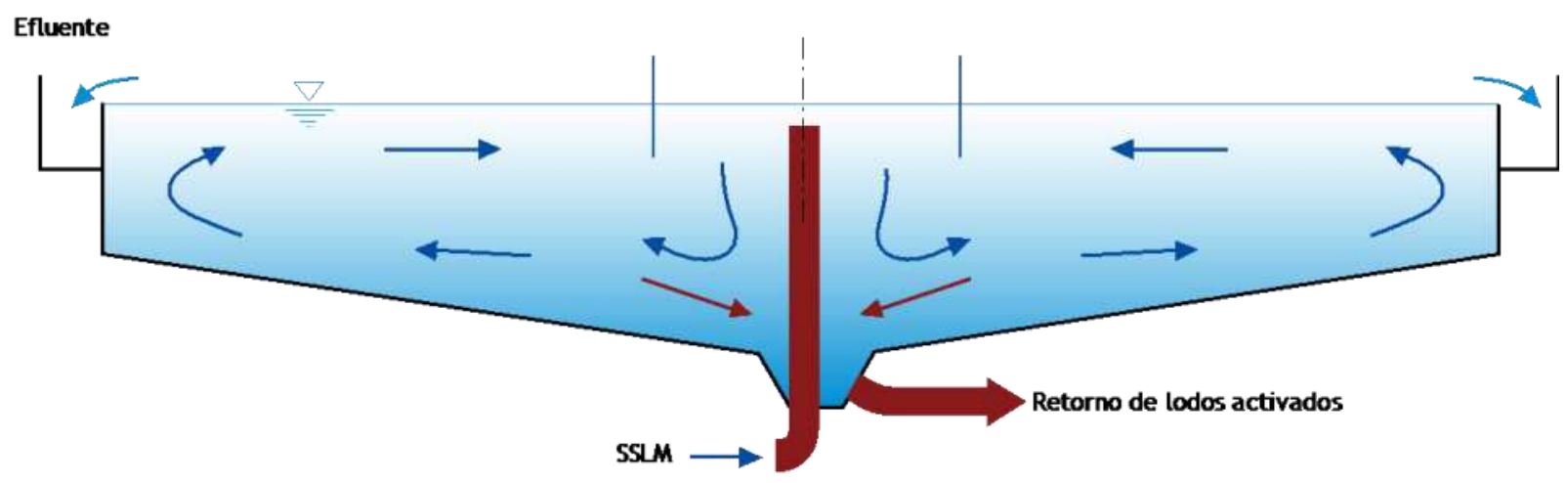

Figura 12.3 llustración conceptual de un tanque de sedimentación circular con patrón de flujo radial 


\subsubsection{Clarificadores rectangulares con patrón de flujo horizontal}

Los clarificadores rectangulares pueden ser construidos compartiendo paredes comunes lo cual conduce a un mejor uso de la superficie disponible. Por lo tanto, las plantas grandes se diseñan generalmente con clarificadores rectangulares (Figura 12.4).

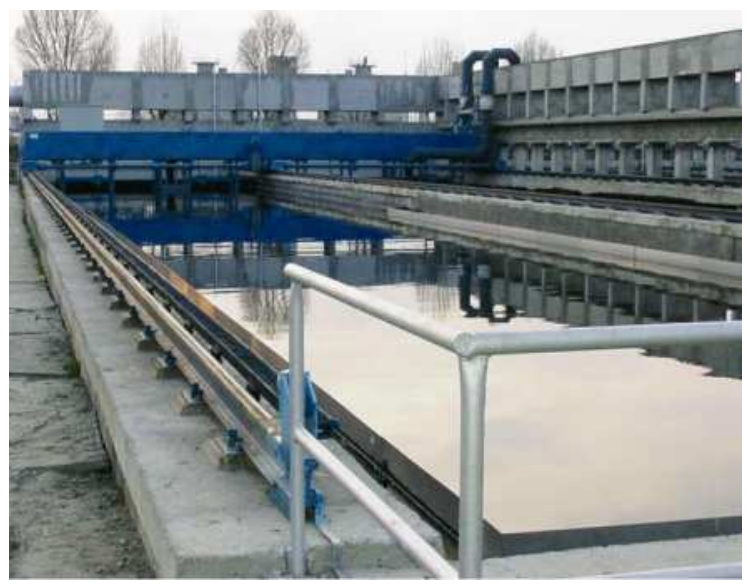

Figura 12.4 Clarificador rectangular (foto: D. Brdjanovic)

De manera similar a los clarificadores circulares, la alimentación y los colectores del efluente pueden estar en diferentes ubicaciones, pero el patrón de flujo en general es horizontal. Una ilustración conceptual de un sistema rectangular se muestra en la Figura 12.5.

En este ejemplo, el licor mezclado se alimenta en la entrada y el efluente se retira en el lado opuesto lo que resulta en un flujo longitudinal. Existen una corriente y un patrón de recirculación, y por lo general están atenuados por medio del uso de deflectores internos. El efluente se recoge a través de vertedores de recolección del agua que rebosa. La eliminación de lodos, que en este ejemplo es en contracorriente con respecto al flujo de líquido clarificado, también podría ser concurrente o de corriente cruzada. El mecanismo de eliminación de lodos suele ser una barredora mecánica.

\subsubsection{Clarificadores profundos con patrón de flujo vertical}

$\mathrm{Si}$ el clarificador es relativamente profundo en comparación con su diámetro, el patrón de flujo se convierte en predominantemente vertical. Este diseño se utiliza sobre todo en Alemania (por ejemplo, el tanque Dortmund). Un dibujo conceptual muestra las principales características de estas estructuras (Figura 12.6).

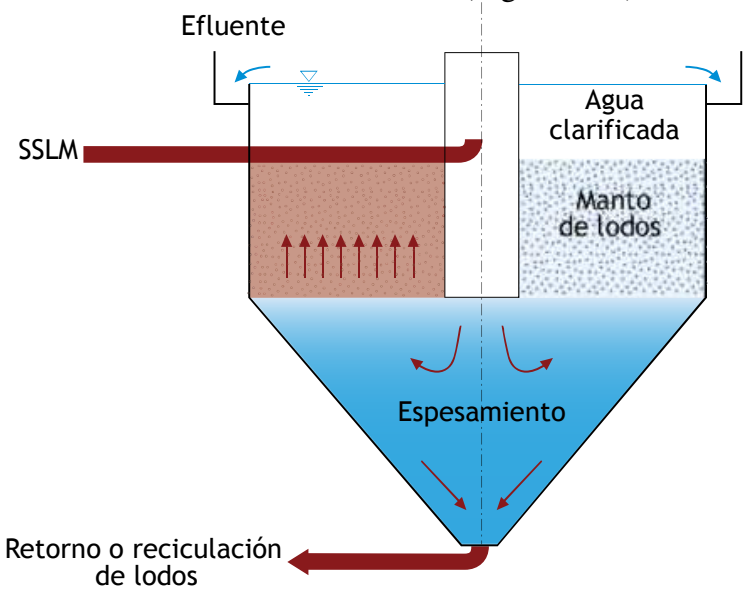

Figura 12.6 Sedimentador de flujo vertical (Tanque Dortmund)

Una característica única del clarificador profundo es el lecho filtrante - los SSLM se introducen por debajo del lecho de lodo, y mientras que fluye a través de él en dirección vertical, fluidifica ligeramente al lecho del lodo. En este proceso las partículas finas se capturan y se filtran. Por lo tanto este tipo de clarificador con frecuencia produce un efluente clarificado con baja concentración de sólidos independiente de la carga hidráulica, siempre y cuando el lecho no se expanda hasta los vertedores.

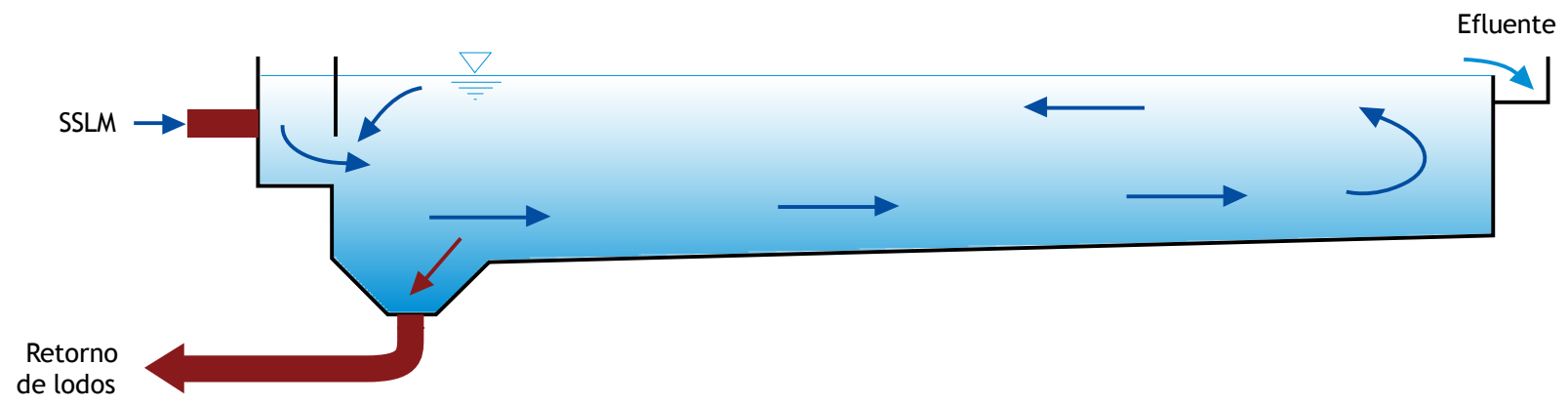

Figura 12.5 Decantador rectangular con flujo horizontal generalizado. 


\subsubsection{Mejoras comunes a todos los tipos de clarificadores}

De las diversas soluciones de ingeniería desarrolladas para mejorar el rendimiento de los clarificadores, se discutirán enseguida cuatro tipos con una breve explicación: pozos de floculación, eliminación de nata (o espuma), deflectores y lamelas (placas paralelas) colocadas en los sedimentadores.

\subsubsection{Pozos de floculación}

No todos los clarificadores están diseñados y construidos con pozos de floculación. Los SSLM también pueden entrar en el clarificador a través de aberturas o puertos directamente desde el tubo de alimentación. Un pozo de floculación bien diseñado puede reducir significativamente la concentración de sólidos del efluente mediante la mejora de la floculación, ya que el lodo en el reactor aireado se encuentra bajo condiciones de altas fuerzas de corte, lo que puede ocasionar la ruptura de los flóculos. Los valores típicos de diseño para un pozo de floculación son 20 minutos de tiempo de residencia hidráulica y un gradiente de valor de velocidad media $(\mathrm{G})$ de $15 \mathrm{~s}^{-1}$. Un pozo de floculación se muestra en la Figura 12.7 (los puertos son visibles donde los SSLM entran en el pozo).

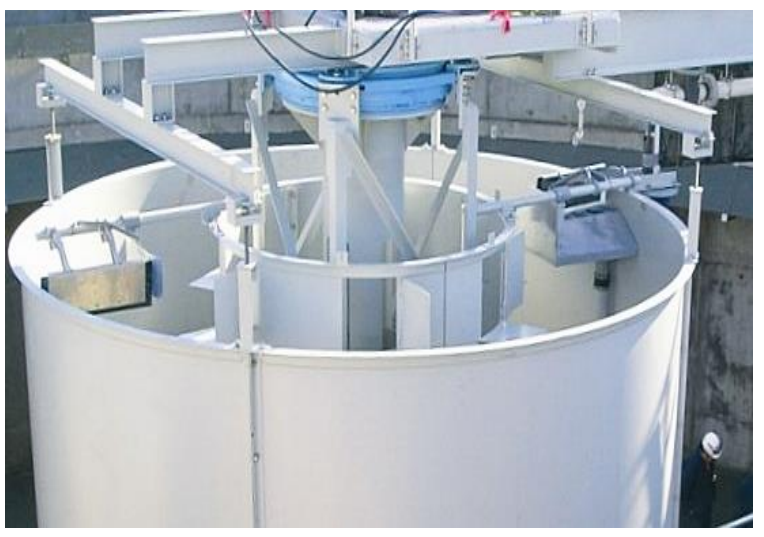

Figura 12.7 Pozo de floculación (foto: Brown y Caldwell)

\subsubsection{Remoción de natas}

La calidad del efluente se puede deteriorar si no se elimina la nata flotante en la parte superior del clarificador (Figura 12.8).

La mayoría de los clarificadores están equipados con deflectores de nata (un ejemplo de diseño se muestra en la Figura 12.9) y diversos mecanismos de eliminación de nata o espuma.

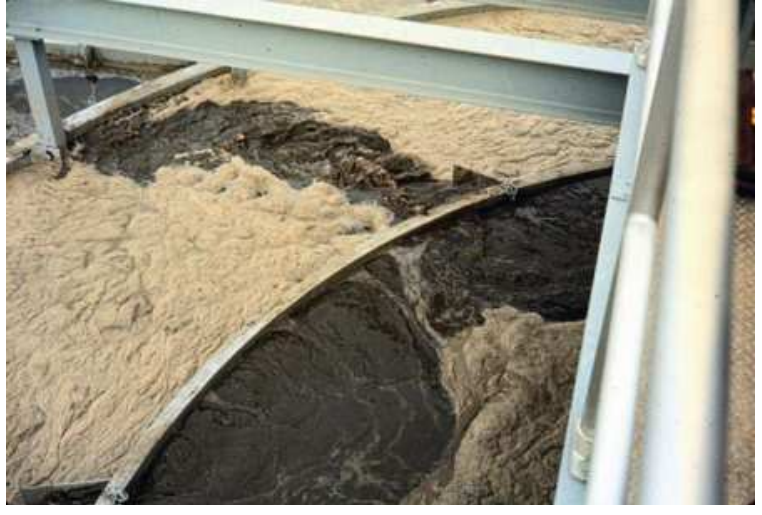

Figura 12.8 Nata en un clarificador (foto: Black y Veatch)

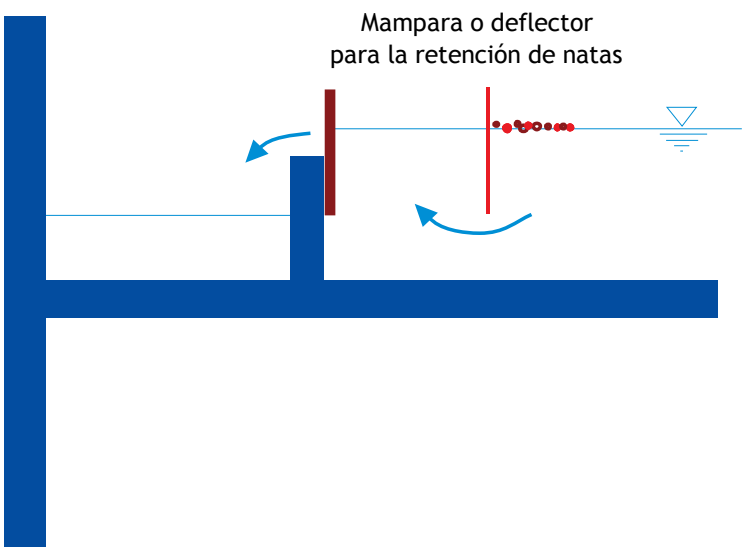

Figura 12.9 Deflector de natas (tipo Black y Veatch)

La nata puede tener diferentes orígenes, mecánicos o biológicos. Pueden ser restos ligeros que no se retiraron antes en la planta de tratamiento de aguas residuales, sólidos biológicos más ligeros debido al contenido de gas (por ejemplo, gas nitrógeno atrapado en el lodo debido a la desnitrificación en el lecho de lodo) o espuma producida biológicamente (por ejemplo por Nocardia). La espuma biológica suele indicar un problema operativo con el reactor de lodos activados y se elimina de una mejor manera antes del clarificador. La recirculación de micro-organismos formadores de espuma en el sistema biológico puede empeorar la situación. La nata se debe quitar de la corriente de agua tan pronto como sea posible y destruirla, con el mínimo uso de agua.

\subsubsection{Deflectores}

Los deflectores (mamparas) son elementos de disipación de energía y de desviación del flujo, que puede ser planos o equipados con ranuras o aberturas. Por lo general, se colocan en el sedimentador secundario cerca de la entrada o salida, aunque los deflectores se han empleado también en medio de tanques para reducir el efecto de 
densidad de corriente. Los deflectores se discuten en más detalle en la sección 12.6 junto con el modelado computacional dinámico de fluidos (CDF).

\subsubsection{Lamelas}

Cuando las partículas discretas sedimentan lentamente a través del líquido clarificado en un clarificador, su distancia de recorrido para alcanzar el manto de lodo, en contra del flujo de agua, es significativa. Las lamelas, tubulares inclinadas o estructuras de placas paralelas son colocados en la zona de clarificado en el sedimentador, reduciendo la distancia de recorrido a unos pocos centímetros. Los sólidos se depositan en la superficie inclinada y se deslizan hacia abajo como una sola masa, en lugar de en forma de partículas individuales. A pesar de esto, las lamelas no se utilizan ampliamente en sedimentadores secundarios, debido a la posibilidad de la acumulación de lodos en el interior de las superficies inclinadas de los tubos o placas, lo que resulta en la necesidad de limpieza y en casos extremos, el taponamiento de la lamela o la producción de cúmulos de grumos de lodos anaerobios que pueden generar gases y causar el flotamiento de los lodos.

\subsubsection{Problemas de operación}

Una planta de tratamiento de aguas residuales es un ambiente complejo, donde los procedimientos operativos deben de estar debidamente documentados. Esto es válido también para la operación de los sedimentadores. Una parte importante de las actividades de mantenimiento y operación se invierte en la limpieza y lubricación de los equipos para que se obtenga el desempeño esperado a través de su vida de diseño. Estos problemas mecánicos no se consideran en detalle en este capítulo, más bien la atención se centra en la ingeniería de procesos.

Muchos problemas de funcionamiento se deben a un diseño defectuoso, y sólo pueden ser corregidos a través de un proyecto de rediseño y reconstrucción/restauración/actualización. Otros problemas en la operación requieren cambios que están dentro de los procedimientos normales de funcionamiento y pueden ser implementados por el personal de gestión, de mantenimiento o de operaciones de la planta.

\subsubsection{Tanques poco profundos}

Debido a las condiciones del lugar o por la elección del diseñador, los sedimentadores se diseñan en ocasiones con menos de 2.5 a $3.0 \mathrm{~m}$ de profundidad. Estos sedimentadores son más susceptibles a la sobrecarga de sólidos, ya que el lecho de lodo puede llegar fácilmente a los vertedores de los efluentes (por ejemplo, debido al aumento de la carga, la pérdida de las propiedades de sedimentación de los lodos o un flujo insuficiente de recirculación). Esto puede conducir al lavado (pérdida o expulsión de sólidos) del lecho de lodos o a un fallo grave del clarificador si el manto de lodos alcanza los vertedores del efluente. Por lo tanto, en clarificadores de poca profundidad, es importante mantener un lecho de lodos de bajo altura (más compacta o una menor concentración de lodos) mediante mayores tasas de recirculación.

\subsubsection{Distribución de flujos irregulares}

Las plantas de tratamiento de aguas residuales por lo general tienen varias unidades de sedimentadores secundarios debido a las siguientes razones: a) el área requerida es demasiado grande y mecánicamente no es factible construir una sola unidad, o b) para proporcionar redundancia para los procedimientos de mantenimiento o fallas mecánicas que se puedan presentar. De esta manera, un clarificador puede ser puesto fuera de servicio $\mathrm{y}$ vaciarse mientras que la planta sigue funcionando con las otras unidades. La distribución del flujo y de sólidos entre los diferentes clarificadores a veces puede ser significativamente desigual, debido a problemas de construcción o de funcionamiento. Esto puede llevar a que uno de los sedimentadores tenga que procesar un flujo mayor o producir un efluente más turbio con una concentración de sólidos en suspensión más alta que los demás. A veces, la inspección visual del flujo a través de los vertedores puede proporcionar una simple idea de las diferencias de carga hidráulica. Los desequilibrios de los flujos con frecuencia pueden ser corregidos midiendo la distribución de los flujos que llegan a cada una de las unidades de sedimentación, corrigiendo la retención de sólidos desigual (manteniendo los SSLM más uniforme en las unidades de lodos activados), y el ajuste de puertas en cajas de división. Dividir los flujos uniformemente por la simple construcción de un canal con paredes niveladas no funciona en la práctica.

\subsubsection{Cargas desiguales en el vertedor}

Los vertedores finales que diseñados de manera incorrecta pueden causar flujo más altos en ciertos segmentos del clarificador, creando velocidades locales mayores (movimiento vertical ascendente de la masa de agua) con un potencial tal que pueda levantar, expandir o desplazar el manto de lodos bajo la zona afectada. El vertedor en estos casos se debe volver a nivelar lo cual 
puede bajar la concentración de sólidos del efluente en las mismas condiciones de carga. Esta es una de las razones para el uso de vertedores de acero en $\mathrm{V}$, colocándolo en el canal de rebose de concreto de modo que el vertedor en $\mathrm{V}$ se pueda montar con precisión con el equipo de nivelación.

\subsubsection{Efecto del viento}

La presencia de un viento fuerte y constante puede afectar el patrón de circulación de flujo en un sedimentador (Figura 12.10). Particularmente los tanques circulares de gran diámetro son propensos a sufrir por la exposición al viento. El patrón de circulación alterado puede resultar en cargas desiguales y de elevada concentración de sólidos en suspensión en el efluente, incluso si los vertedores están perfectamente nivelados. La dirección del viento se debe tomar en cuenta durante el diseño del equipo de eliminación de la nata. Si las condiciones del lugar lo permiten, se deben colocar vallas, árboles o setos para reducir el efecto del viento.

\subsubsection{Cambios súbitos de temperatura}

En ciertos lugares geográficos se presentan variaciones grandes de temperatura diaria o una fuerte exposición a la luz solar produciendo una inversión inducida en los lodos presentes en el sedimentador secundario. El lodo sedimentado normalmente es ligeramente más pesado que las aguas residuales, por lo tanto, ocupa la parte inferior del tanque de sedimentación. Una diferencia de temperatura significativa entre el agua en la superficie del clarificador y el lodo en la parte inferior puede causar una inversión inesperada, lo que resulta en la flotación del lecho de lodos. Esto podría ser resultado de un enfriamiento drástico de la superficie en una noche fría, mientras que el lodo entra en el decantador más caliente debido a la operación durante el día, o el calentamiento del lecho de lodos debido a la luz directa del sol. Si el problema persiste, sólo será posible remediar la situación por medio de una cubierta de la mayor parte del sedimentador o incluso cerrarlo completamente.

\subsubsection{Congelamiento}

En climas fríos, a pesar del contenido de calor natural de las aguas residuales, la acumulación de hielo puede producirse en las superficies expuestas. Esto prevalece particularmente en las plantas con tanques de aireación que usan sistemas de aireación superficiales (por ejemplo, los aireadores mecánicos) que pueden disminuir la temperatura de las aguas residuales. En estos lugares, debe considerarse el uso de reactores y sedimentadores cubiertos, así como de aireación difusa que transfiera algo de calor al líquido.

\subsubsection{Problemas en la recirculación}

En los sedimentadores que emplean tubería de succión para la recolección del lodo y recirculación, usualmente se presenta una pérdida de succión cuando la distancia de la tubería es muy grande, lo cual puede ser un problema. En estos casos, el sistema de recirculación tiene que trabajar con un flujo alto, lo que no siempre es deseable.

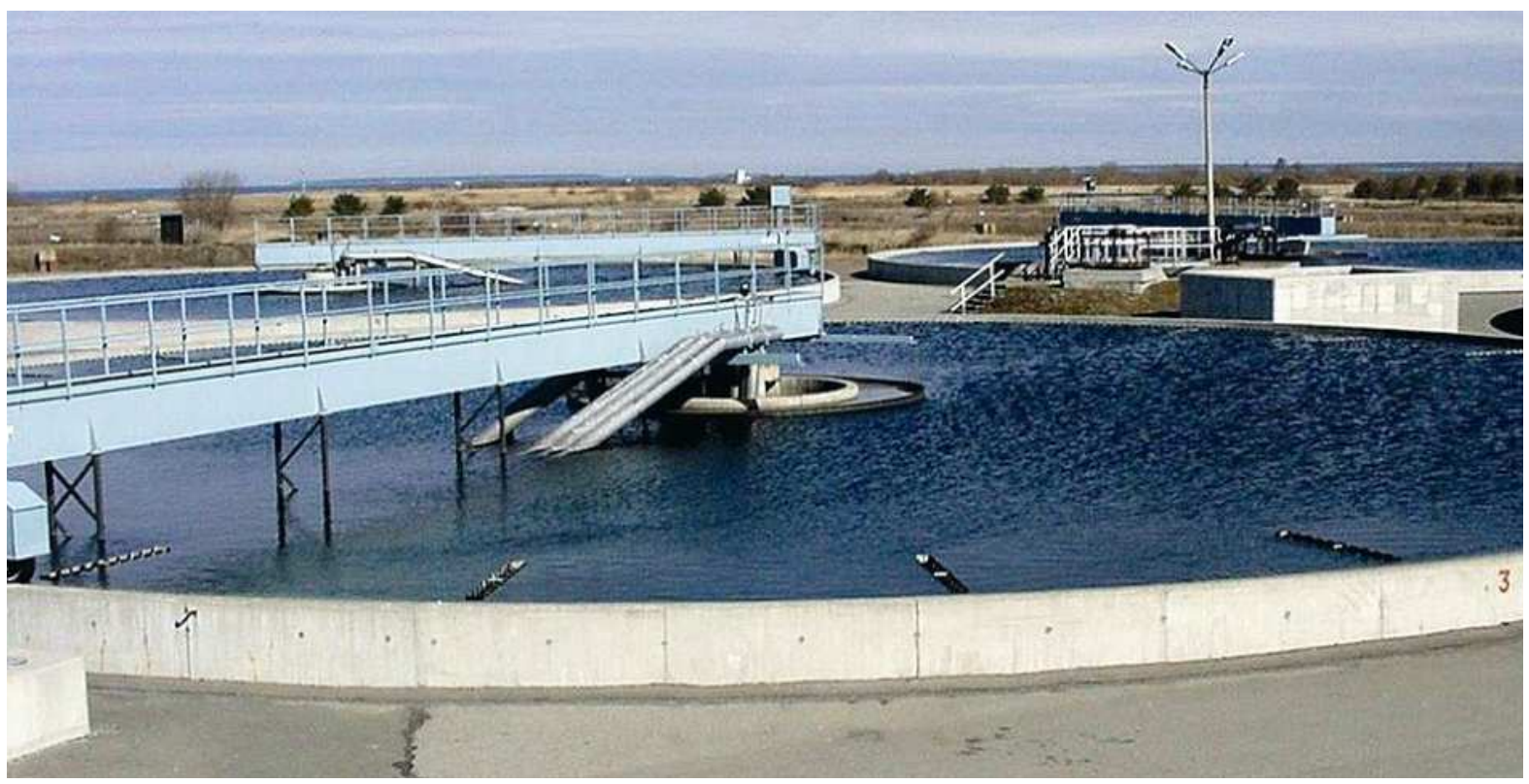

Figura 12.10 Efecto del viento(foto: D. Brdjanovic) 
Otra opción es sustituir las tuberías de succión por raspadores o rastras.

\subsubsection{Algas en vertedores}

La formación de algas ocurre en vertedores y otros lugares expuestos sobre la estructura de los sedimentadores debido a la luz natural del sol y al contenido de fósforo en el efluente (Figura 12.11). Además de ser antiestético esto puede tener un efecto periódico negativo sobre la calidad del efluente o interferir con la operación de equipos, como los canales de eliminación de nata o espuma. Las algas se pueden limpiar manualmente de los vertedores. Algunos diseños clarificadores incluyen cepillos que limpian continuamente las estructuras expuestas. Otras soluciones incluyen la cloración introducida alrededor del vertedor, o el de cubrir el tanque de sedimentación.

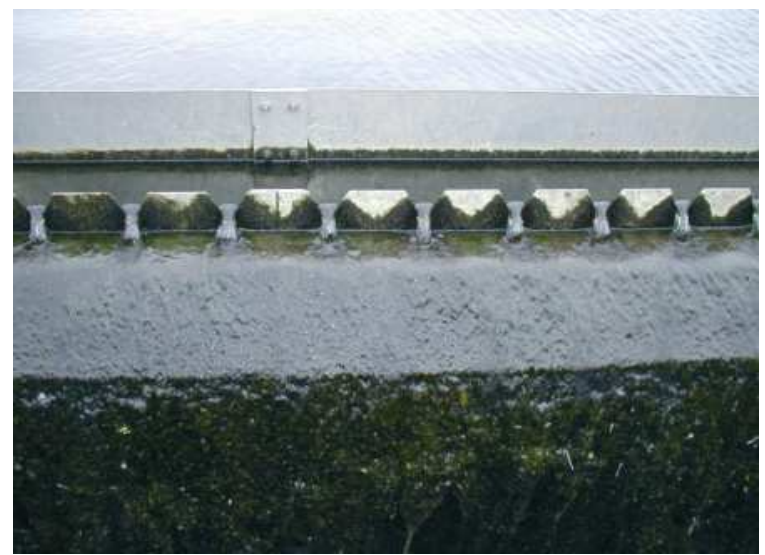

Figura 12.11 Algas en vertedores (foto: D. Brdjanovic)

\subsubsection{Grumos de biomasa anaerobia}

$\mathrm{Si}$ aparecen regularmente grumos flotantes de color marrón oscuro o negro anaerobios en la superficie del tanque de sedimentación secundario, es posible que el mecanismo de recolección de lodos este desalineado, roto o astillado, dejando masas de lodos no recolectados en el fondo del clarificador. Estos aglomerados densos de lodos se vuelven anaerobios y debido a la generación de gas metano, flotan en la superficie. Para determinar la causa de los grumos flotantes será necesario realizar la limpieza de tanques y su inspección.

\subsubsection{Aves}

En ciertas áreas, las gaviotas y otras aves pueden llegar a poblar los sedimentadores secundarios. Sus residuos y plumas pueden contribuir notablemente a la carga de nutrientes del efluente, así como obstaculizar el funcionamiento correcto de los equipos o el aumento de los gastos de limpieza y mantenimiento. Los sedimentadores cubiertos no tienen este problema. Otra solución puede ser extender líneas de cable visibles en todo el clarificador, que no interfieran con la operación pero molesten lo suficiente a las aves para alejarlas de los sedimentadores.

\subsubsection{Lodos filamentosos}

Los lodos filamentosos no sedimentan ni se comprimen a los mismos niveles en el fondo de los sedimentadores secundarios como los lodos normales. Esta condición es $\tan$ frecuente y $\tan$ difícil de superar que un capítulo entero de este libro está dedicado a este fenómeno (Capítulo 11).

\subsubsection{Flotación de lodos}

Los microorganismos heterótrofos presentes en los SSLM continúan su metabolismo incluso después de que el lodo se transfiere al clarificador. Si una cantidad suficiente de sustrato y nitrato se encuentra disponible, gas nitrógeno, en forma de burbujas visibles o microscópicas se puede generar a través de desnitrificación. Las burbujas de gas atrapadas en los flóculos pueden reducir drásticamente su densidad, lo que resulta en la flotación del lodo hacia la superficie. Esta condición puede ser evitada por medio de un tratamiento adecuado, principalmente aplicando un alto nivel de desnitrificación en el proceso biológico, por lo que sólo los bajos niveles de sustrato residual y de nitrato estarían presentes en el flujo de salida de los reactores.

\subsection{MEDICIÓN DE LA SEDIMENTABILIDAD DEL LODO}

Los lodos biológicos, dependiendo de su origen, historia, composición, densidad y capacidad para flocular, sedimentan y compactan de manera diferente. Esta característica se debe tomar en cuenta durante el diseño y funcionamiento de los clarificadores. Por consiguiente, varios métodos de medición se utilizan para cuantificar la sedimentabilidad de los lodos. Los métodos se pueden dividir en dos categorías: (i) aquellos que proporcionan información sobre la velocidad de sedimentación, y (ii) aquellos que dan información sobre la capacidad de compactación. Los métodos más utilizados se describen brevemente a continuación. Para llevar a cabo una prueba real, en cada método se remite al lector a la norma respectiva, la cual contiene una descripción detallada del montaje del experimento y lo detalles que tienen que ser tomados en consideración para obtener resultados 
confiables que pueden ser comparados con otras mediciones del mismo método.

\subsection{1 Índice volumétrico de lodos}

La medición más común para la operación de una planta, debido a su simplicidad, es el Índice Volumétrico de Lodos, IVL (llamado Índice de Möhlmann en algunos países). En esta prueba (APHA et al., 2006), se toma una muestra de lodo en una probeta graduada de 1 litro, y después de la mezcla inicial, se deja reposar durante 30 minutos. La concentración de los lodos se mide a partir de la determinación de los SSLM. El IVL se calcula tomando el volumen (en mililitros/L en la probeta de 1L) que el lecho de lodo ocupa después de 30 minutos y dividiendo por la concentración de los lodos (SSLM) en gramos por litro que se encuentra en la probeta de la prueba, por lo que esencialmente el IVL (ml unidad/g) describe el volumen que 1 gramo de lodos ocupa después de 30 minutos de sedimentación en las condiciones de la prueba.

La prueba de IVL en su forma original es la prueba de sedimentación más simple que se puede realizar, pero tiene varios inconvenientes. 30 minutos es un punto arbitrario en la curva de sedimentación, por lo tanto, los resultados son variables. Los lodos los cuales sedimentan y compactan rápidamente o las pruebas realizadas utilizando concentraciones SSLM más bajos que la concentración operacional, terminan normalmente en 30 minutos con lo que el IVL en estos casos es principalmente un indicador de la capacidad de compactación de los lodos. A concentraciones más altas de sólidos suspendidos en el licor mezclado (SSLM) o en el caso de lodos de sedimentación más lenta, el proceso de sedimentación no finaliza a los 30 minutos y en estos casos el IVL es un indicador de la velocidad de sedimentación de la muestra de lodo. A altas concentraciones de SSLM la prueba falla, por ejemplo, un IVL superior a $150 \mathrm{ml} / \mathrm{g}$ no se puede medir si la concentración en un probeta de $11(1,000 \mathrm{ml})$ es mayor a 1000/150 o $6.7 \mathrm{~g} / \mathrm{l}$. La pared de la probeta también pueden cambiar el IVL medido, debido a los cambios entre probetas pequeñas utilizados en el ensayo los cuales tienen una relación área de pared-volumen muy alta en comparación con clarificadores a escala real.

\subsubsection{Otros métodos de medición}

Se han desarrollado varios métodos para mejorar y normalizar los resultados de la prueba de IVL. La prueba de IVL diluida (IVLD) requiere la dilución de la muestra de lodo del efluente de manera tal que el volumen resultante después de 30 minutos de sedimentación permanezca en el rango de 150-250 ml. Esta prueba evita el problema de altas concentraciones de SSLM, y se puede utilizar como un mejor indicador del potencial de aumento del volumen de lodos filamentosos (IVLD> 150 $\mathrm{ml} / \mathrm{g}$ ). La prueba de IVL agitado a una concentración de $3.5 \mathrm{~g} / 1$ de SSLM (IVLA 3.5 ) es una opción que mejora la prueba. Esta prueba se utiliza como el estándar en varios países (por ejemplo, en Reino Unido), aunque requiere una conFiguración experimental más compleja. Los SSLM están siempre diluidos o concentrados a los mismos $3.5 \mathrm{~g} / \mathrm{l}$, y el recipiente de sedimentación (que por lo general tiene un volumen de 5 litros y un diámetro de $120 \mathrm{~mm}$ ) se agita lentamente a 1-2 rpm. Los resultados de esta prueba son más reproducibles que los de las pruebas de IVL o IVLD.

Ha habido interés de parte de los líderes de la industria para estandarizar los protocolos de estas pruebas en los últimos 20 años, ya que esto mejoraría la calidad de los datos recogidos $y$ el funcionamiento de los sedimentadores secundarios. A pesar de estos esfuerzos y las deficiencias de la prueba de IVL, todavía es de uso generalizado en su forma original, más simple.

La velocidad de la zona de sedimentación (o prueba tomando en cuenta la velocidad de la zona de sedimentación con agitación) es una prueba diseñada para proporcionar cierta información de interés sobre la velocidad de sedimentación de una muestra de lodos mediante el registro de la tasa de descenso real de la interfase de lodos a una cierta concentración de SSLM. Dado que esta prueba se utiliza con frecuencia en el contexto de la teoría del flujo, se describe con mayor detalle en la Sección 12.4.1. Otros métodos totalmente automatizados (por ejemplo medidores automatizados de la capacidad de sedimentación) también se encuentran disponibles.

\subsection{TEORÍA DEL FLUJO PARA LA ESTIMACIÓN DE LA CAPACIDAD DE SEDIMENTACIÓN DEL TANQUE}

El flujo de los sólidos es una forma especial de la tasa de flujo de masa - la masa de sólidos transferidos a través de una unidad de área por unidad de tiempo (expresada por ejemplo en $\mathrm{kg} / \mathrm{m}^{2} / \mathrm{h}$ ). La teoría del flujo, describe los diversos flujos de sólidos que afectan el transporte de sólidos en un clarificador, y se utiliza, entre otros métodos, para estimar el área del sedimentador y parámetros operacionales como la recirculación (retorno). Este capítulo resumirá brevemente el método 
de medición de sedimentación de lodos utilizado y las bases matemáticas de la teoría de flujo, así como otros métodos de diseño utilizados en la práctica.

\subsubsection{Prueba de velocidad de la zona de sedimentación}

La velocidad de la zona de sedimentación (VZS) es la tasa de subsidencia de la interfase de sólidos (lecho de lodo), medida en $\mathrm{m} / \mathrm{h}$ o en unidades similares en un recipiente (normalmente una probeta) de acuerdo con métodos estándar (método D 2710, APHA). La prueba se llama prueba de velocidad de la zona de sedimentación con agitación (VZSA) si el recipiente está equipado con un mecanismo de agitación lenta. La prueba VZSA proporciona una medida más precisa de la sedimentación de lodos, en este caso, solo toma en cuenta la velocidad de la zona de sedimentación, en comparación con el IVL, IVLD o el IVLA 3.5 donde no hay una diferenciación de la velocidad de sedimentación al inicio o final de la prueba. Un ejemplo de cómo va avanzando la prueba en el tiempo se muestra en la Figura 12.12 (para mayor claridad de la foto, se representa una probeta sin agitar, pero la prueba VZS estándar requiere ser agitada a 1-2 rpm). En este caso, una mezcla de SSLM de $5400 \mathrm{mg} / 1\left(5.4 \mathrm{~kg} / \mathrm{m}^{3}\right) \mathrm{se}$ colocó en una probeta y se tomaron fotografías a los 1, 2, 4, 6, 8, 10 y 45 minutos. En la Figura 12.12 se muestran todas las fotografías juntas.

La altura de la interfase de lodos se registra y se representa gráficamente como una función del tiempo, produciendo un gráfico similar a la Figura 12.13.

La curva en la Figura 12.13 se puede dividir en tres secciones distintas:

1) Fase de latencia que dura un minuto o dos al comienzo de la prueba. Esto es debido a la aceleración de las partículas de lodo que componen la interfase y la disipación de la energía de mezcla desde el llenado de la probeta.

2) La sección lineal suele durar 3-30 minutos, dependiendo de la concentración de SSLM y la altura de la columna de sedimentación. La pendiente de esta sección lineal da la velocidad de la zona de sedimentación (VZS) de los lodos en la concentración con la que la columna se llena. Cuando la columna se agita como se requiere para la prueba de velocidad de sedimentación estándar, la pendiente de la sección lineal es la velocidad de la zona sedimentación con agitación (VZSA) a la concentración con la que la columna se llena.

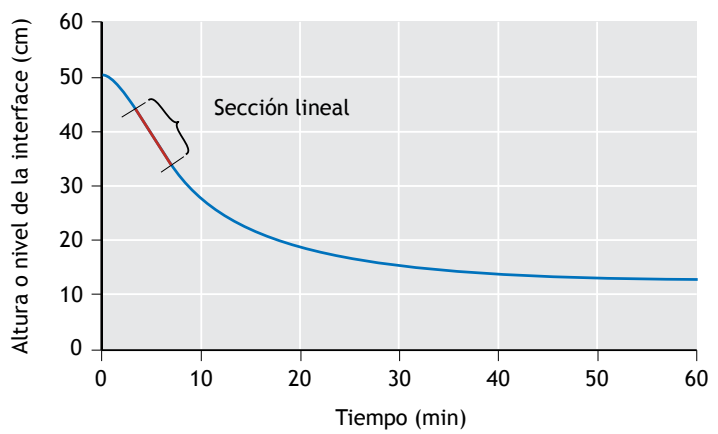

Figura 12.12 Progresión de la prueba de velocidad de sedimentación por zona (a 1, 2, 4, 6, 8, 10 y 45 minutos), (foto: Environment Canada)

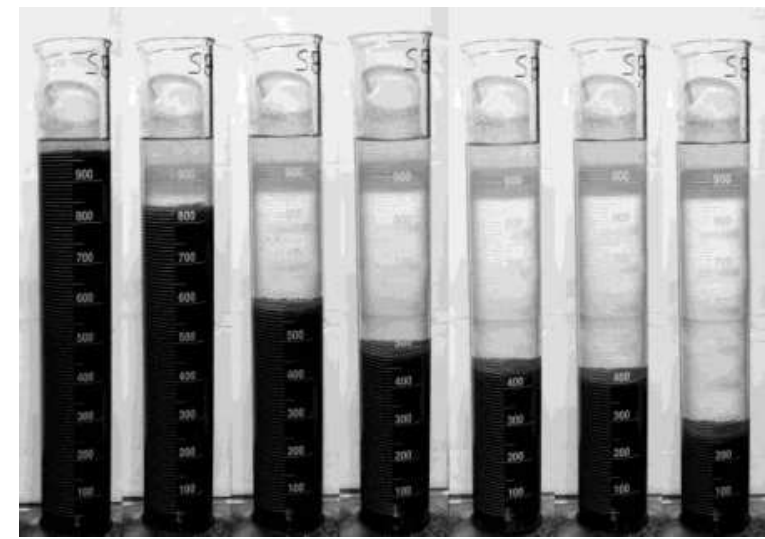

Figura 12.13 Altura de la interfase del lodo como una función del tiempo en una prueba VZS

3) Al final, la compresión de la parte inferior de la probeta resulta en una disminución gradual en la velocidad de sedimentación seguida de una fase linear al final del experimento donde el nivel de la interfase no tiene cambios.

Una serie de pruebas VZSA a diferentes concentraciones de SSLM se realiza generalmente para medir la velocidad de sedimentación de lodos utilizados en la teoría de flujo. La teoría y su aplicación se describen a continuación. La concentración más baja de SSLM donde la prueba se puede realizar con éxito es entre 1 y $1.5 \mathrm{~g} / \mathrm{l}$. A concentraciones muy bajas puede ser difícil determinar la ubicación del lecho o manto de lodos (también llamada zona de sedimentación) como se muestra en la Figura 12.14. 


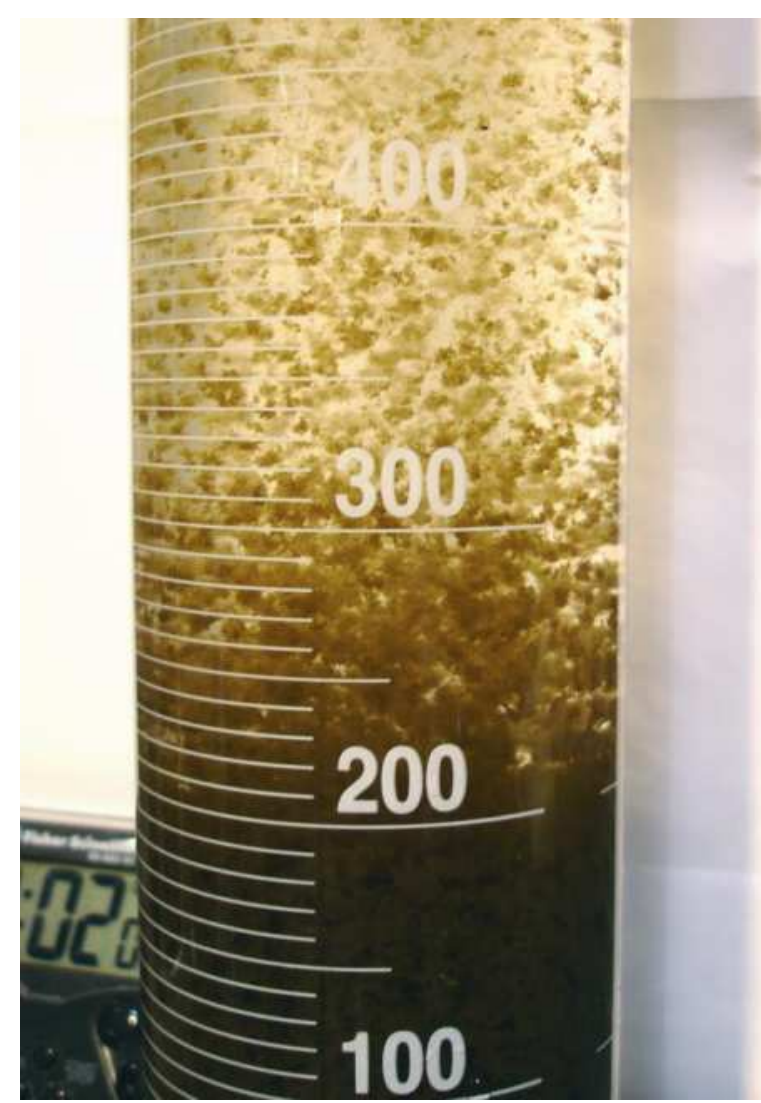

Figura 12.14 Interfase difícil de visualizar (foto: Environment Canada)

Además, con concentraciones diluidas, la tasa de subsidencia es alta, y el inicio de la compresión de la parte inferior puede comenzar dentro de unos pocos minutos. Por el contrario, a altas concentraciones de SSLM, la interfase está bien definida, pero dependiendo de la concentración y la capacidad de compactación de la muestra, la fase lineal de la zona de sedimentación puede ser modificada por la compresión al inicio de la prueba.

\subsubsection{Sedimentación discreta, floculante, obstaculizada (zona de sedimentación) y compresión}

Una suspensión que contiene partículas no floculantes discretas independientes (del mismo tipo, por ejemplo, arena) sedimenta a la misma velocidad independientemente de su concentración conforme a la ley de Stokes. La velocidad de sedimentación de las partículas individuales dependerá solamente de su forma, tamaño (diámetro) y densidad. Una mezcla de SSLM de un reactor de lodos activados se comporta de manera muy diferente en comparación con una suspensión de dicha arena, principalmente debido a su naturaleza floculante.

Al comienzo de un IVL o una prueba de velocidad de la zona de sedimentación, el lodo que incluye flóculos orgánicos grandes y pequeños y las partículas inorgánicas comenzarán a sedimentarse como una matriz coagulada (etapa 1 de la Figura 12.15) y la velocidad de sedimentación se verá influenciada fuertemente por la concentración de SSLM.

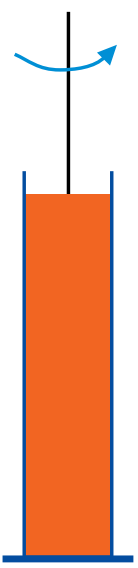

1

Etapas

Sobrenadante clarificado - Sedimentación discreta

SSLM - Zona de sedimentación

Transición

Lodo - Compresión

Figura 12.15 Progreso de la prueba VZS

Esta etapa se conoce como la fase de la zona de sedimentación y se mantiene a través de las etapas 1 a 3 en la Figura 12.15 hasta que no haya más sólidos por encima del manto de lodos o que desaparezca una región de transición en la zona de compresión (Etapa 4). La sedimentación, hasta obtener la compresión, es claramente diferente de la zona de sedimentación - las partículas se apoyan entre sí y la compresión se logra por el desplazamiento del agua hacia fuera de la matriz de lodos. En este punto, la velocidad de sedimentación ya no es una función de la concentración de lodos, pero depende de la presión intersticial, y la compresibilidad y permeabilidad de los lodos. 


\subsubsection{La función de sedimentación de Vesilind}

Si el nivel de la interfase se representa en una prueba VZSA (Figura 12.13), la etapa de sedimentación se puede distinguir por la fase lineal donde el lecho de lodo se asienta con una velocidad constante. El ensayo se puede repetir a varias concentraciones tal y como se muestra en la Figura 12.16.

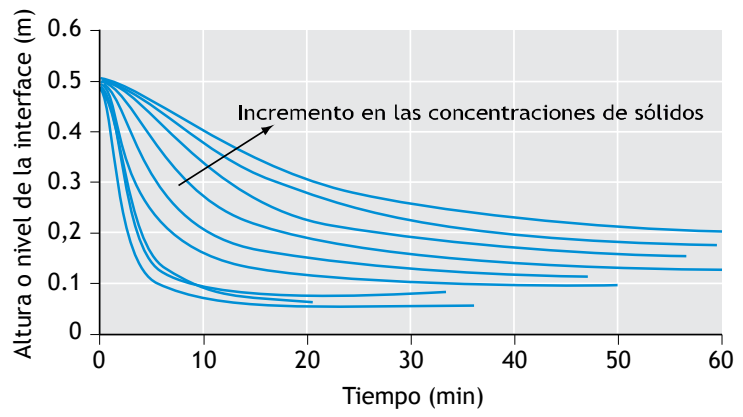

Figura 12.16 Resultados de la prueba VZSA a diferentes concentraciones de SSLM (datos: Environment Canada)

La fase de latencia inicial y la parte lineal son claramente visibles en la gráfica. Las pruebas realizadas con la concentración baja de SSLM muestran una alta velocidad de sedimentación, mientras que aquellas con muestras que contienen una mayor concentración de SSLM son más lentas. Las velocidades de sedimentación (en $\mathrm{m} / \mathrm{h}$ ) se pueden trazar como una función de la concentración de SSLM (mg/l), lo que resulta en una curva que puede ser descrita por una función exponencial (Figura 12.17). Esta función, llamada la función Vesilind, es de la siguiente forma:

$v_{S}=v_{o} \cdot e^{-p_{h i n} \cdot X}$

\begin{abstract}
donde:
vs velocidad de sedimentación $(\mathrm{m} / \mathrm{h})$

vo velocidad de sedimentación inicial $(\mathrm{m} / \mathrm{h})$, una extensión de la curva a la intersección de concentración con un valor de cero

phin parámetro de sedimentación obstaculizada $\left(1 / \mathrm{g} \mathrm{o} \mathrm{m}^{3} / \mathrm{kg}\right)$

X concentración de $\operatorname{SSLM}\left(\mathrm{g} / \mathrm{l}\right.$ o $\left.\mathrm{kg} / \mathrm{m}^{3}\right)$ en varias pruebas de VZSA.
\end{abstract}

Es importante observar que la parte inicial de la curva en la región de concentración baja (0 a aproximadamente $1500 \mathrm{mg} / \mathrm{l}$ en la Figura 12.17) es simplemente una extensión matemática de los puntos de los datos medidos y en realidad la velocidad de la zona de sedimentación no puede extenderse o medirse en este intervalo de concentraciones.

Si los mismos puntos de datos de la Figura 12.17 se representan en una representación semi-logarítmica, la función exponencial se transforma en una representación lineal (Figura 12.18) y la pendiente da la phin, mientras que la ordenada al origen es $\ln \left(\mathrm{v}_{0}\right)$.

La distribución de error de las mediciones es diferente en la representación lineal original y en la semilogarítmica de la función Vesilind. Desde un punto de vista práctico, sin embargo, no hay mucha diferencia entre la extracción de los parámetros $\mathrm{v}_{0}$ y $\mathrm{p}_{\text {hin }}$ directamente de la curva exponencial o su forma

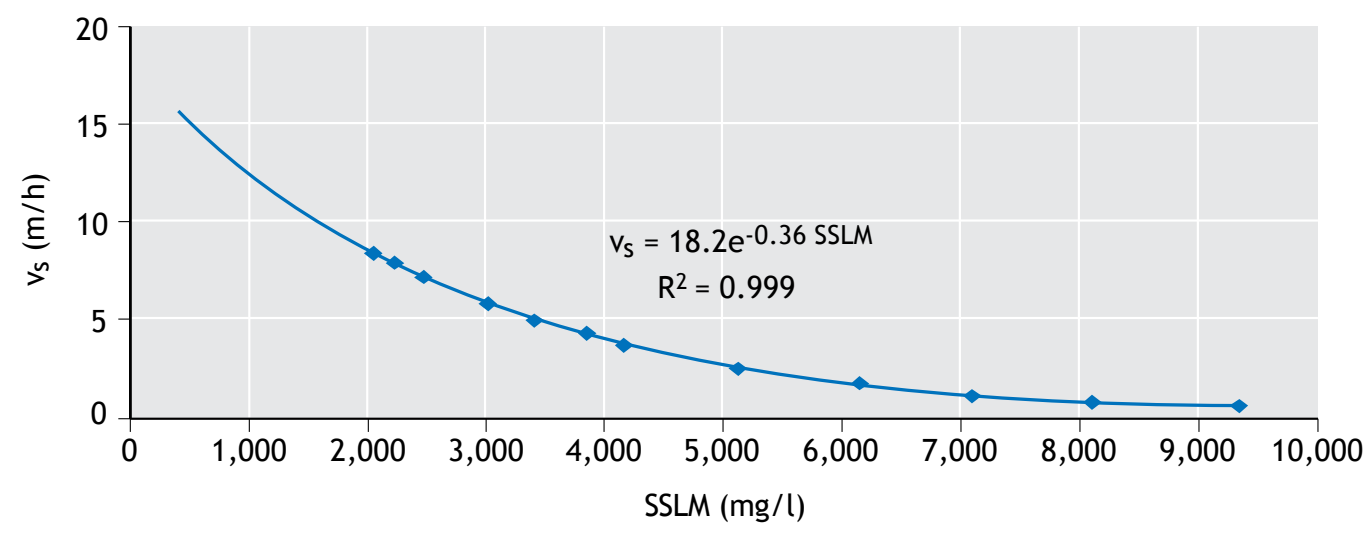

Figura 12.17 La relación de Vesilind entre la velocidad de sedimentación y la concentración de SSLM (datos: Environment Canada) 


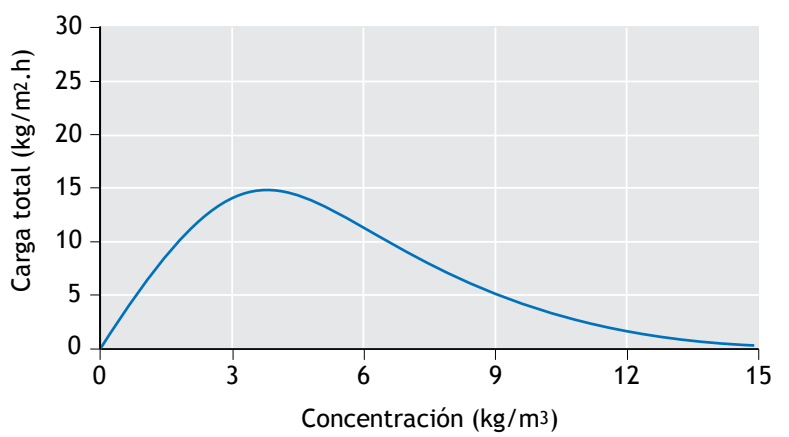

Figura 12.18 La función Vesilind representada en escala semi-logarítmica (datos: Environment Canada)

linealizada. En el primer caso la regresión se realiza directamente sobre los valores de $\mathrm{v}_{\mathrm{s}}$, y en el último de los valores de $\ln \left(\mathrm{v}_{\mathrm{s}}\right)$. Dado que actualmente la mayoría de las evaluaciones se realizan usando funciones de hoja de cálculo (por ejemplo, Excel Solver) a diferencia de los métodos gráficos ampliamente utilizados históricamente, los valores son ligeramente diferentes y se pueden obtener en las dos representaciones diferentes resultados - sin embargo, la exactitud de los resultados dependerá sobre todo de la lectura apropiada de las interfases durante las pruebas VZSA y la selección de la región lineal de la altura de la interfase-curva de tiempo.

\subsubsection{Curvas de sedimentación por gravedad, por recirculación y carga total}

La carga de sólidos ( $\left.\mathrm{J}_{\mathrm{S}}\right)$ que sedimentan por gravedad es la masa de sólidos transportados bajo la influencia de la gravedad que inducen la sedimentación, y se puede calcular como el producto de la velocidad de sedimentación $\left(\mathrm{v}_{\mathrm{s}}\right)$ y la concentración de sólidos $(\mathrm{X})$ :

$$
J_{S}=v_{s} X
$$

donde:

JS carga de sólidos por gravedad $\left(\mathrm{kg} /\left(\mathrm{m}^{2} / \mathrm{h}\right)\right)$

$\mathrm{v}_{\mathrm{s}} \quad$ velocidad de sedimentación $(\mathrm{m} / \mathrm{h})$ a la concentración X (de la Ec. 12.1)

X concentración de sólidos $\left(\mathrm{kg} / \mathrm{m}^{3}\right)$

La carga de sólidos por gravedad, durante la sedimentación de lodos con un IVL de aproximadamente $48 \mathrm{ml} / \mathrm{g}$ se representa en la Figura 12.19. La curva de la carga de sólidos por gravedad tiene un máximo por lo general a una concentración de 2 a $3 \mathrm{~kg} / \mathrm{m}^{3}$. Por debajo de esta concentración la carga disminuye debido a la baja concentración de sólidos, mientras que por encima, disminuye debido a que la velocidad de sedimentación a concentraciones más altas es menor.

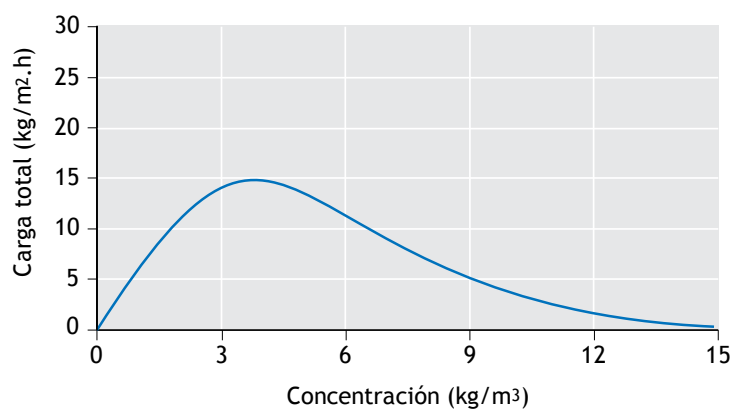

Figura 12.19 Carga de sólidos que sedimentan por gravedad

Los sólidos en el tanque de sedimentación también sedimentan en el fondo del clarificador debido al movimiento descendente generado por la recirculación del lodo (este efecto es despreciable en el cilindro de ensayo VZS, pero obviamente no en un sedimentador real).

$J_{B}=\frac{Q_{R}}{A} X$

donde

$\mathrm{J}_{\mathrm{B}} \quad$ carga de sólidos por recirculación $\left(\mathrm{kg} / \mathrm{m}^{2} / \mathrm{h}\right)$

$\mathrm{Q}_{\mathrm{R}} \quad$ flujo de recirculación $\left(\mathrm{m}^{3} / \mathrm{h}\right)$

A área del sedimentador $\left(\mathrm{m}^{2}\right)$

Con un flujo de recirculación fijo, la carga debida a la recirculación es linealmente proporcional a la concentración de sólidos, X (Figura 12.20). Es decir, cuanto mayor sea $\mathrm{X}$ existirá una mayor carga de sólidos que fluyen hacia la parte inferior del clarificador debido a la tasa del flujo de recirculación de lodos. 


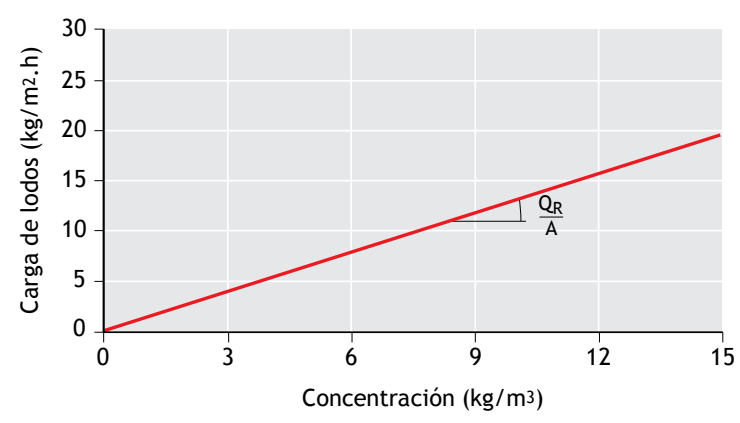

Figura 12.20 Carga de lodos debida a la recirculación

La carga total de transporte de sólidos que sedimentan en la parte inferior del clarificador es la suma de las cargas de sólidos por gravedad y recirculación (Figura 12.21).



Figura 12.21 Carga total de sólidos

La carga total, dada una tasa de recirculación en particular, tiene un valor mínimo a una cierta concentración denominada "concentración limitante", $\mathrm{X}_{\mathrm{L}}$. Si la concentración es menor que la concentración limitante, el aumento en la carga de sedimentación compensa la disminución de la carga por recirculación, mientras que, a concentraciones más altas, el aumento en la carga de sedimentación compensa la disminución en la carga por recirculación.

La capa formada en el sedimentador a la concentración limitante será el cuello de botella debido a que transporta la carga más baja de sólidos o carga limitante, $\mathrm{j}_{\mathrm{L}}$, a la parte inferior en todo el intervalo de concentración. El intervalo de concentraciones en el clarificador va desde la concentración más baja observada, la cual corresponde de la concentración en la alimentación, hasta la concentración más alta del lodo medida en el caudal de recirculación de lodos.

$j_{L}=j_{S\left(X_{L}\right)}+j_{B\left(X_{L}\right)}$
Cuando la carga aplicada (masa de sólidos por área de unidad de sedimentador $\left(\mathrm{kg} / \mathrm{m}^{2} . \mathrm{h}\right)$ ) coincide exactamente con la carga limitante, en ese punto del clarificador está cargado críticamente o está en el punto en el cual puede existir una falla en el sistema. Esta condición por lo general se presenta cuando se alcanza el pico del caudal de descarga máximo (PWWF, por sus siglas en inglés Peak Wet Weather Flow) generalmente alcanzado bajo las condiciones climáticas en las cuales existe un gran volumen de agua que fluye hacia una planta de tratamiento de aguas residuales, durante o poco después de un período de lluvias fuertes. Después de encontrar la concentración limitante $\left(\mathrm{X}_{\mathrm{L}} \mathrm{kg} / \mathrm{m}^{3}\right)$, con base en el mínimo de la curva de la carga total, se puede determinar la carga mínima o limitante $\left(\mathrm{j}_{\mathrm{L}} \mathrm{kg} / \mathrm{m}^{2} / \mathrm{h}\right)$.

\subsubsection{Criterios límite para el manejo de sólidos en el clarificador}

Considerando la carga total tal y como se muestra en la Figura 12.21, si se incrementa la tasa de la carga limitante, las curvas de la carga por recirculación y de la carga total girarían en sentido contrario a las agujas del reloj alrededor del origen $\mathrm{y}$, a una cierta tasa de carga limitante, el mínimo local (y por lo tanto la concentración limitante) desaparecería (Figura 12.22).

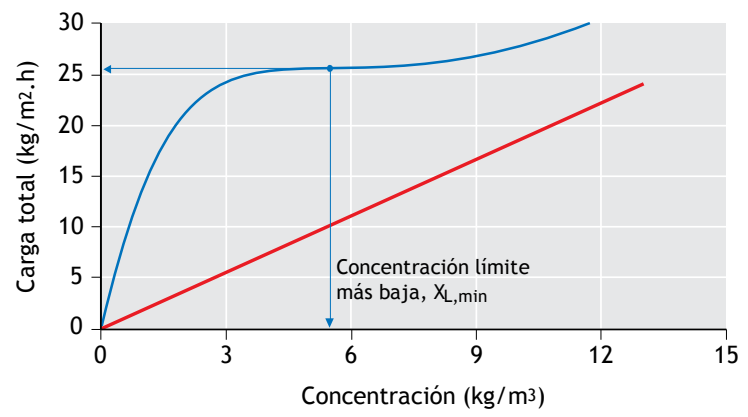

Figura 12.22 Curva de carga total sobre la carga de recirculación crítica

Esta carga hidráulica debida a la recirculación se denomina la carga de recirculación crítica $\left(q_{R, \text { crit }}=Q_{R} / A\right.$ en $\mathrm{m} / \mathrm{h}$ ) y define la concentración limitante más baja que se puede alcanzar $\left(\mathrm{X}_{\mathrm{L}, \mathrm{min}}\right)$. La carga máxima que puede sedimentarse o la máxima capacidad de manejo de lodos del clarificador puede ser determinado por dos criterios diferentes, dependiendo de que el valor de la tasa de recirculación esté por debajo o por encima de este valor crítico. 


\subsubsection{Criterio de manejo de sólidos 1 (CMS I). Limitado por el flujo mínimo de sólidos}

A tasas hidráulicas de recirculación menores que la tasa hidráulica inferior crítica, siempre es posible encontrar una carga mínima de sólidos a la concentración de sólidos limitante.

Esta situación se representa en la Figura 12.21. La carga aplicada al clarificador tiene que ser inferior a esta carga mínima. El clarificador tiene una carga crítica si la carga aplicada coincide con el flujo mínimo. Si se conocen el caudal pico (PWWF) y la concentración de SSLM, el área y la tasa de recirculación pueden seleccionarse de tal manera que la carga total resultante sea igual o menor a la carga mínima.

12.4.5.2 Criterio de manejo de sólidos 2 (CMS II). Limitado por la carga aplicada (tasa de descarga)

A tasas de recirculación por encima de la recirculación crítica, no es posible encontrar una concentración limitante (Figura 12.23).

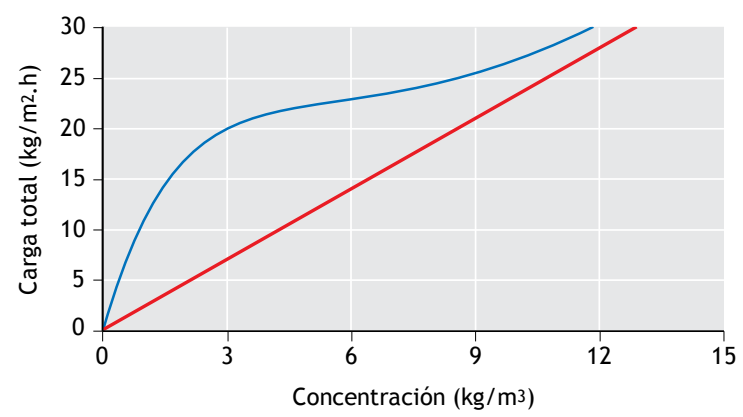

Figura 12.23 Curva de la carga total sin una concentración limitante (tasa de recirculación de lodos superior a la crítica)

Bajo esta condición, la carga de sólidos sobre el clarificador debe ser menor que la carga por gravedad dada la concentración en la alimentación o, de manera equivalente, la carga hidráulica superficial aplicada $(\mathrm{m} / \mathrm{h})$ debe de ser menor que la velocidad de sedimentación de los lodos (definida por la ecuación de Vesilind) a la concentración promedio en la alimentación (SSLM).

$$
q_{I}=\frac{Q_{P W W F}}{A}=v_{S, S S L M}=v_{0} \cdot e^{-\rho_{\text {hin }} \cdot S S L M}
$$

Las secciones siguientes describen con más detalle cómo se aplica la teoría de flujo para el diseño de un clarificador, determinando específicamente el área requerida y la tasa mínima de recirculación de lodos.

\subsubsection{Análisis del punto de estado (State Point Analysis)}

El análisis del punto de estado (SPA por sus siglas en inglés, State Point Analysis) es una forma visual muy práctica para determinar las condiciones bajo las cuales opera el clarificador. El SPA se basa en los balances de masa de los sólidos en el clarificador expresados de una manera gráfica. El método contiene simplificaciones tales como que: (i) se basa en las condiciones de estado, (ii) se considera una sola dimensión (vertical), sin cortocircuitos y sin detalles de los mecanismos de eliminación de lodos, (iii) no se consideran los efectos de la dinámica de los lodos, como por ejemplo los efectos de compresión, y (iv) se desprecian los sólidos presentes en el efluente. A pesar de estas simplificaciones, SPA se usa frecuentemente (a) en el diseño previo para determinar el área del clarificador y la capacidad requerida de las bombas de recirculación, y (b) en el funcionamiento para estimar las máximas concentraciones de SSLM y los flujos de recirculación de lodos necesarios antes de optimizar el funcionamiento de la planta con base en los resultados reales.

El diagrama del punto de estado (Figura 12.24) se construye representando las diversas cargas de sólidos de un clarificador en función de la concentración de sólidos.

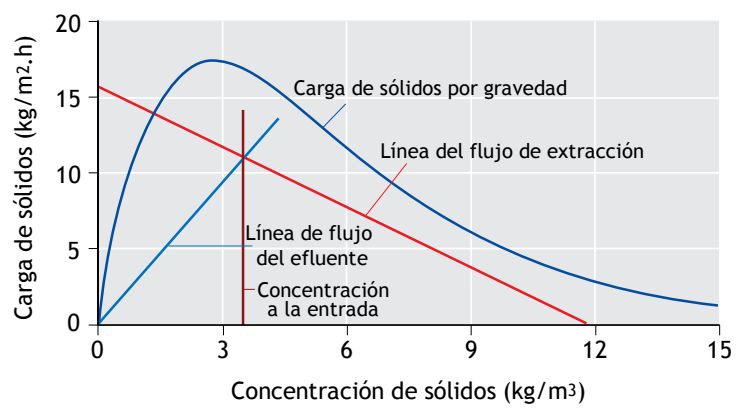

Figura 12.24 Diagrama del punto de estado

El diagrama del punto de estado está basado en la curva de la carga de sedimentación por gravedad de la Figura 12.19. Para graficar esta curva se requiere conocer solamente las dos constantes de Vesilind ( $\mathrm{v}_{0}$ y $\mathrm{p}_{\text {hin }}$ ). En el diagrama se sobreponen sobre la curva de la carga de sedimentación por gravedad, las líneas del caudal del efluente, de recirculación y de alimentación o descarga dentro del clarificador. Las líneas del efluente y de la recirculación representan las cargas de sólidos aplicadas al clarificador generadas por la descarga y las tasas de flujo de recirculación, en las mismas unidades que la carga por gravedad, pero la definición de sus ejes verticales (y) es diferente. 
La línea del caudal del efluente representa el caudal que rebosa o sale del clarificador (el cual fluye en dirección opuesta a la carga por gravedad o sedimentación).

$J_{I}=\frac{Q_{I}}{A} X_{F}$

La pendiente de la línea del caudal del efluente corresponde con la carga hidráulica aplicada, que es qI = $\mathrm{Q}_{\mathrm{I}} / \mathrm{A}(\mathrm{m} / \mathrm{h})$, comúnmente conocida como la carga hidráulica superficial. Es importante tener en cuenta que la carga del efluente no es la carga real de sólidos que recibe el sedimentador. Eso se conoce como la carga total de sólidos aplicada (descrita por la ecuación 12.8).

La línea de concentración de la alimentación es una línea vertical que indica la concentración de sólidos presente en la alimentación o afluente del clarificador secundario. Esta línea intercepta a la línea definida por el caudal efluente en el punto de estado (es decir, en el punto de operación del clarificador). En este punto la carga en el eje $y$ de las ordenadas corresponde con la tasa de carga de sólidos. La línea definida por el caudal de recirculación puede definirse de manera similar a la línea del caudal del efluente:

$J_{R}=\frac{Q_{R}}{A} X_{F}$

Sin embargo, se realizan dos transformaciones para incrementar la utilidad del método.

1) La línea se traza con una pendiente negativa (ya que se mueve en la dirección opuesta a la línea definida por el efluente)

2) La línea de la recirculación (que, originalmente, de acuerdo con la ecuación 12.7, comienza a una carga cero con una concentración cero de sólidos) se desplaza hacia arriba de tal manera que inicie a partir de la carga total aplicada en el eje vertical $(X=0)$. La carga total aplicada de sólidos (también llamada tasa de carga de sólidos) se obtiene sumando la carga definida por el caudal efluente y la carga debida al caudal de recirculación a la concentración de sólidos de la alimentación,

$J_{A P}=\frac{Q_{I}+Q_{R}}{A} X_{F}=\frac{Q_{I}}{A}(1+R) X_{F}$

donde

$\mathrm{R} \quad$ tasa de recirculación de lodos $\left(\mathrm{Q}_{\mathrm{R}} / \mathrm{Q}_{\mathrm{I}}\right)$
Dado que la carga total aplicada es removida del clarificador a la concentración de sólidos presente en la recirculación de lodos (despreciando la concentración de sólidos en el efluente de la planta), el punto donde la línea de la carga por recirculación desplazada cruza el eje X (carga "residual" cero) representa la concentración de sólidos en la recirculación de lodos cuando el clarificador opera con una carga baja de sólidos. Cuando las líneas definidas por el efluente, la concentración de sólidos en la alimentación del clarificador y por la recirculación se cruzan en el punto de estado, entonces se cierra el balance de masa de los sólidos en el clarificador y todos los sólidos que entran en el clarificador son extraídos a través de la recirculación, siempre y cuando el punto de estado y la línea de la recirculación estén por debajo y dentro de la curva de carga por sedimentación por gravedad. Las características más importantes y las concentraciones presentes en un diagrama de punto de estado de estado se muestran en la Figura 12.25.

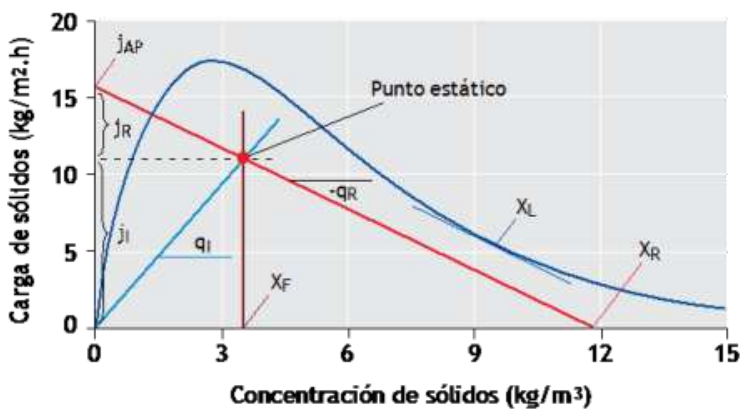

Figura 12.25 Características del diagrama de punto de estado.

Donde, en la Figura 12.15:

$\mathrm{X}_{\mathrm{F}} \quad$ Concentración de sólidos en la alimentación o afluente del clarificador secundario $\left(\mathrm{kg} / \mathrm{m}^{3}\right)$

$\mathrm{X}_{\mathrm{R}} \quad$ Concentración de sólidos en la recirculación de lodos $\left(\mathrm{kg} / \mathrm{m}^{3}\right)$

$\mathrm{X}_{\mathrm{L}} \quad$ Concentración limitante de sólidos $\left(\mathrm{kg} / \mathrm{m}^{3}\right)$

qI Carga hidráulica superficial QI/A, (m/h)

$\mathrm{q}_{\mathrm{R}} \quad$ Carga hidráulica de la recirculación de sólidos, $\mathrm{QR}_{\mathrm{R}} / \mathrm{A},(\mathrm{m} / \mathrm{h})$

jI Carga de sólidos por el caudal efluente, $\mathrm{Q}_{\mathrm{I}} / \mathrm{A} \cdot \mathrm{X}_{\mathrm{F}}\left(\mathrm{kg} / \mathrm{m}^{2} / \mathrm{h}\right)$

jR Carga de sólidos por el caudal de recirculación, $\mathrm{Q}_{\mathrm{R}} / \mathrm{A} \cdot \mathrm{X}_{\mathrm{F}}\left(\mathrm{kg} / \mathrm{m}^{2} / \mathrm{h}\right)$

$\mathrm{j}_{\mathrm{AP}} \quad$ Carga total de sólidos aplicada, $\left(\mathrm{Q}_{\mathrm{I}}+\mathrm{Q}_{\mathrm{R}}\right) / \mathrm{A} \cdot \mathrm{X}_{\mathrm{F}}$ $\left(\mathrm{kg} / \mathrm{m}^{2} / \mathrm{h}\right)$

La posición del punto de estado y de la línea de flujo de recirculación, en relación con la curva de flujo de gravedad, determina el estado de funcionamiento del 


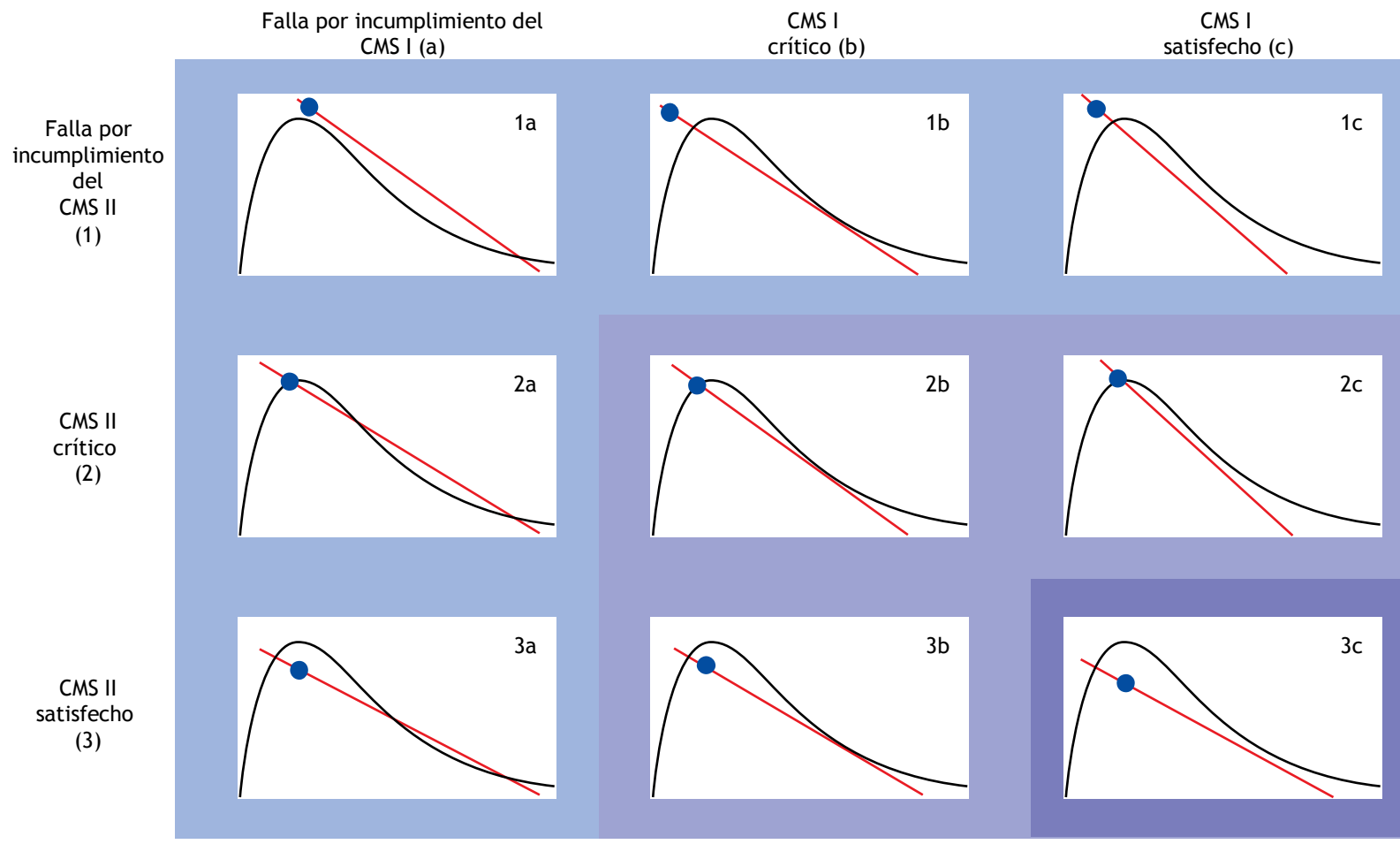

Figura 12.26 Diagramas del punto de estado (la línea de los flujos de descarga y alimentación no se muestran) para diferentes condiciones de carga con base en los criterios de manejo de sólidos I y II (CMSI y CMSII, respectivamente)

clarificador. Todas las combinaciones posibles de operación se presentan visualmente en la Figura 12.26, donde el punto azul es el punto de estado y la línea roja es la línea que describe el caudal de la recirculación de sólidos. La línea del caudal del efluente (no mostrada) conecta el origen y el punto de estado.

Con base en la Figura 12.26:

3) Si el punto de estado está por encima de la curva de la carga por gravedad, el clarificador está sobrecargado (falla del CMS II). En esta condición la carga de sólidos es mayor a la cual puede operar el clarificador. Esto dará lugar a la acumulación de sólidos en el clarificador, el cual no podrá mantenerse estable, y habrá pérdida de sólidos a través del efluente.

4) Si el punto de estado se encuentra sobre la curva de la carga de sedimentación por gravedad, el clarificador es cargado, al menos, críticamente para el cumplimiento de CMS II, y su estado depende de la posición de la línea de la carga por recirculación con relación a la parte descendente de la curva de la carga por gravedad en concentraciones más altas:

- Si la línea de la carga por recirculación cae por debajo de la rama descendente de la curva de la gravedad, el clarificador está cargado críticamente (CMS II crítico, pero se satisface el CMS I).

- Si la línea de la carga por recirculación atraviesa la rama descendente de la curva de la carga de sedimentación por gravedad, el clarificador está sobrecargado (CMS II crítico, falla del CMS I).

5) Si el punto de estado se encuentra por debajo de la curva de carga por gravedad, el clarificador satisface el CMS II, y su condición dependerá del Criterio de Manejo de Sólidos I (CMS I), la carga de sólidos mínima.

- Si la línea de carga por recirculación cae por debajo de la rama descendente de la curva de la gravedad, el clarificador opera a una carga de sólidos baja (y se cumplen tanto el CMS II como el CMS I).

- Si la línea de carga por recirculación es tangencial a la parte descendente de la curva de la gravedad, el clarificador está cargado críticamente (se cumple el CMS II pero el CMS I es crítico).

- Si la línea de carga por recirculación cruza la parte descendente de la curva de carga por 
gravedad, el clarificador está sobrecargado (se cumple CMS II pero falla el CMS I).

El clarificador tiene que cumplir ambos criterios de manejo de sólidos a fin de no tener una carga crítica o una sobrecarga. De los nueve casos ilustrados en la figure 12.26, 1a, 1b, 1c, 2a y 3a están sobrecargados, 2b, 2c y $3 \mathrm{~b}$ están cargados críticamente, y sólo en un caso (3c) está con una carga baja. La teoría de flujo se puede expresar conceptualmente y gráficamente en varias formas diferentes además de la del diagrama de punto de estado presentado anteriormente. Estos métodos se basan en la misma teoría, conteniendo la misma función de sedimentación de Vesilind, y proyectando la misma carga de sedimentación por gravedad y de los caudales o flujos del efluente y de recirculación utilizando diferentes ejes. Estas proyecciones pueden ser más prácticas o convenientes para algunos fines y propósitos de diseño o de operación pero se obtendrán los mismos resultados.

\section{La Gráfica de diseño y operación (D\&O) de Ekama}

Esta gráfica reorganiza la información disponible generada por la teoría de la carga de sólidos y el diagrama del punto de estado. La carga hidráulica superficial (Q/A, en $\mathrm{m} / \mathrm{h}$ ) se grafica en función de la tasa de recirculación en el eje X (Figura 12.27).

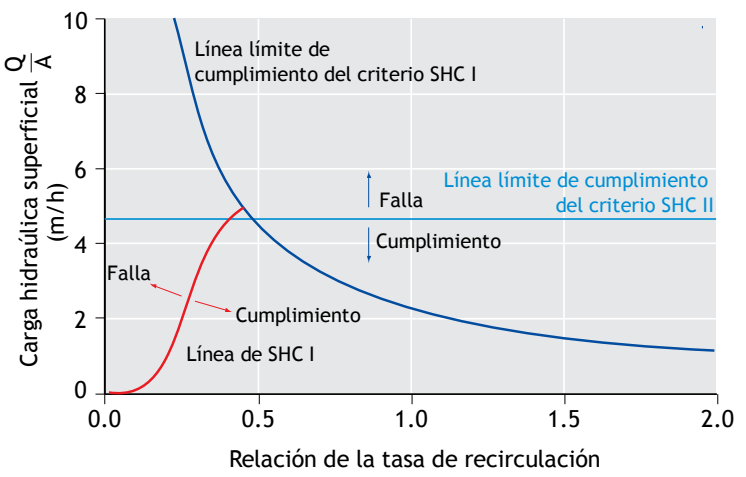

Figura 12.27 La Gráfica de diseño y operación de Ekama

El gráfico incluye tres líneas que ayudan a determinar el estado de funcionamiento de un clarificador con base en su carga hidráulica (caudal efluente) y la tasa de recirculación de lodos.

- Línea del CMS II. La línea recta horizontal representa la velocidad de sedimentación a la concentración de la alimentación, $X_{F}$ (basada en los dos parámetros de Vesilind, $v_{0}$ y phin), tal como se expresa en la ecuación 12.5. En la zona superior de esta línea, el Criterio de Manejo de Sólidos II no se cumple, ya que el clarificador está sobrecargado. Sin embargo, por debajo de la línea horizontal (que depende de la posición de la línea de carga limitante (CMS I)), no se garantiza que el clarificador opera a una carga baja.

- Línea del CMS I. La carga de sólidos permitido de acuerdo con el CMS I aumenta al aumentar la tasa o relación de recirculación. Este concepto de carga mínima se ha explicado anteriormente en la Figura 12.21, y es equivalente a una serie de condiciones de carga crítica, cuando la línea de recirculación es tangencial al flujo por gravedad del Diagrama del punto de estado. La ecuación de esta línea (sin detallar el desarrollo) está descrita con las ecuaciones 12.9 y 12.10. Si el punto de operación cae por debajo de esta línea, el CMS I es satisfecho.

$\frac{Q_{I}}{A}=\frac{v_{0}}{R} \cdot \frac{1+\alpha}{1-\alpha} e^{\frac{-p_{\text {hin }}(1+R) \cdot X_{F} \cdot(1+\alpha)}{2 R}}$

donde:

$\alpha=\sqrt{1-\frac{4 R}{p_{\text {hin }} \cdot(1+R) \cdot X_{F}}}$

- Criterio de la línea límite. De acuerdo con el principio ilustrado en la Figura 12.20, por encima de una cierta tasa de recirculación $(\mathrm{R})$ no es posible determinar una concentración crítica y una carga mínima de sólidos. El criterio de la línea límite o de frontera se encuentra entre (i) las tasas de recirculación más bajas, donde se puede encontrar una carga crítica y (ii) las tasas de recirculación más altas donde no se puede encontrar una carga crítica. Se puede observar que la tasa de recirculación crítica (por encima del cual una carga mínima no existe) es una función hiperbólica del tipo:

$\frac{Q_{I}}{A}=\frac{v_{0}}{e^{2} \cdot R}$

donde:

$\mathrm{q}_{\mathrm{R}, \text { crit }} \quad \mathrm{v}_{0} / \mathrm{e}^{2}(\mathrm{~m} / \mathrm{h})$, y representa la pendiente de la curva de carga por gravedad en su punto de inflexión, que se produce en los valores del doble de $X$ (a $2 / p_{\text {hin }}$ ) de la carga máxima por gravedad (a $\left.1 / \mathrm{p}_{\text {hin }}\right)$. 
Los nueve posibles casos de carga mostrados en la Figura 12.26 también se pueden demostrar en el diagrama D\&O de Ekama (Figura 12.28). Sin embargo, aquí sólo se muestra un detalle de toda la gráfica de la Figura 12.27.

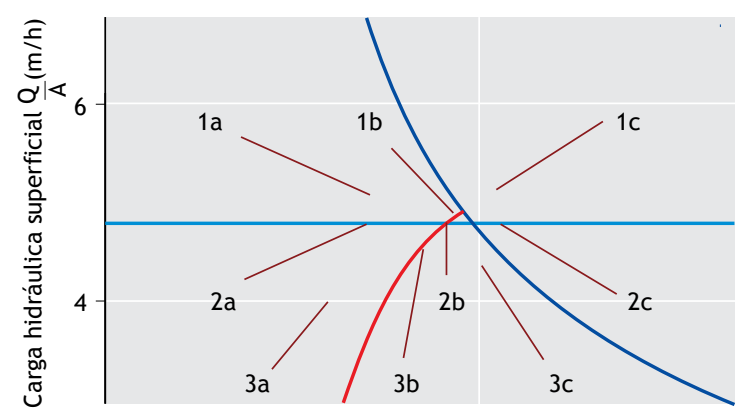

Figura 12.28 Ejemplos de carga en gráfica de D\&O

\subsection{RESUMEN DEL USO DE LA TEORÍA DE CARGA DE SÓLIDOS Y OTROS MÉTODOS DE DISEÑO Y OPERACIÓN}

La teoría de las cargas de sólidos no es el único método actualmente en uso para el diseño de sedimentadores. De hecho, muchas empresas consultoras y contratistas tienen sus propios métodos de diseño basados en la experiencia práctica y de diseño. El uso de la dinámica de fluidos computacional (véase Sección 12.6) para el diseño detallado de los sedimentadores se ha extendiendo en la práctica. Hay varios estándares de diseño en varios países, por ejemplo, en el Reino Unido (WRC), Alemania (ATV) y Países Bajos (STOWA). Estas directrices y métodos de diseño son ampliamente utilizados en estos países y sus países vecinos. El principio de los cinco procedimientos de diseño más ampliamente utilizados (incluyendo la teoría de la carga) se resume a continuación. El objetivo es ilustrar la variedad de principios que se utilizan en estos métodos, sin proporcionar una detallada guía paso a paso de ellos. Para llevar a cabo un procedimiento de diseño actual, el lector debe seguir los pasos originales en las directrices mencionadas. Dado que sólo los elementos más importantes de los procedimientos de diseño se utilizan en estos ejemplos, el clarificador diseñado con el procedimiento real podría ser significativamente diferente al de los resultados de estos ejemplos.

Los siguientes ejemplos simplificados se enfocan en dos parámetros de diseño específicos: (i) Área: qué tan grande debe ser el clarificador para ser capaz de manejar las cargas máximas, y (ii) la capacidad de la bomba de recirculación: ¿qué tipo de bombas de recirculación deben ser instaladas para la operación durante la operación con lluvia y en periodos de sequía?

Los métodos utilizan ecuaciones algebraicas relativamente simples, y por lo general se pueden calcular a mano o en una simple hoja de cálculo. Todos los métodos de diseño requieren que se especifique la carga para la cual está diseñado el clarificador. En estos ejemplos se utilizan los valores presentados en la Tabla 12.1.

De la Tabla 12.1, el pico diurno esperado en un periodo de sequía o sin lluvias en esta planta será de $1,500 \mathrm{~m}^{3} / \mathrm{h}$, y con lluvias se tiene que emplear un flujo máximo de $2,500 \mathrm{~m}^{3} / \mathrm{h}$ para el diseño. Algunos métodos de diseño representan la masa de sólidos transferidos al sedimentador durante las condiciones de flujo máximo (picos del flujo), lo que resulta en una disminución temporal de la concentración de SSLM en el reactor $\left(\mathrm{X}_{\mathrm{F}, \mathrm{PWWF}}\right)$.

Varios métodos de diseño requieren diferentes medidas de las propiedades de sedimentación de los lodos (es decir, vo y $\mathrm{p}_{\text {hin, }}$ o IVL y IVLD, etc.). Los siguientes ejemplos de diseño se basan en un mismo lodo que tiene o cuenta con una buena capacidad de sedimentación. Las propiedades de sedimentación de lodos de esta muestra se midieron utilizando todos los métodos diferentes necesarios, que permiten una comparación directa de los métodos y el diseño resultante del clarificador. En un caso real de diseño los parámetros de sedimentación de los lodos deben ser tomados en cuenta de un modo más conservador.

Tabla 12.1 Ejemplo de diseño de un clarificador y su carga

\begin{tabular}{llll}
\hline Parámetro & Símbolo & Valor & Unidades \\
\hline SSLM y caudal en periodos sin lluvia (DWF) & $\mathrm{X}_{\mathrm{F}, \mathrm{DWF}}$ & 3.5 & $\mathrm{~kg} / \mathrm{m}^{3}$ \\
Flujo promedio en periodos sin lluvia & $\mathrm{Q}_{\mathrm{ADWF}}$ & 1,000 & $\mathrm{~m}^{3} / \mathrm{h}$ \\
Factor de pico diurno (en periodos sin lluvias) & $\mathrm{PF}_{\mathrm{DW}}$ & 1.5 & - \\
Factor de pico de tormentas de lluvia & $\mathrm{PFWW}_{\mathrm{W}}$ & 2.5 & - \\
\hline
\end{tabular}




\subsubsection{Diseño empleando la teoría de las cargas de sólidos}

Los parámetros de sedimentación de Vesilind para el lodo se determinaron con base en una serie de experimentos de zona de sedimentación (Figura 12.16, resultados de la Tabla 12.2). En la aplicación práctica de la teoría de las cargas, se recomienda que se incremente el área superficial (reduciendo el flujo permitido) por un factor de seguridad de $25 \%$ en comparación con el valor teórico. Esto se debe tener en cuenta para la operación no ideal en la estructura real de clarificador, en contraste con la aproximación 1-D ideal establecida en la teoría de cargas (Ekama y Marais 2004).

Los parámetros que se utilizarán en el diseño se despliegan en la Tabla 12.2. No se requiere más información (que no sea de la Tabla 12.1 y la Tabla 12.2) para realizar el diseño por medio de la teoría de las cargas de sólidos.

\section{Pasos de diseño:}

1) La velocidad de sedimentación a una concentración de SSLM dada (Criterio de Manejo de sólidos II) se calcula a partir de la ecuación $12.5\left(\mathrm{v}_{\mathrm{s}, \mathrm{MLSS}}=16.8 \cdot \mathrm{e}^{(-}\right.$ ${ }^{0.36 \cdot 3.5)}=4.8 \mathrm{~m} / \mathrm{h}$ ).

2) La carga hidraúlica superficial durante PWWF no debe exceder esta velocidad, por lo tanto, la superficie mínima requerida es de $523.6 \mathrm{~m}^{2}(=2,500 / 4.8)$.

3) La tasa de recirculación se puede seleccionar mediante dos métodos (los cuales proporcionan los mismos resultados):

a) La tasa mínima de recirculación que satisface los CMS se puede leer en la intersección de las líneas I y II en la gráfico de D\&O de Ekama (Ekama $\mathrm{D} \& \mathrm{O}$ en la hoja de datos) $(\mathrm{R}=0.45)$.

b) Utilizando el diagrama de análisis del punto de estado, las tasas de recirculación que hacen que se puede encontrar la línea de descarga tangente a la curva de flujo por gravedad. Esto se hace tanto para PWWF como para PDW:
- En PWWF se requiere una tasa de recirculación de 0.44 , resultando en un flujo de recirculación de $1,100 \mathrm{~m}^{3} / \mathrm{h}$.

- En PDWW se requiere una tasa de recirculación de 0.31 resultando en un flujo de recirculación de $465 \mathrm{~m}^{3} / \mathrm{h}$.

c) Debido a consideraciones prácticas, se pueden eligir dos bombas, cada una con una capacidad de $550 \mathrm{~m}^{3} / \mathrm{h}$. Por lo tanto, la capacidad total de recirculación será de $1,100 \mathrm{~m}^{3} / \mathrm{h}$.

4) Se aplica el factor de seguridad de $25 \%$ (el área mínima es ahora de $654.5 \mathrm{~m}^{2}$ )

5) Debido a consideraciones prácticas (dibujos de diseño estándar, número de unidades, etc.) el área real elegida podría ser algo mayor que el mínimo requerido teóricamente. En este caso, se escogió $700 \mathrm{~m}^{2}$.

6) La tasa de descarga durante PWWF es 2,500/700 = $3.6 \mathrm{~m} / \mathrm{h}$

7) El área final elegida $\left(700 \mathrm{~m}^{2}\right)$ y los flujos de recirculación son 550 y $1,100 \mathrm{~m}^{3} / \mathrm{h}$, y

a) El punto de Estado y de posición de la línea de flujo de recirculación se pueden verificar en los diagramas de PWWF y de estado de punto de PDWF (similares a la Figura 12.26).

b) El punto de operación en el diagrama de D\&O de Ekama se puede comprobar y así asegurar que cae en la zona de funcionamiento seguro (por debajo de CMS II y a la derecha de CMS I en la Figura 12.27).

\subsubsection{Diseño empírico}

Las reglas de diseño empírico se basan en experiencias prácticas en ingeniería (a menudo local) y, como tal, son muy variadas y dependen de distintos países y áreas. El ejemplo utilizado en este libro se utiliza solo para mostrar los principios de este método de diseño (y no debe interpretarse un método siempre válido en general).

Tabla 12.2 Parámetros de diseño empleados en la teoría de cargas de sólidos

\begin{tabular}{lccc}
\hline Parámetro & Símbolo & Valor & Unidades \\
\hline Velocidad de sedimentación inicial & $\mathrm{V}_{0}$ & 16.8 & $\mathrm{~m} / \mathrm{h}$ \\
Parámetro de sedimentación obstaculizada & $\mathrm{p}_{\text {hin }}$ & 0.36 & $\mathrm{~m}^{3} / \mathrm{kg}$ \\
Factor de seguridad sobre el área & $\mathrm{F}_{\mathrm{A}}$ & 25 & $\%$ \\
\hline
\end{tabular}


La selección del área requerida para el sedimentador se puede basar en la determinación de la carga hidráulica máxima y/o en la carga de sólidos máxima especificada (tal como se presenta en este ejemplo) o de otros criterios. En este caso, se prevé un máximo de $1 \mathrm{~m} / \mathrm{h}$ para PDWF y $2.5 \mathrm{~m} / \mathrm{h}$ para PWWF. Además, el clarificador no debe ser cargado con más de $6 \mathrm{~kg} / \mathrm{m}^{2}$.h durante el tiempo sin lluvia y $15 \mathrm{~kg} / \mathrm{m}^{2} . \mathrm{h}$ temporalmente durante las lluvias. Cada una de estas especificaciones dará como resultado un área requerida para el clarificador. El área más grande será seleccionada, en este caso, $1,108 \mathrm{~m}^{2}$. Las tasas de recirculación entre 0.5 y 1.0 son usualmente satisfactorias.

Este diseño de clarificador resulta en un clarificador significativamente mayor en comparación con el diseño basado en la teoría de flujo $\left(1,100 \mathrm{~m}^{2}\right.$ frente a $\left.700 \mathrm{~m}^{2}\right)$. Esto es debido en gran parte a las excelentes propiedades de sedimentación de los lodos utilizados en este ejemplo $\left(\mathrm{v}_{0}=16.8 \mathrm{~m} / \mathrm{h}, \mathrm{IVL}=60 \mathrm{ml} / \mathrm{g}, \mathrm{IVLA}_{3.5}=48 \mathrm{ml} / \mathrm{g}\right.$ ), que no se consideran en absoluto los criterios de diseño empíricos. En la práctica, se seleccionan parámetros más conservadores de sedimentación de los lodos, incluso si hay evidencia de que el proceso biológico produzca constantemente lodos de una buena capacidad de sedimentación.

\subsubsection{Diseño WRC}

El procedimiento de diseño WRC se basa en la prueba de IVLA $_{3.5}$, que proporciona la medida más fiable de sedimentación (descrito en la Sección 12.3). El IVLA 3.5 de los lodos utilizados en este ejemplo fue de $48 \mathrm{ml} / \mathrm{g}$ (el cual corresponde a un lodo con una muy buena sedimentación y compactación). El método de diseño WRC se presenta y se utiliza aquí tal y como se describe en el reporte científico y técnico de la IWA con una pequeña extensión (IWA Scientific and Technical Report No.6, Ekama et. al, 1997). La extensión se compone de una relación empírica entre la tasa de recirculación crítica y la IVLA 3.5 . De acuerdo con la teoría de flujo, en la cual se basa el WRC, la carga hidráulica superficial sólo puede aumentar hasta la velocidad crítica de recirculación. El método original WRC no tiene esa característica, ya que siempre da una carga hidráulica superficial superior para una tasa de recirculación más alta. La modificación, presentada más abajo en el paso 1, encuentra la tasa de recirculación crítica a partir del IVLA por lo tanto permitiendo calcular la carga hidráulica superficial máxima. Para tasas de recirculación mayores a la crítica, la carga hidráulica superficial no se debe aumentar (con la finalidad de que cumpla con el CMS II de la teoría de cargas de sólidos).

\section{Pasos de diseño:}

1) La tasa de recirculación crítica se calcula con la ecuación $12.12 \mathrm{a}$.

$q_{R, \text { crit }}=1.612-0.00793 \cdot I V L A_{3.5}-$
$0.0015 \cdot \max \left(O,\left(I V L A_{3.5}-125\right)\right)^{1.115}$

Obteniendo $1.23 \mathrm{~m} / \mathrm{h}$.

2) El área requerida se calcula a partir de una ecuación empírica que se obtuvo con base en los parámetros de flujo de sedimentación medidos en 30 plantas en el Reino Unido y correlacionados con el IVLA 3.5 .

$A=\left(\frac{X_{F} \cdot Q_{P W W F}}{306.86 \cdot q_{R, \text { crit }}^{0.68} \cdot I V L A_{3.5}^{-0.77}-X_{F} \cdot q_{R, \text { crit }}}\right)$

El área calculada para el flujo de lluvias es de $642 \mathrm{~m}^{2}$, que es más grande que el área requerida para PDWF.

3) Se aplica el factor de seguridad de $25 \%$ (el área mínima es ahora $802 \mathrm{~m}^{2}$ ).

4) La tasa de descarga PWWF es $2,500 / 802=3.1 \mathrm{~m} / \mathrm{h}$.

\subsubsection{Diseño ATV}

La guía de diseño ATV (recientemente DWA) provee en detalle, una orientación práctica y detallada para muchos aspectos del diseño final de los sedimentadores, como el área, profundidad, tasa de recirculación, vertedores de descarga del efluente, el tiempo de compactación, el número de puentes, la posición de lavado de efluentes, deflectores, etc. Esta guía tiene en cuenta los cambios dinámicos, como los sólidos transferidos al clarificador durante un evento de tormenta, causando una reducción en los SSLM y una reducción en la carga de sólidos. En este capítulo sólo se proporciona un cálculo simplificado para ilustrar el principio.

El principio de diseño de ATV 1976 (y STOWA) se basa en la prueba de IVLD. La prueba IVLD es esencialmente una prueba de IVL realizada en condiciones más uniformes: diluyendo la muestra de lodo con efluente de tal manera que el volumen sedimentado esté en el rango de 150-250 ml. Basado en el IVLD, se 
introducen dos conceptos relacionados con el volumen de lodo sedimentado:

$\mathrm{VSD}_{30}$ es el volumen sedimentado de los SSLM bajo las condiciones de la prueba:

$$
V S D_{30}=X_{F} \cdot I V L D \quad(\mathrm{ml} / \mathrm{l})
$$

La tasa de carga del volumen de lodos ( $\mathrm{q}_{\mathrm{vs}}$ en $\left.1 / \mathrm{m}^{2} / \mathrm{h}\right)$ es

$$
q_{V S}=Q_{i} / A \cdot V S D_{30} \quad\left(1 / \mathrm{m}^{2} / \mathrm{h}\right)
$$

que es la tasa volumétrica de lodo sedimentado descargado en el clarificador, de forma análoga a la carga de sólidos, pero expresado en volumen en lugar de masas.

Pasos de diseño:

1) La tasa de descarga admisible depende de $\mathrm{DSV}_{30}$.

$$
\begin{aligned}
& q_{0}=2400 \cdot V S D_{30}^{-1.34} \\
& \text { el cálculo es } q_{o}=1.86 \mathrm{~m} / \mathrm{h} \\
& \text { 2) } q_{o} \text { debe ser menor a } 1.6 \mathrm{~m} / \mathrm{h} \text {. }
\end{aligned}
$$

3) El área requerida para por PWWF es $2,500\left(\mathrm{~m}^{3} / \mathrm{h}\right) / 1.6$ $(\mathrm{m} / \mathrm{h})=1,563 \mathrm{~m}^{2}$.

4) Por consideraciones prácticas se selecciona 1,500 m.

5) La tasa de recirculación requerida se basa en la capacidad de compresión de los lodos, la concentración máxima de sólidos se puede alcanzar en las condiciones dadas, que se estima a partir de la prueba de IVLD.

Bajo condiciones promedio sin lluvias:

$$
X_{R, A D W F}=\frac{1200}{I V L D}
$$

Bajo condiciones de flujo con lluvias:

$$
X_{R, P W W F}=\frac{1200}{I V L D}+2
$$

donde:

$\mathrm{X}_{\mathrm{R}, \mathrm{ADWF}} 20.0(1,200 / 60)$
$\begin{array}{llllll}\mathrm{X}_{\mathrm{R}, \mathrm{PWWF}} & 22.0 \quad(1,200 / 60+2) & (\mathrm{g} / \mathrm{l}) & \text { son } & \text { las }\end{array}$ concentraciones de recirculación y son calculadas, respectivamente.

6) El flujo de recirculación necesario es calculado con base en un simple balance de masas, presentado en la Ec. 12.18 .

$\left(Q_{I}+Q_{R}\right) \cdot X_{F}=Q_{R} \cdot X_{R}$

donde:

QI Caudal afluente $\left(\mathrm{m}^{3} / \mathrm{h}\right)$

$\mathrm{Q}_{\mathrm{R}} \quad$ Caudal de recirculación $\left(\mathrm{m}^{3} / \mathrm{h}\right)$

$\mathrm{X}_{\mathrm{F}} \quad$ Concentración de sólidos en la alimentación o entrada al clarificador, el cual corresponde a la concentración de sólidos suspendidos del licor mezclado en el reactor $\left(\mathrm{kg} / \mathrm{m}^{3}\right)$

$\mathrm{X}_{\mathrm{R}} \quad$ Concentración de lodos en el caudal de recirculación $\left(\mathrm{kg} / \mathrm{m}^{3}\right)$

Para las dos condiciones se calcularon los caudales de recirculación de lodos 212 y $473 \mathrm{~m}^{3} / \mathrm{h}$, respectivamente. Por consideraciones prácticas se puede seleccionar una bomba de $500 \mathrm{~m}^{3} / \mathrm{h}$.

\subsubsection{Diseño STOWA}

El procedimiento de diseño por medio de STOWA está basado en el diseño ATV.

Pasos de diseño:

1) Calcular la tasa de flujo permisible de descarga de acuerdo con la Ec. 12.19. La tasa de flujo permisible de descarga depende de $\mathrm{VSD}_{30}$ o también denominado $\mathrm{DSV}_{30}$ (por sus siglas en inglés)

$q_{0}=\frac{1}{3}+\frac{200}{D S V_{30}} \quad(\mathrm{~m} / \mathrm{h})$

Se calcula $\mathrm{q}_{0}=1.29 \mathrm{~m} / \mathrm{h}$.

2) Se calcula la tasa de carga de volumen de lodos de acuerdo con la ecuación (13). Se obtiene $\mathrm{q}_{\mathrm{vs}}=270 \mathrm{l} / \mathrm{m}^{2} / \mathrm{h}$. Esta tasa debe estar entre 300 y 400 $1 / \mathrm{m}^{2} / \mathrm{h}$ por lo que 300 se usará para el cálculo del área.

3) La tasa de descarga permisible es calculada a partir de $\mathrm{q}_{\mathrm{o}}=\mathrm{q}_{\mathrm{vs}} / \mathrm{VSD}_{30}=\mathrm{q}_{\mathrm{sv}} /\left(\mathrm{X}_{\mathrm{F}} \cdot \mathrm{IVLD}\right)=300 /(60 \cdot 3.5)=$ $1.43 \mathrm{~m} / \mathrm{h}$. 
4) Por lo tanto, durante las condiciones de ADWF, es necesaria un área de $1,000\left(\mathrm{~m}^{3} / \mathrm{h}\right) / 1.43 \quad(\mathrm{~m} / \mathrm{h})$ $=700 \mathrm{~m}^{2}$.

5) Durante el caudal en época de lluvias, los sólidos transferidos temporalmente al clarificador y la consecuente caída en los SSLM se tienen en cuenta en el paso 3. El cálculo real es iterativo hasta que los sólidos de carga y los lodos almacenados en el lecho del clarificador, se sujeten y ajusten a las condiciones reales. La máxima reducción en $\mathrm{X}_{\mathrm{F}}$ permitida es $30 \%$, y esto se utilizará en este ejemplo simplificado. Por lo tanto, en condiciones PWWF, el área requerida será $0.7 \cdot 2,500\left(\mathrm{~m}^{3} / \mathrm{h}\right) / 1.43(\mathrm{~m} / \mathrm{h})=1,225 \mathrm{~m}^{2}$.

6) Para consideraciones prácticas se selecciona un área de $1,200 \mathrm{~m}^{2}$.

7) El flujo de recirculación puede ser calculado de manera idéntica al método ATV, resultando en una bomba con una capacidad de $500 \mathrm{~m}^{3} / \mathrm{h}$.

\subsubsection{Comparación de los sedimentadores diseñados utilizando diferentes métodos}

Es claro que de los ejemplos anteriores, que se emplean en todo el mundo diferentes principios de diseño del clarificador y la demostración simplificada descrita en este capítulo nos lleva a diferentes tipos de cargas hidráulicas superficiales y de recirculación de lodos (Tabla 12.3). Los clarificadores diseñados con base en la teoría de las cargas de sólidos y el uso de los principios del WRC tienen un área superficial relativamente más pequeña, y requieren bombas más grandes para eliminar el lodo sedimentado desde la parte inferior, a una concentración menor. El ATV y las guías de STOWA conducen a la construcción de sedimentadores más grandes, y cuentan con buena capacidad de compactación de lodos (como es el caso de los lodos empleados en esta demostración) que requiere tasas de bombeo de recirculación más bajas.

\subsection{MODELADO DE SEDIMENTADORES SECUNDARIOS}

Los modelos de sedimentadores secundarios, solos o junto con un modelo del proceso de lodos activados, se utilizan habitualmente en la ingeniería de procesos y el trabajo de diseño. Dependiendo de los objetivos del modelado, están disponibles diferentes niveles de conceptualización. Los dos más utilizados en la práctica son a) el flujo basado en una dimensión (1-D), que son modelos en conjunto con modelos de lodos activados, y b) los modelos computacionales de dinámica de fluidos (CDF) (2-D o 3-D), los cuales se puede utilizar para ayudar al diseño detallado del clarificador. La Figura 12.29 muestra tres diferentes tipos de modelos que se presentarán brevemente en este capítulo.

\subsubsection{Modelos adimensionales}

Esta representación simple es un modelo de un clarificador sin dimensiones de volumen, sin área o profundidad. El único propósito de estos modelos es a menudo el de ayudar a mantener los SSLM en el sistema, y el concepto se basa esencialmente en la obtención de

Tabla 12.3 Tabla de resumen comparativa del diseño de un clarificador secundario por diversos métodos

\begin{tabular}{|c|c|c|c|c|c|c|}
\hline Parámetro & Unidades & Empírico & Carga & WRC & ATV (1976) & STOWA \\
\hline Área del sedimentador & $\mathrm{m}^{2}$ & 1,108 & 700 & 802 & 1,500 & 1,200 \\
\hline \multicolumn{7}{|l|}{ ADWF $1,000 \mathrm{~m}^{3} / \mathrm{h}$} \\
\hline Tasa de descarga & $\mathrm{m} / \mathrm{h}$ & 0.90 & 1.43 & 1.25 & 0.67 & 0.83 \\
\hline Tasa de recirculación & $\mathrm{m} / \mathrm{h}$ & 0.81 & 0.79 & 1.25 & 0.33 & 0.42 \\
\hline \multicolumn{2}{|c|}{ Concentración de sólidos de retorno $\mathrm{kg} / \mathrm{m}^{3}$} & 7.39 & 9.86 & 7.00 & 10.50 & 10.50 \\
\hline Tasa de carga de sólidos & $\mathrm{kg} / \mathrm{m}^{2} / \mathrm{h}$ & 6.00 & 7.75 & 8.72 & 3.50 & 4.38 \\
\hline \multicolumn{7}{|l|}{ PDWF $1,500 \mathrm{~m}^{3} / \mathrm{h}$} \\
\hline Tasa de descarga & $\mathrm{m} / \mathrm{h}$ & 1.35 & 2.14 & 1.87 & 1.00 & 1.25 \\
\hline Tasa de recirculación & $\mathrm{m} / \mathrm{h}$ & 1.20 & 0.64 & 1.25 & 0.33 & 0.42 \\
\hline \multicolumn{2}{|c|}{ Concentración de sólidos de retorno $\mathrm{kg} / \mathrm{m}^{3}$} & 9.33 & 13.05 & 8.75 & 14.00 & 14.00 \\
\hline Tasa de carga de sólidos & $\mathrm{kg} / \mathrm{m}^{2} / \mathrm{h}$ & 7.58 & 10.25 & 10.91 & 4.67 & 5.83 \\
\hline \multicolumn{7}{|l|}{ PWWF $2,500 \mathrm{~m}^{3} / \mathrm{h}$} \\
\hline Tasa de descarga & $\mathrm{m} / \mathrm{h}$ & 2.26 & 3.57 & 3.12 & 1.67 & 2.08 \\
\hline Tasa de recirculación & $\mathrm{m} / \mathrm{h}$ & 0.90 & 1.57 & 1.25 & 0.33 & 0.42 \\
\hline \multicolumn{2}{|c|}{ Concentración de sólidos de retorno $\mathrm{kg} / \mathrm{m}^{3}$} & 12.25 & 11.45 & 12.25 & 21.00 & 21.00 \\
\hline Tasa de carga de sólidos & $\mathrm{kg} / \mathrm{m}^{2} / \mathrm{h}$ & 11.05 & 18.00 & 15.27 & 7.00 & 8.75 \\
\hline
\end{tabular}



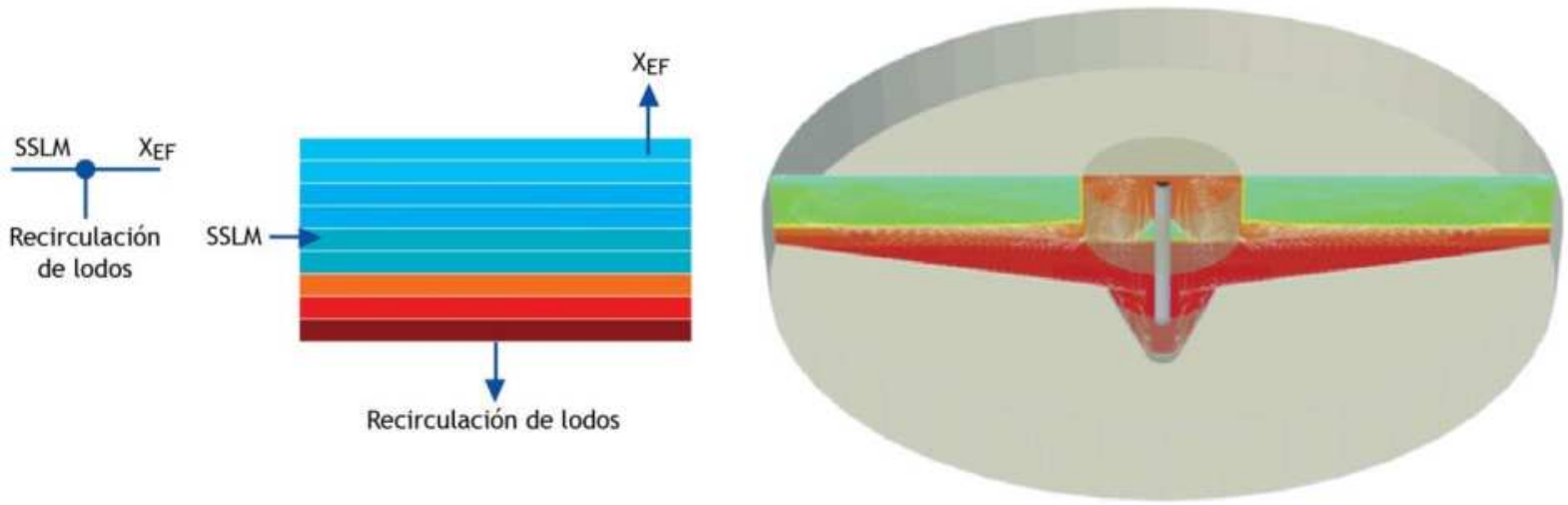

Figura 12.29 Representación del mismo clarificador de manera Adimensional ,1-D y D2-D (imagen: MMI Engineering)

un equilibrio de masas instantánea alrededor del clarificador (por ejemplo, con la ecuación 12.18). La concentración de sólidos en la recirculación de lodos, $\mathrm{X}_{\mathrm{R}}$, (en caso de ser calculada) puede ser expresada a partir de la ecuación 12.18, si se conocen los flujos y la concentración de los SSLM en el sistema en operación. En este modelo, los sólidos presentes en el efluente pueden ser ignorados. La mayoría de los primeros modelos de simulación de lodos activados anteriores a 1990 utilizan este enfoque, ya que su atención se centró en el rendimiento biológico y únicamente en los componentes solubles en el efluente. También es posible calcular los sólidos en el efluente utilizando aproximaciones empíricas simples, por lo general relacionados con los SSLM de entrada (porciento de remoción) o flujo de sólidos aplicado. En este caso, las pérdidas de sólidos a través de los efluentes tienen que ser incluidos en la ecuación 12.18.

\subsubsection{Modelos unidimensionales}

Estos modelos toman en cuenta el volumen del sedimentador. Existen variaciones en esta categoría, incluyendo los modelos simples de dos compartimientos (que sólo consideran la zona clarificada y el lecho de lodo), o una mezcla de balances de masa y basados en modelos empíricos que estiman el flujo de recirculación, efluente y las concentraciones en los lechos y mantos de lodos utilizando diversas ecuaciones algebraicas.

El modelo más ampliamente usado en esta categoría es el modelo de flujo de capas 1-D. Este modelo representa al clarificador como una serie de capas horizontales. El movimiento horizontal se desprecia, de acuerdo con la teoría del flujo. No se distinguen tanques circulares y rectangulares en los modelos 1-D. Las cargas debidas a la recirculación y por sedimentación obtenidas basadas en los balances de masas dinámicas se implementan en cada capa, donde el resultado del modelo es un perfil vertical de sólidos (una sola concentración para cada capa). Aunque la teoría de las cargas de sólidos, como se describe en este capítulo, es la base de estos modelos, ya que no tienen en cuenta la sedimentación discreta ni la compresión de lodos, los modelos basados en estos principios no pueden por sí solos predecir los sólidos en el efluente o un lecho de lodos estable. Hay varias adiciones realizadas en modelos de flujo 1-D que pueden resultar en predicciones más realistas.

La presencia de un lecho de lodos se simula por (i) el uso de un pequeño número (8-15) de capas y la aproximación de un "mínimo de flujos" entre las capas vecinas. En este método, el más pequeño de los dos flujos se utiliza en cada capa, ya sea el que esta basado en la concentración actual de sólidos presente en la capa, o uno que puede ser dado por la capa superior, basado en su propia concentración de sólidos, o (ii) mediante la implementación de un proceso de difusión retromezclado o un proceso de difusión numérico que actúa entre capas. Los sólidos del efluente son simulados utilizando una adición a la función de Vesilind para tomar en cuenta la sedimentación discreta (por ejemplo, el modelo de doble exponencial). Hay esfuerzos en curso para reducir el empirismo en estos modelos y basar las predicciones en la descripción de la sedimentación discreta y compresión de los lodos.

Los modelos dinámicos 1-D debido a su estructura simple no añaden una carga computacional significativa al modelado de proceso y pueden predecir razonablemente las tres funciones principales de los sedimentadores secundarios (clarificación, espesamiento de lodos y almacenamiento). Estos modelos juegan un papel importante en conjunción con los lodos activados 
para las predicciones de globales del proceso de toda la planta.

Los sólidos en el efluente que se predicen de en estos modelos forman una parte importante de la calidad del efluente. Los sólidos de retorno se usan para determinar la purga y afectan el tiempo de retención de lodos, el espesamiento de los lodos y en general la carga y el rendimiento en la línea de sólidos. Por último, el almacenamiento de lodos (la predicción dinámica del lecho de lodo) tiene en cuenta los cambios en el inventario de sólidos del reactor, que pueden tener un efecto significativo en el rendimiento del proceso. En ciertas condiciones, existen reacciones biológicas o químicas que se producen en sedimentadores secundarios, por ejemplo la desnitrificación. Los modelos 1-D son, casi exclusivamente, utilizados para simular estas reacciones ya que los modelos adimensionales (0-D), a falta de un volumen de reactivo, no son adecuados para este propósito, y la implementación de modelos biológicos complejos en modelos hidrodinámicos 2-D y 3-D presenta una demanda computacional prohibitiva. Los modelos en capas 1-D no se pueden utilizar para investigar detalles sobre las estructuras del clarificador, por ejemplo, geometría del tanque o la colocación de un deflector. Se requieren modelos computacionales de dinámica de fluidos (CDF) 2-D o 3-D para este propósito.

\subsubsection{Modelos computacionales de dinámica de fluidos (CFD)}

Los modelos CFD se basan en la conservación de la masa del fluido (continuidad), conservación del impulso en direcciones horizontal y vertical, conservación de la masa de sólidos (transporte de sólidos en suspensión), la conservación de la entalpía (balance de calor), y un modelo de turbulencia. Para lograr una solución numérica estable, el sedimentador tiene que ser discretizado en una matriz fina (fine grid method), a menudo con decenas de miles de elementos de la red. En esta representación se puede dar cuenta de detalles físicos sutiles tales como deflectores, su geometría exacta, la colocación y el ángulo. El anterior conjunto de ecuaciones se resuelve posteriormente en cada nodo en cada paso de tiempo. Esto representa una carga computacional significativa, pero puede resultar en una imagen muy detallada de la distribución de los sólidos y los patrones de flujo en el clarificador como se muestra en la Figura 12.30 (ejemplo de un modelo CFD 2-D). Al adicionar una tercera dimensión, se aumenta aún más la complejidad y el tiempo de ejecución de estos modelos, por lo que sólo debe incluirse si es necesario.

El uso de modelos CFD se ha incrementado considerablemente en los últimos años, debido a los avances en la modelación hidrodinámica y la calibración de modelos. Los detalles de diseño de un clarificador suelen ser verificados u optimizados en un modelo CFD, antes de la implementación en el clarificador a gran escala. Un ejemplo se muestra en la Figura 12.31. En este



Figura 12.30 Resultados de un CFD 2-D (imagen: MMI Engineering) 


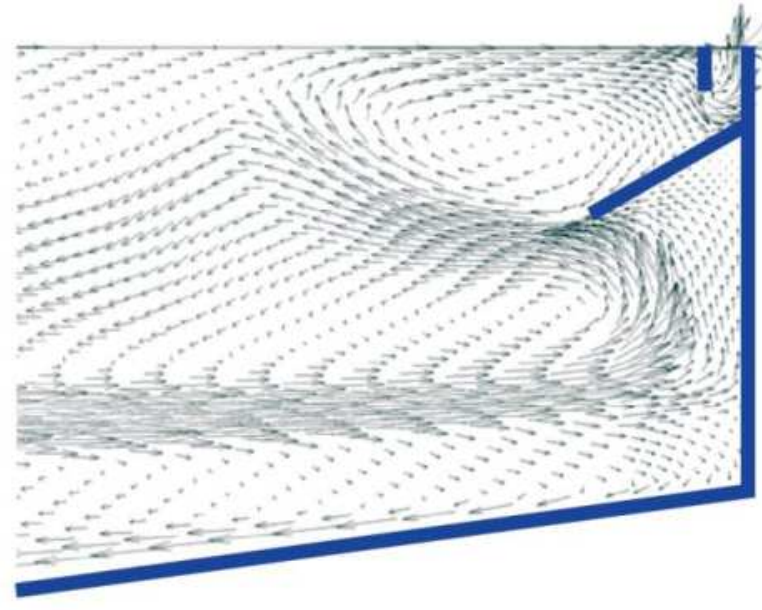

Con mamparas tipo Stamford

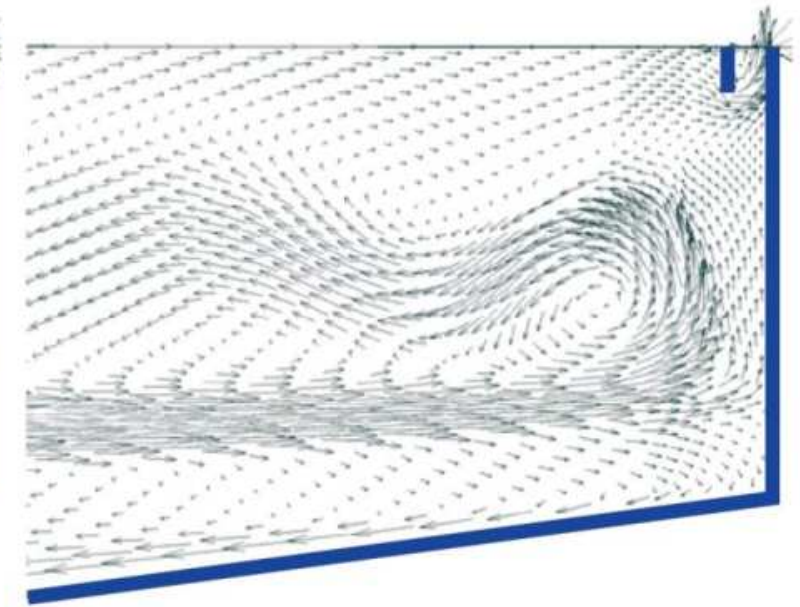

Sin mamparas tipo Stamford

Figura 12.31 Efecto de una mampara sobre los campos de flujo en los alrededores del vertedor (image: MMI Engineering)

caso, se simula un deflector de Stamford, que está diseñado para desviar el flujo lejos de la zona de vertedor del efluente. El efecto del deflector es claramente visible en el campo del flujo; sin embargo, en este caso, la simulación no predijo una mejora significativa en los sólidos en suspensión del efluente.

\subsection{EJEMPLOS DE DISEÑO}

Diseño de un clarificador. Es necesario establecer el área requerida del clarificador y la capacidad de la bomba de recirculación. Se pueden utilizar los métodos simplificados, como se describe en la Sección 12.5 para diseñar el clarificador para las condiciones esperadas de carga tal como se especifica en la Tabla 12.4.

En este caso, no se conocen las propiedades de sedimentación de los lodos, ya que el nuevo proceso que

Tabla 12.4 Especificaciones de diseño

\begin{tabular}{|c|c|c|c|}
\hline Parámetro & Símbolo & Valor & Unidades \\
\hline$\overline{\text { SSLM }}$ & $\mathrm{X}_{\mathrm{F}}$ & 3.2 & $\mathrm{~kg} / \mathrm{m}^{3}$ \\
\hline $\begin{array}{l}\text { ADWF, Flujo promedio bajo } \\
\text { condiciones sin lluvia }\end{array}$ & $\mathrm{Q}_{\mathrm{ADWF}}$ & 240 & $\mathrm{~m}^{3} / \mathrm{h}$ \\
\hline $\begin{array}{l}\text { Factor de pico diurno } \\
\text { (condiciones sin lluvia) }\end{array}$ & $\mathrm{PF}_{\mathrm{DW}}$ & 1.4 & \\
\hline $\begin{array}{l}\text { Factor de pico con tormentas } \\
\text { de lluvias }\end{array}$ & $\mathrm{PF}_{W w}$ & 2.8 & \\
\hline $\begin{array}{l}\text { Factor de seguridad para el } \\
\text { flujo teórico }\end{array}$ & $\mathrm{F}_{\mathrm{A}}$ & 1.25 & \\
\hline $\begin{array}{l}\text { Factor de seguridad del diseño } \\
\text { WRC }\end{array}$ & FWRC & 1.25 & \\
\hline
\end{tabular}

se construirá implementará la eliminación biológica de nutrientes, así como también recibirá $10 \%$ de una contribución industrial en el afluente. La planta actual del sitio hipotético no está obligada a nitrificar y no tiene ninguna entrada de afluente de algún comercio. Por tanto, se supone que los valores promedio de sedimentabilidad son los mostrados en la Tabla 12.5.

Tabla 12.5 Parámetros de sedimentación de lodos asumidos para el cálculo con los distintos métodos

\begin{tabular}{lccc}
\hline Parámetro & \multicolumn{3}{c}{ Símbolo Valor Unidades } \\
\hline IVL & IVL & 190 & $\mathrm{ml} / \mathrm{g}$ \\
IVLD & IVLD & 160 & $\mathrm{ml} / \mathrm{g}$ \\
$\begin{array}{lccc}\text { IVLA } 3.5 \\
\text { Velocidad de sedimentación }\end{array}$ & IVLA $_{3.5}$ & 120 & $\mathrm{ml} / \mathrm{g}$ \\
$\begin{array}{l}\text { inicial } \\
\begin{array}{l}\text { Parámetro de sedimentación } \\
\text { obstruida }\end{array}\end{array}$ & $\mathrm{v}_{0}$ & 5.82 & $\mathrm{~m} / \mathrm{h}$ \\
\hline
\end{tabular}

Los cálculos para este sedimentador se pueden realizar fácilmente a mano.

\section{Pasos para la solución}

Basados en la Tabla 12.4, el pico diurno sin condiciones de lluvias es $336 \mathrm{~m}^{3} / \mathrm{h}$, y el flujo pico en condiciones con lluvias (PWWF) es $672 \mathrm{~m}^{3} / \mathrm{h}$.

1) Diseño empleando la teoría de cargas de sólidos

a) La velocidad de sedimentación a una concentración de SSLM (Criterio de Manejo de Sólidos II) es calculada a partir de la ecuación 12.5 $(1.5 \mathrm{~m} / \mathrm{h})$. 
b) El área mínima requerida durante PWWF es $672 / 1.5=442.7 \mathrm{~m}^{2}$.

La tasa de recirculación mínima del diagrama de D\&O de Ekama es 0.49. Esta será una tasa de recirculación segura ya que no incluye todavía el factor de seguridad.

c) Usando el Análisis del Diagrama del punto de estado (SPA), se dibujan tangentes a la curva de gravedad desde el punto de estado, en PWWF PWWF $0.49\left(329 \mathrm{~m}^{3} / \mathrm{h}\right)$ y a PDWW de 0.32 , la tasa de recirculación es suficiente. La capacidad de la bomba de recirculación se selecciona a $330 \mathrm{~m}^{3} / \mathrm{h}$ (dos bombas).

d) Aplicando el factor de seguridad del 25\% (A = $553.4 \mathrm{~m}^{2}$ ). Lo cual se redondea a $550 \mathrm{~m}^{2}$.

\section{2) Diseño empírico}

La bomba de recirculación se ha seleccionado con $100 \%$ de recirculación de lodos para PDWF o $336 \mathrm{~m}^{3} / \mathrm{h}$. Con una carga hidráulica de $1 \mathrm{~m} / \mathrm{h}$ o una carga de $5 \mathrm{~kg}$ sólidos $/ \mathrm{m}^{2} / \mathrm{h}$ para PDWF y $2 \mathrm{~m} / \mathrm{h}$ de carga hidráulica o una carga de $5 \mathrm{~kg}$ sólidos $/ \mathrm{m}^{2} / \mathrm{h}$ para PWWF, la tasa de carga de $5 \mathrm{~kg} / \mathrm{m}^{2} / \mathrm{h}$ resulta en un clarificador con un área requerida más grande, de $3.2 \cdot(336+672) / 5=369 \mathrm{~m}^{2}$.

Este diseño resulta en un clarificador de menor tamaño en comparación con el diseño basado en la teoría del flujo. Esto se debe al método empírico no toma en cuenta las bajas propiedades de sedimentación esperadas de los lodos.

\section{3) Diseño WRC}

a) Se calcula la tasa de recirculación crítica resultando en $0.66 \mathrm{~m} / \mathrm{h}$ basado en la ec. $12.12 \mathrm{a}$.

b) El área requerida de acuerdo a la ec. $12.12 \mathrm{~b}$ para PWWF es $583 \mathrm{~m}^{2}$ y para PDWF es $292 \mathrm{~m}^{2}$. La más grande con el $25 \%$ de seguridad resulta en $729 \mathrm{~m}^{2}$.

c) La recirculación de PWWF es $481 \mathrm{~m}^{3} / \mathrm{h}$. Se elige una bomba de recirculación de $500 \mathrm{~m}^{3} / \mathrm{h}$. La tasa de descarga a PWWF es $672 / 729=0.92 \mathrm{~m} / \mathrm{h}$.
4) Diseño ATV

a) $\mathrm{El} \mathrm{VSD}_{30}$ de la ecuación 12.11 es $3.2 \cdot 160=512$ $\mathrm{ml} / \mathrm{l}$.

b) La tasa de descarga de la Ec. 12.13 es $0.56 \mathrm{~m} / \mathrm{h}$. Esta es menor que la máxima, $1.6 \mathrm{~m} / \mathrm{h}$.

c) El área necesaria para PWWF es $672\left(\mathrm{~m}^{3} / \mathrm{h}\right) / 0.56$ $(\mathrm{m} / \mathrm{h})=1,196 \mathrm{~m}^{2}$. Por lo que se selecciona como $1,200 \mathrm{~m}^{2}$ como resultado.

d) La concentración de lodo de retorno bajo condiciones ADWF (Ec. 12.16) es $7.5 \mathrm{~g} / \mathrm{l}$, y bajo condiciones PDWF (Ec. 12.17) es $9.5 \mathrm{~g} / 1$.

e) El flujo de recirculación, basado en el balance de la Ec. 12.18 es $179 \mathrm{~m}^{3} / \mathrm{h}$ durante ADWF y 341 $\mathrm{m} 3 / \mathrm{h}$ durante PWWF; por lo que se selecciona 350 $\mathrm{m}^{3} / \mathrm{h}$.

5) Diseño STOWA

a) $\mathrm{DSV}_{30}$ de la Ec. 12.11 es $3.2 \cdot 160=512 \mathrm{ml} / 1 \mathrm{El}$ flujo de descarga basado en la Ec. 12.19 es 0.72 $\mathrm{m} / \mathrm{h}$

b) La tasa de carga volumétrica de la eq 12.14 es 371 $1 / \mathrm{m}^{2} / \mathrm{h}$ (se encuentra entre 300 y $400 \mathrm{l} / \mathrm{m}^{2} / \mathrm{h}$ ). Por lo que se acepta el valor de $0.72 \mathrm{~m} / \mathrm{h}$.

c) El área requerida es 240/0.72 = $332 \mathrm{~m}^{2}$ para ADWF y usando la reducción máxima de SSLM de $70 \%, 0.7 \cdot 672 / 0.72=650 \mathrm{~m}^{2}$.

d) El flujo de recirculación, basado en el balance de masa mostrado en la ec. 12.20 , es $179 \mathrm{~m}^{3} / \mathrm{h}$ durante ADWF y $341 \mathrm{~m}^{3} / \mathrm{h}$ durante PWWF; seleccionando $350 \mathrm{~m}^{3} / \mathrm{h}$.

La Tabla 12.6 presenta un resumen de las áreas y la capacidad de bombas de recirculación seleccionadas empleando los diferentes métodos.

Tabla 12.6 Resumen de las áreas y la capacidad de las bombas de recirculación empleando los diferentes métodos de diseño

\begin{tabular}{lcccccc}
\hline & Unidades & $\begin{array}{c}\text { Teoría de } \\
\text { cargas }\end{array}$ & Empírico & WRC & ATV (1976) & STOWA \\
\hline Área del sedimentador & $\mathrm{m}^{2}$ & 550 & 369 & 729 & 1,200 & 650 \\
Bomba de recirculación & $\mathrm{m}^{3} / \mathrm{h}$ & 330 & 336 & 500 & 350 & 350 \\
\hline
\end{tabular}




\section{REFERENCIAS}

American Public Health Association, American Water Works Association, Water Environment Federation. (2006) Standard Methods for the Examination of Water and Wastewater.

Ekama G.A., Barnard J.L., Günthert F.W., Krebs P., McCorquodale, J.A., Parker D.S. and Wahlberg E.J. (1997) Secondary Settling Tanks: Theory, Modeling,
Design and Operation. IAWQ Scientific and Technical Reports \#6, IAWQ London.

Ekama G.A., Marais P. (2004) Assessing the applicability of the 1D flux theory to full-scale secondary settling tank design with a 2D hydrodynamic model. Wat. Res. 38(3), 495-506.

Water Environment Federation (2005) Clarifier Design Manual of Practice, No. FD-8, $2^{\text {nd }}$ Edn., McGraw-Hill, New York.

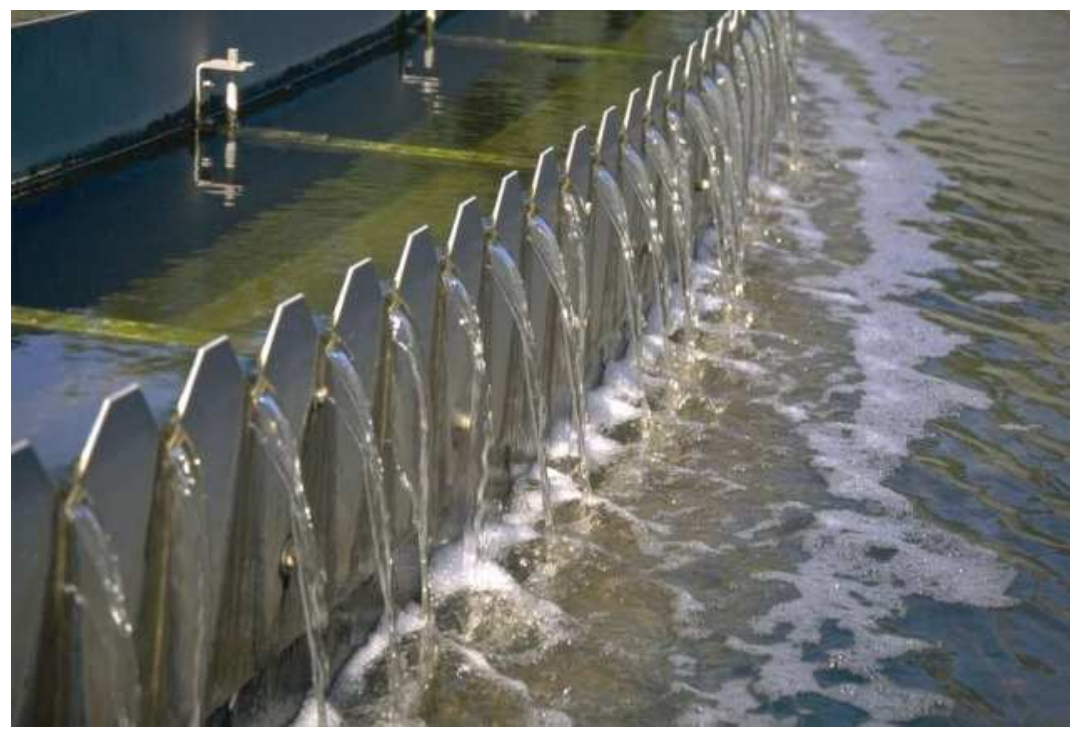

Ejemplo de un sedimentador secundario operado y mantenido apropiadamente, el cual produce un efluente de buena calidad

(Foto D.H. Eikelboom) 


\section{NOMENCLATURA}

\begin{tabular}{|c|c|c|}
\hline Símbolo & Descripción & Unidades \\
\hline$A$ & Área del sedimentador & $\mathrm{m}^{2}$ \\
\hline$D S V_{30}$ & $\begin{array}{l}\text { Volumen sedimentado de los SSLM después de } 30 \text { min bajo las } \\
\text { condiciones de la prueba }\end{array}$ & $\mathrm{ml} / 1$ \\
\hline$F_{A}$ & Factor de seguridad para el área de un clarificador secundario & - \\
\hline$G$ & Gradiente de velocidad & $\mathrm{s}^{-1}$ \\
\hline$j_{A P}$ & Carga total aplicada & $\mathrm{kg} / \mathrm{m}^{2} \cdot \mathrm{h}$ \\
\hline$J_{B}$ & Carga de sólidos debida al flujo de recirculación de lodos & $\mathrm{kg} / \mathrm{m}^{2} / \mathrm{h}$ \\
\hline$j_{I}$ & Carga de sólidos debida al efluente del clarificador & $\mathrm{kg} / \mathrm{m}^{2} \cdot \mathrm{h}$ \\
\hline$J_{L}$ & Carga de sólidos limitante, correspondiente a $\mathrm{X}_{\mathrm{L}}$ & $\mathrm{kg} / \mathrm{m}^{2} \cdot \mathrm{h}$ \\
\hline$j_{R}$ & Carga de sólidos debida a la recirculación de sólidos & $\mathrm{kg} / \mathrm{m}^{2} \cdot \mathrm{h}$ \\
\hline$J_{s}$ & Carga de sólidos debida a la sedimentación por gravedad & $\mathrm{kg} / \mathrm{m}^{2} . \mathrm{h}$ \\
\hline$p_{\text {hin }}$ & Parámetro de obstrucción de la sedimentación & $1 / \mathrm{g}$ or $\mathrm{m}^{3} / \mathrm{kg}$ \\
\hline$q_{I}$ & Carga hidráulica superficial & $\mathrm{m} / \mathrm{h}$ \\
\hline$Q_{I}$ & Caudal del afluente & $\mathrm{m}^{3} / \mathrm{h}$ \\
\hline$q_{o}$ & Carga hidráulica superficial admisible o permisible & $\mathrm{m} / \mathrm{h}$ \\
\hline$Q_{R}$ & Caudal de recirculación de lodos & $\mathrm{m}^{3} / \mathrm{h}$ \\
\hline$q_{R}$ & Carga hidráulica de recirculación & $\mathrm{m} / \mathrm{h}$ \\
\hline$q_{R, \text { crit }}$ & Carga crítica hidráulica de recirculación & $\mathrm{m} / \mathrm{h}$ \\
\hline$q_{s v}$ & Tasa de carga de volumen de lodos & $1 / \mathrm{m}^{2} / \mathrm{h}$ \\
\hline$R$ & Relación de la tasa de recirculación ( $\left.\mathrm{Q}_{\mathrm{R}} / \mathrm{Q}_{\mathrm{I}}\right)$ & - \\
\hline$v_{o}$ & Velocidad inicial de sedimentación & $\mathrm{m} / \mathrm{h}$ \\
\hline$v_{s}$ & Velocidad de sedimentación & $\mathrm{m} / \mathrm{h}$ \\
\hline$x$ & Concentración de los SSLM en varios test del tipo VZS & $\mathrm{g} / \mathrm{l}$ or $\mathrm{kg} / \mathrm{m}^{3}$ \\
\hline$X$ & Concentración de sólidos & $\mathrm{kg} / \mathrm{m}^{3}$ \\
\hline$X_{F}$ & $\begin{array}{l}\text { Concentración de sólidos en la alimentación o afluente de un clarificador } \\
\text { secundario }\end{array}$ & $\mathrm{kg} / \mathrm{m}^{3}$ \\
\hline$X_{L}$ & Concentración limitante de sólidos & $\mathrm{kg} / \mathrm{m}^{3}$ \\
\hline$X_{R}$ & Concentración de sólidos en los lodos de retorno & $\mathrm{kg} / \mathrm{m}^{3}$ \\
\hline Abreviatura & Descripción & \\
\hline ADWF & \multicolumn{2}{|c|}{ Caudal promedio bajo condiciones sin lluvia (Average dry weather flow, por sus siglas en inglés) } \\
\hline CFD & \multicolumn{2}{|l|}{ Modelos computacionales de dinámica de fluidos } \\
\hline IVLD & \multicolumn{2}{|l|}{ Índice volumétrico de lodos diluido } \\
\hline DWF & \multicolumn{2}{|l|}{ Caudal bajo condiciones sin lluvia (Dry weather flow, por sus siglas en inglés) } \\
\hline SSLM & \multicolumn{2}{|l|}{ Sólidos Suspendidos en el Licor Mezclado } \\
\hline PFDW & \multicolumn{2}{|l|}{ Factor pico diurno (condiciones sin lluvias) } \\
\hline PFWw & \multicolumn{2}{|l|}{ Factor pico de tormenta } \\
\hline PWWF & \multicolumn{2}{|c|}{ Caudal pico bajo condiciones con lluvias (Peak wet weather flow, por sus siglas en inglés) } \\
\hline LR & \multicolumn{2}{|l|}{ Sólidos de retorno } \\
\hline TDS & \multicolumn{2}{|l|}{ Tasa de descarga superficial } \\
\hline SPA & \multicolumn{2}{|l|}{ Análisis del punto de estado (State point analysis, por sus siglas en inglés) } \\
\hline IVLA $_{3.5}$ & \multicolumn{2}{|l|}{ Índice volumétrico de lodos agitado a una concentración de SSLM de 3.5 g/l } \\
\hline STOWA & \multicolumn{2}{|c|}{$\begin{array}{l}\text { Stichting Toegepast Onderzoek Waterbeheer (Fundación holandesa para la investigación aplicada en } \\
\text { manejo de agua) }\end{array}$} \\
\hline IVL & \multicolumn{2}{|l|}{ Índice volumétrico de lodos } \\
\hline VZSA & \multicolumn{2}{|l|}{ Velocidad de la zona de sedimentación con agitación } \\
\hline VZS & \multicolumn{2}{|l|}{ Velocidad de la zona de sedimentación } \\
\hline
\end{tabular}




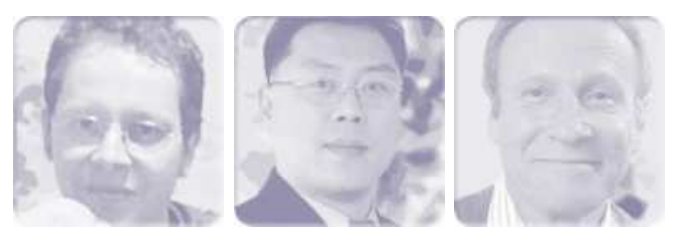

13

\section{Biorreactores de Membrana (MBR)}

\section{Simon Judd, Byung-goon Kim and Gary Amy}

\subsection{PRINCIPIOS DE SEPARACIÓN/FILTRACIÓN CON MEMBRANA}

Una membrana, en lo que respecta al tratamiento de agua y de aguas residuales, es simplemente un material que permite que algunos componentes físicos, químicos, o biológicos puedan pasar más fácilmente a través de ella que otros. Por lo tanto, se dice que las membranas son de permeabilidad selectiva, ya que son más permeable a los componentes que pasan a través de ella (que luego se convierten en el permeado - agua tratada) que aquellos que son rechazados (que forman el rechazo o concentrado). El grado de selectividad depende del tamaño de poro de la membrana. Las membranas de mayor tamaño de poro en el mercado se conocen y denominan como membranas de microfiltración (MF), y pueden rechazar materiales del tipo particulado y también retener alguna de las bacterias, dependiendo del tamaño de la bacteria. Las membranas de ultrafiltración (UF), poseen un tamaño de poro más pequeño que las de MF; adicionalmente de la remoción observada en membranas de MF, las de UF también pueden rechazar algunos virus (dependiendo nuevamente del tamaño de dichos virus). Las membranas de nanofiltración (NF), poseen un tamaño de poro aún más pequeño que las de UF, y por lo tanto es aún más selectiva que la de la UF, rechazando la mayor parte de la materia orgánica y muchos micro-contaminantes. La membrana de ósmosis inversa (OI), la de menor tamaño de poro, y se caracteriza por ser capaz de rechazar incluso materia tan pequeña como son iones monovalentes tales como el sodio $\left(\mathrm{Na}^{+}\right)$y el cloruro $\left(\mathrm{Cl}^{-}\right)$. Dado que el tamaño real de estos iones (o sea, el diámetro hidratado) por lo general es menor a un nanómetro, es lógico que el tamaño de los poros en una membrana de OI sean muy pequeños, de unos pocos nanómetros, mientras que el tamaño de los poros de membranas de microfiltración pueden ser mayores a una micra.

Los cuatro procesos principales de separación/filtración con membrana en los que el agua filtrada es parte del producto, o sea el permeado, son OI, NF, UF y MF (Figura 13.1). Las membranas se pueden clasificar de acuerdo al tipo de separación/filtración en los que se pueden utilizar, lo que directamente da una idea del tamaño de poro requerido de la membrana o del material a separar. El tamaño del poro se puede definir en términos del diámetro equivalente efectivo del poro, normalmente expresado ya sea en $\mu \mathrm{m}$, o en términos de la masa equivalente de la molécula más pequeña que puede ser

(ㄷ) 2017 Simon Judd. Tratamiento Biológico de Aguas Residuales: Principios, Modelación y diseño. Eds. M. Henze, M.C.M. van Loosdrecht, G.A. Ekama y D. Brdjanovic. Eds. (versión en español) C.M. López Vazquez, G. Buitrón Méndez, H.A. García, F.J. Cervantes Carrillo. ISBN (versión impresa): 9781780409139, ISBN (e-Book): 9781780409146. Publicado por IWA Publishing, London, UK. 
Escala en micrómetros $(\mu \mathrm{m})$

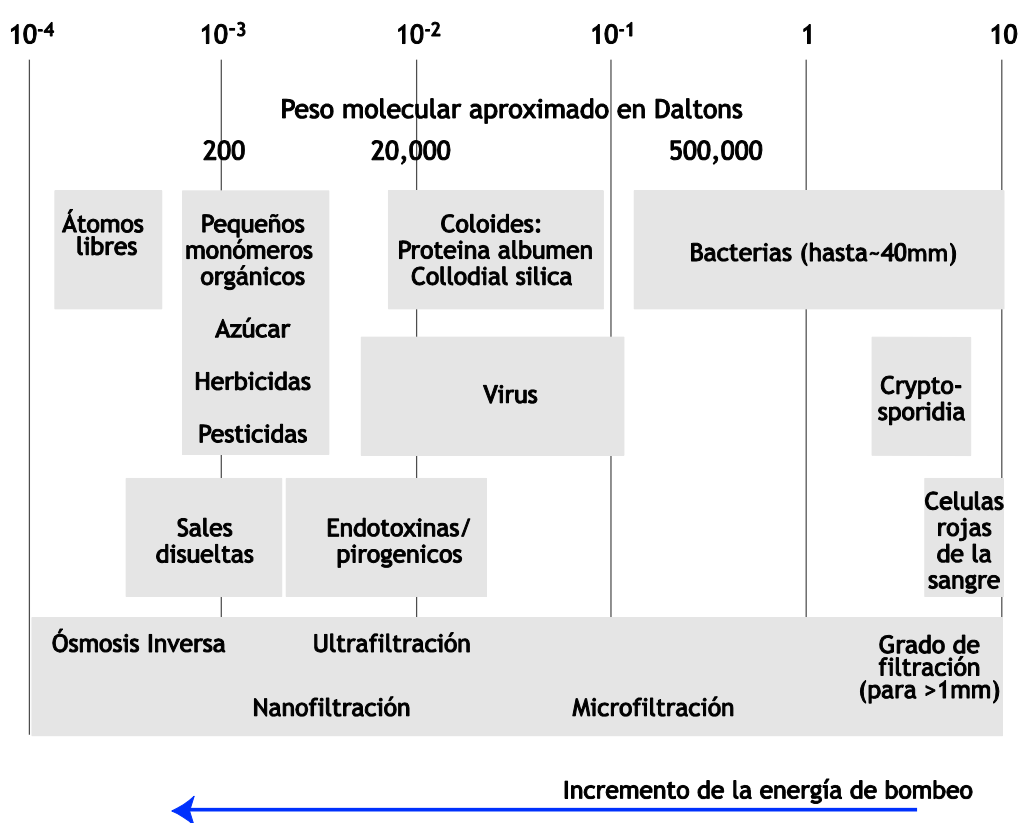

Figura 13.1 Vista general de los procesos de separación con membrana

rechazada expresada en unidades de masa molecular Daltons (Da), donde $1 \mathrm{Da}$ representa la masa del átomo de hidrógeno. Para membranas y procesos de UF y NF la selectividad (tamaño de sustancias rechazadas) se mide por el tamaño de la molécula más pequeña que se puede separar (MWCO por sus siglas en inglés molecular weight cut off) expresado en Daltons. Para membranas y procesos de MF la selectividad se mide en micras. Para los cuatro procesos de membrana identificados, se debe aplicar presión para forzar el pasaje del agua a través de la membrana.

El rango de operación de cada tipo de membrana se muestra en la Figura 13.1, junto con la indicación del mecanismo principal de filtración y por ende el tipo de membrana relacionado con cada proceso. Como producto comercial establecido y confiable para el tratamiento de agua o de aguas residuales el uso de membranas está limitado a dos procesos: los procesos de filtración basados en la aplicación de presión, y los procesos de electrodiálisis (ED) basados en la aplicación de cargas eléctricas. Dichos procesos son muy efectivos para separar iones, en particular, iones problemáticos como pueden ser el nitrato y los asociados a la dureza o salinidad del agua. Las tecnologías de membrana utilizadas en el sector municipal son principalmente las que funcionan basadas en la aplicación de presión. La selectividad a la permeabilidad de la membrana, así como el mecanismo de separación, pueden variar de un proceso a otro; sin embargo, todos ellos tienen en común que generan un producto tratado y purificado (permeado) y un rechazo (concentrado) de residuos/contaminantes separados (Figura 13.2).

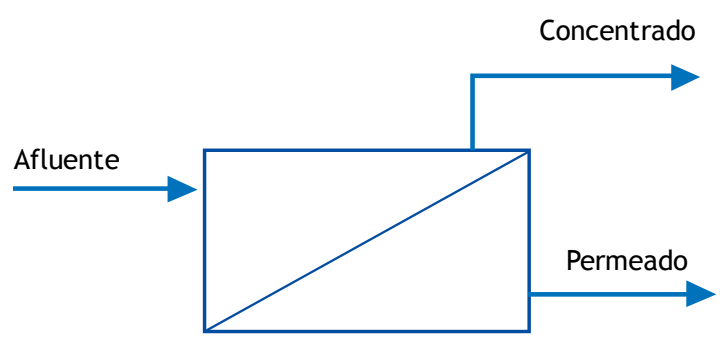

Figura 13.2 Esquema de la membrana

El rechazo de los contaminantes en última instancia, pone una restricción fundamental en todos los procesos de filtración con membrana. Los constituyentes rechazadas en la corriente retenida (concentrado) tienden a acumularse en la superficie de la membrana, produciendo diversos fenómenos que conducen: (i) a una reducción en el flujo (definido como caudal por unidad de superficie) de agua a través de la membrana trabajando a una determinada presión en la membrana (TMP, transmembrane pressure por sus siglas en inglés); o (ii) por el contrario a un aumento de la TMP para sostener un determinado flujo (evidenciado en la reducción de la permeabilidad, que es la relación entre 
el flujo y la TMP). Estos fenómenos se denominan como ensuciamiento (conocido en inglés como "fouling" de la membrana). Dado que el ensuciamiento de la membrana representa la principal limitación a la operación de un proceso de filtración con membrana, no es sorprendente que muchas de las investigaciones y desarrollos sobre nuevos materiales para las membranas y los procesos, estén dedicadas a la caracterización y reducción del ensuciamiento. En los procesos típicos de filtración con membrana, el ensuciamiento se previene y corrige mediante la aplicación de las siguientes acciones:

Operar en modo "tangencial" (conocido en inglés como "Crossflow"), en donde la alimentación a la membrana fluye paralelamente a la superficie de la membrana, y por lo tanto genera un barrido permanente (conocido en inglés como "socuring" que tiende a limitar el depósito de suciedad en la membrana; y/o limpiezas periódicas tanto hidráulicas y/o químicas de la membrana.

Aunque las limpiezas hidráulica y/o química están asociadas a los procesos de filtración con membrana, el modo y frecuencia de las mismas, es fuertemente influida por la hidrodinámica del sistema. El modo tangencial de operación, o cualquier otro que genere un esfuerzo cortante o de cizalla sobre la superficie de la membrana, logra, en cierta medida, controlar el ensuciamiento pero demanda energía. Un componente fundamental del diseño del proceso para los biorreactores de membrana (MBR, membrane bioreactor, por sus siglas en inglés) es lograr el equilibrio entre el flujo, la TMP, la demanda de energía (que en parte se relaciona con la TMP) y la frecuencia de limpieza. La búsqueda de este equilibrio es lo que ha llevado al desarrollo y comercialización de dos configuraciones principales de procesos para MBR, y de tres configuraciones de membranas.

\subsection{EL BIORREACTOR DE MEMBRANA (MBR)}

\subsubsection{Generalidades sobre MBR}

Los biorreactores de membrana combinan tratamiento biológico con filtración/separación por membrana de MF o UF. Las ventajas ofrecidas por este proceso sobre los procesos convencionales de tratamiento biológico son ampliamente reconocidas, siendo las más citadas:

- La producción de un producto permeado (agua filtrada) de alta calidad, clarificado y desinfectado en una única etapa (equivalente a una filtración terciaria).

- Control absoluto e independiente del tiempo de retención de solidos (TRS - SRT por sus siglas en inglés - solid retention time) y del tiempo de retención hidráulico (TRH - HRT por sus siglas en inglés hydraulic retention time), parámetros que normalmente están acoplados en las plantas de tratamiento convencionales.

- La operación a altas concentraciones de sólidos suspendidos del licor de mezcla (SSLM - MLSS por sus siglas en inglés - mixed liquor suspended solids), lo cual reduce el tamaño del reactor requerido y promueve el desarrollo de bacterias nitrificantes específicas y por lo tanto mejora la eliminación de amoníaco.

- La operación a altos tiempos de retención de lodos (TRS), lo cual brinda una oportunidad para utilizar poblaciones bacterianas de crecimiento lento, lo cual posibilita un tratamiento mejorado (p. ej. degradación de micro-contaminantes orgánicos)

- Reducción de la producción de lodos.

De estos, la intensidad del proceso (es decir, un menor requerimiento de espacio) y la superior calidad de agua obtenida en el tratamiento, son generalmente las ventajas más importantes. Un MBR efectivamente reemplaza tres procesos individuales de los sistemas convencionales de tratamiento de aguas residuales (la sedimentación primaria, el sistema de lodos activados y la desinfección), demandando únicamente que se mantenga la fase inicial de tamizado para limitar los efectos perjudiciales de daño sobre la membrana. Dicho esto, comparados con los sistemas convencionales de tratamiento biológico los MBR están en cierta medida limitados por: (i) una mayor complejidad del proceso, y (ii) por necesidad de equipamiento más costoso y mayores costos de operación, así como otros temas menores como son una mayor propensión a la formación de espuma, mayores requerimientos de aireación tanto para los procesos biológicos como para el control del ensuciamiento/incrustación de la membrana, la producción de un lodo más difícil de deshidratar, y en general una mayor sensibilidad a los pulsos de cargas.

Los dos puntos anteriores están relacionados directa o indirectamente con el ensuciamiento de la membrana. Este demanda para su control, la instrumentación de varias medidas paliativas que le agregan complejidad al proceso, tiempos muertos (limpieza de la membrana), y demanda de energía. Por eso no llama la atención que 
muchas de las investigaciones se orienten a los fenómenos de ensuciamiento de la membrana, su caracterización, y formas de minimización y eliminación.

\subsubsection{Procesos y configuraciones de membrana}

La configuración puede referirse tanto al proceso MBR (y específicamente la forma que la membrana está integrada con el biorreactor) o al módulo de la membrana. Hay dos configuraciones principales de proceso de MBR (Figura 13.3): sumergidas o inmersas (iMBR), y externas o con recirculación (eMBR). También hay dos modos de funcionamiento hidráulico: por bombeo (presión positiva) y por "air-lift” (presión de vacío), este último se utiliza casi exclusivamente para los sistemas MBR sumergidos, mientras que el primero para los MBR externos. Finalmente, si bien existen en el mercado diversas geometrías y configuraciones de membranas, tres configuraciones son las que predominan: membrana plana (MP), fibra hueca (FH) y multi-tubo (MT), Figura 13.4.

La configuración iMBR es en general menos intensiva en lo que respecta a la demanda de energía que las de eMBR; el empleo de módulos de membranas en un sistema de bombeo externo de flujo cruzado en la configuración eMBR induce mayores pérdidas de energía debido a las altas presiones necesarias (mayor flujo) y flujos volumétricos requeridos (evitar ensuciamiento) para operar estos sistemas. Para hacer el mayor uso posible de la energía latente, la trayectoria del flujo sobre la membrana debe ser lo más larga posible, de manera que la energía intrínseca existente en el líquido que fluye a alta presión sea utilizada para el procesos de filtración en la membrana. Para lograr una

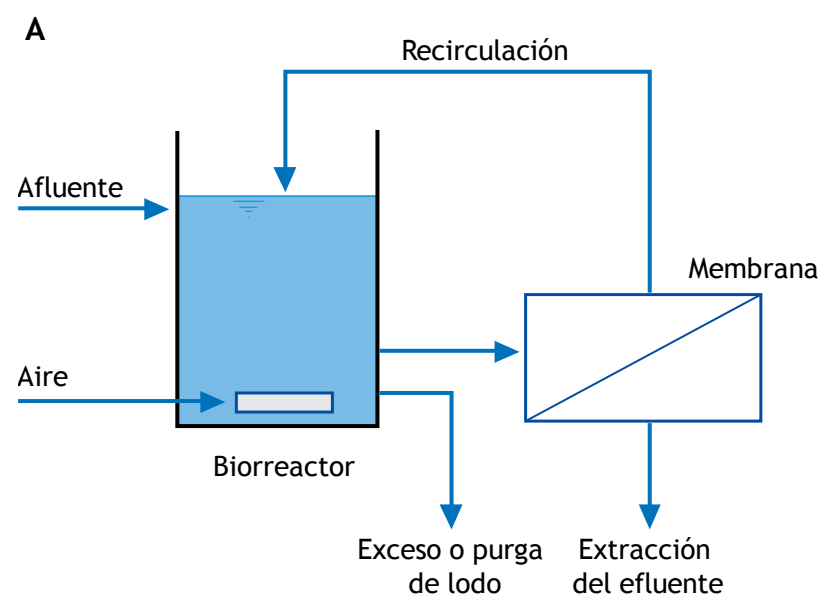

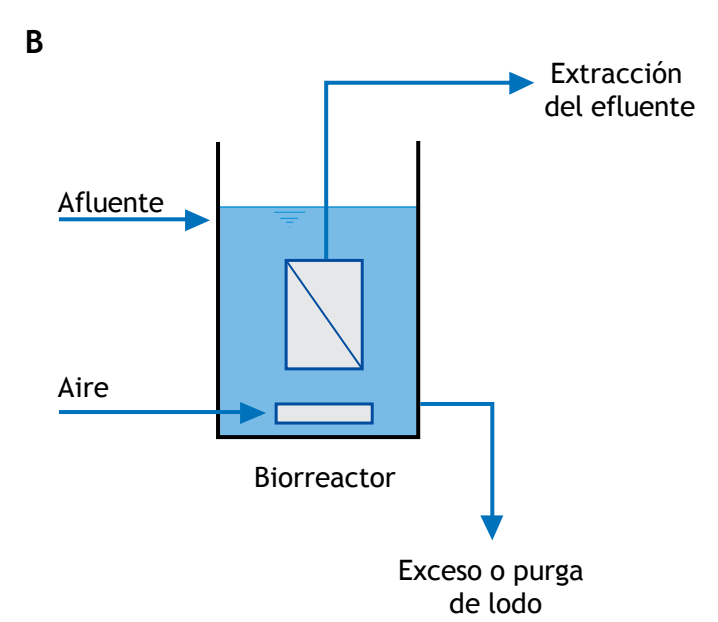

conversión razonable (producción de permeado en función del caudal de alimentación) de aproximadamente $40-50 \%$ a lo largo del módulo, se requiere una trayectoria larga; en ocasiones, se requiere que se excedan los $20 \mathrm{~m}$ de membrana. Esto exige entonces un gran número de módulos de membrana en serie, lo que genera una caída de presión significativa a lo largo de los canales de flujo del concentrado. En lo que respecta a la configuración iMBR, la limpieza de las membranas se consigue mediante la aireación, lo cual conduce a un funcionamiento con requerimientos de energía significativamente más bajos con relación al bombeo del líquido para las configuraciones externas; como contrapartida la operación en la configuración iMBR generalmente opera a menores flujos.

En lo que respecta a la configuración eMBR, se debe lograr una solución de compromiso entre la energía necesaria para el bombeo y el flujo a través de la membrana. Para maximizar el flujo se requiere una alta TMP combinada con una alta velocidad de flujo tangencial o cruzado (VFC o velocidad del rechazo/concentrado $U_{R}$ ). Dado que la demanda de energía es directamente proporcional a $Q_{R} \Delta P$ (flujo del concentrado $\mathrm{x}$ presión), existe interés en reducir los valores de ambos parámetros tanto como sea posible. Sin embargo, dado que $Q_{R}$ determina $U_{R}\left(\mathrm{U}_{\mathrm{R}}=\mathrm{Q}_{\mathrm{R}} / \mathrm{A}_{\mathrm{t}}\right.$, siendo $A_{t}$ el área de la sección transversal de la membrana) y que $\Delta P$ se refiere a la TMP, reduciendo $Q_{R} \Delta P$ inevitablemente se reduce el flujo. Por otra parte, si se reduce $Q_{R}$ disminuyendo el área de la sección transversal tiene como efecto el aumento de la caída de presión a lo largo de la longitud del módulo del lado del concentrado, dado que la resistencia al flujo es inversamente proporcional al $A_{t}$.

Figura 13.3 Configuraciones de MBR (A) MBR externo o con recirculación (eMBR) y (B) MBR sumergido o inmerso (iMBR)

\footnotetext{
Figura 13.3 Configuraciones de MBR (A) MBR externo o con recirculación(eMBR)y (B) MBR sumergido oinmerso(iMBR)
} 

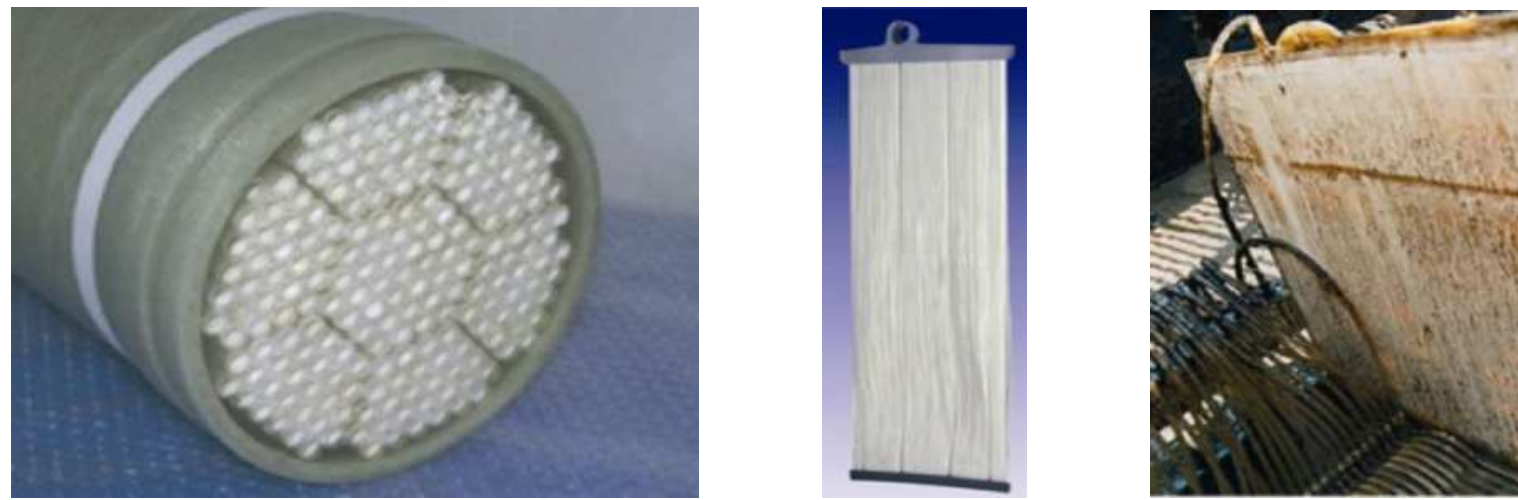

Figura 13.4 Configuración de membranas MBR: multi-tubo (MT, izq.), Fibra hueca (FH, medio) y membrana plana (MP, derecha)

La elección de la configuración de la membrana (en esencia la geometría de la membrana y la dirección de flujo del permeado) está limitada por una serie de factores. Idealmente, un módulo de membrana debería tener los siguientes atributos:

a. Elevada área de membrana con relación al volumen del módulo (p. ej. densidad de empaquetado)

b. Alto grado de turbulencia en la alimentación para mejorar la transferencia de masa.

c. Bajo gasto de energía por unidad de volumen de agua producida.

d. Bajo costo por unidad de área de membrana

e. Diseño que facilite la limpieza

f. Diseño que permita la modulación.

Todos los diseños de módulos de membrana, por definición, permiten la modularización (f), y esto de por sí es una de las características más atractivas de los procesos de membrana. Esto también significa que los procesos de membrana no proporcionan economía de escala significativa con respecto a los costos de membrana, ya que estos son directamente proporcionales al área de la membrana que está directamente relacionada con el caudal. Sin embargo algunas de las características mencionadas anteriormente son mutuamente excluyentes. Por ejemplo, la promoción de turbulencia (b) resulta de un aumento en el gasto de energía (c). La limpieza mecánica de la membrana (e) sólo es posible en módulos con una comparativamente baja área por unidad de volumen (a). Este tipo de diseño modular inevitablemente incrementa el costo por unidad de área de membrana (d), pero son inevitables dado que la limpieza es de fundamental importancia en los procesos de MBR donde los sólidos y la suciedad al ingreso de la membrana, provenientes del lodo del biorreactor son muy altos. Finalmente, no es posible producir una membrana con una gran área con relación al volumen de módulo, sin producir una unidad que tenga canales de flujo para el concentrado muy estrechos, lo que afecta negativamente la promoción de la turbulencia y la facilidad de limpieza.

Si bien, en principio, el tamaño y la forma de los elementos de la membrana es casi ilimitada, en la práctica sólo hay seis configuraciones principales empleadas en los procesos de membrana, todas con diferentes ventajas y limitaciones prácticas. $\mathrm{La}$ naturaleza del proceso de MBR limita la elección práctica de configuración de la membrana a MP, FH y MT. Principalmente por las razones expuestas más arriba: los módulos deben permitir la promoción de turbulencia y/o limpieza. La promoción de la turbulencia se puede generar pasando la alimentación o una mezcla de aire/agua a lo largo de la superficie de la membrana para facilitar el paso de permeado a través de ella. Esta operación de flujo cruzado es utilizado ampliamente en muchas tecnologías de membrana, y su eficacia aumenta cuando aumenta la distancia intersticial en la membrana (es decir, la separación de la membrana). Debido a que MT opera con el flujo que pasa del interior al exterior del tubo (del lado interno al lado de carcaza), mientras que en FH generalmente opera de afuera hacia adentro, la distancia intersticial se define por:

- El diámetro de tubo para membranas MT

- La distancia entre las fibras para membranas FH, y

- El ancho de canal para MP. 
Al igual que en el caso de las propias configuraciones de las membranas, es posible tener un amplio rango de valores para estos parámetros; estas dimensiones críticas en la práctica están condicionadas por aspectos propios de los procesos de MBR y que se relacionan en gran medida con el ensuciamiento y las obstrucciones.

\subsubsection{Ensuciamiento de Membrana}

En un MBR, el ensuciamiento puede tener lugar a través de una serie de mecanismos fisicoquímicos y biológicos que se relacionan con una mayor deposición de material sólido sobre la superficie de la membrana y dentro de la estructura de esta (restricción del poro o tapado/obstrucción del poro). Esto se debe diferenciar de la obstrucción, que es la saturación de los canales de la membrana con material particulado debido a un pobre rendimiento hidrodinámico de la membrana (Figura 13.5). La resistencia de la membrana a la filtración es fija y no debería disminuir, salvo que la permeabilidad global se reduzca debido a componentes del agua de alimentación que se absorben permanentemente sobre y dentro de la membrana. La resistencia generada por la región interfacial es, por otra parte, dependiente de la cantidad total de material con capacidad de ensuciar la membrana que se encuentra en la zona. Esto a su vez depende del espesor de la interfaz, la composición del agua de alimentación (específicamente su contenido en sustancias con capacidad de ensuciar o incrustar la membrana) y del flujo a través de la membrana. La matriz/composición del agua de alimentación y las condiciones operativas determinan en gran medida el rendimiento del proceso. Generalmente las sustancias capaces de ensuciar la membrana se clasifica según tres categorías (Tabla 13.1):

(i) Considerando el Mecanismo del ensuciamiento (fouling), o sea considerando el mecanismos que genera/promueve el ensuciamiento.

(ii) Según observaciones de la Práctica, basados en las observaciones para la recuperación de la permeabilidad.

(iii) Por Tipo de material, basados en la naturaleza u origen químico o físico de la sustancia que general el ensuciamiento.

Los mecanismos a los efectos de describir los procesos de filtración y ensuciamiento son principalmente desarrollados con el fin de interpretar los transitorios de flujo y/o presión, y la interrelación entre estos dos parámetros. Cuatro de dichos modelos, los más generales, se describen bajo la columna mecanismo en la Tabla 13.1. Estos mecanismos son considerados demasiado simplistas para describir los transitorios de la

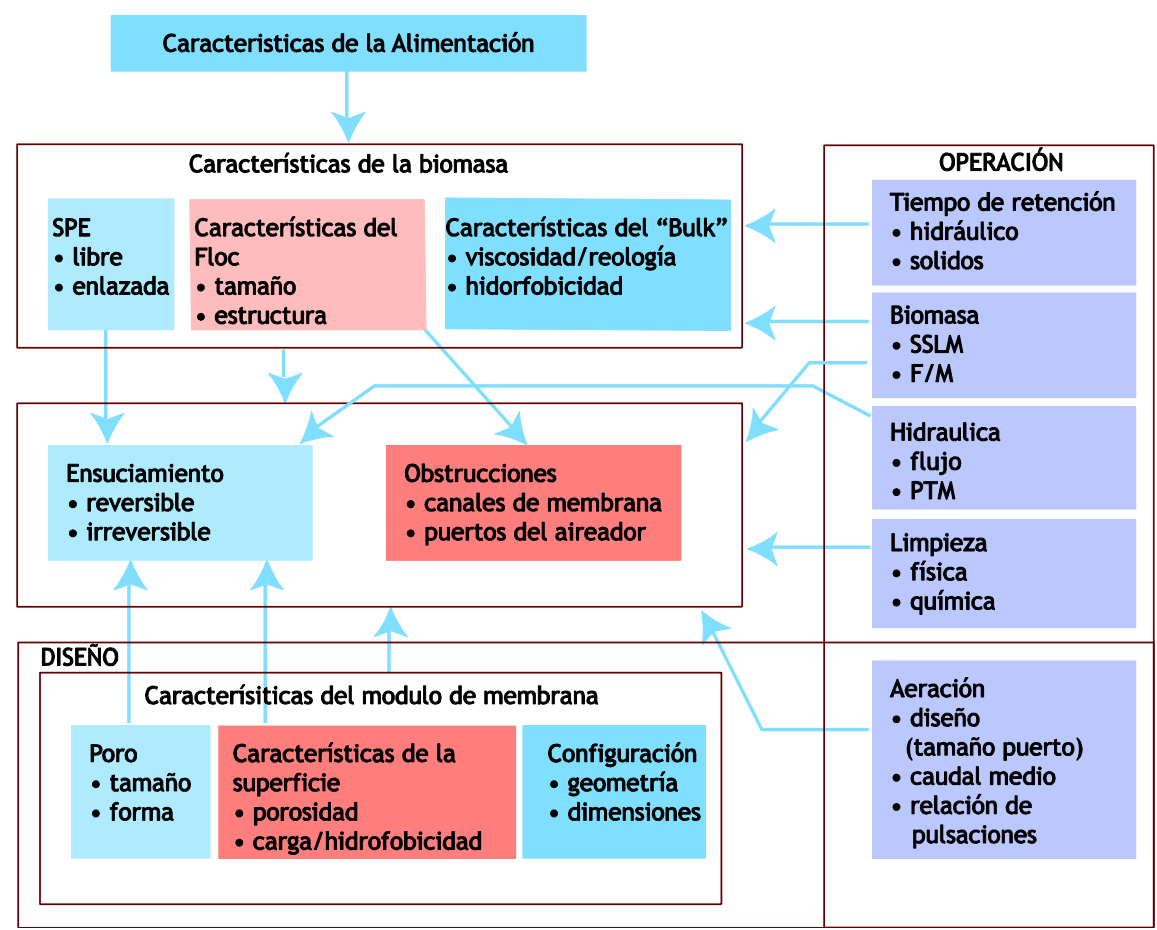

Figura 13.5 Interrelaciones entre los parámetros de MBR y ensuciamiento/obstrucciones (fouling). 
Tabla 13.1 Definición de agentes generadores de suciedad



${ }^{1}$ El ensuciamiento irrecuperable es de largo plazo e insidioso.

${ }^{2}$ eSPE se refiere a los productos microbianos asociados directamente a la pared de la célula mientras que PMS se refiere a los productos microbianos solubles no asociadas con la célula, aunque es probable que haya un equilibrio dinámico entre estos dos componentes.

filtración en sistemas MBR, los cuales se deben a una serie de pasos en los que predominan diferentes comportamientos.

La definición práctica de ensuciamiento o "fouling" es empleada de forma generalizada. El ensuciamiento que es eliminado utilizando una limpieza física, como puede ser por medio de retrolavado o de la relajación (o ambos), suele denominarse hidráulicamente "reversible" o suciedad "temporal"; mientras que el ensuciamiento que es eliminado mediante la aplicación de productos químicos a menudo se denomina "irreversible" o suciedad "permanente", aunque también se utiliza el término "químicamente reversible". Este último término es un nombre algo inapropiado, ya que nunca se recupera la permeabilidad original de la membrana nueva una vez que la membrana se ensucia por su operación normal; por lo tanto, sigue teniendo una resistencia residual que se puede definir como "ensuciamiento irrecuperable". Es este ensuciamiento que se va acumulando con los años de operación de la membrana, el que en última instancia determina la vida útil de la membrana.

La definición de los tipos de compuestos/materiales que ensucian la membrana según el tipo de material de origen es también muy extendida, y ha sido la base de muchas investigaciones y desarrollo en la tecnología de MBR en los últimos años. Extensas revisiones bibliográficas sobre el ensuciamiento de membranas en sistemas MBR se han presentado en diversas revistas científicas en los últimos años; el tema es muy abstruso y complejo, y existen opiniones divergentes en cuanto a la importancia relativa de los componentes individuales y su propensión al ensuciamiento. Sin embargo, existe un importante consenso en el que el ensuciamiento de la membrana en los MBR se puede atribuir principalmente a sustancias poliméricas extracelulares (SPE), quienes representan los materiales de construcción de los agregados microbianos tales como ser las biopelículas, los flóculos, y el licor de lodos activados. El término "SPE" se utiliza como un término general que abarca todas las clases de macromoléculas autóctonas tales como carbohidratos, proteínas, ácidos nucleicos, (fosfo)lípidos y otros compuestos poliméricos que se encuentran fuera y en la superficie de la célula, y así como en el espacio intercelular de los agregados microbianos. Se componen de materiales insolubles (por ejemplo, polímeros capsulares, gel de condensado, polímeros débilmente enlazados, y materia orgánica adherida) y materiales solubles (por ejemplo, proteínas y polisacáridos) secretados por la célula, los cuales se desprenden de la superficie de la célula o se generan por la lisis celular. Con su naturaleza heterogénea y cambiante, las SPE pueden formar una matriz de gel altamente hidratado en el que las células microbianas están integradas y por lo tanto puede ayudar a crear una barrera importante para el flujo de permeado en los procesos de membrana.

Los efectos de las SPE en los procesos de filtración con MBR se han reportado desde mediados de la década de 1990 y han recibido una atención considerable en los últimos años. Si bien se reconoce ampliamente que es 
este componente del licor de mezcla el que tiene el mayor impacto sobre el ensuciamiento de la membrana, hay pruebas contradictorias con respecto a la contribución relativa de los distintos componentes o fracciones de la SPE al ensuciamiento. Las SPE pueden ser clasificadas sobre la base de su origen (si se adhiere a la pared celular microbiana, o si está libre sobre esta), tamaño (partículas, incluyendo macromoléculas coloidales y disueltos) y química (carbohidratos o proteínas). Algunos autores han informado que es la fracción soluble (o libre) - a veces referido como el producto microbiano soluble (PMS) - de los hidratos de carbono la principal responsable del ensuciamiento, mientras que otros lo han asociado con la proteína y otras sustancias más simples con contenido orgánico coloidal. Si bien el debate sobre la importancia relativa de cada componente de SPE en el ensuciamiento persiste, la medida real de la concentración de cada componente de la SPE es fuertemente afectada por la metodología de fraccionamiento. Desafortunadamente, existe un número importante de métodos para el fraccionamiento de SPE y no existe acuerdo entre los investigadores sobre cuál es la más apropiado. Por lo tanto resulta dificultosa la comparación de los datos entre diferentes grupos de investigación.

\subsubsection{Procesos de operación de MBR}

Como se indica en la Figura 13.5, el funcionamiento de un MBR está definida por la inter-relación entre el flujo, la TMP, y para un MBR sumergido en la aireación de la membrana. Es esta última la que se considera que es de importancia crítica; la aireación es un componente clave en iMBR la cual se requiere tanto para mantener la actividad biológica del biorreactor, así como para asegurar la permeación/filtración a través de la membrana.

Mientras que los eMBR han dominado ampliamente el mercado hasta aproximadamente el año 2005, los MBR que emplean membranas sumergidas para rechazar la biomasa representan en la actualidad la más utilizada de todas las configuraciones de MBR; estos sistemas tienen una menor demanda de energía específica, y por lo tanto pueden llegar a ser económicamente más viables para aplicaciones a gran escala. Fundamentalmente, hay cinco elementos clave del proceso de diseño y operación de los iMBR (Figura 13.6), estos incluyen:

1) la membrana, su diseño, y el sostenimiento de la permeabilidad mediante la limpieza
2) el agua de alimentación, sus características y su pretratamiento

3) la aireación, tanto para la membrana, así como para la biomasa contenida en el sistema

4) la extracción de lodos y el tiempo de residencia de lodos (TRS)

5) la bioactividad y la naturaleza de la biomasa.

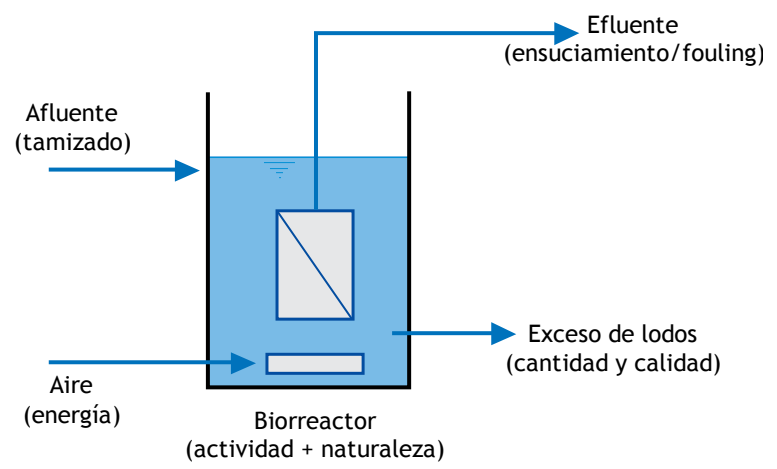

Figura 13.6 Elementos de un MBR

Estos elementos están en gran medida relacionados entre sí (Figura 13.5). La velocidad a la que son retirados los lodos controla el tiempo de residencia (es decir, la TRS) que entonces determina la concentración de la biomasa (o, en sentido estricto, del licor de mezcla). La concentración de SSLM entonces impacta tanto en las propiedades biológicas, es decir, en la bioactividad y la especificidad microbiana, así como también en las propiedades físicas tales como la viscosidad y la velocidad de transferencia de oxígeno. La composición química del agua de alimentación tiene el mayor impacto sobre el funcionamiento del MBR, ya que la propensión al ensuciamiento de la membrana por parte del licor de mezcla está dictada por la naturaleza de la composición del agua de alimentación que lo genera. De manera similar, el rigor con que se realice el pre-tratamiento del agua de alimentación en las operaciones de cribado/tamizado, tiene un impacto significativo en evitar la obstrucción de los canales de la membrana.

\subsubsection{El material de construcción de membranas}

Existen principalmente dos tipos diferentes de material para la construcción de membranas, siendo estos polimérico y cerámica. También existen membrana de filtros metálicos, pero estos tienen aplicaciones muy específicas que no se refieran a la tecnología MBR. El material de la membrana para ser útil debe ser formado (o configurado) de tal manera que permita que el agua pase a través de él. 
Un número importante de diferentes materiales poliméricos y cerámicos se pueden utilizan para formar las membranas; pero en general, casi siempre comprenden una fina capa superficial que proporciona la permeselectividad requerida en la parte superior de una más abierta y gruesa capa de soporte poroso que proporciona estabilidad mecánica. Una membrana clásica es por lo tanto una estructura anisótropa, que tiene simetría sólo en el plano ortogonal a la superficie de la membrana (Figura 13.7).

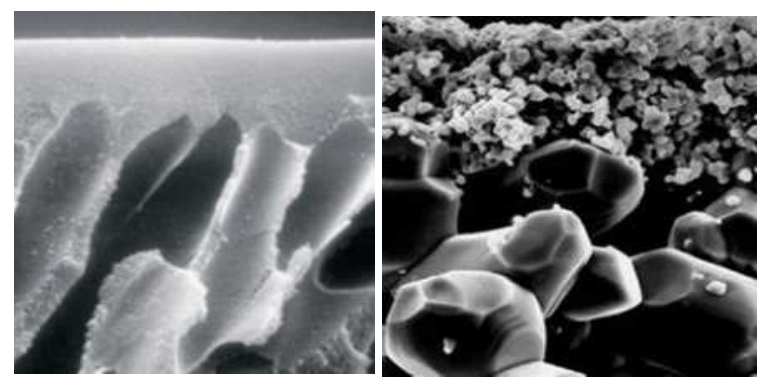

Figura 13.7 Membrana de UF Anisotropica: polimérica (espesor de la "piel" $3 \mu \mathrm{m}$ ) (izquierda), y cerámica (derecha) (foto: Ionics y Pall, respectivamente)

Las membranas poliméricas son normalmente fabricadas ya sea tanto a los efectos de lograr una alta porosidad de la superficie, o porcentaje de la superficie total de poros por área de sección transversal, así como para tener una estrecha distribución de tamaño de poro a los efectos de proporcionar un alto rendimiento y la mayor selectividad del rechazo como sea posible. La membrana también debe ser mecánicamente fuerte, es decir, tener integridad estructural. Por último, el material debe tener normalmente una cierta resistencia al ataque de sustancias químicas, es decir, a los extremos de temperatura, $\mathrm{pH}$ y/o concentración de oxidantes que se presentan normalmente cuando la membrana es sometida a procesos de limpieza química, e idealmente debe ofrecer algo de resistencia al ensuciamiento.

Si bien, en principio, cualquier polímero se puede usar para producir una membrana, sólo un número limitado de materiales son adecuados para la tarea de filtración/separación con membrana, siendo los más comunes: (i) difluoruro de polivinilideno (DFPV), (ii) polietilsulfona (PES), (iii) polietileno (PE), y (iv) polipropileno (PP). Todos los polímeros anteriores pueden transformarse, a través de técnicas de fabricación específicas, en materiales para la elaboración de membranas que tengan las propiedades físicas deseables, y una resistencia química razonable.
Sin embargo, también son hidrófobas, lo que las hace susceptibles a la suciedad por la materia hidrófoba presente en el licor del biorreactor que se va a filtrar. Debido a esto, normalmente se requiere modificaciones de la superficie del material de base para producir una superficie hidrófila, utilizando técnicas tales como la oxidación química, reacción química orgánica, tratamiento de plasma o de injerto. Es este elemento el que más distingue un producto de membrana de otros a partir de la misma base de polímero. Este proceso de modificación, el método de fabricación utilizado para formar la membrana a partir del polímero, mayormente de DFPV y el método para fabricar el módulo de la membrana son considerados como información bajo patente por parte de la mayoría de los proveedores de membranas.

Una propiedad clave de la membrana es el tamaño de poro, que determina el tipo de proceso de filtración con membrana (Figura 13.1). Se considera que poros más pequeños a los efectos permite una mayor protección de la membrana; mediante el rechazo de una gama más amplia de materiales, en relación a su tamaño, tendrá una mayor torta (o capa de ensuciamiento) de resistencia. En comparación con la torta que se forma sobre membranas que tienen poros más grandes, la capa de ensuciamiento es más fácil de eliminar (a poros más pequeños) y menos propensa a ocasionar taponamiento de poro residual o adsorción superficial. Los fenómenos relacionados con esto último son los que causan ensuciamiento irreversible e irrecuperable. Por otro lado, hay muchos datos que sugieren que para algunas membranas se forma una capa dinámica que protege eficazmente la membrana.

Mientras que muchos de los estudios científicos de caracterización de la superficie de la membrana de MBR y/o su modificación se relacionan con incrustaciones de SPE, en la práctica tanto la elección del material de la membrana como del tamaño nominal de poro es limitada. La disponibilidad en el mercado de las membranas y de los sistemas MBR se discuten en la Sección 13.4.

\subsubsection{Limpieza}

Todas las membranas están sujetas a ensuciamiento durante su funcionamiento a una velocidad que dependerá del barrido (scouring) aplicado a la membrana; y más directamente, del flujo operacional. Como el flujo y la presión están relacionados entre sí, se puede fijar cualquiera de ellos dos según las necesidades de diseño. Sin embargo, para el proceso convencional 
de filtración del agua por presión, es habitual fijar el valor del flujo y luego determinar el valor apropiado para la TMP. El impacto principal del flujo operativo determina el período entre limpiezas, la cual se puede realizar ya sea ser por medios físicos o químicos (Figura 13.8). En los sistemas MBR la limpieza física se consigue normalmente ya sea mediante la realización de un lavado a contracorriente, es decir mediante la inversión de la dirección del flujo, o mediante el reposo/relajación de la membrana, que es simplemente dejar de filtrar mientras se mantiene la aireación para permitir que las burbujas barran/frieguen la membrana. Estas dos técnicas se pueden usar combinadas, y el lavado a contracorriente puede ser mejorado mediante la combinación con la relajación. La limpieza química se lleva a cabo con ácidos minerales u orgánicos, sosa cáustica, o más habitualmente en MBRs, hipoclorito de sodio; la limpieza química se puede realizar tanto in situ (conocido como CIP "cleaning in place") o ex situ. Alternativamente, una baja concentración de agente químico de limpieza se puede añadir al agua de retrolavado para producir un retrolavado químicamente mejorado conocido como CEB (chemically-enhanced backflush).

La limpieza física es menos laboriosa que la limpieza química por varias razones. En general, es un proceso más rápido que la limpieza química, con una duración de no más de dos minutos. No son necesarios productos químicos y por lo tanto no produce residuos asociados a estos, y también es menos probable que se afecte la estructura de la membrana. Pero también es menos eficaz que la limpieza química. La limpieza física elimina sólidos gruesos adheridos a la superficie de la membrana, generalmente llamado "reversible" o "ensuciamiento temporal", mientras que la limpieza química elimina el material más resistente que a menudo se denomina "irreversible" o "ensuciamiento permanente", que obviamente es un nombre inapropiado.
Puesto que la permeabilidad de la membrana virgen original nunca se recupera una vez que la membrana se ensucia por la operación normal, sigue habiendo una resistencia residual que se puede definir como "ensuciamiento irrecuperable". Es este ensuciamiento el que se acumula con los años y en última instancia, determina la vida útil de la membrana.

Como el flujo, entre otras cosas, determina la tasa de disminución de la permeabilidad (o aumento de la presión $\mathrm{d} P / \mathrm{d} t$ ), el flujo por lo tanto también determina el período entre la realización de limpiezas físicas (retrolavado o reposo); es decir, el tiempo del ciclo de limpieza física $\left(t_{p}\right)$. Si se utiliza retrolavado, y suponiendo que no hay cambios en otras condiciones de operación, el aumento del flujo disminuye la frecuencia de realización de la limpieza física $t_{p}$. Dado que el retrolavado no puede, en la práctica, volver la permeabilidad a la condición origina; sólo un número finito de ciclos de retrolavado se puede realizar antes de alcanzar una presión umbral $\left(P_{\max }\right)$ más allá del cual el funcionamiento de la filtración no se puede sostener. En este punto, debe llevarse a cabo la limpieza química para volver la presión cerca del valor de línea base original (Figura 13.9).

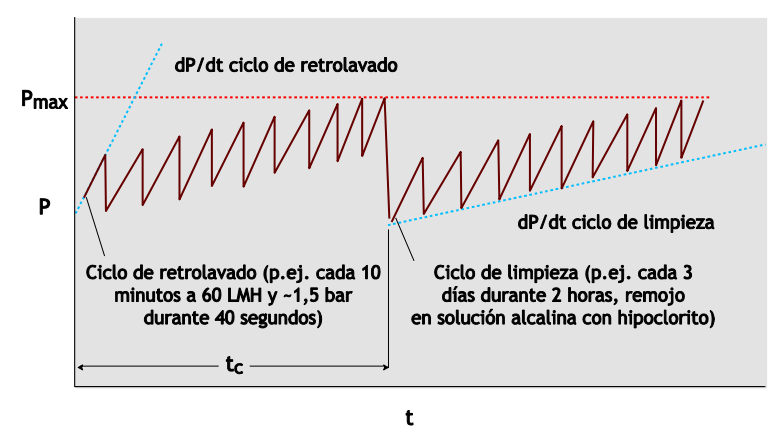

Figura 13.9 Presión transitoria para la operación a flujo constante de un filtro.

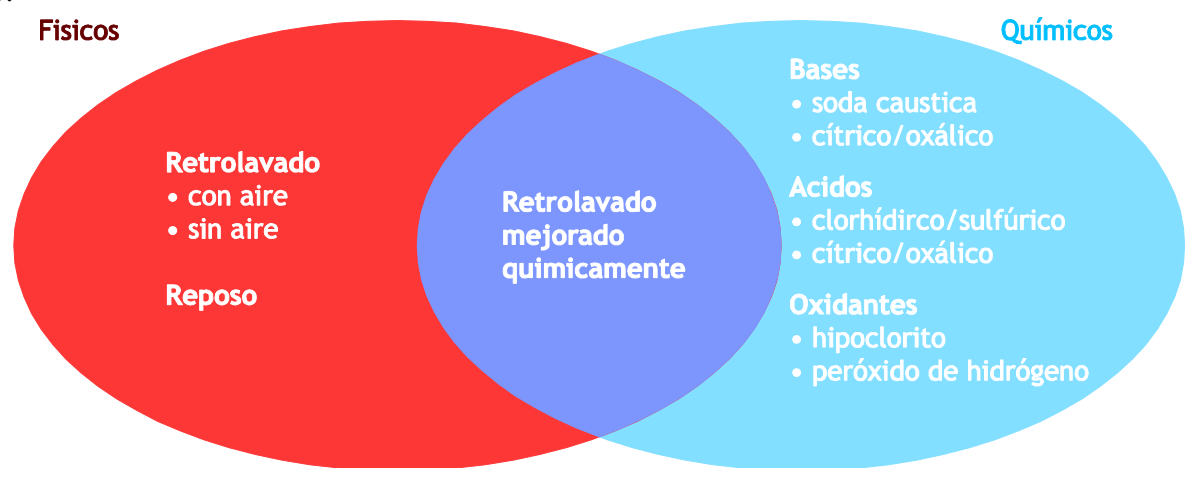

Figura 13.8 Métodos para la limpieza de las membranas 
Al igual que sucede con la limpieza física, la limpieza química nunca recupera la permeabilidad de la membrana original, pero normalmente es bastante más eficaz que la limpieza física. Para el funcionamiento de flujo transversal, como se aplica a un eMBR de corriente tangencial, el lavado a contracorriente normalmente no es una opción debido a la naturaleza del módulo de membrana, y la permeabilidad de la membrana se mantiene por una combinación de reposo y limpieza química.

\subsubsection{Agua de alimentación y licor de mezcla}

Mientras que el ensuciamiento de la membrana en la filtración física de aguas residuales depende directamente de la calidad del agua de alimentación, el ensuciamiento de la membrana en sistemas MBR está más afectado por las interacciones entre la membrana y la suspensión biológica con los lodos, que por el agua de alimentación en sí misma. Las aguas de alimentación más complejas, como son lixiviados de vertederos o efluentes de la industria cervecera, en donde se observan transformaciones bioquímicas más limitadas, la membrana se encuentra expuesta mayoritariamente a la alimentación cruda del afluente y prácticamente sin tratar y por lo tanto está expuesta a condiciones operativas más adversas. En tales casos, la permeabilidad de la membrana es baja en comparación con la que se tiene para el tratamiento de aguas residuales municipales; por lo tanto, el flujo de funcionamiento es proporcionalmente inferior $\mathrm{y} / \mathrm{o}$ la limpieza de la membrana es más frecuente. Las transformaciones biológicas que tienen lugar están influidas tanto por las condiciones de funcionamiento como por la calidad del agua de alimentación.

Un extenso estudio de las suciedades que se generan en el licor de mezcla del MBR está más allá del alcance de este libro de texto, y la caracterización de las sustancias que generan el ensuciamiento se ha discutido ya en la Sección 13.2.3. Sin embargo, las propiedades principales del licor de mezcla (o lodo) comprenden (Figura 13.10):

- Características del flóculo (tamaño, forma, fuerza)

- concentración de sólidos en suspensión, lo cual afecta la viscosidad y la eficiencia de transferencia de oxígeno

- temperatura, que afecta tanto a la viscosidad como a la biocinética.

- Propensión a la generación de espuma, lo que generalmente se relaciona con la concentración de microrganismos específicos y tensoactivos, junto con la intensidad de aireación
- concentración y características de las SPE.

Como ya se ha indicado en la Sección 13.2.3, han habido muchos estudios sobre la propensión al ensuciamiento de la membrana debido a las SPE y sus componentes, pero hay mucho menos estudios relacionados con el impacto de las características de la floculación en la obstrucción del canal.

\subsubsection{Aireación}

La aireación efectiva de la membrana es absolutamente crítica para la operación de un MBR sumergido. Hay muchos aspectos de la aireación de membrana, incluyendo el diseño del aireador (y si está integrado con el módulo de la membrana), la intensidad de aireación (o flujo de aire en relación al módulo) y la intermitencia de aireación (es decir, si es continuo o cíclico). La mayoría de los MBR operan con aireación intermitente para reducir la demanda de energía tanto como sea posible, pero es crítico proporcionar el aire suficiente al módulo de membrana para poder suprimir la obstrucción de los canales de la membrana y el ensuciamiento de su superficie.

Numerosos estudios han sido realizados para investigar el impacto de la aireación en la permeabilidad de la membrana. En general se reconoce que la permeabilidad aumenta con la aireación de la membrana hasta un valor crítico por encima del cual no hay ningún aumento adicional. La aireación puede ser más convenientemente expresada en términos de la demanda con respecto a la superficie de la membrana o al flujo de permeado. Por lo tanto, la normalización del flujo de aire con respecto a la superficie de la membrana produce la demanda específica de aireación (DEA) en $\mathrm{Nm}^{3} / \mathrm{m}^{2} \cdot \mathrm{h}$ :

$D E A_{m}=\frac{Q_{A}}{A}$

Dividiendo esta por el caudal (flujo J x área A) se obtiene la demanda de aireación en $\mathrm{Nm}^{3}$ por $\mathrm{m}^{3}$ de permeado producido:

$D E A_{p}=\frac{Q_{A}}{J A}$

Para un determinado soplador, configuración del aireador, y profundidad, la demanda específica de energía es directamente proporcional a $\mathrm{DEA}_{\mathrm{p}}$, considerando que el término $\mathrm{J}$ se refiere al flujo neto. 


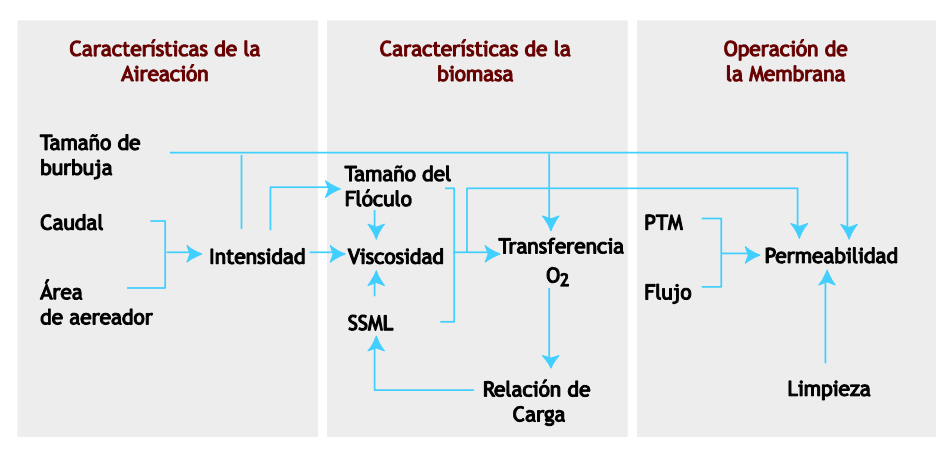

Figura $\mathbf{1 3 . 1 0}$ Interrelaciones de la Biomasa

Cada unidad de volumen de aire está asociada con una cantidad de energía demandada para generar ese volumen. Se ha postulado que la clave en relación con el parámetro que impacta el flujo de aireación puede ser la velocidad de flujo de aire. $U$, la medida de la velocidad del aire en el módulo, se puede obtener de la DEA $_{m}$ y de las dimensiones del módulo y del área de sección transversal libre $\left(A_{x}\right)$ que depende de las dimensiones. Para un módulo MP:

$U=\frac{2 L D E A_{m}}{\delta}$

donde $\delta$ es el espesor del canal, y L es la longitud del panel. Para un módulo FH:

$U=\frac{D E A_{m} L}{\left(\frac{1}{\varphi}-\frac{d}{4}\right)}$

donde $d$ es el diámetro de la fibra y $\varphi$ la densidad de empaquetamiento en $\mathrm{m}^{2}$ de área de membrana por volumen de módulo $\mathrm{m}^{3}$. Así, para un valor de $\mathrm{U}$ común a los dos módulos se tiene:

$\frac{D E A_{m, F H}}{D E A_{m, M P}}=\frac{2 L_{P P}}{L_{F H} \delta}\left(\frac{1}{\varphi}-\frac{d}{4}\right)$

Los datos de estudios en plantas piloto de tratamiento de aguas residuales municipales, muestran que el flujo sostenido se correlaciona con la tasa de aireación de la membrana y se presentan en la Figura 13.11. En esta figura, la velocidad media de gas $U$ incorpora el efecto de la aireación intermitente. Curiosamente, para este conjunto de datos parece existir una velocidad de gas umbral de alrededor de 150-180 $\mathrm{m} / \mathrm{h}$ de velocidad promedio, más allá de la cual la aireación adicional no tiene impacto en el flujo. Por debajo de este valor umbral, el flujo parece aumentar aproximadamente lineal con $U$.

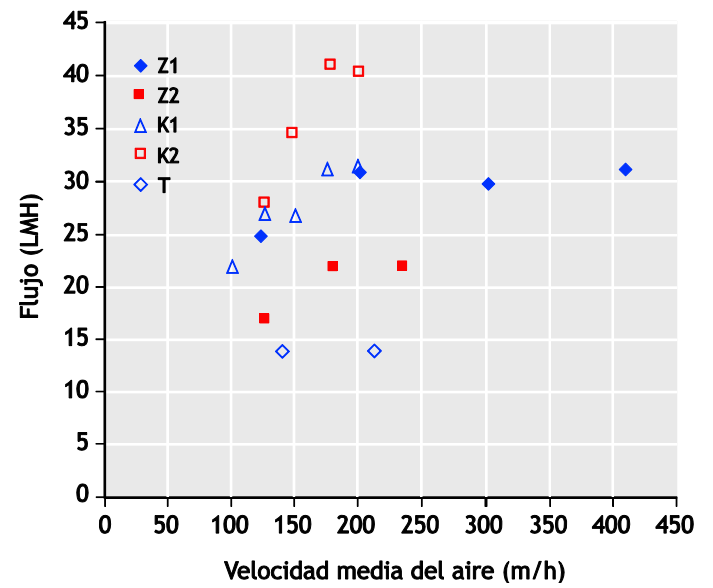

Figura 13.11 Flujo óptimo en función de la velocidad del aire media en el módulo

Correlaciones similares a los mostrados en la Figura 13.11 han sido descritas por varios autores en la literatura, aunque el valor umbral cambia con la configuración del módulo y sus dimensiones, con las características del agua de alimentación, y con los parámetros de funcionamiento del sistema. Sin embargo, si se toman los valores típicos para la pendiente, la intersección, y el umbral entonces se deduce que la demanda específica de energía (en kWh por unidad de volumen de permeado) sigue la tendencia representada en la Figura 13.12. Esto parece sugerir operar en el valor de umbral para que sea el óptimo.

\subsubsection{Retiro de lodos y sus características}

Al igual que con los procesos convencionales de lodos activados, la tasa de eliminación de lodo determina el tiempo de retención de sólidos (TRS), que incide en la concentración de sólidos suspendidos en el licor de mezcla. El TRS incide en la afinidad al ensuciamiento a través de la concentración de SSLM, que aumenta con el aumento de TRS, y por lo tanto reduce la relación F:M alterando las características de la biomasa. 


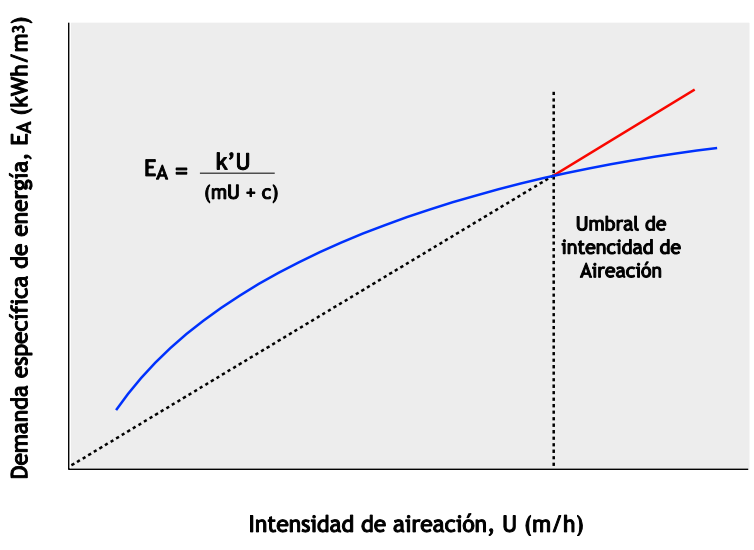

Figura 13.12 Demanda específica de energía en función de la Intensidad de aeración.

Para TRS extremadamente bajos de $\sim 2$ días se ha demostrado que se aumenta drásticamente la tasa de ensuciamiento y la relación F:M. El funcionamiento a TRS largos, por otra parte minimiza la producción de lodos en exceso, pero el aumento en el nivel de SSLM, que inevitablemente tiene lugar, promueve la obstrucción de los canales de membrana; en particular, causado por la materia inerte como pueden ser pelos, pelusa, y materiales celulósicos. El ensuciamiento de la membrana también se incrementa, y la eficiencia de aireación se afecta negativamente; al parecer, disminuye exponencialmente con la concentración de SSLM. Son estos factores los que en los últimos años han promovido un desplazamiento a la disminución de los TRS para controlar los niveles de SSLM en torno a $8 \mathrm{~g} / \mathrm{l}$ para un módulo de FH y 12 g/l para un módulo MP. Un óptimo TRS puede concebirse como el que propicie que las concentraciones de agentes que causan ensuciamiento, en particular en la fracción de PMS, se reducen al mínimo, mientras que la eficiencia de transferencia de oxígeno se mantiene suficientemente alta, y la obstrucción en la membrana tiene un nivel controlable. En la práctica, el TRS tiende a no ser controlado rigurosamente. Además, el TRS probablemente tenga menos impacto en el ensuciamiento que la calidad del agua de alimentación y sus fluctuaciones.

Otra fuente de pérdida de sólidos en el reactor, que se suele pasar por alto en el diseño de MBR, es la formación de espuma. La evidencia empírica sugiere que los MBR son más propensos a la formación de espuma que los sistemas convencionales de lodos activados; posiblemente, debido a la mayor intensidad de aireación provocada por la aireación requerida por la membrana, pero también posiblemente esté ligado a otros aspectos del proceso. En general, la formación de espuma es obviamente indeseable y muchas veces se combate con agentes antiespumantes. Sin embargo, puesto que estos tienen una propensión significativa al ensuciamiento de la membrana no se debe fomentar su uso.

\subsection{DISEÑO DE PLANTAS MBR}

Hay tres elementos principales de un MBR que influyen en su diseño y operación, y específicamente en los costos de operación sin tener en cuenta el remplazo de la membrana (que sólo puede ser estimado). Estos elementos son: (i) bombeo del líquido, (ii) mantenimiento de la membrana y (iii) la aireación.

\subsubsection{Bombeo del líquido}

Por bombeo de líquido nos referimos a la transferencia de los lodos entre los tanques (aerobioanaerobio-anóxico) y a la extracción del permeado. Para un MBR sumergido la TMP es relativamente baja; por lo tanto, la demanda de energía asociada a la extracción del permeado es también baja. La transferencia los lodos entre los tanques generalmente genera una mayor demanda de energía; en particular, cuando se requiere desnitrificación o eliminación de fosforo biológico; el diseño para la eliminación de nutrientes con un MBR emplea los mismos principios que los de las plantas de remoción biológica de nutrientes convencionales (BNR, Biological Nutrient Removal, por sus siglas en inglés).

\subsubsection{Mantenimiento de membranas: limpieza}

En el caso de la configuración de membrana sumergida, esta es mantenida tanto por la aireación como por las limpiezas periódicas. Las limpiezas físicas y químicas de las membranas generan tiempos de inactividad en el proceso, la pérdida de producto permeado (en el caso de retrolavado), y la eventual sustitución de membranas. Esto último se contabiliza en la amortización del equipo, aunque son escasos los datos reales sobre la vida útil de la membrana ya que para la mayoría de las plantas puestas en operación a la fecha son lo suficientemente recientes como para que no hayan tenido que cambiar las membranas originales.

Los requisitos físicos y químicos para el retrolavado dependen principalmente de las configuraciones de la membrana, del proceso, y de la calidad del agua de alimentación. Existen y están disponibles manuales y reglas generales para relacionar la calidad del agua de la alimentación y la operación y mantenimiento (O\&M) de la membrana; los protocolos de O\&M normalmente son 
recomendados por los proveedores de membranas y/o procesos y en ocasiones adaptados para aplicaciones específicas.

Las relaciones fundamentales entre los requisitos de limpieza y las condiciones de operación, el flujo típico, y la aireación de los sistemas sumergidos, se han generado a partir de estudios científicos sobre el ensuciamiento. Sin embargo, podría decirse que las fuentes de información más útiles sobre las necesidades de limpieza de las membrana son ensayos comparativos a realizados a escala piloto; por ejemplo, la evaluación de diferentes tecnologías MBR utilizando la misma agua de alimentación, y las referencias de las instalaciones de referencia a gran escala (Sección 13.5).

Los parámetros claves de diseño con relación a la limpieza de las membranas son:

- Periodo entre limpiezas físicas $\left(t_{p}\right)$, donde la limpieza física puede ser retrolavado o relajación/reposo,

- Duración de la limpieza física $\left(\tau_{p}\right)$,

- Periodo entre limpiezas químicas $\left(t_{c}\right)$,

- Duración de la limpieza química $\left(\tau_{c}\right)$,

- Flujo del retrolavado $\left(J_{b}\right)$,

- Concentración de los reactivos de limpieza $\left(c_{c}\right)$ y su volumen $\left(v_{c}\right)$ normalizado según el área de membrana.

Suponiendo que un ciclo de limpieza química completa, el cual contiene un número de ciclos de limpieza físicas (Figura 13.9), restaura la permeabilidad de la membrana a un nivel sostenible, entonces el flujo neto $J_{\text {net }}$ se puede calcular:

$$
J_{\text {net }}=\frac{n\left(J t_{p}-J_{b} \tau_{p}\right)}{t_{c}+\tau_{c}}
$$

donde $n$ es el número de ciclos de limpieza físicos por limpieza química;

$$
n=\frac{t_{c}}{t_{p}+\tau_{p}}
$$

$t_{c}$ y $t_{p}$ pueden ser determinadas por los valores umbrales de los parámetros, específicamente la presión máxima o la permeabilidad mínima de la membrana.

Otros costos a considerar en la limpieza química es el costo del reactivo químico utilizado. La masa total del reactivo químico de limpieza es simplemente el producto del volumen utilizado y su concentración. Para una limpieza química periódica in situ (CIP), ya sea de mantenimiento o recuperación, la masa específica por unidad de producto permeado es simplemente:

$$
M_{c}=\frac{c_{c} v_{c}}{J_{n e t} A_{m}\left(t_{c}+\tau_{c}\right)}
$$

donde $A_{m}$ es el área de la membrana. Si el reactivo de limpieza se vacía a través de la membrana in situ, entonces el volumen de reactivo de limpieza utilizado se puede encontrar a partir de:

$$
v_{c}=J_{c} A_{m} \tau_{c}
$$

donde $J_{c}$ es el flujo de limpieza. De las dos ecuaciones anteriores se obtiene:

$$
M_{c}=c_{c} \frac{J_{c}}{J_{\text {net }}} \frac{\tau_{c}}{\left(t_{c}+\tau_{c}\right)}
$$

La ecuación 13.8 es aplicable tanto a un retrolavado químicamente mejorado (CEB) como a uno CIP, los valores para $c_{c}, t_{c}$ and $\tau_{c}$ son de menor magnitud para el CEB.

\subsubsection{Aireación}

\subsubsection{Demanda del tratamiento aérobico}

La aireación es requerida en primer lugar para satisfacer las necesidades operacionales del bioreactor; específicamente, la necesidad del licor mezclado (lodos) de aireación a los efectos de proveer agitación y mezclado de los sólidos (para mantener los sólidos en suspensión) y también para mantener los niveles necesarios y deseados de oxígeno disuelto (OD) para garantizar el proceso biológico (el mantenimiento de una población de microrganismos viables para realizar el bio-tratamiento). En tratamiento biológico de efluentes, el OD es normalmente un parámetro clave para el diseño de dichos sistemas. El requerimiento de oxígeno para un sistema biológico se relaciona con el caudal de alimentación, la degradación del sustrato, la producción de lodos, y la concentración de NTK de la alimentación que se oxida para formar nitrato. Esta relación se deriva de un balance de masa, el cual es el mismo independientemente del sistema de tratamiento biológico en consideración.

El oxígeno se suele transferirse a la biomasa por burbujeo de aire en el sistema, o en algunos casos de oxígeno puro, a través de difusores de burbuja. Sólo una porción del aire, u oxígeno, que se alimenta al sistema 


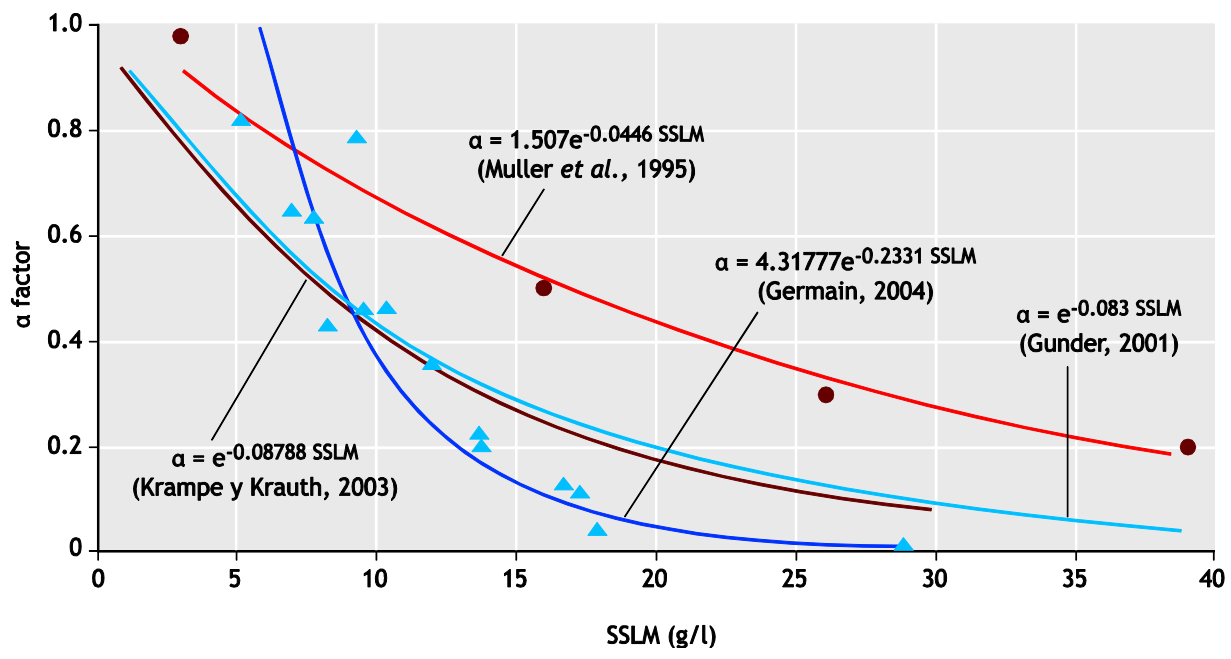

Figura 13.13 Factor alpha vs. concentración de SSLM (Judd, 2006)

se transfiere a la biomasa. Esto se cuantifica por la eficiencia de transferencia de oxígeno (ETO). La eficiencia de transferencia depende del tipo de difusor utilizado y del diseño específico del sistema. Los fabricantes proporcionan las ETOs para sus respectivos sistemas de difusores de burbuja en agua limpia y a una temperatura de $20{ }^{\circ} \mathrm{C}$; sin embargo, las ETOs para el licor de mezcla del proceso MBR (o sea en el biorreactor) es siempre inferior, debido principalmente a la presencia de sólidos suspendidos. La relación entre las ETO en el licor de mezcla (biorreactor con lodo) y la ETO en agua (biorreactor con agua) se expresa a menudo como $\alpha$ (el "factor alfa"), y se ha demostrado por una serie de autores que este parámetro disminuye exponencialmente con la concentración de SSLM (Figura 13.13).

Las diferencia principal entre los bio-tratamientos de efluentes usando un sistema MBR en comparación con un bio-proceso convencional de tratamiento de efluentes radica en la concentración de biomasa, que tiende a ser significativamente más alta en un MBR. Dichas concentraciones de biomasa más elevadas lleva a proporciones generalmente menores de alimento a los microrganismos (menores tasas de F:M), y el tamaño de los flóculos tienden a ser más pequeños. La transferencia de oxígeno es inherentemente menos eficaz para un MBR debido a las concentraciones más altas de SSLM. Los flóculos más pequeños, presumiblemente generados por los esfuerzos cortantes ejercidos por la aireación en la membrana, tienden a producir lodos más difíciles de deshidratar. Sin embargo, el funcionamiento con mayores tiempos de retención de lodos e inferiores relaciones F:M reduce la producción de lodos.

Dado que el bio-tratamiento aeróbico es una tecnología madura y bien entendida, existen expresiones matemáticas para definir su funcionamiento, basadas en la cinética de Monod, como se describe en otra parte de este libro. Los mismos principios y expresiones se pueden aplicar a las tecnologías MBR con respecto al componente de tratamiento biológico, y se utilizan de la misma manera para estimar valores de parámetros claves del proceso, tales como la tasa de producción de lodos, la demanda de aireación y el tamaño del tanque de bio-tratamiento. Los parámetros relativos a la eficiencia en la transferencia de oxígeno deben entonces, ser ajustado de acuerdo a las condiciones específicas de funcionamiento, como se indica en la Figura 13.13, así como el diseño del sistema y en particular el aireador. Sin embargo, es evidente que los valores de las constantes biocinéticas claves pueden requerir modificación. La biocinética de MBR ha recibido alguna atención en la literatura, pero todavía no es claro que valores de parámetros requieren ajustes y el grado en que se necesita modificación.

\subsubsection{Demanda de aireación en la membrana}

Como se describe en la Sección 13.2.4, la aireación en la membrana se puede expresar en términos de demanda de específica de aireación (DEA) con respecto al área de la membrana (Ec. 13.1) o al flujo de permeado (Ec. 13.2). En la práctica, el valor de aireación en la membrana no se define teóricamente ya que la relación entre la aireación y la disminución del flujo no es bien comprendida en la actualidad. Los 
valores de aireación de membrana se basan en experiencias anteriores, y en muchos casos los proveedores recomiendan una velocidad de aireación apropiada. Como se vio en el caso de los regímenes limpieza de la membrana, los datos más valiosos son los que se obtienen de ensayos experimentales y estudios de casos a escala real.

La demanda de energía para aireación en $\mathrm{kWh}$ por $\mathrm{m}^{3}$ de permeado está dada por la siguiente relación:

$E_{A}=\frac{k_{1} p T D E A_{p} \gamma}{(\gamma-1) \zeta}\left[\frac{(0.1 y+p)}{p}^{\left(1-\frac{1}{\gamma}\right)}-1\right]$

Donde:

$\gamma \quad$ constante de aireador $\sim 1.4$

$\zeta \quad$ eficiencia del soplador, normalmente entre 0,4

y 0,7

y profundidad del aireador, entre 2,5 y $5 \mathrm{~m}$, dependiendo de la altura del módulo de membrana

p presión de ingreso al aireador, en bar

$\mathrm{T}$ temperatura absoluta del aire

k1 constante, 0,366, si la presión es en bar

y, sobre la región lineal de los puntos mostrados en la Figura $13.13 D E A_{p}=U A_{x} /(m U+c)$, donde $m$ y $c$ son constantes empíricas

\subsubsection{Diseño: resumen}

Para un determinado conjunto completo de datos, la determinación de la demanda de energía se obtiene a través del cálculo de:

- El oxígeno requerido por la biomasa

- coeficiente de transferencia de oxígeno a partir de las características del aireador

- factor alfa de relaciones empíricas

- demanda específica de aireación obtenida de la tasa de aireación y el flujo neto

- flujo de aire a través del soplador

- requerimiento de energía del soplador

- energía para el bombeo necesario para la extracción del permeado y la recirculación.

El diseño por lo tanto depende críticamente del flujo

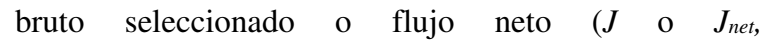
respectivamente) y de la demanda de aireación necesaria para mantener este flujo, conocido como $R_{v}$, bajo las condiciones de limpieza física y química empleadas. La demanda total de aireación también dependerá del grado en el que la aireación de la membrana genera oxígeno disuelto que se utiliza posteriormente para mantener la biomasa. Dado que actualmente no existen guías específicas que relacionen el flujo y la oxigenación de la membrana para un flujo de tres fases (agua, lodo, y aire), como existe en un MBR sumergido, es necesario revisar la información empírica sobre este tema para identificar las relaciones apropiadas que posteriormente se puedan utilizar para fines de diseño.

Las interrelaciones dentro de un proceso MBR son complejas, pero las relaciones más importantes con respecto a los costos de operación, son aquellas relacionadas con la aireación, ya que esto proporciona el mayor componente del costo de operación del proceso. Ya se han comentado los impactos de la aireación en los diferentes parámetros de funcionamiento, junto con los parámetros biológicos y físicos utilizados para la determinación de los costos operativos. Es más consistente normalizar contra los costos que contra el volumen de producto permeado producido, a los efectos de obtener componentes específicos relacionados con la demanda de energía. Dado que la demanda de energía se relaciona con el bombeo, se requiere conocimiento de la eficiencia de energía en el bombeo, así como el costo por unidad de energía eléctrica. Los costos de reactivos químicos son también un factor que contribuye, pero estos (representado por $M c$, en la ecuación 13,10) son normalmente muy pequeños en comparación con la demanda de energía y la sustitución de la membrana. Este último $(F)$ es, obviamente, un parámetro clave y está relacionado a las incrustaciones irrecuperables. Desafortunadamente, no hay datos históricos suficientes para poder determinar $F$, pero es normal que los proveedores den una garantía a sus productos de membrana que permite establecer $F$ con el propósito de determinar los costos. Al igual que en todos los procesos biológicos, los costos de eliminación de lodos contribuyen a los gastos de funcionamiento de un sistema MBR. Como la generación de lodo se reduce en los procesos MBR, la cantidad de lodos generada es relativamente baja en comparación con los sistemas convencionales. Sin embargo, la eliminación de lodos es un componente cada vez más importante de los costos operativos de los bio-tratamientos, independientemente del tipo de proceso.

\subsection{TECNOLOGÍAS DE MEMBRANA COMERCIALES}

Las tecnologías comerciales disponibles y en desarrollo de sistemas MBR para el tratamiento de 
aguas residuales se pueden clasificar de acuerdo a la configuración de la membrana: membrana plana (MP), fibra hueca $(\mathrm{FH})$ y multitubo (MT). Muchos de estos productos existen y muchos más se están desarrollando; no es posible contar con una descripción completa de todas las tecnologías disponibles a nivel mundial. Sin embargo, una revisión general de la mayoría de los sistemas disponibles (Tabla 13.2) revela que la mayoría se puede clasificar como de membrana plana sumergida o fibra hueca sumergida (así MP o FH iMBR).

Los MBR con separación de biomasa se comercializaron por primera vez en la década de 1970 por Dorr Oliver. Había sistemas de flujo externo o recirculación que operaban a lo que hoy en día se considera demandas específicas de energía muy altas. Los sistemas sumergidos, de consumos de energía más bajos, no se comercializaron hasta veinte años después, cuando se introdujo el Kubota iMBR MP por primera vez en 1990 en el mercado japonés, seguido tres años más tarde por el primer iMBR FH, introducido por Zenon en América del Norte. Debido a la alta demanda de energía para su funcionamiento, hoy en día los eMBRs se emplean, aunque en menor medida que iMBRs, y son casi todos de configuración multitubo.
Las propiedades claves de un módulo de membrana MBR son el material de la membrana, el tamaño de poro y las dimensiones de los módulos (Tabla 13.3). De estos últimos los parámetros claves pueden resumirse en:

- MP: $\quad$ ancho de placa $(w)$

espesor de canal o separación de la $\operatorname{membrana}(\delta)$

- FH: diámetro externo de la fibra $(d)$ separación media de la membrana $(\delta)$

- MT: diámetro interno de tubo $(d)$

- Todos: longitud o altura de membrana $(h)$ Densidad de empacado $(\varphi)$ en $\mathrm{m}^{2}$ de área de membrana por $\mathrm{m}^{3}$

Es evidente que algunos de estos parámetros están relacionados entre sí, ya que pequeñas separaciones de membrana producen mayores densidades de empaque. Sin embargo, un límite superior en la densidad de empaquetamiento es impuesto por la propensión del módulo a obstruirse con sólidos. En el caso de módulos multitubo, el límite debido a la obstrucción se impone en el diámetro interior dado que la dirección de flujo es desde dentro hacia fuera a diferencia del otro caso que el flujo es de fuera hacia dentro.

Tabla 13.2 Ejemplos de sistemas MBR disponibles comercialmente

\begin{tabular}{|c|c|c|c|}
\hline & \multicolumn{3}{|c|}{ Configuración del Proceso } \\
\hline & & Sumergida (iMBR) & Externa (eMBR) \\
\hline & MP & A3 & Novasep-Orelis \\
\hline & & Colloide & \\
\hline & & Brightwater & \\
\hline & & Huber $^{1}$ & \\
\hline & & Kubota & \\
\hline & & Microdyn-Nadir & \\
\hline & & Toray & \\
\hline \multirow{13}{*}{ 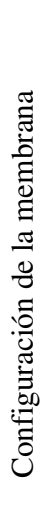 } & $\mathrm{FH}$ & Asahi Kasei & Polymem \\
\hline & & Han-S Environmental & Ultraflo \\
\hline & & ITT & \\
\hline & & Koch-Puron & \\
\hline & & Kolon & \\
\hline & & Korea Membrane Separation (KMS) & \\
\hline & & Mitsubishi Rayon & \\
\hline & & Motimo & \\
\hline & & Siemens-Memcor & \\
\hline & & Zenon & \\
\hline & MT & & Berghof $^{2}$ \\
\hline & & & Millenniumpore \\
\hline & & & Norit X-Flow ${ }^{2}$ \\
\hline
\end{tabular}


Tabla 13.3 Especificaciones de productos de membrana

\begin{tabular}{|c|c|c|c|c|c|c|c|}
\hline Proveedor & $\begin{array}{c}\text { Membrana } \\
\text { (Configuración/ } \\
\text { Material) }\end{array}$ & $\begin{array}{c}\text { Tamaño } \\
\text { de Poro } \\
\mu \mathrm{m}\end{array}$ & $\begin{array}{c}\text { Diámetro }(\mathrm{d}) \\
\text { o espesor de } \\
\text { canal }(\delta) \\
\mathrm{mm}\end{array}$ & $\begin{array}{c}\text { Separación } \\
\text { media de la } \\
\text { fibra } \\
(\delta) \\
\mathrm{mm}\end{array}$ & $\begin{array}{l}\text { Longitud de } \\
\text { membrana } \\
\text { (L) } \\
\mathrm{mm}\end{array}$ & $\begin{array}{c}\text { Área }{ }^{l} \text { de } \\
\text { superficie } \\
\text { específica } \phi \\
\mathrm{m}^{-1}\end{array}$ & $\begin{array}{c}\text { Nombre del } \\
\text { propietario de la } \\
\text { membrana o el } \\
\text { módulo }\end{array}$ \\
\hline Brightwater & MP/PES & 0.08 & 9 & - & 950 & 110 & MEMBRIGHT $^{\circledR}$ \\
\hline Colloide & MP/PES & 0.04 & 10 & - & 1,000 & 160 & Sub Snake \\
\hline Huber & MP/PES & 0.038 & 6 & - & $2,000-3,000^{2}$ & 160 & VRM \\
\hline Kubota & $\mathrm{MP} / \mathrm{PE}$ & 0.4 & 8 & - & 1,000 & 150 & Kubota \\
\hline Toray & MP/DFPV & 0.08 & 7 & - & 1,608 & 130 & Toray \\
\hline Ultraflo & FH/PAN & $0.01-0.1$ & 2.1 & 0.7 & 1,515 & 1,020 & SS60 \\
\hline Asahi Kasei & FH/DFPV & 0.1 & 1.3 & 1.3 & 2,000 & 710 & Microza \\
\hline Koch-Puron & FH/PES & 0.05 & 2.5 & 3.5 & 2,000 & 260 & Puron \\
\hline Mitsubishi Rayon & $\begin{array}{c}\text { FH/PE } \\
\text { FH/DFPV }\end{array}$ & $\begin{array}{l}0.4 \\
0.4\end{array}$ & $\begin{array}{c}0.54 \\
2.8\end{array}$ & $\begin{array}{l}1.7 \\
2.9\end{array}$ & $\begin{array}{l}1,035 \\
2,000\end{array}$ & $\begin{array}{l}485 \\
333\end{array}$ & $\begin{array}{c}\text { SUR } \\
\text { SADFTM }\end{array}$ \\
\hline Polymem & FH/PS & 0.08 & 1.4 & 1.1 & $1,000-1,500$ & 800 & WW120 \\
\hline Motimo & FH/DFPV & $0.1-0.2$ & 1.0 & 0.9 & 1,510 & 1,100 & Flat Plat \\
\hline Siemens-Memcor & FH/DFPV & 0.04 & 1.3 & 2.5 & 1,610 & 334 & B10R, B30R \\
\hline Zenon & FH/DFPV & 0.04 & 1.9 & 3.0 & $1,940-2,198$ & 300 & ZW500C-D \\
\hline Berghof & MT/PES o DFPV & $\begin{array}{l}0.08 \\
0.12\end{array}$ & 9 & - & 3,000 & 110 & $\begin{array}{l}\text { HyPerm-AE } \\
\text { HyperFlux }\end{array}$ \\
\hline Norit X-Flow & MT/DFPV & 0.038 & $\begin{array}{c}5.2 \\
8\end{array}$ & $\begin{array}{l}- \\
-\end{array}$ & $\begin{array}{l}3,000 \\
3,000\end{array}$ & $\begin{array}{l}320 \\
290\end{array}$ & $\begin{array}{l}\text { F4385 } \\
\text { F5385 }\end{array}$ \\
\hline KMS & FH/PEAD & 0.4 & 0.65 & 1.2 & 300 & 565 & KMS-LF, CF \\
\hline
\end{tabular}

${ }^{1}$ Referencias de los elementos; figuras en cursiva se refieren a los módulos; figuras en negrita se refieren a los elementos y el módulo

${ }^{2}$ Membranas giratorias: diámetro de un panel completo hexagonal/octogonal

$\mathrm{Si}$ bien no es posible realizar una revisión exhaustiva de todas las tecnologías existentes, si se observan ciertas tendencias claves que se pueden resumir a continuación:

1) Todas excepto una tecnología eMBR se basan en módulos MT bombeados, las excepciones son el Orelis Pleaide que es un módulo de membrana MP, el PolyMem (y posiblemente Ultraflo) FH de flujo externo, y el sistema de Norit/Wehrle con recirculación y air-lift.

2) Casi todos los iMBR son o bien (a) módulos FH de DFPV orientados verticalmente de diámetro exterior predominantemente entre 1 y $2.8 \mathrm{~mm}$, o (b) las membranas de placas planas rectangulares 1-1.6 m de profundidad con una separación de membrana entre 6 y $10 \mathrm{~mm}$, exceptuando los casos de:

- el producto Huber VRM giratorio, que es un módulo MP giratorio,

- el módulo FH Mitsubishi Rayon, que comprende las relativamente finas $(0.54 \mathrm{~mm}$ de diámetro) fibras de polietileno orientadas horizontalmente.

A pesar de las aparentes similitudes entre los sistemas comerciales, los dos productos de mayor penetración en el mercado son la iMBR MP de Kubota y la iMBR FH de Zenon. A continuación se describen estas dos tecnologías.

\subsubsection{Kubota}

El módulo de membrana Kubota fue desarrollado a finales de 1980 por la Corporación Kubota, una compañía de ingeniería japonesa, más conocida originalmente en el mercado de maquinaria agrícola. El desarrollo fue en respuesta a una iniciativa del gobierno japonés para promover una nueva generación de procesos de tratamiento de aguas residuales compactos y con una producción de agua tratada de alta calidad. La demostración de la primera planta piloto de las membranas Kubota se llevó a cabo en 1990 y poco después la primera instalación comercial. En la actualidad hay más de 2.200 MBR Kubota en todo el mundo, con aproximadamente el $10 \%$ de ellos instalados en Europa.

La membrana origina era del tipo MP de microfiltración, modelo Tipo 510, que es el más ampliamente utilizado. Comprende una membrana plana de $0.5 \mathrm{~m}$ x $1 \mathrm{~m}$ y $6 \mathrm{~mm}$ de espesor, proporcionando un área efectiva de membrana de $0,8 \mathrm{~m}^{2}$. La membrana es 
hidrofílica de polietileno clorado (PE), apoyada en un muy robusto soporte de resina $\mathrm{ABE}$ (acrilonitrilo butadieno estireno) no entretejido que está soldado por ultrasonido a cada lado de la membrana de con un material separador de fieltro entre la membrana y el soporte. La membrana contiene una serie de canales estrechos para recoger el permeado. El tamaño de poro nominal es de 0,4 micras, pero debido a la formación de una capa de filtración dinámica en la superficie de la membrana, el tamaño de poro efectivo en su operación es considerablemente inferior a esto y puede estar en el rango correspondiente a ultrafiltración (UF).

Los paneles de membrana (Figura 13.14) están firmemente sujetados para formar un módulo (Figura 13.15), proporcionando una separación entre membranas de 7-8 $\mathrm{mm}$.

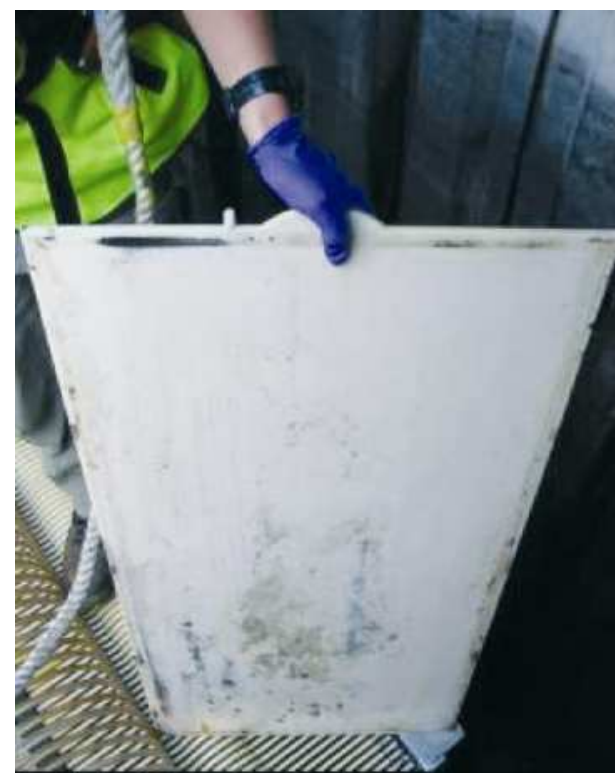

Figura 13.14 Kubota 510 panel de membrana extraído del módulo (foto: S. Judd)

A los efectos de evitar obstrucciones en la membrana es suficiente proveer con un pre-tratamiento compuesto por un tamiz (reja) bidireccional de $3 \mathrm{~mm}$. Considerando esta separación, el área de membrana por unidad de volumen interno del módulo es de $115 \mathrm{~m}^{2} / \mathrm{m}^{3}$. El flujo del exterior al interior del panel puede ser por succión o por gravedad; en general se necesitan entre $0.5 \mathrm{~m}$ y $1.3 \mathrm{~m}$ de altura hidrostática de alimentación para operar por gravedad. El permeado se extrae a partir de un único punto en la parte superior de cada elemento de membrana a través de un tubo de poliuretano. La aireación a través de los aireadores de burbujas gruesas se aplica en la base del tanque a fin de proporcionar aireación para evitar ensuciamiento del módulo de membranas; además esta aireación suministra parte del oxígeno disuelto requerido para el proceso biológico. Los originales sistemas de burbuja gruesa consistentes en tubos de aireación tipo "loop" con agujeros de 8 a 10 $\mathrm{mm}$ de diámetro han sido remplazados por un sistema aireador patentado de lavado de lodos. Este aireador está compuesto por un tubo central con pequeños tubos laterales de ramificación a intervalos regulares. Cada tubo lateral tiene orificios de $4 \mathrm{~mm}$ en la parte superior. La limpieza del aireador se consigue abriendo brevemente una válvula externa conectada a través de un colector a los extremos de la tubería(s) central(es). Esto permite un vigoroso reflujo de aire y lodos de vuelta al tanque. Este reflujo saca el lodo desde el interior del aireador y ayuda a prevenir la obstrucción del sistema de aireación. Para evitar que burbujas de aire escapen sin pasar a través del módulo de membranas, se coloca una base tipo "pollera" en el módulo. Los módulos de membrana pueden contener hasta 200 elementos o en una configuración de dos pisos hasta 400 elementos.

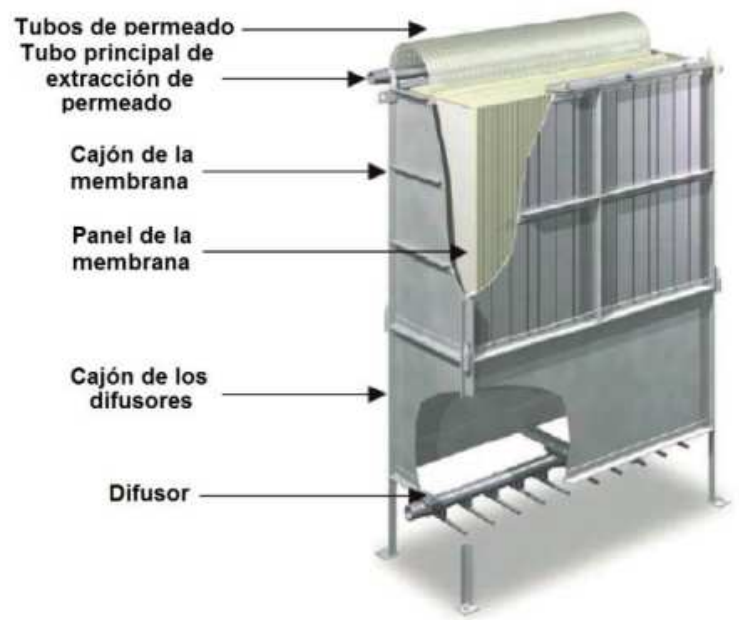

Figura 13.15 Modulo Kubota (ES), basado en el tipo de membrana 510

Un paso en la mejora de la eficiencia se dio con la introducción del modelo EK de doble piso en 2002. En este diseño, los costos de capital se redujeron debido a que el área de membrana disponible por $\mathrm{m}^{2}$ de la planta se duplica, el número de difusores requeridos se redujo a la mitad, y una única base de módulo se utiliza para el montaje de dos bancos de elementos. Además, los costos de funcionamiento se reducen debido a que la tasa de aireación específica de membrana disminuye, aunque la demanda de energía no disminuye proporcionalmente debido a la mayor profundidad del 
aireador en el tanque.

Una alternativa lógica para el diseño de dos pisos es la creación de un único elemento de membrana alargado, que por lo tanto posee una mayor trayectoria de flujo de aire y una gran área de membrana. Kubota ha desarrollado recientemente un módulo más grande

\section{Figura 13.17 Tren de tratamiento ZeeWeed ${ }^{\oplus}$}

(tipo 515) en el que los elementos de membrana se conectan para crear el módulo sin necesidad de una carcasa separada para insertar los elementos. Cada elemento de membrana $(1.5 \mathrm{~m} \times 0.55 \mathrm{~m}$, proporciona un área efectiva de membrana de $1.25 \mathrm{~m}^{2}$ ) contiene canales internos que se conectan a un colector de permeado de sección moldeada. Cuando los paneles se unen entre sí, estas secciones forman el colector de permeado. Este diseño elimina la necesidad de colectores separados y de tubos de permeado y reduce la complejidad de la carcasa (Figura 13.16). Además, la mayor área por panel genera una reducción del consumo de energía necesario para la aireación, la $\mathrm{DEA}_{\mathrm{m}}$ es de $0.34 \mathrm{Nm}^{3} \mathrm{hr}^{-1}$ de aire por $\mathrm{m}^{2}$ de área de membrana. Esto representa una reducción significativa de la demanda de aireación, y por lo tanto del consumo de energía, el modulo ES original observado en la figura tiene una $\mathrm{DEA}_{\mathrm{m}}$ de 0,75 . Esto lleva a una demanda menor de aireación específica por unidad de volumen de permeado $\left(\mathrm{DEA}_{\mathrm{p}}\right)$. Se pueden esperar valores inferiores a 15 de la unidad de dos pisos, para el funcionamiento a velocidades de flujo estándar en el tratamiento de aguas residuales.

\subsubsection{GE Zenon}

GE Zenon es actualmente la mayor empresa de tecnología del procesos MBR, después de haber instalado su primera ZeeWeed ( ${ }^{\circledR}$ sistema FH iMBR en Stoney Creek, Ontario en 1993. La mayoría de los MBR de grandes dimensiones se basan en la tecnología de Zenon. Estos incluyen plantas como la del Campus de John Creek en Georgia, EE.UU. (flujo de 41 MLD mega litros por día - de promedio diario, 94 MLD de
La oferta actual de productos de la compañía para el tratamiento de aguas residuales comprende el modelo ZW500c (23,2 m2 de área de membrana) y ZW500d (31,6 m2), introducidas en 2001 y 2002, respectivamente (Figura 13.17, Tabla 13.4). Ambos diseños representan una mejora sobre el módulo original de ZW500a primero en ser introducido en 1997, proporcionando una mejora en la disminución de la obstrucción y en la facilidad de extracción y reposición de elementos en los módulos anteriores. Los elementos tienen un tamaño de poro de 0,04 micras, 1,9 $\mathrm{mm}$ de diámetro exterior $(0,8 \mathrm{~mm}$ de diámetro interno) de la membrana de DFPV con un núcleo trenzado para proporcionar integridad mecánica. Las membranas están encapsuladas para proporcionar aproximadamente $10 \%$ "holgura" para permitir que se muevan en el tren de burbujas de aire ascendentes a lo largo de la longitud del módulo. El permeado se retira por la parte superior del módulo a través de un cabezal superior. Los módulos, que son de más de $2 \mathrm{~m}$ de altura, se montan en un "cassette" que contiene hasta 22 módulos (Figura 13.18). Estos se colocan entonces en un tren (Figura 13.17) para alcanzar la capacidad requerida.

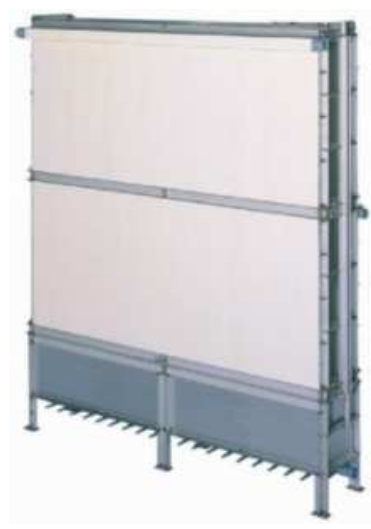

Figura 13.16 Modulo Kubota EW

Tabla 13.4 Módulos ZeeWeed ${ }^{\circledast}$ series 500 y 1000

\begin{tabular}{llll}
\hline & $500 \mathrm{a}$ & $500 \mathrm{c}$ & $500 \mathrm{~d}$ \\
\hline Longitud x Profundidad x Altura $(\mathrm{mm})$ & $688 \times 184 \times 2,017$ & $678 \times 60 \times 1,940$ & $844 \times 56 \times 2,198$ \\
Área de Membrana $\left(\mathrm{m}^{2}\right)$ & 46.5 & 23.2 & 31.6 \\
Densidad de empacado, $\left(\mathrm{m}^{2} / \mathrm{m}^{3}\right)$ & 182.1 & 294.0 & 304.2 \\
\hline
\end{tabular}

Todos los materiales de la membrana son de DFPV hidrofílico con un tamaño nominal de poro de $0.04 \mu \mathrm{m}$. flujo máximo) y Brightwater, Washington, EE.UU. (117 MDL de promedio diario, 144 MLD de flujo máximo). 


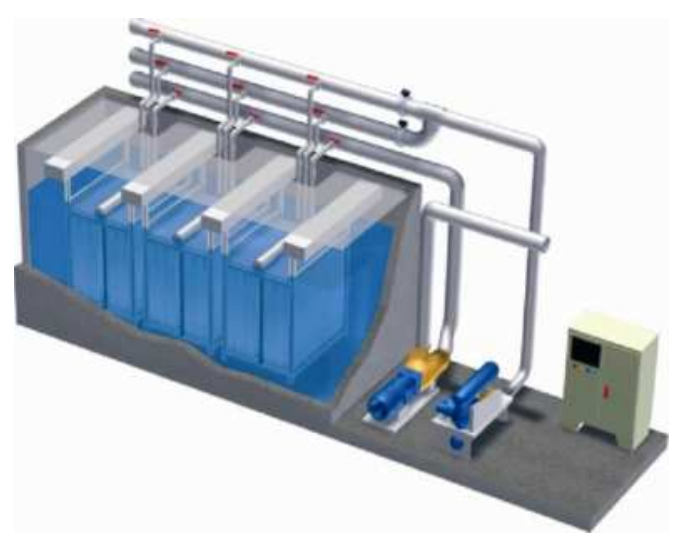

Figura 13.17 Tren ZeeWeed ${ }^{\circledR}$
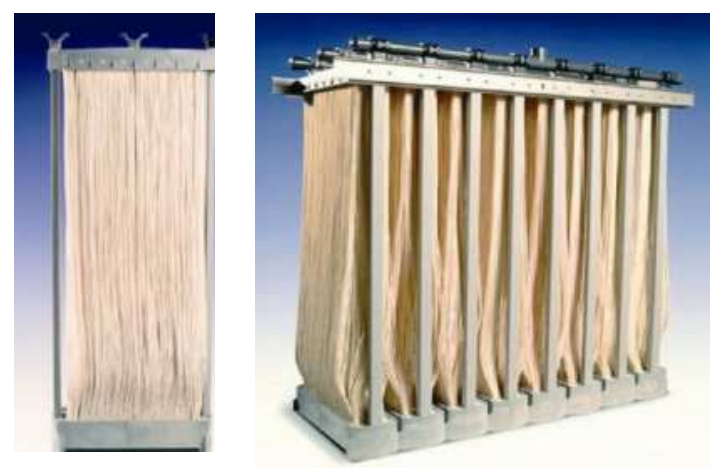

Figura 13.18 Elementos y módulos de la Membrana MBR Zenon: ZeeWeed ${ }^{\circledR} 500 a$

Una característica clave del sistema de Zenon es el uso de la aireación cíclica, que fue patentada y posteriormente introducida comercialmente en el año 2000. En este modo de aireación, los sopladores son operados continuamente a una velocidad fija y la aireación cíclica se logra mediante ciclos de flujo de aire desde la cabecera de aire, de uno a otro, por medio de válvulas de accionamiento neumático. Cada mitad de cada cassette está conectado a la cabecera de aire, lo que permite que el aire ingrese de manera cíclica. Esto es preferible a una aireación continua principalmente por razones técnicas y comerciales. Técnicamente, la aireación continua a menudo generaba la canalización de aire a través del módulo y sólo se podía limpiar a fondo partes del módulo. Al introducir esfuerzos de cizallamiento y de flujos de aire inestables en el proceso a través de la aireación cíclica se elimina la canalización. Los difusores de funcionamiento continuo también tienen una tendencia a bloquearse, pero con el aumento de eficacia en el lavado de los aireadores a través de la acción de la aireación cíclica se reduce significativamente este problema. El ciclo de filtración de 10 segundos prendido / 10 segundos apagado se ha determinado como el más eficaz y es el típicamente empleado en los MBR para plantas municipales de mediano y gran porte. Actualmente hay ensayos que estudian el impacto de reducir aún más la aireación del $50 \%$ al $25 \%$ del tiempo de operación

\subsubsection{KMS (Korea Membrane Separation)}

KMS es la mayor empresa sur coreana de membranas en función del número de sitios instalados. KMS tiene alrededor de 450 instalaciones para plantas de MBR sumergidas en todo el mundo, en la actualidad la mayor parte están en Corea del Sur (las plantas de mayor capacidad son de 18.000 y $25.000 \mathrm{~m}^{3} / \mathrm{d}$ ). KMS ha fabricado membranas de fibra hueca de polipropileno hasta 2002. En la actualidad produce membrana de fibra hueca de polietileno (PE) asimétrico que tienen una mayor resistencia y porosidad. El tamaño nominal de poro de la membrana de PE es 0,4 ๆm, y su diámetro exterior e interior son de 650 y $410 \quad \eta m$, respectivamente. La membrana está recubierta con un polímero hidrófilo y resistente al cloro. KMS cuenta con tres tipos de módulos, F, LF y CF. Los tipos F y LF tienen como subelementos finos difusores rectangulares. El número de sub-elementos se puede regular en función de las condiciones de campo. El recientemente desarrollado tipo CF de módulo cassette consta de 13 sub-unidades de módulos. Las membranas de fibra hueca se colocan verticalmente en esta sub-unidad que luego es colocada en un módulo de cassette como se muestra en la Figura 13.19.

Los módulos de cartucho simplemente se insertan en la estructura como un cassette (Figura 13.20). Debido a que el módulo de cartucho tiene una longitud fija muy corta, de $396 \mathrm{~mm}$, como se muestra en la Tabla 13.5, resulta ventajoso para poder optimizar la altura completa de la estructura libremente de acuerdo con las condiciones del sitio, dando como resultado la maximización de la superficie de membrana por unidad de superficie proyectada. También, los sólidos obstruidos entre las fibras se separan fácilmente por el arrastre debido a la corta longitud de la membrana y del 
Tabla 13.5 KMS módulo de sub-unidades y módulos de cartuchos

\begin{tabular}{lccc}
\hline Dimensiones & Unidad & Modulo de Sub-unidad & Modulo de cartucho (CF) \\
\hline Largo x Profundidad x Altura & $\mathrm{mm}$ & $446 \times 14 \times 368$ & $536 \times 320 \times 396$ \\
Área de membrana & $\mathrm{m}^{2}$ & 1.3 & 16.8 \\
Densidad de empacado & $\mathrm{m}^{2} / \mathrm{m}^{3}$ & 565 & 247 \\
\hline
\end{tabular}

módulo. El módulo de cartucho tiene una estructura simétrica entre la parte superior e inferior. Por lo tanto, si los sólidos se acumulan entre las fibras en el lado superior, simplemente girando el módulo, los sólidos pueden ser fácilmente eliminados de la parte inferior en pocos días con las burbujas de aire ascendentes.

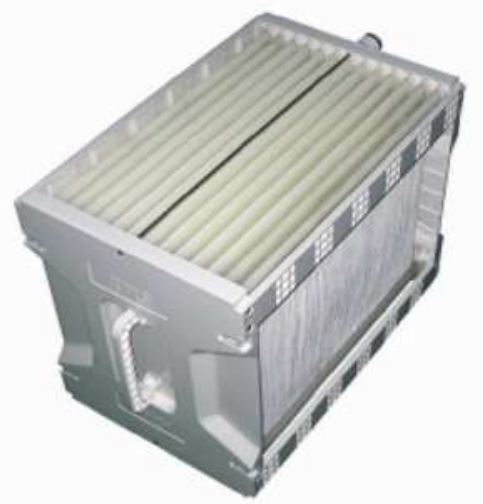

Figura 13.19 Módulo de cartucho que consiste en módulos de 13 sub-unidades (área de superficie de membrana $16.8 \mathrm{~m}^{2}$ )

Además, esta corta longitud de membrana ayuda a minimizar el ensuciamiento causado por la pérdida de presión en la pared interior de las membranas de fibras huecas. Se utilizan burbujas gruesas para la limpieza física en el tanque de aireación. El difusor tiene un tubo colector y muchas tuberías sub-ramificadas con numerosos agujeros. Se obtiene una intensidad de aireación distribuida uniformemente a lo largo de la longitud del tubo, controlando el ángulo de los tubos de distribución. La aireación uniformemente distribuida permite operar el sistema sin aireación excesiva. Este sistema de aireación eficiente desempeña un papel clave en la eficiencia energética de este MBR.

Los sistemas KMS de membrana sumergida han sido operados sin dificultades en muchas plantas sin ningún lavado a contracorriente a un flujo de 0.3 a $0.4 \mathrm{~m}^{3} / \mathrm{m}^{2}$.d. Debido a que este sistema libre de lavado proporciona simplicidad al sistema y reduce los problemas, ha sido preferido por muchas plantas de pequeña y mediana escala en Corea. En este sistema de libre lavado, el período típico de CIP es generalmente de 6 a 12 meses.

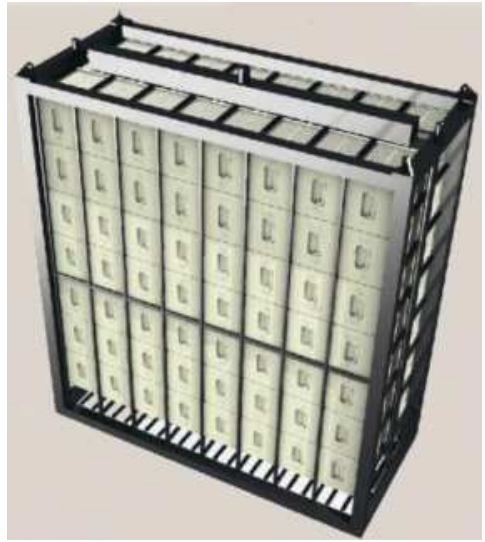

Figura 13.20 Estructura de gran capacidad para plantas de gran escala (KMS-6007CF)

\subsection{IMBR CASOS DE ESTUDIO}

La operación de las plantas de MBR se caracteriza en gran medida por el rendimiento hidráulico y la eficacia de la purificación obtenida. La purificación se define con relación a la DBO y/o la DQO, los sólidos suspendidos totales (SST), el amoniaco $\left(\mathrm{NH}_{4}{ }^{+}-\mathrm{N}\right)$, nitrógeno y fósforo total, y microrganismos, aunque las autorizaciones de descarga no necesariamente abarcan todos estos requisitos.

Las características hidráulicas se centran principalmente en el flujo, los tiempos de ciclos de limpieza físicos y químicos, tiempo de inactividad asociado con la limpieza, la conversión y, en el caso de los sistemas sumergidos, la demanda de aireación. Los tiempos de los ciclos de limpieza son normalmente dictados por el requisito de mantener una permeabilidad media razonable para el sistema; el valor de permeabilidad absoluta apropiado a un proceso de tratamiento MBR dependerá de la tecnología, y más específicamente de la configuración de la membrana. Asimismo, la demanda de aireación de la membrana también varía entre tecnologías, así como con las características del agua de alimentación. 
En las siguientes secciones, serán descriptos tres casos de estudio relacionados con el tratamiento de aguas residuales municipales con base en las tecnologías Kubota, Zenon GE, y Kwater.

\subsubsection{Swanage, Reino Unido}

La planta de Swanage, propiedad de Wessex Water, es una planta de 12,7 MLD (megalitros por día) y se instaló en 1999 tras el éxito de la planta en Porlock - la más antigua planta Kubota en funcionamiento fuera de Japón. El flujo máxima de diseño de la planta es de 33 LMH y opera a generalmente a una SSLM de entre 8 y $12 \mathrm{~g} / \mathrm{l}$. La planta de Swanage es de cierta importancia por ser la instalación más grande de MBR en el mundo en el momento de la instalación en términos de capacidad de flujo máximo. La planta de Swanage es también una de las plantas depuradoras gran escala menos visible. La planta ha sido totalmente ajardinada en la costa de Dorset (Figura 13.21), una hazaña considerable la ingeniería civil con su consecuente costo asociado. La planta cuenta con seis tanques de aireación de 3.3 × 22.5 × $5 \mathrm{~m}$ de dimensión media, con una profundidad de líquido de $3,5 \mathrm{~m}$, dando un volumen de $250 \mathrm{~m}^{3}$, y un total de 132 unidades (22 por tanque) con 150 elementos por unidad y un área de membrana total de $15,840 \mathrm{~m}^{2}$ (Figura 13.22). El módulo de membrana se airea a una velocidad de $0.75 \mathrm{Nm}^{3} \mathrm{hr}^{-1}$ por $\mathrm{m}^{2}$ de área de membrana $\left(D_{\mathrm{mEA}}\right)$, valor estándar de tasa de aireación de burbuja gruesa para el sistema Kubota, lo que significa que cada $\mathrm{m}^{3}$ de permeado producido demanda alrededor de $32 \mathrm{Nm}^{3}$ de aire $\left(\mathrm{DEA}_{\mathrm{p}}=32\right) \mathrm{y}$ también opera con difusores de lavado manuales. Cuando es necesario se procede a la limpieza CIP con hipoclorito $0.5 \%$ en peso.
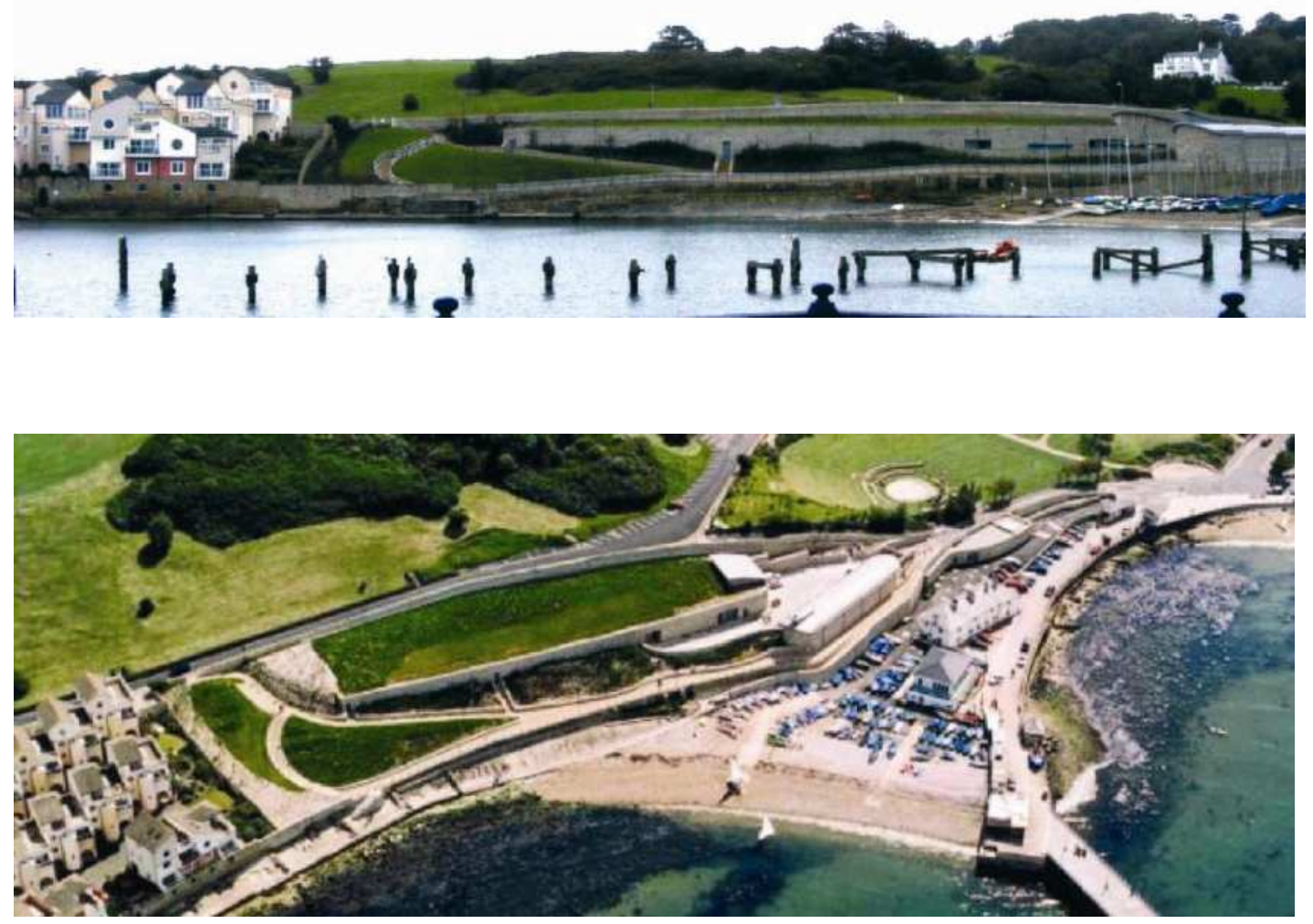

Figure 13.21 Vista de planta de tratamiento de aguas residuales - vistas desde el mar y desde el aire 


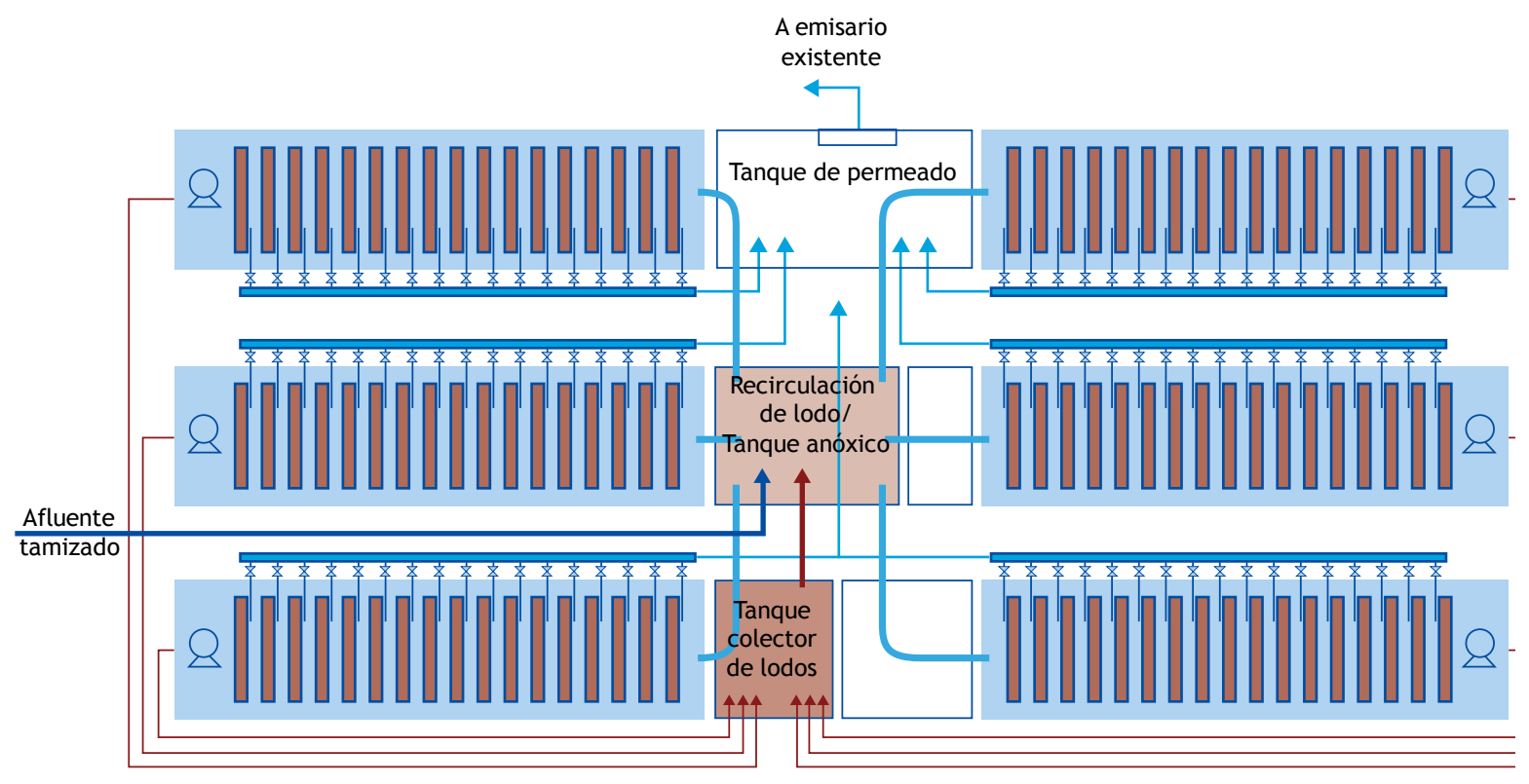

Figura 13.22 Esquema de la planta de Swanage

\subsubsection{Planta de tratamiento de Nordkanal - Kaarst, Alemania}

La planta de Kaarst en Alemania, pertenece y es operado por la Erftverband (Asociación Erft), trata las aguas residuales de los pueblos cercanos de Kaarst, Korschenbroich, y Neuss. Se ha instalado y puesto en operación en enero de 2004, tras el éxito de la primera planta MBR del grupo en Rödingen, una planta más pequeña que fue encargada en 1999. La planta está diseñada para una población equivalente de 80.000 personas y una capacidad de 48 MLD, y en función de esto, es la más grande de Europa.

El sitio cuenta con cinco edificios que albergan el proceso mecánico de deshidratación lodos, las rejas finas, las de malla gruesa, el biorreactor de membrana y los controles de proceso (Figura 13.23). Las instalaciones adicionales incluyen cobertura de tanque de lodos, una cámara de sedimentación, y los tanques de desnitrificación, las dos últimas operaciones son abiertas a la atmósfera. El agua es bombeada desde la planta original de tratamiento de efluentes, a $2.5 \mathrm{~km}$ al este del sitio, pasa por un sistema de rejas de paso de $5 \mathrm{~mm}$, seguido por una cámara de sedimentación aireada. Se alimenta entonces a dos tambores rotativos Huber de $1 \mathrm{~mm}$ de malla de rejillas finas, que sustituyeron a las originales de $0.5 \mathrm{~mm}$, proporcionando cada uno una capacidad de 24 MLD. Hay una reja en "stand-by" de $1 \mathrm{~mm}$ que se conecta en línea en caso de una avería mecánica de alguna de las dos anteriores. Los sólidos recolectados se descargan en un salto y posteriormente son eliminados por incineración fuera del sitio. El agua filtrada se transfiere al MBR.

El bio-tratamiento comprende cuatro tanques cada uno equipado con dos trenes de membrana con una zona de desnitrificación aguas arriba de $3.500 \mathrm{~m}^{3}$ de capacidad total; este último recibe los lodos desde el depósito de membrana de aireación posterior en una relación de recirculación de 4:1. Los trenes de membrana están equipados con 24 cassettes ZW500c de $440 \mathrm{~m}^{2}$ de área de membrana, con un área total de $84.480 \mathrm{~m}^{2}$ (20 m²/elemento; 22 elementos/cassette); los tanques de aireación reciben una agitación mecánica suplementaria a través de agitadores de paleta para mantener la biomasa en suspensión.

El volumen total de los tanques es de $5.800 \mathrm{~m}^{3}$; aproximadamente un tercio comprenden la aireación de membrana, que junto con los tanques de desnitrificación proporcionar una TRH total de aproximadamente 5 horas a un flujo de 48 MLD. Los lodos se deshidratan por centrifugación hasta un contenido en sólidos secos de $25 \%$ en peso. También hay una precipitación simultánea para la eliminación de fósforo.

La planta es operada a un TRS de 25 días, que mantiene el licor de mezcla en concentraciones de entre 10 y $15 \mathrm{~g} / \mathrm{l}$. Las membranas funcionan a un flujo neto de $25 \mathrm{LMH}$ y una permeabilidad media de 150 a 200 $\mathrm{LMH} / \mathrm{bar}$. La aireación intermitente de burbuja gruesa se proporciona a un caudal de $34.000 \mathrm{~m}^{3} / \mathrm{h}$ con una 


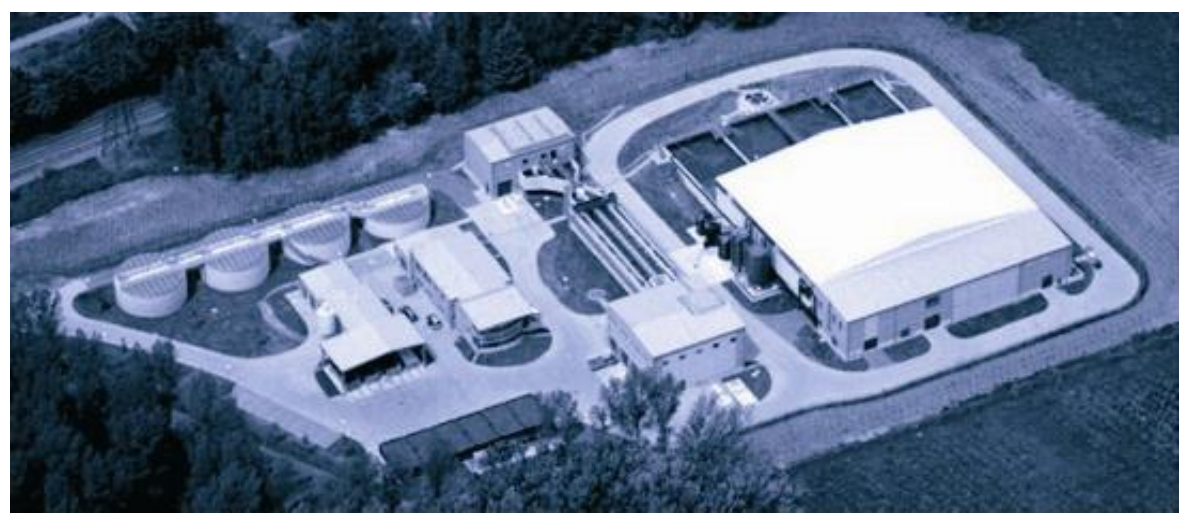

Figura 13.23 Vista aérea del sitio Kaarst

secuencia on/off de 10 segundos de base, dando un $D_{\text {DEA }}$ de $0.40 \mathrm{Nm}^{3} / \mathrm{h}$ por $\mathrm{m}^{2}$ y una DEA $_{p}$ de $17 \mathrm{~m}^{3}$ de aire por $\mathrm{m}^{3}$. La limpieza física comprende una inversión de flujo cada 7 minutos durante 60 segundos a 1,5 veces el flujo de operación. El mantenimiento con limpieza química se lleva a cabo cada dos semanas mediante el drenaje del depósito de membrana y de lavado a contracorriente durante una hora alternativamente con agentes de limpieza diferentes, incluyendo hipoclorito de sodio a $500 \mathrm{mg} / \mathrm{l}$.

La limpieza se lleva a cabo en tanques individuales, por ejemplo de $12.5 \%$ de la capacidad instalada. El número de membranas en línea se ajusta de acuerdo con el flujo, pero esto es controlado de tal manera que se garantice que ningún tren de membrana está fuera de línea durante más de 70 minutos en total. La demanda total de energía específica para todas las operaciones es $0.9 \mathrm{kWh} / \mathrm{m}^{3}$, que se compara con un promedio de 0.5 $\mathrm{kWh} / \mathrm{m}^{3}$ para todas las plantas de tratamiento de aguas residuales convencionales operados por Erftverband.

\subsubsection{Planta de tratamiento en Sari, Korea}

La Sari STP fue operada inicialmente por el gobierno local con un proceso de estabilización de contacto. Esta planta fue actualizada a la tecnología MBR, proceso KSMBR (Kwater Ssangyong Membrane Bio-Reactor), mediante el agregado de módulos de membrana de KMS para lograr una mejor calidad del efluente en septiembre de 2004.

La planta consiste en un reactor anaeróbico (volumen efectivo; $8.5 \mathrm{~m}^{3}$ ), dos reactores de aireación intermitente modificados (volumen efectivo: $16.9 \mathrm{~m}^{3}$ cada uno), un reactor de agotamiento de oxígeno disuelto (volumen efectivo; $4.2 \mathrm{~m}^{3}$ ) y un MBR aerobio (volumen efectivo: $25.26 \mathrm{~m}^{3}$ ) con módulos de membrana sumergidos de fibra hueca (Figura 13.24). El flujo del afluente, SSLM y TRL en el MBR son de $210 \mathrm{~m}^{3} / \mathrm{d}, 8.000 \mathrm{mg} / \mathrm{l}$, y 30 días respectivamente. Además, el TRH total de todos los reactores es de $6 \mathrm{~h}$ (anaeróbico; $0.67 \mathrm{~h}$, dos reactores MIA; 1.5 horas cada uno, agotamiento de oxígeno disuelto; 0.33 horas, MBR: $2 \mathrm{~h}$ ).

En el MBR se tiene una membrana de microfiltración (MF) de polietileno de alta densidad (PEAD) de fibra hueca (KMS; Korea Membrane Separation, de Corea) con un tamaño medio de poro de $0.4 \mu \mathrm{m}$, un diámetro exterior/interior de $0.65 / 0.41 \mathrm{~mm}$, y un área superficial total efectiva por módulo de 11.7 $\mathrm{m}^{2}$. Durante los 6 meses de funcionamiento, la TMP fue de $1 \sim 17 \mathrm{kPa}$ (sin considerar la de presión de la tubería) y el flujo (o velocidad de filtrado) fue de $14.5 \sim 20.8$ $1 / \mathrm{m}^{2} / \mathrm{h}$ (LMH). Mediante el uso de lavado de aire solamente, la limpieza química fuera de línea no fue necesaria, así como tampoco el lavado a contracorriente durante ese período.

Las aguas residuales se reciben en un tanque de ecualización y posteriormente se bombean al reactor anaeróbico a través de una reja. El lodo reciclado, procedente del reactor de agotamiento de oxígeno, también es enviado hacia el reactor anaeróbico. En el reactor anaeróbico, el afluente y el lodo reciclado son alimentados automáticamente en uno de los dos reactores MIA siendo operados en modo de no aireación por un convertidor automático de flujo. En paralelo, otro reactor MIA es operado en modo de aireación sin alimentación. La dirección del flujo se cambia a intervalos de 1 hora. 


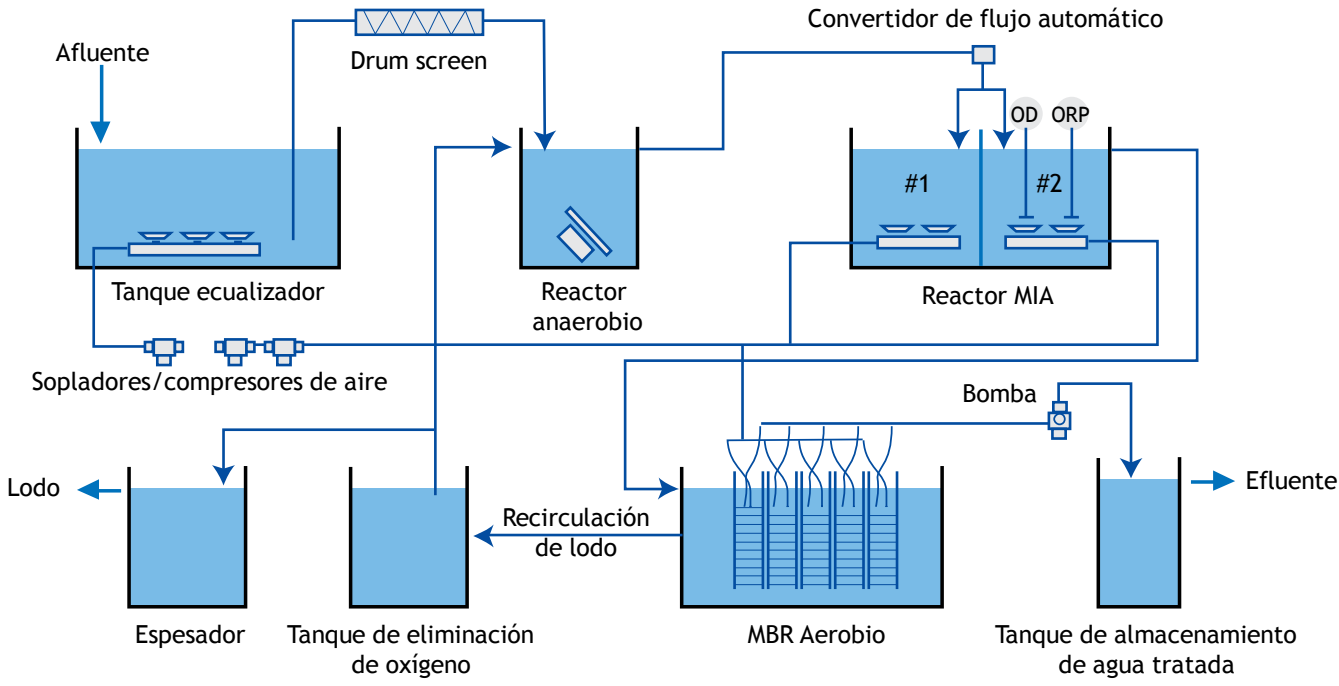

Figura 13.24. Esquema KSMBR

Para solucionar los defectos de la aireación intermitente convencional, se aplica el sistema MIA que lo que hace es dividir en 3 períodos los ciclos: el primero no aireado, el segundo aireado y el tercero una vez más no aireado (NAN). De esta manera, el efecto adverso generado por el oxígeno disuelto remanente en el periodo aireado puede ser eliminado con éxito durante el segundo período no aireado. El perfil de OD con aireación intermitente modificada se muestra en la Figura 13.25.
Las eficiencias de la planta KSMBR se muestran en la Tabla 13.6
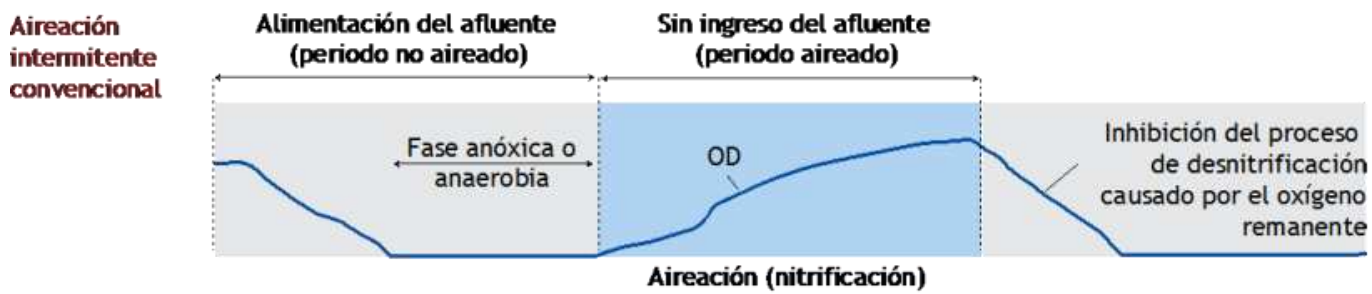

Aireación (nitrificación)
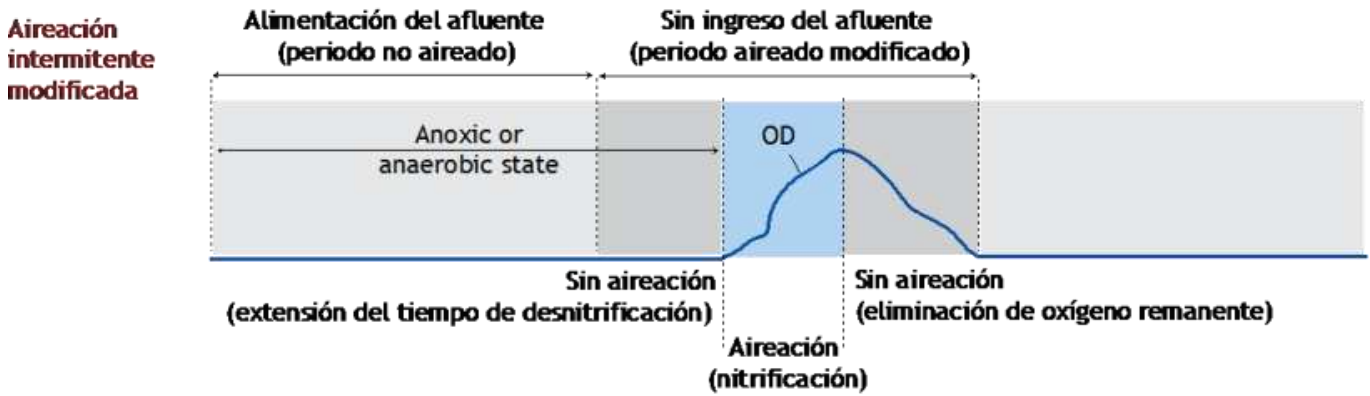

Figura 13.25. Perfil de oxígeno disuelto(OD) en sistema MIA y en la aireación intermitente convencional 
Tabla 13.6 Concentraciones del afluente y efluente en plantas KSMBR así como sus eficiencias

\begin{tabular}{lllllll}
\hline Parámetro & Unidad & $\begin{array}{l}\text { Afluente } \\
\text { Rango }\end{array}$ & Promedio & $\begin{array}{l}\text { Efluente } \\
\text { Rango }\end{array}$ & Promedio & $\begin{array}{l}\text { Eficiencia de remoción } \\
(\%)\end{array}$ \\
\hline DBO $_{5}$ & $\mathrm{mg} / \mathrm{l}$ & $71-186$ & 123 & $0.3-3.8$ & 2.3 & 98.2 \\
DQO $_{\mathrm{Cr}}$ & $\mathrm{mg} / \mathrm{l}$ & $106-424$ & 207 & $7-23$ & 10 & 95.2 \\
$\mathrm{SS}$ & $\mathrm{mg} / \mathrm{l}$ & $40-100$ & 66 & $0-0.5$ & 0.2 & 99.8 \\
$\mathrm{NT}$ & $\mathrm{mg} / 1$ & $13-47$ & 28 & $2.8-14.0$ & 7.8 & 72.7 \\
$\mathrm{PT}$ & $\mathrm{mg} / 1$ & $1.5-6.8$ & 3.2 & $0.02-2.2$ & 0.9 & 71.4 \\
E. coli & $\mathrm{cel} / \mathrm{ml}$ & $67 \times 10^{3}-$ & $528 \times 10^{3}$ & $0-80$ & 44 & 99.9 \\
\hline
\end{tabular}

LMH/bar) y están asociadas con demandas de

\subsubsection{Resumen de los datos}

Dada la importancia de la demanda de aireación y su impacto directo en el consumo de energía, es recomendable estudiar los datos e intentar correlacionar los parámetros claves del funcionamiento (es decir, la permeabilidad y el flujo) con la aireación de la membrana. Un rango de datos de plantas piloto y a gran escala se pueden observar en las Figuras 13.26 y 13.27. Si bien los datos son muy dispersos, si se omiten los valores atípicos entonces se pueden identificar algunas tendencias generales:

a) los sistemas de MP tienden a operar a permeabilidades elevadas (generalmente > 200 LMH/bar) y están asociadas con altas demandas de aireación, tanto $\mathrm{DEA}_{\mathrm{m}}$ como $\mathrm{DEA}_{\mathrm{p}}$. No se observan tendencias evidentes en este subconjunto de datos, aunque para la más alta (y probablemente no óptima) $\mathrm{DEA}_{\mathrm{p}}$ los valores se encuentran dentro del rango de 20-40.

b) Los sistemas de $\mathrm{FH}$ tienden a operar a permeabilidades más bajas (en general <200 aireación inferiores, en ocasiones obtenidas mediante el empleo de aireación intermitente. Para estos sistemas la permeabilidad está aproximadamente linealmente relacionada con la demanda de aireación (Figura 13.27), generalmente menos de $0.5 \mathrm{~m}^{3}$ de permeado generado por $\mathrm{Nm}^{3}$ de aire por bar, y los valores de DEA . son generalmente de entre 10 y 30.

Mientras que los datos de la Figura 13.27 sugieren que la demanda de aireación disminuye de manera constante con el aumento de flujo, es necesario mencionar que estos datos se refieren a valores promediados y que las plantas no son operadas con la demanda de aireación de la membrana ligada al flujo. Dicho esto, las mejoras en la eficiencia energética en general y de la eficiencia de la aireación de la membrana en particular son permanentes, con valores de DEAp que probablemente disminuyan en el futuro con la introducción de nuevas mejoras en el diseño y operación de los iMBR. 


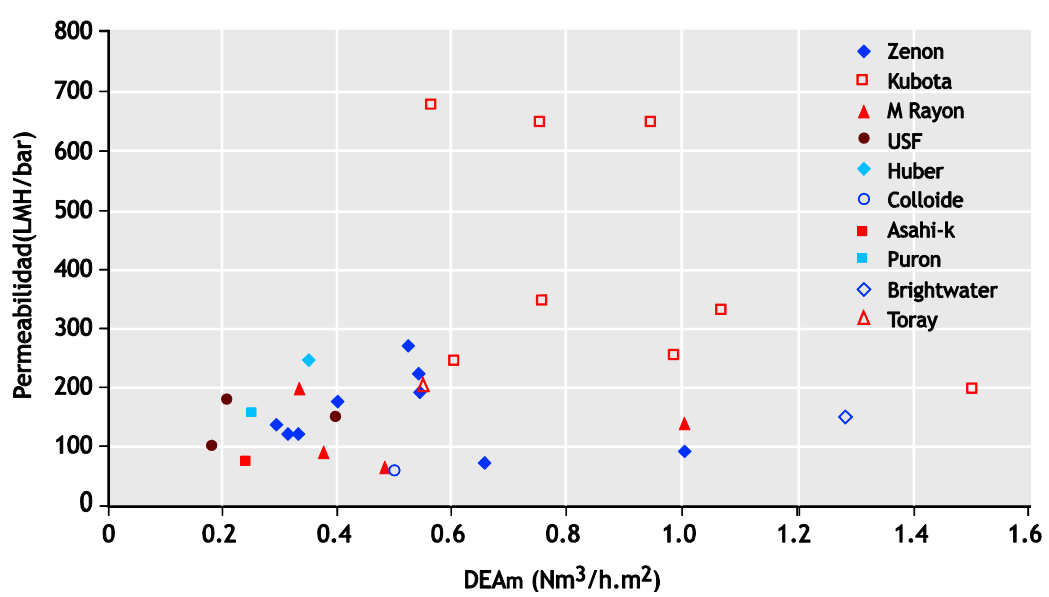

Figura 13.26 Permeabilidad en función de la demanda específica de aireación

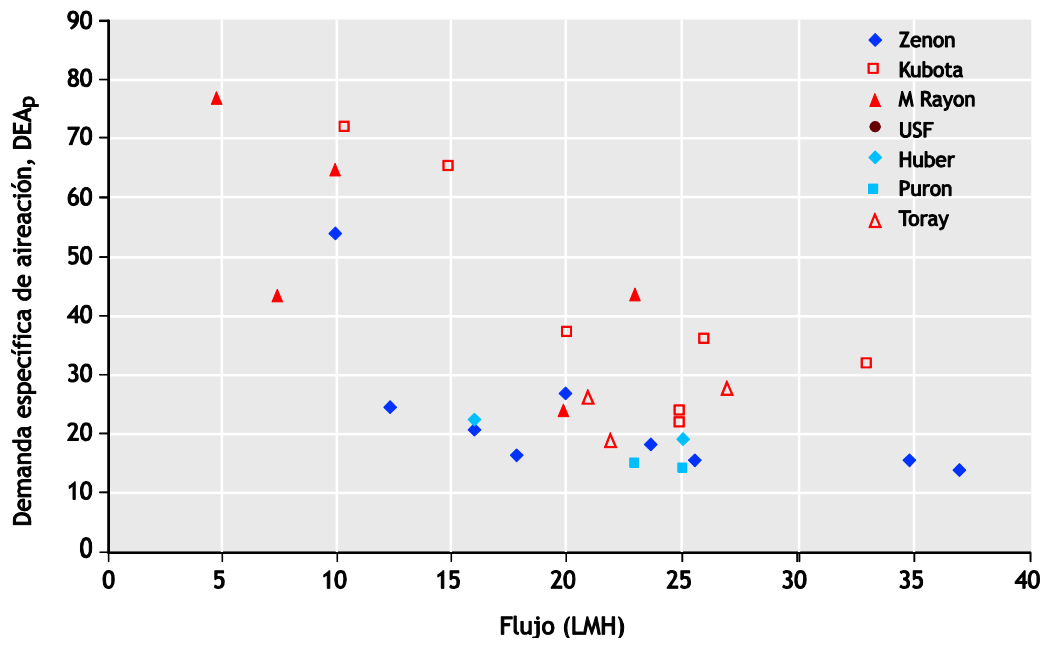

Figura 13.27 Demanda específica de aireación en función del flujo 


\section{REFERENCIAS}

La información de este capítulo está tomada en gran parte del libro "The MBR Book" de Simon Judd, publicado por Elsevier en 2006, utilizado con permiso de los editores.

\section{NOMENCLATURA}

\begin{tabular}{|c|c|c|}
\hline Símbolo & Descripción & Unidad \\
\hline$A_{m}$ & Área de membrana & $\mathrm{m}^{2}$ \\
\hline$A_{t}$ & Área de la sección transversal del tubo & $\mathrm{m}^{2}$ \\
\hline$A_{x}$ & Área libre de la sección transversal del módulo & $\mathrm{m}^{2}$ \\
\hline$c_{c}$ & Concentración de reactivos de limpieza & $\mathrm{kg} / \mathrm{m}^{3}$ \\
\hline $\mathrm{d}$ & Diámetro de fibra & $\mathrm{m}$ \\
\hline $\mathrm{d}_{\mathrm{p}} / \mathrm{d}_{\mathrm{t}}$ & Tasa de disminución de la permeabilidad & $\mathrm{bar} / \mathrm{h}$ \\
\hline $\mathrm{E}_{\mathrm{A}}$ & Demanda de energía para aireación por volumen de permeado & $\mathrm{kWh} / \mathrm{m}^{3}$ \\
\hline $\mathrm{f}$ & Modularización & \\
\hline $\mathrm{F}$ & Ensuciamiento irrecuperable & \\
\hline $\mathrm{J}$ & Flujo & $\mathrm{m} / \mathrm{h}$ \\
\hline $\mathrm{J}_{\mathrm{b}}$ & Flujo de retrolavado & $\mathrm{m} / \mathrm{h}$ \\
\hline k1 & Constante para el cálculo de la demanda de energía de aireación & \\
\hline $\mathrm{L}$ & Longitud de panel & $\mathrm{m}$ \\
\hline $\mathrm{M}_{\mathrm{c}}$ & Masa específica por unidad de permeado producido & \\
\hline $\mathrm{n}$ & Número de ciclos de limpiezas físicas por limpieza química & \\
\hline $\mathrm{P}$ & Presión de entrada al aireador & bar \\
\hline$P_{\max }$ & $\begin{array}{l}\text { Umbral de presión más allá del cual el funcionamiento no puede ser } \\
\text { sostenido }\end{array}$ & bar \\
\hline $\mathrm{Q}_{\mathrm{A}}$ & Caudal de aire & $\mathrm{Nm}^{3} / \mathrm{h}$ \\
\hline $\mathrm{Q}_{\mathrm{R}}$ & Caudal de retenido & $\mathrm{m}^{3} / \mathrm{h}$ \\
\hline $\mathbf{R}_{\mathrm{v}}$ & Demanda de aireación requerida para mantener el flujo seleccionado & $\mathrm{Nm}^{3} / \mathrm{h}$ \\
\hline $\mathrm{DEA}_{\mathrm{m}}$ & Demanda específica de aireación con respecto al área de la membrana & $\mathrm{Nm}^{3} / \mathrm{m}^{2} \cdot \mathrm{h}$ \\
\hline $\mathrm{DEA}_{\mathrm{p}}$ & Demanda específica de aireación con respecto al volumen de permeado & $\mathrm{Nm}^{3} / \mathrm{m}^{3}$ \\
\hline $\mathrm{T}$ & Temperatura absoluta del aire & ${ }^{\circ} \mathrm{C}$ \\
\hline$t_{c}$ & Período entre limpiezas químicas & $\mathrm{h}$ \\
\hline$t_{p}$ & Tiempo de los ciclos de limpieza física & $\mathrm{h}$ \\
\hline $\mathrm{U}$ & Velocidad del flujo de aire & $\mathrm{m} / \mathrm{h}$ \\
\hline $\mathrm{U}_{\mathrm{R}}$ & Velocidad del retenido & $\mathrm{m} / \mathrm{h}$ \\
\hline $\mathrm{v}_{\mathrm{c}}$ & Volumen de agentes de limpieza & $\mathrm{m}^{3}$ \\
\hline $\mathrm{y}$ & Profundidad del aireador & $\mathrm{m}$ \\
\hline$\Delta \mathrm{P}$ & Presión & bar \\
\hline
\end{tabular}

\begin{tabular}{ll}
\hline & Descripción \\
\hline ABE & Acrilonitrilo butadieno estireno \\
PLA & Proceso de lodos activados \\
BNR & Remoción biológica de nutrientes, por sus siglas en inglés Biological nutrient removal \\
DBO & Demanda bioquímica de oxígeno \\
CEB & Retrolavado mejorado químicamente, por sus siglas en inglés Chemically enhanced backwashing \\
VFC & Velocidad de flujo cruzado \\
CIP & Limpieza en el lugar, por sus siglas en inglés Cleaning in place
\end{tabular}




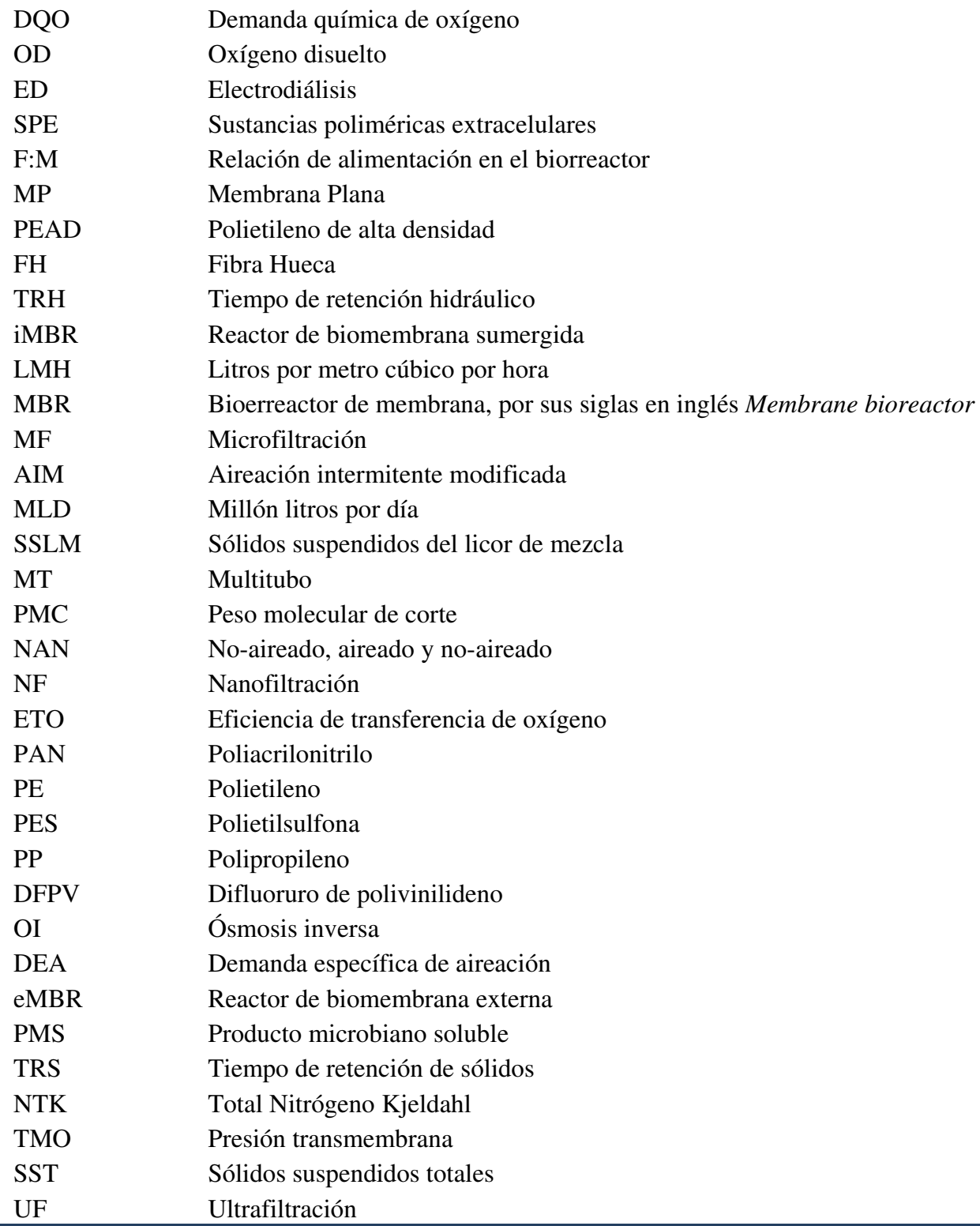

\begin{tabular}{clc}
\hline $\begin{array}{c}\text { Símbolos } \\
\text { Griegos }\end{array}$ & Explicación & Unidad \\
\hline$\alpha$ & Relación de ETO entre el proceso con licor de mezcla y el de agua & \\
$\gamma$ & Constante de Aireación & $\mathrm{m}$ \\
$\delta$ & Espesor de canal & $\mathrm{h}$ \\
$\zeta$ & Eficiencia del soplador & $\mathrm{h}$ \\
$\tau_{\mathrm{c}}$ & Duración de la limpieza química & $\mathrm{m}^{2} / \mathrm{m}^{3}$ \\
\hline
\end{tabular}






14

\section{Modelación del Proceso de Lodos Activados}

\section{Mark C.M. van Loosdrecht, George A. Ekama, Mark C. Wentzel, Damir Brdjanovic y Christine M. Hooijmans}

\section{1 ¿QUÉ ES UN MODELO?}

Un modelo puede describirse como una representación o descripción útil, a menudo simplificada, de un sistema de interés (Wentzel and Ekama, 1997). Consecuentemente, un modelo no representa de manera exacta a la realidad que describe. Por lo tanto, la pregunta ¿Describe este modelo a una planta de tratamiento de aguas residuales (PTAR) de forma adecuada?, no tiene sentido a menos que se defina en primer lugar qué o cuales partes de la PTAR el modelo debe describir. Un modelo nunca se desarrolla para describir cada uno de los organismos presentes, cada molécula de agua o cada detalle en un proceso de tratamiento de aguas. Los modelos se utilizan como una simplificación de la realidad de tal manera que solo describan las partes de la realidad relevantes para poder entender y manejar los procesos. Por último, es importante mencionar que un modelo matemático es exitoso, únicamente si cumple con las expectativas que las personas que lo utilizan tienen del mismo.

Existen dos aspectos de gran importancia a tener en cuenta para la modelación: el tiempo y la escala. En relación con el tiempo, los procesos en general pueden separarse en tres grupos. Esta división incluye a los procesos en estado dinámico, estado estático y en estado estacionario.

Los modelos dinámicos se utilizan para describir la variación de los diferentes estados y variables como una función del tiempo. Los procesos estáticos describen procesos que también varían en el tiempo, pero que en las escalas temporales de interés puede considerarse que no lo hacen. Por ejemplo, si nos interesa conocer la dinámica diaria de una PTAR, es necesario tener en cuenta la variación en el tiempo de la concentración de amoniaco en el efluente, así como la variación de la concentración de nitrato en los reactores, entre otros parámetros. Sin embargo, durante el día, la concentración de amoniaco y nitrato en el digestor de lodos, el cual puede ser parte del modelo de lodos activados, no va a cambiar. El tiempo de retención hidráulica (TRH) en un digestor es usualmente de 30 días, lo que a su vez resulta en un tiempo característico de cambio del orden de dos a tres semanas. Por consiguiente, el proceso que se lleva a cabo en el digestor se puede considerar estático ya que las variaciones diarias en los procesos son imperceptibles en

(C) 2017 Mark van Loosdrecht. Tratamiento Biológico de Aguas Residuales: Principios, Modelación y Diseño. Eds. M. Henze, M.C.M. van Loosdrecht, G.A. Ekama y D. Brdjanovic. Eds. (versión en español) C.M. López Vázquez, G. Buitrón Méndez, H.A. García, F.J. Cervantes Carrillo. ISBN (versión impresa): 9781780409139, ISBN (e-Book): 9781780409146. Publicado por IWA Publishing, London, UK. 
comparación con las que tienen lugar en la línea principal de tratamiento de aguas residuales.

Por otra parte, existen procesos que son tan rápidos que se pueden considerar en estado estacionario o de equilibrio. Estos procesos ocurren a una velocidad tal, que la rapidez del cambio excede enormemente la dinámica en la cual se tiene interés. Los cambios habitualmente de interés en el tratamiento de aguas residuales incluyen, por ejemplo, el cambio en la concentración de amoniaco, el cual tiene una tasa de cambio con una magnitud del orden de horas. Aquellos cambios que son relevantes para el control de procesos pueden tener tasas de cambio con magnitudes del orden de minutos. No obstante, si se tienen en cuenta los procesos de precipitación química, estos ocurren de forma casi instantánea en el transcurso de unos pocos segundos. Estos procesos rápidos no necesitan ser descritos de forma dinámica debido a que ocurren tan rápidamente que se puede asumir que se encuentran en una condición de equilibrio o que el proceso se ha llevado a cabo por completo. Por ello, una de las primeras consideraciones a tener en cuenta es la determinación de los procesos de interés, seguido por una determinación del marco temporal de relevancia, una evaluación de la dinámica de los procesos, y finalmente una buena descripción de aquellos procesos que varían en el tiempo. Los otros procesos, que corresponden a estados estáticos $\mathrm{y}$ estacionario, no son primordiales ya que se pueden incluir de una manera más rápida y sencilla en el modelo, o incluso pueden ser completamente omitidos. Esto se debe a que bajo determinadas condiciones, se pueden considerar como procesos continuos con concentraciones estables, como en el caso de los digestores. Así, el aspecto del tiempo es la primera cuestión importante al tratar de simplificar la realidad. Lo que se recomienda es tener en cuenta las constantes de tiempo y seleccionar aquellos procesos cuya dinámica sea del orden de las constantes de tiempo en las que se tiene interés. Para las plantas de tratamiento de aguas residuales, esto significa usualmente dinámicas horarias o diarias, y en algunos casos anuales. En este último caso es claro que la digestión será importante ya que en el año el desempeño de un digestor varía con la producción de lodos, la cual a su vez varía a lo largo del año.

El segundo aspecto relevante a la hora de modelar es la resolución espacial. En teoría, es posible realizar un modelo que describa cada centímetro cuadrado de una planta de lodos activados. No obstante, uno se puede preguntar si es necesaria una descripción tan detallada. La respuesta va a depender nuevamente del propósito del modelo. En general, en la práctica del tratamiento de aguas, los reactores tienen tamaños en el orden de decenas de metros. Para poder describir los gradientes de concentración de los componentes relevantes en los reactores, de los cuales el oxígeno es uno de los más importantes, usualmente es necesaria una escala de unos pocos metros. En una escala diferente, existen gradientes de concentración dentro de los flóculos de lodo activado que en teoría pueden ser descritos por un modelo. Sin embargo, en la modelación convencional de lodos activados no se tienen en cuenta, debido a que no son suficientemente relevantes. Esto implica que los modelos de lodos activados usualmente no están diseñados para describir un sistema en la escala del tamaño de un flóculo de lodo activado, sino solamente en la escala del tamaño del reactor.

El siguiente paso en la modelación de lodos activados corresponde a la definición del nivel relevante de detalle del modelo microbiano. Los métodos tradicionales de diseño para el tratamiento de aguas residuales se basan en los llamados modelos de "caja negra", los cuales se enfocan principalmente en las características del afluente $\mathrm{y}$ el efluente de la planta de tratamiento, mientras que poco o casi nada se conoce de lo que sucede al interior de la misma. Los parámetros de diseño convencionales, como la relación alimento microorganismo (F/M, por sus siglas en inglés, Food Microorganisms Ratio) no se basan en un entendimiento de los procesos dentro de la planta de tratamiento. Sin embargo, una planta puede diseñarse razonablemente bien utilizando cargas orgánicas adecuadas, sin necesidad de conocer los procesos que realmente se llevan a cabo en su interior. Por esta razón los modelos de caja negra pueden funcionar bien en la práctica (Figura 14.1).

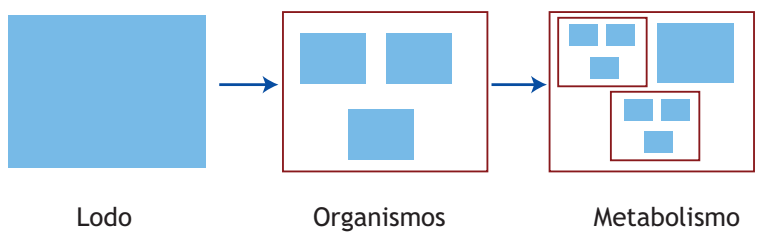

Relación F/M > ASM1,2,2d > ASM3 > Modelos metabólicos

Figura 14.1 Representación esquemática de los pasos de refinamiento de un modelo (Smolders et al., 1995)

Un modelo de caja negra no es por definición incorrecto ni carece de rigor científico, pero su aplicación depende en gran parte del propósito del modelo. Si el propósito consiste en diseñar una planta de tratamiento de aguas residuales, la práctica ha mostrado que la relación $\mathrm{F} / \mathrm{M}$ puede ser una buena aproximación para el diseño, aun cuando este método no aporta información 
sobre la composición del lodo. Esta aproximación puede refinarse obteniendo así modelos de "caja grises", como es el caso específico del Modelo de Lodos Activados No. 1 (ASM1, por sus siglas en inglés, Activated Sludge Model, Henze et al., 1987) No. 2 (ASM2, Henze et al., 1995), y No. 2d (ASM2d, Henze et al., 1999). En estos modelos, el lodo se divide en diferentes fracciones relevantes: una fracción de materia orgánica inerte, una fracción de bacterias nitrificantes, bacterias heterótrofas, bacterias desnitrificantes, y una fracción de bacterias removedoras de fosfato. Los diferentes aspectos funcionales del lodo se especifican para un modelo basado en diferentes poblaciones, donde comunidades microbianas específicas dentro del lodo activado son seleccionadas e incorporadas en el modelo.

Adicionalmente, también es posible describir el metabolismo de los organismos y las rutas metabólicas dentro de los mismos. Con este incremento en la información del modelo, la aproximación se acerca a un modelado de "caja de cristal" (como el Modelo de Lodos Activados No.3: ASM3, Gujer et al., 1999, y el modelo de remoción biológica de fósforo TU Delft: el modelo TUDP, Van Veldhuizen et al., 1999). Esto a su vez resulta en un modelo de mayor tamaño y mayor complejidad. El reto aquí se convierte en encontrar el nivel de descripción adecuado para cada proceso. La pregunta en este caso es la siguiente: ¿aumenta la calidad de un modelo al aumentar la complejidad del mismo?, o puesto en otras palabras, ¿resulta un modelo más complejo en una mejor descripción de una PTAR? Por ejemplo, se ha podido demostrar que incrementar el nivel de detalle en la descripción del proceso de nitrificación resulta en una mejora marginal del desempeño del modelo. Sin embargo, la inclusión de una descripción metabólica del proceso de remoción de fósforo resulta en una ganancia significativa en el desempeño del modelo. Por lo tanto, la preferencia entre modelos de caja negra, caja gris o caja de cristal depende en gran medida del propósito y la aplicación del modelo. Este es el punto donde a menudo la modelación se aplica de forma incorrecta ya que los modeladores ignoran el propósito de la aplicación del modelo, y convierten al modelo en el propósito mismo de la modelación.

Por supuesto, es posible continuar con el siguiente nivel de complejidad en un modelo e incluir los fundamentos de la genética microbiana y el cambio genético. Si bien esto es en principio y técnicamente posible, debe hacerse dependiendo del propósito y la aplicación. Un modelo que se hace muy complicado y en el que se incluyen demasiados parámetros en relación con el objetivo final buscado, generalmente se considera como una pérdida de tiempo y de esfuerzo. No es absolutamente necesario que un modelo describa exactamente la realidad. Que tanto debe acercarse el modelo a la realidad si nuevamente va a depender del propósito. Por ejemplo, si se quiere tener una idea sobre la emisión de $\mathrm{N}_{2} \mathrm{O}$ en plantas de tratamiento de aguas residuales, se podrían crear tres o cuatros teorías e incorporarlas en el modelo. En este punto es de principal interés mirar los resultados de la simulación de los diferentes modelos en términos de las tendencias y en la medida que estas tendencias reflejan la realidad. En esta etapa hay que enfocarse en las tendencias y en obtener una buena calibración únicamente; un ajuste exacto o un conocimiento preciso de los valores de los parámetros no es necesario. Por otro lado, por ejemplo, si se quiere predecir el desempeño de una planta a la hora de cumplir los requerimientos legales, los cuales exigen tener una concentración en el efluente por debajo de $1 \mathrm{mgNH}_{4} / \mathrm{l}$, la precisión de los parámetros utilizados en el modelo debe ser entonces mucho mayor. Es necesario garantizar que la predicción del modelo se encuentre por debajo de 1 $\mathrm{mgNH}_{4} / \mathrm{l}$ exactamente. Los dos ejemplos anteriores muestran nuevamente porque los modelos deben ser siempre juzgados con base en el propósito de su utilización.

Dependiendo del tipo de modelo matemático se pueden identificar dos extremos: modelos empíricos y modelos mecanísticos. Un modelo empírico se basa en el reconocimiento de los parámetros que parecen ser esenciales para describir el patrón de comportamiento de interés, y vincularlos mediante relaciones empíricas establecidas mediante observación. Los mecanismos y/o procesos que operan en el sistema no se conocen o se ignoran: el clásico enfoque de caja negra. En contraste, un modelo mecanístico se basa en la conceptualización de algunos de los mecanismos biológicos/físicos que operan en el sistema, es decir, se basa en una idea conceptual (o modelo). La complejidad del modelo mecanístico va a depender del grado de entendimiento que se tiene de los procesos químicos y biológicos que ocurren en el sistema. Debido a que los modelos mecanísticos tienen una base conceptual, son usualmente más confiables que los modelos empíricos.

Debido a su enfoque de caja negra, los modelos empíricos tienen una aplicación limitada estrictamente a las condiciones de frontera (por ejemplo, las características del agua residual, los parámetros del sistema) dentro de las cuales se desarrolló el modelo; solo es posible aplicar interpolaciones a los resultados. Por 
otro lado, los modelos mecanísticos tienen una mayor confiabilidad en su aplicación por fuera de los límites dentro de los cuales se desarrolló; es posible aplicar tanto interpolación como extrapolación. No obstante, todos los modelos corresponden a una racionalización de los patrones de comportamiento de procesos que se consideran de particular interés. Debido a esta racionalización, todos los modelos necesitan calibrarse de forma rigurosa y verificarse haciendo uso de pruebas adecuadas. Adicionalmente, deben delinearse claramente las condiciones dentro de las cuales se espera que un modelo opere de forma exitosa. Para los modelos empíricos corresponde estrictamente a las condiciones bajo las cuales el modelo se desarrolló. En el caso de los modelos mecanísticos, corresponde a las condiciones bajo las cuales se espera que el comportamiento conceptualizado continúe siendo válido. Es evidente de la discusión anterior que los modelos de base mecanística tienen un mayor potencial para la aplicación en plantas de tratamiento de agua residual, y consecuentemente se brindará una mayor atención a estos modelos.

Un modelo mecanístico se basa en la definición de un modelo conceptual, el cual a su vez se puede establecer una vez se identifiquen los procesos que operan en un sistema y los compuestos en los que éstos actúan. Las diferentes interacciones entre procesos y compuestos, deben delinearse de manera descriptiva. Para poder desarrollar un modelo mecanístico a partir de un modelo conceptual es necesario hacer una formulación matemática de las tasas de los diferentes procesos y de las interacciones estequiométricas de los compuestos. El equivalente matemático del modelo mecanístico muy probablemente no va a incluir todos los procesos y compuestos que están presentes en el sistema; sólo deben figurar los que tengan importancia para el cumplimiento de los objetivos establecidos para el modelo.

El arte de construir un modelo conceptual y un modelo mecanístico consiste en eliminar todos los procesos y compuestos que contribuyen poco o nada al cumplimiento de los objetivos establecidos para el modelo. Es una pérdida de tiempo y esfuerzo desarrollar un modelo complicado cuando un modelo más simple resulta adecuado. Es muy poco probable que un modelo desarrollado describa un fenómeno por completo. Teóricamente una descripción completa debería incluir aspectos hasta el nivel de detalle más fundamental. El nivel de organización usualmente se ajusta en función de los objetivos del modelo. Por ejemplo, en el modelado del comportamiento biológico en sistemas de tratamiento de agua residual, no es posible incorporar directamente mecanismos de control bioquímico (como son las relaciones de ADP/ATP y NAD/NADH), o incluso el comportamiento de especies de microorganismos específicas. El licor mezclado en un sistema de lodos activados contiene una amplia variedad de diferentes especies de microorganismos cuya enumeración e identificación ha sido solo posible con el uso de técnicas recientemente disponibles. Sin embargo, estas técnicas son dispendiosas y requieren de tiempo y trabajo adicional. En vez de modelar cada microorganismo dentro del lodo activado, las especies que cumplen una función particular (por ejemplo, degradación aerobia de materia orgánica o nitrificación) se agrupan en una sola entidad, la cual se conoce como organismo "surrogado". A este organismo surrogado se le asignan una serie de características únicas que reflejan el comportamiento del grupo pero que no reflejan las características de organismos individuales o especies específicas dentro del grupo. Para ilustrar lo anterior, este enfoque es similar al modelado del comportamiento "macroscópico" de un bosque en vez de modelar por separado el comportamiento "microscópico" de cada árbol que forma parte del bosque. Teniendo en consideración lo anterior, un parámetro que puede ser modelado en un bosque es por ejemplo, la producción de dióxido de carbono $\left(\mathrm{CO}_{2}\right)$. El bosque como una entidad va a tener una tasa de producción y consumo de $\mathrm{CO}_{2}$ definida. Las especies de árboles individuales dentro del bosque, o inclusive cada uno de los árboles, pueden tener una tasa específica de producción y consumo de $\mathrm{CO}_{2}$ que difiera de manera significativa de la tasa específica del bosque como entidad. Sin embargo, el producto del modelado del bosque como una entidad, es una reproducción acertada de la contribución neta y acumulativa de los efectos de modelar cada uno de los árboles o de las especies presentes en el bosque por separado. La gran ventaja de este enfoque en el cual se modela la entidad global y no las especies individuales, es que se requiere una cantidad considerablemente menor de información para desarrollar y calibrar el modelo.

En el modelado de sistemas biológicos para el tratamiento de aguas residuales, un ejemplo clásico es la utilización de substrato por parte de los microorganismos de acuerdo a la ecuación de Monod (Monod, 1949). Esta ecuación se utiliza para relacionar la tasa específica de crecimiento de un organismo surrogado con la concentración de substrato disponible, donde los organismos que forman parte del grupo surrogado pueden tener diferentes tasas de crecimiento o incluso responder de manera diferente a los diferentes substratos que se pueden encontrar en el agua residual afluente. Por 
ende, para la modelación de sistemas de tratamiento de aguas residuales, el nivel de organización que se modela es el comportamiento en masa de un grupo específico de microorganismos. En los modelos desarrollados para sistemas de lodos activados, los principales grupo de microorganismos, sus funciones y las zonas en las cuales operan sus funciones se encuentran de forma resumida en el Capítulo 2.

Los parámetros al nivel descrito anteriormente que requieren ser incluidos en el modelo matemático dependen en gran medida de los objetivos del modelo una vez se acepte el nivel de organización descrito. Para realizar una modelación matemática de un sistema de tratamiento de aguas residuales normalmente se desarrollan modelos de dos tipos: modelos en estado estacionario y modelos dinámicos. Los modelos en estado estacionario se caracterizan por tener caudales y cargas constantes, y tienden a ser relativamente sencillos. Esta sencillez convierte a estos modelos en una herramienta ideal para el diseño. En este tipo de modelos una descripción completa de los parámetros del sistema no es necesaria. Estos están orientados a determinar los parámetros de diseño más importantes. Por otra parte, los modelos dinámicos se caracterizan por caudales y cargas variables y por ende incluyen al tiempo como variable. Los modelos dinámicos son más complejos que los modelos en estado estacionario. Los modelos dinámicos son útiles en la predicción de la respuesta de un sistema propuesto ante el cambio de variables que son función del tiempo. Su complejidad a la vez significa que para su aplicación es necesario definir completamente los parámetros del sistema. Por esta razón, se restringe el uso de modelos dinámicos en el diseño de sistemas. Es usual que los modelos en estado estacionario y los modelos dinámicos evolucionen de forma conjunta e interactiva. Los modelos cinéticos dinámicos pueden brindar una guía para el desarrollo de modelos en estado estacionario; ayudan a identificar los parámetros de diseño que tienen una gran influencia en la respuesta del sistema y ayudan a eliminar aquellos procesos que no son de gran importancia en el estado estacionario.

En los modelos dinámicos, con su elevada complejidad, solo los parámetros que parecen ser de importancia se consideran para su inclusión en el modelo. Hasta hace poco en los sistemas de lodos activados, la selección del nivel de organización de los organismos surrogados estaba estructurada para tener en consideración únicamente los efectos netos en la masa líquida. Por ejemplo, utilizando la ecuación de Monod, la tasa cinética se calcula en función del contenido de demanda química de oxígeno (DQO) soluble en el líquido y en la concentración de organismos surrogados. No obstante, con las extensiones hechas a los modelos con el fin de incluir la remoción aumentada de fósforo biológica (EBPR, por sus siglas en inglés, Enhanced Biological Phosphorus Removal), es necesario incluir parámetros internos de la biomasa sucedánea, como son el contenido de poli-hidroxi-alcanoatos (PHA), glucógeno y poli-fosfatos. Aunque un modelo puede que se encuentre en un nivel particular de organización, con los desarrollos mencionados anteriormente es importante, y en ocasiones esencial, tener información sobre el comportamiento de los procesos en los niveles más básicos y fundamentales de organización, particularmente a la hora de identificar los procesos clave que controlan la respuesta del sistema. Usualmente la información de los niveles más básicos y fudamentales de organización es de naturaleza microbiológica y/o bioquímica, y entre más completa sea esta información más confiable será el modelo. Para hacer uso de esta información, se identifican organismos "modelo" que formen parte del surrogado, y las características microbiológicas y bioquímicas conocidas se utilizan para obtener un mejor entendimiento del surrogado. Estudios recientes han encontrado que el enfoque del organismo surrogado es inadecuado en la descripción de algunos patrones de comportamiento observados en sistemas de lodos activados; por ejemplo, en el uso de selectores (Gabb et al., 1991), en el estudio de la inhibición del uso de substratos en transferencias de zonas anóxicas a zonas aerobias (Casey et al., 1994), y en los estudios de generación de productos intermedios del proceso de desnitrificación (Casey et al., 1994). Para poder describir estas y otras observaciones similares, es necesario seleccionar un nivel de organización más fundamental: se requiere modelar la actividad y la síntesis de cierto tipo de enzimas que son claves en los procesos en que participan (Wild et al., 1994). Este tipo de modelación a este nivel de organización se conoce como modelación con biomasas estructurada. Para poder llevar a cabo este tipo de modelado, es necesario contar con información microbiológica y bioquímica detallada (Wentzel and Ekama, 1997).

Cabe señalar que existe una diferencia esencial entre un modelo de lodos activados y un modelo de una planta de tratamiento de aguas residuales. El segundo término se usa para indicar el conjunto de modelos que describen a una instalación de tratamiento de aguas residuales a escala real, los cuales incluyen: modelo de lodos activados, modelo hidráulico, modelo de transferencia de oxígeno y modelo del tanque de sedimentación (Gernaey 
et al., 2004). El modelo de una planta de tratamiento de aguas debe distinguirse adicionalmente de un modelo completo de la planta de tratamiento el cual combina un modelo de tratamiento del agua residual con un modelo del tratamiento de los lodos.

\section{2 ¿POR QUÉ MODELAR?}

Las ventajas más importantes de la utilización de modelos en el tratamiento de aguas residuales son:

- Obtener información sobre el rendimiento de las plantas

- Evaluar posibles escenarios para optimizar los procesos

- Evaluar un nuevo diseño de una planta

- Brindar soporte en la toma de decisiones para la operación de la planta

- Desarrollar nuevos esquemas de control

- Brindar entrenamiento a los operadores

La modelación obliga al modelador a hacer su trabajo de forma explícita. En la literatura es común encontrar comparaciones cualitativas como "mejor", "más grande", "más pequeño", "más alto", etc. Estas comparaciones no resultan muy útiles y son por naturaleza subjetivas, ya que por ejemplo, la percepción de "grande" o "pequeño" de un investigador en el laboratorio o de un operador de una PTAR no es necesariamente la misma. A la hora de modelar no es posible utilizar elementos descriptivos, sino que es necesario usar valores cuantitativos para la definición de los diferentes tamaños, tasas y conversiones, ya que un modelo requiere valores numéricos como datos de entrada. Esto también obliga a los modeladores a ser más cuantitativos y objetivos en sus enfoques y de esa forma el conocimiento del proceso se vuelve más claro. Por supuesto, es posible hacer investigaciones sin la necesidad de modelar, pero al hacer modelos a menudo se produce una infraestructura en la que todos los aspectos que se consideran relevantes son tomados en cuenta. Adicionalmente, la modelación exige una toma de datos extensiva y más estructurada lo que a su vez promueve la organización del modelador. También ayuda a exponer limitaciones en el conocimiento y en los datos, como por ejemplo sobre ciertos caudales o tiempos de retención de sólidos (TRS). Asimismo apoya los esfuerzos encaminados a la mejora de la calidad de los datos, y promueve buenas prácticas de monitoreo en las plantas de tratamiento. Por lo tanto no es de extrañar que obtener información sobre el rendimiento de una planta (cuantificación de la información, balances de masa y reconciliación de datos) y aprender sobre la PTAR en cuestión puede ser inclusive más importante que el modelado mismo.

La segunda razón principal para utilizar modelos es la posibilidad de ahorrar tiempo y dinero en el proceso de selección de una tecnología y/o proceso. La comparación del rendimiento de diferentes sistemas en una forma cuantitativa en vez de cualitativa permite en muchos casos una toma de decisiones más fácil y una comparación de opciones más rápida. En comparación con una descripción cualitativa, como por ejemplo, "un sistema es más eficiente que otro", los resultados arrojados por un modelo pueden indicar que "un sistema es $2 \%$ (o 20\%) más eficiente que otro", lo que es mucho más informativo y útil. Si la información de importancia y los diferentes criterios de selección (como la eficiencia de la purificación, la calidad del efluente, la producción de lodos, los requerimientos de oxígeno, etc.) son cuantificados, la aplicación de modelos permite la evaluación de posibles escenarios de optimización y hace la comparación de alternativas mucho más rápida y efectiva, que si se hicieran discusiones sobre cuestiones que suelen ser empíricas, intuitivas, largas y a menudo engorrosas. Con el propósito de evaluar ciertos escenarios de mejoras, no es necesario obtener un modelo muy correcto y realizar un procedimiento exhaustivo de calibración, ya que la verdadera incertidumbre está asociada con los datos de entrada del modelo y no con los parámetros del mismo. En general se considera mucho más conveniente utilizar tendencias como punto de comparación debido a que las pequeñas diferencias no son relevantes en el contexto del horizonte de diseño habitual utilizado en la ingeniería de tratamiento de aguas residuales. En el caso de la evaluación de un nuevo diseño para una PTAR, es de nuevo innecesario tener un modelo finamente ajustado debido a la incertidumbre en las condiciones de los procesos en los siguientes 10 a 20 años. Para el diseño de PTAR usualmente se utilizan modelos en estado estacionario mientras que los modelos dinámicos son empleados para hacer análisis de sensibilidad y optimización. Un reto adicional es el hecho de que las aguas residuales tienen una composición muy compleja e incierta. Los caudales y las concentraciones del agua residual son por naturaleza dinámicas y difíciles de controlar, a pesar de existir un cierto número limitado de posibilidades para influenciar la composición del agua residual (Capítulo 3).

Muchos procesos tienen lugar dentro de una PTAR, algunos de estos son relevantes para el tratamiento y muchos otros no lo son. No obstante, muchos de estos procesos ocurren de forma simultánea, incluso en un solo 
tanque de proceso. Para poder manejar esta compleja situación, es necesario que el modelo incorpore el conocimiento de los procesos relevantes. A pesar del hecho de que desde la perspectiva del diseño una modelación como tal no es estrictamente necesaria, cada vez se utiliza más como una parte del proceso de diseño. Mediante la aplicación de métodos estadísticos que evalúen la posibilidad de que ocurra el peor escenario posible, se pueden lograr importantes ahorros y la planta de tratamiento puede inclusive alcanzar los estándares de calidad de los efluentes para alrededor del $95 \%$ de los casos. A menudo en el diseño se asume que las peores circunstancias posibles se producen al mismo tiempo lo que conduce a un escenario muy poco probable.

Otra importante razón para utilizar modelos es la posibilidad de disminuir y minimizar riesgos. Al hacer uso de modelos, es posible evaluar escenarios del tipo ¿Qué pasa si...? de una forma cuantitativa y por ende obtener información sobre los posibles efectos o los riesgos potenciales. Este tipo de cuantificación del tipo caja de cristal (en contraposición al tipo caja negra) es invaluable en la evaluación y selección de los riesgos aceptables, rechazando cualquier riesgo que no puede ser asumido, e identificando de antemano las medidas que pueden tomarse para mitigar o controlas esos riesgos. Por ejemplo, el uso de modelos puede responder apropiadamente a preguntas como ¿Cuál es el efecto de duplicar el caudal afluente? y/o ¿Cuál es el efecto de ese incremento en la calidad del efluente? Adicionalmente, el uso de modelos permite minimizar los riesgos relacionados con el escalamiento de sistemas (escala de laboratorio, escala piloto y escala real). Los riesgos relacionados a lo anterior se desprenden del hecho que las condiciones de mezclado, variaciones de carga, entre otras, son diferentes para instalaciones en escalas de laboratorio y en escala real. Desde la perspectiva del control de procesos, las plantas en escala piloto dan una respuesta mucho más rápida en comparación con las plantas en escala real las cuales tienen una mayor inercia.

La aplicación de modelos adicionalmente mejora la transferencia de conocimiento y la toma de decisiones. La ingeniería del tratamiento de aguas y ambiental son en general campos multidisciplinarios que requieren conocimientos de diferentes disciplinas, como microbiología, bioquímica, e ingeniería mecánica, física y biológica. Adicionalmente, cada grupo de expertos involucrados, ya sean operadores, ingenieros o científicos, tienen usualmente su propia perspectiva para un mismo tema. Al expresar los temas en un contexto matemático es posible utilizar una misma herramienta (lenguaje) de comunicación. Este tipo de enfoque multidisciplinario permite una mejor descripción de la realidad, donde cada disciplina contribuye a lograr un mejor entendimiento de la realidad de tal forma que puede ser estructurada, organizada y finalmente incorporada de una forma cuantitativa dentro del modelo. La comunicación en los temas relacionados con el modelado tuvo una mejora drástica después de la introducción del ASM1 en 1987. Antes de la introducción del ASM1, existían por lo menos cinco o seis descripciones diferentes de como modelar plantas de tratamiento de aguas residuales. Cada modelo contaba con sus propios enfoques de escritura, notación e implementación de las ecuaciones, lo que hacía extremadamente difícil la comprensión y la comparación de los diferentes modelos y sus resultados. La estandarización y uniformización de los contextos que se logró gracias a la introducción del ASM1, en términos de notación, estructura y simbología, ha hecho la transferencia de conocimiento mucho más fácil y adicionalmente ha fomentado la aplicación de modelos.

Los modelos son hoy en día herramientas invaluables para el entrenamiento. Los operadores de una PTAR pueden, por ejemplo, investigar de forma segura mediante el uso de un modelo las consecuencias de la toma de una decisión sin tomar el riesgo de afectar la operación normal de la planta misma. Por otra parte, los modelos resultan muy útiles para hacer la transferencia de conocimiento desde los ingenieros de diseño hacia los operadores, y por supuesto, en el ambiente académico, donde la modelación se vuelve cada vez más una parte de los planes de estudio para ingenieros y científicos de todo el mundo. En la práctica y desde la perspectiva del control de procesos, aún no existen controladores que funcionen basados en modelos, y su aplicación permanece solamente en el ámbito científico. En la práctica, los controladores simples se calibran utilizando modelos, lo que permite una optimización mucho más rápida de la estrategia de control en instalaciones a gran escala (Capítulo 15).

En el marco de una modelación de sistemas integrados de aguas urbanas, el modelado del tratamiento de las aguas residuales es un componente importante y es necesario vincular el tratamiento de las mismas con el sistema de alcantarillado (para tomar en cuenta los efectos de, por ejemplo, las avenidas extremas de aguas residuales combinadas o de procesos que tienen lugar en el sistema de alcantarillado) de un lado, y/o con la calidad y la cantidad del agua en los cuerpos receptores del otro lado. La modelación integrada de sistemas se está 
convirtiendo en una herramienta cada vez más popular para apoyar la toma de decisiones a nivel de la gestión del sistema de agua en zonas urbanas, ya que aporta objetividad y da una idea cuantitativa de las diferencias relevantes entre las diferentes opciones.

\subsection{FUNDAMENTOS DE MODELACION}

\subsubsection{Construcción de un modelo}

Existen muchos diferentes tipos de modelos; estos pueden ser categorizados en $(i)$ físicos, (ii) verbales o conceptuales y (iii) matemáticos. Los modelos físicos son una representación física del sistema a modelar en una escala determinada. Por ejemplo, los modelos a escala de laboratorio y a escala piloto utilizados por científicos e ingenieros para investigar la respuesta y el comportamiento de un sistema corresponden a modelos físicos. Los modelos verbales o conceptuales dan una descripción cualitativa del sistema de estudio y usualmente se desarrollan a partir de observaciones detalladas; estos modelos se pueden representar mediante diagramas esquemáticos, como diagramas de flujo. La preparación de un modelo mecanístico (verbal) es la parte más importante en la construcción de un modelo, y a la vez es la parte más compleja. El modelo matemático es el que brinda una descripción cuantitativa del sistema. En este tipo de modelos, las tasas de conversión de los procesos que actúan en el sistema y las relaciones e interacciones estequiométricas con los compuestos se formulan matemáticamente. Estas formulaciones son luego solucionadas mediante un procedimiento (algoritmo de solución numérica) que tenga en cuenta las condiciones físicas y las características impuestas por el sistema en el cual se llevan a cabo los procesos, como por ejemplo, temperatura, y condiciones de mezclado. Los modelos matemáticos rara vez se desarrollan de forma aislada, es decir que usualmente evolucionan interactivamente a partir de un modelo conceptual que en algunos casos puede a su vez estar basado en experimentación en un modelo físico a escala de laboratorio y/o piloto (Wentzel and Ekama, 1997).

En el ámbito académico, el uso de metodologías de investigación que combinan modelos verbales, físicos y matemáticos (Figura 14.2) ayudan enormemente a tener un rápido progreso en la evaluación de nuevos sistemas.

Varios factores deben ser considerados con respecto al modelado y simulación de lodos activados. Es necesario un enfoque paso a paso para poder avanzar desde la definición del propósito del modelo hasta el punto en que el modelo está listo para simular la PTAR. En este proceso se pueden distinguir los siguientes pasos (Coen et al., 1996; Petersen et al., 2002; Hulsbeek et al., 2002):

- Definición del propósito del modelo o de los objetivos del estudio de simulación

- Selección del modelo entre las diferentes opciones que son necesarias para poder describir las diferentes unidades dentro de una PTAR, como el modelo de lodos activados, el modelo de sedimentación, entre otros.

- Determinación de los modelos hidráulicos para la planta y/o los tanques de la planta.

- Caracterización del agua residual y de la biomasa, incluyendo las características de sedimentación de la biomasa.

- Calibración de los parámetros del modelo de lodos activados.

- Refutabilidad del modelo.

- Evaluación de escenarios.

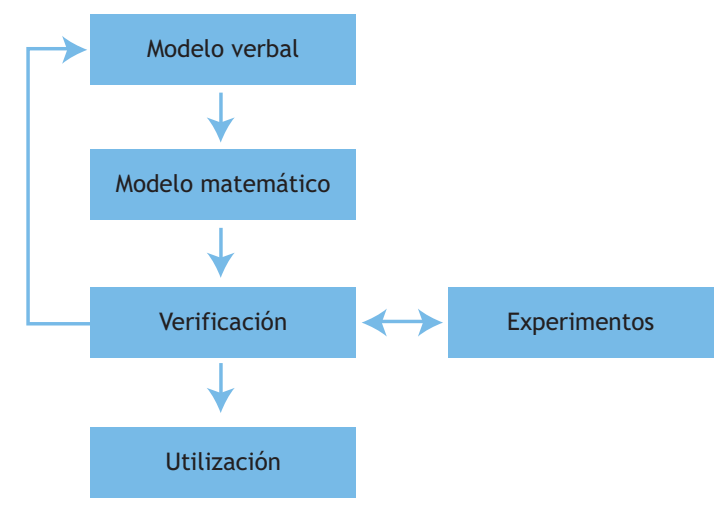

Figura 14.2 Proceso de construcción de un modelo

La descripción detallada de la metodología se puede encontrar en Petersen et al., (2002).

\subsubsection{Preparación general de un modelo}

Las ecuaciones de balance forman la base de la descripción de cualquier modelo. Estas ecuaciones describen el cambio en la concentración en el tiempo de un reactor como el resultado de una serie de conversiones químicas y biológicas, y de fenómenos de transporte. En el caso de los modelos en estado estacionario, el cambio de la concentración como una función del tiempo es igual a cero. Los procesos de transporte y conversión corresponden a dos partes diferentes de un modelo y son de naturaleza física y química/biológica, 
respectivamente. Los procesos biológicos dependen únicamente de la concentración en el reactor en el lugar donde las conversiones se llevan a cabo. En esencia los procesos de conversión son independientes del tipo del reactor o del tamaño del mismo (los microorganismos no tienen conocimiento del tipo de reactor en el que se encuentran, sea de concreto o acero, en flujo pistón o completamente mezclado, de lodos activados o un reactor de biopelícula, etc.). Por consiguiente, las conversiones químicas y biológicas se conocen como micro-cinéticas y pueden ser fácilmente estudiadas a nivel de laboratorio sin presentar cambios en instalaciones a escala real. Esta parte del proceso es entonces universal y puede formularse como un modelo general de lodos activados, como es el caso de los modelos ASM. Las concentraciones en un reactor van a depender de los fenómenos de transporte a los que se ven sujetos los compuestos dentro del sistema de reactores o PTAR. Cuando se comparan diferentes sistemas a escala real, la diferencia se encuentra efectivamente en las diferencias de los procesos de transporte.

La ventaja de los procesos de transporte (como flujo convectivo, mezclado y aireación) es que han sido estudiados de forma muy completa y pueden ser descritos por reglas generales. Por consiguiente, estos procesos pueden predecirse relativamente bien para diferentes escalas y tipos. Gracias a esto es posible estudiar la biología y la química a nivel de laboratorio (por ejemplo el efecto de los cambios en la temperatura, la concentración y la presión sobre los microorganismos) y luego utilizar modelos físicos de transporte para predecir los efectos en escala real. El entendimiento que se tiene de los procesos y su integración con el modelo matemático se mejora debido a que los microbios no sufren ningún tipo de cambio entre las condiciones de laboratorio y escala real, a diferencia de los procesos de transporte. Este tipo de integración permite que los modelos sean parte del proceso de diseño (selección de bioreactores, tipo de unidades, estabilidad de los procesos, optimización, control y automatización, escalamiento etc.)

Los componentes del modelo completo de una PTAR se presentan de forma esquemática en la Figura 14.3. Al inicio, los diferentes parámetros medidos en el agua residual afluente se transforman en un vector de concentraciones de entrada al modelo (Capítulo 3). Las diferentes zonas y compartimientos de los reactores en la de la PTAR, incluyendo los clarificadores, se modelan hidráulicamente. Las características de mezclado y transferencia de masa (por ejemplo, aireación) de cada compartimiento de un reactor se modelan de forma individual. Es común modelar los reactores como tanques

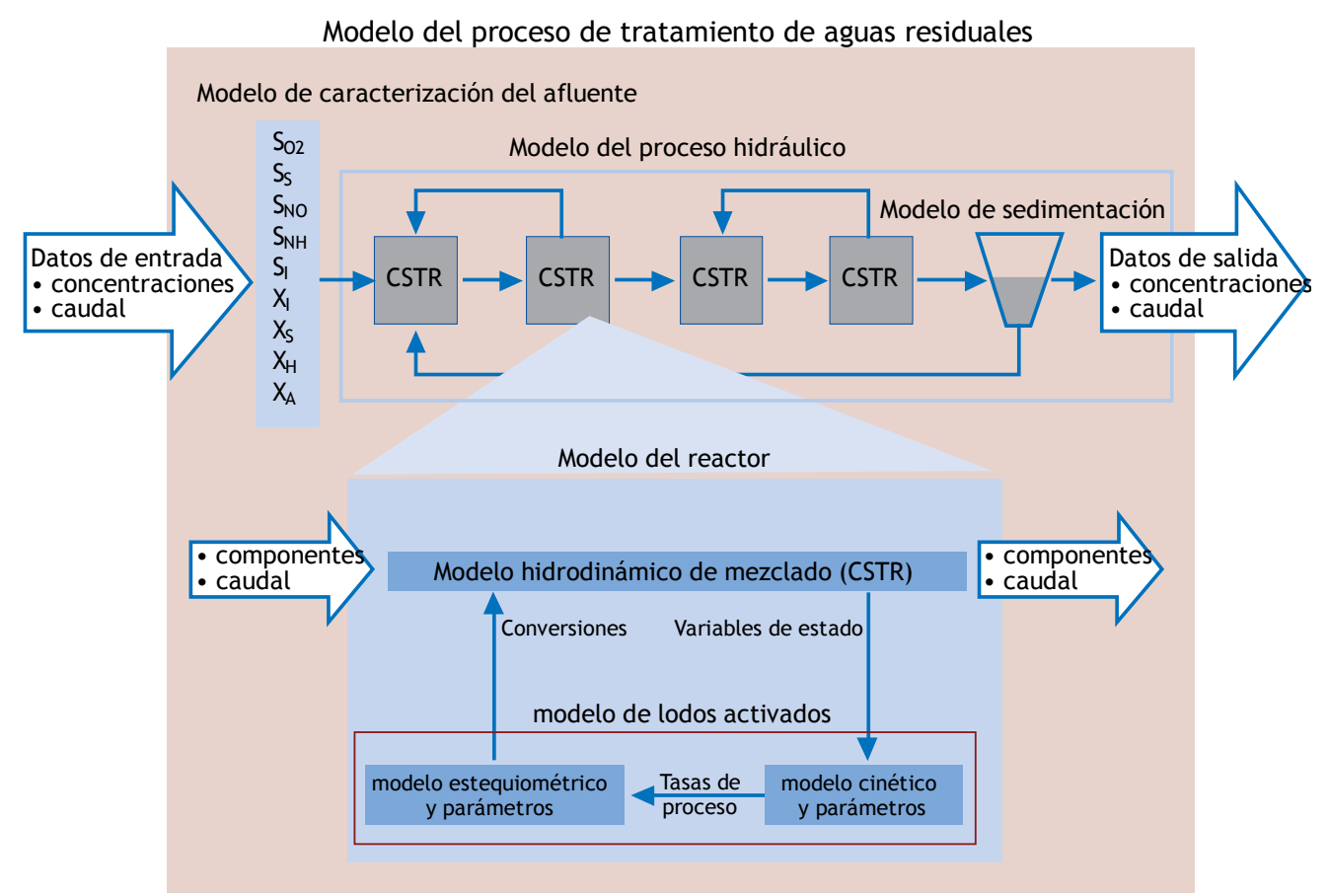

Figura 14.3 Representación esquemática de un modelo de una planta de tratamiento de agua residuales completa (Meijer, 2004) 
completamente mezclados. En cada uno de los reactores se aplica una ecuación de balance de masa. Dentro de esta ecuación de balance se incluye el modelo que describe las conversiones biológicas. En el modelo global, todos los compartimentos están acoplados al vector de estado que incluye las concentraciones y los caudales de los enlaces entre compartimientos. Este modelo global normalmente se resuelve numéricamente obteniendo así las concentraciones de todos los compuestos en función del tiempo, para cada uno de los compuestos incluidos en el modelo. Así, efectivamente se puede hablar de la existencia de cuatro modelos: el modelo del proceso, el modelo hidráulico, el modelo de compartimientos/reactores y finalmente el modelo de lodos activados. Solo este último modelo es general.

La ecuación de balance de masa en estado estacionario en términos matemáticos se puede escribir como:

$$
\begin{aligned}
& \frac{\delta\left(S_{\text {in }} \cdot Q_{\text {in }}\right)}{\delta t}=\frac{\delta\left(S_{\text {out }} \cdot Q_{\text {out }}\right)}{\delta t}+ \\
& (\alpha \cdot q \cdot X \cdot V)+\left(k_{l} A \cdot\left(S_{\max }-S\right)\right)
\end{aligned}
$$

donde:

$\begin{array}{ll}\alpha & \text { estequiometría } \\ \mathrm{A} & \text { área superficial }\left[\mathrm{m}^{2}\right] \\ \mathrm{k}_{1} & \text { coeficiente de transferencia de masa }[\mathrm{m} / \mathrm{h}] \\ \mathrm{q} & \text { tasa específica de conversión }[1 / \mathrm{h}] \\ \mathrm{Q}_{\text {in }} & \text { caudal afluente }\left[\mathrm{m}^{3} / \mathrm{h}\right] \\ \mathrm{Q}_{\text {out }} & \text { caudal efluente }\left[\mathrm{m}^{3} / \mathrm{h}\right] \\ \mathrm{S}_{\max } & \text { concentración de saturación }\left[\mathrm{gDQO} / \mathrm{m}^{3}\right] \\ \mathrm{S} & \text { concentración en el líquido }\left[\mathrm{gDQO} / \mathrm{m}^{3}\right] \\ \mathrm{S}_{\text {in }} & \text { concentración en el afluente }\left[\mathrm{gDQO} / \mathrm{m}^{3}\right] \\ \mathrm{S}_{\text {out }} & \text { concentración en el efluente }\left[\mathrm{gDQO} / \mathrm{m}^{3}\right] \\ \mathrm{t} & \text { tiempo }[\mathrm{h}] \\ \mathrm{V} & \text { volumen }\left[\mathrm{m}^{3}\right] \\ \mathrm{X} & \text { concentración de la biomasa }\left[\mathrm{gDQO} / \mathrm{m}^{3}\right]\end{array}$

Esta ecuación establece que un compuesto que ingresa al reactor puede salir con el efluente, o sufrir una conversión dentro del reactor o pasar a la fase gaseosa del compartimiento. Cada término de la ecuación de balance tiene dimensiones de masa sobre tiempo. Es bueno resaltar que con el fin de analizar un sistema complejo es mejor trabajar con unidades de flujo másico o cargas que en términos de concentraciones.

\subsubsection{Estequiometría}

Para la definición de un sistema es necesario tener en cuenta únicamente aquellos compuestos que se consideran importantes y/o aportan una parte considerable a la masa total del sistema (siendo al menos un pequeño porcentaje de la misma). Por ejemplo, en el caso del proceso de nitrificación, la concentración de nitrito en la mayoría de las plantas permanece en niveles muy bajos o cercanos al límite de detección, de tal forma que desde la perspectiva del balance de masa no es necesario tener en cuenta al nitrito. De manera similar, en la digestión anaerobia no hay necesidad de tener en cuenta la producción de hidrógeno ya que la mayor parte de la materia orgánica se convierte finalmente en metano, resultando en concentraciones muy bajas de hidrógeno en el biogás. El uso de estos productos intermedios solo se especifica si se considera de importancia para el modelo, por ejemplo, cuando la concentración de nitrito o la acumulación de hidrógeno son relevantes. Dentro del modelo ASM1 (por sus siglas en inglés, Activated Sludge Model No. 1) no se incluye la concentración de nitrito, mientras que en el Modelo de Digestión Anaerobia (ADM1, por sus siglas en inglés, Anaerobic Digestion Model, Batstone et al., 2000) el hidrógeno se incluye ya que juega un papel muy importante en la estabilidad de un sistema anaerobio. Los modelos ASM están expresamente diseñados para aplicaciones a temperaturas bajas $\left(5\right.$ a $\left.20^{\circ} \mathrm{C}\right)$, bajo las cuales no se espera que se presente ninguna acumulación significativa de nitrato. De forma similar, durante el proceso de desnitrificación, solo una pequeña fracción del nitrato se convierte a $\mathrm{N}_{2} \mathrm{O}$, de tal forma que desde la perspectiva de la remoción de nitrógeno no es relevante tener en cuenta la contribución de $\mathrm{N}_{2} \mathrm{O}$. Sin embargo, si la planta tiene que cumplir con un límite de emisión de gases es importante tener en cuenta esa contribución. Nuevamente, el propósito del modelado va a definir la aplicación del modelo.

Más allá de la determinación de los procesos y compuestos relevantes, es también esencial definir los balances necesarios. Cada balance de masa conservativo indica que el número de átomos que forma parte de un compuesto que ingresa a la planta debe ser igual al número de átomos a la salida. Los balances de conversión de nitrógeno, fósforo, DQO o conversión de alcalinidad son ejemplos de balances de tipo conservativo. A través del planteamiento de las ecuaciones de balances de masa es posible calcular los coeficientes estequiométricos. Esto reduce substancialmente la cantidad de información necesaria para el modelo ya que se disminuye el número de incógnitas a calcular. La medición de la demanda bioquímica de oxígeno (DBO) como parámetro característico del agua residual está cayendo en desuso, y los enfoques modernos se basan en la medición de la DQO. El diseño basado en la DBO está asociado al 
enfoque de caja negra; la $\mathrm{DBO}$ es un parámetro no conservativo y depende de muchos factores (como tiempo de reacción y temperatura) lo que no permite su uso en el cálculo de balances. En la práctica aún se utiliza para relacionar los resultados de los modelos ASM con el impacto sobre las aguas receptoras (donde la DBO es aún un indicador importante de la calidad del agua). En contraste, el balance de DQO si es conservativo y se desprende de la definición misma de la DQO. La DQO es la cantidad de electrones que son transferidos al oxígeno para poder oxidar toda la materia orgánica del sistema obteniendo como productos finales $\mathrm{CO}_{2}$ y agua. Por esta razón es que la modelación de las PTAR está basado en la DQO en vez de la DBO.

Mediante el uso de ecuaciones de balance sobre los compuestos relevantes involucrados en las reacciones del sistema, es posible determinar los coeficientes estequiométricos respectivos. Por ejemplo, en la reacción de crecimiento heterotrófico, los compuestos relevantes incluyen materia orgánica, oxígeno, amoniaco, alcalinidad, biomasa, dióxido de carbono y agua. Durante esta etapa de desarrollo de la ecuación no es necesario aún determinar cuál compuesto se utiliza o cuál se produce ya que simplemente van a recibir un signo positivo o negativo, o en otras palabras, no es importante saber en cual lado de la ecuación se ubica el parámetro. El siguiente paso consiste en escoger un coeficiente y asignarle un valor igual 1 y usalo en la ecuación de balance para calcular todos los demás coeficientes. En el ejemplo a continuación, se pueden escribir 5 ecuaciones de balance (para el carbón, oxígeno, hidrógeno, nitrógeno y carga) siendo que hay 7 coeficientes que se desconocen. Uno de estos coeficientes se puede hacer igual a 1, en cuyo caso solo queda un coeficiente para determinar, por ejemplo la cantidad de oxígeno consumida por cantidad de DQO o la cantidad de biomasa producida por masa de substrato utilizado (coeficientes de rendimiento). Este es un procedimiento general que se puede aplicar para determinar la estequiometría de las reacciones para cualquier proceso biológico, por ejemplo, si la materia orgánica (o DQO) se utiliza de forma aerobia $\left(\operatorname{con~} \mathrm{O}_{2}\right)$.

$? \mathrm{DQO}+? \mathrm{O}_{2}+? \mathrm{NH}_{4}^{+}+? \mathrm{HCO}_{3}$

$\rightarrow$ ? Biomasa-DQO + ? $\mathrm{CO}_{2}+? \mathrm{H}_{2} \mathrm{O}$

En los sistemas de tratamiento de aguas residuales usualmente no se tiene interés en la producción de $\mathrm{CO}_{2}$ y $\mathrm{H}_{2} \mathrm{O}$, y el balance de DQO se utiliza para reemplazar el balance de uno de los elementos. Si al coeficiente del substrato (como DQO) se le asigna un valor igual a la unidad, y si se conoce el coeficiente de rendimiento de la biomasa, la Ec. 14.2 se convierte en:

$1 D Q O+\left(1-Y_{H}\right) \mathrm{O}_{2}+f_{N} Y_{H} \mathrm{NH}_{4}^{+}+f_{N} Y_{H} \mathrm{HCO}_{3}^{-}$

$\rightarrow Y_{H}$ Biomasa-DQO

donde:

$\mathrm{Y}_{\mathrm{H}} \quad$ rendimiento de organismos heterotróficos [gBiomasa-DQO /gSubstrato DQO], y

$\mathrm{f}_{\mathrm{N}} \quad$ fracción de nitrógeno en la biomasa [gN/gBiomasa-DQO]

Para poder derivar la ecuación anterior es necesario utilizar el balance de carga orgánica (DQO), nitrógeno, y carga. El balance de DQO establece que los procesos de producción de biomasa y consumo de oxígeno están siempre acoplados; no hay forma de reducir el consumo de oxígeno y producir una menor cantidad de lodo, ya que o el substrato (DQO) es oxidado por el oxígeno o éste se convierte en lodo. Del balance de nitrógeno se puede calcular la cantidad de amoniaco necesaria, y del balance de cargas es posible determinar la cantidad de bicarbonato (alcalinidad), etc. Las reacciones estequiométricas pueden escribirse como una función del rendimiento $\mathrm{y}$, en este ejemplo en particular, de la cantidad de nitrógeno dentro de la biomasa. Los coeficientes estequiométricos de cada compuesto se incluyen en la matriz del modelo (Tabla 14.1).

\subsubsection{Cinética}

Cada reacción tiene una tasa definida por una ecuación propia. La ecuación de reacción especifica la tasa de conversión de un compuesto con el coeficiente de rendimiento igual a 1 . La tasa de conversión de otros compuestos se puede calcular multiplicando cada coeficiente de rendimiento con la ecuación de reacción. El modelo puede estar basado en una cinética del substrato (el coeficiente estequiométrico del substrato es igual a 1) o en una cinética del crecimiento (el coeficiente estequiométrico de la biomasa es igual a 1). No se recomienda usar los dos tipos de cinética al mismo tiempo en un mismo modelo. En el modelo ASM1 las tasas están basadas en la tasa de crecimiento; por ende el coeficiente de la biomasa es igual a 1. En los modelos ASM, se utiliza una ecuación de saturación como ecuación de reacción estándar. La cinética de saturación (Monod) incluye dos parámetros principales, la tasa máxima y la afinidad o constante de saturación (el valor de $\mathrm{K}$, definido como la concentración a la mitad de la tasa máxima). El término de saturación $\mathrm{S} /(\mathrm{K}+\mathrm{S})$ puede tomar un valor entre 0 y 1 , y puede tener una función diferente dentro del modelo. Muchos términos de la afinidad 
reflejan un valor real, por ejemplo el término de la afinidad del oxígeno corresponde un parámetro observado. Sin embargo, en algunos casos, el término de la saturación solo corresponde a un término que funciona como un interruptor. Por ejemplo, una función interruptor se utiliza en un modelo para detener el proceso de crecimiento cuando no hay presencia de amoniaco (Ec. 14.4). La constante de afinidad del amoniaco es efectivamente muy pequeña y difícilmente medible, de tal forma que el coeficiente que hace parte de la ecuación cumple el único propósito de garantizar que no hay más crecimiento una vez se agota el amoniaco. Esto a la vez significa que este valor no necesita ser calibrado. La distinción entre cuando los parámetros pueden ser medidos o cuando actúan como un interruptor es difusa y poco explícita en los modelos de lodos activados. Por consiguiente es importante entender cuando los valores de $\mathrm{K}$ se incluyen en el modelo como parámetros reales o como función interruptor para detener un proceso cuando un compuesto relevante no está presente.

$\mu=\mu^{\max } \frac{S}{K_{S}+S} \cdot \frac{S_{O}}{K_{O}+S_{O}} \cdot \frac{S_{N}}{K_{N}+S_{N}} \cdots$

Para describir la cinética de inhibición, se utiliza un enfoque similar, pero en este caso la constante de afinidad se denomina constante de inhibición (Ec. 14.5). De esta forma es posible definir un término de inhibición el cual nuevamente tiene un valor que varía entre 0 y 1 . La constante de inhibición es igual a la concentración de substrato en la cual la tasa de reacción del proceso disminuye a un $50 \%$. Existen también otros términos mucho más complejos para describir el proceso de inhibición, pero en los modelos ASM este es el término que se aplica usualmente, especialmente en la inhibición por substrato.

$1-\frac{S}{K_{S}+S}=\frac{K_{S}}{K_{S}+S}$

Es importante agregar que la multiplicación de varios factores resulta en una desviación de los resultados debido a que estos factores nunca son exactamente 1 . Si se multiplican dos factores con un valor de 0.9 con el valor de un tercer factor de 0.5 , el resultado será igual a 0.4 , mientras que el valor real debería ser del orden de 0.5 ya que es en efecto el factor limitante. Esto significaría un valor $20 \%$ inferior para la tasa. Por consiguiente es mejor utilizar operadores lógicos dentro del modelo y de esta forma escoger el factor con el valor mínimo entre los términos (Ec 14.7) en vez de multiplicar los factores entre sí (Ec. 14.6) ya que de esta forma los resultados sea aproximan mejor a la realidad.

$$
\begin{aligned}
& \mu=\mu^{\max } \cdot \frac{S}{K_{S}+S} \cdot \frac{S_{O}}{K_{O}+S_{O}} \cdot \frac{S_{N H}}{K_{N H}+S_{N H}} \cdot \frac{S_{K I}}{K_{I}+S_{K I}} \\
& \mu=\mu^{\max } \cdot \operatorname{MIN}\left(\frac{S}{K_{S}+S} ; \frac{S_{O}}{K_{O}+S_{O}} ; \frac{S_{N H}}{K_{N H}+S_{N H}} ; \frac{S_{K I}}{K_{I}+S_{K I}}\right)
\end{aligned}
$$

La razón para que la Ecuación 14.6 se siga utilizando obedece en parte a un hábito heredado. Durante los años 70 , en la etapa inicial del desarrollo de los modelos, el uso de operadores lógicos en conjunto con ecuaciones diferenciales integrales resultaba en un proceso difícil y costoso en términos de tiempo y por consiguiente no se utilizaba. Al final no es tan importante cual ecuación se utilice en un modelo de lodos activados; el punto a tener en cuenta es poder entender las razones de las diferentes decisiones que se tomaron a lo largo de las diferentes etapas de desarrollo del modelo.

\subsubsection{Transporte}

Un modelo convencional de una PTAR contiene varios términos de transporte, los cuales a menudo son dependientes del tiempo (Figura 14.3). Los datos de entrada del modelo son el caudal en función del tiempo y la composición del agua residual. El proceso se describe a través de un modelo hidráulico el cual representa las condiciones hidráulicas de la planta completa. La Figura 14.4 brinda un ejemplo.

El principal problema está asociado a la creación de un modelo hidráulico de la PTAR. Una solución rigurosa sería la de hacer un modelo dinámico completo de la dinámica de fluidos de la planta, donde se pudieran describir de manera exacta los diferentes patrones de flujos en los reactores. Sin embargo, los detalles que se obtienen de un modelo de esta naturaleza son en general muy elevados para la mayoría de los modelos de conversión. Ya que el interés principal se centra en los procesos de conversión biológica, es necesario describir adecuadamente los cambios en las concentraciones dentro de la planta. La medición de diferentes compuestos relevantes puede ayudar a definir el modelo hidráulico. Para modelos de lodos activados, estos compuestos generalmente son oxígeno, amoniaco y nitrato, y fosfato en el caso de sistemas con remoción de fósforo. Como un primer paso se puede hacer una división entre las zonas aerobias, anóxicas y anaerobias. 



Figura 14.4 Esquema hidráulico del proceso PhoStrip ${ }^{\oplus}$ en la PTAR de Haarlem Waarderpolder en los Países Bajos y su respectiva representación en el paquete de simulación y modelación SIMBA (adaptado de Brdjanovic et al., 2000)

Dentro de cada zona se debe observar, por ejemplo en el caso de un tanque aireado, si existe un gradiente en la concentración de oxígeno. Mientras la concentración de oxígeno se mantenga siempre por encima del coeficiente de saturación utilizado en las ecuaciones cinéticas, no existe la necesidad de describir los cambios de concentración en la zona aerobia, y los tanques se pueden considerar completamente mezclados. El modelo hidráulico debe predecir adecuadamente los cambios de concentración en los casos en que los compuestos que 
forman parte de la reacción se acercan o bajan de los valores de la constante de saturación. En términos generales, esto significa utilizar un modelo de flujo pistón o describir el sistema como una serie de tanques consecutivos en serie. En el caso en que la concentración observada de amoniaco en un tanque aireado sea, por ejemplo de $4 \mathrm{mg} / \mathrm{l}$ a lo largo del tanque, se puede considerar que el tanque se encuentra completamente mezclado y se puede representar como un solo reactor en el esquema hidráulico de la planta. No obstante, si el nivel de amoniaco cambia de $4 \mathrm{mg} / \mathrm{l}$ en la entrada del tanque aireado, a $0 \mathrm{mg} / \mathrm{l}$ en la salida, hay una indicación de la existencia de un gradiente de concentración considerable y consecuentemente es mucho mejor modelar el sistema como una serie de compartimentos más pequeños, completamente mezclados y conectados en serie. El segundo aspecto a tener en cuenta es la transferencia de compuestos entre las fases gaseosa y líquida (como el caso del oxígeno) en reactores aireados o entre el líquido y la biopelícula en reactores de biopelícula. Este tema se describe en detalle en los Capítulos 9 y 17, respectivamente.

\subsubsection{Notación matricial}

La ecuación de balance (Ec.14.1) puede ser utilizada para cada componente individual. El gran número de componentes y conversiones de interés hacen de un modelo de lodos activados un sistema complejo. La formulación de un número elevado de ecuaciones de balance resulta en una pérdida de la visión de conjunto del sistema. El grupo de trabajo (Henze et al., 1987) de la sociedad internacional de la calidad del agua (IAWQ, por sus siglas en inglés, International Association on Water Quality) encargado de la "Modelación matemática del tratamiento de aguas residuales" recomienda utilizar la notación matricial para la presentación de los modelos.

Este formato facilita la presentación de los compuestos, los procesos y sus interacciones en una sola página de una forma clara e inequívoca. Adicionalmente, la notación matricial permite hacer una comparación de forma fácil entre diferentes modelos, y facilita la transformación del modelo en un programa de computadora. Una matriz se representa por una serie de filas y columnas; una columna para cada compuesto y una fila para cada proceso. Un ejemplo simplificado de una matriz se muestra en la Tabla 14.1.

El primer paso en la definición de una matriz es la identificación de los compuestos de relevancia para el modelo. Los compuestos se representan mediante símbolos en la parte superior de la tabla incluyendo las unidades en una fila ubicada inmediatamente debajo.

El segundo paso en la definición de la matriz consiste en identificar los procesos biológicos que ocurren en el sistema. Estas corresponden a conversiones o transformaciones que afectan a los compuestos considerados en el modelo y deben escribirse una por una del lado izquierdo de la matriz. Las tasas de reacción de los procesos se formulan matemáticamente y se incluyen al lado derecho de la matriz en la fila del proceso correspondiente. A lo largo de cada fila se insertan los coeficientes estequiométricos de conversión de un compuesto a otro, de tal forma que cada columna de un compuesto contiene los coeficientes estequiométricos de los procesos en los que participa. Por claridad, cuando los coeficientes estequiométricos son iguales a cero no se incluyen en la matriz. La convención de signos aceptada per se y utilizada en la matriz para cada compuesto es "signo negativo para consumo" y "signo positivo para producción”. Bajo esta convención las tasas de reacción de los procesos tienen siempre un signo positivo. Es importante recordar que el oxígeno se asume como una DQO negativa debido a que el oxígeno acepta electrones: los electrones se transfieren del substrato al oxígeno para formar agua. Debe prestarse especial atención a las unidades utilizadas en las tasas de los procesos. Los coeficientes estequiométricos se simplifican enormemente si se trabaja con unidades consistentes.

En el ejemplo presentado en la Tabla 14.1 los compuestos están expresados como DQO equivalente. Partiendo de que las unidades se hayan usado de forma consistente, la continuidad de los parámetros estequiométricos puede verificarse moviéndose a través de cualquiera de las filas de la matriz; la suma de los coeficientes estequiométricos debe ser igual a cero. Esta matriz permite la visualización de un resumen conciso de las complejas interacciones entre los diferentes compuestos y procesos. Adicionalmente facilita la incorporación de cambios en los procesos, compuestos, estequiometría y cinética del sistema.

La matriz muestra dos aspectos importantes del proceso: la ecuación de reacción para cada proceso está representada en las diferentes filas. En las columnas se puede observar directamente en cuales conversiones está involucrado el compuesto. Multiplicando los factores estequiométricos con sus respectivas ecuaciones de tasa de proceso se puede obtener la ecuación de conversión total para cada compuesto. 
Tabla 14.1 Ejemplo de una matriz estequiométrica simple para la modelación del proceso de lodos activados (Henze et al., 1987)

\begin{tabular}{|c|c|c|c|c|}
\hline Componentes i & 1: So & $2: \mathrm{S}_{\mathrm{S}}$ & $3: \mathrm{X}_{\mathrm{H}}$ & Ecuación de reacción del proceso $\rho_{j}$ \\
\hline \multicolumn{5}{|l|}{ Lista de procesos $\mathrm{j}$} \\
\hline Crecimiento aerobio & $-\frac{1}{Y_{H}}+1$ & $\frac{1}{Y_{H}}$ & +1 & $\mu_{\mathrm{H}}^{\max } \cdot \frac{\mathrm{Ss}_{\mathrm{s}}}{\mathrm{Ks}_{\mathrm{s}}+\mathrm{S}_{\mathrm{s}}} \cdot \mathrm{X}_{\mathrm{H}}$ \\
\hline Lisis & & +1 & -1 & $\mathrm{~b}_{\mathrm{H}} \cdot \mathrm{X}_{\mathrm{H}}$ \\
\hline Tasas de transformación observadas $r_{i}$ & \multicolumn{3}{|c|}{$\mathrm{r}_{\mathrm{i}}=\sum_{\mathrm{j}} \mathrm{V}_{\mathrm{j}, \mathrm{i}} \cdot \rho_{\mathrm{j}}\left[\mathrm{MiL}^{-3} \mathrm{~T}^{-1}\right]$} & \\
\hline $\begin{array}{l}\text { Definición de parámetros } \\
\text { estequiométricos: } \\
\mathrm{Y}_{\mathrm{H}} \quad \text { Coeficiente de rendimiento de } \\
\quad \text { Heterótrofos }\left[\mathrm{M}_{\mathrm{H}} \mathrm{Ms}^{-1}\right]\end{array}$ & 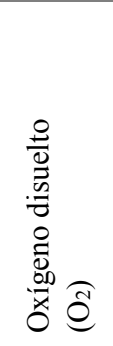 & 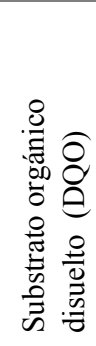 & 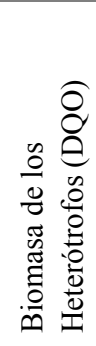 & $\begin{array}{l}\begin{array}{l}\text { Definición de los parámetros } \\
\text { cinéticos: }\end{array} \\
\mu_{\mathrm{H}}^{\max } \quad \begin{array}{l}\text { Tasa específica máxima de crecimiento } \\
{\left[\mathrm{T}^{-1}\right]}\end{array} \\
\mathrm{K}_{\mathrm{S}} \quad \begin{array}{l}\text { Coeficiente de saturación del substrato } \\
{\left[\mathrm{McoD}^{-3}\right]}\end{array} \\
\mathrm{b}_{\mathrm{H}} \quad \begin{array}{l}\text { Tasa de decaimiento } \\
\end{array} \quad\left[\mathrm{T}^{-1}\right]\end{array}$ \\
\hline
\end{tabular}

Por conveniencia, se pueden agregar dos aspectos adicionales a la descripción de la matriz (Tabla 14.2). El primer aspecto es la inclusión de una matriz con la composición, en términos de los balances de conservación, en este caso DQO, nitrógeno y carga. La biomasa se expresa en la matriz estequiométrica en términos de la DQO, pero también contiene nitrógeno. En la matriz de composición esto se incluye. Ya que la matriz de composición y la matriz estequiométrica contienen todos los balances de conservación, la multiplicación de las dos matrices es igual a cero.
Como segundo aspecto es importante poder visualizar los compuestos expresados en otras unidades diferentes a las del modelo, y que se relacionen con parámetros que puedan ser medidos $\mathrm{y} / \mathrm{u}$ observados. Por ejemplo, la cantidad de lodo normalmente se mide como sólidos suspendidos totales (SST) y no como DQO. La matriz de parámetros observables contiene estas conversiones entre, por ejemplo gDQO y gSST. Otras cantidades observables de potencial interés para incluir son el nitrógeno total de Kjeldahl (NTK), los sólidos suspendidos volátiles (SSV) y la DBO.

Tabla 14.2. Ejemplo de una matriz estequiométrica para la modelación de lodos activados (adaptado de Gujer y Larsen, 1995)

\begin{tabular}{|c|c|c|c|c|c|c|c|c|c|c|}
\hline Componente & $\begin{array}{l}\stackrel{0}{\bar{d}} \\
\stackrel{\infty}{x} \\
\stackrel{x}{0}\end{array}$ & $\stackrel{\mathscr{E}}{\stackrel{\Xi}{\Xi}}$ & 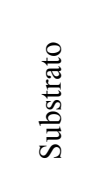 & 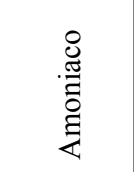 &  & 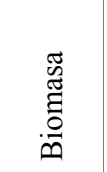 & $\underset{\Xi}{\stackrel{\Xi}{0}}$ & 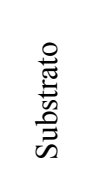 & $\ddot{\mathscr{n}}$ & $\underset{\mathscr{E}}{\mathscr{E}}$ \\
\hline Símbolo & So & $\mathrm{S}_{\mathrm{I}}$ & SS & $\mathrm{S}_{\mathrm{NH}}$ & $\mathrm{S}_{\mathrm{HCO}}$ & $\mathrm{X}_{\mathrm{H}}$ & $\mathrm{X}_{\mathrm{I}}$ & $\mathrm{X}_{\mathrm{S}}$ & $\mathrm{X}_{\mathrm{TSS}}$ & \\
\hline Unidad & $\mathrm{gO}_{2}$ & $\mathrm{gDQO}$ & $\mathrm{gDQO}$ & $\mathrm{gN}$ & mole & gDQO & gDQO & gDQO & gSST & \\
\hline Proceso & \multicolumn{10}{|c|}{ MATRIZ ESTEQUIOMETRICA } \\
\hline Hidrólisis & & & 1 & & & & & -1 & -0.75 & $\mathrm{r}_{1}$ \\
\hline Crecimiento aerobio & -0.5 & & -1.5 & -0.08 & -0.005714 & 1 & & & 0.9 & $\mathrm{r}_{2}$ \\
\hline Lisis & & & & 0.07 & 0.005 & -1 & 0.2 & 0.8 & -0.12 & $\mathrm{r}_{3}$ \\
\hline Conservativo & \multicolumn{8}{|c|}{ MATRIZ DE COMPOSICIÓN } & & \\
\hline OD/DQO Teórica & -1 & 1 & 1 & 0 & & 1 & 1 & 1 & & \\
\hline $\mathrm{N}$ & & 0.02 & & 1 & & 0.08 & 0.05 & 0 & & \\
\hline Carga & & & & 0.071429 & -1 & & & & & \\
\hline \multicolumn{9}{|l|}{ Observable } & & \\
\hline SST & & & & & & 0.9 & 0.9 & 0.75 & & \\
\hline
\end{tabular}




\subsection{DESARROLLO PASO A PASO DE UN MODELO BIOCINÉTICO: ASM1}

El desarrollo de un modelo se hace por etapas, de abajo hacia arriba, y sólo se deben incluir los procesos estrictamente necesarios para cumplir el propósito final del modelo. El principio rector en el desarrollo de un modelo es el de comenzar con un modelo sencillo y gradualmente aumentar la complejidad del mismo a medida que sea necesario. En general, los modelos de lodos activados de la familia ASM se han desarrollado para describir la tasa de consumo de oxígeno (OUR, por sus siglas en inglés, Oxygen Uptake Rate), la producción de lodos (acoplada al balance de DQO), y las conversiones de nitrógeno y fósforo en plantas de tratamiento de aguas residuales domésticas.

No obstante, a pesar del hecho de haber sido diseñados para aplicaciones prácticas ( $\mathrm{y}$ no con propósitos académicos), no son modelos con aplicaciones sanitarias ya que no describen ni tienen en cuenta la remoción de patógenos. Probablemente la mejor manera de describir el proceso paso a paso en el desarrollo de un modelo de lodos activados se basa en el esquema original seguido por Ekama y Marais (1978), más tarde descrito por Dold et al., (1980), y desarrollado adicionalmente en Gujer and Henze (1991). El resultado final de éste enfoque guarda semejanza con el modelo ASM1 y se describe brevemente a continuación. El sistema experimental utilizó un reactor completamente mezclado de lodos activados tratando un agua residual doméstica clarificada. La Tabla 14.3 muestra las condiciones operativas del sistema, y la caracterización básica de los parámetros del afluente y del lodo.

El objetivo de este estudio fue el uso del modelo para poder predecir de manera acertada el contenido de biomasa en el sistema, la tasa de consumo de oxígeno (OUR) de la biomasa y la conversión de nitrógeno. Para empezar, es posible utilizar un modelo simplificado el cual contenía solo tres compuestos relevantes (Oxígeno disuelto So, substrato orgánico disuelto Ss y biomasa heterotrófica $\mathrm{X}_{\mathrm{H}}$ ) y dos procesos de conversión (crecimiento aerobio y lisis). Con un incremento del TRS, la biomasa (organismos vivos), representada como una fracción de la masa de lodos (SSV) decrece. Para describir esto, se utilizó el proceso de muerte y regeneración o lisis (Capítulo 4), es decir la desintegración de las células muertas resulta en una generación de substrato soluble biodegradable que puede ser utilizado nuevamente en la generación de nueva biomasa. La lisis heterotrófica representa todos los procesos que conllevan a una pérdida de biomasa (descomposición, lisis, respiración endógena, depredación, etc.). La descomposición endógena o mantenimiento puedo haber sido también utilizada para describir la reducción de biomasa. Para el proceso de crecimiento aerobio, todos los compuestos son relevantes; el oxígeno disuelto y el substrato orgánico son utilizados por la biomasa bajo condiciones aerobias (coeficiente negativo) para producir biomasa (coeficiente positivo). En general, una matriz puede simplificarse si es posible asignar libremente un valor de $+1 \mathrm{o}-1$ a los coeficientes estequiométricos de cada proceso. La selección del coeficiente de rendimiento $\mathrm{Y}_{\mathrm{H}}(0.67$ gDQO/gDQO) junto con la ecuación de conservación de la DQO es suficiente para determinar todos los coeficientes estequiométricos para el crecimiento aerobio (Figura 14.5). Para ambos procesos es posible definir una tasa; para el crecimiento aerobio éste es un producto de la tasa específica máxima de crecimiento, la afinidad del substrato y la concentración de la biomasa (asumiendo que el oxígeno no limita el crecimiento)

La lisis es un tipo de proceso de primer orden, donde la biomasa se descompone en proporción a la concentración de biomasa presente y una constante de proporcionalidad (constante de descomposición). Substituyendo los coeficientes en el modelo biocinético se obtiene la matriz para el modelo A (Tabla 14.4).

Tabla 14.3 Resumen de datos del sistema experimental de Ekama y Marais (1978)

\begin{tabular}{ll}
\hline Parámetro & Valor \\
\hline Régimen de alimentación & $12 \mathrm{~h} / \mathrm{d}$ (encendido durante las 02:00 y 14:00) \\
Caudal & $18 \mathrm{l} / \mathrm{d}$ \\
Volumen del reactor & 6.731 \\
Procesos & Remoción de DQO y nitrificación (completamente aerobia) \\
Contenido de biomasa del reactor & $1,375 \mathrm{mgSSV} / 1$ o 2,090 mgDQO/1 \\
Tiempo de retención de sólidos (TRS) & $2.5 \mathrm{~d}$ \\
Temperatura & $20.4^{\circ} \mathrm{C}$ \\
Concentración de DQO afluente & $570 \mathrm{mgDQO} / 1$ \\
Concentración de NTK afluente & $46.8 \mathrm{mgN} / 1$ \\
\hline
\end{tabular}


Tabla 14.4 Representación matricial del modelo A

\begin{tabular}{|l|c|c|c|c|}
\hline Componente & So & $\mathrm{S}_{\mathrm{S}}$ & $\mathrm{X}_{\mathrm{H}}$ & Tasa de reacción \\
\hline Crecimiento & -0.5 & -1.5 & 1.0 & $\mu_{\mathrm{H}}^{\max } \cdot \frac{\mathrm{S}_{\mathrm{S}}}{\mathrm{K}_{\mathrm{S}}+\mathrm{S}_{\mathrm{S}}} \cdot \frac{\mathrm{S}_{\mathrm{O}}}{\mathrm{K}_{\mathrm{O}, \mathrm{H}}+\mathrm{S}_{\mathrm{O}}} \cdot \mathrm{X}_{\mathrm{H}}$ \\
\hline Lisis & & +1.0 & -1.0 & $\mathrm{~b}_{\mathrm{H}} \cdot \mathrm{X}_{\mathrm{H}}$ \\
\hline
\end{tabular}

Si los resultados de este modelo se comparan con la OUR medida experimentalmente (Figura 14.5), se puede observar que las observaciones experimentales se desvían considerablemente de las predicciones del modelo, a excepción de las primeras dos horas y justo al final del experimento (respiración endógena). En general, si las predicciones del modelo se desvían con respecto de los niveles de los parámetros de interés, estas son relativamente fáciles de ajustar cambiando el valor de los parámetros seleccionados del modelo. Sin embargo, si las predicciones del modelo en términos de las tendencias y las formas son incorrectas, es muy probable que no se hayan tenido en cuenta todos los procesos relevantes.

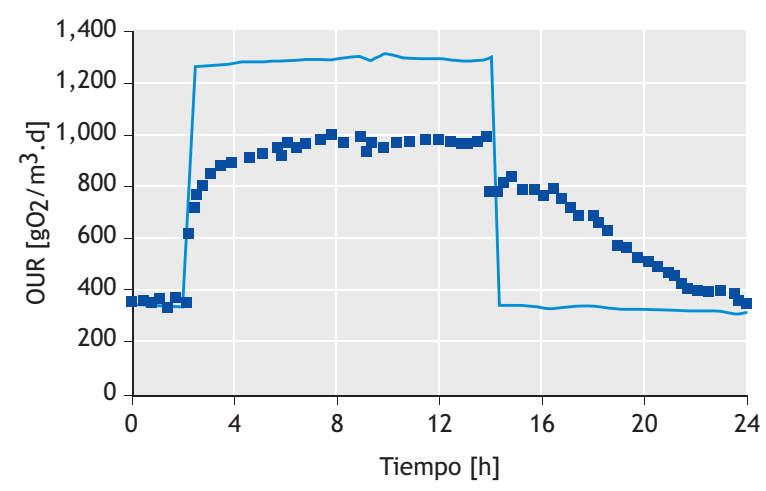

Figura 14.5 Modelo A: comparación de los valores observados experimentalmente (puntos) y la predicción teórica de la tasa de consumo de oxígeno (línea continua) (adaptado de Ekama y Marais, 1978; Gujer y Henze, 1991)

En este experimento, la diferencia entre el consumo total de oxígeno observado a lo largo de 24 horas y el calculado por el modelo es pequeña. Sin embargo, la desviación entre el modelo y los resultados experimentales fue lo que condujo a Dold et al., (1980) a sugerir una división de la degradación de la materia orgánica en dos procesos (fracciones): un proceso relativamente rápido de biodegradación de una parte de la DQO compuesta de materia orgánica como ácidos grasos volátiles (AGV) y glucosa, y otro proceso relativamente lento de degradación de la DQO (celulosa, almidón, proteínas etc.). Este fraccionamiento en DQO lentamente biodegradable $\mathrm{y}$ DQO rápidamente biodegradable (DQO ${ }_{\mathrm{lb}}$ y $\mathrm{DQO}_{\mathrm{rb}}$, respectivamente) fue motivado por la observación experimental del perfil de
OUR, el cual mostró una caída drástica casi inmediatamente después de detener la alimentación (a las 14:00 horas), seguida de una lenta disminución hasta el final del experimento donde alcanzó el valor en estado estacionario observado en las primeras dos horas del experimento. Por lo tanto, el proceso de lisis fue descrito de manera razonablemente buena por el modelo. Esto permitió adicionalmente concluir que la DQO $\mathrm{Db}_{\mathrm{lb}}$ se convierte en $\mathrm{DQO}_{\mathrm{rb}}$ por el proceso relativamente lento de hidrólisis (Figura 14.5).

Esto implica que existe la necesidad de extender el modelo A e introducir dos tipos de substrato (DQO $\mathrm{DQO}_{\mathrm{rb}}$ ) y un proceso adicional (hidrólisis). En el modelo ASM1 también se asume que el substrato lentamente biodegradable está formado enteramente de substrato suspendido o particulado $\left(\mathrm{X}_{\mathrm{S}}\right)$, lo cual si bien no es necesariamente cierto, se asume como tal en el modelo. La distinción entre substrato suspendido y particulado (X) y substrato soluble es necesaria para poder determinar cuáles compuestos van a sedimentar en el clarificador y cuáles van a salir del sistema con el efluente. La introducción de una fracción $\left(\mathrm{X}_{\mathrm{S}}\right)$ no afectó el proceso de crecimiento heterotrófico ya que se asume que este crecimiento no se basa directamente en la DQO$_{\mathrm{lb}}$. El proceso de lisis fue también ajustado bajo la suposición de que los productos de descomposición son lentamente biodegradables, y como tal, contribuyen al contenido de $\mathrm{X}_{\mathrm{S}}$. A través del proceso de hidrólisis, estos productos a la vez se convierten en compuestos biológicamente disponibles para el crecimiento heterotrófico aerobio. Esto significa que existen dos tipos de substrato particulado: uno derivado del agua residual afluente, y un segundo generado por la descomposición de la biomasa. En algunos casos estos productos se agrupan (como es el caso actual), mientras que en otros modelos se tienen en cuenta separadamente. Sin embargo, ambas opciones resultan en una diferencia neta prácticamente nula. Adicionalmente, se asume que el material hidrolizable $X_{S}$ se adsorbe en la biomasa heterotrófica $\mathrm{X}_{\mathrm{H}}$ lo que resulta en una expresión cinética de tipo Lagrangiana para la ecuación de reacción de la hidrólisis. Debido a esto, lo importante en este caso es la relación entre el substrato y la biomasa (reacción 
limitante) y no la concentración de substrato con respecto del líquido como es el caso para la DQO $\mathrm{rb}$. El modelo B se desarrolló al implementar estos cambios al modelo original (Tabla 14.5). del modelo B no fueron modificadas debido a la buena descripción del perfil de OUR.

Tabla 14.5 Representación matricial del modelo B

\begin{tabular}{|l|c|c|c|c|c|}
\hline Componente & So & Ss & $\mathrm{X}_{\mathrm{H}}$ & $\mathrm{XS}$ & Tasa de reacción \\
\hline Crecimiento & -0.5 & -1.5 & 1.0 & & $\mu_{\mathrm{H}}^{\max } \cdot \frac{\mathrm{S}_{\mathrm{S}}}{\mathrm{K}_{\mathrm{S}}+\mathrm{S}_{\mathrm{S}}} \cdot \frac{\mathrm{S}_{\mathrm{O}}}{\mathrm{K}_{\mathrm{O}, \mathrm{H}}+\mathrm{S}_{\mathrm{O}}} \cdot \mathrm{X}_{\mathrm{H}}$ \\
\hline Lisis & & & -1.0 & +1.0 & $\mathrm{~b}_{\mathrm{H}} \cdot \mathrm{X}_{\mathrm{H}}$ \\
\hline Hidrólisis & & +1.0 & & -1.0 & $\mathrm{k}_{\mathrm{H}} \cdot \frac{\left(\mathrm{X}_{\mathrm{S}} / \mathrm{X}_{\mathrm{H}}\right)}{\mathrm{K}_{\mathrm{x}}+\left(\mathrm{X}_{\mathrm{S}} / \mathrm{X}_{\mathrm{H}}\right)} \cdot \mathrm{X}_{\mathrm{H}}$ \\
\hline
\end{tabular}

El modelo B describe la OUR de forma realmente satisfactoria (Figura 14.6). No obstante, la predicción de la concentración de lodos activados fue $22 \%$ menor que la concentración de lodos medida. Esto indicó la necesidad de incrementar la producción de lodo introduciendo una fracción no biodegradable de la DQO en el agua residual afluente $\left(\mathrm{X}_{\mathrm{I}}\right)$. El término "no biodegradable" se utiliza en el contexto del tratamiento de aguas residuales en donde el compuesto no es degradado por los microorganismos durante su retención en el sistema. Materiales como plásticos, maderas y materiales fibrosos, uñas, y cabellos son todos considerados orgánicos y pueden ser degradados, pero no en una PTAR. Un compuesto como la celulosa puede inclusive considerarse como no biodegradable en sistemas de alta carga y considerarse biodegradable en sistemas de baja carga. Además del material particulado e inerte derivado del agua residual afluente, existe un segundo componente generado por la descomposición de la biomasa. Éste último surge debido a que la pared celular de los microorganismos constituye una DQO muy lentamente biodegradable la cual se considera no biodegradable en una PTAR. Resultados experimentales del proceso de lisis muestran una división de $92 \%$ de productos $\mathrm{X}_{\mathrm{S}} \quad$ (biodegradable), y $\quad 8 \% \quad \mathrm{X}_{\mathrm{I}} \quad$ (no biodegradable). Consecuentemente las tasas de reacción

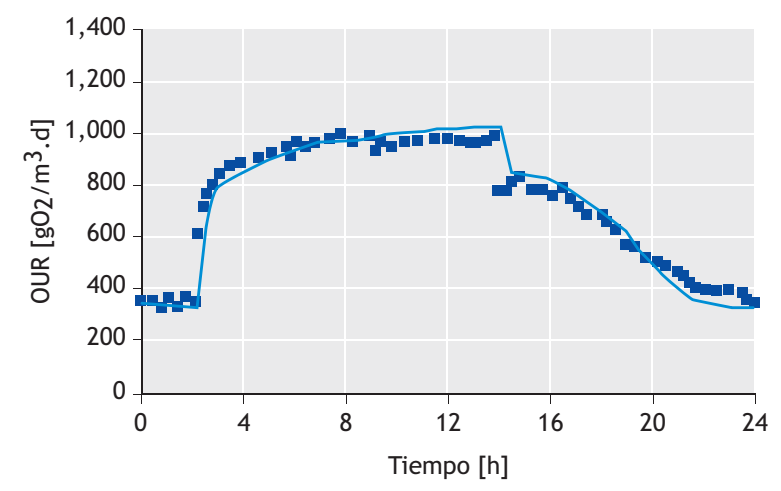

Figura 14.6 Modelo B: comparación de los valores observados experimentalmente (puntos) y la predicción teórica de la tasa de consumo de oxígeno (línea continua) (adaptado de Ekama y Marais 1978; Gujer y Henze 1991)

La inclusión de $\mathrm{X}_{\mathrm{I}}$ resultó en el desarrollo del modelo C, descrito en la Tabla 14.6. La predicción hecha por el modelo de concentración observada de biomasa en el reactor fue adecuada, sin embargo, debido a la mayor producción/remoción de lodo (DQO) del sistema, el consumo de oxígeno fue subestimado significativamente por el modelo (a pesar de que el perfil de OUR se ajustó correctamente, Figura 14.7). Esto era de esperar debido al acople que existe en el balance de la DQO entre el consumo de oxígeno y la producción de lodo, y por consiguiente, un incremento en la producción de lodo

Tabla 14.6 Representación matricial del modelo $C$

\begin{tabular}{|l|c|c|c|c|c|c|}
\hline Componente & $\mathrm{S}_{\mathrm{O}}$ & $\mathrm{S}_{\mathrm{S}}$ & $\mathrm{X}_{\mathrm{H}}$ & $\mathrm{X}_{\mathrm{S}}$ & $\mathrm{X}_{\mathrm{I}}$ & Tasa de reacción \\
\hline Crecimiento & -0.5 & -1.5 & 1.0 & & & $\mu_{\mathrm{H}}^{\max } \cdot \frac{\mathrm{S}_{\mathrm{S}}}{\mathrm{K}_{\mathrm{S}}+\mathrm{S}_{\mathrm{S}}} \cdot \frac{\mathrm{S}_{\mathrm{O}}}{\mathrm{K}_{\mathrm{O}, \mathrm{H}}+\mathrm{S}_{\mathrm{O}}} \cdot \mathrm{X}_{\mathrm{H}}$ \\
\hline Lisis & & & -1.0 & +0.92 & +0.8 & $\mathrm{~b}_{\mathrm{H}} \cdot \mathrm{X}_{\mathrm{H}}$ \\
\hline Hidrólisis & & +1.0 & & -1.0 & & $\mathrm{k}_{\mathrm{H}} \cdot \frac{\left(\mathrm{X}_{\mathrm{S}} / \mathrm{X}_{\mathrm{H}}\right)}{\mathrm{K}_{\mathrm{x}}+\left(\mathrm{X}_{\mathrm{S}} / \mathrm{X}_{\mathrm{H}}\right)} \cdot \mathrm{X}_{\mathrm{H}}$ \\
\hline
\end{tabular}


ocasiona una reducción en la demanda de oxígeno. El modelo $\mathrm{C}$ no fue capaz de predecir correctamente tanto la producción de lodos como el consumo de oxígeno.

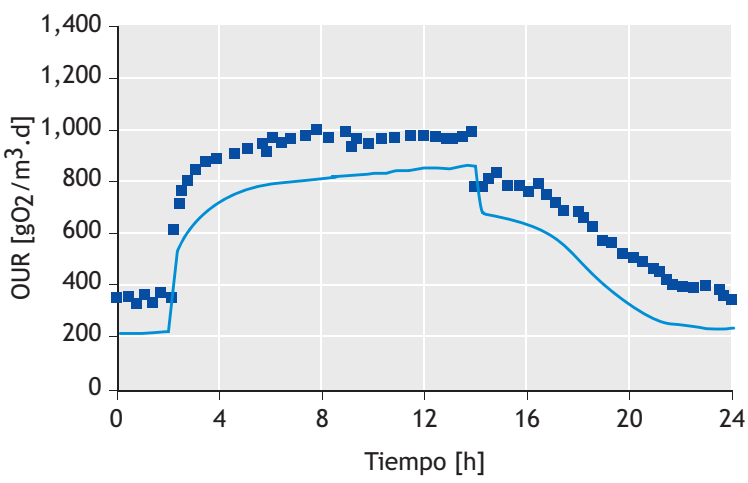

Figure 14.7 Modelo C: comparación de los valores observados experimentalmente (puntos) y la predicción teórica de la tasa de consumo de oxígeno (línea continua) (adaptado de Ekama y Marais 1978; Gujer y Henze 1991)

Las observaciones experimentales (no incluidas) indicaron que el efluente de la planta de tratamiento contenía nitrato lo que mostró la necesidad de incluir el proceso de nitrificación en el modelo. Al incluir el proceso de nitrificación es necesario añadir tres compuestos y dos procesos adicionales. Los compuestos incluyen amoniaco $\left(\mathrm{NH}_{4}^{+}, \mathrm{S}_{\mathrm{NH}}\right)$, nitrato $\left(\mathrm{NO}_{3}{ }^{-}, \mathrm{S}_{\mathrm{NO}}\right)$ y biomasas de los organismos nitrificantes $\left(\mathrm{X}_{\mathrm{A}}\right)$. Los procesos incluyen el crecimiento aerobio de los organismos nitrificantes y la lisis de los nitrificantes. Nuevamente fue necesario evaluar la influencia de cada uno de los materiales adicionales en las reacciones existentes. El amoniaco no solo se utiliza en el proceso de nitrificación sino que las células lo usan para su crecimiento, lo que obligó a la inclusión de un coeficiente estequiométrico para el amoniaco en el proceso de crecimiento heterotrófico. Si el contenido de nitrógeno en la biomasa es de $8 \%(0.08 \mathrm{mgN} / \mathrm{mgDQO})$, entonces el factor se toma como 0.08. Además, se asumió que durante el proceso de lisis el nitrógeno permanecía dentro de la biomasa. No obstante, en el proceso de hidrólisis, la DQO $\mathrm{lb}$ se degrada (por ejemplo, de proteínas a amino ácidos) lo que resulta en una liberación de amoniaco. Esto tiene la consecuencia de que además de la unidad de substrato, 0.08 unidades de amoniaco también se producen. Esto también ocurre con la DQO - a medida que la fracción proteica del afluente se degrada, se libera amoniaco - las proteínas se miden en el afluente como nitrógeno orgánico, es decir la diferencia entre el NTK y el amoníaco libre y salino. En el proceso de nitrificación se consume una cantidad determinada de oxígeno y amoniaco para producir nitrato y biomasa. La cantidad de amoniaco consumido no es exactamente igual a la cantidad de nitrato producido, debido al uso dual que tiene el amoniaco, a saber $(i)$ para la generación de energía en el proceso de nitrificación, y (ii) como fuente de nitrógeno para el crecimiento de la biomasa heterotrófica. La diferencia entra el amoniaco consumido y el amoniaco producido es 0.08 , que representa el contenido de nitrógeno en la biomasa heterotrófica. El balance general de nitrógeno en este caso si se ajusta $(4.25=4.17+0.08 \times 1.0)$. Adicionalmente, se asumió que el proceso de lisis de los autótrofos es igual al de los heterótrofos, mediante el cual se produce substrato particulado y una pequeña cantidad de substrato inerte. La tasa de reacción del proceso de lisis de los autótrofos se genera de forma análoga al de los heterótrofos con términos de saturación para el amoniaco y el oxígeno. La inclusión de los tres compuestos y los dos procesos adicionales resultó en el modelo $\mathrm{D}$, el cual satisface tanto el balance de DQO como el de nitrógeno. Al tener este modelo fue posible dividir el consumo total de oxígeno para la oxidación de amoniaco y el consumo de oxígeno para la degradación de la DQO. Esto muestra el valor agregado de utilizar el modelo en el análisis de procesos, para conocer y obtener información sobre donde se utiliza el oxígeno y en cuales procesos.

Los resultados del modelo D para las simulaciones de la OUR se muestran en la Figura 14.8.

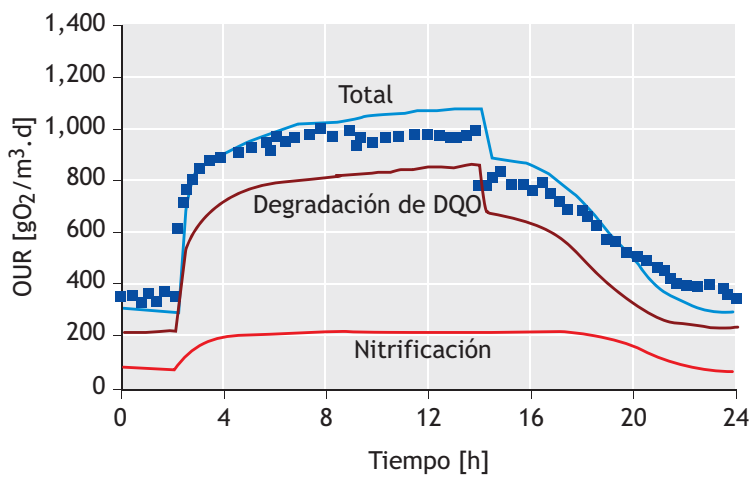

Figura 14.8 Modelo D: comparación de los valores observados experimentalmente (puntos) y la predicción teórica de la tasa de consumo de oxígeno (línea continua). El consumo de oxígeno para la degradación de la DQO y para la nitrificación se muestra de forma separada (adaptado de Ekama y Marais 1978; Gujer y Henze 1991)

Con el modelo en el estado actual, surgieron una serie de dilemas sobre su desarrollo, como "¿Es el ajuste del modelo lo suficientemente exacto?" o "¿es una desviación del 5 al 10\% aceptable en la predicción de la OUR aceptable en la hora 14:00?". La respuesta a estos interrogantes depende completamente de la calidad de los datos experimentales. Si los balances de DQO y 
nitrógeno de los datos son exactamente $100 \%$, entonces vale la pena buscar mejoras en el modelo para obtener una mejor predicción ya que se cuenta con datos experimentales fiables y precisos. Si los balances de DQO y nitrógeno no son del $100 \%$, sino un rango entre 95-105\%, entonces no tiene mucho sentido en hacer el modelo mucho más preciso. Hacer modelos es relativamente fácil, pero la parte más difícil del desarrollo de modelos para sistemas de tratamiento de aguas residuales es poder obtener datos experimentales que cumplan con los balances de masa de forma confiable y precisa. Si los equipos de medición resultan en una imprecisión de 5-10\%, entonces no tiene sentido hacer los modelos más precisos. Es importante no olvidar que un modelo solo es exitoso cuando cumple las expectativas del modelador. Si el propósito del modelo es el de describir correctamente las tendencias generales, no es necesario hacer refinamientos adicionales. Por supuesto que es importante la puesta a punto y calibración de un modelo para que se ajuste lo mejor que sea posible, pero esto aumenta la complejidad del modelo. Para el caso del modelo actual, se decidió que no era necesario adicionar compuestos o procesos extra, ya que la etapa final de calibración puede hacerse de manera directa cambiando algunos de los parámetros del modelo. En general, las simulaciones del modelo indicaron que los datos medidos y los datos modelados se ajustan bastante bien: la OUR, nitrificación y producción de lodos se predicen de forma acertada (datos no mostrados, ver Dold et al., 1980; Gujer y Henze, 1991). Para el objetivo predefinido, el modelo se considera correcto, lo cual no significa que las suposiciones hechas para derivar el modelo sean correctas. De hecho, al usar esas suposiciones, se obtuvo una descripción matemática lo suficientemente apropiada para el propósito definido. Sin embargo, el modelo D omitió algunos procesos que juegan un papel importante en la realidad, como el caso de la actividad de los protozoos (Tabla 14.7). En este caso, se evaluó que la inclusión de los protozoos en el modelo no aumentaría su poder descriptivo y consecuentemente el proceso no se incluyó.

El siguiente paso en el desarrollo de un modelo es la inclusión del proceso de desnitrificación. Existen dos caminos posibles que en última instancia conducen a los mismos resultados finales. Es posible asumir que o bien existe un grupo especial de bacterias que llevan a cabo la desnitrificación, o que todos los organismos heterotróficos son capaces de desnitrificar pero solo a una fracción de la velocidad que bajo condiciones aerobias. En otras palabras, o existe una población especializada de microorganismos que pueden utilizar oxígeno y nitrato, y una población que solo puede utilizar oxígeno, o todos los organismos heterotróficos pueden desnitrificar pero a una tasa reducida, la cual se corrige con un factor $\eta$ (factor de reducción del crecimiento bajo condiciones anóxicas). Estas suposiciones conceptuales son diferentes pero matemáticamente conducen a la misma ecuación. Debido a que la segunda suposición simplifica el modelo, ésta ha sido escogida para ser usada en la estequiometría de la desnitrificación y en conjunto con las bacterias normalmente catalogadas como organismos heterotróficos ordinarios. Aunque la realidad es probablemente mucho más compleja, se ha podido demostrar que en la práctica el enfoque simplificado funciona de forma satisfactoria.

Otro aspecto importante se relaciona con la diferenciación entre las fracciones de materia inerte y las fracciones de nitrógeno, las cuales corresponden a características que difieren entre los diferentes modelos comerciales. Como se mencionó anteriormente, el

Tabla 14.7 Representación matricial del modelo D

\begin{tabular}{|c|c|c|c|c|c|c|c|c|c|}
\hline Componente & So & $\mathrm{S}_{\mathrm{S}}$ & $\mathrm{S}_{\mathrm{NH}}$ & $\mathrm{S}_{\mathrm{NO}}$ & $\mathrm{X}_{\mathrm{H}}$ & $\mathrm{X}_{\mathrm{S}}$ & $\mathrm{X}_{\mathrm{I}}$ & $\mathrm{X}_{\mathrm{A}}$ & Tasa de reacción \\
\hline Crecimiento & -0.5 & -1.5 & -0.08 & & +1.0 & & & & $\mu_{\mathrm{H}}^{\max } \cdot \frac{\mathrm{S}_{\mathrm{S}}}{\mathrm{K}_{\mathrm{S}}+\mathrm{S}_{\mathrm{S}}} \cdot \frac{\mathrm{S}_{\mathrm{O}}}{\mathrm{K}_{\mathrm{O}, \mathrm{H}}+\mathrm{S}_{\mathrm{O}}} \cdot \frac{\mathrm{S}_{\mathrm{NH}}}{\mathrm{K}_{\mathrm{N}, \mathrm{H}}+\mathrm{S}_{\mathrm{NH}}} \cdot \mathrm{X}_{\mathrm{H}}$ \\
\hline Lisis & & & & & -1.0 & +0.92 & +0.08 & & $\mathrm{~b}_{\mathrm{H}} \cdot \mathrm{X}_{\mathrm{H}}$ \\
\hline Hidrólisis & & +1.0 & +0.08 & & & -1.0 & & & $\mathrm{k}_{\mathrm{H}} \cdot \frac{\left(\mathrm{X}_{\mathrm{S}} / \mathrm{X}_{\mathrm{H}}\right)}{\mathrm{K}_{\mathrm{x}}+\left(\mathrm{X}_{\mathrm{S}} / \mathrm{X}_{\mathrm{H}}\right)} \cdot \mathrm{X}_{\mathrm{H}}$ \\
\hline $\begin{array}{l}\text { Crecimiento } \\
\text { Autotrófico }\end{array}$ & -18.0 & & -4.25 & +4.17 & & & & +1.0 & $\mu_{\mathrm{A}}^{\max } \cdot \frac{\mathrm{S}_{\mathrm{O}}}{\mathrm{K}_{\mathrm{O}, \mathrm{A}}+\mathrm{S}_{\mathrm{O}}} \cdot \frac{\mathrm{S}_{\mathrm{NH}}}{\mathrm{K}_{\mathrm{N}, \mathrm{A}}+\mathrm{S}_{\mathrm{NH}}} \cdot \mathrm{X}_{\mathrm{A}}$ \\
\hline $\begin{array}{l}\text { Lisis } \\
\text { Autotrófica }\end{array}$ & & & & & & +0.92 & +0.08 & -1.0 & $\mathrm{~b}_{\mathrm{A}} \cdot \mathrm{X}_{\mathrm{A}}$ \\
\hline
\end{tabular}


material inerte puede encontrarse en el afluente o provenir de la degradación de la biomasa, y el contenido final de la degradación de la biomasa, el material inerte, puede tener una composición diferente a la del material inerte que se encuentra normalmente en el afluente. Esto también puede tenerse en cuenta en el modelo; el material inerte puede ser separado o agrupado. En principio, no es estrictamente necesario definir estas fracciones de forma separada, pero algunas veces se hace con propósitos estéticos, o por un requerimiento específico de la aplicación. Un razonamiento similar aplica para el fraccionamiento del nitrógeno. El desarrollo del modelo descrito por Ekama y Marais (1978) todavía se considera válido y el modelo $\mathrm{D}$ con la extensión adicional del proceso de desnitrificación se acerca bastante al modelo ASM1 (Henze et al., 1987). Detalles adicionales del modelo ASM1 pueden encontrarse en Dold et al. (1980); van Haandel et al. (1981); Alexander et al. (1983); Warner et al. (1986); y Henze et al. (1987, 2000).

Una de las limitaciones más notables de los modelos ASM es que no describen la ocurrencia de lodo filamentoso. Por lo tanto, si se utiliza un modelo ASM, por ejemplo para mejorar el proceso de nitrificación, es necesario revisar si los cambios propuestos van a conducir a la generación de lodo filamentoso. Una aireación limitada, la cual es benéfica para la remoción de nitrógeno, inevitablemente va a conducir a la formación de lodo filamentoso. La formación de este lodo no puede ser modelada de una forma que sea lo suficientemente confiable para ser implementado en los paquetes de simulación comerciales a pesar de algunos intentos descritos en la literatura científica (Krebs, 1995). Consecuentemente, esto significa que el modelo no puede predecir con exactitud concentraciones muy bajas en los efluentes cuando se implementan procesos de alta eficiencia. Adicionalmente, lo análogo también es considerado valido para el proceso de desnitrificación. Por otra parte, aun cuando un modelo es capaz de predecir una concentración de amoniaco de $0.5 \mathrm{mg} / \mathrm{l}$, existen siempre imprecisiones e imperfecciones en los procesos analíticos y en los procedimientos de toma y manejo de muestras.

Otra limitación de los modelos ASM es que no tienen en cuenta la remoción de micro-contaminantes como metales, compuestos xenobióticos o compuestos disruptores endocrinos. Esto se debe en parte al aumento de la complejidad que generaría en el modelo y en parte por la falta de conocimientos sobre los microorganismos y las reacciones bioquímicas en las que se involucran estos compuestos. En algunos casos, como en el tratamiento de aguas residuales en refinerías de petróleo, es necesario predecir la reducción de fenoles. Para apoyar el proceso de desnitrificación a menudo se adiciona metanol bajo condiciones anóxicas y por lo tanto este proceso de conversión debe incluirse. Existen casos en los que, por ejemplo, hay un interés particular en la reducción de sulfuro. En todos estos casos es necesario incluir un organismo especializado en el modelo, ya que la biomasa presente en el modelo ASM1 no realiza la conversión de estos micro-contaminantes. Ejemplos de estas extensiones se pueden encontrar en la literatura científica, y hoy en día algunos paquetes de simulación incluyen por defecto la utilización de metanol. En el caso de otros compuestos de la DQO como los ácidos grasos volátiles (AGV), no es necesario extender el modelo ya que los organismos ordinarios que normalmente remueven la DQO del agua residual también pueden convertir estos compuestos. Más allá del nivel del ASM1, el modelo puede extenderse para tener en cuenta la transferencia de oxígeno, $\mathrm{pH}$, alcalinidad, digestión anaerobia, remoción química de fósforo y precipitación, unidades adicionales (como clarificadores etc.), procesos en la línea de agua secundaria, procesos en la fase gaseosa, etc. Finalmente, va a depender de la finalidad del modelo si se requiere o no una extensión al mismo.

\section{5 $\mathrm{ASM}_{3}$}

En esencia el modelo ASM3 describe el mismo proceso que el ASM1, sin embargo el modelo ASM3 se desarrolló con el fin de corregir las deficiencias encontradas en el modelo ASM1. Esto se debe en parte a observaciones experimentales de la OUR de lodos activados, las cuales revelaron que las bacterias consumen de forma rápida la $\mathrm{DQO}_{\mathrm{rb}}$ y la guardan internamente como substrato el cual convierten posteriormente de forma lenta (conversión de $D_{\text {DQ }}$ rb en DQO ${ }_{\mathrm{lb}}$. Cuando se adiciona acetato como substrato al lodo activado, la OUR observada sugiere la presencia de dos substratos. La Figura 14.9 muestra la OUR asociada a degradaciones rápida y lenta del substrato.

El modelo ASM1 representa estos hallazgos como si existieran dos tipos diferentes de substratos ( $\mathrm{S}_{\mathrm{S}} \mathrm{y} \mathrm{X}_{\mathrm{S}}$ ) mientras que en la realidad solo se dosificó acetato $\left(\mathrm{S}_{\mathrm{S}}\right)$. Para poder describir la OUR observada usando el modelo ASM1, en este caso en particular es necesario definir que el acetato es parcialmente soluble y parcialmente particulado, una práctica no recomendada. Esta deficiencia se puede resolver introduciendo un compuesto de almacenamiento, $\mathrm{X}_{\mathrm{STO}, \mathrm{S}}$, en el modelo ASM3. Esto significa que el substrato es tomado 
rápidamente y almacenado por las bacterias, mientras que el substrato almacenado se utiliza para el crecimiento. Ambos modelos pueden describir la OUR observada, pero solo el ASM3 describe adecuadamente el proceso de consumo del acetato. Aun así, el modelo ASM1 puede utilizarse sin inconvenientes en sistemas con remoción de nitrógeno debido a que este proceso ocurre lentamente, lo que brinda suficiente tiempo para la degradación de la DQO lentamente biodegradable.

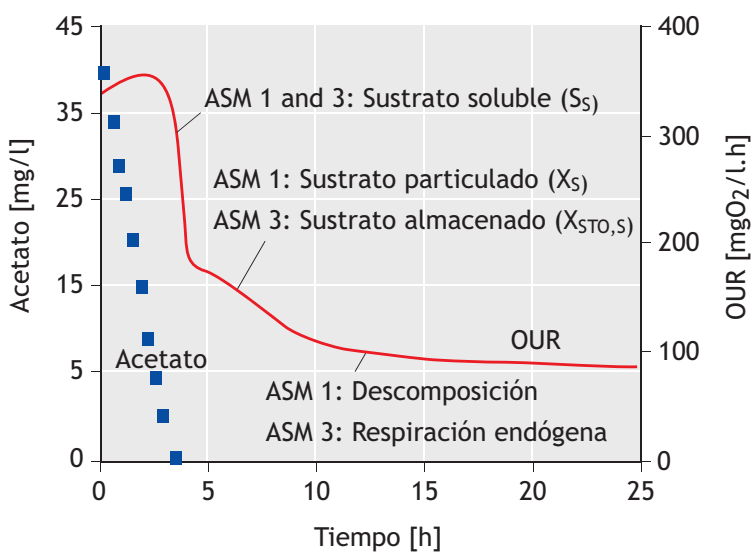

Figura 14.9 Diferencias entre el modelo ASM1 y ASM3

La segunda razón para el desarrollo del modelo ASM3 fue que debido al éxito de los modelos ASM1 en la simulación de plantas de tratamiento de aguas residuales muchos comenzaron a creer que el modelo ASM1 era una representación fidedigna de los procesos que ocurren en la realidad. No obstante, como se puede constatar con los mecanismos de almacenamiento exhibidos por la biomasa, el modelo ASM1 no es completamente preciso desde el punto de vista mecanístico pero se acerca lo suficiente para cumplir su propósito. Por esta razón, el modelo ASM3 también ha jugado un papel educativo fundamental al demostrar las diferentes formas (no necesariamente mejores las unas de las otras) en que se puede modelar una misma PTAR.

No obstante, la razón más importante para la introducción del ASM3 fue el reconocimiento de la importancia de tres diferentes tasas de consumo de oxígeno en el proceso, a saber: la tasa de consumo rápido de oxígeno para la degradación de DQO $\mathrm{rb}_{\mathrm{rb}}$, la tasa lenta de consumo asociada a la degradación de $\mathrm{DQO}_{\mathrm{lb}}$, y la tasa aún más lenta asociada a la OUR endógena (Figura 14.9). En contraste, en el modelo ASM1 existe solo un proceso que consume oxígeno, por lo cual el proceso de calibración resulta muy difícil, ya que es necesario calibrar otros procesos que indirectamente afectan el proceso de consumo de oxígeno.

Otro problema del modelo ASM1 es la recirculación de DQO en el proceso. La DQO particulada que se libera como parte del proceso de descomposición, y luego de ser hidrolizada se utiliza nuevamente en el proceso de crecimiento. Debido a esta recirculación, el cambio de un parámetro en el modelo, afecta a todos los demás procesos, lo que a la vez hace difícil la automatización del proceso de calibración. En el modelo ASM3, este problema ha sido resuelto reemplazando el proceso de descomposición (muerte y regeneración) por el proceso de respiración endógena, el cual elimina el problema de la recirculación de DQO (Figura 14.10). En otras palabras, una vez que se han producido células, estas comienzan a oxidarse a ellas mismas y mediante este proceso la biomasa se reduce a través de la mineralización aerobia (el proceso clásico de respiración endógena).

A

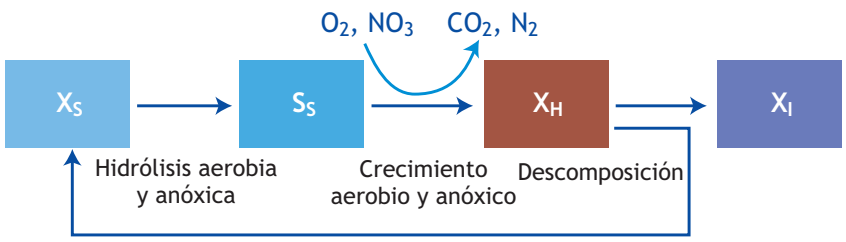

B

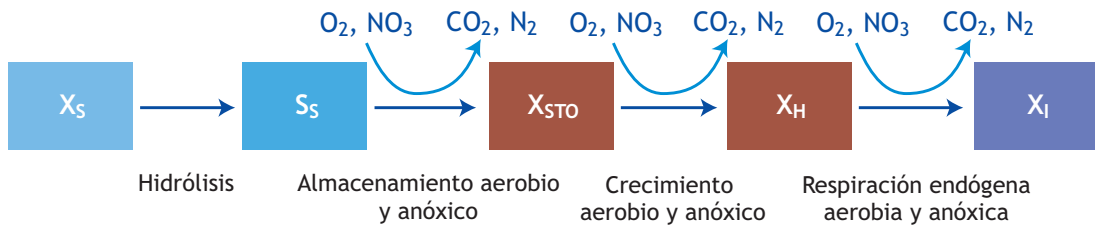

Figura 14.10 Degradación de la DQO en el modelo (A) ASM1 y (B) ASM3 
Si bien este proceso no está exento de controversias conceptuales, por ejemplo, ¿por qué habría un organismo de oxidarse a sí mismo (es decir hacer una dieta) si hay suficiente alimento a su alrededor?, resulta muy útil en la eliminación de las interacciones entre los bioprocesos producto de la recirculación de substrato, una característica del modelo de muerte y regeneración.

Adicionalmente, en el modelo ASM3 el consumo de oxígeno se divide en tres procesos (almacenamiento, crecimiento y respiración endógena) en vez de solo uno como en el ASM1. En el modelo ASM3, si se conoce el proceso al cual darle prioridad, es posible ajustar de una de las tres tasas de consumo de oxígeno, lo que directamente vincula las mediciones con los parámetros. El hecho del consumo y acumulación de la DQO $\mathrm{rb}$ es irrelevante para la mayor parte de las plantas de tratamiento (así como la elección entre usar el ASM1 o ASM3).

La aplicación donde realmente tiene sentido el uso exclusivo del modelo ASM3 es en reactores en flujo pistón, como en el caso de selectores. Si, por ejemplo, se requiere remover acetato en un selector para prevenir la aparición de lodo filamentoso, el diseño del selector va a estar gobernado por el tiempo necesario para el almacenamiento del acetato y la cantidad de oxígeno requerido. $\mathrm{Si}$ se utiliza el modelo ASM1, los requerimientos de oxígeno van a ser significativamente sobreestimados. En realidad la mayor parte del acetato se almacena en la biomasa, y una vez almacenado se eliminan los problemas de una posible aparición de lodo filamentoso. Si se quiere diseñar e incluir un modelo de selector aerobio en el sistema, lo mejor es utilizar el modelo ASM3.

Otros casos de aplicación del modelo ASM3, es en la descripción de plantas con remoción de nitrógeno y predesnitrificación, y TRS cortos. En este caso en particular, hay una diferencia substancial entre tener o no DQO rápidamente y lentamente biodegradable, y entre tener o no DQO almacenada. En sistemas con TRS elevados (entre 10-20 días dependiendo de la temperatura), una gran parte de la remoción de nitrato está asociada a: $(i)$ la DQO lentamente biodegradable del afluente y el proceso de muerte-regeneración en el reactor de predesnitrificación, y (ii) el proceso de muerte-regeneración en el reactor de pos-desnitrificación, de tal forma que la sensibilidad de la relación exacta entre $\mathrm{DQO}_{\mathrm{lb}}$ y DQO $\mathrm{rb}$ es mucho menor. Lo mismo aplica para la diferenciación entre el ASM1 y el ASM3. En sistemas con cargas elevadas, la respiración endógena es menos importante mientras que la acumulación de DQO en la forma de polímeros de almacenamiento y su transporte en la fase aireada de la PTAR puede ser significativo.

En conclusión, el uso del modelo ASM3 se recomienda para ( $i$ ) la simulación de sistemas con altas cargas de nitrificación-desnitrificación y con periodos de retención anóxica cortos, (ii) el modelado de selectores, y (iii) calibración automática de parámetros del modelo. En todas las demás circunstancias, el modelo ASM1 es igualmente exitoso en la modelación de plantas de tratamiento.

La consecuencia de introducir la EBPR y los organismos acumuladores de fósforo (PAOs, por sus siglas en inglés, Phosphorus Accumulating Organisms) en un modelo ASM es que el modelo resultante se torna bastante complejo, como se ilustra en la Figura 14.11. El lado izquierdo de la figura representa parte de las conversiones realizadas por los organismos nitrificantes y los organismos heterotróficos ordinarios, mientras que el lado derecho muestra la extensión necesaria para incluir la compleja fisiología de los PAOs.

Los organismos nitrificantes y los organismos heterotróficos ordinarios utilizan oxígeno para oxidar el substrato que consumen formando $\mathrm{CO}_{2}$ o nitrato, y biomasa. La fisiología de este grupo de microorganismos es relativamente simple lo que resulta en procesos simples dentro del modelo. La fisiología de los PAOs incluye el almacenamiento interno de polímeros (PHA, glucógeno y poli-fosfato) y su comportamiento bajo condiciones anaerobias, anóxicas y aerobias, el cual es diferente en cada una de las fases. Los PAOs también se comportan de forma diferente en condiciones aerobias dependiendo de si hay substrato presente o no. Es evidente que existen muchas variaciones posibles y la inclusión de la EBPR en el modelo aumenta su complejidad sustancialmente (el número de procesos en el modelo ASM aumenta de 11 a 22). La situación se vuelve aún más compleja cuando se incluyen los organismos acumuladores de glucógeno (GAOs, por sus siglas en inglés, Glycogen Accumulating Organisms) (Capítulo 7). Los modelos ASM2 y ASM2d son similares al ASM1 al asumir un modelo de caja negra a diferencia de un modelo metabólico el cual tiene en cuenta lo que sucede dentro de la célula. 


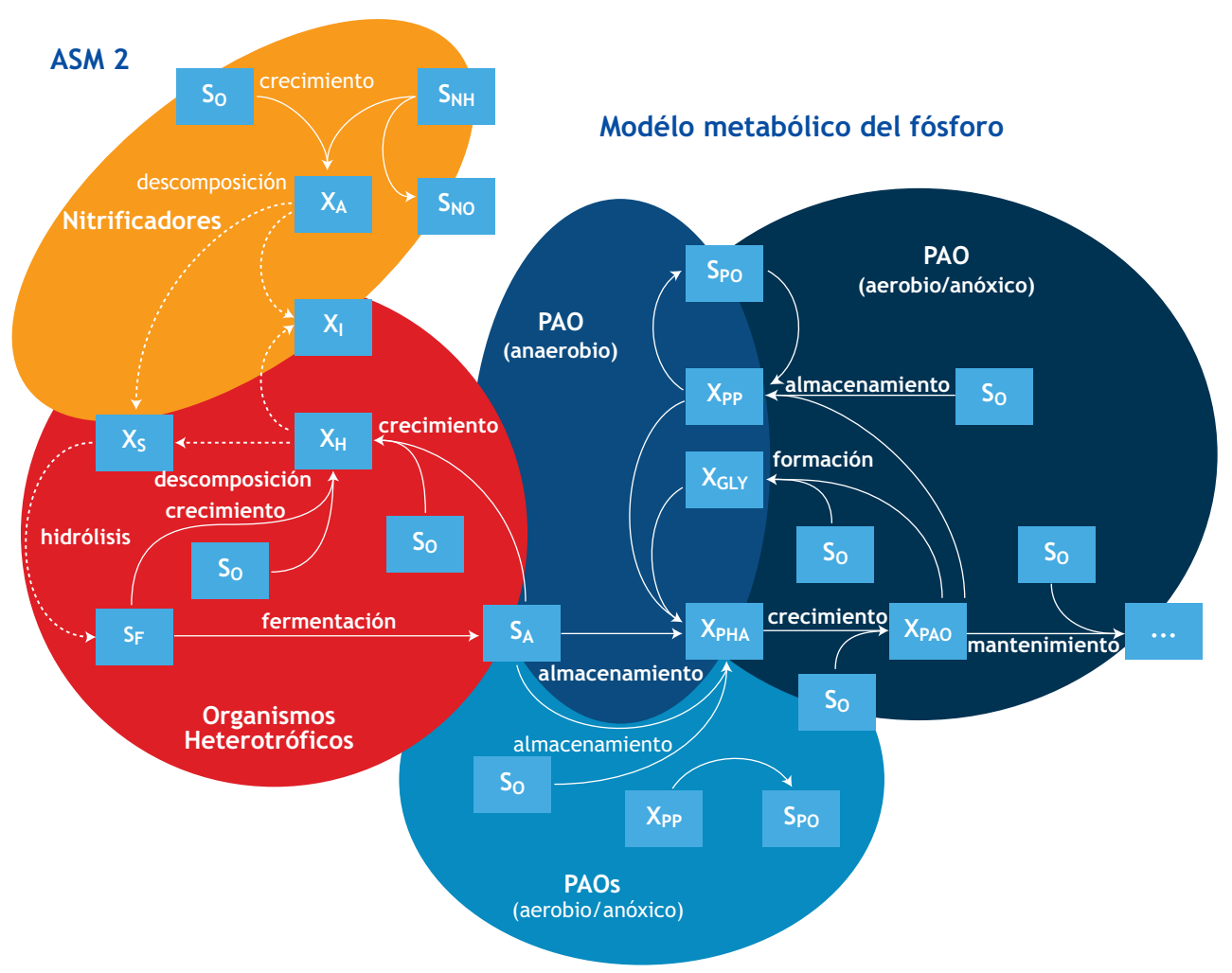

Figura 14.11 Interacciones en el modelo integrado de la TUDelft. Las conversiones anaerobias se muestran con líneas gruesas y las conversiones anóxicas y aerobias se muestran con líneas delgadas. Las conversiones independientes de oxígeno y nitrato se muestran con líneas a trazos (Meijer, 2004)

\subsection{MODELACIÓN METABÓLICA}

¿Por qué es útil un modelo metabólico? En el modelo estándar de crecimiento heterotrófico existen 7 compuestos relevantes (substrato, oxígeno, carga, dióxido de carbono, agua, amoniaco y biomasa), 5 balances independientes (carbono, hidrógeno, oxígeno, nitrógeno y carga), y dos grados de libertad. Si se conoce un rendimiento y un coeficiente de la tasa de reacción, es posible describir el sistema completo con un modelo. Si se describe la remoción de la DQO y la nitrificación a un nivel metabólico, no se obtiene ninguna ganancia debido a que el rendimiento y las tasas de reacción son todavía necesarios. Si bien la estequiometría metabólica permite el seguimiento de los elementos $(\mathrm{C}, \mathrm{H}, \mathrm{O}, \mathrm{N}, \mathrm{P})$ y los flujos de carga a través del sistema, al brindar más información al modelo, este se torna más complejo y sus resultados no son mucho más precisos. Todas las tasas están acopladas a través de relaciones de conservación (estequiometría) y, por ende, la opción entre tasa de proceso, tasa de crecimiento, tasa de toma de substrato o consumo de oxígeno no es importante (Figura 14.12).

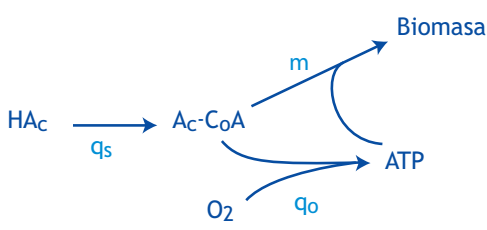

Figura 14.12 Acoplamiento de tasas a través de relaciones de conservación en el modelo metabólico de crecimiento heterotrófico.

El enfoque de caja negra puede continuar utilizandose como se ha venido haciendo en el caso del modelo ASM1. Para un sistema de lodos activados convencional no se requiere un seguimiento detallado de $\mathrm{C}, \mathrm{H}, \mathrm{O}$ y carga, ya que con la DQO y el nitrógeno es suficiente. Sin embargo cuando los modelos ASM se integran con modelos de digestión anaerobia, es importante hacer un seguimiento de $\mathrm{C}, \mathrm{H}, \mathrm{O}$ y de las cargas ya que son indispensable en la evaluación de la producción y composición del biogás y la generación de alcalinidad en un sistema de digestión anaerobia (Brink et al., 2007). 
No obstante, si es necesario describir la situación conjunta del crecimiento de organismos heterotróficos y la formación de productos de almacenamiento (polímeros) de los PAOs, el número relevante de compuestos se incrementa. Cada polímero adicional de almacenamiento añade al modelo un componente extra sin incrementar el número de balances, lo que significa que los grados de libertad (variables desconocidas) aumentan como un resultado directo de los nuevos compuestos incluidos. En este caso es necesario conocer al menos un coeficiente de rendimiento y una tasa, y ahora la elección de la tasa de los procesos si se torna importante. Por ejemplo, los PAOs en condiciones aerobias utilizan el PHA almacenado para producir Acetil-CoA (compuesto intermedio), el cual se utiliza para el crecimiento de la biomasa, la formación de glucógeno y creación de la energía requerida por estos procesos, y para la formación de poli-fosfato intracelular (Figura 14.13).

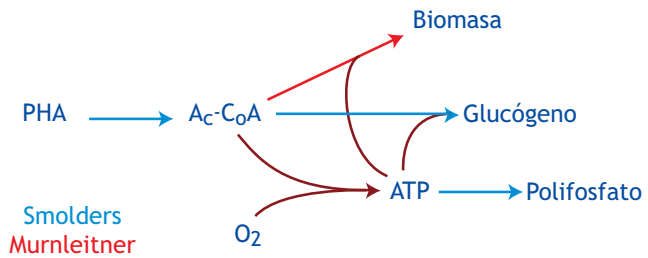

Figura 14.13 Conversiones simplificadas del almacenamiento intracelular de materiales en los PAOs bajo condiciones aerobias: aproximación de Smolders et al., 1994, ajustada por Murnleitner et al., 1997

Como es evidente, la introducción de los compuestos de almacenamiento crea una red más complicada de procesos. En este caso es necesario escoger tres tasas de proceso. Originalmente, el modelo metabólico para la remoción de fosfato se creó con tasas supuestas para el crecimiento de la biomasa, la formación de glucógeno y la formación de poli-fosfato (Smolders et al., 1994). Más adelante se pudo observar que esta suposición no era adecuada y que los PAOs están regulados de tal forma que consumen polímeros de almacenamiento (PHA) a una tasa determinada y producen glucógeno y polifosfato. La conversión excedente de PHA es utilizada para el crecimiento. Por ende para corregir el modelo se encontró que es más apropiado definir la tasa de consumo de PHA, las tasa de formación de glucógeno y polifosfato, junto con un acople estequiométrico para calcular la cantidad de biomasa formada (Murnleitner et al., 1997).

En los procesos con compuestos de almacenamiento adicionales es también necesario incluir coeficientes de rendimiento extras. Sin embargo, la eficiencia de los procesos de conversión va a ser la misma para todos los rendimientos. Al hacer una descripción metabólica es posible vincular los rendimientos metabólicos macroscópicos con los rendimientos metabólicos a través de la eficiencia de generación de energía (ATP) por unidad de substrato oxidado. La oxidación de substrato se relaciona con la transferencia de electrones al oxígeno o con el consumo de nitrato. Los coeficientes de rendimiento son por ende función de los parámetros básicos (ATP producido por par de electrones transferidos) y el número de parámetros de rendimiento independientes es menor en una descripción metabólica para esto organismos complejos.

Es claro que al utilizar información metabólica, los grados de libertad de un modelo pueden reducirse. Un mejor entendimiento de los procesos metabólicos de un organismo permite producir un modelo de caja transparente o de cristal. El incremento de la complejidad de los procesos se refleja consecuentemente en los modelos. Sin embargo, la mejora en el entendimiento de las complejas interacciones que se llevan a cabo dentro de una célula producto de la introducción de un enfoque metabólico, brinda mayor confianza y consistencia en la aplicación de modelos de lodos activados. Esta metodología es en efecto, la recopilación de información en un nivel más fundamental de organización para ayudar a entender y modelar los procesos que ocurren en un nivel superior de organización. Para más detalles sobre los modelos ASM2, ASM2d, ASM3 y metabólicos se remite al lector a Henze et al. (2000).

\subsection{HISTORIA DEL DESARROLLO DE LOS MODELOS DE LODOS ACTIVADOS}

En esta sección se mencionan los modelos de lodos activados utilizados más frecuentemente, con el fin de brindar información al modelador en la etapa de selección del modelo. El enfoque se hace sobre los desarrollos recientes en los modelos de lodos activados, principalmente en la familia de modelos desarrollados por la asociación internacional del agua (IWA, por sus siglas en inglés, International Water Association) y en el modelo desarrolla por la TU Delft (el modelo TUPD). La Tabla 14.8 resume las características esenciales de estos y otros modelos de lodos activados.

El modelo ASM1 puede considerarse como el modelo de referencia ya que este modelo fue el encargado de fomentar la aceptación del uso de modelos de plantas de tratamiento, primero en la comunidad científica y luego en la práctica ingenieril. Esta evolución fue sin duda 
Tabla 14.8 Descripción general de diferentes modelos de lodos activados (basado en Gernaey et al., 2004)

\begin{tabular}{|c|c|c|c|c|c|c|c|c|c|c|c|c|}
\hline$\frac{\frac{0}{0}}{\frac{0}{0}}$ & 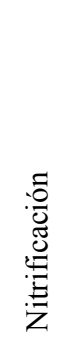 & 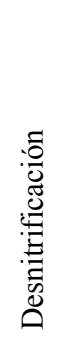 & 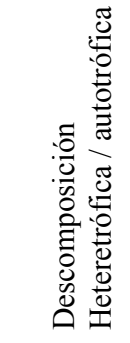 & 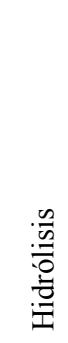 & $\begin{array}{l}\stackrel{\alpha}{a} \\
\text { 寽 }\end{array}$ & 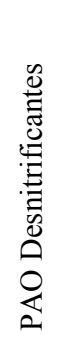 & 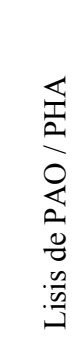 & 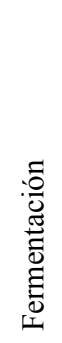 & 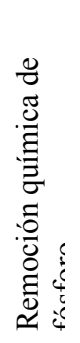 & 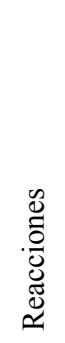 & 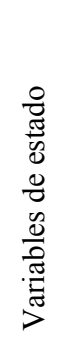 & 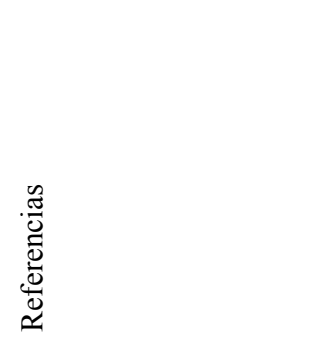 \\
\hline UCTOLD & - & $\bullet$ & MR, Cst & $\mathrm{AE}$ & & & & & & 8 & 13 & Dold et al., 1980, 1991 \\
\hline ASM1 & $\bullet$ & $\bullet$ & MR, Cst & $\mathrm{AE}$ & & & & & & 8 & 13 & Henze et al., 1987 \\
\hline ASM3 & $\bullet$ & $\bullet$ & RE, EA & Cst & & & & & & 12 & 13 & Gujer et al., 1999 \\
\hline UCTPHO & - & $\bullet$ & MR, Cst & $\mathrm{AE}$ & $\bullet$ & & Cst & $\bullet$ & & 19 & 19 & Wentzel, 1988, 1989a,b \\
\hline ASM2 & - & $\bullet$ & MR, Cst & $\mathrm{AE}$ & - & & Cst & $\bullet$ & $\bullet$ & 19 & 19 & Henze et al., 1995 \\
\hline ASM2d & $\bullet$ & $\bullet$ & MR, Cst & $\mathrm{AE}$ & $\bullet$ & $\bullet$ & Cst & $\bullet$ & $\bullet$ & 21 & 19 & Henze et al., 1999 \\
\hline $\mathrm{B} \& \mathrm{D}$ & $\bullet$ & $\bullet$ & MR, Cst & $\mathrm{AE}$ & $\bullet$ & $\bullet$ & $\mathrm{AE}$ & $\bullet$ & & 36 & 19 & Barker and Dold, 1997 \\
\hline TUDP & - & $\bullet$ & MR, Cst & $\mathrm{AE}$ & $\bullet$ & $\bullet$ & $\mathrm{AE}$ & $\bullet$ & & 21 & 17 & Meijer, 2004 \\
\hline ASM3-bioP & $\bullet$ & $\bullet$ & RE, AE & Cst & $\bullet$ & $\bullet$ & $\mathrm{AE}$ & & & 23 & 17 & Rieger et al., 2001 \\
\hline
\end{tabular}

PAO Desnitrificantes, actividad de los PAO desnitrificantes incluida en el modelo; MR,concepto de muerte y regeneración; AE, dependiente del aceptor de electrones; RE, concepto de respiración endógena; $\mathrm{Cst}=$ independiente del aceptor de electrones

apoyada por la disponibilidad de computadores más potentes. El modelo ASM1 es en esencia un modelo consensual resultado de las discusiones que en su momento se dieron entre los diferentes grupos de modelación, cuya participación más prominente incluye Sudáfrica, Estados Unidos de América, Suiza, Japón y Dinamarca. Muchos de los conceptos básicos adoptados en el modelo ASM1 se adaptaron del modelo definido por Dold et al. (1980). Jeppsson (1996) publicó un resumen de los desarrollos de investigación que resultaron en el modelo ASM1. Incluso hoy en día, el modelo ASM1 sigue siendo considerado en muchos casos el estado del arte en el modelado de sistemas lodos activados (Roeleveld and van Loosdrecht, 2002). El modelo ASM1 se ha convertido en una referencia para muchos proyectos científicos y prácticos, y ha sido implementado (en algunos casos con modificaciones) en la mayoría de los paquetes comerciales disponibles para el modelado y simulación de plantas con remoción de nitrógeno. Copp (2002) ha reportado las experiencias ganadas en la implementación del modelo ASM1 en diferentes plataformas de software. El modelo ASM1 se desarrolló principalmente para plantas de tratamiento de lodos activados municipales para poder describir la remoción de compuestos orgánicos carbonáceos y la remoción de nitrógeno, con oxígeno y nitrato como aceptores finales de electrones. El modelo tiene como objetivo adicional, brindar una buena descripción de los lodos producidos. La demanda bioquímica de oxígeno
(DQO) se adoptó como la medida estándar de la concentración de carga orgánica. En el modelo, la amplia variedad de compuestos orgánicos de carbono y compuestos nitrogenados se subdividen en un número limitado de fracciones basadas en consideraciones sobre la biodegradabilidad y la solubilidad.

El modelo ASM3 se desarrolló también para describir la remoción biológica de nitrógeno en las plantas, con básicamente los mismos objetivos que el modelo ASM1. El modelo ASM3 está destinado a convertirse en el nuevo modelo estándar, debido a incorpora varias correcciones a un número de defectos que han aparecido durante el uso del modelo ASM1 (Gujer et al., 1999). La mayor diferencia entre los modelos ASM1 y ASM3 es que el último reconoce la importancia del almacenamiento de polímeros en las conversiones heterotróficas del lodo activado. El crecimiento de la biomasa a partir de substratos externos directamente como se describe en el modelo ASM1, ya no se considera en el modelo ASM3. Una diferencia adicional entre el ASM1 y el ASM3 es que el modelo ASM3 resulta en una calibración más fácil de obtener. Esto se debe principalmente al cambio del modelo de crecimiento-descomposición-crecimiento (muerte y regeneración) por un modelo de crecimientorespiración endógena, el cual evita la recirculación de materia orgánica (DQO) (Figura 14.11). 
Mientras que en el modelo ASM1, todas las variables se ven directamente influenciadas por un cambio en el valor de un parámetro, en el modelo ASM3 la influencia directa es en efecto mucho menor lo que permite una mejor identificación. Koch et al. (2000) concluye que el ASM1 y el ASM3 son ambos capaces de describir el comportamiento dinámico en plantas de tratamiento convencionales, mientras que el ASM3 se desempeña mejor en situaciones donde el almacenamiento de substrato rápidamente biodegradable es significativo (aguas residuales industriales) o en plantas con una fracción de zonas no aireadas elevada. El modelo ASM3 puede extenderse para incluir un modelo de EBPR similar al modelo ASM2 (Ky et al., 2001; Rieger et al., 2001).

La revisión general de los modelos incluyendo el EBPR se puede comenzar con el modelo ASM2, el cual amplía las capacidades del ASM1 para incluir EBPR. Adicional a esto también incluyó la eliminación química de fósforo a través de precipitación. La publicación del modelo ASM2 menciona de forma explícita que el modelo permite la descripción del proceso de EBPR, pero que aún no incluye todos los fenómenos observados. Cabe resaltar que el modelo de EBPR se basa exclusivamente en el comportamiento aerobio de consumo de fósforo. El modelo ASM2d se construye sobre el ASM2, incluyendo la actividad desnitrificante de los PAOs la cual permite una mejor descripción de las dinámicas del fósforo y el nitrato. No obstante, este modelo únicamente permite que el consumo de fósforo comience en el reactor anóxico utilizando la misma cinética que en el reactor aeróbico, la cual no tiene en cuenta la reducción observada en la remoción de fósforo cuando el consumo ocurre en el reactor anóxico (Ekama and Wentzel, 1999; Hu et al., 2002). Los modelos posteriores de EBPR buscan incluir la descripción de este fenómeno (Hu et al., 2007a,b). El modelado de EBPR se ilustra en la Figura 14.14.

Los PAOs se modelan teniendo en cuenta la estructura celular interna y todos los productos orgánicos de almacenamiento se agrupan en un componente único del modelo (X $\left.\mathrm{X}_{\mathrm{PHA}}\right)$. Los PAOs solo pueden crecer utilizando el material orgánico almacenado internamente; el almacenamiento no depende de los aceptores de electrones disponibles, pero solo ocurre cuando hay disponibilidad de productos de la fermentación, como el acetato. En la práctica, esto significa que el almacenamiento usualmente solo se observa en los tanques anaerobios del sistema de lodos activados.

El modelo TUPD combina el modelo metabólico EBPR desnitrificante y no-desnitrificantes de Murnleitner et al. (1997) con el modelo ASM1 (reacciones autótrofas y heterótrofas). Contrario a los modelos ASM2/ASM2d, el modelo TUPD tiene en cuenta el metabolismo completo de los PAOs y permite modelar todos los compuestos de almacenamiento orgánico de forma explícita (X $\mathrm{X}_{\mathrm{PHA}} \mathrm{y} \mathrm{X}_{\mathrm{GLY}}$ ), como se muestra en la Figura 14.14. Más aún, Meijer (2004) y de
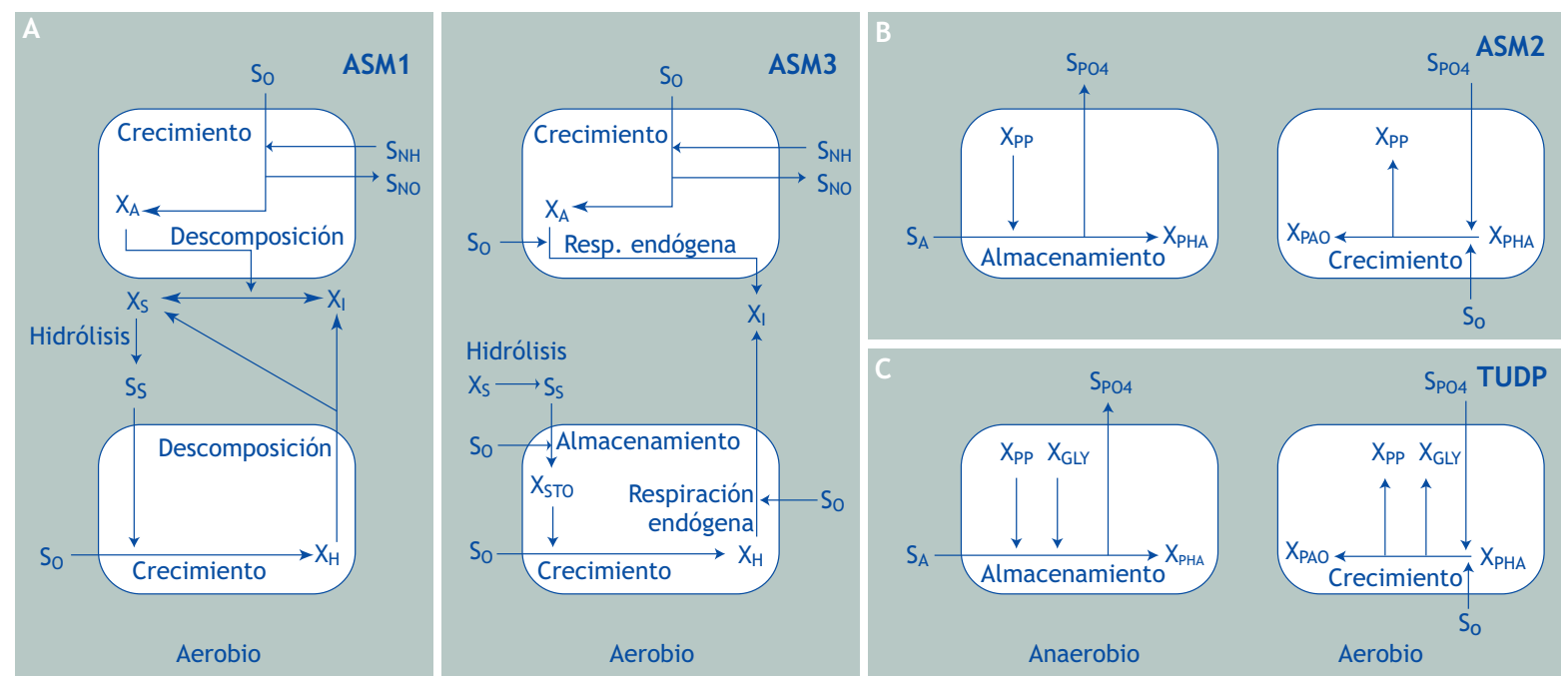

Figura 14.14 Esquemas simplificados del flujo de substratos para (A) biomasa autótrofa y heterótrofa en los modelos ASM1 y ASM3 (modificado de Gujer et al., 1999), (B) almacenamiento y crecimiento de PAOs en el modelo ASM2 (Henze et al. 1995), y (C) amacenamiento y crecimiento aerobio de PAOs en el modelo TUDP (van Veldhuizen et al., 1999; Brdjanovic et al., 2000). Adaptado de Gernaey et al., 2004 
Kreuk et al. (2007) presentan una descripción completa del modelo TUPD. La matriz estequiométrica del modelo se muestra en la Tabla 14.9

En algunos casos, como por ejemplo con $\mathrm{pH}$ elevados (>7.5) y concentraciones de $\mathrm{Ca}^{++}$elevadas, puede ser necesario incluir una precipitación biológica inducida al modelo de EBPR (Maurer et al., 1999; Maurer and Boller, 1999a). De hecho, bajo ciertas condiciones las reacciones de EBPR coinciden con una precipitación natural que puede representar una parte importante de la remoción de fósforo, la cual no está relacionada con la EBPR ni incluida en los modelos descritos hasta ahora. La formación de estos precipitados, en su mayoría fosfatos de calcio, se promueve por una concentración elevada de fósforo y un incremento en la fuerza iónica durante la liberación anaerobia de fósforo por parte de las PAOs. Las ecuaciones y componentes necesarios para describir el proceso de precipitación en el modelo fueron descritas por Maurer and Boller (1999b). En general puede decirse que la introducción de la familia de modelos ASM por parte de la IWA fue de gran importancia en este campo, brindando a los investigadores y profesionales un conjunto de modelos básicos aplicables principalmente a sistemas de tratamiento de agua residual domésticos, pero fácilmente adaptables a situaciones específicas como el tratamiento de aguas residuales industriales (e.g. Pinzón et al., 2007).

\subsection{PAQUETES DE SIMULACIÓN}

Un simulador de plantas de tratamiento de agua residual puede describirse como un software que le permite al modelador simular una configuración determinada de una PTAR. Una descripción detallada de los diferentes simuladores que existen para la modelación de plantas de tratamiento se puede encontrar en Olsson y Newell (1999) y Copp (2002). Existen simuladores de propósito general y simuladores específicos para el tratamiento de aguas residuales. Los simuladores de propósito general normalmente ofrecen un alto grado de flexibilidad, pero el modelador debe suplir los modelos que deben utilizarse para modelar una configuración específica de una planta. Esta última tarea puede consumir bastante tiempo. Sin embargo, cuando se van a ejecutar muchas simulaciones es mejor gastar un tiempo prudencial en el desarrollo y depuración del modelo, que usar un modelo que luego resulta erróneo para una tarea específica. Como consecuencia, los modelos de propósito general requieren de un usuario experimentado que entienda completamente lo que cada línea del código implica para el modelo. MATLAB $^{\mathrm{TM}} / \mathrm{SIMULINK}^{\mathrm{TM}}$ (www.mathworks.com) es un ejemplo popular de un simulador multipropósito. Los simuladores específicos para el tratamiento de aguas residuales contienen una librería extendida de modelos de unidades predefinidas, por ejemplo un bioreactor completamente mezclado de tipo ASM1 o ASM2d, o un modelo unidimensional de 10 capas de un clarificador. La simulación de la configuración de un proceso determinada puede construirse fácilmente conectando los diferentes bloques que representan unidades del proceso. El ajuste y modificación de los parámetros del modelo se puede hacer a través de ventanas auxiliares. A continuación se enumeran (alfabéticamente) ejemplos de simuladores comerciales para el tratamiento de aguas residuales:

- BioWin (www.envirosim.com)

- GPS-X (www.hydromantis.com)

- SIMBA (www.ifak-system.com)

- $\quad$ STOAT (www.wrcplc.co.uk)

- WEST (www.dhisoftware.com)

Adicionalmente hay alternativas de simuladores libres y de código abierto:

- AQUASIM (www.aquasim.eawag.ch)

Más información sobre simuladores en particular se puede encontrar en Olsson and Newell (1999) o en los sitios web respectivos. En algunos sitios web es común encontrar la posibilidad de descargar una versión de prueba de los simuladores con el fin de evaluar sus capacidades. Este tipo de simuladores al permitir al modelador la fácil construcción de una configuración, también tienen el riesgo de que un usuario simule configuraciones de procesos sin verdaderamente entender la estructura del modelo, con la implicación de que los supuestos del modelo y las limitaciones también sean pasados por alto.

\subsection{CONCLUSIONES}

Los modelos pueden ser unas herramientas extremadamente útiles en el diseño y operación de plantas de tratamiento de agua residual, y en la investigación del comportamiento de las mismas. Para el diseño, brindan una guía en la identificación y cuantificación de los parámetros de diseño claves para garantizar un desempeño óptimo.

Para la operación, brindan predicciones cuantitativas de la calidad del efluente esperada, y permiten evaluar el efecto de modificaciones o en la operación de PTAR. En 
investigación, permiten probar la validez de una hipótesis en una forma integrada y consistente, permiten dirigir la atención hacia elementos no obvios del sistema físico y conducen a un mejor y más profundo entendimiento de los patrones que controlan la respuesta de un sistema.

Pero, los modelos solo son racionalizaciones de patrones de comportamiento de los parámetros concebidos como importantes. Debido a esta racionalización, los modelos necesitan: (i) ser verificados rigurosamente para confirmar los balances de masa

\section{REFERENCIAS}

Alexander W.V., Ekama G.A. and Marais G.v.R. (1980) The activated sludge process Part 2 - Application of the general kinetic model to the contact stabilization process. Wat. Res. 14, 1737-1747

Barker P.S. and Dold P.L. (1997) General model for biological nutrient removal activated sludge systems: Model presentation. Wat. Environ. Res., 69, 969-984.

Batstone D. J., Keller J., Newell R. B. and Newland M. (2000) Modelling anaerobic degradation of complex wastewater. I: model development. Biores. Tech. 75(1), 67-74.

Brdjanovic D., van Loosdrecht M.C.M., Versteeg P., Hooijmans C.M., Alaerts G.J. and Heijnen J.J. (2000) Modelling COD, N and P removal in a full-scale WWTP Haarlem Waarderpolder. Wat. Res. 34, 846-858.

Brink I.C., Wentzel M.C. and Ekama G.A. (2007) New developments in modelling wastewater treatment plants - Using stoichiometry to build a plant-wide mass balance based steady state WWTP model. Proc. $10^{\text {th }}$ IWA Conference on Design, Operation and Economics of WWTP, Vienna, 9-13 Sept.

Casey T.G., Ekama G.A., Wentzel M.C. and Marais G.vR (1994) An hypothesis for the causes and control of F/M filamentous organism bulking in nitrogen $(\mathrm{N})$ and nutrient $(\mathrm{N} \& \mathrm{P})$ removal activated sludge systems. Wat. Sci. Tech. 29(7), 203-212.

Coen F., Vanderhaeghen B., Boonen I., Vanrolleghem P.A., Van Eyck L. and Van Meenen P. (1996) Nitrogen removal upgrade of a WWTP within existing reactor volumes: A simulation supported scenario analysis. Wat. Sci. Tech. 34(3/4), 339-346.

Copp J.B. (2002) The COST Simulation Benchmark: Description and Simulator Manual. Office for Official Publications of the European Community, Luxembourg. pp. 154. ISBN 92-894-1658-0.

de Kreuk M.K., Picioreanu C., Hosseinin M., Xavier J.B., and van Loosdrecht M.C.M. (2007) Kinetic model of a granular sludge SBR: Influences on nutrient removal. Biotech. Bioeng. 97(4), 801-815.

Dold P.L., Ekama G.A. and Marais G.v.R. (1980) A general model for the activated sludge process. Prog. Wat. Tech., 12(6), 47-77. internos, (ii) ser validados adecuadamente contra pruebas experimentales apropiadas y, (iii) definirse claramente las condiciones dentro de las cuales se espera que el modelo se desempeñe satisfactoriamente. Por último, es importante recordar que un modelo se puede catalogar como exitoso cuando cumple con las expectativas que las personas tienen del mismo.

Dold P.L., Wentzel M.C., Billing A.E., Ekama G.A. and Marais G.v.R. (1991) Activated sludge simulation programs: Nitrification and nitrification/denitrification systems (version 1.0). Water Research Commission, PO Box 824, Pretoria 0001, South Africa. TT 52/91, ISBN 0947.

Gabb G.M.D., Still D.A., Ekama G.A., Jenkins D. and Marais G.v.R. (1991) The selector effect on filamentous bulking in long sludge age activated sludge system. Wat. Sci. Tech. 23, 867-877.

Gujer W. and Larsen T.A. (1995) The implementation of biokinetics and conservation principles in ASIM. Wat. Sci. Tech. 31(2), 257-266.

Ekama G.A. and Marais G.v.R. (1978) The dynamic behaviour of the activated sludge process. Research Report W27, Dept. of Civil Eng., University of Cape Town, Rondebosch, 7701, RSA.

Gernaey K.V., Van Loosdrecht M.C.M., Mogens Henze M., and Jørgensen S.B. (2004) Activated sludge wastewater treatment plant modelling and simulation: state of the art. Env. Modelling \& Software 19, 763-783

Gujer W. and Henze M. (1991) Activated sludge modelling and simulation. Wat. Sci. Tech. 23, 1011-1023.

Gujer W., Henze M., Mino T. and van Loosdrecht M.C.M. (1999) Activated Sludge Model No. 3. Wat. Sci. Tech 39(1), 183-193.

Henze M., Grady C.P.L. Jr., Gujer W., Marais G.v.R. and Matsuo T. (1987) Activated Sludge Model No. 1. IAWQ Scientific and Technical Report No. 1, London, UK.

Henze M., Gujer W., Mino T., Matsuo T., Wentzel M.C.M. and Marais G.v.R. (1995) Activated Sludge Model No. 2. IWA Scientific and Technical Report No. 3, London, UK.

Henze M., Gujer W., Mino T., Matsuo T., Wentzel M.C., Marais G.v.R. and van Loosdrecht M.C.M. (1999) Activated Sludge Model No.2d. ASM2D. Wat. Sci. Technol., 39(1), 165-182.

Henze M., Gujer W., Mino T., van Loosdrecht M.C.M. (2000) Activated Sludge Models ASM1, ASM2, ASM2d and ASM3. IWA Scientific and Technical Report No. 9, London, UK.

Hu Z., Wentzel M.C. and Ekama G.A.(2002) The significance of denitrifying polyphosphate accumulating 
organisms in biological nutrient removal activated sludge systems. Wat. Sci. Tech. 46(1/2), 129-138.

Hu Z., Wentzel M.C. and Ekama G.A. (2007a) A general model for biological nutrient removal activated sludge systems - Model development. Biotech. Bioeng. 98(6) 1242-1258.

$\mathrm{Hu}$ Z., Wentzel M.C. and Ekama G.A. (2007b) A general model for biological nutrient removal activated sludge systems - Model evaluation. Biotech. Bioeng. 98(6) 1259-1275.

Hulsbeek J.J.W., Kruit J., Roeleveld P.J. and van Loosdrecht M.C.M. (2002) A practical protocol for dynamic modelling of activated sludge systems. Wat. Sci. Tech. 45(6), 127-136.

Jeppsson U. (1996) Modelling aspects of wastewater treatment processes. $\mathrm{PhD}$ thesis, Lund Institute of Technology, Sweden. (available online: http://www.iea.lth.se/publications )

Koch G., Kuhni M., Gujer W. and Siegrist H. (2000) Calibration and validation of activated sludge model no. 3 for Swiss municipal wastewater. Wat. Res. 34, 35803590 .

Krebs P. (1995) Succes and shortcomings of clarifier modelling. Wat. Sci. Tech. 32 (2), 181-191.

Ky R.C., Comeau Y., Perrier M. and Takacs I. (2001) Modelling biological phosphorus removal from a cheese factory effluent by an SBR. Wat. Sci. Tech. 43(3), 257264.

Maurer M., Abramovich D., Siegrist H. and Gujer W.(1999a) Kinetics of biologically induced phosphorus precipitation in waste-water treatment. Wat. Res. 33, 484-493.

Maurer M. and Boller M. (1999b) Modelling of phosphorus precipitation in wastewater treatment plants with enhanced biological phosphorus removal. Wat. Sci. Tech. 39(1), 147-163.

Meijer S.C.F., van der Spoel H., Susanti S., Heijnen J.J. and van Loosdrecht M.C.M. (2002) Error diagnostics and data recondiliation for activated sludge modelling using mass balances. Wat. Sci. Tech. 45(6), 145-156.

Meijer S.C.F., van Loosdrecht M.C.M. and Heijnen J.J. (2001) Metabolic modelling of full-scale biological nitrogen and phosphorus removing WWTP's. Wat. Res. 35, 2711-2723.

Meijer S.C.F. (2004) Theoretical and practical aspects of modelling activated lsdge processes. $\mathrm{PhD}$ Thesis Delft University of Technology, ISBN 90-9018027-3.

Monod J. (1949) The growth of bacterial culture. Pasteur Institute. Paris.

Murnleitner E., Kuba T., van Loosdrecht M.C.M. and Heijnen J.J. (1997) An integrated metabolic model for the aerobic and denitrifying biological phosphorus removal. Biotech. Bioeng. 54, 434-450.

Olsson G. and Newell B. (1999) Wastewater treatment systems. Modelling, diagnosis and control. IWA Publishing, London, UK.

Petersen B., Gernaey K., Henze M. and Vanrolleghem P.A. (2002) Evaluation of an ASM1 model calibration procedure on a municipal-industrial wastewater treatment plant. J. Hydroinfor. 4, 15-38 .
Pinzón-Pardo A.L., Brdjanovic D., Moussa M.S., LópezVázquez C.M., Meijer S.C.F., Van Straten H.H.A., Janssen A.J.H., Amy G. and van Loosdrecht M.C.M. (2007) Modelling of an oil refinery wastewater treatment plant. Env. Tech. 28, 1273-1284.

Rieger L., Koch G., Kühni M., Gujer W. and Siegrist H. (2001) The EAWAG bio-P module for activated sludge model No. 3. Wat. Res. 35, 3887-3903.

Roeleveld P.J. and van Loosdrecht M.C.M. (2002). Experience with guidelines for wastewater characterisation in The Netherlands. Wat. Sci. Tech., 45(6), 77-87.

Smolders G.L.F., van der Meij J., van Loosdrecht M.C.M. and Heijnen J.J. (1994) Stoichiometric model of the aerobic metabolism of the biological phosphorus removal process. Biotech. Bioeng. 44, 837-848.

Smolders G.L.F. (1995) A metabolic model of the biological phosphorus removal: stochiometry, kinetics and dynamic behavior. PhD Thesis. Delft University of Technology.

van Haandel A.C., Ekama G.A. and Marais G.v.R. (1981) The activated sludge process Part 3 - Single sludge denitrification. Wat. Res. 15(10) 1135-1152.

van Veldhuizen H.M., van Loosdrecht M.C.M. and Heijnen J.J. (1999) Modelling biological phosphorus and nitrogen removal in a full scale activated sludge process. Wat. Res. 33, 3459-3468.

Warner A.P.C., Ekama G.A. and Marais G.v.R. (1986) The activated sludge process Part 4 - Application of the general kinetic model to anoxic-aerobic digestion of waste activated sludge. Wat. Res. 20(8) 943-958.

Wentzel M.C. Loewenthal R.E., Ekama G.A. and Marais G.v.R. (1988) Enhanced polyphosphate organism cultures in activated sludge systems - Part 1: Enhanced culture development. Water $S A$, 14(2) 81-92.

Wentzel M.C., Ekama G.A., Loewenthal R.E., Dold P.L. and Marais G.v.R. (1989a) Enhanced polyphosphate organism cultures in activated sludge systems Part II Experimental behaviour. Water SA, 15(2) 71-88.

Wentzel M.C., Dold P.L., Ekama G.A. and Marais G.v.R.(1989b) Enhanced polyphosphate organism cultures in activated sludge systems Part III - Kinetic model. Water SA, 15(2) 89-102.

Wentzel M.C. and Ekama G.A. (1997) Principles in the modelling of biological wastewater treatment plants, in Microbial community analysis: The key to the design of biological wastewater treatment systems. IWA Scientific and Technical Report $n r .5$.

Wild D., Schulthess R.V. and Gujer W. (1994) Synthesis of denitrification enzymes in activated sludge; modelling with structured biomass. Wat. Sci. Tech. 30(6), 113-122 
Tabla 14.9 Matriz estequiométrica y matriz de composición de componentes del modelo de la TUDelft (Meijer, 2004)

\begin{tabular}{|c|c|c|c|c|c|c|c|c|c|}
\hline & & & \multirow[b]{2}{*}{ Componente $\rightarrow$} & 1 & 2 & 3 & 4 & 5 & 6 \\
\hline & & & & $\mathrm{S}_{\mathrm{O}}$ & $\mathrm{S}_{\mathrm{F}}$ & $\mathrm{S}_{\mathrm{A}}$ & $\mathrm{S}_{\mathrm{NH}}$ & $\mathrm{S}_{\mathrm{NO}}$ & $\mathrm{S}_{\mathrm{N} 2}$ \\
\hline \multicolumn{4}{|l|}{ 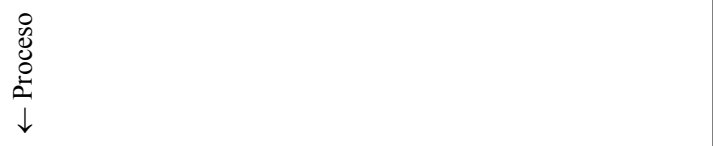 } & $\overbrace{0 \infty}^{E}$ & 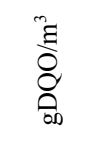 & ஓ્ & $\overbrace{\text { Zo }}^{z}$ & 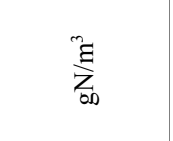 & $\overbrace{\infty}^{E}$ \\
\hline 1 & $\mathrm{r}_{\mathrm{h}}^{\mathrm{O}}$ & Hidrólisis aerobia & $\mathrm{gDQO}_{\mathrm{XS}} / \mathrm{d}$ & & $1-f_{S I}$ & & $\mathrm{c}_{\mathrm{N}, 1}$ & & \\
\hline 2 & $\mathrm{r}_{\mathrm{h}}^{\mathrm{NO}}$ & Hidrólisis anóxica & $\mathrm{gDQO}_{\mathrm{XS}} / \mathrm{d}$ & & $1-f_{\mathrm{SI}}$ & & $\mathrm{c}_{\mathrm{N}, 1}$ & & \\
\hline 3 & $\mathrm{r}_{\mathrm{h}}^{\mathrm{AO}}$ & Hidrólisis anaerobia & $\mathrm{gDQO}_{\mathrm{XS}} / \mathrm{d}$ & & $1-f_{\mathrm{SI}}$ & & $\mathrm{c}_{\mathrm{N}, 1}$ & & \\
\hline \multicolumn{10}{|c|}{ Organismos heterótroficos regulares $\mathrm{X}_{\mathrm{H}}$} \\
\hline 4 & $\mathrm{r}_{\mathrm{SF}}^{\mathrm{O}}$ & Crecimiento aerobio $\mathrm{S}_{\mathrm{F}}$ & $\mathrm{gDQO}_{\mathrm{XH}} / \mathrm{d}$ & $-\left(1 / Y_{H}-1\right)$ & $-1 / Y_{\mathrm{H}}$ & & $\mathrm{c}_{\mathrm{N}, 4}$ & & \\
\hline 5 & $\mathrm{r}_{\mathrm{SA}}^{\mathrm{O}}$ & Crecimiento aerobio con $\mathrm{S}_{\mathrm{A}}$ & $\mathrm{gDQO}_{\mathrm{XH}} / \mathrm{d}$ & $-\left(1 / Y_{H}-1\right)$ & & $-1 / \mathrm{Y}_{\mathrm{H}}$ & $\mathrm{c}_{\mathrm{N}, 5}$ & & \\
\hline 6 & $\mathrm{r}_{\mathrm{SF}}^{\mathrm{NO}}$ & Crecimiento anóxico con $\mathrm{S}_{\mathrm{F}}$ & $\mathrm{gDQO}_{\mathrm{XH}} / \mathrm{d}$ & & $-1 / \mathrm{Y}_{\mathrm{H}}$ & & $\mathrm{c}_{\mathrm{N}, 6}$ & $-\frac{\left(1 / \mathrm{Y}_{\mathrm{H}}-1\right)}{2.86}$ & $\frac{\left(1 / Y_{H}-1\right)}{2.86}$ \\
\hline 7 & $\mathrm{r}_{\mathrm{SA}}^{\mathrm{NO}}$ & Crecimiento anóxico con $\mathrm{S}_{\mathrm{A}}$ & $\mathrm{gDQO}_{\mathrm{XH}} / \mathrm{d}$ & & & $-1 / Y_{H}$ & $\mathrm{c}_{\mathrm{N}, 7}$ & $-\frac{\left(1 / \mathrm{Y}_{\mathrm{H}}-1\right)}{2.86}$ & $\frac{\left(1 / Y_{H}-1\right)}{2.86}$ \\
\hline 8 & $\mathrm{r}_{\mathrm{fe}}^{\mathrm{AN}}$ & Fermentación & $\mathrm{gDQO}_{\mathrm{SF}} / \mathrm{d}$ & & -1 & 1 & $\mathrm{c}_{\mathrm{N}, 8}$ & & \\
\hline 9 & $\mathrm{r}_{\mathrm{HL}}$ & Lisis heterotróficaLysis & $\mathrm{gDQO}_{\mathrm{XH}} / \mathrm{d}$ & & & & $\mathrm{c}_{\mathrm{N}, 9}$ & & \\
\hline \multicolumn{10}{|c|}{ Organismos acumuladores de fósforo $\mathrm{X}_{\mathrm{PAO}}$} \\
\hline 10 & $\mathrm{r}_{\mathrm{SA}}^{\mathrm{AN}}$ & Almacenamiento anaerobio de $\mathrm{S}_{\mathrm{A}}$ & $\mathrm{gDQO}_{\mathrm{SA}} / \mathrm{d}$ & & & -1 & & & \\
\hline 11 & $\mathrm{r}_{\mathrm{M}}^{\mathrm{AN}}$ & Mantenimiento anaerobio & $\mathrm{gP} / \mathrm{d}$ & & & & & & \\
\hline 12 & $\mathrm{r}_{\mathrm{SA}}^{\mathrm{NO}}$ & Almacenamiento anóxico de $\mathrm{S}_{\mathrm{A}}$ & $\mathrm{gDQO}_{\mathrm{SA}} / \mathrm{d}$ & & & -1 & & $-\frac{\left(1-\mathrm{Y}_{\mathrm{SA}}^{\mathrm{NO}}\right)}{2.86}$ & $\frac{\left(1-\mathrm{Y}_{\mathrm{SA}}^{\mathrm{NO}}\right)}{2.86}$ \\
\hline 13 & $\mathrm{r}_{\mathrm{PHA}}^{\mathrm{NO}}$ & Consumo anóxico de PHA & $\mathrm{gDQO}_{\mathrm{PHA}} / \mathrm{d}$ & & & & $\mathrm{c}_{\mathrm{N}, 13}$ & $-\frac{\left(1-1 / \mathrm{Y}_{\mathrm{PHA}}^{\mathrm{NO}}\right)}{2.86}$ & $\frac{\left(1-1 / \mathrm{Y}_{\mathrm{PHA}}^{\mathrm{NO}}\right)}{2.86}$ \\
\hline 14 & $\mathrm{r}_{\mathrm{PP}}^{\mathrm{NO}}$ & $\begin{array}{l}\text { Almacenamiento anóxico de poli- } \\
\text { fosfato }\end{array}$ & $\mathrm{gP} / \mathrm{d}$ & & & & $\mathrm{c}_{\mathrm{N}, 14}$ & $-\frac{\left(1 / \mathrm{Y}_{\mathrm{PP}}^{\mathrm{NO}}\right)}{2.86}$ & $\frac{\left(1 / \mathrm{Y}_{\mathrm{PP}}^{\mathrm{NO}}\right)}{2.86}$ \\
\hline 15 & $\mathrm{r}_{\mathrm{GLY}}^{\mathrm{NO}}$ & Formación anóxica de glucógeno & $\mathrm{gDQO}_{\mathrm{GLY}} / \mathrm{d}$ & & & & $\mathrm{c}_{\mathrm{N}, 15}$ & $-\frac{\left(1 / \mathrm{Y}_{\mathrm{GLY}}^{\mathrm{NO}}-1\right)}{2.86}$ & $\frac{\left(1 / \mathrm{Y}_{\mathrm{GLY}}^{\mathrm{NO}}-1\right)}{2.86}$ \\
\hline 16 & $\mathrm{r}_{\mathrm{M}}^{\mathrm{NO}}$ & Mantenimiento anóxico & $\mathrm{gDQO}_{\mathrm{PAO}} / \mathrm{d}$ & & & & $\mathrm{c}_{\mathrm{N}, 16}$ & $-1 / 2.86$ & $1 / 2.86$ \\
\hline 17 & $\mathrm{r}_{\mathrm{PHA}}^{\mathrm{O}}$ & Consumo aerobio de PHA & $\mathrm{gDQO}_{\mathrm{PHA}} / \mathrm{d}$ & $1 / \mathrm{Y}_{\mathrm{PHA}}^{\mathrm{O}}-1$ & & & $\mathrm{c}_{\mathrm{N}, 17}$ & & \\
\hline 18 & $\mathrm{r}_{\mathrm{PP}}^{\mathrm{O}}$ & $\begin{array}{l}\text { Almacenamiento aerobio de poli- } \\
\text { fosfato }\end{array}$ & $\mathrm{gP} / \mathrm{d}$ & $-1 / Y_{\mathrm{PP}}^{\mathrm{O}}$ & & & $\mathrm{c}_{\mathrm{N}, 18}$ & & \\
\hline 19 & $\mathrm{r}_{\mathrm{GLY}}^{\mathrm{o}}$ & Formación aerobia de glucógeno & $\mathrm{gDQO}_{\mathrm{GLY}} / \mathrm{d}$ & $1-1 / \mathrm{Y}_{\mathrm{GLY}}^{\mathrm{O}}$ & & & $\mathrm{c}_{\mathrm{N}, 19}$ & & \\
\hline 20 & $\mathrm{r}_{\mathrm{M}}^{\mathrm{O}}$ & Mantenimiento aerobio & $\mathrm{gDQO}_{\mathrm{PAO}} / \mathrm{d}$ & -1 & & & $\mathrm{c}_{\mathrm{N}, 20}$ & & \\
\hline \multicolumn{10}{|c|}{ Organismos autotróficos nitrificantes $\mathrm{X}_{\mathrm{A}}$} \\
\hline 21 & $\mathrm{r}_{\mathrm{A}}^{\mathrm{O}}$ & Crecimiento autotrófico & $\mathrm{gDQO}_{\mathrm{XA}} / \mathrm{d}$ & $1-4.57 / \mathrm{Y}_{\mathrm{A}}$ & & & $\mathrm{c}_{\mathrm{N}, 21}$ & $1 / \mathrm{Y}_{\mathrm{A}}$ & \\
\hline 22 & $\mathrm{r}_{\mathrm{AL}}$ & Lisis autotrófica & $\mathrm{gDQO}_{\mathrm{XA}} / \mathrm{d}$ & & & & $\mathrm{c}_{\mathrm{N}, 22}$ & & \\
\hline \multirow{2}{*}{\multicolumn{4}{|c|}{ Componente $\rightarrow$}} & 1 & 2 & 3 & 4 & 5 & 6 \\
\hline & & & & $\mathrm{S}_{\mathrm{O}}$ & $\mathrm{S}_{\mathrm{F}}$ & $\mathrm{S}_{\mathrm{A}}$ & $\mathrm{S}_{\mathrm{NH}}$ & $\mathrm{S}_{\mathrm{NO}}$ & $\mathrm{S}_{\mathrm{N} 2}$ \\
\hline \multicolumn{4}{|c|}{$\downarrow$ Composición } & $\mathrm{gO}_{2}$ & gDQO & gDQO & $\mathrm{gN}$ & $\mathrm{gN}$ & $\mathrm{gN}$ \\
\hline 1 & \multicolumn{2}{|c|}{ DQO } & gDQO & -1 & 1 & 1 & & -2.86 & $\cdots$ \\
\hline 2 & \multicolumn{2}{|c|}{$\mathrm{COT} / \mathrm{DQO}$} & $\mathrm{gC} / \mathrm{gDQO}$ & & $\cdots$ & 0.4 & & & \\
\hline 3 & \multicolumn{2}{|c|}{ Nitrógeno } & $\mathrm{gN}$ & & $\mathrm{i}_{\mathrm{N}, \mathrm{SF}}$ & $\mathrm{i}_{\mathrm{N}, \mathrm{SA}}$ & 1 & 1 & 1 \\
\hline 4 & \multicolumn{2}{|c|}{ Fósforo } & $\mathrm{gP}$ & & $\mathrm{i}_{\mathrm{P}, \mathrm{SF}}$ & $\mathrm{i}_{\mathrm{P}, \mathrm{SA}}$ & & & \\
\hline 5 & \multicolumn{2}{|c|}{ Carga iónica } & Moles & & & $-1 / 64$ & $+1 / 14$ & $-1 / 14$ & \\
\hline 6 & \multicolumn{2}{|l|}{ SST } & $\mathrm{g}$ & & & & & & \\
\hline
\end{tabular}


Tabla 14.9 ... continuación (para la definición de los símbolos ver Meijer (2004))

\begin{tabular}{|c|c|c|c|c|c|c|c|c|c|c|c|}
\hline 7 & 8 & 9 & 10 & 11 & 12 & 13 & 14 & 15 & 16 & 17 & 18 \\
\hline $\mathrm{S}_{\mathrm{PO}}$ & $\mathrm{S}_{\mathrm{I}}$ & $\mathrm{S}_{\mathrm{HCO}}$ & $\mathrm{X}_{\mathrm{I}}$ & $\mathrm{X}_{\mathrm{S}}$ & $\mathrm{X}_{\mathrm{H}}$ & $\mathrm{X}_{\mathrm{PAO}}$ & $\mathrm{X}_{\mathrm{PP}}$ & $\mathrm{X}_{\mathrm{PHA}}$ & $\mathrm{X}_{\mathrm{GLY}}$ & $\mathrm{X}_{\mathrm{A}}$ & $\mathrm{X}_{\mathrm{TSS}}$ \\
\hline$\overbrace{\infty}^{\text {ह }}$ & 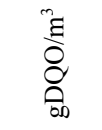 & $\begin{array}{l}\stackrel{n}{\Xi} \\
\frac{n}{0} \\
\stackrel{0}{0} \\
\Xi\end{array}$ & 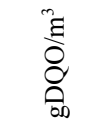 & 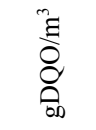 & 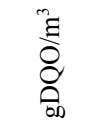 & 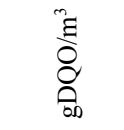 & 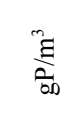 & 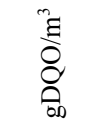 & 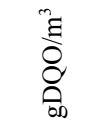 & 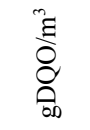 & 苟 \\
\hline $\mathrm{c}_{\mathrm{P}, 1}$ & $\mathrm{f}_{\mathrm{SI}}$ & $c_{e, 1}$ & & -1 & & & & & & & $\mathrm{c}_{\mathrm{TSS}, 1}$ \\
\hline $\mathrm{c}_{\mathrm{P}, 1}$ & $\mathrm{f}_{\mathrm{SI}}$ & $\mathrm{c}_{\mathrm{e}, 1}$ & & -1 & & & & & & & $\mathrm{c}_{\mathrm{TSS}, 1}$ \\
\hline $\mathrm{c}_{\mathrm{P}, 1}$ & $\mathrm{f}_{\mathrm{SI}}$ & $c_{e, 1}$ & & -1 & & & & & & & $\mathrm{c}_{\mathrm{TSS}, 1}$ \\
\hline $\mathrm{c}_{\mathrm{P}, 4}$ & & $\mathrm{c}_{\mathrm{e}, 4}$ & & & 1 & & & & & & $\mathrm{c}_{\mathrm{TSS}, 4}$ \\
\hline $\mathrm{c}_{\mathrm{P}, 5}$ & & $\mathrm{c}_{\mathrm{e}, 5}$ & & & 1 & & & & & & $\mathrm{c}_{\mathrm{TSS}, 5}$ \\
\hline $\mathrm{c}_{\mathrm{P}, 6}$ & & $\mathrm{c}_{\mathrm{e}, 6}$ & & & 1 & & & & & & $\mathrm{c}_{\mathrm{TSS}, 6}$ \\
\hline $\mathrm{c}_{\mathrm{P}, 7}$ & & $c_{e, 7}$ & & & 1 & & & & & & $\mathbf{c}_{\mathrm{TSS}, 7}$ \\
\hline $\mathrm{c}_{\mathrm{P}, 8}$ & & $\mathrm{c}_{\mathrm{e}, 8}$ & & & & & & & & & $\mathrm{c}_{\mathrm{TSS}, 8}$ \\
\hline $\mathrm{c}_{\mathrm{P}, 9}$ & & $c_{e, 9}$ & $\mathrm{f}_{\mathrm{XI}, \mathrm{H}}$ & $1-f_{X I, H}$ & -1 & & & & & & $\mathrm{c}_{\mathrm{TSS}, 9}$ \\
\hline & & & & & & & & & & & \\
\hline $\mathrm{Y}_{\mathrm{PO}}^{\mathrm{AN}}$ & & $c_{e, 10}$ & & & & & $-\mathrm{Y}_{\mathrm{PO}}^{\mathrm{AN}}$ & $\mathrm{Y}_{\mathrm{SA}}^{\mathrm{AN}}$ & $1-\mathrm{Y}_{\mathrm{SA}}^{\mathrm{AN}}$ & & $\mathrm{c}_{\mathrm{TSS}, 1 \mathrm{C}}$ \\
\hline 1 & & $c_{e, 11}$ & & & & & -1 & & & & $\mathrm{c}_{\mathrm{TSS}, 1}$ \\
\hline $\mathrm{Y}_{\mathrm{PO}}^{\mathrm{NO}}$ & & $c_{e, 12}$ & & & & & $-\mathrm{Y}_{\mathrm{PO}}^{\mathrm{NO}}$ & $\mathrm{Y}_{\mathrm{SA}}^{\mathrm{NO}}$ & & & $\mathbf{c}_{\mathrm{TSS}, 1}$ \\
\hline $\mathrm{c}_{\mathrm{P}, 13}$ & & $\mathrm{c}_{\mathrm{e}, 13}$ & & & & $1 / Y_{\mathrm{PHA}}^{\mathrm{NO}}$ & & -1 & & & $\mathrm{c}_{\mathrm{TSS}, 13}$ \\
\hline $\mathrm{c}_{\mathrm{P}, 14}$ & & $\mathrm{c}_{\mathrm{e}, 14}$ & & & & $-1 / Y_{P P}^{\mathrm{NO}}$ & 1 & & & & $\mathrm{c}_{\mathrm{TSS}, 1}$ \\
\hline $\mathrm{c}_{\mathrm{P}, 15}$ & & $\mathrm{c}_{\mathrm{e}, 15}$ & & & & $-1 / \mathrm{Y}_{\mathrm{GLY}}^{\mathrm{NO}}$ & & & 1 & & $\mathrm{c}_{\mathrm{TSS}, 1}$ \\
\hline $\mathrm{c}_{\mathrm{P}, 16}$ & & $c_{e, 16}$ & & & & -1 & & & & & $\mathrm{c}_{\mathrm{TSS}, 1 \mathrm{C}}$ \\
\hline $\mathrm{c}_{\mathrm{P}, 17}$ & & $\mathrm{c}_{\mathrm{e}, 17}$ & & & & $1 / \mathrm{Y}_{\mathrm{PHA}}^{\mathrm{O}}$ & & -1 & & & $\mathrm{c}_{\mathrm{TSS}, 1}$ \\
\hline $\mathrm{c}_{\mathrm{P}, 18}$ & & $\mathrm{c}_{\mathrm{e}, 18}$ & & & & $-1 / Y_{\mathrm{PP}}^{\mathrm{O}}$ & 1 & & & & $\mathrm{c}_{\mathrm{TSS}, 18}$ \\
\hline $\mathrm{c}_{\mathrm{P}, 19}$ & & $c_{e, 19}$ & & & & $-1 / \mathrm{Y}_{\mathrm{GLY}}^{\mathrm{O}}$ & & & 1 & & $\mathrm{c}_{\mathrm{TSS}, 1 \mathrm{~s}}$ \\
\hline $\mathrm{c}_{\mathrm{P}, 20}$ & & $\mathrm{c}_{\mathrm{e}, 20}$ & & & & -1 & & & & & $\mathrm{c}_{\mathrm{TSS}, 2 \mathrm{C}}$ \\
\hline & & & & & & & & & & & \\
\hline$c_{\mathrm{P}, 21}$ & & $c_{e, 21}$ & & & & & & & & 1 & $\mathrm{c}_{\mathrm{TSS}, 2}$ \\
\hline $\mathrm{c}_{\mathrm{P}, 22}$ & & $c_{e, 22}$ & $\mathrm{f}_{\mathrm{XI}, \mathrm{A}}$ & $1-f_{X I, A}$ & & & & & & -1 & $\mathrm{c}_{\mathrm{TSS}, 2 \mathrm{Z}}$ \\
\hline 7 & 8 & 9 & 10 & 11 & 12 & 13 & 14 & 15 & 16 & 17 & 18 \\
\hline $\mathrm{S}_{\mathrm{PO}}$ & $\mathrm{S}_{\mathrm{I}}$ & $\mathrm{S}_{\mathrm{HCO}}$ & $X_{I}$ & $\mathrm{X}_{\mathrm{S}}$ & $\mathrm{X}_{\mathrm{H}}$ & $\mathrm{X}_{\mathrm{PAO}}$ & $\mathrm{X}_{\mathrm{PP}}$ & $\mathrm{X}_{\mathrm{PHA}}$ & $\mathrm{X}_{\mathrm{GLY}}$ & $\mathrm{X}_{\mathrm{A}}$ & $\mathrm{X}_{\mathrm{TSS}}$ \\
\hline \multirow[t]{4}{*}{$\mathrm{gP}$} & gDQO & moles & gDQO & gDQO & gDQO & gDQO & $\mathrm{gP}$ & gDQO & gDQO & gDQO & $\mathrm{g}$ \\
\hline & 1 & & 1 & 1 & 1 & 1 & & 1 & 1 & 1 & \\
\hline & $\ldots$ & & $\ldots$ & $\ldots$ & $\ldots$ & $0.334(\alpha)$ & & 0.334 & 0.375 & $\ldots$ & \\
\hline & $\mathrm{i}_{\mathrm{N}, \mathrm{SI}}$ & & $\mathrm{i}_{\mathrm{N}, \mathrm{XI}}$ & $\mathrm{i}_{\mathrm{N}, \mathrm{XS}}$ & $\mathrm{i}_{\mathrm{N}, \mathrm{XH}}$ & $\mathrm{i}_{\mathrm{N}, \mathrm{BM}}$ & & & & $\mathrm{i}_{\mathrm{N}, \mathrm{BM}}$ & \\
\hline 1 & $\mathrm{i}_{\mathrm{P}, \mathrm{SI}}$ & & $\mathrm{i}_{\mathrm{P}, \mathrm{XI}}$ & $\mathrm{i}_{\mathrm{P}, \mathrm{XS}}$ & $\mathrm{i}_{\mathrm{P}, \mathrm{XH}}$ & $i_{P, B M}$ & 1 & & & $i_{P, B M}$ & \\
\hline \multirow[t]{2}{*}{$-1.5 / 31$} & & -1 & & & & & $-1 / 31$ & & & & \\
\hline & & & $\mathrm{i}_{\mathrm{TSS}, \mathrm{XI}}$ & $\mathrm{i}_{\mathrm{TSS}, \mathrm{XS}}$ & $\mathrm{i}_{\mathrm{TSS}, \mathrm{BM}}$ & $\mathrm{i}_{\mathrm{TSS}, \mathrm{BM}}$ & $\mathrm{i}_{\mathrm{TSS}, \mathrm{PP}}$ & $\mathrm{i}_{\mathrm{TSS}, \mathrm{PHA}}$ & $\mathrm{i}_{\mathrm{TSS}, \mathrm{GLY}}$ & $\mathrm{i}_{\mathrm{TSS}, \mathrm{BM}}$ & 1 \\
\hline
\end{tabular}




\section{NOMENCLATURA}

\begin{tabular}{|c|c|c|}
\hline Símbolo & Descripción & Unidades \\
\hline$A$ & Área superficial & $\mathrm{m}^{2}$ \\
\hline$b_{A}$ & Tasa específica de pérdida de masa endógena de los organismos nitrificantes & $1 / \mathrm{d}$ \\
\hline$b_{H}$ & $\begin{array}{l}\text { Tasa específica de pérdida de masa endógena de los organismos heterotróficos } \\
\text { ordinarios (OHOs) }\end{array}$ & $1 / \mathrm{d}$ \\
\hline$F / M$ & Relación alimento-microorganismos o factor de carga (LF) & gDQO/gSSV.d \\
\hline$f_{H}$ & Fracción no biodegradable de los OHOs & mgDQO/mgDQO \\
\hline$f_{N}$ & Contenido de nitrógeno de los SSV & $\mathrm{mgN} / \mathrm{mgSSV}$ \\
\hline$F S A$ & Amoniaco libre y salino & $\mathrm{mgN} / 1$ \\
\hline$K$ & Constante de saturación media & \\
\hline$k_{H}$ & $\begin{array}{l}\text { Tasa específica máxima de hidrólisis de la DQOrb por los OHOs bajo } \\
\text { condiciones aerobias }\end{array}$ & mgDQO/mgDQO.d \\
\hline$K_{I}$ & Constante de saturación media del compuesto inhibidor & $\mathrm{mg} / \mathrm{l}$ \\
\hline$K_{l}$ & Coeficiente de transferencia & $\mathrm{m} / \mathrm{h}$ \\
\hline$K_{N}$ & $\begin{array}{l}\text { Constante de saturación media de crecimiento con nitrógeno (FSA) de los } \\
\text { organismos }\end{array}$ & $\mathrm{mgN} / 1$ \\
\hline$K_{N, A}$ & $\begin{array}{l}\text { Constante de saturación media de crecimiento con nitrógeno (FSA) de los } \\
\text { nitrificantes }\end{array}$ & $\mathrm{mgN} / 1$ \\
\hline$K_{N, H}$ & \multicolumn{2}{|l|}{ Constante de saturación media de crecimiento con nitrógeno (FSA) de los OHOsmgN/1 } \\
\hline$K_{O}$ & Constante de saturación media de oxígeno disuelto & $\mathrm{mgO}_{2} / 1$ \\
\hline$K_{O, A}$ & Constante de saturación media de los nitrificantes para el oxígeno disuelto & $\mathrm{mgO}_{2} / 1$ \\
\hline$K_{O, H}$ & Constante de saturación media de los OHOs para el oxígeno disuelto & $\mathrm{mgO}_{2} / 1$ \\
\hline$K_{S}$ & Constante de saturación media para la utilización de materia orgánica soluble & $\mathrm{mgDQO} / 1$ \\
\hline$K_{x}$ & Constante de saturación media para la utilización de DQOrb por los OHOs & mgDQO/mgDQO.d \\
\hline$q$ & Tasa específica de conversión & $1 / \mathrm{h}$ \\
\hline$Q_{\text {in }}$ & Caudal afluente & $\mathrm{m}^{3} / \mathrm{h}$ \\
\hline$Q_{\text {out }}$ & Caudal efluente & $\mathrm{m}^{3} / \mathrm{h}$ \\
\hline$r_{i}$ & Tasa observada de transformación para el proceso i & $\mathrm{ML}^{-3} \mathrm{~T}^{-1}$ \\
\hline$S$ & Concentración de material soluble en el líquido & $\mathrm{mgDQO} / 1$ \\
\hline$S_{H C O}$ & Concentración de bicarbonato & $\mathrm{mg} / \mathrm{l}$ \\
\hline$S_{I}$ & Concentración de DQO soluble no biodegradable & $\mathrm{mgDQO} / 1$ \\
\hline$S_{\text {in }}$ & Concentración del substrato en el afluente & $\mathrm{mgDQO} / 1$ \\
\hline$S_{K I}$ & Concentración del compuesto inhibidor & $\mathrm{mg} / 1$ \\
\hline$S_{\max }$ & Concentración de saturación & $\mathrm{gDQO} / \mathrm{m}^{3}$ \\
\hline$S_{N}$ & Concentración de nitrógeno (amoniaco o nitrato) & $\mathrm{mgN} / 1$ \\
\hline$S_{N H}$ & Concentración de amoniaco libre y salino & mgFSA-N/1 \\
\hline$S_{N O}$ & Concentración de nitrato & $\mathrm{mgNO}_{3}-\mathrm{N} / 1$ \\
\hline$S_{O}$ & Concentración de oxígeno disuelto & $\mathrm{mgO}_{2} / 1$ \\
\hline Sout & Concentración de substrato en el efluente & $\mathrm{mgDQO} / 1$ \\
\hline$S_{S}$ & DQO soluble rápidamente biodegradable & $\mathrm{mgDQO} / 1$ \\
\hline$t$ & Tiempo & $\mathrm{h}$ \\
\hline$V$ & Volumen del reactor & $\mathrm{m}^{3}$ \\
\hline$v_{j, i}$ & $\begin{array}{l}\text { Término estequiométrico general dentro del modelo matricial para el } \\
\text { componente } i \text { del proceso } j\end{array}$ & \\
\hline$X$ & Concentración de biomasa & $\mathrm{gDQO} / \mathrm{m}^{3}$ \\
\hline$X_{A}$ & Concentración de biomasa de los organismos autrótofos nitrificantes & $\mathrm{mgDQO} / 1$ \\
\hline$X_{H}$ & Concentración de biomasa de los organismos heterotróficos ordinarios & $\mathrm{mgDQO} / 1$ \\
\hline$X_{I}$ & Materia orgánica no biodegradable del agua residual afluente & $\mathrm{mgDQO} / 1$ \\
\hline
\end{tabular}




\begin{tabular}{|c|c|c|}
\hline$X_{S} / X_{H}$ & Relación de concentración de $\mathrm{DQO}_{\mathrm{sb}} / \mathrm{OHO}$ & $\mathrm{mgDQO} / \mathrm{mgDQO}$ \\
\hline$X_{S}$ & Concentración de DQO lentamente biodegradable & $\mathrm{mgDQO} / 1$ \\
\hline$X_{S T O, S}$ & Concentración de materia orgánica almacenada intracelularmente & $\mathrm{mgDQO} / 1$ \\
\hline$X_{T S S}$ & Concentración de SST en el reactor & $\mathrm{mgSST} / 1$ \\
\hline$Y_{H}$ & Rendimiento de los OHOs & $\mathrm{mg}$ DQO/mgDQO \\
\hline Abreviación & Descripción & \\
\hline $\mathrm{ADM}$ & $\begin{array}{l}\text { Modelo de digestión anaerobia } \\
\text { (por sus siglas en inglés, Anaerobic digestion model) }\end{array}$ & \\
\hline AGV & Ácidos graso volátil & \\
\hline ASM & $\begin{array}{l}\text { Modelo de lodos activados } \\
\text { (por sus siglas en inglés, Activated sludge model) }\end{array}$ & \\
\hline $\mathrm{COT}$ & Carbono orgánico total & \\
\hline CSTR & $\begin{array}{l}\text { Reactor de mezcla completa (por sus siglas en inglés, Complete stirred tank } \\
\text { reactor) }\end{array}$ & \\
\hline DBO & Demanda bioquímica de oxígeno & \\
\hline DQO & Demanda química de oxígeno & \\
\hline $\mathrm{DQO}_{\mathrm{lb}}$ & DQO lentamente biodegradable & \\
\hline $\mathrm{DQO}_{\mathrm{rb}}$ & DQO rápidamente biodegradable & \\
\hline EA & Aceptor de electrones & \\
\hline EBPR & $\begin{array}{l}\text { Remoción biológica aumentada de fósforo } \\
\text { (por sus siglas en inglés, Enhanced biological phosphorus removal) }\end{array}$ & \\
\hline ER & Respiración endógena & \\
\hline GAOs & $\begin{array}{l}\text { Organismos acumuladores de glucógeno } \\
\text { (por sus siglas en inglés, Glycogen accumulating organisms), }\end{array}$ & \\
\hline IWA & $\begin{array}{l}\text { Asociación Internacional del Agua } \\
\text { (por sus siglas en inglés, International Water Association) }\end{array}$ & \\
\hline MR & Muerte y regeneración & \\
\hline NTK & Nitrógeno total de Kjeldahl & \\
\hline OD & Oxígeno disuelto & \\
\hline OHOs & Organismos heterotróficos ordinarios & \\
\hline OUR & Tasa de consumo de oxígeno & \\
\hline PAOs & $\begin{array}{l}\text { Organismos acumuladores de fósforo } \\
\text { (por sus siglas en inglés, Phosphorus accumulating organisms) }\end{array}$ & \\
\hline PHA & Poli-hidroxi-alcanoatos & \\
\hline PTAR & Planta de tratamiento de aguas residuales & \\
\hline SST & Sólidos suspendidos totales & \\
\hline TRH & Tiempo de retención hidráulica & \\
\hline TRS & Tiempo de retención de sólidos & \\
\hline TUDP & $\begin{array}{l}\text { Modelo de remoción aumentada de fósforo de la Universidad Tecnológica de } \\
\text { Delft }\end{array}$ & \\
\hline
\end{tabular}

\begin{tabular}{lll}
\hline Símbolos Griegos & Descripción & \\
\hline$\alpha$ & Símbolo representando una fórmula estequiométrica & \\
$\eta$ & Factor de reducción para la utilización de DQO $\mathrm{rb}$ bajo condiciones anóxicas & \\
$\mu$ & Tasa específica de crecimiento de los organismos & $1 / \mathrm{d}$ \\
$\mu_{A}^{\max }$ & Tasa específica máxima de crecimiento de los nitrificantes & $1 / \mathrm{d}$ \\
$\mu_{H}$ & Tasa específica de crecimiento de los OHOs & $1 / \mathrm{d}$ \\
$\mu_{H}^{\max }$ & Tasa específica máxima de crecimiento de los OHOs & $1 / \mathrm{d}$ \\
$\mu^{\max }$ & Tasa específica máxima de crecimiento de los organismos & $1 / \mathrm{d}$ \\
$\rho_{j}$ & Tasa cinética del proceso j & $\mathrm{ML}^{-3} \mathrm{~T}^{-1}$ \\
\hline
\end{tabular}




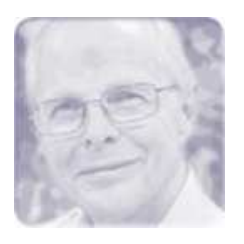

15

\section{Control de Procesos}

\section{Gustaf Olsson}

\subsection{MOTIVACIÓN}

La instrumentación, control y automatización (ICA) no corresponde a una nueva tecnología en el área del tratamiento de aguas residuales. La ICA ha sido reconocida por la Asociación Internacional del Agua (IWA, por sus siglas en inglés, International Water Association) por casi 30 años. Todavía, sin embargo, el control de procesos en sistemas dinámicos rara vez forma parte del plan general de estudios de las carreras de ingeniería civil o ambiental. Por lo tanto, muchos diseñadores de sistemas de tratamiento de aguas residuales no son conscientes del potencial que ofrece la ICA.

Se ha demostrado que la ICA puede incrementar la capacidad de remoción de nutrientes en un 10 a 30\% en plantas de tratamiento de aguas residuales (PTAR). El conocimiento avanzado de los mecanismos implicados en la eliminación biológica de nutrientes hoy en día está produciendo un aumento en la comprensión de los procesos y la posibilidad de controlarlos. Existe una relación sofisticada entre los parámetros operacionales en un sistema de tratamiento, su población microbiana y la reacción bioquímica, y por lo tanto su rendimiento. Con una mejor comprensión y aprovechamiento de estas relaciones las mejoras debidas a ICA pueden llegar a ser del 20 a $50 \%$ de las inversiones totales del sistema en los próximos 10 a 20 años. Un sistema ideal de ICA contiene cuatro componentes funcionales:

- Un equipo de calidad con personas que posean un profundo sentido de pertenencia al sistema y a la planta de tratamiento, y que adicionalmente estén comprometidos con una ética de mejora continua.

- Un sistema de instrumentación para poder recopilar información adecuada sobre las variables de los procesos.

- Un sistema de monitoreo para adquirir, procesar y visualizar los datos, detectar y aislar situaciones anormales, asistir en el diagnóstico y toma de decisiones, y finalmente simular las consecuencias de los diferentes ajustes en la operación. Es crucial contar con un sistema adecuado de adquisición y reporte de datos.

- Un sistema de control para alcanzar los objetivos de operación. Esto puede llevarse a cabo tanto a nivel local en el proceso de tratamiento, a través de sistemas de control de bajo nivel, o mediante la coordinación 
de los diversos procesos dentro de la planta y con el sistema de alcantarillado.

Los mecanismos de control avanzado que se requieren cada vez con mayor frecuencia en los sistemas de tratamiento de agua potable y aguas residuales han sido objeto de una gran cantidad de aplicaciones en diversos procesos industriales. Varios casos de estudio han demostrado un ahorro significativo en los costos de operación y una reducción considerable en los tiempos de amortización. Sin embargo, la aplicación del control de procesos en sistemas de tratamiento de aguas residuales se ha desarrollado de forma tardía con respecto a otras industrias como la de producción de pulpa de papel y la de procesos químicos y, por lo tanto, puede aprender de los procesos en este tipo de industrias. En general, el conocimiento de los procesos, la tecnología de los sensores y la forma en que las plantas han sido diseñadas y construidas puede imponer limitaciones en lo que se puede lograr hoy en día mediante el control de procesos. Los procesos de aguas residuales cuentan con algunas características particulares únicas: los caudales, las perturbaciones las bajas concentraciones, los microorganismos, su separación y el hecho de que toda la "materia prima" tiene que ser aceptada y tratada.

Lo que es realmente diferente son las actitudes e incentivos en las diferentes industrias. Por supuesto, las actitudes a menudo dependen de los incentivos. Tanto la industria de las aguas residuales, los alimentos o la minera afirman ser diferentes. Realmente lo que sucede es que el sector del tratamiento de las aguas residuales hasta hace relativamente poco tiempo no contaba con los incentivos para poner a prueba el trabajo que la industria petrolera sentó como base a inicios de la década de 1970 .

A continuación se hace una descripción de los diferentes temas a tratar en este capítulo. Las perturbaciones en los sistemas de tratamiento de aguas residuales son significativas, siendo esto la razón para el control de procesos que se explica en la sección 15.2. El rol del control de procesos se describe con más detalle en la sección 15.3. Los instrumentos son la base de toda la información; su función para llevar a cabo el monitoreo y el control se discute en la sección 15.4. Los sistemas de aguas residuales son sistemas complejos y dinámicos y por lo tanto cualquier corrección requiere de tiempo para poder ser observada en el sistema; este fenómeno se describe en la sección 15.5. Para manipular cualquier sistema son necesarios solenoides para poder traducir las decisiones en acciones mecánicas, tales como la activación de motores, bombas, compresores y válvulas.
Estos temas se ilustran en la sección 15.6. Las dos secciones siguientes, 15.7 y 15.8 describen los principios básicos de control y algunas aplicaciones típicas en el tratamiento de aguas residuales. Energía, agua potable y tratamiento de aguas residuales están estrechamente relacionados. La energía y otros costos operacionales se discuten en la sección 15.9. Una PTAR involucra diversos procesos unitarios y la interacción entre estos procesos debe tomarse en consideración, como se describe en la sección 15.10, para así poder efectuar un control más avanzado. Finalmente algunas referencias se presentan en la sección 15.11. Para el lector interesado se encuentra disponible una descripción general de control de los sistemas de tratamiento de aguas residuales en el libro de texto de Olsson-Newell (1999). Una descripción actualizada del estado del arte de los problemas que pueden aparecer en el control de sistemas de aguas residuales se muestra en Olsson et al. (2005). Este capítulo se centra específicamente en el control de sistemas de lodos activados y deliberadamente omite la operación de sistemas de alcantarillado.

\subsection{PERTURBACIONES EN LOS SISTEMAS DE TRATAMIENTO DE AGUAS RESIDUALES}

Uno de los principales incentivos para el control de procesos es la presencia de perturbaciones en el funcionamiento de una PTAR. El impacto de estas perturbaciones debe ser cuantificado y compensado de alguna forma. Es preferible si las perturbaciones se pueden atenuar o incluso eliminar antes de que lleguen a la PTAR. En comparación con la mayoría de los procesos industriales, las perturbaciones a las que está sujeta una PTAR son muy grandes. Las aguas residuales del afluente por lo general varían considerablemente tanto en concentración, como en composición y caudal, con escalas de tiempo que oscilan desde horas hasta meses. Eventos discretos tales como tormentas de lluvia, derrames tóxicos y picos de carga también pueden ocurrir de vez en cuando. Como resultado, la planta casi nunca se encuentra en un estado de equilibrio, sino que está sujeta a un comportamiento transitorio o dinámico todo el tiempo.

Muchas perturbaciones en una PTAR están relacionadas con el caudal afluente. El afluente varía tanto en caudal, como en concentración y composición (Figura 15.1). Cualquiera de estos cambios tiene que ser medido y compensado. Si el resultado de alguna perturbación se mide dentro de la planta, tal como un cambio en el nivel de oxígeno disuelto, la elevación del manto de lodos, o una concentración variable de sólidos 

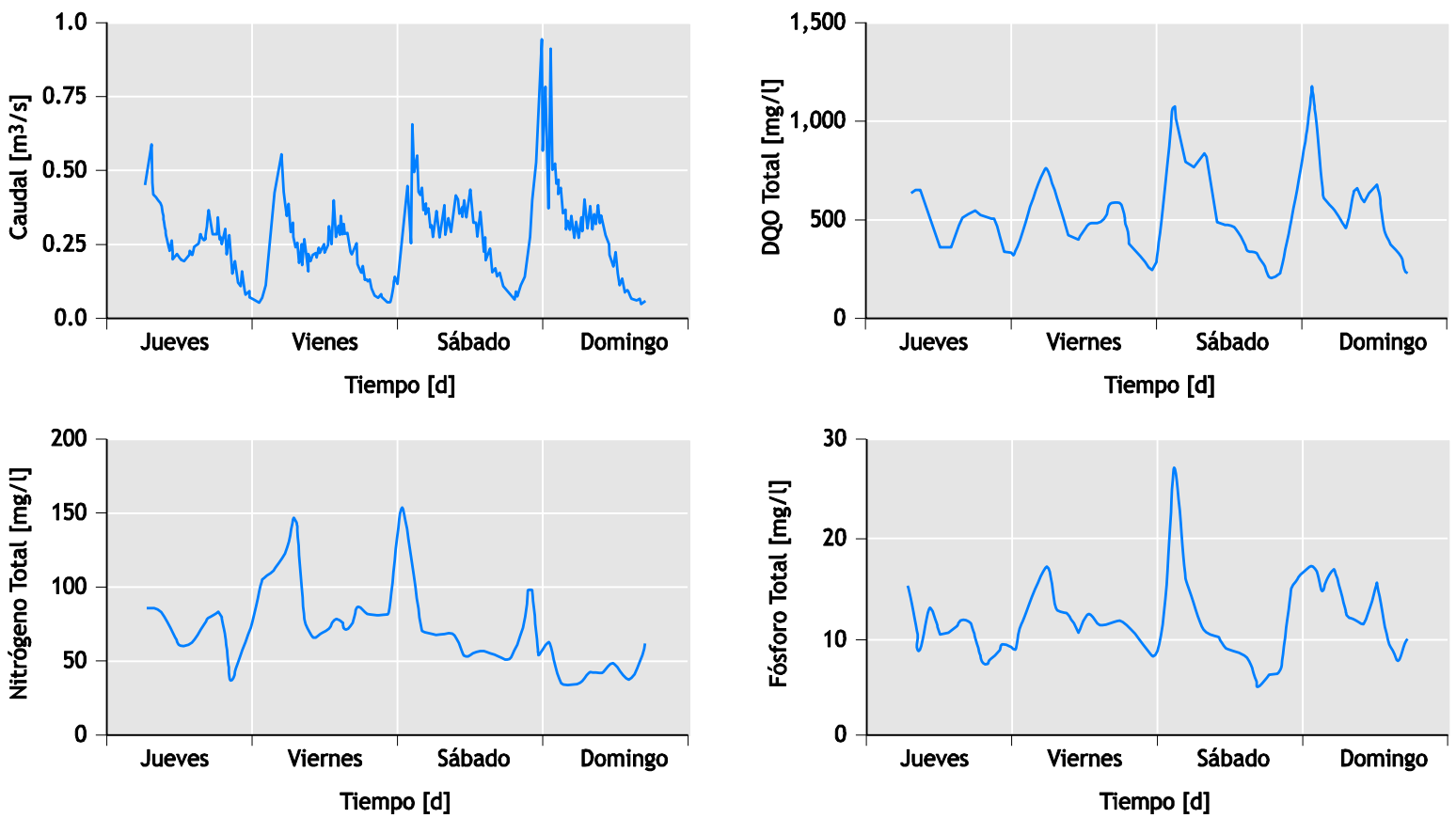

Figura 15.1 Variaciones diurnas típicas durante un periodo sin lluvias en un municipio con aguas residuales de origen mayoritariamente doméstico. Los datos muestran las variaciones de jueves a domingo (note la concentración máxima pico de fósforo el día sábado)

en suspensión, la información medida es retroalimentada (feed back) a un controlador el cual activa una bomba, una válvula, o un compresor, de manera que la influencia en el comportamiento de la planta se reduce al mínimo.

Ante la existencia de estas perturbaciones debe mantenerse un rendimiento uniforme. La forma tradicional de amortiguar estas perturbaciones ha sido la de diseñar plantas con grandes volúmenes para poder atenuar las elevadas fluctuaciones de la carga. Esta solución ocasiona altos costos de capital, sin embargo, los sistemas de control en línea, que han demostrado hacer frente a la mayor parte de estas variaciones, son una alternativa mucho más rentable y por lo tanto mucho más atractiva. El control y la eliminación de estas perturbaciones es de hecho uno de los principales incentivos para la introducción del control de procesos en línea en los sistemas de tratamiento de aguas residuales.

A veces un cambio en la carga orgánica puede medirse aguas arriba, antes de que entre en la PTAR. En este momento, la información puede ser pre-alimentada (feed forward) para preparar el sistema. Por ejemplo, la aireación se puede incrementar antes de que un aumento en la carga ocurra. Otro ejemplo es cuando la recirculación de lodo se incrementa para reducir el manto de lodos y así preparar al clarificador secundario para un aumento en la carga hidráulica. Desafortunadamente, muchas de las perturbaciones se crean dentro de la planta debido a una operación inadecuada. A menudo, esto ocurre por la falta de entendimiento de cómo las diferentes partes de la planta interactúan entre sí. Un ejemplo de esto se observa en la Figura 15.2, donde el caudal afluente se bombea con tres bombas de encendido y apagado, lo que da lugar a cambios repentinos en la velocidad de flujo. Dicho desempeño tendrá un efecto perjudicial sobre el comportamiento del clarificador secundario.

El retrolavado de los filtros puede en algunas ocasionas causar grandes problemas operacionales. En un caso, el retrolavado aumentó el caudal afluente en casi un 50\%, como se ilustra en la Figura 15.3. En este caso la planta para remoción de nutrientes contaba con un reactor anaerobio como tratamiento inicial. Este reactor fue expuesto no sólo a un gran caudal, sino también a un agua rica en oxígeno, la cual a la vez se propagó y descargó en la zona anóxica siguiente llevando un alto contenido de oxígeno residual. Es claro que las reacciones biológicas se vieron afectadas y como consecuencia la calidad del efluente fue insatisfactoria. Aparentemente, el bombeo debía realizarse de una manera diferente, y una vez que se comprendió el patrón de la perturbación, el problema se resolvió rápidamente. En general, las bombas de 
encendido y apagado pueden generar muchos inconvenientes operativos. En particular, el clarificador primario y secundario son sensibles a los cambios de caudal repentinos.

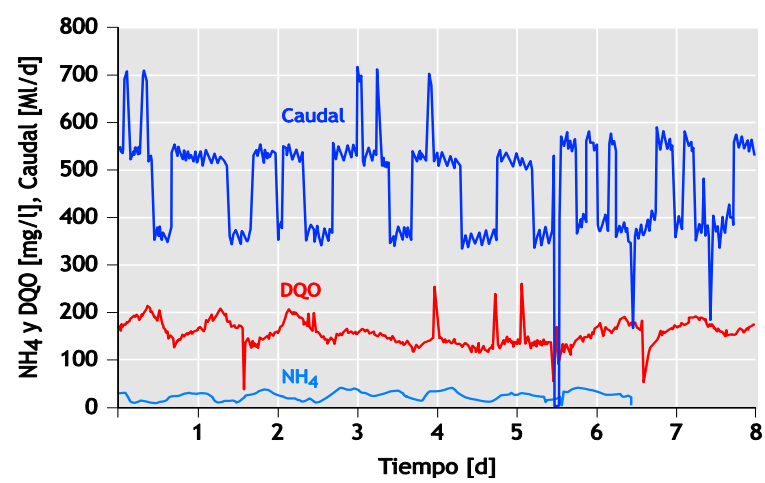

Figura 15.2 Variaciones del caudal afluente en una planta de tratamiento de aguas residuales de gran tamaño que cuenta únicamente con bombas primarias de encendido y apagado, dando como resultado variaciones repentinas no deseadas del caudal en la planta

En un país de clima frío, la temperatura del agua afluente puede cambiar rápidamente como consecuencia de un evento de lluvia. La Figura 15.4 muestra con un registro de datos de tres semanas cómo las fuertes lluvias durante la temporada de otoño influyen en la temperatura del agua, lo que resulta en una menor actividad microbiana y en una carga extra tanto para el clarificador primario como para el secundario. Los caudales elevados tendrán un efecto significativo en el rendimiento del clarificador (Figura 15.5).

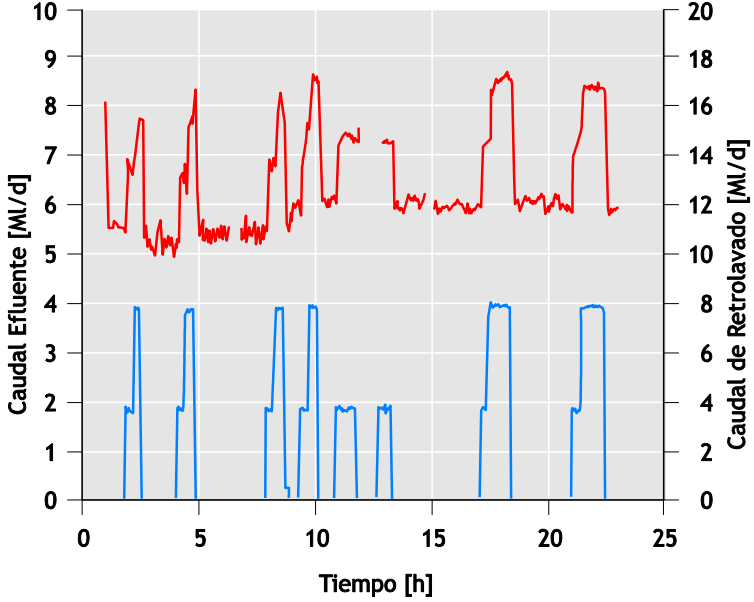

Figura 15.3 Retrolavado del filtro (curva inferior) y su impacto en la velocidad del caudal afluente y la operación de la planta (curva superior).

Si el sobrenadante se recircula al afluente de la planta durante una carga elevada, entonces la carga de nitrógeno a la planta puede llegar a ser muy grande (Figura 15.6). La figura muestra cómo la tasa de consumo de oxígeno incrementa significativamente a medida que el sobrenadante se recircula dentro de la planta. Es crucial identificar las fuentes de las perturbaciones con el fin de obtener un alto rendimiento en la operación de una planta. De esta manera, el sistema de control puede estar estructurado de manera que las perturbaciones sean atenuadas o incluso evitadas.
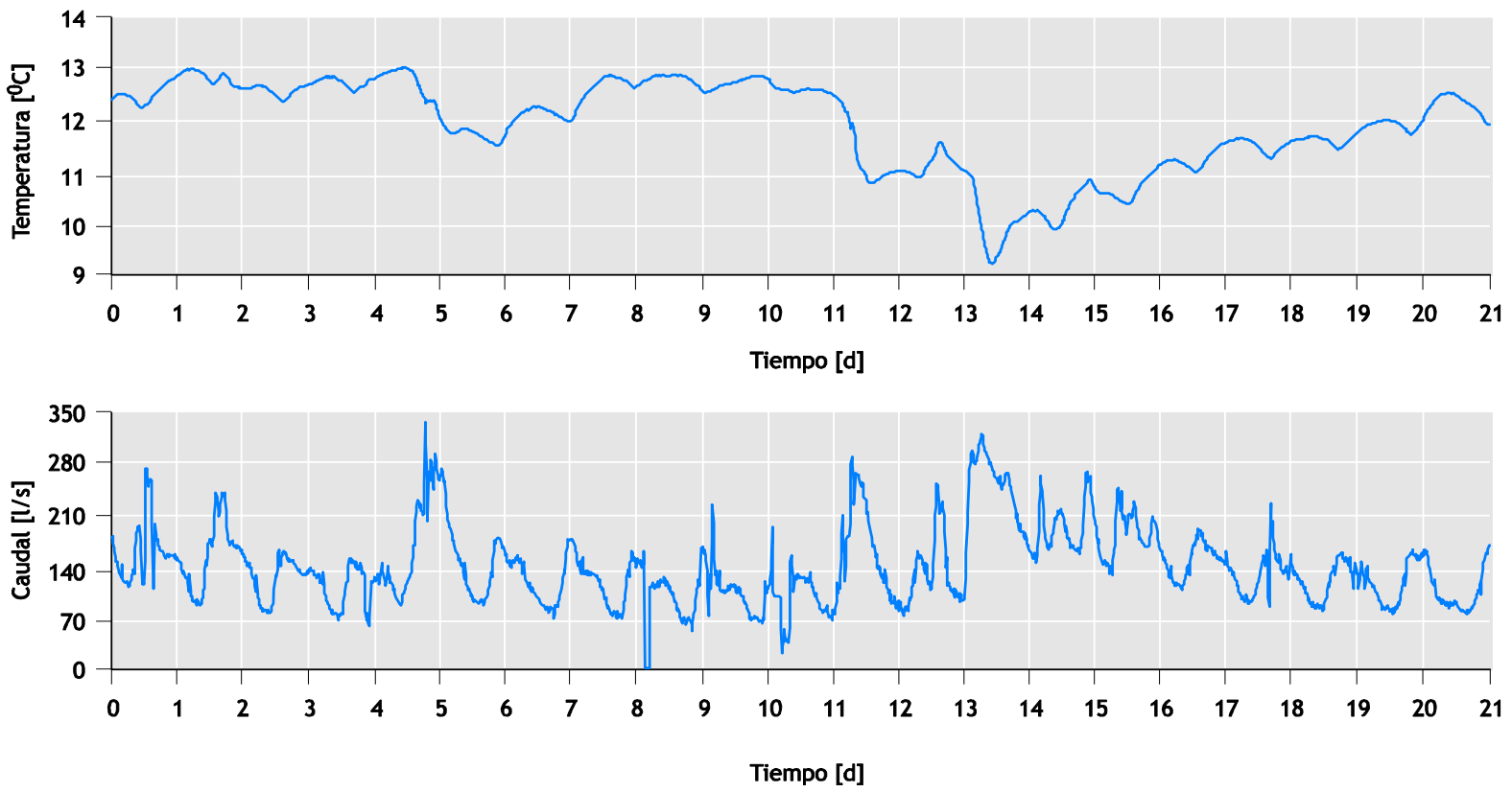

Figura 15.4 Variaciones del caudal afluente durante tres semanas en la temporada de otoño. La curva inferior muestra las variaciones diarias y algunos períodos de lluvia. La curva superior muestra la forma en que la temperatura disminuye como resultado de las lluvias. 

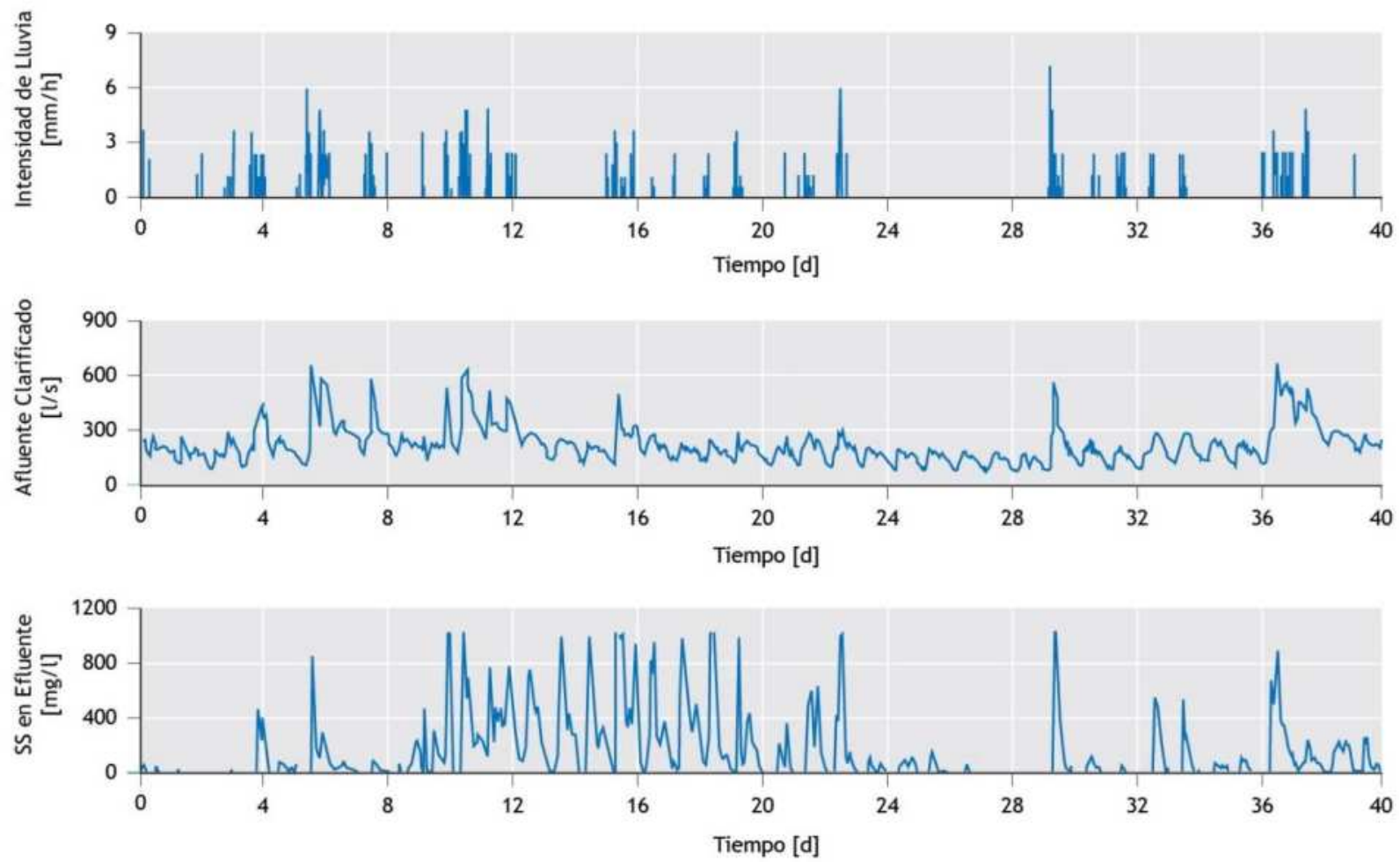

Figura 15.5 Relación entre las perturbaciones hidráulicas y calidad del efluente. La curva superior muestra la intensidad de la lluvia durante 40 días, y la curva de en medio corresponde al caudal afluente de la planta de tratamiento doméstica. La curva inferior muestra los sólidos en suspensión después del sedimentador secundario. Se puede apreciar como el clarificador está claramente trabajando cerca de su capacidad máxima y falla durante los picos hidráulicos elevados, lo que resulta en grandes valores de concentración de sólidos suspendidos en el efluente.
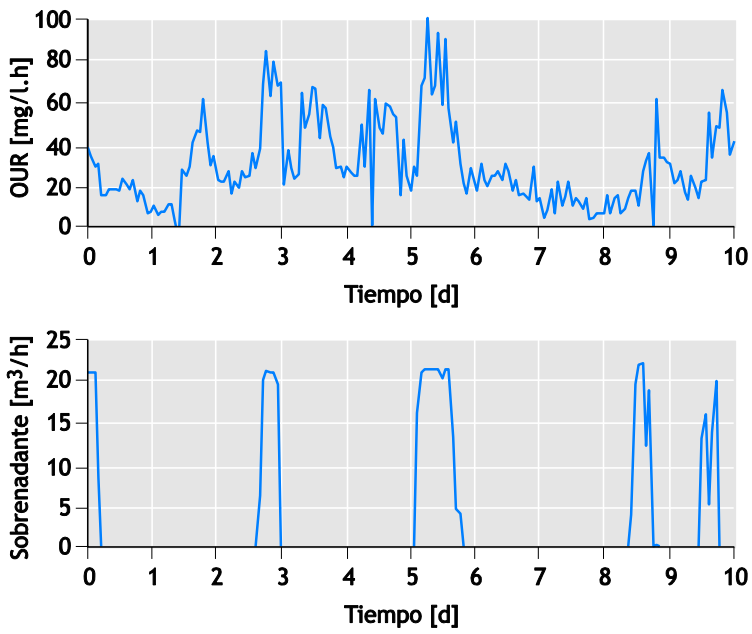

Figura 15.6 El efecto de la recirculación en el sobrenadante en una planta durante un período de 10 días. La curva inferior muestra el caudal de sobrenadante (que no es muy alto, pero tiene una concentración elevada). La curva superior muestra la tasa de consumo de oxígeno en el aireador (cortesía de MK Nielsen, Dinamarca)
Las perturbaciones también surgen a partir del cambio de las poblaciones de bacterias y el cambio de sus propiedades físicas y microbianas. Por ejemplo, no es raro que un sistema de tratamiento tenga problemas de decantación de lodos debido a la aparición de bacterias filamentosas. Las operaciones impuestas por el uso de sistemas de control en línea pueden a su vez ser la causa de un cambio en la población bacteriana. Estas perturbaciones deben ser tratadas adecuadamente en el diseño y la evaluación del sistema de control. Otras perturbaciones internas pueden ser generadas por operaciones inadecuadas o inapropiadas, incluyendo errores humanos, solenoides inadecuados o en mal funcionamiento y/o averías en los sensores. Estos pueden potencialmente causar importantes problemas de funcionamiento. En muchas plantas también se producen cambios repentinos de caudal, producto del encendido o apagado de una bomba (sin ningún control de velocidad variable) o retrolavados repentinos de los filtros. Muchos de estas perturbaciones se pueden evitar (o sus efectos reducirse al mínimo) a través de la introducción de 
sistemas de control en línea, en particular con el uso de sistemas de alerta temprana.

\subsection{EL ROL DEL CONTROL Y LA AUTOMATIZACIÓN}

Los sistemas de ICA en el tratamiento de aguas residuales han recorrido un largo camino y ahora constituyen un área de tecnología reconocida y establecida en la profesión. Una serie de factores se han combinado para hacer posible este progreso:

- La tecnología de instrumentación se encuentra hoy en día mucho más establecida. Instrumentos complejos, como sensores de nutrientes en línea y respirómetros in situ son ahora utilizados regularmente en el campo del tratamiento de aguas. Sin embargo, sólo unos pocos sensores se utilizan en sistemas de control cerrado (closed-loop, ver Sección 15.7).

- Los solenoides han mejorado con los años. Hoy en día, es común utilizar accionamientos de velocidad variable en bombas y compresores para permitir un mejor control de las plantas.

- El poder de computo requerido para el control de procesos puede considerarse casi "gratuito" en comparación con los costos totales de la PTAR y su operación.

- La recopilación de datos ya no se considera como un gran obstáculo. Hoy en día existen paquetes de software para la adquisición de datos y el control de la planta cuyos beneficios no se ponen en duda. Muchas empresas de servicios están diseñando e instalando sistemas de Supervisión, Control y Adquisición de Datos (SCADA, por sus siglas en inglés, Supervisory Control and Data Acquisition) y de control de procesos de segunda e incluso de tercera generación. Las herramientas de procesamiento de datos vienen en su mayoría del área de la estadística multivariable y de "soft-computing" (redes neuronales y sistemas de lógica difusa). No obstante, aún no se han explorado a fondo la integración de estas herramientas con sistemas de control cerrado (closed-loop) de bajo nivel en los procesos.

- La teoría de control y automatización ofrece herramientas poderosas. La evaluación comparativa de los diferentes métodos de control está actualmente siendo reconocida y se han desarrollado nuevas herramientas para la evaluación del rendimiento de la estrategia de control, basándose en el costo, la robustez y el rendimiento.

- Se han desarrollado modelos dinámicos avanzados de muchos de los procesos unitarios que ocurren en una
PTAR y existen simuladores comerciales que permiten condensar este conocimiento de la dinámica de la planta en un paquete de software.

- Los operadores e ingenieros de procesos tienen hoy en día una mayor comprensión en instrumentación, informática e ideas de control. Sin embargo, todavía hay una gran necesidad de una mejor educación.

- Existen varios incentivos obvios para la implementación de ICA, no solo desde el punto de vista económico. Las plantas son cada vez más complejas lo que requiere de automatización y control para su correcta operación.

El desarrollo de enfoques de control de los procesos a nivel completo de la planta se encuentra todavía en sus inicios. Las implementaciones están ganando impulso, pero a una velocidad muy baja. La ICA ha sido aceptada como un componente estándar de los sistemas de tratamiento de aguas residuales. Las empresas prestadoras del servicio de tratamiento de aguas residuales dependen hoy en día de ICA para minimizar los recursos necesarios para operar con eficacia las instalaciones. A pesar de la aceptación casi universal, todavía hay una gran cantidad de oportunidades para la aplicación de ICA. Las encuestas muestran que aproximadamente el $50 \%$ de los sistemas de control actualmente son operados en modo manual. Es obvio, que los sensores en línea ya no representan la principal limitación para el control en línea, sin embargo la falta de flexibilidad en los procesos es ahora más problemática y limitante. Finalmente, el diseño y la operación de las plantas de tratamiento deben integrarse de forma sistemática.

\subsubsection{Estableciendo prioridades}

Cualquier operador de una planta de tratamiento debe establecer las prioridades para lograr un adecuado funcionamiento de la misma. Es evidente que una buena operación depende del buen funcionamiento de los equipos. Todos los eslabones de la cadena deben trabajar con el fin de obtener un sistema operacional. El hardware incluye no sólo la instrumentación, sino también todos los diferentes elementos mecánicos y del equipo del sistema de tratamiento implicados, como compresores, bombas, motores y válvulas. Los sistemas de comunicación son cada vez más importantes en los sistemas de control de una planta. El software no sólo se basa en algoritmos de control apropiados, sino también en bases de datos, sistemas de comunicación, sistemas de adquisición de datos y pantallas amigables para la visualización de datos. Sin embargo, es necesario 
recordar que lo más importante son las personas. Ningún sistema de control puede ser presentado a los operadores si estos no han influido de alguna forma en el diseño del mismo. Cualquier sistema de control bien intencionado y en buen funcionamiento puede ser un total fracaso si las personas que lo manejan no confían en él. Por lo tanto, la participación de las personas y la educación es una parte crucial de la creación y operación de un sistema exitoso. Así que, ¿cuáles son las prioridades?:

- Mantener la planta en funcionamiento. Asegurar que el equipo funcione, que las bombas, válvulas y motores operen correctamente, que los instrumentos están calibrados y bien mantenidos, y que las señales se comuniquen correctamente al sistema de control. Esto también incluye el "control de nivel bajo", como es el control de los caudales locales, los niveles, la presión de aire o las diferentes concentraciones que no tienen un vínculo directo con la calidad final del efluente. La mayoría de estas acciones de control corresponden a sistemas de control de procesos tradicionales, como por ejemplo, el control de la presión del aire, el control de nivel del líquido y el control del caudal.

- Cumplir con los requerimientos de calidad del efluente. No es suficiente con mantener los valores de los parámetros físicos en niveles correctos. Otras variables que están directamente relacionadas con la calidad del efluente también deben controlarse y esto se realiza a este nivel. Esto incluye la manipulación de las diferentes variables de los procesos unitarios como son el control de la dosificación para la precipitación química, el control del oxígeno disuelto (OD) en procesos aerobios, y el control de la recirculación de lodos o control del tiempo de residencia de sólidos (TRS, o edad de lodos), entre otros. Normalmente, cada uno de estos sistemas de control corresponde a un sistema de control simple basado en una sola variable de proceso.

- Minimizar el costo. En cada uno de los procesos unitarios el sistema de control puede ser más elaborado. Un ejemplo es el control del OD, donde el punto de ajuste de OD es variable, no sólo a lo largo del tanque de aireación, sino también variable en el tiempo (ver sección 15.8). El último objetivo en este nivel consiste en optimizar la operación del proceso unitario. Todo esto depende del uso de sensores e instrumentos adecuados. El costo puede ser influenciado a través de la disminución de la demanda de energía (por aireación o por mezcla), la reducción del costo por dosificación de productos químicos en la precipitación de fósforo o en la operación de los sistemas de deshidratación de lodos (sobre todo de las centrifugadoras). El costo está también relacionado al personal. Muchas plantas hoy en día funcionan satisfactoriamente durante las tardes, noches y fines de semana sin requerir de operarios.

- Integrar la operación de la planta. El objetivo final de esto es también para satisfacer los requerimientos de calidad de los efluentes al coste mínimo. Mediante la coordinación de varios procesos, es posible disminuir el impacto de las perturbaciones en una planta de tratamiento. La operación combinada de los procesos puede hacer que sea posible utilizar de manera óptima los volúmenes disponibles y el lodo obteniendo así el mejor funcionamiento.

Los estándares actuales a nivel de hardware y software en los equipos de cómputo así como el aumento en el número de mediciones confiables y en tiempo real (apropiadamente validadas) para una creciente gama de parámetros diferentes, permiten la operación sistemas de control cerrado (closed-loop) avanzados en plantas de tratamiento de aguas residuales, resultando en una mayor seguridad en el funcionamiento y una mejor economía operativa. Sin embargo, estos beneficios pueden estar limitados por el diseño mismo de las plantas de tratamiento cuando este diseño no se realiza teniendo en cuenta el control de procesos y su posible implementación.

\subsection{INSTRUMENTACION Y MONITOREO}

"Medir es saber". Por un largo tiempo, la instrumentación (definida aquí por los términos comunes: instrumentos de medición o instrumentación para sensores, analizadores y algunos otros instrumentos relacionados) era considerada un obstáculo importante para la realización del control en línea. Los instrumentos necesarios para medir las variables relevantes no estaban disponibles o eran poco fiables para ser utilizados en aplicaciones prácticas. Los acontecimientos de las últimas dos décadas han cambiado esto (Tabla 15.1) y la creciente confianza en la instrumentación está ahora impulsada por el hecho de que existen definiciones claras de las características de eficiencia junto pruebas estandarizadas para la instrumentación (ISO 15839:2003). Junto con las medidas más comunes hay otros sistemas de instrumentación disponibles para el 
control, como respirómetros, sensores de ácidos grasos volátiles (AGV) y sensores de alcalinidad, véase también Vanrolleghem y Lee (2003).

La estandarización de las especificaciones de los instrumentos hace posible ahora especificar, comparar y seleccionar la instrumentación más adecuada - no sólo en términos técnicos, sino también en términos económicos a través del cálculo del costo de propiedad (los cuales no solo toman en cuenta los costos de adquisición sino todos los costos involucrados durante su vida útil) (Tabla 15.2). Los costos de inversión para un dispositivo en sí son a menudo solo una fracción de los costos totales durante toda la vida útil del mismo. Las mediciones de los instrumentos van a estar disponibles 24 horas al día durante 7 días a la semana y la información debe ser extraída correctamente de los datos medidos. Por lo tanto, la instrumentación siempre tiene que combinarse con una revisión adecuada de los datos, un procesamiento de las mediciones y una extracción más o menos sofisticada de las características de las mediciones.

El seguimiento que se realiza del estado operativo actual de un sistema a través de la instrumentación se conoce como monitoreo. Sin embargo, aun cuando un instrumento de medición es fiable, este también puede fallar durante la operación, lo que a la vez puede tener graves consecuencias si la instrumentación se utiliza en sistemas de control cerrado (closed-loop). Por lo tanto, es necesario validar los datos en tiempo real antes de usarlos con fines de control del sistema. La validación de datos se puede realizar por métodos bastante simples en mediciones de instrumentos únicos o a través de una validación cruzada en mediciones de varios instrumentos si existe una correlación entre los mismos (LynggaardJensen y Frey, 2002). Si la confianza en una medida disminuye, a corto plazo se puede utilizar un valor estimado, pero eventualmente el control debe ajustarse a un esquema de funcionamiento con valores iniciales o de fábrica predeterminados hasta que la confianza en la medición se restaure.

En una planta de tratamiento sofisticada existe un flujo de datos considerable que viene de los diferentes procesos. El uso de más instrumentos y el desarrollo de nuevos instrumentos proporcionarán aún más datos. A diferencia de los seres humanos, las computadoras pueden estar infinitamente más atentas y pueden detectar patrones anormales en los datos de la planta. La capacidad de las computadoras para extraer patrones (información útil) se utiliza poco más allá de la simple representación gráfica. La tecnología de la información no se utiliza comúnmente para encapsular los conocimientos de los diferentes procesos, es decir, conocimientos acerca de cómo funciona un proceso y la mejor forma de hacerlo funcionar. Por lo general, los conocimientos de los procesos se construyen a partir de la experiencia de los operadores y los ingenieros, pero a menudo este conocimiento desaparece con ellos cuando dejan de laborar en la planta u oficina en cuestión. Si este conocimiento del proceso se puede encapsular, entonces no sólo se puede conservar sino que además la computadora puede ayudar en la toma de decisiones de la operación de la planta. El aporte substancial de soporte al operador para el diagnóstico y la toma de acciones correctivas ya se ha demostrado anteriormente; sin embargo, tiene que ser adoptado por la industria del agua y del tratamiento de aguas residuales.

La mayoría de los cambios que ocurren en las plantas de tratamiento de aguas residuales son lentos cuando el proceso se está recuperando de un estado "anormal" a un

Tabla 15.1 Mediciones comúnmente realizadas mediante el uso de instrumentación en plantas de tratamiento de aguas residuales

\begin{tabular}{lll}
\hline Caudal & Conductividad & Amonio \\
Nivel, presión & Oxígeno disuelto & Nitrato \\
Temperatura & Turbidez & Fosfato \\
pH & Concentración de lodos & Materia orgánica \\
Potencial redox & Nivel del manto de lodos & Producción de biogás \\
\hline
\end{tabular}

Tabla 15.2 Elementos (y ejemplos) incluidos en el cálculo del costo total de propiedad en instrumentación

\begin{tabular}{ll}
\hline Instrumentación & Costo del instrumento mismo \\
Acondicionamiento & Costo de aparatos, construcción, bombas, tuberías, pre-tratamiento \\
Instalación & Costos de proyecto y mano de obra calificada \\
Integración & Costos de programación del sistema SCADA, sistemas de control \\
Consumibles & Costos de químicos, energía, etc. \\
Mantenimiento & Costo de contrato de servicios y calibración, limpieza \\
Piezas de repuesto & Costo de piezas de repuesto \\
\hline
\end{tabular}




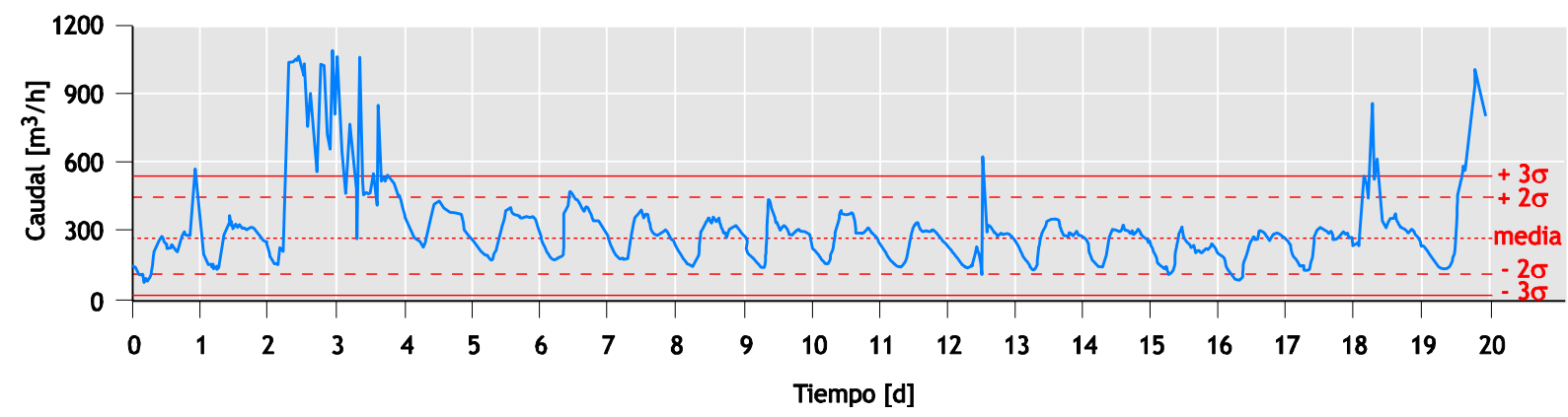

Figura 15.7 Variaciones del caudal afluente durante un período de tres semanas

estado "normal". La detección temprana de fallos en los procesos biológicos es muy eficaz porque permite tomar acciones correctivas que deben tomarse antes de que la situación se vuelva desfavorable. Algunos cambios pueden no ser inmediatamente evidentes, pero pueden crecer poco a poco hasta que se conviertan en un problema de funcionamiento grave. A continuación se describen algunos ejemplos de control básico. La Figura 15.7 ilustra las variaciones diarias (durante unas 3 semanas) del caudal afluente. En este periodo algunos picos significativos de caudal son evidentes. En la curva se indican el valor medio y la desviación $2 \sigma \mathrm{y} \pm 3 \sigma \pm$ de la media. Es claro que para las desviaciones que sean mayores de $3 \sigma$ deben observarse cuidadosamente para así poder implementar las operaciones adecuadas.

La Figura 15.8 muestra lo que sucede cuando el sensor falla. La figura superior muestra la señal de medición de un sensor y bajo esta circunstancia un operador atento puede notar un cambio en el carácter de la señal a partir de 900 segundos. No obstante, al aplicar un filtro a la señal los cambios se pueden hacer más evidentes. Un filtro de paso alto (HPF, por sus siglas en inglés, Highpass Filter) muestra esencialmente la variabilidad (algo similar a la primera derivada) de la señal. La señal filtrada se muestra en la curva inferior y revela un cambio significativo en el carácter del ruido de la señal, lo que revela un problema en el sensor.
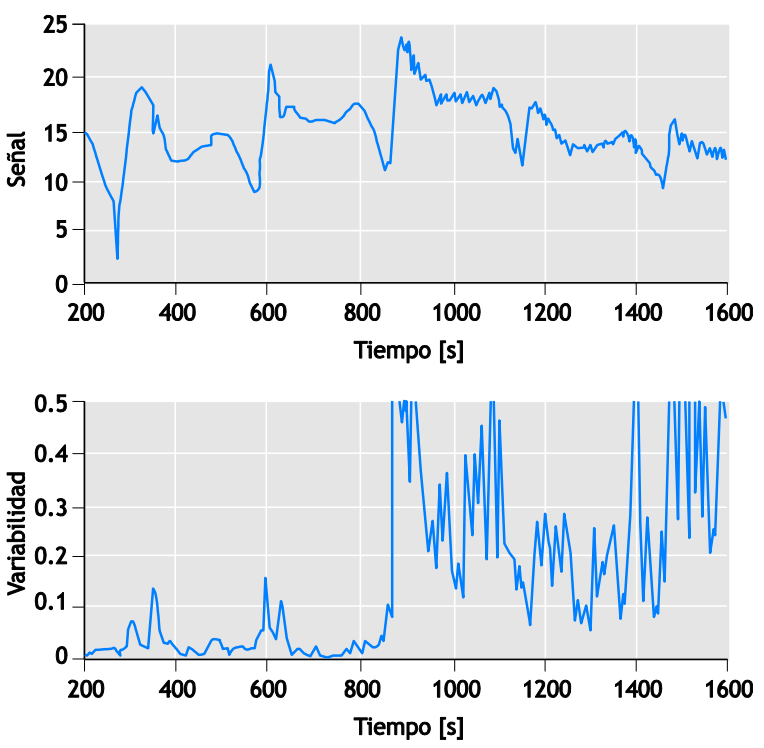

Figura 15.8 Detección de un problema en un sensor. La curva superior muestra la señal del sensor. El nivel de ruido en el sensor cambia después de 900 segundos, lo que indica un problema en el mismo. La curva inferior muestra la variabilidad de la señal. Cuando la variabilidad excede un umbral (por ejemplo 0.15) el sistema de seguimiento puede activar una alarma automática

\section{$15 \cdot 5$ \\ LA IMPORTANCIA DE LA DINÁMICA DEL SISTEMA}

Desde la perspectiva del control de sistemas, los aspectos dinámicos son fundamentales. Básicamente esto significa que el resultado de una acción correctiva toma algún tiempo antes de llevarse a cabo, es decir, nunca va a ocurrir de forma instantánea. Por lo tanto, el conocimiento de los intervalos de tiempo de los cambios en los procesos es muy importante. La dinámica de un sistema de tratamiento de aguas residuales incluye una amplia gama de intervalos temporales, que van desde algunos segundos hasta varios meses. La dinámica de las unidades de procesos típicos se puede clasificar como 
rápida, media y lenta, como se muestra en la Tabla 15.3 y esta clasificación a la vez influye en el tipo de modelo que se puede desarrollar y también en el diseño de las estrategias de control.

De la Tabla 15.3 se puede concluir que existe una gran diferencia entre las escalas temporales rápidas y lentas. En realidad, esto significa que las diversas acciones de control pueden a menudo ser separadas en diferentes dominios de tiempo. En particular, esto significa que en un intervalo de tiempo rápido las variables que cambian muy lentamente se pueden considerar constantes. Por ejemplo, la concentración de oxígeno disuelto puede cambiar dentro de una fracción de una hora. En este intervalo de tiempo la concentración de biomasa puede considerarse constante. En cuanto a un intervalo de tiempo lento, por ejemplo cuando uno tiene como objetivo controlar la cantidad total de lodos, el cambio en la concentración de oxígeno disuelto puede considerarse instantáneo.

Esta separación en los tiempos hace que el problema de control sea menos complejo. Esto a su vez significa que las acciones de control pueden separarse en intervalos de tiempo rápido, medio y lento y se pueden considerar y a menudo analizar por separado. Otra característica típica de un sistema de tratamiento de aguas residuales es que nunca se encuentra en un estado estacionario. La razón es que el caudal del afluente, su concentración y composición están cambiando continuamente. Como consecuencia, el proceso estará en un estado transitorio todo el tiempo. El sistema de control tiene que reconocer esto y mediante mediciones en línea y acciones correctivas traer las distintas variables del proceso a los valores deseados. En un reactor discontinuo secuencial (SBR, por sus siglas en inglés, Sequencing Batch Reactor) el sistema se opera en un estado transitorio a propósito. Una primera fase de oxidación continúa hasta que se completa la oxidación, y luego una fase de reducción (por ejemplo desnitrificación) se lleva a cabo y termina cuando la reducción se completa. Por lo tanto, un sistema secuencial discontinuo se presta de forma adecuada para aplicar un control de proceso dinámico.

Algunas veces es necesario tener consideración del tiempo requerido para las mediciones. Una lectura de oxígeno disuelto en un reactor toma algunos segundos para medirse. Sin embargo, este tiempo es pequeño en comparación con el tiempo requerido para que ocurra un cambio en el valor del OD, el cual normalmente es inferior a una hora. Una lectura de un respirómetro tardará aún más tiempo, y por lo general alrededor de una media hora. Es evidente que una medición de este tipo se puede utilizar sólo para acciones correctivas más lentas, del orden de horas. Es importante recordar que el valor de una medición a menudo se distorsiona a causa de ruidos en el sensor. Las variaciones de ruido pueden ser bastante rápidas y el controlador no debe reaccionar a las variaciones rápidas y falsas. Por esta razón el filtrado de la señal es crucial en el correcto desempeño de un sistema de control.

Es importante siempre recordar la dinámica del proceso cuando se cierra un ciclo. El control de la cantidad total de lodos en el sistema a través de la regulación del caudal de purga de lodos es un proceso muy lento. La tasa de cambio depende de la tasa de crecimiento de la biomasa y el marco de tiempo por lo general es del orden de varios días. Normalmente, para cambiar el tiempo de retención de lodos de 10 a 11 días, se requieren alrededor de 10 a 20 días. El tiempo de retención de lodos es por tanto un valor promedio y no se puede calcular sobre la base del día a día. En cambio, los caudales y concentraciones de lodos deben ser promediados sobre períodos más largos, por lo general semanas.

Tabla 15.3 Tiempos de respuesta de un proceso dinámico de eliminación biológica de nutrientes

\begin{tabular}{lll}
\hline Velocidad & Intervalo de tiempo & Mecanismo de tratamiento del agua residual \\
\hline Rápida & Minutos - horas & Hidráulica y dinámica de fluidos \\
& & Transferencia de oxígeno \\
& & Precipitación química \\
& & Dinámica del oxígeno disuelto \\
& & Separación entre sólidos y líquidos \\
Media & Horas - muchas horas & Cambios en concentración \\
& & Remoción de nutrientes \\
Lenta & Días - meses & Crecimiento de la biomasa \\
\hline
\end{tabular}


A veces, los controles que se aplican tratan de ser demasiado "ambiciosos". Por ejemplo, un sensor de oxígeno puede reproducir un valor de concentración de oxígeno cada minuto. Esto por supuesto, no quiere decir que el flujo de aire se debe cambiar cada minuto. Dado que el tiempo de respuesta típico de un aireador de escala completa es de 15-30 minutos al cambio del flujo de aire cada minuto sólo producirá acciones de control sin sentido y desgaste de las válvulas. En su lugar una acción de control cada 10-12 minutos es más adecuada.

La modelación para el control de sistemas no es lo mismo que la modelación para lograr comprender los mecanismos cinéticos básicos de un proceso. Consecuentemente modelos como los Modelos de Lodos Activados (ASM, por sus siglas en inglés, Activated Sludge Models) 1, 2 y 3 (Henze et al., 2000) o el Modelo de Digestión Anaerobia (ADM, por sus siglas en inglés, Anaerobic Digestion Model) (Batstone et al., 2002) no están diseñados para servir como el fundamento de operación de un controlador. En lugar de ello, representan una descripción detallada de la forma en que se entienden los mecanismos de los procesos biológicos. En el control de procesos, por otro lado, se tienen que identificar ciertos parámetros clave que son cruciales para el funcionamiento de la planta. Estos parámetros pueden ser la tasa de consumo de oxígeno, tasa de respiración, y las tasas de reacción para remoción de la demanda bioquímica de oxígeno (DBO), nitrificación o desnitrificación. El potencial de óxido-reducción (redox) puede reflejar el progreso de las reacciones, en particular, en los procesos ejecutados en ausencia de oxígeno como la desnitrificación, donde el nitrato se reduce a nitrógeno gaseoso.

Los parámetros clave tienen que ser calculados a partir de mediciones más simples. Por ejemplo, la concentración de OD se puede utilizar como una base para la estimación de las tasas de consumo de oxígeno. Mediciones en línea de amoniaco o de nitrato pueden calcularse con más detalle para encontrar las velocidades de reacción adecuadas. Consecuentemente, la estimación de parámetros dinámicos es una parte importante de la modelación que pueden formar la base para un control más avanzado.

\subsection{VARIABLES Y SOLENOIDES MANIPULABLES}

Existen un buen número de variables que se pueden utilizar para manipular los procesos biológicos en aguas residuales. Aun así, las posibilidades de ejercer un control flexible en una PTAR son bastante limitadas. Un problema predominante en muchas plantas es la falta de capacidad de control de las bombas o compresores. Como se describe en la Sección 15.2, las bombas que sólo se pueden controlar mediante un mecanismo de encendido/apagado pueden crear problemas más adelante en el proceso. El uso de bombas con un control de velocidad variable constituye una tecnología probada y es un importante pre-requisito para un buen control, tanto para el bombeo de los caudales de agua y lodo, como para controlar el flujo de aire en el control del oxígeno disuelto.

Las variables a manipular se pueden clasificar en los siguientes grupos:

- Hidráulicas, incluyendo las variables de que hacen referencia a la cantidad de lodos y la recirculación

- Adiciones de productos químicos o fuentes de carbono

- Suministro de aire u oxígeno

- Pre-tratamiento del agua residual afluente

Existen otras variables manipulables en una planta que están relacionadas con el equipo y con los circuitos de control básicos del proceso, tales como controladores de flujo, controladores de nivel, etc. Estos no se incluyen en la siguiente discusión.

\subsubsection{Variables hidráulicas}

La mayoría de las variables manipulables cambian los patrones hidráulicos de flujo en la planta. Los diferentes caudales influyen en los tiempos de retención de las distintas unidades. Por otra parte, la tasa de cambio es crucial en muchas partes de la planta de tratamiento, ya que influye en los procesos de clarificación y de espesamiento. Los flujos hidráulicos también determinan la interacción entre los diferentes procesos unitarios. Por lo tanto, las variables hidráulicas manipulables se pueden dividir en cuatro grupos:

- Variables que controlan el caudal afluente

- Variables que controlan la producción de lodos y su distribución

- Recirculación interna en el proceso biológico

- Flujos de recirculación externos, que influyen en las interacciones entre los diferentes procesos unitarios 
En esta categoría también se incluyen el control de la duración de cada una de las fases en reactores SBR, ya que esto es equivalente a controlar el tiempo de retención en una unidad continúa.

El caudal afluente al sistema de lodos activados puede ser manipulado de varias formas. Desde el punto de vista de la planta, el caudal afluente puede ser considerado como una perturbación externa que tiene que ser manejada por los diversos sistemas de control. Se enfatiza además que el bombeo del caudal afluente debe manejarse sin sobresaltos y que una velocidad variable de bombeo es recomendable. Por otro lado, si hay un tanque de ecualización disponible o si la red de alcantarillado puede ser utilizada como un tanque de ecualización, entonces el caudal afluente se convierte en una variable de control. Los volúmenes adicionales antes de la planta nos permitirán controlar el caudal afluente a fin de minimizar las consecuencias perjudiciales del afluente.

Muchas plantas están diseñadas con dos o más tanques de aireación paralelos. El proceso de división de flujo es fundamental para que la carga se distribuya de manera uniforme. Esto a menudo no es el caso, lo que resulta en una sobrecarga aparente en algunas partes del sistema. En muchas plantas la división del flujo se hace por una disposición fija de canales, que no puede en absoluto garantizar que el flujo real se divida correctamente. Si se debe garantizar la división del flujo, los caudales deben ser medidos y los caudales individuales controlados.

Hacer una derivación (bypass) debe ser una variable manipulable en el sentido de que nunca debe ocurrir, a menos que se ordene específicamente. Esto tiene que ser comparado con la alternativa de no realizar una derivación, y tiene que hacerse sobre la base de algún cálculo cuantitativo con un horizonte de tiempo adecuado.

Todos los diferentes modos de control de flujo afluente en una PTAR son simplemente diferentes maneras de tener un mayor poder de control. En otras palabras, drenajes o ecualización o control de una derivación o bypass, todo contribuye a hacer más fácil la obtención de una tasa de flujo uniforme en la planta. Su objetivo es el rechazo de perturbaciones. Una variación suave del caudal es crucial para la buena operación de un clarificador secundario. Para evitar perturbaciones, no sólo requiere una velocidad variable en el bombeo a un nivel operativo, sino que requiere adicionalmente una capacidad de almacenamiento suficiente en pozos o tanques localizados aguas arriba para poder amortiguar las perturbaciones que no se puedan evitar. Un control de bombeo deficiente puede deteriorar considerablemente el rendimiento de una planta. La razón principal es que por lo general el clarificador es muy sensible al aumento del caudal, como se comentó en la Sección 15.2.

La cantidad de lodos puede ser controlada principalmente por tres variables manipulables:

- Caudal de lodos de purga

- Caudal de lodos recirculados

- Caudal de alimentación por etapas

La manipulación del caudal de lodos de purga se utiliza para controlar la producción total de lodos en el proceso. Dado que la producción total de lodos es función de la tasa total de crecimiento de los organismos, esta se utiliza para controlar el tiempo de residencia de sólidos, o la edad de lodos. La manipulación de esta variable influye en el sistema en una escala de tiempo de varios días a semanas.

La manipulación del caudal de lodo recirculado se utiliza para distribuir el lodo entre los tanques de aireación y las unidades clarificadoras, o entre los reactores acidogénicos y metanogénicos en sistemas anaerobios en dos etapas. La recirculación que viene de los tanques clarificadores constituye una variable importante para la obtención de un punto adecuado de funcionamiento en los reactores, pero rara vez es útil para el control sobre una base de intervalo horario (hora a hora). Algunos sistemas están equipados con múltiples puntos de alimentación para el lodo de retorno. Esto tiene potencial para poder hacer una redistribución de lodos para ciertas cargas, como la presencia de una carga tóxica. Una combinación de diferentes flujos de recirculación puede ser importante y ventajosa. En sistemas con precipitación química, los lodos del clarificador secundario pueden combinarse con lodos químicos de una unidad de sedimentación posterior a la precipitación. De esa manera las propiedades de floculación pueden ser influenciadas, y los productos químicos mejor utilizados para la remoción de fósforo.

Mediante un control de alimentación por etapas en una planta de lodos activados, el lodo dentro del tanque de aireación se puede redistribuir, dada una cantidad adecuada de tiempo. Como un caso especial del control de alimentación por etapas se puede obtener una estructura de estabilización por contacto. También el lodo de retorno puede ser alimentado de nuevo no sólo en la entrada del tanque de aireación, pero en diferentes 
puntos de a lo largo del tanque, conocido como control por etapas de lodos recirculados. Esto puede llegar a ser una forma eficaz de prevenir el aumento de volumen de los lodos.

Las recirculaciones internas o externas proporcionan acoplamientos entre las distintas unidades de la planta. Los flujos de recirculación pueden ser considerados como perturbaciones controlables para el sistema reactorclarificador. Estos deben manipularse de tal modo que su efecto perjudicial se reduzca al mínimo. Algunas de las recirculaciones en una planta tienen caudales muy elevados, tales como la recirculación de nitrato en una planta de pre-desnitrificación. Cuando se tiene un sistema con pre-desnitrificación, es necesario recircular el agua rica en nitrato de la salida del aireador nitrificante. En este caso en particular, el contenido de oxígeno del agua recirculada puede limitar la tasa de desnitrificación en la zona anóxica.

En la Sección 15.2 se presentó como el caudal de retrolavado de un filtro de lecho profundo puede crear grandes perturbaciones si no se manipula correctamente. Otras corrientes de agua pueden tener concentraciones extremadamente grandes, tales como los sobrenadantes del tratamiento de lodos, como se indicó en la Sección 15.2. En la mayoría de los casos estos caudales se pueden manipular deliberadamente para lograr un mejor rendimiento de la planta. En un sistema de remoción biológica aumentada de fósforo (EBPR, por sus siglas en inglés Enhanced biological phosphorus removal) hay tres tipos de reactores, anaerobio, anóxico y aerobio. Dependiendo del tipo de diseño, pueden existir muchos diferentes patrones de recirculación en la planta. En un sistema anaerobio de dos etapas la recirculación ayuda a mantener los organismos metanógenicos que fueron lavados en la etapa de acidificación; adicionalmente se devuelve la capacidad amortiguadora del $\mathrm{pH}$ y así se reduce el uso de agentes cáusticos.

\subsubsection{Adición de agentes químicos}

Los productos químicos se adicionan por dos razones diferentes, para lograr la precipitación química en la eliminación de fósforo, o para formar una mejor decantación de los lodos. Para la eliminación de fósforo ferroso, se añaden sales férricas o de aluminio para obtener la precipitación química mediante la formación de fosfatos insolubles. Un cambio en la dosis de un producto químico puede tener una influencia rápida en la formación de flóculos y en el asentamiento de los mismos. En la Sección 15.8 se discute el control de la precipitación química.

Más allá del uso normal de productos químicos para la eliminación de fósforo, se pueden añadir productos químicos para mejorar las propiedades de sedimentación de los lodos en el clarificador secundario. A veces, los productos químicos se añaden al clarificador primario para reducir la carga y el uso del aireador. Sin embargo, esto a veces puede conducir a una cantidad insuficiente de carbono para la eliminación de nutrientes.

La adición de polímeros se puede utilizar en situaciones de emergencia para evitar grandes fallas en el clarificador. Periódicamente se pueden utilizar para el acondicionamiento de los lodos y así poder mejorar las propiedades de deshidratación. Además, los polímeros se pueden utilizar para mejorar aún más la eficiencia del proceso de pre-precipitación. La adición de sosa cáustica se utiliza en procesos anaerobios de dos etapas para poder controlar el pH, que puede inhibir a los microorganismos metanogénicos.

\subsubsection{Adición de una fuente de carbono}

La adición de alguna fuente de carbono externa es a veces necesaria en la desnitrificación para poder obtener una relación adecuada de carbono/nitrógeno en el sistema. Un déficit de carbono resulta en una desnitrificación incompleta, mientras que un exceso de carbono añade un costo en el uso del producto químico y crea costos adicionales relacionados con su posterior eliminación. El intervalo de tiempo de una operación de este tipo está relacionado con el tiempo de retención del proceso de desnitrificación. Para un sistema de pre-desnitrificación el carbón se suministra generalmente a través del agua residual afluente. Sin embargo, esto puede ser insuficiente durante los períodos de baja carga, de modo que tienen que añadirse algunas fuentes de carbono. En un sistema de post-desnitrificación una fuente de carbono (tal como metanol o etanol) siempre tiene que añadirse. En estos casos el problema se reduce a cómo ajustar la dosis a las necesidades de carbono de la planta sin requerir de mediciones extensas y complejas.

\subsubsection{Suministro de aire u oxígeno}

El oxígeno disuelto (OD) es una variable clave en el funcionamiento de un sistema de lodos activados. Desde un punto de vista biológico, la elección de un punto de ajuste (set point) de oxígeno disuelto adecuado es crucial. La dinámica del oxígeno disuelto es tal que el OD puede 
verse influenciado en fracciones de una hora. Los siguientes factores relacionados con el suministro de OD son clave: el suministro tota de aire, el punto de ajuste del OD, y la distribución espacial del OD. Para poder obtener un perfil de OD deseado se necesitan mediciones individuales del flujo de aire y realizar un control de retroalimentación sobre las válvulas. El control de OD se discute más adelante en la Sección 15.8.

El caudal de aire es reconocido como una variable de gran importancia para toda la operación de un sistema de lodos activados y por ende es razonable suponer que existe un control adecuado de OD en la planta. Sin embargo, ya que el costo de energía es significativo, también es de interés reducir al mínimo el suministro de aire. Es bien sabido, que un suministro insuficiente de aire influirá en el crecimiento de los microorganismos, en la formación de flóculos y en las propiedades de sedimentación del lodo. No obstante, una vez que se ha permitido la formación de los organismos no deseados, no siempre es obvia la manera de deshacerse de ellos controlando únicamente el nivel de OD.

\subsection{CONCEPTOS BASICOS DE CONTROL}

El principio fundamental del control es la retroalimentación, ilustrada por la Figura 15.9. El proceso (por ejemplo, un aireador, un sistema de dosificación química, o un reactor anaerobio) está todo el tiempo sujeto a perturbaciones externas. Estas son causadas principalmente por las variaciones en la carga del afluente, pero también pueden ser causadas por los cambios internos, como recirculaciones, bombeos, etc. El estado actual del proceso tiene que medirse con un sensor y esta es la base para la toma de una decisión. Con el fin de tomar una decisión, la meta o el propósito de este proceso tiene que ser establecida. Después de haber tomado la decisión ésta se implementa a través de un actuador, el cual es típicamente un motor, una bomba, una válvula o un compresor.

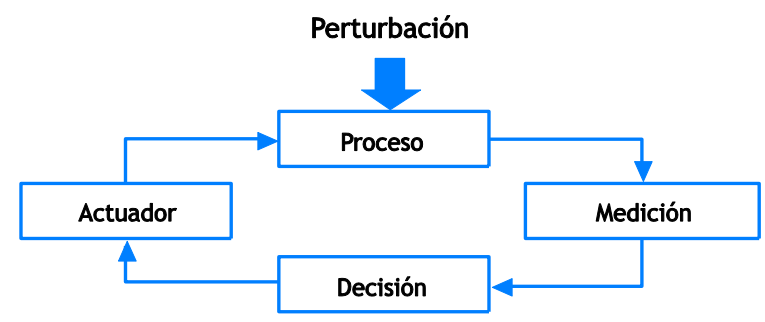

Figura 15.9 llustración del principio de retroalimentación

Los seres humanos estamos sujetos a un mecanismo de retroalimentación en nuestra vida diaria. En el cuerpo humano las células nerviosas detectan la temperatura y el cerebro controla los músculos para restringir los capilares de la piel. El balance del cuerpo requiere que nosotros sintamos la dirección a través de nuestro sistema de equilibrio. El cerebro a su vez controla los músculos de los pies y las piernas para mantenernos en pie. Al conducir un auto el conductor aplica todo el tiempo la retroalimentación. Los ojos miran el velocímetro y la carretera, etc. y el cerebro integra toda esta información para tomar una decisión sobre qué hacer en el siguiente momento. Esto se traduce a los músculos para mover el volante, frenar y acelerar. La razón de la retroalimentación es precisamente por el cambio permanente y continuo al que está sujeta la escena. En otras palabras, el "proceso" está sujeto a perturbaciones que nos obligan a usar el mecanismo de retroalimentación.

En otras palabras: el control es acerca de cómo operar una planta o un proceso hacia una meta definida, a pesar de las perturbaciones. Con las variables manipuladas y controladas, identificadas en un paso anterior, se debe seleccionar una estructura de control adecuada y se debe elegir el algoritmo de control para implementar la estrategia de control. Una estructura simple para un controlador por retroalimentación, utilizada a menudo en el control de procesos, se representa en la Figura 15.10.

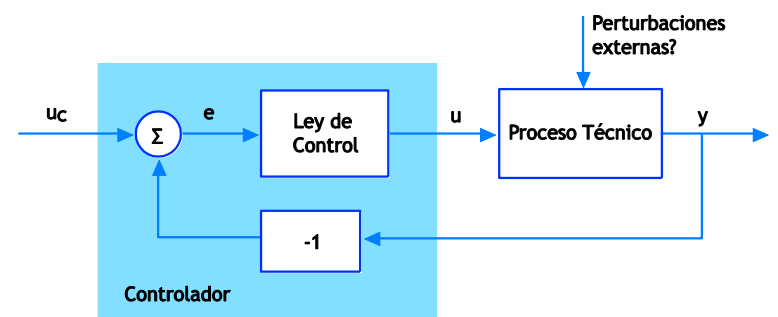

Figura 15.10 La estructura más simple de control por retroalimentación

Este es el tipo más simple de control por retroalimentación (feedback) y está representado por un diagrama de bloques que describe las señales del sistema de control. Es importante tener en cuenta que los términos "control de circuito cerrado" (closed-loop control), "control por retroalimentación" o simplemente "control" se utilizan a menudo como sinónimos. Este tipo de sistemas de control aparecen en todo el control local de niveles, presiones, temperaturas y caudales. El controlador tiene dos valores de entrada, la medición real $y$, y el valor de referencia (o punto de ajuste) $u_{c}$ y un valor de salida, la señal de control $u$. Sin embargo, en este caso simplificado el controlador utiliza sólo la diferencia entre los dos valores de entrada. 
Las propiedades del controlador (los parámetros del controlador) se pueden cambiar (esto se denomina procedimiento de sintonización) de modo que la salida del sistema se ajusta tan cerca como sea posible del punto de ajuste. El controlador entonces trata de hacer que el error e $=u_{c}-y$ sea lo más pequeño posible. Es razonable pensar que mientras un controlador complejo tenga más parámetros, tiene más grados de libertad. Con la ayuda de estos parámetros esto se pueden cambiar a voluntad y el comportamiento del sistema de circuito cerrado también se puede cambiar de formas más arbitraria.

Observe la diferencia entre un circuito abierto y cerrado de control. En un controlador de circuito abierto la acción de control no se basa en ninguna retroalimentación o medición, sino más bien se basa en el tiempo. Por ejemplo, un compresor que proporciona aire a un aireador se puede activar y desactivar en determinados momentos. No se hace una medición del oxígeno disuelto y no hay una garantía de que la concentración de oxígeno disuelto sea correcta. Tal sistema de circuito abierto es completamente diferente al control de circuito cerrado, donde el cambio de aireación se basa en medidas reales del oxígeno disuelto.

El diseño de controladores por retroalimentación ha atraído considerable atención en la literatura científica sobre el control de procesos. Muchos algoritmos de control avanzados se han basado en, por ejemplo, modelos dinámicos, redes neuronales y lógica difusa. Sin embargo, no hay pruebas convincentes disponibles que sugieran que estos algoritmos avanzados producen un mejor rendimiento de control en los sistemas de tratamiento de aguas residuales que el algoritmo convencional PID (proporcional-integral-derivativo), que ha sido más utilizado en aplicaciones prácticas de control de proceso (más de $95 \%$ de los controladores en una industria de papel y celulosa típicos son controladores PID). Los sistemas de control basados en reglas simples (control basado en reglas) también han encontrado aplicaciones exitosas.

\subsection{EJEMPLOS DE CONTROL DE RETROALIMENTACIÓN EN SISTEMAS DE TRATAMIENTO DE AGUAS RESIDUALES}

El control tradicional de una planta se sigue orientado en gran medida en los procesos unitarios. Entre algunos ejemplos del estado del arte en las tecnologías del control de sistemas se pueden mencionar (ver también Olsson et al., 2005):
- Control del OD con un punto de ajuste constante o variable como parte de la operación del proceso unitario del aireador.

- Control de la duración de la fase de aireación en fases alternantes (por ejemplo, aireadas y no aireadas), basado en sensores de nutrientes, pero aún a nivel local.

- Control de recirculación de nitratos en una planta de pre-desnitrificación, el cual se puede basar en mediciones de nitrato y OD en el aireador y en la zona anóxica.

- Control avanzado de la edad de lodos, basado en mediciones locales de concentración de amoníaco en los efluentes y de estimaciones de la capacidad de nitrificación.

- Control de lodos recirculados, el cual puede basarse en mediciones del manto de lodos en el clarificador.

- La sedimentación en el tanque de aireación es una forma de aumentar temporalmente la capacidad de la planta en condiciones de lluvia (Nielsen et al 1996; Gernaey et al 2004).

- El control de los procesos anaerobios tiene por objeto regular el flujo de biogás, estabilizar el proceso y maximizar su productividad. Aun así la tecnología de vanguardia actual se centra en la operación del proceso unitario.

- Un control de precipitación química exitoso puede basarse en mediciones locales de la concentración de fosfato.

\section{Ejemplo 15.1: Control de oxígeno disuelto}

El control del oxígeno disuelto tiene una importancia primordial en el proceso de lodos activados, tanto en las plantas con recirculación como en sistemas intermitentes o alternantes. El control de la aireación ha sido objeto de una considerable investigación desde 1970, cuando los sensores de oxígeno disuelto (OD) alcanzaron un nivel de robustez y precisión adecuada para el control por retroalimentación. Hoy en día, el control de OD usando un punto de ajuste puede ser considerado como una tecnología madura desde el punto de vista metodológico, aunque en realidad todavía sufre de bajo rendimiento e incluso se encuentran fallas ocasionales debido a las limitaciones físicas (por ejemplo, la capacidad inadecuada de los sopladores) y/o el mal funcionamiento del hardware (como puede ser el deterioro de un sensor de oxígeno). El control de la concentración de OD se considera aquí como ajustado a un punto pre-definido a través de la manipulación del flujo de aire, como se ilustra en la Figura 15.11. 
El oxígeno disuelto (OD) normalmente se mide en un punto dentro del aireador. Esta concentración se compara con el punto de ajuste de OD y el controlador de OD (el controlador maestro) calculará el cambio de la circulación de aire necesaria requerida para cambiar la concentración de oxígeno hacia el valor deseado. Sin embargo, el controlador de OD no manipula directamente la válvula de aire. En cambio, el flujo de aire deseado se utiliza como un punto de referencia a un segundo controlador, el controlador de flujo de aire (el controlador esclavo). Este controlador recibe la medición de flujo de aire y lo compara con el flujo de aire deseado. Esta diferencia hará entonces que el actuador (un compresor o una válvula) cambie el flujo de aire al valor adecuado. Este tipo de circuito se llama control en cascada y es la configuración estándar en este tipo de sistemas.

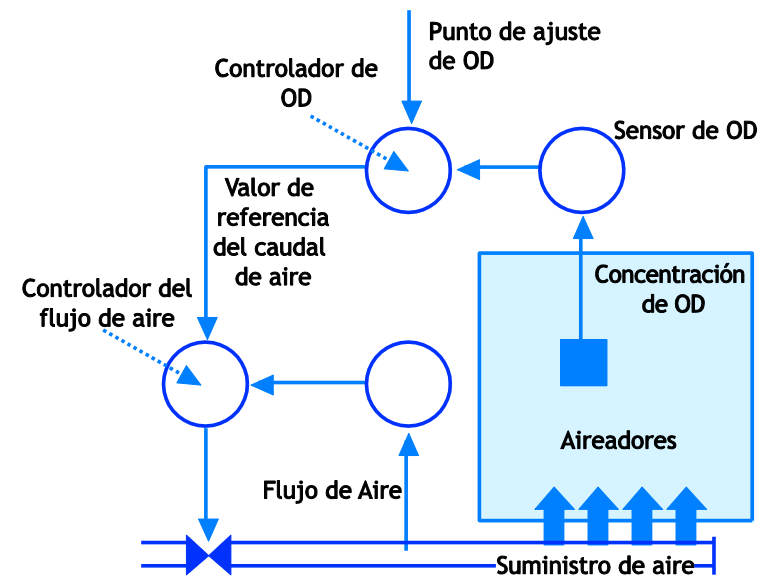

Figura 15.11 Estructura de un circuito de control de oxígeno disuelto estándar

Hay dos razones importantes por las que el controlador de OD no está acoplado directamente a la válvula. La primera razón tiene que ver con las características de la válvula. Por lo general, las válvulas no son lineales, como en una válvula de mariposa. Un cambio del $10 \%$ de la señal de la válvula producirá respuestas significativamente diferentes si la válvula está casi cerrada, en un punto medio o casi totalmente abierta. Esto significa que un cambio de flujo de aire deseado tiene que dar lugar a movimientos muy diferentes de la válvula si la válvula está casi cerrada o si está casi completamente abierta. Si se mide el flujo de aire, a continuación, el controlador de flujo es capaz de producir sólo la tasa de flujo que es requerida. Utilizando un controlador de circuito cerrado con esclavo asegura que el controlador maestro recibe una tendencia lineal en el sistema de flujo de aire. La segunda razón tiene que ver con la puesta en marcha del sistema de control. El controlador esclavo está sintonizado mientras que el controlador maestro se establece como manual. Entonces uno puede asegurarse de que la respuesta del sistema de flujo de aire es la adecuada. Una vez se ha hecho esto, el controlador maestro puede ser puesto en modo automático y posteriormente sintonizado.

Ejemplo 15.2: Control de punto de ajuste (set-point control) de OD basado en mediciones de amonio

Con el desarrollo de sensores de nutrientes ha sido posible extender el control de oxígeno disuelto para permitir un ajuste en línea del nivel de suministro de oxígeno. Para un sistema de recirculación esto significa que el punto de referencia apropiado de OD se puede determinar a través de mediciones en línea.

En este tipo de control un medidor de amoniaco en línea se coloca cerca de la salida del tanque de aireación. En condiciones ideales la concentración de amoníaco disminuirá a lo largo del aireador y llegar a un valor bajo justo antes de la salida. Si la concentración de amoníaco es demasiado baja, entonces la aireación puede modificarse y la calidad del efluente puede entonces alcanzarse con menos aire. En consecuencia, el punto de ajuste de OD se puede disminuir en las últimas zonas del aireador. Del mismo modo, si la concentración de amoníaco es demasiado alta en la salida, entonces es necesario tratar de mejorar la tasa de nitrificación aumentando el punto de ajuste de OD de modo que la concentración baja deseada de amoníaco puede ser alcanzada. Sin embargo, aumentar el flujo de aire puede no ser suficiente. La carga puede ser simplemente demasiado alta y la capacidad de nitrificación insuficiente para esta carga. Por lo tanto el valor superior del punto de ajuste de OD debe limitarse.

La Figura 15.12 muestra el resultado del control del OD con un valor de variable del punto de ajuste en la PTAR de Kallby en Lund, Suecia. Es una planta con predesnitrificación y una población equivalente (PE) de 100.000. En esta PTAR se ha probado el uso de una de dos líneas idénticas paralelas con un controlador de punto de ajuste de OD en base a las concentraciones de amonio al final de la parte aireada de la planta. Un controlador simple de tipo proporcional-integral (PI) se utiliza para cambiar el valor del punto de ajuste del OD, basado en la señal del sensor de amoníaco en la salida del aireador. El valor del punto de ajuste luego se envía al sistema controlador de OD como el que se muestra en la Figura 15.11. El controlador resultante consiste ahora una estructura jerárquica de tres controladores que trabajan 

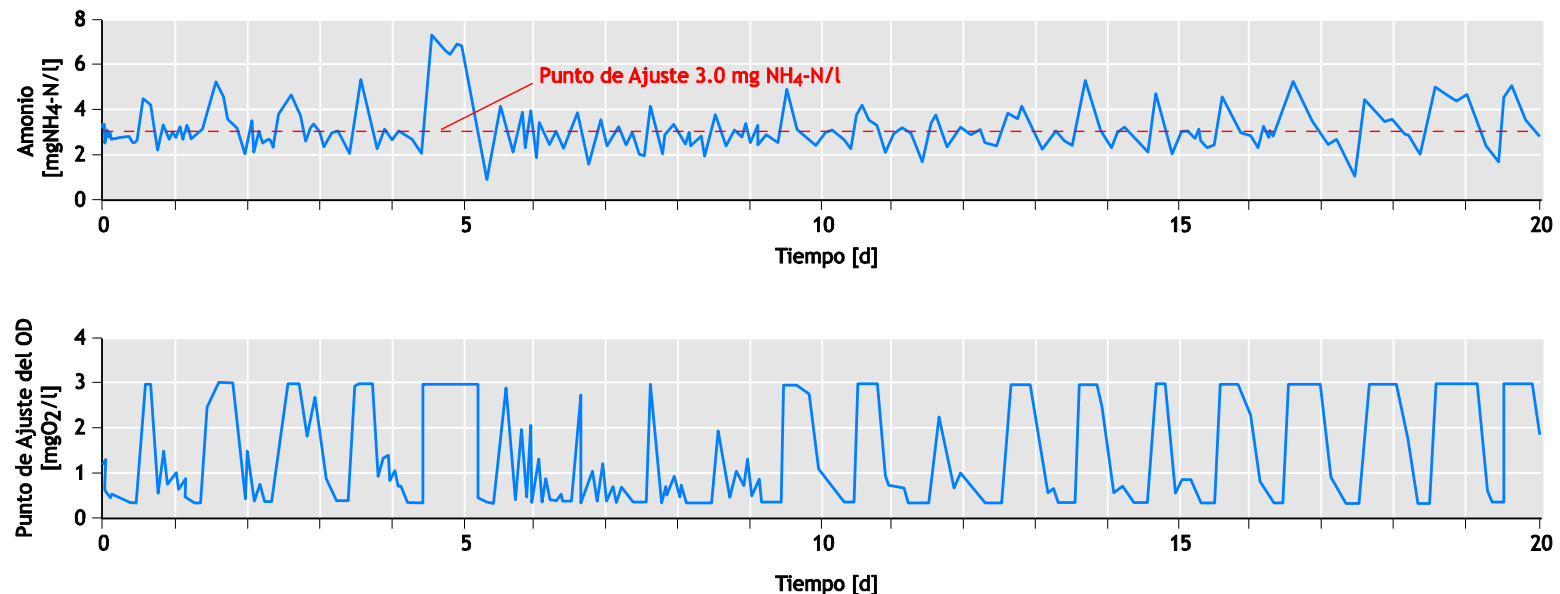

Figura 15.12 Control de OD con punto de ajuste de OD variable. El gráfico superior muestra la concentración de amonio en el extremo de la parte aireada de la planta. El punto de ajuste de amonio es de $3 \mathrm{mg} / \mathrm{l} \mathrm{NH} 4-\mathrm{N}$. El gráfico inferior muestra el punto de ajuste de OD durante el mismo tiempo. El punto de ajuste de OD está limitado entre 0.5 y $3 \mathrm{mg} / \mathrm{l}$ (de Ingildsen, 2002)

en una cascada con el principio maestro-esclavo. El rendimiento del controlador se muestra en la Figura 15.12. En ocasiones, en presencia de una alta concentración de amoniaco en el afluente, el punto de ajuste del OD se eleva al valor máximo de $3 \mathrm{mg} / \mathrm{l}$. En períodos de baja carga de amoniaco el punto de ajuste de OD se puede disminuir a valores mucho más pequeños.

En este caso se limita a no ser inferior de $0.5 \mathrm{mg} / \mathrm{l}$. Al permitir un punto de ajuste del OD variable es posible ahorrar energía para aireación. Durante el periodo de pruebas en esta planta, se obtuvieron ahorros energéticos en aireación del orden $28 \%$ en comparación con la línea paralela en la que se aplicó un punto de ajuste del OD constante. Esto corresponde a una parte significativa de los costos de funcionamiento y puede motivar el costo adicional de un dispositivo en línea para la medición de amoníaco.

\section{Ejemplo 15.3: Control de la precipitación química}

En muchas plantas la eliminación de fósforo se obtiene mediante precipitación química. Los procesos de precipitación química son mucho más rápidos que las reacciones biológicas. En comparación con la escala de tiempo de las variaciones en el caudal de aguas residuales y la composición, se puede asumir que la precipitación química ocurre instantáneamente. Esto representa una característica interesante desde el punto de vista del control, ya que implica que la perturbación puede ser tratada rápidamente a través del control por retroalimentación. No obstante, lo difícil en esta situación es lograr una medida oportuna y fiable de las variables clave del proceso para poder establecer un sistema de control por retroalimentación.

La precipitación química se puede aplicar antes o después de la etapa de tratamiento biológico, lo que se conoce como pre-precipitación y post-precipitación respectivamente. Los productos químicos también se pueden agregar directamente en el aireador, en lo que se denomina una precipitación simultánea. Muchas plantas aplican una combinación de estos diferentes tipos de precipitación. A continuación se muestra como con un sensor de fosfato, se puede lograr un excelente rendimiento de control usando un controlador por retroalimentación sencillo. Lo anterior se ilustra para el proceso de post-precipitación.

El fósforo se precipita mediante post-precipitación en la planta de tratamiento Källby, Lund, en Suecia. La línea consiste de un sistema de dosificación, donde los productos químicos de precipitación se introducen en la corriente de agua que va a una cámara de floculación donde una mezcla suave asegura la formación de flóculos químicos, seguido de un tanque de sedimentación, donde se extrae el lodo. El tiempo medio de permanencia en la cámara de floculación es de 1 hora y el tiempo medio de permanencia en las cámaras de sedimentación es de 4.3 horas. Las líneas biológicas anteriores logran una eliminación biológica de fósforo parcial y la precipitación química se aplica para eliminar la cantidad restante de fosfato, cuyo valor es típicamente de $2 \mathrm{mgP} / \mathrm{l}$.

A continuación, se comparan dos estrategias de control: 
- Dosificación proporcional al flujo: Se trata de una estrategia común, pero se basa en la suposición de que la concentración de fósforo es constante. Sin embargo, este no es siempre el caso. La suposición de una relación constante entre la carga de fosfato afluente y la dosificación puede no ser del todo correcta, ya que factores como el $\mathrm{pH}$ pueden influir en el proceso.

- Control por retroalimentación: en este caso se aplica un sistema de retroalimentación que controla la dosificación alrededor de punto de ajuste determinado de fosfato en el efluente. La señal de retroalimentación proviene de un dispositivo de medición de fosfato en línea situado al final del reactor de floculación.

Un controlador de flujo proporcional fue probado durante 35 días. El rendimiento en términos del fosfato efluente se puede ver en la Figura 15.13.

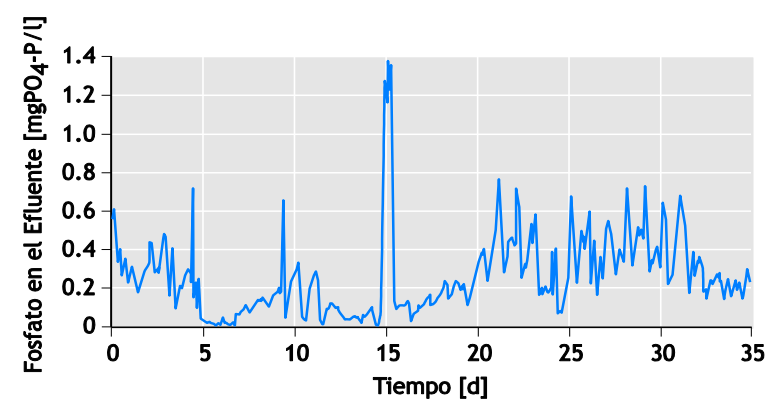

Figura 15.13 La concentración de fosfato en el efluente con control de dosificación química basada en la tasa de flujo hidráulico (tomado de Ingildsen 2002)

Se pueden observar cuatro períodos en los cuales la concentración de fosfato efluente no se controló adecuadamente (días 9, 10, 11 y 15). Especialmente el último incidente (día 15) se puede apreciar fácilmente, ya que la concentración de fosfato en el efluente aumenta drásticamente. El criterio para el efluente es de $0.5 \mathrm{mg} / \mathrm{l}$, y es obvio que la concentración es a menudo menor que $0.5 \mathrm{mg} / \mathrm{l}$. En otros períodos es mucho mayor, por lo que la variabilidad del fosfato en el efluente es alta. Obviamente, a veces el esquema de dosificación es demasiado ambicioso y esto se refleja directamente en los costos de operación.

El tiempo de retención en la cámara de floculación es corto y en promedio alrededor de 1 hora. Esto es considerablemente menor que la constante de tiempo de variación en la carga afluente de fosfato a la etapa química. Por lo tanto, debería ser posible controlar la precipitación de fosfato por medio de un control por retroalimentación basado en un sensor de fosfato in situ localizado en el efluente de la cámara de floculación. La concentración de fosfato en el afluente varió de 1 a 3 $\mathrm{mg} / \mathrm{l}$, mientras que el valor objetivo era de $0.5 \mathrm{mg} / \mathrm{l}$.

El rendimiento en términos de la concentración de fosfato en el efluente se puede ver en la Figura 15.14. El punto de ajuste se cambió a propósito de 0.5 a $0.4 \mathrm{mg} / \mathrm{l}$ de $\mathrm{PO}_{4}-\mathrm{P}$ en el día 23 y de nuevo a $0.5 \mathrm{mg} / \mathrm{l}$ en el día 33 . La concentración pico en el día 31 se debe a un fallo de funcionamiento de la bomba de dosificación. El controlador propuesto se basa en la concentración de fosfato en el efluente, mientras que la mayoría de los límites permisibles para efluentes se definen en términos de la concentración de fósforo total. En la planta de Källby se verificó que el fósforo total y las concentraciones de ortofosfato están linealmente correlacionados, con un valor de regresión de 0.96. Esto significa que es posible controlar el proceso hacia un determinado punto de ajuste de fosfato y estar razonablemente seguros de que la concentración de fósforo total cumple con los requisitos.

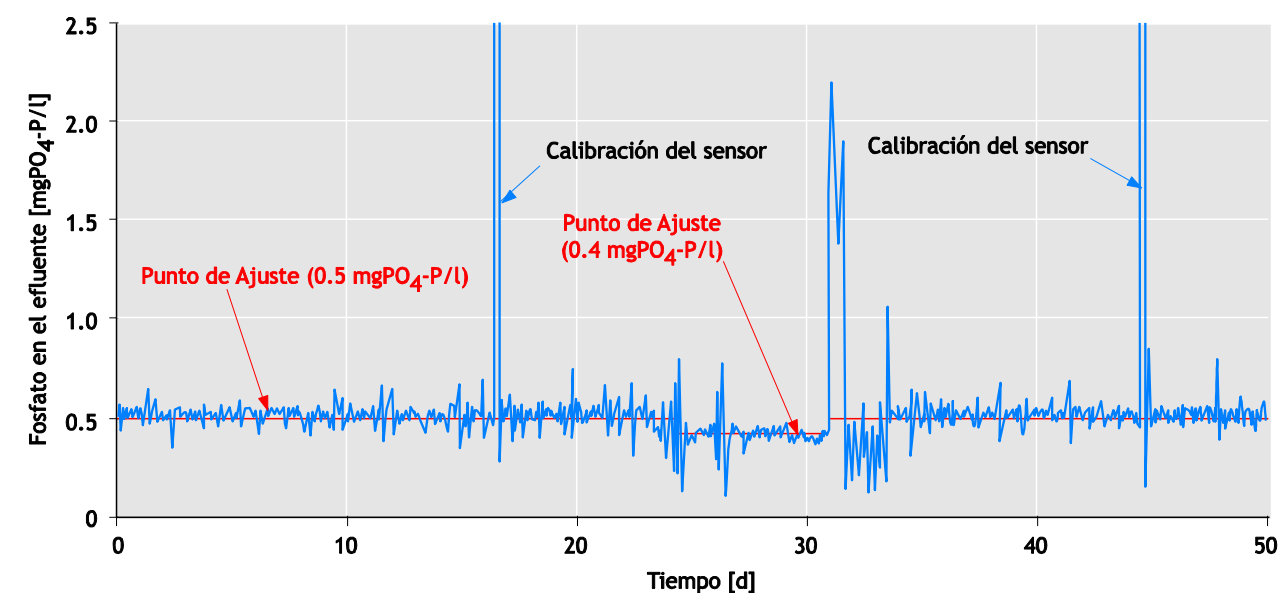

Figura 15.14 La concentración de fosfato efluente con control de dosificación química basado en mediciones de fosfato in situ (Ingildsen, 2002) 
El controlador por retroalimentación funciona bien en términos de precisión. Esto puede utilizarse para cuantificar los ahorros cuando se comparan diversas estrategias de control. El control por retroalimentación in situ con $0.5 \mathrm{mg} / \mathrm{l}$ como punto de ajuste se utiliza como base para la comparación. Ahora se puede comparar la dosis química de las distintas estrategias basadas en el 90\% de cumplimiento. Si se acepta el cumplimiento de $90 \%$ del tiempo, esto significa que para el $10 \%$ del tiempo la dosificación puede ser menor que en el controlador de retroalimentación. Este cumplimiento del 90\% se incluye para evitar situaciones extremas. En este caso una línea de la planta se hizo funcionar con una dosificación proporcional al flujo, mientras que la línea paralela se hizo funcionar sobre la base de las mediciones de fosfato. La cantidad de sustancias químicas se puede disminuir en más del 35\% comparado una dosificación proporcional al caudal con una dosificación por retroalimentación. El tiempo de recuperación de la inversión para un equipo de medición de fosfato en línea es por lo tanto muy pequeño, y en este caso en particular inferior a seis meses.

\section{Ejemplo 15.4: Control del reactor anaerobio}

La principal desventaja de la digestión anaerobia es que a menudo se percibe como inestable durante las operaciones de puesta en marcha y el estado de equilibrio. Un desequilibrio en el ecosistema microbiano puede conducir a una sobrecarga orgánica, que puede causar una severa reducción en la capacidad de degradación y un lavado de los microorganismos del sistema, lo que resulta en una mala calidad del efluente del reactor. La forma tradicional de evitar este tipo de inestabilidades es operar el proceso muy por debajo de la capacidad teórica del reactor. Adicionalmente, la naturaleza de las características del afluente implica que existen variaciones dinámicas tanto en el caudal como en la composición, lo cual puede ocasionar una perturbación de los procesos. La manipulación de estas perturbaciones mediante atenuación o eliminación, es por lo tanto importante para obtener un funcionamiento estable. Un enfoque más viable económicamente para superar el problema es mediante la aplicación de una estrecha vigilancia y control automático del proceso, con el fin de mejorar la estabilidad operacional para atenuar y rechazar perturbaciones y para permitir el tratamiento de residuos y la producción de biogás a una tasa específica más alta (Liu, 2003).
Muchos bioreactores anaerobios todavía están siendo operados sin una estrecha vigilancia y control. Esto no sólo se debe al hecho de que el proceso anaerobio implica un complicado mecanismo de pasos de degradación, sino también es debido a la falta de dispositivos analíticos apropiados. De hecho, la tecnología de los sensores constituye la parte más débil de la cadena del proceso (Liu, 2003; Olsson et al, 2005). Un control y monitoreo constante del proceso de digestión requiere en primer lugar de la identificación de los parámetros de proceso adecuados, los cuales pueden dar indicios de desequilibrios en el ecosistema microbiano y a la vez advertir sobre la existencia de perturbaciones externas. La actividad de los diferentes grupos microbianos implicados en el proceso de digestión se puede medir indirectamente mediante el monitoreo de los metabolitos. En general, hoy en día es posible medir el pH, alcalinidad, flujo y composición del biogás, AGVs, materia orgánica biodegradable, hidrógeno disuelto, y la toxicidad en línea mediante el uso de sensores e instrumentos menos costosos (Liu, 2003).

Las variables típicas de medición incluyen al $\mathrm{pH}$ y la información de la fase gaseosa debido a que dependen de dispositivos de medición disponibles en el mercado los cuales hoy en día son muy fiables, robustos y de bajo costo, y que además requieren de poco mantenimiento. En algunos casos también se han utilizado la alcalinidad y el contenido de hidrógeno en la fase gaseosa. Por lo general, la tasa de alimentación constituye la variable de control. Otro enfoque interesante reportado en los últimos años es la estrategia de control por sondeo basado en el análisis del efecto de perturbaciones que se introducen a propósito con el caudal afluente (Steyer et al., 1999). Al aumentar el caudal afluente durante un corto período de tiempo, el aumento de la producción de biogás se puede comparar con la producción esperada.

La puesta en marcha de reactores anaerobios es relativamente lenta debido al bajo crecimiento neto de la biomasa anaerobia y la adaptación que requieren a los componentes específicos de las aguas residuales. Por lo tanto, la puesta en marcha es un proceso crítico que depende en gran medida de la habilidad de los operadores. Después del período de puesta en marcha el proceso es también vulnerable a perturbaciones tales como sobrecargas temporales, el lavado de la biomasa y toxicidad. Con un buen sistema de control el reactor anaerobio puede - incluso durante el arranque transitorio y con carga elevada - ser operado cerca de su capacidad máxima y aun así mantener un funcionamiento estable 
(Liu et al, 2004.). Diferentes esquemas de control para el proceso de digestión anaerobia se han reportado en el Simposio de la IWA sobre la digestión anaerobia, por ejemplo el trabajo de Van Lier y Lubberding (2002).

\section{Observaciones sobre el control}

Si un sistema de control no puede desempeñarse lo suficientemente bien por retroalimentación directa de variables observadas, entonces se puede tratar de incorporar un modelo del sistema en el controlador. Este modelo constituye la base de un control predictivo sofisticado. En consecuencia, los modelos dinámicos simplificados que permiten que todos los parámetros del modelo que se actualicen de forma única a partir de mediciones disponibles en línea y con diferentes horizontes temporales de predicción pueden ser muy útiles. Naturalmente, la escala de tiempo de los modelos también debe estar relacionada con la escala de tiempo en el que la variable controlada puede influir en el proceso. La eficacia para manejar una alta complejidad del proceso por modelos jerárquicos y modulares se ha demostrado en numerosas aplicaciones en la industria de procesos. En consecuencia, se sugiere que los sistemas de control de procesos para proyectos futuros en el sector del tratamiento de agua y saneamiento se basen en principios similares.

Para mejorar la fiabilidad de un sistema de control, es esencial contar con un control alternativo del sistema. Cuando se producen fallas graves, por ejemplo un fallo en el actuador o fallos en los sensores, el sistema de control debe reaccionar y aplicar una estrategia de control robusta que puede no ser óptima, pero que evite fallos significativos en los procesos. Una vez que la funcionalidad de los equipos se restaure, el sistema de control puede devolver el proceso a un estado de funcionamiento más eficiente. Para cualquier aplicación de control exitosa también es necesario que el proceso sea lo suficientemente flexible como para permitir un grado razonable de libertad en términos de la manipulación por parte del sistema de control. Naturalmente, cualquier proceso nuevo debe estar diseñado para tal flexibilidad en lugar de tener que ser sometido a costosas reconstrucciones en el futuro. En muchas situaciones esto es un obstáculo importante para una implementación exitosa del control de procesos en sistemas de agua y aguas residuales.

\subsection{AHORROS DE COSTOS DE OPERACION DEBIDOS AL CONTROL}

El consumo de energía eléctrica está estrechamente relacionado con los sistemas de tratamiento de aguas residuales avanzados. El tratamiento y conducción de agua y aguas residuales requiere de grandes cantidades de energía. En un país como Suecia las operaciones de agua y aguas residuales utilizan el $1 \%$ de la oferta nacional total de energía eléctrica. Mientras que el costo de la energía eléctrica ha sido bastante bajo no se ha prestado mucha atención a este aspecto. Sin embargo, ya que los precios están aumentando el interés en el ahorro de energía ha ido en aumento. Los requisitos energéticos para un sistema se pueden definir de diferentes formas, tales como $\mathrm{kWh} /$ persona/año o $\mathrm{kWh} / \mathrm{kg}$ de $\mathrm{N}$ eliminado, etc. En esta sección no se discutirán los diversos métodos para la estimación de la utilización de energía. En lugar de ello, se mencionan y resaltan factores importantes donde el control y la automatización pueden reducir los requerimientos de energía eléctrica.

El control del oxígeno disuelto ha sido discutido previamente. Es bastante obvio que incluso un sencillo control de OD, sobre la base de un solo sensor de oxígeno, genera un ahorro importante de la cantidad de energía eléctrica necesaria en comparación con no tener ningún control en absoluto. Además, teniendo un punto de ajuste variable de la concentración del OD el consumo de energía se puede reducir aún más, tal y como se discutió en la Sección 15.8. Hay otras posibilidades para el ahorro de energía en el control del OD. La presión de aire también se puede minimizar. Supongamos que una planta tiene dos o más aireadores funcionando en paralelo. El sistema de aire puede garantizar un suministro de aire suficiente para la planta. Sin embargo, en ocasiones la presión puede bajar. Esto se puede observar cuando las válvulas de flujo de aire no están completamente abiertas y se produce entonces una caída de presión en las válvulas. La idea es reducir gradualmente la presión del flujo de aire de tal manera que la válvula de flujo de aire más abierta se lleve a un estado casi completamente abierto. Posteriormente, la caída de presión se reduce al mínimo y los ahorros de energía posibles son aún mayores. Tales métodos de control ya han sido aplicados; véase, por ejemplo OlssonNewell (1999).

Las bombas de gran capacidad, principalmente utilizadas para el manejo del agua de los afluentes, son a menudo los equipos que consumen más energía en una planta de tratamiento. En muchos casos, el equipo de 
bombeo no ha sido diseñado adecuadamente para los caudales que recibe. Si la bomba está sobre-diseñada entonces puede llegar a ser operada con una eficiencia baja para caudales pequeños. En algunos casos específicos ha resultado rentable instalar una bomba especial encargada de manejar caudales muy pequeños. El uso de bombas que operan fuera de su punto de máxima eficiencia es un problema bastante común.

La aireación mediante el uso de compresores debería tener un mecanismo de variación de forma continua. El control del flujo de aire mediante el cierre de válvulas de flujo provoca una gran cantidad de pérdidas de energía. El uso de compresores de velocidad variable permite ahorrar energía de manera significativa. En términos generales, el requisito de potencia para un flujo de aire es proporcional a $\mathrm{n}^{3}$, donde $\mathrm{n}$ es la velocidad de rotación. Esto significa que al reducir un flujo de aire a la mitad sólo se requiere utilizar 1/8 de la potencia necesaria. En consecuencia, el potencial ahorro de energía es grande.

El costo de los productos químicos es significativo en plantas donde se utiliza precipitación química. En la Sección 15.8 se demostró que el control por retroalimentación puede contribuir a bajar los costos de operación.

Una planta de tratamiento de aguas residuales debería considerarse como una planta de recuperación de nutrientes y energía. Si se tiene en cuenta el potencial de energía en la digestión anaerobia hay un enorme potencial no utilizado en la mayoría de las instalaciones de tratamiento de aguas. Esto se puede ilustrar con un buen ejemplo de la planta de tratamiento de aguas residuales Rya en Gotemburgo (Suecia): la planta utiliza $41 \mathrm{kWh} /$ persona/año de energía eléctrica. Al mismo tiempo, la planta produce biogás correspondientes a 72 kWh/cap.año. Adicionalmente, el contenido de calor de las aguas residuales efluentes se recupera mediante bombas de calor las cuales producen $336 \mathrm{kWh} /$ cap.año. Esta planta es de hecho, un importante productor de energía.

Datos recientes muestran que la digestión anaerobia sólo utiliza alrededor del $20 \%$ de la energía contenida en las aguas residuales. Los subproductos del tratamiento de las aguas residuales pueden proporcionar una valiosa fuente de energía si se gestiona y se utiliza con eficacia. Adicionalmente, los costos de transporte y disposición de lodos, que actualmente representan una carga importante en la industria, se podrían reducir. La Sección 15.8 describe el potencial del uso de ICA en la operación de digestores anaerobios.

\subsection{INTEGRACION Y CONTROL DE TODA LA PLANTA}

La integración tiene como objetivo minimizar el impacto en las aguas receptoras, al tiempo que garantiza una mejor utilización de los recursos. La capacidad de recuperación del sistema es un factor importante. Esto incluye su capacidad para atenuar las perturbaciones, pero también debe reflejar su sensibilidad a perturbaciones importantes o incluso ataques intencionados y dañinos. En el enfoque integrado la meta final corresponde a formular un criterio para la calidad ecológica de los cuerpos de aguas receptoras, al mismo tiempo que satisfacer las diversas limitaciones económicas y técnicas. Hay un gran reto a la hora de relacionar este rendimiento con el efluente de la planta y el posible desbordamiento del alcantarillado. Es necesario obtener indicadores del rendimiento de la operación de la planta que relacionen la calidad del efluente con los recursos que se necesitan para lograrlo, tales como energía, productos químicos y otros materiales, y costos de operación. Esto no está aún resuelto de manera satisfactoria, pero existen investigaciones prometedoras en curso, como el proyecto de investigación CD4WC (2005) de la Unión Europea. Algunos modelos se están desarrollando para encontrar estrategias que permitan encontrar dinámicamente, una máxima carga de la planta de acuerdo a un monitoreo continuo y a una predicción del estado de funcionamiento de la misma. Un ejemplo es la maximización de la capacidad de nitrificación en el proceso de lodos activados, dependiendo de la carga del sistema. Rosen $e t$ al. $(2004,2006)$ han reportado algunos resultados a escala real. Otro aspecto importante es la gestión del almacenamiento (en el sistema de alcantarillado y en los tanques de retención), no sólo durante los eventos de lluvia, sino también durante la operación normal del sistema. Mediante la mezcla de diferentes tipos de aguas residuales se puede compensar por ejemplo, el déficit de nutrientes o la capacidad de la planta, y de esta forma maximizar la capacidad operacional de la panta.

Toda integración implica algún tipo de compromiso en los sistemas. Si no existiera ningún tipo de interacción entre los diferentes componentes del sistema, entonces la mejor estrategia sería la de optimizar individualmente cada proceso unitario. En la aplicación práctica, el acoplamiento de los diferentes procesos permite lograr 
un mejor resultado. Esta es la esencia del uso de índices multi-criterio: diversos rendimientos son calculados, ponderados y comparados entre sí. A continuación se ilustra esta idea con algunos ejemplos:

- La interacción entre el aireador y el clarificador es un problema clásico de integración, que refleja el compromiso que se tiene que lograr mediante el control del caudal de lodos de recirculación.

- La zona anóxica en una planta de pre-desnitrificación interactúa estrechamente con el aireador nitrificante. El agua rica en oxígeno se recircula desde el tanque de aireación a la zona anóxica. El nivel de OD se tiene que ajustar a un punto medio que garantice una suficientemente buena nitrificación y desnitrificación (Figura 15.15).

- Existe una interacción entre los procesos vinculados en serie. Por ejemplo, una pre-precipitación química en un clarificador primario eliminará no sólo los fosfatos, sino también partículas de material orgánico. Esto ahorrará energía de aireación, pero por otro lado, la pre-desnitrificación puede entonces recibir poco carbono. Del mismo modo, si la precipitación se combina con un proceso de EBPR, este último podría estar limitado por el carbono.

- Las corrientes de recirculación interconectan distintas partes de una planta de tratamiento. Los sobrenadantes del tratamiento de lodos tienen a menudo altas concentraciones de nutrientes y tienen que estar sincronizados a tiempo con la carga del afluente que llega a la planta.

- El agua de retrolavado de filtros de lecho profundo se recircula a la entrada de la planta. Dado que las tasas de flujo son a menudo significativas es necesario tener un control sincronizado del caudal y la carga de la planta.

- El objetivo en la producción de lodos no es el mismo en diferentes plantas. A veces, el objetivo consiste en maximizar la producción de metano, mientras que en otras plantas la producción de lodos debe minimizarse.

- En la operación combinada de un alcantarillado y una PTAR, las operaciones individuales del sistema a veces entran en conflicto por lo que el objetivo general de reducir la carga que llega al agua receptora, tiene que hacer caso omiso de los objetivos individuales (Rauch-Harremoës, 1996a;. Schütze et al, 1999; Vanrolleghem et al., 1996). Un enfoque inicial para el control integrado fue publicado por Rauch-Harremoës (1996b).

Un sistema de control global para toda la planta supone que todos los diferentes procesos unitarios se controlan a nivel local. Adicional a esto, se tiene en cuenta la interacción entre las diferentes partes de la planta, por ejemplo, mediante el cálculo de puntos de ajuste adecuados para los diferentes controladores locales. El sistema de control del alcantarillado controla la velocidad de flujo en las diferentes partes del sistema de alcantarillado con la información que brindan los sensores de nivel de agua y caudal, equipos de bombeo, y pluviómetros. El acoplamiento entre el sistema de alcantarillado y el control de la planta de tratamiento se alcanza cuando el caudal afluente puede predecirse y manipularse. Las mediciones típicas y los elementos de control para el manejo integrado de un sistema de alcantarillado y una planta de tratamiento de aguas residuales se mencionan en la Tabla 15.4 .

Tabla 15.4 Objetivos, medidas y control de funcionamiento para la operación de un sistema combinado de alcantarillado y tratamiento de aguas residuales

\begin{tabular}{|c|c|c|c|}
\hline Sub-sistema & o parcial & Medi & Elementos de control \\
\hline $\begin{array}{ll}\text { Sistema } & \text { de } \\
\text { alcantarillado } & \end{array}$ & $\begin{array}{l}\text { - Minimizar el desbordamiento } \\
\text { aguas arriba } \\
\text { - Utilizar tanques para el agua } \\
\text { más contaminada }\end{array}$ & ación & $\begin{array}{l}\text { - Estaciones de bombeo } \\
\text { - Vertederos ajustables } \\
\text { - Tanques }\end{array}$ \\
\hline $\begin{array}{l}\text { Planta de } \\
\text { tratamiento de } \\
\text { aguas residuales }\end{array}$ & $\begin{array}{l}\text { - Tratar la mayor cantidad } \\
\text { posible de agua residual } \\
\text { durante y después de una } \\
\text { lluvia } \\
\text { - Reducir la carga hidráulica y } \\
\text { la carga de lodos en los } \\
\text { clarificadores secundarios }\end{array}$ & $\begin{array}{l}\text { - Caudales (entrada, salida, } \\
\text { lodo recirculado, } \\
\text { recirculación) } \\
\text { - Sólidos suspendidos } \\
\text { (tanques de aeración y } \\
\text { lodo recirculado) } \\
\text { - Manto de lodos }\end{array}$ & $\begin{array}{l}\text { - Bombeo de lodos de recirculación } \\
\text { (control de manto de lodos en los } \\
\text { clarificadores secundarios) } \\
\text { - Control de la sedimentación en tanques } \\
\text { de aireación } \\
\text { - Bombeo primario (derivación antes de la } \\
\text { sección biológica o el total de la planta) }\end{array}$ \\
\hline
\end{tabular}






Figura 15.15 Detalle de la medición y el control del tanque de aireación en un sistema de lodos activados (foto: D. Brdjanovic)

\subsection{OBSERVACIONES FINALES}

La automatización consiste en el método que hace que un proceso o un sistema operen automáticamente. La incertidumbre en el proceso o en el ambiente alrededor del proceso hace que la automatización sea a la vez una gran oportunidad y un gran reto. Las perturbaciones se encuentran en todas partes y son la razón principal del control de sistemas. La aplicación de la automatización en la operación de un sistema de tratamiento de aguas residuales se puede decir que cumple dos funciones principales: la adquisición de información y el control de los procesos. Para la primera, el nivel de automatización es relativamente alto. Muchas variables, a menudo miles (hay plantas con hasta 30,000 variables), se registran hoy en día en línea en los sistemas SCADA de las plantas de tratamiento, los cuales cuentan con componentes estándar para la operación del tratamiento y el control de calidad y permiten realizar análisis de datos más o menos sofisticados. Sin embargo, la segunda función para el control de los procesos, se encuentra menos desarrollada y con frecuencia limitada a unos pocos sistemas de control de procesos unitarios. Cabe señalar que el funcionamiento de una planta es sub-óptimo si solo opera con controladores locales. El potencial de automatización global de una planta consiste en coordinar los diversos procesos unitarios de tal modo que los requerimientos globales de rendimiento y tratamiento puedan realizarse con mayor eficacia.

Es bastante evidente que una buena operación depende de que los equipos funcionen adecuadamente. Todos los eslabones de la cadena tienen que estar trabajando para obtener un buen sistema operativo. El hardware incluye no sólo la instrumentación, sino también todos los diferentes solenoides, tales como compresores, bombas, motores y válvulas.

Los desarrollos a futuro van a beneficiarse de la enorme capacidad para la distribución de datos que es posible hoy en día. Muchos sistemas SCADA también implementan comunicaciones a través de internet lo que le da un potencial casi ilimitado para la evaluación de datos de forma remota y la toma de decisiones. La posibilidad de tener una sala de control distribuida ya es posible hoy en día. Aun así, existe un límite de cuanta especialización puede permitirse una planta de tratamiento. Sin embargo, dado que los datos de la planta pueden estar disponibles en cualquier lugar, es posible utilizar las competencias especializadas donde quiera que estas se encuentren. No obstante, existen varios aspectos de gestión del personal para el manejo de la distribución de la responsabilidad y la toma de decisiones en diversos sectores. En el proyecto TELEMAC UE se desarrolló un sistema de monitoreo y control remoto para uso en instalaciones de tratamiento de aguas residuales de vinos, en donde un experto se encuentra remotamente supervisando unas 20 plantas de tratamiento pequeñas. Ya existen software comerciales disponibles de este tipo para realizar monitoreos y control de procesos. Naturalmente deben tomarse precauciones para prevenir la divulgación de datos sensibles o un uso indebido de la información. También, hay necesidad de garantizar que los datos se interpreten correctamente desde cada planta individual.

La creciente incorporación de ICA en la operación de plantas de tratamiento de aguas no ha sido impulsada únicamente por el impresionante desarrollo tecnológico de la instrumentación y las tecnologías de la información, la modelización y el control, y los avances en la automatización. El auge de ICA también responde por una parte a las obligaciones ambientales y los beneficios económicos que resultan de su implementación, lo que en definitiva la convierte en una verdadera inversión. Ya se ha demostrado en varias instalaciones que las inversiones en ICA han dado frutos rápidamente y a la vez se espera que la ICA se convierta en una parte cada vez más importante de la inversión total en proyectos de tratamiento de aguas.

Existe un gran cuerpo de evidencia reciente que muestra como las poblaciones microbianas y sus propiedades se determinan conjuntamente por la composición de las aguas residuales, y el diseño y operación del sistema de tratamiento. El impacto de los 
sistemas de control en las comunidades microbianas no ha llamado mucho la atención en el pasado, y la optimización de la población de los lodos a través del control de procesos en línea sigue siendo un concepto emergente (Yuan y Blackall, 2002). Es de fundamental importancia llevar a cabo estudios sistemáticos para entender cómo se seleccionan ciertos microorganismos y cómo las propiedades de las bacterias se ven influenciadas por diseños específicos de plantas de tratamiento y su operación. Diferentes técnicas moleculares modernas, tales como la hibridación fluorescente in situ (Amann et al., 1995), que permite la identificación y cuantificación de microorganismos presentes en un sistema, son herramientas indispensables para llevar a cabo estos estudios. Los avances fundamentales más importantes vendrán de la incorporación de los datos detallados a micro-escala en los modelos matemáticos actuales, de tal manera que estos modelos representen de forma más acertada los procesos que ocurren dentro de los lodos, permitiendo así la optimización de los controles basados en las modelos de poblaciones microbianas. Aun se requiere un gran esfuerzo por parte de los microbiólogos e ingenieros para lograr la aplicación práctica de estos métodos en el contexto del control de procesos.
La ICA se percibe a menudo como una tecnología oculta, es decir que sólo se nota su presencia cuando no funciona adecuadamente. La complejidad de las plantas modernas se refleja a menudo en los sistemas de ICA que implementan. Varias especialidades de la tecnología de procesos y automatización deben juntarse en un solo sistema. El reto de la automatización es el de comprender los aspectos del sistema desde una perspectiva de los procesos unitarios y a la vez de comprender los aspectos del proceso desde una perspectiva del sistema completo. Este desafío tiene profundas consecuencias en la profesión y en los enfoques educativos fundamentales, no menos importante en los planes de estudios de las carreras de ingeniería civil e ingeniería ambiental. Un aspecto importante es que los especialistas en el control de procesos tienen que ser capaces de apreciar las implicaciones de la ICA. Del mismo modo, los ingenieros informáticos $\mathrm{y}$ de sistemas tienen que entender la capacidad de control que se puede tener sobre los procesos y sus limitaciones. Esto destaca el carácter multidisciplinario de las operaciones necesarias en el control de procesos en el tratamiento de aguas residuales y a la vez muestra el desafío que debe inspiración para las futuras generaciones. 


\section{REFERENCES}

Amann R.I., Ludwig W., y Schleifer K. H. (1995) Phylogenetic identification and in situ detection of individual microbial cells without cultivation. Microbiol. Rev. 59, 143-169.

Batstone D.J., Keller J., Angelidaki R.I., Kalyuzhnyi S.V., Pavlostathis S.G., Rozzi A., Sanders W.T.M., Siegrist H. y Vavilin V.A. (2002) Anaerobic Digestion Model No.1. Scientific and Technical Report No.13, IWA Publishing, London.

CD4WC (2005) The EU research project "Cost-effective development of urban wastewater systems for water framework directive compliance" $<\mathrm{http} / /$ www.cd4wc.org >

Dochain D. y Vanrolleghem P.A. (2001) Dynamical Modelling and Estimation in Wastewater Treatment Processes. IWA Publishing, London. 342 pp.

Gernaey K.V., Nielsen M.K., Thornberg D., Höök B., Munk-Nielsen T., Ingildsen P. and Jørgensen S.B. (2004) First principle suspended solids distribution modelling to support ATS introduction on a recirculating WWTP. $2^{\text {nd }}$ Int. IWA Conf. on Automation in Wat. Quality Monitoring, Vienna.

Henze M., Gujer W., Mino T. y van Loosdrecht M.C.M. (2000) Activated Sludge Models: ASM1, ASM2, ASM2d and ASM3. Scientific and Technical Report No.9, IWA Publishing, London.

Ingildsen P. (2002) Realising Full-Scale Control in Wastewater Treatment Systems Using in Situ Nutrient Sensors. PhD thesis, Dept. of Ind. Electrical Engineering and Automation (IEA), Lund Univ, Lund.

ISO (2003) ISO15839:2003 Water Quality - On-line sensors/analysing equipment for water - Specifications and performance tests. First edition. International Standard Organization.

Liu J. (2003) Instrumentation, Control and Automation in Anaerobic Digestion. PhD thesis, Dept Biotech., Lund Univ, Lund.

Liu J., Olsson G. y Mattiasson B. (2004) Control of an Anaerobic Reactor towards Maximum Biogas Production, Wat. Sci. Tech., 50(11), 189-198.

Lynggaard-Jensen A. y Frey M. (2002) Use and Reporting of Data - Data Handling and Validation. In On-line Monitoring for Drinking Water Utilities. American Water Works Association Research Foundation, Denver, Colorado.

Nielsen M.K., Carstensen J. y Harremöes P. (1996) Combined control of sewer and treatment plant during rainstorm. Wat. Sci. Tech., 34(3-4), 181-187.
Olsson G. y Newell B. (1999) Wastewater Treatment Systems. Modelling, Diagnosis and Control. IWA Publishing, London.

Olsson G., Nielsen M.K., Yuan Z., Lynggaard-Jensen A., y Steyer J.P. (2005) Instrumentation, Control and Automation in Wastewater Treatment Systems. Scientific and Technical Report No.15, IWA Publishing, London.

Rauch W. y Harremoës P. (1996a) The importance of the treatment plant performance during rain to acute water pollution. Wat. Sci. Tech., 34(3-4), 1-8.

Rauch W. y Harremoës P. (1996b) Minimizing acute river pollution from urban drainage systems by means of integrated real time control. Proc. 1st Int. Conf. On New/Emerging Concepts for Rivers (RIVERTECH '96), Sept. 22-26, Chicago.

Rosen C., Ingildsen P., Guildal T., Nielsen M.K., Jacobsen B.N. y Ønnerth T. (2004) On-line estimation of nitrification and denitrification capacity at Avedøre wastewater treatment plant. Proc. Int. Conf. Upgrading of Wastewater Treatment Plants (AquaTech2004), Sept. 30-Oct. 1, Amsterdam.

Rosen C., Ingildsen P., Guildal T., Nielsen M.K., MunkNielsen T., Jacobsen B.N. y Thomsen H. (2006) Introducing biological phosphorous removal in an alternating plant by means of control - a full scale study. Wat. Sci. Tech., 53(4-5), 133-141.

Schütze M., Butler D. y Beck M.B. (1999) Optimisation of control strategies for the urban wastewater system - an integrated approach. Wat. Sci. Tech., 39(9), 209-216.

Steyer J.P., Buffiére P., Rolland D. y Moletta R. (1999) Advanced control of anaerobic digestion processes through disturbances monitoring. Wat. Res. 33(9), 2059-2068.

Van Lier J. y Lubberding H. (Eds.) (2002) Selected proceedings of the 9th World Congress on Anaerobic Digestion, Antwerp, 2-6 September 2001. Wat. Sci. Tech. 45 (10).

Vanrolleghem P., Fronteau C. y Bauwens W. (1996) Evaluation of design and operation of the sewage transport and treatment system by an EQO/EQS based analysis of the receiving water immission characteristics. Proc. WEF Conf. Urban Wet Weather Pollution, June 16-19, Québec, 14.35-14.46.

Vanrolleghem P.A. y Lee D.S. (2003) On-line monitoring equipment for wastewater treatment processes: State of the art. Wat. Sci. Tech., 47(2), 1-34.

Yuan Z. y Blackall L. (2002) Sludge Population Optimisation, A New Dimension for the Control of Biological Wastewater Treatment Systems. Wat. Res. 36 (2), 482-490. 
NOMENCLATURA

\begin{tabular}{ll}
\hline Abreviación & Descripción \\
\hline ADM & Modelo de digestión anaerobia (por sus siglas en inglés, Anaerobic Digestion Models) \\
AGV & Ácidos grasos volátiles \\
ASM & Modelo de lodos activados (por sus siglas en inglés, Activated Sludge Model) \\
ATS & Sedimentación del tanque de aireación (por sus siglas en inglés, Aireated Tank Settling) \\
DA & Digestión anaerobia \\
DBO & Demanda bioquímica de oxígeno \\
EBPR & Remoción biológica aumentada de fósforo (por sus siglas en inglés Enhanced biological phosphorus \\
HPF & removal) \\
ICA & Filtro de paso alto (por sus siglas en inglés, High-pass Filter) \\
IWA & Instrumentación, control y automatización \\
OD & Asociación Internacional del Agua (por sus siglas en inglés, International Water Association) \\
PI & Oxígeno disuelto \\
PID & Proporcional, integral \\
PTAR & Proporcional, integral, derivativa \\
SBR & Planta de tratamiento de aguas residuales \\
SCADA & Reactor discontinuo secuencial (por sus siglas en inglés, Sequencing Batch Reactor) \\
TRS & Supervisión, Control y Adquisición de Datos (por sus siglas en inglés, Supervisory Control and Data \\
& Acquisition)
\end{tabular}

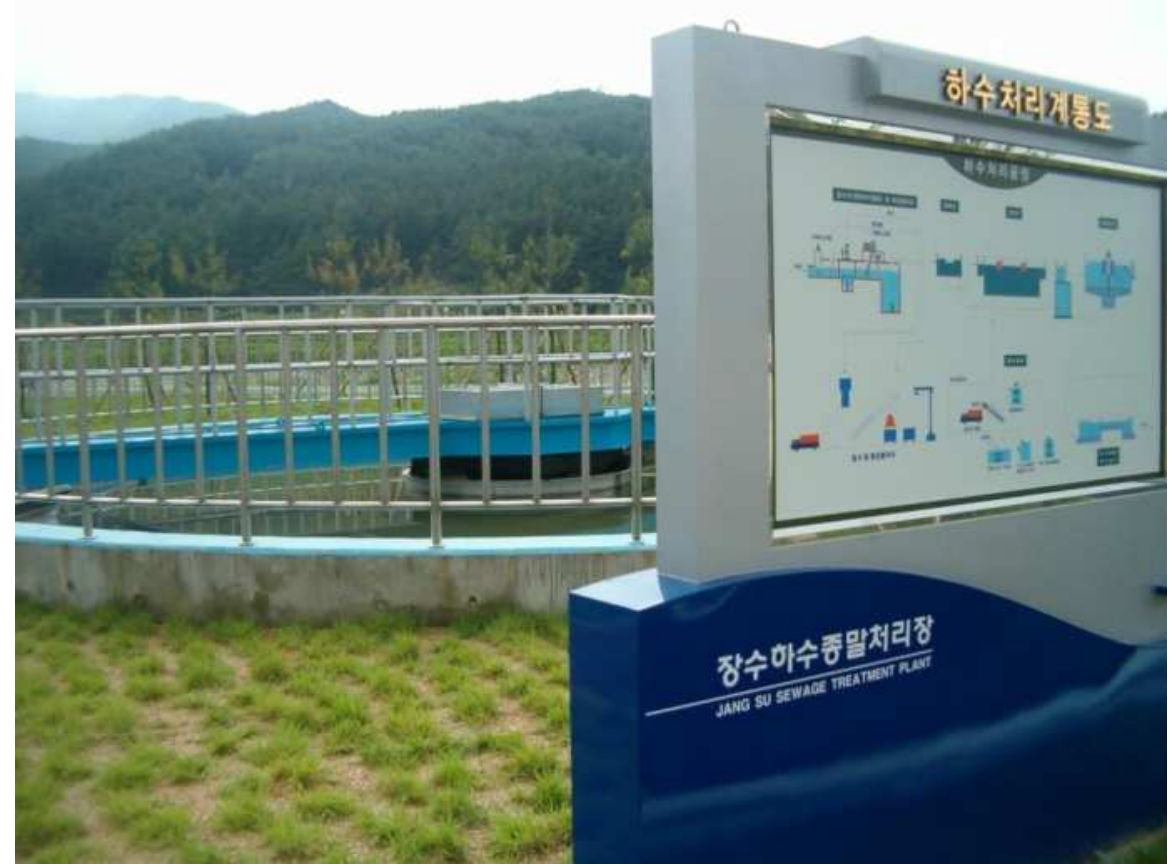

Planta de tratamiento de aguas residuales Jang Do en Corea, equipada con tecnología de instrumentación técnica, control y automatización (foto: K-water) 


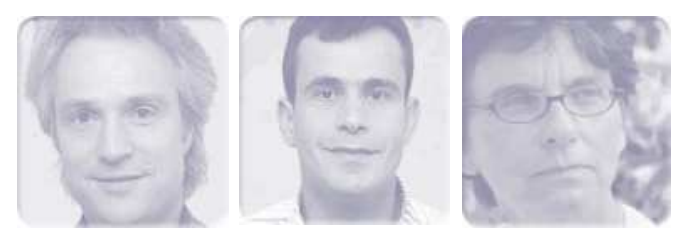

\title{
16
}

\section{Tratamiento Anaerobio de Aguas Residuales}

\author{
Jules B. van Lier, Nidal Mahmoud y Grietje Zeeman
}

\subsection{SOSTENIBILIDAD EN EL TRATAMIENTO DE AGUAS RESIDUALES \\ 16.1.1 Definición y beneficios ambientales de los procesos anaerobios}

El proceso de fermentación en el cual se degrada el material orgánico y se produce biogás (compuesto principalmente por metano y dióxido de carbono), se conoce como digestión anaerobia. Los procesos de digestión anaerobia se pueden llevar a cabo en diferentes lugares en donde se encuentre disponible materia orgánica y el potencial redox sea bajo (en ausencia de oxígeno). Este suele ser el caso de estómagos de rumiantes, pantanos, sedimentos de lagos o lagunas, vertederos municipales, o inclusive alcantarillas municipales.

El tratamiento anaerobio por si sólo es muy efectivo en la remoción de compuestos orgánicos biodegradables, dejando compuestos mineralizados como $\mathrm{NH}_{4}{ }^{+}, \mathrm{PO}_{4}{ }^{3-}, \mathrm{S}^{2-}$ en la solución. Puede llevarse a cabo en sistemas técnicamente sencillos, y los procesos pueden ser aplicados a cualquier escala y en casi cualquier lugar. Por otra parte, la cantidad de lodo producido en exceso es muy pequeña y este se encuentra bien estabilizado, inclusive puede tener un valor en el mercado cuando se produce el llamado lodo granular anaerobio en el bioreactor. Por otro lado, se produce energía útil en forma de biogás en lugar de un alto consumo de energía. Aceptando de hecho que la digestión anaerobia simplemente remueve los contaminantes orgánicos, existen muy pocos o prácticamente ningún tipo de inconvenientes graves restantes, inclusive ninguno con respecto a la velocidad de arranque del sistema. La Figura 16.1 muestra el destino del carbono y la energía en los tratamientos aerobios y anaerobios (AnWT, por sus siglas en inglés Anaerobic Wastewater Treatment) de aguas residuales, suponiendo que $1 \mathrm{~kg}$ de DQO requiere $1 \mathrm{kWh}$ de energía de aireación. En comparación con el tratamiento anaerobio, el tratamiento aerobio se caracteriza, por lo general, por los altos costos operacionales (energía), mientras que una gran fracción de los residuos es convertida en otro tipo de residuo (lodo). El tratamiento aerobio en un proceso convencional de lodos activados, produce alrededor de un 50\% (o más) de lodo nuevo a partir de la DQO convertida, el cual requiere de un tratamiento posterior, 
por ejemplo digestión anaerobia antes de su reúso, disposición o incineración. Los principios de flujo del carbono y energía en la bio-conversión aerobia y anaerobia, tienen un efecto significativo en el establecimiento del sistema de tratamiento de agua residual correspondiente. Resulta poco sorprendente que actualmente, el AnWT ha evolucionado hasta convertirse en una tecnología de tratamiento de aguas residuales competitiva. Muchos tipos de contaminantes orgánicos diferentes contenidos en las aguas residuales, inclusive aquellos que antes se pensaba no eran adecuados para su tratamiento en AnWT, ahora pueden ser tratados por procesos anaerobios con una alta tasa de conversión.

En países como Holanda, la mayoría de las aguas residuales agro-industriales son tratadas actualmente por sistemas de reactores anaerobios. Su potencial de aplicación, por ejemplo en la industria petroquímica, está creciendo rápidamente. En la Figura 16.2 se muestra el incremento gradual en el número de reactores anaerobios de alta tasa utilizados desde mediados de los setentas.

Hoy en día, un total de 2,266 de los sistemas instalados a gran escala, se encuentran en operación, los cuales han sido construidos por compañías de renombre como Paques, Biothane, Biotim, Enviroasia, ADI, Waterleau, Kurita, Degremont, Envirochemie, GWE, Grontmij, así como también algunas otras compañías locales. A este número se pueden adicionar otros 500 reactores "hechos en casa", los cuales fueron construidos por compañías locales muy pequeñas o por las mismas industrias pero que no aparecen en las estadísticas.
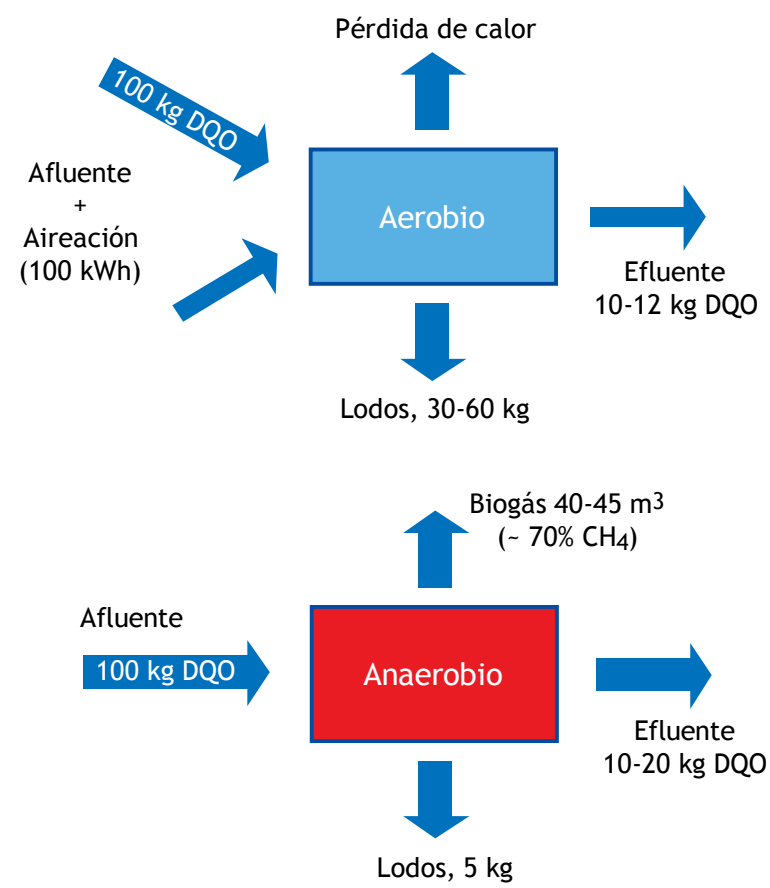

Figura 16.1 Destino del carbono y la energía en el proceso de tratamiento de aguas residuales aerobio (arriba) y anaerobio (abajo)

Analizando las razones por las cuales los sistemas AnWT fueron seleccionados, se pueden mencionar las siguientes ventajas importantes de los AnWT sobre los sistemas convencionales de tratamiento aerobio:

- reducción de hasta un $90 \%$ en la producción de lodo en exceso.

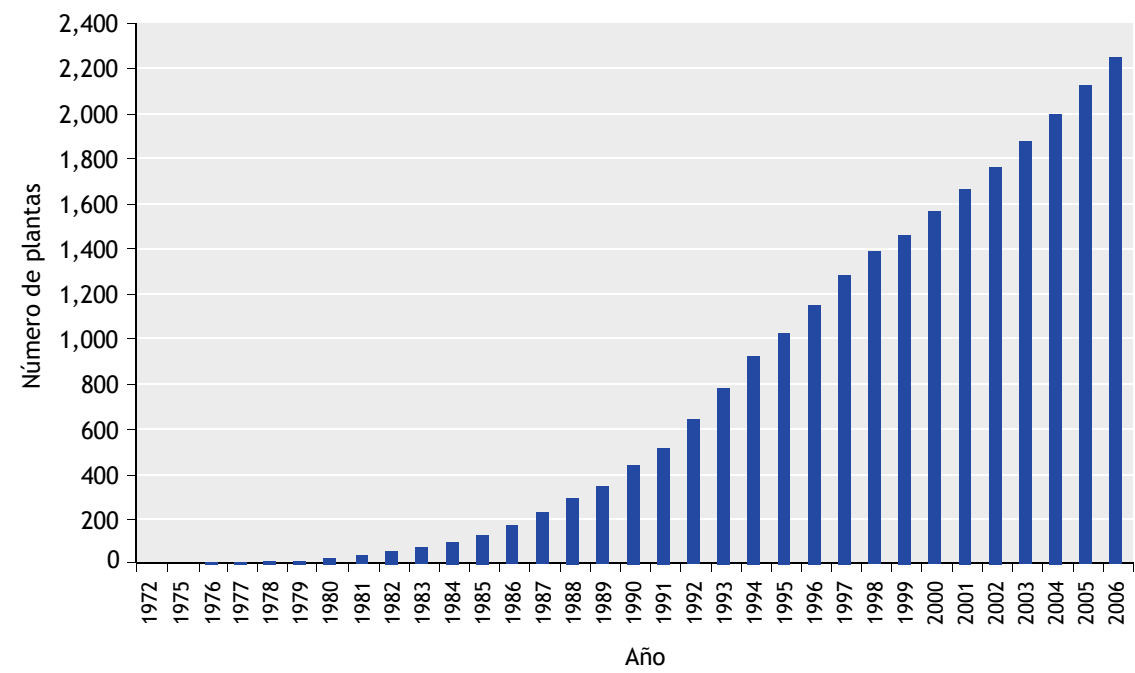

Figura 16.2 Incremento en el número de reactores anaerobios de alta tasa instalados a nivel mundial en el periodo de 1972-2006 
- más de un $90 \%$ de reducción en los requerimientos de espacio cuando se utilizan sistemas de lodos de lecho expandido.

- aplicables para altas tasas de carga orgánica alcanzando hasta 20-35 kg DQO por $\mathrm{m}^{3}$ de reactor por día, requiriendo de menores volúmenes de reactor.

- no es necesario el uso de combustibles fósiles para el tratamiento, ahorrando alrededor de $1 \mathrm{kWh} / \mathrm{kgDQO}$ removida, dependiendo de la eficiencia en la aireación.

- producción energética de alrededor de $13.5 \mathrm{MJ}_{-} \mathrm{CH}_{4}$ $/ \mathrm{kg}$ DQO removida, generando $1.5 \mathrm{kWh}$ de electricidad (asumiendo una eficiencia de conversión de energía eléctrica del 40\%).

- rápida puesta en marcha ( $<1$ semana), utilizando lodo granular anaerobio como inóculo.

- no es necesario el utilizar químicos o estos pueden ser utilizados en pequeñas cantidades.

- tecnología simple con altas eficiencias de tratamiento.

- el lodo anaerobio puede ser almacenado sin alimentar, los reactores pueden ser operados durante campañas de agricultura únicamente (por ej., 4 meses por año en la industria azucarera).

- el lodo en exceso tiene un valor en el mercado.

- los sistemas de alta tasa facilitan la recirculación del agua en las fábricas (generando un circuito cerrado).

Obviamente, la clasificación exacta de las ventajas mencionadas anteriormente dependerá de las condiciones socioeconómicas locales. En Holanda, el manejo del lodo en exceso es el factor de costo determinante para la operación de los sistemas de tratamiento de aguas residuales. Debido a que el uso de vertederos no es una opción para la disposición de los lodos de desecho en exceso ni para residuos biológicos, mientras que el precio para la incineración alcanza hasta $€ 500 /$ ton de lodo húmedo o más, la baja producción de lodos en los reactores anaerobios es un beneficio económico inmediato. La compacidad del sistema, otra ventaja importante en los AnWT, se puede mostrar utilizando un ejemplo a gran escala, donde un reactor anaerobio de $6 \mathrm{~m}$ de diámetro y una altura de $25 \mathrm{~m}$, es suficiente para tratar
25 ton de DQO diariamente. El lodo producido, el cual es menos de 1 ton de masa seca por día en este ejemplo, no es considerado un desecho, sino que es utilizado como inóculo para nuevos reactores. Esta compacidad hace que la implementación del sistema sea adecuada para instalaciones industriales o inclusive en algunas ocasiones en el interior de los edificios de la fábrica. Esto último, resulta de particular interés en áreas densamente pobladas o para aquellas industrias en donde se desee utilizar el tratamiento anaerobio como primer paso en un tratamiento para la recuperación de agua de proceso.

El renovado interés en los aspectos energéticos de los AnWT, resulta directamente del constante aumento en los precios de la energía y la preocupación global sobre el calentamiento global. Las 25 ton de $\mathrm{DQO} / \mathrm{d}$ de residuos agro-industriales (agua) mencionadas anteriormente, pueden ser convertidas en $7,000 \mathrm{~m}^{3} \mathrm{CH}_{4} / \mathrm{d}$ (suponiendo un $80 \%$ de $\mathrm{CH}_{4}$ recuperado), con un equivalente energético de $250 \mathrm{GJ} / \mathrm{d}$. Trabajando con un motor moderno de generación combinada de calor y electricidad (CHP, por sus siglas en inglés Cogeneration or Combined Heat and Power), alcanzando una eficiencia del $40 \%$, se puede llegar a obtener 1.2 MW de potencia eléctrica a la salida (Tabla 16.1). La recuperación total de energía puede ser inclusive más alta (llegando hasta un 60\%), si todo el calor en exceso se utiliza en las instalaciones de la industria o en las inmediaciones. Asumiendo que el tratamiento aerobio completo requerirá alrededor de $1 \mathrm{kWh} / \mathrm{kg}$ DQO removida, o $1 \mathrm{MW}$ de la potencia eléctrica instalada en el caso anterior, el beneficio energético total de utilizar un AnWT sobre un proceso de lodos activados es de 2.2 MW. A un precio de $0.1 € / \mathrm{kWh}$ de energía, esto equivale a alrededor de 5,000 €/d. Adicional a la energía generada, algunos otros estímulos actuales incluyen los bonos de carbono que pueden obtenerse al generar energía renovable utilizando AnWT (Tabla 16.1). Para una planta de energía generada por carbón, la generación de $1 \mathrm{MW}$ de electricidad emite alrededor de 21 ton $\mathrm{CO}_{2} / \mathrm{d}$, mientras que para una planta de gas natural se emite la mitad de ese valor. A un precio estable previsto de $€ 20 /$ ton $\mathrm{CO}_{2}$, el

Tabla 16.1 Energía obtenida y reducción en las emisiones de $\mathrm{CO}_{2}$ utilizando sistemas anaerobios de alta tasa para el tratamiento de aguas residuales

\begin{tabular}{lc}
\hline Capacidad de carga $\left(\mathrm{kg} \mathrm{DQO} / \mathrm{m}^{3} . \mathrm{d}\right)$ & $5-35$ \\
Energía obtenida $\left(\mathrm{MJ} / \mathrm{m}^{3}\right.$ reactor instalado por d) & $55-390$ \\
Potencia eléctrica obtenida $\left(\mathrm{kW} / \mathrm{m}^{3}\right.$ reactor instalado) & $0.25-1.7$ \\
$\begin{array}{l}\text { Reducción en la emisión de } \mathrm{CO}_{2} \text { (ton } \mathrm{CO}_{2} / \mathrm{m}^{3} \mathrm{y} \text {, con base en una central eléctrica } \\
\text { impulsada por carbono) }\end{array}$ & $1.9-13$ \\
\hline
\end{tabular}

Suposiciones: $80 \% \mathrm{CH}_{4}$ recuperado con respecto a la carga de DQO en el afluente y $40 \%$ de eficiencia de conversión eléctrica utilizando un generador moderno de energía combinada de calor. 
ejemplo de la industria mencionada anteriormente puede ganar $€ 500 / \mathrm{d}$ en bonos de carbono (con base en una planta de energía a partir de carbón), además de que no se utilizan combustibles fósiles para el tratamiento del agua residual. Aun cuando esta cantidad puede considerarse despreciable en países industrializados, puede ser un incentivo real en países en desarrollo para comenzar a tratar el agua residual utilizando sistemas de alta tasa AnWT, y como consecuencia proteger el ambiente local. La política de bonos de carbono puede, por lo tanto, ser considerada como un subsidio de países industrializados para la implementación de los sistemas AnWT en países menos prósperos.

La Tabla 16.1 presenta un resumen de la energía esperada, así como la estimación de la reducción de las emisiones de $\mathrm{CO}_{2}$ (si el $\mathrm{CH}_{4}$ producido se convierte en electricidad) en un reactor anaerobio, operado a cargas orgánicas disponibles comercialmente.

\subsection{MICROBIOLOGÍA DE LAS CONVERSIONES ANAEROBIAS}

\subsubsection{Degradación anaerobia de polímeros orgánicos}

La ruta de degradación anaerobia del material orgánico es un proceso en multi etapas formado por varias reacciones en serie y en paralelo. Este proceso de degradación de la materia orgánica se lleva a cabo en cuatro etapas sucesivas, conocidas como: (i) hidrólisis, (ii) acidogénesis, (iii) acetogénesis, y (iv) metanogénesis. Las cuales se discuten a continuación.

Las arqueobacterias metanogénicas se encuentran localizadas al final de la cadena trófica anaerobia y, en parte gracias a su actividad, no se acumulan grandes cantidades de materia orgánica en los ambientes anaerobios, en donde esta materia es inaccesible para los organismos aerobios. El proceso de digestión anaerobio involucra una compleja red trófica, en la cual la materia orgánica se degrada secuencialmente por una gran variedad de microorganismos. El consorcio microbiano involucrado en conjunto convierte la materia orgánica y finalmente es mineralizada a metano $\left(\mathrm{CH}_{4}\right)$, dióxido de carbono $\left(\mathrm{CO}_{2}\right)$, amonio $\left(\mathrm{NH}_{3}\right)$, ácido sulfhídrico $\left(\mathrm{H}_{2} \mathrm{~S}\right)$ y agua $\left(\mathrm{H}_{2} \mathrm{O}\right)$.

El ecosistema anaerobio es el resultado de complejas interacciones entre microorganismos de varias especies. Los grupos de bacterias principales y las reacciones que se llevan a cabo son: $(i)$ bacterias fermentativas, (ii) bacterias acetogénicas productoras de hidrógeno, (iii) bacterias acetogénicas consumidoras de hidrógeno, (iv) reductores de dióxido de carbono, y (v) metanógenos acetoclásticos. Las reacciones que cada uno de ellos realizan, se muestran en la Figura 16.3.

El proceso de digestión se puede subdividir en los siguientes cuatro pasos:

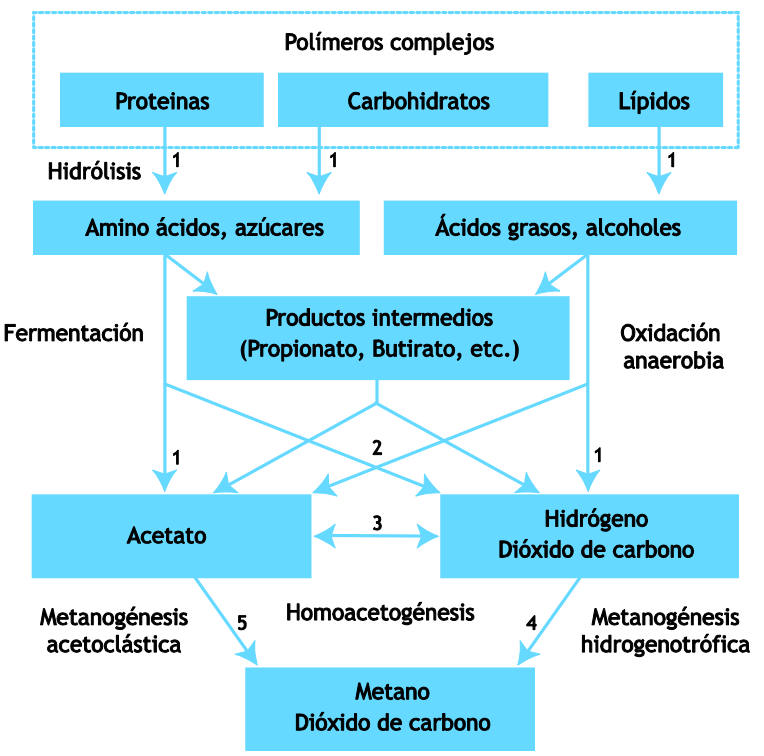

Figura 16.3 Esquema representativo de las reacciones llevadas a cabo durante la digestión anaerobia de materiales poliméricos. Los números indican el grupo de bacterias involucrado: 1 . Bacterias hidrolíticas y fermentativas, 2. Bacterias acetogénicas, 3. Bacterias homo-acetogénicas, 4. Metanógenos hidrogenotróficos, 5. Metanógenos acetoclásticos (Gujer and Zehnder, 1983)

13 Hidrólisis, en donde las enzimas excretadas por las bacterias fermentativas (llamadas "exo-enzimas") convierten el material complejo no disuelto en compuestos disueltos menos complejos, que pueden pasar a través de las paredes y membranas celulares de las bacterias fermentativas.

2) Acidogénesis, en donde los compuestos disueltos presentes en las células de las bacterias fermentativas, son convertidos en compuestos simples, los cuales son excretados. Los compuestos producidos durante esta fase incluyen ácidos grasos volátiles (AGVs), alcoholes, ácido láctico, $\mathrm{CO}_{2}, \mathrm{H}_{2}, \mathrm{NH}_{3}$ y $\mathrm{H}_{2} \mathrm{~S}$, así como también material celular nuevo.

3) Acetogénesis (producción intermedia de ácido), en donde los productos de la digestión son transformados a acetato, hidrógeno $\left(\mathrm{H}_{2}\right)$ y $\mathrm{CO}_{2}$, así como en nuevo material celular. 
4) Metanogénesis, en donde el acetato, bicarbonato, ácido fórmico o metanol son convertidos a metano, $\mathrm{CO}_{2}$ y nuevo material celular.

En este esquema global, se pueden distinguir los siguientes sub-procesos (Figura 16.3):

is Hidrólisis de biopolímeros:

- hidrólisis de proteínas

- hidrólisis de polisacáridos

- hidrólisis de grasas

2) Acidogénesis/fermentación:

- oxidación anaerobia de aminoácidos y azúcares

- oxidación anaerobia de ácidos grasos de cadena larga y alcoholes

33. Acetogénesis:

- formación de ácido acético e $\mathrm{H}_{2}$ a partir de los productos intermedios (especialmente AGVs)

- homoacetogénesis: formación de ácido acético a partir de $\mathrm{H}_{2}$ y $\mathrm{CO}_{2}$

4) Metanogénesis:

- formación de metano a partir de ácido acético

- formación de metano a partir de hidrógeno y dióxido de carbono

En la Figura 16.3 se muestra la degradación unidireccional de la materia orgánica hasta obtener los productos finales $\mathrm{CH}_{4} \quad$ y $\mathrm{CO}_{2}$. El proceso de homoacetogénesis, ilustra la interconversión de acetato, el mayor precursor de $\mathrm{CH}_{4}, \mathrm{y} \mathrm{H}_{2} / \mathrm{CO}_{2}$. En la práctica, pueden ocurrir otras reacciones adicionales, por ejemplo la formación de AGVs o alcoholes a partir de acetato y propionato. Estas reacciones adicionales son de particular importancia en caso de que el reactor anaerobio funcione inadecuadamente o existan algunas perturbaciones, o cuando se quiere realizar una reacción en específico. Para aplicaciones normales de los AnWT, es decir, para la operación estable del reactor bajo condiciones mesofílicas, el acetato es el mayor precursor de $\mathrm{CH}_{4}$ (aproximadamente un 70\% del flujo de la DQO). Una observación importante es que, únicamente, se lleva a cabo la conversión de la DQO y no su destrucción. La remoción de DQO tiene lugar debido a que el producto final de la reacción en cadena, $\mathrm{CH}_{4}$, es gaseoso y altamente insoluble en agua.

En caso de que se encuentren presentes aceptores de electrones alteros, como $\mathrm{NO}_{3}{ }^{-}$y $\mathrm{SO}_{4}{ }^{2-}$, otros grupos de bacterias estarán presentes en el reactor anaerobio, tales como desnitrificantes y reductores de sulfato (ver la Sección 16.4).
16.2.1.1 Hidrólisis

Debido a que las bacterias son incapaces de consumir la materia orgánica particulada, el primer paso de la degradación anaerobia consiste en la hidrólisis de los polímeros. Este proceso es un fenómeno meramente superficial, en el cual las partículas poliméricas son degradadas a través de la acción de exo-enzimas para generar moléculas de menor tamaño, las cuales pueden cruzar la barrera celular. Durante los procesos enzimáticos de hidrólisis, las proteínas son hidrolizadas a aminoácidos, los polisacáridos a azúcares simples y los lípidos a ácidos grasos de cadena larga (AGCL). La hidrólisis es, en la mayoría de los casos, marcadamente con sustratos (semi-) sólidos y con aguas residuales con una relación alta de sólidos suspendidos (SS)/DQO, la etapa limitante para la velocidad de digestión global. Por otra parte, la hidrólisis es muy sensible a la temperatura y fluctuaciones en la misma. Por esta razón, el diseño para digestores anaerobios, para sustratos (semi-) sólidos y aguas residuales con relaciones altas de SS/DQO, como corrientes de destilería y aguas residuales domésticas a baja temperatura, se basa generalmente en el proceso de hidrólisis.

La hidrólisis se puede definir como un proceso en el cual los sustratos poliméricos complejos, disueltos o particulados, son transformados en compuestos monoméricos o diméricos que pueden ser fácilmente consumidos por las bacterias acidogénicas. Durante la digestión anaerobia de sustratos complejos, la hidrólisis es por lo general el primer paso. Aunque en algunos casos incluya un paso preparatorio, es decir, un pretratamiento fisicoquímico o conminución, para que se pueda llevar a cabo. Con la digestión de los lodos biológicos, tales como los lodos activados residuales, la hidrólisis del lodo es precedida por la muerte o lisis de la biomasa. La hidrólisis se logra por medio de exo-enzimas, las cuales son producidas por las bacterias acidogénicas. Los productos de esta reacción son los sustratos para las bacterias acidogénicas. En la Figura 16.4 se presenta un esquema del proceso de hidrólisis de los lípidos hacia AGCLs.

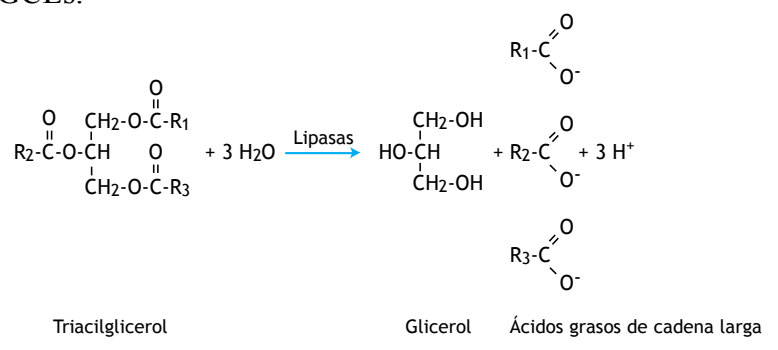

Figura 16.4 Hidrólisis de los lípidos 
Como se mencionó, la hidrólisis puede considerarse el paso limitante durante la digestión anaerobia de sustratos complejos. Sin embargo, por lo general esto no es debido a la falta de actividad enzimática, si no a la disponibilidad de área superficial libre en las partículas y a la estructura general del sustrato sólido (Chandler et al., 1980; Zeeman et al., 1996). Inclusive en aguas residuales diluidas, como aguas residuales domésticas con temperaturas bajas, la hidrólisis determinará el proceso general y como consecuencia el diseño del reactor. Debe señalarse que el $45-75 \%$ del agua residual doméstica, y el $80 \%$ de los lodos primarios, están constituidos por materia suspendida. Los principales biopolímeros en las aguas residuales son proteínas, carbohidratos y lípidos.

\subsubsection{Acidogénesis}

Durante la acidogénesis, los productos de la hidrólisis (aminoácidos, azúcares simples, AGCLs), los cuales son compuestos solubles relativamente pequeños, se difunden en el interior de las células bacterianas a través de la membrana celular $\mathrm{y}$, posteriormente, son fermentados u oxidados anaeróbicamente. La acidogénesis es una reacción muy común y se lleva a cabo por un grupo grande de microorganismos hidrolíticos y no hidrolíticos. Alrededor de un $1 \%$ de todas las bacterias conocidas son fermentadoras (facultativas). Los productos de la acidificación consisten en una variedad de compuestos orgánicos pequeños, principalmente $\mathrm{AGVs}$, es decir, acetato $\mathrm{y}$ ácidos orgánicos superiores como propionato y butirato, así como $\mathrm{H}_{2}, \mathrm{CO}_{2}$, ácido láctico, etanol y amonio (Figura 16.3).

Característicamente, los compuestos neutros como azúcares y proteínas, se convierten a AGVs y ácido carbónico, siendo los productos principales de la reacción. Por lo tanto, los organismos fermentativos son designados comúnmente como microorganismos acidificantes o acidogénicos $\mathrm{y}$, el proceso por lo tanto es conocido como acidogénesis. En la Tabla 16.2, se enlistan varias reacciones acidogénicas, comenzando por la sacarosa y generando diferentes cantidades de AGVs, $\mathrm{HCO}_{3}{ }^{-}, \mathrm{H}_{2}, \mathrm{H}^{+}$. Aparentemente, el tipo de productos finales dependerá de las condiciones en las que se encuentre el medio en el reactor. De la Tabla 16.2, se deduce que el $\Delta \mathrm{G}^{\text {ol }}$ para las reacciones acidogénicas menos favorables energéticamente con sacarosa como sustrato, depende fuertemente de las concentraciones de $\mathrm{H}_{2}$ que prevalecen. $\mathrm{Si}$ el $\mathrm{H}_{2}$ se remueve eficientemente por organismos consumidores de $\mathrm{H}_{2}$ como metanógenos, el acetato será el producto final principal. Sin embargo, si se retarda la metanogénesis y se acumula $\mathrm{H}_{2}$, algunos productos más reducidos como propionato y butirato aparecerán $\mathrm{y}$, posiblemente algunos otros compuestos aún más reducidos como lactato y alcoholes. Por lo tanto, los efluentes de los reactores sobrecargados o con perturbaciones (o los reactores diseñados como reactores acidificantes en un proceso anaerobio de dos etapas), siempre contienen estos productos intermedios más reducidos.

La acidogénesis es la etapa de conversión más rápida en la cadena trófica anaerobia. $\mathrm{El} \Delta \mathrm{G}^{\circ 1}$ de las reacciones acidificantes es el más alto que todas las conversiones anaerobias, dando como resultado velocidades de crecimiento de las bacterias, diez o veinte veces más altas, y rendimientos de las bacterias y velocidades de conversión, cinco veces más altos comparados con las reacciones metanogénicas (Tabla 16.3). Por esa razón, los reactores anaerobios son susceptibles a la acidificación, es decir, a repentinas caídas de $\mathrm{pH}$, cuando existen sobrecargas en los reactores o perturbaciones por compuestos tóxicos. Una vez que se ha consumido la alcalinidad por los ácidos producidos, el $\mathrm{pH}$ comienza a bajar, resultando en concentraciones más altas de AGVs no disociados, y generando una inhibición más severa de los metanógenos. Esto último, obviamente conduce a una acumulación más rápida de $\mathrm{AGVs} \mathrm{y}$, subsecuentemente, a una caída de $\mathrm{pH}$ (Figura 16.5).

El hecho de que los microorganismos acidificantes son activos inclusive a $\mathrm{pH}$ bajo (4), significa que el reactor se acidificará a un pH 4 o 5, cuando la capacidad metanogénica del sistema se sobrepasa.

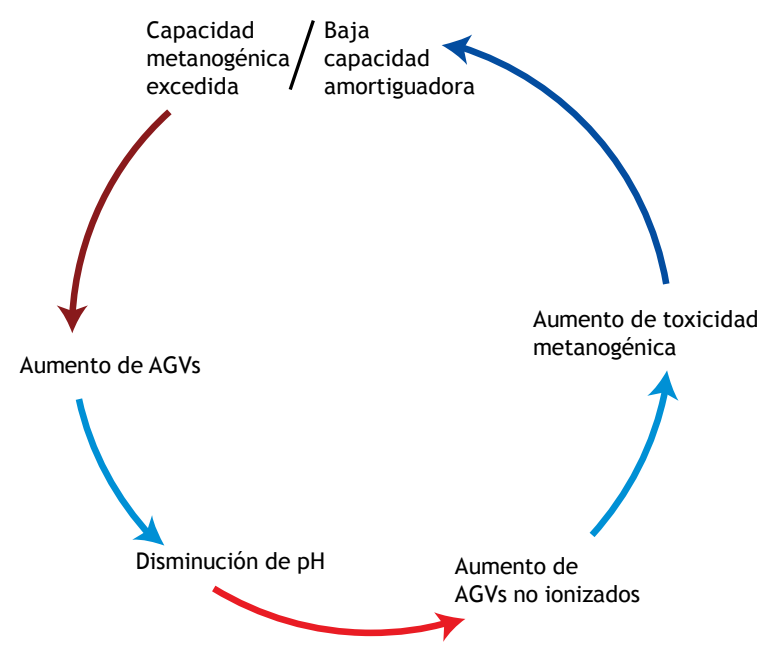

Figura 16.5 Caída de pH de un reactor como resultado de una sobrecarga de metanógenos y una acumulación de AGVs 
Tabla 16.2 Reacciones acidogénicas con sacarosa como sustrato y sus correspondientes cambios de energía libre $\left(\Delta \mathrm{G}^{\circ}\right)$ a $25^{\circ} \mathrm{C}$

\begin{tabular}{|c|c|c|}
\hline Reacciones & $\Delta \mathrm{G}^{\circ \prime}(\mathrm{kJ} / \mathrm{mol})$ & Ec. \\
\hline $\mathrm{C}_{12} \mathrm{H}_{22} \mathrm{O}_{11}+9 \mathrm{H}_{2} \mathrm{O} \rightarrow 4 \mathrm{CH}_{3} \mathrm{COO}-+4 \mathrm{HCO}_{3^{-}}+8 \mathrm{H}++8 \mathrm{H}_{2}$ & -457.5 & $(16.1)$ \\
\hline $\mathrm{C}_{12} \mathrm{H}_{22} \mathrm{O}_{11}+5 \mathrm{H}_{2} \mathrm{O} \rightarrow 2 \mathrm{CH}_{3} \mathrm{CH}_{2} \mathrm{CH}_{2} \mathrm{COO}-+4 \mathrm{HCO}_{3-}+6 \mathrm{H}++4 \mathrm{H}_{2}$ & -554.1 & $(16.2)$ \\
\hline $\mathrm{C}_{12} \mathrm{H}_{22} \mathrm{O}_{11}+3 \mathrm{H}_{2} \mathrm{O} \rightarrow 2 \mathrm{CH}_{3} \mathrm{COO}-+2 \mathrm{CH}_{3} \mathrm{CH}_{2} \mathrm{COO}-+2 \mathrm{HCO}_{3^{-}}+6 \mathrm{H}++2 \mathrm{H}_{2}$ & -610.5 & $(16.3)$ \\
\hline
\end{tabular}

La conversión acidogénica de los aminoácidos por lo general ocurre por la reacción de Stickland, en la cual los aminoácidos son desamonificados por oxidación anaerobia, produciendo AGVs y $\mathrm{H}_{2}$, en conjunto con la desamonificación reductiva de otros aminoácidos consumiéndose el $\mathrm{H}_{2}$ producido. De ambas reacciones se deprende $\mathrm{NH}_{3}$ y posteriormente actúa como aceptor de protones, generando con ello un aumento en el pH. En esta reacción no hay producción neta de protones y no hay un cambio en la caída de $\mathrm{pH}$ del reactor.

\subsubsection{Acetogénesis}

Los ácidos grasos de cadena corta (AGCC), diferentes al acetato, que son producidos durante la acidogénesis, son convertidos posteriormente a acetato, hidrógeno y dióxido de carbono por las bacterias acetogénicas. Los principales sustratos acetogénicos son el propionato y butirato, los cuales son intermediarios importantes en la digestión anaerobia. Pero también el lactato, etanol, metanol e inclusive el $\mathrm{H}_{2}$ y $\mathrm{CO}_{2}$, son convertidos homoacetogénicamente a acetato, tal y como se muestra en la Figura 16.3 y en la Tabla 16.4. Los AGCLs son transformados por las bacterias acetogénicas específicas, de acuerdo a la $\beta$-oxidación, en donde algunas fracciones de acetato se separan de la cadena alifática (Tabla 16.4). Los AGCLs con número de átomos de $\mathrm{C}$ impares, también producen propionato después del acetato. AGCLs no saturados como el oleato y linoleato, se saturan primero por adición de $\mathrm{H}_{2}$, antes de que se lleve a cabo la $\beta$-oxidación. Las bacterias acetogénicas son productoras obligadas de hidrógeno y su metabolismo se ve inhibido por este gas, que se forma inmediatamente a partir de la conversión estequiométrica, por ejemplo del propionato:

$$
\Delta G^{\prime}=\Delta G^{o,}+R T \ln \frac{[\text { Acetato }] \cdot\left[\mathrm{CO}_{2}\right] \cdot\left[\mathrm{H}_{2}\right]^{3}}{[\text { Propionato }]}
$$

Algunos estudios realizados en conversiones acetogénicas, han dilucidado las estrechas relaciones requeridas entre las bacterias acetogénicas productoras de $\mathrm{H}_{2}$ y las arqueobacterias metanogénicas consumidoras de $\mathrm{H}_{2}$, regulando así los niveles de $\mathrm{H}_{2}$ en su ambiente. Esto es de vital importancia, ya que estas reacciones son termodinámicamente desfavorables, indicado por el signo positivo del $\Delta \mathrm{G}^{\circ}$, en la Tabla 16.4. De esta tabla se deduce que las reacciones para el etanol, butirato, propionato y el AGCL palmitato, no se llevarán a cabo bajo condiciones estándares, ya que el $\Delta \mathrm{G}^{\circ}$, es positivo, y por lo tanto la producción de energía por las bacterias es negativa.

Sin embargo, bajo condiciones estables de digestión, la presión parcial del hidrógeno se mantiene en un nivel extremadamente bajo. Esto se logra mediante un consumo efectivo de hidrógeno por las arqueobacterias metanogénicas o por bacterias sulfato-reductoras. Las arqueobacterias metanogénicas por lo general utilizan el hidrógeno molecular en el digestor anaerobio tan rápidamente, que la presión parcial del hidrógeno cae por debajo de $10^{-4} \mathrm{~atm}$, lo cual es suficiente para asegurar que se lleve a cabo la reacción acetogénica de producción de hidrógeno (Figura 16.6).

Esta interdependencia significa que la degradación de los ácidos grasos superiores y alcoholes depende principalmente de la actividad de los organismos consumidores de electrones como las arqueobacterias metanogénicas. Las asociaciones microbianas, en donde los organismos productores de $\mathrm{H}_{2}$ pueden crecer únicamente en presencia de organismos consumidores de

Tabla 16.3 Propiedades cinéticas promedio de los acidificantes y metanógenos

\begin{tabular}{lcccc}
\hline Proceso & $\begin{array}{c}\text { Velocidad de conversión } \\
\text { gDQO/gSSV.d }\end{array}$ & $\begin{array}{c}\mathrm{Y} \\
\mathrm{gSSV} / \mathrm{gDQO}\end{array}$ & $\begin{array}{c}\mathrm{K}_{\mathrm{s}} \\
\mathrm{mgDQO} / 1\end{array}$ & $\begin{array}{c}\mu_{\mathrm{m}} \\
1 / \mathrm{d}\end{array}$ \\
\hline Acidogénesis & 13 & 0.15 & 200 & 2.00 \\
Metanogénesis & 3 & 0.03 & 30 & 0.12 \\
Global & 2 & $0.03-0.18$ & - & 0.12 \\
\hline
\end{tabular}


$\mathrm{H}_{2}$, se conocen como asociaciones sintróficas. El acoplamiento entre producción y consumo de $\mathrm{H}_{2}$ es conocido como transferencia de hidrógeno entre las especies. En una instalación productora de metano funcionando adecuadamente, la presión parcial del hidrógeno no excederá de $10^{-4} \mathrm{~atm}$ y por lo general se encuentra entre $10^{-4}-10^{-6} \mathrm{~atm}$. A esta concentración tan baja de hidrógeno, la degradación de etanol, butirato o propionato se vuelve exergónica y por lo tanto se producirá energía para los acetogénicos.

De manera similar a los otros sustratos acetogénicos, la conversión de AGCL es altamente endergónica y por lo general limita el proceso completo de digestión (Novak y Carlson, 1970). Ensayos utilizando reactores anaerobios de lecho de lodos con flujo ascendente (UASB), fueron parcialmente exitosos cuando el AGCL tendió a absorberse en el lodo formando cúmulos grasos de biomasa con poca o ninguna actividad metanogénica. Los reactores de lecho expandido, en donde el AGCL se encuentra distribuido homogéneamente sobre la biomasa disponible, fueron más exitosos (Rinzema, 1988). Algunos otros autores proponen de hecho, el uso de la capacidad adsorbente del lodo y cargan periódicamente el lodo con AGCL, después de lo cual la digestión en estado sólido convertirá el material adsorbido en $\mathrm{CH}_{4}$ (Pereira et al., 2004). Esta forma de operación en lecho secuencial requiere múltiples reactores para el tratamiento en flujo continuo de agua residual.

\subsubsection{Metanogénesis}

Las arqueobacterias metanogénicas se encargan de lograr el paso final en la conversión anaerobia global de la materia orgánica a metano y dióxido de carbono. Durante esta cuarta y última etapa de la degradación anaerobia de la materia orgánica, el grupo de las archeae

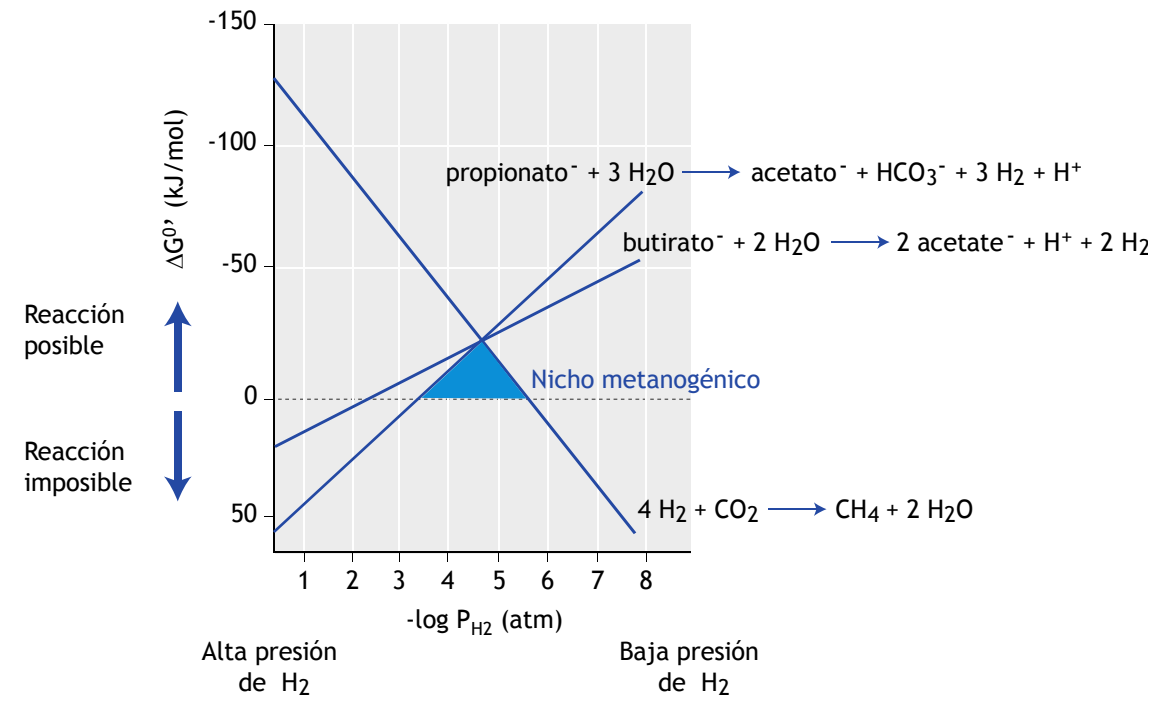

Figura 16.6 Cambio en la energía libre de Gibbs en función de la presión parcial del $\mathrm{H}_{2}$. Un valor negativo en $\Delta \mathrm{G}^{\circ}$ es indicativo de que puede ocurrir la reacción mencionada

Tabla 16.4 Estequiometría y cambio en la energía libre de Gibbs $\left(\Delta \mathrm{C}^{\circ}\right)$ para algunas reacciones acetogénicas, suponiendo un $\mathrm{pH}$ neutro, a una temperatura de $25^{\circ} \mathrm{C}$ y una presión de $1 \mathrm{~atm}(101 \mathrm{kPa})$. Se considera al agua como un líquido puro y que todos los compuestos solubles tienen una actividad de $1 \mathrm{~mol} / \mathrm{kg}$

\begin{tabular}{llrr}
\hline Compuesto & Reacción & $\Delta \mathrm{G}^{\circ}(\mathrm{kJ} / \mathrm{mol})$ & -4.2 \\
Lactato & $\mathrm{CH}_{3} \mathrm{CHOHCOO}^{-}+2 \mathrm{H}_{2} \mathrm{O} \rightarrow \mathrm{CH}_{3} \mathrm{COO}^{-}+\mathrm{HCO}_{3}^{-}+\mathrm{H}^{+}+2 \mathrm{H}_{2}$ & +9.6 & $(16.5)$ \\
Etanol & $\mathrm{CH}_{3} \mathrm{CH}_{2} \mathrm{OH}+\mathrm{H}_{2} \mathrm{O} \rightarrow \mathrm{CH}_{3} \mathrm{COO}^{-}+\mathrm{H}^{+}+2 \mathrm{H}_{2}$ & +48.1 & $(16.6)$ \\
Butirato & $\mathrm{CH}_{3} \mathrm{CH}_{2} \mathrm{CH}_{2} \mathrm{COO}^{-}+2 \mathrm{H}_{2} \mathrm{O} \rightarrow 2 \mathrm{CH}_{3} \mathrm{COO}^{-}+\mathrm{H}^{+}+2 \mathrm{H}_{2}$ & +76.1 & $(16.7)$ \\
Propionato & $\mathrm{CH}_{3} \mathrm{CH}_{2} \mathrm{COO}^{-}+3 \mathrm{H}_{2} \mathrm{O} \rightarrow \mathrm{CH}_{3} \mathrm{COO}^{-}+\mathrm{HCO}_{3}^{-}+\mathrm{H}^{+}+3 \mathrm{H}_{2}$ & -2.9 & $(16.8)$ \\
Metanol & $4 \mathrm{CH}_{3} \mathrm{OH}+2 \mathrm{CO}_{2} \rightarrow 3 \mathrm{CH}_{3} \mathrm{COOH}_{2}+2 \mathrm{H}_{2} \mathrm{O}$ & -70.3 & $(16.9)$ \\
Hidrógeno- $\mathrm{CO}_{2}$ & $2 \mathrm{HCO}_{3}^{-}+4 \mathrm{H}_{2}+\mathrm{H}^{+} \rightarrow \mathrm{CH}_{3} \mathrm{COO}^{-}+4 \mathrm{H}_{2} \mathrm{O}$ & +345.6 & $(16.10)$ \\
Palmitato & $\mathrm{CH}_{3}-\left(\mathrm{CH}_{2}\right)_{14} \mathrm{COO}_{-}+14 \mathrm{CH}_{2} \mathrm{O} \rightarrow 8 \mathrm{CH}_{3} \mathrm{COO}-+7 \mathrm{H}^{+}+14 \mathrm{H}_{2}$ & $(16.11)$ \\
\hline
\end{tabular}


metanogénicas se encarga de reducir el dióxido de carbono utilizando al hidrógeno como donador de electrones y de descarboxilar acetato para formar $\mathrm{CH}_{4}$ (Figura 16.3). Es únicamente en esta etapa cuando la DQO del afluente se convierte a una forma gaseosa que abandona el reactor automáticamente. Los metanógenos son anaerobios obligados, con un espectro de sustratos muy estrecho. Algunos únicamente pueden utilizar cierto tipo de sustratos como el acetato, metilaminas, metanol, formiato, $\mathrm{y} \mathrm{H}_{2} / \mathrm{CO}_{2} \mathrm{o} \mathrm{CO}$. Para propósitos ingenieriles, los metanógenos se clasifican en dos grandes grupos: los que convierten el acetato o metanógenos acetoclásticos y los que utilizan el hidrógeno o metanógenos hidrogenotróficos (Tabla 16.5). En general, alrededor de un $70 \%$ del metano producido se forma a partir del acetato como precursor principal. El resto se forma principalmente a partir de $\mathrm{H}_{2}$ y $\mathrm{CO}_{2}$. La velocidad de crecimiento de los metanógenos acetoclásticos es muy baja, resultando en tiempos de duplicación de varios días o inclusive mayores. Estas velocidades de crecimiento extremadamente bajas explican el por qué los reactores anaerobios requieren un periodo de puesta en marcha muy largo cuando el inóculo no se encuentra adaptado y por qué se procuran altas concentraciones de lodo. Las bacterias hidrogenotróficas tienen una velocidad de crecimiento mucho más rápida que las bacterias acetoclásticas, con tiempos de duplicación de 4 a 12 horas. Debido a esta característica y a pesar del delicado paso de la reacción acetogénica que se discutió en la sección anterior, los sistemas anaerobios de alta tasa ejercen una estabilidad notable bajo condiciones variables. En la Tabla 16.5 se enlistan dos tipos de metanógenos acetoclásticos con características cinéticas muy diferentes. Además, las características morfológicas de ambos géneros de metanógenos son muy diferentes tal y como se indica en la Figura 16.7.
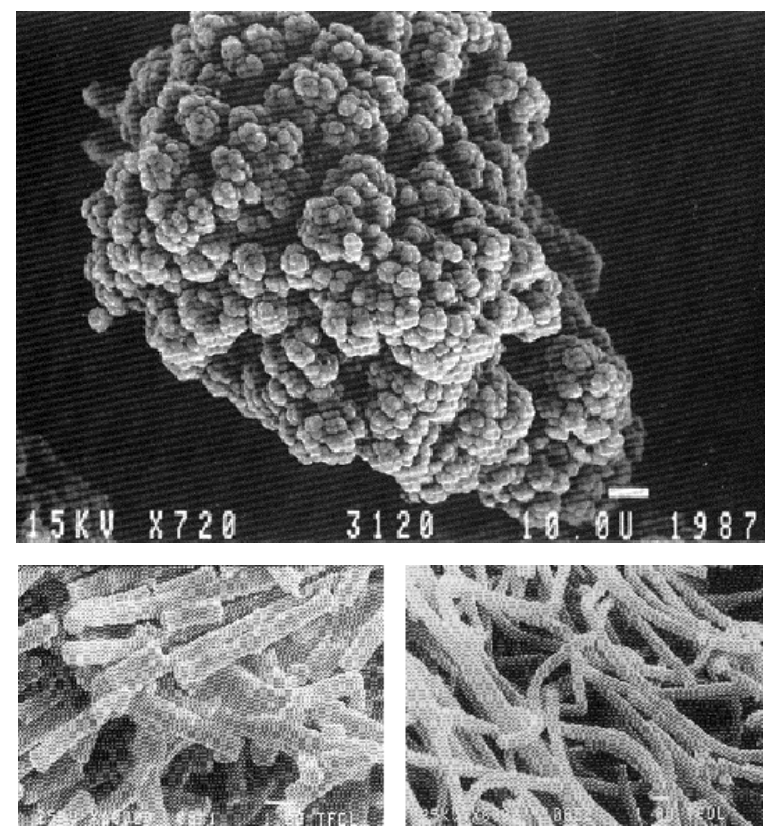

Figura 16.7 Morfología y apariencia de los metanógenos acetoclásticos más importantes pertenecientes al género Methanosarcina (arriba) y Methanosaeta (abajo)

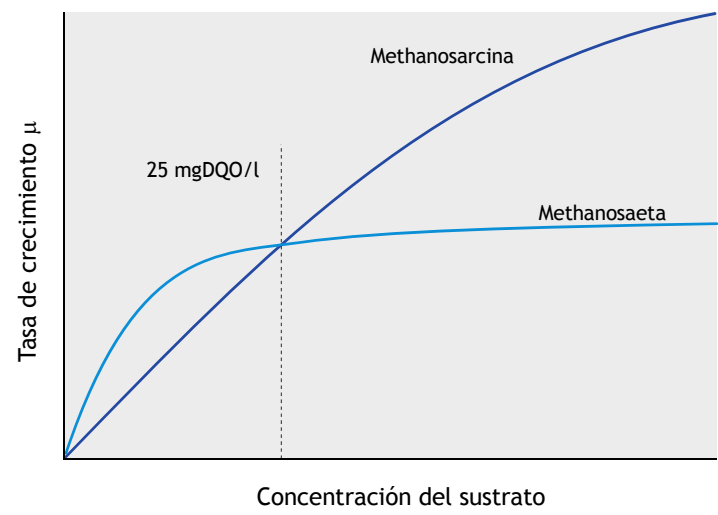

Figura 16.8 Curvas de crecimiento de Monod para los metanógenos acetoclásticos, Methanosarcina spp. y Methanosaeta spp. Tanto la $\mu_{\max }$ como la constante de saturación de Monod $\left(\mathrm{K}_{\mathrm{s}}\right)$ de ambos géneros se presentan en la Tabla 16.5

Tabla 16.5 Reacciones metanogénicas más importantes, su cambio de energía libre de Gibbs correspondiente $\left(\Delta G^{\circ}\right)$ y algunas propiedades cinéticas

\begin{tabular}{|c|c|c|c|c|c|c|}
\hline Etapa funcional & Reacción & $\begin{array}{r}\Delta \mathrm{G}^{\circ \prime} \\
\mathrm{kJ} / \mathrm{mol}\end{array}$ & $\begin{array}{r}\mu_{\max } \\
1 / \mathrm{d}\end{array}$ & $\begin{array}{r}T_{d} \\
d\end{array}$ & $\begin{array}{r}\mathrm{K}_{\mathrm{s}} \\
\mathrm{mgDQO} / \mathrm{l}\end{array}$ & Ec. \\
\hline $\begin{array}{l}\text { Metanogénesis } \\
\text { acetoclástica* }\end{array}$ & $\mathrm{CH}_{3}^{-} \mathrm{COO}^{-}+\mathrm{H}_{2} \mathrm{O} \rightarrow \mathrm{CH}_{4}+\mathrm{HCO}_{3}^{-}$ & -31 & $\begin{array}{l}0.12^{\mathrm{a}} \\
0.71^{\mathrm{b}}\end{array}$ & $\begin{array}{l}5.8^{\mathrm{a}} \\
1.0^{\mathrm{b}}\end{array}$ & $\begin{array}{r}30^{\mathrm{a}} \\
300^{\mathrm{b}}\end{array}$ & (16.12) \\
\hline $\begin{array}{l}\text { Metanogénesis } \\
\text { hidrogenotrófica }\end{array}$ & $\mathrm{CO}_{2}+4 \mathrm{H}_{2} \rightarrow \mathrm{CH}_{4}+2 \mathrm{H}_{2} \mathrm{O}$ & -131 & 2.85 & 0.2 & 0.06 & (16.13) \\
\hline
\end{tabular}

${ }^{*}$ Dos metanógenos diferentes pertenecientes a las especies a Methanosarcina sp. y ${ }^{\mathrm{b}}$ Methanosaeta $\mathrm{sp}$. 
Una vez que las especies de Methanosaeta son dominantes en el lecho de lodos, se obtiene un sistema de tratamiento de aguas residuales muy efectivo, llegándose a obtener concentraciones extremadamente bajas de acetato en el efluente. Considerando las propiedades cinéticas inferiores de la especie Methanosarcina a concentraciones bajas de sustrato y sus propiedades inferiores de adherencia, se recomienda mantener las concentraciones de acetato en el efluente a su nivel más bajo durante el arranque del reactor anaerobio cuando el inóculo no se encuentra adaptado.

\subsection{PREDICCIÓN DE LA PRODUCCIÓN DE CH4}

Los contaminantes orgánicos se pueden clasificar con respecto a su solubilidad (soluble e insoluble) y/o a su biodegradabilidad.

Ambos son de gran importancia para el proceso de tratamiento. Considerando la enorme variedad de compuestos orgánicos que se encuentran presentes por lo general en el agua residual, resulta impráctico e inclusive imposible determinar estos compuestos por separado. Con el objeto de cuantificar los contaminantes orgánicos en la práctica, se ha utilizado el hecho de que estos contaminantes pueden ser oxidados por agentes oxidantes fuertes. Para fines prácticos ingenieriles en el tratamiento de aguas residuales, se utilizan dos pruebas estándares basadas en la oxidación del material orgánico: la demanda bioquímica de oxígeno (DBO) y la demanda química de oxígeno (DQO) (Capítulo 3). En ambas pruebas, el material orgánico se oxida y la cantidad de oxígeno consumido representa el valor del parámetro. La DBO se refiere a la cantidad de oxígeno bioquímico requerido por los organismos aerobios para oxidar la materia orgánica. Por lo tanto, el valor de la DBO se encuentra estrechamente relacionado con la biodegradabilidad. Para la aplicación en el tratamiento anaerobio, es preferible utilizar algún otro tipo de prueba anaerobia de biodegradabilidad estandarizada en lugar de la prueba aerobia convencional de DBO. En esta prueba anaerobia, una muestra del agua residual se expone a una cantidad disponible de lodo anaerobio para determinar la cantidad total de $\mathrm{CH}_{4}$ producido, una vez que se ha finalizado el proceso de digestión, posteriormente, este valor se relaciona con la cantidad de materia orgánica presente en la muestra. Debido a que cierta cantidad de $\mathrm{CH}_{4}$ es equivalente a cierta cantidad de DQO, lo que se determina en realidad es la $\mathrm{DBO}_{\text {anaerobia. }}$.

Dado que, por lo general, no todos los contaminantes orgánicos pueden ser biodegradables y considerando que cierta parte del sustrato orgánico se utilizará para la síntesis celular, el valor de la DBO por lo general es más bajo que el valor de la DQO. Esto último corresponde al caso particular de la prueba de DBO para un sistema convencional aerobio, y en menor grado para la prueba de DBO anaerobia debido al rendimiento de crecimiento significativamente bajo cuando se tienen condiciones anaerobias. En la actualidad se están haciendo esfuerzos para la estandarización de las pruebas utilizadas en el laboratorio.

En las pruebas estandarizadas de DQO, las cuales por lo general utilizan dicromato como medio oxidante a una temperatura elevada $\left(150^{\circ} \mathrm{C}\right)$, la mayoría de los contaminantes orgánicos son convertidos completamente a $\mathrm{CO}_{2}$ y $\mathrm{H}_{2} \mathrm{O}$. Por otro lado, el nitrógeno orgánico presente en los contaminantes se convierte a $\mathrm{NH}_{3}$, mientras que la materia orgánica que contiene sales cuaternarias de amonio como betaína (trimetil glicina) permanece reducida y es "invisible" en las pruebas de DQO.

El carbono orgánico total (COT) es otra medición utilizada; sin embargo, es un parámetro menos útil. La concentración del carbono orgánico es medida en forma de dióxido de carbono después de la incineración de la materia orgánica presente en la muestra de agua residual. Se debe de aplicar una corrección para el carbono inorgánico presente en la muestra original. El valor teórico para un compuesto puro sigue la Ec. 16.14:

$$
\begin{gathered}
C O T_{t}=12 n /(12 n+a+16 b+14 d) \\
\left(\mathrm{gCOT}^{\mathrm{g}} \mathrm{gC}_{\mathrm{n}} \mathrm{H}_{\mathrm{a}} \mathrm{O}_{\mathrm{b}} \mathrm{N}_{\mathrm{d}}\right)
\end{gathered}
$$

\subsubsection{DQO}

La DQO es sin duda el parámetro más importante para conocer la concentración de los contaminantes presentes en aguas residuales, en particular para las aguas residuales de tipo industrial. Esta característica en la cual la materia orgánica se oxida casi completamente, hace que las pruebas de DQO sean muy adecuadas para realizar los balances de DQO. La forma en la que se calcula la DQO del sustrato y la cantidad teórica de metano producido se presenta a continuación.

La DQO de un compuesto orgánico $\mathrm{C}_{\mathrm{n}} \mathrm{H}_{\mathrm{a}} \mathrm{O}$, se puede calcular fácilmente con base en la reacción química de oxidación, suponiendo una oxidación completa:

$$
\mathrm{C}_{n} \mathrm{H}_{a} \mathrm{O}_{b}+\frac{1}{4}(4 n+1-2 b) \mathrm{O}_{2} \rightarrow n \mathrm{CO}_{2}+(a / 2) \mathrm{H}_{2} \mathrm{O}
$$


La Ec. 16.15 muestra que 1 "mol" de materia orgánica requiere $1 / 4(4 n+a-2 b)$ moles de $\mathrm{O}_{2}$ o $8(4 n+a-2 b) \mathrm{gO}_{2}$. Por lo tanto, la demanda teórica de oxígeno de la materia orgánica se puede expresar como:

$$
\begin{gathered}
D Q O_{t}=8(4 n+a-2 b) /(12 n+a+16 b) \\
\left(\mathrm{gDQO} / \mathrm{gC}_{\mathrm{n}} \mathrm{H}_{\mathrm{a}} \mathrm{O}_{\mathrm{b}}\right)
\end{gathered}
$$

Obviamente, con compuestos que contienen nitrógeno (proteínas y aminoácidos), la Ec. 16.16 debe ser corregida para el número de electrones que permanecerán con el $\mathrm{N}$ y el peso total del $\mathrm{N}$ en el compuesto.

$$
\begin{gathered}
D Q O_{t}=8(4 n+a-2 b-3 d) /(12 n+a+16 b+14 d) \\
\left(\mathrm{gDQO} / \mathrm{gC}_{\mathrm{n}} \mathrm{H}_{\mathrm{a}} \mathrm{O}_{\mathrm{b}} \mathrm{N}_{\mathrm{d}}\right)
\end{gathered}
$$

A partir de la ecuación de la oxidación química para el ácido acético,

$$
\mathrm{CH}_{3} \mathrm{COOH}+2 \mathrm{O}_{2} \rightarrow 2 \mathrm{CO}_{2}+2 \mathrm{H}_{2} \mathrm{O}
$$

considerando que $1 \mathrm{~mol}$ (60 gramos) de ácido acético (el número de oxidación del átomo de $\mathrm{C}$ es 0 ) requiere 2 moles (64 gramos) de oxígeno. Esto significa que 1 gramo de ácido acético requiere 64/60 (1.067) gramos de oxígeno, por lo tanto 1 gramo de ácido acético corresponde a 1.067 gramos de DQO.

La relación entre los valores de la DQO y el COT se calculan a partir de:

$D Q O / C O T=8(4 n+a-2 b-3 d) /(12 n)=$

$8 / 3+2(a-2 b-3 d) /(3 n)$

En la Tabla 16.6 se presenta un resumen de los valores teóricos calculados de DQO por unidad de masa, para algunos compuestos orgánicos cuya fórmula es $\mathrm{C}_{\mathrm{n}} \mathrm{H}_{\mathrm{a}} \mathrm{O}_{\mathrm{b}} \mathrm{N}_{\mathrm{d}}$. La DQO por unidad de masa será muy diferente dependiendo del compuesto químico del que se trate. En el caso de compuestos fuertemente reducidos, por ejemplo el metano, esta DQO es alta. Utilizando la Ec. 16.2 para el metano ( $\mathrm{CH} 4$, es decir, $n=1, a=4, b=0$, $\mathrm{d}=0$ ) en la Ec. 16.4 se puede calcular:

$$
\begin{aligned}
& \mathrm{DQO}_{\mathrm{CH}_{4}}=8(4 \cdot 1+4-2 \cdot 0-3 \cdot 0) / \\
& (12 \cdot 1+4+16 \cdot 0+14 \cdot 0)=4 \mathrm{gDQO} / \mathrm{gCH}_{4}
\end{aligned}
$$

Es claro que la relación entre la DQO y el COT difiere substancialmente para varios compuestos. Esto se explica por la diferencia entre el estado de oxidación promedio del carbono orgánico. El estado de oxidación del carbono
(C-ox.) puede variar de -4 (el estado más reducido del carbono, como se encuentra para el $\mathrm{CH}_{4}$ ) a +4 , el más oxidado como se encuentra en el $\mathrm{CO}_{2}$. La Figura 16.9 representa el C-ox. para cierto número de compuestos con relación a la composición teórica del biogás producido, el cual obviamente genera una correlación lineal (Tabla 16.6).

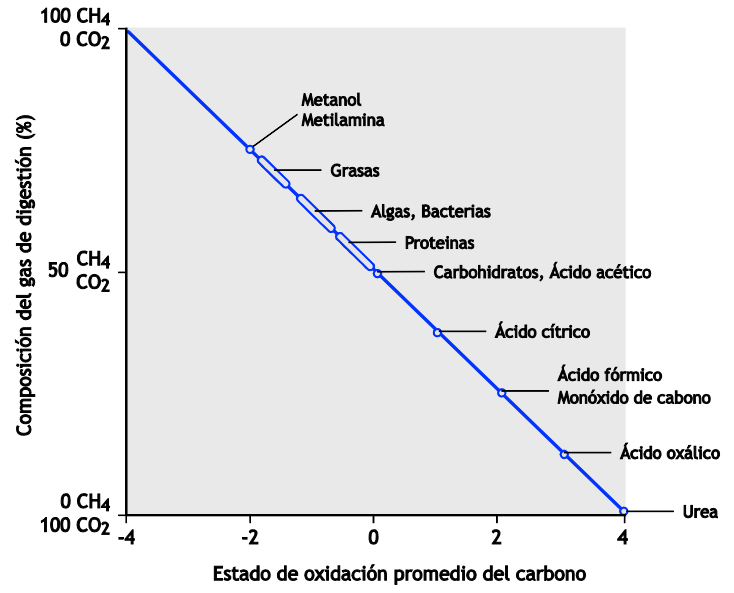

Figura 16.9 Composición teórica del biogás producido con relación al estado de oxidación promedio del carbono en sustratos específicos, suponiendo que se lleva a cabo la mineralización completa del sustrato

Entre más bajo sea el estado de oxidación del carbono en un compuesto (es decir, más negativo), se puede ligar más oxígeno al compuesto, y en consecuencia el valor de DQO será más alto.

Debido a que el $\mathrm{N}$ orgánico puede ser convertido a $\mathrm{NH}_{3}-\mathrm{N}$ en las pruebas de DQO (por lo tanto la cantidad de $\mathrm{N}$ en el compuesto será considerada por estar en su estado reducido, es decir, habiendo tomado 3 electrones), y a que un átomo de $\mathrm{H}$ produce un electrón y un átomo de $\mathrm{O}$ consumirá dos electrones, el número de oxidación promedio de un átomo de $\mathrm{C}$ en el compuesto $\mathrm{C}_{\mathrm{n}} \mathrm{H}_{\mathrm{a}} \mathrm{O}_{\mathrm{b}} \mathrm{N}_{\mathrm{d}}$ sigue la siguiente ecuación:

$C-$ estadoox. $=(2 b-\mathrm{a}+3 d) / n$

El número de electrones libres por átomo de $\mathrm{C}$ en la oxidación completa de $\mathrm{C}_{\mathrm{n}} \mathrm{H}_{\mathrm{a}} \mathrm{O}_{\mathrm{b}} \mathrm{N}_{\mathrm{d}}$ da como resultado:

$4-(2 b+3 d-a) / n=4+(a-2 b-3 d) / n$

Por lo tanto, el número de moléculas de $\mathrm{O}_{2}$ requeridas para la oxidación será:

$n+1 / 4 a-1 / 2 b-3 / 4 d$ 
Así, la ecuación para la oxidación química completa de un compuesto es:

$$
\begin{aligned}
& \mathrm{C}_{n} \mathrm{H}_{a} \mathrm{O}_{b} \mathrm{~N}_{d}+(n+a / 4-b / 2-3 d / 4) \mathrm{O}_{2} \rightarrow \\
& n \mathrm{CO}_{2}+(a / 2-3 d / 2) \mathrm{H}_{2} \mathrm{O}+d \mathrm{NH}_{3}
\end{aligned}
$$

En el caso de que el compuesto $\left(\mathrm{C}_{\mathrm{n}} \mathrm{H}_{\mathrm{a}} \mathrm{O}_{\mathrm{b}} \mathrm{N}_{\mathrm{d}}\right)$ sea completamente biodegradable $\mathrm{y}$ sea transformado completamente por los organismos anaerobios (sin producción de lodo) en $\mathrm{CH}_{4}, \mathrm{CO}_{2}$ y $\mathrm{NH}_{3}$, la cantidad teórica de metano $\left(\mathrm{y} \mathrm{CO}_{2}\right)$ producida puede ser calculada utilizando la ecuación de Buswell:

$$
\begin{aligned}
& \mathrm{C}_{n} \mathrm{H}_{a} \mathrm{O}_{b} \mathrm{~N}_{d}+(n-a / 4-b / 2+3 d / 4) \mathrm{H}_{2} \mathrm{O} \rightarrow \\
& (n / 2+a / 8-b / 4-3 d / 8) \mathrm{CH}_{4}+ \\
& (n / 2-a / 8+b / 4+3 d / 8) \mathrm{CO}_{2}+d \mathrm{NH}_{3}
\end{aligned}
$$

La DQO proporciona la información correcta con respecto al estado de oxidación de un compuesto; por lo tanto, se puede conocer la cantidad de metano que se produce a partir de ésta (Tabla 16.6, Figura 16.9). La única excepción son las sales cuaternarias de amonio, como la ya mencionada betaína, las cuales permanecen reducidas durante las pruebas de DQO a nivel laboratorio. Por lo tanto, la DQO es aceptada, por lo general, como el parámetro más adecuado para cuantificar la concentración de la materia orgánica y no el COT. Para predecir la cantidad relativa de $\mathrm{CH}_{4}$ en el biogás producido cuando la composición exacta de la materia orgánica se desconoce, la relación de DQO/COT es una herramienta muy útil. Esta última se basa en la correlación lineal entre el estado de oxidación promedio y la relación DQO/COT (Figura 16.10).

Con la presencia de aceptores de electrones inorgánicos específicos, como el nitrato, sulfato o sulfito, la producción de metano disminuirá, debido a la ocurrencia de, por ejemplo, las siguientes reacciones:

$$
\begin{aligned}
& 10 \mathrm{H}+2 \mathrm{H}^{+}+2 \mathrm{NO}_{3}^{-} \rightarrow \mathrm{N}_{2}+6 \mathrm{H}_{2} \mathrm{O} \\
& 8 \mathrm{H}+\mathrm{SO}_{4}{ }^{2-} \rightarrow \mathrm{H}_{2} \mathrm{~S}+2 \mathrm{H}_{2} \mathrm{O}+2 \mathrm{OH}^{-}
\end{aligned}
$$

Para aguas residuales que contienen un exceso de donadores de electrones orgánicos con respecto a la cantidad de nitrato $\left(\mathrm{NO}_{3}{ }^{-}\right)$, nitrito $\left(\mathrm{NO}_{2}{ }^{-}\right)$, sulfato $\left(\mathrm{SO}_{4}{ }^{2-}\right)$ o sulfito $\left(\mathrm{SO}_{3}{ }^{2}\right)$ presente, puede llevarse a cabo la reducción completa de estos aceptores de electrones (donadores de oxígeno). Debido a que la solubilidad del $\mathrm{H}_{2} \mathrm{~S}$ en el agua es considerablemente más alta que la del $\mathrm{CH}_{4}$, se tendrá una remoción de DQO considerablemente más baja en la fase líquida, en caso de que el agua residual contenga sulfato.

La cantidad de $\mathrm{CO}_{2}$ presente en el biogás producido, generalmente es más baja que la obtenida por medio de la ecuación de Buswell o la relación DQO/COT como se observa en la Figura 16.10. Esto se debe a: (a) la relativamente alta solubilidad del $\mathrm{CO}_{2}$ en el agua y (b) debido a que parte del $\mathrm{CO}_{2}$ se encontrará químicamente ligado a la fase acuosa, debido a la formación de amonio durante la conversión anaerobia de compuestos orgánicos conteniendo nitrógeno y debido a cationes presentes en el agua residual como sales de $\mathrm{AGVs}, \mathrm{SO}_{4}{ }^{2-}$ y $\mathrm{NO}_{3}{ }^{-}$.

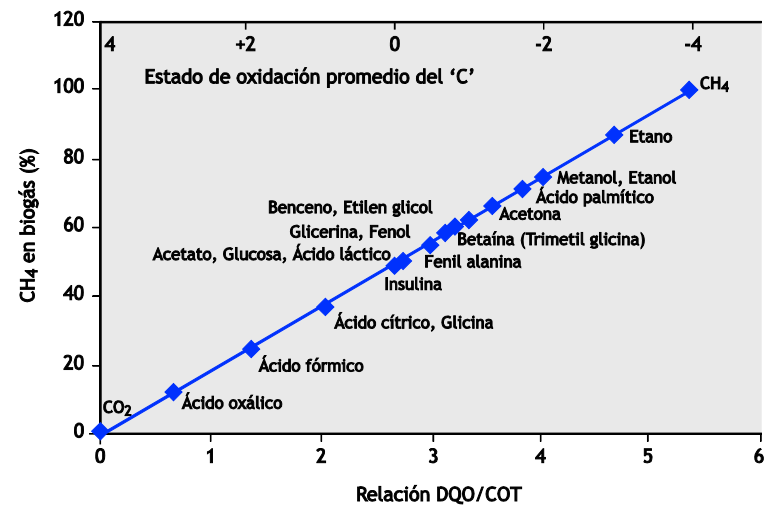

Figura 16.10 Porcentaje de $\mathrm{CH}_{4}$ esperado en el biogás producido en función de la relación DQO/COT: $\mathrm{CH}_{4} \%=18.75 \cdot \mathrm{DQO} / \mathrm{COT}$

\subsection{IMPACTO DE ACEPTORES DE ELECTRONES ALTERNOS}

\subsubsection{Conversiones bacterianas bajo condiciones anóxicas}

Los digestores anaerobios contienen una mezcla de comunidades microbianas. Además de las asociaciones metanogénicas descritas con anterioridad, otras bacterias pueden estar presentes, las cuales pueden competir con los metanógenos por los sustratos metanogénicos (Tabla 16.7). Las bacterias enlistadas poseen diferentes sistemas de respiración microbiana y pueden utilizar diferentes aceptores de electrones, tales como el oxígeno $\left(\mathrm{O}_{2}\right)$ por las bacterias aerobias (facultativas), nitrato $\left(\mathrm{NO}_{3}{ }^{-}\right)$por las desnitrificantes, sulfato $\left(\mathrm{SO}_{4}{ }^{2-}\right)$ o sulfito $\left(\mathrm{SO}_{3}{ }^{2-}\right)$ por las bacterias sulfato reductoras y hierro $\left(\mathrm{Fe}^{3+}\right)$ por las reductoras de hierro. El término anóxico significa que el oxígeno en estado gaseoso $\left(\mathrm{O}_{2}\right)$ no se encuentra disponible como un aceptor de electrones. 
Tabla 16.6 Valores estequiométricos para la DQO y el COT por unidad de masa para diferentes compuestos orgánicos puros $\mathrm{C}_{\mathrm{n}} \mathrm{H}_{\mathrm{a}} \mathrm{O}_{\mathrm{b}} \mathrm{N}_{\mathrm{d}}$, valores de DQO/COT y estado de oxidación promedio del carbono para estos compuestos, además del \% de $\mathrm{CH}_{4}$ en el biogás

\begin{tabular}{|c|c|c|c|c|c|c|c|c|c|}
\hline Compuesto & $\mathrm{n}$ & $\mathrm{a}$ & $\mathrm{b}$ & $\mathrm{d}$ & 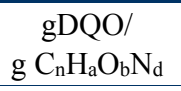 & $\begin{array}{c}\mathrm{gCOT} / \\
\mathrm{g} \mathrm{C}_{\mathrm{n}} \mathrm{H}_{\mathrm{a}} \mathrm{ObN}_{\mathrm{d}}\end{array}$ & $\mathrm{DQO} / \mathrm{COT}$ & C-ox. & $\mathrm{CH}_{4} \%$ \\
\hline Metano & 1 & 4 & 0 & 0 & 4 & 0.75 & 5.33 & -4 & 100 \\
\hline Etano & 2 & 6 & 0 & 0 & 3.73 & 0.8 & 4.67 & -3 & 87.5 \\
\hline Metanol & 1 & 4 & 1 & 0 & 1.5 & 0.38 & 4 & -2 & 75 \\
\hline Etanol & 2 & 6 & 1 & 0 & 2.09 & 0.52 & 4 & -2 & 75 \\
\hline Ciclohexano & 6 & 12 & 0 & 0 & 3.43 & 0.86 & 4 & -2 & 75 \\
\hline Etileno & 2 & 4 & 0 & 0 & 3.43 & 0.86 & 4 & -2 & 75 \\
\hline Ácido palmítico & 16 & 32 & 2 & 0 & 3.43 & 0.75 & 3.83 & -1.75 & 72 \\
\hline Acetona & 3 & 6 & 1 & 0 & 2.21 & 0.62 & 3.56 & -1.33 & 67 \\
\hline Etilenglicol & 2 & 6 & 2 & 0 & 1.29 & 0.39 & 3.33 & -1 & 62.5 \\
\hline Benceno & 6 & 6 & 0 & 0 & 3.08 & 0.92 & 3.33 & -1 & 62.5 \\
\hline Betaína & 5 & 11 & 2 & 1 & $1.64^{\mathrm{a}}$ & 0.51 & 3.2 & -0.8 & 60 \\
\hline Glicerina & 3 & 8 & 3 & 0 & 1.22 & 0.39 & 3.11 & -0.67 & 58 \\
\hline Fenol & 6 & 6 & 1 & 0 & 2.38 & 0.77 & 3.11 & -0.67 & 58 \\
\hline Lisina & 6 & 14 & 2 & 2 & 1.53 & 0.49 & 3.11 & -0.67 & 58 \\
\hline Fenilalanina & 9 & 11 & 2 & 1 & 1.94 & 0.65 & 2.96 & -0.44 & 56 \\
\hline Insulina & 254 & 377 & 75 & 65 & 1.45 & 0.53 & 2.72 & -0.08 & 51 \\
\hline Glucosa & 6 & 12 & 6 & 0 & 1.07 & 0.4 & 2.67 & 0 & 50 \\
\hline Ácido láctico & 3 & 6 & 3 & 0 & 1.07 & 0.4 & 2.67 & 0 & 50 \\
\hline Ácido acético & 2 & 4 & 2 & 0 & 1.07 & 0.4 & 2.67 & 0 & 50 \\
\hline Ácido cítrico & 6 & 8 & 7 & 0 & 0.75 & 0.38 & 2 & 1 & 37.5 \\
\hline Glicina & 2 & 5 & 2 & 1 & 0.64 & 0.32 & 2 & 1 & 37.5 \\
\hline Ácido fórmico & 1 & 2 & 2 & 0 & 0.35 & 0.26 & 1.33 & 2 & 25 \\
\hline Ácido oxálico & 2 & 2 & 4 & 0 & 0.18 & 0.27 & 0.67 & 3 & 12.5 \\
\hline $\begin{array}{l}\text { Dióxido } \\
\text { carbono }\end{array}$ & 1 & 0 & 2 & 0 & 0 & 0.27 & 0 & 4 & 0 \\
\hline
\end{tabular}

a Teóricamente: con la prueba estándar de DQO con dicromato no se medirá DQO

\subsubsection{Reducción del sulfato}

En presencia de sulfato, sulfito o tiosulfato, las bacterias sulfato reductoras (BSR), las cuales tienen un espectro de sustratos más amplio, se encuentran disponibles para utilizar varios intermediarios del proceso de mineralización anaerobia (Tabla 16.7). Estas bacterias convierten al sulfato en sulfuro de hidrógeno. Además de los sustratos metanogénicos directos, tales como el hidrógeno molecular $\left(\mathrm{H}_{2}\right)$, formiato, acetato, metanol y piruvato, las BSR también pueden utilizar el propionato, butirato, ácidos grasos superiores y ramificados, lactato, etanol y alcoholes pesados, fumarato, succinato, malato y compuestos aromáticos (Colleran et al., 1995). Por lo tanto, los principales productos intermedios del proceso de degradación anaerobia $\left(\mathrm{H}_{2} / \mathrm{CH}_{3} \mathrm{COO}^{-}\right)$pueden ser convertidos por las BSR, metanógenos y/o las bacterias obligadas productoras de hidrógeno (BOPH). Debido a que estos tres grupos de bacterias operan bajo las mismas condiciones ambientales ( $\mathrm{pH}$, temperatura), competirán por los mismos sustratos. El resultado de esta competencia dependerá de la cinética de conversión (ver la Sección 16.10).

Si la materia orgánica se oxida por la vía de sulfatoreducción, 8 electrones pueden ser aceptados por cada molécula de sulfato. Debido a que una molécula de oxígeno sólo puede aceptar 4 electrones, la capacidad aceptora de 2 moles de $\mathrm{O}_{2}$ equivale a $1 \mathrm{~mol}$ de $\mathrm{SO}_{4}{ }^{2-}$, lo que es equivalente a $0.67 \mathrm{~g}_{\text {de }} \mathrm{O}_{2}$ por $\mathrm{g}$ de $\mathrm{SO}_{4}{ }^{2-}$. Esto significa que para descargas de desecho con una relación de DQO/sulfato igual a 0.67 , teóricamente se encontrará suficiente sulfato disponible para remover la materia orgánica completamente (DQO) por medio de la reducción del sulfato. Para relaciones de $\mathrm{DQO} /$ sulfato menores a 0.67 , la cantidad de materia orgánica es insuficiente para la reducción completa del sulfato presente $\mathrm{y}$, por lo tanto, será necesaria una cantidad adicional de sustrato si el objetivo del tratamiento es la remoción de este compuesto. Por el contrario, para aguas 
Tabla 16.7 Estequiometría y cambio de la energía libre de Gibbs $\Delta \mathrm{G}^{\mathrm{o}^{\prime}}(\mathrm{kJ} / \mathrm{mol}$ de sustrato) para las conversiones del hidrógeno y acetato, bajo diferentes condiciones

\begin{tabular}{|c|c|c|}
\hline Reacción & $\Delta \mathrm{G}^{\circ \prime}(\mathrm{kJ} / \mathrm{mol}$ de sustrato $)$ & Ec. \\
\hline \multicolumn{3}{|l|}{ Aerobios } \\
\hline $\mathrm{H}_{2}+0.5 \mathrm{O}_{2} \rightarrow \mathrm{H}_{2} \mathrm{O}$ & -237 & $(16.27)$ \\
\hline $\mathrm{CH}_{3} \mathrm{COO}^{-}+2 \mathrm{O}_{2} \rightarrow 2 \mathrm{HCO}_{3}^{-}+\mathrm{H}^{+}$ & -844 & $(16.28)$ \\
\hline \multicolumn{3}{|l|}{ Desnitrificantes } \\
\hline $\mathrm{H}_{2}+0.4 \mathrm{NO}_{3}{ }^{-}+0.4 \mathrm{H}^{+} \rightarrow 0.2 \mathrm{~N}_{2}+1.2 \mathrm{H}_{2} \mathrm{O}$ & -224 & $(16.29)$ \\
\hline $\mathrm{CH}_{3} \mathrm{COO}^{-}+1.6 \mathrm{NO}_{3}^{-}+0.6 \mathrm{H}^{+} \rightarrow 2 \mathrm{HCO}_{3}^{-}+0.8 \mathrm{~N}_{2}+0.8 \mathrm{H}_{2} \mathrm{O}$ & -792 & $(16.30)$ \\
\hline \multicolumn{3}{|l|}{ Bacterias reductoras de $\mathrm{Fe}^{3+}$} \\
\hline $\mathrm{H}_{2}+2 \mathrm{Fe}^{3+} \rightarrow 2 \mathrm{Fe}^{2+}+2 \mathrm{H}^{+}$ & -228 & $(16.31)$ \\
\hline $\mathrm{CH}_{3} \mathrm{COO}^{-}+4 \mathrm{Fe}^{3+}+4 \mathrm{H}_{2} \mathrm{O} \rightarrow 4 \mathrm{Fe}^{2+}+5 \mathrm{H}^{+}+2 \mathrm{HCO}_{3}$ & -352 & $(16.32)$ \\
\hline \multicolumn{3}{|l|}{ Bacterias sulfato-reductoras } \\
\hline $\mathrm{H}_{2}+0.25 \mathrm{SO}_{4}{ }^{2-}+0.25 \mathrm{H}^{+} \rightarrow 0.25 \mathrm{HS}^{-}+\mathrm{H}_{2} \mathrm{O}$ & -9.5 & $(16.33)$ \\
\hline $\mathrm{CH}_{3} \mathrm{COO}^{-}+\mathrm{SO}_{4}^{2-} \rightarrow \mathrm{HS}^{-}+2 \mathrm{HCO}_{3}^{-}$ & -48 & $(16.34)$ \\
\hline \multicolumn{3}{|l|}{ Metanógenos } \\
\hline $\mathrm{H}_{2}+0.25 \mathrm{HCO}_{3}^{-}+0.25 \mathrm{H}^{+} \rightarrow 0.25 \mathrm{CH}_{4}+0.75 \mathrm{H}_{2} \mathrm{O}$ & -8.5 & $(16.35)$ \\
\hline $\mathrm{CH}_{3} \mathrm{COO}^{-}+\mathrm{H}_{2} \mathrm{O} \rightarrow \mathrm{CH}_{4}+\mathrm{HCO}_{3}^{-}$ & -31 & (16.36) \\
\hline
\end{tabular}

residuales con una relación de $\mathrm{DQO} /$ sulfato que exceda a 0.67 , únicamente se podrá lograr una remoción completa de la materia orgánica si, además de la reducción del sulfato, se lleva a cabo la metanogénesis.

En presencia de sulfato, no necesariamente se degradará con menor facilidad la materia orgánica, pero en comparación con el metano, el sulfuro de hidrógeno posee la gran desventaja de que se disuelve mucho mejor en el agua que el metano. Esto significa que, para el mismo grado de degradación del residuo orgánico, una menor cantidad de DQO será reducida en el agua residual que contiene sulfato. La producción de sulfuro puede ocasionar posteriormente los siguientes problemas técnicos durante el proceso de digestión anaerobia:

- El $\mathrm{H}_{2} \mathrm{~S}$ es tóxico para las arqueobacterias metanogénicas (AM), bacterias acetogénicas (BA) y BSR. En caso de que se lleve a cabo el tratamiento metanogénico del agua residual, algunos de los compuestos orgánicos contenidos en ésta serán consumidos por las BSR en lugar de las AM y, por lo tanto, no serán convertidos en metano. Esto resultará en una menor producción de metano por unidad de residuos orgánicos degradados $\mathrm{y}$, por lo tanto, afectará de manera negativa al balance global de energía del proceso. Por otra parte, la calidad del biogás se verá reducida debido a que, una parte del sulfuro producido terminará como $\mathrm{H}_{2} \mathrm{~S}$ en el biogás, requiriéndose un proceso de remoción posterior.
- El sulfuro producido tienen un olor desagradable y puede causar problemas de corrosión en las tuberías, motores y calderas. Así, los costos de mantenimiento de la instalación serán mayores y se requerirá de costos adicionales de inversión para evitar este tipo de problemas.

- Una parte del sulfuro se presentará en el efluente del reactor anaerobio. Tal y como se mencionó con anterioridad, esto resultará en una menor eficiencia global del tratamiento, debido a que el sulfuro contribuye en la DQO del agua residual (por cada mol de sulfuro se requieren dos moles de oxígeno para llevar a cabo una oxidación completa a sulfato). Por otra parte, el sulfuro puede alterar la eficiencia del post-tratamiento aerobio, por ej., con el crecimiento de algas en las lagunas o aumento en el volumen de los lodos activados. Así, se requerirá de un sistema de post- tratamiento adicional para remover el sulfuro presente en el agua residual.

Con base en el consumo de sustrato, las BSR pueden clasificarse en los siguientes tres grupos:

1) BSR consumidoras de hidrógeno (BSRH)

2) BSR consumidoras de ácido acético (BSRA)

3) BSR consumidoras de ácidos grasos (BSRAG) 
En el último grupo, se pueden distinguir dos rutas de oxidación:

$$
\begin{aligned}
& \mathrm{CH}_{3} \mathrm{CH}_{2} \mathrm{COOH}+2 \mathrm{H}_{2} \mathrm{O} \rightarrow \\
& \mathrm{CH}_{3} \mathrm{COOH}+3 \mathrm{H}_{2}+\mathrm{CO}_{2}(\mathrm{BOPH})
\end{aligned}
$$

$$
\begin{aligned}
& \mathrm{CH}_{3} \mathrm{CH}_{2} \mathrm{COOH}+0.75 \mathrm{SO}_{4}^{2-} \rightarrow \\
& \mathrm{CH}_{3} \mathrm{COOH}+0.75 s^{2-}+\mathrm{CO}_{2}(\mathrm{BSRAG})
\end{aligned}
$$

$$
\begin{aligned}
& \mathrm{CH}_{3} \mathrm{CH}_{2} \mathrm{COOH}+1.75 \mathrm{SO}_{4}^{2-} \rightarrow \\
& 1.75 \mathrm{~S}^{2-}+3 \mathrm{CO}_{2}+3 \mathrm{H}_{2} \mathrm{O}(\mathrm{BSRAG})
\end{aligned}
$$

Algunas BSR son capaces de oxidar completamente los AGVs dando $\mathrm{CO}_{2}$ y sulfuro como productos finales. Otras BSR no poseen el ácido tricarboxílico y llevan a cabo una oxidación incompleta del AGV, generando como productos finales acetato y sulfuro. En este último caso, el ácido acético es excretado del medio. Además, debe de observarse que la oxidación incompleta del ácido propiónico por una BSR genera los mismos productos que la conversión por BOPH y BSRH. Por lo tanto, no es posible deducir por medio de los balances de masa cuál bacteria ha llevado a cabo esta conversión.

Además de la reducción de sulfato, la reducción de sulfito y tiosulfato es muy común en las BSR (Widdel and Hansen, 1992). Se ha reportado que las cepas de Desulfovibrio son capaces de reducir el di-, tri- y tetrationato (Fitz and Cypionka, 1990). Una habilidad única de las BSR, por ej. Desulfovibrio dismutans y Desulfobacter curvatus, es la dismutación del sulfito o tiosulfato (Widdel and Hansen, 1992):

$$
\begin{aligned}
& 4 \mathrm{SO}_{3}{ }^{2-}+H^{+} \rightarrow 3 \mathrm{SO}_{4}{ }^{2-}+\mathrm{HS}^{-} \\
& \Delta \mathrm{G}^{\mathrm{o}^{\prime}}=-58.9 \mathrm{~kJ} / \mathrm{mol} \mathrm{SO}_{3}{ }^{2-} \\
& \mathrm{S}_{2} \mathrm{O}_{3}{ }^{2-}+\mathrm{H}_{2} \mathrm{O} \rightarrow \mathrm{SO}_{4}{ }^{2-}+\mathrm{HS}^{-}+H^{+} \\
& \Delta \mathrm{G}^{\mathrm{o}^{\prime}}=-21.9 \mathrm{~kJ} / \mathrm{mol} \mathrm{S}_{2} \mathrm{O}_{3}{ }^{2-}
\end{aligned}
$$

La ecología microbiana de las BSR se ha estudiado por medio de varias técnicas analíticas nuevas, por ej. mediante la aplicación de microelectrodos de sulfuro, resonancia magnética de ${ }^{13} \mathrm{C}$ y ${ }^{31} \mathrm{P}(\mathrm{NMR}$, Santos et al., 1994) y RNA 16s ribosomal (rRNA) (Raskin et al., 1995). Se encontró que algunas BSR podían respirar oxígeno, a pesar de haber sido clasificadas como anaerobias estrictas. La habilidad de las BSR para llevar a cabo la reducción de sulfato bajo condiciones aerobias
(Canfield and Des Marais, 1991, Frund and Cohen, 1992) es muy intrigante $y$ puede resultar significativa ingenierilmente.

En ausencia de un aceptor de electrones, las BSR pueden crecer por medio de una reacción de fermentación $\mathrm{o}$ acetogénesis. El piruvato, lactato y etanol son compuestos que pueden ser fácilmente fermentables por varias BSR (Dolfing, 1987; Widdel et al., 1988). Una característica importante de las BSR es su habilidad para llevar a cabo la oxidación acetogénica junto con las arqueobacterias metanogénicas hidrogenotróficas (AMH), como se describe para los co-cultivos de AMH con Desulfovibrio sp. utilizando lactato y etanol (Widdel et al., 1988; Oude Elferink et al., 1994), o con bacterias Desulfobulbus utilizando propionato (Wu et al., 1991).

La oxidación acetogénica del propionato por Desulfobulbus sp., ha sido reportada también en algunos reactores UASB (Wu et al., 1992), de lecho fluidizado (Heppner et al., 1992) y de lecho fijo (Zellner and Neudörfer, 1995). En presencia de sulfato, sin embargo, estas bacterias se comportan como verdaderas BSR y pueden metabolizar el propionato como donador de electrones para la reducción del sulfato.

$\mathrm{Si}$ el $\mathrm{SO}_{4}{ }^{2-}$ se encuentra presente en el agua residual, no se puede prevenir la reducción de $\mathrm{SO}_{4}{ }^{2-}$ por las BSR. Se realizaron varios intentos para tratar de evitar la competencia en un sistema de tratamiento simple; sin embargo, estos no tuvieron éxito. Por otro lado, existen varias soluciones tecnológicas en el mercado para disminuir la concentración de $\mathrm{H}_{2} \mathrm{~S}$ en el reactor anaerobio y con ello minimizar la toxicidad de las AM (Figura 16.11).

\subsubsection{Desnitrificación}

En general, no se lleva a cabo la desnitrificación durante la purificación anaerobia y la digestión. El nitrógeno ligado orgánicamente será convertido a amonio. Se puede esperar que ocurra la desnitrificación únicamente cuando el afluente contiene nitrato (ver el Capítulo 5).

La desnitrificación se lleva a cabo por microorganismos desnitrificantes, es decir, por bacterias quimioheterótrofas, las cuales son capaces de oxidar la materia orgánica con nitrato. El nitrato es entonces convertido, vía nitrito y óxido de nitrógeno, en gas $\mathrm{N}_{2}$. Por lo general, los microorganismos desnitrificantes prefieren el oxígeno como aceptor de electrones, debido a que, este último compuesto produce una mayor cantidad de energía (Tabla 16.7). En los procesos de 
A

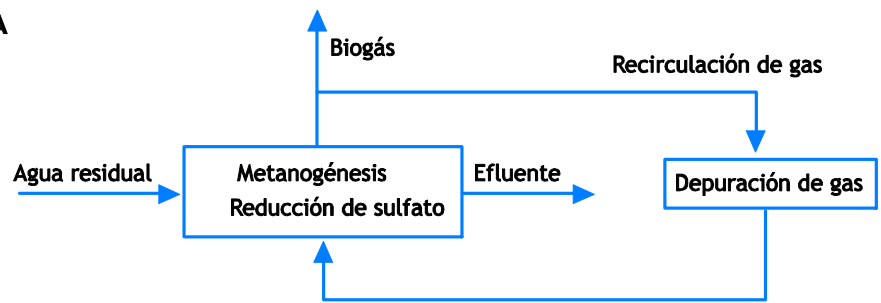

B
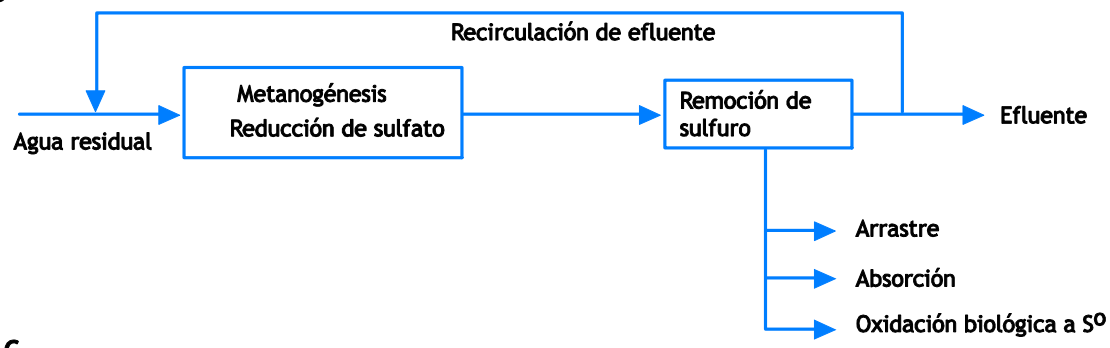

C

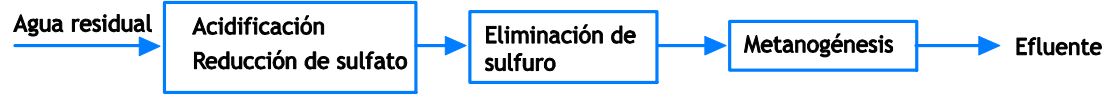

Figura 16.11 Soluciones tecnológicas para disminuir la concentración de $\mathrm{H}_{2} \mathrm{~S}$ en el reactor anaerobio. (A) aumento del $\mathrm{H}_{2} \mathrm{~S}$, por medio de la recirculación del biogás y la extracción del sulfuro en la línea de gas, (B) remoción de $\mathrm{H}_{2} \mathrm{~S}$ en un sistema de post-tratamiento micro aerobio y recirculación del efluente tratado hacia el afluente del reactor anaerobio para dilución, (C) combinación de una pre-acidificación y la reducción de sulfato con remoción de sulfuro para disminuir el contenido de $\mathrm{S}$ en el reactor anaerobio. En esta última estrategia, la mayoría del $\mathrm{H}_{2} \mathrm{~S}$ será extraída en el paso de acidificación, generando la prevalencia de un pH bajo

tratamiento aerobios, se comienza por utilizar el nitrato tan rápido como el $\mathrm{O}_{2}$ se agota para hacer frente a la carga orgánica. En una planta de lodos activados, el proceso de desnitrificación normalmente ocurrirá a una concentración de $\mathrm{O}_{2}$ disuelto de $1 \mathrm{mg} / \mathrm{l}$ o por debajo de esta.

La desnitrificación es un proceso heterotrófico que requerirá de un donador de electrones. La estequiometría de la oxidación del metanol con nitrato y nitrito se lleva a cabo de acuerdo a las siguientes reacciones:

$$
\begin{aligned}
& \mathrm{CH}_{3} \mathrm{OH}+2 \mathrm{NO}_{2}{ }^{-} \rightarrow \mathrm{N}_{2}+\mathrm{CO}_{3}{ }^{2-}+2 \mathrm{H}_{2} \mathrm{O} \\
& 5 \mathrm{CH}_{3} \mathrm{OH}+6 \mathrm{NO}_{3}{ }^{-} \rightarrow 3 \mathrm{~N}_{2}+4 \mathrm{HCO}_{3}{ }^{-}+\mathrm{CO}_{3}{ }^{2-}+8 \mathrm{H}_{2} \mathrm{O}
\end{aligned}
$$

Estas reacciones muestran que la desnitrificación resultará en un aumento de $\mathrm{pH}$ (producción de carbonato).

\subsection{TRABAJANDO CON EL BALANCE DE DQO}

Como cualquier otro sistema biológico, el proceso de tratamiento anaerobio requiere del monitoreo de sus principales parámetros, y se deben evaluar las mediciones para una adecuada operación y control. En la Sección 16.3 se discute la utilidad de la DQO como un parámetro de control en los sistemas anaerobios. La razón de esto es que, en comparación con los sistemas aerobios, en los reactores anaerobios no hay destrucción de la DQO. Durante el tratamiento anaerobio la DQO únicamente se "re-arregla". Los compuestos orgánicos complejos son convertidos a productos intermedios más simples y eventualmente son mineralizados a $\mathrm{CH}_{4} \mathrm{y} \mathrm{CO}_{2}$. Toda la DQO que entra al sistema es convertida a $\mathrm{CH}_{4}$, sustrayendo la DQO que es incorporada en la nueva masa bacteriana. Debido a que un balance de masa perfecto puede realizarse únicamente utilizando la DQO como parámetro, por lo tanto, se considera por lo general como una herramienta de control para operar el sistema anaerobio:

$$
D Q O_{\text {entrada }}=D Q O_{\text {salida }}
$$

Para propósitos prácticos, la Ec. 16.44 debe ser expandida considerando las diferentes salidas del reactor anaerobio como se muestra en la Figura 16.12. 


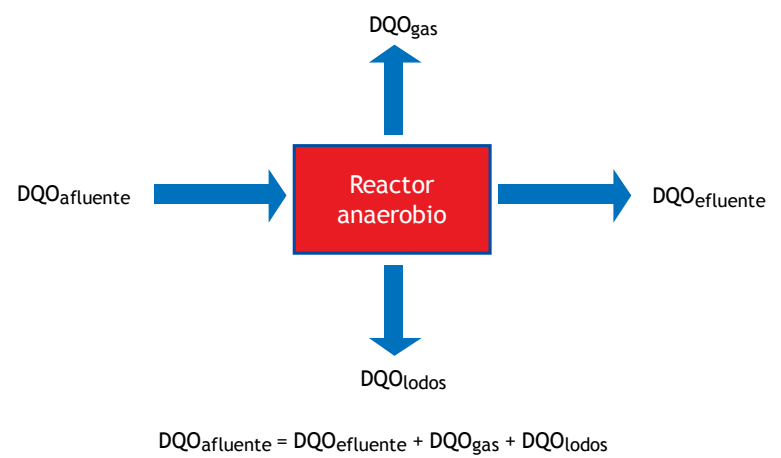

Figura 16.12 Balance de DQO en el reactor anaerobio. Mediante la diferenciación de las fracciones de DQO en el gas, líquido y sólidos, los parámetros faltantes pueden ser estimados a partir de los parámetros más fácilmente medibles

Para identificar el destino de la DQO en el reactor anaerobio, se deberá de realizar un análisis detallado de las salidas gaseosas, líquidas y sólidas (Tabla 16.8).

Con base en las características básicas del afluente, como la velocidad de flujo y las concentraciones de DQO, y la información de la biodegradabilidad de la DQO, se puede estimar fácilmente la velocidad de producción esperada de $\mathrm{CH}_{4}$. De la sección 16.3.1, se obtiene que:

$$
\mathrm{CH}_{4}+2 \mathrm{O}_{2} \rightarrow \mathrm{CO}_{2}+2 \mathrm{H}_{2} \mathrm{O}
$$

lo que significa que $22.4 \mathrm{~m}^{3} \mathrm{CH}_{4}$ (STP) requiere 2 moles de $\mathrm{O}_{2}$ (DQO), lo cual equivale a $64 \mathrm{~kg}$ DQO. Por lo tanto, teóricamente, $1 \mathrm{~kg}$ DQO se convierte en $0.35 \mathrm{~m}^{3}$ $\mathrm{CH}_{4}$.

De manera similar, la DQO teórica equivalente para 1 kg "SSV bacterianos", con una composición estimada de
$\mathrm{C}_{5} \mathrm{H}_{7} \mathrm{O}_{2} \mathrm{~N}$, se puede calcular como $1.42 \mathrm{kgDQO} / \mathrm{kgSSV}$. Teniendo ambos productos finales $\mathrm{CH}_{4}$ y la nueva biomasa expresados como DQO, el balance se puede realizar cuando el afluente y efluente se miden adecuadamente.

Por lo general siempre se presentan "lagunas" en el balance de DQO, las cuales pueden ser atribuidas por lo general a la "pérdida de electrones", cuando estos son canalizados hacia aniones oxidados como $\mathrm{SO}_{4}{ }^{2-}$ y $\mathrm{NO}_{3}{ }^{-}$, como se explicó en la sección 16.4. Por lo tanto, en este caso, para cerrar el balance de DQO, pueden ser considerados todos los gases reducidos o se deberán medir las concentraciones de los aceptores de electrones. Debe tenerse en cuenta que la DQO soluble contiene gases como el $\mathrm{H}_{2} \mathrm{~S}$, los cuales estarán presentes en el efluente. En este ejemplo, la DQO orgánica se convierte a DQO inorgánica, de la cual una fracción dependiente del $\mathrm{pH}$ terminará en el biogás mientras que el resto permanecerá en el efluente.

Otra causa frecuentemente citada de una posible laguna de DQO, es el atrapamiento o acumulación de DQO en el lecho de lodos, en algunas ocasiones cambiando drásticamente el valor estequiométrico de $1.42 \mathrm{kgDQO} / \mathrm{kgSSV}$. Lo anterior es particularmente cierto durante el tratamiento de aguas residuales conteniendo grasas o AGVCL. Con estos sustratos, las eficiencias de remoción de DQO son por lo general muy altas; sin embargo, las velocidades bajas de producción de $\mathrm{CH}_{4}$ ocasionarán enormes lagunas en el balance. En este ejemplo, las lagunas de DQO indican graves problemas de funcionamiento a largo plazo. La acumulación de sólidos deteriora la SMA de los lodos, lo cual resultará finalmente en una completa falla del proceso anaerobio.

Tabla 16.8 Diferentes fracciones de DQO y su destino en un reactor anaerobio. El número de puntos indica la importancia relativa de la fracción de DQO en su respectivo compartimento (afluente, efluente, lodo, biogás)

\begin{tabular}{lccc}
\hline Fracción de DQO & Afluente & Efluente & Lodo \\
\hline Orgánica soluble & $\bullet \bullet \bullet$ & $\bullet \bullet \bullet$ & $\bullet$ \\
Inorgánica soluble & $\bullet$ & $\bullet$ & $\bullet$ \\
Orgánica suspendida & $\bullet \bullet \bullet$ & $\bullet$ & $\bullet$ \\
Inorgánica suspendida & & & $\bullet \bullet \bullet$ \\
Coloidal & $\bullet$ & $\bullet$ & $\bullet$ \\
Absorbida & $\bullet$ & & $\bullet \bullet$ \\
Acumulada & & & $\bullet$ \\
$\mathrm{CH}_{4}$ & & & $\bullet$ \\
$\mathrm{H}_{2}$ & $\bullet$ & & $\bullet$ \\
$\mathrm{H}_{2} \mathrm{~S}$ & & $\bullet$ & $\bullet$ \\
$\mathrm{N} 2$ & & & $\bullet$ \\
\hline
\end{tabular}


Al operar el reactor anaerobio, utilizando el balance de DQO como herramienta para el monitoreo del funcionamiento del reactor, le proporciona al operador información vital sobre el funcionamiento del sistema. Se deberán tomar acciones adecuadas antes de que ocurra un daño irreversible en el sistema. Además, el impacto del uso de aceptores de electrones alternos en la velocidad de producción de $\mathrm{CH}_{4}$, puede ser evaluado fácilmente, mientras que con base en la producción de gas y los valores de DQO del efluente, se puede realizar una estimación de la cantidad de biomasa nueva y atrapada en el sistema.

\subsection{INMOBILIZACIÓN Y GRANULACIÓN DEL LODO}

La clave para un proceso biotecnológico moderno de alta tasa, sin importar el sistema que sea considerado, es la inmovilización de las bacterias adecuadas. La alta retención de lodo requerida en los sistemas de tratamiento anaerobio se basa en la inmovilización, aunque no es solo cuestión de la inmovilización de las bacterias si no de un consorcio bacteriano adecuadamente balanceado. Con respecto a la ocurrencia de varias reacciones sintróficas en la conversión anaerobia de la mayoría de los compuestos orgánicos, el efecto perjudicial de las altas concentraciones de intermediarios específicos y el fuerte efecto de algunos factores ambientales como el $\mathrm{pH}$ y el potencial redox, el desarrollo de un consorcio bacteriano balanceado es un pre-requisito para que un sistema de tratamiento anaerobio funcione adecuadamente. Se ha progresado significativamente en los conocimientos fundamentales del proceso de inmovilización, desde su desarrollo y exitosa implementación de los sistemas de tratamiento anaerobio de alta tasa en los años 70. La inmovilización puede llevarse a cabo en el material inerte de soporte montado en una matriz fija, en los llamados filtros anaerobios (AF), los cuales pueden ser operados en flujo ascendente o descendente. La matriz también puede encontrarse en libre flotación, como en los bioreactores de lecho móvil y en los sistemas de lecho fluidizado (FB). Si no se utiliza algún material inerte como soporte, la llamada "auto-inmovilización" puede ocurrir, la cual se entiende como una inmovilización de bacterias sobre ellas mismas formando conglomerados bacterianos, o en partículas muy finas de material inerte u orgánico presente en el agua residual. Los conglomerados bacterianos madurarán con el tiempo y formarán gránulos redondos de lodo.

Con respecto a la inmovilización, particularmente el fenómeno de granulación ha desconcertado a varios investigadores de diferentes disciplinas. La granulación de hecho es un proceso completamente natural. Se llevará a cabo en todos los sistemas en donde se presenten las condiciones básicas para que ocurra, como en la mayoría de los sustratos solubles y en reactores operados con flujo ascendente, con tiempos de retención hidráulicos (TRH) más bajos que los tiempos de duplicación de las bacterias. Debido a las bajas velocidades de crecimiento de las AM acetoclásticas más importantes, particularmente bajo condiciones sub-óptimas, las condiciones mencionadas con anterioridad se pueden lograr fácilmente. La granulación del lodo, también ocurrió utilizando flujo reversible en digestores tipo Dorr Oliver Clarigesters aplicados en África del Sur, desde los años cincuenta del siglo pasado. Sin embargo, esto sólo fue aparente en 1979, al observar las muestras de lodo tomadas de este digestor. De manera sorprendente, no se había puesto atención en las características del lodo del Clarigester, tales como el tamaño, forma y la resistencia mecánica, densidad y porosidad de los flóculos o agregados del lodo. A pesar de todos los esfuerzos realizados para el desarrollo de sistemas con una alta tasa de retención de lodos, aparentemente nadie se había dado cuenta de que la mayor parte del lodo consistía en un tipo de lodo granular. Mientras se estudiaba la puesta en marcha y factibilidad de los filtros anaerobios de flujo ascendente, Young and McCarty (1969), reconocieron la habilidad del lodo anaerobio para formar agregados fácilmente sedimentables. Estos gránulos tenían un tamaño de 3.1 $\mathrm{mm}$ de diámetro y sedimentaban fácilmente. En experimentos de AF con aguas residuales conteniendo almidón de papas y soluciones de metanol, llevados a cabo en Holanda, se realizaron las mismas observaciones (Lettinga et al., 1972, 1979). Mientras el interés en los sistemas AnWT en EUA y África del Sur disminuyó, en Holanda se puso gran énfasis en el desarrollo de sistemas a escala industrial, en donde la instalación de nuevas regulaciones de protección del agua superficial coincidió con la crisis mundial energética de los sesenta. Como resultado, se dio un énfasis creciente en la investigación aplicada y fundamental en este campo, particularmente también en el fenómeno de granulación del lodo. A nivel mundial, aumentó el interés tanto en los aspectos ingenieriles como microbiológicos. Como resultado, la visión en el mecanismo del proceso de granulación del lodo para un tratamiento anaerobio, ha sido dilucidado suficientemente, al menos para una aplicación práctica (e.g. de Zeeuw, 1982; 1987; Hulshoff Pol and Lettinga, 1986; Wiegant and de Man, 1986; Beeftink and Staugard, 1986; Hulshoff Pol et al., 1987, 2004; Wu, 1987; Dolfing, 1987; Wu et al., 1991; Grotenhuis, 1992; van Lier et al., 1994; Thaveesri et al., 1994; Fang et al., 
1994). La granulación puede ocurrir bajo condiciones mesofílicas, termofílicas y psicrofílicas. Es de vital importancia para la práctica, el mejorar la visión en las preguntas fundamentales con respecto al crecimiento de cultivos mixtos balanceados. Esto ayudará a que el proceso pueda ser aplicado en la degradación de una gran variedad de compuestos difícilmente degradables. Estas preguntas desafiantes deberán ser atacadas en conjunto por medio de los esfuerzos realizados por científicos y microbiólogos.

\subsubsection{Mecanismos importantes durante la granulación del lodo}

En esencia, la granulación de los lodos tiene su base en el hecho de que la retención de las bacterias es imperativa, cuando las velocidades de dilución exceden las velocidades de crecimiento bacteriano. La inmovilización requerirá la presencia de un material de soporte y/o un núcleo específico de crecimiento. La ocurrencia de la granulación puede ser explicada como sigue:

1) Un núcleo de crecimiento adecuado, por ej., materiales inertes orgánicos o inorgánicos de soporte para las bacterias así como agregados bacterianos, se encuentran presentes en el inóculo.

2) La materia finamente dispersa, incluyendo la materia bacteriana viable, será retenida cada vez menos, una vez que las velocidades superficiales del líquido y el gas aumenten, aplicando tasas de dilución mayores a las tasas de crecimiento bacteriano bajo las condiciones ambientales que prevalezcan. Como resultado, se formará una película y/o agregados automáticamente.

3) El tamaño de los agregados y/o el espesor de la biopelícula, dependerá de la resistencia intrínseca (fuerzas de unión y el grado de entrelazamiento bacteriano) y las fuerzas externas ejercidas en las partículas/películas (esfuerzo cortante). Por lo tanto, a su debido tiempo, las partículas/película se desprenderán, permitiendo el desarrollo de la siguiente generación. La(s) primera(s) generación(es) de agregados, conocidas por Hulshoff Pol et al. (1983) como "gránulos filamentosos", consisten principalmente en largas cadenas multi-celulares de bacterias. Estas son bastante voluminosas y de hecho más en forma de flóculos que de gránulos.

4) Los núcleos secundarios retenidos aumentarán de tamaño nuevamente y también, la densidad bacteriana. El crecimiento no está restringido a la periferia, también puede llevarse a cabo en el interior de los agregados. A su debido tiempo, estos se desprenderán nuevamente, permitiendo el desarrollo de una tercera generación, etc.

5) Los gránulos gradualmente "madurarán” o se volverán más "viejos". Como resultado de este proceso de maduración, los "gránulos filamentosos" voluminosos, los cuales son predominantes durante las etapas iniciales del proceso de granulación, desaparecerán y comenzarán a ser desplazados por gránulos densos en forma redonda. En un lodo granular maduro, los gránulos filamentosos por lo general estarán ausentes.

Durante el proceso de selección descrito anteriormente, tanto la carga orgánica como la hidráulica se incrementarán gradualmente, aumentando el esfuerzo cortante en el interior del sistema. Esto último generará la formación de agregados del lodo más firmes y estables con una alta densidad y alta velocidad superficial. En la Figura 16.13, se muestra una imagen del curso temporal de las concentraciones del lodo en el reactor, expresadas como gSSV/1, y la carga orgánica aplicable. El inicio se consigue cuando se alcanza la tasa de carga deseada. Para la mayoría de las aguas residuales solubles, las cuales se encuentran parcialmente acidificadas, el lodo granular

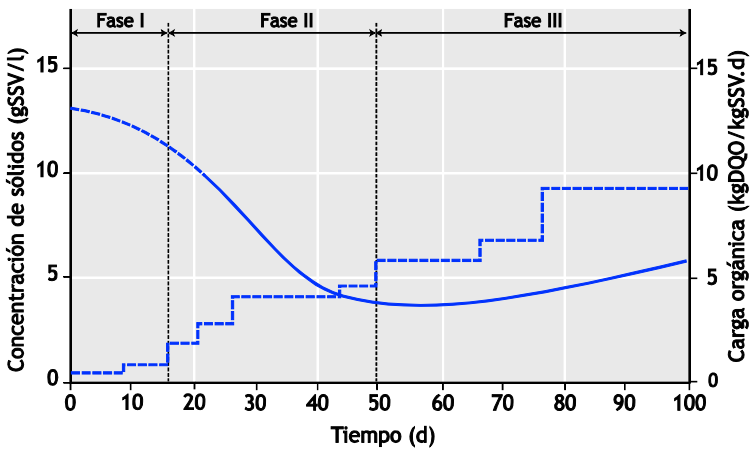

podrá ser cultivado fácilmente.

Figura 16.13 Dinámica de los lodos durante la primera etapa de arranque de un reactor UASB. Fase I: Carga orgánica aplicada $<3$ $\mathrm{kgDQO} / \mathrm{m}^{3} . \mathrm{d}$, expansión de la cama de lodo y retrolavado de la fracción coloidal del lodo, puede presentarse una capa de flotación y la actividad específica metanogénica comenzará a incrementarse. Fase II: retrolavado del lodo pesado mientras se lleva a cabo la selección entre el lodo pesado y ligero, aumento importante en la carga orgánica y formación de agregados densos. Fase III: aumento en la concentración total del lodo, aumento en la cantidad de lodo granular, la carga orgánica puede incrementarse

En la Tabla 16.9 se enlistan algunas características comunes del lodo granular metanogénico.

Con respecto al proceso de granulación, esencialmente no existen diferencias importantes entre los reactores 
UASB, inoculados con lodos residuales digeridos, y un reactor de flujo ascendente con material flotante inerte como soporte como en un reactor $\mathrm{FB}$, el cual utiliza partículas de arena o piedra pómez para la biomasa en crecimiento. La granulación de hecho puede llevarse a cabo correctamente en un sistema FB, siempre y cuando el reactor sea operado con una resistencia moderada sobre las partículas, por ej., de tal manera que la biopelícula pueda crecer lo suficiente en espesor y/o diferentes partículas puedan crecer juntas. Las experiencias a gran escala, han demostrado que no es necesaria la fluidización completa y que, es de hecho, perjudicial para la obtención de biopelículas suficientemente estables y espesas. En la actualidad, los reactores de lecho expandido granular (EGSB), resultan de mayor interés para aplicaciones comerciales que los sistemas más caros como los FB (ver además la Sección 16.7.2.4).

\subsection{REACTORES ANAEROBIOS}

Los reactores anaerobios han sido utilizados desde el siglo XIX, cuando Mouras y Cameron, desarrollaron el captador automático y el tanque séptico para reducir la cantidad de sólidos en el sistema de alcantarillado. Aunque a una tasa muy pobre, los primeros procesos de estabilización anaerobia se llevaron a cabo en los tanques diseñados para acumular los sólidos de las aguas negras. El primer reactor anaerobio se desarrolló en 1905, cuando Karl Imhoff diseñó el tanque Imhoff, en el cual los sólidos sedimentables eran estabilizados en un solo tanque. El sistema actual controlado de digestión, para acumular los sólidos en un reactor separado, fue desarrollado por Ruhrverband, Essen-Relinghausen en Alemania.

En la misma década, Buswell comenzó a adoptar la misma tecnología para tratar los residuos líquidos y las aguas residuales industriales. Todos estos sistemas se caracterizan por ser de tasa baja, debido a que no se incluyeron características especiales en el diseño para aumentar la capacidad catabólica anaerobia. La facilidad del proceso en estos sistemas, dependía principalmente de la tasa de crecimiento del consorcio anaerobio. Como resultado, los reactores eran muy grandes y su operación muy frágil. En las últimas décadas del siglo XIX, también se realizaron las primeras pruebas de reactores de lecho fijo de flujo ascendente; sin embargo, era demasiado rápido para que estos sistemas tuvieran éxito (McCarty, 2001). Las lagunas anaerobias, también pueden considerarse como sistemas de tratamiento anaerobio de baja carga. Las lagunas anaerobias, por lo general, son construidas en conjunto con las lagunas facultativas y de maduración. La carga orgánica aplicada varía entre

Tabla 16.9 Definiciones propuestas y características de un lodo granular de buena calidad (Imágenes: Biothane B.V.)



Definición: Conglomerados microbianos densos en forma esférica, constituidos por microorganismos, material inerte y sustancias poliméricas extracelulares (EPS), los cuales se caracterizan por una "alta actividad metabólica" y una "alta capacidad de sedimentación". 
0.025-0.5 $\mathrm{kgDQO} / \mathrm{m}^{3} . \mathrm{d}$, cuando se utilizan profundidades de $4 \mathrm{~m}$. La mayor desventaja de estos sistemas, son los problemas relacionados con olores, ya que se sobrecargan fácilmente. Además, la pérdida de energía por el escape de $\mathrm{CH}_{4}$ al ambiente, es otra de las desventajas reconocidas.

\subsubsection{Sistemas anaerobios de alta tasa}

Uno de los mayores éxitos en el desarrollo del tratamiento anaerobio de aguas residuales, fue la introducción de los reactores de alta tasa, en los cuales la retención de la biomasa y la retención del líquido se encuentran desacopladas. De manera contraria a los procesos aerobios, en los procesos anaerobios o anóxicos (desnitrificación), la máxima carga permitida no depende de la máxima tasa a la cual algún reactivo necesario puede ser suministrado (por ej., el oxígeno durante el proceso aerobio), sino de la cantidad de biocatalizadores anaerobios o bacterias anaerobias que se encuentran en contacto directo con los constituyentes del agua residual. En los sistemas anaerobios de alta tasa, se obtienen altas concentraciones de lodo por medio de la retención física o la inmovilización de lodo anaerobio. Altas concentraciones de biomasa permiten la aplicación de cargas orgánicas altas, mientras se mantengan TRLs prolongados a TRHs relativamente cortos. Durante las últimas tres décadas, se desarrollaron diferentes sistemas de alta tasa incluyendo los procesos de contacto anaerobio (ACP, por sus siglas en inglés Anaerobic Contact Processes), filtros anaerobios, reactor UASB, reactores FB y EGSB y reactores con deflectores.

Para permitir que un reactor anaerobio se acople a cargas orgánicas altas en el tratamiento de un agua residual en específico, se deben de lograr las siguientes condiciones:

- Alta retención de lodo en el reactor bajo las condiciones de operación. Entre más alta sea la cantidad de lodo retenida, mayor será el potencial de carga del sistema. Por lo tanto, resulta necesario el inocular una buena biomasa sedimentable o inmovilizar biomasa.

- Contacto suficiente entre la biomasa bacteriana y el agua residual. En el caso de que una parte del lodo retenido en el reactor permanezca fuera de contacto con el sustrato, este lodo no tendrá valor alguno o muy poco.

- Altas tasas de reacción y ausencia de limitaciones graves de transporte. Está claro que la cinética del proceso de degradación es un factor de gran importancia. Es esencial que los productos finales del proceso metabólico puedan escapar fácilmente de los agregados. El tamaño de la biopelícula deberá permanecer relativamente pequeña y la accesibilidad de los organismos en el interior de la biopelícula deberá ser alta.

- La biomasa deberá estar lo suficientemente adaptada y/o aclimatada. Para el tratamiento de cualquier tipo de agua residual, el lodo deberá poder adaptarse a las características específicas de la misma.

- Prevalencia de las condiciones ambientales favorables para todos los organismos requeridos en el interior del reactor, bajo todas las condiciones operacionales impuestas, enfocándose en los pasos limitantes de la velocidad de reacción. Se deberá enfatizar aquí, que esta condición no significa que las circunstancias serán similares en cualquier punto dentro del reactor y a un instante determinado. De hecho, ocurre todo lo contrario. Considerando el hecho de que, una gran variedad de diferentes organismos se encuentran relacionados con la degradación de compuestos complejos, la existencia de micro-nichos dentro del sistema es un pre-requisito absoluto. Únicamente de esta manera se podrá lograr el crecimiento de los diferentes organismos requeridos. Hay que hacer notar que, particularmente en el interior de la biopelícula y de los gránulos, la concentración de los sustratos y metabolitos, son lo suficientemente bajos para permitir que inclusive las reacciones acetogénicas muy endergónicas se lleven a cabo, por ej. la oxidación de propionato a concentraciones muy bajas de hidrógeno.

Tal y como se mencionó anteriormente, Stander en África del Sur y Schroepfer y colaboradores fueron los primeros en reconocer la importancia de mantener una gran población de bacterias en el reactor metanogénico. Sin embargo, la idea en realidad no era completamente nueva durante este tiempo, ya que la necesidad de contar con concentraciones altas de biomasa en los sistemas de tratamiento aerobio, ya se había aplicado desde principios de los años cincuenta en reactores a gran escala. Por lo tanto, era de esperarse que los partidarios del concepto "anaerobio" trataran de aplicar el concepto de "lodos activados aerobios" para los sistemas de tratamiento anaerobio. El proceso de contacto anaerobio desarrollado por Schroepfer et al. (1955), resultó ser un éxito para el tratamiento de aguas residuales industriales con alta carga. Con algunas excepciones, difícilmente se pensaba en ese tiempo, que el tratamiento anaerobio pudiera convertirse en un proceso factible para aguas residuales de baja carga. Considerando los problemas 


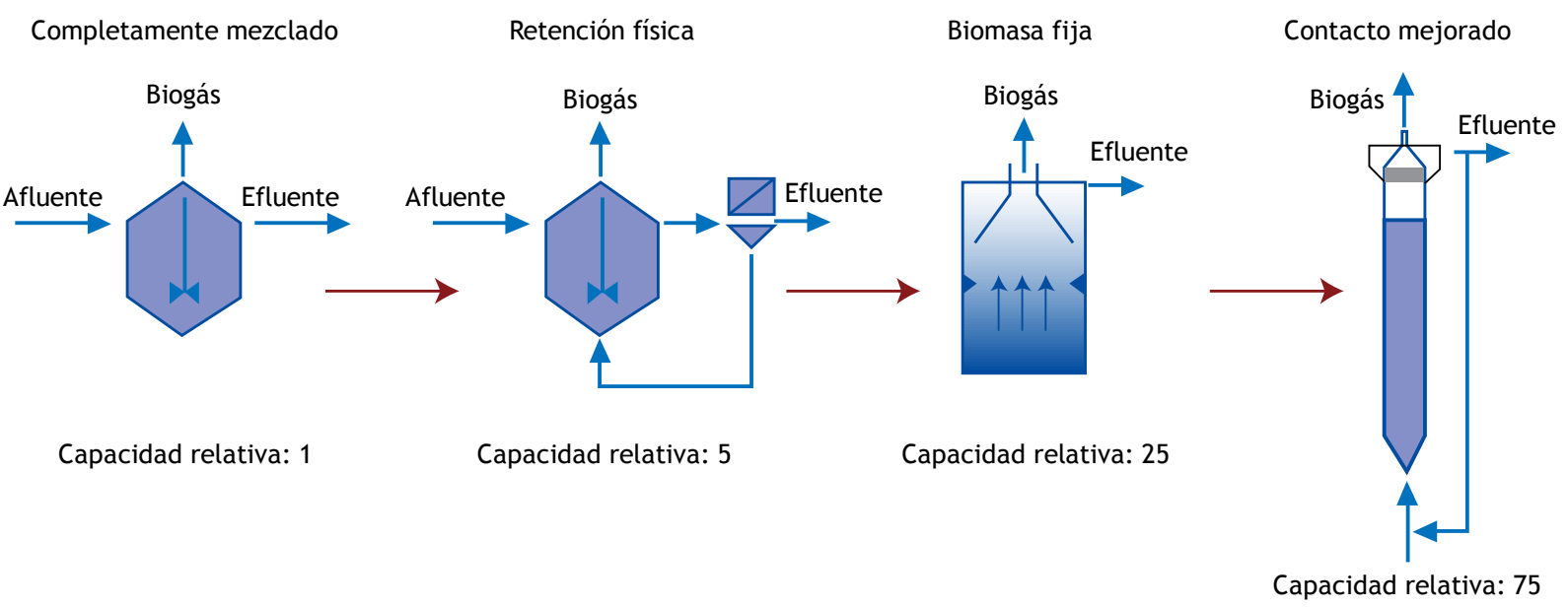

Figura 16.14 Capacidad relativa de carga de los diferentes sistemas AnWT. Las máximas cargas orgánicas aplicadas a gran escala alcanzan los $45 \mathrm{kgDQO} / \mathrm{m}^{3}$.d, aplicando sistemas con contacto mejorado como en EGSB

experimentados con varias versiones de los procesos de contacto anaerobios, sólo muy pocos creían que el tratamiento anaerobio podría ser aplicable en el tratamiento de aguas residuales con carga media. Sin embargo, en los sesenta y setenta la situación cambió rápidamente, $\mathrm{y}$ en los noventa el concepto de tratamiento anaerobio se volvió factible para aguas residuales de baja carga a temperaturas ambientales bajas. Estos acontecimientos imprevistos, pueden atribuirse a los métodos mejorados de retención de lodos, basados en la inmovilización del lodo. En la Figura 16.14, se muestra el desarrollo de los reactores de alta tasa y su impacto en el mejoramiento de la retención del lodo y mejoramiento del contacto a las cargas orgánicas aplicables. Mientras que las primeras pruebas de Buswell, no lograron obtener cargas orgánicas de $1 \mathrm{kgDQO} / \mathrm{m}^{3} . \mathrm{d}$, los sistemas modernos de AnWT que se venden en el mercado garantizan cargas orgánicas que exceden a los 40 $\mathrm{kgDQO} / \mathrm{m}^{3} \cdot \mathrm{d}$.

En la actualidad, la mayoría de las aplicaciones de los AnWT, pueden encontrarse como un proceso de tratamiento al final de la descarga para aguas residuales del procesamiento de alimentos y aguas residuales agroindustriales. La Tabla 16.10 enlista los diferentes sectores industriales en donde los 2,266 reactores examinados se encuentran instalados. Es importante observar que el número de aplicaciones de los sistemas anaerobios en otros sectores diferentes al alimenticio, está creciendo rápidamente. Algunos ejemplos comunes son efluentes del sector del papel y aguas residuales de la industria química, como aquellas que contienen formaldehído, benzaldehídos, tereftalatos, etc. (RazoFlores et al., 2006). Esto último es sorprendente ya que, resulta particularmente difícil para las industrias químicas el utilizar tecnologías anaerobias, debido a los prejuicios generales en contra de los sistemas de tratamiento biológicos y en particular el tratamiento anaerobio. Con respecto a los compuestos químicos, es importante mencionar que ciertos compuestos, como los poli-cloro-aromáticos y poli-nitro-aromáticos, así como colorantes tipo azo, sólo pueden ser degradados cuando se utiliza una etapa reductora (anaerobia) en el tren de tratamiento. Por lo tanto, los procesos anaerobios pueden

Tabla 16.10 Aplicación de la tecnología anaerobia en aguas residuales industriales. El número total de reactores instalados a nivel mundial es de 2,266 según el censo de Enero del 2007, de acuerdo con van Lier (2007) (ver además la Figura 16.2)

\begin{tabular}{llcc}
\hline Sector Industrial & Tipo de agua residual & No. de reactores & $\%$ \\
\hline Industria agro-alimentaria & $\begin{array}{l}\text { Azúcar, papa, almidón, levadura, pectina, ácido cítrico, fábrica } \\
\text { de conservas, confitería, frutas, vegetales, lechería, panadería }\end{array}$ & 816 & 36 \\
Bebidas & $\begin{array}{l}\text { Cerveza, malta, refrescos, vinos, jugo de frutas, café } \\
\text { Destilerías }\end{array}$ & $\begin{array}{l}\text { Jugo de caña, melaza de caña, melaza de remolacha, vino de } \\
\text { uva, cereales, fruta }\end{array}$ & 227 \\
Industria de la pulpa y papel & $\begin{array}{l}\text { Papel reciclado, pasta de madera, NSSC, pulpa de sulfito, paja, } \\
\text { bagazo } \\
\text { Misceláneos }\end{array}$ & 249 & 10 \\
& $\begin{array}{l}\text { Química, farmacéutica, licor de lodo, lixiviados de rellenos } \\
\text { sanitarios, drenados ácidos de mina, aguas residuales } \\
\text { municipales }\end{array}$ & 317 \\
\hline
\end{tabular}


ser complementarios de los aerobios para lograr el tratamiento completo.

Hasta hace poco, los sistemas AnWT de alta tasa fueron desarrollados para tratar aguas residuales frías y con muy poca carga. Además del agua residual municipal, muchas aguas residuales industriales son descargadas a muy bajas temperaturas, por ej., las aguas residuales de la industria cervecera o de la malta. Los resultados obtenidos a gran escala muestran que cualquiera de las aguas residuales citadas puede ser tratada anaeróbicamente utilizando los inóculos comunes, demostrando la robustez y flexibilidad de los procesos anaerobios.

\subsubsection{Reactores anaerobios de una sola etapa}

\subsubsection{El proceso de contacto anaerobio (ACP)}

Como se explicó en la sección 16.7.1, los procesos que emplean sedimentadores externos y recirculación de lodos se conocen como procesos de contacto anaerobios (ACP), ver la Figura 16.15.

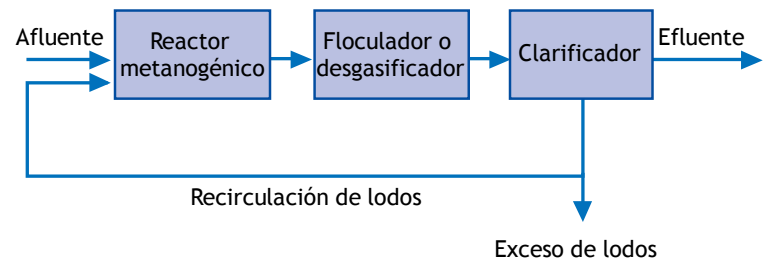

Figura 16.15 Proceso de contacto anaerobio, equipado con una unidad de floculación o un desgasificador para mejorar la sedimentación del lodo en el clarificador secundario

Las diferentes versiones de la primera generación de tratamientos anaerobios de "alta tasa", para aguas residuales de carga media, no fueron muy exitosos. En la práctica, la principal dificultad parecía ser la separación del lodo del agua tratada. Estas dificultades podían deberse principalmente, al hecho de que era necesaria una agitación muy intensa en el bio-reactor. La idea era que entre más intenso fuese el mezclado, el contacto entre el lodo y el agua residual sería mejor. Sin embargo, en ese tiempo no se había considerado el efecto perjudicial de un mezclado muy intenso sobre la estructura del lodo, además de su sedimentabilidad y el impacto negativo en la presencia micro-ecosistemas balanceados, es decir, asociaciones sintróficas (Sección 16.2.1.3).

Se han probado y/o utilizado varios métodos para la separación del lodo en diferentes versiones de ACP. Estos métodos incluyen la desgasificación al vacío en conjunto con la sedimentación, la adición de polímeros orgánicos y floculantes inorgánicos, la centrifugación e incluso aireación (para detener la digestión). Sin embargo, los resultados no fueron satisfactorios en general. En la actualidad, con los conocimientos que se tienen sobre las tecnologías de digestión anaerobia, se utiliza un mezclado más suave y de forma intermitente. Con esta estrategia, el lodo adquirirá y mantendrá excelentes propiedades de sedimentabilidad y el proceso de contacto anaerobio puede ciertamente hacer una importante contribución en la protección al ambiente y la recuperación de energía, de manera particular en las aguas residuales que contienen altas fracciones de sólidos suspendidos y residuos semi-líquidos. Si se diseña de manera correcta, un sistema moderno de ACP puede lograr cargas orgánicas de $10 \mathrm{kgDQO} / \mathrm{m}^{3}$.d.

\subsubsection{Filtros Anaerobios (AF)}

La versión moderna de los filtros anaerobios de flujo ascendente (UAF), fue desarrollada en EUA por Young y McCarty $(1964,1982)$ a finales de los sesenta. El tiempo de retención del lodo en el UAF se basa en:

- la adhesión de la biopelícula en el material de soporte (estacionario),

- la sedimentación y retención de las partículas del lodo entre los espacios intersticiales del material de empaque y la formación de agregados de lodo con muy buena sedimentabilidad.

Inicialmente, era difícil encontrar un material de soporte adecuado (Young, 1991). Se han investigado varios tipos de empaques sintéticos y materiales naturales como grava, coque y pedazos de bambú. Resultando que la forma, el tamaño y el peso del material de empaque son aspectos importantes a considerar. Además, son importantes las características de la superficie con respecto a la adhesión de las bacterias. Por otra parte, se encontró que el lecho debería tener una estructura abierta, para proporcionar una mayor fracción de espacios disponibles para la adhesión de las bacterias. La aplicación de una material de soporte adecuado en los sistemas $\mathrm{AF}$ se inició rápidamente, debido a la eficiente adherencia de los organismos anaerobios al material inerte. La facilidad de arranque de los sistemas fue la principal razón de su popularidad en los ochenta y noventa. Ocurren algunos problemas en los sistemas UAF, en particular, durante la operación a largo plazo. La mayor desventaja de estos sistemas es la dificultad que presentan para mantener el contacto necesario entre el lodo y el agua residual, debido a que el taponamiento del "lecho" puede ocurrir con facilidad. Este es el caso en particular de las aguas residuales parcialmente solubles. 
Obviamente estos problemas de taponamiento pueden ser solucionados (al menos parcialmente) aplicando un sedimentador primario y/o una etapa de pre-acidificación (Seyfried, 1988). Sin embargo, esto requerirá de la construcción y operación de unidades adicionales. Por otra parte, además de los altos costos, no se eliminará completamente el problema de corto circuito (taponamiento del lecho) en los flujos, generando eficiencias en el tratamiento decepcionantes.

Desde 1981, se han puesto en operación alrededor de 140 reactores UAF a gran escala para el tratamiento de varios tipos de aguas residuales, lo cual representa alrededor de un $6 \%$ de todos los reactores de alta tasa instalados (Figuras 16.2 y 16.15). Las experiencias con estos sistemas, sin duda, son bastante satisfactorias, aplicando cargas orgánicas desde muy modestas hasta relativamente altas por arriba de los $10 \mathrm{kgDQO} / \mathrm{m}^{3}$.d. El sistema UAF continuará siendo atractivo para el tratamiento de la mayoría de las aguas residuales disminución en el número de sistemas AF instalados a gran escala. En los últimos 5 años, únicamente 6 nuevos sistemas AF fueron construidos, lo cual corresponde a alrededor del $1 \%$ de la cantidad total de los sistemas AnWT nuevos instalados (Figura 16.16).

Para minimizar el taponamiento y la acumulación del lodo en los intersticios del material filtrante, los sistemas anaerobios en algunas ocasiones son operados en flujo descendente, en los llamados reactores de película fija de flujo descendente. Se han investigado varios modos de operación y materiales filtrantes, pero su aplicación a gran escala ha sido bastante decepcionante. El factor limitante es la baja carga orgánica que se puede aplicar debido a la limitada cantidad de biomasa que puede ser retenida en estos sistemas, ya que se basa principalmente en la adherencia de la biomasa en la superficie del material de soporte. En los filtros UAF, la mayoría de la actividad anaerobia se encuentra en la biomasa en suspensión.
$1981-2007, N=2266$

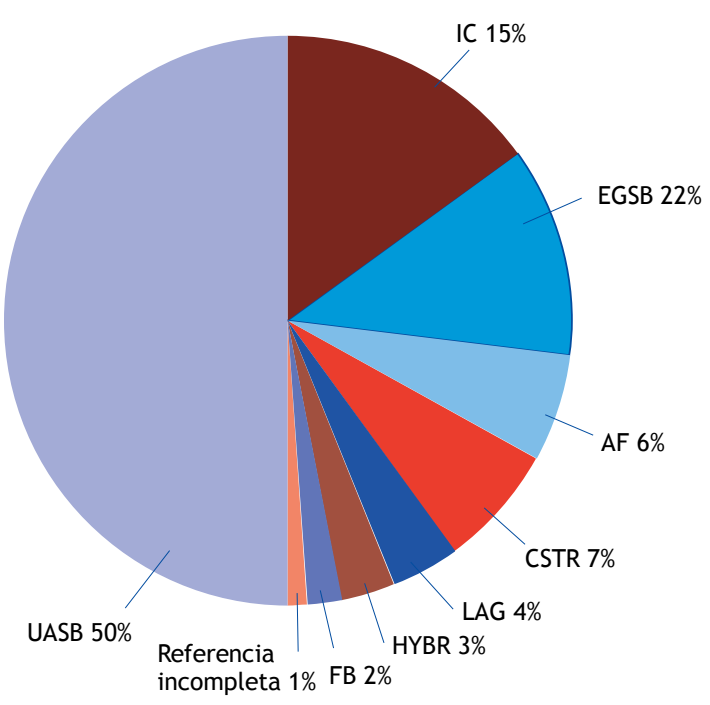

Reactores de lecho expandido: $29 \%$ Lecho de lodo granular: $77 \%$

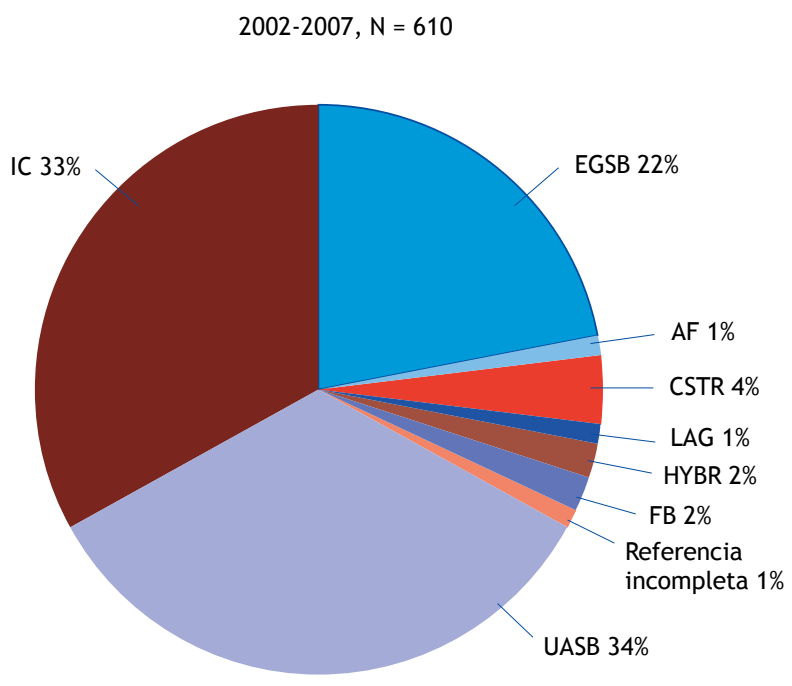

Reactores de lecho expandido: $57 \%$ Lecho de lodo granular: $89 \%$

Figura 16.16 Implementación de las tecnologías anaerobias en aguas residuales industriales mostradas para el periodo de 1981-2007 (izquierda) y para el periodo del 2002-2007 (derecha). UASB: reactor anaerobio de lecho de lodos con flujo ascendente, EGSB: reactor granular de lecho expandido, IC (): reactor de circulación interna, sistema del tipo EGSB con biogás impulsado por la hidrodinámica, AF: filtro anaerobio, CSTR: reactor de agitación continua, Lag.: laguna anaerobia, Hybr.: sistema híbrido combinado con lecho de lodos en el fondo y filtro en la parte superior, FB: reactor de lecho fluidizado (van Lier, 2007)

solubles, particularmente cuando el proceso de la granulación del lodo no se lleve a cabo satisfactoriamente. Por otra parte, los problemas a largo plazo en el sistema, debido al taponamiento y la estabilidad del material filtrante, han ocasionado una

\subsubsection{Reactores anaerobios de lecho de lodos (ASBR)}

Los reactores anaerobios de lecho de lodos (ASBR) hasta el momento son, sin duda, los sistemas AnWT más 
A

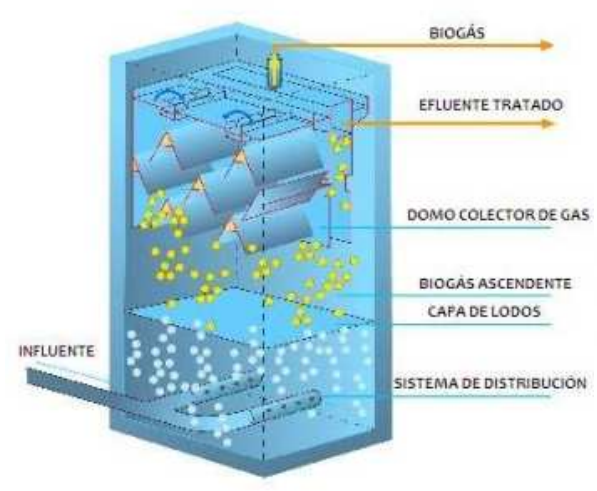

B

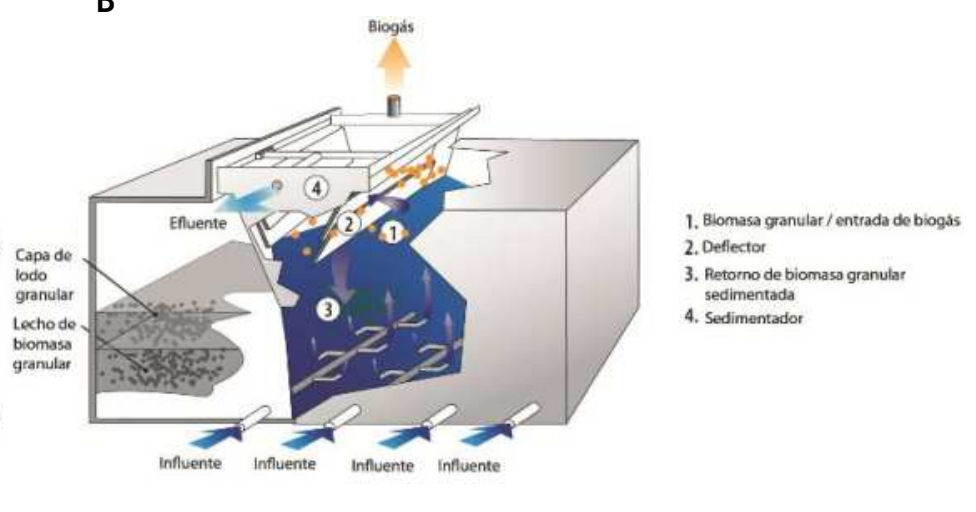

Figura 16.17. Reactores UASB de las principales manufactureras de sistemas anaerobios UASB: (A) Paques B.V. y (B) Biothane B.V.

populares. La retención del lodo en estos reactores, se basa en la formación de agregados de lodo fácilmente sedimentables (flóculos o gránulos), y en la aplicación de un sistema de separación interno gas-líquido-sólido (dispositivo GLSS).

Por mucho, el mejor ejemplo para este concepto es el reactor anaerobio de lecho de lodos de flujo ascendente (UASB), el cual fue desarrollado en Holanda a principios de los años setenta (Lettinga et al., 1976, 1980). Con vista en sus perspectivas, y al hecho de que casi el $90 \%$ de los reactores nuevos instalados de alta tasa, son sistemas de lecho de lodos (Figura 16.16), el proceso UASB se describirá con mayor detalle que los otros sistemas (Sección 16.8). A principios del 2007, alrededor de 1,750 reactores UASB fueron puestos en operación a gran escala. La mayoría de estos reactores a gran escala son utilizados para el tratamiento de aguas residuales agroindustriales; sin embargo, su aplicación en el tratamiento de aguas residuales provenientes de las industrias químicas ha ido en aumento (Tabla 16.10). La Figura 16.17 muestra una representación esquemática de un reactor UASB. En la Figura 16.18 se muestran dos ejemplos de reactores UASB instalados a gran escala.

De manera similar a los sistemas UAF, el agua residual se desplaza de forma ascendente a través del reactor. Sin embargo, contrario a los sistemas $\mathrm{AF}$, por lo general no se requiere de un material de empaque en el recipiente del reactor. El concepto de un reactor de lecho de lodos se basa en las siguientes ideas:

1) El lodo anaerobio tiene o adquiere buenas propiedades de sedimentación, siempre y cuando se mantenga un mezclado mecánico suave en el reactor y el proceso sea operado de manera correcta. Por esa razón, y además de que se reducen los costos de inversión y mantenimiento, no se aplica un mezclado mecánico en los reactores UASB. Debido a las excelentes características de sedimentabilidad del lodo, se pueden aplicar altas velocidades superficiales del líquido, sin tener el riesgo de perder por arrastre una considerable cantidad de lodo.

3. El buen contacto entre el lodo y el agua residual requerido en los sistemas UASB, por lo general siempre se logra $(i)$ alimentando el agua residual lo más uniformemente posible en el fondo del reactor, o (ii) como resultado de la agitación causada por la producción de biogás.

3) De manera particular para las aguas residuales con baja carga, se utilizan reactores con una gran relación altura-diámetro, con alturas de hasta 20-25 m (ver la sección 16.7.2.4). Un área superficial baja facilitará la alimentación de los sistemas, mientras que la acumulación del biogás producido a lo largo de la torre del reactor, ocasionará la formación de un flujo turbulento. Además, el aumento en la velocidad de flujo ascendente permitirá un mejor contacto entre el lodo y los contaminantes. Con aguas residuales que contienen compuestos biodegradables, adicionalmente se logra aplicando un flujo de recirculación del líquido. Como resultado, se obtiene un patrón de flujo completamente mezclado y la estratificación del sustrato y productos intermediarios a través del reactor se minimiza, minimizándose así el potencial de inhibición.

क) La pérdida por arrastre de los agregados del lodo se previene separando el biogás producido, utilizando un domo de colección de gas instalado en la parte superior del reactor. De esta manera, se forma una 

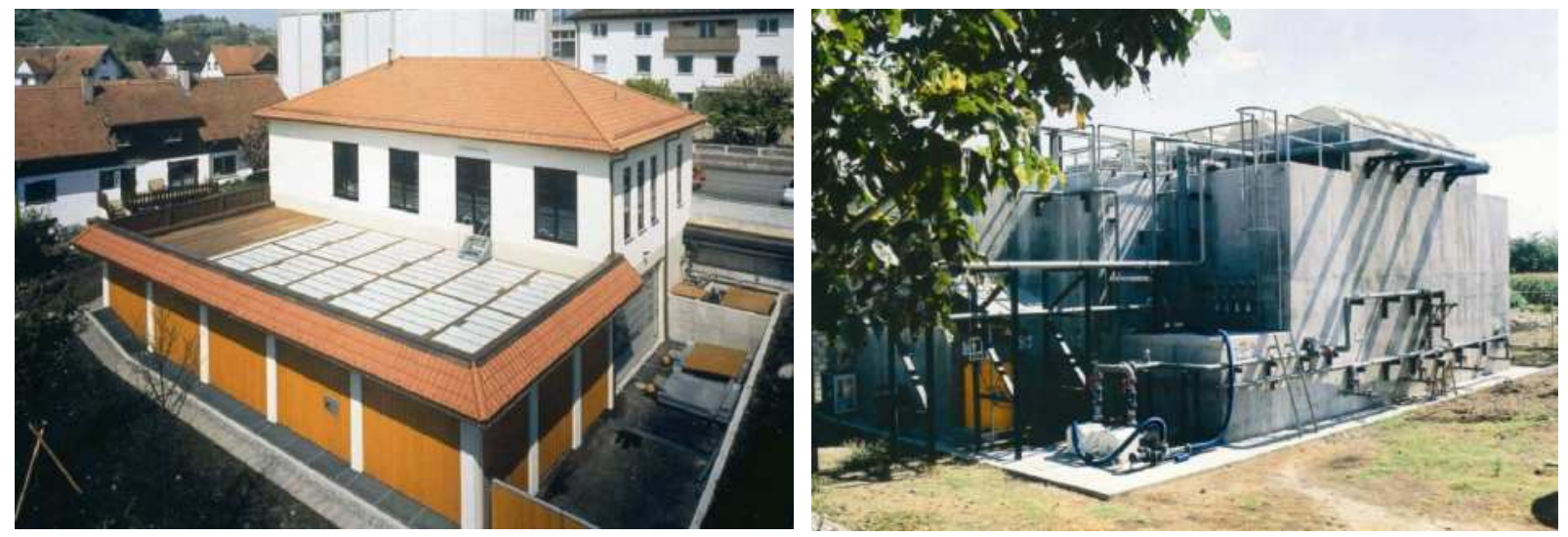

Figura 16.18 Instalaciones de UASB para el tratamiento de (A) agua residual proveniente de una fábrica de jugo de frutas en Bregenz, Alemania y (B) agua residual de una industria de lácteos en Indonesia (Imágenes: Paques B.V. y Biothane B.V. respectivamente)

zona con relativamente muy poca turbulencia en la parte superior del reactor; por consiguiente, el reactor está equipado con un clarificador secundario incorporado. El colector de gas actúa como un GLSS de tres fases. La unidad GLSS es una parte esencial del reactor UASB y se utiliza para:

a) Colectar, separar y descargar el biogás producido. Para un funcionamiento satisfactorio, el área superficial gas-líquido dentro de la unidad, deberá ser lo suficientemente grande, de tal manera que el gas pueda escapar fácilmente. Esto es de particular importancia en el caso de que se desarrollen capas de nata. Para combatir este fenómeno deberá prevalecer un mezclado suficiente por turbulencia del biogás en la interface gas-líquido. Debido a que la formación de capas de nata es un fenómeno muy complejo con una amplia diversidad de apariencia, resulta imposible el dar una guía específica unificada y clara de las dimensiones de la interface gas-líquido.

b) Reducir las turbulencias en el líquido en el compartimento del sedimentador, para mejorar la sedimentabilidad del lodo que resulta de la producción de gas. Con el fin de evitar el burbujeo del biogás en la zona de sedimentación en la parte superior, se pueden instalar uno o más deflectores debajo de la abertura entre el domo del gas así como entre el domo de gas y la pared del reactor.

c) Remover las partículas del lodo por medio del mecanismo de sedimentación, floculación y/o acumulación en el lecho de lodos (si están presentes en el sedimentador). El lodo colectado puede deslizarse de regreso al compartimento de digestión, en caso de que el lecho de lodos no llegue al sedimentador, o puede ser descargado ocasionalmente junto con el lodo en exceso del compartimento del digestor.

d) Limita la expansión del lecho de lodos en el compartimento del digestor. El sistema actúa más o menos como una barrera contra la expansión excesiva de la parte más ligera del lecho de lodos. En caso de que el lecho de lodos se expanda hasta el sedimentador, el lodo tenderá a espesar (debido a la separación del gas). Este espesamiento, conocido como lodo pesado, presente en el sedimentador, se establece en la superficie del lodo más voluminoso que tiende a moverse hacia el sedimentador.

e) Reduce o previene la flotación de partículas de lodo para evitar que sean removidas del sistema. Para este propósito deberá ser instalado un deflector delgado enfrente del vertedero del efluente. Este deflector en particular es esencial para el tratamiento de aguas residuales con baja carga, debido a que la pérdida por arrastre de la biomasa deberá mantenerse a niveles muy bajos.

f) Lograr el pulimiento del agua residual con respecto a la materia suspendida.

Algunos investigadores y profesionales sugieren el reemplazamiento de la unidad GLSS por un lecho empacado en la parte superior del reactor. Este reactor híbrido de flujo ascendente es una mezcla entre los reactores UASB y UAF. En algunos diseños, el material de empaque se coloca únicamente en el compartimento de sedimentación, manteniendo el GLSS en su posición original. Alrededor de un 2 al 3\% de todos los reactores anaerobios instalados, son reactores híbridos (ver la Figura 16.16). En muchas de las aplicaciones, la mayor cantidad de materia orgánica convertida se localiza en la 
sección del lecho de lodos, mientras que, la remoción de una fracción específica de contaminantes se localiza en el área filtrante en la parte superior. Aguas residuales químicas específicas, muestran una mejor eficiencia en el tratamiento para todos los compuestos utilizando sistemas híbridos en comparación con los reactores UASB. El ejemplo más conocido es el tratamiento de ácido tereftálico purificado (PTA) (Kleerebezem, 1999a, b). Los resultados muestran que la conversión del ácido tereftálico a benzoato sólo es posible a concentraciones bajas de acetato y benzoato. Aplicando un sistema híbrido, los dos últimos compuestos son convertidos en el área correspondiente al lecho de lodos, mientras que, el ácido tereftálico se convierte en la sección híbrida, en donde una flora específica es retenida para degradar el compuesto recalcitrante. La principal desventaja de los reactores híbridos, es el deterioro de la sección filtrante después de periodos de operación prolongados. Los reactores híbridos también presentan la ventaja de lograr un mejor pulimento en el efluente ya que la materia coloidal queda atrapada en la parte superior del sistema. De hecho, algunas pruebas con agua residual de tipo doméstico mostraron un mejoramiento en la remoción de los sólidos suspendidos y la materia coloidal (Elmitwalli et al., 2002). La biomasa que se acumula en el material de empaque, asegura un contacto prolongado del agua residual con la biomasa disponible; en ausencia de un material de empaque se presentará muy poca biomasa en la parte superior del reactor, debido al régimen de descarga de lodo aplicado, por lo general, en las plantas de tratamiento de aguas residuales de tipo anaerobio. El material de empaque además ayuda a mejorar la floculación de la fracción fina de sólidos suspendidos presente en el agua residual.

\subsubsection{Sistemas anaerobios de lecho expandido y de lecho fluidizado (EGSB y FB)}

Los sistemas de lecho expandido y de lecho fluidizado, son considerados como la segunda generación de reactores de lecho de lodos que han logrado operar bajo condiciones de carga orgánica extrema (excediendo 30$40 \mathrm{~kg} \mathrm{DQO} / \mathrm{m}^{3}$.d). El proceso FB se basa en la ocurrencia de la adhesión bacteriana a las partículas de un material de soporte móvil, que consiste, por ejemplo, de arena fina (0.1-0.3 mm), basalto, piedra pómez, o plástico. El FB puede ser visto como una tecnología anaerobia avanzada (Li and Sutton, 1981; Heijnen, 1983, 1988), que puede alcanzar cargas orgánicas de 50-60 $\mathrm{kgDQO} \mathrm{DQO} / \mathrm{m}^{3} . \mathrm{d}$. Sin embargo, su operación estable a largo plazo parece ser problemática. El sistema se basa en la formación de una biopelícula adherida y/o partículas más o menos uniformes (en espesor, densidad, resistencia). Para poder mantener una situación estable con respecto al desarrollo de la biopelícula, se considera necesaria una preacidificación de alto grado y la alimentación deberá estar ausente de materia dispersa (Ehlinger, 1994). A pesar de eso, el mantener un espesor de biopelícula uniforme es muy difícil de controlar y en muchas situaciones puede ocurrir la segregación de diferentes tipos de biopelículas a lo largo del reactor. En reactores a gran escala, por lo general son segregadas partículas de la biopelícula que pueden generar problemas operacionales. Con el objeto de mantener las partículas de la biopelícula en el reactor, es necesario realizar ajustes en el flujo después de los cuales el material de empaque comenzará a acumularse en la parte inferior del reactor como una especie de lecho estacionario, mientras que ligeros agregados esponjosos (biopelícula desprendida) estarán presentes en la parte superior. Esto último sólo se puede lograr cuando la velocidad superficial permanece baja, lo cual en realidad no es el objetivo de los sistemas FB.

Los sistemas modernos de FB, como el sistema Anaflux (Holst et al., 1997), se basan en un lecho expandido en lugar de un lecho fluidizado. Debido a que los sistemas de lecho expandido permiten una distribución mucho más amplia de la biopelícula que prevalece, el sistema resulta mucho más fácil de operar. Tal y como sucede en los reactores AF, en el sistema Anaflux también se utiliza un material inerte poroso para la adhesión de los microorganismos (partículas $<0.5 \mathrm{~mm}$, densidad de alrededor de 2). El reactor Anaflux utiliza un separador de tres fases en la parte superior, más o menos similar a una unidad GLSS en los reactores UASB y EGSB. Cuando la biopelícula adherida al medio se vuelve excesivamente desarrollada, y los respectivos agregados (ligeros) tienden a acumularse en la unidad de separación, el material se extrae periódicamente del reactor por medio de una bomba externa, la cual está sometida a una resistencia suficiente para remover parte de la biopelícula. Posteriormente, tanto el medio como la biomasa removida son recirculadas al reactor, y la biomasa en suspensión puede ser removida del sistema. De esta manera se puede controlar la densidad del medio y con ello tener un reactor con un lecho más homogéneo. Hasta 30-90 kg SSV $/ \mathrm{m}^{3}$ reactor pueden ser retenidos de esta manera, y debido a las altas velocidades de flujo ascendente aplicadas, es decir, por arriba de los $10 \mathrm{~m} / \mathrm{h}$, se puede lograr un excelente contacto entre el líquido y la biomasa. El sistema puede ser utilizado en aguas residuales con una concentración de sólidos suspendidos $<500 \mathrm{mg} / \mathrm{l}$. En la actualidad, alrededor de 50 reactores anaerobios FB han sido instalados a gran escala (Figura 
16.16), de los cuales la mayoría corresponden al proceso Anaflux.

El sistema EGSB utiliza lodo granular, el cual se caracteriza por tener buenas propiedades de sedimentación y una alta actividad metanogénica (ver además la Tabla 16.9). Cuando se utilizan cargas de lodo muy extremas, la capacidad de sedimentación será menor debido al biogás que queda atrapado en los gránulos. Debido a la alta sedimentabilidad del lodo, se pueden aplicar altas velocidades superficiales del líquido, es decir, aquellas que exceden $\operatorname{los} 6 \mathrm{~m} / \mathrm{h}$. Estas altas velocidades del líquido, en conjunto con la acción de elevación del gas desprendido en el lecho, conducen a una ligera expansión del lecho de lodo. Y como resultado de eso, permanece un excelente contacto entre el lodo y el agua residual en el sistema, produciendo potenciales de carga significativamente altos en comparación con las instalaciones convencionales de UASB. En algunos sistemas de lecho expandido, por ej., el reactor Biopaques IC ${ }^{\circledR}$ (Figura 16.19), las velocidades de flujo netas del líquido, las cuales resultan de la suma de los flujos hidráulico y del gas, pueden variar entre 25-30 $\mathrm{m} / \mathrm{h}$, ocasionando casi un mezclado completo en el medio del reactor con la biomasa disponible.

Contrario a los sistemas Anaflux, en los reactores FB, por lo general, no existe la necesidad de controlar el tamaño de la biomasa, aunque en algunos casos específicos se ha observado que el tamaño de los gránulos tiende a volverse muy grande. Los sistemas EGSB confían en una retención completa del lodo granular. Se han obtenido excelentes resultados utilizando instalaciones modernas de EGSB a gran escala con diferentes tipos de aguas residuales, logrando cargas orgánicas superiores a los 40-45 $\mathrm{kgDQO} / \mathrm{m}^{3}$.d. Resulta interesante que, al utilizar los reactores EGSB, muchos otros tipos de aguas residuales que no podían ser tratadas por medio de los sistemas convencionales UASB, pueden ser tratadas, como por ejemplo:

3) Aguas residuales que contienen compuestos biodegradables. Los reactores a gran escala muestran un funcionamiento estable durante muchos años, cuando tratan aguas residuales con metanol y formaldehído, caracterizadas por tener una concentración de 10g/1 de formaldehído (Zoutberg and Frankin, 1996).

2) Aguas residuales frías (incluso a $<10^{\circ} \mathrm{C}$ ) y diluidas $(\mathrm{DQO}<<1 \mathrm{~g} / \mathrm{L})$, es decir, cuando la producción específica de gas es muy baja y no se presenta un mezclado por el biogás (Rebac et al., 1998). Los reactores EGSB se caracterizan por tener una mezcla hidráulica mejorada, independientemente de la producción del biogás. Por el contrario, en todos los sistemas UASB se utiliza el lodo retenido, mientras que, las partículas pequeñas inactivas son removidas del sistema.

3 . Aguas residuales que contienen ácidos grasos de cadena larga (Rinzema, 1988). A velocidades de flujo ascendente bajas (UASB), los AGCLs tienden a adsorberse en el lodo $\mathrm{y}$ forman grumos grasos inaccesibles. A velocidades de flujo ascendente altas (EGSB), el sustrato es adicionado a una menor concentración y se distribuye más homogéneamente en la biomasa.

A) Aguas residuales con problemas de espuma en los sistemas UASB.

Debido al éxito de estos sistemas anaerobios de "súper" altas velocidades, las grandes compañías venden en la actualidad más sistemas EGSB que UASB (Figura 16.19).

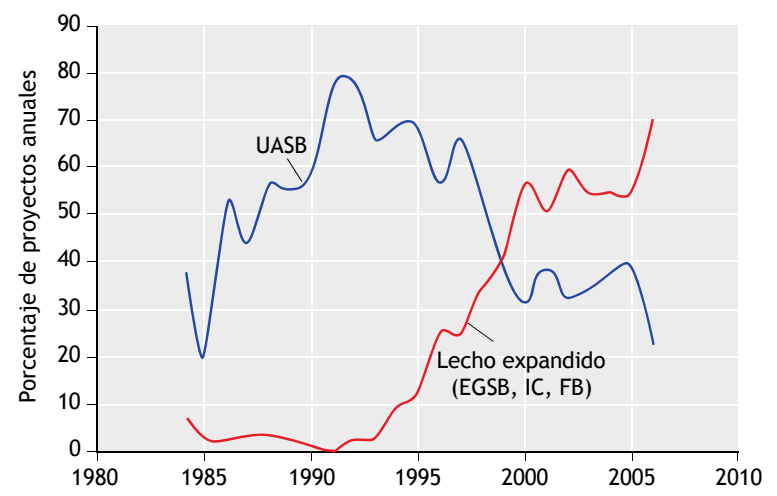

Figura 16.19 Comparación de los sistemas UASB y EGSB en los sistemas de tratamiento anaerobio instalados a gran escala en el periodo de 1984-2007. Los reactores EGSB incluyen EGSB, IC ${ }^{\circledast}$, y FB.

Una versión especial del concepto EGSB, es el llamado reactor de Circulación Interna ( $\mathrm{IC}^{\circledR}$ ) (Vellinga et $a l ., 1986)$. En este tipo de reactor, el biogás producido es separado del líquido en la mitad del reactor, por medio de una unidad de separación gas/líquido, y transportado hacia arriba a través de una tubería a una unidad de desgasificación o de expansión. Aquí, el biogás separado se remueve del sistema, mientras que, la mezcla lodoagua cae al fondo del reactor a través de otra tubería. De hecho, las fuerzas de elevación del biogás colectado, son utilizadas para lograr una recirculación del líquido y del lodo granular en la parte baja del reactor, lo cual resulta 

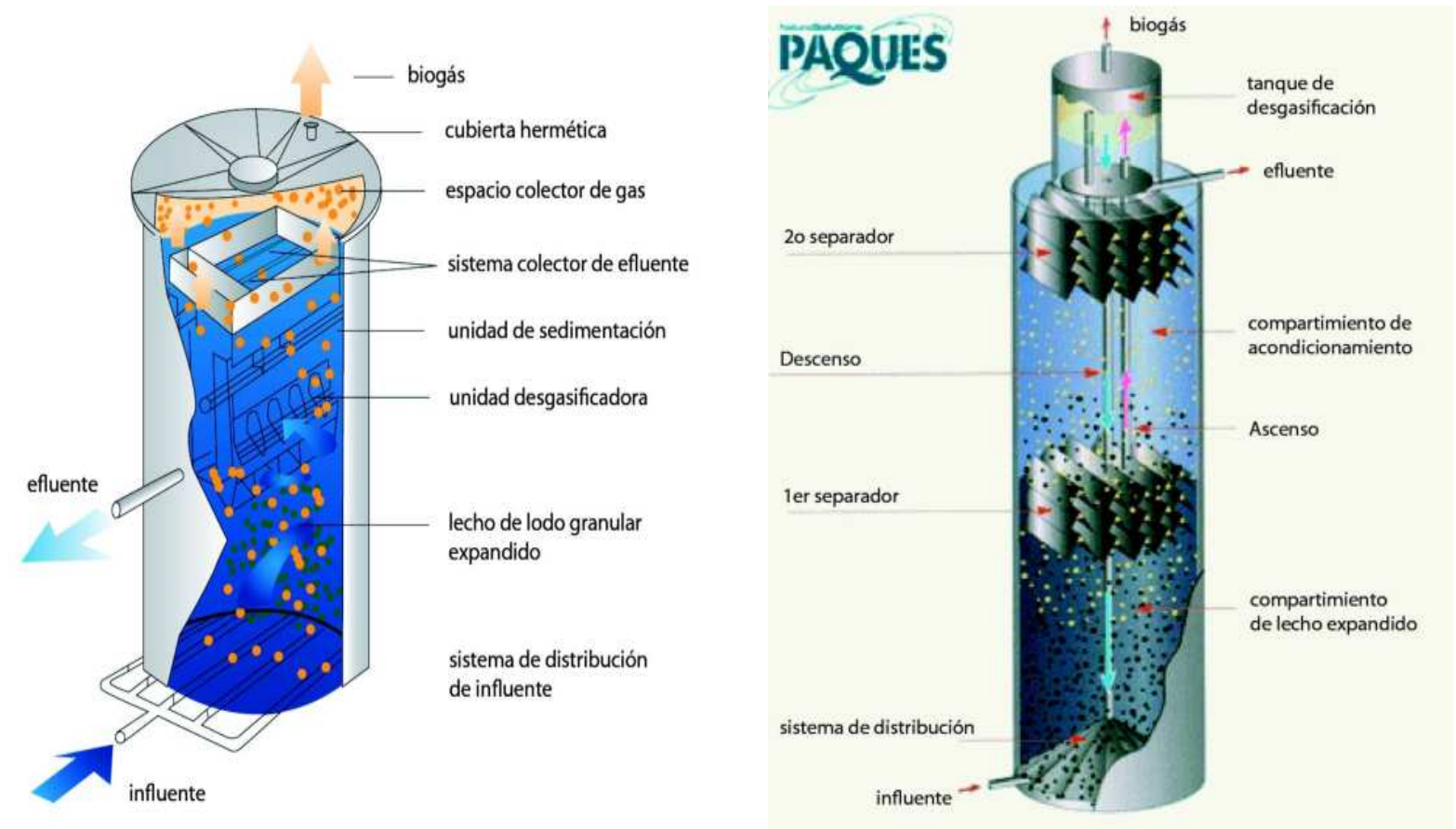

Figura 16.20 Reactores EGSB e IC ${ }^{\circledR}$ de los principales fabricantes de sistemas anaerobios Biothane B.V. (izquierda) y Paques B.V. (derecha)

en el mejoramiento del contacto entre el lodo y el agua residual. La relación de recirculación líquido/lodo dependerá de la producción de gas. En la Figura 16.20 se muestran los sistemas EGSB más comunes. Algunos ejemplos de sistemas IC y EGSB a gran escala se muestran en la Figura 16.21.

Las cargas extremas de DQO de los sistemas EGSB dan como resultado tasas de carga de biogás extremas. Una retención eficiente de la biomasa se obtiene aplicando unidades GLSS específicamente diseñadas. En tales condiciones, las unidades convencionales diseñadas de GLSS no son utilizadas (Sección 16.8.2).

\subsubsection{Otros sistemas anaerobios de alta tasa}

Donde los reactores ACP, UASB y EGSB se basan en un contenido que va de un mezclado a completamente mezclado, se han probado varios diseños que utilizan la puesta en escena de varias fases del tratamiento anaerobio (van Lier et al., 2001). Un ejemplo extremo es el proceso en dos etapas, en donde el paso de acidificación se separa completamente del paso de metanogénesis (ver la sección 16.7.2.6). La estratificación horizontal se obtiene en los reactores anaerobios con deflectores (ABR), los cuales son mejor caracterizados como unidades de reactores UASB operados en serie.

Aunque algunas aplicaciones a gran escala fueron hechas para el tratamiento de aguas residuales de tipo doméstico, este tipo de reactor ya no se encuentra en desarrollo. El principal problema son las limitaciones hidrodinámicas generando, como consecuencia, limitaciones en los TRL alcanzables en el sistema, debido a que la velocidad superficial del líquido en un sistema con deflectores es sustancialmente mayor que en un reactor de lecho de lodos en una sola etapa. De acuerdo a la lógica, resulta que la mayoría del lodo se moverá con el líquido a través de los diversos compartimentos y, posteriormente, tiene que ser separado en el último compartimento en un sedimentador y después ser recirculado a la parte superior del reactor. Los reactores verticales estratificados, como los sistemas de lecho de lodos de flujo ascendente en etapas (van Lier et al., 1994, 2001, Tagawa et al., 2001), fueron desarrollados en específico para el tratamiento a altas temperaturas. Aunque el reactor estratificado muestra resultados bastante prometedores a escala piloto, hasta el momento no se ha desarrollado a gran escala. 


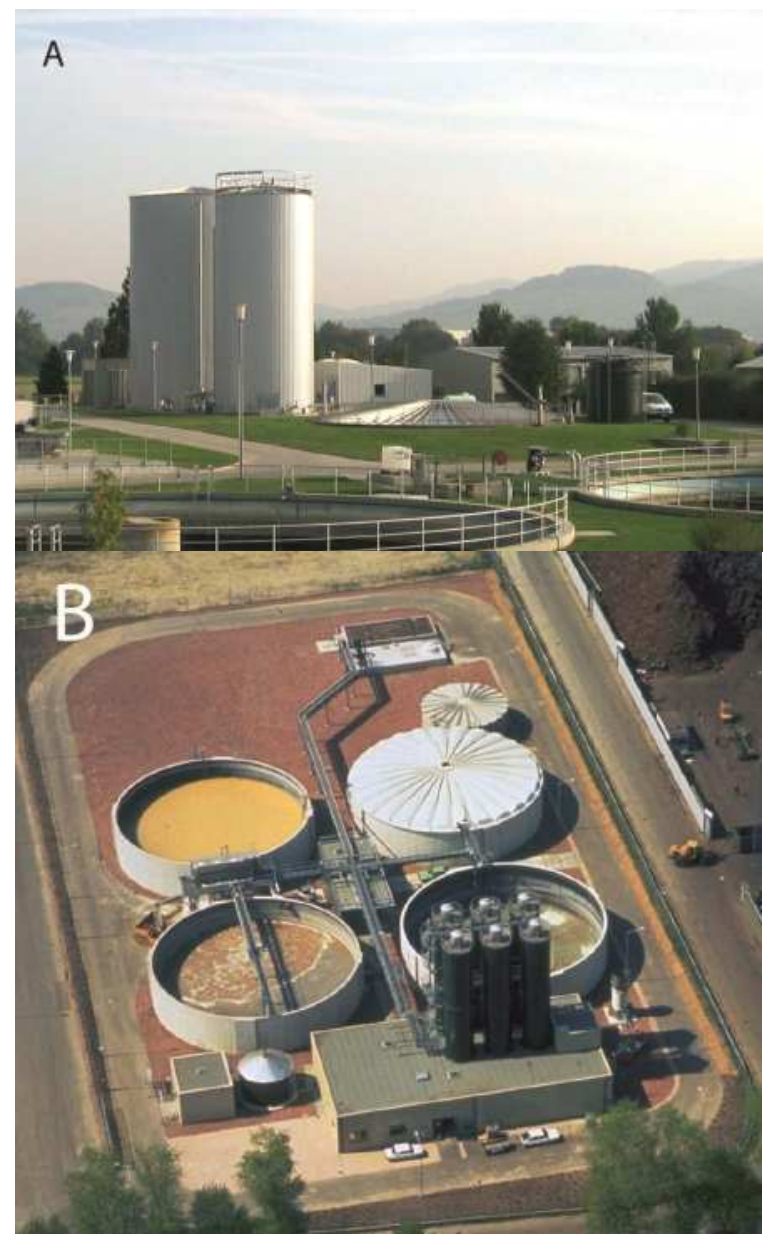

Figura 16.21 (A) EGSB instalado para el tratamiento de agua residual municipal en Alemania y (B) IC instalado para el tratamiento de agua residual de la industria cervecera en Den Bosch en Holanda (Imágenes: Biothane B.V. y Paques B.V., respectivamente)

Existen posibilidades muy interesantes para los reactores anaerobios secuenciales en lote (ASBR), las cuales consisten en una serie de reactores anaerobios operados en lote utilizando el método de "llenado y vaciado". Una cierta cantidad del agua residual cruda es suministrada al reactor anaerobio, después de que el líquido sobrenadante de un reactor en lote previo ha sido descargado. Posteriormente, se comienza con un mezclado "suave" del contenido del reactor, con el objetivo de permitir que el lodo viable a sedimentar pueda estar en contacto con el agua residual y eliminar la materia orgánica biodegradable. Después de un periodo de reacción suficiente, se permite la sedimentación del lodo y la solución sobrenadante se descarga. Entonces se comienza con el nuevo ciclo. El proceso de granulación se lleva a cabo adecuadamente en aguas residuales diluidas en un ASBR, inclusive a bajas temperaturas ambientales (Banik et al., 1997). Se observó que los sistemas ASBR eran de particular interés para aguas residuales que contienen AGCL (Alves et al., 2001). Durante el periodo de llenado, los AGCLs son absorbidos en el lodo anaerobio, posteriormente se lleva a cabo un periodo de digestión suave, durante el cual el lodo absorbido se estabiliza y se regenera completamente a biomasa metanogénica altamente activa.

Recientemente, se han estudiado los bioreactores anaerobios de membrana con mayor intensidad (Liao et al., 2006, Jeison y van Lier, 2006). La tecnología de membranas puede considerarse como una opción interesante para aquellos casos en los que las tecnologías ya establecidas pueden fallar. Éste probablemente es el caso en el que prevalecen condiciones extremas, tales como altas temperaturas y alta salinidad, o aguas residuales con compuestos recalcitrantes y/o tóxicos. Algunas experiencias a gran escala han demostrado que, bajo estas condiciones, la inmovilización del lodo por medio de la formación de gránulos, no se desarrolla satisfactoriamente, afectando de manera negativa la retención del lodo. Se espera que los requerimientos para el tratamiento de aguas residuales bajo condiciones extremas se vuelvan más y más comunes, siguiendo la tendencia actual de la industria de cerrar los ciclos del agua de proceso. Bajo estas condiciones, los sistemas MBR son muy efectivos en la retención de ciertos microorganismos específicos, los cuales se requieren para la remoción de los compuestos recalcitrantes acumulados en los procesos industriales de ciclo cerrado. En la actualidad se encuentran en operación muy pocos sistemas AMBR a gran escala. Considerando la fuerte caída en los precios de las membranas, se esperaría un aumento en la utilización de esta tecnología emergente.

\subsubsection{Reactores acidificantes e hidrolíticos}

Con excepción de los reactores de tanque agitado, hasta el momento no se han desarrollado reactores específicos para la acidogénesis. El proceso de acidogénesis, por lo general, se lleva a cabo de manera muy rápida en un reactor de tanque agitado y en la práctica, por lo general, no existe una necesidad real para llevar a cabo la acidogénesis completa. Por otra parte, se entiende completamente que el unir los procesos de acidificación y metanogénesis resulta beneficioso para la formación de los gránulos (Verstraete et al., 1996). Además, se acepta cada vez más que la presencia de altas concentraciones de organismos acidificantes en la alimentación del reactor metanogénico, es perjudicial para el lodo granular metanogénico presente en ese reactor. Esto último 
significa que se debe mejorar el tiempo de retención del lodo en un reactor acidogénico.

Los reactores acidificantes pueden combinarse con sistemas de acumulación de sólidos, salvaguardando al reactor metanogénico de las altas cargas de SS. Se realizaron pruebas combinando la clarificación primaria con la estabilización anaerobia en agua residual doméstica. Aunque Wang (1994) implementó algunos sistemas a gran escala en China, no se han realizado nuevas implementaciones hasta el momento.

\subsection{REACTOR ANAEROBIO DE LECHO DE LODOS DE FLUJO ASCENDENTE (UASB)}

\subsubsection{Descripción del proceso}

El reactor UASB es la tecnología anaerobia de alta tasa más exitosa y ampliamente utilizada para el tratamiento de diferentes tipos de aguas residuales (Figura 16.17). El éxito de los reactores UASB puede atribuirse a su capacidad de retención de altas concentraciones de lodo, mientras se alcanza una separación eficiente de sólidos, líquidos y agua. El reactor UASB consiste en un tanque rectangular o circular, en el cual el residuo (agua o lodo) fluye en dirección de flujo ascendente a través de un lecho de lodos activados anaerobios, este lecho ocupa alrededor de la mitad del volumen del reactor y consiste en gránulos o flóculos altamente sedimentables (Figura 16.17). Durante el paso a través del lodo anaerobio, se lleva a cabo el proceso de tratamiento mediante el atrapamiento de los sólidos y la conversión de la materia orgánica a biogás y lodo. Las burbujas producidas de biogás ascienden de manera automática hacia la superficie del reactor, llevando consigo agua y partículas de sólidos, es decir, lodo biológico y sólidos residuales. Las burbujas de biogás son dirigidas hacia la superficie gas-líquido en la parte superior del reactor (por medio de deflectores), ayudando a que la GLSS sea más eficiente. Las partículas sólidas caen de nuevo en la parte superior del lecho de lodos, mientras que los gases liberados son capturados en un cono invertido o en alguna estructura similar, localizada en la parte superior del reactor. El agua fluye a través de las aberturas que se encuentran entre los deflectores, llevando algunas partículas de sólidos, las cuales pueden sedimentar en el área de sedimentación debido a que la velocidad de flujo ascendente disminuye con el aumento del área de la sección transversal. Después de la sedimentación, los sólidos se deslizan hacia el lecho de lodos, mientras que el agua abandona la zona de sedimentación por los vertedores.

\subsubsection{Consideraciones de diseño en los reactores UASB}

\subsubsection{Máxima carga hidráulica superficial}

La capacidad metanogénica de conversión en los reactores UASB, expresada en $\mathrm{kgDQO} / \mathrm{m}^{3} . \mathrm{d}$, se encuentra directamente relacionada con la cantidad de biomasa retenida y la actividad metanogénica específica del lodo acumulado. Además de la calidad y cantidad del lodo retenido, los potenciales máximos de carga orgánica también dependen de un mezclado adecuado del lodo con el agua residual entrante. El tiempo de retención de lodo (TRL) requerido, establece límites aplicables para las velocidades de flujo ascendente del líquido $\left(\mathrm{V}_{\text {upw }}\right)$, así como también para las cargas específicas de biogás resultantes del proceso de conversión anaerobia (Lettinga y Hulshoff Pol, 1991). El diseño de los reactores UASB, combina las características de un bioreactor de alta tasa con aquellas de un clarificador secundario incluido en la parte superior del reactor. Por lo tanto, las $\mathrm{V}_{\text {upw }}$ promedio en el área de sección transversal de los reactores UASB y la sección de clarificación en la superficie, se encuentran en el intervalo de $0.5-1.0 \mathrm{~m} / \mathrm{h}$. Cargas hidráulicas más altas pueden generar la pérdida no deseada de biomasa si se acumulan lodos floculentos durante la operación del reactor. Esto último puede ocurrir, por ejemplo, durante la primera etapa de arranque del reactor, cuando éste es inoculado con un material que no se encuentra adaptado como lodos digeridos o durante el tratamiento anaerobio de aguas residuales domésticas. $\mathrm{La} \mathrm{V}_{\text {upw }}$ se puede calcular utilizando el flujo promedio y el área de la sección transversal del reactor, A (Ec. 16.46), como sigue:

$V_{\text {upw }}=\frac{Q_{\text {inf }}}{A}$

donde:

Q inf velocidad de flujo del afluente (o influente)

Con el crecimiento y acumulación de lodo floculento espeso, o lodo granular, se pueden utilizar cargas hidráulicas mucho más altas en el reactor. En reactores de lecho expandido se aplican altos valores de $\mathrm{V}_{\text {upw }}$, alcanzando hasta $8-10 \mathrm{~m} / \mathrm{h}$. 
Con base en la máxima $\mathrm{V}_{\text {upw }}$ permitida, las mínimas dimensiones superficiales pueden ser calculadas de acuerdo a la Ec. 16.47:

$A$ min $=\frac{Q_{\text {inf }}}{V_{u p w, \max }}$

A un determinado tiempo de retención hidráulico (TRH, $\Theta$ ), la máxima velocidad de flujo ascendente determina la relación $\mathrm{H} / \mathrm{A}$, en donde $\mathrm{H}$ es la altura del reactor de acuerdo a la Ec. 16.48 .

$\Theta=\frac{A \min \cdot H \max }{Q}$

Vreactor $=\Theta \cdot Q$

$\left(\mathrm{m}^{3}\right)(16.49)$

Para alguna situación en la cual la capacidad de carga orgánica no es restrictiva, la Ec. 16.49 proporciona el volumen requerido del reactor UASB. Esto último sólo ocurre en aguas residuales diluidas, tales como la mayoría de las aguas residuales domésticas en la zona tropical de América Latina, las cuales tienen valores de DQO $<1,000 \mathrm{mg} / \mathrm{l}$. Aquí, la carga hidráulica determina completamente la cantidad de lodo acumulada, mientras que, la capacidad metanogénica en el reactor generalmente excede las velocidades de carga orgánica aplicadas.

\subsubsection{Capacidad de carga orgánica}

En la mayoría de los casos, los reactores UASB son utilizados para el tratamiento de aguas residuales más concentradas (Tabla 16.10). La capacidad volumétrica de conversión de la tasa de carga orgánica (OLR) en $\mathrm{kgDQO} / \mathrm{m}^{3}$ reactor dependerá entonces de:

- la cantidad de biomasa acumulada, X, en kg de sólidos suspendidos volátiles $\mathrm{SSV} / \mathrm{m}^{3}$ reactor.

- la actividad metanogénica específica del lodo (SMA) en $\mathrm{kgDQO} / \mathrm{kgSSV}$.d.

- el factor de contacto $\left(f_{c}\right)$, entre 0 y 1 .

La OLR puede ser calculada utilizando la Ec. 16.50, con base en una cinética de Monod:

$$
\begin{aligned}
O L R=r v=f_{c} A c T X=\left[f_{c}\left(\frac{V_{\max } \cdot S}{K_{m}+S}\right) \cdot X\right] T \\
\\
\left(\mathrm{kgDQO} / \mathrm{m}^{3}\right)(16.50)
\end{aligned}
$$

La velocidad de conversión $\mathrm{V}_{\max }$, y/o la SMA dependen de varios factores, tales como:

- la temperatura

- la presencia de compuestos tóxicos o inhibitorios

- la biodegradabilidad del sustrato

- la presencia de sólidos suspendidos (SS) en el afluente

- el grado de pre-acidificación del agua residual

En los reactores UASB, la cantidad de lodo anaerobio, por lo general, varía entre $35-40 \mathrm{~kg} \mathrm{SSV} / \mathrm{m}^{3}$ del volumen del reactor (incluido el sedimentador). El factor de contacto $\left(f_{c}\right)$ depende de la efectividad y homogeneidad de la distribución de la alimentación y de la velocidad de carga orgánica aplicada con la producción resultante de biogás, contribuyendo enormemente en el mezclado del reactor.

Considerando el número de factores desconocidos, es indispensable realizar una caracterización completa del agua residual antes de diseñar el reactor UASB. Además, por lo general se realizan pruebas a escala piloto para obtener un mejor conocimiento del crecimiento y desarrollo del lodo anaerobio en un agua residual específica. Con base en varias pruebas piloto realizadas en décadas pasadas y el subsecuente número de experiencias a gran escala, se ha desarrollado una tabla de las posibles velocidades de carga orgánica que se pueden utilizar dependiendo de la temperatura del reactor (Tabla 16.11). Cuando se conocen las OLR o $r_{v}$ permitidos, se puede calcular fácilmente el volumen requerido de reactor a partir de la velocidad de flujo y la concentración del afluente (Ec. 16.51):

$V_{\text {reactor }}=\frac{C \inf . Q \inf }{r v}$

Un reactor UASB puede estar limitado tanto por la carga hidráulica como por la orgánica, en cuyos casos el volumen del reactor se calcula por medio de la Ec. 16.49 o 16.51. Si se desconoce la situación actual, por lo general se calcula el volumen del reactor con base en ambas consideraciones, después de esto, el mayor volumen sugerido por cualquiera de estas dos ecuaciones se asume como el volumen de diseño. En la Figura 16.22 se presenta el impacto que tiene la concentración del agua residual (en $\mathrm{kgDQO} / \mathrm{m}^{3}$ ) sobre el volumen requerido. Suponiendo un TRH mínimo de $4 \mathrm{~h}$ para prevenir la pérdida por arrastre del lodo, el volumen mínimo requerido para el reactor será de al menos $1,000 \mathrm{~m}^{3}$, independientemente de la concentración del agua residual. A altas concentraciones de DQO del afluente, obviamente, el volumen requerido del reactor dependerá 
Tabla 16.11 Cargas orgánicas permisibles en reactores UASB de una sola etapa para varios tipos de aguas residuales con relación en la temperatura de operación aplicada. La biomasa consiste en lodo granular

\begin{tabular}{ccccc}
\hline \multirow{2}{*}{ Temperatura $\left({ }^{\circ} \mathrm{C}\right)$} & \multicolumn{4}{c}{ Carga orgánica $\left(\mathrm{kgDQO} / \mathrm{m}^{3} . \mathrm{d}\right)$} \\
\cline { 2 - 5 } & $\begin{array}{c}\text { Agua residual con } \\
\text { AGV }\end{array}$ & $\begin{array}{c}\text { Agua residual sin } \\
\text { AGV }\end{array}$ & $\begin{array}{c}\text { Agua residual con } \\
<5 \% \text { SS-DQO }\end{array}$ & $\begin{array}{c}\text { Agua residual con } \\
30-40 \% \text { SS-DQO }\end{array}$ \\
\hline 15 & $2-4$ & $1.5-3$ & $2-3$ & $1.5-2$ \\
20 & $4-6$ & $2-4$ & $4-6$ & $2-3$ \\
25 & $6-12$ & $4-8$ & $6-10$ & $3-6$ \\
30 & $10-18$ & $8-12$ & $10-15$ & $6-9$ \\
35 & $15-24$ & $12-18$ & $15-20$ & $9-14$ \\
40 & $20-32$ & $15-24$ & $20-27$ & $14-18$ \\
\hline
\end{tabular}

directamente de la concentración del agua residual, puesto que la velocidad de carga orgánica permanecerá fija.

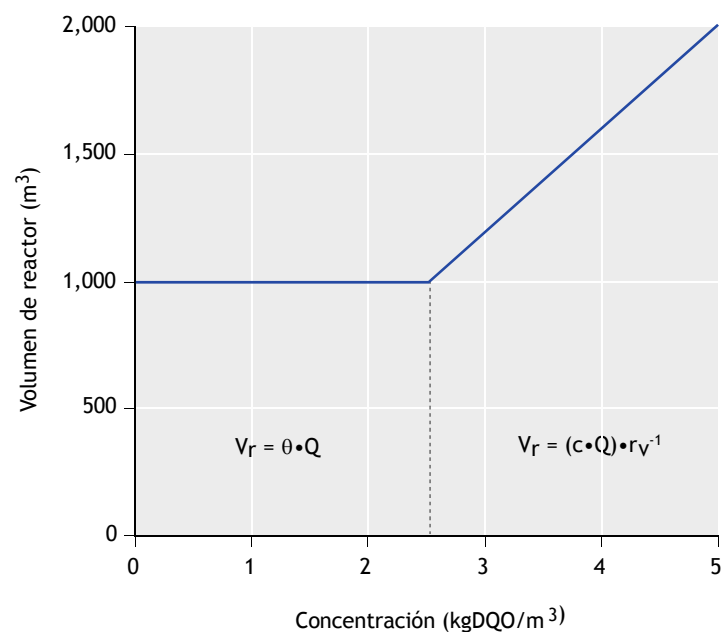

Figura 16.22 Cálculo del volumen requerido del reactor UASB utilizando las siguientes suposiciones: $\Theta_{\min }=4 \mathrm{~h}, \mathrm{Q}=250 \mathrm{~m}^{3} / \mathrm{h}, \mathrm{r}_{\mathrm{v}}$ $=15 \mathrm{kgDQO} / \mathrm{m}^{3} \cdot \mathrm{d}, \mathrm{T}=30^{\circ} \mathrm{C}$. El volumen puede ser determinado ya sea por la velocidad de carga hidráulica o la velocidad de carga orgánica (obtenido de Lettinga y Hushoff Pol, 1991)

A menudo el factor más desconocido es la carga hidráulica máxima potencial o el mínimo TRH. Es imposible el dar números brutos debido a que depende directamente del lodo que será cultivado en esa agua residual en específico. Por lo general, para los reactores UASB, y en particular para aquellos que operan con lodo no granular, se considera una velocidad máxima de flujo ascendente de $1 \mathrm{~m} / \mathrm{h}$. En la Figura 16.23, se muestra el impacto en el volumen requerido del reactor cuando se pueden tolerar velocidades de flujo ascendente de $6 \mathrm{~m} / \mathrm{h}$, en el caso de que se cultive un lodo granular de buena calidad. En el ejemplo se considera la

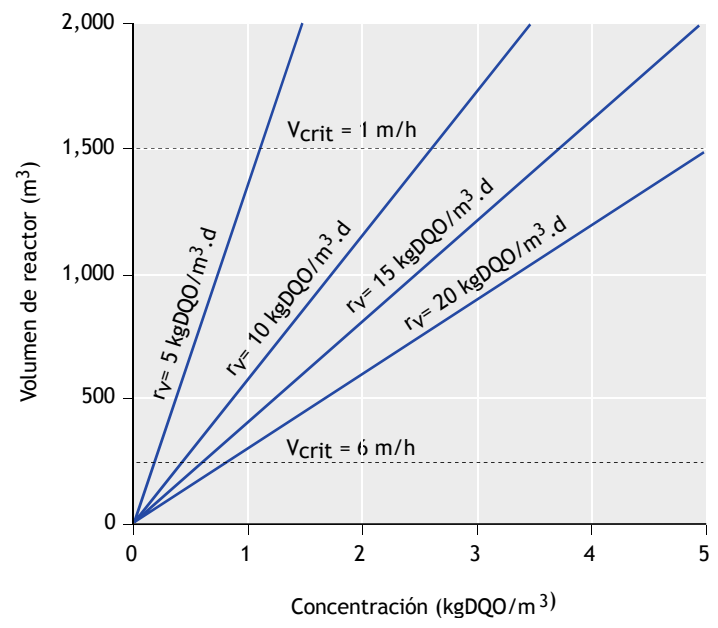

Figura 16.23 Cálculo del volumen requerido del reactor UASB utilizando las siguientes suposiciones: $\mathrm{Q}=250 \mathrm{~m}^{3} / \mathrm{h}$, altura del reactor $=6 \mathrm{~m}, \mathrm{~T}=30^{\circ} \mathrm{C}$. El volumen se determina ya sea por la velocidad de carga hidráulica o la velocidad de carga orgánica. $V_{\text {crit. }}$ determina el nivel de "corte" para el mínimo volumen de reactor requerido con base en las limitaciones hidráulicas (obtenido de Lettinga y Hushoff Pol, 1991)

misma altura del reactor. Efectivamente, el volumen del reactor puede reducirse en un factor de 6 .

Además de las velocidades del líquido, las altas cargas en los reactores se encuentran limitadas por la turbulencia que se genera debido al gas producido. La velocidad de flujo ascendente del biogás ( $\mathrm{V}_{\text {biogas }}$ ) puede calcularse utilizando la Ec. 16.52.

Vbiogás $=D Q O \cdot \frac{E_{f f}-\text { meth }}{100} \cdot \frac{0.35}{F_{m e t h-b i o g a s}}$.

$\frac{(T+273)}{273} \cdot$ Vupw, liquido

En la cual $\mathrm{E}_{\text {ff-meth }}$ es el \% de DQO convertido a $\mathrm{CH}_{4}$ $\left(\mathrm{en} \mathrm{kg} / \mathrm{m}^{3}\right.$ ), $\mathrm{T}$ es la temperatura en ${ }^{\circ} \mathrm{C}$, y $\mathrm{F}_{\text {meth-biogas }}$ es la 
fracción de $\mathrm{CH}_{4}$ en el biogás (generalmente entre $0.6 \mathrm{y}$ 0.9 para aguas residuales). Es importante considerar que el valor real de $\mathrm{F}_{\text {meth-biogás será más alto que el teórico }}$ estimado utilizando 18.75/100 - DQO/COT (Figura 16.10), debido a la alta solubilidad del $\mathrm{CO}_{2}$ en el medio y a la unión química del $\mathrm{HCO}_{3}{ }^{-}$con cationes como el $\mathrm{Na}^{+}$, $\mathrm{K}^{+}$, y $\mathrm{NH}_{4}{ }^{+}$(sección 16.3.1). Con unidades GLSS diseñadas convencionalmente, la $\mathrm{V}_{\text {biogás }}$ máxima permitida se encuentra entre 2 y $3 \mathrm{~m} / \mathrm{h}$.

Particularmente, para reactores caracterizados por una relación altura/diámetro muy alta, se debe tener un cuidado especial en el diseño detallado del separador gas/líquido, tal y como se observa en la Figura 16.17.

\subsubsection{Partes internas del reactor}

Las partes internas del reactor UASB más importantes y que requieren de consideraciones especiales, son el distribuidor de la alimentación, la salida del efluente, y la unidad GLSS. La mayoría de los constructores y contratistas utilizan sus propios diseños -por lo general patentados-. Se encuentra fuera de los alcances de este capítulo el abordar el diseño detallado de estas partes internas. En la Sección 16.11 se dan algunas observaciones importantes, en donde se mencionan algunas características generales en el diseño de los reactores para tratamiento anaerobio de aguas residuales.

De crucial importancia es la uniformidad y consistencia del sistema de distribución de la alimentación, de manera particular cuando el sistema UASB se aplica a velocidades de carga bajas, es decir, cuando la turbulencia provocada por la producción del biogás es limitada. La Tabla 16.12, proporciona algunos valores indicativos aplicables para los reactores UASB operados ya sea con lodos floculentos o granulares.
Algunas pruebas realizadas con sistemas a gran escala muestran que a velocidades de carga orgánica que exceden los $5 \mathrm{kgDQO} / \mathrm{m}^{3}$.d, la turbulencia inducida por el biogás es suficiente para generar un mezclado adecuado en el reactor, disminuyendo la velocidad de transferencia de masa a un nivel apropiado. En comparación con los reactores UASB, la distribución del afluente en los sistemas EGSB es menos crítica debido a la superficie relativamente pequeña del reactor.

La Tabla 16.13 muestra una guía tentativa para el diseño de las unidades GLSS convencionales en un reactor UASB. Algunas otras características de diseño son explicadas a detalle, por ej. por van Haandel y Lettinga (1994), y los parámetros más críticos para la construcción de un reactor UASB para el tratamiento de agua residual doméstica se muestran en la Figura 16.25.

\subsubsection{Tanque séptico UASB}

El tanque séptico UASB, es un nuevo sistema que resulta de particular interés para la aplicación en conceptos descentralizados de saneamiento. El afluente de estos reactores consistirá principalmente de aguas residuales domésticas relativamente diluidas o corrientes concentradas de residuos, tales como aguas negras colectadas separadamente. De manera similar al reactor UASB, este tipo de reactor se opera en modo de flujo ascendente, con velocidades de flujo muy bajas, variando de alrededor de $0.01 \mathrm{~m} / \mathrm{h}$ para sistemas de aguas negras a $0.20 \mathrm{~m} / \mathrm{h}$ para aguas residuales domésticas diluidas. Debido a las bajas cargas hidráulicas, se puede obtener una mejor separación de sólidos. De hecho, los tanques sépticos UASB funcionan como un sistema de acumulación y estabilización para sólidos y un reactor metanogénico para compuestos orgánicos solubles. A diferencia de los reactores UASB, el tanque séptico UASB puede estar equipado con un "agitador" central

Tabla 16.13 Resumen de una guía tentativa para el diseño de la unidad de separación gas-líquido-sólido

Unidad GLSS para UASB

1 La pendiente del fondo del sedimentador (es decir, la pared inclinada del colector de gas) debe estar entre $45-60^{\circ}$.

2 El área superficial de las aberturas entre los colectores de gas, deberá ser del 15-20\% del área superficial del reactor.

3 La altura del colector de gas, deberá ser de 1.5-2 $\mathrm{m}$ a alturas del reactor de 5-6 $\mathrm{m}$.

4 Para facilitar el escape y colección de las burbujas de gas y para combatir la formación de una capa de nata, se debe mantener una interface líquido-gas en el colector de gas.

5 Para evitar que las burbujas que fluyen de manera ascendente, entren al compartimento de sedimentación, la superposición de los deflectores instalados debajo de las aberturas deberá ser de $15-20 \mathrm{~cm}$.

6 Por lo general, se deberán instalar deflectores enfrente de los vertedores del efluente para remover la capa de nata.

7 El diámetro de la tubería de escape del gas deberá ser suficiente para garantizar una fácil remoción del biogás de la tapa de colección, particularmente en caso de que se forme espuma.

8 En la parte superior del colector de gas, se deberán colocar dispersores de spray anti-espuma en el caso de que el tratamiento del agua residual venga acompañado de la formación intensiva de espuma. 
para realizar movimientos muy suaves y periódicos del lecho de lodos.

\subsection{CINÉTICA DEL PROCESO ANAEROBIO}

Las velocidades de conversión de las bacterias, incluyendo los procesos anaerobios, por lo general se describen utilizando las cinéticas de conversión de sustrato de Monod (ver el Capítulo 2). Las cinéticas de conversión anaerobias, incluyendo todos los parámetros cinéticos, han sido revisadas extensivamente por Batstone et al. (2002) que presentan un modelo de digestión anaerobia unificado, denominado ADM1, en analogía con el ASM1 para lodos activados. El ADM1 fue desarrollado a partir de diferentes modelos anaerobios, los cuales han sido presentados en la literatura desde décadas pasadas. Para la misma conveniencia, como se explicó en las secciones 16.3 y 16.5, el modelo ADM1 también se basa en el balance de DQO para describir el flujo de electrones durante el proceso de conversión anaerobia. Llaman la atención las grandes variaciones en los parámetros cinéticos evaluados para las reacciones de conversión específicas, ver la Tabla 16.14 obtenida de Batstone et al. (2000). Esto significa que la configuración del proceso, la microflora exacta que prevalece y la operación actual del sistema, determinan en gran medida los parámetros cinéticos que son aplicables.

Hasta el momento, el ADM1 es una herramienta muy útil para describir los sistemas existentes, dando una idea de la dinámica de los procesos y el impacto que tiene el cambiar algunos parámetros del proceso, tales como la concentración de alimentación, el flujo de sustrato, temperatura, etc. en el proceso global de digestión.
Tabla 16.12 Área requerida $\left(\mathrm{m}^{2}\right)$ por punto de alimentación en un reactor UASB, dependiendo del tipo de lodo y la velocidad de carga aplicada

\begin{tabular}{lrr}
\hline Tipo de lodo & $\begin{array}{r}\text { Velocidad de carga } \\
\left(\mathrm{kg} \mathrm{DQO} / \mathrm{m}^{3} . \mathrm{d}\right)\end{array}$ & $\begin{array}{r}\text { Área superficial por } \\
\text { punto de alimentación } \\
\left(\mathrm{m}^{2}\right)\end{array}$ \\
\hline Medio & $<1-2$ & $1-2$ \\
floculante grueso & $>3$ & $2-5$ \\
$\left(20-40 \mathrm{kgST} / \mathrm{m}^{3}\right)$ & $<1$ & $0.5-1$ \\
floculante denso & $1-2$ & $1-2$ \\
$\left(>40 \mathrm{kgST} / \mathrm{m}^{3}\right)$ & $>2$ & $2-3$ \\
& $<2$ & 0.5 \\
Lodo granular & $2-4$ & $1-2$ \\
& $>4$ & $>2$ \\
\hline
\end{tabular}

Utilizando los datos reales del reactor, se pueden ajustar los parámetros cinéticos para predecir de manera real su funcionamiento en cuanto a la remoción de DQO y a la producción de $\mathrm{CH}_{4}$. Además, para propósitos de enseñanza, el ADM1 es una herramienta valiosa que da una idea de la importancia de las etapas de conversión en la cadena completa de reacciones consecutivas. Por otra parte, el ADM1 aún no cuenta con las cinéticas de la biopelícula y la hidrodinámica del sistema, las cuales determinan en gran parte las cinéticas reales en los sistemas de tratamiento anaerobio de alta tasa.

Por ejemplo, en un sistema de 3 fases en donde el transporte de masa convectivo a nivel micro y macro, el cual es inducido por los productos gaseosos finales, puede afectar en gran medida los parámetros cinéticos y la dinámica real del sistema, pueden invalidar completamente los parámetros de entrada del modelo. Por lo tanto, y hasta el momento, como una herramienta de diseño, el ADM1 no se puede utilizar y el desafío

Tabla 16.14 Parámetros cinéticos de los principales sustratos y productos intermedios en el proceso de conversión anaerobia (obtenidos de Batstone et al., (2000). Datos obtenidos a partir de varios tipos de sistemas de digestión anaerobia. En la Tabla se presentan los datos obtenidos a partir de una revisión de la literatura más citada; de no ser así, se tomaron los valores típicos. Todos los pesos de sustrato y SSV se expresan en términos de DQO.

\begin{tabular}{lrrrrr}
\hline Sustrato & $\begin{array}{r}\text { Tasa de remoción } \\
\mathrm{kg} / \mathrm{kgVSS} . \mathrm{d}\end{array}$ & $\begin{array}{r}\mu_{\max } \\
1 / \mathrm{d}\end{array}$ & $\mathrm{Y}$ & $\begin{array}{r}\mathrm{K}_{\mathrm{s}} \\
\mathrm{kg} / \mathrm{m}^{3}\end{array}$ & $\begin{array}{r}\mathrm{K}_{\mathrm{d}} \\
1 / \mathrm{d}\end{array}$ \\
\hline Hidrógeno & $2-65$ & $0.02-12$ & $0.014-0.183$ & $0.00002-0.0006$ & 0.009 \\
Acetato & $3-18$ & $0.05-1.4$ & $0.014-0.076$ & $0.011-0.930$ & $0.004-0.036$ \\
Propionato & $0.16-0.31$ & $0.004-0.016$ & $0.025-0.05$ & $0.06-1.15$ & $0.01-0.04$ \\
Butirato & $5-14$ & $0.35-0.90$ & 0.066 & $0.012-0.30$ & 0.027 \\
Valerato & $15-19$ & $0.86-1.20$ & $0.058-0.063$ & $0.062-0.36$ & $0.01-0.03$ \\
AGCL & $1.4-37$ & $0.10-1.65$ & $0.045-0.064$ & $0.06-2.0$ & $0.01-0.20$ \\
Amino ácidos & $36-107$ & $2.36-16$ & $0.06-0.15$ & $0.05-1.4$ & $0.01-3.2$ \\
Monosacáridos & $29-125$ & $0.41-21.3$ & $0.01-0.17$ & $0.022-0.63$ & $0.02-3.2$ \\
\hline
\end{tabular}


actual es el combinar el modelo ADM1 con algunos otros modelos hidrodinámicos y químicos para crear una herramienta de diseño comprensible o una herramienta de utilidad, cuando se opere un sistema anaerobio en un ambiente dinámico.

\subsection{TRATAMIENTO ANAEROBIO DE AGUA RESIDUAL DOMÉSTICA Y MUNICIPAL}

El agua residual municipal es el tipo de agua residual más abundante en la tierra. La descarga de aguas residuales sin tratamiento en las aguas superficiales tiene un gran impacto ambiental y genera grandes problemas de salud a la población. Los dos incentivos principales para el desarrollo de una tecnología de tratamiento adecuado para aguas residuales en las sociedades occidentales, fueron la minimización tanto de los riesgos a la salud humana como los riesgos ambientales (ver Capítulo 1). En muchos otros países menos prósperos, las limitaciones financieras restringen la aplicación de estas tecnologías y se han buscado algunas otras alternativas. Los AnWT ofrecen una alternativa rentable, la cual ha sido reconocida desde mediados de los setentas del siglo pasado por Lettinga y colaboradores. Los tratamientos de aguas residuales anaerobios de alta tasa, sin embargo, se diseñaron para aguas industriales con alta carga, mientras que, las aguas residuales domésticas o municipales se caracterizan por estar muy diluidas. En varias partes del mundo, las concentraciones de DQO del agua residual municipal son $<1,000 \mathrm{mg} / 1$ y por lo general menores a $500 \mathrm{mg} / \mathrm{l}$. De acuerdo a la Figura 16.22, el tratamiento anaerobio de este tipo de aguas residuales se encuentra limitado por las restricciones hidrodinámicas del sistema, en lugar de su capacidad de conversión de la materia orgánica. Sin embargo, las temperaturas de las aguas residuales domésticas, son por lo general más bajas que las presentadas por las aguas residuales industriales. Sólo bajo condiciones de clima tropical, el agua residual municipal puede alcanzar la temperatura ideal para los AnWT (van Haandel y Lettinga, 1994). Las primeras experiencias con sistemas de tratamiento anaerobio compactos de alta tasa, utilizando reactores UASB para el tratamiento de agua residual doméstica, comenzaron a principios de los ochentas en Cali, Colombia (van Haandel y Lettinga, 1994). Los resultados obtenidos durante la operación de un reactor piloto UASB de 64 $\mathrm{m}^{3}$ mostraron la factibilidad de este sistema bajo las condiciones ambientales prevalecientes y las características del agua residual. Estas primeras pruebas fueron seguidas rápidamente por experiencias en reactores a gran escala en Colombia, Brasil e India. En la Tabla 16.15 se enlistan algunos de los resultados obtenidos durante la operación de estos reactores UASB a gran escala. Desde principios de los noventas, se han construido cientos de reactores UASB a gran escala con volúmenes que van desde 50 hasta $50,000 \mathrm{~m}^{3}$ (von Sperling y Chernicharo, 2005), de manera particular bajo condiciones (sub)-tropicales (Draaijer et al., 1992; Schellinkhout y Osorio, 1994). Por lo general, se obtiene una eliminación de DBO del 75 al $85 \%$, con concentraciones de DBO en el efluente menores a 40 $50 \mathrm{mg} / \mathrm{l}$. Con respecto a la remoción de DQO y SST, los resultados son mayores al $70-80 \%$ e inclusive mayores en algunas ocasiones (von Sperling y Chernicharo, 2005; Van Haandel y Lettinga, 1994). Con el objeto de cumplir con las normas de descarga locales, los sistemas UASB se acoplan con un sistema de post-tratamiento adecuado, como por ejemplo: lagunas facultativas, filtración con arena, humedales artificiales, filtros percoladores, un tratamiento fisicoquímico, y un tratamiento con lodos activados (Schellinkhout y Osorio, 1994; von Sperling y Chernicharo, 2005).

El reactor UASB y el post-tratamiento pueden ser implementados consecutivamente o en una configuración más integrada. En la Tabla 16.16, se enlistan las características más importantes de los tratamientos anaerobios de aguas residuales domésticas de alta tasa.

Tabla 16.15 Funcionamiento del tratamiento en las primeras plantas de tratamiento de aguas residuales municipales, utilizando reactores UASB a gran escala. La DQO hace referencia a la DQO total del agua residual cruda (obtenida de van Haandel y Lettinga, 1994)

\begin{tabular}{|c|c|c|c|c|c|c|}
\hline País & $\begin{array}{l}\text { Volumen } \\
\mathrm{m}^{3}\end{array}$ & $\begin{array}{l}\text { Temperatura } \\
{ }^{\circ} \mathrm{C}\end{array}$ & $\begin{array}{c}\mathrm{TRH} \\
\mathrm{h}\end{array}$ & $\begin{array}{l}\text { DQO del afluente } \\
\mathrm{mg} / 1\end{array}$ & $\begin{array}{l}\text { DQO del efluente } \\
\mathrm{mg} / \mathrm{l}\end{array}$ & $\begin{array}{l}\% \text { de DQO } \\
\text { removido }\end{array}$ \\
\hline Colombia & 64 & $24-26$ & $4-6$ & 267 & 110 & 65 \\
\hline Colombia & 6,600 & 25 & 5.2 & 380 & 150 & $60-80$ \\
\hline Brasil & 120 & 23 & $4.7-9$ & $315-265$ & 145 & $50-70$ \\
\hline Brasil & 67.5 & 23 & 7 & 402 & 130 & 74 \\
\hline Brasil & 810 & 30 & 9.7 & 563 & 185 & 67 \\
\hline India & 1,200 & $20-30$ & 6 & 563 & 146 & 74 \\
\hline
\end{tabular}

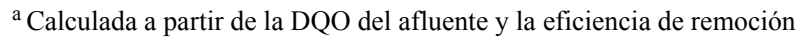


Tabla 16.16 Principales ventajas y limitaciones ${ }^{\mathrm{a}}$ del tratamiento anaerobio de aguas residuales domésticas, en sistemas anaerobios de alta tasa

Ventajas

- Ahorros substanciales, alcanzando el $90 \%$, en costos operacionales debido a que no se requiere energía para aireación

- Del 40-60\% en reducción del costo de inversión, debido a que se requieren menos unidades de tratamiento

- Si se implementan en una escala adecuada, el $\mathrm{CH}_{4}$ producido resulta de interés para la recuperación de energía o la producción de electricidad

- Las tecnologías no requieren el uso de equipos de alta tecnología, excepto para la montura de bombas especiales y cribas finas. El sistema de tratamiento es menos dependiente de tecnología de importación.

- El proceso es robusto y puede manejar altas tasas de carga hidráulica y orgánica periódicamente.

- La tecnología es compacta con TRHs promedios entre 6 y $9 \mathrm{~h}$ y, por lo tanto, pueden ser aplicables en áreas urbanas, minimizando los costos de transporte

- La aplicación a pequeña escala permite la descentralización del tratamiento, haciendo que el tratamiento del agua residual doméstica sea menos dependiente de la extensión de las redes de alcantarillado

- El lodo producido en exceso es poco, bien estabilizado y fácilmente deshidratado, por lo cual, no se requiere de un posttratamiento

- Los nutrientes valiosos ( $\mathrm{N}$ y P) se conservan, lo cual da un alto potencial para el riego de cultivos.

- Un buen diseño del reactor UASB, permite el filtrado de los huevos de Helminto presentes en el afluente, lo cual es un prerequisito para el reúso del agua en la agricultura

Limitaciones

- El tratamiento anaerobio es un tratamiento parcial, requiriendo de un post-tratamiento para lograr los criterios de descarga o reúso.

- $\quad \mathrm{El} \mathrm{CH}_{4}$ producido se disuelve en gran parte en el efluente (dependiendo de la concentración de DQO en el afluente). Hasta el momento no se toman medidas para prevenir que el $\mathrm{CH}_{4}$ escape a la atmósfera.

- $\quad \mathrm{El} \mathrm{CH}_{4}$ colectado por lo general no se recupera.

- Existe poca experiencia en la aplicación a gran escala con temperaturas moderadas a bajas.

- Algunos gases reducidos como el $\mathrm{H}_{2} \mathrm{~S}$, que se encuentran disueltos en el efluente pueden escapar generando malos olores.

${ }^{\text {a }}$ Comparado con el proceso de lodos activados

La mayoría de las ventajas concuerdan con las ventajas enlistadas para los reactores anaerobios industriales (Sección 16.1.1).

Durante las primeras etapas de desarrollo del tratamiento anaerobio de las aguas residuales domésticas, algunas limitaciones de los sistemas fueron ignoradas o simplemente no se tomaron en cuenta para el diseño a gran escala, debido a las limitaciones financieras. Esto, sin embargo, resultó en experiencias negativas. Actualmente, se deben evitar las emisiones de gases de efecto invernadero sin control y se deberá prohibir el que no se queme el $\mathrm{CH}_{4}$ colectado. Si por el contrario se utiliza toda la energía, y con el aumento de los precios de la energía y los bonos de $\mathrm{CO}_{2}$ transferibles (sección 16.1.1), el tratamiento anaerobio del agua residual doméstica puede llegar a ser una inversión asequible para muchos países en desarrollo. Para la mayoría de las limitaciones listadas, se encuentran disponibles algunas soluciones técnicas, o al menos en desarrollo; por ejemplo, la recuperación de metano del efluente parece factible utilizando aire, el cual es enviado subsecuentemente hacia la flama o hacia un horno para la quema del aire y captura de $\mathrm{CH}_{4}$. Con todas las limitaciones consideradas, el tratamiento anaerobio de las aguas residuales domésticas tiene un gran potencial para resolver los grandes problemas relacionados con el agua residual en países en desarrollo.

Se puede observar la simplicidad del sistema en la Figura 16.24, en la cual se comparan las unidades funcionales de un proceso de lodos activados con aquellas presentes en un sistema anaerobio de alta tasa.

Un reactor UASB de un solo paso, comprende las siguientes 4 unidades funcionales:

1 .) Clarificador primario: remoción/acumulación de los sólidos suspendidos del afluente no biodegradables

2) Reactores biológicos (tratamiento secundario): Remoción de compuestos orgánicos biodegradables por medio de la conversión a metano. 
A

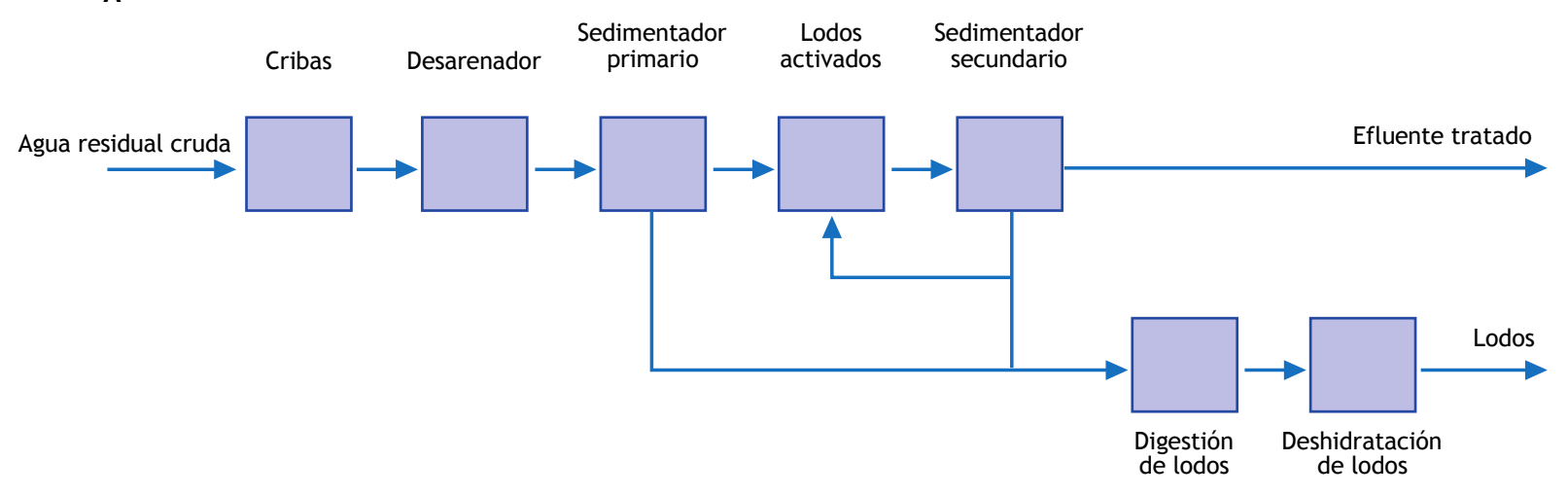

B

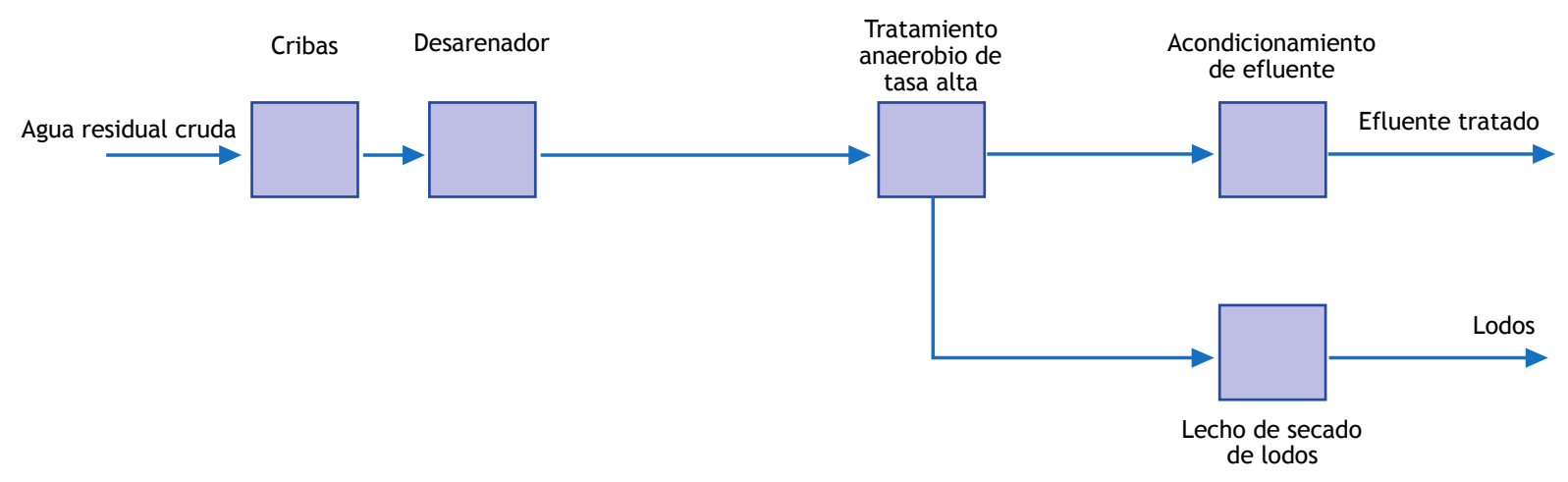

Figura 16.24 Unidades funcionales de una planta de tratamiento de aguas residuales, comparando las tecnologías de lodos activados (A) $y \operatorname{UASB}(B)$

3 Clarificador secundario: clarificación del efluente tratado en la zona de sedimentación ubicada en la parte superior del reactor UASB.

4) Digestor de lodos: estabilización (digestión) y mejoramiento de las características de deshidratación del lodo retenido.

Obviamente, los principales sistemas, es decir, tanques de bombeo, bombas si no se puede utilizar la gravedad, cribado y desarenado, son necesarios para cualquier sistema de tratamiento compacto. El tratamiento anaerobio de aguas residuales generalmente requiere de cribas finas, $<8-10 \mathrm{~mm}$ de distancia libre entre las barras, después del cribado grueso para minimizar los problemas operacionales, tales como la obstrucción de la tubería del afluente. En la mayoría de los casos, el cribado fino es la parte más cara del sistema de tratamiento. El lodo del reactor de tratamiento anaerobio de agua residual doméstica, es bastante estable debido a los largos TRLs y puede ser secado utilizando lechos de secado de lodos. De los lechos de secado de lodos no se perciben olores.
De acuerdo a la Figura 16.22, el diseño de un reactor UASB para el tratamiento de agua residual doméstica es relativamente simple debido a que sólo resultan de importancia los criterios hidráulicos. El tamaño volumétrico del reactor UASB, alimentado con un agua residual doméstica moderada con $500 \mathrm{mgDQO} / \mathrm{l}$, se puede calcular utilizando la Ec.16.49, aplicando un TRH de alrededor de $8 \mathrm{~h}$. Considerando una altura de $5 \mathrm{~m}$, el área requerida puede ser estimada de manera aproximada.

Los aspectos más críticos del diseño se muestran en la Figura 16.25 y se encuentran bien explicados por van Haandel y Lettinga (1994) y von Sperling y Chernicharo (2005). En la Tabla 16.17 se proporcionan algunos números clave con base en los diferentes reactores instalados a gran escala en América Latina. 


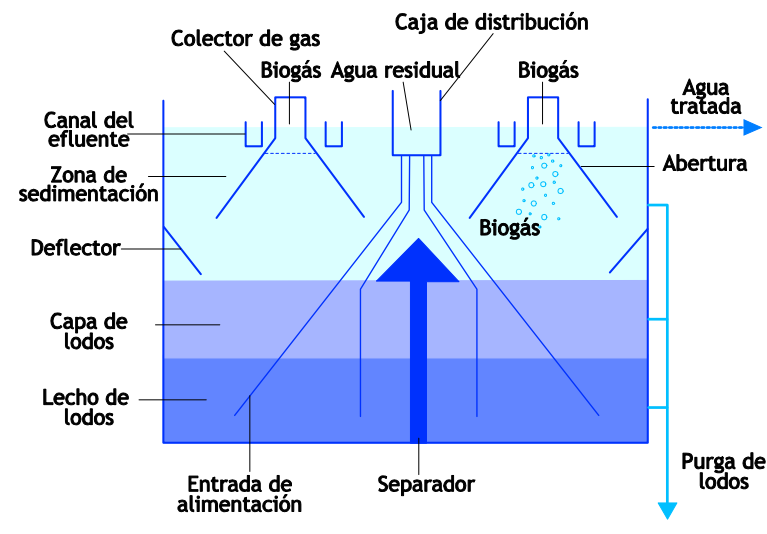

Figura 16.25 Representación esquemática de un reactor UASB para el tratamiento de agua residual doméstica. Se indican los aspectos más importantes del diseño

Tabla 16.17 Algunos criterios de diseño de reactores UASB tratando aguas residuales en países tropicales

\begin{tabular}{|c|c|}
\hline Parámetro & Valor \\
\hline TRH promedio mínimo & $4 \mathrm{~h}$ \\
\hline Altura & $4-5 \mathrm{~m}$ \\
\hline Puntos de alimentación & 1 alimentación por cada 1 a $4 \mathrm{~m}^{2}$ \\
\hline $\begin{array}{l}\text { Distribución de la } \\
\text { alimentación }\end{array}$ & $\begin{array}{l}\text { Cada tubería de alimentación de un } \\
\text { compartimento separado }\end{array}$ \\
\hline $\begin{array}{l}\text { Presión estática en la } \\
\text { caja de alimentación }\end{array}$ & Por arriba de $50 \mathrm{~cm}$ \\
\hline $\begin{array}{l}\text { Velocidad de flujo } \\
\text { ascendente en la } \\
\text { abertura }\end{array}$ & $\begin{array}{l}\text { Promedio diario } 4 \mathrm{~m} / \mathrm{h} \\
\text { Durante } 2-4 \mathrm{hrs}, 8 \mathrm{~m} / \mathrm{h}\end{array}$ \\
\hline $\begin{array}{l}\text { Velocidad de flujo } \\
\text { ascendente }\end{array}$ & $0.5-0.7 \mathrm{~m} / \mathrm{h}$ \\
\hline
\end{tabular}

Aunque el agua residual doméstica es un tipo de aguas residuales diluidas, también se caracteriza por ser un tipo de agua residual compleja, con un contenido relativamente alto de sólidos suspendidos, es decir, una relación baja de $\mathrm{DQO}_{\text {soluble }} / \mathrm{DQO}_{\text {total }} \mathrm{y}$ temperatura baja. Los sólidos suspendidos pueden representar de un 50$65 \%$ de la DQO total. Por lo tanto, la conversión total de DQO se encuentra limitada en gran parte por la hidrólisis del material particulado.

Particularmente cuando la temperatura del agua residual doméstica baja hasta $<20^{\circ} \mathrm{C}$, la capacidad de conversión biológica determinará la remoción total de DQO en lugar de las condiciones hidráulicas prevalecientes. De hecho, debido a las bajas temperaturas y las altas relaciones de SST/DQO, el intervalo en el cual el TRH $(\Theta)$ determina el tamaño volumétrico del reactor UASB, $V_{r}=\Theta \cdot Q$ (Ec. 16.49), es distintivamente más pequeño que el intervalo indicado en la Figura 16.20. Cuando la temperatura disminuye y se empieza a acumular el lodo no digerido en el lecho de lodos, la capacidad hidrolítica y metanogénica del lodo disminuirá gradualmente, deteriorando tanto la remoción de la DQO soluble como particulada, y eventualmente ocasionará el fallo del reactor.

Aparentemente, el principal criterio de diseño, inclusive con aguas residuales domésticas diluidas, es el tiempo de retención de sólidos (TRS), el cual deberá estar por encima de un valor mínimo con el objeto de mantener la capacidad de conversión metanogénica del lodo. Con aguas residuales domésticas bajo condiciones tropicales, DQO $<1,000 \mathrm{mg} / 1$ y $\mathrm{T}>20^{\circ} \mathrm{C}$, siempre se logrará esta condición. El TRS imperante dependerá de varias características del agua residual, tales como:

- la temperatura del agua residual.

- la concentración de los sólidos suspendidos del afluente.

- la tasa de digestión de sólidos en el reactor.

- la capacidad filtrante del lecho de lodos, la cual está determinada por las velocidades de flujo ascendente aplicadas y las características del lodo.

- el crecimiento y decaimiento del nuevo lodo.

- la retención del lodo en el sedimentador, determinada por las velocidades del líquido aplicado.

- la remoción de los lodos en exceso.

El TRS puede calcularse utilizando la Ec.16.19,

$$
T R S=\frac{X_{\text {reactor }} \cdot V_{\text {reactor }}}{Q_{\text {effl }} \cdot X_{\text {effl }}+Q_{\text {lodo }}-\text { exceso } \cdot \text { Xlodo }- \text { exceso }}
$$
donde:

$\mathrm{X}$ concentración de la biomasa disponible $\left(\mathrm{kg} / \mathrm{m}^{3}\right)$

$\mathrm{V} \quad$ volumen del reactor $\left(\mathrm{m}^{3}\right)$

Q flujo $\left(\mathrm{m}^{3} / \mathrm{d}\right)$

Como una regla de oro, el TRS mínimo deberá ser siempre 3 veces mayor al tiempo de duplicación $\left(\mathrm{T}_{\mathrm{d}}\right)$ de la biomasa, responsable de la etapa limitante de la velocidad. Con aguas residuales domésticas bajo condiciones tropicales, éstos son los metanógenos, con un valor estimado de $\mathrm{T}_{\mathrm{d}}$ a $25^{\circ} \mathrm{C}$ de alrededor de 10 días. Por lo tanto, los TRSs de los sistemas de tratamiento de aguas residuales a gran escala nunca deberán ser menores a 30 días. El impacto de la temperatura en el TRS requerido en el reactor UASB se muestra en la Figura 16.26 . 


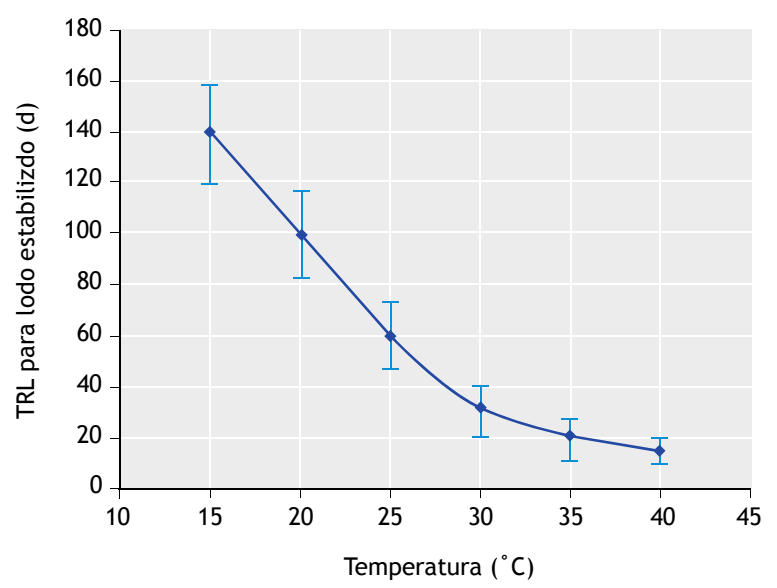

Figura 16.26 TRS requerido para el tratamiento de agua residual doméstica como una función de la temperatura

Considerando la importancia del TRS, resulta claro que el diseño de los reactores UASB convencionales para aguas residuales municipales necesita ser reconsiderado cuando la temperatura desciende y la concentración de DQO excede los 1,000 mg/l. En muchos países con clima árido y con un abastecimiento limitado de agua, las concentraciones del agua residual varían entre 1,000 y 2,500 mgDQO/1, por ejemplo en el Medio Oriente, en el norte de África, la península Arábica, etc. Además, las temperaturas en el Medio Oriente y en el Norte de África se caracterizan por inviernos fríos, particularmente en las áreas montañosas.

Experiencias recientes en Jordania y Palestina, muestran concentraciones de DQO en el agua residual municipal que alcanzan los 2,500 $\mathrm{mg} \mathrm{DQO} / \mathrm{l}$ a una relación de SST/DQO de 0.6 (Mahmoud et al., 2003), mientras que las temperaturas en invierno descienden hasta $15^{\circ} \mathrm{C}$. Utilizando el diseño convencional del reactor UASB, el TRH debe ser incrementado alcanzando valores de 20-24 horas (Hallalsheh, 2002). Esto obviamente, afectará la hidrodinámica del sistema requiriendo cambios en la distribución del afluente para prevenir cortos circuitos. Alternativamente, las altas cargas de sólidos suspendidos pueden ser solucionadas en unidades separadas al reactor, tales como un clarificador primario o el mejoramiento de la remoción de sólidos en los filtros de flujo ascendente, acoplados con un digestor de lodos (Elmitwalli, 2000). Un enfoque novedoso es el unir el reactor UASB a un digestor con intercambio de lodos (Mahmoud, 2002; Mahmoud et al., 2004). Con este último sistema, los sólidos acumulados serán digeridos a altas temperaturas, mientras que, la actividad metanogénica en el reactor aumentará debido a un flujo de recirculación de lodos digeridos.

Actualmente, se ha puesto en marcha el primer reactor a gran escala en la región del Medio Oriente en Fayoum, al sur de Cairo, Egipto. El diseño se basa en el enfoque convencional considerando la relativamente alta carga del agua residual, dando como resultado de alguna manera un alto TRH con un promedio de $12 \mathrm{~h}$. Pruebas a escala piloto en Amman, muestran la viabilidad del sistema como un método ideal de pre-tratamiento económico para disminuir la carga de DQO, mientras se genera energía para un post-tratamiento. En la Tabla 16.18 se enlistan brevemente los resultados más importantes (Hallalsheh et al., 2005).

Aunque las perspectivas de la aplicación a gran escala en Amman resultan muy prometedoras (Tabla 16.18), recientemente se tomaron algunas decisiones para cambiar el sistema de lagunas existente por un sistema moderno de lodos activados. Con respecto a la sustentabilidad en el tratamiento de aguas residuales domésticas, ésta se considera una oportunidad desaprovechada. Particularmente, debido a que las aguas residuales municipales más concentradas son de hecho ideales para el pre-tratamiento anaerobio. La energía recuperada puede entonces ser utilizada beneficiosamente en el sitio para un tratamiento posterior, hasta cumplir con los estándares de descarga o

Tabla 16.18 Pruebas realizadas con reactores UASB a escala piloto en Amman - Zarqa, laguna de estabilización en 'Khirbet As Samra', Jordan

\begin{tabular}{|c|c|c|}
\hline \multicolumn{2}{|c|}{ Características promedio del afluente } & Funcionamiento del tratamiento (incluyendo la post-clarificación) \\
\hline Flujo & $180,000 \mathrm{~m}^{3} / \mathrm{d}$ & por arriba del $80 \%$ \\
\hline DQO & $1,500 \mathrm{mg} / 1$ & por arriba del $85 \%$ \\
\hline DBO & $500-700 \mathrm{mg} / 1$ & por arriba del $80 \%$ \\
\hline SST & $600-700 \mathrm{mg} / \mathrm{l}$ & Patógenos: negativo \\
\hline $\mathrm{NH}_{4}^{+}-\mathrm{N}$ & 70-130 mg/1 & Producción de $\mathrm{CH}_{4}: \quad 0.15 \mathrm{Nm}^{3} \mathrm{CH}_{4} / \mathrm{kgDQO}_{\text {removida }}$ \\
\hline NTK & $90-200 \mathrm{mg} / 1$ & \multirow{3}{*}{$\begin{array}{l}\text { Producción potencial de } \mathrm{CH}_{4}: 27,000 \mathrm{~m}^{3} / \mathrm{d} \text {, equivalente a una fuente de } \\
\text { poder potencial de } \approx 5 \mathrm{MW} \text { (suponiendo una eficiencia del } 40 \% \text { para } \\
\text { un sistema combinado de energía y calor }(\mathrm{CHP}) \text { ). }\end{array}$} \\
\hline$P_{\text {tot }}$ & $10-40 \mathrm{mg} / 1$ & \\
\hline $\mathrm{T}$ & $16-28^{\circ} \mathrm{C}$ & \\
\hline
\end{tabular}


reúso. Cualquier exceso de energía puede ser utilizada como una fuente de poder para, por ejemplo, bombas de irrigación o para asentamientos en los alrededores de la planta.

Considerando la reciente preocupación con respecto al consumo de combustibles fósiles, el tratamiento anaerobio de aguas residuales domésticas ofrece una alternativa factible para el tratamiento de grandes flujos de aguas residuales domésticas y municipales en varias partes del mundo. En vista de la problemática actual de los gases de efecto invernadero, la recuperación de todo el $\mathrm{CH}_{4}$ producido deberá ser una parte intrínseca en el diseño de la planta de tratamiento. Debido a su compacidad, los sistemas de tratamiento anaerobio de aguas residuales de alta tasa también pueden ser aplicados en áreas urbanas. Esto último generará una reducción de costos enorme en la construcción de redes de alcantarillado, estaciones de bombeo y redes de transporte. Debe de observarse que únicamente el 35\% de las aguas residuales municipales producidas en Asia son tratadas, mientras que en América Latina este valor es de tan solo el 15\% (WHO/UNICEF 2000). En África, las aguas residuales generadas son difícilmente colectadas y su tratamiento, con excepción de la parte del Mediterráneo y el Sur de África, casi no se realiza. Con un aumento en el entendimiento básico del proceso anaerobio y el incremento de las experiencias a gran escala, el tratamiento anaerobio se convertirá sin duda en uno de los principales métodos para el tratamiento de corrientes de aguas residuales contaminadas orgánicamente.

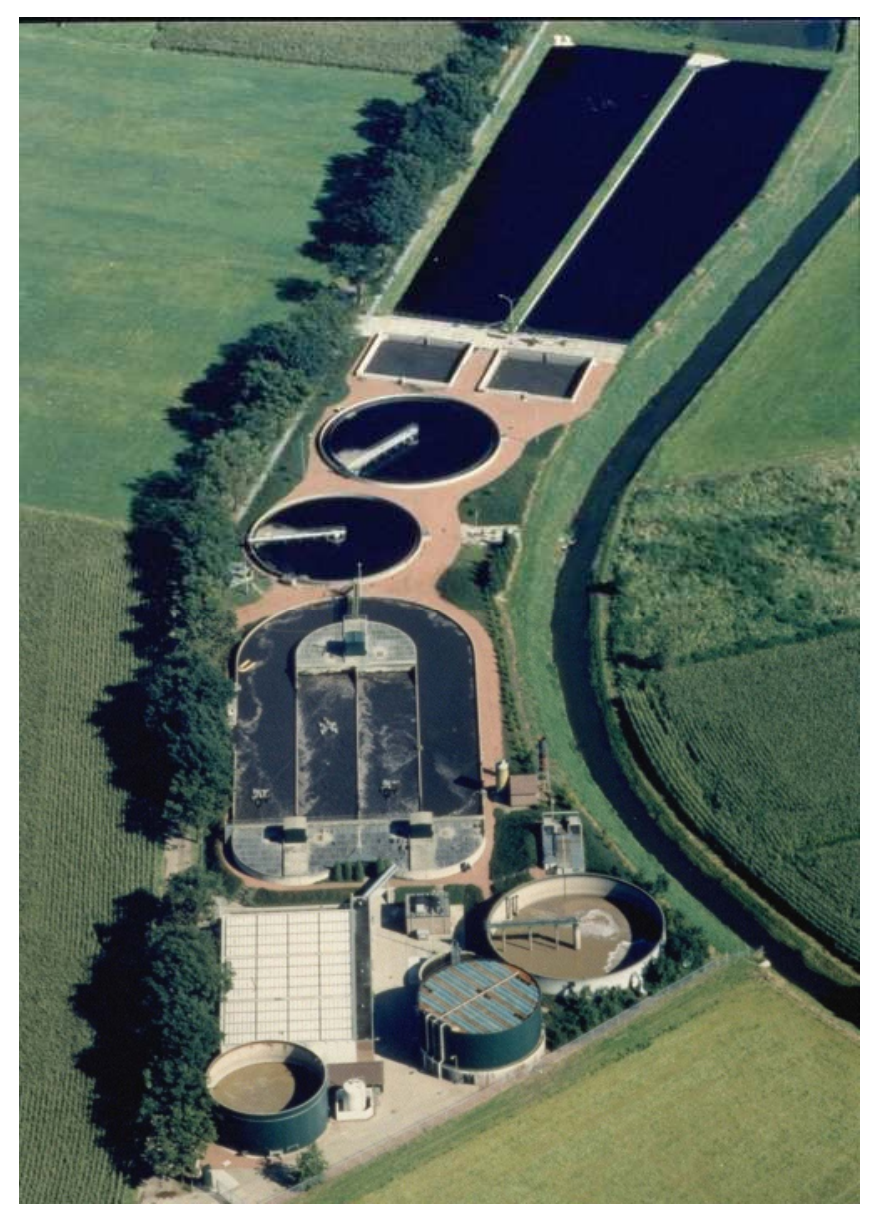

Aplicación a gran escala de la tecnología UASB: planta de tratamiento de aguas residuales de la industria cervecera de Bavariaen Lieshout, Holanda. El reactor UASB se encuentra en frente del Carrusel (Imágen: J.B. van Lierpor cortesía de Bavaria N.V.) 


\section{REFERENCIAS}

Alves M.M., Vieira J.A.M., Álvares Pereira R.M., Pereira M.A. and Mota M. (2001) Effects of lipids and oleic acid on biomass development in anaerobic fixed-bed reactors. Part II: Oleic acid toxicity and biodegradability. Wat. Res. 35(1), 264-270.

Banik G.C. and Dague R.R. (1997) ASBR treatment of low strength industrial wastewater at psychrophilic temperatures. Wat. Sci. Tech. 36(2-3), 337-344.

Batstone D.J. Keller J., Angelidaki I., Kalyuzhnyi S.V., Pavlostathis S.G., Rozzi A., Sanders W.T.M., Siegrist H., Vavilin V.A. (2002) The IWA Anaerobic digestion Model No 1 (ADM1). IWA Publishing, 2002. (Scientific and Technical Report , 13). - ISBN 1900222787. - p. 77

Beeftink H. H. and Staugard (1986) Structure and dynamics of anaerobic bacterial aggregates in a gaslift reactor. Appl. Env. Micr. 52, 1139-1146.

Canfield D.E. and Des Marais D.J. (1991) Aerobic sulfate reduction in microbial mats. Science (2515000), 1471-1473.

Chandler J.A., Jewell W.J., Gossett J.M., van Soest P.J. and Robertson J.B. (1980) Predicting methane fermentation biodegradability. Biotech. Bioeng. Symbosium 10, 93-107.

Colleran E., Finnegan S. and Lens P. (1995) Anaerobic treatment of sulphate-containing waste streems. Antonie van Leeuwenhoek 67, 29-46.

De Zeeuw W.J. (1982) Korrelslibbvorming bij de anaerobe zuivering van destruktieafvalwater, intern rapport, Vakgroep Waterzuivering, Landbouwhogeschool Wageningen.

De Zeeuw W.J. (1987) Granular sludge in UASBraectors, in "Granular Anaerobic Sludge, Microbiology and Technology", in proceedings of the GASMAT-workshop, Lunteren 25-27 October.

Dolfing J. (1987) Microbiological aspects of granualr methanogenic sludge. Ph.D. thesis, Agricultural University, Wageningen, The Netherlands.

Draaijer H., Maas J.A.W., Schaapman J.E. and Khan A. (1992) Performance of the 5 MLD UASB raector for sewage treatment in Kanpur, India. Wat. Sci. Tech. 25(7), 123-133.

Ehlinger F. (1994) Anaerobic biological fluidized beds: Operating experiences in France. In proceedings of $7^{\text {th }}$ International symposium on anaerobic digestion, Cape Town, January 23-27.
Elmitwalli T. A. (2000) Anaerobic Treatment of Domestic Sewage at Low Temperature. Wageningen University.

Elmitwalli T. A., Sklyar V., Zeeman G., Lettinga G., (2002) Low temperature pre-treatment of domestic sewage in an anaerobic hybrid or an anaerobic filter reactor. Biores. Tech. 82, 233-239.

Fang H.H.P., Chui H.K. and Li Y.Y. (1994) Microbial structure and activity of UASB granules treating different wastewaters. Wat. Sci. Tech. 30(12), 87-96.

Fitz R.M., Cypionka H. (1990) Formation of thiosulfate and trithionate during sulfite reduction by washed cells of Desulfovibrio desulfuricans. Arch. Microbiol. 154, 400-406

Fründ C. and Cohen Y. (1992) Diurnal cycles of sulfate reduction under oxic conditions in cyanobacterial mats. Appl. Environ. Microbiol. 58, 70-77

Grotenhuis J.T.C. (1992) Structure and stability of methanogenic granular sludge, proefschrift, Wageingen.

Gujer W., and Zehnder A.J.B. (1983) Conversion processes in anaerobic digestion. Wat. Sci.Techn. 15(8/9), 127-167.

Halalsheh M., Sawajneh Z., Zu'bi M., Zeeman G., Lier J., Fayyad M. and lettinga G. (2005) Treatment of strong domestic sewage in a $96 \mathrm{~m}^{3}$ UASB reactor operated at ambient temperatures: two-stage versus single-stage reactor. Biores. Tech. 96, 577-585.

Heijnen J.J. (1983) Anaerobic wastewater treatment. Proceedings of the European symbosium on anaerobic wastewater treatment, Noordwijkerhout, November, 23-25 .

Heijnen J.J. (1988) Reprints Verfahrenstechnik Abwassereiningung, GVC-Diskussionstagung Large scale anaerobic-aerobic treatment of complex industrila wastewater using immobilized biomass. Baden Baden, Oktober, 17-19.

Heppner B., Zellner G. and Diekmann, H. (1992) Startup operation of a propionate-degrading fluidized-bed reactor, Appl. Microbiol. and Biotechnol. 36, 810-16.

Holst T.C., Truc A. and Pujol R. (1997) Anaerobic fluidised beds: ten years of industrial experience. Wat. Sci. Tech. 36(6-7), 415-422.

Hulshoff Pol L.W. and Lettinga G. (1986) Advanced reactor design, opeartion and economy. Wat. Sci. Tech. 18(12), 99-108.

Hulshoff Pol L.W., de Zeeuw W.J. Velzeboer C.T.M. and Lettinga G. (1983) Granulation in UASB-reactors. Wat. Sci. Tech. 15(8/9), 291-304. 
Hulshoff Pol L.W., Heijnekamp K. and Lettinga G. (1987) The selection pressure as driving force behind the granulation of anaerobic sludge. In proceedings of the Gasmat-Workshop, Lunteren, Oct. 25-27.

Hulshoff Pol L.W., de Castro Lopes S.I., Lettinga G. and Lens P.N.L. (2004) Anaerobic Sludge Granulation. Wat. Res. 38(6), 1376-1389.

Jeison D. and Van Lier J.B. (2006) Cake layer formation in anaerobic submerged membrane bioreactors (AnSMBR) for wastewater treatment. J. Memb. Scien. 284, 227-236.

Jewell W. J. (1994) Resorce Recovery Wastewater treatment. American Sci. 82, 366-375.

Kleerebezem R., Hulshoff Pol L.W. and Lettinga G. (1999b) Anaerobic degradation of phthalate isomers by methanogenic consortia. Appl. Env. Micr. 65(3), 1152.

Kleerebezem R., Hulshoff Pol L.W. and Lettinga G.(1999a) The role of benzoate in anaerobic degradation in terephthalate. Appl. Env. Micr. 65(3), 1161-1167.

Lettinga G. and Hulshoff Pol L. W. (1991) UASB process design for various types of wastewater. Wat. Sci. Tech. 24(8), 87-107.

Lettinga G., Sar van der J. and Ben van der J. (1976) Anaerobe zuivering van het afvalwater van de bietsuikerindustrie (2). H2O 9, 38-43.

Lettinga G., Velsen A. F. M. v., Hobma S. W., Zeeuw W. J. de and Klapwijk A. (1980) Use of the Upflow Sludge Blanket (USB) reactor concept for biological wastewater treatment. Biotech. Bioeng. 22, 699-734.

Lettinga G., Velsen L. van, Zeeuw W. de, and Hobma S.W. (1979) The application of anaerobic digestion to industrial pollution traetment. Proceedings $1^{\text {st }}$ Int. Symp. on anaerobic digestion. 167-186, Cardiff UK.

Lettinga G. and Hulshoff Pol L.W. (1991) UASB process design for various types of wastewater. Wat. Sci. Tech. 24(8), 87-107.

Li A. and Sutton P.M. (1981) Dorr Oliver Anitron system, Fluidized Bed technology for methane production from dairy wastes. Proceedings, Whey Products Institute Annual Meeting, April, Chicago.

Liao B.Q., Kraemer J.T. and Bagley D.M. (2006) Anaerobic membrane bioreactors: applications and research directions. Crit. Rev. in Env. Sci. Tech. 36 (6), 489-530.

Mahmoud N., Zeeman G., Gijzen H. and Lettinga G. (2003) Solids removal in upflow anaerobic reactors. Biores. Tech. 90(1), 1-9.

Mahmoud N., Zeeman G., Gijzen H. and Lettinga G. (2004) Anaerobic sewage treatment in a one-stage
UASB reactor and a combined UASB-Digester system. Wat. Res. 38(9), 2348-2358.

Mahmoud N. (2002) Anaerobic Pre-treatment of Sewage Under Low Temperature $\left(15^{\circ} \mathrm{C}\right)$ Conditions in an integrated UASB-Digester System. Wageningen University.

McCarty P.L. (1964) Anaerobic waste treatment fundamentals, Part I. Chemist. Microb. Pub. Works 95, 107.

McCarty P.L. (1982) In: (D.E. Hughes, D.A. Stafford, B.F. Weatley, W. Beader, G. Lettinga, E.J. Nuns, W. Verstraete and R.L. Wentworth, eds.) Anaerobic Digestion. Elsevier Biomedical, Amsterdam, pp. 322. McCoy, J.H. (1962) J. Appl. Bact. 25, 213-224.

McCarty P.L. (2001) The development of anaerobic treatment and its future. Wat. Sci. Tech. 44(8), 149156.

Novak J.T. and Carlson D. (1970) The kinetics of anaerobic long chain fatty acids degradation. J. Water Pollut. Control Fed. 42 (2), 1932-1943.

Oude Elferink S.J.W.H., Visser A., Hulshoff Pol L.W. and Stams A.J.M. (1994) Sulfate reduction inmethanogenic bioreactors. Fems Microbiology Reviews. 15, 119-136.

Pereira M. A., Sousa D. Z., Mota M., and Alves M. M. (2004) Mineralization of LCFA associated with anaerobic sludge: kinetics, enhancement of methanogenic activity, and effect of VFA. Biotech. Bioeng. 88 (4), 502-511.

Raskin L., Amann R.I. Poulsen L.K., Rittmann B.E. and Stahl D.A. (1995) Use of ribosomal RNA-based molecular probes for charactesrisation of compelx microbial communinties in anaerobic biofilms, L. Raskin, Univ. Illinois Dept. Civil Eng. Lab 3221 Newmark 205 N Mathews Urbana, IL 61801 USA 0273-1223. Wat. Sci. Tech. 31(1), 261-272.

Razo-Flores E., Macarie H. and Morier F. (2006) Application of biological treatment systems for chemical and petrochemical wastewaters. In: Advanced Biological Treatment Processes for Industrial Wastewaters, IWA publications, London.

Rebac S., van Lier J.B., Lens P., van Cappellen J., Vermeulen M., Stams A.J.M., Swinkels K.Th. M. and Lettinga G. (1998) Psychrophilic $\left(6-15^{\circ} \mathrm{C}\right)$ high rate anaerobic traetment of malting wastewater in a twomodule expanded granular sludge bed system. Biotech. Progress 14, 856-864.

Rinzema A. (1988) Anaerobic treatment of wastewater with high concentrations of lipids or sulfate. $\mathrm{PhD}$ thesis, Wageninegn Agricultural University, Wageningen. 
Santos H., Fareleira P., Legall J. and Xavier A.V. (1994) In vivo nuclear magnetic resonance in study of physiology of sulfate-reducing bacteria. Methods in Enzymol. 243, 543-558.

Schellinkhout A. and Osorio E. (1994) Long-term experinence with the UASB technology for sewage treatment on large scale. Paper reprints Seventh Inte. Synp. On Anaerobic Digestion, Cape Town, January 23-27.

Schroepfer G.J., Fullen W.J., Johnson A.S., Ziemke N.R. and Anderson J.J. (1955) The anaerobic contact process as applied to packinghouse wastes. Sew. and Ind. Waste 24, 61.

Seyfried C.F. (1988) Reprints Verfahrenstechnik Abwasserreinigung, GVC - Diskussionstagung, Baden, Oktober 17-19.

Tagawa T., Takahashi H., Sekiguchi Y., Ohashi A. and Harada H. (2002) Pilot-plant study on anaerobic treatment of a lipid- and protein-rich food industrial wastewater by a thermophilic multi-staged UASB reactor. Wat. Sci. Tech. 45 (10), 225-230.

Thaveesri J., Boucneu G., Gernaey K., Kaonga B. and Verstraete W. (1994) Organic and ammonia nitrogen in relation to granular slduge growth. Reprints seventh international symposium on anaerobic digestion, 54-63, Cape Town, January 23-27.

Van Haandel A.C. and Lettinga G. (1994) Anaerobic Sewage Treatment. John Wiley and Sons Ltd, England.

Van Haandel, AC. and Lettinga, G., (1994) Anaerobic Sewage Treatment. A Practical Guide for Regions with a Hot Climate. John Wiley and Sons, New York.

Van Lier J.B. (2007) Current and future trends in anaerobic digestion: diversifying from waste(water) treatment to resource oriented conversion techniques. In: Proc. of the 11th IWA-International Conference on Anaerobic Digestion, Brisbane, September 23-27.

Van Lier J.B., Boersma F., Debets M.M.W.H. and Lettinga G. (1994) High rate thermophilic wastewater treatment in compartmentalized upflow reactors. Wat. Sci. Tech. 30(12), 251-261.

Van Lier J.B., van der Zee, Tan F.P., Rebac S. and Kleerebezem R. (2001) Advances in high-rate anaerobic traetment: staging of reactor systems. Wat. Sci. Tech. 44(8), 15-25.

Vellinga S.H.J., Hack P.J.F.M. and Vlugt A.J. van der (1986). New type "high rate" anaerobic reactor, first experience on semi-technical scale with a revolutionary and high loaded anaerobic system. In: Proc. of Anaerobic Treatment, a Grown-up
Technology, Aquatech 1986, 15-19 September, Amsterdam, The Netherlands, 547-562.

Verstraete W., Beer D. de, Pena M., Lettinga G. and Lens P. (1996) Anaerobic bioprocessing of organic wastes. World J. of Microb. and Biotech. 12, 221-238.

Von Sperling M. and C. A. de Lemos Chernicharo (2005) Biological Wastewater Treatment in Warm Climate Regions. IWA Publishing, London.

Wang K. (1994) Integrated anaerobic and aerobic treatment of sewage. Ph.D. thesis, Department of Environmental Technology, Wageningen University, Wageningen.

WHO/Unicef (2000). Global water supply and sanitation assessment 2000 report. World Health Organisation, United Nations Children's Fund, Geneva, p. 80.

Widdel F. and Hansen T.A. (1992) The dissimilatory sulfate- and sulfur-reducing bacteria in the Prokaryotes, $2^{\text {nd }}$ edn. springer-Verlag, New York.

Widdel F., Rouviere P.E. and Wolfe R.S. (1988) Classification of secondary alcohol-utilizing methanogens including a new thermophilic isolate. Arch. Microbiol. 150, 477-481.

Wiegant W.M. and de Man A.W.A. (1986) Granulation of biomass inthermophilic anaerobic sludge blanket reactors traeting acidified wastewaters. Biotech. Bioeng. 28, 718-727.

Wu W.-M. (1987) Granular sludge in upflow anaerobic sludge blanket (UASB) reactors and ist properties. Water Treat. 2, 148-157.

Wu W.-M., Hickey R.F. and Zeikus J.G. (1991) Characterisation of metabolic performance of methanogenic granules treating brewrey wastewater: Role of sulfate-reducing bacteria. Appl. Env. Micr. 57, 3438-3449.

Wu W-M., Jain M.K., Conway de Macario E., Thiele J.H. and Zeikus J.G. (1992) Microbial composition and characterisation of prevalent methanogens and acetogens isolated from syntrophic methanogenic granules. Appl. Microbiol. Biotechnol. 38, 282-290.

Young J.C. (1991) Factors affecting the design and performance of anaerobic filters. Wat. Sci. Tech. 24(8), 133-156.

Young J.C. and McCarty P.L. (1969) The anaerobic filter for waste treatment. J. Water Pollut. Control Fed. 41, 160-173.

Zeeman G., Sanders W.T.M., Wang K.Y. and Lettinga G. (1996) Anaerobic treatment of complex wastewater and waste activated sludge- application of an upflow anaerobic removal (UASR) reactor for the removal and pre-hydrolysis of suspended COD. 
IAWQ-NVA conference for 'Advanced wastewater treatment', Amsterdam, 23-25.

Zeeman G. and Lettinga G. (1999) The role of anaerobic digestion in closing the water and nutrient cycle at community level. Wat. Sci. Tech 39 (5), 187-194.

Zellner G. and Neudörfer F. (1995) Stability and metabolic versatility of a propionate-degrading biofilm operating in an anaerobic fluidised bed reactor. J. Ferment. Bioeng. 80(4), 389-393.

Zoutberg G.R. and Frankin R. (1996) Anaerobic treatment of chemical and brewery waste water with a new type of anaerobic reactor, the Biobed ${ }^{\circledR}$ EGSB reactor. Wat. Sci. Tech. 34(5-6), 375-381.

\section{NOMENCLATURA}

\begin{tabular}{|c|c|c|}
\hline Símbolo & Descripción & Unidades \\
\hline$A$ & Área de la sección transversal del reactor & $\mathrm{m}^{2}$ \\
\hline$A_{\min }$ & Área superficial mínima & $\mathrm{m}^{2}$ \\
\hline$E_{f f-m e t h}$ & Porcentaje de DQO en $\mathrm{kg} / \mathrm{m}^{3}$ convertida a $\mathrm{CH}_{4}$ & $\%$ \\
\hline$f_{c}$ & Factor de contacto, entre 0 y 1 & \\
\hline$F_{m e t h-b i o g a s}$ & Fracción de $\mathrm{CH}_{4}$ en el biogás, generalmente entre 0.6 y 0.9 & \\
\hline$H$ & Altura del reactor & $\mathrm{m}$ \\
\hline$K_{s}$ & Constante media de saturación de Monod & $\mathrm{mgDQO} / 1$ \\
\hline$Q_{i n f}$ & Velocidad de flujo del afluente & $\mathrm{m}^{3} / \mathrm{h}$ \\
\hline$r_{v}$ & Velocidad de carga orgánica & $\mathrm{kgDQO} / \mathrm{m}^{3} \cdot \mathrm{d}$ \\
\hline$T$ & Temperatura & ${ }^{\circ} \mathrm{C}$ \\
\hline$T_{d}$ & Tiempo de duplicación de la biomasa & $\mathrm{d}$ \\
\hline$V$ & Volumen del reactor & $\mathrm{m}^{3}$ \\
\hline$V_{\text {biogas }}$ & Velocidad ascendente del biogás & $\mathrm{m} / \mathrm{h}$ \\
\hline$V_{c r i t}$ & $\begin{array}{l}\text { Nivel de corte para el mínimo volumen requerido del re } \\
\text { limitaciones hidráulicas }\end{array}$ & $\mathrm{m} / \mathrm{h}$ \\
\hline$V_{\text {reactor }}$ & Volumen del reactor & $\mathrm{m}^{3}$ \\
\hline$V_{u p w}$ & Velocidad ascendente del líquido & $\mathrm{m} / \mathrm{h}$ \\
\hline$V_{u p w, \max }$ & Máxima velocidad ascendente permitida del líquido & $\mathrm{m} / \mathrm{h}$ \\
\hline$X$ & Cantidad de biomasa acumulada & $\mathrm{kgSSV} / \mathrm{m}^{3}$ reactor \\
\hline$X_{\text {reactor }}$ & Concentración de la biomasa disponible en el reactor & $\mathrm{kg} / \mathrm{m}^{3}$ \\
\hline$\Delta G^{\circ \prime}$ & Cambio de energía libre de Gibbs & $\mathrm{kJ} / \mathrm{mol}$ \\
\hline
\end{tabular}




\begin{tabular}{|c|c|}
\hline Abreviación & Descripción \\
\hline BA & Bacterias acetogénicas \\
\hline $\mathrm{ABR}$ & Reactor anaerobio de deflectores \\
\hline $\mathrm{ACP}$ & Proceso de contacto anaerobio \\
\hline ADM1 & Modelo de digestión anaerobia \\
\hline $\mathrm{AF}$ & Filtro anaerobio \\
\hline AMBR & Bioreactor anaerobio de membrana \\
\hline AnWT & Tratamiento anaerobio del agua residual \\
\hline ASBR & Reactor anaerobio de lecho de lodos \\
\hline ASBR & Reactor anaerobio secuencial en lote \\
\hline ASM1 & Modelo de lodos activados no.1 \\
\hline BSRA & Bacterias sulfato reductoras oxidantes de ácido acético \\
\hline CHP & Potencia combinada de calor y energía \\
\hline CSTR & Reactor en continuo de tanque agitado \\
\hline EGSB & Lecho de lodos granular expandido \\
\hline EPS & Sustancias poliméricas extracelulares \\
\hline BSRAG & Bacterias sulfato reductoras oxidantes de ácidos grasos \\
\hline FB & Reactor de lecho fluidizado \\
\hline GLSS & Sistema de separación gas-líquido-sólido \\
\hline $\mathrm{AMH}$ & Arqueobacterias hidrogenotróficas metanogénicas \\
\hline TRH & Tiempo de retención hidráulico \\
\hline BSRH & Bacterias sulfato reductoras oxidantes del hidrógeno \\
\hline IC & Reactor con circulación interna \\
\hline AGCL & Ácidos grasos de cadena larga \\
\hline $\mathrm{AM}$ & Arqueobacterias metanogénicas \\
\hline BOPH & Bacterias obligadas productoras de hidrógeno \\
\hline OLR & Velocidad de carga orgánica \\
\hline PTA & Ácido tereftálico purificado \\
\hline AGCC & Ácidos grasos de cadena corta \\
\hline SMA & Actividad metanogénica específica del lodo \\
\hline BSR & Bacterias sulfato reductoras \\
\hline TRL & Tiempo de retención de lodos \\
\hline UAF & Filtro anaerobio de flujo ascendente \\
\hline UASB & Lecho de lodos anaerobio de flujo ascendente \\
\hline AGV & Ácidos grasos volátiles \\
\hline SSV & Sólidos suspendidos volátiles \\
\hline
\end{tabular}

\section{SímBOLOS}

\begin{tabular}{lll}
\hline $\begin{array}{l}\text { Símbolos Explicación } \\
\text { griegos }\end{array}$ & Unidad \\
\hline$\mu_{\max }$ & Tasa de crecimiento máximo & $1 / \mathrm{d}$ \\
$\Theta$ & Tiempo de retención hidráulico $(\mathrm{TRH})$ & $\mathrm{h}$ \\
\hline
\end{tabular}




\section{7}

\section{Modelación Matemática de Biopelículas}

\section{Eberhard Morgenroth}

\section{1 ¿QUÉ SON LAS BIOPELÍCULAS?}

Los procesos de tratamiento biológico tienen las siguientes dos condiciones en común: (i) los microorganismos activos deben de concentrarse dentro del sistema y (ii) los microorganismos deben de ser eliminados del efluente tratado antes de que el agua sea retirada del sistema. En los sistemas de lodos activados, los microorganismos crecen como flóculos suspendidos en el agua y, por lo tanto, se requiere de una separación sólido-líquido para retener la biomasa dentro del sistema (por ejemplo, utilizando un tanque de sedimentación o por medio de membranas). En los reactores de biopelícula, los microorganismos se encuentran inmovilizados formando una capa densa, la cual crece adherida a una superficie sólida. Para mantener la biomasa activa en el reactor de biopelícula no se requiere de un proceso de sedimentación. Las bacterias en suspensión pueden ser eliminadas por el flujo de agua; sin embargo, las bacterias que se encuentran en la biopelícula no son afectadas por este flujo de agua y pueden crecer en zonas en donde la fuente de alimento se encuentra de manera abundante. La formación de una biopelícula en el sistema, por lo tanto, dependerá del arrastre de la biomasa suspendida (o el tiempo de retención de sólidos). Si la tasa de arrastre de las bacterias en suspensión es mayor que la tasa de crecimiento de un grupo específico de microorganismos, entonces estos microorganismos crecerán de manera preferencial formando una biopelícula. Con tasas de arrastre pequeñas existe una menor posibilidad de que las bacterias formen una biopelícula. Una biopelícula está compuesta por bacterias atrapadas en una matriz de sustancias poliméricas extracelulares (SPE), las cuales contienen polisacáridos, proteínas, ácidos nucleicos de cadena libre y agua (Sutherland, 2001). Las SPE son consideradas básicamente como el pegamento que mantiene a la biopelícula en su lugar. Las concentraciones de biomasa activa en el interior de la biopelícula son mucho mayores en comparación con los sistemas de lodos activados. En la Figura 17.1 se muestra una imagen de la biopelícula formada en un reactor de lecho móvil.

En la Figura 17.2B se muestra un esquema con las diferentes partes que conforman una biopelícula, las cuales son: líquido en suspensión, capa límite, biopelícula y soporte de la biopelícula (acarreador). El transporte de masa del sustrato y los aceptores de 
electrones dentro de la biopelícula se basan principalmente en la difusión molecular, la cual por lo general es lenta en comparación con la eliminación del sustrato, dando como resultado la formación de gradientes de sustrato dentro de ella. .

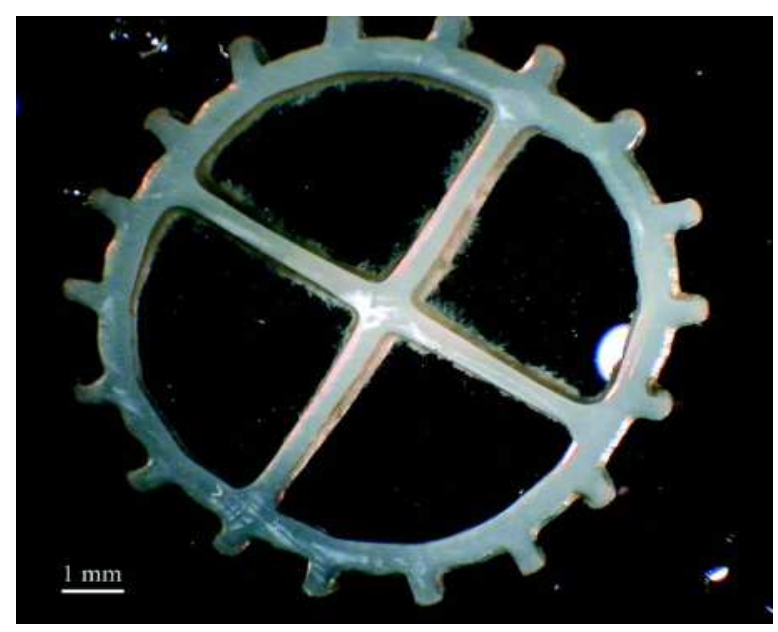

Figura 17.1 Biopelícula formada en un soporte en suspensión (Imagen: D. Brockmann)

Una consecuencia de esta formación de gradientes es que la eliminación de sustrato en la biopelícula se encuentra limitada por lo general por el transporte de masa. Esto se considera una desventaja de los reactores de biopelícula. Por otra parte, estos gradientes de sustrato también permiten el desarrollo de diferentes nichos ecológicos dentro de la biopelícula, dependiendo de las concentraciones de sustrato locales y los aceptores de electrones. Un ejemplo es la presencia de condiciones anóxicas, las cuales se pueden desarrollar dentro de la biopelícula aun cuando el líquido en suspensión se encuentra en condiciones aerobias, esto trae como consecuencia el que se lleven a cabo procesos de desnitrificación en el interior de la biopelícula. Para tener una mejor comprensión del comportamiento global de la biopelícula en el sistema, es necesario conocer la interacción que existe entre el transporte de masa y la conversión de sustrato durante el proceso.

Las biopelículas pueden ser beneficiosas, por ejemplo en el tratamiento de aguas residuales y agua potable, en la remediación de suelos y en la formación de barreras para contener la diseminación de contaminantes. Por otro lado, las biopelículas también pueden resultar perjudiciales; por ejemplo en las redes de distribución de abastecimiento de agua, en intercambiadores de calor, en la higiene dental, los implantes de biomateriales o en los cascos de naves. Las biopelículas pueden ser beneficiosas o perjudiciales debido a que (i) convierten los compuestos contenidos en el líquido, lo cual es utilizado en los tratamientos biológicos de aguas residuales o agua potable para la eliminación de compuestos indeseables, (ii) ocupan el espacio vacío y pueden interferir con el flujo del agua, lo cual en algunas ocasiones puede ser deseable (por ej. en la formación de bio-barreras) y en algunos otros casos resulta perjudicial (por ej. en intercambiadores de calor), (iii) pueden ayudar al crecimiento de microorganismos patógenos, los cuales son difíciles de eliminar o inactivar dentro de la biopelícula. Este capítulo se enfoca en describir modelos matemáticos en el transporte y conversión del sustrato en biopelículas, el desarrollo de una biopelícula y el funcionamiento en general de los reactores con biopelículas.
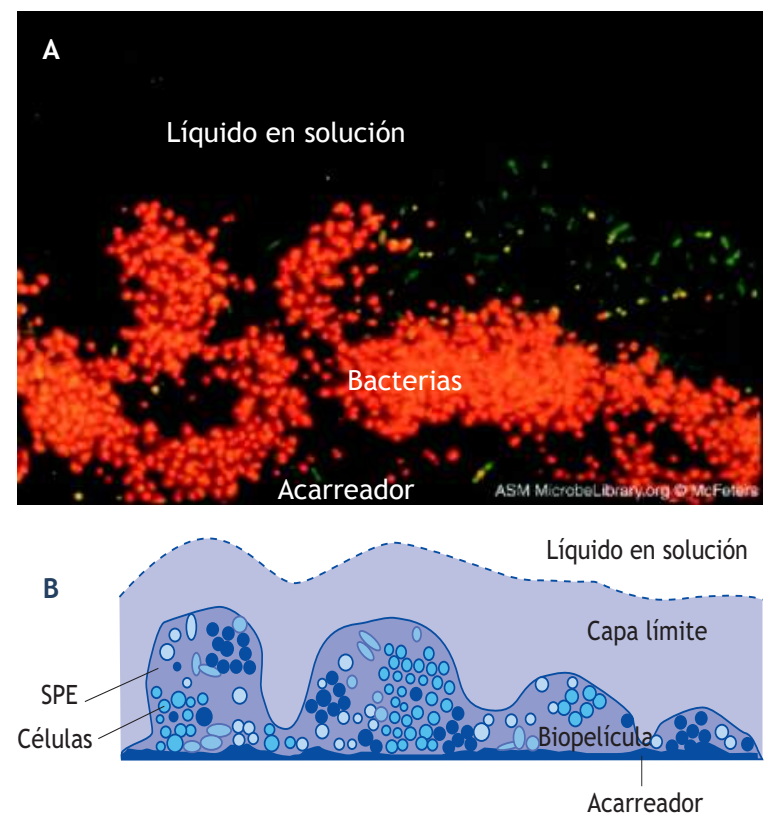

Figura 17.2 Crecimiento de la biopelícula en una imagen del canal de flujo utilizando microscopía confocal laser (A) (Imagen: Hung et al., 1995; McFeters, 2002), y una representación esquemática de los diferentes componentes de un sistema de biopelícula: líquido en suspensión, capa límite, biopelícula y acarreador (B) (adaptada de Wanner et al., 2006)

\subsection{MOTIVACIÓN PARA MODELAR BIOPELÍCULAS Y ¿CÓMO SELECCIONAR LOS MODELOS MATEMÁTICOS ADECUADOS?}

Una gran cantidad de modelos matemáticos de biopelículas se han desarrollado, los cuales varían en términos de los procesos considerados en el interior de la biopelícula, la información predicha por el modelo y el esfuerzo requerido para resolver el modelo- variando 
desde un análisis simple hasta la utilización de modelos numéricos multidimensionales complejos. Antes de tomar una decisión sobre la estrategia del modelo a utilizar es necesario definir con claridad cuál es el objetivo del modelo. Los siguientes objetivos y preguntas son relevantes para predecir el comportamiento de los reactores de biopelícula y serán resueltas en este capítulo:

- Flujo de sustrato en función de la concentración de sustrato en la fase líquida: ¿Cómo es que las limitaciones del transporte de masa y la cinética microbiana en el interior de la biopelícula influyen en las tasas de conversión de sustrato? ¿Cómo es que las limitaciones de transporte en la capa límite de transferencia de masa influyen en la disponibilidad de sustrato dentro de la biopelícula? El modelo debe proporcionar el flujo de sustrato en la biopelícula $\left(\mathrm{J}_{\mathrm{LF}}\right)$ (cuantificando la tasa promedio de transformación de sustrato en el interior de la biopelícula) en función de las concentraciones de sustrato presentes en la fase líquida $\left(\mathrm{C}_{\mathrm{B}}\right)$ (Figura 17.3A).

- Difusión multi-componente: ¿Cómo es que la disponibilidad de donadores de electrones y aceptores de electrones y la presencia local de compuestos inhibitorios influye en el proceso microbiano? El modelo debe predecir la penetración de múltiples sustratos en la biopelícula como un parámetro básico para determinar el sustrato limitante (Figura 17.3B).

- Distribución de los microorganismos: ¿Cómo es que la disponibilidad de sustrato influye en la distribución de microorganismos y cómo, a su vez, la distribución de microorganismos influye en la eliminación de sustrato? El modelo debe predecir la distribución de biomasa y las correspondientes eliminaciones de sustrato (Figura 17.3C).

- Funcionamiento global del reactor: ¿Cómo es que los flujos locales de sustrato en la biopelícula se encuentran relacionados con el funcionamiento global del reactor? El modelo debe de integrar los flujos locales de sustrato para predecir el funcionamiento global del reactor de biopelícula (Figura 17.3D).

La selección adecuada de la estrategia del modelo, requerirá de un balance del nivel de detalle que se requiere para poder alcanzar el objetivo del modelo y la complejidad con la que se quiere que éste trabaje. Por ejemplo, asumir la homogeneidad de la biopelícula en una sola dimensión, resulta en la mayoría de los casos suficiente para evaluar la oxidación de carbono. Sin embargo, para la evaluación de la competencia entre las bacterias heterótrofas y autótrofas por el sustrato y el espacio disponible, se requiere un modelo que prediga las distribuciones de biomasa sobre el espesor de la biopelícula. Se encuentran disponibles las soluciones analíticas de biopelículas unidimensionales con distribuciones homogéneas de organismos sobre el espesor de la biopelícula, que tienen una cinética de orden cero o primer orden. Asumir una cinética de Monod también requiere la aplicación de soluciones numéricas. Este capítulo presentará los conceptos básicos para los modelos junto con las estrategias analíticas necesarias para resolver los modelos de biopelículas simples o encontrar herramientas numéricas para modelos más complejos. Las soluciones numéricas de este capítulo fueron obtenidas utilizando el software AQUASIM (Reichert, 1998). Los archivos de las simulaciones se encuentran disponibles para su descarga, de tal manera que, los lectores que cuenten con la posibilidad de correr el programa AQUASIM, pueden explorar estas simulaciones por su cuenta. Los programas numéricos para resolver los modelos se encuentran cada vez más disponibles en simuladores de plantas de tratamiento de aguas residuales. Para trabajar con estos programas numéricos, es necesario tener un conocimiento sólido de los mecanismos básicos y se deberán de realizar regularmente algunos cálculos a mano utilizando soluciones analíticas para simplificar el modelo de la biopelícula y corroborar la plausibilidad de los resultados para modelos con mayor complejidad.

\subsection{ENFOQUE DEL MODELADO DE UNA BIOPELÍCULA, ASUMIENDO QUE EXISTE UN SOLO SUSTRATO LIMITANTE Y CONSIDERANDO DESPRECIABLE LA RESISTENCIA EXTERNA A LA TRANSFERENCIA DE MASA}

Las biopelículas, como se muestra en la Figura 17.2, son agregados complejos y heterogéneos. ¿Cómo es que estos agregados pueden ser descritos de manera simple en un modelo matemático? ¿Qué características son relevantes y cuáles pueden ser omitidas? Existen modelos numéricos complejos y caros, que tienen como objetivo describir y predecir la estructura espacial multidimensional heterogénea de las biopelículas, tal como se muestra en la Figura 17.2. Algunas aplicaciones de estos modelos complejos se discutirán en la sección 17.10; sin embargo, el análisis y solución detallados de estos modelos multidimensionales se encuentran fuera de los alcances del presente capítulo. El objetivo principal de este capítulo consiste en describir el efecto que tienen las limitaciones de transferencia de masa en la distribución heterogénea de los sustratos y de la biomasa 


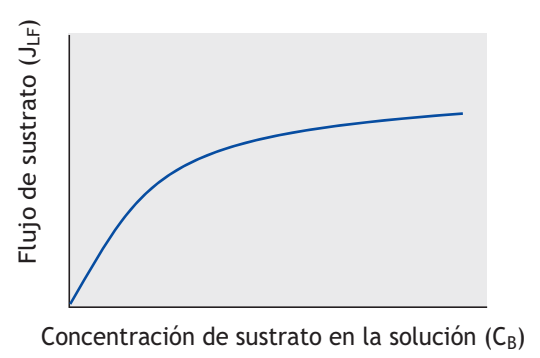

C Organismo A domina en Organismo B domina en la el fondo de la biopelícula superficie de la biopelícula

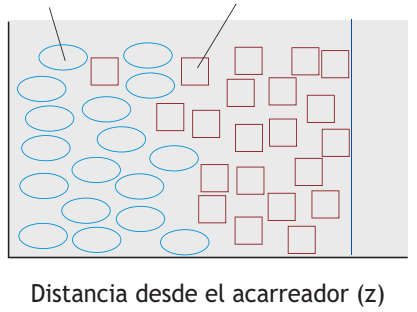

B
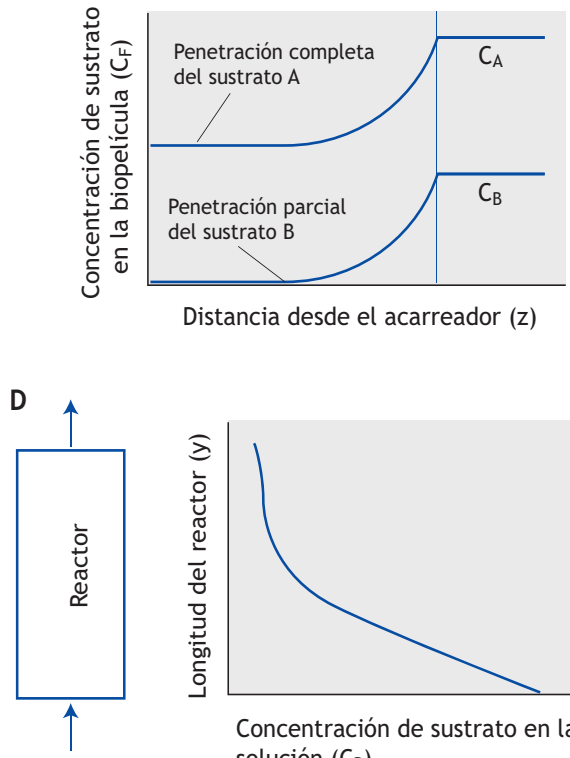

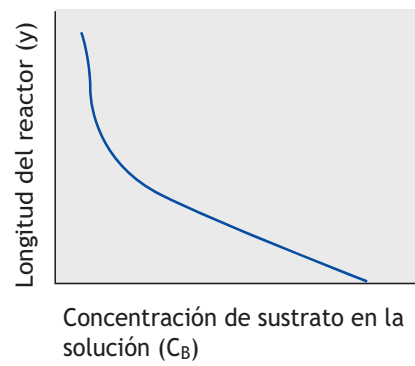

Figura 17.3 Representaciones esquemáticas de las diferentes preguntas que deben ser resueltas por el modelo matemático: (A) ¿Cómo es que el flujo de sustrato en la biopelícula depende de las concentraciones de sustrato en la fase en solución? (B) En el caso de reacciones que involucren múltiples sustratos (por ej., donador de electrones y aceptor de electrones)- ¿cuál de estos sustratos será limitante en el proceso de conversión? (C) ¿De qué manera se encontrarán distribuidos los microorganismos sobre el espesor de la biopelícula? y ¿Cómo esta distribución de la biomasa afectará el proceso de conversión? (D) ¿Cómo es que el funcionamiento global del reactor de biopelícula puede ser integrado para los flujos de sustrato locales?

en una sola dimensión. En este sentido, se asume que las velocidades del proceso, la densidad y composición de la biomasa en la biopelícula y las concentraciones del sustrato pueden ser promediadas de acuerdo al plano paralelo del material acarreador. Con estas simplificaciones supuestas, la biopelícula puede ser descrita como una estructura de una sola dimensión, con reacciones y difusión molecular en el interior de ésta y una capa de transferencia de masa límite externa, como se muestra en la Figura 17.4.

Para la mayoría de los modelos utilizados en este capítulo, se asume que la densidad de la biomasa en la biopelícula $\left(\mathrm{X}_{\mathrm{F}}\right)$ y su composición son conocidas a priori y permanecen constantes sobre el espesor de la biopelícula. Utilizando las simulaciones numéricas, la composición de la biomasa sobre el espesor de la biopelícula se puede predecir como un resultado del modelo (ver el ejemplo en la sección 17.9).

\subsubsection{Ecuaciones Básicas}

La ecuación diferencial parcial que describe la difusión molecular, la utilización del sustrato en el interior de la biopelícula, y la acumulación dinámica para un solo sustrato limitante, se encuentra dada por:

$$
\underbrace{\frac{\partial C_{F}}{\partial t}}_{\text {Acumulación }}=\underbrace{D_{F} \frac{\partial^{2} C_{F}}{\partial x^{2}}}_{\text {Difusión }}-\underbrace{r_{F}}_{\text {Reacción }}
$$

donde:

$\mathrm{C}_{\mathrm{F}} \quad$ concentración de sustrato en la biopelícula $\left(\mathrm{M} / \mathrm{L}^{3}\right)$

$\mathrm{x} \quad$ distancia desde la superficie de la biopelícula (L)

$\mathrm{t} \quad$ tiempo $(\mathrm{T})$

$\mathrm{D}_{\mathrm{F}} \quad$ coeficiente de difusión en la biopelícula $\left(\mathrm{L}^{2} / \mathrm{T}\right)$

$\mathrm{r}_{\mathrm{F}} \quad$ velocidad de conversión del sustrato por volumen de biopelícula $\left(\mathrm{r}_{\mathrm{F}}>0\right.$ para la eliminación $\mathrm{y} \mathrm{r}_{\mathrm{F}}<0$ para procesos de producción) $\left(\mathrm{M} / \mathrm{L}^{3} \mathrm{~T}\right)$

La Ec. 17.1 se basa en la segunda ley de Fick para la difusión. La derivación detallada de la Ec. 17.1 se encuentra en la NOTA de la sección 17.3.4. En la Tabla 17.1 se encuentran definidas diferentes ecuaciones de velocidad para la degradación del sustrato limitante en el interior de la biopelícula. Las soluciones analíticas para la Ec. 17.1 se encuentran disponibles únicamente para expresiones de velocidad de orden cero y primer orden y asumiendo estado estacionario. Se requieren soluciones numéricas para expresiones de velocidad más complejas. 

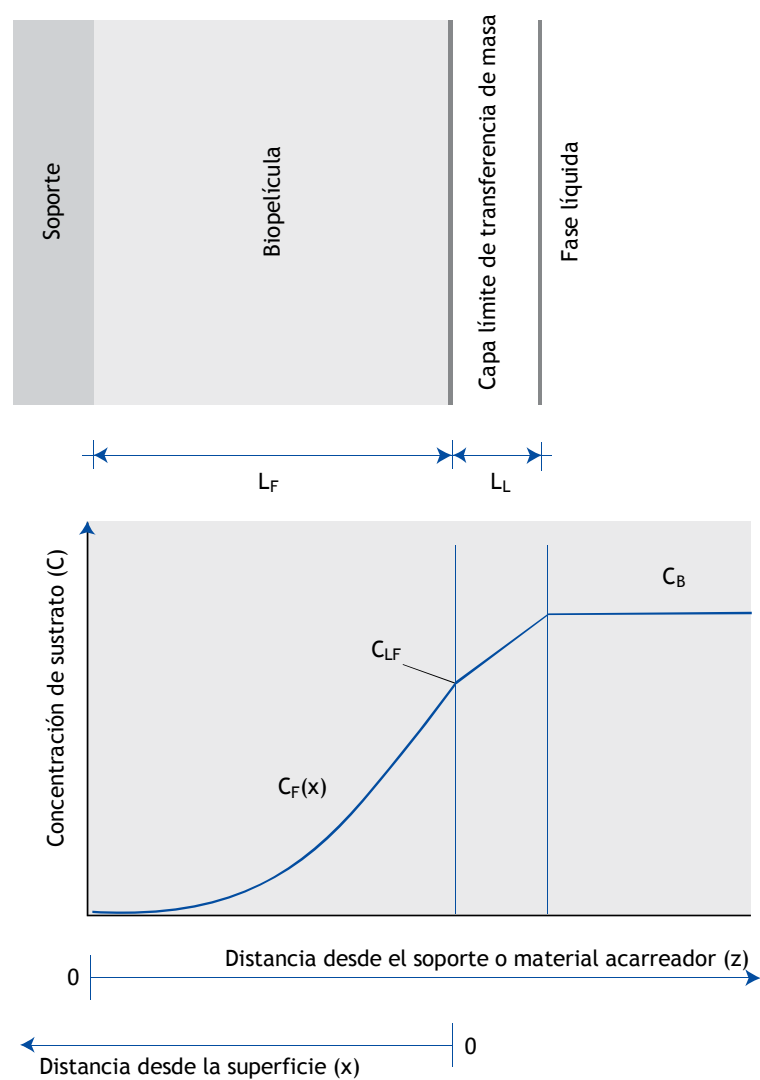

Figura 17.4 Concentración en el interior de la biopelícula, en la capa límite de concentración y en la solución. Las coordenadas espaciales pueden ser medidas desde el fondo de la biopelícula (z, típicamente utilizada para simulaciones numéricas) o a partir de la superficie de la biopelícula (x, simplifica la solución para cálculos manuales)

Observe que en la Tabla 17.1, en las constantes de orden cero ( $\mathrm{k}_{0, \mathrm{~F}}$, Ec. 17.2) y primer orden $\left(\mathrm{k}_{1, \mathrm{~F}}\right.$, Ec. 17.3), las velocidades de degradación de sustrato pueden representarse por una cinética de Monod (Ec. 17.4) como sigue:

$$
\begin{array}{ll}
k_{0, F} \approx \frac{\mu_{\max }}{Y} & \text { para } \mathrm{C}_{\mathrm{F}}>>\mathrm{K}_{\mathrm{C}} \\
k_{1, F} \approx \frac{\mu_{\max }}{Y \cdot K_{C}} & \text { para } \mathrm{C}_{\mathrm{F}}<<\mathrm{K}_{\mathrm{C}}
\end{array}
$$

La expresión general de velocidad en la Ec. 17.5 se refiere a sistemas más complejos con múltiples procesos y compuestos en el interior de la biopelícula (por ej., en la Tabla 17.11 para bacterias heterótrofas y autótrofas), con coeficientes estequiométricos $v_{\mathrm{i}, \mathrm{j}} \mathrm{y}$ velocidades de proceso $\rho_{\mathrm{j}}$, para una matriz de proceso con componentes (i) y procesos (j). El concepto de una matriz cinética y estequiométrica fueron descritos en el Capítulo 14.
Para resolver la ecuación diferencial de segundo orden (Ec. 17.1), se requieren dos constantes que pueden ser derivadas de las siguientes dos condiciones límite:

$\mathrm{BC} 1: \quad \frac{d C_{F}}{d x}=0 \quad \mathrm{ax}=\mathrm{L}_{\mathrm{F}}$

$\mathrm{BC} 2: \quad C_{F}=C_{L F} \quad \mathrm{ax}=0$

El flujo de sustrato en una determinada zona en el interior de la biopelícula $(\mathrm{J}(\mathrm{x}))$, es proporcional al gradiente de concentración en esta zona $(\mathrm{x})$ dentro de la biopelícula:

$J_{F}(x)=-D_{F} \frac{d C_{F}(x)}{d x}$

donde $\mathrm{D}_{\mathrm{F}}$ es el coeficiente de difusión del sustrato en el interior de la biopelícula. Utilizando la Ec. 17.10, se puede calcular el flujo a través de la superficie de la biopelícula $\left(\mathrm{J}_{\mathrm{LF}}\right)$ como sigue:

$J_{L F}=-D_{F} \frac{d C_{F}}{d x} \quad \mathrm{ax}=0$

Este flujo de sustrato, JLF, será utilizado de manera subsecuente en los balances de materia para el funcionamiento global del reactor.

\subsubsection{Soluciones de las ecuaciones de difusión- reacción en biopelículas para diferentes expresiones de velocidad de reacción}

17.3.2.1 Velocidad de eliminación de sustrato de primer orden en el interior de la biopelícula

Combinando la Ec. 17.1 con la expresión de velocidad de primer orden dado en la Ec. 17.3, y asumiendo estado estacionario $\left(\partial \mathrm{C}_{\mathrm{F}} / \partial \mathrm{t}=0\right)$ se obtiene la siguiente ecuación diferencial de segundo orden:

$0=D_{F} \frac{d^{2} C_{F}}{d x^{2}}-k_{l, F} X_{F} C_{F}$ 
Tabla 17.1 Expresiones de velocidad para $\mathrm{r}_{\mathrm{F}}$ en la Ec. 17.1 (M/L $\left.\mathrm{L}^{3} \mathrm{~T}\right)$, donde $\mathrm{X}_{\mathrm{F}}$ es la concentración de la biomasa activa en el interior de la biopelícula $\left(\mathrm{M} / \mathrm{L}^{3}\right), \mathrm{k}_{\mathrm{O}, \mathrm{F}}$ y $\mathrm{k}_{1, \mathrm{~F}}$ son las constantes cinéticas de orden cero y primer orden y $\mu_{\max }, \mathrm{K}_{\mathrm{c}}$, $\mathrm{Y}$ son las velocidades de crecimiento máximo, constante media de saturación y la constante de rendimiento, respectivamente. En la Ec. 17.5, $v_{i, j}$ y $\rho_{j}$ son los coeficientes estequiométricos genéricos y velocidades del proceso j, respectivamente.

\begin{tabular}{|c|c|c|}
\hline Tipo de velocidad de reacción & Expresión de velocidad & Ec. \\
\hline Orden cero & $r_{F}=k_{0, F} X_{F}$ & $(17.2)$ \\
\hline Primer orden & $r_{F}=k_{1, F} C_{F} X_{F}$ & $(17.3)$ \\
\hline \multirow{2}{*}{$\begin{array}{l}\text { Utilización de sustrato asumiendo una cinética de crecimiento de } \\
\text { Monod }\end{array}$} & $r_{F}=\underbrace{\frac{1}{Y}} \cdot \underbrace{\mu_{\max } \frac{C_{F}}{K_{C}+C_{F}} X_{F}}$ & \multirow[t]{2}{*}{ (17.4) } \\
\hline & $\begin{array}{l}\begin{array}{l}\text { Coeficiente } \\
\text { estequeometrico }\end{array} \\
(v)\end{array}$ & \\
\hline $\begin{array}{l}\text { Expresiones generales de velocidad por componente } C_{F, i} \text { que es } \\
\text { afectado por múltiples procesos }(\mathrm{j})\end{array}$ & $r_{F, i}=\sum_{j=1}^{n} v_{i, j} \rho_{j}$ & $(17.5)$ \\
\hline
\end{tabular}

La ecuación diferencial 17.12 de segundo orden puede ser resuelta considerando las dos condiciones límite (Ec. 17.8 y 17.9), resultando en una solución analítica para la concentración del sustrato en el interior de la biopelícula asumiendo una reacción de primer orden $\left(\mathrm{C}_{\mathrm{F}, 1}\right)$ de:

$$
C_{F, I}(x)=\frac{\cos \left(\frac{L_{F}-x}{L_{c r i t}}\right)}{\cos \left(\frac{L_{F}}{L_{c r i t}}\right)} C_{L F}
$$

donde $\mathrm{L}_{\text {crit }}$ es una longitud característica que se define como sigue,

$$
L_{c r i t}=\sqrt{\frac{D_{F}}{k_{l, F} X_{F}}}
$$

Las biopelículas con un espesor mucho más denso que $\mathrm{L}_{\text {crit }}$ estarán limitadas por la transferencia de masa (en algunas ocasiones conocidas como biopelículas profundas) y las biopelículas mucho más delgadas que $\mathrm{L}_{\text {crit }}$ son penetradas completamente (en algunas ocasiones conocidas como biopelículas poco profundas). Puede resultar de utilidad para el lector resolver la diferencial dada en la Ec. 17.13 por duplicado y verificar que el resultado para $\mathrm{C}_{\mathrm{F}, 1}$, de hecho, satisface tanto a la ecuación diferencial original (Ec. 17.12) como a las dos condiciones límite (Ec. 17.8 y 17.9). De acuerdo al perfil de concentración (Ec. 17.13), el flujo de sustrato en el interior de la biopelícula, asumiendo una eliminación de primer orden $\left(\mathrm{J}_{\mathrm{LF}, 1}\right)$, puede ser calculado directamente utilizando la Ec. 17.11:

$$
J_{L F, I}=\underbrace{D_{F} \frac{\tan \left(\frac{L_{F}}{L_{c r i t}}\right)}{L_{c r i t}}}_{k_{l, 4}} C_{L F}
$$

en donde los términos de la derecha de la Ec. 17.15 que no son dependientes de $C_{L F}$ pueden ser resumidos de manera global por una constante $\left(\mathrm{k}_{1, \mathrm{~A}}\right)$. Utilizando esta constante se puede observar que para cierto espesor de biopelícula el flujo de sustrato tiene una dependencia de primer orden en $\mathrm{C}_{\mathrm{LF}}$

$J_{L F, l}=k_{1, A} C_{L F}$

Se puede observar que $\mathrm{k}_{1, \mathrm{~A}}$ es constante únicamente si el espesor de la biopelícula, $\mathrm{L}_{\mathrm{F}}$, permanece constante. Para los casos en donde el espesor de la biopelícula varía, se observa que $\mathrm{k}_{1, \mathrm{~A}}$ aumentará con el aumento de $\mathrm{L}_{\mathrm{F}}$. Un parámetro que puede ser de utilidad para el cálculo de la influencia de las limitaciones del transporte de masa en el flujo de sustrato, es el factor de eficiencia $\varepsilon$. El factor de eficiencia $\varepsilon$ se define como la relación entre $\mathrm{J}_{\mathrm{LF}, 1}$ en la Ec. 17.15 y el flujo de sustrato hipotético que asume que la velocidad en el interior de la biopelícula no se reducirá por la difusión:

$\varepsilon=\frac{J_{L F, 1, \text { con difusión }}}{J_{L F, 1, \text { sin resistencia a la difusión }}}$

Asumiendo un flujo hipotético sin resistencia a la difusión $\left(=\mathrm{k}_{1, \mathrm{~F}} \mathrm{X}_{\mathrm{F}} \mathrm{LF}_{\mathrm{F}} \mathrm{C}_{\mathrm{LF}}\right)$ el valor de $\varepsilon$ puede calcularse a partir del flujo con difusión (Ec. 17.15) como: 


$$
\varepsilon=\frac{\tan \left(\frac{L_{F}}{L_{c r i t}}\right)}{\frac{L_{F}}{L_{c r i t}}}
$$

Para valores pequeños de $\mathrm{L}_{\mathrm{F}} / \mathrm{L}_{\text {crit }}(<0.4)$ la biopelícula se penetra completamente y el valor de $\varepsilon \approx 1$. Para biopelículas gruesas $\left(\mathrm{L}_{\mathrm{F}} / \mathrm{L}_{\text {crit }}>4\right)$, el valor de $\varepsilon$ en la Ec. 17.18 disminuye, la conversión del sustrato en la biopelícula se verá limitada por el transporte de masa, y se puede calcular como sigue:

$\varepsilon \approx \frac{L_{c r i t}}{L_{F}}$ para $\mathrm{LF}_{\mathrm{F}} / \mathrm{L}_{\text {crit }}>4$

Los perfiles de concentración de sustrato sobre el espesor de la biopelícula y los valores correspondientes de $\varepsilon$ se muestran en la Figura 17.5 para diferentes valores de $\mathrm{L}_{\mathrm{F}} / \mathrm{L}_{\text {crit }}$.

\section{Ejemplo 17.1: Eliminación de sustrato en la biopelícula con cinética de primer orden}

\section{Problema:}

Calcular la concentración de acetato para una biopelícula con un espesor de $400 \mu \mathrm{m}$, asumiendo que la concentración de acetato en la superficie de la biopelícula, $\mathrm{C}_{\mathrm{LF}}$, es de $3 \mathrm{mg} \mathrm{DQO} / \mathrm{l}$, con un valor de la constante de primer orden, $\mathrm{k}_{1, \mathrm{~F}}$, de $2.4 \mathrm{~m}^{3} / \mathrm{g}$ DQO.d, una densidad de biomasa de la biopelícula de 10,000 $\mathrm{g}$ $\mathrm{DQO} / \mathrm{m}^{3}$, y un coeficiente de difusión de $0.8 \times 10^{-4} \mathrm{~m}^{2} / \mathrm{d}$. Posteriormente, calcular el flujo de acetato en el interior de la biopelícula para las concentraciones de la fase en solución de 3 ó $30 \mathrm{mg}$ DQO/1. Discutir los principales



problemas identificados al momento de realizar los cálculos.

Solución:

Paso 1: Cálculo de $\mathrm{L}_{\text {crit: }}$

$$
\begin{aligned}
& L_{\text {crit }}=\sqrt{\frac{\left(0.8 \times 10^{-4} \mathrm{~m}^{2} / \mathrm{d}\right)}{\left(2.4 \mathrm{~m}^{3} / \mathrm{gDQO} . \mathrm{d}\right)\left(10.000 \mathrm{gDQO} / \mathrm{m}^{3}\right)}} \\
& =58 \mu \mathrm{m}
\end{aligned}
$$

Observe que $\mathrm{L}_{\text {crit }}$ es independiente de la concentración del sustrato en la superficie de la biopelícula.

Paso 2: Calcular $\mathrm{L}_{\mathrm{F}} / \mathrm{L}_{\text {crit: }}$ :

$\frac{L_{F}}{L_{\text {crit }}}=\frac{400 \mu m}{58 \mu m}=6.9$

Con $\mathrm{LF}_{\mathrm{F}} / \mathrm{L}_{\text {crit }}>4$ la biopelícula puede ser considerada como una biopelícula profunda que se encuentra limitada por el transporte de masa.

Paso 3: Calcular la concentración del sustrato en la base de la biopelícula, $\mathrm{C}_{\mathrm{F}}\left(\mathrm{x}=\mathrm{L}_{\mathrm{F}}\right)$, asumiendo $\mathrm{C}_{\mathrm{LF}}=3 \mathrm{mg}$ DQO/1

$C_{F}\left(x=L_{F}\right)=\frac{\overbrace{\cos (0)}^{\cos (0)=1}}{\cos (400 / 58)} \times 3 \mathrm{mg} / \mathrm{l}$
$=0.0061 \mathrm{mg} / l$

Paso 4: Calcular el flujo de sustrato correspondiente a $\mathrm{C}_{\mathrm{LF}}$ $=3 \mathrm{mg} \mathrm{DQO} / \mathrm{l}$ :

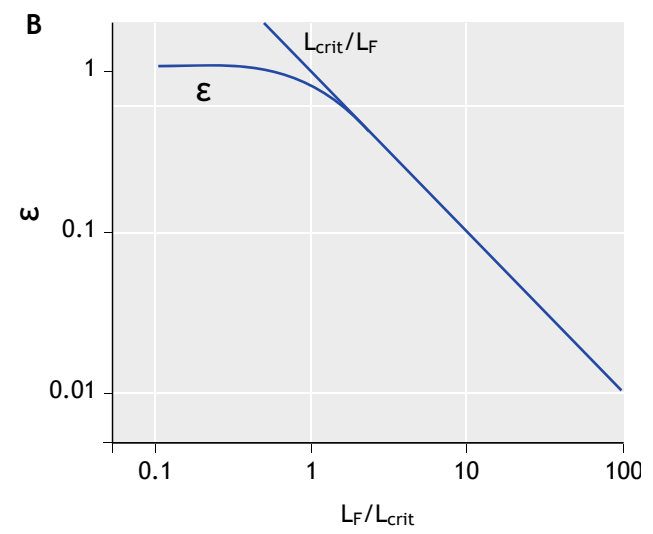

Figura 17.5 Concentraciones de sustrato $\left(C_{F} / C_{L F}\right)$ con respecto a la profundidad de la biopelícula $\left(x / L_{F}\right)$ para diferentes valores de $L_{F} / L_{c r i t}$ (números en el gráfico) asumiendo cinéticas de reacción de primer orden en el interior de la biopelícula (A). El valor de $\varepsilon$ se obtuvo de acuerdo a la Ec. 17.18 y 17.19 para un intervalo de $L_{F} / L_{c r i t}(B)$ 


$$
\begin{aligned}
& J_{L F}=0.8 \times 10-4 \mathrm{~m}^{2} / \mathrm{d} \frac{\tan (400 / 58)}{58 \times 10^{-6} \mathrm{~m}} 3 \mathrm{~g} / \mathrm{m}^{3} \\
& =4.1 \mathrm{~g} / \mathrm{m}^{2} . d
\end{aligned}
$$

El factor de eficiencia correspondiente $\varepsilon$ puede ser calculado de la Ec. (17.18) como sigue:

$$
\varepsilon=\frac{\tan \left(\frac{L_{F}}{L_{c r i t}}\right)}{\frac{L_{F}}{L_{c r i t}}}=\frac{\tan (400 / 58)}{400 / 58}=0.145
$$

Así, el flujo de sustrato en el interior de la biopelícula es $14.5 \%$ del flujo esperado si la biopelícula fuera completamente penetrada, despreciando los efectos de la limitación del transporte de masa. Observe que el valor de $\varepsilon$ es independiente de la concentración del sustrato en la superficie de la biopelícula.

Paso 5: Ahora calcular el flujo de sustrato para una concentración de sustrato en la superficie de la biopelícula de $30 \mathrm{mg} \mathrm{DQO} / 1$.

$$
\begin{aligned}
& J_{L F}=0.8 \times 10-4 \mathrm{~m}^{2} / d \frac{\tan (400 / 58)}{58 \times 10^{-6} \mathrm{~m}} 30 \mathrm{~g} / \mathrm{m}^{3} \\
& =41 \mathrm{~g} / \mathrm{m}^{2} . d
\end{aligned}
$$

Observe que el flujo calculado es exactamente 10 veces el flujo asumiendo que $\mathrm{C}_{\mathrm{LF}},=3 \mathrm{mg} \mathrm{DQO} / \mathrm{l}$. Este flujo es muy elevando para la realidad. ¿Por qué ocurre esto? Las suposiciones que se hicieron para resolver este ejemplo fueron: $(i)$ que el sustrato consumido en la biopelícula era de primer orden y (ii) que el acetato es el sustrato limitante. Mientras que ambas suposiciones resultan razonables para $\mathrm{C}_{\mathrm{LF}}=3 \mathrm{mg} \mathrm{DQO} / \mathrm{l}$, se puede esperar que ninguna de ellas satisfaga a $\mathrm{C}_{\mathrm{LF}}=30 \mathrm{mg} \mathrm{DQO} / \mathrm{l}$. Por lo tanto, se debe tener cuidado al utilizar las soluciones desarrolladas en este capítulo para que las suposiciones hechas se satisfagan adecuadamente. La pregunta de ¿cuándo utilizar ecuaciones de velocidad de reacción de primer orden, orden cero, y Monod en el interior de la biopelícula?, se discutirá en la sección 17.3.2.3. La duda sobre la difusión dual del sustrato será atendida en la sección 17.8.

\section{7-3.2.2 Eliminación de sustrato en el interior de la biopelícula por cinética de orden cero}

Combinando la Ec. 17.1 con la expresión de velocidad de orden cero y asumiendo estado estacionario, se obtiene la siguiente ecuación diferencial ordinaria de segundo orden:

$0=D_{F} \frac{d^{2} C_{F}}{d x^{2}}-\left\{\begin{array}{cc}k_{0, F} X_{F} & \text { para } C_{F}>0 \\ 0 & \text { para } C_{F} \leq 0\end{array}\right.$

La solución a la Ec. 17.20 dependerá de que el sustrato alcance la base de la biopelícula $\left(\mathrm{C}_{\mathrm{F}}>0\right.$ para $0<\mathrm{x}<\mathrm{LF}_{\mathrm{F}}$ o una biopelícula "completamente penetrada") o si el sustrato decrece hasta cero en alguna zona dentro de la biopelícula (biopelícula "parcialmente penetrada").

Biopelículas parcialmente penetradas $(B \leq 1)$ asumiendo una eliminación del sustrato de orden cero

Resolviendo la Ec. 17.20 para una biopelícula parcialmente penetrada requiere de la obtención de tres constantes - dos de ellas se obtienen al integrar la ecuación diferencial de segundo orden y la tercera constante que describe la penetración del sustrato en la biopelícula, donde $\mathrm{r}_{\mathrm{F}}$ tiene un valor de cero. $\mathrm{La}$ penetración del sustrato en la biopelícula con relación al espesor de la misma ( $\beta$ ) (Figura 17.6), se define como:

$\beta=\frac{\text { penetración del sustrato en la biopelícula }}{L_{F}}$

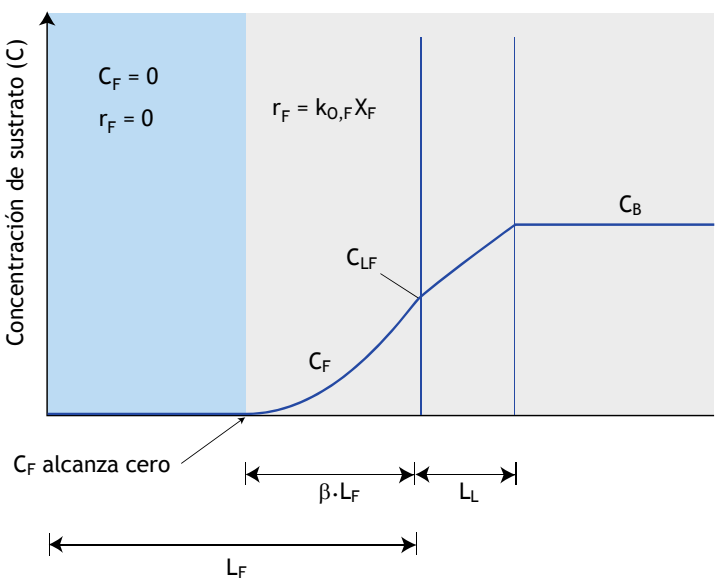

Figura 17.6 Penetración parcial de la biopelícula con una eliminación de sustrato de orden cero para $x<\beta \cdot L_{F}$ y una zona inactiva sin eliminación de sustrato para $x>\beta \cdot L_{F}$ (sombra azul) ( $L_{F}$ es el espesor de la biopelícula y LL es el espesor de la capa límite de transferencia de masa) 
A continuación se definen tres condiciones límite que deben ser consideradas para obtener el valor de las dos constantes de integración y además el valor de $\beta$ :

BC1a: $\frac{d C_{F}}{d x}=0 \quad$ a x $=\beta L_{F}$

BC1b: $C_{F}=0 \quad \mathrm{ax}=\beta \mathrm{L}_{\mathrm{F}}$

BC2: $\quad C_{F}=C_{L F} \quad \mathrm{ax}=0$

Con estas tres condiciones límite la integración de la Ec. 17.20 genera el siguiente resultado:

$C_{F, 0, p}(x)=C_{L F}-\left(x \beta L_{F}-\frac{x^{2}}{2}\right) \frac{k_{0} X_{F}}{D_{F}}$

el cual puede ser reacomodado como:

$C_{F, 0, p}(x)=C_{L F}\left(1-\left(\frac{2 x}{\beta L_{F}}-\frac{x^{2}}{\left(\beta L_{F}\right)^{2}}\right)\right)$

en donde:

$\beta=\sqrt{\frac{2 C_{L F} D_{F}}{L_{F}{ }^{2} k_{0} X_{F}}}$

La Ec. 17.25 puede ser reacomodada para obtener la profundidad de penetración $\left(\beta \mathrm{L}_{\mathrm{F}}\right)$ :

$\beta L_{F}=\sqrt{\frac{2 C_{L F} D_{F}}{k_{0} X_{F}}}$

Nuevamente, el lector deberá verificar que la Ec. 17.24a y la Ec. 17.24b satisfacen de hecho la ecuación diferencial (Ec. 17.20) y las tres condiciones límite mencionadas con anterioridad. El flujo en la biopelícula asumiendo una velocidad de orden cero, en una biopelícula parcialmente penetrada $\left(\mathrm{J}_{\mathrm{LF}, 0, \mathrm{p}}\right)$, se puede calcular por medio de la Ec. 17.24a calculando el gradiente de sustrato en la superficie de la biopelícula (Ec.17.11) como:

$J_{L F, 0, p}=\beta L_{F} k_{0} X_{F}$

Observe que $\beta$ depende de la concentración de sustrato en la superficie de la biopelícula $\left(\mathrm{C}_{\mathrm{LF}}\right)$. Sustituyendo $\beta$ en la Ec. 17.27 provee una relación directa entre el flujo y la concentración de sustrato en solución:

$J_{F, 0, p}=\underbrace{\sqrt{2 D_{F} k_{0} X_{F}}}_{k_{\theta, p, A}} \sqrt{C_{L F}}$

Retomando todos los términos de la Ec. 17.27 que son independientes de la $\mathrm{C}_{\mathrm{F}}$, provee una dependencia de medio orden del flujo de sustrato en $\mathrm{C}_{\mathrm{LF}}$ con una velocidad de reacción en la superficie basada en $\mathrm{k}_{0, \mathrm{p}, \mathrm{A}}$ $\left[\mathrm{M}^{0.5} \mathrm{~L}^{-0.5} \mathrm{~T}^{-1}\right]$ :

$J_{L F, 0, p}=k_{0, p, A} \sqrt{C_{L F}}$

Penetración completa de la biopelícula $(B \geq 1)$ asumiendo una eliminación de sustrato de orden cero

La solución a la Ec. 17.20 asumiendo una penetración completa con las condiciones límite originales (Ec. 17.8 y Ec. 17.9) genera la siguiente solución para la concentración de sustrato en la biopelícula:

$C_{F, 0, f}(x)=C_{L F}-\left(x L_{F}-\frac{x^{2}}{2}\right) \frac{k_{0} X_{F}}{D_{F}}$

la cual puede ser re-arreglada como sigue:

$C_{F, 0, f}(x)=C_{L F}\left(1-\left(\frac{2 x}{L_{F} \beta^{2}}-\frac{x^{2}}{L_{F}^{2} \beta^{2}}\right)\right)$

El flujo en la biopelícula asumiendo una velocidad de orden cero en una biopelícula completamente penetrada

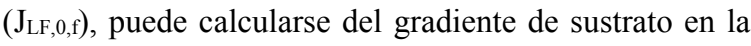
superficie como:

$J_{L F, 0, f}=L_{F} k_{0} X_{F}$

La relación entre los flujos encontrados para reacciones de orden cero en el interior de una biopelícula parcialmente penetrada (Ec. 17.26) y una biopelícula completamente penetrada (Ec. 17.30) es $\beta$. Los perfiles de concentración en el interior de la biopelícula para diferentes valores de $\beta$, se muestran en la Figura 17.7 para ambos casos, una biopelícula parcialmente y completamente penetrada. 


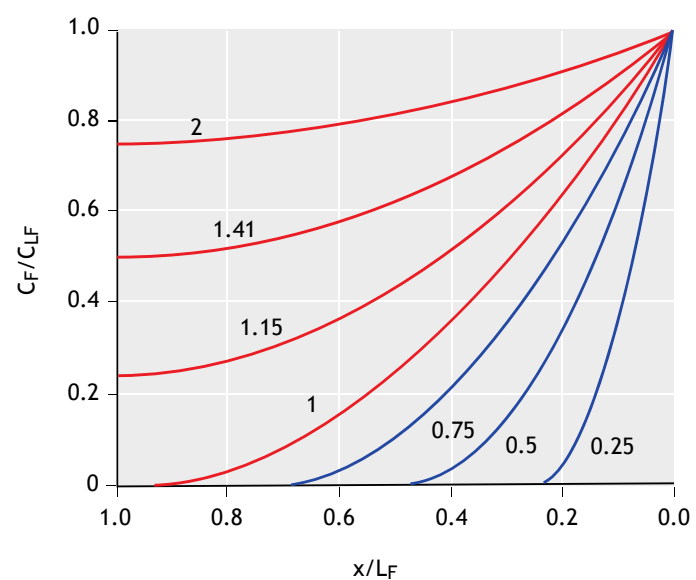

Figura 17.7 Concentraciones de sustrato $\left(C_{F} / C_{L F}\right)$ sobre la profundidad de la biopelícula $\left(x / L_{F}\right)$ asumiendo una velocidad de reacción de la biopelícula de orden cero y diferentes valores de $\beta$ (números en el gráfico). Observe que es necesario utilizar diferentes ecuaciones diferenciales para una biopelícula parcialmente y completamente penetradas: Ec. 17.24 para $\beta<1$ (líneas azules) y Ec. 17.29 para $\beta \geq 1$ (líneas rojas).

\subsubsection{Cinética de Monod en el interior de la biopelícula}

Expresiones de velocidad más complicadas para la eliminación del sustrato en el interior de la biopelícula (por ej., cinéticas de Monod, Ec. 17.4), en la mayoría de los casos no permiten la obtención de soluciones analíticas de la ecuación diferencial original, que describe la reacción y difusión en una sola dimensión de la biopelícula (Ec. 17.1). Sin embargo, hoy en día se encuentran disponibles varias herramientas que proporcionan soluciones numéricas a la Ec. 17.1 y éstas pueden ser utilizadas para evaluar el estado estacionario o las condiciones dinámicas. Un ejemplo es AQUASIM, un programa computacional para la identificación y simulación de sistemas acuáticos (Wanner y Morgenroth, 2004; Wanner y Reichert, 1996, Wanner y Morgenroth, 2004). En la NOTA de la sección 17.3.5, se presenta una breve introducción de cómo se puede utilizar AQUASIM para modelos matemáticos de biopelículas. El lector puede elegir algún otro programa de simulación de plantas de tratamiento de aguas residuales disponible en el mercado, para replicar los resultados obtenidos en este capítulo por medio de AQUASIM. El flujo obtenido cuando se tiene un solo compuesto limitante, asumiendo una cinética de Monod, puede obtenerse también utilizando soluciones pseudo-analíticas (Saez y Rittmann, 1992; Rittmann y McCarty, 2001; Saez y Rittmann, 1992; Wanner et al., 2006). Las soluciones pseudo-analíticas se basan en los resultados derivados de simulaciones numéricas que se combinan en un pequeño conjunto de ecuaciones algebraicas.

AQUASIM tiene la habilidad de resolver simultáneamente ecuaciones múltiples de procesos de difusión y degradación de sustratos solubles, producción $\mathrm{y}$ utilización de intermediarios, $\mathrm{y}$ crecimiento, decaimiento y desprendimiento de diferentes fracciones de biomasa. En esta sección, únicamente para el cálculo de la conversión de sustrato, utilizando una cinética de Monod, se considera despreciable el crecimiento de la biomasa.

Esto permite una comparación directa de las soluciones analíticas obtenidas con anterioridad, con los resultados del modelo numérico. En secciones posteriores (por ej., en la sección 17.9) las biopelículas serán evaluadas con múltiples procesos y componentes.

Para identificar claramente los procesos y componentes que se incluyeron en una simulación, se utilizó la notación matricial (tal y como se presentó en el Capítulo 14). Para un proceso simple consumiendo un solo sustrato, la cinética de Monod en la Ec. 17.4 se puede representar en la "matriz" simple que se muestra en la Tabla 17.2.

Los resultados de las soluciones numéricas para una biopelícula en estado estacionario, utilizando una cinética de Monod, se compararon con las soluciones analíticas obtenidas utilizando expresiones de velocidad de primer orden y orden cero en la Figura 17.8. Para

Tabla 17.2 Matriz de ecuaciones cinéticas y estequiométricas para la eliminación de sustrato heterotrófico, asumiendo que el reactivo limitante es el sustrato orgánico. Se asume que el espesor de la biopelícula y la densidad de la biomasa en la misma, son constantes. Para símbolos y numerología referirse a la Tabla 17.12

\begin{tabular}{|l|c|c|}
\hline$\downarrow \mathrm{j} \rightarrow \mathrm{i}$ & $C_{\mathrm{S}}$ & Velocidad del proceso, $\rho_{\mathrm{j}}$ \\
\hline Nombre del proceso & $-\frac{1}{\mathrm{Y}_{\mathrm{H}}}$ & $\mu_{\text {max } \mathrm{H}} \frac{\mathrm{C}_{\mathrm{S}}}{\mathrm{K}_{\mathrm{S}}+\mathrm{C}_{\mathrm{S}}} \mathrm{X}_{\mathrm{H}}$ \\
\hline Consumo del sustrato heterotrófico & $\mathrm{DQO}$ & \\
\hline Unidades & \\
\hline
\end{tabular}


poder comparar los resultados obtenidos de las diferentes simulaciones, los parámetros correspondientes a las cinéticas de primer orden y orden cero, se derivaron de la velocidad de crecimiento máximo y la concentración media de saturación, utilizando la Ec. 17.6 y la Ec. 17.7. Las velocidades de consumo de sustrato en el interior de la biopelícula se muestran en la Figura 17.8A. Los flujos de sustrato correspondientes al primer orden $\left(\mathrm{J}_{\mathrm{LF}, 1}\right)$, orden cero de una biopelícula parcialmente penetrada $\left(\mathrm{J}_{\mathrm{LF} 0, \mathrm{p}}\right)$, orden cero de una biopelícula completamente penetrada $\left(\mathrm{J}_{\mathrm{LF}, 0, \mathrm{f}}\right)$, y una cinética de Monod ( $\left.\mathrm{J}_{\mathrm{LF}, \mathrm{Monod}}\right)$, se muestran en la Figura 17.8B y 17.8C para un espesor de biopelícula de 200 y $80 \mu \mathrm{m}$, respectivamente. Se puede observar que la velocidad local, asumiendo un cinética de Monod

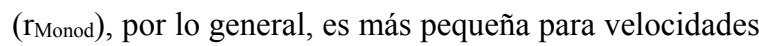
de primer orden $\left(\mathrm{r}_{1}\right) \mathrm{u}$ orden cero $\left(\mathrm{r}_{0}\right)$ (Figura 17.8A). Como resultado, los flujos de sustrato, asumiendo una A

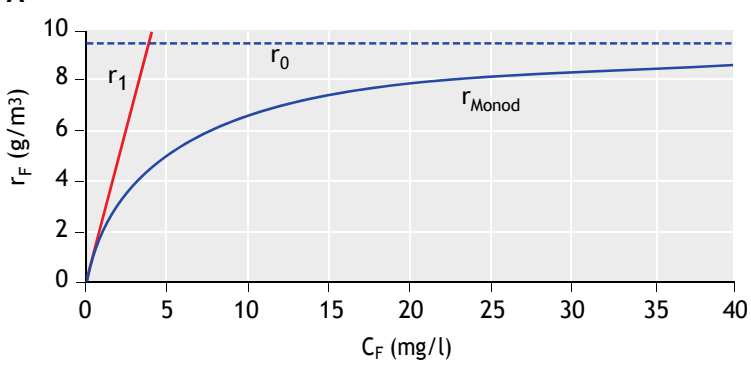

B

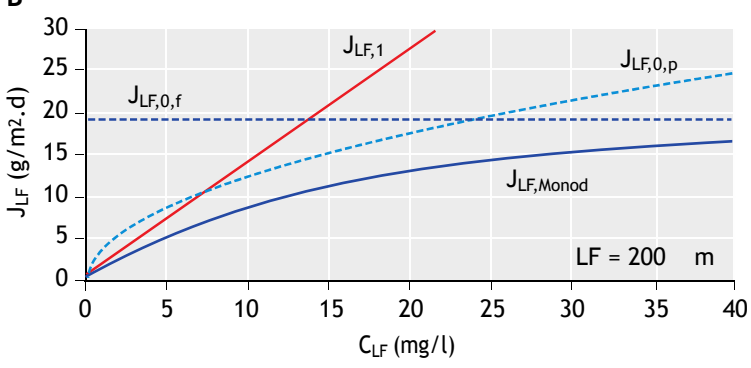

C

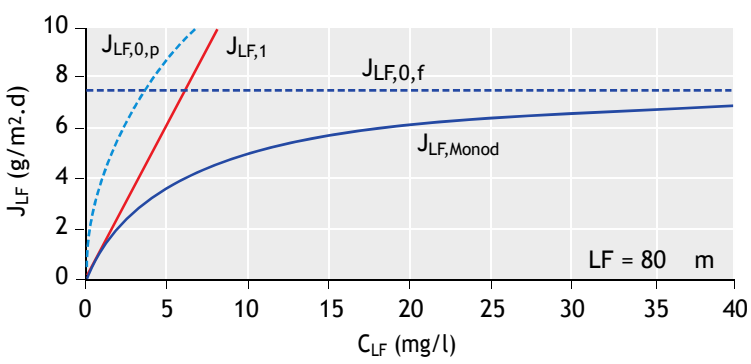

Figura 17.8 Las velocidades de reacción de primer orden, orden cero y Monod en la biopelícula $\left(r_{F}\right)$, se muestran como una función de las concentraciones de sustrato local $\left(C_{F}\right)$ en $(A)$. Los flujos correspondientes de sustrato, como una función de la concentración de sustrato en la superficie de la biopelícula ( $\mathrm{C}_{\mathrm{LF}}$ ), se calcularon para un espesor de biopelícula de $200 \mu \mathrm{m}$ (B) u 80 $\mu \mathrm{m}$ (C). (Parámetros: $\mu_{\max }=6 / \mathrm{d}, \mathrm{K}_{\mathrm{s}}=4 \mathrm{mg} / \mathrm{l}, \mathrm{Y}_{\mathrm{H}}=0.63 \mathrm{~g} \mathrm{DQO} / \mathrm{g}$ DQO, $D_{F}=0.00008 \mathrm{~m}^{2} / \mathrm{d}, X_{F}=10,000 \mathrm{~g} / \mathrm{m}^{3}$ ), dando como resultado $\mathrm{k}_{1}=2.38 \mathrm{~m}^{3} / \mathrm{g} . \mathrm{d}($ Ec. 17.7$), \mathrm{k}_{0}=9.521 / \mathrm{d}\left(\right.$ Ec. 17.6), $\mathrm{y} \mathrm{L}_{\text {crit }}=$ $58 \mu \mathrm{m}$ (EC. 17.14) cinética de Monod, son siempre más pequeños que los flujos de sustrato obtenidos al asumir órdenes de reacción de cero o primer orden (Figura 17.8B y 17.8C).

Observe que las soluciones para una cinética de la biopelícula de orden cero en la Figura 17.8, basadas en la Ec. 17.27, son válidas únicamente para biopelículas parcialmente penetradas $(\beta \leq 1) \mathrm{y}$, las que se basan en la Ec. 17.30, son válidas únicamente para biopelículas completamente penetradas $(\beta \geq 1)$. La transición entre una biopelícula parcialmente penetrada y una completamente penetrada, ocurre en la intersección de $\mathrm{J}_{\mathrm{LF}, 0, \mathrm{p}}$ y $\mathrm{J}_{\mathrm{LF}, 0, \mathrm{f}} \mathrm{O}$ a $\beta=1$. Con base en la definición de $\beta$ (Ec. 17.25), la concentración de sustrato en la superficie de la biopelícula $\left(\mathrm{C}_{\mathrm{LF} \text {,transición }}\right)$ que resulta en $\beta=1$ es:

$C_{L F, \text { transición }}=\frac{L_{F}^{2} k_{0} X_{F}}{2 D_{F}}$

Las soluciones para flujos de sustrato correspondientes a cinéticas de primer orden $\mathrm{u}$ orden cero, se pueden combinar, donde se asume que los flujos de primer orden $\left(\mathrm{J}_{\mathrm{LF}, 1}\right)$ son aplicables a bajas concentraciones de sustrato $\left(\mathrm{C}_{\mathrm{LF}}\right) \mathrm{y}$, los flujos de sustrato para cinéticas de reacción de orden cero se aplican a altas concentraciones de sustrato. Los flujos de sustrato asumiendo una cinética de primer orden de la biopelícula ( $\mathrm{J}_{\mathrm{LF}, 1}$, Ec. 17.15), se interceptan con las cinéticas de medio orden $\left(\mathrm{J}_{\mathrm{LF}, 0, \mathrm{p}}\right.$, Ec. 17.27) para un espesor de biopelícula de $200 \mu \mathrm{m}$, mientras que, para un espesor de biopelícula de $80 \mu \mathrm{m}$, se intercepta con una cinética de orden cero $\left(\mathrm{J}_{\mathrm{LF}, 0, \mathrm{f}}\right.$, Ec. 17.30). Una estrategia para combinar las diferentes ecuaciones analíticas de flujo, consiste en simplemente seleccionar el mínimo de las tres soluciones analíticas, en donde $\mathrm{J}_{\mathrm{LF}, 1}$ y $\mathrm{J}_{\mathrm{LF}, 0, \mathrm{p}}$, son una función de $\mathrm{C}_{\mathrm{LF}} \mathrm{y} \mathrm{J}_{\mathrm{LF}, 0, \mathrm{f}}$ es independiente de $\mathrm{C}_{\mathrm{LF}}$ :

$J_{L F}\left(C_{L F}\right)=\min \left(J_{L F, I}\left(C_{L F}\right), J_{L F, 0, p}\left(C_{L F}\right), J_{L F, 0, f}\right)$

Una estrategia más sofisticada consiste en utilizar una combinación lineal de los diferentes flujos de sustrato descritos por Perez et al., 2005 (con correcciones en Gapes et al., 2006). La conveniencia de utilizar soluciones analíticas simples y soluciones numéricas más complejas, se discute en Wanner et al., 2006, para una gran variedad de aplicaciones. 


\subsubsection{Resumen de las soluciones analíticas encontradas para un solo sustrato limitante}

En la Tabla 17.3 se presenta un resumen de las soluciones analíticas para diferentes perfiles de sustrato sobre el espesor de la biopelícula y sus correspondientes flujos de sustrato. La extensión de la limitación en la transferencia de masa para cinéticas de primer orden y orden cero (biopelícula parcialmente penetrada), se describen utilizando $\varepsilon$ y $\beta$, en donde ambos parámetros se refieren a la relación que existe entre el flujo de sustrato con respecto al flujo de sustrato hipotético, asumiendo que no existen limitantes en la transferencia de masa. Así, $\varepsilon \approx 1$ y $\beta \approx 1$, describen situaciones en donde el flujo de sustrato no es limitado por el transporte de masa en la biopelícula. Por otra parte, $\varepsilon<<1$ y $\beta<<$ 1 , significan que el transporte de sustrato en la biopelícula, se encuentra significativamente limitado por el consumo de sustrato.

\subsubsection{NOTA: derivación de la ecuación de reacción de difusión (Ec. 17.1), para el balance de masa en el interior de la biopelícula}

La ecuación de la reacción de difusión en la Ec. 17.1, se puede derivar de un balance de masa para el volumen de control entre $\mathrm{x} \mathrm{y} \mathrm{x}+\Delta \mathrm{x}$, tal y como se muestra en la Figura 17.9.

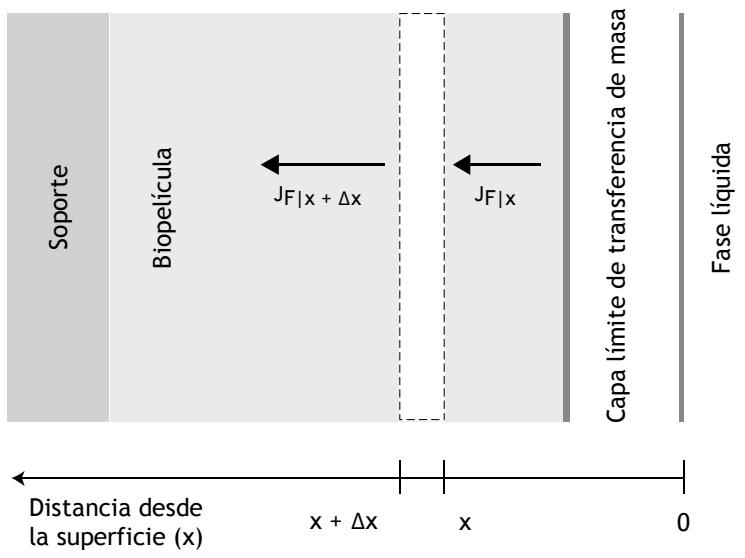

Figura 17.9 Balance de masa para una sección de la biopelícula con un espesor $\Delta \mathrm{x}$, flujos de sustratos de entrada y salida del volumen de control, y consumo de sustrato dentro del volumen de control $(\Delta x A)$

$\underbrace{\Delta x A \frac{\partial C_{F}}{\partial t}}_{\text {Acumulación }}=\underbrace{A J_{F}(x)}_{\text {Entrada }}-\underbrace{A J_{F}(x+\Delta x)}_{\text {Salida }}-\underbrace{\Delta x A r_{F}}_{\text {Consumo }}$ donde $A_{F}$, es el área superficial de la biopelícula $\left(\mathrm{L}^{2}\right)$. Utilizando la primera ley de Fick, por medio de la cual se calcula el flujo de sustrato con base en el coeficiente de difusión y los gradientes de concentración locales:

$J_{F}(x)=-D_{F} \frac{\partial C_{F}(x)}{\partial x}$

$\mathrm{y}$

$J_{F}(x+\Delta x)=-D_{F} \frac{\partial C_{F}(x+\Delta x)}{\partial x}$

La Ec. 17.32 se puede modificar a:

$\frac{\partial C_{F}}{\partial t}=D_{F} \frac{\frac{\partial C_{F}(x+\Delta x)}{\partial x}-\frac{\partial C_{F}(x)}{\partial x}}{\Delta x}-r_{F}$

Suponiendo que $\Delta \mathrm{x}$ se aproxima a cero, la Ec. $17.34 \mathrm{da}$ como resultado la Ec. 17.1:

$$
\underbrace{\frac{\partial C_{F}}{\partial t}}_{\text {Acumulación }}=\underbrace{D_{F} \frac{\partial^{2} C_{F}}{\partial x^{2}}}_{\text {Difusión }}-\underbrace{r_{F}}_{\text {Reacción }}
$$

\subsubsection{NOTA: Descripción general de AQUASIM}

Esta nota ofrece una breve descripción de las ecuaciones resueltas numéricamente por AQUASIM y algunos comentarios iniciales de cómo utilizar AQUASIM para la simulación de biopelículas. Información más detallada se encuentra disponible en Wanner y Reichert (1996); Wanner y Morgenroth (2004); Wanner y Reichert (1996), y en el manual de operación de AQUASIM (Reichert, 1998).

\section{Ecuaciones subyacentes}

AQUASIM evalúa el comportamiento de una biopelícula asumiendo que la solución se encuentra completamente mezclada, que existe una capa límite de transferencia de masa y una sola dimensión de la biopelícula. AQUASIM resuelve simultáneamente los balances de masa correspondientes que se describen a continuación. Las entradas del modelo incluyen la definición de las características iniciales de la biopelícula, la cinética de desprendimiento de la biopelícula, y la matriz cinética y estequeométrica de acuerdo a la Ec. 17.5. El modelo realiza simulaciones dinámicas y los resultados en estado estacionario se obtienen a partir de la simulación bajo condiciones de operación constantes durante un tiempo suficientemente largo. Las salidas del modelo incluyen 
Tabla 17.3. Descripción general de la cinética de biopelícula, en función de la cinética en el interior de la misma

\begin{tabular}{|c|c|c|c|c|}
\hline $\begin{array}{c}\text { Cinética de la } \\
\text { biopelícula }\end{array}$ & $\begin{array}{l}\text { Perfil de concentración sobre el } \\
\text { espesor de la biopelícula }\left(\mathrm{C}_{\mathrm{F}}\right)\end{array}$ & $\begin{array}{l}\text { Flujo de sustrato en la } \\
\text { biopelícula }\left(\mathrm{J}_{\mathrm{C}}\right)\end{array}$ & $\begin{array}{c}\text { Extensión de la limitación } \\
\text { de transporte }\end{array}$ & Ec. \\
\hline Primer orden & $\begin{array}{c}C_{F, I}(x)=\frac{\cos \left(\frac{L_{F}-x}{L_{c r i t}}\right)}{\cos \left(\frac{L_{F}}{L_{c r i t}}\right)} C_{L F} \\
L_{\text {crit }}=\sqrt{\frac{D_{F}}{k_{l, F} X_{F}}}\end{array}$ & $\begin{array}{l}J_{L F, I}=\underbrace{D_{F} \frac{\tan \left(\frac{L_{F}}{L_{c r i t}}\right)}{L_{c r i t}}}_{k_{l, A}} C_{L F} \\
=k_{l, A} C_{L F}\end{array}$ & $\begin{array}{l}J_{L F, 1}=\underset{\begin{array}{c}\text { Efecto de las } \\
\text { limitaciones de } \\
\text { transporte }\end{array}}{\varepsilon} \cdot \underbrace{k_{1, F} X_{F} L_{F} C_{L F}}_{\begin{array}{c}\text { Flujo sin limitaciones } \\
\text { en el transporte de masa }\end{array}} \\
\varepsilon=\frac{\tan \left(\frac{L_{F}}{L_{c r i t}}\right)}{\frac{L_{F}}{L_{\text {crit }}}}\end{array}$ & $\begin{array}{l}(17.13), \\
(17.14), \\
(17.15), \\
(17.18)\end{array}$ \\
\hline $\begin{array}{l}\text { Orden cero, } \\
\text { parcialmente } \\
\text { penetrada }(\beta \leq \\
\text { 1) u orden } \\
\text { medio }\end{array}$ & $\begin{array}{l}C_{F, 0, p}(x)=C_{L F}-\left(x \beta L_{F}-\frac{x^{2}}{2}\right) \frac{k_{0, F} X_{F}}{D_{F}} \\
=C_{L F}\left(1-\left(\frac{2 x}{\beta L_{F}}-\frac{x^{2}}{\left(\beta L_{F}\right)^{2}}\right)\right)\end{array}$ & $\begin{array}{l}J_{L F, 0, p}=\underbrace{\sqrt{2 D_{F} k_{0, F} X_{F}}}_{k_{0, p, A}} \sqrt{C_{L F}} \\
=k_{0, p, A} \sqrt{C_{L F}}\end{array}$ & $\begin{aligned} J_{L F, 0, p} & =\underbrace{\beta}_{\begin{array}{c}\text { Efecto de } \\
\text { las limitaciones en } \\
\text { el transporte de masa }\end{array}} \cdot \underbrace{k_{0, F} X_{F} L_{F}}_{\begin{array}{c}\text { Flujo sin limitaciones en } \\
\text { el transporte de masa }\end{array}} \\
\beta & =\sqrt{\frac{2 D_{F} C_{L F}}{k_{0, F} X_{F} L_{F}^{2}}}\end{aligned}$ & $\begin{array}{l}(17.24), \\
(17.25), \\
(17.26), \\
(17.27)\end{array}$ \\
\hline $\begin{array}{l}\text { Orden cero } \\
\text { completament } \\
\text { penetrada }(\beta \geq \\
\text { 1) }\end{array}$ & $\begin{array}{l}C_{F, 0, f}(x)=C_{L F}-\left(x L_{F}-\frac{x^{2}}{2}\right) \frac{k_{0, F} X_{F}}{D_{F}} \\
=C_{L F}\left(1-\left(\frac{2 x}{\beta^{2} L_{F}}-\frac{x^{2}}{\left(\beta L_{F}\right)^{2}}\right)\right)\end{array}$ & $\begin{array}{l}J_{L F, 0, f}=\underbrace{k_{0, F} X_{F} L_{F}}_{k 0, f, A} \\
=k_{0, f, A}\end{array}$ & $\begin{array}{l}\text { Penetración completa y } \beta \geq 1 \\
\text { corresponde a una biopelícula en } \\
\text { donde el flujo no es afectado por el } \\
\text { transporte de masa }\end{array}$ & $\begin{array}{l}(17.30), \\
(17.31)\end{array}$ \\
\hline
\end{tabular}

las características de la biopelícula y las concentraciones de sustrato en el interior de la misma y en la fase en solución, para cada punto con respecto al tiempo.

\section{Parámetros relevantes del proceso}

Las ecuaciones generales del balance de masa para el comportamiento de la biopelícula, se describen en Wanner y Reichert (1996) (Ec. 22, 23 y 24) y en el manual de operación de AQUASIM. Una diferencia importante entre el balance de masa de la Ec. $17.1 \mathrm{y}$ el balance de masa obtenido en AQUASIM, es el hecho de que distingue entre la fracción sólida $\left(\varepsilon_{\mathrm{s}}\right)$ y la fracción líquida $\left(\varepsilon_{1}\right)$ en el interior de la biopelícula. En AQUASIM se asume que el proceso de difusión se lleva a cabo únicamente en la fracción líquida, mientras que, en la ecuación general de la reacción de difusión (Ec. 17.1) no existe diferencia entre las fracciones sólida y líquida.

Así, el balance de masa para un sustrato soluble, tomando en cuenta las diferentes definiciones de concentración de sustrato por volumen del elemento (y despreciando los términos menores), está dado por (un mayor detalle del balance de masa se encuentra en Wanner y Reichert, 1996):

$$
\begin{aligned}
& \text { Masa de } \mathrm{C}_{\mathrm{F}} \\
& \frac{\partial \overbrace{\left(\varepsilon_{\ell} \cdot C_{F}\right)}^{\text {por volumen total }}}{\partial t}=\underbrace{\varepsilon_{\ell} \cdot D_{W}}_{\begin{array}{c}
\text { Coeficiente efectivo } \\
\text { de difusión en } \\
\text { la biopelícula }\left(=\mathrm{D}_{\mathrm{F}}\right)
\end{array}} \frac{\partial^{2} C_{F}}{\partial z^{2}}+r_{F}
\end{aligned}
$$

donde: $D_{\mathrm{W}}$ es el coeficiente de difusión en el agua y $\varepsilon_{1} \cdot D_{\mathrm{W}}$ es el coeficiente efectivo de difusión de la biopelícula $\mathrm{D}_{\mathrm{F}}$ en la Ec. 17.1. El término de la acumulación también considera que los componentes solubles se pueden acumular en la fracción soluble en el interior de la biopelícula. Además, AQUASIM automáticamente considera la conversión de sustrato en la fase soluble, con base en la actividad de la biomasa, el volumen de líquido proveniente del afluente de la biomasa, el desprendimiento de la biomasa de la biopelícula y el crecimiento de la biomasa en suspensión (Nogueira et $a l ., 2005)$. Observe que en las coordenadas espaciales de AQUASIM, z, es la distancia desde el material de soporte (acarreador), en lugar de ser la coordenada espacial $x$, la cual se utilizó en las soluciones analíticas (Figura 17.4). AQUASIM no genera el flujo de salida del sustrato como un resultado; sin embargo, el usuario puede calcular el flujo a través de la superficie de la biopelícula por medio de las concentraciones de sustrato calculadas con base en 
la Ec. (17.10), utilizando $\varepsilon l \cdot D_{\mathrm{w}}$ como el coeficiente efectivo de difusión:

$$
J_{L F}=-\underbrace{\varepsilon_{\ell} \cdot D_{W}}_{\begin{array}{c}
\text { Coeficiente efectivo } \\
\text { de difusión en } \\
\text { la biopelicula }
\end{array}} \frac{d C_{F}}{d z} \text { a } \mathrm{z}=\mathrm{LF}_{\mathrm{F}}
$$

En AQUASIM, el flujo del compuesto $\mathrm{C}_{\mathrm{F}}$ se puede aproximar mediante la sustitución de la diferencial $\left(\mathrm{dC}_{\mathrm{F}} / \mathrm{dz}\right)$ con la secante de la concentración del sustrato $\left(\Delta \mathrm{C}_{\mathrm{F}} / \Delta \mathrm{z}\right)$. El valor de $\Delta \mathrm{C}_{\mathrm{F}}$ puede ser calculado en AQUASIM utilizando las llamadas "variables de prueba" para diferentes zonas, $\mathrm{z}$, dentro de la biopelícula y eligiendo a $\Delta \mathrm{z}$ con un valor menor al tamaño de la malla con la cual se realizó la simulación de la biopelícula:

$J_{L F} \approx-\varepsilon_{\ell} \cdot D_{W} \frac{C_{F}\left(z=L_{F}\right)-C_{F}\left(z=L_{F}-\Delta z\right)}{\Delta z}$

Un concepto alternativo para el cálculo del flujo en el interior de la biopelícula, se basa en el cambio de concentración sobre la capa superficial:

$$
J=-D_{W} \frac{C_{B}-C_{L F}}{L_{L}}
$$

donde $\mathrm{L}_{\mathrm{L}}$ es el espesor de la capa límite. AQUASIM calcula el espesor de la biopelícula $\left(\mathrm{L}_{\mathrm{F}}\right)$ a partir de un balance de la biomasa en crecimiento, en decaimiento, adherida y desprendida (Wanner y Reichert, 1996):

$$
\underbrace{\frac{d L_{F}}{d t}}_{\begin{array}{c}
\text { Cambio } \\
\text { global en el espesor } \\
\text { de la biopelicula }
\end{array}}=\underbrace{u_{F}\left(L_{F}\right)}_{\text {Crecimiento- decaimiento }}+u_{a, S}-u_{d, S}
$$

donde $u_{F}\left(L_{F}\right)$ es el efecto neto de la expansión de la biopelícula, como resultado de los procesos de crecimiento y decaimiento en el interior de la misma ( $\mathrm{L}$ $\mathrm{T}^{-1}$ ), la velocidad de la biopelícula debido al crecimiento si no hubiera adherencia o desprendimiento, $\mathrm{u}_{\mathrm{a}, \mathrm{S}}$ es la velocidad de adherencia, y $u_{\mathrm{d}, \mathrm{S}}$ es la velocidad de desprendimiento. Para la simulación de biopelículas con un espesor constante predefinido, la velocidad de desprendimiento $\mathrm{u}_{\mathrm{d}, \mathrm{S}}$ puede ser igual a $\mathrm{u}_{\mathrm{F}}\left(\mathrm{LF}_{\mathrm{F}}\right)$ (asumiendo $\left.\mathrm{u}_{\mathrm{a}, \mathrm{S}}=0\right)$.
17.4



Una motivación para calcular el flujo de sustrato en el interior de la biopelícula, es el conocer el funcionamiento global del reactor. Esta relación entre el flujo de sustrato $\mathrm{y}$ el funcionamiento global del reactor, se ilustra utilizando ejemplos de diferentes tipos de reactores y expresiones de velocidad.

\subsubsection{Reactor completamente mezclado}

El caso más simple para un reactor de biopelícula, es asumir que la fase en solución se encuentra completamente mezclada, tal y como se muestra en la Figura 17.10.

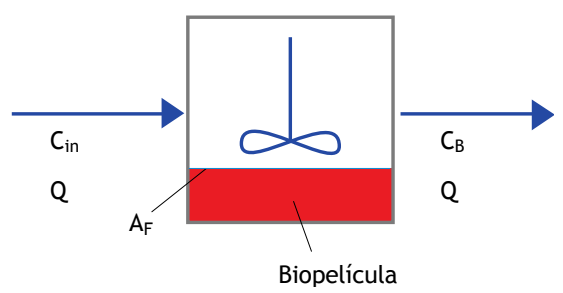

Figura 17.10 Reactor de biopelícula completamente mezclado y con un área superficial de la biopelícula $A_{F}$

Para este sistema, el balance de masa en estado estacionario para el sustrato en solución es:

$0=Q\left(C_{\text {in }}-C_{B}\right)-J_{L F} \cdot A_{F}-r_{B} \cdot V_{B}$

donde:

$\mathrm{C}_{\text {in }} \quad$ concentración del sustrato en el afluente $\left[\mathrm{M} / \mathrm{L}^{3}\right]$

$\mathrm{A}_{\mathrm{F}} \quad$ área superficial de la biopelícula $\left[\mathrm{L}^{2}\right]$

$\mathrm{r}_{\mathrm{B}} \quad$ conversión del sustrato en solución, debido a la conversión de la biomasa suspendida $\left[\mathrm{M} / \mathrm{L}^{3} \mathrm{~T}\right]$

$\mathrm{V}_{\mathrm{B}} \quad$ volumen de la solución $\left[\mathrm{L}^{3}\right]$

Asumiendo que los procesos de conversión de la fase soluble son despreciables $\left(\mathrm{r}_{\mathrm{B}} \cdot \mathrm{V}_{\mathrm{B}}<<\mathrm{J}_{\mathrm{LF}} \cdot \mathrm{A}_{\mathrm{F}}\right)$, el balance de materia de la Ec. 17.40, puede ser utilizado para predecir la concentración del sustrato en el efluente $C_{B}$ para un flujo de sustrato dado en el interior de la biopelícula $\left(\mathrm{J}_{\mathrm{LF}}\right)$ :

$C_{B}=C_{i n}-\frac{J_{L F} A_{F}}{Q}$

Un problema que puede presentarse al utilizar la Ec. 17.43 es que $J_{L F}$ es una función de la concentración de 
sustrato en la solución $\left(\mathrm{C}_{\mathrm{B}}\right)$. Para resolver Ec. 17.43, se requiere resolver simultáneamente esta ecuación junto con la ecuación adecuada para el flujo de sustrato (por ej., de la Tabla 17.3). Dependiendo del tipo de ecuación de flujo, la Ec. 17.43 puede ser resuelta ya sea de manera analítica, por iteraciones, o gráficamente. Observe que el balance de masa en la Ec. 17.42 se encuentra limitado por el sustrato soluble. El destino del material particulado en los reactores de biopelícula resulta más complejo. Las partículas que entran a un reactor de biopelícula pueden ser retenidas por procesos de adsorción y algunas de ellas pueden ser hidrolizadas, dando como resultado la formación de un sustrato soluble, el cual puede ser degradado en el interior de la biopelícula.

\subsubsection{Solución analítica}

Para el caso de una expresión de velocidad de primer orden (Ec. 17.16) se puede obtener un solución analítica de la Ec. 17.43. Asumiendo una cinética de reacción de primer orden, el flujo de sustrato en la biopelícula se calcula como:

$$
J_{L F, 1}=k_{1, A} C_{L F}
$$

Considerando despreciable la resistencia externa a la transferencia de masa, $\mathrm{C}_{\mathrm{LF}}$ es igual a $\mathrm{C}_{\mathrm{B}}$. Entonces, $\mathrm{J}_{\mathrm{LF}, 1}$ de la Ec. 17.16 puede ser sustituido de la Ec. 17.40 resultando:

$$
C_{B}=\frac{C_{i n}}{\frac{k_{1, A} A_{F}}{Q}+1}
$$

Se puede observar de la Ec. 17.44 que la concentración de sustrato en el efluente es independiente del volumen de la solución pero es dependiente del área superficial de la biopelícula, la velocidad de flujo del afluente, la concentración de sustrato en el afluente, y la velocidad de consumo de primer orden.

\subsubsection{Prueba y error o enfoque iterativo}

Una estrategia simple para encontrar $C_{B}$ y el valor correspondiente de $\mathrm{J}_{\mathrm{LF}}$ que solucione la Ec. 17.43 es el realizar iteraciones. Primero se selecciona un valor inicial de $C_{B}$, con éste se calcula $J_{L F}$ utilizando la ecuación de velocidad apropiada (por ej. Tabla 17.3), posteriormente se utiliza la Ec. 17.43 para calcular un nuevo valor de la concentración en la fase en solución y se continua con la iteración hasta que el valor de $C_{B}$ y $J_{L F}$ no presenten variaciones significativas entre las iteraciones. Para la mayoría de los datos de flujo, estas iteraciones serán numéricamente estables y proporcionarán una solución única para la Ec. 17.43.

\subsubsection{Solución gráfica}

Si se cuenta con una representación gráfica de los flujos de sustrato por medio de cálculos, simulaciones numéricas, o de datos experimentales, entonces la concentración de sustrato en el efluente puede ser leída directamente de esta gráfica para determinados valores de Q, Af y $C_{\text {in. }}$ El balance de materia para la Ec. 17.43 puede ser reacomodado de la siguiente manera:

$J_{L F}=\underbrace{\frac{Q C_{i n}}{A_{F}}}_{\text {const. }}-\underbrace{\frac{Q}{A_{F}}}_{\text {pendiente }} C_{B}$

La Ec. 17.45 describe una línea recta en el gráfico de flujo que intercepta al eje de las y $\left(C_{B}=0\right)$ en $J_{L F}=$ $\mathrm{QC}_{\text {in }} / \mathrm{A}_{\mathrm{F}}$, al eje de las $\mathrm{x}\left(\mathrm{J}_{\mathrm{LF}}=0\right)$ en $\mathrm{C}_{\mathrm{B}}=\mathrm{C}_{\text {in }} \mathrm{y}$ tiene una pendiente igual a $\mathrm{Q} / \mathrm{A}_{\mathrm{F}}$. La intercepción entre la Ec. 17.45 y el flujo de sustrato trazado, proporciona la solución para las concentraciones de sustrato en solución y el flujo de sustrato, que satisfacen tanto a la ecuación del balance de masa del reactor, como al balance de masa de la biopelícula (Figura 17.11).

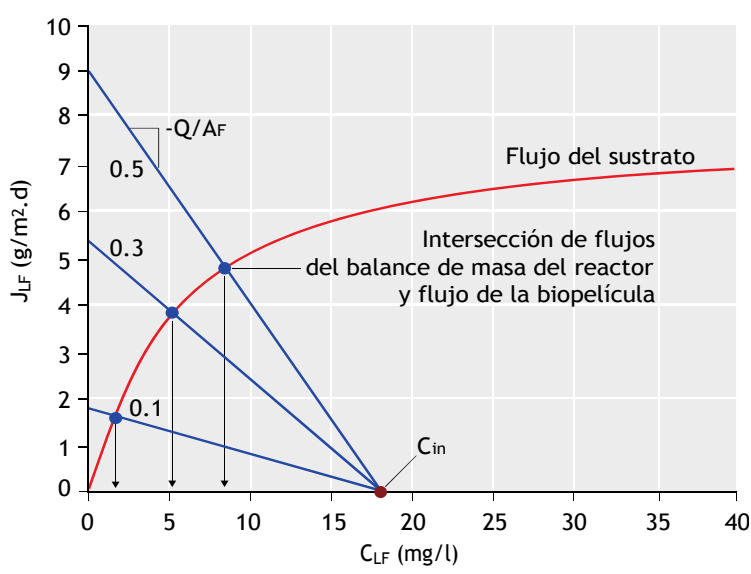

Figura 17.11 Solución gráfica de la Ec. 17.41 para un flujo de sustrato dado (de la Figura 17.8c) y para tres valores diferentes de $Q / A_{F}$ (números en el gráfico) y $C_{\text {in }}=18 \mathrm{mg} / \mathrm{l}$. Las flechas indican los resultados encontrados de las concentraciones de sustrato en el efluente para los tres diferentes valores de $Q / A_{F}$

Esta solución gráfica resulta de utilidad cuando se evalúan los datos del flujo medido vs los datos de la concentración en la fase en solución. Además, proporciona una percepción visual de la manera en la que el cambio de las concentraciones del sustrato en el afluente o las velocidades de flujo del afluente, pueden afectar las concentraciones de sustrato del efluente. 
17.4.1.4 Solución numérica (por ej., utilizando AQUASIM)

Tal y como se describió en la sección 17.3.5, AQUASIM puede resolver simultáneamente los balances de masa para el proceso que ocurre en el interior de la biopelícula y además se obtienen las concentraciones de sustrato en la fase en solución como un resultado directo del modelo.

17.4.2 Condiciones de flujo pistón en la fase en solución

Las condiciones de mezclado en la fase en solución de los filtros percoladores o biofiltros, son más similares a las condiciones de un reactor en flujo pistón que a las condiciones presentes en un reactor completamente mezclado. El balance de masa en estado estacionario para el consumo de sustrato en la biopelícula asumiendo condiciones de flujo pistón, tal y como se muestran en la Figura 17.12 es:

$$
\begin{gathered}
0=Q\left(C_{B}(y)-C_{B}(y+\Delta y)\right)-J_{L F}\left(C_{B}\right) . \\
\underbrace{a_{F} \cdot \Delta y \cdot A_{R}}_{\begin{array}{l}
\text { Superficie } \\
\text { de la biopelícula en el volumen } \\
\text { de control }
\end{array}}
\end{gathered}
$$

donde

$y \quad$ Distancia a lo largo de la longitud del reactor

[L]

$\Delta y \quad$ Espesor del volumen de control [L]

$\mathrm{C}_{\mathrm{B}}(y)$ Concentración del sustrato en la fase en solución en el punto $y\left[\mathrm{M} / \mathrm{L}^{3}\right]$

$\mathrm{J}_{\mathrm{LF}}\left(\mathrm{C}_{\mathrm{B}}\right) \quad$ Flujo de sustrato en función de $\mathrm{C}_{\mathrm{B}}(y)\left[\mathrm{M} / \mathrm{L}^{2} \mathrm{~T}\right]$ $\mathrm{a}_{\mathrm{F}} \quad$ Área superficial específica de la biopelícula $=$ $\mathrm{A}_{\mathrm{F}} / \mathrm{V}_{\mathrm{R}}[1 / \mathrm{L}]$

$A_{R} \quad$ Área transversal del reactor de biopelícula en la dirección de flujo $\left[\mathrm{L}^{2}\right]$

Dividiendo la Ec. (17.46) entre $\Delta y \cdot A_{R}$ y dejando que $\Delta y$ tienda a cero, se obtiene:

$$
\begin{aligned}
& \frac{d C_{B}(y)}{d y}=-J_{L F}\left(C_{B}\right) \frac{a_{F}}{q_{A}}(17.47) \\
& \text { donde } \\
& \mathrm{q}_{\mathrm{A}} \quad \text { Velocidad del filtro }=\mathrm{Q} / \mathrm{A}_{\mathrm{R}}[\mathrm{L} / \mathrm{T}]
\end{aligned}
$$

Dependiendo de cómo se relacione la velocidad de flujo $\left(\mathrm{J}_{\mathrm{LF}}\right)$ con la concentración del sustrato $\left(\mathrm{C}_{\mathrm{B}}\right)$, la Ec. (17.47) puede ser resuelta en ocasiones especiales de manera analítica o numérica (por ej., describiendo al reactor como una serie de sistemas completamente mezclados y resolviendo de acuerdo a la sección 17.4.1).
Asumiendo una cinética de reacción de primer orden (Ec. 17.16) y despreciando la transferencia de masa externa, la Ec. (17.47) se transforma en:

$$
\frac{d C_{B}}{d y}=-\frac{k_{1, A} \cdot a_{F}}{q_{A}} C_{B}
$$

la cual puede ser resuelta de manera analítica cuando $\mathrm{C}_{\mathrm{B}}(y=0)=\mathrm{C}_{\mathrm{in}}$, tal y como se muestra en la Ec. (17.49)

$$
C_{B}(y)=C_{\text {entrada }} \cdot \exp \left(-\frac{k_{1, A} \cdot a_{F}}{q_{A}} y\right)
$$

y para las concentraciones del efluente en un reactor de altura $h$ como:

$$
\begin{aligned}
C_{B, \text { salida }} & =C_{B}(y=h) \\
& =C_{\text {entrada }} \cdot \exp \left(-\frac{k_{1, A} \cdot a_{F}}{q_{A}} h\right)
\end{aligned}
$$

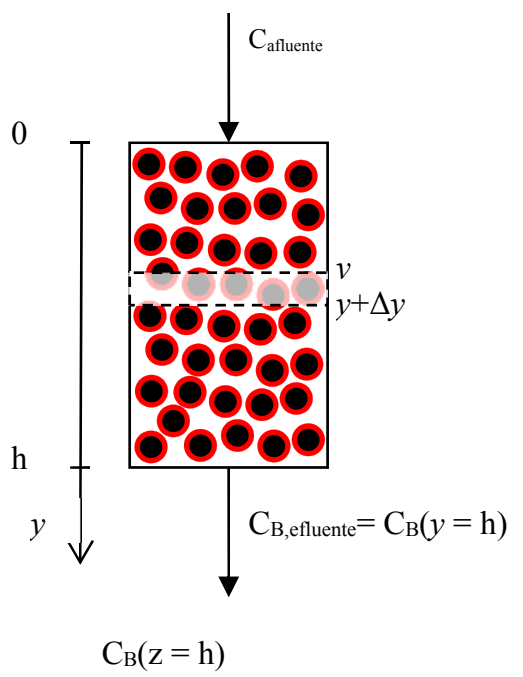

Figura 17.12 Reactor de biopelícula en donde la fase en solución puede ser descrita como flujo pistón.

\subsection{EFECTO DE LA RESISTENCIA EXTERNA A LA TRANSFERENCIA DE MASA}

En la sección 17.3, se calcularon los perfiles de concentración en el interior de la biopelícula, asumiendo que la concentración del sustrato en la superficie de la biopelícula $\left(\mathrm{C}_{\mathrm{LF}}\right)$ es igual a la concentración de sustrato en la solución $\left(\mathrm{C}_{\mathrm{B}}\right)$. Pero inclusive cuando se aplica un 
mezclado vigoroso a la fase en solución, existe aún una capa límite a la transferencia de masa que deberá ser considerada. La concentración en la fase en solución aumenta gradualmente tal y como se muestra en la Figura 17.13 .



Figura 17.13 Perfil de concentración fuera de la biopelícula y representación idealizada de la concentración en la capa límite con $L_{L}=R_{L} \cdot D_{W}$ (Ec. 17.52) ( $L_{F}$ es el espesor de la biopelícula y $L_{L}$ es el espesor de la capa límite a la transferencia de masa)

Este gradiente de concentración por lo general no se puede modelar explícitamente; sin embargo, se puede modelar como una resistencia a la transferencia de masa:

$J_{B L}=\frac{1}{R_{L}}\left(C_{B}-C_{L F}\right)$

donde $\mathrm{J}_{\mathrm{BL}}$ es el flujo de sustrato en la fase líquida y $\mathrm{R}_{\mathrm{L}}$ es la resistencia externa a la transferencia de masa. Resulta de utilidad el visualizar $\mathrm{R}_{\mathrm{L}}$ introduciendo el concepto de la concentración en la capa límite. Un espesor de esta concentración en la capa límite genera una comprensión más intuitiva en comparación con la resistencia. La resistencia y el espesor de la concentración en la capa límite se encuentran relacionadas por:

$R_{L}=\frac{L_{L}}{D_{W}}$

en donde $\mathrm{L}_{\mathrm{L}}$ es el espesor de la capa límite a la transferencia de masa externa y $\mathrm{D}_{\mathrm{W}}$ es el coeficiente de difusión en el agua.

El flujo de sustrato en la capa límite (Ec. 17.51), se encuentra relacionado con el flujo de sustrato en la superficie de la biopelícula (Ec. 17.11). Esto genera una ecuación adicional (condición límite) que es necesaria para calcular el valor adicional desconocido de la concentración en la superficie de la biopelícula:

BC3: $J_{B L}=J_{L F}$

\subsubsection{Flujo de sustrato para velocidades de reacción de primer orden con una capa límite externa}

El concepto de relacionar el flujo de sustrato en la biopelícula y la resistencia externa a la transferencia de masa se puede demostrar calculando la solución analítica, asumiendo una cinética de reacción de primer orden en el interior de la biopelícula. Combinando el flujo que pasa a través de la superficie de la biopelícula (Ec. 17.16) y el flujo a través de la capa límite externa (Ec. 17.51) se encuentra que:

$J_{L F}=k_{1, A} C_{L F}=\frac{1}{R_{L}}\left(C_{B}-C_{L F}\right)$

Esta ecuación puede ser resuelta para $\mathrm{C}_{\mathrm{LF}}$ :

$C_{L F}=\frac{C_{B}}{k_{1, A} R_{L}+1}$

y el correspondiente flujo de sustrato se puede calcular substituyendo la Ec. 17.55 en la Ec. 17.16:

$$
J_{L F}=k_{l, A} C_{B} \underbrace{\frac{1}{k_{1, A} R_{L}+1}}_{\begin{array}{c}
\text { Reducción del } \\
\text { flujo debido a la resistencia } \\
\text { externa a a la transferencia de masa }
\end{array}}
$$

De la Ec. 17.56, considerando la resistencia externa a la transferencia de masa, se puede observar que el grado de aumento de la resistencia externa a la transferencia de masa se incrementa con un aumento en los valores de $\mathrm{k}_{1, \mathrm{~A}}$ y R $R_{L}$ Evaluando la Ec. 17.56 para casos extremos resulta:

$J_{L F}=\left\{\begin{array}{cl}C_{B} \frac{1}{R_{L}} & \text { para } R_{L} k_{1, A}>>1 \\ C_{B} k_{1, A} & \text { para } R_{L} k_{1, A}<<1\end{array}\right.$

Para $R_{L} k_{1, A}>>1$ la degradación del sustrato se encuentra limitada por la transferencia de masa externa y el flujo en la Ec. 17.57 iguala a la Ec. 17.51 con $C_{L F}=0$. Para $R_{L} k_{1, A}$ $<<1$, el consumo de sustrato se encuentra limitado por la degradación y la transferencia de masa en el interior de 
la biopelícula dando como resultado, $\mathrm{C}_{\mathrm{LF}}=\mathrm{C}_{\mathrm{B}}$. El valor de $\mathrm{R}_{\mathrm{L}} \mathrm{k}_{1, \mathrm{~A}}$ puede ser utilizado para evaluar diferentes estrategias para aumentar la conversión global de sustrato. Si la resistencia a la transferencia de masa externa es significativa (por ej. $R_{L} k_{1, A}>>1$ ), entonces $J_{L F}$ puede incrementarse aumentando el mezclado en la fase en solución, reduciendo el espesor de la concentración en la capa límite $\left(\mathrm{L}_{\mathrm{L}}\right) \mathrm{y}$, por lo tanto, reduciendo $\mathrm{R}_{\mathrm{L}}$. El aumentar el mezclado en la fase en solución, no tiene un efecto directo en $\mathrm{J}_{\mathrm{LF}}$ para el caso en el que $\mathrm{R}_{\mathrm{L}} \mathrm{k}_{1, \mathrm{~A}}>>1$.

\subsubsection{Flujo de sustrato para velocidades de reacción de orden cero (biopelícula parcialmente penetrada) con una capa límite externa}

La influencia de la resistencia a la transferencia de masa externa, en el caso de una biopelícula parcialmente penetrada, con una velocidad de reacción de orden cero en el interior de esta, puede calcularse combinando la Ec. (17.29) y (17.54):

$J_{L F}=k_{0, p, A} \sqrt{C_{L F}}=\frac{1}{R_{L}}\left(C_{B}-C_{L F}\right)$

La Ec. 17.58, es una ecuación cuadrática en términos de $\sqrt{C_{L F}}$ que puede ser resuelta como sigue:

$$
\sqrt{C_{L F}}=-\frac{k_{0, p, A} R_{L}}{2}+\sqrt{\left(\frac{k_{0, p, A} R_{L}}{2}\right)^{2}+C_{B}}
$$

Substituyendo $\sqrt{C_{L F}}$ de la Ec. 17.59 en la Ec. 17.29, para el flujo de sustrato en el interior de una biopelícula parcialmente penetrada, con una velocidad de reacción de orden cero, se obtiene:

$$
J_{L F}=k_{0, p, A}\left(-\frac{k_{0, p, A} R_{L}}{2}+\sqrt{\left(\frac{k_{0, p, A} R_{L}}{2}\right)^{2}+C_{B}}\right)
$$

El parámetro adimensional $\zeta$ se define a continuación (Ec. 17.61), como la relación entre el flujo de sustrato en la biopelícula, despreciando la resistencia externa a la transferencia de masa $\left(C_{L F}=C_{B}\right.$ en la Ec. 17.29) y el flujo de sustrato en la capa límite de transferencia de masa externa asumiendo $\mathrm{C}_{\mathrm{LF}}=0$ :

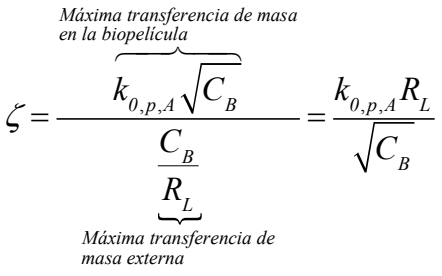

Substituyendo $\zeta$ de la Ec. 17.61 en la Ec. 17.60, da como resultado el flujo de sustrato como una función de la concentración de sustrato en la solución $\left(\mathrm{C}_{\mathrm{B}}\right)$ y el parámetro $\zeta$ :

$J_{L F}=k_{0, p, A} \sqrt{C_{B}}\left(-\frac{\zeta}{2}+\sqrt{\left(\frac{\zeta}{2}\right)^{2}+1}\right)$

Evaluando la Ec. 17.62 para casos extremos se obtiene:

$J_{L F}=\left\{\begin{array}{cl}\frac{1}{R_{L}} C_{B} & \text { for } R_{L} k_{0, p, A}>C_{B} \text { or } \zeta \rightarrow \infty \\ k_{0, p, A} \sqrt{C_{B}} & \text { for } R_{L} k_{0, p, A} \ll C_{B} \text { or } \zeta \rightarrow 0\end{array}\right.$

Una biopelícula con $\zeta \rightarrow \infty$, se encuentra limitada por la resistencia a la transferencia de masa externa, mientras que, para una biopelícula con $\zeta \rightarrow 0$ se puede despreciar la transferencia de masa externa.

Es importante observar que la separación estricta entre la resistencia a la transferencia de masa externa e interna, es de alguna manera artificial. En el enfoque actual de modelos matemáticos, el mezclado de la solución únicamente tiene influencia en la resistencia a la transferencia de masa externa. En la realidad, el mezclado externo tendrá una influencia en el desarrollo de la biopelícula, la densidad de la biomasa en esta y la ocurrencia de canales de flujo. Un menor mezclado y menor cizallamiento, propicia la formación de biopelículas más suaves y gruesas, mientras que un mayor cizallamiento, resulta en una más densas (van Loosdrecht et al., 1995).

\subsubsection{Flujo de sustrato para cinéticas de Monod en el interior de la biopelícula con una capa límite externa}

Para demostrar la importancia de la resistencia externa a la transferencia de masa, se realizaron simulaciones en AQUASIM utilizando los mismos parámetros cinéticos y de la biopelícula, mostrados en la Figura 17.8B, donde los flujos de sustrato se calcularon considerando 
despreciable la resistencia externa a la transferencia de masa (Figura 17.14).

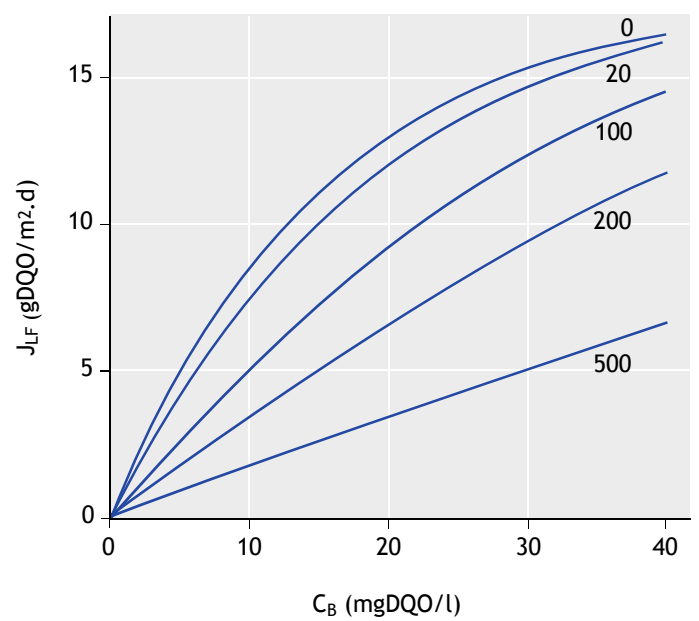

Figura 17.14 Flujos de sustrato para diferentes concentraciones del mismo en el afluente, como una función del espesor de la capa límite externa (los números en el gráfico corresponden a $L_{L}$ en $\mu \mathrm{m}$ ), para un espesor de biopelícula de $200 \mu \mathrm{m}$. Como se muestra en la Figura 17.8, el consumo del sustrato en la biopelícula se modeló utilizando una cinética de Monod (Tabla 17.2) y los parámetros proporcionados en la Tabla 17.12

Los resultados mostrados en la Figura 17.14 se basan en un espesor de la capa límite a la transferencia de masa externa $\left(L_{L}\right)$ variando de 0 a $500 \mu \mathrm{m}$. Se puede observar que al aumentar la concentración del sustrato en la solución y disminuir el espesor de la capa límite, el flujo se incrementa. Un espesor de la capa límite de $\mathrm{L}_{\mathrm{L}}=500$ $\mu \mathrm{m}$, disminuye el flujo más del 70\%.

\subsection{RELACIÓN DEL CRECIMIENTO Y DECAIMIENTO CON EL DESPRENDIMIENTO}

En la mayoría de los modelos de biopelículas y en todos los cálculos que se realizan en las secciones posteriores, el usuario deberá asumir un espesor de la biopelícula constante. El modelo matemático puede predecir el desarrollo de la biopelícula con respecto al tiempo e inclusive un espesor en estado estable basado en los procesos de crecimiento, decaimiento y desprendimiento:

$$
\underbrace{\frac{d L_{F}}{d t}}_{\begin{array}{c}
\text { Cambio } \\
\text { promedio del } \\
\text { espesor de la } \\
\text { biopelícula }
\end{array}}=\underbrace{\frac{Y \cdot J_{L F}}{X_{F}}}_{\text {Crecimiento }}-\underbrace{b_{\text {ina }} L_{F}}_{\text {Decaimiento }}-\underbrace{u_{d, S}}_{\begin{array}{c}
\text { Velocidad } \\
\text { de desprendiemiento } \\
\text { en la superficie }
\end{array}}
$$

Mientras que el fijar el balance para el espesor de la biopelícula (Ec. 17.64) resulta sencillo, el encontrar las expresiones adecuadas para la velocidad de decaimiento $\left(\mathrm{u}_{\mathrm{d}, \mathrm{S}}\right)$ no lo es. En la Tabla 17.4 se presenta un panorama general de las expresiones de velocidad de desprendimiento. Se puede observar que los mecanismos de desprendimiento son muy diferentes para cada una de las investigaciones realizadas. Tampoco existe un acuerdo sobre la estimación de los valores para los coeficientes de la ecuación de velocidad de desprendimiento con base en la operación y el tipo de reactor.

Existen diferentes enfoques para cuantificar las velocidades de desprendimiento (Morgenroth, 2003). En la Ec. 17.64, las tasas de desprendimiento se describen como una constante de velocidad de desprendimiento $\left(\mathrm{u}_{\mathrm{d}, \mathrm{S}}\right)(\mathrm{L} / \mathrm{T})$. Algunas otras referencias expresan el desprendimiento como una función de la masa de biopelícula eliminada por unidad de área y tiempo ( $\left.\mathrm{u}_{\mathrm{d}, \mathrm{M}}\right)$ $\left(\mathrm{M} / \mathrm{L}^{2} \mathrm{~T}\right)$, o como una fracción del volumen de la biopelícula desprendida por unidad de tiempo $\left(\mathrm{u}_{\mathrm{d}, \mathrm{V}}\right)$ $(1 / T)$. Estas diferentes expresiones de tasas de desprendimiento se encuentran relacionadas con la velocidad de desprendimiento como sigue:

$$
\begin{aligned}
& u_{d, V}=\frac{u_{d, S}}{L_{F}} \\
& u_{d, M}=u_{d, S} X_{F}
\end{aligned}
$$

en la cual $X_{F}$ es la densidad de biomasa de la biopelícula $\left(\mathrm{M} / \mathrm{L}^{3}\right)$. La mayoría de los modelos de desprendimiento de la biopelícula utilizan coeficientes de tasas de desprendimiento constantes. El desprendimiento dinámico difiere de la superficie y el volumen desprendidos, en el sentido en que el desprendimiento se modela no como un proceso continuo sino como eventos discretos que ocurren en ciertos intervalos.

Un ejemplo de desprendimiento dinámico de la biopelícula es el retrolavado de los reactores de biopelícula. El cambio resultante del espesor global de la biopelícula, se puede calcular asumiendo una expresión dinámica de la tasa de desprendimiento:

$u_{d, S}= \begin{cases}k_{d}^{\prime} \cdot L_{F} & \text { durante una operación normal } \\ k_{d}^{\prime \prime} \cdot\left(L_{F}-L_{\text {con base en el espesor }}\right) & \text { durante el retrolavado }\end{cases}$ 
Tabla 17.4 Expresiones para la tasa de desprendimiento (modificado de Morgenroth, 2003; Peyton y Characklis, 1993; Tijhuis et al., 1995,)'

\begin{tabular}{|c|c|c|}
\hline $\begin{array}{l}\text { Mecanismos de desprendimiento } \\
\text { relacionados con }\end{array}$ & $\begin{array}{l}\text { Expresiones reportadas para la tasa de } \\
\text { desprendimiento, } \mathrm{u}_{\mathrm{d}, \mathrm{M}}\left(\mathrm{M} \mathrm{L}^{-2} \mathrm{~T}^{-1}\right)\end{array}$ & Referencia \\
\hline \multirow[t]{2}{*}{ No especificado } & 0 & $\begin{array}{l}\text { Kissel et al., 1984; Fruhen et al., } \\
1991\end{array}$ \\
\hline & Espesor de la biopelícula constante & Wanner y Gujer, 1985 \\
\hline \multirow{3}{*}{ Espesor de la biopelícula } & $\mathrm{k}_{\mathrm{d}}\left(\mathrm{X}_{\mathrm{F}} \mathrm{L}_{\mathrm{F}}\right)^{2}$ & $\begin{array}{l}\text { Bryers, 1984; Trulear y Characklis, } \\
1982\end{array}$ \\
\hline & $\mathrm{k}_{\mathrm{d}} \mathrm{X}_{\mathrm{F}} \mathrm{LF}_{\mathrm{F}}^{2}$ & Wanner y Gujer, 1986 \\
\hline & $\mathrm{k}_{\mathrm{d}} \mathrm{X}_{\mathrm{F}} \mathrm{LF}_{\mathrm{F}}$ & $\begin{array}{l}\text { Chang y Rittmann, 1987; } \\
\text { Kreikenbohm y Stephan, 1985; } \\
\text { Rittmann, } 1989\end{array}$ \\
\hline \multirow{2}{*}{ Esfuerzo cortante } & $\mathrm{k}_{\mathrm{d}} \mathrm{X}_{\mathrm{F}} \tau$ & Bakke et al., 1984 \\
\hline & $\mathrm{k}_{\mathrm{d}} \mathrm{X}_{\mathrm{f}} \mathrm{L}_{\mathrm{F}} \tau^{0.58}$ & Rittmann, 1982b \\
\hline \multirow[b]{2}{*}{$\begin{array}{l}\text { Tasa de crecimiento o tasa de utilización de } \\
\text { sustrato }\end{array}$} & $\mathrm{L}_{\mathrm{F}}\left(\mathrm{k}_{\mathrm{d}}^{\prime}+\mathrm{k}_{\mathrm{d}} " \mu\right)$ & Speitel y DiGiano, 1987 \\
\hline & $\mathrm{k}_{\mathrm{d}} \cdot \mathrm{rS}_{\mathrm{S}} \cdot \mathrm{L}_{\mathrm{F}}$ & $\begin{array}{l}\text { Peyton y Characklis, 1993; } \\
\text { Robinson et al., 1984; Tijhuis et } \\
\text { al., } 1995\end{array}$ \\
\hline Retrolavado hacia un espesor base predefinido & $\begin{array}{ll}\mathrm{k}_{\mathrm{d}}^{\prime} \cdot L_{F} & \text { operación normal } \\
\mathrm{k}_{\mathrm{d}}^{\prime \prime} \cdot\left(\mathrm{L}_{\mathrm{F}}-\mathrm{L}_{\text {espesor base }}\right) & \text { retrolavado }\end{array}$ & $\begin{array}{l}\text { Lackner et al., 2008; Morgenroth y } \\
\text { Wilderer, 1999; } \\
\text { Rittmann } \text { et al., } 2002\end{array}$ \\
\hline
\end{tabular}

${ }^{1}$ Significado de los símbolos: $\mathrm{k}_{\mathrm{d}}, \mathrm{k}_{\mathrm{d}}{ }^{\prime}, \mathrm{k}_{\mathrm{d}}{ }^{\prime \prime}=$ coeficientes de la tasa de desprendimiento, $\mathrm{X}_{\mathrm{F}}=$ densidad de biomasa en la biopelícula $\left(\mathrm{M} \mathrm{L}^{-3}\right), \mathrm{L}_{\mathrm{F}}$ $=$ espesor de la biopelícula $(\mathrm{L}), \mathrm{L}_{\text {espesor base }}=$ espesor de la biopelícula predefinido después del retrolavado $(\mathrm{L}), \mu=$ tasa de crecimiento específico $\left(\mathrm{T}^{-1}\right), \mathrm{r}_{\mathrm{S}}=$ tasa de utilización del sustrato $\left(\mathrm{M} \mathrm{L}^{-2} \mathrm{~T}^{-1}\right), \tau=$ esfuerzo cortante $\left(\mathrm{M} \mathrm{L}^{-1} \mathrm{~T}^{-2}\right)$.

donde $\mathrm{u}_{\mathrm{d}, \mathrm{S}}$ puede ser definido de tal manera que toda la biopelícula por arriba de un espesor predefinido se elimina durante el retrolavado (Morgenroth y Wilderer, 1999; Morgenroth, 2003).

\subsubsection{Influencia del desprendimiento $\left(\mathrm{u}_{\mathrm{d}, \mathrm{s}}\right)$ en el espesor de la biopelícula en estado estacionario $\left(L_{F}\right)$ y en el flujo de sustrato $\left(\mathrm{J}_{\mathrm{LF}}\right)$}

El balance de masa de la Ec. 17.56, se puede resolver analíticamente para algunas eliminaciones de sustrato seleccionadas y expresiones de tasa de desprendimiento o bien numéricamente utilizando AQUASIM.

Ejemplo 17.2: Predicción del espesor de la biopelícula asumiendo un flujo de sustrato de medio orden

Asumiendo el siguiente flujo de sustrato y desprendimiento:

$$
\begin{aligned}
& J_{L F, 0, p}=k_{0, p, A} \sqrt{C_{L F}} \\
& u_{\text {det }}=k_{d} L_{F}
\end{aligned}
$$

Con estas definiciones la Ec.17.64 para condiciones de estado estacionario se convierte en:

$$
0=\frac{Y k_{0, p, A} \sqrt{C_{L F}}}{X_{F}}-b_{\text {ina }} L_{F}-k_{d} L_{F}
$$

la cual puede ser resuelta para $\mathrm{L}_{\mathrm{F}}$ :

$$
L_{F}=\frac{Y k_{0, p, A} \sqrt{C_{L F}}}{X_{F}\left(b_{i n a}+k_{d}\right)}
$$

Por lo tanto, un aumento en el decaimiento ( $b_{\text {ina }}$ ) y desprendimiento $\left(\mathrm{k}_{\mathrm{d}}\right)$ da como resultado una disminución en el espesor de la biopelícula. Un aumento en las velocidades de eliminación $\left(\mathrm{k}_{0, \mathrm{p}, \mathrm{A}}\right)$ y las concentraciones en la superficie $\left(\mathrm{C}_{\mathrm{LF}}\right)$ generará biopelículas más gruesas.

Ejemplo 17.3: Predicción del espesor de la biopelícula asumiendo un flujo de sustrato de orden cero

También se puede encontrar una solución analítica para el espesor de la biopelícula para velocidades de eliminación de orden cero:

$J_{L F}=k_{0} X_{F} L_{F}$ 
pero considerando una expresión de tasa de desprendimiento diferente:

$u_{d, S}=k_{d} L_{F}^{2}$

Observe que la tasa de desprendimiento de la Ec. 17.71 en lugar de la Ec. 17.68 se asumió meramente para facilitar la solución analítica. Insertando estas expresiones de velocidad en la Ec. 17.64 se obtiene:

$0=\frac{Y k_{0} X_{F} L_{F}}{X_{F}}-b_{\text {ina }} L_{F}-k_{d} L_{F}{ }^{2}$

la cual puede ser resuelta para $\mathrm{LF}_{\mathrm{F}}$

$L_{F}=\frac{Y k_{0}-b_{i n a}}{k_{d}}$

Nuevamente, el espesor de la biopelícula disminuye con el aumento de los valores de decaimiento ( $b_{\text {ina }}$ ) y desprendimiento $\left(\mathrm{k}_{\mathrm{d}}\right)$ y disminuyendo las tasas de consumo de sustrato $\left(\mathrm{k}_{0}\right)$.

Ejemplo 17.4: Predicción del espesor de la biopelícula utilizando una solución numérica y asumiendo una cinética de Monod

Las soluciones analíticas para el espesor de la biopelícula se encuentran disponibles únicamente para combinaciones específicas de las expresiones de velocidad de crecimiento y desprendimiento. Utilizando AQUASIM podemos evaluar la influencia de diferentes

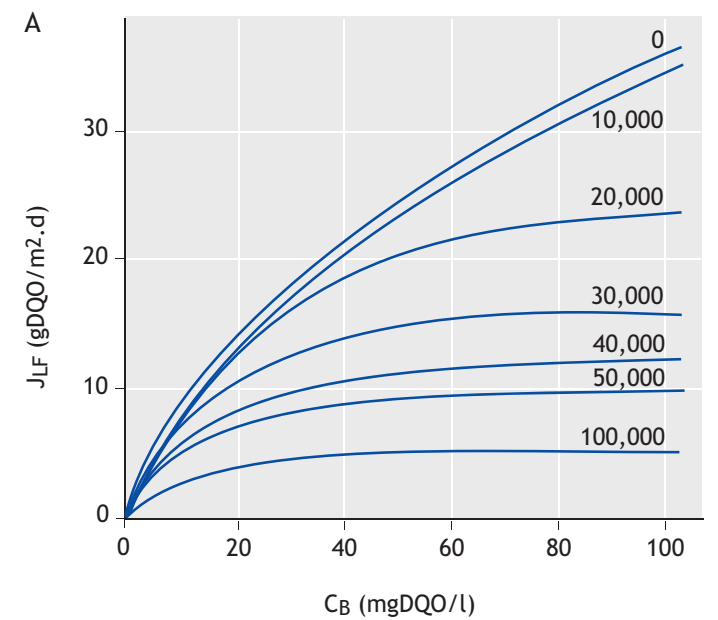

velocidades de desprendimiento, asumiendo una cinética de Monod en el interior de la biopelícula. Las simulaciones se realizaron utilizando concentraciones de sustrato en la solución que variaban entre 0.5 a 100 mg/l y para cinéticas de desprendimiento de:

$u_{d, S}=k_{d} L_{F}^{2}$

con un coeficiente de desprendimiento $\mathrm{k}_{\mathrm{d}}$ variando entre 0 y 100,000 1/d.m. En la Figura 17.15 se muestran los flujos de sustrato y espesores de la biopelícula para diferentes concentraciones de sustrato en solución; cada línea representa un valor diferente de $\mathrm{k}_{\mathrm{d}}$. Se puede observar que al aumentar los valores de los coeficientes de desprendimiento, $\mathrm{k}_{\mathrm{d}}$, tanto el flujo de sustrato como el espesor de la biopelícula disminuyen, mientras que, ambos valores aumentan con el aumento de las concentraciones de sustrato en la solución. Esta interdependencia entre el flujo de sustrato y el espesor de la biopelícula también se presenta en la Figura 17.16.

Los flujos de sustrato se obtuvieron para diferentes espesores de biopelícula fijados y cada una de las líneas de la Figura 17.16 representa una concentración diferente en la solución. Para biopelículas muy delgadas, un aumento en el espesor de la misma incrementará el flujo de sustrato -las conversiones de sustrato en biopelículas muy delgadas se encuentran limitadas por la biomasa. Para biopelículas relativamente muy delgadas, el espesor de la biopelícula tiene únicamente una influencia limitada en los flujos de sustrato. Al incrementar el espesor de la biopelícula se incrementa el flujo de sustrato únicamente si las concentraciones de sustrato en

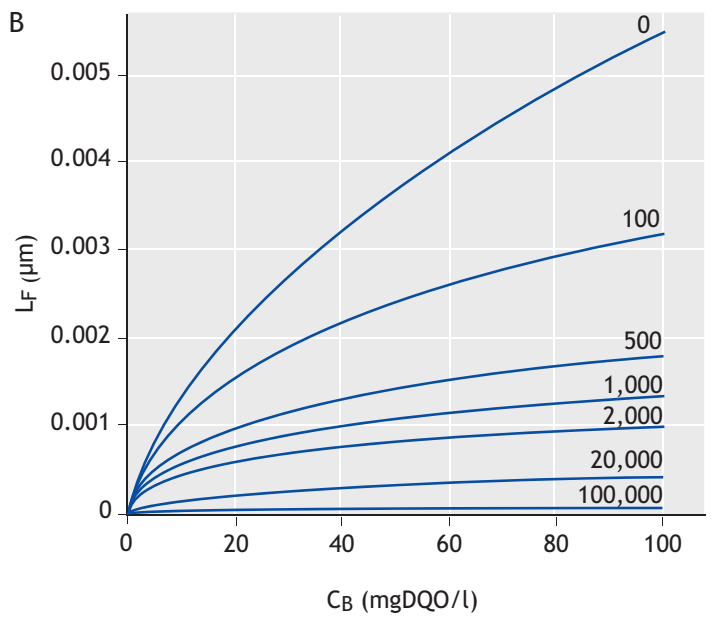

Figura 17.15 Influencia de la concentración de sustrato en la solución y coeficiente de desprendimiento en el flujo de sustrato (izquierda) y espesor de la biopelícula (derecha). Los números en el gráfico son los valores de $k_{d}$ en la Ec. 17.71. Las unidades para $k_{d}$ son $1 / m . d$. El modelo de la biopelícula incluye el consumo del sustrato y el crecimiento utilizando los parámetros que se encuentran en la Tabla 17.12 
solución son suficientemente altas, de tal manera que, el sustrato pueda penetrar hasta el fondo de la biopelícula.

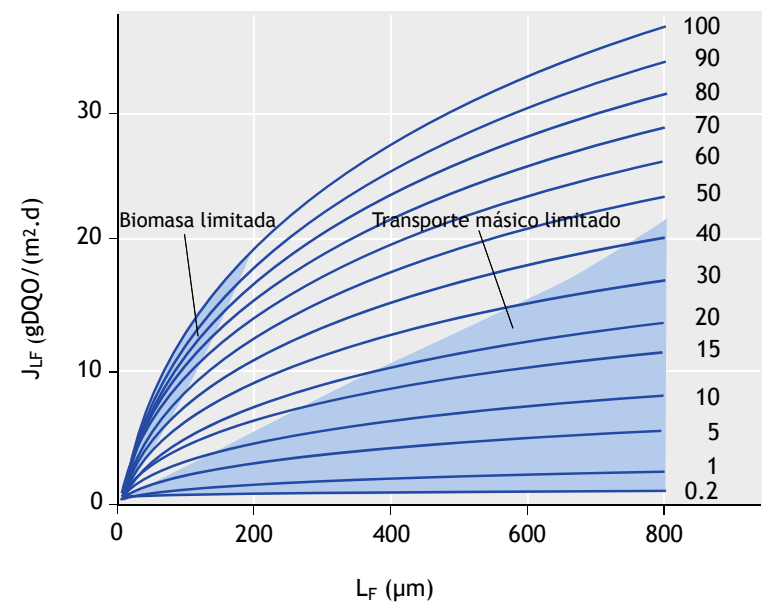

Figura 17.16 Influencia del espesor de la biopelícula en el flujo de sustrato para diferentes concentraciones de éste en la solución (los números en el gráfico se encuentran en $\mathrm{mg} / \mathrm{l}$ ). Se observan dos áreas diferentes: las biopelículas delgadas pueden estar limitadas por el sustrato, en donde al aumentar su espesor se obtendrá un aumento significativo del flujo de sustrato. Para las biopelículas gruesas, un aumento en el espesor de la biopelícula no aumenta significativamente el flujo de sustrato, debido a que el consumo del sustrato en la biopelícula se encuentra limitado por la transferencia de masa y las regiones más bajas de la biopelícula no se encontrarán activas. El consumo de sustrato en la biopelícula se modeló utilizando una cinética de Monod y los parámetros que se muestran en la Tabla 17.12

\subsection{PARÁMETROS DERIVADOS}

\subsubsection{Tiempo de retención de sólidos}

Para plantas de tratamiento de lodos activados, el tiempo de retención del lodo (sólidos, TRL) es un parámetro clave en el diseño y operación. El tiempo de retención de los sólidos puede ser utilizado para calcular las concentraciones de sustrato en el efluente, la cantidad de biomasa en el sistema, y el rendimiento promedio. ¿Hasta qué punto este concepto del tiempo de retención de sólidos puede ser utilizado en los sistemas de biopelículas? En un sistema de lodos activados, la eliminación de los sólidos es un proceso estocástico, en donde se eliminan flóculos de las descargas de lodos y del efluente secundario de manera aleatoria. Por lo tanto, el tiempo de retención de sólidos representa el tiempo promedio que una partícula permanece en el sistema. La eliminación de biomasa en la biopelícula no es un proceso aleatorizado, debido a que durante el desprendimiento se eliminan partículas preferentemente de la superficie de la biopelícula mientras que las partículas que se encuentran en el fondo estarán más protegidas. Por lo cual, no se puede aplicar de manera directa el concepto de tiempo de retención de sólidos en las biopelículas.

En el caso de biopelículas con múltiples grupos de organismos compitiendo por el sustrato y el espacio disponibles en el interior de la misma, los diferentes tiempos de retención que resultan de un desprendimiento preferencial de la superficie de la biopelícula, tienen una influencia significativa en la competencia entre grupos de microorganismos y por lo tanto, el realizar un cálculo del tiempo de retención de sólidos no es de utilidad (Morgenroth, 2003; Morgenroth y Wilderer, 2000). Sin embargo, en el caso de una biopelícula homogénea, con un solo tipo de microorganismos, el cálculo del tiempo de retención permite realizar una comparación entre diferentes condiciones de crecimiento en los sistemas de lodos activados. El tiempo de retención promedio de sólidos en los sistemas de biopelículas se define como:

$$
\begin{aligned}
T R L & =\frac{\text { masa promedio de la biopelícula }}{\text { tasa promedio de desprendimiento de la biopelícula }} \\
& =\frac{L_{F} X_{F}}{u_{d, S} X_{F}}
\end{aligned}
$$

La definición del TRL se puede combinar con el balance de masa para conocer el desarrollo promedio de la biopelícula (Ec. 17.64). Asumiendo estado estacionario, la Ec. 17.64 se puede reacomodar de la siguiente manera:

$u_{d, S}=\frac{Y \cdot J_{L F}}{X_{F}}-b_{\text {ina }} L_{F}$

la cual puede ser sustituida en la Ec. 17.72 para dar como resultado:

$$
T R L=\frac{L_{F}}{\frac{Y J_{L F}}{X_{F}}-b_{\text {ina }} L_{F}}=\frac{1}{\frac{Y J_{L F}}{X_{F} L_{F}}-b_{\text {ina }}}
$$

De la Ec. 17.74 se puede observar que el TRL aumenta cuando decrece el flujo de sustrato y aumenta el espesor de la biopelícula. Indirectamente, el TRL es influenciado por las concentraciones presentes en la fase en solución (al disminuir las concentraciones de la solución se obtiene como resultado la disminución de los flujos de sustrato) y el desprendimiento de la biopelícula (la disminución del desprendimiento resulta en 
biopelículas más densas). Nuevamente se debe tomar en cuenta que la Ec. 17.76 está basada en la suposición de estado estacionario, donde el crecimiento de la biopelícula se encuentra balanceado por el desprendimiento.

El lector debe de observar que el TRL se interpreta de manera diferente en los sistemas de lodos activados y los sistemas de biopelículas. En los sistemas de lodos activados, cada uno de los flóculos tiene la misma probabilidad de ser eliminado durante la descarga del lodo de desecho. En las biopelículas, la probabilidad de eliminación a través del desprendimiento es significativamente mayor en la superficie de la biopelícula en comparación con el fondo de la misma. El valor del TRL calculado de la Ec. 17.76, generará el tiempo de retención promedio de sólidos, mientras que, también es posible calcular el tiempo de retención de sólidos para diferentes zonas en el interior de la biopelícula (Morgenroth y Wilderer, 2000). Los tiempos de retención de sólidos en el fondo de la biopelícula serán mayores que el promedio general, esto ayudará a que se formen nichos ecológicos para bacterias de crecimiento lento. Un ejemplo de este tipo de bacterias son las bacterias nitrificantes, tal y como se discute en el ejemplo de la sección 17.9. Además, se ha sugerido que el fondo de la biopelícula, puede ser también un nicho ecológico para organismos especializados que puedan degradar compuestos xenobióticos difícilmente biodegradables.

Ejemplo 17.5: Tiempo de retención de sólidos para una biopelícula asumiendo una cinética de Monod

Se realizaron simulaciones utilizando AQUASIM para calcular el TRL a diferentes concentraciones de sustrato en solución y espesores de la biopelícula, con base en la simulación de las tasas de desprendimiento $\left(\mathrm{u}_{\mathrm{d}, \mathrm{S}}\right)$ y utilizando la Ec. 17.74. En la Figura 17.17 se observa que el TRL aumenta al disminuir las concentraciones del sustrato en la solución. Las diferentes líneas de la Figura 17.17, representan diferentes espesores de la biopelícula, en donde el TRL es mayor cuando el espesor de la biopelícula es mayor. El efecto de las diferentes concentraciones de sustrato en la solución, el espesor de la biopelícula, y la tasa de desprendimiento son similares tal y como se discutió en la Ec. 17.74 mencionada con anterioridad.



Figura $\mathbf{1 7 . 1 7}$ Influencia de la concentración de sustrato en la solución y el espesor de la biopelícula (líneas en el gráfico) en el cálculo del TRL utilizando la Ec. 17.74 asumiendo un espesor de la biopelícula constante e incluyendo los procesos de crecimiento, decaimiento, y desprendimiento. El consumo del sustrato y el crecimiento de la biopelícula se modelaron utilizando una cinética de Monod (Tabla 17.2) y con los parámetros encontrados en la Tabla 17.12

\subsubsection{Concentración baja de sustrato en el efluente relacionada con el crecimiento de la biomasa $\left(C_{\min }\right)$}

Las diferentes concentraciones de sustrato presentes en el efluente de un reactor de biopelícula dependerán de la disponibilidad de una cantidad suficiente de biomasa en la superficie de la biopelícula y de las condiciones de operación del reactor. Las concentraciones de sustrato en el efluente para reactores CSTR (reactores completamente mezclados), al igual que los reactores de biopelícula, se discutieron en la sección 17.4. Sin embargo, en esta sección se consideró un espesor fijo de la biopelícula como el modelo de entrada, independientemente de los procesos de decaimiento y desprendimiento de la biopelícula. La pregunta a discutir a continuación, es ¿cuál será la mínima concentración en el efluente que se puede obtener en un reactor CSRT?, suponiendo las siguientes condiciones: (i) el desprendimiento de la biopelícula puede considerarse despreciable $\left(\mathrm{u}_{\mathrm{d}, \mathrm{S}}=0\right)$, (ii) el crecimiento de la biopelícula puede ser descrito de acuerdo a una cinética de Monod, (iii) el decaimiento se describe como una cinética de primer orden $\left(\mathrm{b}_{\mathrm{ina}} \mathrm{X}_{\mathrm{F}}\right)$, (iv) las tasas de flujo del afluente son muy bajas lo cual genera una biopelícula muy delgada, en donde se pueden despreciar las limitaciones en la transferencia de masa. 
Despreciando el desprendimiento y asumiendo estado estacionario, la Ec. 17.64 puede simplificarse como:

$0=\frac{Y \cdot J_{L F}}{X_{F}}-b_{\text {ina }} L_{F}$

El flujo de sustrato en la biopelícula, despreciando las limitaciones del transporte de masa y asumiendo una cinética de Monod es:

$J_{L F}=\frac{1}{Y} \mu_{\max } \frac{C_{L F}}{K_{S}+C_{L F}} X_{F} L_{F}$

Combinando la Ec. 17.77 y la Ec. 17.78 da como resultado la concentración mínima de sustrato necesaria para el crecimiento de la biopelícula $\left(\mathrm{C}_{\min }\right)$ :

$C_{\min }=\frac{K_{S} b_{\text {ina }}}{Y \mu_{\max }-b_{\text {ina }}}$

Se ha demostrado de manera experimental que el concepto de $\mathrm{C}_{\min }$ (Rittmann y McCarty, 1980), tiene implicaciones prácticas en la eliminación de contaminantes a concentraciones muy bajas (Rittmann, 1982a), y el valor de $\mathrm{C}_{\min }$ puede ser utilizado con un factor de escalamiento para la obtención de soluciones pseudo-analíticas (Rittmann y McCarty, 2001; Saez y Rittmann, 1992; Wanner et al., 2006).

\subsubsection{Tiempos característicos y números adimensionales que describen la dinámica de las biopelículas}

Los procesos en las biopelículas pueden ocurrir a diferentes escalas de tiempo. Los procesos de crecimiento ocurren en escalas en el orden de horas a días, mientras que, los procesos de difusión e hidrodinámicos se encuentran en el orden de segundos a minutos (Esener et al., 1983; Gujer y Wanner, 1990; Kissel et al., 1984; Picioreanu et al., 2000). Este concepto de los tiempos característicos es de utilidad cuando se evalúa qué tan rápido se puede lograr la estabilidad de un sistema, como base para definir los parámetros adimensionales, y cuando se implementan soluciones numéricas para modelar las biopelículas.

El concepto de tiempos característicos puede ser explicado utilizando un ejemplo sencillo. Para una reacción de primer orden, la ecuación del balance de masa para la degradación del sustrato Cs en un proceso operado en modo semicontinuo es: $\frac{d C_{S}}{d t}=-k_{1} \cdot C_{S}$

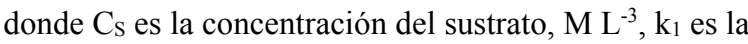
constante cinética de primer orden, $\mathrm{T}^{-1}, \mathrm{y} \mathrm{t}=$ tiempo, $\mathrm{T}$. Resolviendo la Ec. 17.80 con $\mathrm{C}_{\mathrm{S}}(\mathrm{t}=0)=\mathrm{C}_{\mathrm{S}, 0}$ resulta:

$\frac{C_{S}(t)}{C_{S, 0}}=e^{-k_{l} \cdot t}$

Con base en la Ec. 17.81, el tiempo característico de la reacción de primer orden $\left(\tau_{\text {reacción, } 1}\right)$ se puede definir como:

$\tau_{\text {reacción,l }}=\frac{1}{k_{1}}$

Observe que para una reacción de primer orden, esta selección del tiempo característico resulta en $\mathrm{Cs}_{\mathrm{S}}(\mathrm{t}=\tau)=$ $\exp (-1) \cdot \mathrm{C}_{\mathrm{s}, 0}=36.8 \% \cdot \mathrm{C}_{\mathrm{S}, 0}$. Sin embargo, no existe nada especial en el valor de $36.8 \%$ (existen algunos otros); simplemente resulta conveniente matemáticamente (Clark 1996). Por ejemplo, el tiempo característico para una reacción de orden cero $\tau_{\text {reacción, }, 0}$ corresponde a $\mathrm{Cs}_{\mathrm{s}}(\mathrm{t}=\tau)$ $=0$ en una reacción en lote. La escala de tiempo es simplemente la medida de la velocidad con la que se llevará a cabo el proceso. En la Tabla 17.5, se enlistan los tiempos característicos para los diferentes procesos considerados de importancia, para la descripción de una biopelícula. En la Figura 17.18 se encuentran los intervalos típicos.

Como se puede observar para el proceso de crecimiento, existen diferentes maneras de definir los tiempos característicos con base en la tasa de crecimiento máximo ( $\left.\tau_{\text {crecimiento }}\right)$ o una aproximación de la tasa de crecimiento real del sistema $\left(\tau_{\text {crecimiento }}{ }^{*}\right)$. Debido a que no existen reglas estrictas que definan los tiempos característicos, es responsabilidad del usuario el entender los aspectos básicos de cómo y cuándo los tiempos característicos y los números adimensionales (sección 17.7.3.2) se pueden derivar de la información con la que se cuenta y utilizar su buen juicio. 
Tabla 17.5. Tiempos característicos para algunos procesos relevantes en la biopelícula (basado en Clark, 1996; Esener et al., 1983; Gujer y Wanner, 1990; Kissel et al., 1984; Picioreanu et al., 2000)

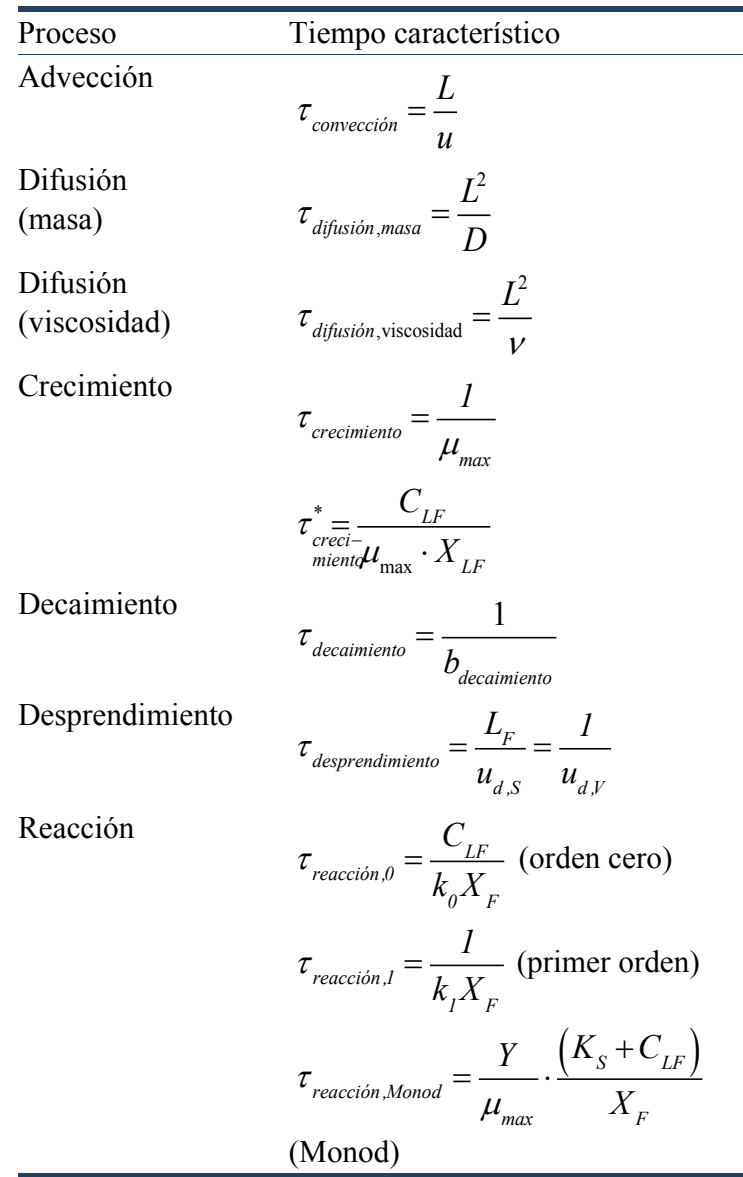

$\mathrm{L}=$ distancia característica $(\mathrm{L}), \mathrm{u}=\operatorname{velocidad}\left(\mathrm{L} \mathrm{T}^{-1}\right), \mathrm{D}=$ coeficiente de difusión $\left(\mathrm{L}^{2} \mathrm{~T}^{-1}\right), v=\operatorname{viscosidad}\left(\mathrm{L}^{2} \mathrm{~T}^{-1}\right), \mathrm{k}_{0}, \mathrm{k}_{1}=$ tasas volumétricas de reacción para orden cero y primer orden $(\mathrm{M}$ $\mathrm{L}^{-3} \mathrm{~T}^{-1} \mathrm{y} \mathrm{T}^{-1}$, respectivamente), $\mathrm{b}_{\text {decaimiento }}=$ coeficiente de decaimiento $\left(\mathrm{T}^{-1}\right), \mu, \mu_{\max }=$ tasa de crecimiento máxima $\left(\mathrm{T}^{-1}\right), \mathrm{Y}=$ coeficiente de rendimiento $\left(\mathrm{M} \mathrm{M}^{-1}\right), \mathrm{C}_{\mathrm{LF}}, \mathrm{X}_{\mathrm{F}}=$ concentración de sustrato y biomasa $\left(\mathrm{M} \mathrm{L}^{-3}\right), \mathrm{K}_{\mathrm{S}}=$ constante media de saturación de sustrato de Monod, $\left(\mathrm{M} \mathrm{L}^{-3}\right)$

\subsubsection{Aplicación de los tiempos característicos para la estimación de los tiempos de respuesta}

Cuando se corre un modelo de biopelícula, se debe de definir la escala de tiempo de interés $\left(\tau_{0}\right)$. Todos los procesos que tienen escalas de tiempo más pequeñas que $\tau_{0}$ (es decir, procesos rápidos) pueden ser considerados como procesos de pseudo estado estacionario. Los procesos con mucho mayores escalas de tiempo (es decir, procesos lentos) pueden ser descritos como si estuvieran "detenidos" en el tiempo (Picioreanu et al., 2000; Wanner et al., 2006). Así pues, para aquellos experimentos que se realizan en pocas horas, los perfiles de concentración de sustrato pueden ser considerados como estado estacionario $\tau_{\text {difusión }}<<\tau_{0}$. Sin embargo, algunos cambios en el espesor de la biopelícula pueden considerarse despreciables $\tau_{\text {crecimiento }} \gg \tau_{0}$. Sin embargo, cuando se evalúa el desarrollo de la biopelícula sobre periodos de tiempo de semanas, entonces, el crecimiento de esta puede considerarse explícito, como $\tau_{\text {crecimiento }}$ siendo del mismo orden que $\tau_{0}$. Un resumen de los tiempos característicos de los sistemas de biopelícula en general y para el ejemplo de la Figura 17.8 en específico, se encuentran en la Figura 17.18.

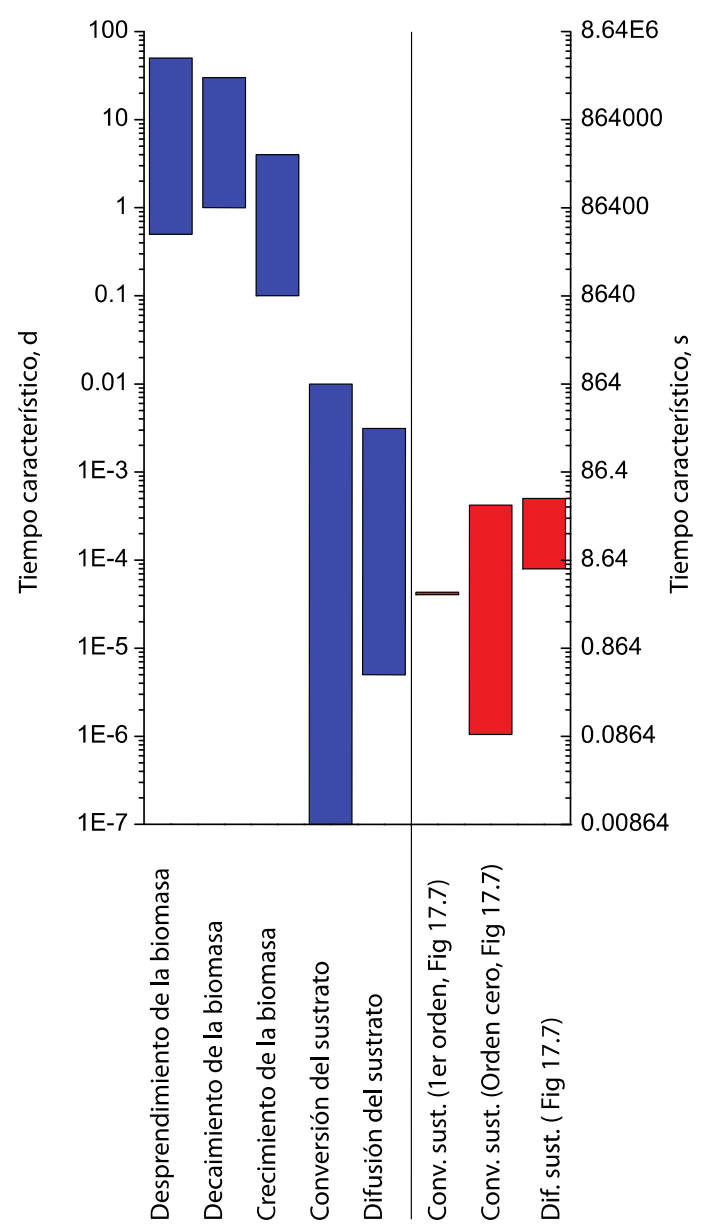

Figura 17.18 Tiempos característicos para parámetros típicos de las biopelículas calculados de la Tabla 17.5 (las columnas azules se basan en Kissel et al., 1984; Picioreanu et al., 2000). Además, se calcularon los tiempos característicos para conversiones de sustrato de orden cero y primer orden, utilizando los parámetros de la Figura 17.8 y asumiendo $L_{F}=80-200 \mu m$ y $C_{L F}=0.1-40 \mathrm{mg} / \mathrm{l}$ (columnas rojas) 
Crank (1975) demostró que para la difusión de un sustrato soluble en la biopelícula (en una superficie plana) el tiempo requerido para aproximarse al estado

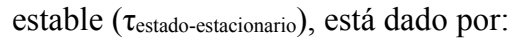

$\tau_{\text {estado-estacionario }}=0.45 \cdot \tau_{\text {difusión,masa }}$

Asumiendo un coeficiente de difusión $\mathrm{D}_{\mathrm{F}}=8 \times 10^{-5}$ $\mathrm{m}^{2} / \mathrm{d}$ (para el acetato) y $\mathrm{L}_{\mathrm{F}}=500 \mu \mathrm{m}$, se encuentra que el tiempo requerido para aproximarse al estado estacionario es de $4.5 \mathrm{~min}$, utilizando la Ec. 17.83. Observe que este tiempo para lograr el estado estacionario en la biopelícula, es independiente de que el consumo de sustrato se encuentre limitado por la difusión o no. Las escalas de tiempo para que los microorganismos se aproximen al estado estacionario en el interior de la biopelícula $\left(\tau_{\text {crecimiento }} \mathrm{o} \tau_{\text {crecimiento }}{ }^{*}\right)$ son mucho mayores, encontrándose en el intervalo de días o semanas. La competencia en el interior de ella es un proceso inclusive más lento, debido a que se basa en el diferencial de la tasa de crecimiento de los organismos $\mathrm{A}\left(\mu_{\mathrm{A}}\right)$ y organismos $\mathrm{B}$ $\left(\mu_{\mathrm{B}}\right)$ dentro de la biopelícula $\left(\tau_{\Delta \text {-crecimiento }}=\left(\mu_{\mathrm{A}}-\mu_{\mathrm{B}}\right)^{-1}\right)$.

\subsubsection{Parámetros adimensionales:}

Número de Damköhler (Da"), Módulo de Thiele (Ф), Parámetro de Crecimiento (G)

El comparar los valores de los tiempos característicos para procesos acoplados permite estimar cuál de estos procesos resulta ser limitante para la velocidad de reacción y cuál de ellos puede ser despreciado. Un ejemplo es el acoplamiento de la reacción y difusión del sustrato en la biopelícula. Asuma, por ejemplo, que para una biopelícula determinada el tiempo característico de conversión de sustrato $\left(\tau_{\text {reacción }}\right)$ es pequeño (es decir, la reacción es muy rápida), mientras que el tiempo característico para la difusión ( $\left.\tau_{\text {difusión }}\right)$ es grande (es decir, la difusión es lenta). Si el tiempo de difusión es más pequeño que el tiempo de reacción, se puede asumir que éste último es el limitante para el proceso. En el caso de conversiones de sustrato que siguen una cinética de orden cero $\left(\mathrm{r}_{\mathrm{F}}=\mathrm{k}_{0, \mathrm{~F}} \mathrm{X}_{\mathrm{F}}\right.$, Ec. 17.1), entonces la relación entre $\tau_{\text {difusión } \mathrm{y}} \tau_{\text {reacción }}$ en la biopelícula se define como:

$\frac{\tau_{\text {difusión }}}{\tau_{\text {reacción }}}=\frac{L_{F}^{2}}{D_{F}} \cdot \frac{k_{0} X_{F}}{C_{L F}}$

En la literatura de ingeniería química, esta relación de los tiempos característicos de la Ec. 17.84, se conoce como el segundo número de Damköhler $\left(\mathrm{Da}^{\mathrm{II}}\right)$ (Boucher y Alves, 1959):
$D a^{I I}=\frac{L_{F}{ }^{2}}{D_{F}} \cdot \frac{k_{0} X_{F}}{C_{L F}}$

Para una difusión limitada en la biopelícula (gruesa), $\mathrm{Da}^{\mathrm{II}}>>1$; para una reacción limitada en la biopelícula (delgada), $\mathrm{Da}^{\mathrm{II}}<<1$. Comparando $\mathrm{Da}^{\mathrm{II}}$ con la solución explícita para una biopelícula con una cinética de reacción de orden cero (Tabla 17.3), se puede observar que $\mathrm{Da}^{\mathrm{II}}$ se encuentra directamente relacionado con la penetración del sustrato en la biopelícula $(\beta)$ :

$\beta=\sqrt{\frac{2}{D a^{I I}}}$

Con base en la Ec. 17.86 una biopelícula con difusión limitada $\mathrm{Da}^{\mathrm{II}}>>1$ tiene un valor de $\beta<<1$. Esto tiene sentido, ya que, en una biopelícula limitada por la difusión, únicamente se lleva a cabo la penetración parcial del sustrato. Observe que al utilizar los tiempos característicos, podemos evaluar si el proceso limitante es la difusión o la reacción sin necesidad de resolver explícitamente las ecuaciones diferenciales. El segundo número de Damköhler se encuentra relacionado con otro parámetro adimensional, el Módulo de Thiele $(\Phi)$ que se define como:

$\Phi=\sqrt{D a^{I I}}=\frac{\sqrt{2}}{\beta}$

Picioreanu et al. (1998) adicionaron el parámetro de crecimiento $(\mathrm{G})$ en su estudio, evaluando con ello la influencia de la difusión local del sustrato y las velocidades de crecimiento en el desarrollo de biopelículas con una estructura multi-dimensional. La definición de $\mathrm{G}$ es:

$G=\frac{\tau_{\text {difusión }}}{\tau_{\text {crecimiento }}^{*}}$

en donde utilizamos la definición de $\tau_{\text {crecimiento }}{ }^{*}$ (Tabla 17.5) de:

$\tau_{\substack{\text { creci-i } \\ \text { miento }}}^{*} \mu_{\max } \cdot X_{L F}$

Combinando la Ec. 17.88 con la Ec. 17.89 y la

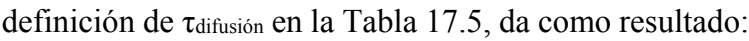

$G=\frac{L_{F}{ }^{2}}{D_{F}} \cdot \frac{\mu_{\max } X_{L F}}{C_{L F}}$ 
Observe que $\mathrm{G}$ es idéntico a $\mathrm{Da}^{\mathrm{II}}$, excepto cuando se utiliza para la velocidad de crecimiento máximo $\left(\mu_{\max }\right)$ en lugar de la constante de eliminación de sustrato de orden cero (k0). Picioreanu et al. (1998) fueron capaces de demostrar, utilizando los modelos matemáticos multidimensionales, que para el crecimiento con sustrato limitado en la biopelícula y valores muy altos del número $\mathrm{G}$ (por ej., $\mathrm{G}>20$ ), se desarrolla una biopelícula porosa con varios canales y espacios vacíos. Para biopelículas con crecimiento limitado y para valores pequeños del número $\mathrm{G}$ (por ej., $\mathrm{G}<7$ ), se desarrollan biopelículas compactas y densas.

Se pueden aprender dos lecciones de los diferentes parámetros adimensionales presentados con anterioridad ( $\left.\mathrm{Da}^{\mathrm{II}}, \beta, \Phi, \mathrm{y} \mathrm{G}\right)$. La primera de ellas es que, no existe una manera única de definir los parámetros adimensionales, ya que estos cuatro números se relacionan con la difusión del sustrato y los procesos metabólicos de la biopelícula; sin embargo, también presentan ciertas diferencias en su definición. La segunda es que, los parámetros adimensionales pueden servir para múltiples propósitos, por ejemplo, para predecir la forma en la que se lleva a cabo la difusión en la biopelícula, para diferenciar los diferentes regímenes limitantes de difusión y reacción, y para la predicción de la estructura de la biopelícula.

\section{Número de Biot (Bi)}

Otro ejemplo de parámetro adimensional que puede derivarse de la relación entre los tiempos característicos, es el número de Biot $(\mathrm{Bi})$ :

$$
B i=\frac{\tau_{\text {difusión,niterna }}}{\tau_{\text {reacción,externa }}}=\frac{L_{l}^{2}}{D f} \cdot \frac{D w}{L_{l}^{2}}
$$

donde $\tau_{\text {difusión,interna }}\left(=\mathrm{LF}^{2} / \mathrm{D}_{\mathrm{F}}\right)$, es el tiempo característico para la difusión en el interior de la biopelícula, mientras que, $\tau_{\text {difusión,externa }}\left(=\mathrm{L}_{\mathrm{L}}{ }^{2} / \mathrm{D}_{\mathrm{W}}\right)$, es el tiempo característico para la difusión en la capa límite externa de concentración. Si la difusión en el interior de la biopelícula es más rápida que en la capa límite de concentración (es decir, $\mathrm{Bi}<<1$ ), entonces, para una difusión limitada de la biopelícula, se esperaría que la resistencia externa a la transferencia de masa se encuentre limitando los procesos de conversión globales en el interior de la misma.
Número de Peclet $(P e)$

El número de Peclet $(\mathrm{Pe})$, se puede utilizar para comparar el tiempo característico de la difusión con el tiempo característico para la advección:

$P e=\frac{\tau_{\text {difusion }}}{\tau_{\text {advección }}}=\frac{L^{2} u}{D L}$

El número de Peclet se utiliza por lo general para evaluar el grado de dispersión axial en estudios de reactores - la difusión en dirección con el flujo de agua con respecto al transporte fluyendo a través del reactor. Con $\mathrm{Pe}>>1$, el transporte de difusión es más pequeño en comparación con la advección global. Cuando se utiliza el número de Peclet, ¿qué longitud, L, deberá de utilizarse en la Ec. 17.92? En el caso de comparar el transporte por advección con el de difusión a lo largo de la longitud del reactor, la longitud a utilizar será la correspondiente a la longitud total del reactor. Otra aplicación del número de Peclet, es la de evaluar la importancia relativa de la difusión y advección en una biopelícula porosa, que permita el flujo de cierta cantidad de agua a través de ella (Libicki et al., 1988). En este caso, la longitud característica será el espesor de la biopelícula. Este ejemplo de dos escalas de longitud muy diferentes, que se pueden utilizar en la Ec. 17.81, demuestra que siempre existen algunas opciones disponibles para definir los tiempos característicos y los parámetros adimensionales. No existen reglas específicas para la elección de las opciones apropiadas; sin embargo, la selección deberá basarse en el entendimiento de los principios básicos. El utilizar demasiados parámetros adimensionales se debe a la falta de entendimiento de cómo los procesos que se están comparando en términos de los tiempos característicos se encuentran relacionados uno con el otro. 


\subsection{DIFUSIÓN MULTI-COMPONENTE}

\subsubsection{Difusión de dos componentes, donador y aceptor de electrones}

Los procesos de conversión en una biopelícula, por lo general, requieren de la difusión de un donador de electrones y un aceptor de electrones presentes en la solución. El comparar la penetración relativa del sustrato, del donador y aceptor de electrones en la biopelícula, permite identificar al componente limitante para la conversión total del sustrato. Pueden presentarse tres casos diferentes tal y como se muestra en la Figura 17.19:

- Caso 1: El donador de electrones no penetra completamente la biopelícula y la conversión del sustrato se encuentra limitada por la disponibilidad del donador de electrones en el fondo de la biopelícula.

- Caso 2: El aceptor de electrones no penetra completamente la biopelícula y existe una limitación de la conversión total del sustrato.

- Caso 3: Tanto el donador de electrones como el aceptor de electrones penetran completamente la biopelícula. La conversión del sustrato no se encuentra limitada por la transferencia de masa.
En la sección 17.3.2.2, se discutió la manera en la que el sustrato puede penetrar a la biopelícula, para un solo sustrato y asumiendo una cinética de reacción de orden cero con base en el valor de $\beta$ (Ec. 17.25). La misma estrategia, para el cálculo de la penetración del sustrato, se puede aplicar para un sistema de difusión con dos componentes, donde el valor de $\beta$ se calcula de forma separada para el donador de electrones $\left(\beta_{\text {ed. }}\right)$ y el aceptador de electrones $\left(\beta_{\text {e.a. }}\right)$. Con base en los valores de $\beta_{\text {e.d. }}$ y $\beta_{\text {e.d. }}$ se puede evaluar cuál de los tres casos que aparecen en la Figura 17.19 aplica:

Caso 1: $\beta_{\text {e.d. }}<1$ y $\beta_{\text {e.d. }}<\beta_{\text {e.a. }}$

Caso 2: $\beta_{e . a .}<1$ y $\beta_{e . d .}>\beta_{e . a .}$

Caso 3: $\beta_{\text {e.d. }}>1$ y $\beta_{\text {e.a. }}>1$

Para diferenciar entre el Caso 1 y el Caso 2, existe una manera simple de evaluar explícitamente $\beta_{\text {e.d. }}$ y $\beta_{\text {e.a }}$ por medio del cálculo de las relaciones de $\beta$ 's en lugar de comparar sus valores específicos. Asumiendo que las velocidades de conversión del donador de electrones $\left(\mathrm{r}_{0, \text { e.d. }}\right)$ y aceptor de electrones $\left(\mathrm{r}_{0, \text { e.e. }}\right)$, se encuentran estequiométricamente relacionadas, entonces la velocidad de utilización del donador y aceptor de
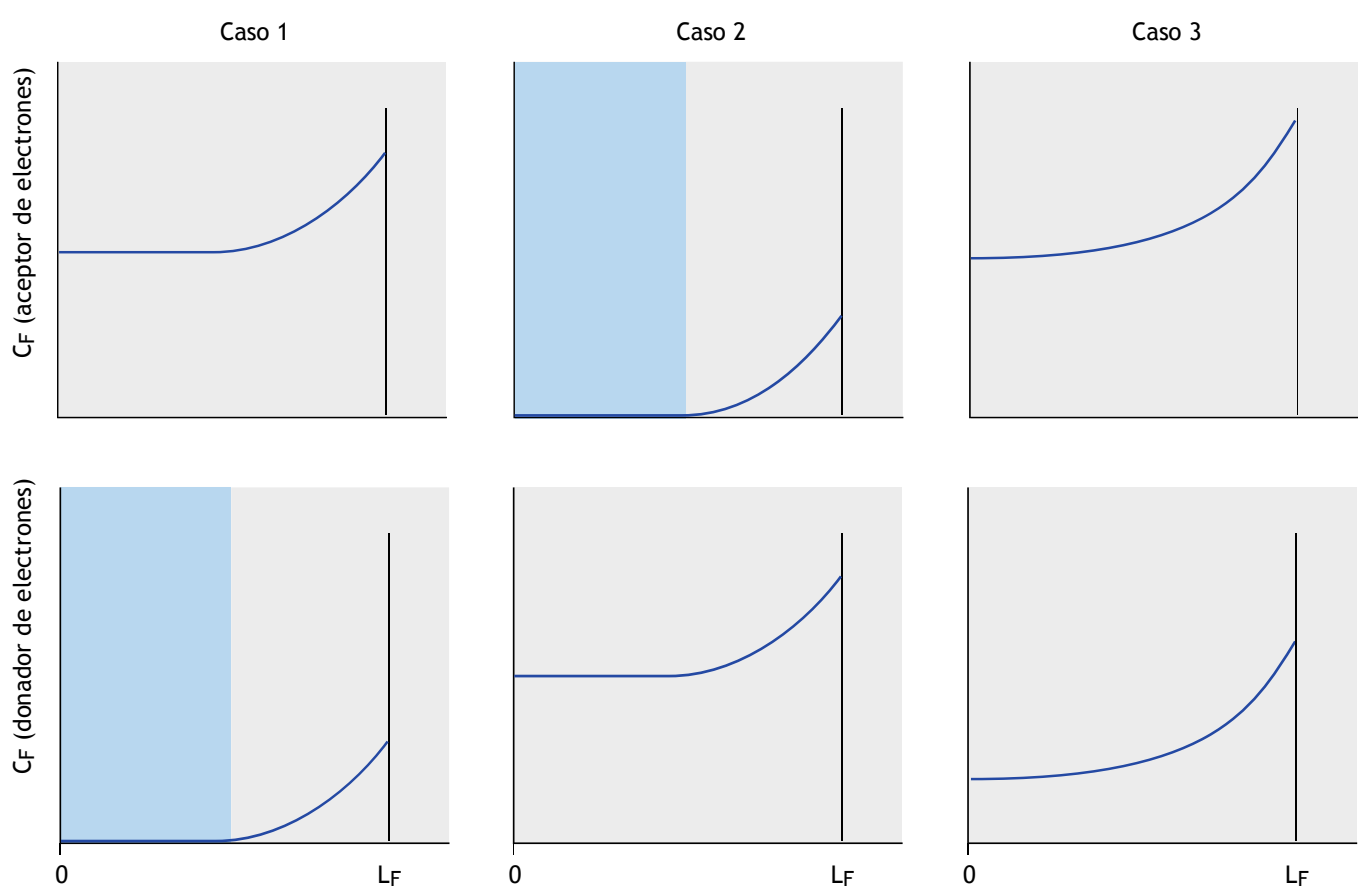

Figura 17.19 Penetración del sustrato en la biopelícula, asumiendo que el donador de electrones es el limitante (Caso 1), que el aceptor de electrones es el limitante (Caso 2), o que ninguno de los dos es limitante (Caso 3). En la zona sombreada de la biopelícula, no se lleva a cabo ninguna conversión de sustrato debido a que el donador o el aceptor de electrones se encuentran limitados (LF es el espesor de la biopelícula) 
electrones en la biopelícula, siguiendo una cinética de orden cero, está dada por:

$r_{0, e . d .}=k_{0, F, e . d .} \cdot X_{F}$

$r_{0, \text { e.a. }}=(\alpha-Y) \cdot k_{0, F, \text { e.d. }} \cdot X_{F}$

en la cual Y es la biomasa producida, $\alpha$ es un factor estequiométrico relacionado con la utilización del donador y aceptor de electrones en la reacción catabólica. Para sustratos orgánicos el valor de $\alpha=1 \mathrm{~g} \mathrm{O}_{2} / \mathrm{g}$ DQO, para nitrificación $\alpha=4.57 \mathrm{~g} \mathrm{O}_{2} / \mathrm{g} \mathrm{N}$. Los valores de $\beta_{\text {e.d. }}$ y $\beta_{\text {e.a. }}$ pueden ser comparados calculando su relación $\left(\gamma_{\text {e.d.e.e.a. }}\right)$ :

$\gamma_{\text {e.d.e.a. }}=\frac{\beta_{e . d .}}{\beta_{e . a .}}$

Sustituyendo los $\beta$ 's en la Ec. 17.96 utilizando las constantes para una cinética de orden cero de la Ec. 17.94 y 17.95 y la definición de $\beta$ (Ec. 17.25), se obtiene:

$$
\gamma_{\text {e.d.e.a. }}=\frac{\sqrt{\frac{2 D_{F, e . d .} C_{L F, e . d .}}{k_{0, F, e . d .} X_{F} L_{F}{ }^{2}}}}{\sqrt{\frac{2 D_{F, \text { e.a. }} C_{L F, \text { e.a. }}}{(\alpha-Y) k_{0, F, \text { e.d. }} X_{F} L_{F}{ }^{2}}}}
$$

en donde $\mathrm{D}_{\mathrm{F}, \text { e.d. }} \mathrm{y} \mathrm{D}_{\mathrm{F}, \text { e.a. }}$ son los coeficientes de difusión para el donador y aceptor de electrones, $\mathrm{C}_{\mathrm{LF} \text {,e.d. }} \mathrm{y} \mathrm{C}_{\mathrm{LF} \text {,e.a. }}$ son las concentraciones de sustrato en la superficie de la biopelícula, respectivamente. La ventaja de calcular los valores de $\beta$ 's, es aparente en la Ec. 17.97 ya que varios parámetros pueden ser cancelados y la ecuación puede simplificarse obteniéndose:

$$
\gamma_{\text {e.d.,e.a. }}=\sqrt{(\alpha-Y) \frac{D_{F, e . d .} C_{L F, e . d .}}{D_{F, e . a .} C_{L F, e . a .}}}
$$

Utilizando $\gamma_{\text {e.d.,e.a., }}$ pueden diferenciarse los casos $1 \mathrm{y}$ 2:

- Caso 1: $\gamma_{\text {e.d.,e.a. }}<1$ - El donador de electrones se encuentra potencialmente limitado en el interior de la biopelícula; sin embargo, el aceptor de electrones penetrará completamente la biopelícula. Observe que con esto se asume que la conversión en la biopelícula se encuentra limitada por la transferencia de masa.

- Caso 2: $\gamma_{\text {e.d.e.a. }}>1$ - El aceptor de electrones se encuentra potencialmente limitado en el interior de la biopelícula; sin embargo, el donador de electrones penetrará completamente la biopelícula. Observe que con ello se asume que la conversión en la biopelícula se encontrará limitada por el transporte de masa.

La Ec. 17.98 puede ser reacomodada para diferenciar entre el Caso 1 y 2, con base en las concentraciones del donador y aceptor de electrones en la superficie de la biopelícula:

$\frac{C_{L F, \text { e.d. }}}{C_{L F, \text { e.a. }}}<\frac{1}{(\alpha-Y)} \frac{D_{F, \text { e.a. }}}{D_{F, \text { e.d. }}}$

$\Rightarrow$ el donador de electrones está potencialmente limitado (Caso 1)

$\frac{C_{L F, \text { e.d. }}}{C_{L F, \text { e.a. }}}>\frac{1}{(\alpha-Y)} \frac{D_{F, \text { e.a. }}}{D_{F, \text {.e.d. }}}$

$\Rightarrow$ el aceptor de electrones está potencialmente limitado (Caso 2)

Algunos ejemplos de crecimiento heterotrófico en un sustrato orgánico y crecimiento autotrófico en amonio, se pueden encontrar en la Tabla 17.6, así como las condiciones de oxígeno (es decir, aceptor de electrones) o limitaciones del donador de electrones.

Una vez que se conoce cuál es el reactivo limitante en el proceso de conversión en el interior de la biopelícula, ya sea el donador o aceptor de electrones, entonces se puede calcular el flujo de sustrato para el componente limitante utilizando las expresiones cinéticas desarrolladas con anterioridad para un solo sustrato limitante. El flujo de sustrato para el componente en exceso puede calcularse de acuerdo a la estequiometria general:

$$
J_{L F, \text { e.a. }}=(\alpha-Y) J_{L F, \text { e.d. }}
$$

Ejemplo 17.6: flujos de sustrato $\left(J_{\mathrm{LF}}\right)$ y profundidades de penetración $\left(B \cdot L_{F}\right)$ para el crecimiento heterotrófico o autotrófico, asumiendo una cinética de orden cero

El consumo de sustrato se encuentra limitado generalmente por la transferencia de masa. Los flujos de sustrato y la penetración en el interior de la biopelícula, dependen de las concentraciones de sustrato en la superficie de esta, las velocidades de reacción en el interior de la biopelícula, y la difusión del transporte de masa. En la Tabla 17.7 se muestran los flujos de sustrato y las profundidades de penetración $\left(\beta \cdot \mathrm{LF}_{\mathrm{F}}\right)$ para acetato, amonio, y oxígeno, asumiendo un consumo de sustrato de orden cero en una biopelícula parcialmente penetrada. Al comparar las profundidades de penetración de los donadores de electrones (acetato o amonio) y el aceptor de electrones, se demuestra que para la mayoría de las concentraciones del donador de electrones, el consumo 
Tabla 17.6 Cálculo del componente limitante para el crecimiento en un sustrato orgánico o en nitrificación (Los parámetros estequiométricos fueron tomados de la Tabla 17.12, asumiendo que $D_{F}=0.8 \cdot D_{w}, y D_{w}$, corresponden a los valores presentados en la Tabla 17.8)

\begin{tabular}{|c|c|c|}
\hline & Eliminación del sustrato orgánico & Nitrificación \\
\hline Donador de electrones & Sustrato orgánico & $\mathrm{NH}_{4}^{+}$ \\
\hline DF,e.d. & $0.8 \cdot 94.1 \cdot 10^{-6} \mathrm{~m}^{2} / \mathrm{d}$ & $0.8 \cdot 169.1 \cdot 10^{-6} \mathrm{~m}^{2} / \mathrm{d}$ \\
\hline Aceptor de electrones & $\mathrm{O}_{2}$ & $\mathrm{O}_{2}$ \\
\hline DF,e.a. $_{1}$ & $0.8 \cdot 209.1 \cdot 10^{-6} \mathrm{~m}^{2} / \mathrm{d}$ & $0.8 \cdot 209.1 \cdot 10^{-6} \mathrm{~m}^{2} / \mathrm{d}$ \\
\hline$\alpha$ & $1 \mathrm{~g} \mathrm{O}_{2} / \mathrm{g} \mathrm{DQO}$ & $4.57 \mathrm{~g} \mathrm{O}_{2} / \mathrm{g} \mathrm{N}$ \\
\hline Y & $0.4 \mathrm{~g} \mathrm{DQO} / \mathrm{g}$ DQO & $0.22 \mathrm{~g} \mathrm{DQO} / \mathrm{g} \mathrm{N}$ \\
\hline Aceptor de electrones limitante (con base en la Ec. 17.88) & $\frac{C_{L F, S}}{C_{L F, O 2}}>3.7 \mathrm{gCOD} / g \mathrm{O}_{2}$ & $\frac{C_{L F, N H 4-N}}{C_{L F, O 2}}>0.28 \mathrm{gN} / g O_{2}$ \\
\hline $\begin{array}{l}\text { El oxígeno será el limitante (con base en la Ec. } 17.88 \text { ) } \\
\text { asumiendo } C_{\mathrm{LF}, \mathrm{O} 2}=8 \mathrm{mg} / \mathrm{l} \text { y cuando } C_{\mathrm{LF} \text {,e.d. es mayor }}\end{array}$ & $29.6 \mathrm{mg} \mathrm{DQO} / 1$ & $2.3 \mathrm{mg} \mathrm{N} / 1$ \\
\hline
\end{tabular}

se encuentra limitado por la disponibilidad de oxígeno. Además, se vuelve obvio que la penetración en la biopelícula es únicamente de unos cientos micrómetros. Por lo tanto, las biopelículas más espesas (para valores típicos ver la Tabla 17.10), por lo general no son benéficas para los procesos aerobios de la biopelícula.

\subsubsection{Caso general de una difusión multi- componente}

El concepto para la aplicación de $\gamma_{\text {e.d.e.a., puede }}$ expandirse para más de dos componentes. Se debe observar que la Ec. 17.96 se basa únicamente en suponer que se lleva a cabo el transporte de difusión en el interior de la biopelícula y que existe una relación estequiométrica entre la utilización del donador y aceptor de electrones. Así, aun cuando la derivación de la Ec. 17.97 se basó en una cinética de orden cero, el concepto de $\gamma_{\text {e.d.e.a }}$ también puede aplicarse para otras cinéticas de reacción, siempre y cuando las constantes de conversión $\left(\mathrm{r}_{\mathrm{F}, \mathrm{i}}\right)$ se encuentren relacionadas con la misma velocidad total del proceso $(\rho)$ (Gujer y Boller, 1986).

De esta manera, la ecuación puede expresarse como:

$r_{F, i}=v_{i} \cdot \rho$

donde $\rho$ puede ser cualquier función de $\mathrm{C}_{\mathrm{F}, \mathrm{i}} \mathrm{y} v_{\mathrm{i}}$ es el coeficiente estequiométrico para la eliminación del compuesto $\mathrm{C}_{\mathrm{F}, \mathrm{i}}$. (Ec. 17.5).

Tabla 17.7 Profundidad de la penetración y flujo de sustrato estimado para una cinética de reacción de orden cero en la biopelícula, utilizando la Ec. 25 y 27 en la Tabla 17.3 y los parámetros cinéticos de la Tabla 17.12

\begin{tabular}{|c|c|c|c|c|c|}
\hline \multicolumn{6}{|c|}{ Crecimiento heterotrófico } \\
\hline $\begin{array}{l}\mathrm{C}_{\mathrm{B}, \mathrm{O} 2} \\
\mathrm{~g} / \mathrm{m}^{3}\end{array}$ & $\begin{array}{l}\text { Profundidad de la } \\
\text { penetración } \\
\mu \mathrm{m}\end{array}$ & $\begin{array}{l}\mathrm{J}_{\mathrm{LF}, \mathrm{O} 2} \\
\mathrm{~g} / \mathrm{m}^{2} \cdot \mathrm{d}\end{array}$ & $\begin{array}{l}\mathrm{C}_{\mathrm{B}, \mathrm{HAc}} \\
\mathrm{g} \mathrm{DQO} / \mathrm{m}^{3}\end{array}$ & $\begin{array}{l}\text { Profundidad de la } \\
\text { penetración } \\
\mu \mathrm{m}\end{array}$ & $\begin{array}{l}\mathrm{J}_{\mathrm{LF}, \mathrm{HAc}} \\
\mathrm{g} \mathrm{DQO} / \mathrm{m}^{2} . \mathrm{d}\end{array}$ \\
\hline 1 & 68 & 4.9 & 1 & 35 & 4.3 \\
\hline 3 & 118 & 8.5 & 5 & 79 & 9.5 \\
\hline 5 & 153 & 11.0 & 15 & 137 & 16.5 \\
\hline 8 & 193 & 13.9 & 150 & 434 & 52.1 \\
\hline \multicolumn{6}{|c|}{ Nitrificación } \\
\hline $\begin{array}{l}\mathrm{C}_{\mathrm{B}, \mathrm{O} 2} \\
\mathrm{~g} / \mathrm{m}^{3}\end{array}$ & $\begin{array}{l}\text { Profundidad de la } \\
\text { penetración } \\
\mu \mathrm{m}\end{array}$ & $\begin{array}{l}\mathrm{J}_{\mathrm{LF}, \mathrm{O} 2} \\
\mathrm{~g} / \mathrm{m}^{2} \cdot \mathrm{d}\end{array}$ & $\begin{array}{l}\mathrm{C}_{\mathrm{B}, \mathrm{NH} 4} \\
\mathrm{~g} \mathrm{~N} / \mathrm{m}^{3}\end{array}$ & $\begin{array}{l}\text { Profundidad de la } \\
\text { penetración } \\
\mu \mathrm{m}\end{array}$ & $\begin{array}{l}\mathrm{J}_{\mathrm{LF}, \mathrm{NH} 4} \\
\mathrm{~g} \mathrm{~N} / \mathrm{m}^{2} \cdot \mathrm{d}\end{array}$ \\
\hline 1 & 42 & 7.9 & 1 & 79 & 3.4 \\
\hline 3 & 73 & 13.7 & 5 & 177 & 7.6 \\
\hline 5 & 94 & 17.7 & 15 & 307 & 13.2 \\
\hline 8 & 119 & 22.4 & 70 & 662 & 28.6 \\
\hline
\end{tabular}


Combinando con la Ec. 17.1 y asumiendo estado estacionario resulta:

$\rho=\frac{D_{F, 1}}{v_{1}} \frac{\partial^{2} C_{F, 1}}{\partial x^{2}}=\frac{D_{F, 2}}{v_{2}} \frac{\partial^{2} C_{F, 2}}{\partial x^{2}}=\cdots=\frac{D_{F, i}}{v_{i}} \frac{\partial^{2} C_{F, i}}{\partial x^{2}}$

Una relación estequiométrica directa entre los flujos de los diferentes sustratos $\mathrm{C}_{\mathrm{F}, \mathrm{i}}$ con base en la Ec. 17.102 es (Gujer y Boller, 1986):

$$
\frac{J_{L F, 1}}{v_{1}}=\frac{J_{L F, 2}}{v_{2}}=\cdots=\frac{J_{L F, i}}{v_{i}}
$$

La Ec. 17.103 se puede utilizar para el cálculo de los flujos de los componentes en exceso con base en el flujo de sustrato del componente limitante. Esto significa que la Ec. 17.103, es una forma más general de la Ec. 17.100 que genera una relación entre los flujos del aceptor y donador de electrones.

La velocidad del componente limitante puede ser calculada - similar a la estrategia basada en $\gamma_{\text {e.d.e.a. }}$ en la Ec. 17.98- encontrando el componente con el valor más bajo de la siguiente relación (Andrews, 1988; Wanner et al., 2006):

$\frac{D_{F, i} C_{L F, i}}{v_{i}}$

Una vez que se ha calculado el flujo del componente limitante, puede calcularse de manera directa el flujo de los otros componentes utilizando la Ec. 17.103. Observe que una suposición importante para la Ec. 17.103 es el asumir que todos los procesos en la biopelícula se encuentran relacionados estequiométricamente.

\subsubsection{Complicaciones en los procesos múltiples dentro de la biopelícula}

Observe que la obtención de la Ec. 17.100 y Ec. 17.101, se basó en suponer que la utilización del aceptor de electrones se encuentra directamente relacionada con la utilización del donador de electrones y, que algunos procesos de crecimiento como la respiración endógena, en donde los aceptores de electrones pueden ser utilizados, inclusive en ausencia de un donador de electrones, pueden considerarse despreciables. Debido a esta simplificación, el concepto de $\gamma_{\text {e.d.e.a. debe ser }}$ utilizado con precaución para $\gamma_{\text {e.d.e.a. }} \approx 1$ y no se pueden deducir conclusiones claras del sustrato limitante. Para $\gamma_{\text {e.d.e.e.a. }} \approx 1$, se deberá utilizar un modelo multi-sustrato para la evaluación de la biopelícula (Wanner et al., 2006).

\subsection{IMPLICACIONES DE LA DISPONIBILIDAD DEL SUSTRATO EN SUSTRATOS LIMITANTES, COMPETENCIA MICROBIOLÓGICA, Y DESEMPEÑO DEL REACTOR}

Los modelos de la biopelícula utilizados en las secciones anteriores se limitaron a un solo sustrato (secciones 17.3 a 17.6) o para dos sustratos (sección 17.8), para una biopelícula con una fase en solución completamente mezclada. En la práctica, muchos reactores de biopelícula pueden tener condiciones de mezclado que pueden ser mejor descritas por flujo pistón o múltiples compartimentos de reactores de biopelícula conectados en serie (Figura 17.20). En esta sección se realizará una discusión cualitativa de algunos sistemas relevantes. Un análisis detallado de estos sistemas acoplados con múltiples sustratos y múltiples poblaciones de microorganismos se encuentra fuera de los alcances de este libro. Se recomienda al lector que esté interesado, evaluar dichos sistemas utilizando simuladores numéricos.

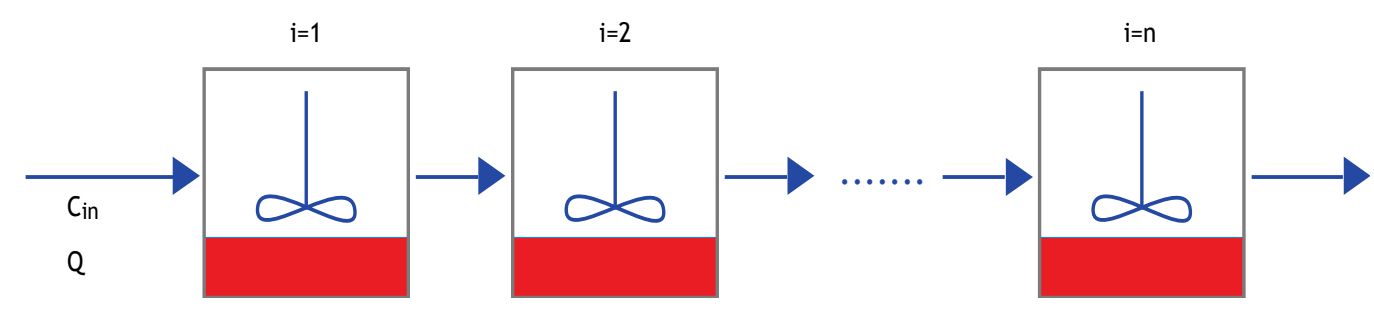

Figura 17.20 Las condiciones de mezclado en muchos reactores de biopelícula puede aproximarse a múltiples compartimentos de biopelículas en serie. 
Ejemplo 17.7: Cambios en el sustrato limitante a lo largo del reactor de biopelícula

Este primer ejemplo evalúa las concentraciones de amonio esperadas a lo largo de un reactor de biopelícula nitrificante. Se considera que el reactor se encuentra en condiciones de mezclado en flujo pistón. El reactor se airea lo cual da como resultado concentraciones constantes de oxígeno a lo largo del mismo. Tal y como se muestra en la Tabla 17.6, el oxígeno actúa como el sustrato limitante cuando las concentraciones de amonio son mayores a $0.27 \mathrm{~g} \mathrm{~N} / \mathrm{g} \mathrm{O}_{2}$. Para concentraciones de oxígeno en solución de $8 \mathrm{mg} \mathrm{O}_{2} / \mathrm{l}$, esto corresponde a concentraciones de amonio de $2.2 \mathrm{mg} \mathrm{N} / \mathrm{l}$. Así, cerca de la entrada, los reactores nitrificantes de biopelícula se encuentran limitados, por lo general, por el oxígeno en lugar del amonio. Para una concentración constante de oxígeno en solución, el flujo correspondiente de amonio en la biopelícula permanece constante, tal y como se muestra en la Figura 17.21.
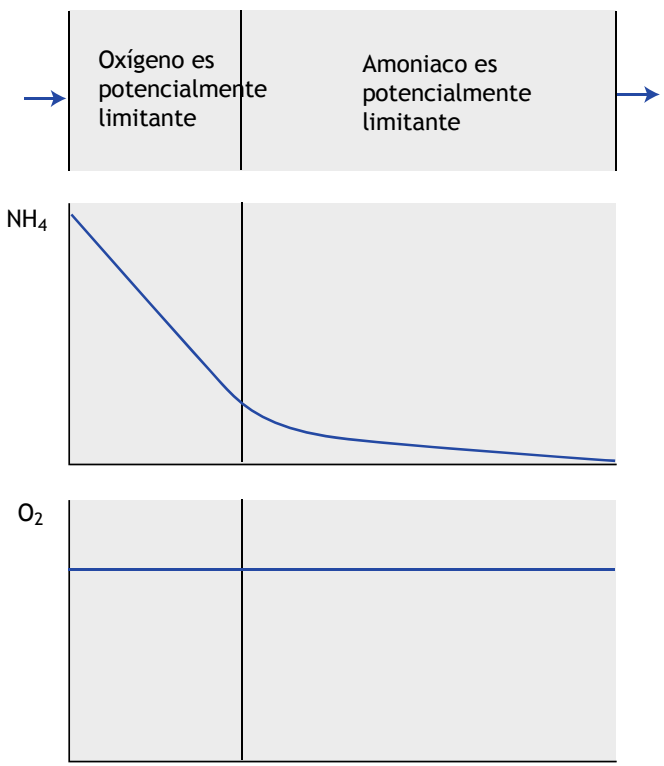

Figura 17.21 Reactor de biopelícula nitrificante con aireación, dando como resultado concentraciones de oxígeno constantes en la fase en solución. Dependiendo de las concentraciones de amonio en solución, el componente limitante se desplazará a lo largo del reactor

Una vez que las concentraciones de amonio en solución han disminuido por debajo de $0.27 \mathrm{~g} \mathrm{~N} / \mathrm{g} \mathrm{O}_{2}$, entonces el componente limitante será el amonio. El flujo de amonio en la biopelícula y el consumo observado se encontrarán entonces en función de las concentraciones de amonio en solución.
Ejemplo 17.8: Procesos heterogéneos en la biopelícula permitiendo procesos paralelos

Este segundo ejemplo evalúa una biopelícula heterogénea que se expone a altas concentraciones de sustrato orgánico y dos diferentes aceptores de electrones: oxígeno y nitrato. Para la mayoría de las bacterias heterotróficas, el oxígeno es el aceptor de electrones ideal y la desnitrificación no ocurrirá en presencia de oxígeno. Las limitaciones de la transferencia de masa en la biopelícula pueden, sin embargo, resultar en diferentes zonas redox en el interior de la misma, con el consumo de sustrato aeróbico en la superficie de la biopelícula y desnitrificación en el fondo de la misma (Figura 17.22).

Los perfiles de concentración de la Figura 17.22 se basan en la suposición de que el sustrato orgánico tiene una penetración mayor en la biopelícula en comparación con el oxígeno (es decir, $\gamma_{\mathrm{DBO}, \mathrm{O} 2 .}>1$ ), dando como resultado el que se genere una zona anóxica en el fondo de la misma. Las bacterias en esta zona anóxica se encuentran expuestas al nitrato como su único aceptor de electrones disponible, dando como resultado la desnitrificación a pesar del incremento de las concentraciones de oxígeno en la fase en solución. Observe que en la Figura 17.22 la concentración de nitrato es una línea recta en la zona aerobia de la biopelícula, ya que este compuesto es transportado únicamente por difusión, pero no es consumido.

Ejemplo 17.9: Competencia entre diferentes grupos de microorganismos por el sustrato y el espacio vacío disponibles en el interior de la biopelícula

Tal y como se mostró en el ejemplo anterior, pueden ocurrir diferentes procesos de conversión en diferentes regiones de la biopelícula, lo cual, como resultado, puede tener una influencia en las comunidades microbianas que se establecerán en las diferentes capas de la biopelícula. Un ejemplo clásico de cómo la disponibilidad del sustrato y las velocidades de crecimiento de los microorganismos pueden influir en la competencia microbiana y el consumo del sustrato, es la competencia entre las bacterias heterótrofas y autótrofas por el oxígeno en la biopelícula (Wanner y Gujer, 1985; Wanner y Gujer, 1986; Wanner y Reichert, 1996).

La predicción de la distribución de las bacterias heterótrofas y autótrofas en las diferentes capas de la biopelícula, requiere de modelos matemáticos de los procesos locales de crecimiento en el interior de la 
biopelícula y únicamente puede ser resuelto utilizando modelos numéricos. A continuación se presentan algunos resultados seleccionados de Wanner y Gujer (1985).
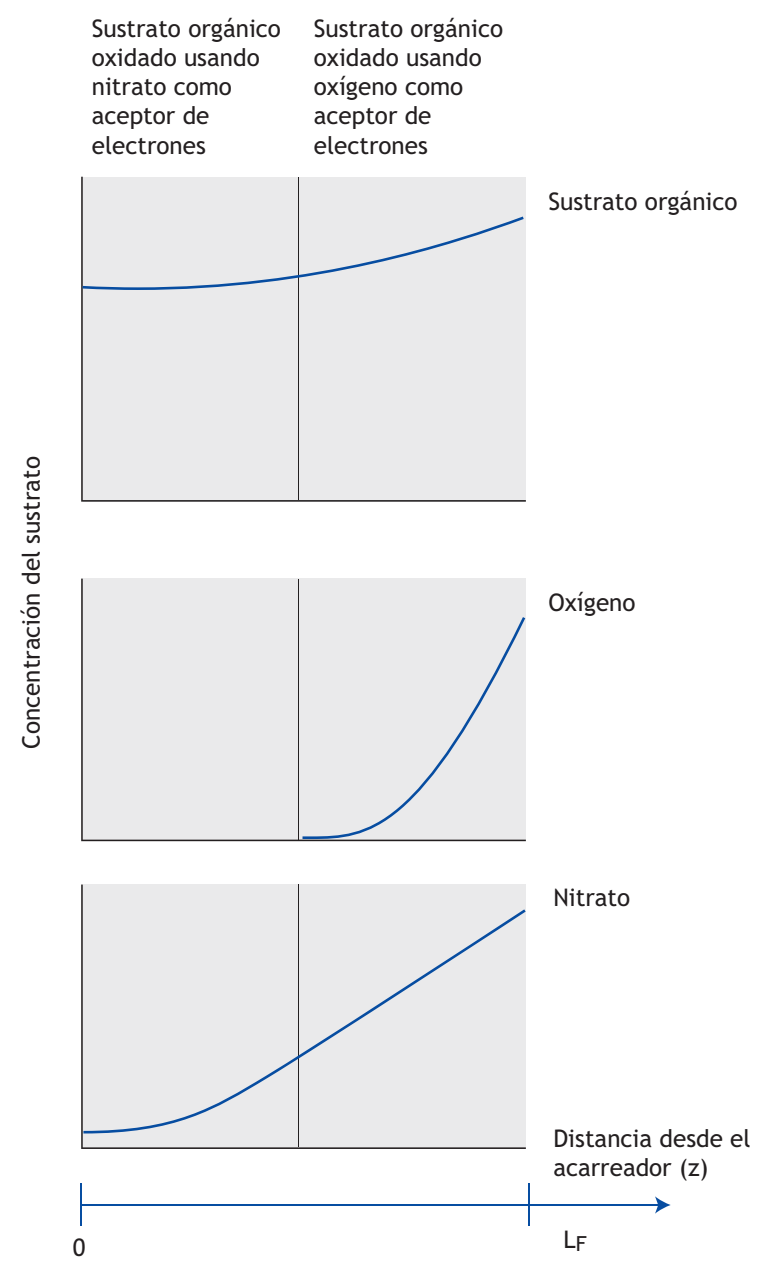

Figura 17.22 Concentración sobre la profundidad de la biopelícula, para una biopelícula expuesta a un sustrato orgánico como donador de electrones y oxígeno y nitrato como aceptores de electrones ( $L_{F}$ es el espesor de la biopelícula)

En la Figura 17.23 se muestran algunos perfiles para el oxígeno y la biomasa sobre el espesor de la biopelícula predichos por medio de modelos matemáticos para cuatro diferentes concentraciones de DQO en la solución. Una observación general de estas simulaciones es que entre más rápido sea el crecimiento de las bacterias heterótrofas, tienden a crecer más las bacterias autótrofas de lento crecimiento. Esto implica dos cosas: (i) el crecimiento heterótrofo y la eliminación de DQO se ven influenciadas muy poco por el crecimiento autótrofo, (ii) el crecimiento autótrofo y la oxidación de amonio son influenciados significativamente por la cantidad de oxígeno utilizado por la biomasa heterótrofa, debido a que las bacterias autótrofas dependen del oxígeno que pasa a través de la capa de bacterias heterótrofas.

Para las distribuciones de la biomasa que se muestran en la Figura 17.23, se puede observar que las bacterias autótrofas y heterótrofas únicamente pueden coexistir cuando las concentraciones de DQO en la solución son menores a $30 \mathrm{mg} / \mathrm{l}$. Esto se puede explicar utilizando el concepto de la limitación dual de sustrato (sección 17.8).

Para concentraciones de DQO en la solución de 30 $\mathrm{mg} / \mathrm{l}$, se puede esperar que las bacterias heterótrofas de la biopelícula se encuentren limitadas por el oxígeno (comparar la Tabla 17.6) y no habrá oxígeno disponible para el crecimiento autótrofo por debajo de la capa heterótrofa. Así, la coexistencia de bacterias heterótrofas y autótrofas, será posible únicamente si la oxidación del sustrato orgánico se encuentra limitada por la DQO y no por el oxígeno.

En la Figura 17.24 se muestran los flujos de sustrato para cierto intervalo de concentraciones de DQO y amonio en la solución.

Se puede observar que el flujo de DQO en la biopelícula se incrementa con el aumento de las concentraciones de DQO en la solución, hasta que la eliminación de DQO se encuentra limitada por el oxígeno a una concentración de DQO de $28 \mathrm{mg} \mathrm{DQO} / \mathrm{l}$. Resulta interesante observar que el flujo de amonio en el interior de la biopelícula se encuentra controlado también por las concentraciones de DQO presentes en la solución, en lugar de las concentraciones de amonio (al menos para concentraciones de amonio mayores a $5 \mathrm{mg} \mathrm{N} / \mathrm{l}$ ). Esta fuerte influencia de las concentraciones de DQO en los flujos de amonio se debe al hecho de que la cantidad de oxígeno que pasa a través de la capa heterótrofa disminuirá con el aumento de las concentraciones de DQO, dejando cada vez menos oxígeno disponible para las bacterias autótrofas. La manera en la que una biopelícula que oxida el carbono orgánico, se verá limitada por el oxígeno o el carbono orgánico, puede ser determinada utilizando la Ec. 17.98. Como se muestra en la Figura 17.25, el valor de $\gamma_{\text {e.d.e.a. }}$ en la Ec. 17.98, puede ser directamente correlacionada con el oxígeno disponible en el interior de la biopelícula, para la nitrificación y la velocidad de nitrificación observada.

Con base en los flujos de la Figura 17.24, los perfiles cualitativos para el amonio, DQO y el oxígeno en la solución, se muestran en la Figura 17.26. 


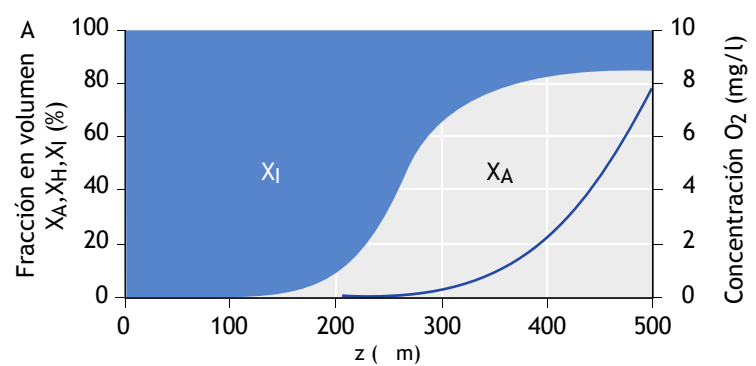

$$
\begin{array}{lll}
\mathrm{C}_{\mathrm{B}, \mathrm{NH} 4}=13.0 & \mathrm{~g} \mathrm{~N} / \mathrm{m}^{3} \\
\mathrm{C}_{\mathrm{B}, \mathrm{DQO}}= & 0 & \mathrm{~g} \mathrm{DQO} / \mathrm{m}^{3} \\
\mathrm{~J}_{\mathrm{LF}, \mathrm{NH} 4}= & 3.2 \mathrm{~g} \mathrm{~N} / \mathrm{m}^{2} . \mathrm{d} \\
\mathrm{J}_{\mathrm{LF}, \mathrm{DQO}}= & 0 & \mathrm{~g} \mathrm{DQO} / \mathrm{m}^{2} . \mathrm{d} \\
\mathrm{J}_{\mathrm{LF}, \mathrm{O} 2}=13.8 & \mathrm{~g} \mathrm{O} / \mathrm{m}^{2} . \mathrm{d}
\end{array}
$$

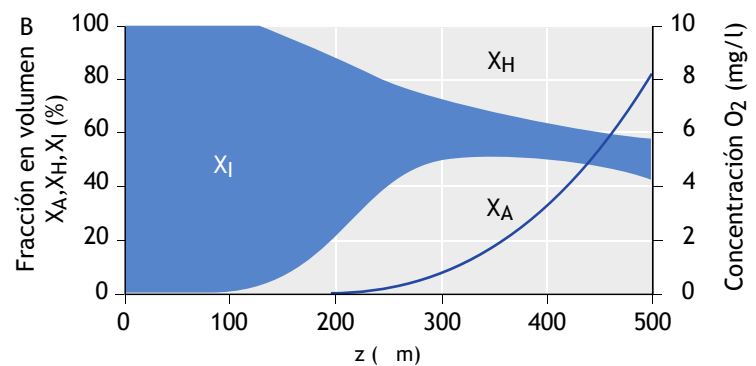

$$
\begin{array}{lll}
\mathrm{C}_{\mathrm{B}, \mathrm{NH} 4}=13.0 & \mathrm{~g} \mathrm{~N} / \mathrm{m}^{3} \\
\mathrm{C}_{\mathrm{B}, \mathrm{DQO}}= & 3.0 \mathrm{~g} \mathrm{DQO} / \mathrm{m}^{3} \\
\mathrm{~J}_{\mathrm{LF}, \mathrm{NH} 4}=2.3 \mathrm{~g} \mathrm{~N} / \mathrm{m}^{2} . \mathrm{d} \\
\mathrm{J}_{\mathrm{LF}, \mathrm{DQO}}=1.3 \mathrm{~g} \mathrm{DQO} / \mathrm{m}^{2} . \mathrm{d} \\
\mathrm{J}_{\mathrm{LF}, \mathrm{O} 2}=11.0 \mathrm{~g} \mathrm{O} / \mathrm{m}^{2} . \mathrm{d}
\end{array}
$$

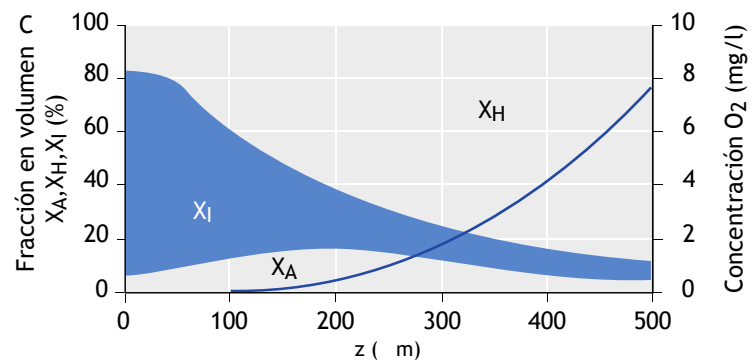

$$
\begin{array}{lll}
\mathrm{C}_{\mathrm{B}, \mathrm{NH} 4}=13.0 & \mathrm{~g} \mathrm{~N} / \mathrm{m}^{3} \\
\mathrm{C}_{\mathrm{B}, \mathrm{DQO}}=13.0 & \mathrm{~g} \mathrm{DQO} / \mathrm{m}^{3} \\
\mathrm{~J}_{\mathrm{LF}, \mathrm{NH} 4}=0.8 \mathrm{~g} \mathrm{~N} / \mathrm{m}^{2} . \mathrm{d} \\
\mathrm{J}_{\mathrm{LF}, \mathrm{DQO}}=7.2 \mathrm{~g} \mathrm{DQO} / \mathrm{m}^{2} . \mathrm{d} \\
\mathrm{J}_{\mathrm{LF}, \mathrm{O} 2}=7.9 \mathrm{~g} \mathrm{O} / \mathrm{m}^{2} . \mathrm{d}
\end{array}
$$

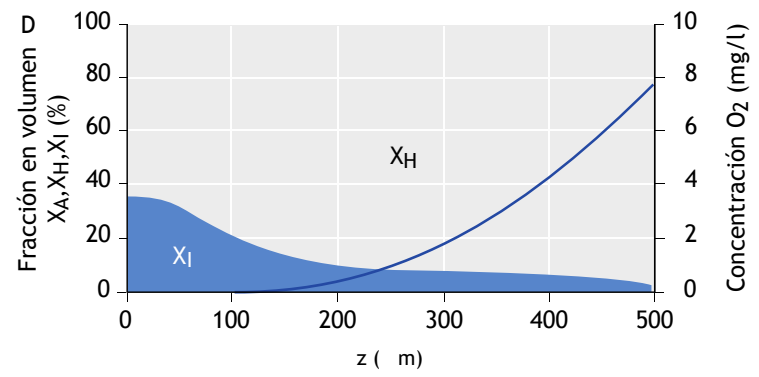

$$
\begin{array}{ll}
\mathrm{C}_{\mathrm{B}, \mathrm{NH} 4}=13.0 & \mathrm{~g} \mathrm{~N} / \mathrm{m}^{3} \\
\mathrm{C}_{\mathrm{B}, \mathrm{DQO}}=30.0 & \mathrm{~g} \mathrm{DQO} / \mathrm{m}^{3} \\
\mathrm{~J}_{\mathrm{LF}, \mathrm{NH} 4}=0 & \mathrm{~g} \mathrm{~N} / \mathrm{m}^{2} . \mathrm{d} \\
\mathrm{J}_{\mathrm{LF}, \mathrm{DQO}}=13.2 & \mathrm{~g} \mathrm{DQO} / \mathrm{m}^{2} . \mathrm{d} \\
\mathrm{J}_{\mathrm{LF}, \mathrm{O} 2}=8.3 & \mathrm{~g} \mathrm{O} / \mathrm{m}^{2} \cdot \mathrm{d}
\end{array}
$$

Figura 17.23 Concentración de oxígeno con respecto a la profundidad de la biopelícula y su correspondiente distribución de bacterias heterótrofas $\left(\mathrm{X}_{\mathrm{H}}\right)$, bacterias autótrofas $\left(\mathrm{X}_{\mathrm{A}}\right)$ y biomasa inerte $\left(\mathrm{X}_{\mathrm{I}}\right)$ para diferentes concentraciones de sustrato orgánico en la solución de o (A), 3 (B), 13 (C), y $30 \mathrm{mg}$ DQO/I (D). Las concentraciones de oxígeno y amonio en la solución son de $8 \mathrm{mg} \mathrm{O}_{2} / \mathrm{l} \mathrm{y} 13 \mathrm{mg} \mathrm{N} / \mathrm{l}$, respectivamente, para todos los casos (de Wanner y Gujer, 1985) 

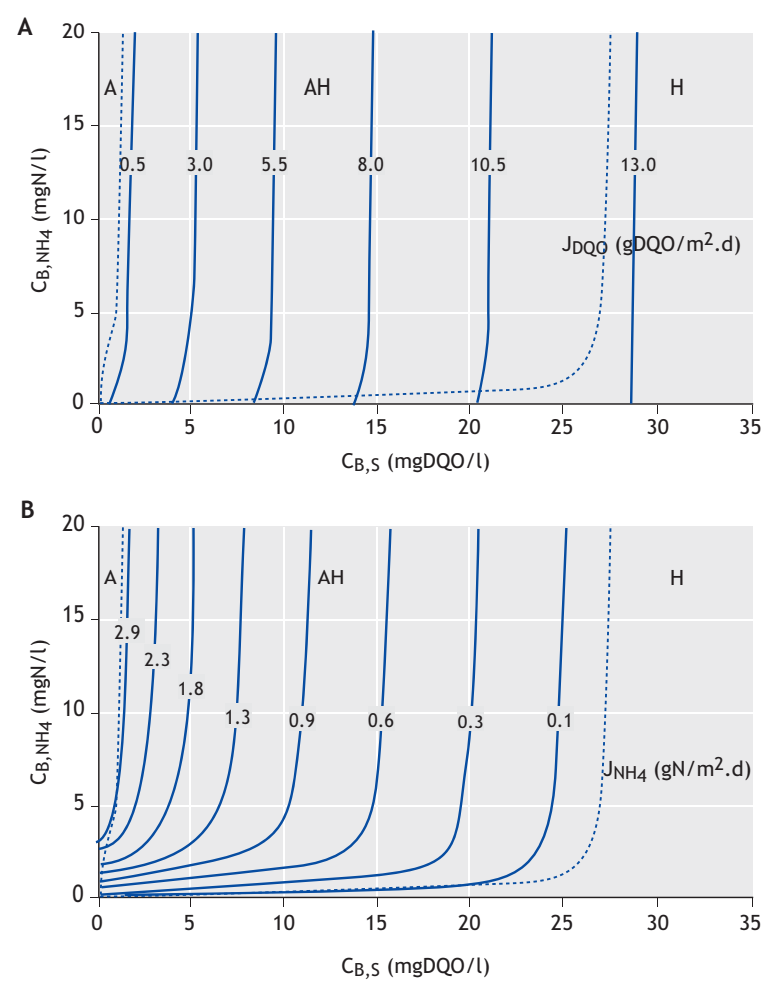

Figura 17.24 Flujo de sustrato orgánico (A) y amonio (B), ambos son determinados principalmente por la concentración de sustrato orgánico en la solución (Wanner y Gujer, 1985)

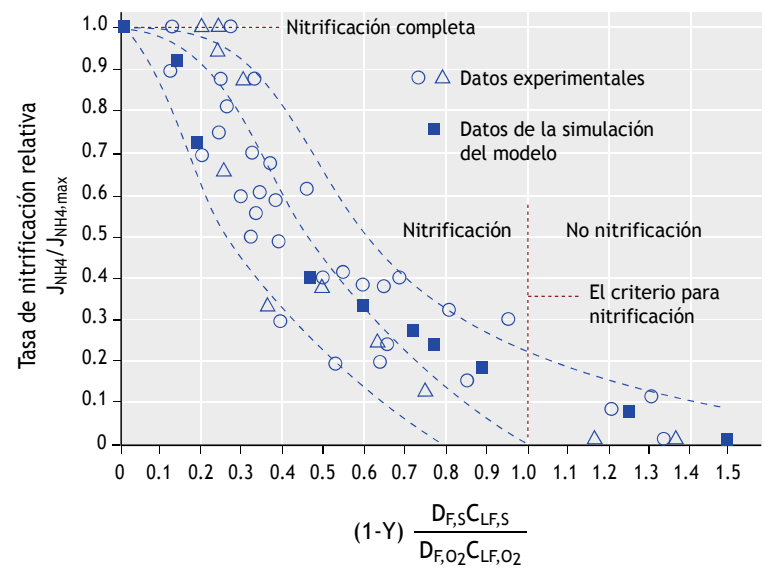

Figura 17.25 Datos experimentales que demuestran la disminución de la velocidad de nitrificación con el aumento de las concentraciones del sustrato orgánico presente en la solución en un biofiltro. El eje de las $x$ corresponde a $\gamma_{\text {e.d.,e.a. }}$ en la Ec. 17.83 (Henze et al., 2002)
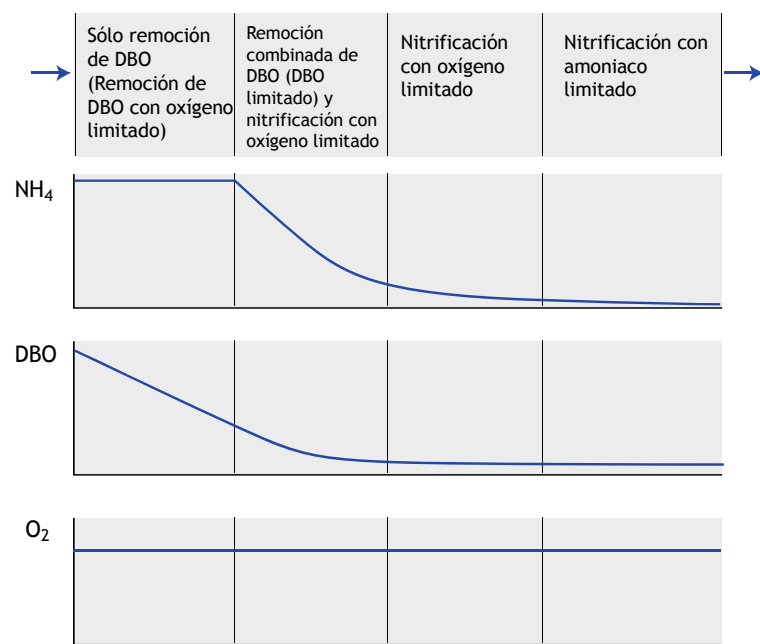

Figura 17.26 Transporte del aceptor y donador de electrones, los cuales se encuentran potencialmente limitados por la complejidad del reactor junto con la oxidación de la DBO y el amonio. Observe que habrá cierta eliminación de $\mathrm{NH}_{4}{ }^{+}$asociada a la eliminación de la DBO, debido a la acumulación de nitrógeno por la síntesis celular

\subsection{0 ¿CÓMO ES QUE LAS ESTRUCTURAS EN 2D/3D PUEDEN INFLUIR EN EL FUNCIONAMIENTO DE LA BIOPELÍCULA?}

Si en alguna ocasión ha tenido oportunidad de observar de cerca las biopelículas en los reactores o sistemas naturales, entonces se habrá dado cuenta de que tienen una estructura bastante heterogénea. Usted deberá de preguntarse así mismo, si realmente los modelos en una sola dimensión descritos en las secciones anteriores serán adecuados para describir una biopelícula de manera real. En todas las secciones anteriores se asumió que los gradientes de concentración paralelos al acarreador son mucho más pequeños que los gradientes de concentración perpendiculares a él, resultando en una ecuación de reacción de difusión en una sola dimensión (Ec. 17.1).

En los últimos 15 años, se han desarrollado modelos multi-dimensionales para predecir la formación de una estructura heterogénea de la biopelícula dependiendo de la disponibilidad local del sustrato. Como consecuencia, estos modelos predicen la influencia de esta estructura heterogénea en la ecología microbiana dentro de la biopelícula y, subsecuentemente, en los flujos de sustrato. Ya sea que un modelo simplificado en 1-D sea adecuado o no, o que se deba aplicar un modelo multidimensional, dependerá de preguntas específicas a ser contestadas utilizando el modelo matemático. En Wanner et al. (2006), se encuentra una evaluación sistemática de 
los diferentes modelos y su disponibilidad de aplicación para diferentes sistemas.

Si el objetivo es el predecir los flujos de sustrato para procesos, tales como la oxidación aeróbica de carbono, nitrificación y desnitrificación, entonces, los modelos en 1-D son una excelente opción. Estos modelos en 1-D permitirán predecir las limitaciones del transporte de masa para el sustrato limitante, la difusión multicomponente, y la competencia microbiana, con base en un crecimiento heterótrofo rápido $\mathrm{y}$ un crecimiento autótrofo lento de la biomasa en las diferentes capas.

Las situaciones en las cuales se justifica el uso de un modelo multi-dimensional incluyen: $(i)$ una geometría compleja del acarreador (por ej., estudios a micro-escala del desarrollo de la biopelícula en un medio poroso) y para la distribución espacial de la biopelícula (por ej., crecimiento "irregular" de la biopelícula con colonias aisladas); (ii) cuestiones ecológicas complejas que están influenciadas por la agregación local de diferentes grupos de microorganismos y por el transporte de masa local. Ejemplos de este tipo de cuestiones ecológicas, incluyen modelos de la cadena trófica anaerobia en lodos granulares anaerobios (Batstone et al., 2002). Otra cuestión ecológica es la formación de diferentes estructuras en la superficie de las biopelículas y en el lodo granular, donde la morfología superficial tiene, por ejemplo, una influencia significativa en la resistencia externa a la transferencia de masa (Picioreanu et al., 2000). Los modelos multi-dimensionales se utilizan típicamente para responder cuestiones específicas basadas en un mejor entendimiento de las interacciones dentro de la biopelícula. En algunos casos, estas interacciones dentro de la biopelícula tienen un impacto significativo en su funcionamiento general. En estos casos, los resultados y mecanismos obtenidos por medio de estos modelos multi-dimensionales, tendrán que ser considerados también para su aplicación práctica en reactores de biopelícula.

Ejemplo 17.10: Distribución en 2-D de microorganismos productores y consumidores de hidrógeno en los agregados microbianos

La digestión anaerobia es un proceso en multi etapas que se lleva a cabo por una variedad de microorganismos que viven en relación simbiótica. Las concentraciones locales de los sustratos e intermediarios dependen de la distribución espacial que tengan estos microorganismos. Un aspecto importante es la transferencia de hidrógeno entre las especies productoras de hidrógeno y consumidoras de hidrógeno. Batstone et al., 2006, utilizaron un modelo matemático en 2-D para evaluar el desarrollo de la organización espacial de los microorganismos dentro de los gránulos anaerobios. En la Figura 17.27 se comparan las distribuciones de organismos presentes en un gránulo y aquellas obtenidas por medio de simulaciones. Batstone et al., 2006, fueron capaces de confirmar las mediciones de relaciones sintróficas entre los microorganismos productores y consumidores de hidrógeno con los resultados de sus modelos. La distribución de los microorganismos en su modelo, se basa en el crecimiento local combinado con la difusión de la biomasa al azar, sin suponer algún mecanismo de los microorganismos (por ej., a través de

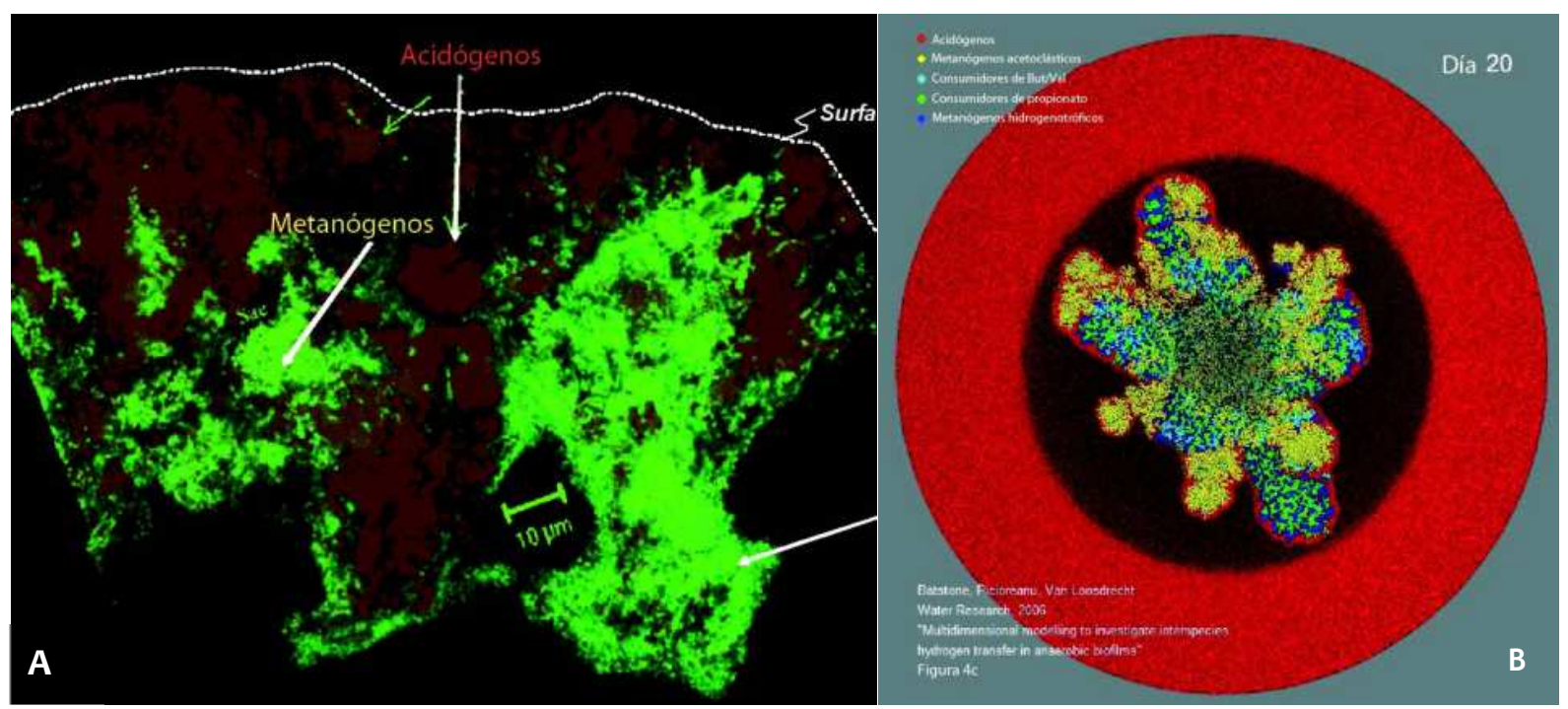

Figura 17.27 Distribución espacial de microorganismos acidógenos (rojo) y metanógenos (verde) en imágenes de gránulos anaerobios, obtenidas utilizando fluorescencia de hibridación in-situ (A). Distribución modelada de los acetogénicos (rojo), consumidores de butirato/valerato (azul claro), consumidores de propionato (verde), y metanógenos (amarillo o azul) (Imágenes: Batstone et al., 2006) 
quimiotaxis). Al evaluar los mecanismos potenciales, resulta en parámetros espaciales específicos que requieren el uso de modelos multidimensionales. Tal zona de célula a célula no está definida en los modelos 1$\mathrm{D}$ donde las distribuciones de biomasa se promedian en planos paralelos al acarreador.

\subsection{PARÁMETROS DEL MODELO}

El elegir los parámetros apropiados para el modelo es esencial para obtener predicciones confiables. Los parámetros en modelos de biopelículas pueden clasificarse en tres categorías: (i) parámetros microbiológicos que son independientes de la manera en la que crece la biopelícula o los microorganismos en suspensión (por ej., Y, $\mu_{\max }$, etc.), (ii) parámetros de transferencia de masa que son independientes en el sistema (por ej., $\mathrm{D}_{\mathrm{w}}$ ), (iii) parámetros de la biopelícula que son dependientes del tipo y operación del reactor (por ej., $L_{F}, L_{L}, X_{F}$, etc.). Para la aplicación de los modelos matemáticos para sistemas que se utilizan en la práctica, únicamente se encuentran disponibles mediciones limitadas. Las mediciones directas in-situ de los parámetros de la biopelícula y la toma de muestras representativas es difícil, y la biopelícula no se encuentra distribuida homogéneamente sobre el sistema completo. De tal manera que, por lo general, no es posible identificar todos los parámetros del modelo dependientes en el sistema con base en mediciones, así que éstos tendrán que ser asumidos de información encontrada en la literatura. A continuación se presenta una discusión sobre algunos de los parámetros relevantes de los modelos.

\subsubsection{Densidad de la biomasa en la biopelícula $\left(\mathrm{X}_{\mathrm{F}}\right)$}

Las densidades de la biomasa en los reactores de biopelícula $\left(\mathrm{X}_{\mathrm{F}}\right)$, son significativamente mayores comparadas con los sistemas de lodos activados. Típicamente se encuentran en un intervalo de:

$\mathrm{X}_{\mathrm{F}}=10$ a $60 \mathrm{~g} \mathrm{SSV} / \mathrm{L}$

Aún en algunos casos $\mathrm{X}_{\mathrm{F}}$ puede ser tan alta como 200 g SSV/L. Una comparación directa de las concentraciones de la biomasa en un reactor de biopelícula con densidades de biomasa en sistemas de lodos activados, que se encuentran en un intervalo de 2 a $6 \mathrm{~g} \mathrm{SSV/L}$, depende de las cantidades relativas de la biopelícula, agua, aire y el medio de soporte que puede variar significativamente entre diferentes tipos de sistemas de biopelícula. El valor de $\mathrm{X}_{\mathrm{F}}$ depende de las condiciones de crecimiento. Las biopelículas que crecen bajo un aumento del cizallamiento suelen ser típicamente más densas y fuertes. La densidad de la biomasa puede ser fácilmente medida a partir del volumen y los sólidos cuantificados de la biomasa, tal y como se describe, por ejemplo, en Horn y Hempel (1997).

Nota para los usuarios de AQUASIM: en AQUASIM, se considera que la biopelícula está constituida por diferentes fases. En este caso, la densidad de la fase sólida se puede calcular a partir de la densidad promedio de la biomasa dividida entre la fracción de sólidos presentes en el volumen total $(=\Sigma \varepsilon s, \mathrm{i})$.

\subsubsection{Coeficientes de difusión $\left(D_{W}, D_{F}\right)$}

Los coeficientes de difusión en el agua $\left(\mathrm{D}_{\mathrm{W}}\right)$, se encuentran disponibles en la literatura para la mayoría de los compuestos (Lide, 2008; Perry y Green, 1984). Estas referencias además proporcionan aproximaciones para compuestos que no se encuentran en la lista, basados en sus propiedades, tales como el peso molecular. Los coeficientes de difusión $\left(\mathrm{D}_{\mathrm{F}}\right)$ en el interior de la biopelícula, son más pequeños que los coeficientes de difusión en el agua, dependiendo de la densidad de biomasa presente en la biopelícula y de las propiedades del componente. Por lo general, se utiliza un factor de reducción del 80\% (Horn y Morgenroth, 2006; Stewart, 1998):

$D_{F}=0.8 \cdot D_{W}$

La reducción de los coeficientes de difusión dentro de la biopelícula no puede ser medida fácilmente en los reactores; sin embargo, la Ec. 17.105 puede utilizarse en la mayoría de los casos. En la Tabla 17.8 se presenta un condensado de los valores de $\mathrm{D}_{\mathrm{W}}$.

\subsubsection{Transferencia de masa externa ( $\left.L_{L}, R_{L}\right)$}

Para condiciones hidrodinámicas bien definidas, el espesor de la capa límite externa a la transferencia de masa $\left(L_{L}\right)$ o la resistencia externa a la transferencia $\left(\mathrm{R}_{\mathrm{L}}=\right.$ $\left.L_{L} / D_{\mathrm{w}}\right)$, pueden ser estimadas utilizando correlaciones empíricas a partir de la literatura en ingeniería química. El número adimensional de Sherwood (Sh) es una función de $\mathrm{R}_{\mathrm{L}}, \mathrm{D}_{\mathrm{w}}$, y una longitud característica (por ej. el diámetro de una partícula de biopelícula presente en el soporte) $\left(d_{p}\right)$. 
El número de Sherwood puede expresarse como:

$S h=\frac{d_{p}}{R_{L} D_{W}}$

Tabla 17.8 Coeficientes de difusión en el agua ( $\left.D_{w}\right)$ (Para mayores referencias ver Lide, 2008; Perry y Green, 2008; Stewart, 2003)

\begin{tabular}{|c|c|c|}
\hline Compuesto & $\begin{array}{r}\mathrm{D}_{\mathrm{W}} \\
\mathrm{m}^{2} / \mathrm{d}\end{array}$ & \\
\hline Oxígeno, $\mathrm{O}_{2}$ & $209.1 \cdot 10^{-6}$ & (a) \\
\hline Dióxido de carbono, $\mathrm{CO}_{2}$ & $165.0 \cdot 10^{-6}$ & (a \\
\hline Hidrógeno, $\mathrm{H}_{2}$ & $441.5 \cdot 10^{-6}$ & (a \\
\hline Sulfuro de hidrógeno, $\mathrm{H}_{2} \mathrm{~S}$ & $117.5 \cdot 10^{-6}$ & (a \\
\hline Ión de sulfuro de hidrógeno, $\mathrm{HS}^{-}$ & $149.6 \cdot 10^{-6}$ & (a \\
\hline Metano, $\mathrm{CH}_{4}$ & $128.7 \cdot 10^{-6}$ & (a \\
\hline Nitrógeno, $\mathrm{N}_{2}$ & $172.8 \cdot 10^{-6}$ & (a \\
\hline Óxido nitroso, $\mathrm{N}_{2} \mathrm{O}$ & $222.0 \cdot 10^{-6}$ & (a \\
\hline Amonio, $\mathrm{NH}_{4}^{+}$ & $169.1 \cdot 10^{-6}$ & (a \\
\hline Nitrito, $\mathrm{NO}_{2}^{-}$ & $165.2 \cdot 10^{-6}$ & (a \\
\hline Nitrato, $\mathrm{NO}_{3}^{-}$ & $164.3 \cdot 10^{-6}$ & (a \\
\hline Perclorato, $\mathrm{ClO}_{4}^{-}$ & $154.8 \cdot 10^{-6}$ & (a \\
\hline Clorato, $\mathrm{ClO}_{3}^{-}$ & $148.6 \cdot 10^{-6}$ & \\
\hline Cloruro, $\mathrm{Cl}^{-}$ & $175.6 \cdot 10^{-6}$ & (a \\
\hline $\mathrm{H}_{2} \mathrm{PO}_{4}^{-}$ & $76.0 \cdot 10^{-6}$ & $(\mathrm{~b}$ \\
\hline $\mathrm{HPO}_{4}{ }^{2-}$ & $65.7 \cdot 10^{-6}$ & \\
\hline Hidróxido, $\mathrm{OH}^{-}$ & $455.6 \cdot 10^{-6}$ & (a) \\
\hline Hidronio, $\mathrm{H}^{+}$ & $804.5 \cdot 10^{-6}$ & (a) \\
\hline Bicarbonato, $\mathrm{HCO}_{3}^{-}$ & $102.4 \cdot 10^{-6}$ & (a) \\
\hline Carbonato, $\mathrm{CO}_{3}{ }^{2-}$ & $79.7 \cdot 10^{-6}$ & \\
\hline Acetato, $\mathrm{CH}_{3} \mathrm{COO}^{-}$ & $94.1 \cdot 10^{-6}$ & (a) \\
\hline Glucosa, $\mathrm{C}_{6} \mathrm{H}_{12} \mathrm{O}_{6}$ & $57.9 \cdot 10^{-6}$ & \\
\hline Etanol & $107.1 \cdot 10^{-6}$ & (a) \\
\hline Tolueno & $73.4 \cdot 10^{-6}$ & (a \\
\hline Metanol & $110.6 \cdot 10^{-6}$ & (a) \\
\hline Benceno & $88.1 \cdot 10^{-6}$ & (a) \\
\hline DBO soluble $(3-30 \mathrm{kDa})$ & $9.7 \cdot 10^{-6}$ & (c) \\
\hline DBO soluble $(30-50 \mathrm{kDa})$ & $7.3 \cdot 10^{-6}$ & \\
\hline DBO soluble $(50-100 \mathrm{kDa})$ & $5.6 \cdot 10^{-6}$ & $(\mathrm{c}$ \\
\hline DBO soluble $(100-500 \mathrm{kDa})$ & $4.3 \cdot 10^{-6}$ & (c) \\
\hline DBO soluble $(500-1,000 \mathrm{kDa})$ & $2.6 \cdot 10^{-6}$ & (c) \\
\hline \multicolumn{3}{|l|}{ (a) Para $25^{\circ} \mathrm{C}$ (Lide, 2008) } \\
\hline (b) Para $25^{\circ} \mathrm{C}$ (Stewart, 2003) & & \\
\hline
\end{tabular}

El número de Sherwood se puede expresar como una función del número adimensional Reynolds $\left(\operatorname{Re}=U d_{p} / v\right)$ y el número de Schmidt $\left(\mathrm{Sc}=v / D_{i}\right)$ :
$S h=A+B \cdot R e^{m} S c^{n}$

donde $\mathrm{U}$ es la velocidad de flujo libre alrededor de la partícula y $v$ es la viscosidad cinemática. El número de Reynolds depende del flujo y la geometría, mientras que el número de Schmidt únicamente depende de las propiedades del fluido.

Los parámetros $A, B, m, \mathrm{y} n$ son, en la mayoría de los casos, determinados empíricamente de datos experimentales obtenidos de un sistema específico. Por ejemplo, para un caso simple del flujo de un fluido alrededor de una partícula esférica rígida $A=2, B=0.95$, $m=1 / 2, n=1 / 3$ (para $100<\operatorname{Re}<700$ y $1200<\mathrm{Sc}<$ 1525, Garner y Suckling, 1958).

Para suspensiones de tres fases con flujo no ideal Nicolella et al. (1998) aproximaron el número de Sherwood utilizando la Ec. 17.96 con $A=2, B=0.265$, $\mathrm{m}=0.241, \mathrm{n}=1 / 3, \mathrm{y}$ asumiendo una expresión alterna para el número de Reynolds con base en la teoría de la turbulencia de Kolmogoroff:

$\operatorname{Re}=\frac{\varepsilon_{\text {disipación }} d_{p}^{4}}{v^{3}}$

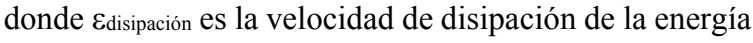
por unidad de masa.

Para reactores de lecho empacado, Wilson y Geankoplis (1966), generaron la siguiente estimación del número de Sherwood ( $\left.\varepsilon_{\text {porosidad }}\right)$ que es aplicable para porosidades entre 0.35 y 0.75 :

$S h=\left\{\begin{array}{lc}\frac{1.09}{\varepsilon_{\text {porosidad }}} S^{1 / 3} & \text { para }\left\{\begin{array}{l}0.0016<\mathrm{Re}_{\mathrm{pb}}<55 \\ 165<\mathrm{Sc}<70,600\end{array}\right. \\ \frac{0.25}{\varepsilon_{\text {porosidad }}} \mathrm{Re}_{p b}^{0.69} \mathrm{Sc}^{1 / 3} & \text { para }\left\{\begin{array}{l}55<\mathrm{Re}_{\mathrm{pb}}<1,500 \\ 165<\mathrm{Sc}<10,690\end{array}\right.\end{array}\right.$

El número de Reynolds en la Ec. 17.109, se define como $\mathrm{Re}_{\mathrm{pb}}=U_{\text {sup }} d_{p} / \mathrm{v}$, donde $\mathrm{U}_{\text {sup }}$ es la velocidad superficial del lecho, la cual es el flujo total a través del lecho dividido entre el área transversal (Clark, 1996).

Más correlaciones de Sh se pueden encontrar por ejemplo en las Tablas 5-20 a 5-24 en Perry y Green (2008) o en Kissel (1986). Es importante notar que la mayoría de las correlaciones utilizadas para estimar Sh se derivaron para aplicaciones en Ingeniería Química 
Tabla 17.9 Valores típicos para la transferencia de masa en la capa superficial del espesor de la biopelícula (modificado de Kissel, 1986)

\begin{tabular}{lcccc}
\hline Tipo de reactor & $\begin{array}{c}\text { Velocidad del líquido } \\
\text { en } \mathrm{m} / \mathrm{h}\end{array}$ & $\begin{array}{c}\text { Tamaño de la partícula } \\
\text { en } \mathrm{mm}\end{array}$ & $\begin{array}{c}\text { Fracción volumétrica } \\
\text { del líquido }\end{array}$ & $\mathrm{L}_{\mathrm{L}}$ en $\mu \mathrm{m}$ \\
\hline Filtro de arena lento & 0.04 & 0.6 & 0.4 & 100 \\
Filtro de arena rápido & 5 & 0.7 & 0.4 & 20 \\
Lecho fluidizado & 33 & 1 & 0.7 & 20 \\
Reactor UASB & 1 & 3 & 0.5 & 200 \\
Filtro percolador (baja tasa) & 0.08 & 40 & 0.4 & 1,500 \\
Filtro percolador (alta tasa) & 1.7 & 40 & 0.9 & 20 \\
Reactor de biopelícula & $2-10$ & $2-6$ & 0.5 & 100 \\
sumergida & & & & \\
\hline
\end{tabular}

relativamente simples, y deberán de ser aplicadas con precaución en los sistemas de biopelícula.

Los parámetros $A, B, m, \mathrm{y} n$, dependen de la geometría del medio de soporte y son válidas únicamente para cierto intervalo de Re y Sc. El extrapolar, a partir de estas condiciones, puede generar error en los resultados. Para geometrías complejas, la Ec. 17.96 puede no ser suficiente y algunas otras formas de $\mathrm{Sh}=f(\mathrm{Re}, \mathrm{Sc})$ deberán ser utilizadas para el ajuste de los datos experimentales. La mayoría de las correlaciones de Sh se derivaron de partículas rígidas; sin embargo, la naturaleza elástica y heterogénea de la biopelícula puede influir en la transferencia de masa externa. Diferentes autores han sugerido que $\mathrm{R}_{\mathrm{L}}$ puede incrementarse (Nicolella et al., 2000) o disminuir (Horn y Hempel, 2001), como resultado del cubrimiento del medio de soporte por la biopelícula.

El modelo matemático de la resistencia a la transferencia de masa externa en este capítulo, se limitó a la transferencia de masa de la solución hacia la superficie de la biopelícula. Muchos reactores de biopelícula son, sin embargo, sistemas de tres fases (sólido/biopelícula, líquido, gas), donde la velocidad de transferencia de masa, por ejemplo, oxígeno de la fase gaseosa hacia la solución, puede limitar el funcionamiento general del proceso. La transferencia de masa de la solución hacia la fase gas también es importante para la eliminación de productos metabólicos como $\mathrm{N}_{2}$ o $\mathrm{CO}_{2}$ presentes en la solución. Al aumentar el mezclado (por ej., aumentando el flujo de agua) y el flujo de gas, influenciará ambos tipos de transferencia de masa de la solución hacia la superficie de la biopelícula y de la fase gas hacia la fase líquida.

\subsubsection{Espesor $\left(\mathrm{L}_{\mathrm{F}}\right)$ y desprendimiento $\left(\mathrm{u}_{\mathrm{d}, \mathrm{S}}, \mathrm{u}_{\mathrm{d}, \mathrm{v}}\right.$, $\left.\mathbf{u}_{\mathrm{d}, \mathrm{M}}\right)$ de la biopelícula}

El espesor de la biopelícula $\left(\mathrm{L}_{\mathrm{F}}\right)$ y las velocidades de desprendimiento de la misma ( $\left.\mathrm{u}_{\mathrm{d}, \mathrm{S}}, \mathrm{u}_{\mathrm{d}, \mathrm{V}}, \mathrm{u}_{\mathrm{d}, \mathrm{M}}\right)$, se encuentran directamente relacionados para cierto flujo de sustrato con base en la Ec. 17.56. Las simulaciones de la biopelícula pueden realizarse ya sea fijando el espesor o las velocidades de desprendimiento de la misma. Para diferentes tipos de reactores se encuentran disponibles los intervalos típicos de espesor de la biopelícula (Tabla 17.9). El estimar un espesor representativo de la biopelícula (y el desprendimiento de la misma) en la práctica, resulta por lo general difícil debido a que se encuentran distribuidas de manera heterogénea sobre el medio de soporte y sobre el reactor en general. En aplicaciones prácticas, el realizar un muestreo y mediciones representativas, también son por lo general difíciles. En reactores con biopelículas relativamente densas, esta incertidumbre en la estimación de $\mathrm{LF}_{\mathrm{F}}$, no es un problema, ya que para biopelículas densas el flujo de sustrato en la biopelícula no es sensible a cambios en $\mathrm{L}_{\mathrm{F}}$. $\mathrm{Si}$ las capas más profundas de la biopelícula se encuentran limitadas por el sustrato (es decir, $L_{F}>>L_{\text {crit }}$ para cinéticas de primer orden o $\beta<1$ para cinéticas de orden cero), entonces un aumento en el espesor de la biopelícula sólo incrementará la cantidad de sustrato limitado en la biomasa en el fondo de ella.

\subsubsection{Precauciones al utilizar parámetros que provienen de otro tipo de modelos}

La estimación de los parámetros para sistemas complejos es difícil y, en muchos casos, los parámetros cinéticos y estequiométricos se toman de la literatura. Esto se debe de realizar con precaución (Wanner et al., 2006). Un ejemplo de uso erróneo es el aplicar directamente las 
Tabla 17.10 Intervalos típicos del espesor de la biopelícula (a) para diferentes tipos de reactores

\begin{tabular}{ll}
\hline Tipo de reactor & Intervalo de LF en $\mu \mathrm{m}$ \\
\hline Filtro percolador, biofiltro & $200-10,000$ \\
Biofiltro sumergido con retrolavados regulares & $20-300$ \\
Reactor de lecho fluidizado, tipo "air lift" & $20-150$ \\
Reactor de lecho móvil & $50-500$ \\
Reactores de membrana & $20-500$ \\
\hline
\end{tabular}

(a) Observe que los intervalos en esta tabla tienen que ser utilizados con extrema precaución, ya que el espesor de la biopelícula dependerá de múltiples factores, incluyendo la carga de sustrato, el tipo de sustrato, las fuerzas de desprendimiento y la operación global del reactor.

constantes medias de saturación de modelos de lodos activados para la simulación de las biopelículas. Las constantes medias de saturación (por ej., $\mathrm{K}_{\mathrm{S}}, \mathrm{K}_{\mathrm{O} 2}$, etc) en la ecuación de Monod (por ej. la Ec. 17.4), pueden ser reacomodadas como parámetros microbiológicos fundamentales que no dependen de la configuración del sistema. En el tratamiento de aguas residuales, sin embargo, las constantes medias de saturación se estiman, por lo general, con base en experimentos realizados con biomasa aglomerada. Los modelos de lodos activados, por lo general, se utilizan para estimar los valores de las constantes medias de saturación para tales experimentos. La estructura de estos modelos de lodos activados no considera las limitaciones de transferencia de masa en los flóculos, lo cual resulta en la observación de constantes medias de saturación que son artificialmente altas. En las biopelículas, las limitaciones en la transferencia de masa se modelan explícitamente, por lo cual es necesario aplicar el valor real de las constantes medias de saturación. Así, el valor resultante de las constantes medias de saturación para los modelos de biopelículas deberá ser menor al valor calculado para los modelos de lodos activados.

\subsection{HERRAMIENTAS DEL MODELO MATEMÁTICO}

El propósito de los Capítulos 17 y 18 es enfocarse en los principios básicos de las biopelículas y los reactores de biopelícula. Pero, ¿cómo pueden ser implementados los modelos resultantes en casos prácticos ingenieriles o en investigación? La respuesta a esta pregunta dependerá, primero, del objetivo por el cual se utiliza un modelo. La pregunta referente a la selección del modelo apropiado para el diseño de los reactores de biopelícula se resolverá en el Capítulo 18. Una discusión completa de los diferentes tipos de modelos y su uso apropiado se encuentra disponible en Wanner et al., 2006. Una vez que se ha seleccionado un modelo, la siguiente pregunta es ¿cómo se debe implementar el modelo seleccionado? Los siguientes párrafos proveen de una breve discusión sobre las estrategias comúnmente utilizadas:
- Soluciones analíticas: En este capítulo se presentaron una serie de soluciones analíticas. Un beneficio importante de las soluciones analíticas es que proveen al usuario de un entendimiento directo de cómo diferentes parámetros pueden influir en los resultados del modelo y además son importantes para enseñar el concepto del transporte de masa en la biopelícula. Para muchos problemas prácticos de las biopelículas en donde el usuario se encuentra principalmente interesado en el flujo de sustrato para un solo compuesto limitante, las soluciones analíticas generan resultados rápidos y exactos. Sin embargo, para problemas complejos, las soluciones analíticas se vuelven muy complejas y poco posibles.

- Soluciones pseudo-analíticas: Las soluciones pseudo-analíticas se basan en soluciones numéricas de la cinética de Monod para un solo compuesto limitante en una biopelícula homogénea. Las soluciones pueden implementarse convenientemente en hojas de cálculo (Rittmann y McCarty, 2001; Saez y Rittmann, 1992). La aplicación de soluciones pseudo-analíticas se encuentra, como las soluciones analíticas, limitada a sistemas relativamente simples.

- Soluciones numéricas (1-D, distribución homogénea de la biomasa): Las soluciones numéricas se utilizan para calcular los perfiles de concentración del sustrato, para sustratos múltiples que son degradados o producidos dentro de la biopelícula. Las fracciones de biomasa se encuentran homogéneamente distribuidas sobre el espesor de la biopelícula. Una sola fracción de la biomasa se puede asumir a priori como se mostró en la sección 17.2. O bien, la densidad de diferentes fracciones de biomasa en el interior de la biopelícula, se puede determinar a cada intervalo de tiempo, a partir del balance del crecimiento, decaimiento y desprendimiento (Boltz et al., 2008; Rauch et al., 1999). Mientras que los cambios en las fracciones de la biomasa sobre el tiempo sean considerados, se asume que todas las fracciones de la biomasa se encuentran homogéneamente distribuidas sobre el espesor de la biopelícula, simplificando ampliamente las 
Tabla 17.11 Matriz de expresiones cinéticas y estequiométricas, para los procesos de biopelícula heterotróficos y autotróficos (adaptada de Wanner et al., 2006)

\begin{tabular}{|c|c|c|c|c|c|c|c|}
\hline$\rightarrow \mathrm{i}$ & 1 & 2 & 3 & 4 & 5 & 6 & \\
\hline Nombre del proceso & $\mathrm{X}_{\mathrm{H}}$ & $\mathrm{X}_{\text {Aut }}$ & $\mathrm{X}_{\mathrm{I}}$ & $\mathrm{Cs}_{\mathrm{s}}$ & $\mathrm{C}_{\mathrm{NH} 4}$ & $\mathrm{Co} 2$ & Velocidad del proceso, $\rho_{j}$ \\
\hline 1: Crecimiento heterotrófico & 1 & & & $-\frac{1}{\mathrm{Y}_{\mathrm{H}}}$ & & $\frac{-\left(1-Y_{H}\right)}{Y_{H}}$ & $\mu_{\max , \mathrm{H}} \frac{\mathrm{C}_{\mathrm{S}}}{\mathrm{K}_{\mathrm{S}}+\mathrm{C}_{\mathrm{S}}} \frac{\mathrm{C}_{\mathrm{O} 2}}{\mathrm{~K}_{\mathrm{O} 2, \mathrm{H}}+\mathrm{C}_{\mathrm{O} 2}} \mathrm{X}_{\mathrm{H}}$ \\
\hline 2: Inactivación heterotrófica & -1 & & 1 & & & & $\mathrm{~b}_{\mathrm{in}, \mathrm{H}} \mathrm{X}_{\mathrm{H}}$ \\
\hline 3: Respiración heterotrófica & -1 & & & & & -1 & $\mathrm{~b}_{\mathrm{res}, \mathrm{H}} \frac{\mathrm{C}_{\mathrm{O} 2}}{\mathrm{~K}_{\mathrm{O} 2, \mathrm{H}}+\mathrm{C}_{\mathrm{O} 2}} \mathrm{X}_{\mathrm{H}}$ \\
\hline 4: Crecimiento autotrófico & & 1 & & & $-\frac{1}{Y_{\text {Aut }}}$ & $\frac{-\left(4.57-\mathrm{Y}_{\text {Aut }}\right)}{\mathrm{Y}_{\text {Aut }}}$ & $\mu_{\max , \text { Aut }} \frac{\mathrm{C}_{\mathrm{NH} 4}}{\mathrm{~K}_{\mathrm{N}}+\mathrm{C}_{\mathrm{NH} 4}} \frac{\mathrm{C}_{\mathrm{O} 2}}{\mathrm{~K}_{\mathrm{O} 2, \mathrm{~N}}+\mathrm{C}_{\mathrm{O} 2}} \mathrm{X}_{\text {Aut }}$ \\
\hline 5: Inactivación autotrófica & & -1 & 1 & & & & $\mathrm{~b}_{\text {ina,Aut }} \mathrm{X}_{\text {Aut }}$ \\
\hline 6: Respiración autotrófica & & -1 & & & & -1 & $\mathrm{~b}_{\text {res,Aut }} \frac{\mathrm{C}_{\mathrm{O} 2}}{\mathrm{~K}_{\mathrm{O} 2 \text {,Aut }}+\mathrm{C}_{\mathrm{O} 2}} \mathrm{X}_{\text {Aut }}$ \\
\hline Unidades & DQO & DQO & DQO & DQO & $\mathrm{N}$ & - DQO & \\
\hline
\end{tabular}

$r_{i, V}=\sum_{j} v_{i, j} \rho_{j}$ (con matriz estequiométrica $v_{\mathrm{i}, \mathrm{j}} \mathrm{y}$ vector de la velocidad del proceso, $\rho_{\mathrm{j}}$ )

Tabla 17.12 Parámetros cinéticos, estequiométricos y de diffusión (adaptado de Wanner y Gujer, 1985; Wanner y Reichert, 1996)

\begin{tabular}{|c|c|c|c|c|c|}
\hline \multicolumn{3}{|c|}{ Crecimiento heterotrófico } & \multicolumn{3}{|l|}{ Nitrificación } \\
\hline$\alpha_{\mathrm{H}}$ & 1 & $\mathrm{gO}_{2} / \mathrm{gDQO}$ & $\alpha_{\text {Aut }}$ & 4.57 & $\mathrm{gO}_{2} / \mathrm{gN}$ \\
\hline$\mu_{\max , \mathrm{H}}$ & 4.8 & $1 / \mathrm{d}$ & $\mu_{\max , \text { Aut }}$ & 0.95 & $1 / \mathrm{d}$ \\
\hline $\mathrm{Y}_{\mathrm{H}}$ & 0.4 & gDQO/gDQO & $Y_{\text {Aut }}$ & 0.22 & $\mathrm{gDQO} / \mathrm{gN}$ \\
\hline $\mathrm{K}_{\mathrm{s}}$ & 5 & $\mathrm{gDQO} / \mathrm{m}^{3}$ & $\mathrm{~K}_{\mathrm{N}}$ & 1 & $\mathrm{gN} / \mathrm{m}^{3}$ \\
\hline $\mathrm{K}_{\mathrm{O}, \mathrm{H}}$ & 0.1 & $\mathrm{gO}_{2} / \mathrm{m}^{3}$ & $\mathrm{~K}_{\mathrm{O}, \mathrm{Aut}}$ & 0.1 & $\mathrm{gO}_{2} / \mathrm{m}^{3}$ \\
\hline$b_{\text {ina,H }}$ & 0.1 & $1 / \mathrm{d}$ & $\mathrm{b}_{\text {ina,Aut }}$ & 0.1 & $1 / \mathrm{d}$ \\
\hline bres,H $_{\mathrm{H}}$ & 0.2 & $1 / \mathrm{d}$ & bres,Aut & 0.05 & $1 / \mathrm{d}$ \\
\hline $\mathrm{k}_{0}, \mathrm{COD}, \mathrm{H}$ & 12.0 & gDQO/gDQO.d & $\mathrm{k}_{0, \mathrm{NH} 4, \mathrm{Aut}}$ & 4.3 & gN/g DQO.d \\
\hline $\mathrm{k}_{0, \mathrm{O}, \mathrm{H}}$ & 7.2 & $\mathrm{gO}_{2} / \mathrm{gDQO} . \mathrm{d}$ & $\mathrm{k}_{0, \mathrm{O} 2, \mathrm{Aut}}$ & 18.8 & $\mathrm{gO}_{2} / \mathrm{gDQO} . \mathrm{d}$ \\
\hline $\mathrm{X}_{\mathrm{H}}$ & 10,000 & $\mathrm{gDQO} / \mathrm{m}^{3}$ & $\mathrm{X}_{\text {Aut }}$ & 10,000 & $\mathrm{gDQO} / \mathrm{m}^{3}$ \\
\hline $\mathrm{D}_{\mathrm{W}, \text { acetate }}$ & $1.00 \cdot 10^{-04}$ & $\mathrm{~m}^{2} / \mathrm{d}$ & $\mathrm{D}_{\mathrm{W}, \mathrm{NH} 4}$ & $1.70 \cdot 10^{-04}$ & $\mathrm{~m}^{2} / \mathrm{d}$ \\
\hline $\mathrm{D}_{\mathrm{W}, \mathrm{O} 2}$ & $2.10 \cdot 10^{-04}$ & $\mathrm{~m}^{2} / \mathrm{d}$ & $\mathrm{D}_{\mathrm{W}, \mathrm{O} 2}$ & $2.10 \cdot 10^{-04}$ & $\mathrm{~m}^{2} / \mathrm{d}$ \\
\hline
\end{tabular}

soluciones numéricas. Este enfoque de biopelículas 1-D con una distribución homogénea, se utiliza en algunos simuladores de plantas de tratamiento de aguas residuales de uso comercial.

- Soluciones numéricas (1-D, distribución heterogénea de la biomasa): Esta estrategia considera los gradientes de concentración del sustrato soluble y la fracción de biomasa que resulta de los procesos de crecimiento, decaimiento y desprendimiento, con respecto al tiempo. Se presentó en la sección 17.8 utilizando el software AQUASIM y posteriormente se aplicó en la sección 17.9 cuando se realizó la evaluación de la competencia entre las bacterias heterótrofas y autótrofas presentes en la biopelícula.
Varios simuladores de plantas de tratamiento de aguas residuales comerciales, han incluido soluciones numéricas para biopelículas 1-D con una distribución heterogénea de la biomasa.

- Soluciones numéricas (2-D, 3-D): La aplicación de modelos multi-dimensionales se discutió en la sección 17.10. La aplicación de estos modelos se encuentra actualmente en investigación. La disponibilidad de contar con computadoras personales más rápidas para la simulación de modelos multi-dimensionales puede ser relativamente rápida. Pero sin importar la velocidad de las computadoras, la implementación y aplicación de estos modelos y la interpretación de los resultados multi-dimensionales resulta compleja. 


\section{REFERENCIAS}

Andrews,G. (1988): Effectiveness Factors for Bioparticles with Monod Kinetics. Chemical Engineering Journal And The Biochemical Engineering Journal, 37 (2), B31B37.

Bakke,R., Trulear,M.G., Robinson,J.A. and Characklis,W.G. (1984): Activity of Pseudomonas aeruginosa in biofilms: Steady state. Biotechnol.Bioeng., 26, 1418-1424.

Batstone,D.J., Keller,J., Angelidaki,I., Kalyuzhnyi,S.V., Pavlostathis,S.G., Rozzi,A., Sanders,W.T.M., Siegrist,H. and Vavilin,V.A. (2002): Anaerobic Digestion Model No.1 (ADM1). ed. Scientific and Technical Report No. 13. IWA Task Group for Mathematical Modelling of Anaerobic Digestion Processes (ed.) IWA Publishing, London.

Batstone,D.J., Picioreanu,C. and van Loosdrecht,M.C.M. (2006): Multidimensional modelling to investigate interspecies hydrogen transfer in anaerobic biofilms. Water Res., 40 (16), 3099-3108.

Boltz,J.P., Johnson,B.R., Daigger,G.T. and Sandino,J. (2008): Modeling integrated fixed film activated sludge (IFAS) and moving bed biofilm reactor (MBBR) systems I: mathematical treatment and model development. Water Environ.Res., 81(6), 555-575.

Boucher,D.F. and Alves,G.E. (1959): Dimensionless numbers. Chemical Engineering Progress, 55 (9), 55 64.

Bryers,J.D. (1984): Biofilm formation and chemostat dynamics: Pure and mixed culture considerations. Biotechnol.Bioeng., 26, 948-958.

Chang,H.T. and Rittmann,B.E. (1987): Mathematical modeling of biofilm on activated carbon. Environmental Science and Technology, 21 (3), 273280.

Clark,M.M. (1996): Transport modeling for environmental engineers and scientists Wiley, New York.

Crank,J. (1975): The Mathematics of Diffusion. ed. 2nd edition Oxford University Press, London.

Esener,A.A., Roels,J.A. and Kossen,N.W.F. (1983): Theory and Applications of Unstructured Growth-Models Kinetic and Energetic Aspects. Biotechnol.Bioeng., 25 (12), 2803-2841.

Fruhen,M., Christan,E., Gujer,W. and Wanner,O. (1991): Significance of spatial distribution of microbial species in mixed culture biofilms. Water Sci.Technol., 23 (7-9), 1365-1374.

Gapes,D., Perez,J., Picioreanu,C. and van Loosdrecht,M.C.M. (2006): Corrigendum to "Modeling biofilm and floc diffusion processes based on analytical solution of reaction-diffusion equations": [Water Res. 39 (2005) 1311-1323]. Water Res., 40 (15), 2997-2998.

Garner,F.H. and Suckling,R.D. (1958): Mass transfer from a soluble solid sphere. Aiche Journal, 4 (1), 114-124.

Gujer,W. and Boller,M. (1986): Design of A Nitrifying Tertiary Trickling Filter Based on Theoretical Concepts. Water Res., 20 (11), 1353-1362.

Gujer,W. and Wanner,O. (1990): Modeling mixed population biofilms. In: Marshall,K.C. (ed.), Biofilms, (11), pp. 397-443. New York Wiley.

Henze,M., Harremoës,P., Jansen,J.1.C. and Arvin,E. (2002): Wastewater Treatment. ed. 3rd ed. Springer, Berlin.

Horn,H. and Hempel,D.C. (1997): Substrate utilization and mass transfer in an autotrophic biofilm system: Experimental results and numerical simulation. Biotechnol.Bioeng., 53 (4), 363-371.

Horn,H. and Hempel,D.C. (2001): Simulation of substrate conversion and mass transport in biofilm systems. Chemical Engineering \& Technology, 24 (12), A225A228.

Horn,H. and Morgenroth,E. (2006): Transport of oxygen, sodium chloride, and sodium nitrate in biofilms. Chem.Eng.Sci., 61 (5), 1347-1356.

Hung,C., Yu,F., McFeters,G. and Stewart,P. (1995): Nonuniform spatial patterns of respiratory activity within biofilms during disinfection. Appl.Environ.Microbiol., 61 (6), 2252-2256.

Kissel,J.C. (1986): Modeling mass-transfer in biological waste-water treatment processes. Water Sci.Technol., 18 (6), 35-45.

Kissel,J.C., McCarty,P.L. and Street,R.L. (1984): Numerical simulation of mixed-culture biofilm. J.Environ.Eng.-ASCE, 110 (2), 393-411.

Kreikenbohm,R. and Stephan,W. (1985): Application of a two-compartment model to the wall growth of Pelobacter acidigallici under continuous culture conditions. Biotechnol.Bioeng., 27, 296-301.

Lackner,S., Terada,A. and Smets,B.F. (2008): Heterotrophic activity compromises autotrophic nitrogen removal in membrane-aerated biofilms: Results of a modeling study. Water Res., 42 (4-5), 1102-1112.

Libicki,S.B., Salmon,P.M. and Robertson,C.R. (1988): Effective diffusive permeability of a nonreacting solute in microbial cell aggregates. Biotechnol.Bioeng., 32 (1), 68-85.

Lide,D.R. (2008): CRC Handbook of Chemistry and Physics Taylor and Francis Group, London.

Logan,B.E., Hermanowicz,S.H. and Parker,D.S. (1987a): A Fundamental Model for Trickling Filter Process Design. J.Water Pollut.Control Fed., 59 (12), 1029-1042. 
Logan,B.E., Hermanowicz,S.H. and Parker,D.S. (1987b): A fundamental model for trickling filter process design. J.Water Pollut.Control Fed., 59 (12), 1029-1042.

McFeters,G. (2002): Biofilm of Two Bacteria. ASM MicrobeLibrary.org.

Morgenroth,E. (2003): Detachment - an often overlooked phenomenon in biofilm research and modeling. In: Wuertz,S., Wilderer,P.A. and Bishop,P.L. (eds.), Biofilms in wastewater treatment, pp. 264-290. IWA Publishing.

Morgenroth,E. and Wilderer,P.A. (1999): Controlled biomass removal - The key parameter to achieve enhanced biological phosphorus removal in biofilm systems. Water Sci.Technol., 39 (7), 33-40.

Morgenroth,E. and Wilderer,P.A. (2000): Influence of detachment mechanisms on competition in biofilms. Water Res., 34 (2), 417-426.

Nicolella,C., van Loosdrecht,M.C.M. and Heijnen,J.J. (1998): Mass transfer and reaction in a biofilm airlift suspension reactor. Chem.Eng.Sci., 53 (15), 2743-2753.

Nicolella,C., van Loosdrecht,M.C.M. and Heijnen,J.J. (2000): Wastewater treatment with particulate biofilm reactors. Journal Of Biotechnology, 80 (1), 1-33.

Nogueira,R., Elenter,D., Brito,A., Melo,L.F., Wagner,M. and Morgenroth,E. (2005): Evaluating heterotrophic growth in a nitrifying biofilm reactor using fluorescence in situ hybridization and mathematical modeling. Water Sci.Technol., 52 (7), 135-141.

Perry,R.H. and Green,D. (2008): Perry's Chemical Engineers' Handbook. ed. 8th ed. McGraw-Hill.

Peyton,B.M. and Characklis,W.G. (1993): A StatisticalAnalysis of the Effect of Substrate Utilization and Shear-Stress on the Kinetics of Biofilm Detachment. Biotechnol.Bioeng., 41 (7), 728-735.

Picioreanu,C., van Loosdrecht,M.C.M. and Heijnen,J.J. (1998): Mathematical modeling of biofilm structure with a hybrid differential discrete cellular automaton approach. Biotechnol.Bioeng., 58 (1), 101-116.

Picioreanu,C., van Loosdrecht,M.C.M. and Heijnen,J.J. (2000): Effect of diffusive and convective substrate transport on biofilm structure formation: A twodimensional modeling study. Biotechnol.Bioeng., 69 (5), 504-515.

Polson,A. (1950): Some Aspects of Diffusion in Solution and a Definition of a Colloidal Particle. The Journal of Physical Chemistry, 54 (5), 649-652.

Rauch,W., Vanhooren,H. and Vanrolleghem,P.A. (1999): A simplified mixed-culture biofilm model. Water Res., 33 (9), 2148-2162.

Reichert,P. (1998): Aquasim 2.0 - User manual. Computer program for the identification and simulation of aquatic systems Swiss Federal Institute for Environmental
Science and Technology (EAWAG). $\mathrm{CH} \quad 8600$ Dübendorf, Switzerland.

Rittmann,B.E. (1982a): Comparative Performance of Biofilm Reactor Types. Biotechnol.Bioeng., 24, 13411370 .

Rittmann,B.E. (1982b): The effect of shear stress on biofilm loss rate. Biotechnol.Bioeng., 24, 501-506.

Rittmann,B.E. (1989): Detachment from biofilms. In: Characklis,W.G. and Wilderer,P.A. (eds.), Structure and function of biofilms, pp. 49-58. New York Wiley.

Rittmann,B.E. and McCarty,P.L. (1980): Evaluation of Steady-State-Biofilm Kinetics. Biotechnol.Bioeng., 22, 2359-2373.

Rittmann,B.E. and McCarty,P.L. (2001): Environmental Biotechnology: Principles and Applications McGrawHill, New York.

Rittmann,B.E., Stilwell,D. and Ohashi,A. (2002): The transient-state, multiple-species biofilm model for biofiltration processes. Water Res., 36 (9), 2342-2356.

Robinson,J.A., Trulear,M.G. and Characklis,W.G. (1984): Cellular reproduction and extracellular polymer formation by Pseudomonas aeruginosa in continuous culture. Biotechnol.Bioeng., 26, 1409-1417.

Saez,P.B. and Rittmann,B.E. (1992): Communicaion to the Editor: Accurate Pseudoanalytical Solution for SteadyState Biofilms. Biotechnol.Bioeng., 39, 790-793.

Speitel,G.E. and DiGiano,F.A. (1987): Biofilm shearing under dynamic conditions. J.Environ.Eng.-ASCE, 113 (3), 464-475.

Stewart,P.S. (1998): A review of experimental measurements of effective diffusive permeabilities and effective diffusion coefficients in biofilms. Biotechnol.Bioeng., 59 (3), 261-272.

Stewart,P.S. (2003): Diffusion in biofilms. Journal of Bacteriology, 185 (5), 1485-1491.

Sutherland,I.W. (2001): The biofilm matrix - an immobilized but dynamic microbial environment. Trends in Microbiology, 9 (5), 222-227.

Tijhuis,L., van Loosdrecht,M.C.M. and Heijnen,J.J. (1995): Dynamics of biofilm detachment in biofilm airlift suspension reactors. Biotechnol.Bioeng., 45 (6), 481487.

Trulear,M.G. and Characklis,W.G. (1982): Dynamics of biofilm processes. J.Water Pollut.Control Fed., 54 (9), 1288-1301.

van Loosdrecht,M.C.M., Eikelboom,D., Gjaltema,A., Mulder,A., Tijhuis,L. and Heijnen,J.J. (1995): Biofilm structures. Water Sci.Technol., 32 (8), 35-43.

Wanner,O., Eberl,H.J., Morgenroth,E., Noguera,D.R., Picioreanu,C., Rittmann,B.E. and van Loosdrecht,M.C.M. (2006): Mathematical Modeling of 
Biofilms IWA Publishing, London, UK. Series: Scientific and Technical Report Series Report No. 18.

Wanner,O. and Gujer,W. (1985): Competition in biofilms. Water Sci.Technol., 17 (2-3), 27-44.

Wanner,O. and Gujer,W. (1986): A multispecies biofilm model. Biotechnol.Bioeng., 28, 314-328.

Wanner,O. and Morgenroth,E. (2004): Biofilm modeling with AQUASIM. Water Sci.Technol., 49 (11-12), 137 144.

Wanner,O. and Reichert,P. (1996): Mathematical-modeling of mixed-culture biofilms. Biotechnol.Bioeng., 49 (2), 172-184.

Wilson,E.J. and Geankoplis,C.J. (1966): Liquid Mass Transfer at Very Low Reynolds Numbers in Packed Beds. Industrial \& Engineering Chemistry Fundamentals, 5 (1), 9-14. 


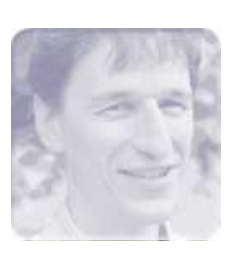

\section{8}

\section{Reactores de biopelícula}

\section{Eberhard Morgenroth}

\subsection{REACTORES DE BIOPELÍCULA}

Los reactores de biopelícula pueden alcanzar objetivos similares a los sistemas de lodos activados, tales como eliminación de materia orgánica, nitrificación, desnitrificación y eliminación química o biológica de fósforo. Los mismos tipos de microorganismos se encuentran involucrados y éstos deben de estar expuestos a las mismas condiciones ambientales locales, en términos de disponibilidad de donadores de electrones, aceptores de electrones, $\mathrm{pH}$ y temperatura. Sin embargo, los reactores de biopelícula presentan algunas diferencias en comparación con los sistemas de lodos activados: los procesos de conversión en los reactores de biopelícula se encuentran limitados típicamente por el transporte de masa, de tal manera que, únicamente las bacterias que se encuentran en la capa superficial de la biopelícula, contribuyen a la eliminación global del sustrato. Estas limitaciones del transporte de masa tienen algunas implicaciones en el diseño y operación de los reactores de biopelícula, así como también en la ecología microbiana en el interior de la misma. La competencia entre los microorganismos no se basa únicamente en la disponibilidad de sustrato en solución, sino que también dependerá de la distribución de los diferentes grupos de bacterias que se encuentran dentro de la biopelícula. Las bacterias que se encuentran cerca de la superficie de la biopelícula, presentan la ventaja de tener un acceso directo al sustrato contenido en la solución. Por otra parte, las bacterias que se encuentran más alejadas de la superficie de la biopelícula estarán más protegidas del desprendimiento.

En la Figura 18.1 se muestra un panorama general de los diferentes tipos de bioreactores existentes. A pesar de sus diferencias, todos ellos deberán de cumplir con las siguientes características: (i) la retención de los microorganismos se basa en la adhesión de la biomasa en la superficie del medio de soporte (acarreador), en lugar de la separación sólido-líquido y la recirculación de la biomasa; (ii) el agua que contiene los compuestos contaminantes permanece en contacto con la biopelícula $\mathrm{y}$ las condiciones de mezclado y turbulencia determinarán la eficiencia del transporte de masa de la solución hacia la superficie de la biopelícula; (iii) el crecimiento y desprendimiento de la biopelícula deberán de estar balanceados para evitar el taponamiento del reactor, mientras se retiene la biomasa activa suficiente en una biopelícula estable; (iv) de ser necesario, se deberán adicionar donadores de electrones, aceptores de electrones, nutrientes o alcalinidad al sistema. Por

() 2017 Eberhard Morgenroth. Tratamiento Biológico de Aguas Residuales: Principios, Modelación y Diseño. Eds. M. Henze, M.C.M. van Loosdrecht, G.A. Ekama y D. Brdjanovic. Eds. (versión en español) C.M. López Vázquez, G. Buitrón Méndez, H.A. García, F.J. Cervantes Carrillo. ISBN (versión impresa): 9781780409139, ISBN (e-Book): 9781780409146. Publicado por IWA Publishing, London, UK. 
A

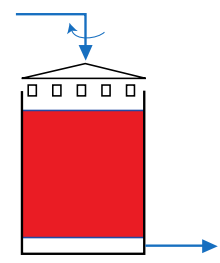

E

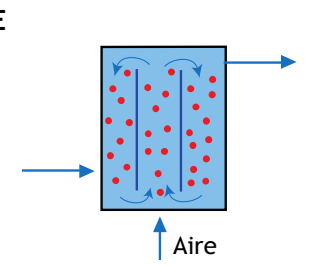

B

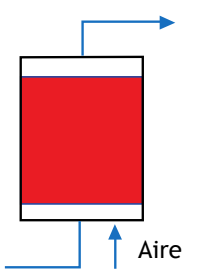

C

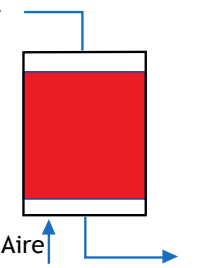

G

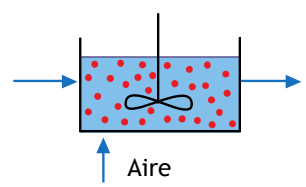

D

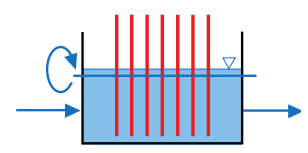

F

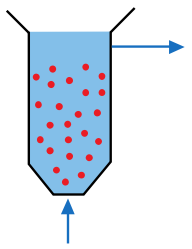

H



Figura18.1 Tipos de reactores de biopelícula: (A) filtros percoladores; (B) reactores de biopelícula sumergida de lecho fijo, operados con flujo ascendente o (C) flujo descendente; (D) reactores biológicos rotativos de contacto; y (E) reactores de biopelícula suspendida incluyendo reactores tipo "air-lift", (F) reactores de lecho fluidizado, (G) reactores de lecho móvil, y (H) reactores de biopelícula adherida a una membrana (modificado de Wanner et al., 2006).

ejemplo, se puede adicionar oxígeno en los sistemas aerobios por medio de aireadores.

En este capítulo se presenta un panorama general de algunos de los procesos de tratamiento básicos que se llevan a cabo en la biopelícula y algunos enfoques de diseño basados en los principios mostrados en el Capítulo 17.

\subsubsection{Tipos de reactores}

Los reactores de biopelícula se pueden agrupar en tres categorías básicas: $(i)$ sistemas no-sumergidos, en los cuales se incluyen los filtros percoladores y reactores biológicos rotativos de contacto (Figura 18.1A y Figura D); (ii) reactores de biopelícula sumergida de lecho fijo (Figura 18.1B y Figura 18.1C); y (iii) diferentes tipos de reactores de lecho fluidizado (Figura 18.1E-G). Además, en la actualidad existen varias investigaciones en las cuales se están utilizando membranas para el crecimiento de las biopelículas, en donde el sustrato es adicionado por medio de difusión a través de la membrana (Figura 18.1H). Algunas diferencias importantes entre estos tipos de reactores son: el área superficial específica (Tabla 18.1), los mecanismos de eliminación de la biomasa en exceso y la transferencia del gas.

Tabla 18.1 Área superficial específica para diferentes tipos de soportes y reactores de biopelícula

\begin{tabular}{|c|c|c|c|c|}
\hline Tipo de reactor & Material de soporte & $\begin{array}{l}\text { Tamaño del material, } \\
\mathrm{mm}\end{array}$ & $\begin{array}{c}\text { Área superficial } \\
\text { específica del soporte } \\
(\mathrm{a}), \mathrm{m}^{2} / \mathrm{m}^{3}\end{array}$ & Referencia \\
\hline \multirow[t]{2}{*}{ Filtro percolador } & Roca & $40-80$ & $50-100$ & ATV-DVWK, 2001 \\
\hline & Plástico & - & $100-200$ & ATV-DVWK, 2001 \\
\hline \multirow[t]{2}{*}{ Filtro rotatorio (RBC) } & Plástico & - & $100-200$ & ATV-DVWK, 2001 \\
\hline & $\begin{array}{l}\text { Plástico }\left(\mathrm{K}_{1}\right)(60 \% \text { del } \\
\text { volumen de llenado) }\end{array}$ & $7-9$ & 300 & Rusten et al., 2006 \\
\hline $\begin{array}{l}\text { Reactores de lecho } \\
\text { móvil (MBBR) }\end{array}$ & $\begin{array}{l}\text { Plástico }\left(\mathrm{K}_{3}\right)(60 \% \text { del } \\
\text { volumen de llenado })\end{array}$ & $12-25$ & 300 & Rusten et al., 2006 \\
\hline \multirow[t]{6}{*}{ Biofiltro sumergido } & Arcilla porosa & $1.3-8$ & $1,000-1,400$ & ATV, 1997 \\
\hline & Cal & $2-8$ & $1,200-1,400$ & ATV, 1997 \\
\hline & Poliestireno & $3-6$ & 1,100 & ATV, 1997 \\
\hline & Antracita & $2.5-3.5$ & 1,900 & ATV, 1997 \\
\hline & Arena de cuarzo & $0.7-2.2$ & 3,000 & ATV, 1997 \\
\hline & Basalto & $1.4-2.2$ & 3,600 & ATV, 1997 \\
\hline Lodo granular & - & - & $2,000-3,000$ & \\
\hline Lecho fluidizado & Arena o basalto & $0.2-0.8$ & $3,000-4,000$ & Nicolella et al., 2000 \\
\hline
\end{tabular}




\subsubsection{Filtros percoladores}

Los filtros percoladores son los sistemas más viejos de reactores de biopelícula, estos comenzaron a utilizarse a principios del siglo $\mathrm{XX}$ y actualmente se siguen operando. El soporte de la biopelícula es estacionario y consiste en rocas grandes de 5-20 $\mathrm{cm}$ o algún material de empaque plástico (Figura 18.2). La altura de los filtros percoladores varía de 1 a $3 \mathrm{~m}$ cuando se utilizan piedras de 4 a 12 m cuando el medio de soporte es plástico. El agua residual de entrada se distribuye sobre la superficie del filtro y posteriormente se percola por el material de empaque. El medio de soporte utilizado en los filtros percoladores se elige con un tamaño de poro lo suficientemente grande para permitir la ventilación del mismo con aire, a pesar del crecimiento de la biopelícula y el agua que se percola a través del filtro. El uso de materiales de empaque grandes, ayuda a evitar el taponamiento y además permite contar con áreas superficiales específicas de la biopelícula $\left(\mathrm{a}_{\mathrm{F}}\right)$ de 50 a 200 $\mathrm{m}^{2} / \mathrm{m}^{3}$, las cuales son relativamente más pequeñas en comparación con otro tipo de reactores de biopelícula (Tabla 18.1). El agua residual se distribuye utilizando brazos rotatorios colocados en la superficie del filtro y posteriormente desciende a lo largo del mismo. El agua tratada sale del fondo del filtro, los sólidos son eliminados en un sedimentador, y parte del efluente es recirculado para asegurar una carga hidráulica adecuada en el filtro percolador (Figura 18.3). Las tasas de recirculación $\left(\mathrm{Q}_{\mathrm{R}}\right)$ por lo general varían de 0.5 a 4 veces el flujo del afluente, pero pueden llegar a ser hasta 10 veces más que el afluente, cuando se trata de aguas residuales industriales de alta carga (WEF y ASCE, 1998). La ventilación en los filtros percoladores por lo general ocurre por convección natural; sin embargo, en algunos casos, se puede mejorar utilizando ventilación forzada.

El crecimiento de la biopelícula en los filtros percoladores es regulado por eventos periódicos de desprendimiento. Los mecanismos de desprendimiento no son bien comprendidos; sin embargo, en algunas ocasiones pueden estar ligados a las condiciones anaerobias presentes en el fondo del espesor de la biopelícula, las cuales disminuyen la estabilidad de la misma. Otro factor que puede generar el desprendimiento, es el desarrollo de lombrices y larvas que se alimentan de la biopelícula y que pueden generar desestabilizaciones locales. Durante el proceso de desprendimiento puede perderse una fracción considerable de la biomasa total. Sin embargo, esta pérdida de biomasa activa, por lo general, tiene un impacto menor en el funcionamiento del filtro percolador. La presencia de moscas, lombrices y caracoles en los filtros percoladores puede ser muy molesta; sin embargo, puede controlarse por medio de lavados periódicos con cargas hidráulicas de alta intensidad, inundamiento periódico del filtro o por medio de tratamientos químicos (Boltz et al., 2008; WEF y ASCE, 1998).

Los filtros percoladores son utilizados para la oxidación de la materia orgánica y amonio en la mayoría de los casos.

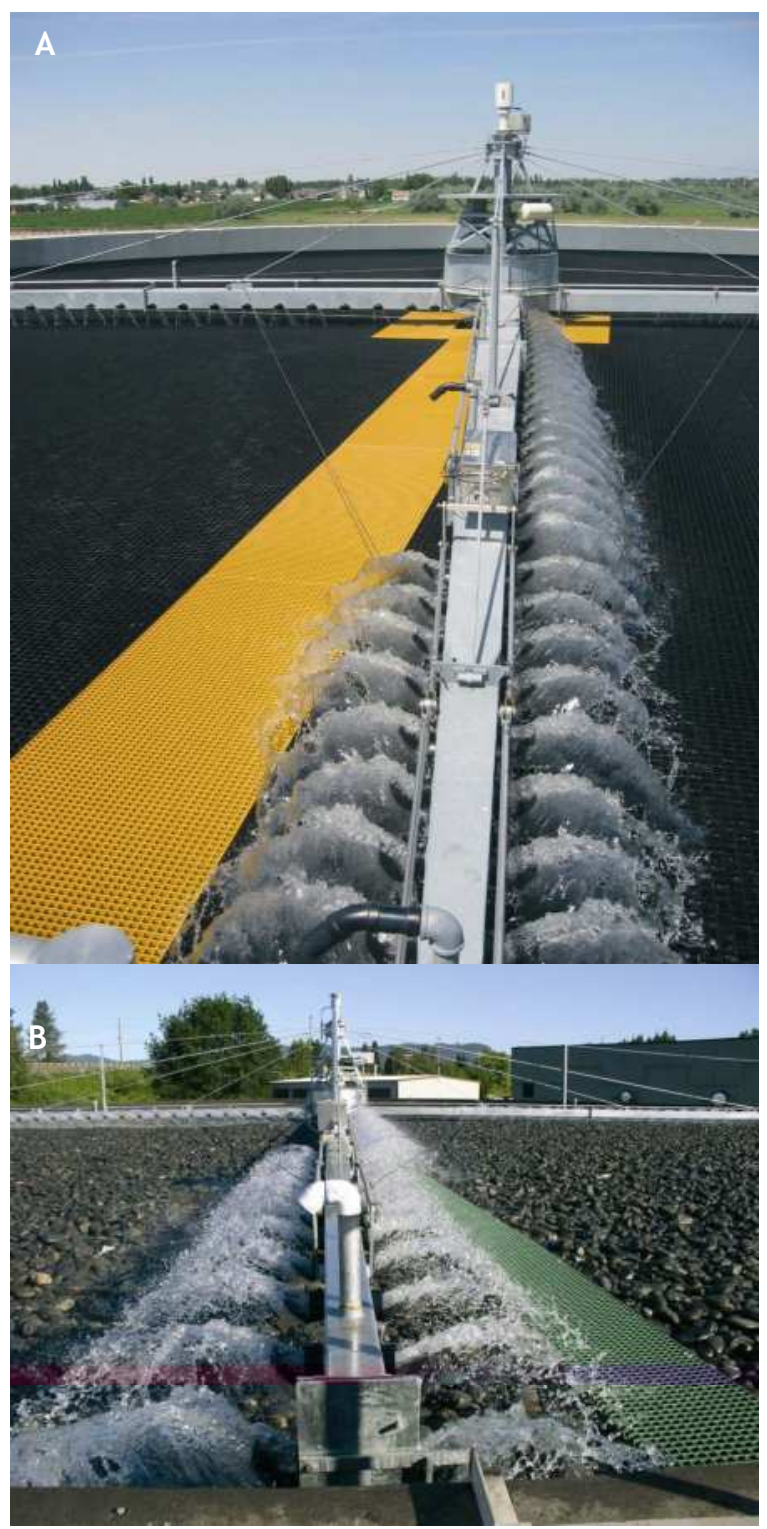

Figura 18.2 Filtros percoladores utilizando (A) plástico o (B) rocas como medio de soporte (Imágenes: WesTech Engineering Inc.) 
Los sustratos solubles que se difunden al interior de la biopelícula pueden ser eliminados eficientemente; sin embargo, la eliminación de partículas y la biofloculación son menos eficientes (Parker y Newman, 2006). Además, los filtros percoladores pueden ser utilizados para llevar a cabo la desnitrificación cuando se impide el proceso de convección de aire a través del reactor.

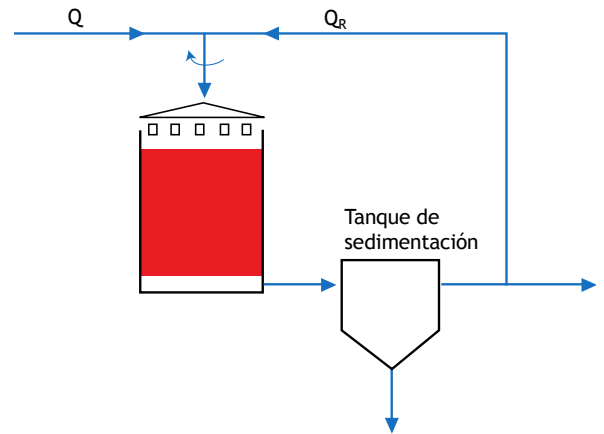

Figura 18.3 Esquema representativo de un filtro percolador con recirculación del efluente clarificado

\subsubsection{Reactores biológicos rotativos de contacto}

Los reactores biológicos rotativos de contacto (RBCs, por sus siglas en inglés Rotating Biological Contactors), utilizan discos de plástico ligero montados sobre un eje giratorio, los cuales se encuentran parcialmente sumergidos en el agua. Los RBCs fueron utilizados por primera vez en los años 60s y pueden ser convenientes debido a su baja demanda de energía y su operación simple. La rotación de los discos proporciona tanto la aireación (cuando la biopelícula se encuentra fuera del agua), como las fuerzas hidráulicas de corte necesarias para controlar el crecimiento de la biopelícula (cuando la biopelícula se mueve a través del agua). En la Figura 18.4 se muestra un ejemplo de $\mathrm{RBC}$, utilizando plástico corrugado como medio de soporte.

18.1.1.3 Reactores de biopelícula sumergida de lecho fijo

Comenzando desde los años 80, un gran número de reactores de biopelícula sumergida se han desarrollado utilizando tamaños pequeños $(2-8 \mathrm{~mm})$ de un medio granular, que se encuentra sumergido completamente en el agua. Un tamaño pequeño del medio de soporte, da como resultado altas áreas superficiales específicas $\left(1,000-3,000 \mathrm{~m}^{2} / \mathrm{m}^{3}\right)$ en comparación con los filtros percoladores y los RBCs (Tabla 18.1). Además, un tamaño pequeño de poro ayuda a que el espesor de la biopelícula sea controlado efectivamente evitando el taponamiento del filtro. Un tamaño pequeño de medio de soporte en los reactores de lecho fijo, puede permitir la combinación de los procesos de conversión biológicos, con la retención de los sólidos suspendidos a través del filtrado.

La eliminación de la biopelícula en exceso, se logra típicamente utilizando retrolavados regulares del filtro, en los cuales se adicionan aire y agua tratada en el reactor para expandir temporalmente el lecho del filtro, eliminando la biomasa desprendida y atrapando la materia particulada. Los retrolavados se realizan cuando la pérdida de presión en el reactor excede un valor crítico o después de ciertos periodos de tiempo fijados (por lo general de alrededor de $24 \mathrm{~h}$ ). Los reactores de biomasa sumergida que se diseñan específicamente para la combinación de los procesos biológicos y la eliminación de sólidos, se conocen como filtros biológicos aireados (BAF, por sus siglas en inglés Biological Aerated Filters).

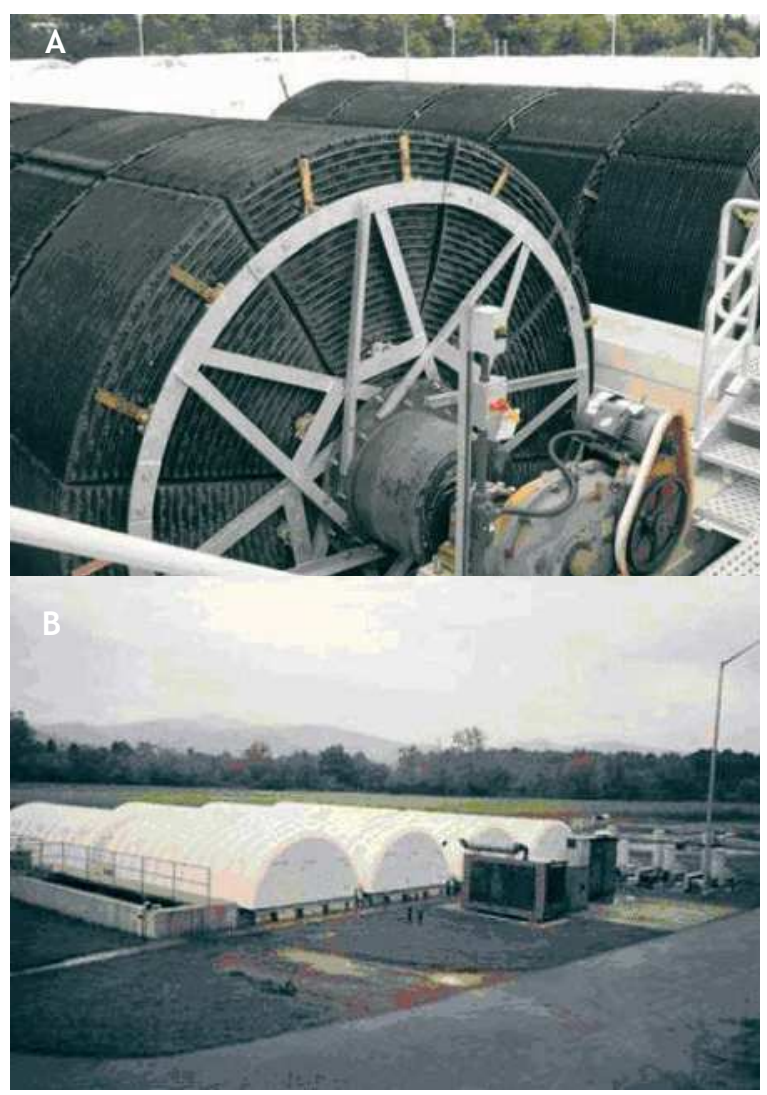

Figura 18.4 (A) Reactores biológicos rotativos de contacto utilizando plástico corrugado como medio de soporte. (B) El RBC puede cubrirse durante su operación (Imágenes: Siemens) 
En un SAF, la eliminación de sólidos se debe llevar a cabo por separado en un clarificador o filtro (WEF y ASCE, 1998).

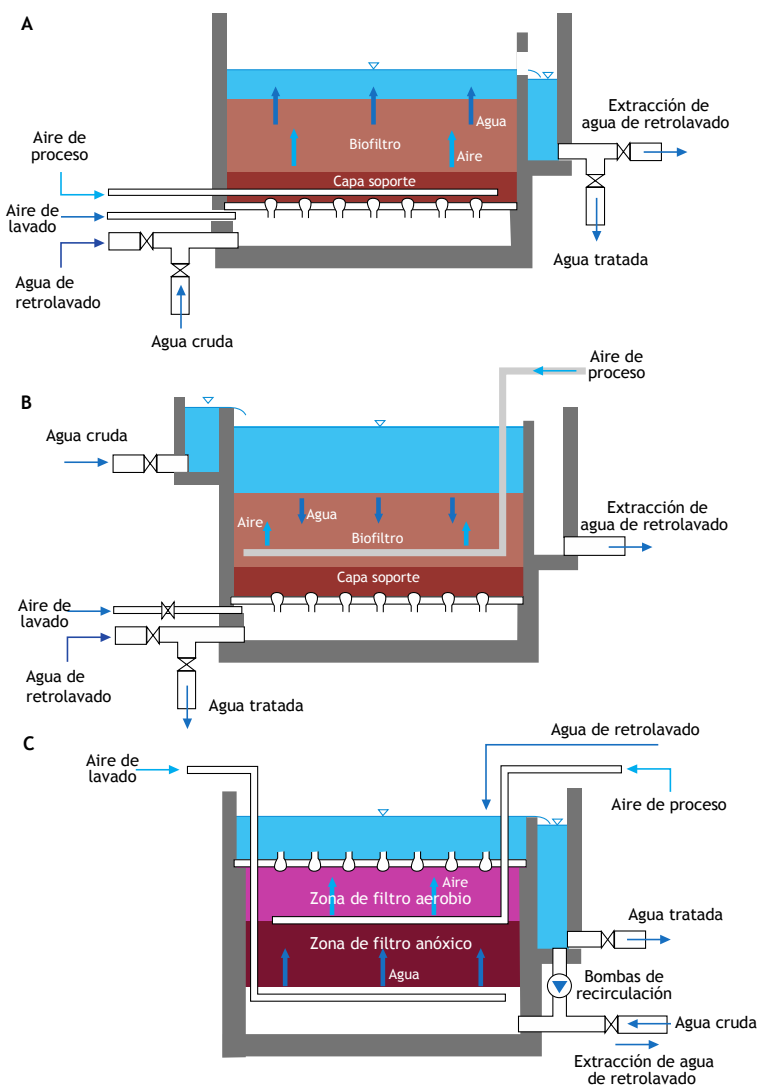

Figura 18.5 Reactores de biopelícula sumergida: (A) de flujo ascendente con medio de soporte denso (Biofor ${ }^{\circledR}$ ), (B) de flujo descendente con medio de soporte denso (Biocarbone ${ }^{\circledR}$ ) y (C) de flujo ascendente con medio de soporte flotante (Biostyr ${ }^{\circledR}$ ) (modificado de ATV, 1997; Tschui, 1994)

En los reactores de biopelícula sumergida de lecho fijo, el oxígeno se debe adicionar introduciendo aire en el fondo del filtro (Figura 18.5). La transferencia de oxígeno ocurre a través del lecho filtrante, por medio del ascenso de burbujas de aire hacia la superficie del reactor. Diferentes tipos de reactores de biopelícula sumergida se encuentran disponibles, los cuales pueden ser operados introduciendo agua en el fondo del reactor (flujo ascendente) (Figura 18.5A, C) o en la superficie (flujo descendente) (Figura 18.5B).

El material de empaque puede ser más denso que el agua y se encuentra soportado junto con una válvula de drenado por debajo de éste (Figura 18.5 A, B), o puede ser más ligero que el agua y se encuentra soportado con una placa y válvulas por encima del mismo (Figura 18.5C). En la Figura 18.6A, B se muestran algunas imágenes de los materiales de empaque utilizados en los reactores de biopelícula sumergida de lecho fijo.

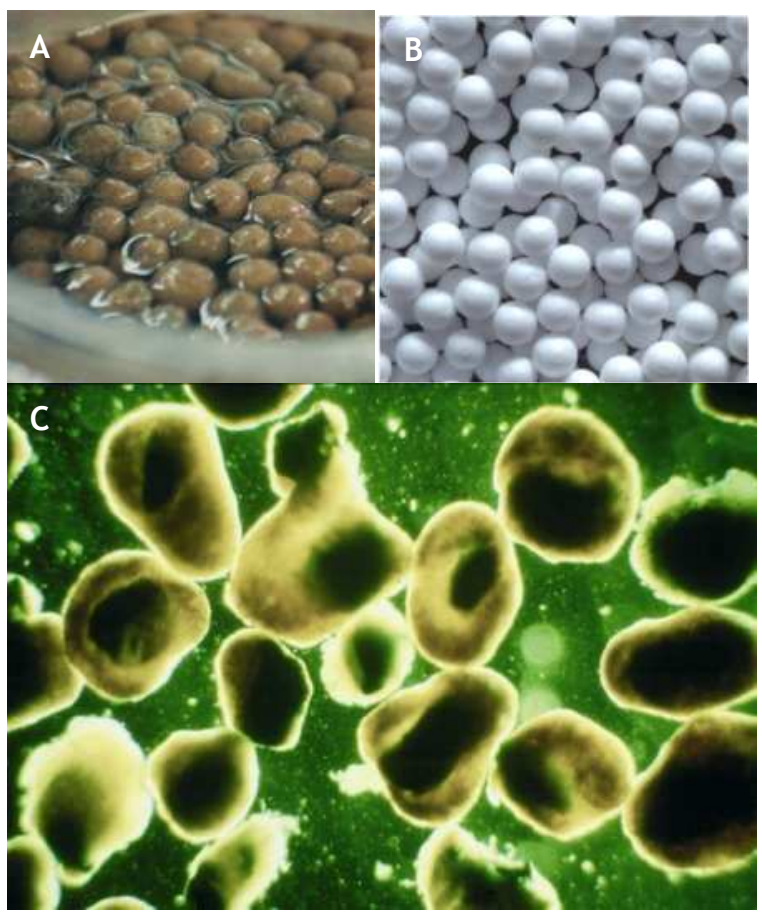

Figura 18.6 Medios de soporte (A) Biofor ${ }^{\circledR}$ y (B) BioStyr ${ }^{\circledR}$ en reactores de biopelícula sumergida de lecho fijo. Se puede utilizar arena o basalto como medio de soporte en los reactores de lecho fluidizado (C). El diámetro del medio de soporte en (A) y (B) es de $4 \mathrm{~mm}$ y en (C) es de $1 \mathrm{~mm}$. (Imágenes: E. Morgenroth, Veolia, y M.C.M. van Loosdrecht, respectivamente)

En la Figura 18.5, se muestran algunos esquemas representativos de reactores de biopelícula sumergida, con detalles de la forma en la que el aire y el agua son adicionados durante una operación normal y durante el retrolavado (fregado). La mayoría de los reactores de biopelícula de lecho fijo se operan como reactores de flujo en continuo; sin embargo, también pueden ser operados como reactores secuenciales semicontinuos de biopelícula (SBBR, por sus siglas en inglés Sequencing Batch Biofilm Reactors), en donde el reactor se llena con agua residual al principio de un ciclo de operación; posteriormente, el agua residual se recircula a través del reactor durante la fase de reacción y, finalmente, el agua limpia es descargada al final del ciclo de operación. Un motivo por el cual se operan los reactores de biopelícula de lecho fijo como SBBRs, es el permitir que se lleve a cabo la eliminación biológica de fósforo (Morgenroth yWilderer, 1999). 


\subsubsection{Reactores de biopelícula de lecho fluidizado y lecho expandido}

En los reactores de lecho fluidizado, el medio de soporte se mantiene en suspensión mediante el suministro de agua o aire en el fondo del reactor, lo cual da como resultado flujos ascendentes de altas velocidades. Las velocidades de flujo ascendente varían entre 10 y $50 \mathrm{~m} / \mathrm{h}$ (Boltz et al., 2009; Nicolella et al., 2000).

Los reactores de lecho expandido son similares a los reactores de lecho fluidizado; sin embargo, estos últimos se operan con menores velocidades de flujo ascendente, resultando en una fluidización incompleta del medio de soporte. Esta agitación continua permite que se puedan utilizar medios de soporte más pequeños en comparación con los reactores de lecho sumergido, con superficies aún mayores con respecto al volumen (Tabla 18.1).

En los reactores convencionales de lecho fluidizado, las velocidades de flujo ascendente deseadas pueden obtenerse independientemente de las velocidades de flujo del afluente por medio de la recirculación del agua tratada (Figura 18.1F). Su operación requiere de un ajuste cuidadoso de las velocidades de flujo ascendente del agua. Si las velocidades de flujo ascendente son muy bajas, entonces el medio filtrante se sedimentará en el fondo del reactor. Por el contrario, si las velocidades de flujo ascendente son muy altas, entonces el medio filtrante será eliminado del reactor. Un segundo problema que se puede presentar es la estratificación de las partículas de la biopelícula dependiendo de su velocidad de sedimentación. Las partículas que tienen una estructura más abierta o porosa y por consiguiente ligera, sedimentan más lentamente y se acumulan en la superficie del lecho filtrante, en donde se experimenta una menor fuerza de corte. Como consecuencia, la biopelícula se vuelve más suave y las partículas que se encuentran en la parte superior del reactor comienzan a ser eliminadas. La necesidad de contar con una velocidad de flujo ascendente definida y la inherente inestabilidad de la biopelícula en el sistema, limita la aplicación de los reactores de lecho fluidizado o lecho expandido en comparación con los sistemas de crecimiento lento, como por ejemplo, el tratamiento anaerobio de aguas residuales o la nitrificación.

En los reactores airlift, se puede lograr una suspensión completa de las partículas introduciendo aire en el fondo del reactor tal y como se muestra en la Figura 18.7A. Debido a que todas las partículas en el reactor airlift (llamados de esta manera por la fuerza ascendente generada por el suministro de aire el cual mantiene en suspensión a la biomasa) experimentan velocidades con un efecto de corte similares, el control de la biopelícula es más sencillo que en los reactores de lecho fluidizado $\mathrm{y}$, por lo tanto, pueden ser utilizados satisfactoriamente para la eliminación de DQO y la nitrificación. Es esencial para una aireación eficiente que el reactor sea diseñado de tal manera que las burbujas también circulen sobre el conducto de aire del reactor (van Benthum et al., 1999). En la parte superior del reactor se coloca una unidad de separación de tres fases, la cual se utiliza para separar el líquido, gas y las partículas. Todos los tipos de reactores de lecho fluidizado son sensibles al diseño hidráulico; por lo tanto, por lo general se utilizan en industrias en donde las velocidades de flujo del afluente son más constantes comparadas con el agua residual municipal.
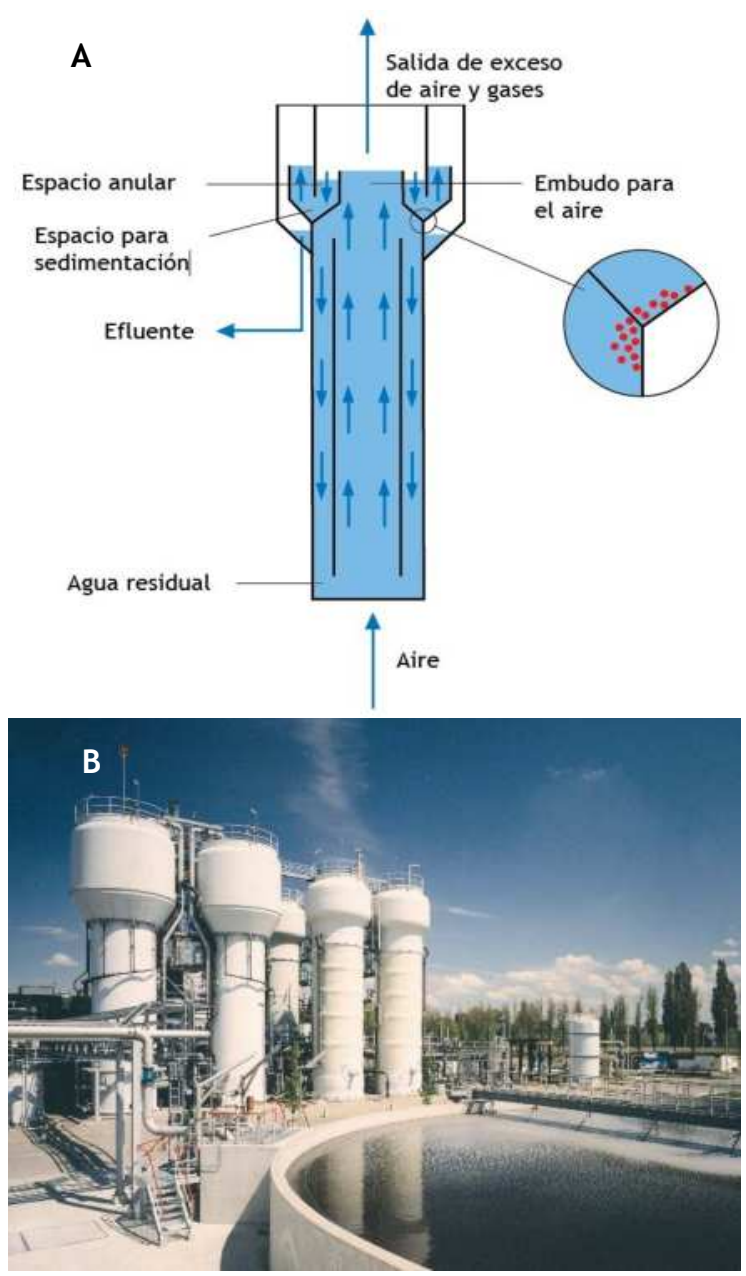

Figura 18.7 (A) Esquema e (B) imágen de un reactor airlift (las dos torres a la derecha), con un sedimentador integrado en la parte superior del reactor: industria de fermentación DSM en Delft, Holanda (Imágen: J. Blom) 


\subsubsection{Reactores de lodo granular}

Las biopelículas granulares pueden crecer también sin un medio de soporte (Hulshoff Pol et al., 1982). Aún cuando se piensa que el lodo granular no coincide con la definición estricta del crecimiento de los microorganismos en la superficie de un soporte sólido, presentada en el Capítulo 17, los gránulos comparten varias características comunes a los sistemas de biopelículas. La morfología, densidad y el tamaño del lodo granular se encuentran, como en los sistemas de biopelícula, directamente influenciadas por las fuerzas de corte o cizallamiento y el correspondiente desprendimiento en el reactor (Liu y Tay, 2002; Tay et al., 2006; van Loosdrecht et al., 1995). Especialmente en el hecho de que la estructura del gránulo es, al igual que en la biopelícula, "fija" y no se encuentra sujeta a la disrupción/floculación, como en el caso de los flóculos formados en los sistemas de lodos activados, lo cual significa que existen gradientes de poblaciones microbianas al igual que en la biopelícula. Una diferencia existente entre los sistemas de lodos activados y los lodos granulares es que durante la sedimentación de los gránulos no ocurre el espesamiento, mientras que, en los sistemas de lodos activados, el espesamiento y agregación son dos características importantes para la sedimentación (ver el Capítulo 11). La definición de granulación, por lo tanto, ha sido propuesta cuando el valor del IVL, después de 5 minutos de sedimentación, es similar al que se obtiene después de 30 minutos de sedimentación en una prueba estándar. Un valor típico del IVL para lodo granular después de 5 minutos de sedimentación es de 40-60 $\mathrm{ml} / \mathrm{g}$. El proceso de granulación se observa tanto en reactores aerobios como en anaerobios, en donde la formación de agregados microbianos más grandes y de más rápida sedimentación, proporciona una ventaja ecológica cuando el reactor se opera de tal manera que los flóculos más pequeños son lavados fuera del sistema. Los reactores anaerobios de lecho de lodos con flujo ascendente (UASB, por sus siglas en inglés Upflow Anaerobic Sludge Blanket), son una tecnología ampliamente utilizada para lograr la granulación bajo condiciones anaerobias (ver el capítulo 16). Una manera comúnmente utilizada para lograr la granulación aerobia, es el operar el reactor secuencial de manera semicontinua con tiempos cortos de sedimentación (Beun et al., 1999; Morgenroth et al., 1997). Dependiendo de la operación del reactor, el tamaño de los gránulos puede variar desde unos pocos micrómetros hasta pocos milímetros (Figura 18.8) (Liu y Tay, 2002). El lodo granular aerobio que se forma cuando el crecimiento de las bacterias es lento, es más estable en comparación con el formado en condiciones de crecimiento rápido (van Loosdrecht et al., 1995). Por lo tanto, el uso de organismos acumuladores de polyfosfatos para convertir la DQO (crecimiento lento) en lugar de bacterias heterótrofas normales (crecimiento rápido), estabilizará el sistema y los hará más fáciles de operar (de Kreuk y van Loosdrecht, 2004). Estos procesos de lodo granular aerobio están siendo desarrollados en la actualidad para la eliminación de nutrientes en el tratamiento de aguas residuales municipales. Debido a que durante su operación se lleva a cabo la sedimentación en el tanque, en lugar de utilizar un separador de tres fases en la parte superior del reactor, las variaciones de carga hidráulica no son un problema significativo para los sistemas de lodo granular.

\subsubsection{Reactores de biopelícula de lecho móvil}

Los reactores de biopelícula de lecho móvil (MBBR, por sus siglas en inglés Moving Bed Bioreactor) utilizan medios de soporte con una densidad cercana a la del agua, de modo que, la biomasa se puede mantener en suspensión suministrando una mínima cantidad de energía en el mezclado, ya sea por aireación o mezclado mecánico (Odegaard, 2006). Los medios de soporte para la biopelícula son fabricados en diferentes formas y lo suficientemente largos, de manera que puedan ser

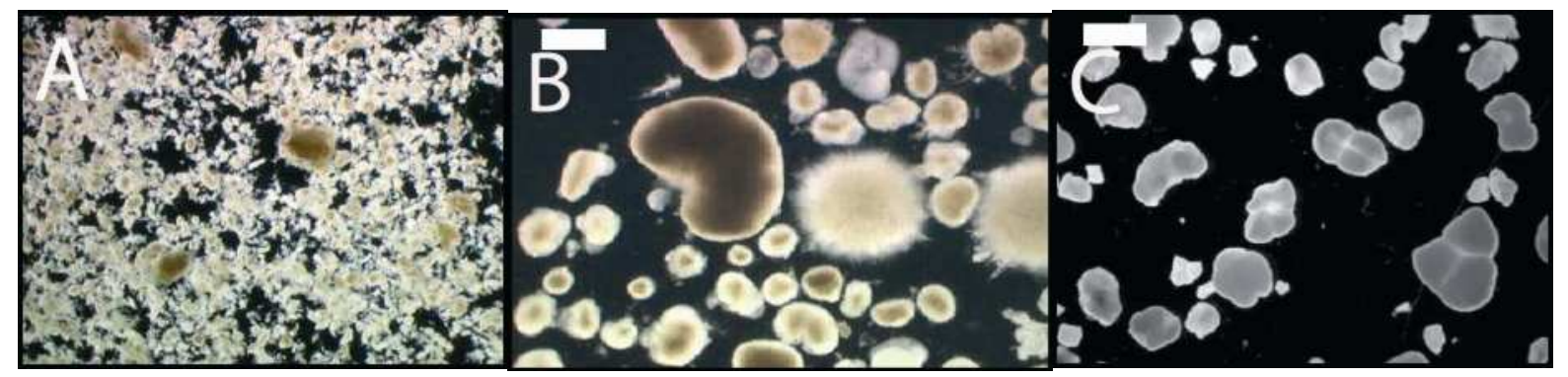

Figura 18.8 Desarrollo de un lodo aerobio granular en un reactor secuencial airlift semicontinuo, inoculado inicialmente con lodos activados convencionales, después de 4 (A), 13 (B), y 87 (C) días de operación del reactor (escala= 1 mm) (Imágenes: M.C.M. van Loosdrecht) 
retenidos en el reactor por medio de mallas o cuñas de alambre (Figura 18.9).

Los MBBRs se pueden operar con o sin recirculación de lodo. Sin recirculación (Figura 18.9B), el tiempo de retención de la biomasa en el MMBR se encuentra limitado por la cantidad de biopelícula retenida en el medio de soporte. Un sistema con recirculación de biomasa, permite la retención tanto de la biopelícula como de la biomasa suspendida. Este tipo de reactor se discutirá en la siguiente sección (Figura 18.9C).

\subsubsection{Sistemas híbridos de biopelícula/lodo activado}

El utilizar un medio de soporte para la biopelícula puede resultar útil para mejorar el funcionamiento de los sistemas de lodos activados. Estos sistemas se conocen como sistemas híbridos o como sistemas de lodos activados de película fija integrada (IFAS, por sus siglas en inglés Integrated Fixed Activated Sludge). Un sistema híbrido tanto con biopelícula como con lodo activado se muestra en la Figura 18.9C. El material de empaque se deberá seleccionar de tal manera que no se presente el problema de taponamiento por el lodo activado en suspensión en el reactor. Algunos materiales de empaque incluyen medios suspendidos (como en el MBBR) o materiales de empaque fijos como por ejemplo, cadenas de plástico, empaques estructurados de PVC, o contactores biológicos rotatorios sumergidos (Tchobanoglous et al., 2003). En general, las bacterias de lento crecimiento se acumularán preferencialmente en la biopelícula. De esta manera, una carga alta en el sistema (tiempos de retención hidráulicos cortos) puede, por ejemplo, aumentar la nitrificación (van Benthum et al., 1997). Además, se han propuesto los sistemas híbridos en el tratamiento anaerobio de aguas residuales, en donde los metanógenos crecen en la biopelícula mientras que los acidogénicos están presentes en el lecho del lodo floculado.

\subsubsection{Reactores de biopelícula adherida a una membrana}

Las biopelículas pueden crecer en membranas permeables al gas, permitiendo la transferencia de masa del sustrato tanto en la superficie como en el fondo de la biopelícula (Figura 18.10).

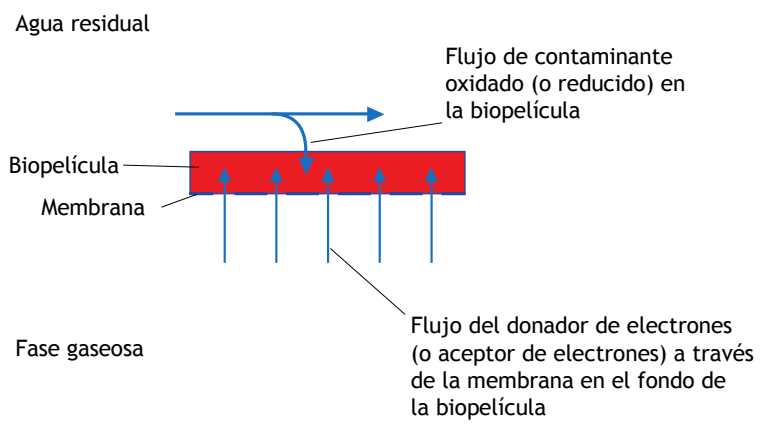

Figura 18.10 Esquema representativo del transporte de masa en una biopelícula adherida a una membrana

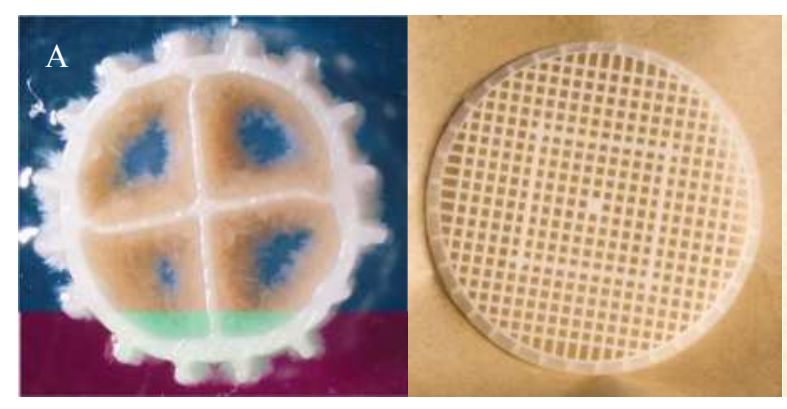

B

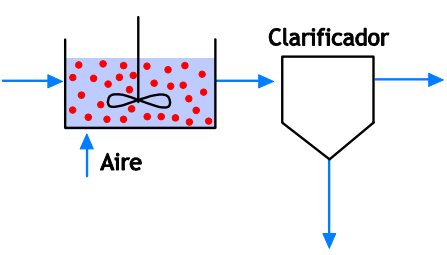

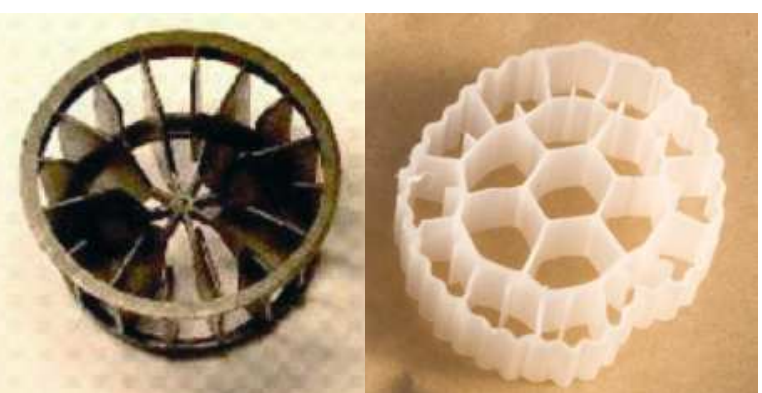

C

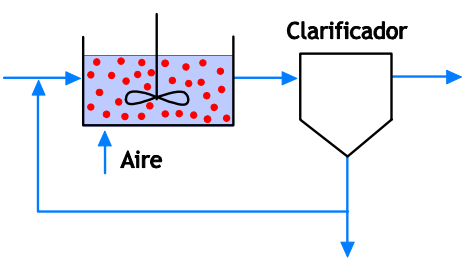

Figura 18.9 Medios plásticos utilizados en los reactores de biopelícula de lecho móvil (MBBR) (A) los cuales pueden ser configurados sin (B) o con (C) recirculación de la biomasa en suspensión (Imágenes: AnoxKaldnes) 
Si el contaminante es un compuesto oxidante (por ej., nitrato o perclorato), entonces se puede adicionar un donador de electrones (por ej., gas hidrógeno) en el fondo de la biopelícula a través de la membrana (Nerenberg y Rittmann, 2004). O si el contaminante es un compuesto reductor (por ej., amonio), entonces será necesario adicionar un aceptor de electrones (por ej., oxígeno) a través de la membrana (Terada et al., 2007). Los reactores biológicos de membrana aún no han sido utilizados a gran escala; sin embargo, estos proporcionan oportunidades interesantes con estratificación controlada de las condiciones redox sobre el espesor de la biopelícula.

\subsubsection{Elección de diferentes materiales de filtrado}

Los medios de soporte se producen en diferentes materiales y pueden encontrarse en diferentes formas y tamaños. Entre más grande sea el material de soporte y los correspondientes espacios vacíos en el reactor, menor será el riesgo de taponamiento y formación de canales con la acumulación de la biopelícula. Algunos ejemplos típicos de reactores de biopelícula con grandes espacios vacíos son los filtros percoladores y los RBC. La desventaja de tener grandes espacios vacíos es que las áreas específicas se vuelven relativamente pequeñas. El uso de materiales de soporte pequeños requiere tanto de retrolavados regulares como de la fluidización continua del material de soporte para prevenir los problemas de taponamiento. Las correspondientes áreas superficiales específicas de los medios pequeños pueden ser un orden de magnitud mayores, en comparación con los filtros percoladores y el RBC. El área superficial específica $\left(\mathrm{a}_{\mathrm{F}}\right)$ $\left(\mathrm{L}^{-1}\right)$ se define como:

$$
a_{F}=\frac{A_{F}}{V_{R}}
$$

en donde $A_{F}$ es el área superficial efectiva de la biopelícula $\left(\mathrm{L}^{2}\right)$ y $\mathrm{V}_{\mathrm{R}}$ es el volumen del reactor considerando el material filtrante $\left(\mathrm{L}^{3}\right)$. Observe que $\mathrm{A}_{\mathrm{F}}$ es típicamente más pequeña que el área superficial total del material filtrante debido al cubrimiento incompleto de la biopelícula. Dependiendo del tipo de reactor, $V_{R}$ puede ser más pequeño que el volumen total del reactor, considerando que no se incluyen las zonas de agua libres arriba y abajo del medio filtrante. En la Tabla 18.1 se presenta un resumen de las áreas superficiales específicas y algunas propiedades seleccionadas de los diferentes materiales de soporte.
Algunos otros factores, además del área superficial específica, que pueden afectar la selección del material filtrante, incluyen el costo, densidad (material flotante o algún otro material que sea más pesado que el agua), resistencia al agotamiento y disponibilidad para la adhesión de la biopelícula (Lazarova y Manem, 2000).

\subsection{PARÁMETROS DE DISEÑO}

El diseño de los reactores de biopelícula se basa en el uso de una gran variedad de medios de soporte, condiciones de mezclado, tipos de aireación y métodos de eliminación en la biopelícula. El diseño detallado de estos sistemas, dependerá del tipo de reactor del que se trate y se encuentra fuera del alcance de este libro. Sin embargo, existen algunos principios generales de diseño comunes en los diferentes tipos de reactores. Estos principios comunes serán discutidos en la presente sección. Una mayor información detallada del diseño, se encuentra disponible como parte de la literatura técnica (por ej., ATV, 1997; Grady et al., 1999; Tchobanoglous et al., 2003; WEF y ASCE, 1998) y también puede estar disponible dentro de algunas compañías, siendo por lo general de su propiedad.

\subsubsection{Flujo de sustrato y tasas de carga}

El consumo de sustrato en los reactores de biopelícula, por lo general, se encuentra limitado por el transporte de masa. Como resultado, el grado de eliminación de sustrato en el reactor no se encuentra determinado por la cantidad total de biomasa en el sistema, sino por el área superficial disponible de la biopelícula $\left(\mathrm{A}_{\mathrm{F}}\right)$ y el flujo de sustrato en la misma $\left(\mathrm{J}_{\mathrm{LF}}\right)$. Utilizando las estrategias desarrolladas en el Capítulo 17, se puede calcular el flujo de sustrato con base en las concentraciones de sustrato en el efluente, la resistencia externa a la transferencia de masa, el transporte de masa y las reacciones que ocurren en la biopelícula. El área superficial de la biopelícula, necesaria para un reactor operado bajo condiciones de mezcla completa del líquido (por ej., un reactor de biopelícula de lecho móvil), se puede calcular como:

$A_{F}=\frac{Q\left(C_{i n}-C_{B}\right)}{J_{L F}}$

considerando que el consumo de sustrato en la solución puede ser despreciable. Para reactores con condiciones de mezclado más complejas (por ej., condiciones de flujo pistón en reactores de lecho fijo), el modelado se puede realizar como si se tratara de varios compartimentos de biopelícula conectados en serie (Figura 17.19). El valor 
de $A_{F}$ requerido para el reactor total, es la suma de las áreas superficiales de la biopelícula en cada uno de los compartimentos. El volumen mínimo del reactor $\left(V_{R}\right)$, puede ser calculado a partir de $\mathrm{A}_{\mathrm{F}}$ utilizando la definición del área superficial específica de la biopelícula $\left(\mathrm{a}_{\mathrm{F}}\right)$ :

$V_{R}=\frac{A_{F}}{a_{F}}$

Muchas guías de diseño para reactores de biopelícula, no calculan explícitamente el área superficial con base en los flujos de sustrato locales en el interior del reactor, por lo que se basan en las cargas de diseño obtenidas empíricamente para ciertos tipos de reactores. Las cargas de diseño se pueden expresar como cargas superficiales $\left(\mathrm{B}_{\mathrm{A}}, \mathrm{M} / \mathrm{L}^{2} . \mathrm{T}\right)$

$$
A_{F}=\frac{Q \cdot C_{i n}}{B_{A}}
$$

o como cargas volumétricas $\left(\mathrm{Bv}, \mathrm{M} / \mathrm{L}^{3} . \mathrm{T}\right)$ :

$$
V_{R}=\frac{Q \cdot C_{i n}}{B_{V}}
$$

$\mathrm{B}_{\mathrm{A}} \mathrm{y} \mathrm{B}_{\mathrm{V}}$ se encuentran directamente relacionadas con el área superficial específica $\left(\mathrm{a}_{\mathrm{F}}\right)($ Ec. 18.1):

$$
B_{V}=B_{A} \cdot a_{F}
$$

Para un reactor completamente mezclado, la Ec. 18.2 y la Ec. 18.3 pueden combinarse para generar la Ec. 18.6 que relaciona los flujos de sustrato y las velocidades de carga superficiales.

$$
J_{L F}=B_{A}-\underbrace{\frac{Q C_{B}}{A_{F}}}_{\begin{array}{c}
\text { Pequeño } \\
\text { para valores } \\
\text { bajos de } \mathrm{C}_{\mathrm{B}}
\end{array}}
$$

Para bajas concentraciones de sustrato en el efluente, el flujo de sustrato y las velocidades de carga superficiales de diseño son virtualmente idénticos. En la Sección 18.3 se proporcionan algunas estrategias para la elección de flujos de diseño o velocidades de carga apropiados.

\subsubsection{Carga hidráulica}

Las condiciones de mezclado y las cargas hidráulicas en un reactor de biopelícula influyen en: los gradientes de concentración a lo largo del reactor, la resistencia a la transferencia de masa externa y en la exposición de la biopelícula al corte. La carga hidráulica $\left(\mathrm{q}_{\mathrm{A}}\right)(\mathrm{L} / \mathrm{T})$ en algunos sistemas, también conocida como la velocidad de filtrado, se define como:

$q_{A}=\frac{Q_{i n}+Q_{R}}{A_{R}}$

donde $A_{R}$ es el área de la sección transversal del reactor de biopelícula en dirección al flujo $\left(\mathrm{L}^{2}\right)$. Por ejemplo, para un filtro percolador circular, con un radio $r, A_{R}=r^{2} \pi$. El caudal total determinado en la Ec. 18.7 es la suma del caudal afluente a la planta de tratamiento ( $\left.Q_{\text {in }}\right)$ y del caudal de recirculación $\left(\mathrm{Q}_{\mathrm{R}}\right)$ (por ej., en la Figura 18.3). En la Tabla 18.2 se muestran algunos valores típicos de las cargas hidráulicas para reactores de biopelícula.

Tabla 18.2 Intervalos típicos de velocidad de filtrado ( $q_{A}$, Ec.18.7) para diferentes tipos de reactores de biopelícula. Observe que las velocidades de filtrado son fuertemente dependientes del pre-tratamiento, la mezcla aire-agua (para biofiltros sumergidos), la frecuencia de los retrolavados y los objetivos del tratamiento

\begin{tabular}{llll}
\hline Tipo de reactor & Material de soporte & Velocidad de filtrado $\left(\mathrm{q}_{\mathrm{A}}\right), \mathrm{m} / \mathrm{h}$ & Referencia \\
\hline Filtro percolador & Roca & $0.4-1.0$ & ATV, 1997 \\
& Plástico & $0.6-1.8$ & ATV, 1997 \\
UASB & Ninguno & $1-5$ & Nicolella et al., 2000 \\
Biofiltro sumergido & Arcilla porosa & $2-6$ (máx. 10) (eliminación de & ATV, 1997; Pujol et al., 1994 \\
& & orgánicos) & \\
& & 10 (nitrificación) & \\
& Roca porosa & $2-5$ (máx. 10) & ATV, 1997 \\
& Poliestireno & $2-6$ (máx. 10) & ATV, 1997 \\
& Arena de cuarzo & $5-15$ & ATV, 1997 \\
Lecho fluidizado & Antracita & $5-15$ & ATV, 1997 \\
\hline
\end{tabular}




\section{3 ¿CÓMO SE PUEDEN DETERMINAR LOS FLUJOS MÁXIMOS DE DISEÑO O LAS VELOCIDADES DE CARGA DE DISEÑO?}

\subsubsection{Modelo basado en la estimación del flujo máximo de sustrato}

Los reactores de biopelícula se pueden diseñar con base en la calidad deseada en el efluente de sustrato soluble, utilizando para ello los cálculos del Capítulo 17. El nivel de complejidad necesario dependerá de que el contaminante sea el sustrato limitante y de la manera en la que las limitaciones a la transferencia de masa influyen en la competencia microbiana dentro de la biopelícula. Las estrategias más simples de diseño basadas en soluciones analíticas son, por lo general, suficientes para propósitos de diseño. Para algunas preguntas más específicas, los modelos numéricos más complejos serán de mayor utilidad. Se pueden diferenciar cuatro niveles de complejidad tal y como se muestra en la Figura 18.6.

18.3.1.1 Nivel 1 de diseño: El compuesto de interés es el sustrato limitante

Si el contaminante a ser eliminado en el reactor de biopelícula es el compuesto limitante de la velocidad de la tasa de reacción, entonces, el diseño puede basarse en los flujos estimados para un solo sustrato limitante (Sección 17.3). Los criterios para determinar cuál de los compuestos actúa como el reactivo limitante, fueron desarrollados en la Sección 17.8. Algunos ejemplos para el Nivel 1 de diseño son: la eliminación de carbono a concentraciones bajas de DQO en la solución o la nitrificación a concentraciones muy bajas de amonio (Figura 18.11A).

\subsubsection{Nivel 2 de diseño: La eliminación del compuesto de interés se encuentra limitada por su correspondiente donador/aceptor de electrones}

En los sistemas donde el contaminante no es el reactivo limitante se tiene que considerar la difusión multicomponente. En este caso, primero se tiene que determinar el flujo del compuesto limitante. Posteriormente, se puede calcular el flujo del contaminante con base en la estequiometria de la reacción (Ecs. 17.89 y 17.92). Un ejemplo para el Nivel 2 de diseño es el proceso de nitrificación, el cuál se encuentra típicamente limitado por el oxígeno en lugar del amonio (Figura 18.11B). En este caso, el flujo de amonio se ve limitado por el flujo de oxígeno en la biopelícula. El flujo de oxígeno depende de la concentración de oxígeno en la solución, el cual a su vez depende del tipo de aireación y las velocidades de transferencia de oxígeno.

A
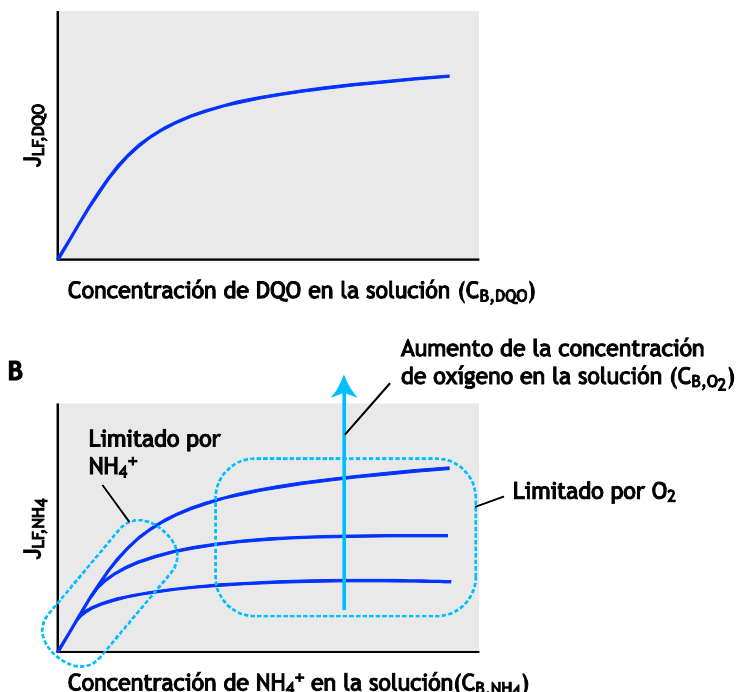

Aumento de la concentración de oxígeno/DQO en la solución $\left(\mathrm{C}_{\mathrm{B}, \mathrm{O}_{2}} / \mathrm{C}_{\mathrm{B}, \mathrm{DQO}}\right)$

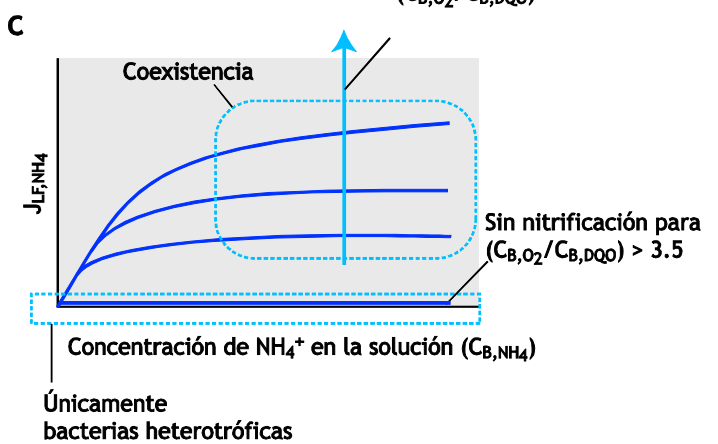

Figura18.11 Ejemplos de los tres diferentes niveles de complejidad como base para el diseño: eliminación de sustrato orgánico, en donde éste es el factor limitante en la velocidad (A: Nivel 1 de diseño); nitrificación, en donde la oxidación del amonio se encuentra limitada por el oxígeno (B: Nivel 2 de diseño, ver también la Figura 17.20 para el frente del reactor); nitrificación, en donde la oxidación del amonio disminuye con el aumento del crecimiento heterótrofo y la competencia por el oxígeno y el espacio disponible dentro de la biopelícula (C: Nivel 3 de diseño, ver además la Figura 17.23, en donde el flujo de amonio se encuentra determinado en gran parte por la concentración de DBO presente en la solución) 
18.3.1.3 Nivel 3 de diseño: La eliminación del compuesto de interés se encuentra limitada por los procesos de crecimiento y la competencia microbiológica por el sustrato y el espacio disponible en el interior de la biopelícula

Los dos niveles anteriores de diseño suponen que los microorganismos se encuentran distribuidos homogéneamente sobre el espesor de la biopelícula y que el consumo de sustrato se encuentra limitado por la difusión en la biopelícula. Sin embargo, las limitaciones en el transporte de masa pueden generar nichos ecológicos que a su vez dan como resultado una distribución heterogénea de diferentes grupos de microorganismos sobre el espesor de la biopelícula. Un ejemplo en donde la competencia por el sustrato y el espacio disponible en la biopelícula influye significativamente en el funcionamiento del reactor, es la combinación de la oxidación del amonio y el sustrato orgánico. Tal y como se discutió en la Sección 17.9, las bacterias nitrificantes tienden a ser invadidas por bacterias heterótrofas de más rápido crecimiento. Como resultado, el flujo de amonio en la biopelícula es controlado por la cantidad relativa de oxígeno $\left(\mathrm{C}_{\mathrm{B}, \mathrm{O} 2}\right)$ y el sustrato orgánico $\left(\mathrm{C}_{\mathrm{B}, \mathrm{DQO}}\right)$ en la solución (Figura

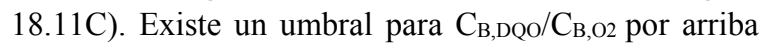
del cual las bacterias nitrificantes no pueden competir y no se lleva a cabo la nitrificación.

\subsubsection{Nivel 4 de diseño: Modelo matemático detallado de los perfiles de concentración y de la estructura heterogénea de la biopelícula y diseño para condiciones ambientales dinámicas}

Las velocidades de crecimiento microbiano, no sólo se ven influenciadas por las concentraciones del donador o aceptor de electrones, sino además, por factores como la temperatura, el $\mathrm{pH}$, y la disponibilidad de nutrientes y una fuente apropiada de carbono (por ej. $\mathrm{CO}_{2}$ para el crecimiento autótrofo). Resulta necesario realizar simulaciones numéricas para considerar este tipo de interacciones complejas. Las soluciones numéricas para biopelículas heterogéneas 1-D, se encuentran fácilmente utilizando AQUASIM y muchos otros simuladores comerciales para el tratamiento de aguas residuales. La ventaja de utilizar soluciones numéricas consiste en que a-priori, las suposiciones de un sustrato limitante o la distribución de la biomasa no son necesarias, las interacciones complejas que ocurren en el interior de la biopelícula pueden ser implementadas fácilmente y los procesos en la fase en solución $\left(\mathrm{r}_{\mathrm{B}} \cdot \mathrm{V}_{\mathrm{B}}\right.$ en la Ec. 17.42) son considerados que ocurren de manera automática. La desventaja es que puede resultar difícil mantener una visión general y un entendimiento sólido de cuáles son los factores que realmente dominan el funcionamiento del sistema. Se recomienda siempre ser flexible y combinar diferentes niveles de diseño. Los cálculos realizados a mano pueden ser de gran utilidad para diseños iniciales y para evaluar la factibilidad de las simulaciones numéricas.

\subsubsection{Velocidades empíricas de carga máxima}

En la práctica ingenieril, los reactores de biopelícula se diseñan, por lo general, con base en las velocidades de carga $\left(\mathrm{B}_{\mathrm{A}} \mathrm{o} \mathrm{BV}\right)$, las cuales se basan en observaciones empíricas de las velocidades máximas de carga que dan como resultado concentraciones satisfactorias en el efluente - en donde las características específicas de las concentraciones satisfactorias del efluente se encuentran definidas de manera vaga en muchas publicaciones y guías. Los valores de diseño para las cargas superficiales $\left(\mathrm{B}_{\mathrm{A}}\right)$ y las cargas volumétricas $\left(\mathrm{B}_{\mathrm{V}}\right)$ se relacionan, en principio, directamente (Ec. 18.5) suponiendo el área superficial específica $\left(\mathrm{q}_{\mathrm{A}}\right)$. Sin embargo, para sistemas, tales como los biofiltros sumergidos, el área superficial específica no se encuentra bien definida y algunos valores tabulados para $\mathrm{B} v$, proporcionan una velocidad agregada que incluye el flujo de sustrato en la biopelícula para colonizar el medio de soporte y además la eliminación de sustrato por la biomasa suspendida en el sistema (es decir, $\mathrm{r}_{\mathrm{B}} \cdot \mathrm{V}_{\mathrm{B}}$ en la Ec. 17.42).

Algunas cargas típicas de diseño para la oxidación de carbono y el proceso de nitrificación se encuentran en la Tabla 18.3 y para el proceso de desnitrificación en la Tabla 18.4. El lector deberá comparar estas cargas empíricas de diseño para los flujos de sustrato calculados en la Tabla 17.7, para el oxígeno, sustrato orgánico y amonio. Estos valores recomendados de velocidades máximas de carga deberán de ser utilizados con precaución, ya que serán dependientes de las características del agua residual, la temperatura, la operación del reactor y los objetivos deseados del tratamiento. Y, como siempre, al utilizar los valores de diseño establecidos, se recomienda seriamente que el usuario revise las condiciones específicas y referencias asociadas con estos valores (ATV, 1997; Grady et al., 1999; Tchobanoglous et al., 2003; WEF y ASCE, 1998). 
Tabla 18.3 Velocidades de carga superficiales de diseño $\left(B_{A}\right)$ y velocidades de carga volumétricas $\left(B_{V}\right)$ para la oxidación de la DBO, la oxidación combinada de amonio y DBO, o nitrificación terciaria. Los valores aplican para obtener una eliminación significativa en el tratamiento del agua residual municipal (por ej., una concentración del efluente $<10 \mathrm{mg} / \mathrm{l}$ para la DBO y $<3 \mathrm{mg} \mathrm{N} / \mathrm{l}$ para el amonio) a temperaturas normales $\left(10-15^{\circ} \mathrm{C}\right)$. Observe que estos valores dependen del pre-tratamiento utilizado y de la composición del agua residual

\begin{tabular}{|c|c|c|c|c|c|c|}
\hline \multirow[t]{2}{*}{ Tipo de reactor } & \multirow{2}{*}{$\begin{array}{l}\text { Material de } \\
\text { soporte }\end{array}$} & \multicolumn{2}{|c|}{ Carga de DBO } & \multicolumn{2}{|c|}{ Carga de amonio } & \multirow[t]{2}{*}{ Referencia } \\
\hline & & $\begin{array}{c}\mathrm{B}_{\mathrm{A}} \\
\mathrm{g} \mathrm{DBO} / \mathrm{m}^{2} \cdot \mathrm{d}\end{array}$ & $\begin{array}{c}\mathrm{Bv} \\
\mathrm{kg} \mathrm{DBO} / \mathrm{m}^{3} \cdot \mathrm{d}\end{array}$ & $\begin{array}{c}\mathrm{B}_{\mathrm{A}} \\
\mathrm{g} \mathrm{N} / \mathrm{m}^{2} \cdot \mathrm{d}\end{array}$ & $\begin{array}{c}\mathrm{Bv} \\
\mathrm{kg} \mathrm{N} / \mathrm{m}^{3} \cdot \mathrm{d}\end{array}$ & \\
\hline \multicolumn{7}{|l|}{ Oxidación de la DBO } \\
\hline \multirow[t]{2}{*}{ Filtro percolador } & Roca & 4 & $0.4^{(1)}$ & & & ATV, 1997 \\
\hline & Plástico & 4 & $0.4-0.8^{(1)}$ & & & ATV, 1997 \\
\hline $\begin{array}{l}\text { Reactor biológico } \\
\text { rotativo de contacto } \\
\text { (RBC) }\end{array}$ & Plástico & $8-20^{(2)}$ & & & & Tchobanoglous et al., 2003 \\
\hline \multirow[t]{3}{*}{ Biofiltro sumergido } & $\begin{array}{l}\text { Arcilla porosa } \\
\text { (Biofor) }\end{array}$ & & 10 & & & ATV, 1997 \\
\hline & $\begin{array}{l}\text { Roca porosa } \\
\text { (Biocarbone) }\end{array}$ & & 10 & & & ATV, 1997 \\
\hline & $\begin{array}{l}\text { Poliestireno } \\
\text { (Biostyr) }\end{array}$ & & 8 & & & ATV, 1997 \\
\hline MBBR & & $5-15^{(2)}$ & & & & WEF y ASCE, 1998 \\
\hline \multicolumn{7}{|c|}{ Oxidación combinada de amonio y DBO } \\
\hline \multirow{2}{*}{ Filtro percolador } & Roca & 2 & $0.2^{(1)(3)}$ & & & ATV, 1997 \\
\hline & Plástico & 2 & $0.2-0.4^{(1)(3)}$ & & & ATV, 1997 \\
\hline $\begin{array}{l}\text { Reactor biológico } \\
\text { rotativo de contacto } \\
\text { (RBC) }\end{array}$ & Plástico & $5-16$ & & $0.75-1.5$ & & Tchobanoglous et al., 2003 \\
\hline MBBR & & 4 & & 0.8 & & Odegaard, 2006 \\
\hline \multicolumn{7}{|l|}{ Nitrificación terciaria } \\
\hline \multirow[t]{2}{*}{ Filtro percolador } & Roca & & & $0.5-2.5$ & $0.05-0.25^{(1)}$ & Tchobanoglous et al., 2003 \\
\hline & Plástico & & & $0.5-2.5$ & $0.05-0.5^{(1)}$ & Tchobanoglous et al., 2003 \\
\hline $\begin{array}{l}\text { Reactor biológico } \\
\text { rotativo de contacto } \\
\text { (RBC) }\end{array}$ & Plástico & $1-2$ & & 1.5 & & Tchobanoglous et al., 2003 \\
\hline \multirow[t]{3}{*}{ Biofiltro sumergido } & $\begin{array}{l}\text { Arcilla porosa } \\
\text { (Biofor) }\end{array}$ & & & & 1.2 & ATV, 1997 \\
\hline & $\begin{array}{l}\text { Roca porosa } \\
\text { (Biocarbone) }\end{array}$ & & & & 0.7 & ATV, 1997 \\
\hline & $\begin{array}{l}\text { Poliestireno } \\
\text { (Biostyr) }\end{array}$ & & & & 1.5 & ATV, 1997 \\
\hline
\end{tabular}

\footnotetext{
(1) Las cargas superficiales $\left(\mathrm{B}_{\mathrm{A}}\right)$ para filtros percoladores fueron convertidas a cargas volumétricas $\left(\mathrm{B}_{\mathrm{V}}\right)$ utilizando la Ec. $18.5 \mathrm{y}$ asumiendo áreas superficiales específicas típicas $\mathrm{q}_{\mathrm{A}}$ de $100 \mathrm{~m}^{2} / \mathrm{m}^{3}$ para filtros percoladores utilizando roca y $100-200 \mathrm{~m}^{2} / \mathrm{m}^{3}$ usando plástico como medio de soporte.

(2) Cargas de $\mathrm{DBO}>10 \mathrm{~g} \mathrm{DBO} / \mathrm{m}^{2}$.d por lo general resultan en bajas eficiencias de eliminación (por ej. eliminación de $\mathrm{DBO}<80 \%$ ).

${ }^{(3)}$ En ATV, (1997) la oxidación combinada de DBO y amonio se basa únicamente en las cargas de DBO y se asumen composiciones típicas de aguas residuales municipales en términos de las relaciones de DBO/NTK.
}

\subsubsection{Ejemplos de diseño}

Ejemplo 18.1: Eliminación de sustrato orgánico (Nivel 1 de diseño)

Problema:

Se deberá diseñar un MBBR para tratar la siguiente agua residual y obtener una concentración de materia orgánica biodegradable en el efluente de $10 \mathrm{mg}$ DQO/l. Calcular el volumen del reactor y el tiempo de retención hidráulico. Es posible asumir que el MBBR puede ser considerado como un reactor completamente mezclado y que la concentración de oxígeno en el reactor es de 8 $\mathrm{mg} / \mathrm{L}$. 
Tabla 18.4 Velocidades de carga superficiales de diseño $\left(B_{A}\right)$ y velocidades de carga volumétricas $\left(B_{V}\right)$ para la desnitrificación. Los valores se pueden aplicar para obtener eliminaciones significativas en el tratamiento de aguas residuales municipales $(>90 \%)$ a temperaturas normales $\left(10-15^{\circ} \mathrm{C}\right)$. Observe que estos valores dependen de los objetivos fijados para el tratamiento, el pre-tratamiento específico, la composición del agua residual y la cantidad y el tipo de fuente de carbono externa adicionada

\begin{tabular}{|c|c|c|c|c|}
\hline \multirow[b]{2}{*}{ Tipo de reactor } & \multirow[b]{2}{*}{ Material de soporte } & \multicolumn{2}{|c|}{ Carga de nitrato } & \multirow[b]{2}{*}{ Referencia } \\
\hline & & $\begin{array}{c}\mathrm{B}_{\mathrm{A}} \\
\mathrm{g} \mathrm{N} / \mathrm{m}^{2} \cdot \mathrm{d}\end{array}$ & $\begin{array}{c}\mathrm{B}_{\mathrm{V}} \\
\mathrm{kg} \mathrm{N} / \mathrm{m}^{3} . \mathrm{d}\end{array}$ & \\
\hline \multicolumn{5}{|l|}{ Desnitrificación } \\
\hline \multirow[t]{5}{*}{ Biofiltro sumergido } & Arcilla porosa (Biofor) & & 2 & ATV, 1997 \\
\hline & Roca porosa (Biocarbone) & & 0.7 & ATV, 1997 \\
\hline & Poliestireno (Biostyr) & & $1.2-1.5$ & ATV, 1997 \\
\hline & Arena de cuarzo & & $1.5-3$ & \\
\hline & Antracita & & $1.5-3$ & \\
\hline MBBR & $\mathrm{K} 1$ & $\begin{array}{l}2.5-3^{(1)} \\
1-5-2^{(2)}\end{array}$ & & $\begin{array}{l}\text { Aspegren et } \\
\text { al., } 1998\end{array}$ \\
\hline
\end{tabular}

(1)Utilizando etanol como donador de electrones

${ }^{(2)}$ Utilizando metanol como donador de electrones

Características del agua residual:

$\mathrm{Q}=150 \mathrm{~m}^{3} / \mathrm{d}$

$\mathrm{L}_{\mathrm{F}}=200 \mu \mathrm{m}$

$\mathrm{C}_{\text {afluente }}=300 \mathrm{mg} \mathrm{DQO} / 1$

Área superficial específica del medio de soporte $\mathrm{a}_{\mathrm{F}}=300 \mathrm{~m}^{2} / \mathrm{m}^{3}$

\section{Respuesta:}

Paso 1: Las concentraciones del sustrato orgánico en la solución, en el reactor completamente mezclado, serán idénticas a la concentración deseada del efluente de 10 mg DQO/L. Determinar si el oxígeno o el sustrato orgánico son limitantes utilizando la Ec. 17.88 o la Tabla 17.6:

$\frac{C_{L F, D Q O}}{C_{L F, O 2}}=\frac{10}{8} \mathrm{gDQO} / \mathrm{gO}_{2}$

$=1.25 \mathrm{~g} \mathrm{DQO} / \mathrm{g} \mathrm{O}_{2}<3.5 \mathrm{~g} \mathrm{DQO} / \mathrm{g} \mathrm{O}_{2}$

$\Rightarrow$ El sustrato orgánico es el reactivo limitante

Paso 2: Encontrar el flujo de sustrato suponiendo que su concentración en la solución es de 10 mg DQO/l. De la Figura 17.7:

$\mathrm{J}_{\mathrm{LF}, \mathrm{S}}=12.3 \mathrm{~g} \mathrm{DQO} / \mathrm{m}^{2} \cdot \mathrm{d}$

(suponiendo una cinética de orden cero y penetración parcial)

$\mathrm{J}_{\mathrm{LF}, \mathrm{S}}=8.5 \mathrm{~g} \mathrm{DQO} /\left(\mathrm{m}^{2} . \mathrm{d}\right.$

(suponiendo una cinética de Monod)
Paso 3: Calcular el área superficial necesaria:

$$
\begin{aligned}
& A_{F}=\frac{Q\left(C_{\text {influente }}-C_{B}\right)}{J_{L F}} \\
& =353.7 \mathrm{~m}^{2} \text { (orden cero, penetración parcial) } \\
& =511.8 \mathrm{~m}^{2} \text { (cinética de Monod) }
\end{aligned}
$$

Paso 4: Calcular el volumen del reactor y el TRH

$$
V_{R}=\frac{A_{F}}{a_{F}}=\frac{353.7 \mathrm{~m}^{2}}{300 \mathrm{~m}^{2} / \mathrm{m}^{3}}=1.18 \mathrm{~m}^{3}
$$

(orden cero, penetración parcial)

$$
V_{R}=\frac{A_{F}}{a_{F}}=\frac{511.8 \mathrm{~m}^{2}}{300 \mathrm{~m}^{2} / \mathrm{m}^{3}}=1.71 \mathrm{~m}^{3}
$$

(cinética de Monod)

Paso 5: ¿Cómo puede cambiar el flujo de sustrato considerando ahora que existe una capa límite externa a la transferencia de masa de $200 \mu \mathrm{m}$ ? Los flujos de sustrato asumiendo diferentes espesores de capa límite se encuentran en la Figura 17.13:

$\mathrm{J}_{\mathrm{LF}, \mathrm{S}}=4 \mathrm{~g}$ DQO $/ \mathrm{m}^{2} . \mathrm{d}$ (suponiendo una cinética de Monod y $\left.\mathrm{LL}_{\mathrm{L}}=200 \mu \mathrm{m}\right)$

Los correspondientes TRHs son 11 y 16 min, suponiendo una cinética de orden cero y una penetración parcial o una cinética de Monod, respectivamente. 
El coeficiente estequiométrico para un sustrato orgánico es $v_{\mathrm{S}}=1 / \mathrm{Y}$ y para el oxígeno $v_{\mathrm{O} 2}=(1-\mathrm{Y}) / \mathrm{Y}$. Así, el flujo de oxígeno $\left(\mathrm{J}_{\mathrm{LF}, \mathrm{O} 2}\right)$ puede calcularse a partir de:

$$
J_{L F, O 2}=\frac{v_{O 2}}{v_{S}} J_{L F, S}=(1-Y) J_{L F, S}
$$

Suponiendo un flujo del sustrato orgánico de $4 \mathrm{~g}$ $\mathrm{DQO} / \mathrm{m}^{2} . \mathrm{d}$ y un coeficiente de rendimiento de $0.4 \mathrm{~g}$ $\mathrm{DQO} / \mathrm{g}$ DQO, el flujo de oxígeno en la biopelícula será de $2.4 \mathrm{~g} \mathrm{O}_{2} / \mathrm{m}^{2}$.d.

\section{Ejemplo18.2: Nitrificación (Nivel 2 de diseño)}

Se deberá diseñar un RBC para nitrificación terciaria con una concentración deseada en el efluente de $5 \mathrm{mg} \mathrm{NH}_{4}$ $\mathrm{N} / 1$. Se puede suponer que la fase en solución se encuentra completamente mezclada con una concentración de oxígeno disuelto de $8 \mathrm{mg} / \mathrm{l}$.

Las características del agua residual son:

$\mathrm{Q}=150 \mathrm{~m}^{3} / \mathrm{d}$

$\mathrm{L}_{\mathrm{F}}=200 \mu \mathrm{m}$

$\mathrm{C}_{\text {afluente }}=40 \mathrm{mg} \mathrm{NH}_{4}-\mathrm{N} / 1$

El área superficial específica del medio de soporte es $\mathrm{a}_{\mathrm{F}}=300 \mathrm{~m}^{2} / \mathrm{m}^{3}$

Paso 1: Evaluar si el oxígeno o el amonio serán reactivos limitantes. Esto puede realizarse utilizando la Ec.17.88, o utilizando directamente las profundidades de penetración para el amonio y el oxígeno de la Tabla 17.7. De la Tabla 17.7, las profundidades de penetración para una concentración de amonio de $5 \mathrm{mg} \mathrm{N} / 1$ y una concentración de oxígeno de $8 \mathrm{mg} / \mathrm{l}$ son:

Profundidad de penetración del amonio $=177 \mu \mathrm{m}$ Profundidad de penetración del oxígeno $=120 \mu \mathrm{m}$

Así, para las concentraciones en la solución dadas, la disponibilidad del oxígeno en el interior de la biopelícula se encontrará limitada por la eliminación del amonio.

Paso 2: El flujo de oxígeno puede ser tomado directamente de la Tabla 18.2, el cual será de:

$$
\mathrm{J}_{\mathrm{LF}, \mathrm{O} 2}=22.5 \mathrm{~g} \mathrm{O}_{2} / \mathrm{m}^{2} . \mathrm{d}
$$

Paso 3: El flujo de amonio deberá ser calculado a partir del flujo de oxígeno utilizando la Ec. 17.89:

$$
\begin{aligned}
& J_{L F, N H 4}=\frac{v_{N H 4}}{v_{O 2}} J_{L F, O 2}= \\
& =\frac{\frac{1}{Y_{A}}}{\frac{4.57-Y_{A}}{Y_{A}}} J_{L F, O 2}= \\
& =\frac{1}{4.57-0.22} 22.5=5.17 \mathrm{~g} \mathrm{~N} / \mathrm{m}^{2} \cdot d
\end{aligned}
$$

Observe que este flujo de $5.17 \mathrm{~g} \mathrm{~N} /\left(\mathrm{m}^{2}\right.$.d) es menor al valor proporcionado en la Tabla 17.7 para una concentración de amonio en la solución de $5 \mathrm{mg} \mathrm{N} / 1$. Esto se debe a que los flujos de amonio de la Tabla 17.7 se calcularon suponiendo que no existen limitaciones de oxígeno en el sistema.

Paso 4: Los flujos de la Tabla 17.7 no consideran las resistencias externas a la transferencia de masa. En el Capítulo 17, Sección 5, se discutió el efecto de la resistencia externa a la transferencia de masa y el valor del flujo de oxígeno se calculó explícitamente. En muchos casos, sin embargo, los valores de diseño para la oxidación del amonio se encuentran disponibles con base en los flujos medidos en sistemas similares y han sido resumidos en la Tabla 18.3. Los flujos de amonio para el proceso de nitrificación se encuentran en el intervalo de 1 a $3 \mathrm{~g} \mathrm{~N} / \mathrm{m}^{2}$.d. Por lo tanto, para el presente sistema, puede seleccionarse un valor de diseño de $2.5 \mathrm{~g} \mathrm{~N} / \mathrm{m}^{2}$.d.

Así, los pasos del 1 al 4 no serán necesarios y se puede utilizar directamente la Tabla 18.3. Un problema al utilizar estos valores de diseño sin realizar cálculos adicionales, es que por lo general no resulta aparente conocer cuáles son los factores limitantes para la eliminación. A partir de los Pasos 2 al 4, resulta aparente que el proceso de nitrificación se encuentra limitado por el oxígeno y por lo tanto los flujos de sustrato se encuentran determinados por la penetración de oxígeno en la biopelícula. Utilizando las profundidades de penetración proporcionadas en el interior de las características deseadas de la biopelícula y realizando los cálculos explícitos, resulta inmediatamente claro bajo qué condiciones la biopelícula se encontrará limitada por el amonio en lugar del oxígeno.

Paso 5: Calcular el área superficial necesaria y el volumen tomando como base el ejemplo anterior. 
Ejemplo 18.3: Combinando la eliminación del sustrato orgánico y el proceso de nitrificación (Nivel 3 de diseño)

Se deberá diseñar un filtro percolador utilizando un medio de soporte plástico para combinar la oxidación del carbono y nitrificación.

Características del agua residual:

$\mathrm{Q}_{\text {in }}=150 \mathrm{~m}^{3} / \mathrm{d}$

$\mathrm{C}_{\mathrm{DBO} \text {,afluente }}=200 \mathrm{mg} \mathrm{DBO} / 1$

$\mathrm{C}_{\mathrm{N}, \text { affuente }}=40 \mathrm{mg} \mathrm{NH}-\mathrm{N} / \mathrm{l}$

Se deberán suponer los parámetros típicos del diseño.

Solución1: El modelo matemático detallado para la combinación de los procesos de oxidación de carbono y nitrificación, se discutió en la Sección 17.9, con lo cual se demostró que una condición necesaria para que se lleve a cabo el proceso de nitrificación es el tener concentraciones de DBO lo suficientemente bajas en la fase líquida, para concentraciones dadas de oxígeno. La oxidación del carbono y la nitrificación pueden ser evaluadas explícitamente por modelos de los flujos de sustrato y la estructura heterogénea de la biopelícula, en donde, la DBO primeramente es oxidada seguida por la nitrificación (Wanner y Gujer, 1985). Las simulaciones pueden realizarse utilizando los módulos de biopelículas disponibles en los simuladores comúnmente utilizados para el diseño de plantas de tratamiento de aguas residuales o el programa AQUASIM, presentado en el Capítulo 17.

Solución 2: Tal y como se mostró en la Figura 17.25, habrá tres regiones en un filtro percolador operado para la oxidación de carbono y la nitrificación: (i) únicamente oxidación de carbono, (ii) combinación de la oxidación del carbono con nitrificación, y (iii) nitrificación (primero bajo condiciones de limitación de oxígeno y posteriormente limitado por el amonio). Una estrategia simplificada del diseño consiste en considerar despreciable la región en donde se combinan la oxidación del carbono con la nitrificación y el calcular separadamente las dimensiones para las otras dos regiones:

$V_{R, \text { total }}=V_{R, S}+V_{R, N H 4}$

Donde $\mathrm{V}_{\mathrm{R}, \text { total }}$ es el volumen total del reactor y $\mathrm{V}_{\mathrm{R}, \mathrm{S}} \mathrm{y}$ $\mathrm{V}_{\mathrm{R}, \mathrm{N}}$ son los volúmenes para la oxidación de carbono que ocurren en la parte superior y la nitrificación en la parte inferior del filtro percolador. Utilizando las velocidades de carga típicas de la Tabla 18.3 para $0.6 \mathrm{~kg} \mathrm{DBO} / \mathrm{m}^{3} . \mathrm{d}$ (para la oxidación de la DBO) y $0.1 \mathrm{~kg} \mathrm{~N} / \mathrm{m}^{3}$.d (para la nitrificación terciaria), podemos estimar el volumen total como:

$V_{R, S}=\frac{Q \cdot C_{i n, S}}{B_{V, S}}=\frac{\left(150 \mathrm{~m}^{3} / \mathrm{d}\right)\left(200 \mathrm{gDBO} / \mathrm{m}^{3}\right)}{0.6 \mathrm{kgDBO} /\left(\mathrm{m}^{3} . d\right)}=50 \mathrm{~m}^{3}$

y

$V_{R, N H 4}=\frac{Q \cdot C_{i n, N H 4}}{B_{V, N H 4}}=\frac{\left(150 \mathrm{~m}^{3} / d\right)\left(40 \mathrm{gN} / \mathrm{m}^{3}\right)}{0.1 \mathrm{kgN} / \mathrm{m}^{3} \cdot d}=60 \mathrm{~m}^{3}$

Así, la Ec. 18.13 da como resultado:

$$
V_{R, \text { total }}=50 \mathrm{~m}^{3}+60 \mathrm{~m}^{3}=110 \mathrm{~m}^{3}
$$

Por lo tanto, un volumen total de $110 \mathrm{~m}^{3}$ puede proporcionar tanto una oxidación confiable del sustrato orgánico como la nitrificación. El diseñador tiene la opción de utilizar un reactor muy largo o dos reactores separados con extracción sólido-líquido, el primer reactor para la oxidación de carbono y el segundo reactor para la nitrificación.

\subsection{ALGUNAS OTRAS CONSIDERACIONES PARA EL DISEÑO}

El presente capítulo proporcionó un panorama general de las diferentes tecnologías de reactores de biopelículas y se enfocó en remarcar las características comunes en el diseño de estos sistemas. Para el diseño de biopelículas, también deben considerarse otras condiciones como la aireación, la distribución del flujo, el control de la biopelícula y la eliminación de sólidos.

\subsubsection{Aireación}

Para sistemas aerobios es necesario proporcionar una fuente suficiente de oxígeno. Los filtros percoladores y el $\mathrm{RBC}$, por lo general, dependen de la aireación natural por convección. De ser necesario, la aireación puede mejorarse utilizando ventilación forzada o difusores de aire sumergidos en los filtros percoladores y RBC, respectivamente. Los reactores de biopelícula sumergida dependen completamente de la aireación forzada. Para reactores de lecho fijo, el aire se introduce hacia el material filtrante por medio de una malla que ayuda a que la distribución sea homogénea sobre la sección transversal del reactor. Conforme las burbujas de aire se 
desplazan a través del material filtrante, se unen rápidamente dando como resultado la formación de burbujas más grandes (Stenstrom et al. 2008). En los reactores de biopelícula suspendida, el proceso de aireación por lo general es utilizado con un doble propósito, el de proveer oxígeno y además el adicionar energía para el mezclado.

\subsubsection{Distribución de flujo}

Para los reactores de lecho fijo y lecho fluidizado, una distribución homogénea del flujo de agua del afluente sobre la sección transversal del reactor es crítica para que se lleve a cabo el tratamiento de manera efectiva. La distribución del agua influye tanto en las velocidades de carga del sustrato como en las fuerzas de corte que actúan sobre la biopelícula. En los reactores de lecho fijo con una distribución de flujo no homogénea, se pueden formar canales, disminuir la eliminación del sustrato y se puede presentar el taponamiento del material filtrante.

\subsubsection{Control de la biopelícula}

Una operación adecuada del reactor deberá permitir la formación de una biopelícula lo suficientemente gruesa para llevar a cabo el consumo del sustrato $\mathrm{y}$, al mismo tiempo, prevenir la acumulación de demasiada biopelícula, con el objeto de evitar el taponamiento del material filtrante. Los filtros percoladores y los RBC dependerán del desprendimiento espontáneo para eliminar el exceso de la biopelícula. Las fuerzas de corte o cizallamiento en los filtros percoladores, son una función de la carga hidráulica $\left(\mathrm{q}_{\mathrm{A}}, \mathrm{L} / \mathrm{T}, \mathrm{Ec} .18 .7\right)$, el número de brazos en el distribuidor rotatorio $(a)$, y la velocidad de rotación del distribuidor en revoluciones por tiempo (n, 1/T). Estos diferentes factores que afectan las fuerzas de cizallamiento y el desprendimiento en los filtros percoladores, se pueden combinar en el Spülkraft (SK, L, fuerza de lavado en alemán)

$$
S K=\frac{q_{A}}{a \cdot n}
$$

Los valores típicos para el SK varían de 4 a 8 $\mathrm{mm} /$ brazo (ATV-DVWK, 2001).

En los reactores de biopelícula suspendida, las altas tasas de desprendimiento y la formación de biopelículas delgadas son el resultado de las altas tasas de abrasión y de los esfuerzos cortantes. En los reactores de biopelícula fija, se deberán de realizar retrolavados en intervalos regulares de tiempo para eliminar el exceso de biopelícula y los sólidos suspendidos que puedan acumularse en los espacios porosos del medio filtrante.

\subsubsection{Eliminación de sólidos}

La biomasa eliminada de los reactores de biopelícula deberá ser separada del agua utilizando sedimentadores $u$ otros mecanismos, como por ejemplo, la extracción sólido-líquido. Existen diferencias significativas en cuanto al tamaño de partícula y la sedimentabilidad de la biomasa eliminada de los diferentes sistemas. Los diferentes tipos de reactores de biopelícula varían significativamente en la forma en la que se elimina el material suspendido del agua residual del afluente. Por ejemplo, los reactores sumergidos de lecho fijo pueden ser operados como verdaderos filtros, mientras que, los filtros percoladores o RBCs pueden alcanzar únicamente la eliminación del material particulado (Parker y Newman, 2006). 


\section{REFERENCIAS}

Aspegren,H., NYBERG,U., Andersson,B., Gotthardsson,S. and Jansen,J.C. (1998): Post denitrification in a moving bed biofilm reactor process. Water Sci.Technol., 38 (1), 31-38.

ATV (1997): Biologische und weitergehende Abwasserreinigung [In German]. ed. 4th Edition Ernst \& Sohn, Berlin.

ATV-DVWK (2001): Bemessung von Tropfkörpern und Rotationstauchkörpern (in German) DWA, Hennef.Vol. ATV-DVWK-A 281.

Beun,J.J., Hendricks,A., van Loosdrecht,M.C.M., Morgenroth,E., Wilderer,P.A. and Heijnen,J.J. (1999): Aerobic granulation in a sequencing batch reactor. Water Res., 33 (10), 2283-2290.

Boltz,J.P., Goodwin,S.J., Rippon,D. and Daigger,G.T. (2008): A review of operational control strategies for snails and other macro-fauna infestations in trickling filters. Water Practice, In Press.

Boltz,J.P., Morgenroth,E., deBarbadillo,C., Dempsey,M.J., McQuarrie,J., Ghylin,T., Harrison,J. and Nerenberg,R. (2009): Biofilm Reactor Technology and Design. In: Design of Municipal Wastewater Treatment Plants, Volume 2, Fifth Edition. WEF Manual of Practice No. 8, ASCE Manuals and Reports on Engineering Practice No. 76, McGraw Hill. New York, USA.

de Kreuk,M.K. and van Loosdrecht,M.C.M. (2004): Selection of slow growing organisms as a means for improving aerobic granular sludge stability. Water Sci.Technol., 49 (11-12), 9-17.

Grady,C.P.L., Daigger,G.T. and Lim,H.C. (1999): Biological wastewater treatment. ed. 2nd Edition Marcel Dekker, New York.

Hulshoff Pol,L., Dolfing,J., Dezeeuw,W. and Lettinga,G. (1982): Cultivation of well adapted pelletized methanogenic sludge. Biotechnology Letters, 4 (5), 329332.

Lazarova,V. and Manem,J. (2000): Innovative biofilm treatment technologies for water and wastewater treatment. In: Bryers,J.D. (ed.), Biofilms II: Process Analysis and Application, (6), pp. 159-206. Wiley-Liss, Inc.

Liu,Y. and Tay,J.H. (2002): The essential role of hydrodynamic shear force in the formation of biofilm and granular sludge. Water Res., 36 (7), 1653-1665.

Morgenroth,E., Sherden,T., van Loosdrecht,M.C.M., Heijnen,J.J. and Wilderer,P.A. (1997): Aerobic granular sludge in a sequencing batch reactor. Water Res., 31 (12), 3191-3194.

Morgenroth,E. and Wilderer,P.A. (1999): Controlled biomass removal - The key parameter to achieve enhanced biological phosphorus removal in biofilm systems. Water Sci.Technol., 39 (7), 33-40.

Nerenberg,R. and Rittmann,B.E. (2004): Hydrogen-based, hollow-fiber membrane biofilm reactor for reduction of perchlorate and other oxidized contaminants. Water Sci.Technol., 49 (11-12), 223-230.
Nicolella,C., van Loosdrecht,M.C.M. and Heijnen,J.J. (2000): Wastewater treatment with particulate biofilm reactors. Journal Of Biotechnology, 80 (1), 1-33.

Odegaard,H. (2006): Innovations in wastewater treatment: the moving bed biofilm process. Water Sci.Technol., 53 (9), 17-33.

Parker,D.S. and Newman,J.A. (2006): New process design procedure for dealing with variable trickling filter effluent suspended solids. J.Environ.Eng.-ASCE, 132 (7), 758-763.

Pujol,R., Hamon,M., Kandel,X. and Lemmel,H. (1994): Biofilters: Flexible, reliable biological reactors. Water Sci.Technol., 29 (10-11), 33-38.

Rusten,B., EIKEBROKK,B., Ulgenes,Y. and Lygren,E. (2006): Design and operations of the Kaldnes moving bed biofilm reactors. Aquacultural Engineering, 34 (3), 322-331.

Stenstrom, M.K., Rosso, D., Melcer, H., Appleton, R., Occiano, V., Langworthy, A. and Wong, P. (2008): Oxygen Transfer in a Full-Depth Biological Aerated Filter. Water Environment Research 80(7), 663-671.

Tay,J.H., Tay,S.T.L., Liu,Y., Show,K.Y. and Ivanov,V. (2006): Biogranulation Technologies for Wastewater Treatment: Microbial Granules Elsevier, Amsterdam. Series: Waste Management Series, Volume 6.

Tchobanoglous,G., Burton,F.L. and Stensel,H.D. (2003): Wastewater engineering, treatment and reuse. ed. 4th ed. Mc Graw Hill, New York.

Terada,A., Lackner,S., Tsuneda,S. and Smets,B.F. (2007): Redox-stratification controlled biofilm (ReSCoBi) for completely autotrophic nitrogen removal: The effect of co- versus counter-diffusion on reactor performance. Biotechnol.Bioeng., 97 (1), 40-51.

Tschui,M. (1994): Submerse Festbettreaktoren Skriptum der EAWAG (Dübendorf) für den Studiengang Umweltund Kulturingenieure an der ETH Zürich, Vertieferblock, WS 94/95 [unveröffentlicht].

van Benthum,W.A.J., van der Lans,R.M., van Loosdrecht,M.C.M. and Heijnen,J.J. (1999): Bubble recirculation regimes in an internal-loop airlift reactor. Chem.Eng.Sci., 54 (18), 3995-4006.

van Benthum,W.A.J., van Loosdrecht,M.C.M. and Heijnen,J.J. (1997): Process design for nitrogen removal using nitrifying biofilm and denitrifying suspended growth in a biofilm airlift suspension reactor. Water Sci.Technol., 36 (1), 119-128.

van Loosdrecht,M.C.M., Eikelboom,D., Gjaltema,A., Mulder,A., Tijhuis,L. and Heijnen,J.J. (1995): Biofilm structures. Water Sci.Technol., 32 (8), 35-43.

Wanner,O., Eberl,H.J., Morgenroth,E., Noguera,D.R., Picioreanu,C., Rittmann,B.E. and van Loosdrecht,M.C.M. (2006): Mathematical Modeling of Biofilms IWA Publishing, London, UK. Series: Scientific and Technical Report Series Report No. 18.

Wanner,O. and Gujer,W. (1985): Competition in biofilms. Water Sci.Technol., 17 (2-3), 27-44.

WEF and ASCE (1998): Design of municipal wastewater treatment plants - WEF manual of practice 8, ASCE 
Manual and Report on Engineering Practice No. 76. ed. 4th ed. Water Environment Federation, Alexandria, VA
(USA) and American Society of Civil Engineers, Reston, VA (USA).

\section{AGRADECIMIENTOS}

El autor agradece los comentarios de ayuda proporcionados por los revisores de este capítulo Joshua Boltz, Doris, Brockmann, Nicolas Derlon, Mark van Loosdrecht, Albrecht Morgenroth, Frank Rogalla, Kim Soerensen y Oskar Wanner.

\section{NOMENCLATURA}

\begin{tabular}{|c|c|c|}
\hline Símbolo & Descripción & Unidad \\
\hline$a$ & Número de brazos del distribuidor rotatorio en el filtro percolador & - \\
\hline$A_{F}$ & Área superficial de la biopelícula & $\mathrm{m}^{2}$ \\
\hline$a_{F}$ & Área superficial específica de la biopelícula $=A_{F} / V_{R}$ & $\mathrm{~m}^{2} / \mathrm{m}^{3}$ \\
\hline$A_{R}$ & Área transversal del reactor de biopelícula en dirección al flujo & $\mathrm{m}^{2}$ \\
\hline$B_{A}$ & Velocidad de carga específica superficial & $\mathrm{g} / \mathrm{m}^{2} \cdot \mathrm{d}$ \\
\hline$B i$ & Número de Biot & - \\
\hline$b_{\text {ina,Aut }}$ & Velocidad de inactivación de las bacterias autótrofas & $1 / \mathrm{d}$ \\
\hline$b_{\text {ina }, H}$ & Velocidad de inactivación de las bacterias heterótrofas & $1 / \mathrm{d}$ \\
\hline$b_{r e s, A u t}$ & Velocidad de respiración endógena de las bacterias autótrofas & $1 / \mathrm{d}$ \\
\hline$b_{r e s, H}$ & Velocidad de respiración endógena de las bacterias heterótrofas & $1 / \mathrm{d}$ \\
\hline$B_{V}$ & Velocidad de carga volumétrica específica & $\mathrm{g} / \mathrm{m}^{3} \cdot \mathrm{d}$ \\
\hline$C_{B}$ & Concentración del sustrato soluble ${ }^{(1)}$ en la solución & $\mathrm{mg} / \mathrm{l}$ \\
\hline$C_{F}$ & Concentración de sustrato soluble ${ }^{(1)}$ en el interior de la biopelícula & $\mathrm{mg} / 1$ \\
\hline$C_{F, 0, f}$ & $\begin{array}{l}\text { Solución analítica para la concentración de sustrato }{ }^{(1)} \text { en el interior de la biopelícula, } \\
\text { considerando una cinética de reacción de orden cero y la penetración completa de la } \\
\text { biopelícula }\end{array}$ & $\mathrm{mg} / 1$ \\
\hline$C_{F, 0, p}$ & $\begin{array}{l}\text { Solución analítica para la concentración de sustrato }{ }^{(1)} \text { en el interior de la biopelícula, } \\
\text { considerando una cinética de reacción de orden cero y la penetración parcial de la } \\
\text { biopelícula }\end{array}$ & $\mathrm{mg} / 1$ \\
\hline$C_{F, 1}$ & $\begin{array}{l}\text { Solución analítica para la concentración de sustrato }{ }^{(1)} \text { en el interior de la biopelícula } \\
\text { considerando una cinética de reacción de primer orden }\end{array}$ & $\mathrm{mg} / \mathrm{l}$ \\
\hline$C_{F, N H}$ & Concentración de amonio en el interior de la biopelícula & $\mathrm{mg} \mathrm{N} / 1$ \\
\hline$C_{F, O 2}$ & Concentración de oxígeno en el interior de la biopelícula & $\mathrm{mg} \mathrm{O}_{2} / 1$ \\
\hline$C_{F, S}$ & Concentración del sustrato orgánico en el interior de la biopelícula & $\mathrm{mg} \mathrm{DQO} / 1$ \\
\hline$C_{\text {in }}$ & Concentración del sustrato soluble ${ }^{(1)}$ en el afluente & $\mathrm{mg} / 1$ \\
\hline$C_{L F}$ & Concentración del sustrato soluble ${ }^{(1)}$ en la superficie de la biopelícula & $\mathrm{mg} / \mathrm{l}$ \\
\hline$C_{\text {min }}$ & $\begin{array}{l}\text { Concentración mínima de sustrato }{ }^{(1)} \text { para permitir el crecimiento microbiano en la } \\
\text { biopelícula }\end{array}$ & $\mathrm{mg} / \mathrm{l}$ \\
\hline$C_{N H}$ & Concentración de amonio & $\mathrm{mg} \mathrm{N} / 1$ \\
\hline $\mathrm{CO}_{2}$ & Concentración de oxígeno & $\mathrm{mg} \mathrm{O}_{2} / 1$ \\
\hline$C_{S}$ & Concentración de sustrato orgánico & $\mathrm{mg} \mathrm{DQO} / 1$ \\
\hline$D a^{I I}$ & Segundo número de Damköhler & - \\
\hline$D_{F}$ & Coeficiente de difusión en la biopelícula & $\mathrm{m}^{2} / \mathrm{d}$ \\
\hline$D_{W}$ & Coeficiente de difusión en el agua & $\mathrm{m}^{2} / \mathrm{d}$ \\
\hline$G$ & Parámetro de crecimiento & - \\
\hline$h$ & Altura del reactor con características de flujo pistón en la fase en solución & $\mathrm{m}$ \\
\hline$J$ & Flujo de sustrato ${ }^{(1)}$ & $\mathrm{g} / \mathrm{m}^{2} \cdot \mathrm{d}$ \\
\hline
\end{tabular}




\begin{tabular}{|c|c|c|}
\hline$J_{F}$ & Flujo de sustrato ${ }^{(1)}$ en el interior de la biopelícula & $\mathrm{g} / \mathrm{m}^{2} . \mathrm{d}$ \\
\hline$J_{L F}$ & Flujo de sustrato ${ }^{(1)}$ en la superficie de la biopelícula & $\mathrm{g} / \mathrm{m}^{2} \cdot \mathrm{d}$ \\
\hline$k_{0, F}$ & Velocidad de consumo del sustrato de orden cero ${ }^{(1)}$ en el interior de la biopelícula & $1 / \mathrm{d}$ \\
\hline$k_{0, f, A}$ & $\begin{array}{l}\text { Velocidad de consumo del sustrato de orden cero }{ }^{(1)} \text { por superficie de la biopelícula para } \\
\text { una penetración completa }\end{array}$ & $\mathrm{g} / \mathrm{m}^{2} \cdot \mathrm{d}$ \\
\hline$k_{0, p, A}$ & $\begin{array}{l}\text { Velocidad de consumo del sustrato de orden cero }{ }^{(1)} \text { por superficie de biopelícula para } \\
\text { una penetración parcial }\end{array}$ & $\mathrm{g}^{0.5} / \mathrm{m}^{0.5} . \mathrm{d}$ \\
\hline$k_{l, A}$ & Velocidad de consumo de sustrato de primer orden ${ }^{(1)}$ por superficie de biopelícula & $\mathrm{m} / \mathrm{d}$ \\
\hline$k_{l, F}$ & Velocidad de consumo de sustrato de primer orden ${ }^{(1)}$ en el interior de la biopelícula & $\mathrm{m}^{3} / \mathrm{g} . \mathrm{d}$ \\
\hline$k_{d}$ & Coeficiente de desprendimiento de la biopelícula & (3) \\
\hline$K_{N H 4}$ & Constante media de saturación para $\mathrm{C}_{\mathrm{NH}}$ & $\mathrm{mg} \mathrm{N} / 1$ \\
\hline Ko2,Aut & Constante media de saturación para $\mathrm{Co2}$ para bacterias autótrofas & $\mathrm{mg} \mathrm{O}_{2} / 1$ \\
\hline$K_{O 2, H}$ & Constante media de saturación para $\mathrm{C}_{\mathrm{O} 2}$ para bacterias heterótrofas & $\mathrm{mg} \mathrm{O}_{2} / 1$ \\
\hline$K_{S}$ & Constante media de saturación para $\mathrm{C}_{\mathrm{S}}$ & $\mathrm{mg} \mathrm{DQO} / \mathrm{l}$ \\
\hline$L_{L}$ & Transferencia externa de masa en la capa límite del espesor de la biopelícula & $\mu \mathrm{m}$ \\
\hline$n$ & Velocidad de rotación del distribuidor en el filtro percolador & $1 / \mathrm{d}$ \\
\hline$P e$ & Número de Peclet & - \\
\hline$Q$ & Caudal & $\mathrm{m}^{3} / \mathrm{d}$ \\
\hline$q_{A}$ & Carga hidráulica o velocidad del filtro $=\left(Q+Q_{R}\right) / A_{R}$ & $\mathrm{~m} / \mathrm{d}$ \\
\hline$Q_{\text {in }}$ & Caudal del afluente & $\mathrm{m}^{3} / \mathrm{d}$ \\
\hline$Q_{R}$ & Caudal de recirculación & $\mathrm{m}^{3} / \mathrm{d}$ \\
\hline$r_{F}$ & Velocidad de conversión del sustrato ${ }^{(1)}$ en el interior de la biopelícula & $\mathrm{g} / \mathrm{m}^{3} \cdot \mathrm{d}$ \\
\hline$R_{L}$ & Resistencia externa a la transferencia de masa & $\mathrm{d} / \mathrm{m}$ \\
\hline $\operatorname{Re}$ & Número de Reynolds (= U.dp/v) & - \\
\hline Sc & Número de Schmidt $\left(=v / \mathrm{D}_{\mathrm{i}}\right)$ & - \\
\hline$S K$ & Fuerza de enjuague en el filtro percolador (basado en el trabajo Alemán Spülkraft) & $\mathrm{mm}$ \\
\hline$U$ & Velocidad de flujo característico & $\mathrm{m} / \mathrm{d}$ \\
\hline$u_{d, M}$ & $\begin{array}{l}\text { Velocidad de desprendimiento de la biopelícula en términos de la masa eliminada por } \\
\text { unidad de área y tiempo }\left(=\mathrm{u}_{\mathrm{d}, \mathrm{S}} \cdot \mathrm{X}_{\mathrm{F}}\right)\end{array}$ & $\mathrm{g} / \mathrm{m}^{2} \cdot \mathrm{d}$ \\
\hline$u_{d, S}$ & Velocidad de desprendimiento de la biopelícula & $\mathrm{m} / \mathrm{d}$ \\
\hline$u_{d, S}$ & Velocidad volumétrica de desprendimiento de la biopelícula $\left(=\mathrm{ud}_{\mathrm{d}, \mathrm{S}} / \mathrm{LF}_{\mathrm{F}}\right)$ & $1 / \mathrm{d}$ \\
\hline$V_{R}$ & Volumen del reactor & $\mathrm{m}^{3}$ \\
\hline$x$ & Distancia de la superficie de la biopelícula & $\mathrm{m}$ \\
\hline$X_{\text {Aut }}$ & Densidad de bacterias autótrofas en el interior de la biopelícula & $\mathrm{kg} \mathrm{DQO} / \mathrm{m}^{3}$ \\
\hline$X_{F}$ & Densidad de la biomasa ${ }^{(2)}$ en el interior de la biopelícula & $\mathrm{kg} \mathrm{DQO} / \mathrm{m}^{3}$ \\
\hline$X_{H}$ & Densidad de las bacterias heterótrofas en el interior de la biopelícula & $\mathrm{kg} \mathrm{DQO} / \mathrm{m}^{3}$ \\
\hline$X_{I}$ & Densidad de materia orgánica no biodegradable en el interior de la biopelícula & $\mathrm{kg} \mathrm{DQO} / \mathrm{m}^{3}$ \\
\hline$y$ & Distancia a lo largo de la longitud del reactor & $\mathrm{m}$ \\
\hline$Y$ & Coeficiente de rendimiento para $\mathrm{XF}_{\mathrm{F}}^{(2)}$ creciendo sobre el sustrato genérico $^{(1)}$ & $\mathrm{g} / \mathrm{g}$ \\
\hline$Y_{\text {Aut }}$ & Rendimiento para el crecimiento autótrofo en $\mathrm{C}_{\mathrm{NH} 4}$ & $\mathrm{~g} \mathrm{DQO} / \mathrm{g} \mathrm{N}$ \\
\hline$Y_{H}$ & Rendimiento para el crecimiento heterótrofo en $\mathrm{Cs}_{\mathrm{s}}$ & $\mathrm{g} \mathrm{DQO} / \mathrm{g}$ DQO \\
\hline$z$ & Distancia desde el material de soporte (acarreador) & $\mathrm{m}$ \\
\hline
\end{tabular}




\section{SUBÍNDICES}

\begin{tabular}{ll}
\hline Subíndices & Descripción \\
\hline 0 & Orden cero \\
0 & A un tiempo cero \\
$0, \mathrm{f}$ & Orden cero, biopelícula completamente penetrada \\
$0, \mathrm{p}$ & Orden cero, biopelícula parcialmente penetrada \\
1 & Primer orden \\
$\mathrm{A}$ & Por superficie de biopelícula \\
$\mathrm{Aut}$ & Bacterias autótrofas \\
$\mathrm{B}$ & En la solución \\
e.a. & Aceptor de electrones \\
e.d. & Donador de electrones \\
$\mathrm{F}$ & En la biopelícula \\
$\mathrm{H}$ & Bacterias heterótrofas \\
in & Afluente \\
$\mathrm{LF}$ & En la superficie de la biopelícula \\
$\mathrm{NH}$ & Amonio \\
$\mathrm{O}_{2}$ & Oxígeno \\
$\mathrm{S}$ & Sustrato orgánico \\
$\mathrm{W}$ & En el agua \\
\hline
\end{tabular}

\section{ABREVIACIONES}

\begin{tabular}{ll}
\hline Abreviación & Descripción \\
\hline BAF & Filtros biológicos aireados \\
IFAS & Sistema integrado de lodos activados con biopelícula fija \\
MBBR & Reactor de biopelícula de lecho móvil \\
RBC & Reactor biológico de contacto \\
SAF & Filtros aireados sumergidos \\
SBBR & Reactor secuencial semicontinuo de biopelícula \\
SK & Spülkraft (Alemán) \\
TRL & Tiempo de retención del lodo \\
UASB & Reactor anaerobio de lecho de lodos con flujo ascendente \\
\hline
\end{tabular}




\section{SÍMBOLOS}

\begin{tabular}{|c|c|c|}
\hline $\begin{array}{l}\text { Símbolos } \\
\text { griegos }\end{array}$ & Descripción & Unidades \\
\hline$\beta$ & $\begin{array}{l}\text { Penetración del sustrato }{ }^{(1)} \text { suponiendo velocidades de reacción de orden cero en el } \\
\text { interior de la biopelícula }\end{array}$ & - \\
\hline Be.a. & $\begin{array}{l}\text { Penetración del aceptor de electrones suponiendo velocidades de reacción de orden cero } \\
\text { en el interior de la biopelícula }\end{array}$ & - \\
\hline$\beta_{\text {e.d. }}$ & $\begin{array}{l}\text { Penetración del donador de electrones suponiendo velocidades de reacción de orden cero } \\
\text { en el interior de la biopelícula }\end{array}$ & - \\
\hline$\gamma_{\text {e.d.e.a. }}$ & $\begin{array}{l}\text { Penetración del donador de electrones con respecto a la penetración del correspondiente } \\
\text { aceptor de electrones }\left(=\beta_{\text {e.d. }} / \beta_{\text {e.a. }}\right)\end{array}$ & - \\
\hline$\varepsilon$ & $\begin{array}{l}\text { Factor de eficiencia suponiendo velocidades de reacción de primer orden en el interior } \\
\text { de la biopelícula }\end{array}$ & - \\
\hline$\varepsilon l$ & En AQUASIM: Fracción volumétrica del líquido en el interior de la biopelícula & - \\
\hline$\varepsilon_{s}$ & En AQUASIM: Fracción volumétrica de los sólidos en el interior de la biopelícula & - \\
\hline$\zeta$ & $\begin{array}{l}\text { Relación entre el flujo de sustrato en la biopelícula, despreciando la resistencia a la } \\
\text { transferencia externa de masa, y el flujo de sustrato en la capa límite de transferencia de } \\
\text { masa, considerando } \mathrm{C}_{\mathrm{LF}}=0\end{array}$ & - \\
\hline$\mu_{\max }$ & Velocidad máxima de crecimiento & $1 / \mathrm{d}$ \\
\hline$v$ & Coeficiente estequiométrico & \\
\hline$v$ & Viscosidad cinemática & $\mathrm{m}^{2} / \mathrm{d}$ \\
\hline$\tau$ & Tiempo característico (ver la Tabla 17.5) & $\mathrm{d}$ \\
\hline$\Phi$ & Módulo de Thiele & - \\
\hline
\end{tabular}

${ }^{(1)}$ Observe que en la mayoría del Capítulo 17, el tipo de sustrato limitante y las unidades no se encuentran especificados. Ejemplos de posibles sustratos son: los donadores de electrones como el sustrato orgánico $\left(\mathrm{C}_{\mathrm{F}, \mathrm{S}}\right)$, amonio $\left(\mathrm{C}_{\mathrm{F}, \mathrm{NH} 4}\right)$, o aceptores de electrones como oxígeno $\left(\mathrm{C}_{\mathrm{F}, \mathrm{O} 2}\right)$ o nitrato $\left(\mathrm{C}_{\mathrm{F}, \mathrm{NO} 3}\right)$. Las unidades para el sustrato deben ser consistentes con las unidades de las constantes cinéticas $\mathrm{u}$ estequiométricas.

${ }^{(2)} \mathrm{El}$ tipo de biomasa no se específica. La biomasa activa genérica convierte al sustrato genérico $\mathrm{C}_{\mathrm{F}}$. Algunos ejemplos de posibles tipos de biomasa son: las bacterias heterótrofas $\left(\mathrm{X}_{\mathrm{H}}\right)$ y las bacterias autótrofas $\left(\mathrm{X}_{\mathrm{Aut}}\right)$.

${ }^{(3)}$ Las unidades del coeficiente de desprendimiento dependen de la expresión de velocidad de desprendimiento seleccionada (ver la Tabla 17.4). 




En las últimas decadas, el conocimiento de los procesos de tratamiento de aguas residuales ha avanzado extensamente evolucionando de enfoques basados en procedimientos meramente empíricos a enfoques con principios básicos que abarcan la química, microbiología, física, ingeniería de procesos y matemáticas. La gran mayoría de estos avances han madurado a tal grado que han sido codificados en modelos matemáticos para su simulación en computadoras. La cantidad, complejidad y diversidad de estos nuevos desarrollos puede ser abrumador, en particular para una nueva generación de jóvenes científicos e ingenieros que ingresan al área del tratamiento de aguas residuales, y también por que no existe un fácil acceso a cursos avanzados de postgrado en tratamiento de aguas residuales para los profesionales de países en vías de desarrollo y en transición.

Este libro tiene como objetivo resolver esta deficiencia ya que compila e integra el material de diversos cursos de postgrado de más de una docena de grupos de investigación de todo el mundo que han hecho contribuciones significativas para el desarrollo del tratamiento de aguas residuales.

Cabe resaltar que la edición en inglés del presente libro, forma parte del plan de estudios en tratamiento biológico de aguas residuales ofrecido por IHE Delft que incluye: (i) resúmenes de las presentaciones y clases de los temas cubiertos en el libro, (ii) videos de las clases de los profesores autores de los capítulos del libro y (iii) ejercicios de auto-aprendizaje para los participantes en los cursos.

Al término del plan de estudios antes mencionado, los últimos avances en modelación y simulación de la operación y diseño de los sistemas de tratamiento de aguas residuales (ya sean lodos activados, procesos de remoción biológica de nitrógeno y fósforo, clarificadores secundarios o sistemas de biopelículas) pueden ser abordados con mayor profundidad, conocimientos más avanzados y mayor confianza.

Financiado por:

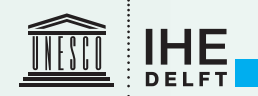

Ministry of Foreign Affairs of the
Netherlands
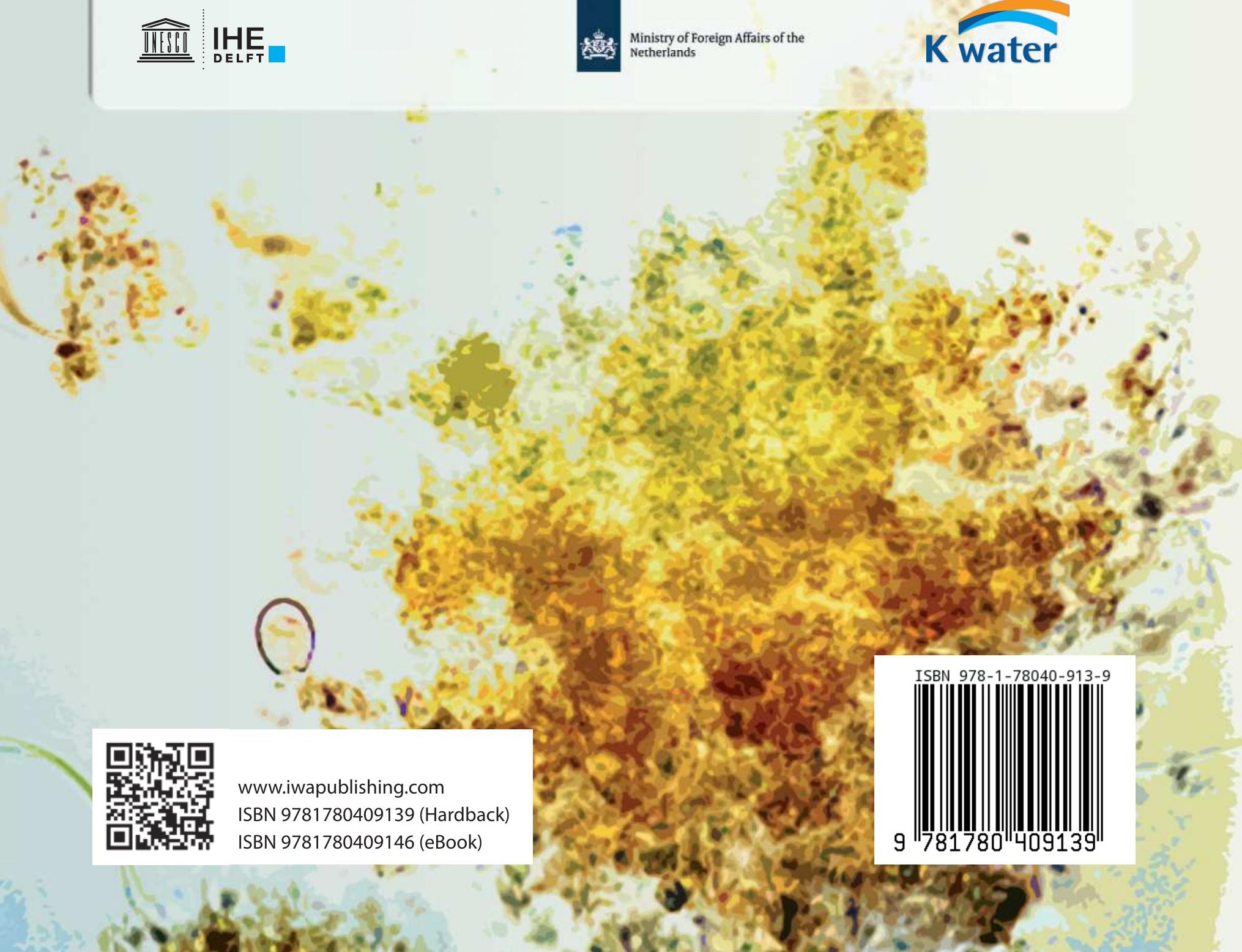